\author{
UNIVERSIDADE DE SÃO PAULO \\ INSTITUTO DE ESTUDOS BRASILEIROS \\ PROGRAMA DE PÓS-GRADUAÇÃO EM CULTURAS E \\ IDENTIDADES BRASILEIRAS
}

MARCELO CASTRO DA SILVA MARANINCHI

\title{
O segredo dos sentimentos sinceros: estudo da marginália de Mário de Andrade na poesia do romantismo brasileiro
}




\author{
UNIVERSIDADE DE SÃO PAULO \\ INSTITUTO DE ESTUDOS BRASILEIROS \\ PROGRAMA DE PÓS-GRADUAÇÃO EM CULTURAS E \\ IDENTIDADES BRASILEIRAS
}

\title{
O segredo dos sentimentos sinceros: estudo da marginália de Mário de Andrade na poesia do romantismo brasileiro
}

\author{
Marcelo Castro da Silva Maraninchi \\ Bolsista FAPESP/CAPES
}

Dissertação apresentada ao Programa de PósGraduação em Culturas e Identidades Brasileiras, do Instituto de Estudos Brasileiros da Universidade de São Paulo, para a obtenção do título de Mestre em Filosofia.

Orientadora: Prof. ${ }^{a}$ Dr. ${ }^{a}$ Therezinha A. Porto Ancona Lopez

São Paulo

2017 
DADOS DE CATALOGAÇÃO NA PUBLICAÇÃO (CIP)

Serviço de Biblioteca e Documentação do

Instituto de Estudos Brasileiros da Universidade de São Paulo

(c) reprodução tota

M311

Maraninchi, Marcelo Castro da Silva

O segredo dos sentimentos sinceros : estudo da marginália de Mário de Andrade na poesia do romantismo brasileiro / Marcelo Castro da Silva Maraninchi -- São Paulo, 2016.

Orientadora : Profa. Dra. Therezinha Apparecida Porto Ancona Lopez.

Dissertação (Mestrado) - Universidade de São Paulo. Instituto de Estudos Brasileiros. Programa de Pós-Graduação em Culturas e Identidades Brasileiras. Área de concentração: Estudos Brasileiros. Linha de pesquisa: Brasil: a realidade da criação, a criação da realidade.

Versão do título para o inglês: The secret of sincere feelings : Mário de Andrade's marginalia on Brazilian romantic poetry.

Descritores: 1. Andrade, Mário de, 1893-1945 2. Crítica literária 3. Crítica genética 4. Poesia 5. Romantismo I. Universidade de São Paulo. Instituto de Estudos Brasileiros. Programa de Pós-Graduação II. Título. 
Nome: MARANINCHI, Marcelo Castro da Silva

Título: O segredo dos sentimentos sinceros: estudo da marginália de Mário de Andrade na poesia do romantismo brasileiro.

Dissertação apresentada ao Programa de PósGraduação em Culturas e Identidades Brasileiras do Instituto de Estudos Brasileiros da Universidade de São Paulo para obtenção do título de Mestre em Filosofia, área de concentração: estudos brasileiros.

Aprovado em: 27 de janeiro de 2017.

Orientadora: Profa. Dra. Therezinha A. Porto Ancona Lopes (USP)

Assinatura:

Banca examinadora

Prof. Dr. Vagner Camilo (USP)

Assinatura:

Prof. Dr. Marcos Antonio de Moraes (USP)

Assinatura:

Dra. Lilian Escorel de Carvalho

Assinatura:

Suplentes:

Prof ${ }^{a}$ Dra. Cristiane Rodrigues de Souza (UFMS)

Prof ${ }^{a}$ Dra. Renata Azevedo Requião (UFPel)

Prof. Dr. Ricardo Souza Carvalho (USP) 


\section{Agradecimentos}

Devo a algumas pessoas e instituições o gosto de concluir esta pesquisa para o mestrado. Agradeço à Fundação de Amparo à Pesquisa do Estado de São Paulo (Fapesp), em conjunto com a Coordenação de Aperfeiçoamento de Pessoal de Nível Superior (Capes), pela bolsa de estudos que permitiu o desenvolvimento do projeto - Processo no. 2014/20620-6.

Sou grato aos servidores e à direção do Instituto de Estudos Brasileiros, particularmente a Elisabete Marin Ribas, Paulo José de Moura e Pedro Marques, no Arquivo; Daniela Piantola, Márcia Dias de Oliveira Leme e Gabriela Giacomini de Almeida, na Biblioteca; e também a Pérola Ramira Ciccone, Regina Aga, Daniele Lopes Freitas, Maria Cristina Pires da Costa, Maria Iracema da Silva e à diretora do Instituto, Profa. Dra. Sandra Nitrini.

Agradeço aos Professores e pesquisadores do IEB-USP: Profs. Drs. Marcos Antonio de Moraes, Alexandre Freitas Barbosa, Ana Paula Cavalcanti Simioni, Jaime Tadeu Oliva, Flávia Camargo Toni, Tatiana Longo Figueiredo e Luciana Barongeno.

O amadurecimento da pesquisa deve muito aos docentes da Faculdade de Filosofia, Letras e Ciências Humanas da USP: Profs. Drs. Vagner Camilo, Joaquim Alves de Aguiar, Murilo Marcondes de Moura, Cilaine Alves Cunha, João Adolfo Hansen, e à Profa. Dra. Lucia Sá, da Universidade de Manchester.

Pude desfrutar do diálogo com os colegas da FFLCH, do IEB e do núcleo de estudos sobre bibliotecas de escritores: Leandro Fernandes, Regiane Matos, Viviane Vilela, José Quintão de Oliveira, Ângela Grillo, Marina Damasceno Sá, Ana Carolina Sá Telles, Cristiane Rodrigues de Souza, Patrícia Guimarães e Lígia Kimori.

No exame de qualificação, contei com os comentários de crítica e estímulo dos Profs. Drs. Cilaine Alves Cunha, Marcos Antonio de Moraes e Telê Ancona Lopez.

Devo muito ao carinho dos de casa - no Sul, na Bahia, em Pernambuco e São Paulo. Agradeço muito afetuosamente a Paula, Renata, Maria Laura, Maria Luiza, Armando, Fabiana, Geovana, André, meus tios Anna e Albenor, Clarissa, Camila, Malu, Rosana, Gabi, Pliger, Marcela, muito ao Pedro, mais ao Gabriel.

Agradeço aos meus irmãos, Eduardo, Fernando e Bianca, às tias muito amadas Tanyra e Eulina, e aos meus pais, Leonor e Artur, pelo amparo e desamparo amoroso.

A orientação amiga e rigorosa, incluindo o apoio gentil do meu xará, devo à Telê, com quem pude exercitar, na linha de Mário de Andrade, a "curiosidade em vias de satisfação". 
"Vou escrever o meu livro sobre os poetas românticos mostrando o bem dessa gente e o valor deles"

(Carta de Mário de Andrade a Carlos Drummond de Andrade, em 16 de outubro de 1925)

"Nome do livro: Lirismo Romântico no Brasil"

(Nota de trabalho autógrafa no dossiê do manuscrito Castro Alves) 


\title{
Resumo.
}

O objeto deste trabalho consiste na transcrição, classificação e análise da marginália de Mário de Andrade (1893-1945) na poesia do romantismo brasileiro. A pesquisa dedicou-se ao estudo das notas de margem apostas pelo escritor modernista nas obras de Gonçalves Dias, Álvares de Azevedo, Casimiro de Abreu, Fagundes Varela e Castro Alves conservadas em sua biblioteca. Como paratextos, as notas vinculam-se a diferentes projetos de crítica do romantismo, inacabados ou concluídos para publicação, assim como revelam matrizes do poeta e ficcionista. Pode-se afirmar que o estudo do autor de Macunaíma sobre os "cinco grandes românticos" nasce na marginália, nutre notas de trabalho, esboços e planos no arquivo - nos dossiês Amor e medo, Castro Alves e Artigos por escrever - e chega às versões publicadas - "Álvares de Azevedo I e II", "Mosqueiro no 2", "Álvares de Azevedo I, II e III", "Momento", "Amor e medo" e "Castro Alves" - sem que os textos éditos esgotem a reflexão original.

Palavras-chave: Mário de Andrade; marginália; poesia brasileira; romantismo; crítica genética.

\begin{abstract}
.
This study consists of the transcription, classification and analysis of Mário de Andrade's marginalia (1893-1945) on Brazilian romantic poetry. The research has been focused on studying the notes made by the Brazilian modernist writer and critic on the books of Gonçalves Dias, Álvares de Azevedo, Casimiro de Abreu, Fagundes Varela and Castro Alves, all of which are part of his personal library kept in IEB-USP. Considered as paratexts, the notes relate to different projects - either finished or unfinished - of studying Brazilian Romanticism, as well as reveal sources for the poet and novelist. It is possible to affirm that Mário de Andrade's study of the "five grand romantics" is born in the marginalia, nourishes notes, sketches and plans in his archives - manuscripts Amor e medo, Castro Alves and Artigos por escrever - and turns into the published versions of his works - "Álvares de Azevedo I e II", "Mosqueiro n 2", "Álvares de Azevedo I, II e III", "Momento", "Amor e medo" and "Castro Alves" without exhausting the original material.
\end{abstract}

Keywords: Mário de Andrade; marginalia; Brazilian poetry; Romanticism; genetic criticism. 


\section{Lista de ilustrações}

Figura 1 - Envelope do escritor gaúcho Augusto Meyer, no dossiê do manuscrito Amor e medo (MA-MMA-05-01), reaproveitado para abrigar notas de trabalho sobre a poesia do romantismo p. 13

Figura 2 - Folha de guarda das Obras completas de Castro Alves; exemplar anotado por MA, contendo a etiqueta de localização do volume na biblioteca do autor, o número de inclusão da obra na Bibliografia para Na pancada do ganzá e verbetes recolhidos para a pesquisa sobre a Zoofonia e o Dicionário musical brasileiro ..p. 24

Figura 3 - Notas de trabalho no dossiê do manuscrito Amor e medo (MA-MMA-0530), destacando aspectos lexicais da obra de Álvares de Azevedo. .p. 32

Figura 4 - Nota de margem no poema "Minh'alma é triste", de Casimiro de Abreu. As primaveras, p. 120 e 121 .... .p. 62

Figura 5 - Nota de margem nas "Páginas de Penseroso", em Macário, de Álvares de Azevedo: Obras (1900) . Ed. cit., vol. 3, p. 320. .p. 66 


\section{SUMÁRIO}

\section{PARTE I}

Ensaio de apresentação: "O segredo dos sentimentos sinceros".

.p. 10

\section{PARTE II}

Marginália Mário de Andrade na poesia do romantismo brasileiro: transcrição, classificação e notas da pesquisa

ABREU, Casimiro. As Primaveras (1909).............................p. 81

ALVES, Castro. Obras Completas (1921)................................p. 125

AZEVEDO, M. A. Álvares de. Obras (1862)...............................p. 217

AZEVEDO, M. A. Álvares de. Obras (1900).................................p. 219

AZEVEDO, M. A. Álvares de. O Conde Lopo (1886)......................... 377

DIAS, A. Gonçalves. Poesias (1919)...............................................p. 389

DIAS, A. Gonçalves. Obras posthumas: Poesias posthumas (1909).........p. 519

VARELLA, L. N. Fagundes. Obras Completas (1919)........................ 528

\section{COMPLEMENTO}

Dossiê do manuscrito Amore medo......................................................... 659

Dossiê do manuscrito Artigos por escrever............................................ 690

Dossiê do manuscrito Castro Alves..................................................... 699

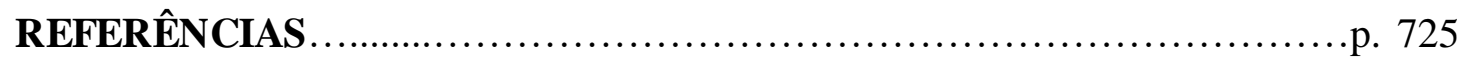




\section{PARTE I}

\section{O segredo dos sentimentos sinceros: estudo da marginália de Mário de Andrade na poesia do romantismo brasileiro}

[ensaio de apresentação]

\section{Ouvertura}

A coleção de arte, a biblioteca e o arquivo no acervo de Mário de Andrade - no patrimônio do Instituto de Estudos Brasileiros da Universidade de São Paulo - atestam os interesses e a complexidade do projeto do escritor. Literatura, cinema, fotografia, pintura, música, antropologia, entre outros, formam um conjunto que convida à pesquisa. A biblioteca, com seus mais de 17 mil volumes, é "seara e celeiro"1 da criação. Possibilita investigações que, ligando-se à série Manuscritos Mário de Andrade, no arquivo, e apoiadas na crítica genética, analisem e retracem caminhos de leitura e criação.

Esta pesquisa para o mestrado, inscrita no Programa de Pós-Graduação Multidisciplinar em Culturas e Identidades Brasileiras do IEB-USP, vincula-se ao projeto de pesquisa coletivo Bibliotecas de escritores e a criação literária ${ }^{2}$. O corpus é composto de notas de margem e manuscritos conservados na biblioteca e no arquivo do escritor, abrangendo os poetas românticos Gonçalves Dias, Álvares de Azevedo, Casimiro de Abreu, Fagundes Varela e Castro Alves. O objetivo do projeto é compreender a relação das leituras e notas com a formulação das ideias de Mário de Andrade sobre a poesia romântica, por meio da transcrição, classificação e análise das notas de margem apostas por ele nos volumes de poesia do romantismo brasileiro, todos situados em sua biblioteca, no IEB-USP, assim como de manuscritos dispostos em três dossiês: "Amor e medo", "Castro Alves" e "Artigos por escrever".

\footnotetext{
${ }^{1}$ LOPEZ, Telê Ancona. “A Biblioteca de Mário de Andrade: seara e celeiro da criação.” In ZULAR, Roberto, org. Criação em processo: Ensaios de Crítica Genética. São Paulo: FAPESP/ Iluminuras/ CAPES, 2002, p. 45-72.

2 Coordenado pela Profa. Telê Porto Ancona Lopez, dá continuidade a um dos aspectos do projeto temático FAPESP/IEB-FFLCH-USP, Estudo do processo de criação de Mário de Andrade nos manuscritos de seu arquivo, em sua correspondência, em sua marginália e em suas leituras. A pesquisa desenvolveu-se com bols a FAPESP/CAPES.
} 
A biblioteca representa um espaço fecundo para a relação intertextual e a prática da escritura: testemunha apropriações, guarda matrizes e revela, na marginália, instâncias do processo criativo. As estantes permitem retraçar a gênese de propostas críticas deixadas nas margens, entrelinhas, em folhas de guarda ou notas apensas. Como paratextos, as anotações constituem um manuscrito sobre o texto impresso de outro autor e, uma vez reunidas, formam um caderno de notas de trabalho. No caso da poesia do romantismo brasileiro, a biblioteca de Mário de Andrade preserva os diálogos do crítico/poeta modernista, de modo explícito, nas notas que participam da marginália, e, de modo implícito, em obras sem anotações autógrafas. Suas linhas mestras são o estudo psicológico e linguístico, alinhados ao projeto de pensar e criar uma obra brasileira, e o interesse pela forma e a musicalidade poéticas.

\section{$\underline{\text { Diálogo batuta }}$}

$\mathrm{O}$ documento $\mathrm{n}^{\mathrm{o}} 1$ no dossiê do manuscrito Amor e medo consiste em um envelope de papel branco, retangular, amarelado por efeito do tempo. Suas dimensões são as de um envelope de cartas comum: 11,8 x 17,2 cm. O timbre da Bibliotheca Publica do Estado do Rio Grande do Sul é impresso a tinta preta, à esquerda, no canto superior. O nome da biblioteca - em maiúsculas, formas retas - guarda ares modernos. Desenhado em círculo, o timbre exibe alguns livros, de tamanhos variados, ao lado de pequenas gavetas, que parecem guardar fichas catalográficas. Em volta do desenho, é possível ler a frase em latim: "Libri Noster Amor Inter Vos Dulce Est Vivere Dulce Mori”, algo como: "Livros, nosso amor: é doce viver e morrer entre vós"3. No campo indicado para os dados do destinatário, a letra cursiva, em preto, indica: "Snr. / Mário de Andrade / Rua Lopes Chaves 108 / São Paulo". O selo de 200 réis, no canto direito, traz uma figura feminina, de feições clássicas, perfil. Com a mão direita graciosamente erguida, o indicador quase toca o sol - sol do amanhecer -, para o qual o olhar também se volta. A palavra "Aviação", escrita sobre um fundo claro, no mesmo tom zarcão do restante do selo, celebra os anos iniciais da aviação comercial no Brasil, em contraste com a figura que evoca as musas da Antiguidade ${ }^{4}$. Redondo, o carimbo dos Correios

\footnotetext{
${ }^{3}$ Agradeço à Profa. Dra. Paula Brauner, docente de língua e literatura latina na Faculdade de Letras da Universidade Federal de Pelotas, pela ajuda na tradução.

${ }^{4}$ O selo pertence à série "Alegorias das Atividades Econômicas do País", emitida em 12 de maio de 1920 e utilizada pelos Correios até 1941. Devo a informação ao pesquisador Miguel Angelo Santiago, do
} 
tinge de preto a frente e o verso do envelope em quatro pontos. A data quase apagada parece indicar, no verso, "15-8-1931". Além dos dados de envio, há no envelope outras sete inscrições autógrafas, perpendiculares e em talhe maior. Em vermelho, a expressão "Lirismo Romantico" mostra-se quatro vezes, e os termos "Amor / e / medo" sobrepõem-se a ela, em grafite, por duas vezes. Também a grafite, o termo "Aristocracia" arremata as inscrições. A última modificação visível no envelope é o código de referência do documento, a lápis - MA-MMA-05-015 - localizando-o no Arquivo Mário de Andrade, parcela do acervo do escritor, no patrimônio do Instituto de Estudos Brasileiros da Universidade de São Paulo.

Para entender a presença do envelope na Série Manuscritos Mário de Andrade, ligado à criação do ensaio "Amor e medo", convém recuar até uma carta de 29 de dezembro de 1930, remetida por Augusto Meyer ao amigo dele, da rua Lopes Chaves: 'Mário velho, conte alguma coisa de V., da sua vida. Escreva. O Bilú agora meteu na mala o bandoneon pra ser diretor da Bibliotheca Publica. A vida não pergunta: o que é que você quer ser? A gente vai sendo, conforme os trancos e barrancos permitirem."

Os acontecimentos políticos daquele ano, enfeixados sob o rótulo de "Revolução de 30", são evocados por Meyer em poucas palavras. Além dos trancos e barrancos, o escritor queixa-se do "crânio vazio" em meio "à encrenca da remodelação nacional”. Na carta, prefere falar de poesia. Saúda, em primeiro lugar, o recémpublicado Remate de males $^{7}$, de "complexidade lírica mais profunda", feito com o "mesmo cuidado de disciplina" de Clã do jabuti (1927). Pergunta se Mário leu os poemas de Murilo Mendes - "Tem pegadas finas como navalha". Afirma enfim o gosto por Carlos Drummond de Andrade: "é um bicho ácido e perigoso, envenena tudo com uma arte demoníaca e finge que nem tem nada com isso". ${ }^{8}$

Museu dos Correios, em Brasília. V. MEYER, Rolf Harald. Catálogo de Selos Brasil 1988. São Paulo: Editora RHM Ltda.,1988, p. 489.

5 A referência é assim formada: "MA" indica o Fundo Mário de Andrade; "MMA", a série "Manuscritos Mário de Andrade"; "05" para o número do dossiê, Amor e medo; "01" para o número do fólio. A pesquis a tratará de outros dois dossiês: Artigos por escrever (MA-MMA-11) e Castro Alves (MA-MMA26).

${ }^{6}$ Documento na série Correspondência Mário de Andrade, no Arquivo do IEB-USP (MA-C-CPL-4735).

${ }^{7}$ ANDRADE, Mário de. Remate de males. São Paulo: Eugenio Cupolo, 1930.

${ }^{8}$ Documento na série Correspondência Mário de Andrade, no Arquivo do IEB-USP (MA-C-CPL-4735). 

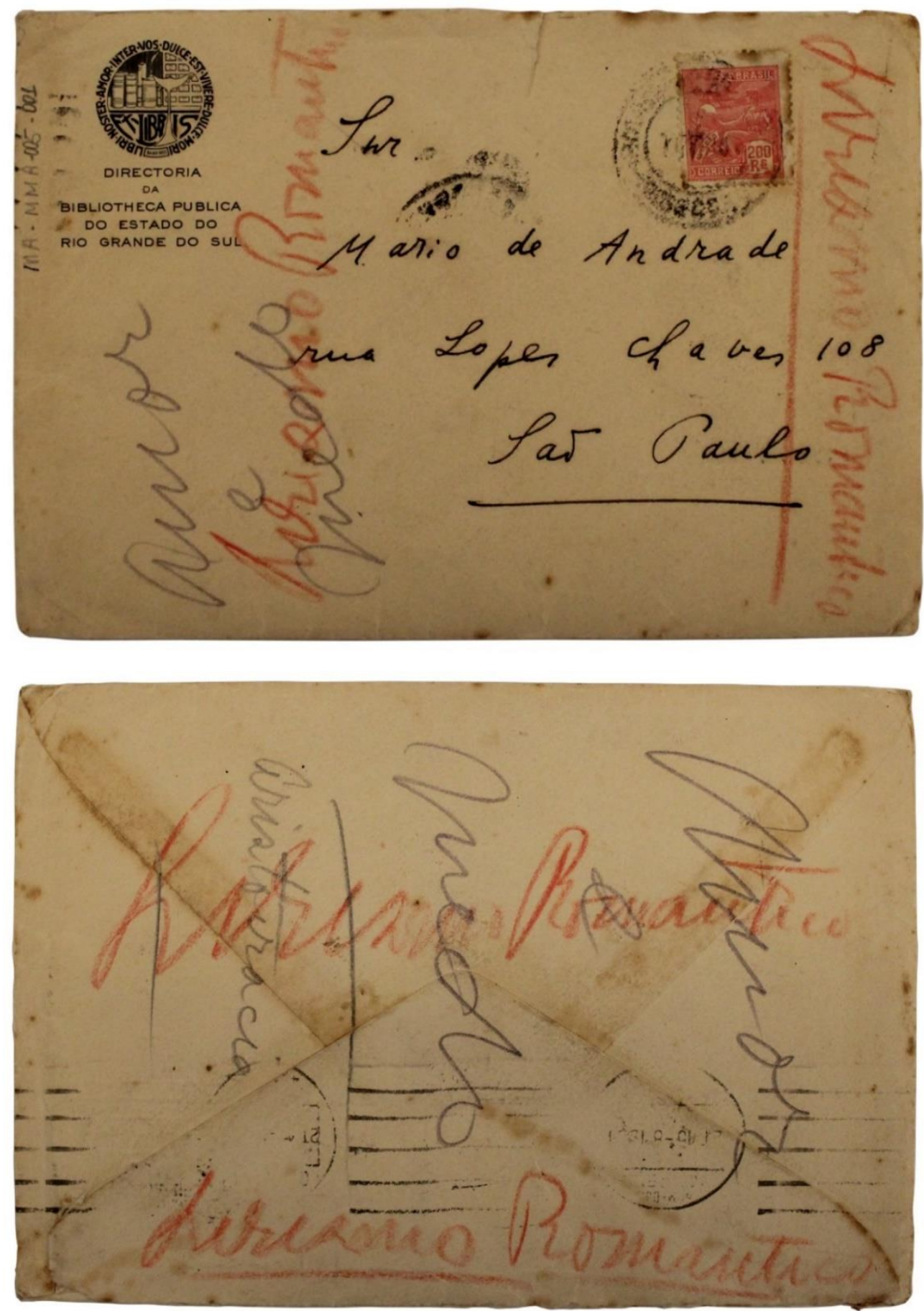

Figura 1

Mário responde ao amigo em janeiro. Entusiasmado com a nomeação de Meyer para o cargo de diretor, o poeta da Pauliceia aceita doar livros seus para a Bibliotheca em Porto Alegre. Também reage satisfeito às considerações sobre o Remate e conta de um estudo crítico sobre a poesia de Drummond, Murilo Mendes e Manuel Bandeira. A crônica longa - conforme Mário classifica o texto “A poesia em 30”, incluído em Aspectos da literatura brasileira (1943) - sairá em uma revista fundada há pouco: 
"Quanto à sua carta, como aliás todas as cartas que você tem me escrito a respeito de livros meus, é um primor de observação fina, está exatíssima nos detalhes. Isso aliás é o que me conforta, ver que certas pessoas me entendem bem pelos meus livros - e você sabe que isso é raríssimo nesses brasis, com os críticos mais bobos que é possível se imaginar. Aliás me retirei completamente da crítica, e como já com o Remate, não pretendo mandar mais livro nenhum meu nem a jornais nem a críticos (pelo menos como críticos), desde que sejam edição de minha propriedade. Acho que não vale a pena sob nenhum ponto de vista. Por isso mesmo: que você, o Murilo Mendes, o Manuel Bandeira, o Drummond me compreendam, me dá mesmo um prazer enorme. Você tem razão: o livro do Murilo é interessantíssimo. Estou mesmo convencido que é o livro de maior importância saído em poesia no ano passado, embora pessoalmente eu prefira outros. Escrevi sobre a Poesia de 1930 uma crônica longa que sairá em 1 de março na Revista Nova que acabamos de fundar Paulo Prado, Alcântara Machado e eu. É uma revista séria, de 150 páginas no mínimo, trimestral, publicando muito pouca literatura, pelo menos literatura gratuita. Muita crítica e muitos estudos de qualquer ordem que tenham imediata correlação com o Brasil. Está claro que na lista dos colaboradores, desde logo você foi incluído."

Passados cinco meses, sob o frio do inverno - "chuva e minuano, um tempo lindo pra roer livros" - Meyer escreverá para saber dos projetos de Mário. Dando seguimento ao diálogo, pergunta, em 29 de junho: 'Depois do Remate em que há coisas lindas, com um sentido mais gratuito de poesia - vai nos dar a Gramatiquinha? Uma 'gramatiquinha' da fala do Macunaíma, o heroi sem pouso, sem preguiça e sem medo? Vam a ver." 10

Em vez de responder em detalhe sobre a Gramatiquinha e falar dos projetos em curso, coisa que fará na carta seguinte, Mário ressente-se do tom adotado pelo amigo. Não gosta das "friezas quase irônicas" e busca pôr o diálogo em panos limpos: "Temos sido sinceros e de pijama um com o outro (...) Por isso, desembuxe. E continuemos nós mesmos"11, diz na carta de 18 de julho. Com Meyer a palavra, para desfazer a má impressão. Na mensagem longa, bem circunstanciada, em 30 de julho, o autor dos Poemas de Bilu explica que a carta anterior fora escrita de pé, na Bibliotheca. Reitera a amizade franca e insiste curioso em saber dos trabalhos de Mário. O carimbo com a data de "15-8-1931" é o indício mais forte para se supor que esta última carta, de 30 de julho, viajou até São Paulo no envelope localizado no dossiê.

\footnotetext{
${ }^{9}$ FERNANDES, Lygia (org.). Mário de Andrade escreve cartas a Alceu, Meyer e outros. Rio de Janeiro: Editôra do Autor, 1968, p.

${ }^{10}$ Documento na série Correspondência Mário de Andrade. Arquivo IEB-USP. Fundo Mário de Andrade. Código MA-C-CPL-4736.

${ }^{11}$ FERNANDES, Lygia (org.). op. cit, ed. cit., p. 85.
} 
A resposta ajuda a historiar os planos dele naquele momento - em um contexto, como se sabe, de voragem política e transição do modernismo ${ }^{12}$. Em 28 de agosto, Mário de Andrade conta em longas linhas o que anda maquinando. No ano seguinte, tenciona publicar a documentação inédita sobre a feitiçaria do Nordeste, "o Catimbó, que difere enormemente da Macumba"13. Esclarece que nunca tivera intenção de escrever a Gramatiquinha, propriamente, queria apenas mostrar que "não estava às escuras, que tinha documentação e estudos a respeito do que estava tentando"14. De estudos musicais, conta dispor de três livros importantíssimos" por sair, "o Pancada do Ganzá, sobre folclore nordestino (e não é só musical)", A Música dos Brasis, acerca dos ameríndios, e o Dicionário musical brasileiro, "que é o mais importante, mais geral e espero minha obra maior". Sobre este último, explica:

"O plano do livro é o seguinte: livro pra uso geral, contendo pois todos os termos musicais da Música, porque assim servirá até pra um aluno que queira saber o que é Cadência. Mas suponhamos: a palavra Alegro, será definida em três linhas, e a palavra Cateretê será exposta em três páginas. Isso que justifica o 'Brasileiro' do título do livro, que terá pois mil, ou mais de mil páginas. E assim mesmo não versará sobre autores, porque sinão o trabalho ultrapassava tudo o que eu posso dar pra ele." 15

Os outros dois trechos da resposta a Augusto Meyer importam diretamente ao interesse de Mário de Andrade pela poesia do romantismo. Instado a enviar ao correspondente no sul os artigos que publica no paulistano Diário Nacional, Mário toca em aspectos materiais de sua colaboração. São artigos "de vário assunto", publicados aos domingos, na "terceira página canto da direita do leitor". O principal: "tenho preguiça franqueza, de ir no jornal, pedir os dias, cortar, mandar etc. Tanto mais que não dou importância pra eles mesmo como pensamento." 6 A mesma carta alude enfim às circunstâncias de redação de "Amor e medo", publicado duas semanas após a carta, em 15 de setembro:

"Estou à espera do Literatura e Poesia que você disse que saía no instante da carta. Aliás sobre livros daí, gostamos muito do estudo do J. Pinto da Silva sobre o Rio Grande do Sul, sai crítica do Alcântara na revista do próximo quinze que aliás é dedicado ao Álvares de Azevedo que se lembrou de fazer centenário num momento social tão inoportuno pro caso dele, um excepcional aristocrata. Escrevi um

\footnotetext{
12 LAFETÁ, João Luiz. 1930: a crítica e o Modernismo. São Paulo: Duas Cidades/Editora 34, 2000.

${ }^{13}$ FERNANDES, Lygia (org.). op. cit., ed. cit., p. 88.

14 IDEM, ibidem, p. 89.

${ }^{15}$ IDEM, ibidem, p. 90.

16 IDEM, ibidem, p. 90.
} 
artigalhão cujo assunto é muito interessante e a documentação que apresento também: o Medo de Amor nos românticos. Apenas os comentários estão fracos porque se estava ajuntando a documentação, o artigo foi escrito em cima do joelho em dois dias, só pra encher a lacuna dum artigo prometido que falhou. Podia comentar milhor, e si algum dia publicar isso num livreco que imagino sobre Álvares de Azevedo que é uma figura humana apaixonante, refarei os comentários." 17

O envelope carrega, em suas dimensões pequenas, dados valiosos para entender os sucessivos projetos. O reaproveitamento dele para guardar notas de trabalho e esboços - sobre Gonçalves Dias, Álvares de Azevedo, Casimiro de Abreu, Fagundes Varela e Castro Alves - explica sua presença no dossiê. As inscrições autógrafas, que associam Mário ao documento, ajudam a marcar as mudanças de escopo. O interesse do fato de o envelope incorporar aspectos representativos do método crítico. A escolha de reutilizar um pedaço de papel - digamos, grosseiramente, um embrulho de carta diz de um gesto caro ao autor de Macunaíma, o heroi que transforma em tembetá a muiraquitã presenteada por Ci. Salvo engano, talvez atenuada, trata-se da prática da bricolagem, que converte o invólucro da carta em repositório de manuscritos, e o próprio invólucro em manuscrito. Dos versos românticos saem o abonamento de verbetes para o Dicionário musical brasileiro e a metáfora empregada pelo narrador para explicar a relação entre Elsa e Tanaka, a preceptora e o mordomo da família Sousa Costa, em Amar, verbo intransitivo. O ensaios de Mário sobre o romantismo envolve m, no mesmo sentido, o uso transformado de materiais anteriores. As notas de trabalho e esboços nutrem novos textos, por vezes com enfoque diverso. Os próprios papéis utilizados na escrita são fruto de reaproveitamento: o verso de um certificado de regis tro dos Correios serve a esboços sobre o parnasianismo; a razão de ser do romantis mo, "dentro da evolução mental e política do Brasil", é posta em uma folha de papel de carta infantil, com o desenho impresso de um menino pescando em uma tina, colorido a mão e acompanhado de uma espécie de tabuleta onde se lê "Simple Simon" 18.

Da mesma forma, diversas camadas de texto que compõem o documento incorporam tempos e sujeitos no plural. As caligrafias de Augusto Meyer e Mário de Andrade são os traços mais evidentes da justaposição, fazendo do envelope um palimpsesto. Antes dos dois - autores -, o trabalho anônimo de outros sujeitos esteve

\footnotetext{
${ }^{17}$ IDEM, ibidem, p. 93.

${ }^{18}$ Documentos no dossiê do manus crito Amor e medo (MA-MMA-5-10) e Castro Alves (MA-MMA-26$10)$.
} 
implicado na elaboração do documento. Para não voltarmos até o agricultor que plantou ou derrubou a árvore transformada em celulose, ou ao operário que fabricou o papel, fiquemos apenas nas escritas conservadas no envelope, como a impressão do timbre e o carimbo repetido de uma postière imaginária. A escrita autógrafa de Mário também convive, justaposta ou adjacente, com a impressão e o carimbo, formas de registro seriado. Nos manuscritos e sobretudo na marginália, gesto comparável: o crítico, que também é poeta, avança com o lápis para além das margens, sobre o texto ou na entrelinha, fazendo dos livros de outros autores o espaço de criação dos seus próprios textos. A dimensão de diálogo para a qual o envelope aponta, enfim, como peça-chave da dinâmica da correspondência, também caracteriza o método crítico de Mário nos volumes de poesia do romantismo. A nota de margem conversa com o texto impresso. Elogia ou censura: "Esta invocação a Byron é belíssima", em Álvares de Azevedo, ou "Boa porcaria. Varela não se presta pra essas eloquências". Elege matrizes: "Até aqui o princípio do discurso de João Bobo. Tomar nota no romance”. Contesta o uso do instrumento indígena em Os Timbiras: "Me parece que G. Dias se engana. O membi era uma flauta e portanto não atroava." Ironiza - "É engraçada a impertinência pretenciosa do rapazola!" - conta caso e até diz besteira:

"Esta quoda de G. D. comove e sublima pelo sentimento geral que a ditou e pela musicalidade genial. É som puro que nem o milhor de Goethe Heine Verlaine. Porém ideias fracas. Erradas mesmo. Sabiá cantando na palmeira já muito se falou que só mesmo estudante de Coimbra podia pregar mentirada dessas. Duma feita me escutando ressoar êsses versos um sitiante me secundou: Homem... até agora no alto do coqueiro só enxerguei urubú dormindo." 19

A dicção da marginália aproxima-se muitas vezes da oralidade. Não raro a interjeição de espanto e o tom exclamativo registram a reação espontânea, imediata, do leitor. E os volumes anotados guardam também, à semelhança do envelope, o caráter remissivo - escólios na folha de guarda, índice de verbetes do campo da música, notas remetendo a outras notas, livros, pedacinhos de papel. Textos que se desdobram, multiplicam, apontam a outros textos.

\section{$\underline{\text { Labirinto }}$}

\footnotetext{
${ }^{19}$ Nota MA, In: DIAS, A. Gonçalves. Poesias. Paris/Rio de Janeiro: Garnier, 1919, vol. 2, p. 88.
} 
Escrevendo a Manuel Bandeira, Mário de Andrade dá pistas, em 1925, da fase inicial do seu projeto de estudar o romantismo. No envelope de 1931, essa fase corresponde à expressão "Lirismo Romantico", grafada em vermelho - primeira etapa sobreposta à escrita do poeta gaúcho, a tinta preta. Na carta a Bandeira, em 11 de maio, 1925, Mário menciona a intenção ambiciosa de tratar a poesia brasileira em conjunto, sob perspectiva histórica e crítica:

"Você me fala dum estudo meu sobre o Romantismo brasileiro. Já pensei nisso muitas e muitas vezes. É possível que o realize um dia. Já tenho até algumas notas sobre isso. Isto é, sobre uma coisa um pouco mais larga e de que desisti: uma História crítica da poesia brasileira até nossos dias. É grande e dificultoso por demais pra mim que já tenho tanto que fazer. Fica a ideia do Romantismo de pé e de um outro livro com o lindo nome Poetagem bonita, em que reunirei os estudos que for publicando sobre os chamados modernistas brasileiros." 20

A correspondência, como "caixa registradora"21, revela que Mário já dispunha de notas sobre a poesia do romantismo em 1925. E tinha o objetivo mais amplo de pensar a poesia brasileira como um todo. $\mathrm{Na}$ decisão de suspender o projeto, face ao tamanho da empresa, não descarta o exame dos versos românticos e a recolha de textos de sua própria lavra, voltados à produção modernista ${ }^{22}$. Esboços da história crítica da poesia brasileira foram conservados por Mário em seu arquivo, transpostos para o dossiê do manuscrito Castro Alves, provavelmente para redigir o ensaio sobre o autor d'Os escravos, em 1939.

Nova carta a Manuel Bandeira, em 1931, 20 de março, confirma que a proposta de estudo do romantismo mantém-se de pé, focada agora na psicologia do sentimento amoroso. O projeto reafirma-se na leitura do teatro de Gonçalves Dias, relatada ao amigo:

"Manu, recebi sua carta faz uns dez minutos e já respondo, foi só o tempo de acabar a leitura de Boabdil de Gonçalves Dias onde estava

\footnotetext{
${ }^{20}$ MORAES, Marcos Antonio (org. introd. e notas). Correspondência Mário de Andrade \& Manuel

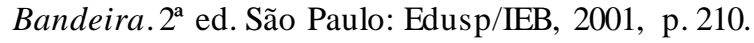

${ }^{21}$ DIAZ, José-Luis. "Qual genética para as correspondências?" (trad. Cláudio Hiro e Maria Sílvia Ianni Barsalini). Manuscrítica: revista de Crítica Genética, 15. São Paulo: Associação de Pesquisadores de Crítica Genética /Humanitas, 2007, p. 122-3.

${ }^{22}$ Marina Damasceno Sá dedica-se à edição do texto fiel e anotado da Poetagem bonita em pesquis a para o doutoramento, no Programa de Pós-Graduação em Literatura Brasileira da FFLCH-USP, sob orientação do Prof. Dr. Marcos Antonio de Moraes.
} 
à procura dos sequestros causados nos românticos pelo tema do 'Amor e medo' que foi por todos glosado à farta. É um caso interessantíssimo de que espero,em memória de Álvares de Azevedo, escrevereiumas coisinhas interessantes. É mais frutífero e importante que o caso de Mãe e Irmã que estive revendo e deu pouca matéria. Mas enfim também vou escrever sobre ele e creio que dedicarei meu ano aos românticos." 23

A carta a Bandeira alude, pois, à segunda modificação de Mário no envelope "Amor e medo", escrito a grafite, sobre o vermelho da etapa anterior. O que se percebe pelas cartas - e se poderá ver em detalhe na classificação da marginália, segunda parte deste estudo - é que o "artigalhão" para a Revista Nova não foi inteiramente preparado às pressas, como sugere a Augusto Meyer em fins de agosto. Seis anos antes, ele já pensava o lirismo romântico, questão pançuda.

O último registro no envelope, a rubrica "Aristocracia", liga-se aos artigos publicados em 23 de agosto, 30 de agosto e 6 de setembro, 1931, no Diário Nacional. A leitura do manuscrito revela que o propósito original era tratar o caráter aristocrático de Álvares de Azevedo no editorial da Revista Nova. Mas as "notas particularíssimas", conforme acrescenta ao publicar o texto na coluna de domingo do Diário Nacional, referida a Meyer, convertem-se nas crônicas de teor crítico para esse veículo alinhado ao Partido Democrático ${ }^{24}$. Antes, em março, o valor de atualidade da crítica acusa o mal-estar gerado pela leitura do autor de Macário, em 1931: “com espaço de sessenta anos quase, chegou a ser regional (e muito mais e essencialmente regional), por aquela maneira sutil comque reflete o aristocracismo paulista de que o Perrepê foi a desastrada conclusão". No mesmo jornal, em abril, usa versos satíricos de Gonçalves Dias para atacar a política ${ }^{25}$.

A criação do crítico, tomando a poesia do romantismo como objeto é, portanto, dilatada. Alonga-se pelos anos e transforma as notas de margem e esboços conforme os sucessivos projetos. Os volumes de poesia na biblioteca de Mário de Andrade flagram o processo em estado nascente. O scriptor recorre à marginália sempre que os

\footnotetext{
${ }^{23}$ MORAES, op. cit., ed. cit., p. 490, grifo meu.

${ }^{24}$ Sérgio Miceli retrata Mário como líder intelectual do Partido Democrático e alude à coluna no Diário Nacional: "O absenteísmo na política, relatado por Francisco de Assis Barbosa, deve ser matizado, levando-se em conta a colaboração que tanto ele como alguns de seus companheiros prestaramao Partido Democrático, em cujo órgão, o Diário Nacional, inicia uma nova seção (“Táxi”), na qual escreve quase diariamente sobre os mais diversos temas." Intelectuais e classes dirigentes no Brasil (1920-1945). São Paulo: Difel, 1979.

${ }^{25}$ ANDRADE, Mário de. Táxi e Crônicas no Diário Nacional. Estabelecimento de texto, introdução e notas de Telê Porto Ancona Lopez. São Paulo: Livraria Duas Cidades/Secretaria da Cultura, Ciência e Tecnologia, 1976, pp.355-357 e 367-369, respectivamente.
} 
românticos voltam à pauta de leitura, o que agrega à escrita nos livros um sentido de permanência, fazendo-as menos instáveis ou aptas ao descarte do que as notas de trabalho no arquivo, por exemplo. O estudo dos cinco grandes românticos nasce na marginália, nutre notas de trabalho/esboços/planos no arquivo - nos dossiês Amor $e$ medo, Castro Alves e Artigos por escrever - e chega às versões publicadas - "Álvares de Azevedo I e II", "Mosqueiro no 2", “Álvares de Azevedo I, II e III", “Momento", "Amor e medo" e "Castro Alves" - sem que os textos éditos esgotem a reflexão do crítico deixada nos volumes da poesia dos românticos brasileiros. Exceção feita ao volume terceiro das Obras de Álvares de Azevedo, dedicado a textos em prosa ricamente anotados e inseparáveis das cogitações críticas no restante do corpus da pesquisa. Estas são as obras nas estantes de Mário:

ABREU, Casimiro J. M. de. As primaveras: com poesias inéditas do autor, o juízo crítico de diferentes escritores e um prólogo por F. D. Ramalho Ortigão. Porto: Livraria Chardron, 1909. $3^{\mathrm{a}} \mathrm{ed}$.// Bibl MA: [A/II/d/61]

ALVES, Castro. Obras completas. Edição crítica comemorativa do cincoentenário do poeta... com um retrato, introducção bibliographica e annotações de Afranio Peixoto. Rio de Janeiro: Francisco Alves, 1921. 2 v. [Poesia] // Bibl. MA: [A/II/f/34] e $[\mathrm{A} / \mathrm{II} / \mathrm{f} / 35]$

AZEVEDO, Álvares de. Obras de Manoel Antonio Álvares de Azevedo precedidas de um discurso biographico e acompanhadas de notas pelo Sr Dr Jacy Monteiro. $3^{\text {a }}$ ed. Acrescentada com as obras ineditas, e um appendice contendo discursos, poesias e artigos feitos a occasião da morte do autor. Rio de Janeiro: Livraria de B. L. Garnier, 1862. tomo segundo. [Prosa] // Bibl. MA: [G/II/c/128]

AZEVEDO, Álvares de. Obras de Manoel Antonio Álvares de Azevedo precedidas do juizo critico de escriptores nacionaes e estrangeiros e de uma noticia sobre o auctor e suas obras por J. Norberto de S. S. 7. ed. Rio de Janeiro: Garnier, 1900. 3 v. // Bibl. MA: [A/II/d/42]; [A/II/d/43] e [A/II/d/44]

AZEVEDO, Álvares de. O Conde Lopo. / Poema. Rio de Janeiro: Typ. G. Leuzinger \& Filhos, 1886. // Bibl. MA: [A/II/d/42] 
DIAS, A. Gonçalves. Poesias. Nova edição organizada e revista por J. Norberto de Souza Silva e precedida de uma notícia sobre o autor e suas obras pelo Cônego Doutor Fernandes Pinheiro. Paris/Rio de Janeiro: Garnier, 1919. 2 vol. // Bibl. MA: [A/II/d/62] e $[\mathrm{A} / \mathrm{II} / \mathrm{d} / 63]$

DIAS, A. Gonçalves. Obras posthumas de A. Gonçalves Dias precedidas de uma noticia da sua vida e obras pelo Dr. Antonio Henriques Leal. Poesias posthumas. Paris: H. Garnier, Livreiro-Editor, s/d. Bibl MA: [A/II/d/65]

VARELLA, L. N. Fagundes. Obras completas de L. N. Fagundes Varella: edição organisada e revista, e precedida de uma noticia biographica por Visconti Coaracy e de um estudo critico pelo Dr. Franklin Tavora. Rio de Janeiro/Paris: Garnier, 1919. 3 v. // Bibl. MA: [A/II/d/58]; [A/II/d/59] e [A/II/d/60]

O estudo de Mário de Andrade - vincado nos livros acima - abre-se à vista panorâmica na correspondência, no relato, como através de práticas e documentos que iluminam o contexto histórico e biográfico, do mesmo modo que o método por ele desenvolvido. As cartas oferecem o sabor cotidiano de uma época, vista por Mário como mais serena e de construção ${ }^{26}$, e ajudam a historiar o projeto sobre o romantis mo. Interessam também pela ideia que nos dão das ferramentas postas sobre a escrivaninha do escritor: cartas, manuscritos, livros anotados, a máquina de escrever de mistura com lápis coloridos - vermelho e azul - e documentos que traduzem o método de trabalho e diálogo crítico do autor de Macunaíma. A divisa em latim e o desenho do móvel com fichas catalográficas, no timbre da Bibliotheca Publica, lembram dois conjuntos de

\footnotetext{
${ }^{26} \mathrm{Na}$ Conferência de 1942, marcando os vinte anos da Semana de Arte Moderna, Mário de Andrade trata do movimento modernista nas artes e nas letras, relacionando-o às transformações de ordem política, econômica e social: "O movimento de Inteligência que representamos, na sua fase verdadeiramente 'modernista', não foi o fator das mudanças politico-sociais posteriores a ele no Brasil. Foi essencialmente um preparador; o criador de um estado-de-espírito revolucionário e de um sentimento de arrebatação. E si numerosos dos intelectuais do movimento se dissolveram na política, si vários de nós participamos das reuniões iniciais do Partido Democrático, carece não esquecer que tanto este como 1930 eram ainda destruição. Os movimentos espirituais precedem sempre as mudanças de ordem social. O movimento social de destruição é que principiou com o P. D. e 1930. E no entanto, é justo por esta data de 1930, que principia para a Inteligência brasileira uma fase mais calma, mais modesta e quotidiana, mais proletária, por assim dizer, de construção. À espera que um dia as outras formas sociais a imitem." (ANDRADE, Mário de. "O Movimento Modernista", In: Aspectos da literatura brasileira. São Paulo: Livraria Martins Editora, 1974, p. 242)
} 
materiais e práticas fortes, no trabalho do polígrafo - a extensa biblioteca de 17 mil livros, a maior parte com marginália, e a elaboração minuciosa do fichário analítico, projeto de enciclopédia pessoal. Nas cartas, Mário aborda o exercício da crítica, dialoga com outros poetas, conta a fundação da Revista Nova, desdenha os próprios artigos dele no Diário Nacional, e relata o estágio em que se acham os projetos: a Gramatiquinha da fala brasileira, a Bibliografia para Na Pancada do Ganzá, o Dicionário musical e o ensaio sobre o medo de amor entre os românticos.

Nesse labirinto da criação - entre livros, manuscritos, artigos de jornal e ensaios - alguns pontos de apoio do percurso genético valem ser retomados. Em 1925, na carta dirigida a Manuel Bandeira, o escritor menciona um projeto de escopo largo sobre a história da poesia brasileira. O lirismo romântico, junto aos estudo sobre autores modernistas, afirma-se como objeto preferencial, uma vez abandonada a proposta ambiciosa da história crítica. Projeto em latência, sem execução imediata, a análise dos românticos vai sendo ruminada no correr dos anos, e nutre no entretempo a criação da rapsódia e do idîlio modernista, Macunaíma e o idîlio Amar, verbo intransitivo, assim como outros projetos, atestando a fertilidade da intenção. Seis anos mais tarde, em 1931, “Amor e medo" aparece na Revista Nova. Então os aspectos psicológicos do sentimento amoroso é que the interessam, escrevendo às pressas, sobre os joelhos ${ }^{27}$. No mesmo ano de 1931, os artigos no Diário Nacional alimentam-se das notas de margem apostas nos volumes de poesia para comentar o centenário de Álvares de Azevedo e a atualidade satírica de versos de Gonçalves Dias. O editorial para a Revista Nova, liberado dessa função, converte-se nos artigos de agosto e setembro, dedicados ao espírito aristocrático do autor de Macário e à superioridade do prosador ante o poeta, no entender de Mário. Passam-se os anos longos e conturbados de 30 - guerra civil, cangaço, constituições criadas e rasgadas, repressão e ditadura - e Mário de Andrade, em exílio no Rio, move-se por outra efeméride, agora o centenário do autor de Espumas flutuantes, a escrever um ensaio para a Revista do Brasil. Em 1939, a sensação de malestar, já acusada em Álvares de Azevedo, é novamente ativada para comentar a obra de Castro Alves, poeta dotado de traços fortes da mentalidade nacional, como dirá Mário. As notas prévias reunidas no dossiê do manuscrito Castro Alves completam o círculo e voltam ao ponto de origem. A abordagem ampla, no conteúdo das notas, mostra os

\footnotetext{
${ }^{27}$ Pauliceia desvairada e Macunaíma são dois exemplos de como Mário de Andrade coincide com o imaginário da criação romântica - fatalizado, em estado de poesia - para relatar a elaboração de suas obras.
} 
planos e fragmentos do projeto inicial, de estudar a poesia brasileira em conjunto e o lirismo romântico em particular. São os esboços do projeto primitivo, manuscrito inacabado, mantido à espera para novos projetos. As páginas a seguir buscam apresentar os ramais e caminhos de Mário de Andrade à margem do romantis mo brasileiro.

\section{Nas margens, a encruzilhada}

Logo ao abrir os livros de poesia do romantismo na biblioteca de Mário de Andrade, veem-se os rastros de dois projetos descritos na correspondência com o escritor gaúcho Augusto Meyer. A Bibliografia para Na pancada do ganzá e o Dicionário musical brasileiro marcam as folhas de guarda de todos os poetas pertencentes a essa estética. ${ }^{28}$ No volume primeiro das Obras completas de Castro Alves, por exemplo, o n 200 , a grafite, corresponde à localização do livro no conjunto de títulos que apoiam o projeto sobre o folclore brasileiro -837 no total. $\mathrm{Na}$ lista bibliográfica, a ordem dos títulos da poesia romântica vem assim disposta: Obras, Álvares de Azevedo - no 191; O Conde Lopo - no 192; Obras posthumas e Poesias, Gonçalves Dias - nº 198 e 199; Obras, Castro Alves - n 200; As primaveras, Casimiro de Abreu - no 223; por fim, Obras completas, Fagundes Varela - n 224. É tentador pensar que a lista corresponde a um roteiro de inscrição das notas de margem, mas o exame da marginália mostra que a composição não resulta da leitura linear.

A etiqueta retangular que situa os livros na casa de Mário de Andrade, na rua Lopes Chaves, tem caráter utilitário: indica, em maiúscula, o cômodo; em algaris mo romano, a estante; em minúscula, a prateleira e, por último, em algarismo arábico, a posição do volume na estante. As salas eram assim distribuídas: o hall de entrada (sala A), com edições das décadas de 1910 e 1920, e obras representando as vanguardas; a saleta de música (B), dotada de partituras e revistas musicais; o escritório (C) e o hall superior (E), com obras de etnografia e etnologia, também dispostas no escritório (F). Um estúdio, que conjugava o escritório (F) e o quarto de dormir (D), guardava edições raras e de luxo. No porão (G), o autor de Pauliceia desvairada conservava a sua coleção

\footnotetext{
${ }^{28} \mathrm{O}$ projeto do dicionário é testemunhado na biblioteca, nos manus critos no arquivo, e na edição póstuma coordenada por Oneyda Alvarenga e Flávia Camargo Toni: ANDRADE, Mário de. Dicionário musical brasileiro. Brasília: Ministério da Cultura/São Paulo: IEB-USP - Edusp/ Belo Horizonte: Editora Itatiaia Ltda, 1989.
} 
do Diário Nacional, para o qual muito escreveu, bem como coleções de revistas brasileiras, inglesas e francesas. ${ }^{29}$

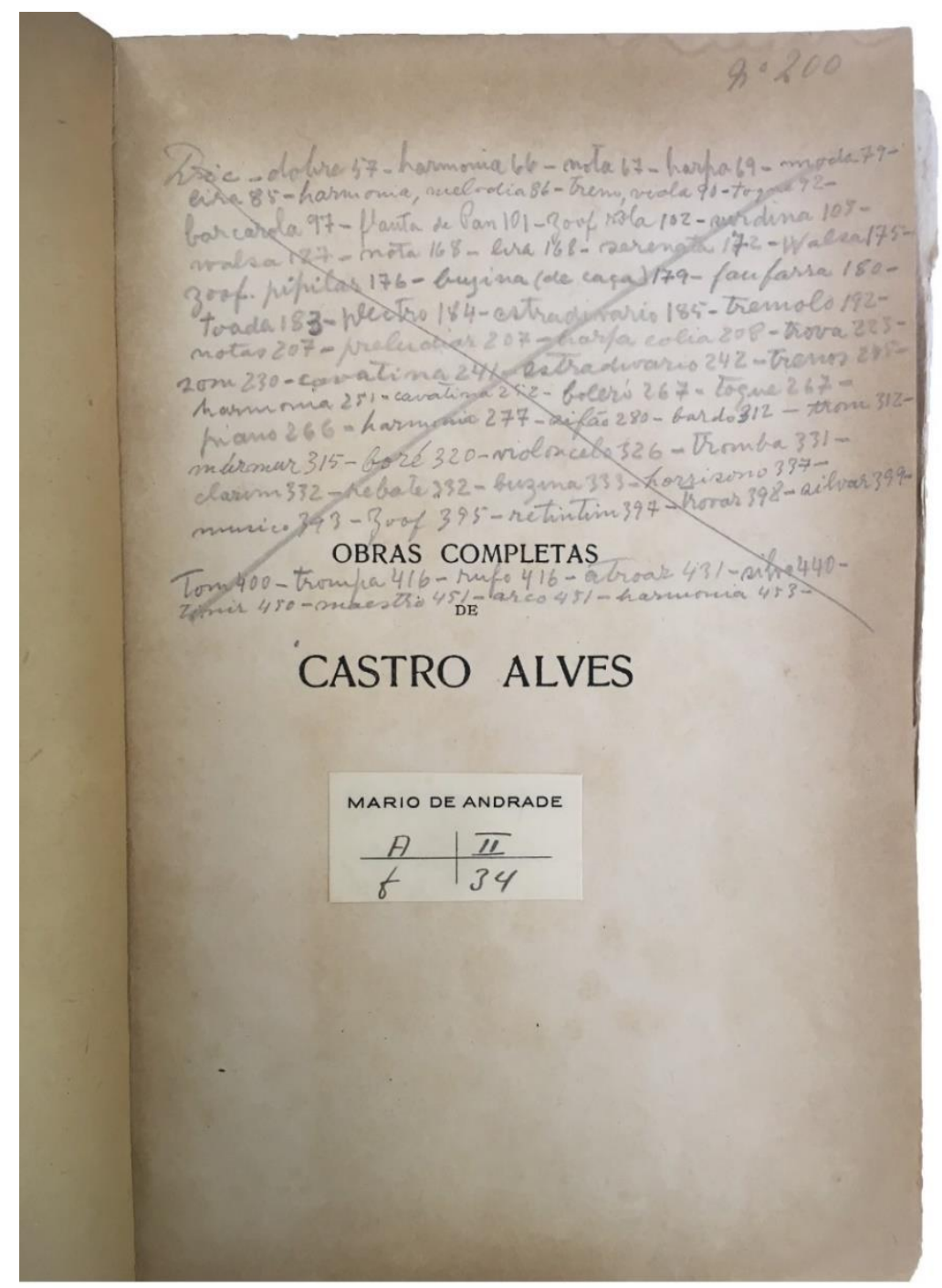

Figura 2

Na folha de guarda, a lista de termos e páginas, sob a abreviatura “dic”, serve ao abonamento de verbetes para o Dicionário musical brasileiro, e a cruzeta que os atravessa sinaliza o aproveitamento. $O$ índice franqueia acesso aos termos que $o$ pesquisador deseja conduzir ao dicionário, facilitando a referência. Ele os recolhe no correr da leitura, como se vê na p. 86, no poema "Amemos":

\footnotetext{
${ }^{29}$ Lígia Kimori relata a distribuição dos livros pela casa da rua Lopes Chaves em Os mestres do passado: Mário de Andrade lê os parnasianos brasileiros. Dissertação de mestrado, sob orientação da Profa. Dra. Telê Porto Ancona Lopez, apresentada ao Programa de Pós-Graduação em Literatura Brasileira, FFLCHUSP, 2014, p. 48.
} 
"Meu Deus!... Só eu compr'endo as harmonias, "dic" De tua alma sublime... As melodias Que tens no coração."30

Sublinha os termos musicais, registra o escólio "dic" e põe a cruzeta. À p. 208, o v. 62 de "Os anjos da meia-noite" presta-se ao mesmo propósito:

"Harpa eolia a esperar que o vento a fira

- Um pedaço de marmore divino...

- É o retrato de Barbora - a Hetaira. -" 31

O registro na folha de guarda convoca o instrumento emblemático do romantismo, sem o escólio "dic", ao preparo do Dicionário e ajuda a caracterizar Castro Alves como "auditivo" - conforme o leitor de Allendy entende ser a forma de sensibilidade predominante no poeta. Em Álvares de Azevedo, igualmente, dezenas de palavras são chamadas a enriquecer a composição do Dicionário, como murmuriar, sonoroso, trova, jogral, solfa, contradança, ouvertura... Em meio à lista de verbetes, ainda no exemplar do livro de Castro Alves, outra rubrica relaciona-se aos projetos que a marginália testemunha: "zoof pipilar 176". A referência é tirada do v. 26, de "Horas de saudade":

\section{"dic" Relembra o pipilar do passarinho." 32}

À margem, o escólio mostra que o estudo da Zoofonia prende-se também à coleta de termos para o Dicionário musical. O escólio específico, "zoof”, é visto com frequência na marginália, em todas as áreas da biblioteca. Ele absorve a denominação da pesquisa principiada, no século XIX, pelo francês Hercule Florence (1804-1879) e colige matéria destinada ao projeto do escritor modernista de reunir palavras e expressões representando as vozes dos animais. O manuscrito Zoofonia, no arquivo, é o reservatório desses termos, composto de documentos musicais, recortes de jornal e notas de trabalho, transcritas de publicações ou captadas em pesquisa de campo por ele e seus colaboradores. Em entrevista de 1943, o escritor filia o projeto a Green Mansions: a Romance of the Tropical Forests, de William Henry Hudson ${ }^{33}$. "Zoof" municiaria anos depois o diálogo O banquete, obra na área de Estética interrompida

\footnotetext{
${ }^{30}$ Nota MA, In: ALVES, Castro. op. cit., ed. cit., p. 86.

${ }^{31}$ Nota MA, In: IDEM, ibidem, p. 208.

32 Nota MA, In: IDEM, ibidem, p. 176.

33 ANDRADE, Mário de. Entrevistas e depoimentos. Edição organizada por Telê Porto Ancona Lopez. São Paulo: T.A. Queiroz, 1983, p. 93.
} 
pela morte do escritor, em 1945. O capítulo 8 previa: “O Passeio em Pássaros. Zoofonia. O canto-enfeite no cio. A mulher vestida de homem e a Lei do Peso. Música da natureza e música descritiva." 34

“A pacuera de Oibê”, capítulo 15 de Macunaíma, faz referência ao projeto. Resgatada a muiraquitã, nas peripécias de retorno à região amazônica, Macunaíma tem de fugir do minhocão temível após devorar a pacuera que assava nas brasas. $\mathrm{Na}$ disparada, encontra Florence. Este, em bom francês, the garante ter inventado a fotografia... em 1927. O heroi gargalha: “- Chi! Isso já inventaram que anos, siô!”. "Então Hércules Florence caiu estuporado sobre a folha de taioba e principiou anotando com música uma memória científica sobre o canto dos passarinhos. Estava maluco. Macunaíma chispou."35

Conforme o poeta de Clã do jabuti explica a Augusto Meyer, o termo "brasileiro", no título do dicionário, enfatiza o interesse na expressão musical representativa do país. Os versos indianistas de Gonçalves Dias, por isso, the oferecem material de grande interesse à pesquisa. A folha de guarda do vol. 2, das Poesias, reúne, entre outros, cascavéis, borés, maracás

"Ouve o anúncio do horrendo fantasma,

Ouve os sons do fiel Maracá"

membis e clarins

$$
\begin{aligned}
& \text { "O atroador } \underline{\text { memby }}^{(1)} \text { soprou com força. "dic / veja p. seg." } \\
& \text { O tronco, o arbusto, a moita, a rocha, a pedra, } \\
& \text { Convertem-se em guerreiros; mais depressa, "dic" } \\
& \text { Quando soa o clarim, núncio de guerra" }
\end{aligned}
$$

Nesse passo do "Canto primeiro" de Os Timbiras, o expoente remete ao rodapé, onde o leitor ponteia: "Me parece que G. Dias se engana. O membi era uma flauta e portanto não atroava." Com um fio, liga o búzio de um verso na página seguinte - "Aos sons do cavo buzio conhecido" - a outra ocorrência do termo "membi", na página seguinte "Os sons guerreiros do memby troante" $"$. O Dicionário musical ilumina o sentido das

\footnotetext{
${ }^{34}$ IDEM. O banquete. Ed. preparada por Jorge Coli e Luiz Dantas. São Paulo: Livraria Duas Cidades, 1977, p. 167.

${ }^{35}$ IDEM. Macunaíma, o herói sem nenhum caráter. Estabelecimento do texto por Telê Ancona Lopez e Tatiana Longo Figueiredo. Rio de Janeiro: Nova Fronteira, 2014, p. 134.

${ }^{36}$ Nota MA, In: DIAS, Gonçalves. Poesias. Ed. cit., vol. 2, p. 93.

${ }_{37}$ Nota MA, In: IDEM, ibidem, vol. 2, p. 161.

${ }^{38}$ Notas MA, In: IDEM, ibidem, vol. 2, p. 162 e 163.
} 
notas e retraça o percurso de leitura do pesquisador, o qual, enquanto colhe verbetes, contesta o poeta que os oferta:

"MEMBI (s.m.) - Instrumento de sopro; empregado de modo confuso por diversos autores, podendo significar uma trombeta ou buzina cerimonial ou simplesmente qualquer instrumento soprado.

1. Gonçalves Dias nos "Timbiras" (Poesias, v. 2, 1919, p. 161) fala que Itajubá "(...) o atroador membi soprou com força”. Noutro passo (III ${ }^{\circ}$ Canto) vem ainda: "Nunca o membi guerreiro (...) troou". Isso indica que o Membi é instrumento guerreiro. Sempre soube que Membi era uma flauta. O qualificativo "atroador" parece estar mal colocado. Montoya um pouco atrapalhadamente diz que "Flauta, bocina, etc." são "mimbí tarará" em guarani. Mas especifica na parte guarani-espanhol do Vocabulário que mimbí é "flauta, chirimia y cosa semejante", ao passo que trombeta, clarim, é "mimbí tarará" ou "mimbí tererê". Isso dá um bocado mais de luz e mostra que Gonçalves Dias empregou membi, abreviadamente, por membitarará. $\mathrm{O}$ que não podia fazer pois membi tem significado próprio. Aliás duas páginas adiante repete "membi troante" o que parece que entendia por membi apenas a buzina ameríndia. No Dicionário da língua tupi, designa Gonçalves Dias o membi (sem mais nada), como "buzina, frauta, trombeta". O Clarim (?) dá como sendo entre os índios "Membi apára"."39

A voz dos animais é também manancial para pesquisa na poesia indianista. Em "O canto do guerreiro", o autor de Lira paulistana sublinha o carpido triste da ave a cantar e anota, à margem, o escólio correspondente. Na oitava estrofe de "O canto do Piaga", os versos

Não ouviste a coruja, de dia,

Sons estrídulos torva soltar? "zoof"

recebem a mesma indicação, que se acha também em Os Timbiras - no Canto I, as aves "docemente attitão"; no Canto II, ouvem-se os "tristonhos pios" que "a acauan desata" ${ }^{40}$. Se as notas exibem a tarefa de elaborar o Dicionário, rendem ao mesmo tempo material e imagens convincentes da realidade brasileira. Como nos inventários de Macunaíma, os registros no manuscrito Zoofonia impressionam pelo efeito colorido, vivo, nem sempre associado apenas à nossa paisagem, mas à presença de psitacídeos tucanos picapaus tapeis tangarás siriemas uritutus sericoias galos andorinhas macacos guaribas saguis capoeiras corós onças grachains raposas jacarés moriches melros corvos cucos pombas pavões. Os verbos, recolhidos de diversas fontes, indicam fartura semelhante.

\footnotetext{
39 ANDRADE, Mário de. Dicionário musical brasileiro. Ed. cit, p. 329.

${ }^{40}$ Notas MA, In: DIAS, Gonçalves. Poesias. Ed. cit., vol. 2, p. 91, 93, 166 e 170.
} 
Se os verbos e substantivos encontrados nos versos românticos alimentam a pesquisa da zoofonia e a coleta de verbetes para o Dicionário musical, o emprego da preposição, a colocação pronominal e a sintaxe são objeto de interesse forte para Mário de Andrade, em busca da estilização literária e da reserva de material para $A$ gramatiquinha da fala brasileira. As duas formas da preposição, "para" e "pra", são intensamente anotadas nas obras de poesia do romantismo. Em "Tabira" -

$$
X \quad \text { "Para o vosso terreiro vos chamo" } 41
$$

- assim como na "Canção do exílio"

"Não permita Deus que eu morra

Sem que eu volte para lá" ${ }^{\prime 2} \quad X$

Ele realça a preposição e acrescenta cruzeta à margem. Faz o mesmo em muitos outros versos, como no poema "O Baile", de Casimiro de Abreu:

$$
\begin{array}{ll} 
& \text { “Tens razão! - Walsa, donzella, } \\
& \text { A mocidade é tão bella } \\
& \text { E a vida dura tão pouco! } \\
X \quad & \text { P'ra que fez Deus as mulheres? } \\
X \quad & \frac{\text { P'ra que ha na vida prazeres? }}{{ }_{43}}
\end{array}
$$

Na folha de guarda d'As primaveras, as duas formas são elencadas, mais o número da página. Em Anchieta ou O Evangelho nas Selvas, o leitor registra no canto III: "Não indico mais o para que é sistemático já em Varela dos ultimos tempos. Indicarei só os prás si os tiver." 44 Adiante, ao anotar o trecho "Margens do Tietê, 24 de julho", no mesmo volume, ele comenta: "Na naturalidade mais familiar do Diario de Lazaro de novo a gente encontra o pra. " 45

Em diferentes pontos de sua reflexão sobre a língua portuguesa falada no Brasil, o uso da forma coloquial, mais corriqueira, é discutido pelo escritor - em especial n' $A$ gramatiquinha da fala brasileira, obra que deixou inacabada. O dossiê do manuscrito, transcrito e classificado por Aline Novais de Almeida, guarda referências sobre o assunto:

\footnotetext{
${ }^{41}$ Nota MA, In: IDEM, ibidem, vol. 2, p. 165.

${ }^{42}$ Nota MA, In: IDEM, ibidem, vol. 2, p. 88.

${ }^{43}$ Nota MA, In: ABREU, Casimiro de. As primaveras, p. 120.

44 Nota MA, In: VARELA, Fagundes. Obras completas, vol. 3, p. 91.

${ }^{45}$ Nota MA, In: IDEM, ibidem, vol. 3, p. 314.
} 
"E dessas tradições a mais pior é o preconceito dos olhos. Os olhos... Mal danado eles fazem prá gente... já viram dum jeito a coisa escrita. Veem de outra, acham feio. E levam a gente a afirmações como essa que tanta gente me faz de que não fala pra sim para. Quando lê, sei que lê para. Porém é incontestável que dic ção pra é geral e até geral não só entre brasileiros como até entre portugas. $" 46$

E em mais dois fólios, o escritor relaciona o emprego da forma corriqueira à marginália: "Se não tivesse os poetas românticos meu 'pra' seria meu. Porém nesse caso o pra não existiria.”. E ainda: "falam 'no pra do Mario' como se isso me pertencesse, e já não estivesse em porcentagem comovente nos romanticos do Brasil". ${ }^{47}$ No ensaio de 1939, publicado na Revista do Brasil, elogia Castro Alves quanto ao uso do "pra" e remete a questão à poesia dele próprio, modernista:

"Escrevia uma linguagem saborosa, de excelente libertação nacional, e deve mesmo, com as Espumas flutuantes, ser considerado o primeiro sistematizador do 'pra', trocando-o oitenta vezes sobre cem ao lerdo e tipográfico 'para'. Só sessenta anos mais tarde outros lhe retomariam a lição..." 48

Ao rasurar os textos de sua própria autoria recortados de periódicos, transformando-os em manuscritos/exemplares de trabalho, autor da Gramatiquinha muitas vezes reconduzia ao original a forma "pra", indevidamente consertada pela composição ou revisão. O diálogo com Sousa da Silveira também registra, anos mais tarde, o pensamento dele sobre o tema. E, na correspondência, ele se defende de críticas ao aproveitamento da forma elidida da preposição. ${ }^{49}$

O estudo linguístico combina-se à análise da versificação quando Mário de Andrade destaca a ocorrência frequente do suarabácti na poesia do romantismo. A

\footnotetext{
${ }^{46}$ ALMEIDA, Aline Novais de. Edição genética d'A gramatiquinha da fala brasileira de Mário de Andrade. Diss ertação apresentada ao Programa de Pós-graduação em Literatura Brasileira, FFLCH-USP, 2013, vol. 2., p. 769.

${ }^{47}$ IDEM, ibidem, vol. 2, p. 777 e 781.

48 ANDRADE, Mário. “Castro Alves”, In: Aspectos da literatura brasileira. São Paulo: Livraria Martins

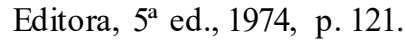

${ }^{49}$ Em 15 de fevereiro, 1935, Mário de Andrade defende seu ponto de vista, argumentando: "No caso do 'pra', de consequências terríveis pra mim, não posso negar a justeza da sua observação quanto a nem sempre se operar a contração. É verdade. Mas em nenhum dos meus livros, nenhum, o Sr. deixará de encontrar o 'para'. Poucas, pouquíssimas vezes, é verdade. Mas conscientemente, sem erro de revisão. Quis provar com is so que não faço questão cega do meu pra e suas consequências. Não desistirei dele quando a ele me levar a rapidez do discurso, que é quasi sempre o caso, mas estou bastante tentado a desistir do 'pro'. Alguns me objetam que teria de levar o 'pra' às suas últimas consequências lógicas, e escrever também 'pruns' (para uns) e 'praqueles' (para aqueles) etc. Como si a língua fosse uma criação da lógica intelectual, e não houvesse outras lógicas predeterminando o ser pequenamente humano..." FERNANDES, Lygia (org.). Cartas a Alceu, Meyer e outros. Ed. cit., 153.
} 
marginália mistura aí o interesse no metro e ritmo dos versos derivados da pronúncia brasileira. Em Fagundes Varela, sublinha e assinala "stigma", "abjectos", "absintho", "ignobil”, “ignoro”, “observou”, “ignotos”, “indignado”, “absortos”, “objecto”, "magnânimo", "reptil". À margem do poema "Aurora", representa a palavra com a vogal intercalada, esboçando a escrita fonética:

Como aos dias primeiros do universo,

O globo se erguerá banhado em luzes, Reflexos de Deus;

"Reflequiços!",50

Também nos decassílabos de Anchieta ou O Evangelho nas Selvas - chamado Evangelho das Selvas na marginália - a contagem das silabas revela a fala brasileira, como no verso que descreve o rosto da Virgem:

"Maria viajava. - Melindroso

Era então seu estado, já na quadra

Em que o tempo decreta a angustiosa

Dôr da maternidade; mas seu rosto,

Pallido como a nivea magnolia

Que desabrocha ao luar;",51

Ainda no registro da pronúncia, há o caso das "c'roas" sinalizadas sobretudo em Gonçalves Dias, em cuja obra Mário relaciona onze ocorrências no volume primeiro e sete no segundo, nas Poesias. A nota de margem no poema "Anhelo", no qual o lápis sublinha o termo em quatro versos, é representativa: "Horrendo por causa do português Croa. 1 vez passa mas 4!" Em Álvares de Azevedo, a sublinha no "Prólogo" de "Bohemios: Ato de uma comédia não escrita" é nuançada pelo comentário no rodapé, que o expoente indica:

\footnotetext{
"O tempo em que se passa agora a cena

É o século dos Bórgias. O Ariosto

Depôs na fronte a Rafael gelado

Sua c'rôa ${ }^{(1)}$ divina e o segue ao tumulo."

“(1) É muito provavel que a dicção da palavra coroa soasse quasi exatamente como crôa por que os no tempo de 1840 pra 1870 mais ou menos. Em Castro Alves tambem vem croa. Procurar nos outros romanticos. É o mesmo caso do pra. Não é licença propriamente, é uma elisão trazida pela naturalidade da dicção oral. ${ }^{, 52}$
}

\footnotetext{
${ }^{50}$ Nota MA, In: VARELA, Fagundes.op. cit., ed. cit., p. 135.

${ }^{51}$ Nota MA, In: IDEM, ibidem, vol. 3, p. 28.

52 Nota MA, In: AZEVEDO, Álvares de. Obras. Ed. cit., vol. 2, p. 216.
} 
No comentário acima, o scriptor contradiz outra nota de trabalho, esta no dossiê do manuscrito Amor e medo: planeja um capítulo sobre as licenças poéticas do romantismo, incluindo o caso do "pra" e das "c'rôas".

Em Álvares de Azevedo, o crítico e leitor também contabiliza inúmeras expressões brasileiras ou invenções do poeta. Encontra casos de colocação pronominal - "Eu soltarei-te" 53 - e regência - "O que sofres?"54 ou "no que scismas?"55 - que não seguem a gramática normativa. A dupla negativa, característica do brasileiro, é recolhida à nota de trabalho: "Eu não rio-me, não!"; "Não sabem não"56. As invenções tiradas da criatividade poética ou da linguagem corrente - "fabuleiro", "tremelear", “desviver (no sentido de gastar a vida)", "desfear", "humidez”, "murchez”, “desfreio", "desroupar", "vaporento", "alembrar", "ourar", "falsia"57 - convergem para notas de trabalho no arquivo. Oemprego de palavras próprias à realidade natural do Brasil enseja o comentário: "lagoa em vez de lago, abrasileirando o estilo nobre em que o autor está. Jamais um parnasiano falaria dum cisne cantando em lagoa! Cisne canta nobremente em lago..."

Em "Horas de Martyrio", de Castro Alves, outras duas construções são ilustrativas da atenção que o leitor confere à colocação pronominal na poesia romântica:

$X \quad$ Conto os risos, que déste-me um dia,

Que rolaram no meu coração.

$X \quad$ Me recordo o logar onde estavas...

$\mathrm{O}$ rugir de teu lindo vestido,

Como as asas de um anjo cahido

Quando roçam nas flores do val... ${ }^{58}$

\footnotetext{
${ }^{53}$ Nota MA, In: IDEM, ibidem., vol. 2, p. 94.

${ }^{54}$ Nota MA, In: IDEM, ibidem, vol. 2, p. 282.

55 AZEVEDO, Álvares de. O Conde Lopo. Ed. cit., p. 90.

${ }^{56}$ Nota MA, In: AZEVEDO, Álvares de. Obras, vol. 1, p. 311.

${ }_{57}$ Arquivo IEB-USP. Fundo Mário de Andrade. Código do documento: MA-MMA-05-30.

${ }^{58}$ Nota MA, In: ALVES, Castro. op. cit., ed. cit., v. 1, p. 80.
} 

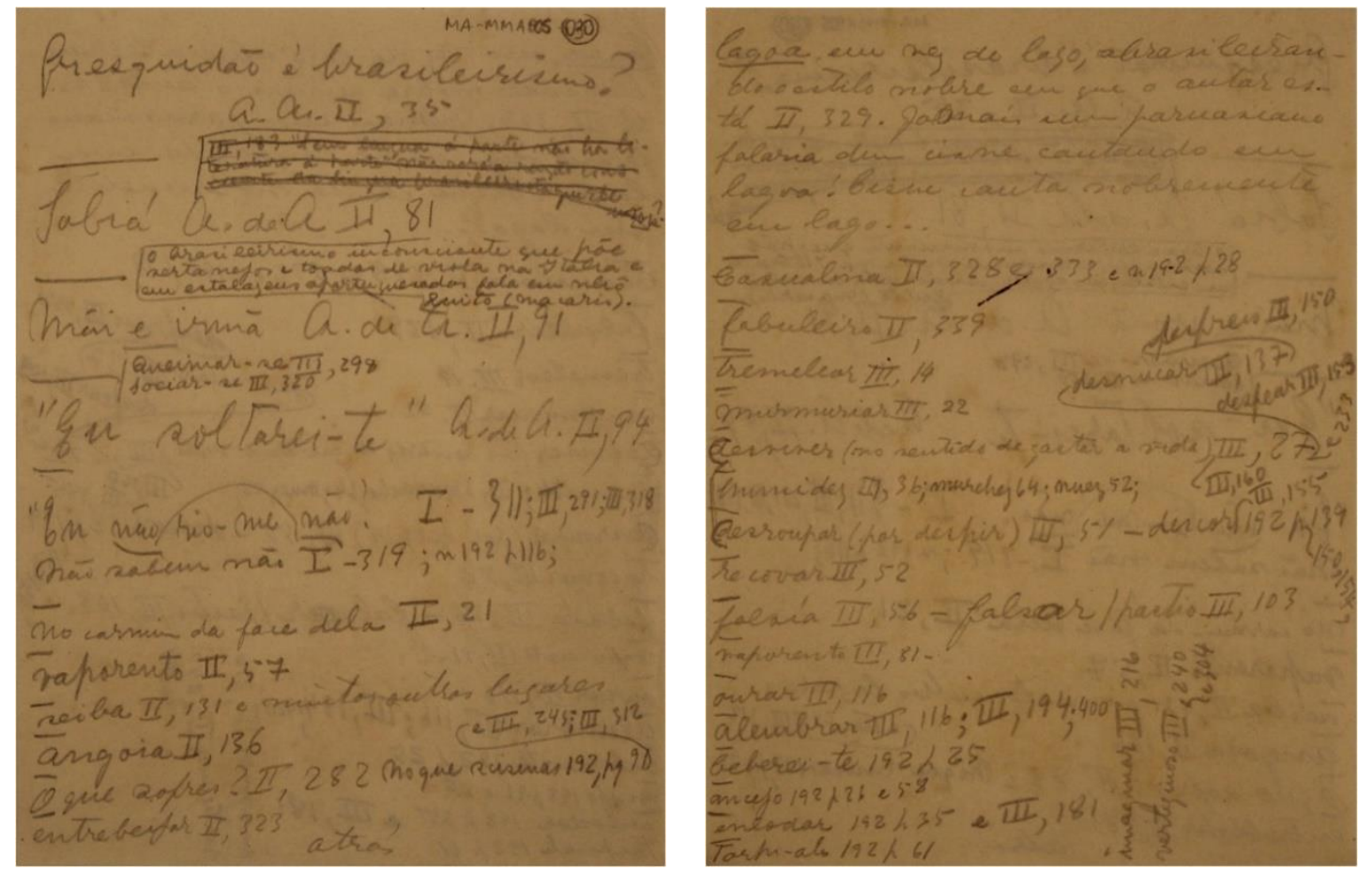

Figura 3

O pronome em início de frase e a ênclise que desconsidera o "que", atrator, são classificados como brasileirismo no manuscrito d'A gramatiquinha da fala brasileira ${ }^{59}$. O exemplo análogo, “Que havendo-lhe”, é retirado do livro Diálogos das grandezas do Brasil, de Ambrósio Fernandes Brandão ${ }^{60}$. O modernista também elenca como brasileirismo sintático o "emprego de 'enquanto que' no povo analfabeto", exemplo que destaca no poema "Pelas sombras", de Castro Alves:

Emquanto que eu tropeço... um grito ao longe róla... ${ }^{61}$

Em "Amemos", sublinha e assinala com a cruzeta a colocação pronominal:

$X \quad$ "Te embalarei com uma canção sentida"

e o caso semelhante em "Menina e moça", nos v. 23 e 24:

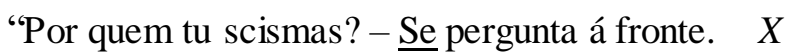

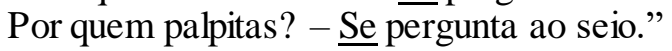

\footnotetext{
${ }^{59}$ Arquivo IEB-USP. Fundo Mário de Andrade. Código dos documentos:MA MMA-51-60 e 66.

${ }^{60}$ Rio de Janeiro: Publicações da Academia Brazileira - II Historia/Officina Industria Graphica, 1930.

${ }^{61}$ Nota MA, In: ALVES, Castro. op. cit., ed. cit., v. 1, p. 186.
} 
A coleta de termos e construções sintáticas próprias da fala popular coaduna-se com outra nota de margem, em que o lápis registra apenas o traço vertical - triplo - para realçar a proposta de Casimiro de Abreu na "Introdução" d'As primaveras:

$$
\| \begin{aligned}
& \text { "O filho dos tropicos deve escrever n'uma linguagem - propriamente } \\
& \text { sua - languida como elle, quente como o sol que o abraza, grande e } \\
& \text { mysteriosa como as suas mattas seculares"62 }
\end{aligned}
$$

Na seara da criação literária, o epílogo de Macunaíma parece se assemelhar ao trecho assinalado acima. Na rapsódia, o narrador qualifica a língua do romance, transmitida pelo papagaio do herói, como uma "fala mansa, muito nova, muito! que era canto e que era caxiri com mel-de-pau, que era boa e possuía a traição das frutas desconhecidas do mato". 63

Em Álvares de Azevedo, outra passagem sobre a língua como meio de expressão da cor local ou critério de independência literária é ressaltada. Na reflexão teórica do autor de Literatura e Civilização em Portugal - "único romântico que teve teorias no Brasil", segundo Mário de Andrade ${ }^{64}$-, o escritor modernista encontra apoio para pensar a autonomia da literatura brasileira em relação à antiga metrópole. Azevedo afirma: "Sem língua à parte não há literatura à parte" ${ }^{95}$. O escritor sublinha o trecho e, em nota de trabalho rasurada, no dossiê do manuscrito Amor e medo, interroga-se: "Não seria razão consciente da lingua brasileirista que êle emprega?"66

Quando se depara com o trecho sobre a herança lusa de nossos grandes poetas, ele considera as ideias de Álvares de Azevedo - "Não há nada nesses homens que resumbre brazileirismo" ou "Os usos eram os mesmos, os homens de aquém-mar sentião como os colonisadores" - uma "digressão importantíssima e quase sempre muito bem pensada". Em vez de tomar o arrazoado como óbice para a consolidação da literatura nacional, define-o como "exatíssimo", digressão que "incita ao brasileiris mo os poetas brasileiros" ${ }^{\text {67 }}$. São notas de implicação profunda para o pensamento de Mário de Andrade. A gramatiquinha indicia parte da importância dada por ele aos românticos como matriz da fala brasileira e de suas cogitações de ordem linguística:

\footnotetext{
${ }^{62}$ Nota MA, In: ABREU, Casimiro de. op. cit., ed. cit., p. 4.

63 ANDRADE, Mário de. Macunaíma, o herói sem nenhum caráter. Ed. cit., p. 159.

${ }^{64}$ Nota MA, In: AZEVEDO, Álvares. Obras. Ed. cit., vol. 3, p. 243.

${ }^{65}$ Nota MA, In: IDEM, ibidem, vol. 3, p. 183.

${ }^{66}$ Arquivo IEB-USP. Fundo Mário de Andrade. Código do documento: MA-MMA-05-30.

${ }^{67}$ Nota MA, In: AZEVEDO, Álvares. Obras. Ed. cit., vol. 3, p. .185-6.
} 
"Brasil romântico, prurido de liberdade, primeira liberdade, a política, a mais consciente de todas as liberdades, e por isso mesmo que consciente um pouco forçada. Nesta fase pelo milagre da libertação nós falávamos o brasileiro, e a língua falada pelos nossos poetas, com ligeira exceção de G. Dias (e assim mesmo!) é a língua falada pelo povo. Fase caótica primitiva em que o Brasil é livre, [...] dá as tendências essenciais da futura fala brasileira." 68

A busca da língua brasileira, pelos modernistas, é comparada por Mário àquela atribuída por ele aos poetas do romantismo: "E [o Modernismo] promoveu uma reacomodação nova da linguagem escrita à falada (já agora com todas as probabilidades de permanência) muito mais eficaz que a dos românticos." $" 69$

O "Posfácio inédito (s.d.)" de Amar, verbo intransitivo trata da língua estilizada no romance, apresentada como "melodia nova". O texto é elaborado em diálogo com o romantismo, o que se percebe tanto na escolha lexical, como no raciocínio que articula língua e autonomia literária. O emprego do verbo "carecer" denota a escolha de aproveitar a lição de Gonçalves Dias. À margem de Os timbiras, Mário observa: "Gonçalves Dias diz sistematicamente carecer por precisar"70. Os comentários assinalados na "Introdução" de Casimiro de Abreu e nos estudos críticos de Álvares de Azevedo confirmam o apoio na marginália:

"Postfacio. A língua que usei. Veio escutar melodia nova. Ser melodia nova não quer dizer que feia. Carece primeiro a gente se acostumar (...) Ninguém me tirará a conviçção arraigada já entre muitos dissabores, brinquedinhos depreciativos de amigos, diz-ques e falar mal por trás e injustiças, que se muitos tentarem também o que eu tento (note-se que não digo 'como eu tento') muito breve se organizará uma maneira brasileira de expressar, muito pitoresca, psicologiquíssima na sua lentidão, nova doçura e variedade, novas melodias bem nascidas da terra e da raça do Brasil. Essa expressão é muito provável que talvez ainda século passe sem que ela se diferencie suficientemente do português a ponto de formar uma nova língua. Não sei. E se tivermos uma língua brasileira é provável também que a diferença entre ela e a portuguesa nunca seja maior que a que tem entre esta e a espanhola. $\mathrm{O}$ importante não é aliás a vaidadinha de ter língua diferente, o importante é se adaptar, ser lógico com a sua terra e o seu povo. Falam que pra que tenha literatura diferente carece que tenha língua diferente... É uma semiverdade. Pra que tenha literatura diferente é só preciso que ela seja lógica e concordante com terra e povo diferente. $\mathrm{O}$ resto sim é literatura

\footnotetext{
68 ALMEIDA, Aline Novais de. op. cit, vol. 2, p. 784.

${ }^{69}$ ANDRADE, Mário de. "Modernismo", In: O empalhador de passarinho. São Paulo: Livraria Martins Editora, 1955, p. 189.

${ }^{70}$ Nota MA, In: DIAS, A. Gonçalves. Poesias. Ed. cit., vol. 2, p. 168.
} 
importada só com certas variantes fatais. É literatura morta ou pelo menos indiferente pro povo que ela pretendeu representar." 71

O périplo breve pelos meandros que ligam a marginália a outros projetos do polígrafo permite que se vislumbre o aproveitamento variado da poesia do romantis mo e, em paralelo, os modos de escrita que a compõem: traços verticais destacando parágrafos, termos sublinhados, cruzetas, expoentes remetendo ao rodapé, escólios. Nessa última categoria, é preciso aludir ao "Sequestro”, que sinaliza, na marginália, a convergência de projetos, aproximando a poesia romântica da criação anônima do povo.

$\mathrm{O}$ termo associa-se em primeiro lugar a $O$ sequestro da dona ausente, longa pesquisa de Mário de Andrade no âmbito do folclore luso-brasileiro, que investiga o encontro amoroso - frustrado pelas navegações e pela escassez de mulheres no Novo Mundo - como objeto de elaboração estética. Em paralelo, constitui versão autoral e aproximativa para o Verdrängung/refoulement, conceito psicanalítico que terá papelchave em "Amor e medo". A circunstância cultural que dá origem à tópica da dona ausente é caracterizada em artigo na revista Atlântico:

"O mar todo-poderoso exige dos que lhe manejam o rito, viverem em castidade completa. Mas a saudade da mulher persegue o casto, o desejo dela o castiga demais. E o marujo, especialmente o lusitano que foi o maior dos navegadores, busca disfarçar o martírio nas imagens e nos símbolos da poesia. $\mathrm{O}$ folclore luso-brasileiro se enriqueceu, com isso, de uma série numerosa e admirável de quadrinhas e cantigas"72

O dossiê da pesquisa abriga planos, esboços e notas prévias, num total de 1.221 documentos $^{73}$. Ricardo Souza de Carvalho transcreveu e analisou o conjunto em Edição genética d'O sequestro da dona ausente de Mário de Andrade ${ }^{74}$. No manuscrito, o f. 590 prende-se à nota de margem no poema "A...", em As primaveras: "Sequestro // $\mathrm{n}$ 223 p 7”. No volume de Casimiro de Abreu, o leitor traça um colchete para destacar a quadra, e acrescenta o escólio à esquerda, em escrita ascendente:

"Sequestro" $\quad\left[\begin{array}{l}\text { "Por ti eu me embarquei, cantando e rindo, } \\ \text { - Marinheiro de amor - no batel curvo, } \\ \text { Rasgando afouto em hymnos d'esperança } \\ \text { As ondas verde-azues d'um mar que é turvo." }\end{array}\right.$

\footnotetext{
${ }^{71}$ ANDRADE, Mário de. "Posfácio inédito", In: Amar, verbo intransitivo. Ed. cit., p. 144 e 145.

72 ANDRADE, Mário de. "A dona ausente".Atlântico, n 3. Lisboa/Rio de Janeiro, Serviço Nacional de Propaganda/ Departamento de Investigação e Propaganda, 1943, p. 9.

${ }^{73}$ Arquivo IEB-USP. Fundo Mário de Andrade. Código do documento: MA-MMA-106.

${ }^{74}$ Dissertação de Mestrado no Programa de Pós-graduação em Literatura Brasileira, FFLCH-USP, 2001. Orientadora: Profa. Dra. Telê Porto Ancona Lopez.
} 
Mesma nota de margem, nos v. 8-10, de "Na Rede":

$\left.\begin{array}{cc} & \text { "De leve embalada no quieto balanço } \\ \text { Qual nauta scismando n'um lago bem manso } \\ \text { "Sequestro" }\end{array}\right]$

E em "A Voz do Rio", combinada a outro escólio, que localiza a paisagem da província:

"Sequestro" $\left[\begin{array}{l}\text { "Lá novos campos outros campos ligam "(R. Grande do Sul)" } \\ \text { E a vista fraca na extensão se perde! } \\ \text { E tu sósinha viverás no exilio } \\ \text { - Garça perdida n’esse mar que é verde! -" } 75\end{array}\right.$

A estrofe é indicada no manuscrito que documenta a pesquisa sobre a dona ausente. Em nota de trabalho, Mário propõe "Dar Casemiro / como o "poeta / do Sequestro" "76. Em "Sempre sonhos", acrescenta ao escólio o comentário - "a imagem do mar vem constante no amor do poeta"77. E em outra nota, referindo-se a mais poemas casimirianos (diria "casemirianos"), registra: "Sempre a imagem com as aguas"78. Embora As primaveras seja o livro de maior ocorrência, entre os poetas do romantis mo, as margens de Álvares de Azevedo e Fagundes Varela também acusam a tópica. ${ }^{79}$

A repressão ou recalcamento, conceito que Mário traduz por sequestro, é um dos conceitos de base da teoria psicanalítica - mecanismo de defesa que permite ao sujeito manter afastado da consciência um conteúdo ideativo que the é desagradável. $\mathrm{O}$ Vocabulário da psicanálise, de Laplanche e Pontalis, acusa as nuances do termo no correr da obra de Freud, onde assume dois sentidos principais:

'No sentido próprio (A), é a operação pela qual o sujeito procura repelir ou manter no inconsciente representações (pensamentos, imagens, recordações) ligadas a uma pulsão. O recalque produz-se nos casos em que a satisfação de uma pulsão - suscetível de proporcionar prazer por si mesma - ameaçaria provocar desprazer relativamente a outras exigências. (...) Em sentido mais amplo (B), o termo é tomado muitas vezes por Freud numa acepçãoque o aproxima de 'defesa'; [por um lado, na medida em que a operação de recalque tomada no sentido A se encontra - ao menos como uma etapa - em numerosos processos

\footnotetext{
${ }^{75}$ Notas MA, In: ABREU, Casimiro. op. cit., ed. cit., p. 7, 39 e 41.

76 Arquivo IEB-USP, Fundo Mário de Andrade, Cód.: MA-MMA-106-591.

${ }^{77}$ Nota MA, In: ABREU, Casimiro. op. cit., ed. cit., p. 88.

78 Arquivo IEB-USP, Fundo Mário de Andrade, Cód.: MA-MMA-106-590.

${ }^{79}$ Notas MA, In: VARELA, Fagundes. Obras completas. Ed. cit., vol. 1, p. 215; AZEVEDO, Álvares de. Obras. Ed. cit., vol. 1, p. 281. Em janeiro de 1944, Manuel Bandeira envia a Mário esta quadrinha: "IMPROMPTU // Cinco segundos de silêncio / Cinco segundos de saudade / - A saudade do Dono Ausente / Mário de Andrade.” MORAES, Marcos A. [Org.] Correspondência Mário de Andrade \& Manuel Bandeira. São Paulo: Edusp, 2001. 2 2a ed., p. 669
} 
defensivos complexos (a parte é então tomada pelo todo), e, por outro lado, na medida em que o modelo teórico do recalque é utilizado por Freud como protótipo de outras operações defensivas" 80

O termo sequestro parece conjugar o recalque com a sublimação. Este, um "processo postulado por Freud para dar conta das atividades humanas aparentemente sem relação com a sexualidade, mas que encontrariam sua origem na força da pulsão sexual". Laplanche e Pontalis esclarecem que Freud "descreveu como atividades de sublimação principalmente a atividade artística e a investigação intelectual. A pulsão é dita sublimada na medida em que é dirigida a uma nova meta não sexual e visa a objetos socialmente valorizados" $"$.

Mário de Andrade travou contato precoce com a psicanálise. Os livros de autoria de Freud em sua biblioteca, todos em francês, atestam o interesse, representado por oito títulos: La psychopathologie de la vie quotidienne: application de la psychanalyse à l'interprétation des actes de la vie courante; Introduction à la psychanalyse; Trois essais sur la théorie de la sexualité; Totem et tabou: interprétation par la psychanalyse de la vie sociale des peuples primitifs; Cinq leçons sur la psychanalyse; Essais de psychanalyse; Le mot d'esprit et ses rapports avec l'inconscient; e Pourquoi la guerre, este em coautoria com A. Einstein ${ }^{82}$. A psicanálise figura ainda como objeto de debate na crítica e matriz importante da criação literária - Amar, verbo intransitivo, Macunaíma e Contos novos são exemplos de realce. A legenda proposta, em 1927, para a fotografia tirada pelo autor viajante no Ceará, de um varal com roupas brancas enfunadas pelo vento, estende o campo das apropriações: "Roupas freudianas / Fortaleza 5-VIII-27 / Sol 1 diaf. 1 / Fotografia refoulenta / Refoulement"83.

\footnotetext{
${ }^{80}$ LAPLANCHE \& PONTALIS. Vocabulário da psicanálise. Tradução de Pedro Tamen. São Paulo: Martins Fontes, 1994, p. 552.

${ }^{81}$ IDEM, ibidem, p. 554.

82 Paris: Payot, 1922; Paris: Payot, 1922; Paris: Nouvelle Revue Français, 1923; Paris: Payot, 1923; Paris: Payot, 1924; Paris: Payot, 1927; Paris: Gallimard, c1930; Paris: Institut International de Coopération Intelectuelle, 1933.

${ }^{83}$ Arquivo IEB-USP, Fundo Mário de Andrade, Código: MA-F-0589. As fotos tiradas por Mário em suas viagens ao Norte e Nordeste do Brasil integram o corpus da pesquisa para o mestrado de Viviane Azevedo Vilela, "Possibilidades de uma câmera moderna", no Programa de Pós-Graduação em Culturas e Identidades Brasileiras, IEB-USP.
} 


\title{
Amor com medo do desejo
}

Antes de escavar o solo fértil onde se cultiva a interpretação proposta em "Amor e medo", cabe fazer um sobrevoo de reconhecimento do ensaio publicado. Mário de Andrade busca caracterizar no $\mathrm{n}^{\mathrm{o}} 3$, ano 1, da Revista Nova um aspecto do sentime nto amoroso manifesto em todos os grandes nomes da poesia romântica, tomando como ponto de partida a "epidemia de suicídios" associada ao movimento. O "cacoete histórico" teria organizado "o destino do homem romântico" ${ }^{44}$. Morrendo cedo, diz o crítico, os românticos poetaram como moços, expressando temas caros à mocidade. Entre eles, elege como estudo o medo da realização amorosa e sexual, um dos "mais terríveis fantasmas que perseguem o rapaz"85.

A página de abertura do ensaio de Mário paga tributo à razão biográfica e ao juízo de sinceridade da poesia. Biografismo de relações, que liga a imagem poética do rapaz morto ao fato de os escritores, em particular Álvares de Azevedo, terem vivido tão pouco. No que toca à sinceridade, o elo entre a morte prematura e a experiência larga, encenada nos versos, estrutura-se como oração concessiva. A alusão ao poetacriador faz-se através do personagem-criatura, conforme o trecho desenha:

\begin{abstract}
"Os nossos poetas românticos foram muito vítimas dessa imagem do rapaz morto. Não só a cantaram às vezes, especialmente Álvares de Azevedo, como viram suas vidas encurtadas, alguns colhidos mesmo numa ainda rapazice irritantemente inacabada. É o caso ainda especialmente de Álvares de Azevedo. E tendo morrido moços, no geral poetaram como moços, muito embora finjam às vezes formidáve 1 experiência da vida. Como ainda especialmente é o caso do nosso Macário. Assim, é agradável a gente buscar na poesia deles os temas preferidos da mocidade, e entre estes escolho, pela sua importância, o do medo do amor." $" 86$
\end{abstract}

As causas desse eros temeroso dividem-se em históricas ("provenientes de educação, de convívios") e temperamentais (oriundas "da nossa psicologia, da nossa fisiologia, da nossa sensibilidade e suas delicadezas e respeitos") ${ }^{87}$. Note-se, de passagem, a ênfase repetida na primeira pessoa do plural, que compreende também o tempo e o autor do ensaio. Se o crítico e os poetas não aparecem estritamente irmanados no topos/sintoma para o qual o ensaio aponta - ou simplesmente: no tema do ensaio -

\footnotetext{
${ }^{84}$ ANDRADE, Mário de. “Amor e medo”, In: Aspectos da literatura brasileira.Ed. cit., p. 199.

${ }^{85}$ IDEM, ibidem, p. 200.

${ }^{86}$ IDEM, ibidem, p. 200.

${ }^{87}$ IDEM, ibidem, p. 200.
} 
parecem pelo menos sujeitos ao mesmo universo de causas. Os românticos brasileiros, sendo líricos, expressaram ricamente o medo de amar.

O título do ensaio vem de um poema de Casimiro de Abreu, citado integralmente pelo crítico:

"Quando eu te fujo e me desvio cauto

Da luz de fogo que te cerca, oh! bela,

Contigo dizes, suspirando amores:

- "Meu Deus! que gelo! que frieza aquela!"

Como te enganas! meu amor é chama

Que se alimenta no voraz segredo,

E si te fujo é que te adoro louco...

És bela - eu moço; tens amor - eu medo!...

Tenho medo de mim, de ti, de tudo,

Da luz, da sombra, do silêncio ou vozes,

Das folhas secas, do chorar das fontes,

Das horas longas a correr velozes.

Ai! si abrasado crepitasse o cedro,

Cedendo ao raio que a tormenta envia,

Diz: - que seria da plantinha humilde

Que á sombra dele tão feliz crescia?

O medo alastrado pelas quadras exprime-se na fuga e no desvio vivenciado pelo eu lírico. O gelo a ele atribuído pela amada contrasta com o fogo visto por ele, contornando-a e impondo-lhe a tarefa de esclarecer que "há distância entre intenção e gesto"; que a fuga traduz o sentimento oposto de quem a adora loucamente. Mário de Andrade liga o medo, no poema, à preservação da virgindade (moral vigente), que ele sinaliza no comentário interpolado entre a terceira e a quarta estrofes. O respeito à mulher, afirma, é visto como a "primeira grande lateralidade em que a timidez de amar se fixa nos românticos" $" 88$. Não será estranho falar em respeito à mulher - questiona, retoricamente - quando as tavernas do romantismo hospedavam Heine, Musset e Byron, autores de intensa liberalidade erótica? A justificativa guarda a mesma lógica compensatória (e proporcional) da fuga do eu lírico casimiriano: é o respeito rigoroso à mulher que leva a "procuras de libertação, conscientes e por isso mesmo exageradas" $"$. Mostra-se no caso da "maneira desabusada" de Álvares de Azevedo, em certos passos, e da "cretina safadeza das minúsculas libertinagens" de Casimiro. A razão psicológica implica também rasgos de estilo. Os avatares da mulher são filtrados

\footnotetext{
${ }^{88}$ IDEM, ibidem, p. 201.

${ }^{89}$ IDEM, ibidem, p. 201.
} 
de sua carga erótica, naturalmente feminina, e ela é transfigurada em anjo, virgem, criança, visão - imagens assexuadas. Quem concentra os paradigmas num só trecho, para o modernista, é o eu lírico de Fagundes Varela, em Anchieta ou O Evangelho nas selvas, que "funde as virgens e as crianças, pra chamar-thes 'aves de Deus" que dentro dos vínculos poéticos e biográficos postulados no ensaio, Varela não é o representante mais apropriado do medo de amar: "Não esqueçamos que ele casou duas vezes..."91 A circunstância do sujeito empírico, o estado civil, explica que a mulher seja cantada por ele "com uma certa franqueza macha", próxima do tom adotado nas modinhas populares.

Gonçalves Dias é chamado a formar o quarteto dos medrosos por conta de um poema da mocidade. Para o poeta maranhense, morto aos quarenta e um anos, a explicação biográfica seria provavelmente mais frágil, mas é que nele o tema conquista outra roupagem. Transcrito no ensaio, o soneto de juventude - 'Pensas tu, bela Anarda, que os poetas" - com resquícios árcades, o que corrobora a ideia de comicidade, manifesta o destemor de amar. O crítico, contudo, descrê da sinceridade dos versos, interpreta-o como prova contrária: "me parece que Gonçalves Dias ao caçoar da literatice dos poetas é que está fazendo literatice, libertando-se duma preocupação por meio duma comicidade que não era própria dele, garganteando o que não sentia"92. Mais tarde, "bem vivido", teria dado provas do prestígio em face da mulher, autor de “Ainda uma vez, adeus!", um dos poemas mais comoventes da tópica que norteia o ensaio.

Até aqui, como se percebe, nada de Castro Alves. Álvares de Azevedo se vê reconvocado para análise: "O amor sexual the repugnava, e pelas obras que deixou é difícil reconhecer que tivesse experiência dele. ${ }^{93}$ As frases sobre o amor, no autor da Lira dos vinte anos, carecem de objetividade, e as poucas que escapam desse padrão podem se explicar pela experiência de leitor. Mário abre um longo rodapé, no qual recolhe elementos da correspondência de Azevedo, provando fartamente a "insensibilidade sexual com que ele trata a mulher nas suas cartas de São Paulo"94. E ao narrar os bailes, o poeta "femininamente presta mais atenção a setins e escumilhas,

\footnotetext{
90 IDEM, ibidem, p. 201.

${ }^{91}$ IDEM, ibidem, p. 201.

92 IDEM, ibidem, p. 202.

93 IDEM, ibidem, p. 202.

94 IDEM, ibidem, p. 202.
} 
que a corpos gostosos da gente apertar na valsa"95. Na obra dele, o contraste entre ideal e realidade traduz-se em três ordens: as mulheres consanguinamente assexuadas (mãe e irmã), as virgens de quinze anos e as prostitutas - "intangíveis ou desprezíveis" 96 . Os vícios tematizados pelo autor de Noite na taverna exibem o habitus, fingido, de libertino e farrista. As maldades de que "se arrota manchado" no fundo não são maldades, antes "falsificações sistematizadas inconscientemente". O poeta soube encontrar expressões enfeitadas mesmo para as meretrizes: "vagabunda do amor", "mulher da noite", "anjo da noite", "rainha da noite". Mário condensa a análise psicológica e biográfica, acrescendo, no ponto seguinte, um elemento novo, que dá conta da teatralidade intensa com que os românticos viveram e produziram suas obras:

"Suas grosserias [de Azevedo] eram mais um desvio, mais ilusão, mais
inverdade, que o transpunham pra fora de sua existência natural e de
si mesmo. Daí o tédio em grande parte, uma fadiga prematura, cujos
acentos são as mais das vezes ferintemente sinceros. Spleen, fadiga,
não de blasé propriamente, mas de artista dramático que não
representava apenas nas noites de espetáculo (as farras em que
possivelmente andou com outros estudantes de Pauliceia), porém, que
fizera da própria vida que cantou em verso e prosa, e imaginava ser a
dele, uma falsificação de teatro." ${ }^{\circ}$

Castro Alves serve de negativo ao sequestro de Azevedo. A mulher comparece à sua poesia de modo bem mais objetivo: "Ele foi de fato um sexual perigoso, duma sexualidade animal bem correta"98. Passa longe, da mesma forma, das perversões com que Casimiro de Abreu "recama a sua burguês dulcidão"; estas manifestam a safadeza de quem "pede beijos por castigo" ou a vontade reiterada de ver a mulher chorando. O prazer das lágrimas - frequente no eu lírico casimiriano - é qualificado pelo crítico como "longes de sadismo" "99. Castro Alves não: é dotado de "sensualidade sadia, marcadamente viril"100, sendo a mulher esculpida com maior clareza em seus poemas. No que se refere ao tema do amor e medo, sua poesia oferece apenas o "sequestro geral e precário" de amar sem ser amado, hesitação comum na juventude, da qual logo se

\footnotetext{
95 IDEM, ibidem, p. 203.

96 IDEM, ibidem,p. 203. Cilaine Alves Cunha lembra que os tipos femininos opostos, na obra de Álvares de Azevedo, podem ser entendidos como "uma convenção que busca, sim, a irrealização do ato sexual, mas objetivando, intencionalmente, tornar eternos e infinitos o desejo e o amor pela mulher, seja no sonho, na imaginação ou, como é o caso do poema em questão [“Lélia”], na morte”. CUNHA, Cilaine Alves. O Belo e o Disforme. São Paulo: Fapesp/Edusp, 1998, p. 50.

${ }^{97}$ IDEM, ibidem, p. 204.

${ }^{98}$ IDEM, ibidem, p. 204.

${ }^{99}$ IDEM, ibidem, p. 205.

100 IDEM, ibidem, p. 205.
} 
libertou o autor de Espumas flutuantes. A propensão às atrizes, supostamente mais liberais nos costumes, comprova-lhe a masculinidade. Seus tremores, ao contrário de Álvares de Azevedo, expressam impaciência. O receio do desengano, de sofrer a ingratidão da amada, é dos poucos aspectos em que o tema se manifesta na poesia dele.

O sequestro marca, em síntese, a obra de todos os autores, que o tematizam conforme sua psicologia. Em Casimiro, como se viu, o medo reprimido aparece lateralmente, no respeito à mulher (medo de desfolhar a virgem), nas manifestações de sadismo e numa preferência frequente pelo sonho, em prejuízo da realidade.

Gonçalves Dias expressou menos o tema. Em certos poemas, como o "Ainda uma vez, adeus!", sacrifica o amor e arrepende-se da falta de ousadia, ao preferir "amar em silêncio"101. Derivação muito frequente em sua obra, a infidelidade atribuída à mulher manifesta o sequestro. Mário de Andrade identifica no poeta das Sextilhas a "filosofia pessimista do amor, bem wagneriana, pra não dizer shopenhauriana", já que o consolo do eu lírico chega com a morte - é o caso de "Se se morre de amor", "Protesto", "Olhos verdes". No teatro - Patkull, Leonor de Mendonça, Beatriz Cenci e Boabdil -, o desejo de morrer de amor é constante. Quando Zoraima cai nos braços dele, mesmo certo de que é correspondido, Boabdil deseja o aniquilamento e suplica: “Alá! Por que não me fulminas neste momento!”. É prova de que o herói não quer a realização erótica, "foge sintomaticamente da realização" e contenta-se com o "reconhecimeno mútuo de amor"102.

Mesmo em Fagundes Varela, cuja obra descreve a mulher de modo mais realista, as "aves de Deus" atenuam a representação feminina. A Juvenília, é verdade, "respira todinha a amor e medo, do mais delicado e tênue", segundo Mário. No poema sétimo - "Ah! quando face a face te contemplo" -, o tema mistura-se às forças da natureza: a tempestade, o furacão, o deserto mostram o medo do eu lírico. Varela "funde e confunde vigorosamente a natureza com a mulher amada"103.

O exemplo máximo do recalque, para o crítico atento aos sentimentos, foi mesmo Álvares de Azevedo. Mais do que simples temor, ele teria sofrido uma "verdadeira fobia do amor sexual", que o impediu de poetizar o tema com franqueza. Ao contrário, o medo apresenta-se em sua obra "sempre inconsciente", muitas vezes camuflado pelo mecanismo da projeção. Se a amada treme, tal como a paisagem natural

\footnotetext{
101 IDEM, ibidem, p. 215.

102 IDEM, ibidem, p. 217.

103 IDEM, ibidem, p. 213.
} 
de Varela, é como encarnação do medo do eu lírico/poeta. "A educação entre saias", "o amor deslumbrante pela irmã”, o episódio em que se fez passar por mulher em um baile de carnaval, "as conversas sobre crivos e bordados", "a preocupação com toaletes femininas" e o "desfervor sexual" são indícios da virilidade parca, recolhidos na correspondência do jovem poeta, signos e fatores do seu complexo. ${ }^{104}$

Mãe e irmã são uma "quase obsessão" para ele. A dedicatória da Lira dos vinte anos é tida por Mário como símbolo do desejo de regressar ao seio materno. O feto é imagem recorrente na poesia e no teatro, e a maternidade envolve a descrição dos amores sexuais em mais de um ponto de sua obra. No mesmo terreno dos desejos proscritos, incestuosos, a irmã é representada como objeto de modo explícito, no episódio que encerra Noite na taverna, "Último beijo de amor". E Macário, tendo ainda "os beiços de criança", fala como saciado, ensejando a pergunta de Satã, àquela altura indicado apenas como Desconhecido: "Quantos seios de mulher beijaste além do seio de tua ama de leite? Quantos lábios além dos de tua irmã?"105

Para disfarçar o sequestro, o analista vê no sono a imagem mais inventiva. O eu lírico ama dormir "filialmente no colo da amada". Nisso demonstra pouca virilidade: “em quase todas estas citações, ele está expressivamente indolente, entregue, sem nenhuma iniciativa, sem atividade" ${ }^{106}$. Mais do que o próprio sono, o autor de $O$ Conde Lopo poetiza em abundância a amada adormecida. Mário indica as ocorrências com afinco e qualifica essa como "a mais bonita e medrosa criação" de Álvares de Azevedo. Eis "o clímax do sequestro: o medo de amor inventa a ideia de possuir a bela adormecida". O sequestro foi convertido em fundamento da obra, talvez também da morte do poeta, gerando a tristeza crescente, o pressentimento-desejo do fim, o tédio real que se apossava dele. Ao largo de "suposições psicopatológicas" específicas sobre Azevedo, o que importa para o ensaio é que o medo de amar "têm valor universal, é de todos" 107 .

Está claro que a análise do sentimento amoroso nos românticos depende em boa medida da reflexão psicanalítica, sintetizada no vocabulário: fantasma, sintomas,

\footnotetext{
${ }^{104}$ Na biblioteca de MA, o exemplar de Dous romanticos brasileiros, de Luiz Felipe Vieira Souto, no qual foram publicadas as cartas de Azevedo, está intensamente marcado (Rio de Janeiro: Imprensa Nacional, 1931). Os trechos da correspondência nutrem o longo rodapé acrescentado por Mário à segunda versão de "Amor e medo", conforme documentado no exemplar de trabalho da Revista Nova (Arquivo IEB-USP. Fundo Mário de Andrade. Código MA-MMA-05-098 e 099).

105 IDEM, ibidem, p. 222.

106 IDEM, ibidem, p. 224.

107 IDEM, ibidem, p. 229.
} 
lateralidade e desvio, sadismo, perversão, sexualidade correta, fixação, complexo de Édipo. A pesquisa da marginália de Mário no seu exemplar dos Trois essais sur la théorie de la sexualité - tradução de Blanche Reverchon (Paris: Éditions de la Nouvelle Revue Française, 1923) - ilustra alguns pontos da teoria freudiana apropriados pelo escritor. Os dois primeiros ensaios - "Les abérrations sexuelles" e "La sexualité infantile" - não contêm qualquer nota de margem. O primeiro traço vertical que se instala no volume fica na página inicial do terceiro ensaio, "Les transformations de la puberté". Nela, o lápis assinala a definição do caráter normal da vida sexual, "assuré par la conjonction, vers l'objet et le but sexuels, de deux courants: celui de la tendresse et celui de la sensualité" "108. A página seguinte, também marcada, importa ao argumento desenvolvido em "Amor e medo". Associa-se, indiretamente, à caracterização de Álvares de Azevedo, e à obsessão dele por mãe e irmã: "Tous les troubles morbides de la vie sexuelle peuvent, à bon droit, être considérés comme résultant d'arrêts dans le cours du développement." O leitor destaca o trecho com um traço vertical e registra o escólio em francês mesmo, imerso no raciocínio proposto por Freud: "Troubles"109. Todo o parágrafo introdutório do capítulo sobre a descoberta do objeto é realçado ${ }^{110}$. Também assinala a passagem que associa ao encontro do objeto o primado das zonas genitais e o desenvolvimento físico, pré-requisito para a consumação do ato sexual. A partir daí, o volume é marcado intensamente: 'Les rapports de l'enfant avec les personnes qui le soignent sont pour lui une source continue d'excitations et de satisfactions sexuelles"111. As relações entre mãe e filho são sublinhadas. Como o trecho se estende, sustendo o interesse do leitor, a sublinha torna-se traço vertical:

"Car elle [a mãe] ne fait qu'accomplir son devoir, quand elle apprend à aimer à l'enfant qui doit devenir un être complet et sain, doué d'une sexualité bien developpé, etqui, dans sa vie, devra suffire à tout ce que l'instinct lui commande. Il est vrai qu'un excès de tendresse maternelle deviendra nuisible parce qu'il pourra amener une sexualité précoce, qu'il 'gâtera' l'enfant, qu'il le rendra incapable de renoncer pendant un temps à l'amour ou de se satisfaire d'un amour plus mesuré. Le fait que l'enfant se montre insatiable dans son besoin de la tendresse maternelle est un des meilleurs symptômes de nervosité ultérieure."112

${ }^{108}$ Nota MA, in: FREUD, S. Trois essais sur la théorie de la sexualité. Ed. cit., p. 111.

109 Nota MA, In: IDEM, ibidem, p. 112.

110 Nota MA, In: IDEM, ibidem, p. 130.

111 IDEM, ibidem, p. 132.

112 IDEM, ibidem, p. 133. 
A atenção de Freud passa ao medo infantil, que teria por origem o sentimento de ausência da pessoa amada, conforme destaca o lápis do crítico. O efeito seria a conversão da libido em angústia, desde o momento em que não pode alcançar satisfação. A inibição do incesto, tópico seguinte, é também ressaltada. A proposição condicional parece ecoar no comentário à obra de Álvares de Azevedo ${ }^{113}$. O caso de mãe e irmã, anotado repetidas vezes à margem, ganha corpo na hipótese apresentada em "Amor e medo", segundo a qual imagens maternas pululam em Macário e na Lira dos vinte anos. E no exemplar de Freud, a sublinha acusa: "Celui qui a évité de fixer le choix de l'objet par une Libido incestueuse n'est pas, par cela même, libéré de l'influence de celle-ci"114. Na conclusão dos Trois essais, há mais material de interesse. O instinto sexual durante a infầncia ainda não está centrado, é sem objeto, autoerótico, afirma Freud - Mário realça a passagem com o traço vertical triplo. Adiante, os tópicos são numerados a grafite: "Constitution et hérédité"; "Elaboration ultérieure"; "Refoulement" e "Sublimation". Em "Refoulement", a ideia elementar, como esquema mental, não recebe notas: "Cette substitution de la névrose à la perversion dans la vie de l'individu, la répartition de cas de perversion et de névroses dans une même famille, tout cela doit être rapporté au fait que la névrose constitue le complément négatif de la perversion." Salvo engano, a mesma lógica rege o conflito formulado em "Amor e medo" - no título, que delineia o embate entre a pulsão do desejo e a força repressora - e em outras formas que operam como negativo psíquico do sequestro: o respeito à mulher e a vontade de liberação dos desejos, resultando nas perversõezinhas de Casimiro e na maneira desabusada de Álvares de Azevedo. O tópico "Sublimation" confere o salvo-conduto para ler a poesia e o ato de criação artística com os óculos da psicanálise:

"Sublimation. - Il peut y avoir une troisième issue, dans le cas d'une constitution anormale, par le processus de la sublimation. Les excitations excessives découlant des différentes sources de la sexualité trouvent une dérivation et une utilisation dans d'autres domaines, de sorte que les dispositions dangereuses au début produiront une augmentation appréciable dans les aptitudes et activités psychiques. $\underline{\text { C'est là une des sources de la production artistique, et l'analyse du }}$

\footnotetext{
113 “Si la tendresse des parents réussit à ne pas éveiller l'instinct sexuel de l'enfant prématurement, c'està-dire si elle évite de lui donner, avant que les conditions physiques de la puberté soient réalisés, une intensité telle que l'excitation psychique se porte d'une façon non douteuse sur le système génital, alors cette tendresse pourra satisfaire à la tâche quilui incombe, et qui consiste à guider l'enfant devenu adulte, dans le choix de l'objet sexuel." IDEM, ibidem, p. 134.

114 IDEM, ibidem, p. 138.
} 
caractère d'individus curieusement doués en tant qu'artistes, indiquera des rapports variable entre la création, la perversion et la névrose, selon que la sublimation aura été complète ou incomplète. (...) Il est ainsi permis de dire que la disposition sexuelle généralement perverse de l'enfant crée, par les réactions qu'elles provoquent, un grand nombre de nos vertus." 115

Os fatores que exercem influência sobre o desenvolvimento sexual, logo enumerados por Freud, são escoliados por seu leitor atento com algarismos romanos: "Précocité $I$ ', 'Le temps, facteur de l'évolution sexuelle - II', 'Persévération - III' e, sem algarismo, "Fixation".

A "projeção", embora ausente dos Trois essais, é um mecanismo que também comparece ao terreno crítico das anotações de margem. O Vocabulário da psicanálise apresenta duas acepções principais para o termo. Em sentido genérico, no âmbito da neurofisiologia e da psicologia, a palavra refere-se ao deslocamento de um fato neurológico ou psicológico - quer do centro à periferia, quer do sujeito ao objeto - com o fim de situá-lo no exterior. A particularidade da acepção psicanalítica está, segundo Laplanche e Pontalis, em que a "projeção" expulsa e localiza no exterior qualidades, sentimentos, desejos e até mesmo "objetos" desconhecidos ou recusados pelo sujeito. Trata-se de um mecanismo de defesa de origens arcaicas, os autores explicam, que atua, particularmente, na paranoia, mas também em modos de pensamento "normais", como a superstição. O ciúme projetivo é descrito por Freud como defesa do sujeito ante o desejo de ser infiel, que passa a atribuir a infidelidade ao parceiro. Vê-se que não é exatamente o mecanismo adotado por Mário para descrever o comportamento erótico do eu lírico de Gonçalves Dias. Neste, a atribuição de infidelidade é sintoma lateral do medo de amar. Mas é descrição justa do sujeito lírico na obra de Fagundes Varela, que projeta o medo em elementos naturais, e também na poesia de Álvares de Azevedo, o qual, ao cantar os tremores femininos, revelaria os próprios. A projeção está presente também, segundo o Vocabulário, no animismo e na mitologia, que fazem incidir qualidades e paixões humanas em forças da natureza. ${ }^{116}$

Se voltarmos à marginália de Mário de Andrade na poesia romântica, encontraremos o revérbero das ideias freudianas nos versos de Castro Alves, em "Gesso e bronze". Ao citá-los, a nota da edição preparada por Afrânio Peixoto é imprescindível:

${ }^{115}$ Nota MA, In: IDEM, ibidem, p. 152.

116 LAPLANCHE \& PONTALIS. Vocabulário da psicanálise. Ed. cit., p. 343. 


\section{“GESSO E BRONZE”}

"Foi Canova ou David... Um mestre, um esculptor, Duas estatuas fez symbolizando o amor...

Uma - pallida e fria, inda amaçada em gesso

No canto da officina ensaio sem apreço!...

Outro - prodigio d'arte, arrojo peregrino,

Encarnação de luz em bronze florentino!...

Uma noite, porém, um raio, o acaso... um nada O incendio arremessando á tenda profanada,...

No verme tho estendal das cinzas do brazido

Viu-se o esboço de pé!... e o bronze derretido!.

Senhora, Deus também ás vezes é esculptor,

E gosta de esculpir nos corações o amor...

De argilla ou de metal, de barro ou de alabastro

Com o limo com que faz a escuridão e o astro...

Mas quando o acaso... um gesto... um riso leviano

Atêa a flamma vil de um zelo ardente, insano...

Sabeis o que se dá?

- $\mathrm{O}$ amor de gesso medra...

De lodo que era ha pouco... enrija... faz-se pedra.

Mas da lava infernal o beijo libertino

Funde a estatua do amor de bronze florentino!!

15 de Junho de 1871.

Cf. com um autographo do Poeta, em. por D. Adelaide de Castro Alves Guimarãe. Pbl. nas Poesias, Bahia (1913): XLVIII.

I) Ainda dirigida a Agnese Trinei Murri: scena de ciume, depois reconhecido sem razão, ajunta D. Adelaide de Castro Alves Guimarães. Alem do gentilico 'florentino' que identificava a amada, o Poeta sublinha o 'bronze', como indicando que seria a materia de que era feita o seu coração. Nas suas ultimas confissões Agnese Murri depõe o contrario: era apenas um coração que a si havia imposto o silencio e, assim, pareceu indifferente ao seu Poeta."

O crítico anota no rodapé: “A poesia foi diretamente, pra C. Alves, mais que uma sublimação, uma vazão da libido. "117 Nesse ponto, localiza-se outro laço que ata os fios principais da leitura: o aspecto biográfico, enfatizado nas edições que integram a biblioteca, é lido sob a perspectiva psicanalítica e certos critérios de poesia afirmados no "Prefácio interessantíssimo" e em A escrava que não é Isaura.

117 Nota MA, In: ALVES, Castro. Obras completas. Ed. cit., p. 284. 
Os traços biográficos de fato assombram o ensaio. Já foi mencionada a referência às segundas núpcias de Varela e à mana Maria Luíza, "que Álvares de Azevedo muito amou, de cujo amor fraternal teve experiência"118. Agreguem-se a eles, a título de exemplo, a “concepção ansiosa de aniquilamento" do eu lírico de Gonçalves Dias, que, "dita com vigor, a gente percebe que o poeta não está apenas fazendo madrigal. É uma concepção intimamente dele". ${ }^{119}$ E a alusão ao personagem de Noite na taverna, que vai na linha das notas de trabalho e anotações marginais: "Arnold (III, 413), numa trapalhada que é preciso ler, pra se observar bem o quanto os sentimentos naturais de Álvares de Azevedo se sobrepunham ao que ele inventava apenas com a inteligência, pedindo pra Giorgia que the sente nos joelhos, que deite a cabeça no ombro dele" ${ }^{120}$. A marginália é rica de indícios de mesma espécie. Ao final das dezesseis estrofes de "Destruição de Jerusalém", o crítico pergunta:

"Aos 15 anos. C. Alves conheceria nessa epoca V. Hugo? Ou o seu condoreirismo, antes por enquanto, essa tendencia pro lirismo heroico era inato e natural, o que mais provavel? Bem, mesmo que conhecesse Hugo era certamente natural. Mas nada de hugoanismo nisso. Não tem antiteses ainda. Ver em Xavier Marques si já conhecia Hugo." ${ }^{121}$

A idade do poeta, a referência ao estilo condoreiro de Victor Hugo e, enfim, a dúvida se a tendência para o lirismo heroico seria natural ou emprestada buscam caução em Xavier Marques, autor de Vida de Castro Alves (1911), livro que não consta da biblioteca do escritor paulistano. No poema precedente, "Ao Natalício", o crítico-le itor também dialogava com a nota de Afrânio Peixoto:

“(2) Não são estes os primeiros versos de Castro Alves, mas 'ao que consta, de 1859, aos doze annos de idade' (Xavier Marques - Vida de Castro Alves, Bahia, 1911, p. 31); são porém os primeiros que se the conhecem, tão infantis, - a idade não permitiria mais; que nelle canta ( $3^{\mathrm{a}}$ estancia), o educador que 'a mocidade dos rigores libertou', allusão á palmatoria e outros castigos corporaes, que abolira o Dr. Abilio Cesar Borges, no seu collegio, com escandalo publico, e satisfação da criançada jubilosa. Neste canto infantil já se vislumbra, pois, o Castro Alves, que havia de clamar contra todas as tyrannias.

Nota MA: "Esta observação é fina e engraçada. Seria preferivel dizer contra 'todas as romanticas tiranias',"122

\footnotetext{
118 ANDRADE, Mário de. “Amor e medo”, In: Aspectos da literatura brasileira. Ed. cit., p. 204n.

119 IDEM, ibidem, p. 216.

${ }^{120}$ IDEM, ibidem, p. 224 (grifei; negrito).

${ }^{121}$ Nota MA, In: ALVES, Castro. op. cit., ed. cit., p. 434.

122 Nota MA, In: IDEM, ibidem, p. 420.
} 
No diálogo que aí se trava, Mário encontra graça na formulação romântica e biográfica do editor, sem contestar o juízo que antecipa no moleque o estilo desenvolvido mais tarde pelo poeta. É bem a mesma toada da nota de margem citada há pouco, que encontra na personalidade a inclinação heroica do futuro condoreiro. O menino é pai do homem, diria o narrador machadiano. O estudo da biografia empreendido na marginália é visível no poema "Ao Dia Sete de Setembro". Como a edição registra as circunstâncias de criação - "Bahia. Gymnasio Bahiano. 7 de Setembro de 1861" -, Mário calcula a idade: "14 anos"123. O longo "Pesadelo" traz outros indícios fortes do olhar biográfico entremeado à identificação de prováveis matrizes. O crítico sublinha o v. 12 - "Como garças formosas que adejavam" - e conclui: "Estava lendo Camões..."124. Versos adiante: "Estava lendo Musset... Byron?..."125. Retorna à assertiva: "Lia Alvares de Azevedo..."126. E pergunta ainda: "Estaria lendo os romanticos portugas?..." ${ }^{127}$. O comentário ao final do poema retoma o lastro psicológico e as hipóteses freudianas quanto ao desenvolvimento sexual dos rapazes: "Isto é uma delicia de delicias. Vontade de amor dum menino que se faz homem, coisa linda."128

Outro passo de biografismo explícito está em "Amemos", evocado na seção anterior pelos verbetes da música e construções sintáticas livres dos preceitos da gramática. O poema de título exortativo colabora ao argumento:

\footnotetext{
"Não tardes tanto assim... Esquece tudo...

Amemos, porque amar é um santo escudo

Amar é não soffrer.

Eu não posso ser de outra... Tu és minha

Almas que Deus uniu na balsa edinea

Hão de unidas viver."
}

Mário prende o trecho sublinhado no v. 64 ao comentário no rodapé, que dispensa o "admirabilíssimo ão"; dialoga, como de costume, no idioma e registro de estilo do texto anotado por ele: "Quam justamente é que fala isso!..." "129. No rodapé de Afrânio Peixo,

\footnotetext{
${ }^{123}$ Nota MA, In: IDEM, ibidem, p. 429.

124 Nota MA, In: IDEM, ibidem, p. 438.

125 Nota MA, In: IDEM, ibidem, p. 438.

${ }_{126}$ Nota MA, In: IDEM, ibidem, p. 438.

${ }^{127}$ Nota MA, In: IDEM, ibidem, p. 440.

128 Nota MA, In: IDEM, ibidem, p. 444.

${ }^{129}$ Nota MA, In: IDEM, ibidem, p. 86.
} 
que explica a escrita de "Tríplice diadema", faz a cruzeta. O editor dá como referente e inspiração do poema a atriz Eugênia Camara, "pela qual estava o Poeta apaixonado"130. E o comentário de Mário de Andrade páginas à frente assume pressuposto semelhante, na investigação do moto lírico: "Enfim com o Gondoleiro do Amor, Eugenia Camara dá ao poeta um lirismo sublime e genial com este poema que é do mais puro gosto romântico e das mais perfeitas líricas do Romantismo universal."

A 'Noticia sobre a vida e obras d'Antonio Gonçalves Dias”, assinada por J. C. Fernandes Pinheiro, é marcada por escólios de naipe similar: "Primeiros Cantos 23 anos"; "Sextilhas 25 anos"; "29 anos"; "34 anos"; "41 anos"132. Mário vai datando os episódios de acordo com a idade do poeta - a nomeação como oficial da secretaria de estado dos negócios estrangeiros; o encaminhamento à publicação do Diccionario da língua Tupy, chamada língua geral dos Indígenas do Brasil e de Os Timbiras; a morte trágica no naufrágio do Ville de Boulogne.

Dois textos de introdução às Obras de Álvares de Azevedo ilustram o quanto as edições lidas por Mário estavam entranhadas do paradigma biográfico. Joaquim Norberto, que assina a "Notícia sobre o autor e suas obras lida em uma das sessões do Instituto Historico Brasileiro no anno de 1872", narra o ano de morte do jovem poeta com tons intensíssimos, enumeração de adjetivos -"continuo conchego, repetidos abraços, e incessantes beijos" - e exclamações:

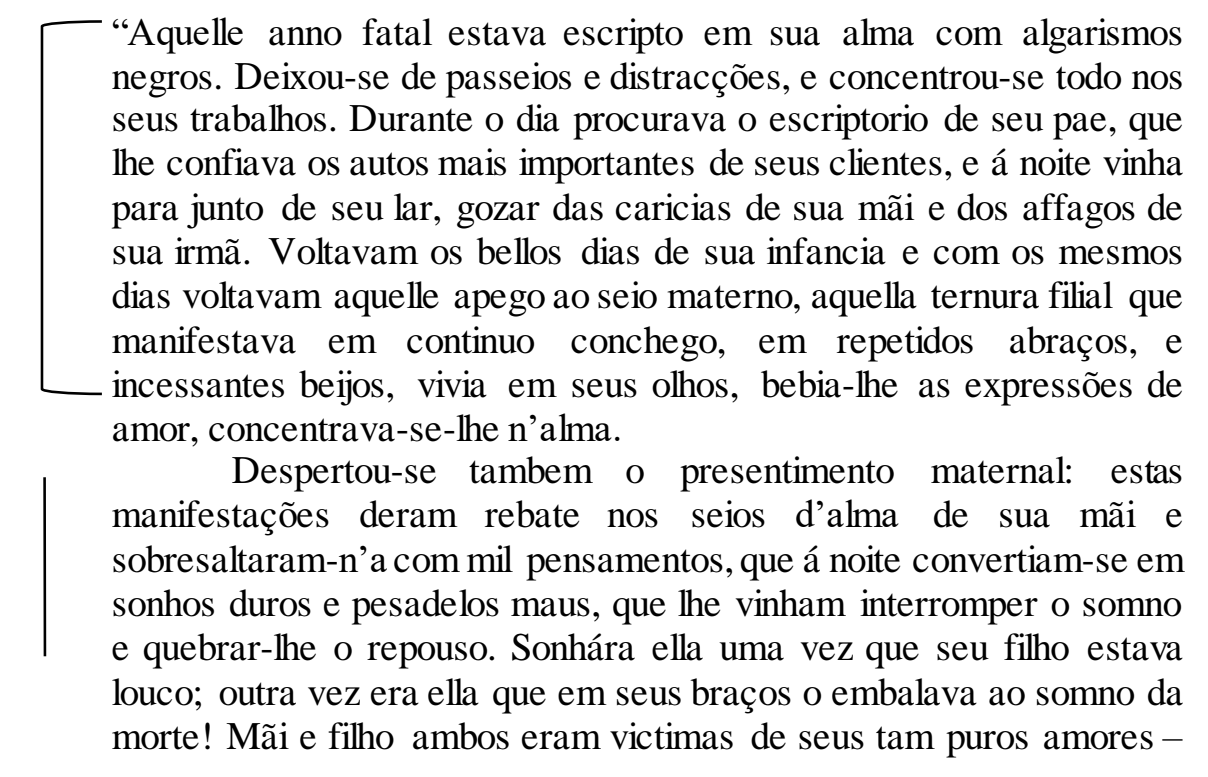

\footnotetext{
${ }^{130}$ Nota MA, In: IDEM, ibidem, p. 88.

${ }^{131}$ Nota MA, In: IDEM, ibidem, p. 98.

132 Nota MA, In: PINHEIRO, J. C. Fernandes. "Noticia sobre a vida e obras d'Antonio Gonçalves Dias", In: DIAS, Gonçalves. Poesias. Ed. cit., p. 27-32.
} 
maternal e filial; ambos luctavam com os mesmos presentimentos, que cautelosos se occultavam mutuamente.

Com a magoa no coração, que se lhe despedaçava fibra por fibra, com o presagio n'alma, que em vão procurava esquecer ou illudir, a mãi o vigiava constantemente. Vinha achal-o as mais das vezes escaldado pela febre do gennio que o devorava, com aquella cabeça ardendo-lhe como um vulcão, debruçado á secretária, dobrado sobre o papel ou curvado sobre os livros, compondo ou lendo á luz do candieiro das lucubrações, e entrando pelas longas horas da noite.

Reprehendia-o ella por causa de tam improbo estudo, pedialhe, instava com elle para que evitasse tam continuas vigilias e que fosse entregar-se á reparação de suas forças; obedecia elle, procurando tranquilisal-a, confessando-se habituado áquelle trabalho n'essas horas mortas e silenciosas que toda a cidade dormia cançada de suas lidas.

Uma noite a surpreza foi cruel para ambos: encontrou-o a mãi debulhado em pranto; e o papel a que entregára os intimos pensamentos de sua alma trahiu-lhe o presentimento de seu coração: eram paginas humedecidas pelas lagrimas, eram versos inspirados pelo amor filial!" 133

Todo o trecho é assinalado a lápis, com traço vertical e colchete. Entre as peças elegíacas abrigadas no exemplar das Obras, está outro texto que Mário destaca à margem e refere no ensaio para a Revista Nova, o "Discurso biographico do Bacharel M. A. Alvares de Azevedo recitado na quarta sessão solemne do Gymnasio Brasileiro pelo socio effectivo e primeiro secretario Domingo Jacy Monteiro". A passagem ficou marcada por colchete e pelo escólio "Amor e medo":

$$
\begin{aligned}
& \text { Amor } \\
& \text { e medo }
\end{aligned}
$$

"No dia 10 de março, do anno que corre para o seu termino, queixou-se M. A. A. de Azevedo pela primeira vez. Tudo the foi feito, e por alguns dias conservou-se no seu quarto, mostrando ledo o semblante quando qualquer se chegava a elle, e até gracejando e dando motivos especiosos da sua molestia. Sua mãi, que o não deixava, dice-lhe um dia que seu quarto era muito quente, e effereceuthe a sua cama. Parece que a fronte do mancebo carregou-se; sorriuse depois e recusou firmemente. - Talvez se lembrasse do sonho a seu respeito que sua mãi the contára (fôra no começo do anno) e do qual - cousa singular! - ella se esquecêra completamente até á sua ultima hora; mas uma esperança de vida bateu ainda n'aquelle coração de 20 annos!...

"Dias depois porém foi elle próprio quem instou para ir para a cama de sua mãi... E desde então não quiz arredar-se mais d'ahi; apenas tres dias antes do seu fallecimento conseguirão a custo tiral-o d'ahi por momentos, tendo elle dicto antes que desejava ficar n'essa cama até o fim, e tendo por mais de uma vez manifestado desejos de vêr certos objectos, respondendo, quando the perguntavão a razão, que era para poder vêl-os antes de se ir embora..." 134

\footnotetext{
${ }^{133}$ NORBERTO, Joaquim. "Notícia sobre o autor e suas obras lida em uma das sessões do Instituto Historico Brasileiro no anno de 1872”, In: AZEVEDO, Álvares de. Obras... Ed. cit., vol. 1, p. 44-5.

${ }^{134}$ MONTEIRO, Jacy. In: AZEVEDO, Álvares de. Obras... Ed. cit., vol. 1, p. 214.
} 
Mário encampa as duas narrativas - esta última e a de Joaquim Norberto - e cita os autores no corpo do ensaio. O caso de Jacy Monteiro é acrescido da explicação psicanalítica entre parênteses. A mãe de Álvares de Azevedo sonha com o filho morto, no leito dela; quando este adoece, ela the oferece a cama, esquecida do conteúdo premonitório: "(e é psicologicamente aceitável este esquecimento em consciência)"135.

$\mathrm{Na}$ edição de Casimiro de Abreu, o pesquisador do sequestro emprega o colchete em um trecho curto do "Prólogo" de Ramalho Ortigão. O que interessa a ele, de lápis em punho, é um aspecto do retrato psicológico de Casimiro esboçado pelo autor das Farpas: "A timidez adorável, que é sempre inseparável sócia do amor impetuoso em anos tenros, aqui está retratada com invejáveis tintas."136 Mário rejeita, no ensaio, o comentário de Ortigão. Mas o que ele refuta é a pertinência da observação, as invejáveis tintas, não o elo entre a poesia e o caráter do autor: "Não me parece. Casimiro de Abreu desvia o tema, pra se comprazer em quasi todas as lindas estrofes do "Amor e medo', em descrever com bastante vivacidade o que sucederia pra virgem si." ${ }^{137} \mathrm{O}$ emprego dessa interrupção abrupta, que define a aposiopese e representa pudor e censura, é um modo de o crítico encenar o sequestro no próprio texto do ensaio. A figura será usada à larga em Amar, verbo intransitivo. Ainda na seara do estilo - o parágrafo exclamativo, quase no remate de "Amor e medo", tempera a impregnação da crítica de viés biográfico no estilo e no raciocínio:

"Quer morrer, abusa mesmo do desejo de morrer, no caso de ajuntar a sua própria data mortuária na parede da pensão em que estavam escritos os nomes do quintanistas mortos. Porque morrer, si tudo o predispunha à vida! Porque tamanho tédio real, que a imitação dos europeus não é suficiente pra explicar! A não ser que the entendiasse a genialidade libérrima, tudo o que estava botando de falsificação em si mesmo e nas obras! Há várias constâncias e pormenores nos escritos de Álvares de Azevedo, que poderiam nos levar a suposições psicopatológicas que não me interessam aqui por serem apenas deste ou daquele indivíduo. Não têm o valor universal do tema do amor e medo, que é de todos." 138

A dialética das máscaras, defendida por Antonio Candido, vale como uma modulação importante para os argumentos apresentados em "Amor e medo". O tópico encabeça a unidade consagrada à segunda geração romântica, em Formação da

\footnotetext{
135 ANDRADE, Mário de. "Amor e medo", In: Aspectos da literatura brasileira. Ed. cit., p. 220. 136 ORTIGÃO, F. D. Ramalho. "Prólogo", In: ABREU, Casimiro. As primaveras. Ed. cit., p. VI.

${ }^{137}$ ANDRADE, Mário de. “Amor e medo", In: Aspectos da literatura brasileira.Ed. cit., p. 212.

138 IDEM, ibidem, p. 229 (grifei; negrito).
} 
literatura brasileira, mas pode ser estendida ao conjunto: 'Para os compreendermos, é através de máscaras que os devemos imaginar, mudando-as ao sabor das sugestões que deles vêm" ${ }^{139}$. Segundo a percepção mais nuançada, a obra literária comporta encenações, e a crítica não deve se basear tão crucialmente na vida dos escritores. Em outros termos, talvez a restrição essencial à abordagem proposta no ensaio seja que poeta e lírico $^{140}$ são identificados de imediato, como emanações da mesma psicologia. Há uma continuidade quase direta entre razões no plano biográfico e psicológico e consequências no plano da expressão poética ${ }^{141}$. Dois passos na marginália demonstram bem a justeza da percepção. O diálogo entre Macário e o Desconhecido conserva a anotação do leitor, mezzo modernista, mezzo romântico:

"O DESCONHECIDO.

Admira-me uma cousa. Tens vinte annos: deverias ser puro como um anjo e és devasso como um conego!"

Nota MA: "É o proprio poeta."

O comentário que toma a fala da personagem como descrição psicológica do poeta, segue na margem superior: "Porem A. de A. se conserva puro na alma imensamente. Um infantil." ${ }^{142}$ Em "Glória moribunda", o estudo da psicologia do sentimento amoroso comparece no comentário aos v. 69 e 70 - "Das virgens no cheiroso travesseiro / Porventura dormi... Meu Deus! que sonhos!". O leitor que analisa registra: “Notar que a libertinagem do poetaé uma libertinagem como que pura. Tem uma infantilidade real que comove, a deste candido devasso." ${ }^{143}$ Nos v. 106 e 107, a observação mais

\footnotetext{
${ }^{139}$ CANDIDO, Antonio. Formação da literatura brasileira: momentos decisivos, 1750-1880. Rio de Janeiro: Ouro sobre Azul; São Paulo: FAPESP, 2009, p. 465.

140 "Não desejo, nem de leve, sugerir nele qualquer incapacidade, des vio ou anormalidade afetiva, mesmo porque estou me referindo ao poeta que, em suas obras, fala na primeira pessoa, não ao homem Álvares de Azevedo, necessariamente.” IDEM, ibidem, p. 499.

${ }^{141}$ Pablo Simpson e Luiz Dantas adotam argumentos similares, em estudo sobre Castro Alves: "É através dessa dimensão teatral que se poderá entender, sem incorrer em risco, todas as personagens, citações e atributos populares, que se inserem, enquanto marcas, ao longo de sua poesia, seja ela abolicionista, amorosa, encomiástica ou de reminiscências.” (ALVES, Castro. Espumas flutuantes e Os escravos. Introdução, organização e fixação de texto Luiz Dantas, Pablo Simpson. São Paulo: Martins Fontes, 2001, p. XXXII) E também Vagner Camilo sustenta que "Amor e medo" tende a "desconsiderar a dimensão da convenção e da construção literárias em favor do psicobiografismo" ("Álvares de Azevedo, o Fausto e o mito romântico do adolescente no contexto político-estudantil do Segundo Reinado", In: Itinerários, n. 33. Araraquara: Unesp, 2011, p. 63).

${ }^{142}$ Nota MA, In: AZEVEDO, Álvares de. Obras. Ed. cit., vol. 3, p. 264.

143 Nota MA, In: IDEM, ibidem, vol. 1, p. 225.
} 
longa acrescenta o próprio crítico à teia de identificações. A percepção é equivale nte, embora vazada no interior dos parênteses e na forma interrogativa:

“(1) Quase todos os herois do poeta (ele?) sonham com a Gloria. I Bocage, Pedro Ivo ("glorias e liberdade")... Aqui A. de / A. atinge uma iluminação fecunda dizendo que a / gloria, o desejo de gloria foi o que fez a genialidade do / poeta. Gloria é a necessidade de subir sobre os homens. //Observar a estranha similitude que ha entre /isso e a necessidade-de-comunicação de que fa-llo em estetica. $O$ desejo de ser entre os homens, / o desejo de ser o Iluminador dos homens. Tudo / essencias de Amor." "144

Antonio Candido propõe que a personalidade literária romântica deve ser vista como "disponibilidade interior para o dramático"145. Será desnecessário investigar, em Álvares de Azevedo, a sinceridade do satanismo ou da libertinagem: "No fundo, a questão é secundária e pouco serve para esclarecer a sua poesia"146. O autor de $O s$ parceiros do Rio Bonito não descarta a análise psicológica para compreender o poeta. É com base nela que percebe as repercussões da adolescência na Lira dos vinte anos. Porém, não busca sintomas: aposta na compreensão de que "toda a ebulição onde se força por vezes dolorosamente a personalidade tem para o espírito um peso que independe do fato de corresponder ou não a causas e situações reais"147. A objeção quanto à abstinência sexual de Álvares de Azevedo - "não apenas sem importância, como de certa forma à margem do problema" - não impede que considere o estudo de Mário "o melhor e mais fecundo trabalho escrito até o presente sobre a psicologia dos românticos brasileiros" $" 148$.

Em linha diversa, João Adolfo Hansen também faz objeções à proposta de "Amor e medo". Defende que "os efeitos poéticos de angelismo e devassidão são lidos" pela crítica de viés biográfico "sem as mediações mais ou menos perversas dos lugarescomuns do mal do século, e Manoel Antônio ora é uma recalcada casta diva, ora um depravado Don Juan"149. O uso da psicanálise para o estudo de personagens literárias seria apenas verossímil - "Seres de papel são puramente funcionais, não são passíveis de juízos de existência, desconhecem o real do desejo". De resto, Hansen recusa como fútil o projeto de recorrer à psicanálise no intuito de buscar nas figurações da poesia a

\footnotetext{
${ }^{144}$ Nota MA, In: IDEM, ibidem, vol. 1, p. 227-8 (grifei; negrito).

145 CANDIDO, op. cit., ed. cit., p. 494.

146 IDEM, ibidem, p. 495.

147 IDEM, ibidem, p. 496.

148 IDEM, ibidem, p. 496.

${ }^{149}$ HANSEN, J. A. "Forma Romântica e Psicologismo Crítico", In: CUNHA, Cilaine A. op. cit., p. 10.
} 
psicologia do homem-autor, pois essa perspectiva não considera "a própria convenção poética como ficção ou metáfora do fingimento poético do erotismo".

Fato é que o biografis mo esposado no ensaio de 1931 não é desprovido de um largo chão histórico. José-Luis Diaz, analisando a razão biográfica na crítica literária francesa, narra o interesse crescente pela vida dos autores, intensificado decisivamente a partir do romantismo. A sagração do escritor, conforme a tese de Paul Bénichou, e a literatura do $e u$ coincidem com o movimento análogo por parte do público - curioso cada vez mais por anedotas privadas, em busca da identificação doméstica com o autor do texto literário. Desde a primeira metade do século XVIII - "era das minúcias" -, os críticos passam, avidamente, a reunir dados biográficos. Os elogios acadêmicos dedicam-se a erguer o busto dos homens de letras ${ }^{150}$, e a atenção ao interior, à alma dos autores, aumenta em paralelo. O relato de idiossincrasias contribui para as mitologias em torno do gênio. Manuscritos passam a ser objeto de culto. A infância converte-se em matéria de interesse, ensejando a narrativa do escritor precoce, ou o seu contrário. A tendência desenvolve-se a tal ponto que o XIX será "um século de biografias", seguindo a fórmula de Sainte Beuve. Reagindo à crítica retórica e normativa, o paradigma biográfico continha àquele tempo a promessa de atingir o "coração palpitante da criação"151. Prejudicou-se a autonomia estética das obras, adverte Diaz, em meio à constituição de quatro sistemas: a biografia erudita, minuciosa, voltada ao elogio da virtude; aquela proposta pela escola doutrinária, que realça o homem como centro da obra; o ideal romântico, identificando o biógrafo e seu modelo, "escrita apaixonada da vida de um outro eu"152; enfim, os retratos de Sainte Beuve, que ajuntam ao estudo do estilo os traços da personalidade, dirigindo-se mais à psicologia do que à biografia. Segundo Diaz, ao focalizar na crítica a infância e juventude dos escritores, Sainte Beuve antecipa Freud: busca o homem antes da construção social da personalidade. ${ }^{153} \mathrm{O}$ crítico das causeries acredita que o caráter original se desenha de

\footnotetext{
150 "Ce n'est pas l'homme réel qu'on va désormais chercher derrière l'homme de lettres ou le philosophe, mais sa figure statufiée." DIAZ, José-Luis. L'homme et l'oeuvre - contribution à une histoire de la critique. Paris: Presses Universitaires de France, 2011, p. 47.

151 “...la critique biographique a pu apparaître comme une drogue nouvelle, comme une quête passionée et illicite, qui devait mener - enfin! - au coeur palpitant de la création..." IDEM, ibidem, p. 104-5.

152 "Le modèle de la biographie romantique proprement dite implique non seulement prise en compte du biographique mais aussi relation de sympathie profonde entre le biographe et son modèle. (...) il faut tout au contraire que se dessine un lien de nature quasi amoureuse entre ce 'poète' dont on narre la vie et cet autre poète en prose qui tente de comprendre cette autre vie au moyen de la sienne." IDEM, ibidem, p. 146.

${ }^{153}$ IDEM, ibidem, p. 164.
} 
imediato, de uma vez por todas (o que rima com a nota de Afrânio Peixoto sobre Castro Alvez rapazola, contra o uso tirânico da palmatória). Embora tenha perdido prestígio, com a ascensão da prosa realista e da poesia parnasiana, o biografismo manteve sua força na edição, na imprensa e no ensino - informa Diaz. Algo do grande crítico francês - focalizado no caráter, na fisionomia do autor - ecoa, mesmo que distante, nos retratos psicológicos desentranháveis do ensaio e da marginália de Mário de Andrade.

A ideia do "Amor e medo" como tema da poesia romântica deixa vestígios explícitos de seu surgimento na marginália. O poema "Meu Segredo", de Castro Alves, ajuda a situar, quanto à investigação do sequestro amoroso, uma ordem para a redação das notas de margem, segundo a qual o poeta das Espumas flutuantes estaria em posição intermediária, antecedido por Casimiro e Álvares de Azevedo, e acompanhado depois por Gonçalves Dias e Varela:

"Sagra ao menos uma hora em tua vida
Ao pobre que sagrou-te a vida inteira,
Que em teus olhos, febril e delirante,
Bebeu de amor a inspiração primeira,
Mas que de um desengano teve medo,
E guardou dentro d'alma o seu segredo!

Nota MA:

"(1) O tema de "Amor e Medo" afinal está como tema universal romântico no Romantismo brasileiro. Este platonismo assustado éo mesmo de Casimiro e de A. de Azevedo. Não me lembro se Fagundes Varella e G. Dias o glosaram também. (Procurar isso)." 154

Uma vez identificada a recorrência do tema, Mário de Andrade busca a explicação lógica. Encontra-a na precocidade das mortes. A razão histórica, "epidemia de suicídios", determina que os poetas tematizem a experiência da mocidade - razão biográfica. Entre os fantasmas que assombram os rapazes, o medo de amar tem lugar de destaque - aqui, agrega-se portanto a justificação psicológica. A tríade é esboçada fora da marginália, a posteriori, e o manuscrito, no ponto específico em que relaciona o sequestro amoroso e o respeito à mulher, transparece o pensamento hesitante: "Do tema 'Amor e Medo' decorre ou ele des o Respeito á Mulher, ou êste aquele dêste.."155

Se a frase rasurada insinua a via de mão dupla, ao articular medo e respeito, sugere o raciocínio ainda incipiente no momento de concatenar o material - ou, quiçá, o ensaio sequestre a incerteza do crítico no que tange ao encadeamento lógico. $\mathrm{O}$ lastro

${ }^{154}$ Nota MA, In: ALVES, Castro. op. cit., ed. cit., vol. 1, p. 55.

155 Arquivo IEB-USP. Fundo Mário de Andrade. Código MA-MMA-26-04. 
argumentativo é baseado nos sintomas diagnosticados através da poesia. O que é interessante e de modo algum simplificador é a combinação de elementos formais e psicológicos, sendo que a própria forma traduz a psicologia do criador. É assim, por exemplo, que a variedade formal de Gonçalves Dias, o apuro técnico, trabalho rigoroso da estrutura, indica a criação insincera, muito menos apoiada na manifestação do eu profundo do que resultado do trabalho de artista. Em outros momentos, como em Casimiro de Abreu, Mário percebe o defeito de fatura como resultado expressivo - não intencional, em consciência - fruto do lirismo transbordante, sincero. "Minh'alma é triste", com suas margens cobertas de notas, suscita o comentário:

"Foram-se as flôres - a minh'alma é triste!

Nota MA:

"Este poema é das mais líricas e exatas expressões do romantismo universal. É maravilhoso. Notar na $4^{a}$ parte a dor arrebentada que fazo poeta perder aquela sua amabilidade comum, a feminilidade da sua imagem pra caracterizar a sua tristeza pelo jeito da araponga. E daí em seguida a dor novamente, rarissima no poeta quase que transborda. E o leva tambem a licenças poéticas, dantes não vindas no poema, como si a ardencia do sofrimento não permitisse mais a preocupação de factura.",156

Paul Dermée apresenta sua concepção de lirismo em dois artigos na revista L'Esprit Nouveau: "Poésie = Lyrisme + Art" e "Découverte du lyrisme". ${ }^{157}$ Em "Poésie = Lyrisme + Art", sustenta: "Le lyrisme est un flux jailli du plus profond de notre être dans notre conscience; il est normal et se répand plus ou moins souvent, avec plus ou moins de force, en chacun de nous." 158 Mário destaca o trecho, inscrevendo o mote em francês, "Qu'est-ce que le lyrisme”. A ideia platônica segundo a qual o poeta não pode

\footnotetext{
${ }^{156}$ Nota MA, In: ABREU, Casimiro de. op. cit., ed. cit., p. 124.

157 Lilian Escorel analis ou a marginália de Mário na revista fundada por Le Corbusier e Amédée Ozenfant em 1920, dedicando-se à importância da publicação para as ideias estéticas e poéticas do autor de Macunaíma: A revista L’Esprit Nouveau nas estantes de Mário de Andrade. São Paulo: Humanitas/FAPESP, 2011. Ao examinar as anotações de margem em "Découverte du lyrisme", a autora toca em dois aspectos essenciais para o argumento deste ensaio, o par conceitual de Paul Dermée e a simultaneidade nas tarefas do crítico/poeta/autor de poéticas: "Na mesma p. 37, as notas [de MA], '(1) Alors je peux bien dire qu'une femme est plus haute que les tours de São Bento!' e 'Tudo is to é lirismo. Não é ainda poesia.', uma presa ao poema de Pauliceia desvairada e a outra à poética em A escrava que não é Isaura, materializam, em um momento, provavelmente dezembro de 1920, a criação simultânea da poesia do artista e a poética moderna do teórico Mário de Andrade.” op. cit., p. 83 (sublinhei).

${ }^{158}$ DERMÉE, Paul. "Poésie = lyrisme + art", In: L'Esprit Nouveau, a. 1, no 3, p. 327. Além dos dois artigos, Mário indica Jean Epstein ("Fenômeno literário"; no 8-13) e Paul Dermée ("Sons e sentidos", $n^{\circ}$ 5, e "Panliris mo", $\mathrm{n}^{\circ}$ 28) como referências para o conceito de liris mo, em documento no fichário analítico (Arquivo IEB-USP. Fundo Mário de Andrade. MA-MMA-48-3536).
} 
obedecer à razão, ou não terá versos a cantar, é sublinhada, e o escólio "Mots de Platon"159 acompanha o período. Mário recupera a "douce foureur" em A escrava que não é Isaura - não só com base em Dermée, está claro - para reconhecer e postular a renovação da sacra furia ${ }^{160}$. A dimensão psicológica e irracional do lirismo é também sublinhada por ele, no mesmo "Poésie = lyrisme + art", na revista: "Ce qui permet le jaillissement du flux lyrique, c'est ou bien un affaiblissement de l'activité rationelle ou un renforcement de l'activité irrationelle." 161 O contraste com a inteligência, embora sem anotações, merece citação: 'Il n'en est rien et rien n'oblige le poète à être bête. Ce qui importe seulement, c'est que le contrôle rationnel puisse être supprimé à certains moments. Ce qui se passe avant ou après n'affecte en rien le lyrisme."162 No dossiê do manuscrito Amor e medo, a poesia romântica é analisada com esse enfoque:

"O que torna A. de A. muito mais interessante que os outros românticos é que nele a reação intelectual é constante quer sob o ponto-de-vista artístico quer sob o de pensamento. Nossos grandes românticos Gonçalves Dias, Castro Alves, Varela, Casemiro de Abreu, foram o que se pode chamar poetas eminentemente burros. Mesmo as 'intenções' que levaram C. Alves ao seu abolicionismo deram reações líricas puramente sentimentais. A. de A. nos desperta constantemente a percepção da inteligência. Nos outros a reação intelectual desaparece. Em A. de A. como ele mesmo falou 'a inteligência é como o óleo, sobrenada a tudo'.”163

A burrice atribuída aos poetas do romantis mo tem como apoio, portanto, os elementos que compõem a fórmula de Dermée: repercute a oposição entre inteligência e expressão do fluxo lírico. A escrava que não é Isaura também rende homenagem a esse raciocínio. ${ }^{164}$ Nas páginas da revista francesa, a conceituação de criador é escoliada:

\footnotetext{
159 “Le poète, dit Platon, est chose légère, volage et sacrée; il ne chantera jamais sans l'intervention d'un transport divin, sans une douce fureur. Loin de lui la raison; dès qu'il veut lui obéir, il n'a plus de vers, il n'a plus d'oracles..." Nota MA, In: IDEM, ibidem p. 327.

160 "Assim pois a modernizante concepção de Poesia que, aliás, é a mesma de Adão e de Aristóteles e existiu em todos os tempos, mais ou menos aceita, levou-nos a dois resultados - um novo, originado dos progressos da psicologia experimental; outro antigo, originado da inevitável realidade: $1^{\circ}$ : respeito à liberdade do subconsciente. Como consequência: destruição do as sunto poético. $2^{\circ}$ : o poeta reintegrado na vida do seu tempo. Por is so: renovação da sacra fúria." ANDRADE, Mário de. "A escrava que não é Isaura", in: Obra imatura. São Paulo: Livraria Martins, 1960, p. 224.

${ }^{161}$ DERMÉE, Paul. "Poésie = lyrisme + art", In: L’Esprit Nouveau. Ed. cit., p. 328.

162 IDEM, ibidem, p. 328.

163 Arquivo IEB-USP. Fundo Mário de Andrade. Código: MA-MMA-05-24.

164 “O poeta, habituado a deixar-se levar pelo eu profundo tão dependente do estado físico, consegue à medida do possível, já se vê, grafar certos instantes de vacuidade em que há como que um eclipse quase total da reação intelectual." ANDRADE, Mário de. "A escrava que não é Is aura”, In: Obra imatura. Ed. cit., p. 255.
} 
"Dans la création esthétique, je ne sais quel élément est le plus puissant et le plus précieux: l'intelligence de l'artiste et son jugement ou son inspiration et son goût. Un créateur - et surtout un poète c'est une âme ardente menée par une tête froide."

Nota MA: "créateur (définition)"

Em "Découvrerte du lyrisme", o escritor belga vê o lirismo como canto da vida profunda - "instintiva, afetiva e passional". A lápis, Mário exclama: "Je le crie en moimême il y a longtemps!"165 Em outros dois passos é posssível ver nitidamente a concepção/matriz que baliza o olhar do autor de Losango cáqui. Entre as conclusões estéticas do artigo, consta que o lirismo tem como antagonista a inteligência. No entanto, Paul Dermé afirma que ambos podem se conjugar em estados psicológicos complexos. A ressalva alegra e redime Mário de Andrade, que se reconhece na file ira dos poetas modernos. Interessa, enfim, referir uma frase do artigo com implicações fecundas para a marginália: "Dans le lyrisme, la personnalité de l'homme se confesse." 166

No "Prefácio interessantíssimo", a equação de Paul Dermée é recomposta na ordem inversa: arte + lirismo $=$ poesia. $\mathrm{A}$ arte representará a correção da sentimentalidade romântica, que brota espontaneamente e carece ser lapidada:

"A inspiração é fugaz, violenta. Qualquer empecilho a perturba e mesmo emudece. Arte, que, somada a Lirismo, dá Poesia, não consiste em prejudicar a doida carreira do estado lírico para avisá-lo das pedras e cercas de arame do caminho. Deixe que tropece, caia e se fira. Arte é mondar mais tarde o poema de repetições fastientas, de sentimentalidades românticas, de pormenores inúteis ou inexpressivos." 167

Lirismo é definido também, no prefácio-manifesto do desvairismo, como "estado afetivo sublime, vizinho da sublime loucura". A censura descoberta por Freud põe em risco a espontaneidade da criação ${ }^{168}$, mas o autor se jacta: Dom Lirismo sabe passar as sedas, nos versos de Pauliceia, sem pagar tributo à fiscal. A marginália na poesia do romantismo apóia-se na assimilação dessas ideias, que explicam o título do livro

165 Nota MA, In: DERMÉE, Paul. "Découverte du lyrisme”, In: L'Esprit Nouveau, n 1, p. 34.

166 IDEM, ibidem, p. 35.

167 ANDRADE, Mário de. "Prefácio interessantíssimo", in: Poesias completas. Edição de texto apurado, anotada e acrescida de documentos por Tatiana Longo Figueiredo e Telê Ancona Lopez. Rio de Janeiro: Nova Fronteira, 2013, vol. 1, p. 63.

168 A marginália no exemplar de L’Esprit Nouveau não as sinala o rodapé de Paul Dermée, de onde Mário extrai a afirmativa do "Prefácio interessantíssimo": “1) Freud a montré l'existence d'un autre contrôle à la sortie du subconscient. Il l'a appelé 'censure', mais aujourd'hui, il l'aurait baptisé sans doute 'centre de camouflage psychique'." DERMÉE, Paul. "Poésie = lyrisme + art”, In: L’Esprit Nouveau, no 3, p. 34. 
inacabado e a insistência com que Mário qualifica os autores como líricos. Em nota de trabalho para o Lirismo romântico no Brasil, afirma:

"Os nossos românticos foram na realidade mais propriamente líricos que poetas. (Chamá-los durante todo o livro de líricos em vez de poetas). Digressão sobre o que é o poeta. No poeta além do expositor de sentimentos (que podem até ser vulgares e corriqueiros) tem o artista que modela esses sentimentos. Os nossos românticos não foram artistas. (Justificam-se por que não quiseram ser artistas, pelo menos Álvares de Azevedo que por certas referências na sua obra, (dá-las), demonstra que estava enfronhado da arte de fazer versos.) Realmente só G. Dias foi artista e artista grande. Castro Alves pretendeu sê-lo porém foi mau artista, antes artífice, adquiriu uns tantos preconceitos formais, ideativos e de exposição de pensamento, repetição de palavras, ideias geminadas, antíteses, condoreirismo etc. Ainda pra ser poeta carece não esquecer que o homem além do sentimento tem a inteligência. A função da inteligência no poeta. Embora receando os paralelismos fáceis e aparentemente paradoxais estou tentado a afirmar que a diferença que tem entre o poeta e o prosador no sentido psicológico destes seres é que o poeta é um sentimento servido pela inteligência e o prosador é uma inteligência servida por um sentimento. (Ou o poeta é uma cabeça a serviço dum coração e o prosista um coração a serviço duma cabeça, ou o poeta é um sentimento expresso com inteligência e o prosista uma inteligência expressa com sentimento.) Fazer notar como por um conceito psicológico de poeta e de prosador desaparece a aparência formalista que fazia de verdadeiros prosadores poetas porque tinham metrificado. Em José de Alencar tem capítulos que são positivamente poesias. Ora os nossos românticos, com a exceção ainda e sempre de Álvares de Azevedo, se esqueceram de que tinham cabeça quando compuseram os versos deles. Mesmo G. Dias. C. Alves então, que tomou tão honrosa parte ativa no momento histórico da escravidão era um homem sem ideias, que agiu nos seus poemas com sentimento e sem o que se chama propriamente pensamento, associação de ideias abstratas sobre escravidão, estudo (Livro e América) etc. A prosa é que agia metaforicamente, pela imagem. Descrevia, contava historias (Navio Negreiro, Os escravos) pra comover e convencer pela comoção."169

Não será imaginoso demais tomar a marginália de Mário na poesia do romantismo, em parte, como elaboração de retratos psicológicos, ancorado na ideia de que o lirismo expressa as instâncias profundas/inconscientes do sujeito. Muitas notas consistem no estudo da psicologia, ao mesmo tempo em que frisam aspectos de estilo e traçam o panorama mais largo da literatura brasileira. Ligam-se, pois, aos dois projetos de meados da década de 1920, a História crítica da poesia brasileira e o Lirismo romântico no Brasil. É possível que a síntese das feições psicológicas falseie

${ }^{169}$ Arquivo IEB-USP. Fundo Mário de Andrade. Código MA-MMA-26-05 (grifei; negrito). 
um pouco o movimento de interpretação e pareça caricatura - dos autores perfilados e do conteúdo da marginália. Para avançar na apresentação das linhas mestras da marginália, explicitando o que diz respeito aos elementos biográficos e psicológicos, talvez o risco tenha serventia.

Mole e adorável cantor dos trópicos, Casimiro de Abreu será, na marginália, o poeta de doçura incomparável. Em seus versos, ressaltam a ternura infinita e o lirismo abundante. A indolência do índio - "Se embala o índio indolente", conforme canta em "Minha terra" 170 - é a própria indolência dele, prova de brasileirismo psicológico. Ao colocar o sabiá na laranjeira, conserta a "Canção do exílio" de Gonçalves Dias: enquanto este criava como artista, Casimiro via. Em outros poemas, ao enfatizar as cores, como se fosse "só olhos", o autor d'As primaveras faz Mário se perguntar se Casimiro não seria um "visual" - aquilo que se vê é mais fácil de cantar. Doce e terno, também sabe ser pernóstico, chato, didático, e nisso revela o pensamento indigente.

Castro Alves, informam as notas de margem, é um lírico esplêndido: nos estribilhos, foi grande artista e legítimo poeta. Exibe a dolência dengosa, o bambolear maxixeiro e o mulatismo sadio, franco, ingênuo. Enorme no lugar-comum, e de posse de uma lira de poucas cordas, seu lirismo escachoante e vívido mostra a denguice, a languidez pegajosa, o amor encostado. Estes traços dele são tidos como encarnações do entusiamo fácil e ingênuo popular. Ele é o rastaquera da imagem. Moderno nos qualificativos, o autor de "O Navio negreiro" é também um precursor de tudo. Discursador eloquente, ele não soube pautar o tamanho de suas poesias, preenhes de comparações e antíteses que sinalizam seu caráter de artífice e virtuose.

O retrato de Álvares de Azevedo, gravado na marginália, é do jovem de estranha erudição para a idade. Dotado de alta nobreza de pensamento, sua obra revela o lírico do tédio e da amargura. A impertinência pretensiosa do rapazola é observada em Litteratura e Civilisação em Portugal, mas é também ela, quem sabe, que fez com que atingisse as grimpas no começo da Noite na taverna. Foi o temperamento mais crítico do nosso Romantismo, o mais inteligente e o mais romântico dos nossos românticos. Na prosa, soube ser mais viril, enérgico e artista do que na poesia. Tudo se dava, para ele, em função do eu interior. Não era precoce nem anormal, tinha 20 anos dos mais normalíssimos. Mário encontra na obra de Azevedo um rir desabusado e um dar de ombros que torna tudo leve.

${ }^{170}$ Nota MA, In: ABREU, Casimiro. As primaveras. Ed. cit., p. 14. 
Gonçalves Dias foi um romântico da pior espécie, romântico de escola, à portuguesa. Poeta de inteligência, consciente em excesso, não foi sincero e franco à brasileira como os outros. Muito baladoso, o mais musical dos nossos poetas: assim a marginália constroi seu perfil. A tristeza calma, regrada e discreta - parnasiana mesmo confirma o grandíssimo artista e erudito. A riqueza artística dele foi muito superior à dos outros românticos. Único deles mais aproximadamente arte-pura. Demonstra ainda a secura realista de pensamento.

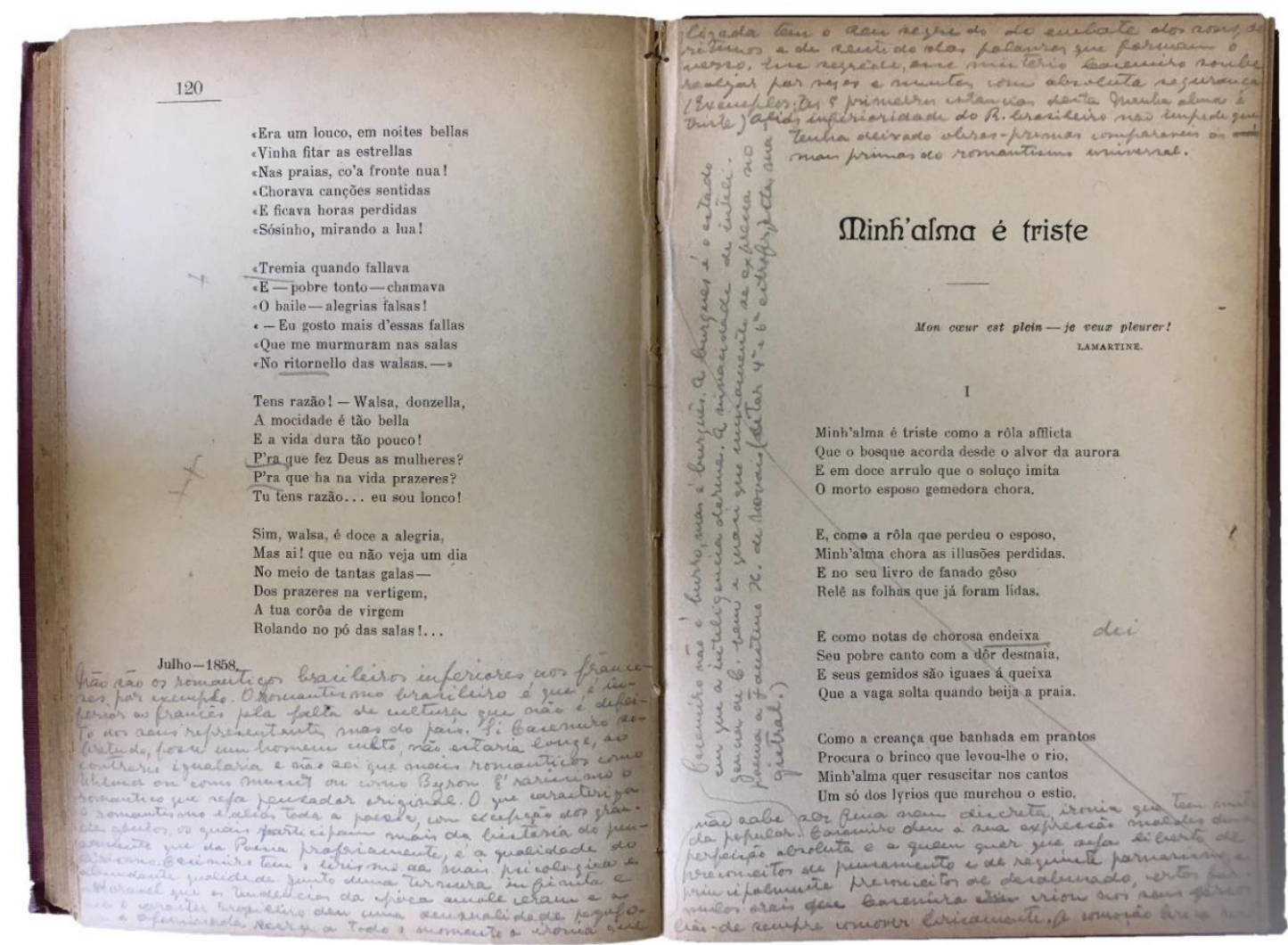

Figura 4

Fagundes Varela é pesadão nas passagens de amargura e tédio, embora mais rico de assunto que os outros. Não passa sem cascatas, torrentes espumosas, regatos, água. Teve uma compreensão verdadeira da natureza - amor tamanho que ofez igualála à mulher amada. Paupérrimo de imaginação e de saber, mesmo descrevendo a paisagem natural, o que vale nele é a infinita doçura do seu verso, porventura o mais doce verso-livre. No tratamento da religião, é carente de força intelectual, raciocínio de inteligência ou verificação de cultura; denota um sensualismo absoluto e pouco consistente. Foi o mais liederesco dos nossos românticos. Em passos raros, como em 
"Mimosa", é um delicioso contador de natureza e costumes brasileiros. Acha na sua miséria expressões formidáveis. Foi um falso descritivo por fazer pintura de ateliê, em vez de pintar d'après nature.

Na margem d'As primaveras, o retrato de Casimiro de Abreu é pintado em meio ao paralelo entre o romantismo brasileiro e o francês. Rasgos de estilo são articulados à posição de classe - como no estudo de Álvares de Azevedo, tido como espírito aristocrático nos artigos no Diário Nacional - e coincidem, na crítica ao tipo burguês, com a caracterização proposta por Mário para o personagem Carlos, de Amar, verbo intransitivo $^{171}$ :

"Não são os românticos brasileiros inferiores aos franceses por exemplo. O romantismo brasileiro é que é inferior ao francês pela falta de cultura que não é defeito dos seus representantes mas do país. Si Casemiro sobretudo, fosse um homem culto, não estaria longe, ao contrario igualaria e não sei que mais românticos como Uhland ou como Musset ou como Byron. É raríssimo o romântico que seja pensador original. O que caracteriza o romantismo e aliás toda a poesia, comexcepção dos grandes gênios, os quaisparticipam mais da história do pensamento que da Poesia propriamente, é a qualidade do lirismo. Casimiro temo lirismo da mais psicológica e abundante qualidade. Junto duma ternura infinita e adorável que as tendências da época amoleceram e a que o caráter brasileiro deu uma sensualidade pegajosa e afeminada. Realça a todo momento a ironia que não sabe ser fina nem discreta, ironia que tem muito da popular. Casimiro não é burro, mas é burguês. A burguesia é o estado em que a inteligência dorme. A vivacidade de inteligência de Casimiro bem e quasi que unicamente se expressa no poema a Faustino X de Novais (citar quarta e sexta estrofe, esta magistral.) Casemiro deu à sua expressão moldes duma perfeição absoluta e a quem quer que seja liberto de preconceitos de pensamento e de requinte parnasiano, e principalmente preconceitos de desabusado, certas fórmulas orais que Casemiro criou nos seus versos hão-de sempre comover liricamente. A comoção lírica realizada temo seu segredo do embate dos sons, de ritmos e de sentidos das palavras que formamo verso. Esse segredo, esse mistério Casemiro souberealizar por vezes e muitas com absoluta segurança (Exemplos: as 5 primeiras estâncias desta Minha alma é triste) Aliás inferioridade do

\footnotetext{
${ }^{171}$ Em carta aberta publicada por Mário de Andrade no Diário Nacional, em 4 de dezembro, 1927, as explicações pessoais do autor consideram a composição da personagem: "Carlos não passa de um burguês chatís simo do século passado. Ele é tradicional dentro da única cousa a que se resume até agora a cultura brasileira: educação e modos. Em parte enorme: má educação e maus modos. Carlos está entre nós pelo incomparavelmente mais numeroso que inda tem no Brasil de tradicionalismo 'cultural' brasileiro burguês octocentista. Ele não chega a manifestar o estado biopsíquico do indivíduo que se pode chamar de moderno. Carlos é apenas uma apresentação, uma constatação da constância cultural brasileira." ANDRADE, Mário de. “A propósito de Amar, verbo intransitivo. 1927”, In: Amar, verbo intransitivo. Ed. cit., p. 148 e 149.
} 
$R$. brasileiro não impede que tenha deixado obras-primas comparáveis às mais primas do romantismo universal." ${ }^{172}$

Desentranhados dos volumes de cada autor, onde se compõem de modo esparso, os perfis autorais também se acham em um bonito retrato de grupo, que infelizmente exclui Varela. Situado nas "Páginas de Penseroso", cujas margens são inteiramente preenchidas a lápis por Mário de Andrade, o comentário sintetiza a tristeza, o sentimento amoroso, a sensibilidade em face da paisagem natural, e a idealização perniciosa, no entender do crítico:

“(1) O que principalmente se nota na tristeza justificável dos nossos românticos é um desejo puramente desperdiçado de amar o amor mais do que amar a vida em si. Enaturalmente um amor ideal. Uma raiva amatória mal-empregada, tão! desconhecendo inteiramente os direitos, a necessidade, a realidade, a própria vitalidade da vida. Dizer que angustiosa monstruosidade da nossa natureza nos faz tristes não basta pra justificar a tristeza dos nossos românticos. Pelo contrário, embora essa monstruosidade pudesse atuar inconscientemente, os românticos sobrepujaram facilmente esse efeito pela ilusão sentimental e pelo entusiasmo com que viramo Brasil com a aparência voluptuosa dum Eldorado benfeitor. Só Álvares não o viu assim. Os nossos românticos com a exceção de G. Dias, o próprio Castro Alves foram insensiveis á natureza. E no próprio G. Dias si pela persistência com que a natureza penetra-lhe a obra se percebe que amou e gosou a natureza, quando a vê como pátria a intelectualiza e quando a vê como universo a lava, a seca e a beneficia segundo os mais idealistas processos românticospara the dar milhor cheiro, milhor cor e milhor corpo pra que possa atingir bom tipo e boa classificação no mercado romântico. A tristeza dos nossos românticos si viesse dofundo tradicional da terra e do homem apenas seria compensada pelo entusiasmo e pela visão cega. A grande tristeza deles foi devido ao total desprezo da vida, ao esquecimento da vida, trocada totalmente pela mania de ideal à força e principalmente do amor. Amadores de aura <ilegível> rimaram-na necessariamente com vertigem. Vertigem de forças, de corageme de visão larga. Os mais animosos procuraram ainda evitar essa vertigeme saldar a desilusão. Álvares de Azevedo quis esquecer-se na saturnal e encontrou tédio. Castro Alves quis esquecer-se no trabalho social e fez bulha e muita bulha. Os outros dois grandes foram incapazes de realizar dentro da vida. Casimiro medroso caiu no saudosismo mais pífio embora admiravelmente caracteristico. G. Dias direi pelo metodo psicanalista que sublimou o amor de amar, amar a mulher <ilegível, página cortada>maior sinão único do grupo e verdadeiro e integral Poeta. Porque os outros foram líricos mais que poetas e Castro Alves na grande maioria das obras mais artifice e virtuose que poeta.",173

${ }^{172}$ Nota MA, In: As primaveras. Ed. cit, p. 120 e 121.

173 Nota MA, In: AZEVEDO, Álvares de. Obras. Ed. cit., vol. 3, p. 320. 
Cortando e costurando os fragmentos, os retratos perdem um pouco em verdade, entendida como correspondência ao movimento de crítica realizado por Mário de Andrade. Será mais proveitoso consultar as notas na segunda parte do trabalho, para ver como os critérios se combinam: lirismo e arte conceituados em diálogo com Paul Dermée e o constante interesse pela sinceridade.

\title{
Sinceridade total
}

Ao estudar a obra de Mário de Andrade, Anatol Rosenfeld sustenta que a estilização linguística intentada pelo escritor paulistano, de modo a exprimir a entidade nacional, não se reduziu a um problema de ordem estético-literária, nem foi expressão de nacionalismo supra-regional e cosmopolita. Trata-se do "problema mais íntimo da descoberta da própria identidade através da procura da identidade nacional":

\begin{abstract}
"A busca de Mário e do Modernismo, como de todo movimento de acentuadas tendências irracionalistas, orientado pelo ethos da libertação de regras convencionais e da revolta contra o espírito coletivo prevalecente é a da sinceridade, da auto-expressão imediata, elementar, espontânea." 174
\end{abstract}

A escrava que não é Isaura contém numerosos pontos em que a sinceridade é proposta como valor/critério da criação poética. A parábola inicial relata imaginosamente a proeza do jovem Rimbaud, que liberou a poesia de seus ornamentos aparatosos - "sedas, setins, chapéus, joias, botinas, máscaras, espartilhos...". Com um chute, o autor do Bateau ivre devolveu-a à simplicidade original: "Tudo desapareceu por encanto. E o menino descobriu a mulher nua, angustiada, ignara, falando por sons musicais, desconhecendo as novas línguas, selvagem, áspera, livre, ingênua, sincera."175 A metáfora de nudez da musa poética, isto é, de uma poesia livre dos preconceitos de forma, é associada aos pudores de vestimenta, que correspondem à moral de policiamento dos corpos: "Pois não há de causar estranheza tanta pele exposta ao vento à sociedade educadíssima, vestida e policiada da época atual?"176 No

\footnotetext{
${ }^{174}$ ROSENFELD, A. "Mário e o cabotinismo", In: Texto/Contexto I. São Paulo: Perspectiva, 1996, p. 187.

${ }^{175}$ ANDRADE, Mário de. "A escrava que não é Isaura”, In: Obra imatura. Ed. cit., p. 202. A alegoria na capa da revista do futurismo Poesia, mostra-se como matriz da parábola de MA.

176 IDEM, ibidem, p. 202.
} 
"Discurso sobre algumas tendências da poesia modernista", o autor coloca-se contra os enigmas de Mallarmé, belos como fatura, mas escassos de "lirismo e sentimento". Recusado pelo "aspecto de coisa falsa" e "preciosismo" que tem sua obra, o autor do Coup des dés é "muito pouco aceitável para a sinceridade sem vergonha dos modernistas" "177. A incitação de Verlaine, a torcer o pescoço da eloquência, também merece descarte: é ideia que não preocupa mais "a sinceridade do poeta modernista"178. Os contemporâneos, para Mário de Andrade, são "poetas sinceros, que sem mentiras nem métricas, refletem a eloquência vertiginosa da nossa vida"179. Eles empreendem um verdadeiro trabalho de construção, "todos irmanados por um mesmo ideal de aventura e sinceridade, escoteiros da nova Poesia!"180

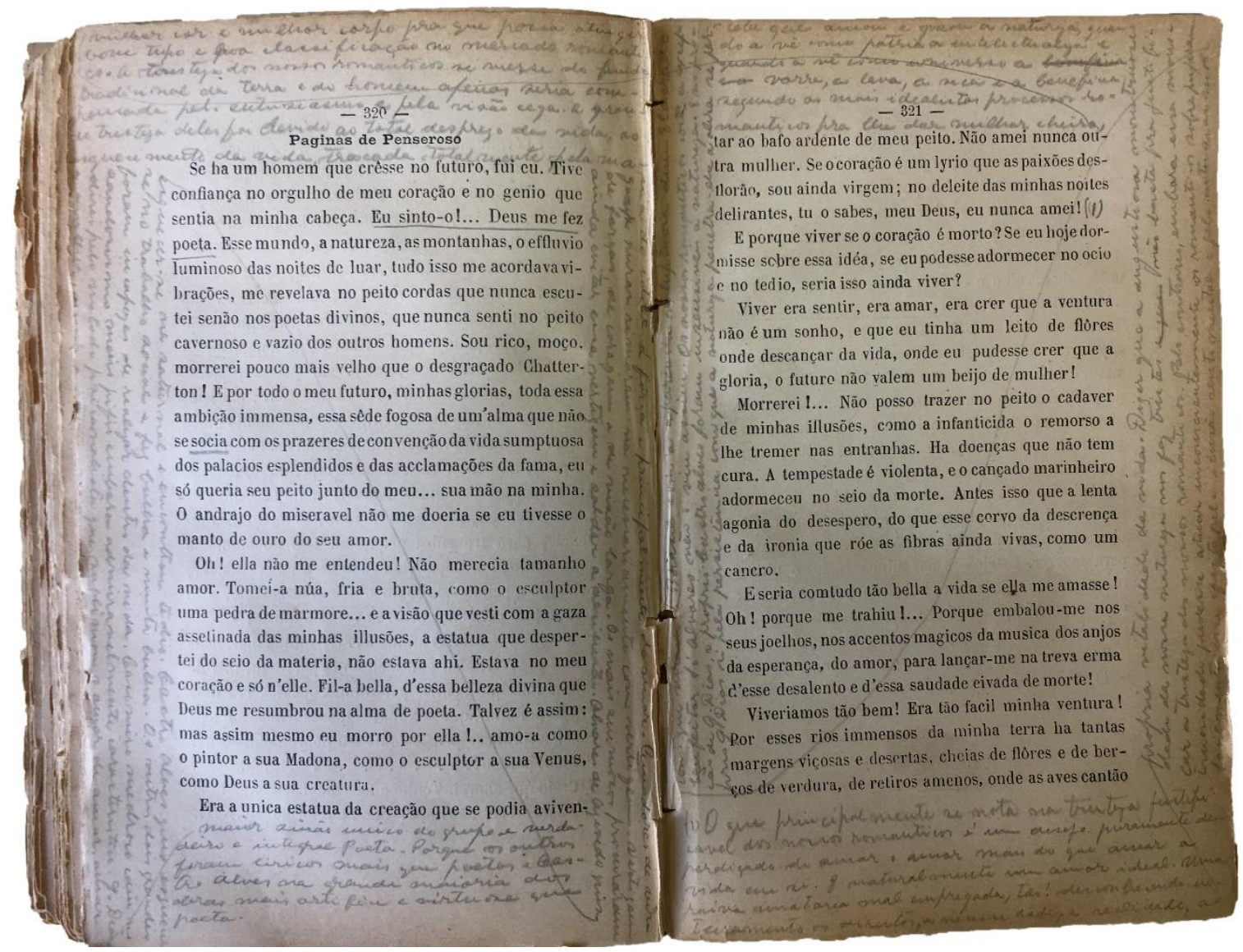

Figura 5

\footnotetext{
177 IDEM, ibidem, p. 282.

178 IDEM, ibidem, p. 220

179 IDEM, ibidem,p. 223. Mário regis tra o comentário sobre a acepção do adjetivo, encontrado na "Carta sobre a actualidade do theatro entre nos": "Vertiginoso não quer dizer rápido pra A. de A. Quer dizer incerto, intercadenciado, cheio de vertigens. Na p 220, como aqui, essa é a acepção de vertiginoso." Nota MA, In: AZEVEDO, Álvares. Obras. Ed. cit., vol. 3, p. 240.

${ }^{180}$ IDEM, ibidem, p. 274.
} 
Tendo sempre a sinceridade como chão, conforme se vê, o caminho propositivo d'A escrava trata do emprego da associação de imagens pela poesia modernista. Adotála como norma fundamental é um erro perigosíssimo (o teorizador previne!), que pode comprometer a sensibilidade - "o liris mo produzido pelas sensações" - e descair em artifício. Mário reitera o superlativo de ameaça, costurando o romantismo ao argumento: "Devemos nos precatar contra o verme do mau romantismo (H) que todo homem infelizmente carrega no corpo"181. O que talvez baste para mostrar que a sinceridade anima fundamente o pensamento estético exposto em A escrava que não é Isaura é o trecho, no apêndice, que aborda o cansaço intelectual dos modernos, gerado pelo duplo apelo da imaginação feroz e da fome de estudo e ciência. Hiper-remissivo, o discurso passa por tratados de psicologia, os dadaístas, a obra de Cendrars, Aragon, Kandinsky. Toca, enfim, no dever de sinceridade do artista:

"Qual a obrigação do artista? Preparar obras imortais que irão colaborar na alegria das gerações futuras ou construir obras passageiras mas pessoais em que as suas impulsões líricas se destaquem para os contemporâneos como um intenso, veemente grito de sinceridade?" 182

Desnecessário dizer que a escolha do autor, ante a pergunta retórica, recai sobre a segunda alternativa, que vale como profissão de fé. As linhas que seguem são admiráveis. Mário pinta o caminho modernista como calvário e incorpora ao texto as acusações de loucura, que os poetas da vanguarda aturaram e ao mesmo tempo assumiram como figuração autoral. O estilo romantiquíssimo, de pontuação e sintaxe transbordantes, ajuda a dar a medida de quanto o leitor incansável é entranhado pelo objeto que estuda na marginália, assimilando-o à própria obra:

"Há nestas duas estradas, numa a obrigação moral que nos (me) atormenta, noutra a coragem de realizar esteticamente a atualidade que seria ingrato quasi infame desvirtuar, mascarar, em nome dum futuro terreno que não nos pertence. Deus nos atirou sobre a Terra para que vivêssemos o castigo da vida ou preparássemos a mentira de beleza para vidas porvindouras? Dores e sofrimentos! Dúvidas e lutas. Sinto-me exausto. Meu coração parou? Um automóvel só, lá

\footnotetext{
181 IDEM, ibidem, p. 249. Entre parênteses, a letra H remete ao apêndice, no qual o ponto é desenvolvido: “O Romantismo usou a observação sincera do eu. Bom caráter. Mas caráter já existente. E uma Safo, um Job, um Catulo, um S. Francisco de Assis, um Gonzaga, tantos e tantos ! apresentam es sa característica com a mesma intensidade que o grande Musset. Mas não é a observação do eu interior que caracteriza o Romantismo escola. É antes o cultivo da dor, o gosto pelo exótico, pelo lendário, o medievalismo sem crítica. Este o verdadeiro Romantismo escola. Este o 'mau Romantismo'. 'La guerre et le Romantisme, fléaux effroyables! (Anatólio France)"”. IDEM, ibidem, p. 285.

${ }^{182}$ IDEM, ibidem, p. 295.
} 
fora... É a tarde, mais serena. E si vedono comparire delle immagini. Há uns mocinhos a assobiar nos meus ouvidos uma vaia de latidos, cocorícos... Os cães rasgam-me as vestes na rua terrível, mordemme os pés, unham-me as carnes... Eis-me despido. Nu. Diante dos que apupam. Despido também da ilusão com que pretendi amar a humanidade oceânica. Mas as vagas humanas batem contra o meu peito que é como um cais de amor. Roem-me. Roem-me. Uma longínqua, penetrante dor... Mas o sal marinho me enrija. Ergo-me mais uma vez. E ante a risada má, inconsciente, universal, tenho a orgulhosa alegria de ser um homem triste. E continuo para frente. Ninguém se aproxima de mim. Gritam de longe: - 'Louco! Louco!' Volto-me. Respondo: - 'Loucos! Loucos!' É engraçadíssimo. E termino finalmente achando em tudo um cômico profundo: na humanidade, em mim, na fadiga, na inquietação e na famigerada liberdade." 183

O excurso por A escrava que não é Isaura e pelas propostas téoricas do livro justifica-se como discussão de base para a crítica tecida na marginália. A sinceridade atravessa as margens da poesia do romantismo na biblioteca do autor de "Amor e medo". Se Álvares de Azevedo se firma como o poeta que mais recebe a atenção do crítico - além de autor mais importante para o argumento do ensaio, ele se torna assunto de cinco artigos no Diário Nacional -é instigante que a antepágina do volume primeiro de suas Obras seja marcada por essa questão:

"Comentário à imitação e à sinceridade. Mostrar que uma não contraria a outra, ao contrário, a imitação provoca a sinceridade porque ninguém imita por esnobismo sinão raramente e não é o caso dos romanticos, imita-se por afinidade, imita-se por espelhar, imitase a mesma coisa que se é, não se imita: identifica-se, correspondese." 184

O incipit da marginália embute o problema das influências e o tema complexo da formação identitária de um autor, considerando-se a apropriação ${ }^{185}$. Que pode ser expandido, ao gosto de Mário, para pensar se o romantismo foi um fenômeno sincero com a entidade nacional, se exprimiu a natureza brasileira. Natureza não restrita à

\footnotetext{
183 IDEM, ibidem, p. 295 e 296.

184 Nota MA, In: AZEVEDO, Álvares de. Obras. Ed. cit., vol. 1, antepágina.

185 Em carta a Carlos Drummond de Andrade, datada de 1924, Mário exprime-se em termos semelhantes: "Agora raciocinemos no que você fala de minha influência sobre você. Em última análise tudo é influência neste mundo. Cada indivíduo é fruto de alguma coisa. Agora tem influências boas e tem influências más. Além do mais se tem que distinguir entre o que é influência e o que é revelação da gente própria. Muitas vezes um livro revela prá gente um lado nosso ainda desconhecido. Lado, tendência, processo de expressão, tudo. O livro não faz que apressar a apropriação do que é da gente." Carta a Carlos Drummond de Andrade, [1924]. In: SANTIAGO, Silviano (Org). Correspondência de Carlos Drummond de Andrade e Mário de Andrade. Rio de Janeiro: Bem-te-vi, 2002, p. 116.
} 
paisagem - que os românticos sentiram pouco, segundo o autor de Macunaíma ${ }^{186}$, aquartelados na copa das palmeiras ${ }^{187}$ - mas como verdade interior. Ainda na antepágina, a anotação seguinte lida - já aqui por um viés negativo - com outras implicações do problema de exprimir autenticamente a nacionalidade:

"Realmente os românticos são duma pobreza mental extraordinária. Poetas tão fatalmente poetas como Álvares de Azevedo nada lhes falta pra serem grandes criadores sinão a tradição de criação quasi ignorada neste país de tradicional palavreado. Álvares de Azevedo tem a fatalidade de manifestação do gênio, faltou-lhe a tradição de criação do gênio que obriga a manifestação a levantar o vulto dos tipos e dos símbolos. Por mais que a leitura o levasse pras civilizações criadoras tradicionais a intensa vida do sentido que fez dos nossos românticos seres tão visceralmente e mesmo inconscientemente nacionais proibiu-lhes a desnacionalização e $o$ despaisamento que lhes permitiria filiarem-se além-mar. O bem deu como resultado um mal $=$ a perda pessoal desses homens tão ricos de lirismo e tão empobrecidos pela grandeza de seremnacionais. " 188

Síntese de grande alcance, o comentário evoca pobreza mental, ausência de tradição criadora, palavreado, manifestações do gênio e influências estrangeiras. Estas últimas não desnaturaram a poesia romântica graças à "intensa vida do sentido". A marginália reforça a aposta de Mário de Andrade em uma psicologia do brasileiro, indiciada pelos traços de fala - como a negação dupla, a disposição dos pronomes, a pronúncia mole do suarabácti - e a expressão do sentimento amoroso, em que se recria por vias eruditas o sequestro de matriz popular. Em 23 de março, 1931, o artigo “Álvares de Azevedo - I", no Diário Nacional recusa ao romantismo a pecha de imitação e atribui a ideia falsa aos equívocos da nossa crítica literária, que procede "sempre nas suas generalizações apressadas e grosseiras 'em função da crítica europeia""189. O articulista sustenta: "Jamais uma coisa importada vinga que não tenha uma razão essencial de ser, uma eficiência nacional, nos países importadores."190

\footnotetext{
186 Em Macário, exclama: "Que coisa esquisita, puxa! Álvares de Azevedo é de todos os nossos românticos aliás o que menos compreendeu e amou a natureza, uma incompreensão quase que total.” Nota MA, In: AZEVEDO, Álvares. Obras. Ed. cit., vol. 3, p. 322.

187 “"Nacionalismo: É curioso de se notar que o nacionalismo naturalista, quero dizer, em relação à natureza, dos nossos românticos si aquartelou na copa da palmeira quasi que só. A Varela coube ir um pouco além. Os outros desque falam no Brasil nacionalistamente, ou por saudade ou por exaltação patriótica lá vem palmeira.” Nota MA, In:DIAS, A. Gonçalves. Poesias. Ed. cit., vol. 2, p. 153.

188 Nota MA, In: IDEM, ibidem, vol. 1, antepágina.

189 ANDRADE, Mário de. “Álvares de Azevedo - I”, In: Táxi e Crônicas no Diário Nacional,p. 355.

${ }^{190}$ IDEM, ibidem, p. 356.
} 
A última nota deixada na antepágina do volume primeiro das Obras trata da "insistência lasciva do beijo nos românticos". O autor dos "Poemas da Negra" remete ao verbo "entrebeijar", sublinhado no "Canto Quarto" de O Conde Lopo: "Ás flôres que na morte se entrebeijão!" "191. Mário considera o termo "delicioso de pegajosismo". No dossiê do manuscrito Castro Alves, sob a larga rubrica "Psicologia do Romantis mo Brasileiro", dá mostras do que planejava analisar no livro inacabado:

"O sentimentalismo amoroso do brasileiro, gente sincera, gente dada, hospitaleira, levando tudo a serio, grafada pelo romantismo. Só Alvares de Azevedo é irônico e é sarcástico e desabusado, sobretudo sarcástico que é traço individual, o brasileiro é irônico também por timidez ou desconfiança." 192

O plano com as "Ideias gerais" para o Lirismo romântico no Brasil divide-se em três entradas. Além da "Psicologia", há outra rubrica dedicada à "Técnica", que abriga exemplos de emprego do "pra" e do pronome oblíquo inicial, e planeja o exame de questões formais - "O soneto romântico", "Modo de contar sílabas" - e da influênc ia "da canção popular, da modinha, da música cantada". Mário escreve no plano/fichamento crítico: "Todos, exceto Azevedo, cantadores seresteiros. Eram músicos ambulantes sem canto exterior. Muitas vezes a gente tem impressão que compunham, improvisavam cantando. Influência disso na técnica." 193 Mas a exceção é rasurada no manuscrito, e o autor da Lira dos vinte anos acaba incluído na seresta. A última rubrica, "Observações gerais", pontua que morrer na flor da idade foi uma fatalidade do nosso romantis mo, conforme o ensaio na Revista Nova dirá logo no início. No mesmo dossiê, a morte prematura não será objeto de lamento:

"Realmente os românticos, apesar de mortos moços alguns, deram tudo o que tinham. Isto é, poderiam fazer mais obras-primas, porém não dariam mais do que já tinham dado, chegaram a realizar todas as possibilidades que possuíam. Porque eram tradicionalmente ignorantes e o que é pior, tradicionalmente se esqueciam da inteligência, do saber, da reflexão quando poetavam. Só de Álvares de Azevedo era licito esperar mais, pelo que mesmo as obras-primas dele profetizam e prenunciam." 194

Outro esboço extenso, no dossiê do manuscrito Castro Alves, avalia o romantismo sob a mesma dúvida quanto à naturalidade ou selo de importação:

\footnotetext{
191 Nota MA, In: IDEM, ibidem, vol. 1, p. 342.

192 Arquivo IEB-USP. Fundo Mário de Andrade. Código MA-MMA-26-04.

193 Arquivo IEB-USP. Fundo Mário de Andrade. Código MA-MMA-26-04.

${ }^{194}$ Arquivo IEB-USP. Fundo Mário de Andrade. Código MA-MMA-26-06.
} 
"O Romantismo brasileiro tem sua razão de ser natural dentro da evolução mental e política do Brasil? Observar isso e filiá-lo dentro da evolução brasileira historicamente e psicologicamente sem me incomodar com o romantismo europeu. O sopro romântico europeu chegou aqui e foi aceito porque vinha quadrar naturalmente com a sensibilidade criada com o alvorecer do império da liberdade política e os primeiros entes individuais do Brasil. Alem disso a sensibilidade evolucionando do arcadismo pro romantismo. - $\mathrm{O}$ romantismo e a psique natural romântica do brasileiro - Estudar o caso de Magalhães e observar-lhe a evolução dentro do Brasil, dos árcades etc aos Suspiros Poéticos.

"Lembrar minimamente a Europa dentro dessa evolução que foi natural, fatal, psicológica e universal. A influência da Europa foi mais uma adoção que outra coisa. Mostrar que pequenina a influência de Byron e de Goethe e de Musset sobre A de Azevedo e mesmo quasi que só formal de V. Hugo sobre C. Alves, poetas que apesar de todas as citações estrangeiras foram nacionalíssimos e nada quasi influenciados. Mostrar a diferenciação de pensamento tradicional e rico nos românticos europeus, paupérrima e monótona nos brasileiros, a maneira do amor em Byron, em Heine em Musset, em Espronceda e nos brasileiros lânguidos melosos. Mostrar assim que o romantismo europeu mais que uma determinante de corrente literária brasileira foi uma adoção desta porque se quadrava com a nossa sensibilidade e o nosso estado mental, no segundo quartel do sec XIX."195

No entender de Mário de Andrade, o lirismo romântico revela mais do que a personalidade individual. Comentários em que a sinceridade comparece como critériochave são muito frequentes na marginália. A função de contraste que ela desempenha mostra-se, por exemplo, junto aos poemas "A minha musa" e "Desejo", de Gonçalves Dias. A mesma página registra avaliações opostas. Sobre o primeiro, o crítico pondera:

"Esta tristeza de G. D. sim me parece bem tema, bem artificial. Seus versos, seu sentimento, sua expressão bem menos impulsiva e brotadanão revelamaquela tristeza de Casemiro e a amargura cheia de tédio de Álvares de Azevedo. Pura máscara. Ao menos a tristeza heroica de C. Alves era ditada por uma ideia social. A de G. Dias nem isso! Romantismo da pior espécie, romantismo de escola. "196

Basta, porém, a estrofe única de "Desejo" para convencê-lo do equilibrio poético de Gonçalves Dias, que combina espontaneidade e pensamento sutil. O comentário mobiliza as categorias apropriadas de Paul Dermée, e a sublinha, traçada pelo leitor no v. 6, acusa a repetição do verbo de cunho psicológico, artifício comum no poeta:

\footnotetext{
195 Arquivo IEB-USP. Fundo Mário de Andrade. Código MA-MMA-26-10 e 11.

${ }^{196}$ Nota MA, In: DIAS, Gonçalves. Poesias. Ed. cit., vol. 1, p. 56.
} 
"DESEJO

Ah! que eu não morra sem provar ao menos

Siquer por um instante, n'esta vida

Amor igual ao meu!

Dá, Senhor Deos, que eu sobre a terra encontre

Um anjo, uma mulher, uma ombra tua,

Que sinta o meu sentir;

Uma alma que me entenda, irmã da minha,

Que escute o meu silêncio, que me siga

Dos ares na amplidão!

Que em laço estreito unidas, juntas, presas,

Deixando a terra e o lodo, aos céos remontem

N'um extasis de amor!

Nota MA:

"Que beleza. Aqui simme parece tão natural. Tão impulsivo! E que arte. A gente sente uma rima que não existe tanto isto é sonoro, é bem cadenciado. Ealém disso um pensamento já bem mais sutil que o dos outros." 197

O juízo de Mário oscila quanto ao autor dos Primeiros cantos. No geral, pende para o diagnóstico de insinceridade, reflexo da inteligência consciente que se dá a perceber em temas e formas muito diversos. Em outra nota de trabalho, com vistas ao livro Lirismo romântico, a arte nos versos é associada à vida: "A vida de G. Dias não foi a incorreta sucessão de festas de lupanar, e amores comprados que nem a de Alvares de Azevedo[.] E daí a grandeza da sua arte que consegue nos comover pela sua transposição artística, puramente artística, enormemente artística, mas insincera em relação ao movimento lírico [...]". ${ }^{198}$ No comentário final ao poema "Quando nas horas", o crítico anota a variedade temática, cotejando-a com a espontaneidade dos versos, e vê em Gonçalves Dias o cultivo da língua árcade :

“(1) Este poema incontestavelmente belíssimo sobretudo na $2^{a}$ parte consegue convencer de que é sincero tal a força de conviç̧ão de sua obra bela. Em parte talvez a insinceridade temática que se nota em G. Dias provenha de ter ele expresso os seus sentimentos românticos numa língua árcade embora sem os tropos nem as imagens árcades. Tudo o que se estereotipa é mais ou menos insincero ao menos na aparência. Porém não tem dúvida que G. Dias é temático por demais

197 Nota MA, In: IDEM, ibidem, p. 56.

198 "A vida de G. Dias não foi a incorreta sucessão de festas de lupanar, e amores comprados que nema de Alvares de Azevedo[.] E daí a grandeza da sua arte que consegue nos comover pela sua transposição artística, puramente artística, enormemente artística, mas insincera em relação ao movimento lírico que nele foi sempre menor que a realização ao passo que em Álvares de Azevedo, em Casimiro era maior que a realização e em Castro Alves se deformava expressionistamente na realização.” (Arquivo IEBUSP. Fundo Mário de Andrade. Código MA-MMA-26-09) 
ou que diverge essencialmente de Álvares de Azevedo e Casemiro." 199

Mário sublinha, em "O ciúme", o verso sobre o desejo de dor. Estuda aí a psicologia do eu lírico e, por extensão, do poeta. A expressão do sentimento amoroso é animada, para o crítico moderno, pela sinceridade lírica:

"Mas que importa este amor que me consome?

Eu quero sentir dôr;

Quero labios que entornem nos meus labios

Alento escaldador!

Nota MA:

"(1) Eis bem uma verdade. G. Dias mais quis sentir dor do que a sentiu realmente. A tristeza de G. Dias é mais uma aspiração que uma realidade. "200

Ao final das oito estrofes de "O assassino", a nota do leitor e crítico elogia a fatura, reiterando a expressão brasileira como valor. Alude ao estudo pregnante dos portugueses e se acredita mais capaz de estimar o teor de verdade dos versos do que o próprio poeta:

"Carece ter a coragem de dizer que isto é esplêndido, perfeitamente bem dito, embora irrite a nossa inteligência desabusada de modernos. Estes versos são perfeitos. Uma eloquência natural, candente, uma psicologia daquele tempo mas duma moral enérgica e por isso mesmo... enternecedora. Não vale nada nem corrigirá nenhum que tenda pra assassino. Não mexe na alma da gente mas é perfeitamente belo no tempo. Tudo isto revela aliás a profunda leitura de portugueses que G. Dias tinha. Isto não é nada brasileiro, é profundamente portuga e se nota que artificial embora o poeta o pudesse imaginar sentido. O que interessa é notar a arte perfeita desses versos, a nobreza de expressão, o equilibrio, a desenvoltura da frase culta e puramente tradicional. G. Dias era um grandíssimo artista mais que tudo. Ebaste pra gente verificar que nem Castilho nem Herculano escreveram versos mais perfeitos que esses. "201

Encerrando o volume primeiro das Poesias, a anotação marginal em "A Tempestade" indica, pela adversativa, o valor dado à sinceridade: "Prova mais cabal do artificialismo de G. Dias não tem. No entanto é uma perfeição" 202 . No volume

\footnotetext{
199 Nota MA, In: DIAS, Gonçalves. Poesias. Ed. cit., vol. 1, p. 184.

200 Nota MA, In: IDEM, ibidem, vol. 1, p. 184.

${ }^{201}$ Nota MA, In: IDEM, ibidem, vol. 1, p. 175 (grifei).

202 Nota MA, In: IDEM, ibidem, vol. 1, p. 342 (grifei).
} 
segundo, comentando o poema "Ao Dr. J. D. Lisboa Serra", diferencia os românticos: "Notar o artificialismo e a mentira destes versos. G. Dias foi um romântico à portuguesa e não sincero e franco à brasileira que nem os outros. " $203 \mathrm{O}$ tratamento do tema indígena também levanta a questão da sinceridade do moto lírico e do caráter artístico e inteligente do poeta das Sextilhas. À margem de "A mangueira", o crítico modernista escreve:

"Realmente só a meio se pode como Alexandre Herculano deplorar não sejam mais numerosas as Poesias Americanas de G. Dias. Só podiam ser mais numerosos os temas geográficos, vegetais do poeta. Na terra ele encontraria com efeito mais temas do que usou porémo indianismo era pobre e utilizado do gosto romântico pode-se dizer que G. Dias explorou tudo o que ele daria de milhor. Com efeito, apesar da vastidão de pensamento de Machado de Assis e da habilidade e riqueza de imaginativa de Bilac nada mais se tirou do indianismo, nem mesmo o Evangelho das Selvas. Só Machado conseguiu ainda uma obra-prima essa mesma só com uma ligeira base no espiritualismo amerindio. O Indianismo era necessariamente um tema intelectual, não um moto lírico organizado da sensibilidade que nem a escravidão (vista, em redor do poeta) o amor, o lar etc. $D$ 'ai serem os poetas de inteligência e os artífices grandes como G. D. Machado e Bilac os que se preocuparam comele. O indianismo do Evangelho das Selvas é um incidente local apenas, o tema é a religião." 204

As "Poesias americanas" oferecem novos matizes aos juízos de verdade quando se lê a nota deixada em "I-Juca Pirama". O leitor dedicado elogia o primor de realização - em língua portuguesa, frise-se - e saúda a habilidade com que Gonçalves Dias canta os valores ameríndios, aparentemente livre do olhar etnocêntrico:

"I-Juca Pirama a grande obra-prima da poesia brasileira em língua portuguesa. Poema a que nada falta, semfalha de concepção, sem falha de realização, unido todo, um marco de literatura universal, a mais perfeita obra literária inspirada, pelo exótico existente no mundo. Chateaubriand desaparece. A pureza deste exotismo em comparação com o exotismo romântico das outras poesias. Não é verdade que os herois de G. Dias estejam vestidos de sentimentos de civilização cristão, são selvagens, o jovem tupi morre entre as lágrimas de prazer do pai, G Dias não transporta os seus herois pra dentro de si, transporta-se pra dentro deles, e consegue a inconcebivel virtuosidade de realizar os índios num português maravilhoso, perfeito, dando o que milhor tinha de si na musicalidade: no ritmo, na graça levemente arcaisante $e$ amaneirada. É formidável. "205

\footnotetext{
${ }^{203}$ Nota MA, In: IDEM, ibidem, vol. 2, p. 33.

204 Nota MA, In: IDEM, ibidem, vol. 2, p. 139.

205 Nota MA, In: IDEM, ibidem, p. 133 (grifei; negrito).
} 
No conjunto, porém, prevalece a avaliação de que a inteligência do poeta se impõe sobre a sensibilidade. Se o particular, culturalmente específico, é retratado com justeza é porque "nas Americanas em geral G. Dias se esquece com muita arte de Portugal portuguesista." 206

O exame de verdade a que Mário submete os versos do romantismo parece comportar duas vertentes, que não se excluem: a verdade vista como expressão da psicologia, por meio do fluxo lírico, e entendida como correspondência entre a poesia e a realidade natural ou biográfica. ${ }^{207}$ Este último juízo é bem menos frequente na marginália, mas digno de nota. A "mentirada" do sabiá na palmeira, que só estudante de Coimbra poderia pregar, ilustra o caso. No "Diário de Lázaro", de Fagundes Varela, o autor d'O baile das quatro artes emprega o mesmo critério. O leitor, em suas marginais, só acata como justo, na apresentação do eu lírico, o enobrecimento pela crença e pela luta, não a riqueza do saber:

"Sim, eis-me aqui, não timido, curvado Ao peso da miseria e da insciencia,

Mas forte pela crença, ennobrecido "verdade" Por longos dias de trabalho e lutas, Rico pelo saber! Quando brilhante, "mentira" Aos fulgores d'aurora, d'entre as ondas" 208

Na parcela da marginália aposta às Obras de Varela, os comentários sobre versificação funcionam como contrapeso à ênfase psicológica e biográfica, ou pelo menos reforçam a percepção de que o retrato dos poetas é elaborado com base na análise atenta de aspectos formais. Há uma nota de margem extensa ao final do "Canto Nono", em Anchieta, ou $O$ evangelho nas selvas, na qual Mário formula a ideia de que há duas instâncias a compor a forma:"há que distinguir dentro da forma a essência intima dela, o esquema ideal, metafisico dela, o que se poderia chamar a inspiração lírica da forma, e a sua realização já puramente material, nem isso: puramente perfilar, exterior, a forma da forma enfim." Varela, considerado na marginália "o maior artífice do verso

${ }^{206}$ Nota MA, In: IDEM, ibidem, p. 200 (grifei; negrito)

207 Em O Espelho e a Lâmpada, Abrams situa as posições em torno da verdade e da sinceridade poéticas no âmbito do romantismo inglês. O enquadramento da questão conclui-se com a tese capitaneada por Wordsworth, similar à concepção esposada na marginália: "a poesia é verdadeira no sentido de que corresponde ao estado mental do poeta: ela é "sincera". Através da poesia religiosa, o termo teria migrado da moral cristã para a crítica literária. Tornou-se, segundo o autor, o "critério fundamental de excelência em poesia", e no período vitoriano ainda é a prova favorita da virtude literária, associada ao espontâneo e o natural. ABRAMS, M. H. O Espelho e a Lâmpada: teoria romântica e tradição crítica. Trad. Alzira Vieira Allegro. São Paulo: Editora Unesp, 2010, p. 421.

${ }^{208}$ Nota MA, In: VARELA, Fagundes.op. cit., ed. cit., vol. 3, p. 307. 
branco brasileiro", tinha "mais completa (no fim da vida principalmente: Evangelho das Selvas, Diário de Lázaro) a concepção total da forma. "209 A anotação ao poema "Scismas á noite", no Livro das sombras, traduz o movimento hesitante e muito comovido do leitor e serve como conclusão à ideia de que a sinceridade estrutura o seu pensamento, enquanto lê a poesia do romantismo ${ }^{210}$ :

"Estancias admiráveis como sentimento e suavidade. Notar que aqui
apesar da repetição do ritmo romântico decassilábico a rítmica do
poema é perfeitamente suportável e mesmo grata da gente ouvir
talvez sustida por, por que meu Deus! é difícil da gente descobrir por
quê! As visões são as mesmas aguadas e inexpressivas... Talvez aqui
o poeta tenha vivido os seus versos. Usava das expressóes da poesia
brasílica do tempo, ainda perturbada pelo artificialismo ideativo da
escola pastoril mineira. Mas viveu e foi bem lírico. Por isso comove
e domina a gente. O segredo dos sentimentos sinceros!... ".211

$\underline{\text { A originalidade na criação do crítico }}$

A intenção de tradicionalizar os românticos move Mário de Andrade ao estudar atentamente a poesia do romantismo:

"Minha convicção é que uma das mais legítimas e certamente das mais brasileiras finalidades que um artista brasileiro possa dar prá obra dele é de seguir e perpetuar a tradição dos nossos grandes românticos. Neles mais que em nenhum outro me parece que está o fundo sentimental da nossa raça e a sua objetivação literária." 212

O longo comentário a propósito das literaturas caudatárias, citado ao final deste ensaio, faz pensar na aposta inversa, de criar aproveitando os sucos das gerações passadas, no meneio das heranças. O que torna a marginália apreensível sob outra perspectiva, não centrada exclusivamente na elaboração dos textos de crítica sobre o romantismo (ensaios na Revista Nova e Revista do Brasil, artigos no Diário Nacional). Viu-se o quanto a leitura dos versos românticos alimenta outros projetos - a elaboração do Dicionário musical e da Bibliografia para Na pancada do ganzá, assim como as pesquisas sobre a Zoofonia e $O$ sequestro da dona ausente. E, de passagem, como a leitura dos Primeiros cantos e da Lira dos vinte anos transborda para outras margens:

\footnotetext{
${ }^{209}$ Nota MA, In: IDEM, ibidem, vol. 3, p. 287 e 288.

210 Ver também Notas MA, In: AZEVEDO, Álvares. Obras. Ed. cit., vol. 1, pp. 232, 276, 293, 364; vol. 2, pp. 35, 36, 63, 73, 175, 178 (!); vol. 3, p. 336 e Notas MA, In: VARELA, Fagundes.op. cit., ed. cit., vol. 1, p. 207; vol. 2, pp. 83, 217, 312.

${ }^{211}$ Nota MA, In: IDEM, ibidem, vol. 1, p. 32.

212 Arquivo IEB-USP. Fundo Mário de Andrade. Código MA-MMA-26-05.
} 
Byron, Heine e Musset hão de ser as referências mais frequentes, mas também nomes de épocas e tradições diversas, como Goethe, Allan Poe ou Catulo Cearense. Ao caráter já múltiplo da marginália soma-se a criação do poeta e ficcionista, que converte a matéria em obra própria, a partir da leitura atenta à filigrana.

Minha hipótese é que Mário lê os românticos com o metro usado para construir a sua própria obra - o par lirismo e arte serve de prova boa, e assim a sinceridade. Também é vincado o sentido de atualidade de sua crítica. O estudo sobre Castro Alves, em 1939, mostra bem isso. E em 1931, ao tratar da obra de Álvares de Azevedo, afirma: é odioso para o nosso tempo o espírito aristocrático de Azevedo, prenunciando o PRP. A crônica de teor crítico, "Mosquero $n^{\circ}$. 2", com os verbos todos no presente (como observa Telê Ancona Lopez ${ }^{213}$ ), lança mão de um poema satírico de Gonçalves Dias para reclamar de modo implícito dos castigos impostos a São Paulo após a Revolução. Todas as associações que Mário faz entre românticos e os contemporâneos dele Guilherme de Almeida, Manuel Bandeira, Tácito de Almeida, Catulo Cearense ou as serestas e modinhas - retornam ao sentido de discernir e afirmar continuidades, em oposição à tendência nossa de estacar nas camadas florais do gênio, nas milietas de manacás, nas florações sem estrado, nas laranjas da Bahia vindas da Califórnia ${ }^{214}$. Desejo de tradição que se confirma também no uso de "A Queimada" de Castro Alves como metáfora psicológica para os empregados da família Souza Costa, cuja caracterização repousa nas ideias da psicologia racial.

O foco muito preso no presente talvez desvirtue - romanticamente? - a sucessão de movimentos estéticos, teleologize as linhagens, do tipo "Cruz e Souza, precursor dos dadaístas" ou "Azevedo e Souza, antecipadores de certas tendências do lirismo modernista" ou "Castro Alves, precursor de tudo"215. Mas, se desfocaliza/desvia um tanto o olhar, analisando o passado em função do hoje, torna a relação palpitante, viva: Mário muito tocado pelo/metido no objeto, assumindo certos traços da dicção romântica. É inegável a adesão ao objeto.

\footnotetext{
213 "Seu comentário, as sim como os trechos citados, só possuemverbos no presente, o que lhes confere maior força de atualidade, valendo como a situação que acredita estar seu leitor experimentando em 1931. Gonçalves Dias, no texto escolhido, através das justas palavras dos anciões, realiza a crônica-'cronos', isto é, análise ideológica de seu tempo, em construções que se caracterizam, léxica e sintaticamente, como denúncia e libelo inflamado." (In: ANDRADE, Mário de. Táxi e Crônicas no Diário Nacional. Ed. cit., p. 370).

214 Nota MA, In: AZEVEDO, Álvares de. Obras (1900). Ed. cit., vol. 3, p. 182.

215 Nota MA, In: ALVES, Castro. op . cit., ed. cit., p. 102.
} 
A carta a Drummond e a anotação na antepágina das Obras de Álvares de Azevedo trazem outra chave para o problema, a ideia de Mário de Andrade segundo a qual não se imita o que não se é. Sempre em jogo a questão da criação muito sincera, que torna a leitura projetiva. Há uma dose alta de projeção na leitura desse modernista voltada para os poetas do romantismo. Afirmá-la não significa, salvo engano, assumir os mesmos pressuspostos psicologizantes do autor. Será perceber, talvez, que o metro do crítico é o mesmo do criador. A projeção nos românticos vai de par com aquilo que ele deseja construir como obra. Os projetos vincados na marginália dão pistas de um conjunto plural e complexo, significando estudar a língua, a versificação, a psicologia, pensar o processo evolutivo (ou não) da literatura brasileira.

Entre as possibilidades da crítica genética está a de mostrar que as "produções do espírito" não se dão sem o exercício paciente e demorado da leitura e da escrita, o lápis sempre alerta, da cruzeta mais simples aos esboços alentados, páginas e também fólios que compõem os manuscritos, fichas que recolhem o material, ou folhas de guarda que organizam notas de margem. Felizmente indiscreta, a escrita revela o operário denodado. Indicia o trabalho de reflexão, ora silente, ora calcado nas páginas. Esse é um trunfo da abordagem genética, desfetichizar o texto como a obra acabada, que esconde o esforço do qual resulta, sem o qual não existe. A análise da marginália de Mário de Andrade - mesmo que em sua parcela modesta, como parte de uma obra muito mais extensa, e localizada em uma biblioteca que conserva milhares de títulos - ajuda a des-sequestrar o trabalho exigido para a criação literária. Como uma fotografia de Marcel Gautherot, que enquadra, na construção de Brasillia, os operários na linha do horizonte, isto é, o trabalho no centro da história ${ }^{216}$. É o trabalho intenso na rua Lopes Chaves, em meio a livros, cartas, pinturas, objetos do folclore, que exime o intelectual, aos nossos olhos, da culpa ante o seringueiro pálido, magro, de cabelo escorrendo nos olhos:

\footnotetext{
"Seringueiro, eu não sei nada!

E no entanto estou rodeado

Dum despotismo de livros,

Estes mumbavas que vivem

Chupitando vagarentos

O meu dinheiro o meu sangue

E não dão gosto de amor...

Me sinto bem solitário
}

\footnotetext{
${ }^{216}$ Remeto ao comentário de Lorenzo Mammì sobre a fotografia de Marcel Gautherot, no Acervo do IMS (Ministérios em Construção, c 1958) disponível em: https://youtu.be/kY1D80HNdk0.
} 
No mutirão de sabença

Da minha casa, amolado

Por tantos livros geniais,

'Sagrados', como se diz...

E não sinto os meus patrícios!

E não sinto os meus gaúchos!

Seringueiro, dorme...

E não sinto os seringueiros

Que amo de amor infeliz!"217

O principal ponto deste meu mestrado, creio eu, é frisar que o instrumento de trabalho organizado através da pesquisa poderá servir para pesquisas futuras e insistir que a criação de Mário de Andrade, em muitos âmbitos de seu projeto literário, passa pelas páginas anotadas e rasuradas dos volumes da poesia do romantismo brasileiro em sua biblioteca.

\begin{abstract}
"A nossa literatura não segue propriamente por evolução; antes por superposição. É o que geralmente se observa em todas as literaturas caudatárias. Não existe essa continuidade tão robusta em si, pela qual cada grande artista, alimentado pelo suco das heranças do passado artístico da pátria dá um passo para frente - passo que reflete as riquezas novas alcançadas no meneio das heranças e no trabalho da personalidade. Isso é evolução. Mas isso geralmente se dá só nas grandes literaturas autonômas e condutoras. A francesa. A italiana. A espanhola. A inglesa. A russa. A portuguesa (até o séc. 19). (As literaturas orientais anteriores a Cristo. A grega. A latina. Mais talvez, duas ou três que desconheço. E agora já está se dando com a literatura norte-americana, na qual ao menos a tradição Whitman, já é característica e racial e se perpetua, evolucionando, por Sandburg, Openheim e outros mais. Em nossa história literária, antes reflexo que propriamente criação o contingente pessoal não representa um esforço de progresso comum; morre com o artista que o criou. Arcadismo, romantismo, verbalismo (chamar de verbalistas aos parnasianos e não de parnasianos. Excluir destes Vicente de Carvalho) não se apresentamem nossa história literária como reações de progresso e personalidades desenvolvidas em parte pelo meio. A sociedade mineira do séc. 18 nada tinha de árcade e renascente. $\mathrm{O}$ início do séc. 19, com a aurora de independência, pouco tinha de romântico; e o indianismo que nele teria razão de ser como nacionalismo reacionário, é apenas imitação de Chateaubriand e Bernardin. O parnasianismo, escola que pela sua impersonalidade impassível e blasé, com seu gosto exasperado da perfeição, só num meio de já grandes progressos técnicos podia aparecer, não teve jeito de aqui se aclimatar quando os imitadores de Banville e Leconte o quiseram. Assim o chamado parnasianismo brasileiro é a orientação cujo nome menos a define que temos. Tivemos sim uma orientação verbalista, a que a língua numerosa e musical admiravelmente se prestou. E apenas. Esses artistas aperfeiçoaram então a visão de arte,
\end{abstract}

217 ANDRADE, Mário de. “Acalanto do seringueiro", In: "Dois poemas acreanos". In: Poesias completas. Ed. cit., vol. 1, p. 290. 
que para nós se confundia até então com cantoria mais ou menos popular nossa transpuseram para nossa língua a tecnica da metrificação.

"Esses verbalistas foram verdadeiramente os inventores da poética brasileira - ofício que antes se confundia com instinto. É verdade que desde logo, um ou outro desses artistas conseguiu criar tal poema que se filiava á escola parnasiana de França. Ainda aí superposição. Não é da matilha de Teófilo Dias que provirá a Deusa das Centauras de Francisca Julia, nem da ingênita perfeição de Machado de Assis que Olavo Bilac tirará a gélida perfeição das "Panóplias". Mas desde logo, o grupo dos nossos chamados parnasianos, enamorados do esplendor sonoro da palavra portuguesa, abandonaram o gosto do mármore pela sensualidade da sinfonia. Criaram o verbalismo brasileiro, que muito embora algumas vezes altissonante, é preciso não confundir com a eloquência condoreira de Castro Alves. Mas, creio que mais ainda que o ardido sensualismo brasileiro o que não permitiu a esses verbalistas de serem parnasianos de França, foi o próprio meio inadaptado ainda, por selvático, à impassibilidade gentleman e o estado quasi virginal e pobre de técnica de nossa poesia. Precisaram antes de mais nada de criar essa ilusão de civilização (e foi o que fizeram principalmente Francisca Júlia, Raymundo e Alberto de Oliveira) e a nossa arte de fazer versos. Criaram-na esta última com grande esplendor. E pela perfeição a que atingiram, deram então motivo a que o parnasianismo surgisse entre nós. Agora é que temos no Brasil verdadeiro parnasianismo. Os parnasianos brasileiros estão vivos; e pela primeira vez realmente, embora ainda reflexo, houve no Brasil uma evolução poética, pois nossos parnasianos de agora, embora ainda com os olhos em França, já tem os ouvidos no Brasil. Assim a sonoridade e a grandeza técnica dos nossos verbalistas permitiu o aparecimento dos noveis parnasianos.

"Voltemos à superposição. Além desse $1^{\circ}$ exemplo - e realmente $1^{\circ}$ pois que coletivo - de evolução do verbalismo do fim do séc. 19 para o parnasianismo presente de alguns cultores do nosso verso, o artista brasileiro sofre um destino trágico. Morre sem descendência. Não houve escola mineira. Não houve escola romântica. Há homens mais ou menos filiados a escolas que além-mar estão, mas cegos para os exemplos de perto e que passarão também despercebidos. Ninguém thes seguirá o trabalho. Ninguem thes reparará no exemplo. Imersos todos os poetas brasileiros no perscrutar o trabalho exótico para depois levantar no campo silvestre nativo primeiro o mosteiro de arquitetura manuelina, para em seguida rodeá-lo com a linha distinta dos relvados do jardim francês. Já agora as rosas de Malherbe em tal e tão espesso rosal se juntaram que sobre ele a arquitetura portuguesa desapareceu. Ah!..."218

218 Provável esboço para a obra inacabada História crítica da poesia brasileira, situado no dos siê do manuscrito Castro Alves. Arquivo IEB-USP. Fundo Mário de Andrade. MA-MMA-26-12 e 13. 


\section{PARTE II}

ABREU, Casimiro J. M. de. As primaveras: com poesias Bibl MA: [A/II/d/61] inéditas do autor, o juízo crítico de diferentes escritores e um prólogo por F. D. Ramalho Ortigão. Porto: Livraria Chardron, 1909. $3^{\mathrm{a}}$ ed.

\section{FOLHA DE GUARDA}

Notas MA a grafite:

1. fichamento de leitura;

2. número 223, no alto, à direita, indicando a inclusão do volume na Bibliografia para $\mathrm{Na}$ pancada do ganzá;

3. captação de matéria para verbetes do Dicionário musical brasileiro, cortada por um X, indicador de aproveitamento;

4. rubricas relacionadas ao estudo da versificação;

5. registro de ocorrências da preposição "para" e da forma elidida "pra":

$$
\text { “4-146-179-181-139- } \quad \text { n } 223 ”
$$

"Dic-temperar 4-lira 13 - alaúde 15 - sino 18 - modular 34 - I pandeiro 37 - sino 46 - trova 46 - hino 47 - modular 53 - / ireno 54 - valsar 61 - A Walsa 65 - bronze 114 - / contradansa 119 - ritornello 120 - endeixa 121 - / flauta 128 - bandolim 157 - guitarra $182-"$

“Versos fracos 22, 23, 24, 26, 27, 31, 32, 47, 49, 53,"

“Rimas erradas ou fracas 23, 28, 54, 89, 164,"

"Emprego do pra 23, 24, 49, 50, 120, 156, 13

Emprego do para 135, 136 mas engano)"

Notas da pesquisa:

1. $\mathrm{O} \mathrm{n}^{\circ} 223$ sinaliza a inclusão d'As Primaveras na Bibliografia para Na pancada do ganzá, conjunto de 837 títulos arrolados por MA para apoiar a organização de seu vasto projeto sobre o folclore brasileiro. Os títulos da poesia dos autores românticos focalizados em "Amor e medo" fazem parte lista bibliográfica. Sob a rubrica "dic", acham-se elencados na folha de guarda termos reservados ao abonamento de verbetes no Dicionário musical brasileiro, projeto empreendido por MA em suas leituras e de documentação extensa no acervo do escritor. A edição do Dicionário coordenada por Oneyda Alvarenga e Flávia Toni inclui, ao final, a Bibliografia para Na pancada do ganzá (Belo Horizonte: Itatiaia, Brasília: Ministério da Cultura, São Paulo: IEB-USP/ Edusp, 1989, p. 634-686). Na sequência “4 - 146 - 179 - 181 - 139”, é provável que MA desejasse reunir exemplos da "verdade poética" atribuída por ele a Casimiro de Abreu, compensando-lhe a pobreza intelectual e falta de gênio, acusadas nas Notas MA à margem do texto dessas páginas.

2. Além do "Prólogo" de Ramalho Ortigão, o volume apresenta o "juízo crítico" de Maciel do Amaral, Jusitiniano José da Rocha, Pedro Luiz P. de Sousa, J. M. Velho da Silva, Reinaldo Carlos Montôro, Ernesto Cibrão, Reinaldo Carlos, Gonçalves Braga, Bruno Seabra, Almeida Cunha, F. V. da Silva Azevedo e Climaco Ananias Barbosa 
d'Oliveira. A Redação do "Acajá - Jornal de Instrução e Recreio" assina um pequeno texto em homenagem ao autor, no qual se lê: "Pertencendo os fundadores e sustentadores d'este jornal em sua quasi totalidade ao commercio, e desejando desenvolverem-se no cultivo das letras, dupla razão lhes assiste na prestação da homenagem devida a esse jovem, já como poeta, já como caixeiro." Excetuado o "Prólogo" de Ortigão, MA não deixou notas de margem nos textos.

\section{$\underline{\text { P.I-XII }}$}

ORTIGÃO, F. D. Ramalho. "Prólogo"

P. VI:

Nota MA: período destacado por colchete; estudo psicológico: sentimento amoroso.

A timidez adorável, que é sempre inseparável sócia do amor impetuoso em anos tenros, aqui está retratada com invejáveis tintas.

Nota da pesquisa: MA rejeita o comentário de Ramalho Ortigão, em seu ensaio "Amor e medo", e cita o trecho em destaque com pequenas variantes: "Para terminar também com Casimiro de Abreu que, como já vimos, desviava o amor e medo pro perigo dele 'machucar com o dedo impuro as pobres flores da grinalda virgem', a verdade é que sofreu muito pouco o medo de amar, embora tenha dado numerosas frases referíveis a ele e inventado o título apropriado a esse estado-de-alma juvenil. Ramalho Ortigão, também impressionado por esse título, descobriu que no poema 'a timidez adorável, que é sempre inseparável do amor impetuoso em tenros anos, está retratada com invejáveis tintas'... Não me parece. Casimiro de Abreu desvia o tema, pra se comprazer em quasi todas as lindas estrofes do 'Amor e medo', em descrever com bastante vivacidade o que sucederia pra virgem si." (“Amor e medo"; In: Aspectos da literatura brasileira. Ed. cit., p. 212) Representando aqui pudor e autocensura, a aposiopese - figura de linguagem caracterizada por uma interrupção abrupta do discurso - encena o sequestro amoroso no próprio texto do ensaio. MA lança mão do recurso numerosas vezes em Amar, verbo intransitivo: "Carlos era inocente por demais para supor que Fräulein já"; "Não tinha propósito trocar de pijama só por quê"; "A comparação tomava assim uns ares insinuantes de pureza que não ficam, pois nós todos já sabemos que."; "Bem que ela desconfiara na primeira noite, Carlos já conhecia o." (ANDRADE, Mário de. Amar, verbo intransitivo. Estabelecimento de texto e apresentação de Marlene Gomes Mendes. Rio de Janeiro: Nova Fronteira, 2013, pp. 71, 77 e 85).

$\underline{\text { P. } 1-168}$

AS PRIMAVERAS

P. 3-5

INTRODUCÇÃO

P. 4:

Notas MA: 
1. parágrafo destacado por traço vertical e expoente “(1)” remetendo ao comentário no rodapé - planejamento da obra Lirismo romântico no Brasil;

2. termo sublinhado, "temperar", e escólio "dic" - destaque do sentido do verbo no âmbito da música, na pesquisa de MA para o Dicionário musical brasileiro:

\begin{tabular}{c|l} 
“(1)” & $\begin{array}{l}\text { De certo, tudo isto são ensaios; a mocidade palpita, e na sêde que a devora, decepa os } \\
\text { louros inda verdes e antes do tempo quer ajustar as cordas do instrumento, que só a } \\
\text { madureza de idade e o tracto dos mestres poderão temperar. }\end{array}$
\end{tabular}

“(1) Citar este período a respeito de Alvares de / Azevedo.”

3. trecho destacado por traço vertical triplo - estudo da língua e da psicologia:

O filho dos tropicos deve escrever n'uma linguagem - propriamente sua - languida como elle, quente como o sol que o abraza, grande e mysteriosa como as suas mattas seculares;

Nota da pesquisa: Parte importante do pensamento e da documentação reunida por MA sobre a língua portuguesa falada no Brasil conserva-se n'A gramatiquinha da fala brasileira. O plano desta obra inacabada previa o capítulo XXX dedicado à psicologia da fala. Já na introdução esboçada, a psicologia é objeto de interesse: "Brasil corpo espandongado, mal costurado que não tem o direito de se apresentar como patria porque não representando nenhuma entidade real, de qualquer caracter que seja nem racial, nem nacional, nem siquer sociologica é um aborto desumano e antihumano. Nesse mostrengo [sic] politico existe uma lingua oficial emprestada e que não representa nem a psicologia, nem as tendencias, nem a indole nem as necessidades nem os ideais do simulacro de povo que se chama o povo brasileiro" (ALMEIDA, Aline Novais de. Edição genética d'A gramatiquinha da fala brasileira de Mário de Andrade. Dissertação no Programa de Pósgraduação em Literatura Brasileira. FFLCH-USP, 2013, v. 1, p. 98). Na seara da criação literária, o epílogo de Macunaíma parece se aproximar do trecho assinalado em Casimiro de Abreu, ao qualificar a língua do romance, transmitida ao narrador-rapsodo pelo papagaio do herói, como uma "fala mansa, muito nova, muito! que era canto e que era caxiri com mel-de-pau, que era boa e possuía a traição das frutas desconhecidas do mato" (Macunaíma, o herói sem nenhum caráter. Apresentação e estabelecimento do texto por Telê Ancona Lopez e Tatiana Longo Figueiredo. Rio de Janeiro: Nova Fronteira, 2012, p. 159). No artigo "Modernismo", MA compara a busca da língua brasileira empreendida pela vanguarda àquela dos escritores do romantismo: " $\mathrm{E}$ [o Modernismo] promoveu uma reacomodação nova da linguagem escrita à falada (já agora com todas as probabilidades de permanência) muito mais eficaz que a dos românticos (ANDRADE, Mário de. "Modernismo", in $O$ empalhador de passarinho, $2^{a}$ ed. São Paulo: Livraria Martins Editora, 1955, p. 189).

P. 7-8

A *** (10 estrofes)

P. 7:

Notas MA:

1. estrofes 1-4 destacadas por traço vertical - seleção de ideias;

2. expressão sublinhada no v. 5, "oh musa do silencio", e traço vertical; 
3. estrofe 4 destacada por colchete e escólio "Sequestro";

4. expoente "(1)” ao final da estrofe 4 remetendo ao comentário na margem superior:

“(1) Até aqui é perfeito. Reparar a estranha / suavidade, a doçura incomparavel e hoInesta de som destas quadras, maravilha / de equilibrio dum lirismo calmo e in-/genuo com a expressão adequada. A / doçura estranha passa despercebida porque se repete mas é tomar cada / verso por si e logo se percebe. Veja o $1^{\circ} /$ como todo em separado, são delicias. $\mathrm{Na} / 5^{a}$ estrofe a inspiração decai $\mathrm{O}$ artifi-/cio aparece $4^{o}$ verso. As 3 est. seguintes são / maravilhas outras vez. A ultima é besteira. / A falta de controle!... Defeito de que só / G. Dias se libertou entre os romanticos. (Es-/tudar sobre isso as variantes de C. Alves)"

Fallo a ti - doce virgem dos meus sonhos Visão dourada d'um scismar tão puro, Que sorrias por noites de vigilia Entre as rosas gentis do meu futuro.

Tu m'inspiraste, oh musa do silencio, Mimosa flôr da lânguida saudade!

Por ti correu meu estro ardente e louco Nos verdores febris da mocidade.

Tu vinhas pelas horas das tristezas Sobre o meu hombro debruçar-te a medo, A dizer-me baixinho mil cantigas, Como vozes subtis d'algum segredo!

"Sequestro" $\left[\begin{array}{l}\text { Por ti eu me embarquei, cantando e rindo, } \\ - \text { Marinheiro de amor - no batel curvo, } \\ \text { Rasgando afouto em hymnos d'esperança } \\ \text { As ondas verde-azues d'um mar que é turvo. }\end{array} \mid\right.$

Nota da pesquisa: O termo "sequestro" cristaliza, na marginália, a convergência de projetos, aproximando a poesia romântica, erudita, da criação anônima do povo. Remete em primeiro lugar a $O$ sequestro da dona ausente, longa pesquisa de MA no âmbito do folclore luso-brasileiro, que investiga o encontro amoroso - frustrado pelas navegações e pela escassez de mulheres no Novo Mundo - como objeto de elaboração estética. Em paralelo, constitui versão autoral e aproximativa para o Verdrängung/refoulement, conceito psicanalítico que tem papel-chave em "Amor e medo". A circunstância cultural que dá origem à tópica da dona ausente é caracterizada por MA em artigo na revista Atlântico: "O mar todo-poderoso exige dos que lhe manejam o rito, viverem em castidade completa. Mas a saudade da mulher persegue o casto, o desejo dela o castiga demais. E o marujo, especialmente o lusitano que foi o maior dos navegadores, busca disfarçar o martírio nas imagens e nos símbolos da poesia. $\mathrm{O}$ folclore luso-brasileiro se enriqueceu, com isso, de uma série numerosa e admirável de quadrinhas e cantigas" (ANDRADE, Mário de. "A dona ausente". Atlântico, n $n^{\circ}$ 3. Lisboa/Rio de Janeiro, Serviço Nacional de Propaganda/ Departamento de Investigação e Propaganda, 1943, p. 9).

O dossiê da pesquisa, na série Manuscritos MA, abriga planos, esboços e notas prévias, num total de 1.221 documentos (MA-MMA-106). O f. 590 traz referência a esta página: "Sequestro // n 223 p 7". Ricardo Souza de Carvalho transcreveu e analisou o conjunto em Edição genética d'O sequestro da dona ausente de Mário de Andrade, 
Dissertação de Mestrado no Programa de Pós-graduação em Literatura Brasileira, FFLCH-USP, 2001.

Vale lembrar que, em janeiro de 1944, Manuel Bandeira envia a MA esta quadrinha: "IMPROMPTU // Cinco segundos de silêncio / Cinco segundos de saudade / - A saudade do Dono Ausente / Mário de Andrade." (MORAES, Marcos A. [Org.] Correspondência Mário de Andrade \& Manuel Bandeira. São Paulo: Edusp, 2001. $2^{\mathrm{a}}$ ed., p. 669).

A repressão ou recalcamento, conceito apropriado por MA, é uma das ideias centrais da teoria psicanalítica. Do ponto de vista do $e u$, trata-se de um mecanismo de defesa que permite ao sujeito manter afastado da consciência um conteúdo ideativo que lhe é desagradável. O Vocabulário da psicanálise acusa as nuances do termo no correr da obra de Freud, onde assume dois sentidos principais. "No sentido próprio (A)", informam os autores, "é a operação pela qual o sujeito procura repelir ou manter no inconsciente representações (pensamentos, imagens, recordações) ligadas a uma pulsão. $\mathrm{O}$ recalque produz-se nos casos em que a satisfação de uma pulsão - suscetível de proporcionar prazer por si mesma - ameaçaria provocar desprazer relativamente a outras exigências". Em sentido mais amplo (B), "o termo é tomado muitas vezes por Freud numa acepção que o aproxima de 'defesa"” (LAPLANCHE \& PONTALIS. Vocabulário da psicanálise. Tradução de Pedro Tamen. São Paulo: Martins Fontes, 1994). O termo sequestro, proposto por MA, parece implicar as ideias de recalque e sublimação. Este, um "processo postulado por Freud para dar conta das atividades humanas aparentemente sem relação com a sexualidade, mas que encontrariam sua origem na força da pulsão sexual". Laplanche e Pontalis esclarecem que Freud "descreveu como atividades de sublimação principalmente a atividade artística e a investigação intelectual. A pulsão é considerada sublimada na medida em que é dirigida a uma nova meta não sexual e visa a objetos socialmente valorizados" (IDEM, ibidem, p. 552-558).

MA travou, como se sabe, contato precoce com as ideias freudianas, as quais figuram como objeto de debate em em sua crítica ("O cabotinismo") e matriz importante de sua criação literária (Amar, verbo intransitivo, Macunaíma e Contos novos). A legenda proposta, em 1927, para a fotografia tirada por MA no Ceará, de um varal com roupas brancas enfunadas pelo vento, estende o campo das apropriações: "Roupas freudianas / Fortaleza 5-VIII-27 / Sol 1 diaf. 1 / Fotografia refoulenta / Refoulement" (V. no Arquivo do IEB/USP, MA-F-0589).

O interesse transparece também na na biblioteca de MA, no IEB-USP, que reúne oito títulos de Freud, todos em francês: La psychopathologie de la vie quotidienne: application de la psychanalyse à l'interprétation des actes de la vie courante (Paris: Payot, 1922); Introduction à la psychanalyse (Paris: Payot, 1922); Trois essais sur la théorie de la sexualité (Paris: Nouvelle Revue Français, 1923); Totem et tabou: interprétation par la pschanalyse de la vie sociale des peuples primitifs (Paris: Payot, 1923); Cinq leçons sur la psychanalyse (Paris: Payot, 1924); Essais de psychanalyse (Paris: Payot, 1927); Le mot d'esprit et ses rapports avec l'inconscient (Paris: Gallimard, c1930); Pourquoi la guerre (Paris: Institut International de Coopération Intelectuelle, 1933), este em coautoria com A. Einstein.

Há duas remissões a esta página no fichamento crítico com vistas ao livro Lirismo romântico no Brasil, documento autógrafo incluído no dossiê do manuscrito Amor e medo: "Doçura, suavidade e calma de Casimiro p. $7 ; 12 ; 124$ ". No mesmo plano, referindo-se ao verso "Sobre o meu hombro debruçar-te a medo", em busca da musicalidade oral, MA escreve: "Aconselhar/ se pronuncie em voz alta certas frases de C. $2,1^{\text {os }}$ versos p 25; 10 p. 7; ultimo p. 124" (MA-MMA-05-03). 
P. 8:

Nota MA: estrofe 9 destacada por traço vertical à esquerda e expoente “(1)” remetendo ao comentário no rodapé:

$$
\text { “(1)” }\left(\begin{array}{l}
\text { Pódes ler o meu livro: - adoro a infancia, } \\
\text { Deixo a esmola na enxerga do mendigo, } \\
\text { Creio em Deus, amo a patria, e em noites lindas } \\
- \text { Minh'alma - aberta em flôr - sonha comtigo. }
\end{array}\right.
$$

"Casimiro se resumiu e ao burguesismo honesto / e muito nobre dele."

Nota da pesquisa: MA retoma em nota de trabalho, no dossiê do manuscrito Amor e medo, a caracterização burguesa de Casimiro de Abreu, manifestada na poesia dele: "Considerações no cap. sobre Casimiro sobre a sua nostalgia que era mais de lar que de patria propriamente. A burguesice do espirito de Casimiro não lhe permitia conceber a patria, sefrer sofrer por ela como Castro Alves, ter a tristeza dela, tristeza esta que G. Dias poude sentir e tematizar porque erudito. Patria é um conceito aristocrata e erudito e resultantemente sentimento aristocrata e superfino. Casemiro sofreu o afastamento do lar que só na burguesice se confunde com patria. O conceito burgues de patria é o lar, casa, arredor e família, quando muito se expande até a cidade e a parentela e amizades." (MAMMA-26-09). MA oscila, conforme se vê, entre "Casemiro" e "Casimiro", ao grafar o nome do poeta.

\section{LIVRO PRIMEIRO}

\section{$\underline{\text { P. } 11-12}$}

CANÇÃO DO EXILIO (7 estrofes)

P. 11:

Nota MA: v. 8, 10, 11 e 12 sublinhados - seleção de ideias:

Oh! que céo, que terra aquella,

Rica e bella

Como o céo de claro anil

Que seiva, que luz, que galas,

Não exhalas

Não exhalas, meu Brazil!

Nota da pesquisa: No fichamento crítico da obra de Casimiro de Abreu, no dossiê do manuscrito Amor e medo, a página encabeça a lista de "Obras-primas 11; 18; 29; 152". No mesmo documento, MA planeja: "Estudar uma das obras-primas dele" (MA-MMA05-03).

P. 12:

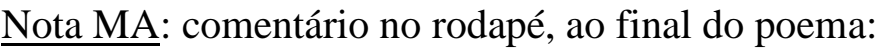

"É uma página perfeita, sem nenhuma / vibração mas forte sem nenhum apelo / original mas "doce e terna". Eis os adjetivos / que resumem este mole e adorável "cantor / dos 
trópicos". Uma sensualidadinha pega-/josa. Um pouco de sono no começo "Onde canta / ele seus suspiros" e no resto só olhos. O que se / vê é mais fácil de cantar. Casimiro será um visual?"

Nota da pesquisa: O fichamento crítico d'As Primaveras remete à página em três rubricas: (1) "Doçura, suavidade e calma de Casimiro p. 7; 12; 124"; (2) "Casimiro será visual? 12; 17; 19”; (3) "Brasileirismo sensual 12” (MA-MMA-05-03).

P. 13-17

MinHA TERRA (15 estrofes)

P. 13:

Notas MA:

1. termo sublinhado no v. 3, "lyra", e escólio "dic" - pesquisa para o Dicionário musical brasileiro:

Nas debeis cordas da lyra "dic"

2. preposição sublinhada no v. 9, "pr'as" - estudo linguístico: emprego de "para/pra":

Correi pr'as bandas do sul:

P. 14:

Notas MA:

1. v. 26 sublinhado e cruzeta:

$X \quad$ D'entre todas - a primeira;

2. v. 48 sublinhado e comentário;

3. expoente (1) à esquerda do v. 48 , remetendo a outro comentário no rodapé;

3. fio prendendo o comentário - estudo da psicologia:

"(1)" Se embala o indio indolente

A indolencia é / do poeta

“(1) A força de expressão brasileira, indolente de deveras deste 'se embala'.,

Nota da pesquisa: MA traslada para o fichamento crítico estas impressões deixadas na marginália, indicando à p. 14 exemplo de "brasileirismo expressional e psicológico" (MA-MMA-05-03).

P. 15:

Notas MA:

1. correção a erro de impressão no v. 52: "Petrarca":

“/tr" O Petárca brazileiro;

2. preposição sublinhada no v. 55 e cruzeta - estudo linguístico: emprego de "para/pra":

$X \quad$ Para o bardo que pulsava 
3. termo sublinhado no v. 56, "alaúde" - pesquisa para o Dicionário musical brasileiro:

Seu alaúde fagueiro.

P. 16:

Notas MA:

1. correção a erro de impressão "bardo", no v. 81, por "brado":

Quando nasci, esse bardo

2. v. 85-88 destacados por traço vertical e juízo de valor:

"Lindo" $\quad\left(\begin{array}{l}\text { Mas não sei o que sentia } \\ \text { Quando, a sós, eu repetia } \\ \text { Cheio de nobre ousadia } \\ \text { O nome da minha terra! }\end{array}\right.$

3. v. 89 e 90 destacados por traço vertical e comentário:

"As chapas entram / direitinho nos seus / lugares, tão natu-/rais!"

(Se brazileiro eu nasci

Brazileiro hei de morrer.

4. termo sublinhado no v. 103, "tyrê”, interrogação e escólio, “zoof” - estudo da zoofonia:

"zoof" ? E pelo tyrê formoso

Notas da pesquisa:

1. O escólio "Zoof", a grafite, de ocorrência frequente na marginália de MA, em todas as áreas de sua biblioteca, absorve a denominação de pesquisa encetada por Hercule Florence e colige matéria destinada ao projeto do escritor de reunir palavras e expressões representando as vozes dos animais. Liga-se, de imediato, ao manuscrito Zoofonia, reservatório e estudo particular desses termos, composto de documentos musicais, recortes de jornal e notas de trabalho, transcritas de publicações ou captadas em pesquisa de campo por MA e seus colaboradores.

Em entrevista de 1943, MA filia seu projeto a Green Mansions: a Romance of the Tropical Forests, de William Henry Hudson (V. ANDRADE, Mário de. Entrevistas e depoimentos. Edição organizada por Telê Porto Ancona Lopez. São Paulo: T.A. Queiroz, 1983, p. 93).

"Zoof" prende-se, também, à coleta de termos para o Dicionário musical brasileiro e $O$ banquete, obra na área de Estética, interrompida pela morte de MA em 1945. Nesta, o capítulo 8 previa: "O Passeio em Pássaros. Zoofonia. O canto-enfeite no cio. A mulher vestida de homem e a Lei do Peso. Música da natureza e música descritiva." (V. ANDRADE, Mário de. O banquete. Ed. preparada por Jorge Coli e Luiz Dantas. São Paulo: Livraria Duas Cidades, 1977, p. 167).

2. Talvez por um lapso, MA tenha incluído esta página, no fichamento crítico, sob a rubrica "Vulgaridade" (MA-MMA-05-03). 
Nota MA: comentário ao final do poema:

"Só sons e cores."

Nota da pesquisa: A página é mencionada no fichamento crítico, acompanhando a pergunta: "Casimiro será visual? 12; 17; 19” (MA-MMA-05-03).

P. 18

SAUDADES (3 estrofes)

Nota MA:

1. v. 13-16 destacados por colchete - estudo do estilo:

O sino do campanario,

Que falla tão solitario

Com esse som mortuario,

Que nos enche de pavor.

2. juízo de valor no rodapé:

"Perfeito. Curto. Esplendido."

Nota da pesquisa: No fichamento crítico das obras de Casimiro de Abreu, plano do estudo Lirismo romântico no Brasil, o poema é elencado entre as obras-primas de Casimiro de Abreu (MA-MMA-05-03).

$\underline{\text { P. } 19-20}$

CANÇÃO DO EXILIO (13 estrofes)

P. 19:

Nota MA: v. 3 e 4 sublinhados e comentário:

Eu quero ouvir na larangeira, á tarde,

Cantar o sabiá!

"Casimiro concerta G. Dias. / Dias criava. Casimiro via."

Nota da pesquisa: Os versos em destaque são dados como indício do caráter visual atribuído por MA a Casimiro de Abreu, segundo se lê no fichamento crítico d'As primaveras (MA-MMA-05-03).

P. 20:

Nota MA: termo sublinhado no v. 37 e comentário no rodapé - estudo do estilo: musicalidade:

Quero morrer cercado dos perfumes

"Ausencia de musicalidade. I Notar a repetição monotona, muito aproximada, I insistencia aqui de curta inspiração e falta / de habilidade." 
Nota da pesquisa: No fichamento crítico d'As primaveras, MA menciona esta página como exemplo de "Pobreza intelectual, falta de riqueza nos assuntos" e a inclui também sob a pergunta "Musicalidade falta?" (MA-MMA-05-03).

$\underline{\text { P. } 21-22}$

MiNHA MÃE (6 estrofes)

P. 22:

Notas MA:

1. termo sublinhado no v. 23 , "anjo" - estudo dos avatares da mulher na poesia do romantismo:

Sentir as caricias do anjo de amores,

2. comentário ao final do poema - estudo da versificação e da psicologia: sentimento amoroso:

"Aqui o refrão de estrofe / e o tema 'Minha Mãe' estão bem milhores"

Nota da pesquisa: A página acha-se indicada na sequência à pergunta "Musicalidade falta?", no fichamento crítico (MA-MMA-05-03).

\section{P. 23-24}

ROSA MURCHA (8 estrofes)

P. 23:

Notas MA:

1. termo sublinhado no v. 4 , "E' uma":

E' uma folha cahida

Do livro da minha vida.

2. v. 8 assinalado por expoente “(1)”, remetendo ao comentário no rodapé:

Ha que tempos! Bem lembro...

Foi n'um dia de novembro: "(1)"

"(1) Gui num dos poemas de Encantamento tam-/bem se serve de novembro pra rimar / com lembro"

3. preposição sublinhada no v. 15, "P'ra", e cruzeta à esquerda - estudo linguístico: emprego de "para/pra":

$X \quad \underline{\text { P'ra quem sabe do lar fagueiro; }}$

Nota da pesquisa: Gui: apelido de Guilherme de Almeida (1890-1969). A Coleção MA na Biblioteca do IEB/USP conserva dezessete títulos do destacado poeta do movimento modernista. O exemplar de Encantamento (São Paulo: Livraria do Globo, 1925), sem notas de margem, traz a dedicatória: "Mario - muito ás pressas, pra / você ler em viagem 
e pensar mui-/to em nós: Baby, Guy e eu. / [assinatura] Guilherme / S. Paulo, 3.VI.1925". A rima aludida por MA encontra-se no poema III na parte "Cartas que eu não mandei": "E eu penso / em ti, no nosso amor, neste desejo immenso / de te vêr, de te ouvir, de irmos os dois, sózinhos / sob este mesmo céo, nestes mesmos caminhos / onde iamos, nas tardes limpas de novembro, / esquecer nossa vida... Amor, como eu me lembro!". Guy é o filho de Guilherme e de Belkiss (Baby) Barroso de Almeida - Guy Sérgio Haroldo Estevão Zózimo Barroso de Almeida, nascido em 1924.

No corpus da pesquisa, Guilherme de Almeida também é aludido na leitura de MA do poema IX da Juvenília, de Varela. À margem dos versos "Estavamos sózinhos sentados no terraço / Que a trepadeira em flôr cobria de perfumes", MA faz um traço vertical e escreve: "Guilherme de Almeida" (V. Nota MA em Obras completas de L. N. Fagundes Varella. Rio de Janeiro/Paris: Garnier, 1919, v. 1, p. 27). Trata-se de ligação importante, referendando uma preocupação do leitor em aproximar duas estéticas. Em 9 de março de 1930, nas páginas do Diário Nacional, MA celebra a eleição do amigo para a Academia Brasileira de Letras e discorre sobre sua obra: "No momento presente, não vejo na literatura brasileira, uma organização mais integral de poeta que a dele: lirismo, grande faculdade imaginativa, artista incomparável. Personalidade fixa, nenhuma vagueza psicológica, cultura adequada e aquele pingo ácido de liberdade em relação aos homens e às coisas, que é parte pela qual os poetas verdadeiros são incomensuráveis pro metro humano." (ANDRADE, Mário de. "Guilherme de Almeida", in Táxi e Crônicas no Diário Nacional. Estabelecimento do texto, introdução e notas de Telê Porto Ancona Lopez. São Paulo: Livraria Duas Cidades/Secretaria da Cultura, Ciência e Tecnologia, 1976, p. 194).

P. 24:

Notas MA:

1. v. 36 sublinhado e número /1/ antes da primeira sílaba, indicando a irregularidade estudo da versificação: métrica:

\section{$\underline{\text { /l/ Morta na flôr dos annos! }}$}

2. termo sublinhado no v. 37, "p'ro", e cruzeta - estudo linguístico: emprego de "para/pra" e suas variações:

$$
\text { Era um anjo! Foi p'ro céo } \quad X
$$

\section{P. $25-26$}

JURITY (7 estrofes)

P. 25:

Nota MA: v. 16 sublinhado e expoente "(1)” remetendo ao comentário no rodapé - estudo da versificação: métrica:

\section{$\underline{\text { A jurity suspira sobre as folhas seccas " }}$ "(1)"}

“(1) O ritmo decassilabico persiste aumentado de / duas silabas iniciais, antes $2^{a}$ e 3 silabas, pois a pri-/meira soa com valor sonoro métrico. Numa antevi-/são quasi do verso 
interior empregado por Vildrac. / Me parece que o ritmo não falta em nenhum dos / versos errados dos românticos. Examinar."

Notas da pesquisa:

1. No fichamento crítico d'As Primaveras, elaborado por MA, os primeiros versos de "Jurity" são recomendados à leitura em voz alta, pelo "Encanto fantastico no descobrir expressões duma sensibilidade maravilhosa" (MA-MMA-05-03). Esta página aparece elencada também sob a rubrica "Modo de contar as sílabas" no plano do estudo Lirismo romântico no Brasil (MA-MMA-26-04).

2.Charles Vildrac (1882-1971), poeta e dramaturgo francês; Fundador do grupo da Abadia de Créteil, Vildrac constitui matriz relevante para a poesia do jovem Mário, cuja obra de estreia, Há uma gota de sangue em cada poema, é tributária do ideal de fraternidade dos unanimistas (V. LOPEZ, Telê Ancona. "A estreia poética de Mário de Andrade", in Mariodeandradiando. São Paulo: Edusp/Hucitec, 1993, p. 3-15). a Coleção MA na Biblioteca do IEB-USP, mostra quatro títulos. No exemplar de Chants $d u$ désespéré: 1914-1920 (Paris: Éditions de la Nouvelle Revue Française, 1920), MA destaca, a lápis, estrofes de dois poemas, "Mobilisation" e "Avec l'herbe". Em Découvertes (Paris: Gallimard, Éditions de la Nouvelle Revue Française, 1923), ressalta, em francês, na folha de guarda: "Récréation pg 27, un chef d'oeuvre". A possibilidade de um acontecimento banal alterar os automatismos da vida cotidiana - como é o caso da narrativa de Vildrac destacada por MA - parece ser o mote/ matriz de "O ladrão", incluído entre os Contos novos.

P. 26:

Notas MA:

1. expressão sublinhada no v. 24, "gentís soluços" - estudo linguístico: sintaxe/posição do adjetivo:

2. v. 25 sublinhado e número " 5 " indicando a irregularidade - estudo da versificação: métrica:

E a voz lhe morre nos gentís soluços,

No final suspiro. $\quad 5$

3. expressão sublinhada no v. 29, "voz desfallecida" - estudo linguístico: sintaxe/posição do adjetivo:

Irei sósinho, a voz desfallecida;

4. comentário ao final do poema:

"Comparações"

P. 27-29

Meus Oito Anos (7 estrofes)

P. 27:

Nota MA: expressão sublinhada no v. 11, "Respira a alma" - estudo da versificação: hiato/métrica: 
P. 28:

Notas MA:

1. colchete destacando os v. 31 e 32 - estudo da psicologia: sentimento amoroso:

De minha mãe as caricias

E beijos de minha irmã!

2. expressões sublinhadas nos v. 36 e 40, "nús" e "azues", ligadas por um fio - estudo da versificação: rima:

- Pés descalços, braços nús -
Correndo pelas campinas
Á roda das cachoeiras,
Atraz das azas ligeiras
Das borboletas azues!

Nota da pesquisa: Os versos 31 e 32 são reproduzidos em "Amor e medo", no trecho dedicado ao caso de mãe e irmã. Afirma MA: "saliento de passagem que todos os nossos grandes românticos amaram intensamente mãe e irmã e falaram muito nelas" (In: Aspectos da literatura brasileira. Ed. cit., p. 218).

P. 29:

Nota MA: comentário ao final do poema:

“Absolutamente perfeito. / É total como ritmo, sonoridade, / infancia, saudade, graça, forma, / até ideas, doce e terno."

Nota da pesquisa: O fichamento crítico reitera a avaliação positiva ao incluir o poema entre as obras-primas, ao mesmo tempo que o reputa exemplo de "Saudosismo objetivo e não idealista como quasi sempre G. Dias" (MA-MMA-05-03). No plano da obra Lirismo romântico no Brasil, o poema ilustra o "Tema 'Como a ave que volta ao ninho antigo' em C. Alves I, 108 e Casimiro Meus oito anos". A Nota MA nas Obras completas de Castro Alves completa o círculo de remissões: " $O$ 'Como a ave que volta ao ninho antigo' já em Casemiro se encontra adorável, aqui magistral embora menos comovente que em Casemiro." (Nota MA, In: ALVES, Castro. Obras completas. Ed. cit., v. 1, p. 108).

$\underline{\text { P. } 31-34}$

No LAR (26 estrofes)

P. 31:

Nota MA: v. 10 sublinhado - estudo da psicologia: seleção de ideias/valores do eu lírico:

Gloria, amores, mocidade e crença,

Nota da pesquisa: Outro exemplo, na visão de MA, do "Saudosismo objetivo e não idealista" de Casimiro de Abreu, comparado a Gonçalves Dias (MA-MMA-05-03).

P. 32: 
Notas MA:

1. preposição sublinhada no v. 24, "para", e cruzeta - estudo linguístico: emprego de "para/pra":

- Noiva enfeitada para o seu noivado! -

2. v. 34 sublinhado - estudo da psicologia:

Nada me esquece!... e esquecer quem ha-de?...

3. v. 46 e 47 destacados por colchete - estudo da psicologia: sentimento amoroso/mãe e irmã;

4. v. 48 sublinhado - estudo da psicologia: presença do sadismo no sentimento amoroso:

E minha mana, tão gentil, dormindo!

E mamãe a contar-me historias lindas

Quando eu chorava e a beijava rindo!

\section{P. 33:}

Notas MA:

1. v. 64 sublinhado - estudo do caráter visual atribuído por MA à poesia de Casimiro de Abreu:

- Sósinho - e orphão das visões ardentes!

2. v. 75 sublinhado e escólio à direita, "choro" - estudo da psicologia: presença do sadismo no sentimento amoroso:

\section{Que ria e chore, que suspire e gema "choro"}

Nota da pesquisa: Ao observar a ênfase dada por Casimiro de Abreu ao choro da mulher, em "Amor e medo", MA menciona o verso destacado: "Mais típica ainda é uma certa constância de perversão que lhe percorre a obra curta: a do choro da virgem desarmando o 'pássaro esfaimado'. São longes de sadismo, porque de fato o poeta se compraz em ver a pequena chorando. Quando no 'Lar' ele pede amor, se observe este detalhe de como quer a amada" ("Amor e medo", In: Aspectos da literatura brasileira. Ed. cit., p. 205).

\section{P. 34:}

Notas MA:

1. v. 87 sublinhado e cruzeta - estudo da versificação: estrutura em quiasma:

$+\quad$ Claros riachos, cachoeiras altas,

2. v. 90 sublinhado e fio prendendo ao v. 100;

3. termo sublinhado no v. 94, "modulai-me" - pesquisa para o Dicionário musical brasileiro;

4. v. 100 sublinhado, ligado por um fio ao v. 90, e expoente “(1)” remetendo ambos ao comentário no rodapé: 


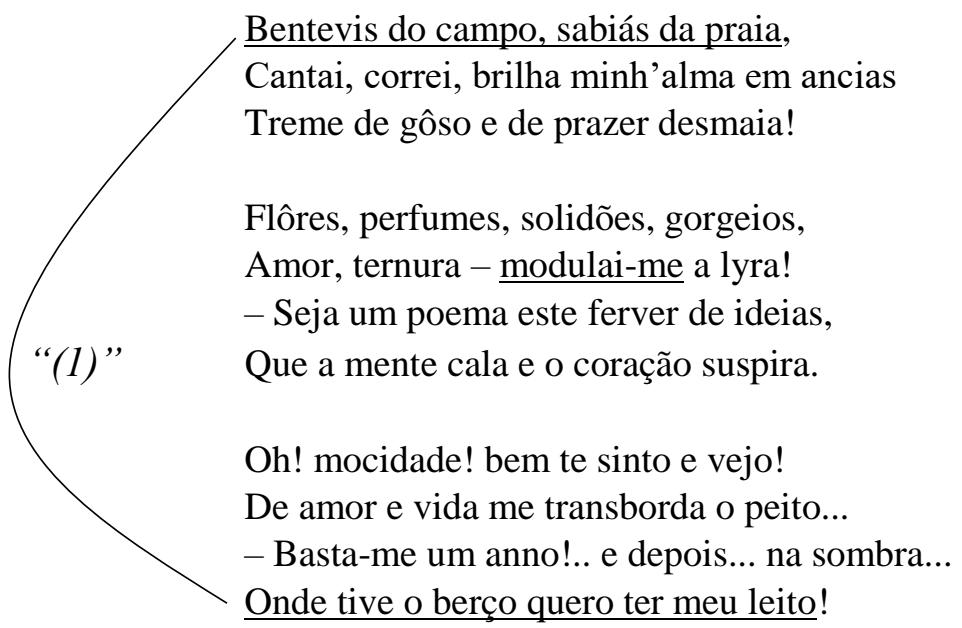

“(1) Mesma nota pra êstes dois versos que a / que está na pg. 25.”

BRAZILIANAS

$\underline{\text { P. } 35-38}$

MORENINHA (17 estrofes)

P. 37:

Notas MA:

1. termo sublinhado no v. 52, "pandeiro", e cruzeta - pesquisa para o Dicionário musical brasileiro:

Rufando alegre o pandeiro, $\quad X$

2. v. 78 sublinhado e cruzeta - estudo psicológico: sentimento amoroso:

No seio te fui bulir! $\quad X$

Nota da pesquisa: MA refere o poema ao analisar a psicologia amorosa de Casimiro de Abreu em "Amor e medo": "[Castro Alves] É exatamente o contrário de Casimiro de Abreu, que irrita pelas perversõezinhas com que recama a sua burguês dulcidão. Casimiro de Abreu é mestre nesse gênero de poesia graciosa, própria dos assustados familiares, que a gente vive esquecendo que no fundo é bem pouco inocente. Por exemplo, a ritmicamente deliciosa Moreninha, em que o poeta à 'meiga' 'inocente' 'gazela' segue 'calado' (...) e quando ela oferece as flores, engana a 'rosa da aldeia' com esta safadeza [cita a estrofe $n^{\circ} 13$, cujo verso final é o que vem sublinhado acima na marginália]. Nessas gracinhas ele é mestre, como na Scena intima, em que pede beijos por castigo e no Juramento" (In: Aspectos da literatura brasileira. Ed. cit., p. 205).

$\underline{\text { P. } 39-40}$

NA REDE (8 estrofes)

P. 39: 
Nota MA: v. 8-10 destacados por colchete e escólio "Sequestro" - ligação com a pesquisa de MA do tema do Sequestro da dona ausente no folclore brasileiro:

$$
\left.\begin{array}{l}
\text { De leve embalada no quieto balanço } \\
\text { Qual nauta scismando n'um lago bem manso } \\
\text { Num leve batel! }
\end{array}\right] \text { "Sequestro" }
$$

Nota da pesquisa: Os versos são indicados no dossiê do manuscrito $O$ Sequestro da dona ausente, em meio a outras referências, no f. 590: "Sequestro / n 223 p 7 / p 39".

$\underline{\text { P. } 41-42}$

A VoZ DO RIO (13 estrofes)

P. 41:

Notas MA: v. 13-16 destacados por colchete e escólios, recolhendo e localizando a tópica do Sequestro da dona ausente, vinculada ao folclore brasileiro:

$\begin{array}{ll}\text { "Sequestro" } & \text { Lá novos campos outros campos ligam } \\ & \text { E a vista fraca na extensão se perde! } \\ & \text { E tu sósinha viverás no exilio } \\ & \text { - Garça perdida n'esse mar que é verde! - }\end{array}$

Nota da pesquisa: A estrofe assinalada justifica a inclusão da página no manuscrito de MA que documenta a pesquisa dele sobre a tópica da dona ausente: "Sequestro / n 223 p 41 / p 84 / = / Dar Casemiro / como o "poeta / do Sequestro"” (MA-MMA-106-591).

\section{P. 42:}

Notas MA:

1. preposição sublinhada no v. 28, "p'ra", e cruzeta à esquerda - estudo linguístico: emprego de "para/pra":

\section{$X \quad$ Porque deixal-o p'ra viver no sul?!}

2. comentário ao final do poema:

"É o porque-me-ufanismo burguês, chato, / didatico, do qual não fica mais nada que o valor / artistico do verso acalantador, deliciosamente / morno, calor 'á sombra de enorme frondosa man-/gueira' embalo de rede, carinho e gosto fisiológico só."

\section{$\underline{\text { P. 43-44 }}$}

SETE DE SETEMBRo (6 estrofes)

P. 44:

Nota MA: comentário ao final do poema:

"Poema lindissimo, pelo ardor, pela / claridade popular que não / diz lugares-comuns porém / realidades essenciais do patrio-/tismo. Muito bonito mesmo." 
Nota da pesquisa: Quanto ao emprego do lugar-comum, o comentário à margem do poema "Quem dá aos pobres, empresta a Deus" permite contrastar esta nota com a avaliação de MA sobre o autor de Espumas flutuantes: "C. Alves é a mais perfeita encarnação do entusiasmo facil e ingênuo popular. Nenhum pensamento verdadeiramente grande porem ninguém como ele concretizou a grandeza do lugar-comum. É enorme nisso" (V. Nota MA, In: ALVES, Castro. Op. cit, ed. cit., p. 314).

\section{CÂNTICOS}

$\underline{\text { P. } 45-47}$

POESIA E AMOR (10 estrofes)

P. 45:

Nota MA: termo sublinhado no v. 9, "harmonia" - pesquisa para o Dicionário musical brasileiro:

Da noite a harmonia

P. 46:

Notas MA:

1. termo sublinhado no v. 26 , "trino" - pesquisa sobre a zoofonia:

$X \quad$ É o trino das aves

2. termo sublinhado no v. 49, "sino", e escólio "dic" à esquerda - pesquisa para o Dicionário musical brasileiro:

"dic" O $\underline{\text { sino }}$ da torre

3. v. 53-56 destacados por traço vertical;

4. termo sublinhado no v. 55, "trova", e escólio "dic" - pesquisa para o Dicionário musical brasileiro:

"dic" $\quad\left(\begin{array}{l}\text { O triste que vela } \\ \text { Cantando á donzella } \\ \text { A trova singela } \\ \text { Do seu coração; }\end{array}\right.$

P. 47:

Notas MA:

1. termo sublinhado no v. 71, "hymnos", e escólio "dic"- pesquisa para o Dicionário musical brasileiro:

São hymnos, são cantos “dic”

2. v. 79 e 80 sublinhados, destacados por traços verticais e comentário - seleção de ideias:

$\left.\left(\frac{\text { Tudo isso é }- \text { poesia! }}{\underline{\text { Tudo isso é }- \text { amor }}}\right)\right) \quad$ " = Casimiro" 
$\underline{\text { P. } 48}$

ORAÇÕES (4 estrofes)

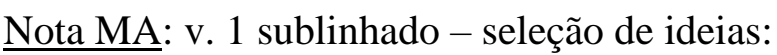

$\underline{\text { A alma, como o incenso, ao céo s'eleva }}$

P. 49

BÁLSAMO (2 estrofes)

Nota MA: preposição sublinhada no v. 7, “p'ra”, e cruzeta - estudo linguístico: emprego de "para/pra":

O esqualido coveiro p'ra dous corpos $X$

$\underline{\text { P. } 50}$

DEUS! (3 estrofes)

Nota MA: termo sublinhado no v. 9, "p'r'os" - estudo linguístico: emprego de "para/ pra" e de suas variações:

Minha mãe a sorrir olhou p'r'os ceus

\section{LIVRO SEGUNDO}

$\underline{\text { P. 53-54 }}$

PRIMAVERAS (10 estrofes)

P. 53:

Notas MA:

1. v. 8 sublinhado - seleção de ideias:

Melhor perfume a violeta exhala.

2. verbo sublinhado no v. 14, "modula", e escólio, "dic / no sentido de / entoar" - pesquisa para o Dicionário musical brasileiro:

Um hymno immenso a creação modula "dic / no sentido de / entoar"

P. 54:

Notas MA:

1. termo sublinhado no v. 24, "threno", e escólio "dic" - pesquisa para o Dicionário musical brasileiro: 
Solta gemendo de amargura um threno "dic"

2. termos sublinhados nos v. 30 e 31, "mancebo" e "enlevo" - estudo da versificação: rima:

Treme nos labios do cantor mancebo,

Em breve a virgem de seu casto enlevo

Nota da pesquisa: MA elenca esta página sob a rubrica "Rimas erradas ou fracas", na folha de guarda do volume.

\section{P. 55-57}

SCENA INTIMA (12 estrofes)

P. 55:

Nota MA: preposição sublinhada no v. 3, "p'ra", e cruzeta - estudo linguístico: emprego de "para/pra":

$$
\text { Só p'ra mim! } \quad X
$$

P. 56:

Nota MA: preposição sublinhada no v. 39, "p'ra”, e cruzeta - estudo linguístico: emprego da forma "pra".

$$
\text { X } \quad \text { P'ra poupar }
$$

\section{P. 58-59}

JURAMENTO (7 estrofes)

Nota da pesquisa: Embora sem marcas de leitura, "Juramento" está entre os poemas que escudam o comentário de MA, em "Amor e medo", sobre as gracinhas "bem pouco inocentes" do eu lírico d'As primaveras (In: Aspectos da literatura brasileira. Ed. cit., p. 205).

P. 61-62

SEGREDOS ( 7 estrofes)

P. 61:

Nota MA: termo sublinhado no v. 22, "walsar", e escólio "dic" - pesquisa para o Dicionário musical brasileiro:

Queimava-me as faces no louco walsar, "dic"

P. 62:

Nota MA: v. 49-52 destacados por colchete - estudo da psicologia: sentimento amoroso:

Trememos de medo... a bocca emmudece Mas sentem-se os pulos do meu coração! Seu seio nevado de amor se entumece... E os labios se tocam no ardor da paixão! 
Nota da pesquisa: Os tremores do eu lírico casimiriano são objeto de análise em "Amor e medo". Ao contrário de Castro Alves, que tremia por impaciência, Casimiro de Abreu "preferia a tremedeira por timidez". MA cita, no entanto, a estrofe assinalada em "Segredos" como exemplo contrário, de "tremor por ansiedade" (In: Aspectos da literatura brasileira. Ed. cit., p. 209).

$\underline{\text { P. } 65-70}$

A VALSA (6 estrofes)

P. 70:

Nota MA: comentário ao final do poema - estudo da versificação: ritmo:

"Ritmo anacrusico masculino em três / tempos. Isto é incontes-/tavelmente um achado de verdadeiro / artista."

\section{P. 71-73}

BORBOLETA (10 estrofes)

P. 71:

Nota MA: preposição sublinhada no v. 11, "P'ra", e cruzeta - estudo linguístico: emprego de "para/pra".

$$
X \quad \underline{\text { P'ra que vaes dar teus desvelos }}
$$

$\underline{\text { P. } 74}$

QUANDO TU CHORAS (6 estrofes)

S/ $\underline{\text { Notas MA }}$

Nota da pesquisa: MA identifica neste poema, que não conserva marcas de sua leitura, a manifestação máxima do sadismo atribuído por ele a Casimiro de Abreu: "E guardei para o fim, o poema Quando tu choras, em que tudo vem claramente confessado. Os grifos são sempre meus. E se note que a poesia é dirigida a uma virgem e gentil donzela." ("Amor e medo", in Aspectos da literatura brasileira. Ed. cit., p. 207).

\section{P. 75-78}

CANTO DE AMOR (20 estrofes)

P. 76:

Notas MA:

1. v. 17-20 destacados por colchete - estudo da psicologia: sentimento amoroso/amada dormida:

No silencio da noite a virgem vinha Soltas as tranças, junto a mim dormir; E era bella, meu Deus, assim sósinha No seu somno d'infante inda a sorrir!... 
2. v. 25-28 destacados por traço vertical - estudo da psicologia: sentimento amoroso/platonismo:

O seu olhar não me cobriu d'affago,

E minha imagem nem sequer guardou,

Qual se reflecte sobre a flôr d'um lago

A branca nuvem que no céo passou.

P. 77:

Notas MA:

1. preposição sublinhada no v. 41, "P'ra", e cruzeta - estudo linguístico: emprego de "para/pra":

$X \quad \underline{\text { P'ra ti, formosa, o meu sonhar de louco }}$

2. preposição sublinhada no v. 56, "para", e cruzeta à esquerda - estudo linguístico: emprego de "para/pra":

$X \quad$ Toda a paixão que para ti guardei.

Nota da pesquisa: Também em "Canto de Amor" MA encontra respaldo para o sadismo atribuído a Casimiro de Abreu. O ensaio alude aos v. 47 e 48: "Se rires - rio, se chorares, choro, / E bebo o pranto que banhar-te a tez" ("Amor e medo", In: Aspectos da literatura brasileira. Ed. cit., p. 207).

P. $80-81$

O QUE? (6 estrofes)

P. 80:

Nota MA: preposição sublinhada no v. 15, "p'ra”, e cruzeta - estudo linguístico: emprego de "para/pra":

$X \quad$ Tu, p'ra saudal-a bem do imo d'alma

P. 81:

Nota MA: preposição sublinhada no v. 22, "para", e cruzeta - estudo linguístico: emprego de "para/pra":

A fronte virgem para ti pendida, $\quad X$

$\underline{\text { P. } 82-83}$

SONHOS DE VIRGEM (6 estrofes)

P. 83:

Nota MA: comentário ao final do poema - estudo da versificação: métrica: 
"Casimiro é o melhor redondilheiro do / grupo romantico. Quasi todos os milhores / poemas dele são em redondilhas. Era um / cantador mas não um musical. Expli-/car esta subtileza."

P. 84

ASSIM (4 estrofes)

Nota MA: v. 1-12 destacados por colchete e escólio "Sequestro" - ligação com a pesquisa de MA sobre a tópica da dona ausente no folclore brasileiro:

Viste o lyirio da campina?

Lá s'inclina

E murcho no hastil pendeu!

- Viste o lyrio da campina?

Pois, divina,

Como o lyrio assim sou eu!

Nunca ouviste a voz da flauta.

A dôr do nauta

Suspirando no alto mar?

- Nunca ouviste a voz da flauta?

Como o nauta

É tão triste o meu cantar!
"Sequestro"

Nota da pesquisa: A flauta é uma das "imagens derivativas" no processo de sublimação do desejo sexual postulado na conferência "O sequestro da dona ausente". O dossiê que reúne os documentos dessa pesquisa de MA faz referência a essa página d'As Primaveras: "Sequestro / n 223 p 41 / p 84 / = / Dar Casemiro / como o "poeta / do Sequestro"" (MAMMA-106-591).

\section{$\underline{\text { P. } 87-88}$}

SEMPRE SONHOS!... (10 estrofes)

P. 87:

Notas MA:

1. preposição sublinhada no v. 3, "p'ra", e cruzeta - estudo linguístico: emprego de "para/pra":

$$
\text { E atirára p'ra longe - sem saudade - } \quad X
$$

2. verso 19 sublinhado e traço apartando a primeira sílaba, de modo a indicar a anacruse; estudo da versificação: métrica.

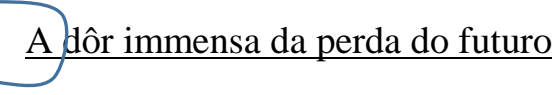

P. 88:

Notas MA: v. 36-40 destacados por traço vertical, sublinha no v. 36, escólio e observação - reconhecimento de vínculo com o tema da dona ausente, estudado por MA no folclore brasileiro: 
"Sequestro a imagem do mar vem constante no amor do poeta"
Como o nauta olha o céo de primavera, $\mathrm{Eu}$, sentado a seus pés, ebrio de amor, Espreitára tremendo no seu rosto A sombra fugitiva d'um desgosto, A nuvem d'uma dôr!

Nota da pesquisa: Em nota de trabalho, no dossiê do manuscrito $O$ sequestro da dona ausente, MA refere esta página: "Sequestro / n” 223 p 88 / / = / p 92 / importante / = / p 114 importante" (MA-MMA-106-592). / p 90 / importante

$\underline{\text { P. } 89}$

O QUE É-SYMPATHIA (4 estrofes)

Nota MA: termos sublinhados nos v. 13 e 14, "gemeas" e "riso", e comentário à direita, "Sem rima"; estudo da versificação: rima.

São duas almas bem gemeas

Que riem do mesmo riso, Sem rima

P. 90-91

PALAVRAS NO MAR

P. 90:

Nota MA: título sublinhado e escólio, "Sequestro".

Nota da pesquisa: No dossiê do manuscrito $O$ sequestro da dona ausente, em nota de trabalho já transcrita aqui, MA classifica como "importante" a referência a esta página (MA-MMA-106-592).

\section{P. 91:}

Nota MA: comentário ao final do poema.

"(É o único poema que ele data / de bordo do Avon [percorrer milhor las poe datas do livro pra ver si / é mesmo][ver a data da viagem / dele pra ver se não tem outros / poemas também de bordo e não / lembrando o navio na data])"

\section{$\underline{\text { P. } 92-93}$}

PEPITA (10 estrofes)

\section{P. 92:}

Notas MA:

1. verso 3 sublinhado e fio ligando à exclamação no alto da página, "Puxa! ";

2. expressão sublinhada no v. 4, "no paiz das flôres", e exclamação à direita - estudo da versificação: rima; 
3. v. 1-5 destacados por traço vertical e escólio "Sequestro" - estudo da psicologia: sentimento amoroso;

4. v. 1-5 e v. 26-30, na página seguinte, presos por fio - estudo da psicologia: sentimento amoroso:

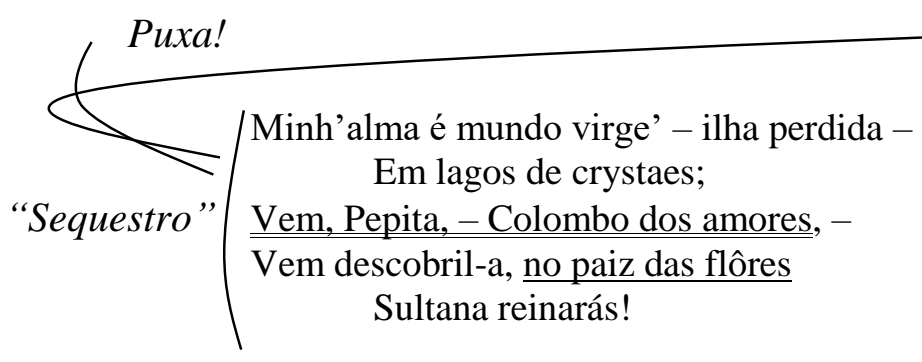

Nota da pesquisa: Conforme nota de trabalho citada, o dossiê do manuscrito $O$ sequestro da dona ausente conserva remissão a esta página, assinalada como importante (MAMMA-106-592).

\section{P. 93:}

Notas MA:

1. v. 26-30 destacados por traço vertical e fio prendendo-os aos v. 1-5 na página anterior - estudo da tópica da dona ausente no folclore brasileiro:

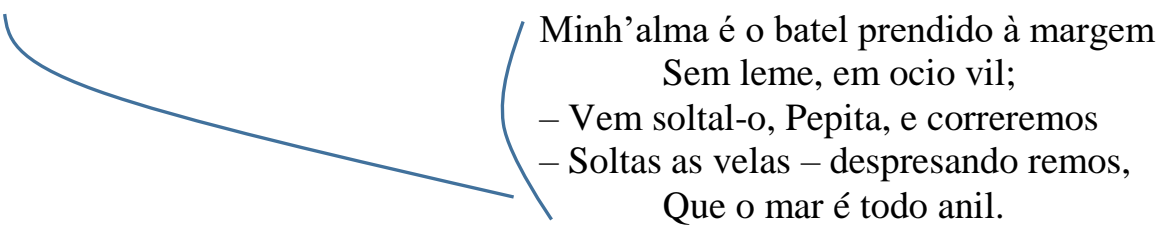

Nota da pesquisa: As embarcações também constam como imagem derivativa no processo de sublimação do desejo sexual, segundo propõe MA em suas cogitações.

2. v. 38-40 destacandos por colchete e escólio "Amor e medo" - estudo da psicologia: sentimento amoroso:

$\left.\begin{array}{c}\text { - Vem, Pepita, das tardes no remanso, } \\ \text { Da rede dos amores no balanço } \\ \text { Comigo adormecer. }\end{array}\right]$ $*$

P. 98-100

AMOR E MEDO (15 estrofes)

P. 98:

Nota MA: v. 5-8 destacados por traço vertical - estudo da psicologia: sentimento amoroso:

Como te enganas! meu amor é chamma

Que se alimenta no voraz segredo,

E se te fujo é que te adoro louco...

És bella - eu moço; tens amor, eu - medo!...

P. 100:

"Amore

medo" 
Nota MA: v. 41-48 destacandos por traço vertical e expoente "(1)" remetendo ao comentário no rodapé desta e da página seguinte - estudo da psicologia: sentimento amoroso:

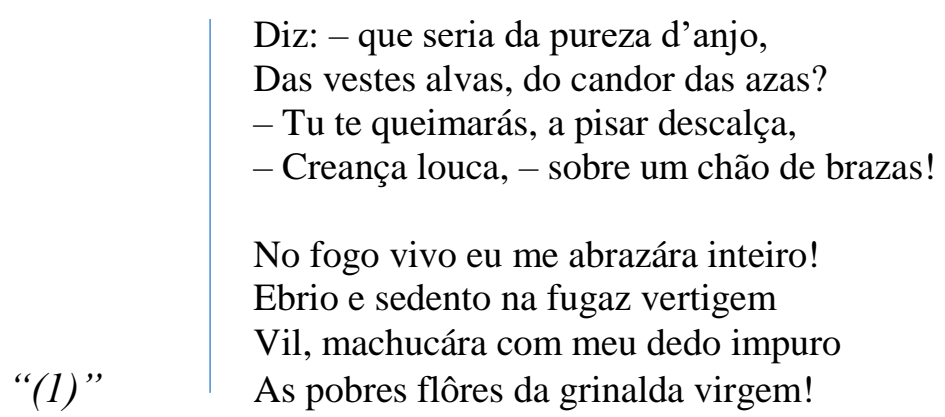

"(1) assim, apesar de tão bem começado / o medo do poeta não é um medo / de amor, se reduz banalissimamen-/te a um medo moral de desfolhar / a virgem. Não é medo de amor, é me-/do estético de perder a beleza duma vir-/gindade - que a Virgem pros romanticos / é um dos ápices da beleza humana. / Veja grifos p 102 e 104."

Nota da pesquisa: MA confirma a anotação no texto do poeta como nota de trabalho ao seu ensaio para a Revista Nova, no qual se lê: "Embora Casimiro de Abreu tenha inventado o título mais apropriado ao nosso tema, o sentido deste Amor e Medo logo se desvia e fixa noutro assunto. O poeta, em vez de ter medo do amor, tem medo mas é de macular a virgem [...] E aqui entra a primeira grande lateralidade em que a timidez de amar, se fixa nos românticos: o respeito à mulher. Parece até cômico se denunciar respeito à mulher, na taverna em que os nossos românticos hospedaram os Heine, Musset e Byron, que tinham no coração, porém a própria maneira desabusada com que Álvares de Azevedo às vezes trata a mulher, ou a cretina safadeza das minúsculas libertinagens de Casimiro de Abreu, são provavelmente procuras de libertação, conscientes e por isso exageradas, daquele respeito." ("Amor e medo", in Aspectos da literatura brasileira. Ed. cit., p. 200). Os grifos aludidos por MA referem-se ao poema seguinte, "Perdão".

P. 101-104

PERDÃO (7 estrofes)

P. 102:

Notas MA:

1. v. 17-24 destacados por traço vertical e escólio “Amor e Medo" - estudo da psicologia: sentimento amoroso:

\begin{tabular}{l|l} 
Medo & Choraste!? - De envergonhada, \\
No teu pudor offendida, \\
Porque minh'alma atrevida \\
No seu palacio de fada, \\
- No sonhar da phantasia - \\
Ardeu em loucos desejos, \\
Ousou cobrir-te de beijos \\
E quiz manchar-te na orgia!
\end{tabular} 
2. preposição sublinhada no v. 28 , "p'ra”, e cruzeta - estudo linguístico: emprego de "para/pra":

$$
X \quad \text { Perdão p'ra mim que não pude }
$$

P. 104:

Nota MA: v. 61-69 destacados por traço vertical e escólio “Amor e Medo" - estudo da psicologia: sentimento amoroso:

\begin{tabular}{l|l} 
Medo & Perdão! Se fui desvairado \\
Manchar-te a flôr d'innocencia, & E do meu canto n'ardencia \\
Ferir-te no coração! & - Será enorme o peccado, \\
Mas tremenda a expiação \\
Se me deres por sentença \\
Da tua alma a indifferença, \\
Do teu labio a maldição!...
\end{tabular}

Nota da pesquisa: O poema respalda o argumento de MA, em "Amor e medo", quanto ao sadismo de Casimiro de Abreu, em particular o prazer do eu lírico d'As primaveras com o choro da mulher amada: "Mais típico ainda, si possível, é o Perdão (...) Poesia toda dum carioquismo seresteiro que nem texto de samba praceano, já é espantoso que a pomba chore pelo que a alma do poeta desejou apenas 'no sonhar da fantasia'. Pois não é tudo. Se veja como o poeta persegue em seguida, e esmiúça, o arrependimento em que ficou. Isso lhe permite repisar bem o que queria fazer para a coitadinha da pomba... E não é só. O poeta inventa ainda o requinte de beber as lágrimas desarmadoras da pomba" ("Amor e medo", In: Aspectos da literatura brasileira. Ed. cit., p. 206).

$\underline{\text { P. } 105-106}$

MOCIDADE (10 estrofes)

P. 106:

Nota MA: termo sublinhado no v. 27, "p'ra", e cruzeta - estudo linguístico: emprego de "para/pra":

$$
\text { Porque não havemos p'ra acalmar as dôres } \quad X
$$

$\underline{\text { P. } 107-108}$

NOIVADO (7 estrofes)

P. 107:

Nota MA: v. 9 sublinhado e remissão à esquerda, “(ver pg 108)”- estudo da versificação: métrica:

Vem! a noite é linda, o mar é calmo, $\quad$ (ver pg 108)

P. 108:

Notas MA: 
1. v. 13-16 destacados por traço vertical e juízo de valor à esquerda, "lindo":

“lindo" $\quad \begin{aligned} & \text { Qual ecco fraco de amorosa queixa } \\ & \text { Perpassa a brisa na magnolia verde, } \\ & \text { E o som magoado do tremer das folhas } \\ & \text { Longe - bem longe - devagar se perde. }\end{aligned}$

2. v. 21 sublinhado e expoente “(1)” remetendo ao comentário no rodapé - estudo da versificação: métrica:

\section{Vem! tudo é tranquilo, a terra dorme, "(1)"}

“(1) O caso singular destes dois decassilabos / heroicos no ritmo (o outro pg anterior) $e$ a / que falta a segunda silaba."

Nota da pesquisa: O planejamento crítico do estudo Lirismo romântico no Brasil contém remissão a esta página, sob a rubrica "Técnica do romantismo brasileiro / Modo de contar as sílabas" (MA-MMA-26-04).

$\underline{\text { P. } 109-110}$

DE JOELHOS (10 estrofes)

P. 109:

Notas MA:

1. v. 2 sublinhado e traço apartando a primeira sílaba, de modo a indicar a anacruse estudo da versificação: métrica;

2. v. 4 sublinhado e anotação à direita, “(fli)” - estudo linguístico: pronúncia / estudo da versificação: métrica:

Qual resa o irmão pelas irmãs queridas,

Ou a mãe que soffre pela filha bella,

$\mathrm{Eu}$ - de joelhos - com as mãos erguidas,

Supplico ao céo a fellicildade della.

3. verso 6 sublinhado e traço apartando a primeira sílaba, de modo a indicar a anacruse estudo da versificação: métrica:

Que daes voz ás brisas e perfume á rosa,

P. 110:

Nota MA: comentário ao final do poema - estudo da versificação: métrica:

"Tem os versos mais censuravelmente fracos do / livro? Nem tanto afinal. O sexto verso afinal é um en-/decassilabo perfeito e o quarto soa ritmicamente como / decassilabo." 


\section{LIVRO TERCEIRO}

$\underline{\text { P. } 113}$

TRES CANTICOS (3 estrofes)

Notas MA: termos sublinhados nos v. 8, 16 e 24 - "hymno", "trovas" e "canto" - e fio ligando-os entre si e ao comentário no rodapé - estudo do estilo: uso da metáfora:

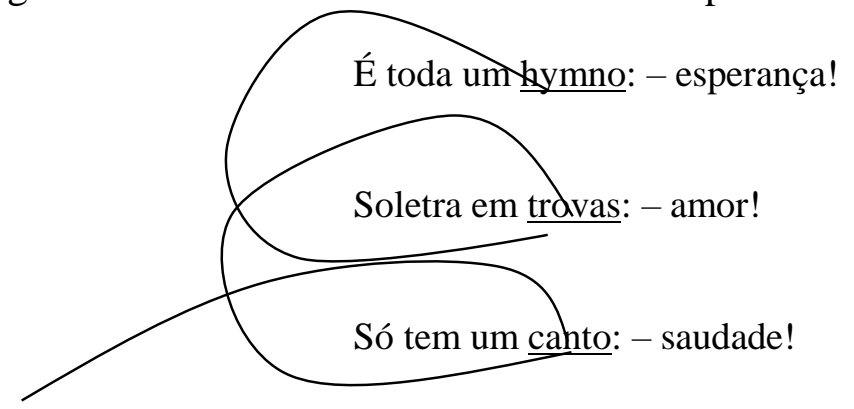

"Notar o conceito musical requintan-/do-se em caracterizar bem a metafora. $/$ O caracter cancioneiro do amor (trova) o / caracter ardente e declamatorio da mocidade / e da esperança (hino) e a palavra canto, bem / escolhida, como que querendo designar uma for-/ma mais livre e um conceito musical mais / vago, pra se referir ao cansaço (alma cansada, de / belos sonhos despida) que chora."

P. 114-115

ILLUSÃO (12 estrofes)

P. 114:

Notas MA:

1. termo sublinhado no v. 9, "bronze", e escólio “dic" à esquerda:

"dic" Quando o bronze da torre da aldeia

2. v. 21-24 destacados por traço vertical, escólio "Sequestro" e fio ligando-os às estrofes seguintes, p. 115 - ligação com a pesquisa de MA sobre o tema do Sequestro da dona ausente no folclore brasileiro:

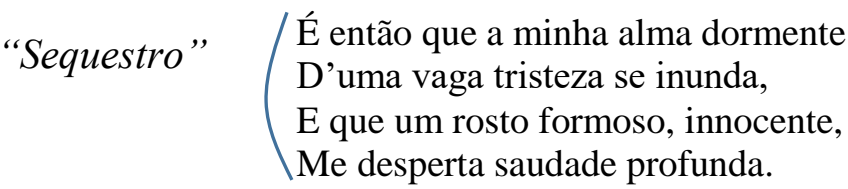

Nota da pesquisa: O dossiê do manuscrito $O$ Sequestro da dona ausente abriga nota de trabalho em que MA classifica como importante a matéria desta página (MA-MMA-106592).

P. 115:

Notas MA:

1. traço destacando os v. 25-48 - ligação com a pesquisa de MA sobre o tema do Sequestro da dona ausente no folclore brasileiro;

2. local sublinhado e fio ligando ao comentário no rodapé: 


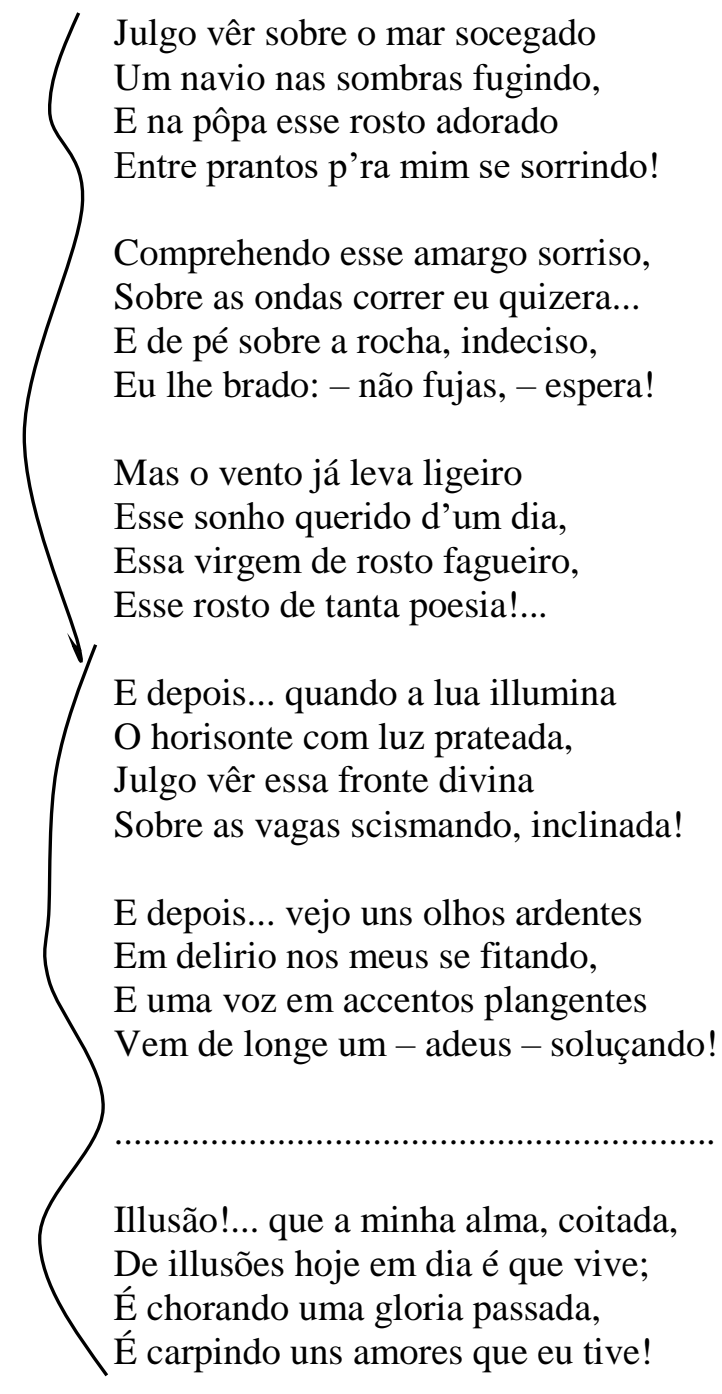

Lisboa -1856.

"Ainda o local em que a poesia / foi feita, 'longe da patria', longe da / amada que ele canta na Rosa Murcha, / é prova do Sequestro."

Nota da pesquisa: MA faz referência ao poema em nota de trabalho, no dossiê do manuscrito $O$ sequestro da dona ausente: "Sequestro / Mulher de barca / Será anterior a Casemiro, na 'Ilusão'? (Com esta pergunta, ligar os poetas eruditos que trataram desta parte do Sequestro). Com efeito esta poesia de Casimiro, publicada na edição de 1859 é tipicamente a mulher vista na barca, chegando a nós e...ilusão (sonho). O poema é de 1859?? (V. edição Sousa da Silveira)" (MA-MMA-106-414). A edição das Obras de Casimiro de Abreu na Biblioteca MA, com organização, apuração do texto, escorço biográfico e notas por Sousa da Silveira (São Paulo: Companhia Editora Nacional, 1940) está ricamente anotada pelo proprietário, que ali registra seu interesse pelo aparato crítico e sua discordância quanto aos critérios do organizador.

\section{P. 116-117}

SONHANDO (5 estrofes) 
P. 116

Nota MA: v. 1-6 destacados por traço vertical e escólio "Sequestro" - ligação com a pesquisa de MA sobre o tema do Sequestro da dona ausente no folclore brasileiro:

"Sequestro" $\mid \begin{aligned} & \text { Um dia, oh linda, embalada } \\ & \text { Ao canto do gondoleiro, } \\ & \text { Adormeceste innocente } \\ & \text { No teu delirio primeiro, } \\ & \text { - Por leito o berço das ondas, } \\ & \text { Meu collo por travesseiro! }\end{aligned}$

Nota da pesquisa: Em nota prévia, no dossiê do manuscrito $O$ sequestro da dona ausente, f. 590, acha-se referência a esta página: "Os dois nagua / p 116".

\section{$\underline{\text { P. } 118}$}

LEMBRANÇA (2 estrofes)

Nota MA: traço destacando as duas estrofes e anotação à esquerda, "Sequestro" - ligação com a pesquisa de MA sobre o tema do Sequestro da dona ausente no folclore brasileiro:

$\begin{aligned} \text { "Sequestro"} & \mid \begin{array}{l}\text { Como o triste marinheiro } \\ \text { Deixa em terra uma lembrança, } \\ \text { Levando n'alma a esperança } \\ \text { E a saudade que consome; } \\ \text { Assim nas folhas do álbum } \\ \text { Eu deixo meu pobre nome. }\end{array} \\ & \mid \begin{array}{l}\text { E se nas ondas da vida } \\ \text { Minha barca for fendida } \\ \text { E meu corpo espedaçado, } \\ \text { Ao ler o canto sentido } \\ \text { Do pobre nauta perdido } \\ \text { Teus lábios dirão: - coitado! }\end{array}\end{aligned}$

Nota da pesquisa: No mesmo f. 590 do dossiê do manuscrito $O$ sequestro da dona ausente, MA registra esta página: "Imagem com o mar / p 118".

P. $119-120$

O BAILE! (8 estrofes)

P. 119:

Notas MA:

1. v. 12 assinalado por expoente "(1)”, remetendo ao comentário no rodapé, associado a leitura contemporânea do crítico:

Tens razão! Mais valem risos

Fingidos, d'esses Narcizos

- Bonecos que a moda enfeita -

Do que a voz sincera e rude 
De quem, presando a virtude,

Os atavios rejeita. "(1)”

“(1) É curioso notar-se como constantemente Casimiro traz / á memória certa maneira pernostica de Catulo Cearense / quando dá pra moralista."

2. termo sublinhado no v. 23, "contradanças", e escólio "por dança dic" - pesquisa para o Dicionário musical brasileiro:

No meio das contradanças "por dança dic"

Nota da pesquisa: MA também evoca Catulo da Paixão Cearense (1863-1946) quando estuda a poesia de Castro Alves na marginália (V. Nota MA in Obras completas. Ed. cit., p. 147) e em seu ensaio sobre o poeta baiano ("Castro Alves", In: Aspectos da literatura brasileira. Ed. cit., p. 114). A Coleção MA conserva, sem anotações suas, apenas um título do poeta e compositor popular bastante conhecido em sua época, Cantor de modinhas brasileiras (Rio de Janeiro: Quaresma, 1927).

\section{P. 120-121:}

Notas MA:

1. termo sublinhado no v. 31, "tremia", e cruzeta - estudo da psicologia: sentimento amoroso:

$X \quad$ "Tremia quando fallava

2. termo sublinhado no v. 36, "ritornello" - pesquisa para o Dicionário musical brasileiro:

"No ritornello das walsas -"

3. preposição sublinhada nos v. 40 e 41, "P'ra", e cruzeta - estudo linguístico: emprego de "para/pra":

$X \quad$ "P'ra que fez Deus as mulheres?

$X \quad$ "P'ra que ha na vida prazeres?

4. comentário ao final do poema, à p. 120, continuando no rodapé da p. 121, com acréscimos à margem direita e concluindo-se na margem superior:

"Não são os romanticos brasileiros inferiores aos france-/ses por exemplo. $O$ romantismo brasileiro é que é in-/ferior ao francês pela falta de cultura que não é defeiIto dos seus representantes mas do país. Si Casemiro so-/bretudo, fosse um homem culto, não estaria longe, ao / contrario igualaria e não sei que mais romanticos como / Uhland ou como Musset ou como Byron. É rarissimo o / romantico que seja pensador original. $O$ que caracteriza / o romantismo e aliás toda a poesia, com excepção dos gran-/des genios, os quais participam mais da historia do pen-/samento que da Poesia propriamente, é a qualidade do / lirismo. Casimiro tem o lirismo da mais psicologica e / abundante qualidade. Junto duma ternura infinita e / adoravel que as tendencias da epoca amoleceram e a / que o caracter brasileiro deu uma sensualidade pegajo-/sa e afeminada. Realça a todo momento a ironia que Inão sabe ser fina nem discreta, ironia 
que tem muito / da popular. -Casimiro não é burro, mas é burguês. A burguesia é o estado I em que a inteligência dorme. A vivacidade de inteli-/gencia de Casimiro bem e quasi que unicamente se expressa no / poema a Faustino $X$ de Novais (citar quarta e sexta estrofe, esta ma-/gistral.) Casemiro deu á sua expressão moldes duma / perfeição absoluta e a quem quer que seja liberto de / preconceitos de pensamento e de requinte parnasiano, e / principalmente preconceitos de desabusado, certas for-/mulas orais que Casemiro atin criou nos seus versos / hão-de sempre comover liricamente. A comoção lirica rea-/lizada tem o seu segredo do embate dos sons, de / ritmos e de sentidos das palavras que formam o / verso. Esse segrêdo, esse misterio Casemiro soube / realizar por vezes e muitas com absoluta segurança / (Exemplos: as 5 primeiras estâncias desta Minha alma é / triste) Aliás inferioridade do R. brasileiro não impede que / tenha deixado obras-primas comparaveis ás mais / mais primas do romantismo universal."

Nota da pesquisa: $\mathrm{O}$ manuscrito contendo as ideias gerais do estudo Lirismo romântico no Brasil liga-se ao comentário desta página sob a rubrica "Inferioridade do Romantismo brasileiro" (MA-MMA-26-04). A Biblioteca MA no IEB/USP abriga dois títulos de Alfred de Musset (1810-1857): Oeuvres complètes (Paris: Garnier, n.d, 4v.), com anotações de leitura, e Choix de poésies de Musset (Rio de Janeiro: Americ-Edit, 1944), sem marcas. Do romântico inglês consta o extenso volume The poetical works of Lord Byron (London: Great New Street, 19-). Quanto ao alemão Johann Uhland (1787-1862), poemas seus e comentário à sua obra são encontrados na edição organizada por Oskar Walzel, Deutsche Dichtung von Gottsched bis zur Gegenwart (Wildpark-Potsdam: Akademische Verlagsgesellschaft Athenaion, 1927, 2v.). Tanto em Byron quanto nos poemas de Uhland presentes na edição de Walzel, MA não registrou notas de margem. $\mathrm{O}$ problema da falta de cultura no Brasil é ideia recorrente nos escritos de MA. Já em "Mestres do passado", o crítico censura a falta "duma larga instrução anterior" entre os parnasianos (in História do modernismo brasileiro. BRITO, Mário da Silva. Rio de Janeiro: Civilização Brasileira, 1997. $6^{a}$ ed. p. 254). O ponto é retomado, sob aspectos variados, em "Cultura musical” (in Aspectos da música brasileira. São Paulo: Livraria Martins Editora, 1965, p. 191), na "Elegia de abril”" (Aspectos da literatura brasileira. Ed. cit., p. 186) e em O banquete (São Paulo: Livraria Duas Cidades, 1978). Cabe indicar que tal observação crítica permeia o ensaio "Castro Alves", no qual MA associa a obra do romântico, enquanto criação muito espontânea, a um traço da mentalidade nacional, menos afeita a esforço e vontade de organização do que ao brilho fácil de "menino prodígio" (In: Aspectos da literatura brasileira. Ed. cit., p. 123).

$\underline{\text { P. } 121-124}$

MINH'ALMA É TRISTE (20 estrofes)

P. 121:

Notas MA:

1. termo sublinhado no v. 9, "endeixa", e anotação "dic" - pesquisa para o Dicionário musical brasileiro:

E como notas de chorosa endeixa "dic" 
Nota MA: v. 61-64 destacados por traço vertical - estudo da psicologia / seleção de ideias:

Minh'alma é triste como o grito agudo

Das arapongas no sertão deserto;

E como o nauta sobre o mar sanhudo,

Longe da praia que julgou tão perto!

P. 124:

Nota MA: v. 80 sublinhado e comentário ao final do poema:

Foram-se as flôres - a minh'alma é triste!

"Este poema é das mais líricas e exatas expres-/sões do romantismo universal. É maravilhoso. / Notar na $4^{a}$ parte a dor arrebentada que faz o / poeta perder aquela sua amabilidade comum, a / feminilidade da sua imagem pra caracte-/rizar a sua tristeza pelo jeito da araponga. E / daí em seguida a dor novamente, rarissima / no poeta quase que transborda. E o leva tam-/bem a licenças poeticas, dantes não vindas / no poema, como si a ardencia do sofrimento / não permitisse mais a preocupação de factura."

Nota da pesquisa: O verso final, em destaque, é referido no fichamento crítico $d$ 'As primaveras, no dossiê do manuscrito Amor e medo, para ser lido em voz alta, como outros já citados (MA-MMA-05-03).

$\underline{\text { P. } 125-126}$

PALAVRAS A ALGUÉM (6 estrofes)

P. 126:

Nota MA: v. 31-36 destacados por traço vertical e escólio, "Sequestro / comp. com / p. 166" - ligação com a pesquisa de MA sobre o tema do Sequestro da dona ausente no folclore brasileiro:

\begin{tabular}{l|l} 
"Sequestro & Conchinha das lisas praias \\
comp. com & Nasceste em alvas areias, \\
p. $166 "$ & Arrebatada tu para os charcos \\
& - Os teus vestidos são brancos... \\
& Olha que tu te enlameias!...
\end{tabular}

Nota da pesquisa: No dossiê do manuscrito $O$ sequestro da dona ausente, MA também alude a esta página: "Sempre a imagem com / as aguas p 126 / e p 134 e p. 164 e 184" (MA-MMA-106-590).

$\underline{\text { P. } 127-128}$

FOLHA NEGRA (7 estrofes)

P. 128:

Nota MA: termo sublinhado no v. 25, "flauta", comparação "Triste como: " e escólio "dic" - estudo linguístico: dicionário musical: 
"Triste como:"

Vozes de flauta longinqua "dic"

P. 129-131

À Morte DE AfFonso de A. Coutinho Messeder (12 estrofes)

P. 129:

Notas MA:

1. preposição sublinhada no v. 8, "P'ra", e cruzeta - estudo linguístico: emprego de "para/pra":

X P'ra que apagas, Senhor, a chamma ardente

2. preposição sublinhada no v. 15, "P'ra", e cruzeta - estudo linguístico: emprego de "para/pra":

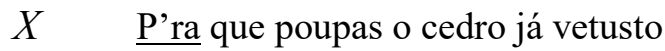

\section{P. 130-131:}

Notas MA: comentário ao final do poema, percorrendo o rodapé, o alto da página e as margens direita e esquerda:

"Casemiro se caracteriza pela curteza dos seus poe-/mas que deviam ser longos mas a que corta no / principio a extraordinária curteza e indigencia / mesmo do pensamento. Tem grande diferença / entre a curteza da quadra, do <ilegível> e a dum / poema como este. Aquelas se satisfazem e care-/cem mesmo da curteza que lhes dá a caracteris-/tica não formal mas de expressão duma idea / dum sentimento. Um poema como este dedicaIdo á morte do Messeder quisera ser longo, quise-/ra e tem no seu desenvolvimento frustrado / coisas lindas e elevadas que ficaram por di-/zer que Casemiro era incapaz. de dizer. Case-/miro é o mais perfeito representante da capa-/cidade e tradição intelectual do burgues bra-/sileiro até o tempo presente, burguês cuja uni-/ca tradição intelectual é a fantastica pobreza / da mentalidade lusitana. Porque pra essa /-tradição nada influiram nem o indio nem o ne-/gro que não apresentaram pra ela outras for/mulas tradicionais de burguesia. A aceita-/ção de Casemiro no seio burgues brasileiro vem / de que ninguem até hoje soube como ele / representar e igualar essa burguesia. Intencio-/nal ou não, certamente não, ainda nessa ma-/neira de ser representativo eu vejo uma das / grandezas de Casemiro. Alem disso carece não / esquecer que si o pensamento é indigente o / lirismo é de grandissima abundancia e da / mais pura qualidade embora não da mais / rara. Mas sob o ponto de vista da Poesia a rarida-/de do lirismo não é uma qualidade, é apenas uma / caracteristica. $O$ raro se amaneira facilmente e se de-/precia quasi sempre como moda. (Ao falar na burgue-/sice de C. salientar o poema a Macedo Junior que é por-/ ventura uma das poesias mais perfeitamente xxxxx / idiotas e vulgares que é possível conceber."

$\underline{\text { P. } 132}$

BERÇO E TÚMULO (3 estrofes) 
Nota MA: comentário ao final do poema:

"A obsessão da flor em Casemiro. Poemas em / agua-de-flores. Sim antes agua-de-flor. Raras Porem / vezes certas vezes ele atingiu a essencia."

P. 133-134

INFÂNCIA (6 estrofes)

P. 134:

Notas MA:

1. v. 25-30 destacados por colchete e escólio "Sequestro" - ligação com a pesquisa de MA sobre o tema do Sequestro da dona ausente no folclore brasileiro:

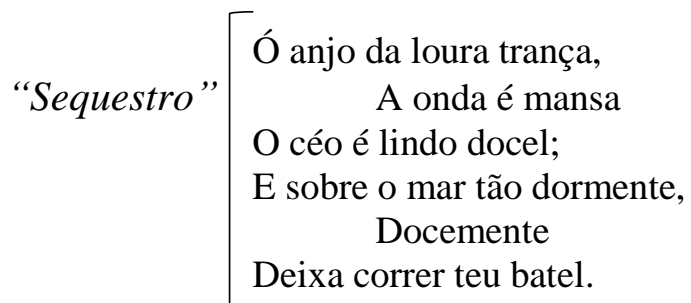

2. comentário ao final do poema - estudo do estilo: musicalidade:

"Notar a sonoridade musical de Casemi-/ro e a sua musicalidade. A repetição mu-/sical e a repetição (rondó) em Casemiro. / A volta em torno duma ideia só. E na mu-/sicalidade oral é um dos maiores poetas da lin-/gua pois que não tem nada de rebuscado, / tudo é natural, é a musicalidade geral / e misteriosa que se encontra na musica / e na poesia popular, mistério que consiste / principalmente numa certa banalidade / que é talvez toda a universalidade / sublime das expressões populares. Case-/miro tem um verso cuja musicalidade en-/contra por si, e sem requinte. A pessoa que leia / sem prestar atenção ao sentido das palavras, / á musicalidade de poemas como Infancia, Uma his-/toria (lirica das mais belas que se conhece) Moreninha, / Visão, Simpatia se deixará sensualmente embalar."

Nota da pesquisa: MA remete a esta página, em nota de trabalho, no dossiê-do manuscrito O sequestro da dona ausente: "Sempre a imagem com / as aguas p 126 / e p 134 e p. 164 e 184" (MA-MMA-106-590). A mesma página indicia, no dossiê Amor e medo, a possível falta de musicalidade de Casimiro de Abreu (MA-MMA-05-03).

$\underline{\text { P. } 135}$

A UMA PLATEIA (3 estrofes)

Notas MA: preposição sublinhada nos v. 4, "p'ra", e v. 5, "Para", e cruzeta - estudo linguístico: emprego de "para/pra":

$X \quad$ E a flôr p'ra ter mais vida

$X \quad$ Para ser - rosa querida - 
$\underline{\text { P. } 136}$

NO TUMULO D'UM MENINO

Notas MA: preposição sublinhada no v. 6, "para", cruzeta e escólio "pra" - estudo linguístico: emprego de "para/pra":

"X pra” Passou do berço para brincar no céo

$\underline{\text { P. } 137-140}$

A J. J. C. MACEDO Junior (15 estrofes)

P. 137:

Notas MA:

1. correção “/ara” à margem do tempo verbal "entornam", no v. 14, transformando-o em "entornaram":

Não sei que vozes me entornam/n'alma “/ara”

2. v. 16 sublinhado e expoente "(1)" remetendo ao comentário que tem inicio no alto da página, continua no rodapé desta e termina no rodapé da folha ao lado, a p. 136 - estudo da versificação: métrica:

“(1)” Uns perdem, como eu, cedo os verdores,

“(1) Um dos grandes segredos dos romanticos / foi deixarem mais fraca a cadencia ritmi/ca em versos frouxos como este, mas não per-/derem a suavidade e naturalidade da dicção. / Grande segredo e valor que foi acoimado de / erro. Que sabiam metrica o proprio Alvares de / Azevedo o demonstrou num passo das suas / obras (cita-lo) porem sab tinham que esco-/lher entre a perfeição da metrica e a dicção / pura. Escolheram esta. Quero saber hoje / quem já não falo sob o ponto de vista do / lirismo, porem sob o proprio ponto de vista / da poetica seria capaz agora de lhes atirar / pedra por isso. Vejase este verso (exa-/minar tambem outros casos dos outros / romanticos). Haveria um jeito da metrica / ficar exata. Era mudar pra [rasura] "alguns" pra "muitos", pra "certos" o "uns" inicial. E/ so mudar e pronunciar pra ver como a / propria cadencia ritmica do verso (coi-/sa misteriosissima que provêm não apenas / dos acentos porem da propria combina-/ção dos sons) se prejudica. O verso que Ca-/simiro "intentou inventou, criou, sentiu / era o que está, natural e puro. / Esse ficou. Si os romanticos tives-/sem andado aqui como em toda a parte, / a corrigir a metrica dos seus versos, / perderiam grande parte do encanto / que os caracteriza. E no Brasil esse encan-/to principal, com excepção de C. Alves, foi / uma doçura sensual e mole, uma / suavidade incomparavel de expres/são que raramente se encontrará igual / na poesia dos outros povos."

Nota da pesquisa: O fichamento crítico no dossiê do manuscrito Amor e medo, refere-se a esta parcela do poema, nesta página, como exemplo de "naturalidade" (MA-MMA-0503). 
P. 138:

Notas MA:

1. termo sublinhado no v. 40, "P'ra", e cruzeta à esquerda; estudo linguístico: emprego da forma "pra"

$X \quad$ Seja a vida p'ra ti só riso e galas

2. termo sublinhado no v. 45 , "saturnaes", e expoente (1) remetendo ao comentário no rodapé; estudo linguístico: vocabulário.

Das longas saturnaes; $\quad$ “(1)”

"(1) Merecia ter a memória infamadada / pra sempre o $1^{\circ}$ poeta brasileiro que em/pregou esta palavra nefasta."

P. 139:

Notas MA:

1. verbo sublinhado no v. 64, "cuspir" , e associado a dois pontos de exclamação à margem que ironizam o emprego:

Se a donzella cuspir nos teus amores

$! !$

2. destaque ao epíteto por meio de aspas e duas sublinhas:

Não vás como "Azevedo - o pobre genio - "

P. $143-147$

No LEITO (14 estrofes)

P. 143:

Notas MA:

1. correção a erro tipográfico: repetição na epígrafe:

Se eu eu morresse amanhã!

2. traço destacando os v. 4-6 - seleção de ideias: comparação:

Quem sabe? - A vida fenece

Como a lampada no templo

Ou como a nota d'um hymno!

3. cacofonia sublinhada em ênclise no v. 16:

Em que vi-te a vez primeira!

P. 144:

Nota MA: termo sublinhado no v. 20, "saibo", e cruzeta - estudo do estilo: vocabulário:

X Como o saibo dos licores, 
Nota da pesquisa: O manuscrito d'A gramatiquinha da fala brasileira conserva nota de trabalho: "Brasileirismo / Saibo / Casemiro / n 223 p 144" (MA-MMA-51-150; V. ALMEIDA, Aline Novais de. Op. cit., p. 519, vol 2).

P. 146:

Notas MA:

1. epíteto sublinhado no v. 80 , "o filho da poesia", ligado por fio à expressão "os fillhos do erro", no v. 96 - seleção de ideias:

$$
\mathrm{Eu}-\underline{\text { o filho da poesia }}-
$$

2. traço destacando os v. 84-91 - seleção de jideias: comparação:

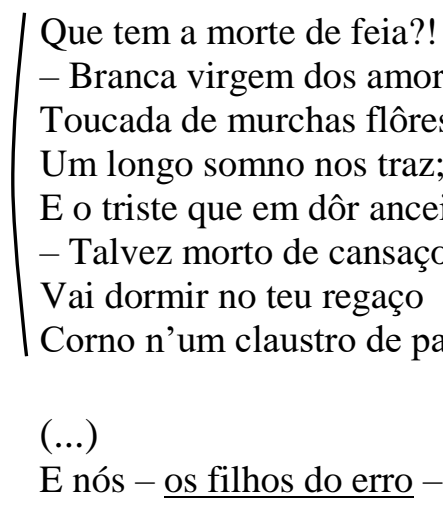

\section{$\underline{\text { P. } 152-153}$}

NO JARDIM (6 estrofes)

P. 153:

Nota MA: comentário ao final do poema:

"No jardim, carece ter a coragem de convir, / é um quadro lindo, encantador, perfeita/mente realizado."

Nota da pesquisa: O poema encerra a lista de obras-primas elencadas no fichamento crítico (MA-MMA-05-03).

\section{LIVRO NEGRO}

\section{$\underline{\text { P. } 155-158}$}

HORAS TRISTES (20 estrofes)

P. 155:

Notas MA: preposição sublinhada no v. 7, "p'ra”, e cruzeta - estudo linguístico: emprego de "para/pra":

$X \quad$ E p'ra contal-a falta á lyra cordas 
P. 156:

Notas MA:

1. trecho sublinhado no v. 21, "eu sou bom moço", e exclamações à direita - seleção de ideias: autoimagem:

E comtudo, meu Deus! eu sou bom moço, $\quad$ !!

2. preposição sublinhada no v. 27, "p'r'o", e cruzeta;

E, mancebo, voltar-me p'r'o futuro, $\quad X$

3. preposição sublinhada no v. 36, "P'ra", e cruzeta - estudo linguístico: emprego da forma "para/pra" e suas variações:

P'ra mim são todos maus! $\quad X$

4. comentário no rodapé - estudo linguístico: brasileirismo:

"As expressões lusas de Casimiro são per-/doaveis pelo que privou com portugueses / alem-mar. E assim mesmo são raras. Coe-/lho Neto tem muito mais."

Nota da pesquisa: A página consta como exemplo de "brasileirismo expressional", no fichamento crítico (MA-MMA-05-03). Ao contestar a tese de Ascendino Leite, de que o "Modernismo foi inútil porque malhou defunto e combateu moinhos de vento", MA evoca o prestígio de Coelho Neto (1864-1934): “Por 1922 ainda os 'novos' sublimizados pela vida brasileira eram Hermes Fontes e Martins Fontes. Coelho Neto era o grande estalão glorioso da nossas prosas, passeado nos ombros da turba, em oposição a Graça Aranha, quando foi da bagunça provocada por este na Academia (...) Percorra Ascendino Leite os jornais do tempo e verá que o Modernismo teve contra que e contra quem reagir" (SÁ, Marina Damasceno. O empalhador de passarinho, de Mário de Andrade - Edição de texto fiel e anotado. Dissertação de Mestrado/Programa de Pós-graduação em Literatura Brasileira, FFLCH-USP, 2013, p. 300, v. 2). Na Coleção MA, na Biblioteca do IEB/USP, há três títulos de autoria do escritor maranhense, todos com notas de margem: Contos escolhidos (Bahia: Livraria Catalina, 1913), Treva (Porto: Livraria Chardron, 1916) e Rei negro: romance barbaro (Porto: Livraria Chardron, 1926). Exemplares de Balladilhas e Falando... acham-se entre os volumes encaminhados por MA para a formação da Biblioteca Municipal de Araraquara. Assim como o autor de Pauliceia desvairada, Coelho Netto, poeta então célebre pelos torneios de frase e elevação de estilo, frequentou o salão da Villa Kyrial. Em 1921, no $2^{\circ}$ Cyclo de Conferencias, coube-lhe discorrer sobre Shakespeare, enquanto a MA, falar sobre "Debussy e o impressionismo". A série de crônicas para a revista carioca Illustração Brasileira, "De São Paulo", evoca a intensa programação cultural capitaneada pelo Sen. Freitas Valle (Cf. CAMARGOS, Marcia. Villa Kyrial - Crônica da belle époque paulistana. São Paulo: Editora Senac São Paulo, 2001). 
Nota MA: termo sublinhado no v. 52, "bandolim”, e cruzeta - pesquisa para o Dicionário musical brasileiro:

$$
\text { Que um doce bandolim; } \quad X
$$

P. 158:

Nota MA: preposição sublinhada no v. 77, "P'ra", e cruzeta - estudo linguístico: emprego de "para/pra":

$X \quad \underline{\text { P'ra ella então seria a minha vida; }}$

P. $159-162$

DÔRES (16 estrofes)

P. 160:

Nota MA: preposição sublinhada no v. 39, "para”, e cruzeta - estudo linguístico: emprego de "para/pra":

$$
X \quad \text { Que vôam para Deus! }
$$

$\underline{\text { P. 161: }}$

Notas MA:

1. preposição sublinhada no v. 50, "Para", cruzeta e escólio "Pra" - estudo linguístico: emprego de "para/pra":

X Pra Para aclimar-se, apertada n'uma estufa

2. preposição sublinhada no v. 69, "para", e cruzeta - estudo linguístico: emprego de "para/pra":

$X \quad$ Sem fogo para amar!

P. 162:

Notas MA: v. 79 destacado, indicando a anacruse, e anotação na sobrelinha, "10 silabas" - estudo da versificação: métrica:

$\frac{\text { "10 silabas" }}{\text { Esquecimento! - mortalha para as dôres - }}$

P. $163-165$

$* * * * *$ (18 estrofes)

P. 164:

Notas MA:

1. termos sublinhados nos v. 29 e 31, "vigilia" e "filha", e fio ligando-os - estudo da versificação: rima;

2. v. 31-40 destacados por colchete e anotação "Sequestro" - ligação com a pesquisa de MA sobre o tema do Sequestro da dona ausente no folclore brasileiro: 


"Sequestro", $\begin{aligned} & \begin{array}{l}\text { E eu soffro, oh anjo; na cruel vigilia } \\ \text { O pensamento inda redobra a dôr, } \\ \text { Soltas as tranças a morrer de amor! }\end{array} \\ & \begin{array}{l}\text { E louco a sigo por desertos mares, } \\ \text { Por doces veigas, por um céo de azul; } \\ \text { Pouso com ella nos gentis palmares } \\ \text { Á beira d'agua, nos vergeis do sul!... }\end{array} \\ & \begin{array}{l}\text { E a virgem foge... e a visão se perde } \\ \text { Por outros climas, n'outro céo de luz; } \\ \text { E eu - desperto do meu sonho verde - } \\ \text { Acordo e choro carregando a cruz! }\end{array}\end{aligned}$

Nota da pesquisa: Também esta página figura entre as referências elencadas por MA em nota prévia que integra o dossiê do manuscrito $O$ sequestro da dona ausente: "Sempre a imagem com / as aguas p 126 / e p 134 e p. 164 e 184" (MA-MMA-106-590).

$\underline{\text { P. } 166}$

FRAGMENTO (2 estrofes)

P. 166:

Notas MA:

1. preposição sublinhada no v. 14, "p'ra”, e cruzeta - estudo linguístico: emprego de "para/pra":

X Tenta enganar-se p'ra curar as mágoas,

2. v. 15-20 destacados por colchete e comentário "Sequestro / compare com / pg. 126" estudo da psicologia e do folclore: sentimento amoroso:

\begin{tabular}{l|l} 
"Sequestro & $\begin{array}{l}\text { Cria phantasmas na cabeça em fogo, } \\
\text { De novo atira o seu batel nas ondas, } \\
\text { pompare com } 126 "\end{array}$ \\
Trabalha, lucta e se afadiga embalde \\
Até que a morte lhe desmancha os sonhos. \\
Pobre insensato - quer achar por força \\
Pérola fina em lodaçal immundo!
\end{tabular}

$\underline{\text { P. } 168}$

ULTIMA FOLHA (5 estrofes)

P. 168:

Notas MA:

1. correção ao verbo, no v. 7 - correção tipográfica:

Vós o disseste $S$ - E eu padeço tanto!... 
2. preposição sublinhada no v. 16, "p'ra", e cruzeta - estudo linguístico: emprego de "para/pra":

Venha o martyrio... mas - perdão p’ra ella!... X

\section{LIVRO QUARTO / POESIAS INEDITAS}

$\underline{\text { P. } 174}$

HONTEM Á NOITE (2 estrofes)

P. 174:

Notas MA:

1. v. 12 destacado, indicando a anacruse, e anotação na sobrelinha, "10 silabas" - estudo da versificação: métrica:

$$
\begin{gathered}
\text { "10 silabas" } \\
\text { Vendo a noite pura, e vendo a ti tão bella, }
\end{gathered}
$$

2. preposição sublinhada no v. 14, "p'ra”, e cruzeta - estudo linguístico: emprego da forma "pra":

Disse a teus olhos: - dae amor p'ra mim! $\quad X$

$\underline{\text { P. } 175-177}$

A FAustino XAVIER DE Novaes (8 estrofes)

P. 176:

Notas MA: v. 41-48 destacados por traço vertical duplo e juízo de valor, “ótimo" - estudo do estilo:

“ótimo" $\mid \begin{aligned} & \text { Pinta este Rio n'um quadro, } \\ & \text { As letras falsas d'um lado, } \\ & \text { As discussões do senado, } \\ & \text { As quebras, os trambulhões; } \\ & \text { Mascates roubando moças, } \\ & \text { E lá no fundo da tela } \\ & \text { Desenha a febre amarella, } \\ & \text { Vida e morte aos cachações. }\end{aligned}$

2. preposição sublinhada no v. 50, "p'ra”, e cruzeta à esquerda; estudo linguístico: emprego da forma "pra".

$X \quad$ E os louros p'ra ti são certos!

$\underline{\text { P. } 178-183}$ 


\section{MEU LIVRO NEGRO (25 estrofes)}

P. 178:

Nota MA: preposição sublinhada no v. 18, "P'ra", e cruzeta - estudo linguístico: emprego de "para/pra":

$$
X \quad \underline{\text { P'ra cobrir-me a nudez! }}
$$

P. 179:

Nota MA: v. 31-36 destacados por colchete e expoente “(1)” remetendo ao comentário no rodapé:

É verdade, na mente deslumbrada, “(1)” Borbulhou n'outro tempo alguma cousa De vago e de ideal!

Eram centelhas! mas dormindo ás soltas, Eu deixei consumir-se o fogo santo - Estupida vestal!

“(1) Da união desta ideia com o $1^{\circ}$ grifo da pg / 146 'Eu, o filho da poesia' mostrar a pobreza / de idea mas a verdade poetica de Casemiro."

P. 180:

Nota MA: preposição sublinhada no v. 43, "P'ra", e cruzeta - estudo linguístico: emprego de "para/pra":

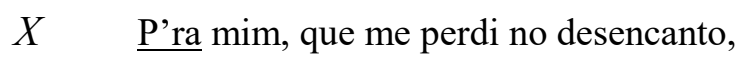

P. 181:

Notas MA:

1. preposição sublinhada no v. 85, "p'r'o", e cruzeta - estudo linguístico: emprego de "para/pra" e suas variações:

\section{Feliz, tu que me acenas p'r'o futuro $\quad X$}

2. v. 95-96 destacados por traço vertical triplo e comentário - seleção de ideias:

A gloria é uma mulher, e tu bem sabes

Eu amo outra mulher!

P. 182:

Notas MA:

1. v. 112-114 destacados por traço vertical - seleção de ideias;

2. termo sublinhado no v. 113, "guitarra", e escólio "dic" - pesquisa para o Dicionário musical brasileiro:

Por noites de luar o sertanejo

"dic" Suspira na guitarra cantilenas

Que a lyra nunca diz!
"Não se
amolava
de ser ar-
tista. Abria
a boca e can-
tava." 
P. 183:

Notas MA:

1. termo sublinhado no v. 143, "gelo", e cruzeta - provável lapso de MA - estudo linguístico: emprego da forma "pra":

Sacudo o gelo p'ra dizer-te d'alma: $\quad X$

2. comentário ao final do poema:

"O poema a Gonçalves Braga é uma das / expressões maiores de Casemiro, em que / o seu burguesismo temperado pelo / romantico triste alcança uma no-/breza e uma elevação equilibradissimas / de expressão, sem abandonar a sua / vulgaridade chata. É realmente um / admiravel poema. E um traço de genio / quando o poeta diz 'A gloria é uma mulher / e tu bem sabes, Eu amo outra mulher'."

$\underline{\text { P. } 184}$

LEMBRANÇA

P. 184:

Nota MA:

1. v. 1-8 destacados por traço vertical, sublinha no v. 2 e comentário - estudo da psicologia: sentimento amoroso:

\begin{tabular}{l|l} 
"Sequestro & Como o triste marinheiro \\
Sempre a & Deixa em terra uma lembrança \\
imagem" & Levando n'alma a esperança \\
& E a saudade que consome \\
& Assim nas folhas do album \\
& Eu deixo meu pobre nome. \\
& E se nas ondas da vida \\
& Minha barca fôr perdida
\end{tabular}

Nota da pesquisa: A página, em função da estrofe em destaque, arremata as referências enumeradas no dossiê do manuscrito $O$ sequestro da dona ausente: "Sempre a imagem com / as aguas p 126 / e p 134 e p. 164 e 184” (MA-MMA-106-590).

P. 186:

Nota MA: comentário:

"Gonçalves Dias é o mais artista dos romanticos / brasileiros. Sextilhas - Poemas brasileiros - " 
ALVES, Castro. Obras completas. Edição crítica

comemorativa do cincoentenário do poeta... com um retrato,

introducção bibliographica e annotações de Afranio Peixoto.

Rio de Janeiro: Francisco Alves, 1921. 2 v. [Poesia]
Bibl MA: [A/II/f/34]

$15 \times 22,5 \times 4,5 \mathrm{~cm}$

IEB: MA 869.9145

a474o v.1

\section{VOLUME 1}

\section{$\underline{\text { FOLHA DE GUARDA }}$}

\section{Notas MA:}

1. anotação no alto, à direita, “ $n^{\circ} 200^{\prime}$, referindo-se à inclusão do volume na Bibliografia para Na pancada do ganzá;

2. lista de verbetes para o Dicionário musical brasileiro e pesquisa da zoofonia, e cruzeta indicando o aproveitamento:

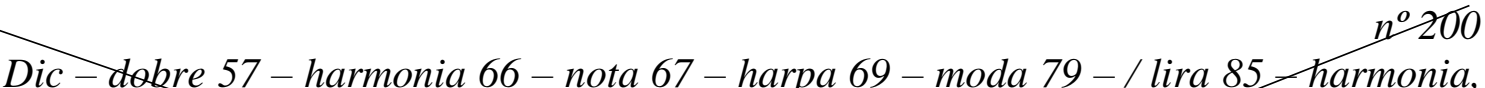
Dic dolire 57-harmonia 66 - nota 67-harpa 69-moda 79 - lira 85 harmonia, melodia 86 - trene, viola 90 - toque 92 - / barcarola 97 - flauta de Pan 101 - zoof rôla 102 - surdina 105 - 入 walsa 127 - nota 168 - lira 168 - serenata 172 - walsa 175 - I zoof pipilar 176 - buzina (de caça) 179 - fanfarra 180 - / toada 183 - plectro 184 estradivario 185 - tremolo 192 - I notas 207 - preludiar 207 - harpa eolia 208 - trova 223 - I som 230 - cavatina 241 - estradivario 242 - trenos 245 - harmonia 251 cavatina 252 - bolero 267 - toque 267 - / piano 266 - harmonia 277 - sifão 280 - bardo 312 - trom 312 - / múrmur 315 - boré 320 - violoncelo 326 - tromba 331 - / clarim 332 - rebate 332 - buzina 333 - horrisono 337 - musico 393 - zoof 395 -retintim 397 trovar 398 silvar 399 - I tom 400 - trompa 416 - rufo 416 - atroar 431 - silvo 440-I tinir 450 - maestro 451 - arco 451 - harmonia 453 -

Notas da pesquisa:

1. O n 200 sinaliza a inclusão das Obras completas de Castro Alves na Bibliografia para Na pancada do ganzá, conjunto de 837 títulos arrolados por MA para apoiar a organização de seu vasto projeto sobre o folclore brasileiro. Os títulos da poesia dos autores românticos focalizados em seu ensaio "Amor e medo" fazem parte da lista bibliográfica. O escólio "dic", a grafite, de ocorrência farta na marginália de MA, indica a pesquisa de dados para abonar registros no Dicionário musical brasileiro, projeto do escritor testemunhado em suas biblioteca, no manuscrito desse título e de outros, em seu arquivo, assim como na edição póstuma coordenada por Oneyda Alvarenga e Flávia Camargo Toni (Brasília: Ministério da Cultura/São Paulo: IEB-USP - Edusp/ Belo Horizonte: Editora Itatiaia Ltda, 1989), p. 634-686).

2. O escólio "Zoof”, a grafite, frequente em todas as áreas da biblioteca de MA, absorve a denominação de pesquisa encetada por Hercule Florence e colige matéria destinada ao projeto do escritor de reunir palavras e expressões representando as vozes dos animais. Liga-se, de imediato, ao manuscrito Zoofonia, reservatório e estudo particular desses termos, composto de documentos musicais, recortes de jornal e notas de trabalho, transcritas de publicações ou captadas em pesquisa de campo por MA e seus colaboradores.

Em entrevista de 1943, MA filia seu projeto a Green Mansions: a Romance of the Tropical Forests, de William Henry Hudson (V. ANDRADE, Mário de. Entrevistas e 
depoimentos. Edição organizada por Telê Porto Ancona Lopez. São Paulo: T.A. Queiroz, 1983, p. 93).

"Zoof" prende-se, também, à coleta de termos para o Dicionário musical brasileiro e $O$ banquete, obra na área de Estética, interrompida pela morte de MA em 1945. Nesta, o capítulo 8 previa: "O Passeio em Pássaros. Zoofonia. O canto-enfeite no cio. A mulher vestida de homem e a Lei do Peso. Música da natureza e música descritiva." (V. ANDRADE, Mário de. O banquete. Ed. preparada por Jorge Coli e Luiz Dantas. São Paulo: Livraria Duas Cidades, 1977, p. 167).

\section{P. 5-42:}

PEIXOTO, AFRÂNIO. “O MAIOR POETA BRASILEIRO”

P. 10:

Nota MA: período destacado por colchete - seleção de ideias:

Ferreira Vianna, um dos libertadores, dez annos depois da sua morte, dizia delle: "a lyra emmudeceu, mas os sons por ella vibrados ainda rebôam cheios de vigor, em nossos ouvidos."

P. 18:

Nota MA: trecho marcado com o expoente “(1)” remetendo ao comentário no rodapé:

“(1) Esta preocupação de saber quem é o $1^{\circ}$, quem / o maior é absolutamente idiota. É bem A. / Peixoto que não vale absolutamente nada como / pensador."

Nenhum poeta, nenhum escriptor brasileiro, nesse tempo, alcançou sequer de longe approximar-se delle. Castro Alves, o grande poeta nacional que Alencar, Machado de Assis, Ruy Barbosa, Nabuco, Euclydes da Cunha, José Verissimo, tantos e tantos mais... o escol da intelligencia brasileira exaltou á nossa admiração, foi tambem o eleito do Povo Brasileiro, da innumeravel multidão dos leitores que o prefere a todos os mais. $\mathrm{O}$ veredicto da Posteridade está apurado: é o primeiro poeta, o maior poeta brasileiro. (1)

Nota da pesquisa: A biblioteca de MA guarda, sem anotações de leitura, Castro Alves: ensaio bio-bibliographico (Rio de Janeiro: Officina Industrial Graphica, 1931), obra de Júlio Afrânio Peixoto (1876-1947). A obra é composta de quatro seções: nota biographica, ensaio de bibliographia, principaes escriptos sobre o Poeta e depoimentos sobre o Poeta. $\mathrm{O}$ acervo conserva outros títulos de Afrânio Peixoto, entre romances - Esfinge, Fruta do mato, Bugrinha, Uma mulher como as outras -, ensaios de história e crítica - Poeira da estrada, Os judeus na história do Brasil, Pequena história das Américas, A igreja de Nossa Senhora da Glória do Outeiro -, bem como volumes de poesia e coleta de documentos do folclore - Trovas populares brasileiras e Missangas. Neste último volume, bastante anotado, MA obtém a crença popular pela qual beber café com suor de cavalo produz loucura, informação de que se apropria em seu romance inacabado Café (ANDRADE, Mário de. Café. Estabelecimento do texto, introdução, posfácio e seleção de imagens por Tatiana Longo Figueiredo. Rio de Janeiro: Nova Fronteira, 2015).

$\mathrm{Na}$ série Correspondência MA, acha-se um cartão postal enviado por Afrânio Peixoto de Petrópolis, em 1928, com a notícia do recebimento de Clã do jaboti e alusão aos poemas "Noturno de Belo Horizonte" e "Carnaval carioca".

Cabe lembrar que MA tece crítica severa ao trabalho de Afrânio Peixoto com o 
folclore, no estudo "O folclore no Brasil", escrito em 1942 para o Handbook of Brazilian Studies, a convite dos coordenadores da obra, Rubens Borba de Moraes, diretor da Biblioteca Municipal de São Paulo, e William Berrien, representante do American Council of Learned Societies. MA suprime a crítica a pedido dos organizadores da edição, mas a mantém na versão em seu arquivo. A republicação de Aspectos do folclore do Brasil, organizada por Angela Teodoro Grillo, reabilita o trecho omitido.

P. 43-222

\section{ESPUMAS FLUCTUANTES}

\section{POESIAS LYRICAS}

$\underline{\text { P. 51-55 }}$

MEU SEGREDO (20 estrofes)

P. 52:

Notas MA:

1. cruzeta no v. 18 - estudo linguístico: emprego da forma "pra":

$X \quad$ Que se debruça p'ra beijar o rio,

2. cruzeta no v. 27 - estudo linguístico: emprego da forma "pra":

$X \quad$ Eu sei... P'ra cada crença de noss'alma,

Nota da pesquisa: O uso do "pra" é abordado por Mário de Andrade em diferentes pontos de sua reflexão sobre a língua portuguesa falada no Brasil, em especial no manuscrito d' $A$ gramatiquinha da fala brasileira, obra que deixou inacabada. A transcrição integral do texto, por Aline Novais de Almeida, em sua dissertação de mestrado, Edição genética d' A gramatiquinha da fala brasileira de Mário de Andrade, no Programa de Pós-graduação em Literatura Brasileira, FFLCH-USP, 2013, mostra, no v. 2, estas referências ao assunto: "E dessas tradições a mais pior é o preconceito dos olhos. Os olhos... Mal danado eles fazem prá gente... já viram dum jeito a coisa escrita. Veem de outra, acham feio. E levam a gente a afirmações como essa que tanta gente me faz de que não fala pra sim para. Quando lê, sei que lê para. Porém é incontestável que dicção pra é geral e até geral não só entre brasileiros como até entre portugas." (p. 769); "Se não tivesse os poetas românticos meu 'pra' seria meu. Porém nesse caso o pra não existiria." (p. 777); "falam 'no pra do Mario' como se isso me pertencesse, e já não estivesse em porcentagem comovente nos romanticos do Brasil"' (p. 781).

No dossiê Castro Alves, na Série Manuscritos Mário de Andrade, o plano de capítulo para o livro Lirismo romântico no Brasil propõe, no fólio 9: "Reunir o caso de croa, do pra, dos decassílabos diminuídos ou aumentados de sílaba num capitulinho sobre as Licenças Poéticas do Romantismo, bem como as rimas toantes e deficientes. Nesse capítulo observar a tendência pro pra e considerações sobre a linguagem brasileira." (V. MA-MMA-26-09).

Em carta a Sousa da Silveira, em 15 de fevereiro de 1935, MA considera: "No caso do 'pra', de consequências terríveis pra mim, não posso negar a justeza da sua observação quanto a nem sempre se operar a contração. É verdade. Mas em nenhum dos meus livros, nenhum, o Sr. deixará de encontrar o 'para'. Poucas, pouquíssimas vezes, é verdade. Mas conscientemente, sem erro de revisão. Quis provar com isso que não faço 
questão cega do meu pra e suas consequências. Não desistirei dele quando a ele me levar a rapidez do discurso, que é quasi sempre o caso, mas estou bastante tentado a desistir do 'pro'. Alguns me objetam que teria de levar o 'pra' às suas últimas consequências lógicas, e escrever também 'pruns' (para uns) e 'praqueles' (para aqueles) etc. Como si a língua fosse uma criação da lógica intelectual, e não houvesse outras lógicas predeterminando o ser pequenamente humano..." (V. FERNANDES, Lygia. (Org.) Mário de Andrade escreve cartas a Alceu, Meyer e outros. Rio de Janeiro: Editora do Autor, 1968, p. 153 e mais comentários à p. 156). No ensaio "Castro Alves", publicado em 1939 na Revista do Brasil, ano 11, $\mathrm{n}^{\circ}$ 9, a questão é relacionada pelo crítico à poesia modernista de sua lavra: "Escrevia uma linguagem saborosa, de excelente libertação nacional, e deve mesmo, com as Espumas flutuantes, ser considerado o primeiro sistematizador do 'pra', trocando-o oitenta vezes sobre cem ao lerdo e tipográfico 'para'. Só sessenta anos mais tarde outros lhe retomariam a lição..." ("Castro Alves", In: Aspectos da literatura brasileira. São Paulo: Livraria Martins Editora, 5a ed., 1974, p. 121). Vale lembrar que MA, ao rasurar textos seus recortados de periódicos, transformando-os em manuscritos/exemplares de trabalho, muitas vezes reconduzia ao original a forma "pra", indevidamente corrigida pela composição ou revisão.

P. 55:

Nota MA: expoente (1) ao final da última estrofe, remetendo ao comentário no rodapé estudo da psicologia: sentimento amoroso:

Sagra ao menos uma hora em tua vida Ao pobre que sagrou-te a vida inteira, Que em teus olhos, febril e delirante, Bebeu de amor a inspiração primeira, Mas que de um desengano teve medo, E guardou dentro d'alma o seu segredo!

"(1) O tema de "Amor e Medo" afinal está como tema / universal romantico no Romantismo brasileiro. Este pla-/tonismo assustado é o mesmo de Casimiro e de A. de I Azevedo. Não me lembro se Fagundes Varella e G. Dias / o glosaram também. (Procurar isso)."

Nota da pesquisa: Em "Amor e medo", MA interpreta esses versos de "Meu Segredo" como uma lateralidade do tema-título do ensaio: "Mas deixemos duma vez os tremores, e voltemos a estudar Castro Alves. Ainda tem uma vez em que ele falou de amor e medo. É no Meu Segredo, onde veremos mais uma vez 'segredo' rimar com 'medo' [...] Está se vendo pra que aspeto novo se desvia o medo de amor agora. É, não medo de amar, porém de encontrar o desengano, a ingratidão da amada - o mesmo medo de amor que Juvenal Galeno pleiteou no Medroso de Amor" (In: Aspectos da literatura brasileira, ed. cit., p. 211).

$\underline{\text { P. } 56-59}$

MOCIDADE E MORTE (14 estrofes)

P. 57:

Notas MA:

1. verso 33 sublinhado, cruzeta e escólio: "Genio" - seleção de ideias;

2. traço vertical destacando a estrofe: 


Eu sinto em mim o borbulhar do genio.
Vejo além um futuro radiante:
Avante! - brada-me o talento n'alma
E o echo ao longe me repete - avante! -
O futuro... o futuro... no seu seio...
Entre louros e bençãos dorme a glória!
Após - um nome do universo n'alma,
Um nome escripto no Pantheon da historia.

\section{Genio}

X

3. termo sublinhado no v. 51, "dobres", e escólio "dic" - estudo linguístico;

4. v. 52 destacado por traço horizontal e escólio, "Parnasianos":

Morrer - é ver extincto dentre as nevoas

O phanal, que nos guia na tormenta:

Condemnado - escutar dobres de sino, dic

Parnasianos

- Voz da morte, que a morte lhe lamenta -

Ai! morrer - é trocar astros por cirios,

Leito macio por esquife immundo,

Trocar os beijos da mulher - no visco

Da larva errante no sepulcro fundo.

Notas da pesquisa:

1. No ensaio "Castro Alves", MA cita o v. 33 ao observar: "[CA] Acredita no próprio gênio e o afirmou" (In: Aspectos da literatura brasileira, ed. cit., p. 111).

2. O escólio "dic", a grafite, de ocorrência farta na marginália, nos títulos da poesia do romantismo brasileiro, indica a pesquisa de elementos para abonar verbetes no Dicionário musical brasileiro, projeto do escritor testemunhado em sua biblioteca, no manuscrito desse título e de outros, em seu arquivo e, na edição póstuma coordenada por Oneyda Alvarenga e Flávia Camargo Toni (Brasília: Ministério da Cultura/São Paulo: IEB-USP - Edusp/ Belo Horizonte: Editora Itatiaia Ltda, 1989).

3. No ensaio "Castro Alves", Mário relaciona o poeta d'Os escravos aos parnasianos em aspectos variados, como trocadilhos verbais, na reiteração de símiles ("poemas de comparação") e processos de encher o verso ("Castro Alves", In: Aspectos da literatura brasileira. Ed. cit, p. 121). No dossiê Castro Alves, onde estão consignadas notas de trabalho e esboços destinados ao livro inacabado Lirismo romântico no Brasil, MA comenta a evolução da literatura no Brasil, assim se referindo à estética parnasiana: "Mas desde logo, o grupo dos nossos chamados parnasianos, enamorados do esplendor sonoro da palavra portuguesa, abandonaram o gosto do marmore pela sensualidade da sinfonia. Criaram o verbalismo brasileiro, que muito embora algumas vezes altissonante, é preciso não confundir com a eloquencia condoreira de Castro Alves." (V., no Arquivo IEB/USP, MA-MMA-26-13).

P. 58:

Nota MA: versos destacados por traço vertical - estudo da psicologia: sentimento amoroso:

Adeus, pallida amante dos meus sonhos!

Adeus, vida! Adeus, gloria! amor! anhelos!

Escuta, minha irmã, cuidosa enxuga

Os prantos de meu pae nos teus cabellos. 
Fôra louco esperar! fria rajada

Sinto que do viver me extingue a lampa...

Resta-me agora por futuro - a terra,

Por gloria - nada, por amor - a campa.

Nota da pesquisa: MA refere-se ao trecho, em "Amor e medo", para demonstrar a sexualidade sadia de Castro Alves: "...saliento de passagem que todos os nossos grandes românticos amaram intensamente mãe e irmã e falaram muito nelas. Bem sintomático: Castro Alves não. Ele, que foi o mais sexuado do grupo, quasi ignora nos versos, o que nos outros poetas é uma constância. Se lembra da mãe (mãe dum amigo) em versos chochos. Se lembra da irmã, só pra gostar do piano dela, ou, na Mocidade e Morte, pedindo pra ela consolar o pai, quando o poeta morrer" ("Amor e medo", in Aspectos da literatura brasileira, ed. cit., p. 218).

P. 66-67

PENSAMENTO DE AMOR (8 estrofes)

P. 66:

Nota MA: termo sublinhado no v. 13, "harmonias", e escólio "dic" - pesquisa para o Dicionário musical brasileiro:

Lá, no theatro, ao som das harmonias, $\quad$ dic

P. 67:

Nota MA: termo sublinhado no v. 27, "notas", e escólio "dic" - pesquisa para o Dicionário musical brasileiro:

Dir-se-ia que essas notas eram doces dic

$\underline{\text { P. } 68-70}$

HEBRÉA (9 estrofes)

P. 69:

Nota MA: termo sublinhado no v. 28, "harpa", e escólio "dic" - pesquisa para o Dicionário musical brasileiro:

Vibrando na harpa do propheta o canto... dic

P. 70:

Nota MA: colchete à esquerda, destacando trecho da nota de rodapé - seleção de ideias:

- Tobias Barreto ouviu a "Hebréa" cantada em uma das egrejas do Norte do Brasil, mudada a intenção pelos crentes, que se dirigiam á Virgem Maria, tambem hebréa (Estudos allemães, Recife, 1882, pag. 101, nota).

P. 71-74

O VOO DO GENIO (9 estrofes) 
P. 72:

Nota MA:

1. traço duplo vertical à esquerda da estrofe - seleção de ideias;

2. traço horizontal próximo ao quarto verso.

"Onde me levas mais, anjo divino?"

- "Vem ouvir, sobre as harpas inspiradas,

O canto das espheras namoradas,

Quando eu encho de amor o azul do céu.

Quero levar-te das paixões nos mares.

Quero levar-te a dedalos profundos,

Onde refervem sóes... e céus... e mundos...

Mais sóes... mais mundos, e onde tudo é meu..."

3. termo sublinhado no v. 43, "murmura" - estudo do caráter auditivo atribuído por MA à poesia de $\mathrm{CA}$ :

A lympha clara, que murmura a medo,

Nota da pesquisa: MA utiliza os dois últimos versos da estrofe como exemplo dos trocadilhos verbais que aproximam a poesia de Castro Alves ao parnasianismo brasileiro ("Castro Alves", in Aspectos da literatura brasileira, ed. cit., p. 121).

P. 73:

Nota MA: termo sublinhado no v. 37 e cruzeta à direita - estudo linguístico: emprego da forma "pra":

Perdão! Perdão! Senhor, p'ra quem soluça $X$

P. 74:

Nota MA: comentário ao final do poema:

"O que diferencia bastante $C$. Alves dos romanti-/cos brasileiros é a variedade dos aspetos do mesmo / assunto. A lira dele tambem possui pouquissimas / cordas mas ele varia pela imagem o assunto, não / propriamente pelo pensamento."

Nota da pesquisa: O escólio é transposto para o dossiê Castro Alves, no plano do livro Lirismo romântico no Brasil, junto ao exemplo do poema "Tríplice diadema": "C. Alves é mais variado. Não vario assunto (lira de poucas cordas) porem varía o aspeto mesmo assunto pela imagem, I, 74 e 88" (MA-MMA-26-02; sublinhei).

P. 75-76

A EUGENIA CAMARA (7 estrofes)

P. 76:

Notas MA:

1. termo sublinhado no v. 20 e cruzeta à esquerda - estudo linguístico: emprego da forma "pra": 


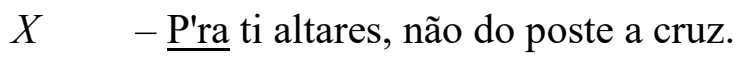

2. termo sublinhado no v. 27 e cruzeta à esquerda - estudo linguístico: emprego da forma "pra":

X Pousa nas nuvens p'ra arrogante em breve

$\underline{\text { P. } 77-79}$

SONHO DA BOHEMIA (9 estrofes)

P. 78:

Notas MA:

1. termos sublinhados nos v. 22 e 23 , "canto" e "canções", e cruzeta no v. 23 - estudo do caráter auditivo atribuído por MA à poesia de $\mathrm{CA}$ :

Ao canto alegre das aves

$X \quad$ As nossas canções suaves,

2. termo sublinhado no v. 29, "cantiga", e cruzeta - estudo do caráter auditivo atribuído por MA à poesia de CA:

X Quanta cantiga faceira

3. termo sublinhado no v. 33, “ouvir", e cruzeta - estudo do caráter auditivo atribuído por MA à poesia de $\mathrm{CA}$ :

$X \quad$ Hei de ouvir os cantos teus...

\section{P. 78-79:}

Notas MA:

1. termo sublinhado no v. 40, "cantarás", e cruzeta;

2. expressão sublinhada no v. 41, "moda hespanhola", e escólio "dic" - pesquisa para o

Dicionário musical brasileiro:

X Tu cantarás, ó Manola, Aquella moda hespanhola dic

Que tantos requebros tem!

3. termo sublinhado no v.40 e cruzeta - estudo linguístico: emprego da forma "pra":

X "P'ra ser feliz basta amar!"

4. data destacada por cruzeta:

X Recife, 1866

P. 80-82

HorAs DE MARTYRIo / DAMA NEGRA (7 estrofes) 
P. 80:

Nota MA: expressão sublinhada no v. 15, “que déste-me", e cruzeta à esquerda - estudo linguístico: brasileirismo/colocação pronominal:

$X \quad$ Conto os risos, que déste-me um dia,

Nota da pesquisa: MA classifica como brasileirismo, no manuscrito d'A gramatiquinha da fala brasileira (MA-MMA-51-66), o exemplo idêntico "Que havendo-lhe", encontrado em Ambrósio Fernandes Brandão: Diálogos das grandezas do Brasil. Introdução de Capistrano de Abreu e notas de Rodolpho Garcia (Rio de Janeiro: Publicações da Academia Brazileira - II Historia/Officina Industria Graphica, 1930. V. ALMEIDA, Aline Novais de. Op. cit., p. 244, vol 1).

P. 81:

Nota MA: expressão sublinhada no v. 17, "Me recordo", e cruzeta à esquerda; estudo linguístico: brasileirismo/colocação pronominal.

$X \quad \underline{\text { Me recordo }}$ o logar onde estavas...

Nota da pesquisa: O pronome no início de frase também é caracterizado como brasileirismo no manuscrito d'A gramatiquinha da fala brasileira (MA-MMA-51-60). $\mathrm{Na}$ carta a Sousa da Silveira, em 15 de fevereiro de 1935, MA pondera: "No caso de iniciar períodos pelas variações pronominais, nada lhe poderei conceder (...) Confesso que a não ser num ou noutro raríssimo, que faz questão de purismo escrito, literário, até no falar, em tôdas as camadas tenho encontrado as variações pronominais iniciando a frase. [...] e como esquecer Gonçalves Dias iniciando uma estrofe com 'Te vejo, te procuro' nas Poesias, Garnier, v. I, p. 148...” (FERNANDES, Lígia (Org.). Ed. cit., p. 154 e 155).

P. 82:

Nota MA: comentário ao final do poema:

"Curioso de notar que sendo C. Alves um / auditivo fortemente marcado (veja-se a / poesia anterior) fosse no entanto o me-/nos musical, no sentido de som valen-/do a volupia do verso, que os outros grandes / romanticos. (Notar a im pro prie dade de / ritmo desta poesia). Sendo como foi um / discursador quase sempre nos seus ver-/sos o poder verbal dele é puramente / oral. Está longe sobretudo da musica-/lização objetiva da poesia tal como a / praticava G. Dias e da musicalidade / natural de Varella e de Casimiro."

Nota da pesquisa: Há extensas considerações sobre a musicalidade no ensaio "Castro Alves", em cuja obra MA reconhece uma "desvalorização da qualidade musical e sugestiva da palavra": "O que eu quero dizer é que mesmo aqueles homens, de um tempo tão perigoso para a poesia, quando maiores como um Gonçalves Dias e o Cláudio Manuel da Costa dos sonetos tinham sabido empregar a palavra, lhe conservando toda a fluidez. Para eles a palavra guarda sempre um valor de música, que não implica a incompreensibilidade do som musical, mas apenas a sua força de sugestão e vagueza de sentido intelectual. [...] aceitemos que o destino primeiro e imprescindível do poeta consistirá nisso de conservar a palavra em sua vagueza individualista de significação, lhe retirando em proveito do seu assunto, o menos possível de valor associativo, sugestivo e 
musical. Não sonoro, mas exatamente musical. O menos que posso conceder é que para se realizar o fenômeno 'poesia' tudo está em conservar às palavras a sua fluidez." (In: Aspctos da literatura brasileira, ed. cit., p. 116).

$\underline{\text { P. } 83}$

AMAR E SER AMADO (1 estrofe)

Nota MA: termo sublinhado no v. 9 e cruzeta - estudo linguístico: emprego da forma "pra":

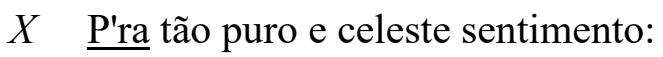

$\underline{\text { P. } 84-86}$

AMEMOS (12 estrofes)

P. 84:

Nota MA: expressão sublinhada na $1^{\text {a }}$ estrofe, "ao som", e cruzeta - estudo do caráter auditivo atribuído por MA à poesia de CA:

$X \quad$ Aqui, ao som de errantes harmonias, Se adormece entre flores.

P. 85

Notas MA:

1. termo sublinhado no v. 22, "cantando", e cruzeta - estudo do caráter auditivo atribuído por MA à poesia de $\mathrm{CA}$ :

No mesmo leito adormecer cantando... $\quad X$

2. termo sublinhado no v. 28, "lyra", e escólio "dic" - pesquisa para o Dicionário musical brasileiro:

Fazer que o mundo se transforme em lyra, dic

3. expressões sublinhadas no v. 35, "Escutarás" e "rumorejos", e cruzeta - estudo do caráter auditivo atribuído por MA à poesia de CA:

Escutarás os doces rumorejos $\quad X$

D'ave do coração.

4. expressão sublinhada no v. 40, "te embalarei", e cruzeta - estudo linguístico: brasileirismo/colocação pronominal:

$X \quad \underline{T e}$ embalarei com uma canção sentida,

P. 85-86:

Notas MA:

1. termo sublinhado no v. 43 e cruzeta - estudo linguístico: emprego da forma "pra"; 
2. termos sublinhados no v. 44, "cantos", v. 47, "canticos", e sublinha rasurada nos v. 44 e 48, "palmas" - estudo do caráter auditivo atribuído por MA à poesia de CA:

Amemos, pois! P'ra ti eu tenho n'alma $\quad X$

Beijos, prantos, sorrisos, cantos, palmas...

Um abysmo de amor...

Sorrisos de uma irmã, prantos maternos,

Beijos de amante, canticos eternos,

$\mathrm{E}$ as palmas do cantor.

P. 86:

Notas MA:

1. estrofe $n^{\circ} 9$ destacada por traço vertical - estudo da psicologia: sentimento amoroso;

2. expressão sublinhada no v. 52, "tremulos de medo", e exclamação - estudo da psicologia: sentimento amoroso;

3. expressão sublinhada no v. 53, "De quem entra no céu":

Ah! fôra bello unidos em segredo,

Juntos, bem juntos... tremulos de medo, !

De quem entra no céu;

Desmanchar teus cabellos delirante,

Beijar teu collo... Oh! vamos minha amante,

Abre-me o seio teu.

Nota da pesquisa: Ao postular a virilidade de Castro Alves em "Amor e medo", MA cita a estrofe para fundamentar sua argumentação: "No Amemos ele fala em ter medo, e apesar da palavra vir como rima de 'segredo', é expressiva, cai muito bem como detalhe psicológico. É o único medo possível pros que não têm medo de amor: aquele caótico paroxismo sensual em que o gozo verdadeiro do amor se obumbra na ânsia dum temperamento caudaloso por demais, que treme não de timidez, mas de impaciência, incapaz de esperar." (“Amor e medo", In: Aspectos da literatura brasileira, ed. cit., p. 208).

4. $10^{\mathrm{a}}$ estrofe destacada por traço vertical - estudo da psicologia:

Eu quero teu olhar, de aureos fulgores,

Ver desmaiar na febre dos amores,

Fitos... fitos em mim.

Eu quero ver teu peito entumescido,

Ao sopro da volupia arfar erguido...

O oceano de setim...

5. $11^{\mathrm{a}}$ estrofe destacada por traço vertical;

6. v. 64 e 65 destacados por colchete;

7. expressão sublinhada no v. 64, "Eu não posso ser de outra", e fio até o comentário no rodapé - estudo da psicologia: 


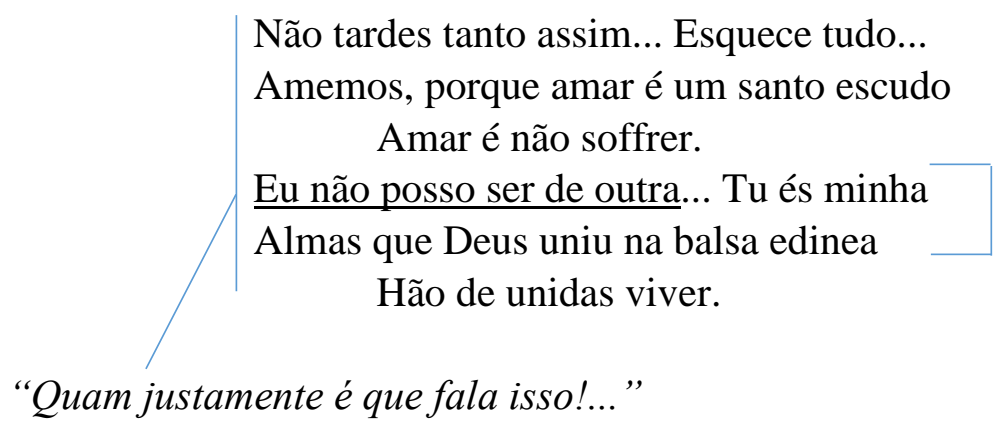

Nota da pesquisa: No dossiê do manuscrito Castro Alves, no plano da obra Lirismo romântico no Brasil, a rubrica "Sinceridade" faz referência a esta página (MA-MMA-2602).

8. termos sublinhados nos v. 67 e 68, "harmonias" e "melodias", traço vertical, escólio "dic" e cruzeta - pesquisa para o Dicionário musical brasileiro:

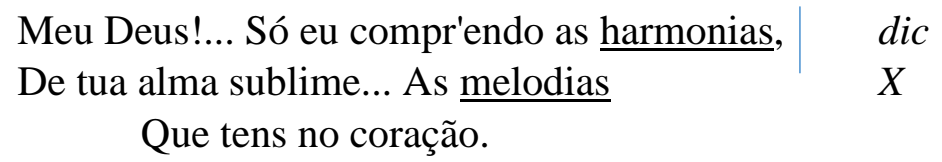

\section{$\underline{\text { P. } 87-88}$}

TRIPLICE DiADEMA (4 estrofes)

$\underline{\text { P. } 87}$

Nota MA: verso final, $1^{\mathrm{a}}$ estrofe, sublinhado e expoente (1) remetendo ao comentário no rodapé:

$$
\text { - Deus se fez Raphael. }
$$

“(1) Que mau gôsto. Ele diminui em vez de engrandecer / Deus.”

Nota da pesquisa: No dossiê do manuscrito Castro Alves, no plano da obra Lirismo romântico no Brasil, MA confirma a rubrica: "Mau gôsto I, 87 107; 242; 306; II, 127; 137; 183" (MA-MMA-26-02; sublinhei). No ensaio, MA alude de passagem: "É certo que o condoreirismo levou Castro Alves a imagens de um mau gosto repulsivo" ("Castro Alves", In: Aspectos da literatura brasileira, ed. cit., p. 122).

P. 88:

Notas MA:

1. nota de Afrânio Peixoto destacada por cruzeta:

I) No album de Eugenia Camara. Sem mesmo a indicação deste destino, pela data e pelo assumpto, era facil saber a quem pertenciam taes diademas belleza, pela qual estava o Poeta apaixonado, - genio, que applaudia no theatro, - coração, que elle sentia de perto, e que, ao tempo, amava tambem a uma interessante criaturinha de sete annos, Mimi, a filha que houvera de Furtado Coelho. Possuia, pois, a amada, o triplice diadema que lhe via seu apaixonado Poeta. 
2. comentário ao final do poema:

“Notar por esta 'Triplice Diadema' a maneira já mais / que brasileiramente romântica, porém posterior ao Roman-/tismo, com que C. Alves dá assuntos temas ao seu assunto."

$\underline{\text { P. } 89-90}$

OS TRES AMORES (3 estrofes)

P.90:

Notas MA:

1. termos sublinhados no v. 4, "threnos" e "viola", e escólio "dic" - pesquisa para o Dicionário musical brasileiro;

2. expoente (1) remetendo ao comentário no rodapé:

III.

$\mathrm{Na}$ volupia das noites andaluzas

O sangue ardente em minhas veias rola...

Sou D. Juan!... Donzellas amorosas,

Vós conheceis-me os threnos na viola!

(1) dic

Sobre o leito do amor teu seio brilha...

Eu morro, se desfaço-te a mantilha...

Tu és - Julia a Hespanhola!...

“(1) Poucos abusaram tanto da impropriedade / como C. A. Seio que é "oceano de cetim” (86), Deus / se faz Rafael (87), viola com trenos (que já é / impropriedade) e trenos em noites de serenata!"

Nota da pesquisa: Os versos referidos por MA situam-se nos poemas "Amemos" e "Tríplice diadema".

P. 91-93

A UMA ACTRIZ (6 estrofes)

P. 91:

Notas MA:

1. termos sublinhados nos v. 8 e 9, "poeta" e "vate", e fio ligando-os;

2. termos sublinhados nos v. 9 e 10, "propheta", e fio ligando-os;

3. versos finais destacados por dois traços, um vertical e outro horizontal;

4. comentário na lateral da estrofe:

"Mudou 'vate' pra não fazer muitos 'etas'",

Branco cysne, que vogavas

Das harmonias no mar,

Pomba errante de outros climas,

Vieste aos cerros pousar. 
Inda bem. Sob os palmares

Na voz do condor, dos mares,

Das cerranias, dos céus...

Sente o hom $\mathrm{m}$, - que é poeta,

Sente o vate - que é propheta,

P. 92:

Sente o propheta - que é/Deus.

Nota MA: termo sublinhado no v. 40, "toque", e escólio "dic" - pesquisa para o Dicionário musical brasileiro:

dic Ao teu toque divinal.

\section{P. 94-96}

FATALIDADE (10 estrofes)

P. 94:

Nota MA: termo sublinhado no v. 10 e cruzeta à esquerda - estudo linguístico: emprego da forma "pra":

X Abri os braços... caminhei p'ra luz...

P. 95:

Nota MA: termo sublinhado no v. 26 e cruzeta à direita; estudo linguístico: emprego da forma "pra".

Lá para o ponto que lhe marca Deus. $\quad X$

$\underline{\text { P. } 97-98}$

O GONDOLEIRO DO AMOR / BARCAROLA (10 estrofes)

P. 97:

Nota MA: subtítulo sublinhado, "Barcarola", e escólio, "dic" - pesquisa para o Dicionário musical brasileiro:

P. 98:

Nota MA: comentário no rodapé:

"Enfim com o Gondoleiro do Amor, Eugenia Camara dá / ao poeta um lirismo sublime e genial com este poema / que é do mais puro gosto romântico e das mais perfeitas / líricas do Romantismo universal."

P. 99-104

Sub TEGMINE FAGI (15 estrofes)

P. 99: 
Nota MA: termo sublinhado no v. 12 e duas cruzetas - estudo linguístico: emprego da forma "pra":

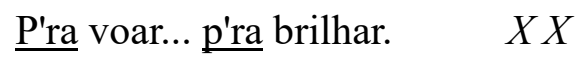

P. 100:

Nota MA: termo sublinhado no v. 21 e cruzeta - estudo linguístico: emprego da forma "pra":

$$
X \quad \text { Das cidades p'ra o céu. }
$$

P. 101:

Nota MA: termo sublinhado, "flauta", e escólio "dic" - pesquisa para o Dicionário musical brasileiro:

$$
\text { Pan na flauta soprou!... dic }
$$

P. 102:

Nota MA:

1. termo sublinhado no v. 81, "carpir", e escólio "zoof" - pesquisa para zoofonia;

2. termo sublinhado no v. 84 , "P'ra", e cruzeta à esquerda - estudo linguístico: emprego da forma "pra".

Nota da pesquisa: O projeto de reunir expressões usadas para representar a voz dos animais liga-se ao Dicionário musical brasileiro — onde o termo "zoofonia", tirado de Hercule Florence, consta como entrada - e a O banquete, diálogo estético interrompido em 1945, cujo capítulo oitavo previa: “O Passeio em Pássaros. Zoofonia. O cantor-enfeite no cio. A mulher vestida de homem e a Lei do Peso. Música da natureza e música descritiva." (ANDRADE, Mário de. O banquete. São Paulo: Livraria Duas Cidades, 1977, p. 167). O manuscrito Zoofonia, no arquivo do escritor, é composto de documentos musicais, recortes de jornal e notas de trabalho, tiradas de publicações ou colhidas in loco por MA e seus colaboradores. Em entrevista, o autor atribui a ideia à leitura de Green Mansions: a romance of the tropical forests, de William Henry Hudson (V. ANDRADE, Mário de. Entrevistas e depoimentos. Edição organizada por Telê Porto Ancona Lopez. São Paulo: T.A. Queiroz, 1983, p. 93).

$\underline{\text { P. } 105-109}$

A BOA VISTA (19 estrofes)

P. 105:

Nota MA:

1. expressão sublinhada nos v. 7 e 8 , "eu escutava attento / A surdina" - estudo do caráter auditivo atribuído por MA à poesia de CA;

2. termo sublinhado no v. 8, "surdina", e escólio "dic" - pesquisa para o Dicionário musical brasileiro:

No drama do crepusculo eu escutava attento

dic

A surdina da tarde ao sol, que morre lento. 
P. 106:

Notas MA:

1. termo sublinhado no v. 16 e cruzeta - estudo linguístico: emprego da forma "pra":

$X \quad$ Ia seguindo triste p'ra o velho lar paterno.

2. termo sublinhado no v. 19 e cruzeta - estudo linguístico: emprego da forma "pra":

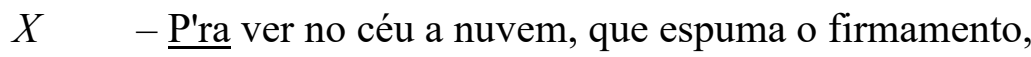

P. 107:

Nota MA: termo sublinhado no v. 54, "parda", e exclamação - estudo da figuração autoral mestiça:

Meu lar está deserto... Um velho cão de guarda

Veio saltando á custo roçar-me a testa parda

P. 108:

Notas MA:

1. expressão sublinhada no v. 84, “ouço-te a solidão", e juízo de valor:

Fala-me o teu silencio - ouço-te a solidão!... "(lindo )"

Povoam-se estas salas...

2. termo sublinhado no v. 93 e cruzeta - estudo linguístico: emprego da forma "pra":

$X \quad$ Roçam por mim as asas voando p'ra o passado.

3. comentário no rodapé:

“O 'Como a ave que volta ao ninho antigo' já em Casemi-/ro se encontra adoravel, aqui magistral embora me-/nos comovente que em Casemiro."

Nota da pesquisa: A Coleção MA, na Biblioteca Municipal de Araraquara, conserva o livro de Luís Guimarães Júnior, Rimas e sonetos (1880), onde consta o poema "Visita à casa paterna".

P. 109:

Nota MA: acréscimo de aspas e ponto e vírgula em verso citado no rodapé: "A mão lamber-me uivando! Talvez assim commigo" - correção tipográfica.

P. 112-1]14

POETA (11 estrofes)

P. 112:

Nota MA: termo sublinhado no v. 2 e cruzeta - estudo linguístico: emprego da forma "pra": 
- Da etherea flor - á noite - debruça-se p'ra o mar, $X$

P. 113:

Nota MA: termo sublinhado no v. 23 e cruzeta - estudo linguístico: emprego da forma "pra":

$$
\text { P'ra ti era o cypreste - o dedo mortuario } \quad X
$$

\section{$\underline{\text { P. } 115-116}$}

No Album do artista Luiz C. Amoedo (3 estrofes)

$\underline{\text { P. } 115}$

Nota MA: termo sublinhado no v. 4 e cruzeta - estudo linguístico: emprego da forma "pra":

$$
\text { Nem um véu p'ra occultar o seio tremulo, } \quad X
$$

\section{P. $121-122$}

PENSO EM TI (5 estrofes)

P. 121:

Notas MA:

1. termo sublinhado no v. 14 e cruzeta - estudo linguístico: emprego da forma "pra":

$$
\underline{\text { Para }} \text { ir se abrigar á tua, ó lyrio, }
$$

$X$

2. expressão corrigida no v. 19, “divino olhar”, invertendo os termos para respeitar a rima.

$$
\text { Crenças desperta o teu divino olhar... }
$$

$\underline{\text { P. } 123-125}$

HYMNO AO SOMNO (10 estrofes)

P. 125:

Nota MA:

1. termo sublinhado no v. 58 e cruzeta - estudo linguístico: emprego da forma "pra":

P'ra mim não é veneno... $\quad X$

2. termo sublinhado no v. 68 e cruzeta - estudo linguístico: emprego da forma "para";

Que volve para mim, $\quad X$

3. colchete e expoente (1) remetendo ao comentário no rodapé - estudo da psicologia: avatares da figura feminina na poesia do romantismo:

Meu anjo... mais ainda...

E' minha amante emfim! 
“(1) O anjo romantico vai sentindo enfim a precisão / humana de se transformar em amante."

Nota da pesquisa: O dossiê do manuscrito Amor e medo conserva nota de trabalho remetendo a esta anotação de leitura: "Amor e Medo // Objetividade do amor em / Castro Alves // Nota (1) em I, 125 // I, 284 // I, 444" (MA-MMA-05-06; sublinhei). O ensaio para a Revista Nova, ano 1, n' 3, ressalta a virilidade do poeta: "Em Castro Alves se sente sempre, ou pelo menos mais que nos outros, a mulher. Ele foi de fato um sexual perigoso, duma sexualidade animal bem correta". Em outro trecho do estudo: "Apenas não me furto a lembrar como não o satisfazia falar em 'anjo', 'virgem' etc, conforme a constância do tempo." (“Amor e medo", In: Aspectos da literatura brasileira, ed. cit., p. 204 e 207).

4. comentário à direita da $10^{\mathrm{a}}$ estrofe:

O' somno! O' Deus noctivago!

Doce influencia amiga!

Genio que a Grecia antiga

"Sem esta última estancia

Chamava de Morpheu.

que é besta, o poema é obra-

Ouve!... E se minhas supplicas

prima."

Em breve realizares...

Voto nos teus altares

Minha lyra de Orpheu!...

Nota da pesquisa: A largueza da oratória é censurada por MA no ensaio dedicado ao poeta: "É certo que o condoreirismo levou Castro Alves a imagens de um mau gosto repulsivo, mas, a meu ver, o maior mal dessa oratória é que Castro Alves, como Rui Barbosa, foi um encompridador. Delirava escutando os sons da própria voz, falou, falou, falou. [...] Não sabia absolutamente pautar o tamanho das suas poesias." Linhas adiante, depois de listar como exemplos de compridez "O Laço de Fita", "Se eu te dissesse", "Aquela mão", "Manuela", "A órfã na sepultura", "Adeus, meu canto" e "Cachoeira de Paulo Afonso", MA considera: "No 'Hino ao sono' se é sempre certo que o poeta poderia subtrair algumas estrofes para valorizar mais a carnadura dura do poema, o espantoso é não ter ele visto que diante da beleza da penúltima estância, a última era quase boçal" ("Castro Alves", In: Aspectos da literatura brasileira, ed. cit., p. 122).

P. 126-127

LAÇO DE FITA (8 estrofes)

P. 127:

Nota MA: termo sublinhado nos v. 26 e 27, "walsa", e escólio "dic" - pesquisa para o

Dicionário musical brasileiro:

Ha pouco voavas na célere walsa dic

$\mathrm{Na}$ walsa que anseia, que estúa e palpita.

$\underline{\text { P. } 128-130}$

BOA NOITE (10 estrofes) 
P. 129:

Nota MA:

1. verso 31 sublinhado - estudo do caráter auditivo atribuído por MA à poesia de $\mathrm{CA}$;

2. termo sublinhado, "teclas" - estudo linguístico;

Das teclas de teu seio que harmonias,

P. 131-132

O “ADEUS” DE THEREZA (4 estrofes)

P. 132:

Nota MA: comentário ao final do poema:

"Isto é sublime".

$\underline{\text { P. } 133-135}$

AHASVERUS E O GENIO ( 8 estrofes)

P. 134:

Nota MA: verso 40 sublinhado e expoente (1), remetendo ao comentário no rodapé:

Invejado! a invejar os invejosos. (1)

“(1) Observação magistral sobre a dúvida de / tantos e tantos geniais.”

P. 135:

Nota MA: comentário ao final do poema:

"Das poesias de comparação que ha-/viam de dar tantos temas pro Parnasianismo. / Não será a unica do Romantismo brasileiro?"

Nota da pesquisa: MA corrobora no ensaio a nota de margem: "[Castro Alves] Afeiçoa os poemas de comparação, Immensis Orbibus Anguis, $O$ tonel das danaides, Ahasverus $e$ o Gênio, que haviam de dar tantos As Pombas para a temática dos períodos seguintes." ("Castro Alves", In: Aspectos da Literatura Brasileira, ed. cit., p. 121).

P. $136-137$

ADORMECIDA (7 estrofes)

\section{P. 137:}

Nota MA:

1. termo sublinhado no v. 23 e cruzeta - estudo linguístico: emprego da forma "pra":

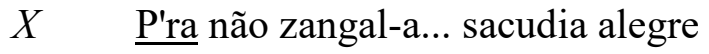

2. comentário referente à última estrofe - estudo de matrizes: 
"É o Casimiro das 'Duas Borboletas"”.

Eu, fitando esta scena, repetia

N'aquella noite languida e sentida:

"O' flor! - tu és a virgem das campinas!

"Virgem! - tu és a flor de minha vida!..."

$\underline{\text { P. } 140-141}$

A VOLTA DA PRIMAVERA ( 8 estrofes)

P. 141:

Nota MA: comentário ao final do poema:

"Ver observação em Varela / sobre estes poemas de decas-/silabo num ritmo só."

Nota da pesquisa: A observação referida por MA acha-se no poema “***” de Fagundes Varela: "Nestes decassílabos e geralmente em quase todos (todos?) os rimados a acentuação cantadeira e abrigada na $4^{\mathrm{a}}$ e $8^{\mathrm{a}}$ sílabas cansa e enjoa horrorosamente. Nos versos brancos é que Varela prima entremeando essa maneira romântica de acentuar com a acentuação heroica na $6^{\text {a }}$ sílaba." (Nota MA, In: Obras completas de L. N. Fagundes Varella: edição organisada e revista, e precedida de uma noticia biographica por Visconti Coaracy e de um estudo critico pelo Dr. Franklin Tavora. Rio de Janeiro/Paris: Garnier, 1919, vol. 1, p. 124).

P. $146-148$

IMMENSIS ORBIBUS ANGUIS (9 estrofes)

P. 146:

Nota MA: palavra sublinhada no v. 10, "matrona", e anotação: “!oh!”.

A Indígena, a gentil matrona do deserto !oh!

P. 147:

Nota MA: comentário ao final do poema:

"Ainda comparação. $O$ / artificialismo da arte de C. Alves em oposição / á arte direta de Gonçalves Dias."

Nota da pesquisa: No dossiê do manuscrito Castro Alves, no plano da obra Lirismo romântico no Brasil, a rubrica "Artificialismo" refere esta página: "Artificialismo I, 147; 150; 272; 218; 328;/ II, 65; 81; 155" (MA-MMA-26-02; sublinhei). Em outra nota de trabalho, MA avança a comparação: "Gonçalves Dias é artista intelectual. A arte dele es/tá principalmente no dominio da inteligencia so-/bre a inspiração organizando-lhe a tematica / as normas, os ideais, as maneiras de se mani-/festar - Castro Alves é artista formal. / A sua arte é mais exterior, mais de frase / que a de Gonçalves Dias. Daí as antiteses, as / ideas paralelas, as comparações, as imagens, / os estupendos refrões. Dizer isso separada-/mente quando tratar individualmente dos $2 /$ poetas. E na parte geral 
anterior á critica indi-/vidual so afirmar rapidamente a superioridade / artistica de Gonçalves Dias e dar rapido os por-/quês" (MA-MMA-26-08).

$\underline{\text { P. } 149-150}$

O TONEL DAS DANAIDES (12 estrofes)

P. 150:

Nota MA: comentário ao final do poema:

"Quanto Guerra Junqueiro com mais artificialis-/mo e exasperos de facil condoreirismo virá depois / incitar, positivamente macaquear C. Alves! E como / lhe é inferior com a sua aparencia de mais pen-/samento e filosostria! Todo o lirismo escachoante / e vívido de C. Alves se transformaria naquele em / árias de Tosti e Denza."

Nota da pesquisa: Dois títulos do português Abílio Manuel Guerra Junqueiro (1850-1923) encontram-se na coleção doada por Mário de Andrade à Biblioteca Municipal de Araraquara: Os simples e A morte de D.João. No Arquivo do escritor, figuram três volumes de F. Paolo Tosti (1846-1916) - Canta la serenata!, Ideale, Melodie vol. 1 - e um álbum musical gravado pelo tenor Enrico Caruso, com músicas daquele e de Meyerbeer. O álbum "Se... / Notte lunare", de Luigi Denza (1846-1922), consta da Coleção de Discos, com a canção “Se...”, composta em coautoria com E. Mancini.

P. $151-153$

É TARDE! (12 estrofes)

P. 153:

Nota MA: comentário ao final do poema:

"Isto Guerra Junqueiro seria / incapaz de escrever."

P. $154-161$

AdEus (23 estrofes)

P. 154:

Notas MA:

1. termo sublinhado no v. 1 e cruzeta - estudo linguístico: emprego da forma "pra":

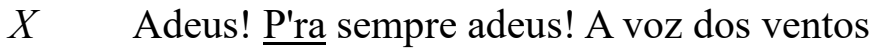

2. fio ligando o "P'ra" no v. 1 à sua repetição na página seguinte, v. 17;

3. v. 7 e 8 sublinhados e juízo de valor à direita, "Estupendo":

Já que nada me resta sobre a terra

Dar-lhe-ei meu cadaver... sou bom filho!... Estupendo!

4. termo sublinhado no v. 11 e cruzeta - estudo linguístico: emprego da forma "pra":

$X \quad$ Ai! primavera que fugiu p'ra sempre, 
P. 155:

Nota MA: termo sublinhado e fio ligando ao v. 17, à página anterior:

Adeus! P'ra sempre adeus! Quando alta noite,

\section{P. 157-158:}

Notas MA:

1. estrofes $\mathrm{n}^{\mathrm{o}} 16$ a 21 destacadas por traço vertical duplo;

2. termo sublinhado nos v. 79 e 80, "para", e cruzeta;

3. termo sublinhado no v. 86 , "pra", e cruzeta;

Mas não! entre nós o abysmo Se estende negro e fatal...

- Jámais! - é palavra escripta No céu, na terra, no val.

$\mathrm{Eu}$ - já não tenho mais vida! $\mathrm{Tu}$ - já não tens mais amor!

$\mathrm{Tu}$ - só vives para os risos.

$\mathrm{Eu}$ - só vivo para a dôr.

Tu vaes em busca da aurora!

Eu em busca do poente!

Queres o leito brilhante!

Eu peço a cova silente!

Não te illudas! O passado

$X \quad$ P'ra sempre quebrado está!

Desce a corrente do rio...

E deixa-o sepulto lá!

Viste-me... E creste um momentos

Qu'inda me tinhas amor!...

Pobre amiga! Era lembrança,

Era saudade... era dôr!

Obrigado! Mas na terra

Tudo entre nós se acabou!

Adeus!... E' o adeus extremo..

A hora extrema soou.

P. 158:

Nota MA: trecho sublinhado no v. 101, "Sinto que vou morrer!", e expoente (1), remetendo ao comentário no rodapé:

"(1) Frase de Alvares de Azevedo. E que... botei por / ironia pouco percebida, creio que ninguém percebeu / na "Cavatina da Abandonada" da "Moral Quotidiana". ." 
(1) Sinto que vou morrer! Posso, portanto

A verdade dizer-te santa e núa:

Não quero mais teu amor!! Porém minh'alma

Aqui, além, mais longe, é sempre tua.

Nota da pesquisa: "Moral Quotidiana", peça teatral em ato único, classificada por MA como "tragédia", apareceu originalmente em Estética, n 2, 1925, e foi incluída em Obra imatura. Na "Cavatina da Abandonada", monólogo final, a Amante lamenta a partida do Marido e da Mulher para os matos americanos, onde, inspirados por Rousseau e Graça Aranha, pretendem integrar-se ao "Todo Universal". No trecho aludido, a personagem exclama: "Fantasmas amigos me rodeiam, e antevendo o futuro, eu quasi sou feliz... Sombras nuas! Sois vós, amigas minhas? ... Ai? (Sorrio encantada!) E's tu, Cleopatra! Minha Aspasia querida? Manon beija meus olhos! Elisabeth de Inglaterra!...! A Schüller canta... os seus lieder para o meu dormir... (Sinto que vou morrer)."

$\underline{\text { P. } 167-170}$

PoESIA E MENDICIDADE (22 estrofes)

P. 168:

Notas MA:

1. termo sublinhado no v. 26, "lyra", e escólio "dic" - pesquisa para o Dicionário musical brasileiro:

dic Pega da lyra... canta... uma canção de amor...

2. termo sublinhado no v. 31, "nota", e escólio "dic" - pesquisa para o Dicionário musical brasileiro:

dic

Subito a nota extrema anseia, treme, róla...

3. termo sublinhado no v. 39 e cruzeta - estudo linguístico: emprego da forma "pra":

$X \quad$ Hoje ha salario p'ra qualquer trabalho,

P. 169:

Nota MA: termo sublinhado no v. 64 e cruzeta à direita - estudo linguístico: emprego da forma "pra":

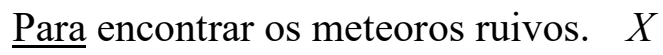

P. 170:

Notas MA:

1. termo sublinhado nos v. 69,71 e 72 e cruzetas - estudo linguístico: emprego da forma "pra":

$X \quad$ E pede á sombra, p'ra aljofrar de orvalhos

A fronte azul da solidão nocturna. 
$X \quad$ E pede ás auras, p'ra affagar os galhos

$X \quad$ E pede ao lirio, p'ra enfeitar a furna.

2. termo sublinhado nos v. 87 e 88 e cruzetas - estudo linguístico: emprego da forma "pra":

$X \quad-$ Versos - á brisa p'ra vos dar um canto...

$X \quad$ Raios ao sol - p'ra vos traçar o nome!...

$\underline{\text { P. } 171-172}$

VERSOS DE UM VIAJANTE (6 estrofes)

P. 172:

Notas MA:

1. termo sublinhado no v. 19, "serenata", e escólio "dic" - pesquisa para o Dicionário musical brasileiro;

2. estrofe $n^{0} 5$ destacada por traço vertical - seleção de ideias:

dic $\quad\left(\begin{array}{l}- \text { Rosa de Hespanha no hibernal Friul - } \\ \text { Quando o estudante e a serenata acordam } \\ \text { As belas filhas do pais do sul. }\end{array}\right.$

Tenho saudades... ai! de ti, São Paulo

P. 173-174

A DUAS FLORES (4 estrofes)

P. 173:

Nota MA: comentário à direita do título:

"Recordação da 'Simpatia' de / Casimiro? Mesmo tipo de / estrofe, ideas similares no / princípio..."

$\underline{\text { P. } 175}$

HoRAS DE SAUDAdE (5 estrofes)

P. 175:

Nota MA: termo sublinhado no v. 7, "walsa", e escólio "dic" - pesquisa para o Dicionário musical brasileiro:

E a walsa entreaberta mostra a phrase, dic

P. 176:

Nota MA: termo sublinhado no v. 26, "pipilar", e escólio "dic" à esquerda; pesquisa para o Dicionário musical brasileiro.

dic Relembra o pipilar do passarinho. 
$\underline{\text { P. } 179-182}$

O HósPEDE (13 estrofes)

P. 179:

Nota MA: termo sublinhado no v. 11, "buzina", e escólio "dic" - pesquisa para o Dicionário musical brasileiro:

"Uma buzina restrugiu no valle dic

P. 180:

Nota MA: termo sublinhado no v. 38, "fanfarra", e escólio "dic!" - pesquisa para o Dicionário musical brasileiro:

dic! Quando a fanfarra toca nas montanhas

P. 181:

Nota MA: estrofe $\mathrm{n}^{\mathrm{o}} 13$ destacada por traço vertical e comentário:

"Isto é formida-/vel. Dum enigma-/tico soberbo que / raramente a gente / encontra no lirismo la-/tino. (ver nota pg seguinte)"

P. 182:

Nota MA: comentário ao final da nota de rodapé da edição crítica:

"Carece acabar com essa historia de saber donde uma / poesia foi inspirada ou não, caso a apropriação não se-/ja flagrante e excessiva. É coisa que não tem importan-/cia e pode levar a equivocos enormes. Esta poesia magistral / não tem nada do poema de Hugo a não ser uma equivalencia de situações."

$\underline{\text { P. } 183-185}$

COUP D'ETRIER (8 estrofes)

P. 183:

Nota MA: termo sublinhado no v. 5, "toada", e escólio "dic" - pesquisa para o Dicionário musical brasileiro:

A espaços ensaiando uma toada dic

P. 184:

Notas MA:

1. termo sublinhado no v. 32, "P'ra", e cruzeta - estudo linguístico: emprego da forma "pra":

X $\quad$ P'ra realce dos lubricos encantos!...

2. verso 40 sublinhado - seleção de ideias: natureza: 


\section{Natureza! Eu voltei... e eu sou teu filho!}

3. termo sublinhado no v. 43, "toada", e escólio "dic" - pesquisa para o Dicionário musical brasileiro:

dic Dá-me um plectro bizarro e magestoso,

Nota da pesquisa: MA remete a esta página em nota de trabalho do dossiê do manuscrito Castro Alves, referindo-se ao verso sublinhado: "Castro Alves / e a / Natureza // n 200 - I - 184 / 192 / 193” (MA-MMA-26-03; sublinhei).

P. 185:

Nota MA: termo sublinhado no v. 53, "estradivario", e escólio "dic" - pesquisa para o Dicionário musical brasileiro:

Onde a soidão é o magno estradivario... $\quad$ dic

P. $186-188$

PELAS SOMBRAS (11 estrofes)

P. 186:

Nota MA: expressão sublinhada no v. 11, "Emquanto que" - estudo linguístico: brasileirismo sintático:

Emquanto que eu tropeço... um grito ao longe róla...

Nota da pesquisa: No manuscrito d'A gramatiquinha da fala brasileira, MA lista "brasileirismos sintaxicos", como a colocação de pronomes e a obliteração dos possessivos, e inclui: “i) emprego de 'enquanto que' no povo analfabeto" (MA-MMA51-261).

P. 189

Á CAPELLA DO ALMEIDA (2 estrofes)

Nota MA: v. 11 destacado por colchete - imaginário geográfico da poesia romântica:

Paris, Napoles, Sevilha,

P. $190-194$

AVES DE ARRIBAÇÃo (23 estrofes)

P. 191:

Notas MA:

1. expressões sublinhadas no v. 19, "São noivos", e no v. 20, "São amantes”, e fio ligandoas: 
- $\underline{\text { São noivos }}$-: as mulheres murmuravam!

E os passaros diziam: - $\underline{\text { São amantes }}-$ !

2. v. 21-24 destacados por traço vertical - estudo do estilo: repetição:

Eram vozes - que uniam-se co'as brisas!

Eram risos - que abriam-se co'as flores!

Eram mais dous clarões - na primavera!

$\mathrm{Na}$ festa universal - mais dous amores!

P. 192:

Notas MA:

1. expressões sublinhadas nos v. 39 e 40 e fio ligando-as - estudo da repetição:

E o passaro inclinava-se das ramas

E a estrella do infinito se inclinava.

2. termo sublinhado no v. 41, "tremolo", e escólio "dic" - pesquisa para o Dicionário musical brasileiro:

dic E a voz cantava o tremolo medroso

3. estrofes $\mathrm{n}^{\circ} 13$ a 17 destacadas por traço vertical e juízo de valor:

"Lindissimo".

A's vezes, quando o sol nas mattas virgens

A fogueira das tardes accendia,

E como a ave ferida ensanguentava

Os pincaros da longa serrania,

Um grupo destacava-se amoroso,

Tendo por tela a opala do infinito

Dupla estatua do amor e mocidade

N'um pedestal de musgos e granito.

E embaixo o valle a descantar saudoso

Na cantiga das moças lavadeiras!...

E o riacho a sonhar nas cannas bravas,

E o vento a s'embalar nas trepadeiras.

O' crepusculos mortos! Voz dos ermos!

Montes azues! Sussurros da floresta!

Quando mais vós tereis tantos affectos

Vicejando comvosco em vossa festa?...

E o sol poente inda lançava um raio

Do caçador na longa carabina...

E sobre a fronte d'Ella por diademas

Nascia ao longe a estrella vespertina. 
P. 193:

Nota MA: verso 80 sublinhado e expoente (1), remetendo ao comentário no rodapé plano da obra:

“(1) Epigrafe pra Fagundes Varela.”

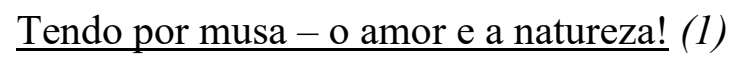

Nota da pesquisa: No dossiê do manuscrito Castro Alves, em nota de trabalho para o livro Lirismo romântico no Brasil, MA confirma o propósito de usar o verso de "Aves de arribação" no capítulo dedicado a Fagundes Varela: "Epigrafe pra Varella: C. Alves I, 193" (MA-MMA-26-06).

P. 194:

Nota MA:

1. juízo de valor ao final do poema:

"Realmente lindo";

2. comentário no rodapé:

"Comparar à Tristesse d'Olympio, a Le Lac, a Sou-/venir... Lamartine e Musset se equiparam a C. Alves. V. / Hugo é inferior.”

Nota da pesquisa: O dossiê do manuscrito Castro Alves guarda remissões aos românticos franceses mencionados no escólio: "Mostrar que / pequenina a influencia de Byron / e de Goethe e de Musset sobre A de / Azevedo e mesmo quasi que so formal de / V. Hugo sobre C. Alves, poetas que apesar / de todas as citações estrangeiras foram / nacionalissimos e nada quasi influen-/ciados. Mostrar a diferenciação de / pensamento tradicional e rico nos / romanticos europeus, pauperrima e / monotona nos brasileiros, a maneira / do amor em Byron, em Heine em / Musset, em Espronceda e nos brasilei-/ros languidos melosos. Mostrar assim / que o romantismo europeu mais que / uma determinante de corrente li-/teraria brasileira foi uma adopção / desta porquê se quadrava com a / nossa sensibilidade e o nosso / estado mental, no segundo quartel / do sec XIX" (MA-MMA-26-10 e 11). Em outra nota de trabalho, MA considera: "Os nossos romanticos foram essencialmente / liricos nada tendo de tragicos ou epicos / porquê lhes faltava aquele instinto narrati-/vo que é de essencia teatral e epica / e que tanto predominou com os franceses / romanticos, exceptuado Lamartine e assim mes-/mo! e em Byron" (MA-MMA-26-07).

A Biblioteca MA no IEB/USP abriga dois títulos de Alfred de Musset (18101857): Oeuvres complètes. Nouvelle édition revue, corrigée et complétée de documents inédits, précédée d'une notice biographique sur l'auteur et suivie de notes par Edmond Biré (Paris: Garnier, n.d, 4v.), com anotações de leitura, e Choix de poésies de Musset (Rio de Janeiro: Americ-Edit, 1944). De Alphonse de Lamartine (1790-1869) consta apenas Raphael (n. p., n. d.). Doze títulos do escritor francês Victor Hugo (1802-1885) foram encaminhados por MA à Biblioteca Municipal de Araraquara: Marion de Lorne; La fin Du Satan; Les quatre vents de l'esprit; Odes et Ballades; Ran d'Islande; Les feuilletes d'automne; Toute la lyre; Les chansons; Les contemplations; L'art d'être grand père; La légende des siecles; Les châtiments. 
P. 203-205

A UMA ESTRANGEIRA (11 estrofes)

P. 203:

Nota MA: termo sublinhado no v. 16 - estudo linguístico: emprego da forma "pra":

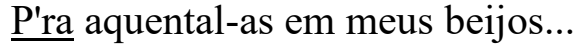

P. 204:

Nota MA: v. 21 e 22 destacados por traço vertical - estudo do caráter auditivo atribuído por MA à poesia de $\mathrm{CA}$ :

Nossos beijos estalavam

Como estala a castanhola...

$\underline{\text { P. 206-212 }}$

OS ANJOS DA MEIA-NOITE (34 estrofes)

P. 207:

Notas MA:

1. termo sublinhado no v. 34, "notas", e escólio "dic" - pesquisa para o Dicionário musical brasileiro:

$$
\text { E no ether, que em notas se perfuma, dic }
$$

2. termo sublinhado no v. 44, "preludia", e escólio "dic" - pesquisa para o Dicionário musical brasileiro:

Preludia um violão na serenata!... $\quad$ dic

P. 208:

Nota MA: termo sublinhado no v. 62, "harpa eolia" - estudo do caráter auditivo atribuído por MA à poesia de $\mathrm{CA}$ :

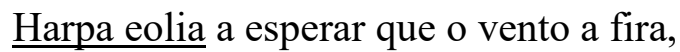

$\underline{\text { P. } 213-222}$

UMA PÁGINA DE Escola REALISTA (DRAMA CÔMICO EM QUATRO PALAVRAS)

P. 217:

Nota MA: preposição sublinhada nos v. 90, 92, 95 e 96 - estudo linguístico: emprego da forma "pra":

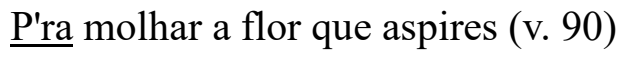

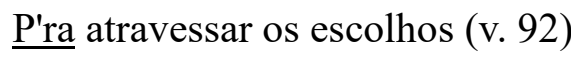

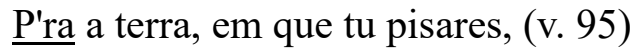

P'ra a sêde, em que te abrasares, (v. 96) 
P. 218:

Nota MA: estrofe destacada por traço horizontal e comentário:

“como são artificiais / estas estancias!”.

Em teu labio, molhado e perfumoso,

O licor entornar de minha vida...

Escutar-te nas vascas da agonia,

Como Fausto as canções de Margarida...

$\underline{\text { P. } 223-224}$

SE EU TE DISSESSE (8 estrofes)

P. 223:

Nota MA: termo sublinhado no v. 19, "trova" - pesquisa para o Dicionário musical brasileiro:

E ousei, na trova em que os pastores geme,

P. 227-228

A CESTINHA DE COSTURA (6 estrofes)

P. 228:

Nota MA: comentário ao final do poema - estudo da psicologia: sentimento amoroso:

"Como é gracioso isto! Inda mais que o 'Laço de Fita'. Toda / a denguice, a languidez pegajosa, o amor encostado do brasi-/leiro, a sua feminilidade amulatada no amor se encontra / aqui."

\section{P. 230-231}

MENINA E MoÇA (9 estrofes)

P. 230:

Nota MA: termo sublinhado no v. 13, "Som", e escólio "dic (por obra musical, estilo...)" - estudo linguístico: pesquisa para o Dicionário musical brasileiro;

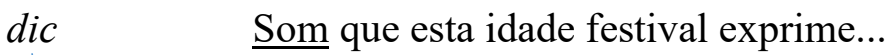

por obra musical, estilo...

P. 231:

Notas MA:

1. termo sublinhado no v. 18, "creança", e cruzeta - estudo da psicologia: avatares da figura feminina na poesia do romantismo:

Agora o typo da creança bella, $\quad X$ 
2. pronome sublinhado nos v. 23 e 24, "Se", e cruzeta - estudo linguístico: brasileirismo/colocação pronominal:

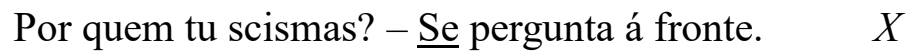

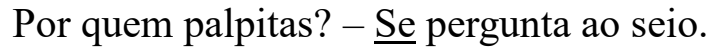

3. juízo de valor no rodapé:

"Outra lindeza".

$\underline{\text { P. 232-234 }}$

A Violeta (10 estrofes)

P. 234:

Nota MA: comentário no rodapé, ao final do poema:

"Eis a modinha brasileira. É o fundamento das / besteiras liricas dos nossos troveiros urbanos com a outra mo-/dalidade que assinalei em Alvares de Azevedo. 'Constelações que fulgurais' / de Hermes Fontes saiu disso, porem com que inferioridade!"

Nota da pesquisa: No dossiê do manuscrito Castro Alves, MA remete a esta página em nota de trabalho: "C. Alves autor de modinhas I, 234; II, 68; 146" (MA-MMA-26-02; sublinhei). No mesmo dossiê, o plano da obra Lirismo romântico no Brasil, em suas "Ideias Gerais", relaciona os românticos à música popular: "Influencia da canção popular, da modinha, da musica cantada. Todos, excepto Azevedo, cantadores seresteiros. Eram musicos ambulan-/tes sem canto exterior. Muitas vezes a gente tem impressão que compunham, improvisavam cantando. Influencia disso na tecnica." (MA-MMA-26-04).

Hermes [Floro Bartolomeu Martins de Araújo] Fontes (1888-1930), compositor e poeta, figura na biblioteca de Mário de Andrade com os títulos Miragem do deserto (Rio de Janeiro: Leite Ribeiro e Maurillo, 1917) e Despertar! Canto Brasileiro (Rio de Janeiro: Jacintho Ribeiro dos Santos, 1922). A modinha "Constelações", composta em coautoria com Cupertino de Menezes, não consta da Coleção de Discos. MA dedicou ao livro "Despertar" um artigo, em Klaxon, ano 1, n' 4.

P. 241-246

CONSUELO (24 estrofes)

P. 241:

Notas MA:

1. versos 9 e 13 sublinhados e fio ligando-os - imaginário geográfico da poesia romântica;

2. termo sublinhado no v. 13, "cavatina", e escólio "dic" - pesquisa para o Dicionário musical brasileiro:

A Italia! a Italia santa! a patria peregrina...

Do artista e do Poeta o magico paiz.

Onde na terra o amor chamou-se - Fornarina.

Lá onde o amor no céu chamou-se Beatriz!

Terra que deu á luz a cavatina e a dhalia.

dic 
P. 242:

Notas MA:

1. termo sublinhado no v. 23 , "estradivario" - pesquisa para o Dicionário musical brasileiro:

Silencio. Quebra a paz a voz do estradivario,

2. expressão sublinhada no v. 35, "sympathico", exclamação e expoente (1), remetendo ao comentário no rodapé:

A espuma foi teu berço, Alcyone sympathico... ! ! (1)

“(1) Castro Alves tem destas descaidas."

P. 243:

Nota MA: termo sublinhado no v. 66, "coroa", e cruzeta - estudo do estilo: licenças poéticas:

$$
\text { Como no genio esta coroa diz!... X }
$$

Nota da pesquisa: O termo "coroa" é assinalado em referência a sua variação, "croa/crôa", destinada a integrar o capítulo sobre as "Licenças Poeticas do Romantismo", conforme se lê no dossiê do manuscrito Castro Alves (MA-MMA-26-09).

P. 245:

Nota MA: termo sublinhado no v. 89, "threnos", e escólio "dic" - pesquisa para o Dicionário musical brasileiro:

Só vós, bella diva! Da musica aos threnos, dic

$\underline{\text { P. } 251-253}$

NO CAMAROTE (10 estrofes)

P. 251:

Notas MA:

1. termo sublinhado no v. 5, "harmonia", e escólio "dic" - pesquisa para o Dicionário musical brasileiro:

Debalde cresce de harmonia o canto... dic

2. termo sublinhado no v. 16 e cruzeta - estudo linguístico: emprego da forma "para":

X Como para rezar as mãos ajunta.

P. 252:

Nota MA: termo sublinhado no v. 22, "cavatina", e escólio "dic" - pesquisa para o Dicionário musical brasileiro:

dic Aos delirios que espalha a cavatina 
$\underline{\text { P. 254-257 }}$

NOITE DE MAIO (18 estrofes)

P. 254:

Nota MA: termo sublinhado no v. 2; estudo linguístico: emprego da forma "pra".

P'ra sempre brilha,

\section{$\underline{\text { P. 261-265 }}$}

A VIRGEM DOS ULTIMOS AMORES (18 estrofes)

P. 262:

Nota MA: termo sublinhado no v. 20 e cruzeta - estudo linguístico: emprego da forma "pra":

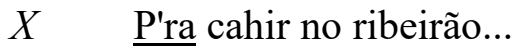

\section{P. 266-268}

A MINHA IRMAN ADELAIDE (6 estrofes)

P. 266:

Notas MA:

1. termo sublinhado no v. 13, “desviver", e cruzeta - estudo do estilo: vocabulário:

X Quando no desviver das horas de atonia,

2. termo sublinhado no v. 18, "piano", e escólio "dic" - pesquisa para o Dicionário musical brasileiro:

dic ....E' tua mão qu'empresta um'alma ao teu piano...

Nota da pesquisa: No corpus da pesquisa, MA também assinala o verbo "desviver" em carta de Álvares de Azevedo ao amigo Luiz Antonio da Silva Nunes e reproduz o verbo em nota de trabalho, no dossiê do manuscrito Amor e medo, precisando-lhe a acepção: “desviver (no sentido de gastar a vida) III, 27 e 233; III, 160” (MA-MMA-05-30).

P. 267:

Notas MA:

1. termo sublinhado no v. 25 , "creança", e cruzeta - estudo da psicologia: avatares da figura feminina na poesia do romantismo:

$X \quad$ Creança! que não vês como é sublime e santo

2. termo sublinhado no v. 29, "toque", escólio "dic" e fio ligando ao complemento: "Toque por / musica, / obra." - pesquisa para o Dicionário musical brasileiro;

3. termo sublinhado no v. 30, "bolero", e escólio "dic" - pesquisa para o Dicionário musical brasileiro: 
Fazer dançar Sevilha, ao toque de Rossini... dic

E o bolero estalar... nas teclas do piano! dic

4. expressão sublinhada no v. 36 e comentário ao final do poema - estudo do caráter auditivo atribuído por MA à poesia de $\mathrm{CA}$ :

Por unica riqueza... a ti... e ao teu piano!

"O interesse pela musica / em C. Alves. Era um auditivo?"

$\underline{\text { P. } 269-271}$

REMORSOS (8 estrofes)

P. 269:

Notas MA:

1. traço à direita dos v. 15 ao 18 e comentário à direita:

Com quem fala Carlota ao sol poente,

Na sombria alameda,

"Até penumbrismo!"

Quando os cysnes se arrufam na corrente...

E o vento, pelas grutas cochichando,

2. termo sublinhado no v. 20, "arrulando" - pesquisa da zoofonia:

Que estão, como dois pombos, arrulando...

P. 270:

Nota MA: termo sublinhado no v. 27 e cruzeta - estudo linguístico: emprego da forma "pra":

Os labios morde... p'ra matar a sêde. $\quad X$

P. 272-275

EM QUE PENSAS? (16 estrofes)

P. 272:

Nota MA: traço à esquerda dos versos 11 e 12 e expoente (1) remetendo ao comentário no rodapé:

$$
\text { (1) ( Nas flores - tuas amigas! }
$$

"(1) O artificialismo das ideas paralelas quasi tão abundan/te em C. Alves como a antitese em Vitor Hugo e a enumera-/ção na ultima fase de Bilac." 
P. 274:

Nota MA: comentário ao final do poema:

"O assunto dá quatro, tres / estrofes. O resto é incon-/gruência, superfetação, I oratoria."

$\underline{\text { P. } 276-278}$

AQUELLA MÃO (9 estrofes)

P. 276:

Notas MA:

1. termo sublinhado no v. 4 e cruzeta - estudo linguístico: emprego da forma "pra":

$X \quad$ Mão p'ra se encher de gemmas e brilhantes,

2. termo sublinhado no v. 6 e cruzeta - estudo linguístico: emprego da forma "pra":

$X \quad$ Mas p'ra estalar as joias e os amantes...

\section{P. 277:}

Notas MA:

1. verso 31 sublinhado e retângulo destacando o "p" em "eclipse" - estudo linguístico e da versificação: suarabácti:

\section{$\underline{\text { Recordava um eclipse de lua... }}$}

2. termo sublinhado no v. 31, "p'ra", e cruzeta - estudo linguístico: emprego da forma "pra":

$X \quad$ Só p'ra o louro atirar... e a lança e a alma...

3. termos sublinhados no v. 51, "harmonia" e "metro", fio ligando ambos, exclamação à direita e escólio "dic" - pesquisa para o Dicionário musical brasileiro:

Mão que ensinava $\underline{d^{\prime} h a r m o n i a}$ o metro $\quad ! \quad$ dic

P. 278:

Notas MA:

1. termo sublinhado no v. 58 e cruzeta - estudo linguístico: emprego da forma "pra":

$X \quad$ Era um'a mão para conter o globo!

2. comentário ao final do poema:

"Um pouco longo porem / admiravel".

$\underline{\text { P. } 279-282}$

REZAS (12 estrofes) 
P. 280:

Notas MA:

1. traço vertical à esquerda dos v. 27 e 28 - estudo do caráter auditivo atribuído por MA à poesia de $\mathrm{CA}$;

2. termo sublinhado no v. 28, "siphões", e escólio "dic" - pesquisa para o Dicionário musical brasileiro:

$$
\begin{array}{l|l}
\text { dic } & \text { E' organista que toca } \\
\text { Nos siphões da cathedral. }
\end{array}
$$

P. 281:

Nota MA: escólio ao final do poema:

"Auditivo (a todo momento referencias a musicas...)".

\section{P. 283-284}

GESSO E BRONZE (5 estrofes)

P. 284:

Nota MA: comentário no rodapé da edição:

"A poesia foi diretamente, pra C. Alves, mais que / uma sublimação, uma vazão da libido."

Cf. com um autographo do Poeta, em. por D. Adelaide de Castro Alves Guimarães. Pbl. nas Poesias, Bahia (1913): XLVIII.

1) Ainda dirigida a Agnese Trinei Murri: scena de ciume, depois reconhecido sem razão, ajunta D. Adelaide de Castro Alves Guimarães. Alem do gentilico "florentino" que identificava a amada, o Poeta sublinha o "bronze", como indicando que seria a materia de que era feita o seu coração. Nas suas ultimas confissões Agnese Murri depõe o contrario: era apenas um coração que a si havia imposto o silencio e, assim, pareceu indifferente ao seu Poeta.

Nota da pesquisa: Após analisar as "perversõezinhas" de Casimiro de Abreu, MA pondera em "Amor e medo": "Em Castro Alves não tem dessas coisas. Sensualidade sadia, marcadamente viril, mesmo nas mais estilizadas metáforas, como no Gesso e Bronze. Não será preciso documentar a objetividade com que ele tratou o amor e a mulher. Todos sabem disso". Em outro passo, observa: "Castro Alves, que mais tarde e com outro vigor, se queixará da Trinei Murri (e notar a masculina propensão dele pelas artistas, que por maior liberalidade de vida, são mais fáceis de se realizar em amor...)" (“Amor e medo", In: Aspectos da literatura brasileira, ed. cit., p. 207 e 208).

$\underline{\text { P. } 285-340}$

\section{POESIAS ÉPICAS}

$\underline{\text { P. 285-286 }}$ 
AOS ESTUDANTES VOLUNTÁRIOS (4 estrofes)

P. 286:

Nota MA: termo sublinhado no v. 25, "trovejem", e escólio:

Que importa os raios trovejem "Auditivo".

Nota da pesquisa: MA menciona o poema "Aos estudantes voluntários" como exemplo das preocupações sociais de CA, observando, contudo, tratar-se de uma "poesia infeliz": "Importante é verificar que ele não foi apenas o 'poeta dos escravos', embora só aí se manifeste com genialidade a sua adesão aos problemas coletivos. Castro Alves foi tendenciosamente um poeta social. Muitos problemas lhe despertaram a paixão de cantar. E de cantar frequentemente mal, com vícios de Béranger e muito de didático. Não me lembro quem disse, creio que foi o interessante Tito Lívio de Castro, que Castro Alves não aderira a certos fatos sociais do tempo menos perfeitos como elevação humana, e não cantara a Guerra do Paraguai. Não é a exata verdade, a meu ver. Numa poesia infeliz ele saudou os moços estudantes, voluntários da guerra, exaltando-lhes a mudança de comportamento: 'Assim sois vós!....Nem se pense / Que o livro enfraquece a mão. / Trocase a pena com o sabre, / Ontem - Numa... Hoje - Catão...". Bem se vê, por estes versos imprudentes, que Castro Alves não tinha aquele comércio dos livros que enfraquece completamente as mãos." ("Castro Alves", in Aspectos da literatura brasileira, ed. cit., p. 113).

P. 287-289

A MACIEL PINHEIRO (6 estrofes)

P. 287:

Notas MA:

1. termos sublinhados nos v. 11 ("serenatas"), 12 ("murmura"), 13 ("canções") e 15 ("voz" e "ruge") e cruzetas - estudo do caráter auditivo atribuído por MA à poesia de CA; 2. traço vertical à esquerda da estrofe e escólio: "Auditivo":

Verás a terra da infeliz Moema,

Bem como a Venus se elevar das vagas;

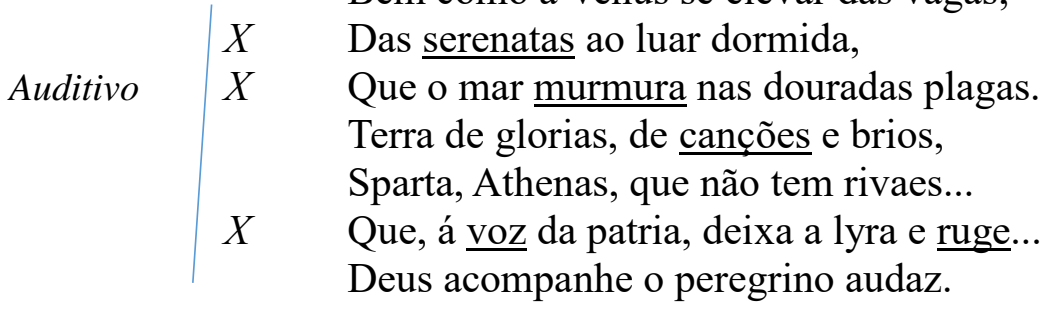

P. 288:

Notas MA:

1. termo sublinhado no v. 28 , "bramindo", e cruzeta;

2. termo sublinhado duas vezes no v. 30, "canta", e cruzeta - estudo do caráter auditivo atribuído por MA à poesia de $\mathrm{CA}$ :

$X \quad$ Soltar bramindo no feroz combate...

E após do fumo das batalhas tincto, 
$X \quad$ Canta essa terra, canta os seus geraes

3. expressão sublinhada no v. 42, "Ruge estridente", e cruzeta - estudo do caráter auditivo atribuído por MA à poesia de CA:

$X \quad$ Ruge estridente do que é grande ao sôpro,

P. 289:

Nota MA: nome sublinhado no v. 47, "Maseppa", e cruzeta - estudo de matrizes e lugares-comuns da poesia romântica:

Deus, que o Maseppa nos steppes guia... $\quad X$

P. 290-300

PEDRO IVO (36 estrofes)

P. 290:

Notas MA:

1. expoente (1) à direita da epígrafe de Álvares de Azevedo, remetendo ao comentário na margem superior:

(1) Isto me parece a origem da linda imagem de Bilac no Caçador / de Esmeraldas: / Como a sombra recua ante a imersão do Sol."

Sonhava nesta geração bastarda

Glorias e liberdade!...

Era um leão sangrento, que rugia,

Da gloria nos clarins se embriagava,

E vossa gente pallida recuava, (1)

Quando elle apparecia.

2. termo sublinhado no v. 1, "Rebramam", e cruzeta;

3. termos sublinhados no v. 3, "Relincha" e "troveja", e cruzeta - estudo do caráter auditivo atribuído por MA à poesia de CA:

$X \quad \underline{\text { Rebramam }}$ os ventos... Da negra tormenta

Nos montes de nuvens galopa o corsel...

$X \quad$ Relincha - troveja... galgando no espaço

Mil raios desperta co'as patas revél.

4. termo corrigido no v. 5, "celestes" em vez de "celese" - correção tipográfica;

5. termo sublinhado no v. 6 , "gemeu", e cruzeta:

E' noite de horrores.... nas grunas celese, tes

$X \quad$ Nas naves ethereas o vento gemeu...

6. termo sublinhado no v. 1, "grito", e cruzeta - estudo do caráter auditivo atribuído por MA à poesia de CA: 
$X \quad$ Tremendo a esse grito que estranho lhes é.

Nota da pesquisa: No dossiê do manuscrito Castro Alves, MA propõe-se: "Fazer um estudo comparativo entre os dois / poemas de Pedro Ivo de Alvares de Azevedo e de / Castro Alves, mostrando quanto o daquele é su-/perior embora menos excitante e exteriormente / agradavel. A grandiloquencia ficticia de Castro / Alves, puro discursoacademico. No entanto o / palavriado vazio, tão brasileiro, era tambem ve-/so de Alvares de Azevedo. Provam-no as prosas / deste. Mas nele era mais intenso, mais verda-/deiro, mais constante, mais continuado, perma-/nente o lirismo psicologico, por isso o seu / Pedro Ivo é mais eloquente, da legitima elo-/quencia da comoção ao passo que os surtos / epicos de Castro Alves não passam na grande / maioria das vezes de formulas de grandilo-/quencia pra agradar povo. Não nascem do ser / inteiro nem duma intenção de pensamento / duma vontade da idea." (MA-MMA-26-08).

P. 291:

Notas MA:

1. termo sublinhado no v. 24 e cruzeta - estudo linguístico: emprego da forma "pra";

P'ra qual a montanha se fez pedestal. $\quad X$

2. termo sublinhado no v. 34, "órgia", e comentário;

3. v. 34 destacado por traço vertical e fio ligando ao comentário no rodapé:

Dorme, cidade maldita,

Teu somno de escravidão!...

Dorme, vestal de pureza,

Sobre os cochins do Sultão!...

Dorme, filha da Georgia,

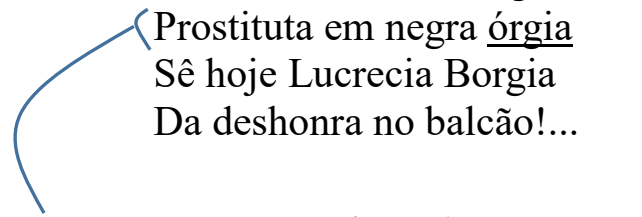

Como Alvares de Azevedo

Dante na apostrofe a Florença

P. 292:

Notas MA:

1. termo sublinhado no v. 37, "grita", e cruzeta - estudo do caráter auditivo atribuído por MA à poesia de $\mathrm{CA}$ :

Dormir?!... Não! Que a infame grita $\quad X$

2. termo sublinhado no v. 46 e cruzeta - estudo linguístico: emprego da forma "pra":

$X \quad$ Que accendeu p'ra as saturnaes,

3. termos sublinhados no v. 49, "grito", e cruzeta - estudo do caráter auditivo atribuído por MA à poesia de $\mathrm{CA}$ :

Que o seu grito de alegria 
4. termos sublinhados no v. 62, "bradando", e cruzeta - estudo do caráter auditivo atribuído por MA à poesia de $\mathrm{CA}$ :

X Saltam bradando os heróes:

P. 293:

Notas MA:

1. termo sublinhado no v. 82, "Para", e cruzeta - estudo linguístico: emprego da forma "para":

$X \quad \underline{\text { Para }}$ tomar emprestada

2. termo sublinhado no v. 91 e cruzeta - estudo linguístico: emprego da forma "pra":

$X \quad \underline{\text { P'ra levar de derribada }}$

3. termo sublinhado no v. 96, "falar", e cruzeta - estudo do caráter auditivo atribuído por MA à poesia de $\mathrm{CA}$ :

$$
\text { Com os labios - quasi a falar... } \quad X
$$

P. 296:

Notas MA:

1. termo sublinhado no v. 183, "Uiva", e cruzeta - estudo do caráter auditivo atribuído por MA à poesia de CA:

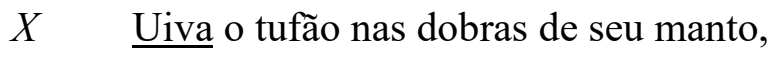

2. expressão sublinhada no v. 187, “Trocando phrases", e cruzeta - estudo do caráter auditivo atribuído por MA à poesia de CA:

X $\quad$ Trocando phrases com os trovões no espaço

P. 297:

Notas MA:

1. v. 200 sublinhado e cruzeta:

Tens uma espada que não foi punhal. $\quad X$

2. termo sublinhado no v. 206, "farfalham", e cruzeta:

Que os cedros farfalham, que ruge o tufão $X$

3. termo sublinhado no v. 207, "murmuram", e cruzeta:

E os labios da noite murmuram nas selvas $X$

4. termo sublinhado no v. 210, “ouvir", e cruzeta: 
Caminha medroso, figura-lhe ouvir $\quad X$

5. termo sublinhado no v. 212, "rugir", e cruzeta - estudo do caráter auditivo atribuído por $\mathrm{MA}$ à poesia de $\mathrm{CA}$ :

Com um grito de gloria na bocca a rugir. $\quad X$

P. 301-304

AS DUAS ILHAS (8 estrofes)

P. 302:

Notas MA:

1. termo sublinhado nos v. 48 e 50, "Diz" - estudo do estilo: repetição:

Diz o céu, astros chorando:

"E Hugo?..." E o mundo pasmando

Diz: "Hugo... Napoleão!..."

2. termo sublinhado no v. 52, "silencio"; estudo do caráter auditivo atribuído por MA à poesia de CA:

Se estende o silencio após...

P. 303:

Notas MA:

1. termo sublinhado no v. 54 e cruzeta - estudo linguístico: emprego da forma "pra":

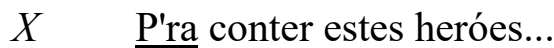

2. termo sublinhado no v. 56 e cruzeta - estudo linguístico: emprego da forma "pra":

$X \quad \underline{\text { Para o leito de Procustos }}$

3. termo sublinhado no v. 63 , "conversam" - estudo do caráter auditivo atribuído por MA à poesia de $\mathrm{CA}$ :

As duas ilhas conversam $\quad X$

4. termo sublinhado no v. 72, "clamam" - estudo do caráter auditivo atribuído por MA à poesia de CA:

Clamam: "Da turba vulgar

$\underline{\text { P. 305-307 }}$

Ao Dous DE JulHo (8 estrofes)

P. 305:

Notas MA:

1. termo sublinhado no v. 3, "Ruge", e cruzeta: 
$X \quad \underline{\text { Ruge o vento - do passado }}$

2. termo sublinhado no v. 6, "Dialoga", e cruzeta:

$X \quad$ Dialoga a Immortalidade...

3. termo sublinhado no v. 7, "Fala" - estudo do caráter auditivo atribuído por MA à poesia de CA:

Fala o heróe com Jehovah!...

P. 306:

Notas MA:

1. traço vertical à esquerda destacando os v. 33 e 34;

Nós que somos borboletas

- Das chrysallidas de avós,

2. termo sublinhado no v. 38 , “dizer", e cruzeta:

$X \quad$ Podemos dizer: "Das campas

3. termo sublinhado no v. 45, “Gemem”, e cruzeta - estudo do caráter auditivo atribuído por MA à poesia de CA:

$X \quad \underline{\text { Gemem }}$ as sombras dos Gracchos,

P. 307:

Notas MA:

1. termo sublinhado no v. 61, "grito", e cruzeta:

Porém aqui não ha grito, $\quad X$

2. expressão sublinhada no v. 62, "nem ai", e cruzeta - estudo do caráter auditivo atribuído por MA à poesia de CA;

Nem pranto, nem ai, nem dor...

P. 308-311

O LIVRO E A AMÉRICA (10 estrofes)

P. 308:

Notas MA:

1. termo sublinhado no v. 1, "Para", e cruzeta - estudo linguístico: emprego da forma "para":

X Talhado para as grandezas,

2. termo sublinhado no v. 2, "P'ra", e cruzeta - estudo linguístico: emprego da forma 
"pra":

$X \quad \underline{\text { P'ra }}$ crescer, crear, subir,

3. termo sublinhado no v. 20, "para", e cruzeta - estudo linguístico: emprego da forma "para":

$X \quad$ Lhe apontam para a amplidão.

P. 309:

Notas MA:

1. termo sublinhado no v. 21, "brada", e cruzeta - estudo do caráter auditivo atribuído por MA à poesia de CA:

Olhando em torno então brada: $\quad X$

2. termo sublinhado no v. 23 , "p'ra", e cruzeta - estudo linguístico: emprego da forma "pra":

$$
\text { "As cataractas - p'ra terra, } \quad X
$$

3. termo sublinhado no v. 24, "para", e cruzeta - estudo linguístico: emprego da forma "para":

$$
\text { “As estrellas - para os céus } \quad X
$$

P. 311:

Nota MA: termo sublinhado no v. 83, "p'ra", e cruzeta - estudo linguístico: emprego da forma "pra":

$X \quad \underline{\text { P'ra o baptismo luminoso }}$

\section{P. 312-314}

QUEM DÁ AOS POBRES, EMPRESTA A DEUS (8 estrofes)

P. 312:

Notas MA:

1. termo sublinhado no v. 5, "bardo", verso destacado por traço vertical e escólio "dic" pesquisa para o Dicionário musical brasileiro:

$$
\text { dic | Canto nest'hora, como o bardo antigo | }
$$

2. termo sublinhado no v. 19, "trom", cruzeta e escólio "dic" - pesquisa para o Dicionário musical brasileiro:

dic $X$ Que ao trom da guerra soluçaste aos filhos:

P. 314:

Nota MA: comentário ao final do poema: 
"Imaginar o entusiasmo natural que / estes poemas de eloquencia clangorante / $e$ sentimental despertavam!... C. Alves é a / mais perfeita encarnação do entusiasmo fa-/cil e ingenuo popular. Nenhum pensa-/mento verda-/deiramente / grande porem / ninguem como / ele concreti-/zou a gran-/deza do / lugar-comum. É enorme nisso. Um mula-/tismo sadio / franco in-/genuo que / chega a co-/mover a gente. Os refrãos que / ele inventa / são geniais sobre esse / ponto de / vista. Nem / Hugo, nem Beranger os imaginaram mais fortes / e impressionantes. Este, o seguinte, o da / poesia pg 287..."

\section{P. 315-317}

Pesadelo de Humaitá (6 estrofes)

P. 315:

Notas MA:

1. termos sublinhados nos v. 1, "som" e "rinchos", 3, "múrmur", e 5, "solta", e cruzetas - estudo do caráter auditivo atribuído por MA à poesia de CA:

Ao som dos rinchos dos cavallos bravos, $\quad X$ Que soltos passam nos sertões remotos, Ao múrmur triste do captivo rio $\quad X$ Que solta gritos sepulcraes, ignotos; $\quad X$

2. termo sublinhado no v. 11, "Brada", e cruzeta - estudo do caráter auditivo atribuído por MA à poesia de $\mathrm{CA}$ :

Brada arrogante do deserto a esposa, $\quad X$

P. 316:

Nota MA: termo sublinhado no v. 38, "Ruge", e cruzeta - estudo do caráter auditivo atribuído por MA à poesia de $\mathrm{CA}$ :

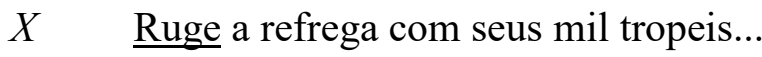

Nota da pesquisa: MA comenta "Pesadelo de Humaitá" no ensaio de 1939: "Mais que essas [do poema "Aos estudantes voluntários"] quatro estâncias (só quatro, em poeta geralmente encompridador), mais que as seis a Maciel Pinheiro, amigo a partir para a guerra, vale o caso curioso da ode Pesadelo de Humaitá. Aqui o poeta se desgasta em todos os defeitos da poetagem guerreira. Mas (e eis enfim um mistério, em quem é tão desprovido deles) relata Afrânio Peixoto, na edição crítica, que o original da poesia traz à margem a indicação 'não se publica'. É certo que Castro Alves disse os versos, da sacada do Diário do Rio de Janeiro, mas não só não os publicou, como deixou a indicação, a todos os indiscretos preciosos, que não publicassem o poema. Que razão o teria levado a se fazer tão nobre justiça? A infelicidade com que tratara o tema? A mim me parece que teria sido o assunto. De qualquer forma, é sempre certo que, apesar-da sua invejável facilidade em versejar, a juventude abundante que o levava a se apaixonar pelos assuntos do dia, esses três poemas apenas provam que Castro Alves ficou, pelo menos como ação, mais ou menos distante da guerra. E ainda a guerra franco-prussiana só lhe arrancaria 
aquele gesto de piedade pelos desválidos, no 'Meeting du Comité du Pain'." ("Castro Alves", in Aspectos da literatura brasileira, ed. cit., p. 113).

\section{P. 318-321}

JESUITAS (15 estrofes)

P. 318

Nota MA: nomes sublinhados nos v. 10 e 11, "Tartaria" e "Arabia", e cruzeta - imaginário geográfico da poesia romântica:

Floria após na India, ou na Tartaria, $X$

No Mississipi, no Perú, na Arabia $X$

P. 319:

Nota MA: termo sublinhado no v. 29 e cruzeta - estudo linguístico: emprego da forma "pra":

$X \quad$ "Pescar almas p'ra o Christo em todo mundo,

P. 320:

Notas MA:

1. termo sublinhado no v. 52 e cruzeta - estudo linguístico: emprego da forma "pra":

X Voltadas p'ra amplidão...

2. expressão sublinhada no v. 56, "Tocava alarma", e cruzeta - estudo do caráter auditivo atribuído por MA à poesia de CA:

$X \quad$ Tocava alarma... embaixo da folhagem

3. termo sublinhado no v. 57, "Rangera", e cruzeta - estudo do caráter auditivo atribuído por MA à poesia de CA:

\section{$X \quad \underline{\text { Rangera estranho pé... }}$}

4. expressão sublinhada no v. 60, "Estrugia", e cruzeta - estudo do caráter auditivo atribuído por MA à poesia de CA:

5. termo sublinhado no v. 60, "boré", e escólio "dic" - pesquisa para o Dicionário musical brasileiro:

$X \quad \underline{\text { Estrugia o }}$ boré. $\quad$ dic

6. v. 66 sublinhado - seleção de ideias:

\section{$\underline{\text { O Piaga do amor. }}$}

7. termo sublinhado no v. 68 , “estalos", e cruzeta - estudo do caráter auditivo atribuído por MA à poesia de CA: 
X Aos estalos sombrios da madeira,

8. termo sublinhado no v. 70, "murmurava", e cruzeta - estudo do caráter auditivo atribuído por MA à poesia de $\mathrm{CA}$ :

$X \quad$ A voz do martyr murmurava ungida

$\underline{\text { P. } 328}$

A Meu Irmão Guilherme de CASTRo Alves (2 estrofes)

Nota MA: estrofes destacadas por traço vertical e escólio - estudo do estilo: comparação:

/ Na cordilheira altissima dos Andes

Os Chimborazos solitarios, grandes, Ardem n'aquellas hibernaes regiões.

Ruge embalde e fumega a solfatéra...

E' dos labios sangrentos da cratera

Que a avalance vacilla aos furacões.

Comparações

A escoria rubra com os geleiros brancos

Misturados resvalam pelos flancos

Dos hombros friorentos do vulcão...

Assim, Poeta, é tua vida immensa,

Cerca-te o gelo, a morte, a indiferença...

E são lavas lá dentro o coração.

$\underline{\text { P. } 331-335}$

DEUSA INCRUENTA (14 estrofes)

P. 331:

Notas MA:

1. termo sublinhado no v. 7, "tromba", escólio "dic" e comentário - pesquisa para o

Dicionário musical brasileiro:

Tinha na mão brilhante a tromba bronzeada!

"dic / por trompa / que na pg seguinte / já é clarim”

2. termo sublinhado no v. 17 e cruzeta - estudo linguístico: emprego da forma "pra":

Abriu braços de mãe p'ra acalentar o mundo, $\quad X$

P. 332:

Notas MA:

1. termo sublinhado no v. 22 e cruzeta - estudo linguístico: emprego da forma "pra": 
$X \quad$ Disse a gruta p'ra o céo: “Que deusa é esta ingente

2. termo sublinhado no v. 28, "clarim", e escólio "dic" - pesquisa para o Dicionário musical brasileiro:

dic Da deusa no clarim gigante reboando,

3. termo sublinhado no v. 48, "rebate", e escólio "dic" - pesquisa para o Dicionário musical brasileiro:

dic $\quad$ - Sineiro que o rebate aos seculos tocou!...

P. 333:

Nota MA: termo sublinhado no v. 71, "buzina", e escólio "dic" - pesquisa para o Dicionário musical brasileiro:

A buzina de cobre os longos ares trôa... dic

$\underline{\text { P. } 336-340}$

No MeEting Du Comite Du PAIN (15 estrofes)

P. 337:

Nota MA: termo sublinhado no v. 32, "horrisono" - estudo do estilo: vocabulário / estudo do caráter auditivo atribuído por MA à poesia de CA:

Que abafe dos canhões o horrisono rugir,

\section{TRADUÇÕES}

Nota da pesquisa: No dossiê do manuscrito Castro Alves, MA planeja estudar a psicologia do poeta por meio das traduções: "Fa-/zer a psicologia de C. Alves pelas traduções que escolheu pra fazer. O caracter subsidiario de documen-/tação psicologica que ás vezes a tradução possui. C. Alves traduz Olimpio...” (MA-MMA-26-02).

\section{P. 347-350}

ELEGIA ( 7 estrofes)

P. 348:

Nota MA: termo sublinhado no v. 36, "c'roa" - estudo do estilo: licenças poéticas:

Se entrance a humilde c'roa,

Nota da pesquisa: No dossiê do manuscrito Castro Alves, MA propõe, no plano de capítulo para o livro Lirismo romântico no Brasil: "Reunir o caso de croa, do pra, dos decassílabos diminuídos ou aumentados de sílaba num capitulinho sobre as Licenças Poéticas do Romantismo, bem como as rimas toantes e deficientes. Nesse capítulo observar a tendência pro pra e considerações sobre a linguagem brasileira." (MA-MMA26-09). 
P. 357-368

A OLYMPIO (75 estrofes)

P. 358:

Notas MA:

1. termo sublinhado no v. 21, "estrafegar-te", e cruzeta - estudo do estilo: vocabulário:

$X \quad$ "Os máus, que haviam vindo estrafegar-te a vida,

2. termo sublinhado no v. 24 e cruzeta - estudo linguístico: emprego da forma "pra":

$X \quad \underline{\text { P'ra ver-te o inferior. }}$

P. 359:

Notas MA:

1. termo sublinhado no v. 45 e cruzeta - estudo linguístico: emprego da forma "pra":

“Tua alma, que tomavam ind'hontem p'ra o direito $\quad X$

2. termo sublinhado no v. 49 e cruzeta - estudo linguístico: emprego da forma "pra":

"P'ra ver na mesa vil a orgia enrouquecida $\quad X$

3. termo sublinhado no v. 69 e cruzeta - estudo linguístico: emprego da forma "pra":

"Mas ai! p'ra quem comprehender esta alma grave $\quad X$

P. 362:

Nota MA: termo sublinhado no v. 130 e cruzeta - estudo linguístico: emprego da forma "pra":

$X \quad$ P'ra ler no teu destino;

P. 368:

Nota MA: título do livro de Victor Hugo corrigido no rodapé da edição crítica, acrescentando uma sílaba /re":

Ire (I) "A Olympio" é um poema de V. Hugo, nas Voix Interieuғs: XXX, datado de 1835.

$\underline{\text { P. 369-371 }}$

A BALLADA DO DESESPERADO (14 estrofes)

P. 370:

Nota MA: termo sublinhado no v. 36 e cruzeta - estudo linguístico: emprego da forma "pra":

$X \quad$ P'ra cada dor que consome! 
P. 387-388

CHANSON (4 estrofes)

P. 387:

Nota MA: termo corrigido no v. 2, "contestas" substituindo "s" por "n" - correção tipográfica:

/n - Não te contestas co'uma só amante?

P. 393-417

DiABO Mundo (125 estrofes)

P. 393:

Nota MA: termo sublinhado no v. 12, "musico", e escólio "dic" - pesquisa para o Dicionário musical brasileiro:

E em musico estrondo horrendo, dic

$\underline{\text { P. } 395}$

Nota MA: termos sublinhados nos v. 75 e 76, "grasnar" e "coruja", e escólio "zoof" pesquisa da zoofonia:

Responde, em rouco grasnar, $\quad$ zoof

Feia coruja agoureira.

P. 397

Notas MA: termo sublinhado no v. 126, "re-tin-tim", e escólio "dic" - pesquisa para o Dicionário musical brasileiro:

Dos ferros o re-tin-tim, dic

P. 398:

Notas MA: termo sublinhado no v. 150, "trovar", e escólio "dic" - pesquisa para o Dicionário musical brasileiro:

dic O resto de algum trovar

P. 399:

Notas MA:

1. termo sublinhado no v. 170, "silva", e escólio "dic" - pesquisa para o Dicionário musical brasileiro:

Já silva o pampeiro! dic

2. termo sublinhado no v. 182 e cruzeta - estudo linguístico: emprego da forma "pra":

P'ra vêr o que ha sido!... $\quad X$ 
P. 400:

Nota MA: termos sublinhados nos v. 211 e 213, "tom" e "som", e escólio "dic" - pesquisa para o Dicionário musical brasileiro:

De um'harpa seguindo o tom,

dic Suba da espuma dos vinhos

De vossos cantos o som...

P. 416:

Nota MA: termos sublinhados nos v. 634 e 635, "trompa" e "rufo", e escólio "dic" pesquisa para o Dicionário musical brasileiro:

Assim quando sôa belligera trompa,

dic Ao rufo candente das caixas... então

\section{JUVENILIA}

$\underline{\text { P. } 418-420}$

Ao NATALiCIO (11 estrofes)

P. 420:

Nota MA: comentário à nota da edição crítica:

(2) Não são estes os primeiros versos de Castro Alves, mas "ao que consta, de 1859, aos doze annos de idade" (Xavier Marques - Vida de Castro Alves, Bahia, 1911, p. 31),; são porém os primeiros que se lhe conhecem, tão infantis, - a idade não permitiria mais; que nelle canta ( $3^{\mathrm{a}}$ estancia), o educador que "a mocidade dos rigores libertou", allusão á palmatoria e outros castigos corporaes, que abolira o Dr. Abilio Cesar Borges, no seu collegio, com escandalo publico, e satisfação da criançada jubilosa. Neste canto infantil já se vislumbra, pois, o Castro Alves, que havia de clamar contra todas as tyrannias.

"Esta observação é fina e engraçada. / Seria preferivel dizer contra 'todas as romanticas / tiranias"”.

$\underline{\text { P. } 427-429}$

Ao Dia SeTE DE SETEMbro ( 8 estrofes)

P. 429:

Nota MA: escólio à direita da data do poema: “14 anos" - estudo da biografia:

Bahia. Gymnasio Bahiano. 7 de Setembro de $1861 . \quad 14$ anos

P. 430-434

DESTRUIÇÃo DE JERUSALÉM (16 estrofes)

P. 431: 
Nota MA: termo sublinhado no v. 37, "atroam", e escólio "dic" - pesquisa para o Dicionário musical brasileiro:

$\mathrm{A}^{\prime}$ terra atroam medonhos dic

P. 434:

Nota MA: comentário ao final do poema:

"Aos 15 anos. C. Alves conheceria nessa epoca V. Hugo? Ou / o seu condoreirismo, antes por enquanto, essa tendencia pro / lirismo heroico era inato e natural, o que mais provavel? / Bem, mesmo que conhecesse Hugo era certamente natural. / Mas nada de hugoanismo nisso. Não tem antiteses ainda. / Ver em Xavier Marques si já conhecia Hugo."

Nota da pesquisa: Vida de Castro Alves, de Xavier Marques (1861-1942), não consta da biblioteca de MA.

\section{P. 435-437}

Ao SnR. FurTado CoElho (6 estrofes)

P. 436:

Nota MA: v. 24-30 destacados por traço vertical - estudo do estilo: repetição:

Na terra da Santa Cruz.

$\mathrm{Na}$ terra das primaveras,

As glorias não são chimeras,

Nem o talento é um nome.

Aqui se admira o genio,

Aqui se adora o proscenio,

Aqui se eleva um renome.

$\underline{\text { P. } 438-444}$

PESADELO (29 estrofes)

P. 438:

Notas MA:

1. expressão sublinhada no v. 12, “que adejavam", e comentário - estudo das matrizes:

Como garças formosas que adejavam. "Estava lendo / Camões..."

2. comentário à estrofe $\mathrm{n}^{\mathrm{o}} 4$ - estudo das matrizes:

Era Joseph - o trovador ardente,

Que o silencio da noite perturbava.

Era o bardo formoso, apaixonado

"Estava lendo Musset...

Que a Andaluza fogosa fascinava. Byron?...”

Pallido o rosto, negro o seu cabello,

Olhar cheio de luz... Elle era bello. 
3. comentário à estrofe $\mathrm{n}^{\mathrm{o}} 6$ - estudo das matrizes:

Era um rosto formoso de madona,

Voava-lhe a madeixa destrançada.

E o seio que tremia, - pelas rendas

"Lia Alvares de Azevedo..."

A lua olhava louca, apaixonada.

Tinha um pé que invejara uma criança.

Bem feliz quem ao peito lhe descança!..

P. 440:

Notas MA:

1. termo sublinhado no v. 55, "silvo", e escólio "dic" - pesquisa para o Dicionário musical brasileiro:

dic Trazia o vento o silvo da rajada

2. comentário à estrofe $n^{\circ} 10$ - estudo das matrizes:

Trazia o vento o silvo da rajada

Que lugubre zunia nos pinheiros,

Trazia gritos pavidos, medrosos,

"Estaria lendo os roman-

Talvez d'alguns perdidos caminheiros, ticos portugas?..."

E no embate co'a bronca penedia,

$\mathrm{O}$ mar sinistro e tetrico rugia.

3. estrofe $\mathrm{n}^{\mathrm{o}} 12$ destacada por traço vertical - estudo das matrizes:

Vae aquecer da prostituta ao collo

De libertino a fronte macilenta.

Vae escaldar esta alma morta e fria

Aos beijos do cognac qu'incendia.

P. 441:

Notas MA: estrofe destacada por traço vertical e comentário:

Vae... Quando a alma s'enjôa deste mundo

Sempre descrente, acerbo de ironia,

O cognac nos dá formosos mundos,

Castellos encantados de poesia.

E entre um gol' de cognac e uma fumaça

Em ditoso delirio a vida passa.

"Muito Alvares de Azevedo. O externo. He"

\section{P. 443:}

Notas MA:

1. termo sublinhado no v. 129 e cruzeta - estudo linguístico: emprego da forma "pra":

Onde só p'ra gemer tristes endechas

$$
X
$$

2. v. 146 sublinhado - seleção de ideias:

3. v. 151 a 154 destacados por traço vertical - estudo da psicologia: 
Ninguem vem te chorar. Não, dentre as sombras

Uma sombra passou branca e ligeira,

Os ramos do arvoredo estremeceram,

Espantada voôu a ave agoureira.

Quem perturba esta lugubre morada?

Uma mulher... E' Laura, apaixonada.

E ella chegou-se rindo e soluçando

C'um rir entre medonho e entre formoso,

Seus labios tressuavam de ironia

Ao mesmo tempo de innocente gozo.

P. 444:

Notas MA:

1. v. 155 e 156 destacados por traço vertical - estudo da psicologia:

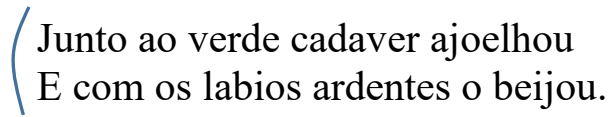

2. comentário ao final do poema - estudo da psicologia:

"Isto é uma delicia / de delicias. Vontade de amor dum menino / que se faz homem, coisa linda."

P. 445-446

CANSAÇO (6 estrofes)

P. 445:

Nota MA: estrofe destacada por colchete e fio ligando os versos ao comentário na página anterior - estudo da psicologia: sentimento amoroso:

- Pois eu sou como o nauta... Após a lucta

Meu amor dorme languido no peito.

Cançado... talvez morto, dorme e dorme

Da indiferença no gelado leito.

Nota da pesquisa: MA invoca esses versos, em "Amor e medo", ao interpretar a psicologia do sentimento amoroso em CA: "Castro Alves rapazola também não escapou do tema do amar sem ser amado (v. Martírio, Noite de Amor). No engraçado Cansaço, se percebe o menino que está fugindo do amor [...] Porém mesmo isso é mínimo nele e perderá cedo porque na verdade não hesitou no amor." (“Amor e medo", In: Aspectos da literatura brasileira, ed. cit., p. 208).

$\underline{\text { P. } 450}$

Ao Dous DE JulHo (4 estrofes)

P. 450:

Notas MA: 
1. acréscimo do número de página, “450" - correção tipográfica;

2. termo sublinhado no v. 5, "tinir", e escólio "dic" à esquerda; pesquisa para o Dicionário musical brasileiro:

dic Dos ferros a tinir a voz sombria

P. 451

Ao Violinista F. Muniz BARRETO FiLho (4 estrofes)

P. 451:

Notas MA:

1. acréscimo do número de página, "451" - correção tipográfica;

2. termo sublinhado no v. 6, "maestros", e escólio - pesquisa para o Dicionário musical brasileiro:

Á sombra dos maestros, sobre os ares, dic

por compositores

por músicos

3. termo sublinhado no v. 16, "arco", e escólio “dic" - pesquisa para o Dicionário musical brasileiro:

No teu arco prendeste a eternidade! dic

$\underline{\text { P. } 453}$

IMPROVISO (4 estrofes)

P. 453:

Notas MA:

1. acréscimo do número de página, "453" - correção tipográfica:

2. termo sublinhado no v. 5, "harmonia", e escólio "dic" - pesquisa para o Dicionário musical brasileiro:

Quando gemes, o archanjo da harmonia dic

P. 455-456

CAPRICHO (6 estrofes)

P. 455:

Nota MA: acréscimo do número de página, “453” - correção tipográfica.

P. 456:

Nota MA: termo sublinhado no v. 35 e cruzeta - estudo linguístico: emprego da forma "pra":

Encontrarei p'ra ti 
P. $457-458$

EXHORTAÇÃO (6 estrofes)

P. 457:

Nota MA: termo corrigido no v. 7, "claustra" - correção tipográfica:

Qual monge ao longe já no claustra exhausto /o

$\underline{\text { P. 459-460 }}$

MARTYRIO (7 estrofes)

P. 460:

Notas MA:

1. expressão sublinhada no v. 18 , "na pobre da flor" - estudo linguístico: brasileirismo:

Por que não cuspiste na pobre da flor?

2. termo sublinhado no v. 24 e cruzeta - estudo linguístico: emprego da forma "pra":

$X \quad$ Só posso meus prantos p'ra sempre esconder-te.

3. termo sublinhado no v. 28 , "c'rôa" - estudo linguístico: pronúncia:

É mais uma palma da c'rôa da dor.

$\underline{\text { P. } 461-462}$

NÃO SABES (5 estrofes)

P. 461:

Nota MA: termo corrigido no v. 4, suprimindo o "i" em "delirio" - correção tipográfica:

E que delirio a suspirar de amor.

$/ X$ 


\section{VOLUME 2}

\section{FOLHA DE GUARDA}

Notas MA:

1. anotação no alto, à direita, “ $n^{\circ} 200$ ”, referindo-se à inclusão do volume na Bibliografia para Na pancada do ganzá;

2. lista de verbetes para o Dicionário musical brasileiro e pesquisa da zoofonia, e cruzeta indicando o aproveitamento:

$$
n^{\circ} 200
$$

Dic-estridulo 6 - murmurío 12 - discorde 14 - cavatina 26 - / lira 28 - tirana 32 orquesta 36 -ode 42 - descantar 49 - / melodia e harmonia 58 - orquestra 66 - valsa 66 - / chôro 68 - preludiax 72 - viola 72 - tinidos 75 - trovar 79 / guitarra 80 - fado 80 - fandango 81 - castanholas 81 - tirana 81 - / bandolim 82 - menestrel 86 - cantilena 87 - troar 88 - canto 93 - /cantilena 94 - ent 95 - trompa 114 - timbalo 120 - clarim 126 - / corneta 126 - canção 129 - viola 129 - tirana 129 - nota 131 - tuba 132 - / tom 139 - moda 140 - estampido 143 - toada 146 - tirana 146- balada 147 - estridulo 152 - 177 e 178 musico 180 - modilhar 180 - I orgão 186 - tirana 196 -melodia 218 trompa 222 - / estridular 254 - trombeta 275 -

\section{P. 5-192}

\section{OS ESCRAVOS}

\section{P. 5-11}

O SÉCULO (13 estrofes)

P. 6:

\section{Nota MA:}

1. termo sublinhado no v. 12 e escólio "dic" - pesquisa para o Dicionário musical brasileiro:

Ás vezes quebra o silencio

dic Ronco estridulo feroz.

2. termo sublinhado nos v. 23 e 29 e cruzeta - estudo linguístico: emprego da forma "pra":

$$
\begin{array}{ll}
X & \underline{\text { P'ra nós o vento da esperança }} \\
X \quad \underline{\text { P'ra dos morros altaneiros }}
\end{array}
$$

P. 7:

Nota MA: expressão sublinhada nos v. 41 e 42 - seleção de ideias: 
Emtanto inda há muita noite

No mapa da creação.

\section{P. 9:}

Nota MA: termo sublinhado no v. 114 e cruzeta à esquerda - estudo linguístico: emprego da forma "pra":

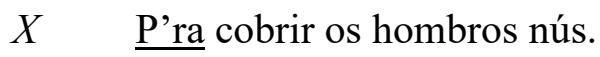

P. 10:

Nota MA: escólio ao final do poema, ao lado da data: "18 anos" - estudo da biografia:

$$
\text { Pernambuco, Agosto de } 1865 . \quad 18 \text { anos }
$$

\section{P. $12-15$}

Ao RoMPER D'Alva (13 estrofes)

P. 12:

Notas MA:

1. termo sublinhado no v. 13, "murmurio", e escólio "dic" - pesquisa para o Dicionário musical brasileiro:

dic Tudo é luz, tudo aroma e murmurio,

2. termo sublinhado no v. 38, "vargea", e fio até o escólio no rodapé - estudo linguístico:

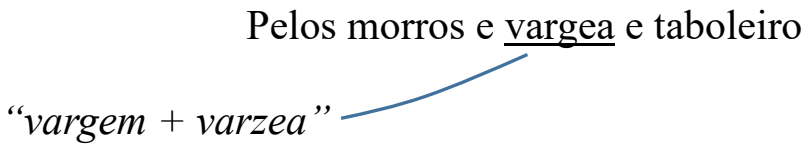

P. 14:

Notas MA:

1. termo sublinhado no v. 55, "orchesta" - estudo linguístico;

2. traços nos v. 55, 56 e 57 - seleção de imagens:

Oh! Deus! não ouves d'entre a immensa orchesta

Que a natureza virgem manda em festa

Soberba, senhoril,

3. termo sublinhado no v. 60, "discorde", e escólio "dic" - pesquisa para o Dicionário musical brasileiro:

dic Um som discorde e vil?

4. v. 61 e 62 destacados por traço vertical - seleção de imagens:

Senhor, não deixes que se manche a tela

Onde traçaste a creação mais bella 
P. 15:

Notas MA:

1. v. 63-66 destacados por traço vertical - seleção de imagens:

De tua inspiração.

O sol de tua gloria foi toldado...

Teu poema da America manchado,

Manchou-o a escravidão.

2. v. 71 a 73 destacados por traço vertical - seleção de imagens:

E as palmeiras se torcem torturadas,

Quando escutam dos morros nas quebradas

O grito de afflicção.

3. v. 73 a 78 destacados por traço vertical - seleção de imagens:

Oh! ver não posso este labéo maldito!

Quando dos livres ouvirei o grito?

Sim...talvez amanhã.

Galopa, meu cavallo, serra acima,

Arranca-me a este sólo. Eia! te anima

Aos bafos da manhã.

$\underline{\text { P. } 16-19}$

A VISÃO DOS MORTOS (7 estrofes)

P. 17:

Notas MA:

1. v. 21 e 22 destacados por traço vertical e expoente “(1)”, remetendo ao comentário que se inicia no rodapé e continua na margem superior:

E o grande Andrada, esse architecto ousado.

Que amassa um povo na robusta mão.

“(1) Castro Alves tem dessas frases-imagens que satisfazem a filo-/sostria e o pensamento burguês de todas as epocas. Inventa coisas / nesse sentido que fôrça é confessar, ficam na memoria da gente por / mais elevada que seja a instrução, desabusado o conhecimento e / aristocratico o pensamento. Mais do que quasi todos os eloquentes do / mundo as teve satisfatorias sob o ponto de vista da mentalidade geral / humana. Alem disso sabia dar porém, e isso sabia ainda / mais a sua poesia grandiloquente, uma dolencia dengosa aos / seus versos, uma ondulação grata e sonorosa, um bambolear / maxixeiro duma delicia imensa de sonoridade e ritmica / que não chega a ser cantador como Beranger e que é bem / intimamente e legitimamente poetica e oral. Estupendo. Os / estribilhos dele então / são achados magistrais / de grande artista e legi-/timo poeta. Este por exemplo / é soberbo. Não tem nada com a escravidão, não tem nada com / o assunto, porém é como o simbolo de todo o assunto e mais / do que como fundo de quadro assume proporções 
sinteticas de / todo o sentimento, toda a comoção que agita o poeta e reper-/cute na gente. Esplendido. / Outros refrãos (procura-los / e da-los) que estão nas Espumas / Flutuantes tem o mesmo / carater."

$\underline{\text { P. } 20-22}$

A CANÇÃO DO AFRICANO ( 9 estrofes)

P. 20:

Nota MA: termo sublinhado no v. 12 e cruzeta - estudo linguístico: emprego da forma "pra":

X Talvez p'ra não o escutar.

P. 21:

Nota MA: termo sublinhado no v. 33 e cruzeta - estudo linguístico: emprego da forma "pra":

$X \quad$ P'ra não acordar com o pranto

P. 22:

Nota MA: comentário ao final da nota da edição:

Esta poesia, não figura no plano do poema d'Os Escravos, como o delineou Castro Alves, num autographo que me em. D. Adelaide de Castro Alves Guimarães: talvez a tivesse perdido das suas collecções, onde não a encontramos, nem nos autographos, nem nos manuscriptos da familia e de amigos. Deviamos omitti-la, quando não depara entre outros versos, e é dos seus primeiros cantos abolicionistas? Tambem, egual criterio foi seguido adiante com o "Voluntario do Sertão" e a "Bainha do Punhal", fragmentos que são reliquias.

"Não de-/via omiti-lo porém porque razão coloca-lo aqui, / quando é de 63 e os poemas anteriores muito mais / Castro Alves e superiores são de 65."

$\underline{\text { P. } 25-29}$

CONFIDENCIA (18 estrofes)

P. 26:

Nota MA:

1. termo sublinhado no v. 21, "para", e cruzeta - estudo linguístico: emprego da forma "para":

$X \quad$ Se elevam para os céus;

2. termo sublinhado no v. 24, "para", e cruzeta - estudo linguístico: emprego da forma "para":

X Voltada para Deus. 
3. termo sublinhado no v. 26, "cavatinas", e escólio "dic" - pesquisa para o Dicionário musical brasileiro:

dic Onde passam gemendo as cavatinas

P. 28:

Notas MA:

1. termo sublinhado no v. 77, "Para", e cruzeta - estudo linguístico: emprego da forma "para":

$X \quad \underline{\quad} \quad$ ara escrever na fronte do perverso:

2. termo sublinhado no v. 82, "lyra", e escólio "dic" - pesquisa para o Dicionário musical brasileiro:

dic Bardo que a lyra prostitues na orgia

3. termo sublinhado no v. 93, "crôas", e cruzeta - estudo do estilo: licenças poéticas:

$X \quad$ Nas c'roas festivaes?

P. 29:

Nota MA: estrofe circulada a lápis-tinta vermelho - seleção de ideias.

Por isso, quando vês as noites bellas,

Onde vôa a poeira das estrellas

E das constellações,

Eu fito o abysmo que a meus pés fermenta,

E onde, como santelmos da tormenta,

Fulgem revoluções!...

P. 30:

Nota MA: termo sublinhado no v. 2, "P'ra", e cruzeta - estudo linguístico: emprego da forma "pra":

$X \quad \underline{\text { P'ra escalar a montanha do infinito }}$

\section{P. $32-40$}

TRAGEDIA NO LAR (39 estrofes)

P. 32:

Nota MA: termo sublinhado no v. 8, "tyrana", e escólio "dic" - pesquisa para o Dicionário musical brasileiro:

dic Uma tyrana indolente,

P. 33:

Nota MA: estrofes $n^{\circ} 6$ a 10 destacadas por traço vertical - seleção de ideias: 
Eu sou como a garça triste

Que mora à beira do rio,

As orvalhadas da noite

Me fazem tremer de frio.

Me fazem tremer de frio,

Como os juncos da lagoa;

Feliz da araponga errante

Que é livre e que livre voa.

Que é livre e que livre voa

Para as bandas do seu ninho,

E nas braúnas à tarde

Canta longe do caminho.

Canta longe do caminho.

Por onde o vaqueiro trilha,

Se quer descansar as asas

Tem a palmeira, a baunilha.

Tem a palmeira, a baunilha.

Tem o brejo, a lavadeira,

Tem as campinas, as flores,

Tem a relva, a trepadeira.

P. 34:

Nota MA: traço à esquerda da estrofe $\mathrm{n}^{\mathrm{o}} 11$ e expoente (1), remetendo ao comentário no rodapé e na p. 35:
Tem a relva, a trepadeira.
Todas têm os seus amores,
Eu não tenho mãe, nem filhos
(1)
Nem irmãos, nem lar, nem flores.

“(1) C. Alves tinha dentro de si um lirico esplendido / que ficou prejudicado dentro do poeta social. Raro / aparece. E C. Alves é mais poeta e vale mais por esse / lirico ocasional."

Nota da pesquisa: No ensaio "Castro Alves", MA remete ao trecho assinalado: "E suas líricas de melhor carícia nacional não será nos versos de amor (talvez demasiadamente sentidos...), que iremos encontrar, mas justamente na vida dos escravos. É lembrar a canção incluída na Tragédia no lar, a lindíssima Canção do Violeiro, A Cruz da Estrada e ainda o Lucas e a Tirana da Cachoeira de Paulo Afonso - páginas do mais caricioso lirismo." (“Castro Alves', In: Aspectos da literatura brasileira, ed. cit., p. 114).

P. 36:

Nota MA: termos sublinhados nos v. 58 e 60, "festa" e "orchesta", e escólio "dic" - estudo linguístico: pronúncia: 
Ás vezes a propria festa

$\mathrm{Tu}$, grande, que nunca ouviste

dic Senão gemidos da orchesta.

P. 37:

Notas MA:

1. termos sublinhados no v. 98, assinalando a repetição, e fio ligando as duas ocorrências; estudo linguístico: brasileirismo:

Que a voz não podia, não.

2. termo corrigido no v. 111, "arrenqueis", rasurando "e" e substituindo-o à direita por "a" - correção tipográfica:

Me arrenqueis o coração! la

P. 38:

Notas MA:

1. v. 127-140 destacados por traço vertical;

2. verso 136 sublinhado e juízo de valor:

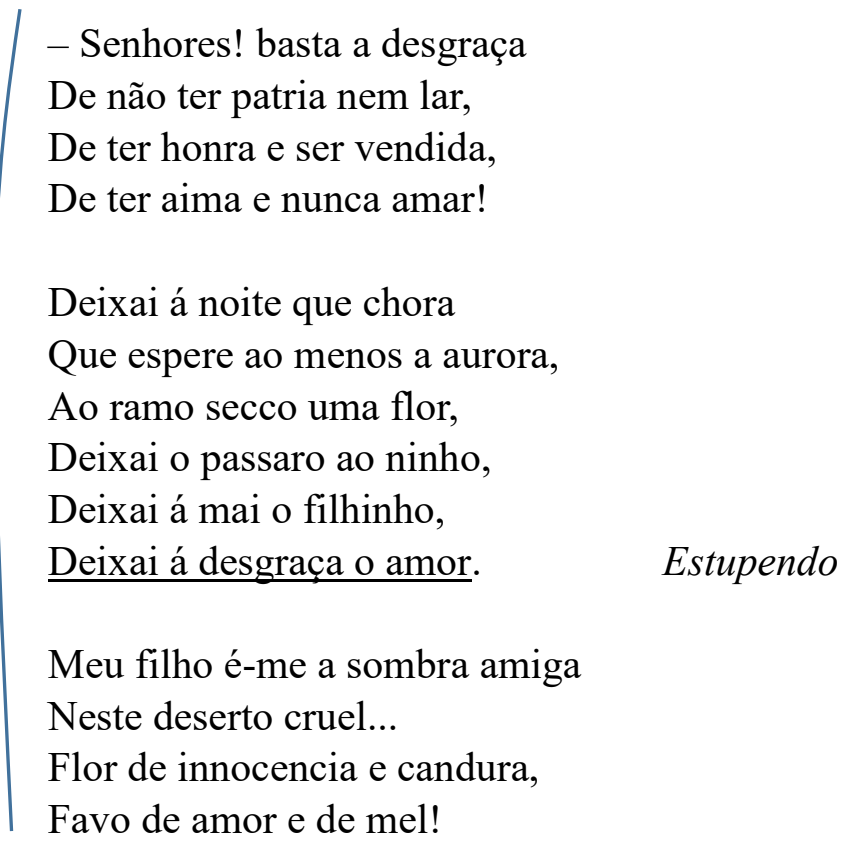

P. 39:

Notas MA:

1. v. 141-146 destacados por traço vertical e comentário:

2. verso 145 sublinhado e juízo de valor:

Seu riso é minha alvorada,

Sua lagrima doirada

Minha estrella, minha luz!

E' da vida o unico brilho... 
( Meu filho! é mais... é meu filho. Estupendo

Deixai-m'o em nome da Cruz!...

"Estou lembrando a fala / de Inês de Castro. Será mais / forte?”

3. v. 151-159 destacados por traço vertical e comentário:

Mudou-se a scena. Já vistes

Bramir na matta o jaguar,

E no furor desmedido

Saltar, raivando atrevido,

O ramo, o tronco estalar,

Mord'er os cães que o morderam.

De victima feita algoz,

Em sangue e horror envolvido

Terrivel, bravo, feroz?

"C. Alves é um

artista."

Nota da pesquisa: Ao comparar O Navio Negreiro e Vozes d'África, no ensaio para a Revista do Brasil, MA elogia a qualidade dramática daquele; no rodapé, reitera a comparação antecipada na marginália: “(2) A fala da mãe preta, na Tragédia no Lar, será que a da Inez de Castro é mais intensa?..." ("Castro Alves", In: Aspectos da literatura brasileira, ed. cit., p. 115).

$\underline{\text { P. } 41-43}$

O SIBARITA ROMANO (12 estrofes)

P. 41:

Nota MA: termo sublinhado no v. 1, "c'rôa", e cruzeta - estudo linguístico: pronúncia:

$$
\text { Escravo, dá-me a c'rôa de amarantho } \quad X
$$

P. 42:

Nota MA: termo sublinhado no v. 33, “ode”, e escólio "dic" - estudo linguístico:

dic Quero a ode de amor que o vento canta,

P. 43:

Nota MA: comentário ao final do poema:

"O Parnasianismo está aqui. / C. Alves não é apenas precursor foi o pri-/meiro duma transição do sentimento psicologico / pro sentimento / temático. E mes-/mo como forma / a não ser muito preconceito de gramatica / portuga e de rimação obrigatoria, êstes verIsos são muito bons. A ação viva excelente, a / evolução do tedio perfeitamente concatenada / e cadenciada, movimento intenso, belo poe-/ma descritivo como os melhores do genero / dados pelo Parnasianismo." 
Nota da pesquisa: O poema "O Sibarita romano" é referido por MA no ensaio "Castro Alves": "Cumpre reconhecer até a habilidade com que o grande poeta usa todos os recursos intelectuais insertos na Poesia ou deformadores dela, pra nos infundir piedade pelo escravo e asco pela escravidão. Nem se esquece, num poema descritivo notável, de nos pintar o tipo capitalista do escravocrata, no mais odioso dos seus passatempos, o tédio (O Sibarita Romano)" (In: Aspectos da literatura brasileira, ed. cit., p. 114). A respeito da transição para o "sentimento temático", conforme a nota de margem, MA desenvolve longo raciocínio no ensaio: "Da mesma forma com que Castro Alves muito razoavelmente, com boa técnica de pragmatismo, converte o assunto da escravidão a temas sentimentais particulares (tragédia no lar, tragédia no mar, mucama que o senhor perde, vozes da África, o escravocrata, etc., etc.), é mais lastimável que desvirtue a generalidade do amor, inventando temas-imagens que o variem. Não nego a variedade com que ele soube converter o amor a versos, antes insisto sobre. Porque esta variedade é de caráter meramente consciente, não implica de forma alguma sensibilidade maior, maior riqueza do ser. É antes um sutil empobrecimento. São criações conscientes, são invenções-metáforas pra encantar burguês, mas que não iludem à verdadeira poesia. A Hebreia, O Voo do Gênio, a temática da Dama Negra, o Tríplice Diadema, Boa Noite, $O$ Adeus de Tereza, O Tonel das Danaides, O Fantasma e a Canção, Fé, Esperança e Caridade, Os Anjos da Meia Noite, Aquela Mão, Gesso e Bronze são provas decisivas de uma mudança profunda na concepção temática do amor na poesia do Brasil. Se é certo que em numerosas outras poesias não há propriamente um tema-imagem, uma ideiametáfora a que o poeta se prenda intelectualmente pra traduzir seus impulsos e demais forças de amar, realmente Castro Alves impunha uma encurtação veemente do assunto a um tema, a uma das suas imagens, a uma das suas transubstanciações metafóricas. E isso seria, até a vinda da literatura contemporânea, um dos maiores empobrecimentos líricos da poesia nacional. No tempo, Castro Alves preludiava o Parnasianismo" (ibidem, ed. cit., p. 120).

P. 46-47

A CRUZ DA EsTRADA (7 estrofes)

P. 47

Nota MA: comentário ao final do poema:

"Que bonito! Sempre é no liris-/mo que Castro Alves é mais / eloquente. Veja-se a 'Tragédia no Lar'.”

\section{$\underline{\text { P. } 48-51}$}

BANDIDO NEGRO (16 estrofes)

P. 49:

Notas MA:

1. termo sublinhado no v. 22 e cruzeta - estudo linguístico: emprego da forma "pra":

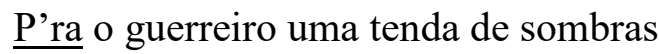

2. termo sublinhado no v. 24, "pullula", e exclamação - estudo do estilo: repetição: 
! Sus! pullula dos quatro horizontes,

3. termo sublinhado no v. 31, "descanta", e escólio "dic" - pesquisa para o Dicionário musical brasileiro:

$$
\text { E o senho que na festa descanta dic }
$$

P. 50:

Notas MA:

1. termo sublinhado no v. 43 e cruzeta - estudo linguístico: emprego da forma "pra":

X $\quad$ P'ra pedir-te as esposas ou mães.

2. termo sublinhado nos v. 55 e 56 e cruzeta em cada verso - estudo linguístico: emprego das formas "para" e "pra":

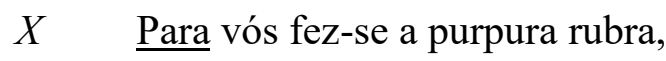

$X \quad$ Fez-se o pranto de sangue p'ra nós.

P. 51:

Nota MA: comentário ao final do poema:

"Tambem estupendo, que galope, puxa!"

P. 52-54

AMERICA (11 estrofes)

P. 52:

Nota MA: termo sublinhado no v. 11, "pullulam", e comentário - estudo do estilo: vocabulário:

Lembrando o passado, seus seios pullulam, Ainda!

\section{P. 55-57}

REMORSO (8 estrofes)

P. 56:

Nota MA: termo sublinhado no v. 35 e cruzeta - estudo linguístico: emprego da forma "pra":

X P'ra aclarar-te fataes vagalumes

P. 56:

Nota MA: comentário ao final do poema:

"Mas nos versos de 9 e 11 silabas / C. Alves não consegue aquela inten-/sidade de G. 
Dias."

Nota da pesquisa: No dossiê do manuscrito Castro Alves, MA discorre, em nota de trabalho para o livro Lirismo romântico no Brasil, acerca da métrica na poesia do romantismo: "No artigo geral fazer considerações sobre o verso romantico e determinar seus caracteres formais. Notar que o verso romantico por excelencia foi o decassilabo e a transformação que este sofreu de heroico pra lirico (de acentuação $6^{a}$ e $10^{a}$ pra $4^{a} /$ e $8^{a}$ ) (1) Em digressão rapida notar que o verso essencial do Parnasianismo foi o alexandrino e notar a influencia do alexandrino sobre o decassilabo sobretudo de Raimundo Correia. Neste com efeito o decassilabo assume a essencia estetica e a função ritmica dum verdadeiro alexandrino. Bons cavalos e esplendidas mulheres é na realidade um alexandrino espiritual com os hemistiquios iguais: dois substantivos e dois qualificativos. Da mesma forma 'Pequeninos elasticos chineses' é um alexandrino ternario. Notar a frequencia de ambos em Raimundo." No manuscrito, o autor liga com um fio as considerações sobre o verso à pergunta: "Não será possível aplicar isto a Castro Alves?" (MA-MMA-26-06). O escólio marginal relaciona-se também ao trecho, já citado, do manuscrito: "Não esquecer tambem os esdruxulos contados com uma silaba de menos, coisa muito usada por Castro Alves mas que G. D. me parece que não empregou." (MAMMA-26-09)

$\underline{\text { P. } 58-60}$

CANTO DO BUG-JARGAL (3 estrofes)

P. 58:

Nota MA:

1. termo sublinhado no v. 10, "melodia", e escólio "dic" - pesquisa para o Dicionário musical brasileiro;

2. termo sublinhado no v. 13, "harmonia" e fio ligando ao termo do v. 10 e ao escólio "dic" - pesquisa para o Dicionário musical brasileiro:

dic Que em melodia escapam de teus labios,

Meu coração palpita em meu ouvido

Misturando um queixoso murmurio

De tua voz álanguida harmonia

P. 59:

Nota MA: termo sublinhado no v. 29, "uragan”, e interrogação - estudo do estilo: vocabulário:

Do deserto o uragan que tem ciumes?

$\underline{\text { P. } 61-65}$

A ORPHÃ NA SEPULTURA (20 estrofes)

P. 62:

Nota MA: expressão sublinhada no v. 32, "do maridedia" - estudo do estilo: vocabulário: 
Á voz do maridedia,

P. 63:

Nota MA: v. 49-56 destacados por traço vertical e comentário - "agudos e/ graves".

"Senhor Deus, que após a noite

"Mandas a luz do arrebol,

"Que vestes a esfarrapada

"Com o manto rico do sol,

"Tu que dás á flor o orvalho,

"Ás aves o céu e o ar,

"Que dás as frutas ao galho,

"Ao desgraçado o chorar;

P. 64:

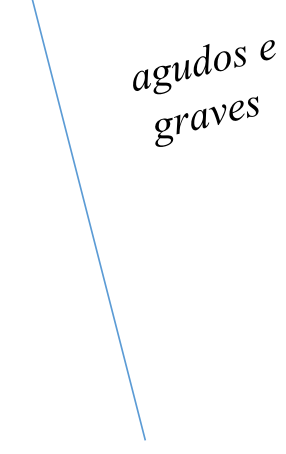

Notas MA:

1. termo sublinhado no v. 81 e cruzeta - estudo linguístico: emprego da forma "pra":

$X \quad$ Sorrindo não sei p'ra quem.

2. termo sublinhado no v. 82, "que", e cruzeta - estudo linguístico: brasileirismo/oralidade:

$X \quad$ Quasi então que eu tive medo...

3. termo sublinhado no v. 87 e cruzeta - estudo linguístico: emprego da forma "pra":

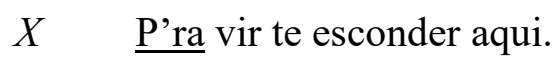

4. termo sublinhado no v. 90 e cruzeta - estudo linguístico: emprego da forma "para":

$X \quad$ Mãe, para ver-te eu fugi...

5. v. 95 e 96 destacados por traço vertical - estudo do estilo: ideias paralelas:

Tu tens por lençol a pedra,

Por travesseiro uma cruz.

P. 65:

Notas MA: v. 99-102 destacados por traço vertical e comentário:

- Ninho infinito de amor.

- Palmeira - quero-te a sombra.

- Terra - dá-me a tua alfombra.

- Santo fogo - o teu calor.

"Já pelos dois versos / grifados da estancia / anterior o artificio prin-/cipiava a se substituir / pela inspiração desfale-/cente." 
$\underline{\text { P. 66-67 }}$

ANTITHESE (5 estrofes)

P. 66:

Notas MA: termos sublinhados nos v. 5 e 6, "orchestra" e "valsa", e escólio "dic" pesquisa para o Dicionário musical brasileiro:

dic Sôa a orchestra... como sylphos

dic Nas valsa os pares perpassam,

\section{P. 68-69}

CANÇÃO DO VIOLEIRO (4 estrofes)

P. 68:

Notas MA:

1. v. 3 e 4 destacados por traço duplo - estudo do estilo: repetição:

Meu coração está deserto,

Stá deserto o mundo inteiro.

2. verso 7 sublinhado, e escólio - pesquisa para o Dicionário musical brasileiro:

chôro dic Chora, chora na viola,

3. traço à esquerda dos v. 13 e 14 ;

O cauan canta bem triste,

Mais triste é meu coração.

P. 69:

Notas MA:

1. v. 17-22 destacados por traço vertical duplo - estudo do estilo

E eu disse: a Senhora volta
Com as flores da sapucaia.
Veiu o tempo, trouxe as flores,
Foi o tempo, a flor desmaia.
Colhereira, que além vôas,
Onde está meu coração?

2. termo sublinhado no v. 28 e cruzeta - estudo linguístico: emprego da forma "para":

Lá para as bandas da serra. $X$

3. comentário ao final do poema: 
"Lindissimo”.

$\underline{\text { P. } 70-71}$

SÚPPLICA (8 estrofes)

P. 71:

Notas MA:

1. termo sublinhado no v. 18 , "corôa", e cruzeta - estudo do estilo: licenças poéticas:

A corôa de cans. $\quad X$

2. termos sublinhados no v. 23, "quebra", "ri" e "do", e cruzeta - estudo linguístico:

$$
\text { E o vicio quebra e ri do nó perpetuo } \quad X
$$

$\underline{\text { P. } 72-75}$

O VIDENTE (8 estrofes)

P. 72:

Notas MA:

1. termo sublinhado no v. 3, "viola";

Quando a viola acorda na choça o sertanejo

2. termo sublinhado no v. 6, "preludia";

3. termo sublinhado no v. 11, "tom", e interrogação - estudo do estilo: metáfora / estudo do caráter auditivo atribuído por MA à poesia de $\mathrm{CA}$;

4. traço à esquerda dos v. 4-6 e 11-13, fio ligando os dois conjuntos de versos e escólio:

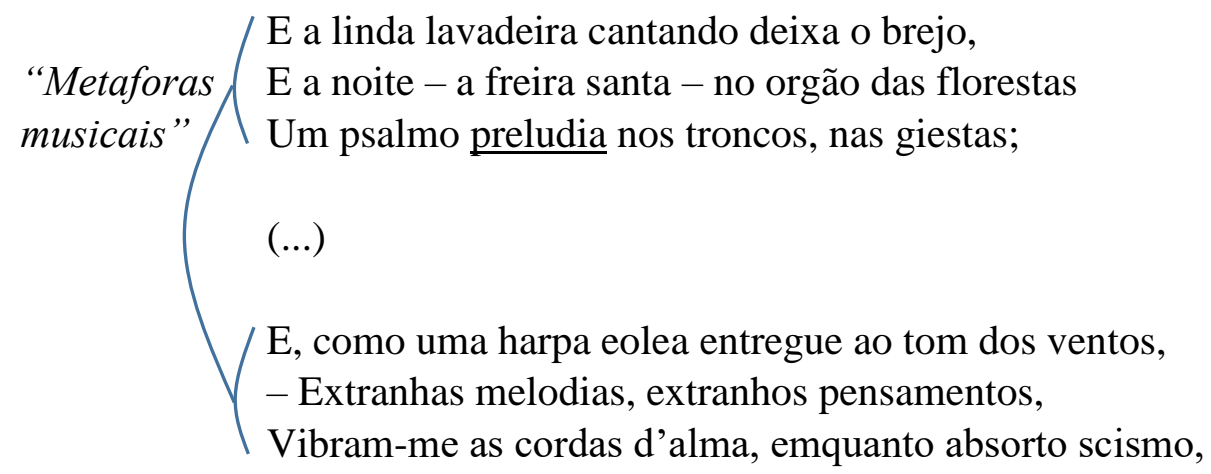

P. 73:

Nota MA: verso 49 sublinhado e escólio à direita:

Feliz se aquece unida a universal familia. "Universalismo"

P. 74: 
Nota MA: termo sublinhado no v. 76, "orchestra", e exclamação - estudo do estilo: metáfora / estudo do caráter auditivo atribuído por MA à poesia de CA:

! E, ao canto do obreiros, na orchestra audaz do malho,

\section{P. 75:}

Notas MA:

1. termo sublinhado no v. 98, "Tinidos", e escólio "dic" - pesquisa para o Dicionário musical brasileiro:

Tinidos de mil ferros, soluços convulsivos, $\quad$ dic

2. comentário ao final do poema:

"Quase Vigny. Esplendido e larguissimo. A / cadencia é magistral."

3. comentário no rodapé:

"Das poesias que mais provam que C. Alves / era um auditivo."

Nota da pesquisa: MA comenta o poema no ensaio "Castro Alves": "E que estranhíssima força, que grande rítmica nos falsos alexandrinos de $O$ Vidente!... São para nos fazer desejar que ao lado do alexandrino clássico, permenecesse entre nós também o processo de os escandir à espanhola. [...] Estes são dos versos mais bem ritmados de nossa língua. E também de grávida e alta poesia. É mesmo estranho que Ronald de Carvalho, tendo a habilidade de salientar o valor poético de Sub Tegmine Fagi, não tenha, talvez assustado com a eloquência legítima do poema, salientado $O$ Vidente." (In: Aspectos da literatura brasileira, ed. cit., p. 115).

\section{$\underline{\text { P. 76-78 }}$}

A Mãe do CAPTIVo (13 estrofes)

P. 77:

Notas MA:

1. expressão sublinhada no v. 16, "Emquanto que" - estudo linguístico: brasileirismo sintático:

Emquanto que o prende cadeia sombria! ...

2. termo sublinhado no v. 20, "P'ra", e cruzeta - estudo linguístico: emprego da forma "pra":

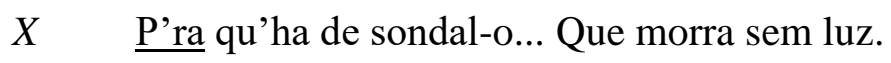

P. 78:

Nota MA: comentário ao final do poema: 
"Notar que parece nascerem as inspirações dos poemas / de Castro Alves das ideas alheias que cita em epigrafe, ao / passo que em Alvares de Azevedo as citações apenas corro-/boram na idea inspirada do proprio poeta. Em Castro Alves / as citações são fontes, em Álvares de Azevedo apendices. Ver nos outros."

\section{P. 79-84}

MANUELA (21 estrofes)

P. 79:

Nota MA: termo sublinhado no v. 6, "trovar" - estudo do caráter auditivo atribuído por MA à poesia de CA:

Soltemos nosso trovar...

P. 80:

Notas MA:

1. termo sublinhado no v. 16, "guitarra", e escólio "dic" - pesquisa para o Dicionário musical brasileiro:

dic Ouvi, pois! que esta guitarra...

2. termo sublinhado no v. 36, "fado", e escólio "dic / (em 1868)" - estudo linguítico: pesquisa para o Dicionário musical brasileiro:

Do fado no turbilhão... " $\quad$ dic / (em 1868)”

P. 81:

Notas MA:

1. termo sublinhado no v. 39, "fandango", e escólio "dic":

No fandango a delirar. dic

2. termo sublinhado no v. 40, "castanholas", e escólio "dic":

Inda ao som das castanholas dic

3. termo sublinhado no v. 48, "Tyrannas", e escólio "dic" - pesquisa para o Dicionário musical brasileiro:

Tyrannas que então gemi. dic

4. v. 61-66 destacados por traço vertical e comentário:

Por teus sombrios olhares - Mares "Notar o delicioso / artificio for-/mal."

Onde eu me afogo de amor...

Pelas tranças que desatas

- Matas

Cheias de aroma e frescor... 
P. 82:

Notas MA:

1. termo sublinhado no v. 81 e cruzeta - estudo linguístico: emprego da forma "pra":

$X \quad$ É p'ra outros, não p'ra mim...

2. termo sublinhado no v. 84, "bandolim", e escólio "dic" - pesquisa para o Dicionário musical brasileiro:

dic Aos sons do meu bandolim...

P. 83:

Notas MA:

1. termo sublinhado no v. 99, “ali”, e exclamação - estudo da versificação: métrica:

Minha esposa ali serás... !

2. termo sublinhado no v. 108, "p'ra", e cruzeta - estudo linguístico: emprego da forma "pra":

Accesas p'ra o hymeneu" $\quad X$

P. 84:

Nota MA: comentário ao rodapé da edição crítica:

Inedita. Cm. por D. Adelaide de Castro Alves Guimarães, num esboço autographo do Poeta e num manuscripto seu, já em fórma definitiva.

"Não creio. Tem / estrofes que são imperfeitissimas, apesar / de lindo o ritmo e belissimo o poema, / estrofes que C. Alves talvez corrigisse si publicasse o livro."

P. $85-87$

FABULA / O PÁSSARO E A FLOR (12 estrofes)

P. 85:

Nota MA: termo sublinhado no v. 7, "bonita”, e cruzeta - estudo linguístico:

$$
\text { Ó Rosa, ó Rosa bonita! } \quad X
$$

P. 86:

Nota MA: termo sublinhado no v. 42, "menestreis", e escólio "dic" - pesquisa para o Dicionário musical brasileiro:

dic Dos louros dos menestreis!...”

P. 87:

Notas MA:

1. termo sublinhado no v. 60, "cantilena", e escólio "dic" - pesquisa para o Dicionário musical brasileiro;

2. termo corrigido, "louçã", com o acréscimo do til - correção tipográfica: 
Na cantilena louçã. dic

$\underline{\text { P. } 88-91}$

ESTROPHES DO SOLITARIO (11 estrofes)

P. 88:

Notas MA:

1. termo sublinhado no v. 8 e cruzeta - estudo linguístico: emprego da forma "pra":

$X \quad$ Parte um grito p'ra os homens - surdo, obscuro,

2. termo sublinhado no v. 9, "para", e cruzeta - estudo linguístico: emprego da forma "pra":

$X \quad$ Mas para os moços, não!

3. termo sublinhado no v. 12, "troa", e escólio "dic" - pesquisa para o Dicionário musical brasileiro:

dic Que troa n'amplidão!

P. 89:

Nota MA: termo sublinhado no v. 40 e cruzeta - estudo linguístico: emprego da forma "pra":

$X \quad$ Em vão nos deste, p'ra maior lembrança,

P. 92-101

O NAVIO NEGREIRO (35 estrofes)

P. 93:

Nota MA: termo sublinhado no v. 27, "canto", e escólio "dic" - pesquisa para o Dicionário musical brasileiro:

Meu Deus! como é sublime um canto ardente dic

P. 94:

Nota MA: termo sublinhado no v. 55, "cantilenas", e escólio “dic" - pesquisa para o Dicionário musical brasileiro:

Do Hespanhol as cantilenas dic

P. 95:

Nota MA: termo sublinhado no v. 69, “entôa", e escólio “dic" - pesquisa para o Dicionário musical brasileiro:

Rijo entôa patrias glorias, dic

P. 98: 


\section{Nota MA:}

1. v. 166-176 destacados por traço vertical;

2. 171-173 destacados por traço vertical - estudo do estilo: composição:

"Reparar na tranzição / energica".

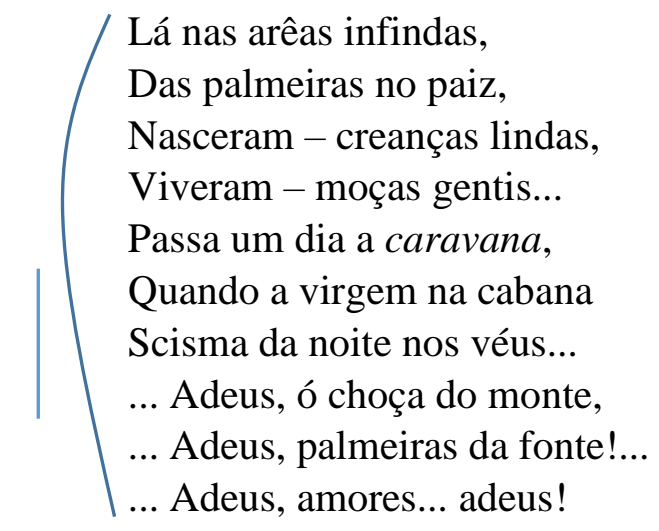

P. 99:

Nota MA:

1. termo sublinhado no v. 183, "p'ra”, e cruzeta - estudo linguístico: emprego da forma "pra":

$$
\text { E cahe p'ra não mais s'erguer!... } \quad X
$$

2. termo sublinhado no v. 200, "p'ra”, e cruzeta - estudo linguístico: emprego da forma "pra":

$$
\text { Nem são livres p'ra morrer... } \quad X
$$

P. 100:

Nota MA:

1. termo sublinhado no v. 218, "P'ra", e cruzeta - estudo linguístico: emprego da forma "pra":

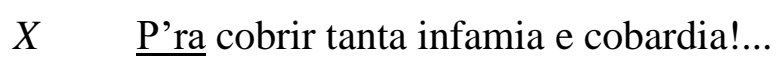

2. v. 223-226 destacados por traço vertical duplo - seleção de ideias:

$$
\begin{aligned}
& \text { /(Silencio, Musa... chora, e chora tanto } \\
& \text { Que o pavilhão se lave no teu pranto!... } \\
& \text { /( Auri-verde pendão da minha terra, } \\
& \text { Que a briza do Brasil beija e balança, }
\end{aligned}
$$

5. v. 228 sublinhado - seleção de verso:

As promessas divinas da esperança... 
6. v. 233 sublinhado - seleção de verso;

7. traço à esquerda dos v. 233-236 - estudo do estilo: imagens:

/ Fatalidade atroz que a mente esmaga!

Extingue nesta hora o brigue immundo

O trilho que Colombo abriu nas vagas,

Como um iris no pelago profundo!

P. 101:

Nota MA: traço à esquerda dos v. 238-240 e comentário:

Levantai-vos, heróes do Novo Mundo!

Andrada! arranca esse pendão dos ares!

Colombo! fecha a porta dos teus mares!

"3 das mais belas oitavas heroi-/cas da lingua. Camões não es-/creveu muitas assim. Versos como os grifa-/dos são dos mais sublimes que se têm escrito / em qualquer / lingua."

$\underline{\text { P. } 102-105}$

LUCIA (12 estrofes)

P. 102:

Nota MA: termo sublinhado no v. 14, "nocturnas", e expoente (1) remetendo ao comentário no rodapé:

Como as plumas nocturnas ${ }^{(1)}$ da grauna;

"Notar a modernidade de certos qualificati-/vos de Castro Alves, esse precursor de tudo."

P. 104:

Notas MA:

1. termo sublinhado no v. 51, "p'ra", e cruzeta - estudo linguístico: emprego da forma "pra":

Adeus! p'ra sempre, adeus, ó meus amigos,

2. verso 53 sublinhado e expoente "(1)", remetendo ao comentário no rodapé:

(1) Patativas saudosas dos coqueiros,

"O que condiz com o sabiá na palmeira, de / G. Dias"

3. termo sublinhado no v. 60 e cruzeta - estudo linguístico: emprego da forma "para".

$X \quad$ Venderam, para longe, a pobre Lucia!"

Nota da pesquisa: Ao assinalar as patativas nos coqueiros, no poema de Castro Alves, comparando-as ao sabiá de Gonçalves Dias, MA parece retomar a percepção de que os 
românticos não primaram pelo realismo no tratamento da natureza. No corpus da pesquisa, à margem da "Canção do exílio", comenta: "Esta quoda de G. D. comove e sublima pelo sentimento geral que a ditou e pela musicalidade genial. É som puro que nem o milhor de Goethe Heine Verlaine. Porém ideias fracas. Erradas mesmo. Sabiá cantando na palmeira já muito se falou que só mesmo estudante de Coimbra podia pregar mentirada dessas. Duma feita me escutando ressoar esses versos um sitiante me secundou: Homem...até agora no alto do coqueiro só enxerguei urubú dormindo." (Nota MA, In: DIAS, A. Gonçalves. Poesias. Nova edição organizada e revista por J. Norberto de Souza Silva e precedida de uma notícia sobre o autor e suas obras pelo Cônego Doutor Fernandes Pinheiro. Paris/Rio de Janeiro: Garnier, 1919, vol. 2, p. 88).

$\underline{\text { P. 105: }}$

Notas MA: termo sublinhado no v. 83, "pasma”; estudo da psicologia. ... A mulher se voltou... fitou-me pasma, *

$\underline{\text { P. } 106-108}$

PROMETHEU (5 estrofes)

P. 106:

Notas MA:

1. comentário à epígrafe de Eschylo - estudo das matrizes:

" $\mathrm{O}$ ' mon auguste mère, et vous enveloppe de la commune lumière, divin éther, voyez quels injustes tourments on me fait souffrir."

Qui compatit à cette grande souffrance, qui s'approche du rocher désert où se tord Prométhée? Quelques pauvres filles, pieds nus.

$$
\text { Eschylo }
$$

"De quem esta tradução francesa? / Procurar. Seria curiosissimo que / C. Alves conhecesse Leconte."

2. termo sublinhado no v. 7 e cruzeta - estudo linguístico: emprego da forma "pra":

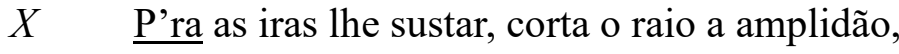

Nota da pesquisa: Promètheus Enchainé - no volume das obras de Ésquilo traduzidas, em prosa, por Leconte de Lisle (1818-1894) - não contém notas de MA. Em Les sept contre Thèbes, MA sublinha, a lápis, o começo de fala de Etéocles: "Je ne redoute point des ornements guerriers. Les emblèmes ne font pas de blessures, les aigrettes et les clochettes ne mordent point sans la lance." (Nota MA, In: Les sept contre Thèba, In: Eschyle, ed. cit., p. 116). Sublinha outro trecho: "C'est une mauvaise destinée que celle qui a fait d'un homme juste le compagnon d'hommes pervers. La pire des choses est d'avoir de mauvais compagnons; on n'en recueille point de fruits, car le champ d'Atè n'en a point d'autres que la mort." (Nota MA, In: Les sept contre Thèba, In: Eschyle, ed. cit., p. 123). Ao final do volume, MA registra os escólios e a remissão às páginas: "Sôbre má companhia pg 123 - Sobre o valor dos / emblemas e ornamentos pg 116 -”. No exemplar dos Poèmes tragiques, MA não deixou marcas de leitura. 
P. 107:

Notas MA:

1. termo sublinhado no v. 20 e cruzeta - estudo linguístico: emprego da forma "pra":

O oceano lhe trazeis, p'ra em prantos derramar... $\quad X$

2. estrofe $n^{\circ} 4$ assinalada por escólio - estudo do estilo: metáfora;

3. termos sublinhados no v. 25 e cruzeta à esquerda; estudo linguístico: emprego da forma "pra/para":

Povo! povo infeliz! Povo, martyr eterno,

"Comparações"

Tu és do captiveiro o Prometheu moderno...

Enlaça-te no poste a cadeia das Leis,

O pescoço do abutre é o sceptro dos maus reis.

Para taes dimensões, p'ra musculos tão grandes, $\quad X X$

Era pequeno o Caucaso... amarram-te nos Andes.

4. sílabas sublinhadas no v. 27 e cruzeta - estudo da sonoridade: aliteração:

E emquanto, $\underline{\text { tu}}, \underline{\text { Titan}}$, sangrento arcas ahi... $\quad X$

$\underline{\text { P. } 108-113}$

VOZES D'ÁFRICA (19 estrofes)

P. 108:

Nota MA: expressão sublinhada no v. 4, "te mandei" - estudo linguístico: brasileirismo/colocação pronominal:

Ha dous mil annos te mandei meu grito,

P. 109:

Notas MA:

1. termo sublinhado no v. 38 , "crôa", e cruzeta - estudo do estilo: licenças poéticas:

Ora uma crôa, ora o barrete-phrygio $\quad X$

2. traço vertical nos v. 39-42 e comentário:

"Imitação da / Europa".

Enflora-lhe a cerviz, O Universo após ella - doudo amante Segue captivo o passo delirante

Da grande meretriz.

\section{$X$}

P. 110:

Notas MA:

1. termo sublinhado no v. 47 e cruzeta - estudo linguístico: emprego da forma "pra": 
$X \quad$ Talvez... p'ra que meu pranto, ó Deus clemente,

2. termo sublinhado no v. 50 e cruzeta - estudo linguístico: emprego da forma "para":

$X \quad \underline{\text { Para cobrir-me nem um templo resta }}$

P. 111:

Notas MA: termo sublinhado no v. 111 e cruzeta - estudo linguístico: emprego da forma "pra":

$X \quad$ Perdão p'ra os crimes meus

P. 112:

Nota MA: comentário ao final do poema:

"Incontestavelmente mais puramente lirico, / mais sem assunto que o Navio negreiro, mais / legitima poesia se poderá dizer, duma abun-/dancia fantastica de imaginação, sem nenhum / desfalecimento, sem nenhuma impropriedade / de imagem agora, é maravilhoso. Aqui juntaram-/se em perfeito comadrio e verdade a eloquencia na-/tural e a grandiloquencia escolastica do poeta. Dai / a perfeição extrema. Porem Navio Negreiro é mais dra-/matico, tem uma base realista que o torna mais / comovente e tem de quando em quando aqueles ver-/sos-bombas que arrebentam, iluminam, devastam, es-/cravizam, sublimam. Nestas Vozes d'Africa nada se com-/para ao final do Navio negreiro."

Nota da pesquisa: No ensaio "Castro Alves", MA comenta: "E enfim, a 'corda de bronze' que o poeta estica em sua 'lira amargurada' nessa nênia admirável, lhe dá os dois poemas formidáveis que são O Navio Negreiro e as Vozes da África. Será inútil repetir o que já se tem dito de bem desses dois poemas. Me permito somente preferir à maior perfeição poética das Vozes da África, o mais dramático Navio Negreiro. Se é certo que naquelas a perfeição encanta, há versos, há estâncias, há apóstrofes, no Navio Negreiro, da mais alta qualidade dramática. Convencem. Porque a paixão também convence" (in Aspectos da literatura brasileira, ed. cit., p. 115).

No dossiê Castro Alves, em nota de trabalho para o Lirismo romântico no Brasil, MA refere: "Lendo Vozes de Africa (citar ainda outra obra-prima mais lirica de C. Alves) a gente sente percebe que $\mathrm{C}$. Alves não daria mais. Nem Casimiro que Meus Oito Anos. Nem G. Dias que Y Juca Pirama e as Sextilhas. Se pode lamentar o que de igual a isso não produziram pela morte prematura, mas nisso apenas consistirá o lamento." (MAMMA-26-06).

\section{$\underline{\text { P. } 114-116}$}

SAUDAÇÃO A PALMARES (7 estrofes)

P. 114:

Nota MA: expressão sublinhada no v. 14, "trompas da caça", e escólio "dic" - pesquisa para o Dicionário musical brasileiro: 
dic $\quad \mathrm{E}$ as trompas da caça atroam...

P. 115:

Notas MA:

1. termo sublinhado no v. 28 e cruzeta - estudo linguístico: emprego da forma "pra":

E olhaste rindo p'ra o val. $\quad X$

2. termo corrigido no v. 34, "marmoros", pelo acréscimo das vogais "eo" - correção tipográfica:

Dos reis os marmores paços, /eo

3. termo sublinhado no v. 44 e cruzeta - estudo linguístico: emprego da forma "pra":

Guardaste-o p'ra um nobre amor. $\quad X$

$\underline{\text { P. } 117-118}$

O VOLUNTARIO DO SERTÃo (11 estrofes)

P. 117:

Notas MA:

1. trecho sublinhado no v. 8 - estudo do estilo: metáfora:

No braço ergue o sol - ostia immensa de luz.

2. trecho sublinhado no v. 10 - estudo do estilo: metáfora:

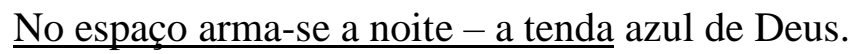

P. $119-120$

A BAINHA DO PUNHAL (3 estrofes)

P. 120:

Notas MA:

1. termo sublinhado no v. 22 e cruzeta - estudo linguístico: emprego da forma "pra":

As loiras tranças p'ra o chão...

2. termo sublinhado no v. 28, "timbalos", e escólio "dic" - pesquisa para o Dicionário musical brasileiro:

dic Soam timbalos na sala... 
$\underline{\text { P. } 125-133}$

ADEUS, MEU CANTO (29 estrofes)

P. 126:

Notas MA:

1. termo sublinhado no v. 20, "c'roa", e cruzeta - estudo do estilo: licenças poéticas:

$X \quad$ Tambem da orgia a c'roa renegaste.

2. termo sublinhado no v. 24, "corneta", e escólio "dic" - pesquisa para o Dicionário musical brasileiro:

dic A corneta esperaste dos alarmas.

3. termo sublinhado no v. 25 e cruzeta - estudo linguístico: emprego da forma "pra":

$X \quad$ É tempo agora p'ra quem sonha a gloria

4. termo sublinhado no v. 31, "para", e cruzeta - estudo linguístico: emprego da forma "para";

5. termo sublinhado no v. 32 e cruzeta - estudo linguístico: emprego da forma "pra":

$X \quad$ Ergue-te, ó luz! - Estrella para o povo,

$X \quad$ - Para os tyrannos lugubre cometa.

P. 127:

Notas MA:

1. v. 55 ao 68 destacados por traço vertical - seleção de ideias;

2. v. 57 e 58 destacados por traço vertical duplo e comentário:

Nas florestas do existir,

Que babam fél e ironia

Sobre o ovo da utopia

Que guarda a ave do porvir.

"Impagavel. O que [...]"

Eu sei que o odio, o egoismo,

A hypocrisia, a ambiçâo,

Almas escuras de grutas,

Onde nâo desce um clarâo,

Peitos surdos ás conquistas,

Olhos fechados ás vistas,

Vistas fechadas á luz,

Do poeta solitario

Lançam pedras ao calvario,

Lançam blasphemias á cruz. 
"Impagavel. O que / caracteriza C. Alves é que / ele é o rastaquera da / imagem. Daí coisas / assim, que não querem / significar uma aluci-/nação, um exagero ex/pressionista, mas puro / desperdicio de imagi-/nação."

P. 129:

Notas MA:

1. termo sublinhado no v. 105, “canção", e escólio "dic":

Eu lancei minha canção, $\quad$ dic

2. termo sublinhado no v. 113, "viola", e escólio "dic":

Ouvi saudoso a viola, $\quad$ dic

3. escólio "dic” no v. 117 - pesquisa para o Dicionário musical brasileiro:

Cantando a molle tyranna, dic

P. 130:

Nota MA: termos sublinhados nos v. 141 e 142 e cruzeta - estudo linguístico: emprego da forma "pra":

"Braços! voltai-vos p'ra terra, $\quad X$

Frontes voltai-vos pr'os céus!" $\quad X$

P. 131:

Nota MA: termo sublinhado no v. 163, "nota", e escólio "dic" - pesquisa para o Dicionário musical brasileiro:

Da harpa do meu amor nota perdida, dic

P. 132:

Notas MA:

1. termo sublinhado no v. 201, "tuba", e escólio "dic" - pesquisa para o Dicionário musical brasileiro:

dic Emboca a tuba lugubre, estridente,

2. data sublinhada ao final do poema: "Recife, $\underline{1865}$ " - estudo da biografia.

P. 135-192

A CACHOEIRA DE PAULO AFONSO

$\underline{\text { P. } 137-139}$

A TARDE (7 estrofes)

P. 137:

Nota MA: expoente (1) ao final do v. 3 e comentário: 
E d'araponga o canto, que soluça, (1)

"Segunda vez que por precisão de rima Castro Alves / diz com grande impropriedade que o grito de araponga / soluça. Esse era o senso de natureza dos nossos ro-/manticos..."

P. 138:

Nota MA:

1. termo sublinhado no v. 32 e cruzeta - estudo linguístico: emprego da forma "para":

$X \quad$ Que mesmo para o riso só tem prantos!...

2. termo sublinhado no v. 35 , "soffrer";

3. termo sublinhado no v. 36 , "embaiba", e cruzeta - seleção de ideias: natureza:

E os ninhos do soffrer que entre os sylvedos

$X \quad$ Da embaiba nos ramos me apontas;

P. 139:

Nota MA: termo sublinhado no v. 48, "som", e escólio “dic" - pesquisa para o Dicionário musical brasileiro:

Fitando o céu ao som dos teus cantares!... dic

$\underline{\text { P. } 139-140}$

MARIA (4 estrofes)

P. 139:

Nota MA: título destacado por cruzeta.

P. 140:

Nota MA: expressão sublinhada no v. 20, "moda hespanhola", e escólio "dic" - pesquisa para o Dicionário musical brasileiro:

dic Te ouvisse a moda hespanhola

P. $140-141$

O BAILE NA FLOR (4 estrofes)

P. 140:

Notas MA:

1. título destacado por cruzeta;

2. termo sublinhado no v. 8 e cruzeta - estudo linguístico: emprego da forma "pra":

$X \quad$ P'ra o baile na flor 
P. 143-144

A QUEIMADA (7 estrofes)

P. 143:

Nota MA: termo sublinhado no v. 16, "estampido", e escólio "dic" - pesquisa para o Dicionário musical brasileiro:

$$
\text { O estampido estupendo das queimadas dic }
$$

P. 144:

Nota MA: termo sublinhado no v. 30 e cruzeta - estudo linguístico: emprego da forma "para":

$X \quad$ Os braços para Deus.

Nota da pesquisa: O narrador de Amar, verbo intransitivo refere-se ao poema "A Queimada", em meio ao longo comentário que contrasta a psicologia racial de japoneses e alemães, representados no romance/idílio pelos criados da família Sousa Costa, Tanaka e Elsa: "Castro Alves cantava que na última contingência da calamidade, quando a queimada galopa destruindo matos, sacudindo as trombas curtas de fogo no ar, a corça e o tigre vão se unir na mesma rocha. Não sei em que país do mundo Castro Alves viu a 'Queimada' dele... Talvez nalgum Éden bíblico ou nas bíblicas proximidades da moradia de Tamandaré, depois do dilúvio. [...] De mais a mais confesso que não vejo, entre os brutos escolhidos por Castro Alves para o mesmo habitat conciliatório, mais que antítese inócua, nem são tão opostos assim! Mais inimigos ainda, mais muitos mais! são o tigre e o tigre" (ANDRADE, Mário de. Amar, verbo intransitivo. Estabelecimento de texto e apresentação de Marlene Gomes Mendes. Rio de Janeiro: Nova Fronteira, 2013, p. 77).

No corpus da pesquisa, em "Anchieta ou O Evangelho nas Selvas", de Fagundes Varela, MA também faz referência ao poema de Castro Alves, no mesmo ensejo de criação do idílio modernista. Sublinha o verso "E o tigre e a presa agonizando juntos" e comenta no rodapé: “Amar, Verbo Intransitivo: 'Afinal F. Varela é que acertou bem quando explicou indiretamente no Evangelho da Selva 'o verso'. Mas está entendido / que trata-se de Castro Alves. Pois...” (Nota MA, In: VARELLA, L. N. Fagundes. Obras completas de L. N. Fagundes Varella: edição organisada e revista, e precedida de uma noticia biographica por Visconti Coaracy e de um estudo critico pelo Dr. Franklin Tavora. Rio de Janeiro/Paris: Garnier, 1919, vol. 3, p. 144).

\section{$\underline{\text { P. } 144-146}$}

LUCAS (6 estrofes)

P. 144:

Notas MA:

1. título destacado por cruzeta;

2. termo sublinhado no v. 20, "alumiado", e cruzeta - estudo linguístico: brasileirismo vocabular:

Vivamente alumiado $X$

3. termo sublinhado no v. 27, "p'ra", e cruzeta - estudo linguístico: emprego da forma 
"pra":

Como quem canta p'ra si $\quad X$

P. 146:

Notas MA:

1. termo sublinhado no v. 40, "toada" - pesquisa para o Dicionário musical brasileiro:

Deixae ouvir a toada

2. termo sublinhado no v. 43 e cruzeta à esquerda - estudo linguístico: emprego da forma "pra":

$X \quad$ Descendo lento p'ra servil cabana

P. 146-147

TYRANA (5 estrofes)

P. 146:

Notas MA:

1. título sublinhado e escólio "dic" - pesquisa para o Dicionário musical brasileiro;

2. título destacado por três cruzetas;

3. termo sublinhado no v. 12 e cruzeta - estudo linguístico: emprego da forma "pra":

$X \quad \underline{\text { P'ra cantar o seu amor }}$

P. 147:

Nota MA: escólio ao final do poema:

"C. Alves e Catulo Cearense."

Nota da pesquisa: A associação entre Castro Alves e Catulo Cearense (1863-1946) é reiterada no ensaio: "E suas líricas de melhor carícia nacional não será nos versos de amor (talvez demasiadamente sentidos...), que iremos encontrar, mas justamente na vida dos escravos. É lembrar a canção incluída na Tragédia no lar, a lindíssima Canção do Violeiro, A Cruz da Estrada e ainda o Lucas e a Tirana da Cachoeira de Paulo Afonsopáginas do mais caricioso lirismo. Nas três últimas, Castro Alves antecipa nitidamente Catulo Cearense, e não foi à toa que este cantador, também genial nos seus primeiros livros, lhe pôs música à Tirana." "“Castro Alves", In: Aspectos da literatura brasileira, ed. cit., p. 114). A Biblioteca de MA conserva um título apenas de Catulo Cearense, Cantor de modinhas brasileiras (Rio de Janeiro: Quaresma, 1927), sem notas de margem.

\section{P. 147-148}

A SENZALA (7 estrofes)

P. 147:

Notas MA:

1. termo sublinhado no v. 5, "ballada", e escólio "dic" - pesquisa para o Dicionário musical brasileiro: 
Assim, cantando a pastoril ballada, dic

2. termo sublinhado no v. 13 e cruzeta à direita - estudo linguístico: emprego da forma "para":

Abre a janella para o campo verde $X$

\section{P. 148-151}

DiALOGO DOS ECHOS (8 estrofes)

P. 148:

Nota MA: termo sublinhado no v. 1 e cruzeta - estudo linguístico: emprego da forma "pra":

$$
X \quad \text { E chegou-se p'ra a vivenda }
$$

P. 149:

Nota MA: termo sublinhado no v. 41 e cruzeta - estudo linguístico: emprego da forma "pra":

Que ella deu-lhes p'ra guardar!... $\quad X$

$\underline{\text { P. } 151-152}$

O NADADOR (6 estrofes)

P. 151:

Notas MA:

1. v. 1-8 destacados por traço vertical duplo e juízo de valor:

Eil-o que ao rio arroja-se;

As vagas bipartiram-se;

Mas rijas contrahiram-se

Por sobre o nadador...

Depois s'entreabre lugubre

Um circulo symbolico...

E' o riso diabolico

Do pego zombador!

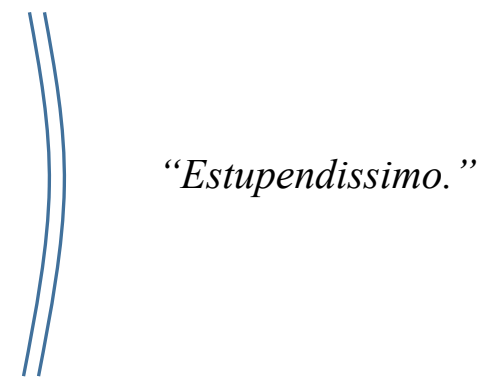

2. v. 9-16 destacados por traço vertical e comentário:

Mas nâo! Do abysmo indomito

Surge-me um rosto pallido,

Como o Neptuno esqualido

Que amaina a crina ao mar;

Fita o batel longinquo

Na sombra do crepusculo,

Rasga com ferreo musculo

$\mathrm{O}$ rio par a par

|


P. 152:

Notas MA:

1. termo sublinhado no v. 36, "boicininga", e cruzeta - estudo do estilo: vocabulário:

$X \quad$ A boicininga a urrar...

2. expoente (1) no v. 38, remetendo ao comentário no rodapé:

Como o corcel da Ukrania, (1)

"Imagens lugares-comuns do Romantismo brasileiro: / Don Juan, Mazepa e algumas mais. nelas se nota prin-/cipalmente a influencia do Romantismo europeu, talvez..."

3. termo sublinhado no v. 42, "estridulo", e escólio "dic" - pesquisa para o Dicionário musical brasileiro:

dic Da correnteza o estridulo?

P. $153-154$

No BARCO (8 estrofes)

P. 154:

Nota MA: termo sublinhado no v. 25 e cruzeta - estudo linguístico: emprego da forma "para":

$X \quad$ “Toda esperança para mim stá morta...

P. $154-155$

ADEUS (9 estrofes)

P. 155:

Notas MA:

1. termo sublinhado no v. 27 e cruzeta - estudo linguístico: emprego da forma "pra":

$X \quad$ P'ra morrer da mesma dor...

2. comentário ao final do poema:

"Antiteses, Paralelismos, nada de valor, / nada vibrado, nada."

$\underline{\text { P. } 155-157}$

Mudo E Quedo (10 estrofes)

P. 156:

Nota MA: verso 12 sublinhado e expoente “(1)” remetendo ao comentário no rodapé estudo do estilo: repetição: 
(1) De lembrar que o passado está passado...

“(1) Estes torneios de frase precursores. C. Al-/ves tem muitos deles. Assinala-los.

P. 157:

Nota MA: verso 55 sublinhado e comentário - estudo do estilo: repetição:

A treda historia desse tredo crime!...

"Ver nota pg. anterior"

$\underline{\text { P. } 157-160}$

NA FONTE (8 estrofes)

P. 159:

Nota MA: crase corrigida no v. 53 - correção tipográfica:

Como é doce em meio as cannas, lás

$\underline{\text { P. } 160-161}$

Nos CAMPOS (7 estrofes)

P. 160:

Nota MA: fio ligando o v. 64 de "Na Fonte" ao v. 1 de "Nos campos" e comentário:

"Mudança rit-/mica magistral. / Lembra Musset / na Noite de Outubro. / Só que naquele a mu-/dança é de ordem psi-/cologica, aqui descritiva / e honomatopaica."

Nota da pesquisa: "La nuit d'octobre" não conserva marcas de leitura na biblioteca de MA.

$\underline{\text { P. } 162}$

No MonTe (4 estrofes)

P. 162:

Nota MA: termo sublinhado no v. 3 e cruzeta - estudo linguístico: emprego da forma "pra":

$X \quad$ Restava inda um segundo... um só p'ra me salvar;

$\underline{\text { P. } 164-165}$

ANJO (3 estrofes)

P. 164:

Nota MA: termo sublinhado no v. 6 e cruzeta - estudo linguístico: emprego da forma "para": 
$X \quad \underline{\text { Para que miseraveis nos fazermos? }}$

P. 165:

Nota MA: verso 10 sublinhado e comentário:

“Vide nota pg 156. Quem se aproveitaria disto principalmente seria Raimundo Correia."

P. 169-171

ULTIMO ABRAÇO (3 estrofes)

P. 165 :

Nota MA: termo sublinhado no v. 34 e cruzeta - estudo linguístico: emprego da forma "pra":

$X \quad \underline{\text { P'ra não morrer nesse instante; }}$

$\underline{\text { P. } 171-172}$

Mãe Penitente (6 estrofes)

P. 171:

Nota MA: termo sublinhado no v. 14 e cruzeta - estudo linguístico: emprego da forma "para":

- Criei um ente para a dor e a fome! $\quad X$

\section{P. $172-175$}

O SEGREDO (19 estrofes)

P. 172:

Nota MA: comentário à esquerda do poema:

"Como C. Alves encomprida / a historia, meu Deus! Quantas / compridezas e discursos. / Quanto mais perfeito / G. Dias no Y-Juca-Pirama, / energico, sobrio, / sem conferencias."

$\underline{\text { P. } 175-176}$

Crepusculo Sertanejo (7 estrofes)

P. 176:

Nota MA:

1. v. 5-8 destacados por traço vertical;

2. v. 7 e 8 destacados por traço vertical duplo - seleção de ideias:

A tarde morria! Nas aguas barrentas

As sombras das margens deitavam-se longas ;

$\mathrm{Na}$ esguia atalaia das arvores seccas

Ouvia-se um triste chorar de arapongas. 
3. traço duplo à esquerda dos v. 17 a 20 :

/ As garças mettiam o bico vermelho

Por baixo das asas - da brisa ao açoite;

E a terra na vaga de azul do infinito

Cobria a cabeça co'as pennas da noite!

4. comentário ao final do poema:

"Nem sempre C. Alves pega o ritmo que convem / pro assunto. Isso não importa que esta descrição / seja bela embora não se veja nada. É simples-/mente bonita, nada mais."

P. $177-178$

O BANDOLIM DA DESGRAÇA (9 estrofes)

P. 177:

Notas MA:

1. termo sublinhado no título, "bandolim", e escólio "dic" - pesquisa para o Dicionário musical brasileiro;

2. termos sublinhados nos v. 2, "tange" e "viola", v. 5, "gusla", v. 7, "chôro", v. 10, "cordas", e escólio "dic" - pesquisa para o Dicionário musical brasileiro:

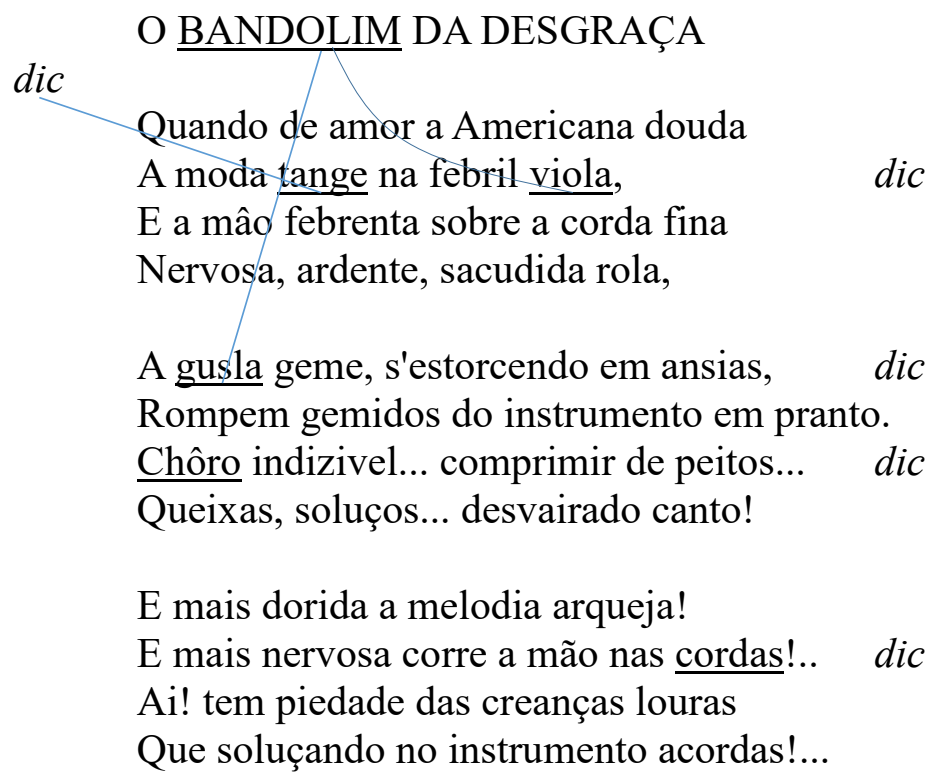

P. 178:

Notas MA:

1. termos sublinhados nos v. 28 ("dedilhar"), 30 ("harpejos") e 34 ("gusla"), e escólio "dic" - pesquisa para o Dicionário musical brasileiro:

dic Feres lasciva em dedilhar tremendo.

Crença, esperança, mocidade e glorla, dic Aos teus harpejos, - gemebundas morrem!..

Resta uma corda... - a dos amores purbs... 
E mais ardentes os teus dedos correm!...

E quando farta a cortezâ cançada

dic A pobre gusla no tapete atira,

2. comentário ao final do poema:

"Discurseira, comparações, compridezas, nada. O / poema vai descaindo, descaindo, perde completamente / a intensidade e a vida. Morre. Cansa que é um hor-/ror. O principio era tão bom! Mas sempre cheio de / excrescencias, como a Queimada, excrescencia bonita."

$\underline{\text { P. } 178-179}$

A CANÔA PHANTASTICA (7 estrofes)

P. 179:

Nota MA: comentário ao final do poema:

"Aqui já vai bem. O tre-/cho é bom e pega."

$\underline{\text { P. } 179-180}$

O SÃO FRANCISCO (5 estrofes)

P. 180:

Notas MA:

1. termo sublinhado no v. 8, "musico", e escólio "dic" - pesquisa para o Dicionário musical brasileiro:

dic Ao musico chorar das casuarinas!

2. termo sublinhado no v. 8, "modilhando", e escólio "dic" - pesquisa para o Dicionário musical brasileiro:

dic Vae nas balsas teu hymno modilhando!

$\underline{\text { P. 181-182 }}$

A CACHOEIRA (7 estrofes)

P. 182:

Nota MA: v. 55 e 56 destacados por traço vertical e comentário:

( E em torno ao pedestal laçados, tredos,

Como filhos chorando-lhe - os penedos

"Bons os dois trechos. S. Francisco e Cachoei-/ra." 
P. $183-184$

UM RAIO DE LUAR (6 estrofes)

P. 183:

Nota MA: v. 16-18 destacados por traço vertical e exclamação - seleção de ideias.

$$
\begin{aligned}
& \text { E como o beija-flor dentro do ovo, } \\
& \text { Ia-lhe o coração no niveo seio } \\
& \text { A titilar. }
\end{aligned}
$$

Nota da pesquisa: O manuscrito inclui esta nota sob a rubrica "Mau gôsto" (MA-MMA26-02).

$\underline{\text { P. } 185-186}$

LOUCURA DIVINA (5 estrofes)

P. 185:

Nota MA: termo sublinhado no v. 6, "creança", e cruzeta - estudo da psicologia: avatares da figura feminina na poesia do romantismo.

$$
\text { - "É o abysmo, creança!...” } \quad X
$$

P. 186

Á BEIRA DO ABYSMO (2 estrofes)

Nota MA: termo sublinhado no v. 32, “orgão", e escólio "dic" - pesquisa para o Dicionário musical brasileiro:

dic Reza um orgão nos céos!

$\underline{\text { P. } 193-320}$

GONZAGA OU A REVOLUÇÃO DE MINAS

P. 217-218:

ATO I, SCENA IX

Nota MA: termo sublinhado, "melodia", e escólio "dic" - pesquisa para o Dicionário musical brasileiro:

dic MARIA. - Mas que dias longos, dize antes tres seculos. Vem tocar-me aquella melodia...

$\underline{\text { P. } 241-250}$

ATO II, SCENA XIV

Nota MA: termo corrigido, "posso", substituindo "o" por "a" - correção tipográfica: 
“/a". O GOVERNADOR. - Sabe V. Ex". que a côrte de Lisboa dar-me-ia muito dinheiro por elles?... Bem vê, seria muita generosidade... Eu não pөsso de um pobre homem

\section{$\underline{\text { P. } 254-255}$}

ATO III, SCENA II

Nota MA: termo sublinhado, "estridulou”, e cruzeta - estudo linguístico:

TIRADENTES. - Entretanto dir-se-ia que uma gargalhada humana ou diabolica $X \quad$ estridulou agora ás nossas costas.

\section{P. 275-277}

ATO III, SCENA XIV

Nota MA: termo sublinhado, "trombeta", e escólio "dic" - pesquisa para o Dicionário musical brasileiro:

CLAUDIO. - Meus amigos, a trombeta de Josaphat nos evoca ao festim da liberdade! As taças estão promptas, o vinho nos espera! dic 
AZEVEDO, Álvares de. Obras de Manoel Antonio Álvares

Bibl MA: [G/II/c/128]

de Azevedo precedidas de um discurso biographico e

acompanhadas de notas pelo Sr Dr Jacy Monteiro. $3^{\mathrm{a}}$ ed.

Acrescentada com as obras ineditas, e um appendice

contendo discursos, poesias e artigos feitos a occasião da

morte do autor. Rio de Janeiro: Livraria de B. L.

Garnier, 1862. tomo segundo. [Prosa]

$11 \times 17 \times 2 \mathrm{~cm}$

IEB: MA 869.908 A994o

$*$

\section{ESTUDOS DRAMATICOS}

$\underline{\text { P. 200-283 }}$

MACARIO

P. 224:

Nota MA: fala destacada / trecho destacado por traço vertical e interrogação, "Onde?”estudo histórico:

SATAN.

É uma propensão singular a do homem pelas ruinas. Devia ser um frade bem sombrio, ebrio de sua crença profunda, o Jesuita que ahi lançou nas montanhas a semente dessa cidade. Seria o acaso quem lhe pôz no caminho, á entrada mesmo, um cemiterio á esquerda e umas ruinas á direita?

\section{"Onde?”}

P. 229:

Nota MA: expoente (1) circulado e fio prendendo à nota de rodapé - estudo histórico:

MACARIO.

Não: lembrei-me agora de uma mulhel Uma noite encontrei na rua uma vagabunda. A noite era escura. Eu ia pelas ruas á toa... Segui-a. Ella levou-me á sua casa. Era um casebre. A cama era um catre: havia um colxão emcima, mas tão velho, tão batido, que parecia estar desfeito ao peso dos que ahi havião-se revolvido. Deitei-me com ella. Estive algumas horas. Essa mulher não era bella: era magra e livida. (...)

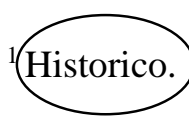

P. 231:

Nota MA: conjunção circulada e fio prendendo-a a cruzeta - estudo da psicologia:

SATAN.

É tarde. Agora é uma caveira a face que beijaste - uma caveira sem labios, sem olhos e sem cabellos. O seio se desfez.... Tudo isso é commum. É uma ideia velha, não? E quem sabe se sobre aquelle cadaver não corrêrão lagrimas de alguma 
esperança que se desvaneceu? se com ella não se enterrou teu futuro de amor? Não gozaste aquella mulher?

MACARIO.

Não $X$

P. 243:

Nota MA: trecho destacado por traço vertical duplo - estudo da psicologia: mãe:

\begin{abstract}
A MULHER.
Um defunto?... não.... elle dorme: não vêdes? É meu filho... Apanhárão-no boiando nas aguas levado pelo rio.... Coitado! como está frio!.... é das aguas! Tem os cabellos ainda gottejantes.... Dizião que elle morreu.... Morrer! meu filho! é impossivel.... Não sabeis? elle é a minha esperança, meu sangue, minha vida. É meu passado de moça, meus amores de velha... Morrer elle? É impossivel. Morrer? Como? Se eu ainda sinto esperanças, se ainda sinto o sangue correr-me nas veias, e a vida estremecer meu coração!
\end{abstract}

P. 246:

Nota MA: trecho sublinhado, "não tenho mãi”, e fala destacada por traço vertical - estudo da psicologia: mãe:

MACARIO.

Não; não tenho mãi. Minha mãi não me embalará endoudecida entre seus joelhos, pensando aquentar com sua febre louca o filho que dorme. Ninguem chorará. Não tenho mãi. 
AZEVEDO, Álvares de. Obras de Manoel Antonio Álvares de Azevedo precedidas do juizo critico de escriptores nacionaes e estrangeiros e de uma noticia sobre o auctor e suas obras por J. Norberto de S. S. 7. ed. Rio de Janeiro: Garnier, 1900. 3 v. [Poesia]
Bibl MA: [A/II/d/42]

$12 \times 18,5 \times 2,5 \mathrm{~cm}$

IEB: MA 869.908 A994o 7.ed v.1

\section{VOLUME 1}

\section{FOLHA DE GUARDA}

\section{Notas MA:}

1. anotação no alto, à direita, “ $n^{\circ} 191$ ”, referindo-se à inclusão do volume na Bibliografia para Na pancada do ganzá;

2. lista de verbetes para o Dicionário musical brasileiro, com três riscos verticais e a expressão “(anotado)”, indicando o aproveitamento:

$$
\begin{aligned}
& \text { Dic - lira 260- guitarra 287-harpa 306-/assonia 315-monodia } 328- \\
& \text { cantilena 350-/ nenia } 362-\quad \text { (anotado)" }
\end{aligned}
$$

Notas da pesquisa:

1. O escólio "dic", a grafite, de ocorrência farta na marginália, nos títulos da poesia do romantismo brasileiro, indica a pesquisa de elementos para abonar verbetes no Dicionário musical brasileiro, projeto de MA testemunhado em sua biblioteca, no manuscrito desse título e de outros, em seu arquivo e, na edição póstuma coordenada por Oneyda Alvarenga e Flávia Camargo Toni (Brasília: Ministério da Cultura/São Paulo: IEB-USP - Edusp/ Belo Horizonte: Editora Itatiaia Ltda, 1989).

2. O vol. 1 das Obras de Álvares de Azevedo inclui uma longa introdução composta de textos celebrando o escritor. São divididos nas seguintes seções, indicado entre parênteses o nome dos colaboradores: "Juizo Critico dos escriptores nacionais e estrangeiros" (Jacy Monteiro, A. P. Lopes de Mendonça, Fernando Woolf, Innocencio Francisco da Silva, Cônego J. C. Fernandes Pinheiro, Emilio Zaluar); "Noticia sobre o autor e suas obras lida em uma das sessões do Instituto Historico Brasileiro no Anno de 1872", assinada por Joaquim Norberto de Souza; "Peças Elegiacas Relativas ao Autor", com os discursos proferidos no funeral de Álvares de Azevedo (Joaquim José Teixeira, Joaquim Manoel de Macedo, Domingos Jacy Monteiro) e na "Sessão Funebre do Ensaio Philosophico Paulistano" (Antonio Ferreira Vianna, Felix Xavier da Cunha, A. C. Ribeiro d'Andrada Machado e Silva, Antonio Carlos Carneiro Viriato Catão, João Pires da Silva Junior, José Diogo de Menezes Fróes, Manoel Antonio Duarte de Azevedo, José Bonifácio de Andrade e Silva, Paulino José Soares de Sousa Júnior, Da Costa Carvalho, Jeronymo José Teixeira Junior, José Maria Corrêa de Sa e Benevides, Manoel Francisco Correia, P. J. M. Rodrigues Costa); "Artigos e poesias sobre a morte do poeta" (M. Ribeiro de Almeira, D. Jacy Monteiro, Leonel Martiniano de Alencar, Pereira Roças, Lindorf Ernesto Ferreira França); "Discurso Biographico do Bacharel M. A. Álvares de Azevedo", recitado por Domingo Jacy Monteiro. 


\section{$\underline{\text { ANTEPÁGINA }}$}

Nota MA: comentários:

"Comentário á imitação e á sinceridade. Mostrar / que uma não contraria a outra, ao contrário, a imitação / provoca a sinceridade porque ninguém imita por esno-/bismo sinão raramente e não é o caso dos romanticos, / imita-se por afinidade, imita-se por espelhar, imita-/ se a mesma coisa que se é, não se imita: identifi-/ca-se, corresponde-se.

Realmente os românticos são duma pobreza / mental extraordinaria. Poetas tão fatalmente / poetas como Alvares de Azevedo nada lhes falta / pra serem grandes criadores sinão a tradição / de criação quasi ignorada neste país de tradicio-/nal palavriado. Alvares de Azevedo tem a fatali-/dade de manifestação do genio, faltou-lhe a tradi-/ção de criação do genio que obriga a manifesta-/ção a levantar o vulto dos tipos $e$ dos simbolos. / Por mais que a leitura o levasse prás civilizações / criadoras tradicionais a intensa vida do senti/do que fez dos nossos românticos seres tão *visce/ralmente* e mesmo inconscientemente nacio-/nais proibiu-lhes a desnacionalização e o des-/paisamento que lhes permitiria filiarem-se / alem-mar. O bem deu como resultado um $/ \mathrm{mal}=$ a perda pessoal desses homens tão / ricos de lirismo e tão empobrecidos pela / grandeza de serem nacionais.

A insistencia lasciva do beijo nos romanticos vem / de toda a artificialidade do sensualismo árcade; an-/tes do sexualismo árcade que deve-se dizer falar...Des/cobriram que era possivel amar em verso um pou-/co mais perto da realidade e pelo muito de proi-/bido ante *de* antipoetico que essa realidade / lhes parecia ter, ficaram no beijo, no abraço e quan-/do muito os mais ousados foram aos peitos da / gosada. Mas a descoberta os deslumbrou: o gôso / do beijo tornou-se obsecante, é uma repetição / sem fim que os não saciava pelo ineditismo dela / (*grifo de* páginas adiante nota entrebeijar)"

Nota da pesquisa: No manuscrito da obra inacabada Lirismo romântico no Brasil, MA associa o comentário registrado na antepágina à percepção dele sobre o "sentimentalismo amoroso do brasileiro, gente sincera, gente dada, hospitaleira, levando tudo a serio, grafado pelo romantismo". No fichamento crítico - documento que contém as "Ideias gerais" para o estudo da poesia romântica, reunido no dossiê "Castro Alves" -, acrescenta: "Só Alvares de Azevedo é ironico e é sarcastico e desabusado, sobretudo sarcastico que é traço individual, o brasileiro é ironico tambem por timidez ou desconfiança”. Em mais duas entradas, faz remissão a esta antepágina: ao elencar a "Insinceridade sincera" de Gonçalves Dias e ao caracterizar os românticos como "Esquecidos da inteligencia e do pensamento" (MA-MMA-26-04).

\section{$\underline{\text { INTRODUCČ̃̃O }}$}

\section{P. 1:}

Notas MA:

1. escólio - "Imagens 221" - remetendo à página inicial do poema "Glória moribunda";

2. fragmento de anotação - "234" - remetendo à p. 234 do poema "Glória moribunda", onde assinalada a preposição "para" e a forma elidida "p'ra"; 
3. escólio - "entrebeijar 342" - remetendo à p. 342, Canto IV, do "Poema do Frade", e comentário entre parênteses:

"entrebeijar 342 (ver $3^{a}$ nota da antepagina. / este verbo é delicioso / de pegajosismo"

P. 29-72:

NORBERTO, JOAQUIM. "Notícia sobre o autor e suas obras lida em uma das sessões do instituto historico brasileiro no anno de 1872"

\section{P. 44-45:}

Nota MA: trecho destacado por colchete e traço vertical à direita - estudo da psicologia: mãe e irmã:

Aquelle anno fatal estava escripto em sua alma com algarismos negros. Deixou-se de passeios e distracções, e concentrou-se todo nos seus trabalhos. Durante o dia procurava o escriptorio de seu pae, que lhe confiava os autos mais importantes de seus clientes, e á noite vinha para junto de seu lar, gozar das caricias de sua mãi e dos affagos de sua irmã. Voltavam os bellos dias de sua infancia e com os mesmos dias voltavam aquelle apego ao seio materno, aquella ternura filial que manifestava em continuo conchego, em repetidos abraços, e incessantes beijos, vivia em seus olhos, bebia-lhe as expressões de amor, concentrava-se-lhe n'alma.

Despertou-se tambem o presentimento maternal: estas manifestações deram rebate nos seios d'alma de sua mãi e sobresaltaram-n'a com mil pensamentos, que á noite convertiam-se em sonhos duros e pesadelos maus, que lhe vinham interromper o somno e quebrar-lhe o repouso. Sonhára ella uma vez que seu filho estava louco; outra vez era ella que em seus braços o embalava ao somno da morte! Mãi e filho ambos eram victimas de seus tam puros amores - maternal e filial; ambos luctavam com os mesmos presentimentos, que cautelosos se occultavam mutuamente.

Com a magoa no coração, que se lhe despedaçava fibra por fibra, com o presagio n'alma, que em vão procurava esquecer ou illudir, a mãi o vigiava constantemente. Vinha achal-o as mais das vezes escaldado pela febre do gennio que o devorava, com aquella cabeça ardendo-lhe como um vulcão, debruçado á secretária, dobrado sobre o papel ou curvado sobre os livros, compondo ou lendo á luz do candieiro das lucubrações, e entrando pelas longas horas da noite.

Reprehendia-o ella por causa de tam improbo estudo, pedia-lhe, instava com elle para que evitasse tam continuas vigilias e que fosse entregar-se á reparação de suas forças; obedecia elle, procurando tranquilisal-a, confessando-se habituado áquelle trabalho n'essas horas mortas e silenciosas que toda a cidade dormia cançada de suas lidas.

Uma noite a surpreza foi cruel para ambos: encontrou-o a mãi debulhado em pranto; e o papel a que entregára os intimos pensamentos de sua alma trahiu-lhe o presentimento de seu coração: eram paginas humedecidas pelas lagrimas, eram versos inspirados pelo amor filial!

Nota da pesquisa: O trecho em destaque, acerca do vínculo estreito entre Álvares de Azevedo e sua mãe, e das demonstrações de afeto recíproco, é reiterado em "Amor e medo". No ensaio, porém, a pureza de sentimento dos dois é assumida por MA com certa carga adverbial de ironia: "Aceitemos lealmente, com Joaquim Norberto, que tanto a mãe 
como o filho, foram vítimas de seus puríssimos amores" (“Amor e medo", In: Aspectos da literatura brasileira. Ed. cit., p. 220).

P. 115-218:

"PeÇAS Elegíacas Relativas aO AUtoR"

P. 152:

Nota MA: termo corrigido no v. 4 do poema elegíaco de José Bonifácio de Andrada e Silva, de modo a constar: "Na terra... e ar... e céo tão socegado!" - correção tipográfica.

P. 191-218:

MONTEIRO, Domingo Jacy. "Discurso biographico do Bacharel M. A. Alvares de Azevedo recitado na quarta sessão solemne de Gymnasio Brasileiro pelo socio effectivo e primeiro secretario Domingo Jacy Monteiro."

P. 214:

Nota MA: trecho destacado por traço vertical à esquerda e escólio "Amor e medo" estudo da psicologia: mãe/amor e medo:

Amor
No dia 10 de março, do anno que corre para o seu termino, queixou-se M. A. A.
de Azevedo pela primeira vez. Tudo lhe foi feito, e por alguns dias conservou-se no seu quarto, mostrando ledo o semblante quando qualquer se chegava a elle, e até gracejando e dando motivos especiosos da sua molestia. Sua mãi, que o não deixava, dice-lhe um dia que seu quarto era muito quente, e effereceu-lhe a sua cama. Parece que a fronte do mancebo carregou-se; sorriu-se depois e recusou firmemente. - Talvez se lembrasse do sonho a seu respeito que sua mãi lhe contára (fôra no começo do anno) e do qual - cousa singular! - ella se esquecêra completamente até á sua ultima hora; mas uma esperança de vida bateu ainda n'aquelle coração de 20 annos!...

Dias depois porém foi elle próprio quem instou para ir para a cama de sua mãi... E desde então não quiz arredar-se mais d'ahi; apenas tres dias antes do seu fallecimento conseguirão a custo tiral-o d'ahi por momentos, tendo elle dicto antes que desejava ficar n'essa cama até o fim, e tendo por mais de uma vez manifestado desejos de vêr certos objectos, respondendo, quando lhe perguntavão a razão, que era para poder vêl-os antes de se ir embora...

Notas da pesquisa:

1. O relato de Domingo Jacy Monteiro é parafraseado em "Amor e medo", onde MA escreve: "Ninguém ignora o importante caso da cama. A mãe de Álvares de Azevedo tivera um pesadelo em que vira o filho morrendo na própria cama dela. Todos os interessados em psicologia hão-de naturalmente reconhecer a importância dum detalhe esquisitíssimo: ela relata ao filho o pesadelo que teve! É o que afirma Jací Monteiro. E menos de três meses depois, quando o filho adoece pra morrer, ela lhe oferece a própria cama, afirmando ainda Jací Monteiro (e é psicologicamente aceitável este esquecimento em consciência) que ela estava completamente esquecida do que sonhara. Álvares de Azevedo recusa no momento, pra dias depois pedir o leito da mãe, onde morre." (In: Aspectos da literatura brasileira, ed. cit., p. 220).

2. O trecho assinalado é referido à margem do "Poema do Frade" (Canto Segundo, v. 14), à p. 291 deste volume. 


\section{POESIAS DIVERSAS}

P. $221-240$

\section{GLORIA MORIBUNDA}

P. 221:

Notas MA:

1. v. 3 e 4 destacados por traço vertical;

2. sublinhado duplo no v. 4, "á sombra dos".

$$
\begin{aligned}
& \text { Foi a cabeça ardente de um poeta, } \\
& \text { Outr'ora á sombra dos cabellos loiros. }
\end{aligned}
$$

P. 222:

Notas MA:

1. traço vertical à esquerda, destacando os v. 26-28, e comentário - seleção de ideias;

2. acréscimo da letra "s" à palavra "electrișmo", no v. 26 - correção tipográfica;

3. termo sublinhado no v. 28, "para", e cruzeta à esquerda - estudo linguístico: emprego de "para/pra":

$$
\begin{array}{ll} 
& \text { E a centelha da vida, o electrismo } \\
\text { Que as fibras tremulantes agitava } \\
X \quad \text { Morreu para animar futuras vidas? }
\end{array}
$$

"Metempsicose.

$[\ldots] "$

"Metempsicose. / Mostrar como / A. de A. mostrava / estranha erudi-/ção prá idade, / pro tempo bra-/sileiro e mesmo / prá epoca. E empregou e falou teorias nos seus / poemas porem sem eiva de scientificismo"

Notas da pesquisa:

1. O editorial da Revista Nova menciona o trecho assinalado como exemplo das "especulações doutrinárias, sem nenhuma espécie de didatismo" de Álvares de Azevedo, "sobretudo a metempsicose pregada por Solfieri (III, 334) e aceita na Gloria Moribunda" (Revista Nova, a. 1, n. 3, p. 313).

2. O editorial redigido por MA para a Revista Nova - documento no dossiê do manuscrito Artigos por escrever - será transformado por ele nas três crônicas de teor crítico publicadas entre agosto e setembro de 1931 no Diário Nacional: "Álvares de Azevedo I, II e III” (ANDRADE, Mário de. Táxi e Crônicas no Diário Nacional. ed. cit., pp. 417427), conforme se percebe pelo cotejo dos textos. Outro fólio, este no dossiê do manuscrito Amor e medo, acusa a elaboração do editorial: "O primeiro episódio do Macário é formidável, uma obra-prima. O segundo já vira discurso brasileiro, muito vazio, muita oratória banal. Da mesma forma é colossal o primeiro capítulo da Noite na Taverna, que hoje publicamos." (MA-MMA-05-25; sublinhei).

P. 223:

Notas MA:

1. comentário ao final da parte I: 
"Todo êste prologo é excelente, A. de A. / é excelente sempre nos prologos."

2. expressão sublinhada no v. 46, "Mulher da noite" - estudo da psicologia: avatares da figura feminina na poesia do romantismo:

- Por quem esperas tremula a deshoras,

Mulher da noite, na deserta rua?

\section{P. 224:}

Nota MA: expressão sublinhada no v. 51 e expoente “(1)” remetendo ao comentário no final da parte II - estudo da psicologia: avatares da figura feminina na poesia do romantismo:

“(1)” Vagabunda de amor, és bella e pallida;

“(1) Prá mulher perdida são talvez as / mais doces, mais comovidas e certo mais / comoventes expressões do poeta. Só aqui / o admirabilíssimo epiteto 'mulher da / noite' e agora êste 'vagabunda do amor'."

Nota da pesquisa: Em “Amor e medo", MA retoma a avaliação aposta à margem do poema, delineando o tratamento dado à mulher em passos diversos da obra de Álvares de Azevedo: "Também se arrota manchado por todas as maldades do Mundo. Mas a verdade é que, si pra Macario as mulheres que não têm cabelo na cabeça o têm no coração (III, 259), si 'não póde haver inferno com senhoras' (II, 230), si na estancia do Poema do Frade, aquele típo tão puro de Madona era um lago a dormir, 'porém sua água azul tinha veneno'; si ainda pra Macario (III, 268), as mulheres paulistanas 'são mulheres, isto é, são lascivas': tudo isso são falsificações sistematizadas inconscientemente, de quem soube achar expressões delicadas mesmo para designar a mulher prostituida, 'vagabunda do amor', 'mulher da noite', 'anjo da noite', 'rainha da noite'." (“Amor e medo", In: Aspectos da literatura brasileira. Ed. cit., p. 204).

\section{P. 225:}

Notas MA:

1. comentário:

"Notar que a libertinagem do poeta / é uma libertinagem como que pura. Tem / uma infantilidade real que comove, a deste / candido devasso."

2. v. 69 e 70 destacados por colchete - estudo da psicologia: sono:

Das virgens no cheiroso travesseiro

Porventura dormi... Meu Deus! que sonhos!

P. 226:

Nota MA: v. 95 sublinhado, retângulo destacando o "a" de "órgia" e expoente (1) remetendo ao comentário no rodapé - estudo da metrificação: 
“(1)” Á órgia! na saturnal entre a loucura

"(1) A. A. conta este a mudo como inexistente"

Nota da pesquisa: No fichamento crítico com as "Ideias gerais" para o livro Lirismo romântico no Brasil, MA refere este verso sob a rubrica "Modo de contar silabas" (MAMMA-05-04).

P. 227-228:

Nota MA: v. 106 e 107 destacados por traço vertical e expoente “(1)”, remetendo ao comentário:

"(1)" (A gloria! a gloria! meu amor foi ella,

Foi meu Deus, o meu sangue... até meu genio...

“(1) Quase todos os herois do poeta (ele?) sonham com a Gloria. / Bocage, Pedro Ivo ("glorias e liberdade")... Aqui A. de / A. atinge uma iluminação fecunda dizendo que a / gloria, o desejo de gloria foi o que fez a genialidade do / poeta. Gloria é a necessidade de subir sobre os homens. // Observar a estranha similitude que ha entre / isso e a necessidade-de-comunicação de que fa-/lo em estetica. $O$ desejo de ser entre os homens, / o desejo de ser o Iluminador dos homens. Tudo / essencias de Amor."

P. 228:

Notas MA:

1. v. 125-127 destacados por traço vertical e expoente “(1)” remetendo ao comentário, localizado entre as partes V e VI:

“(1)”( $\begin{aligned} & \text { Quem pudéra nas ondas do passado, } \\ & \text { Ditoso pescador, erguer no lodo, } \\ & \text { O ramo de coral de teus amores? }\end{aligned}$

“(1) Uma das mais belas expressões dedicadas á / mulher perdida. A. de A. dentro da 'vagabunda / de amor' nunca se esquece da virgem passada. / Alias um dos mais curiosos traços romanticos é / esse não esquecer nunca diante do presente / ruim as bonitezas do passado. - Uma como que / infantilização perpetua e idealizadamente real / do adulto. 'Creança' é expressão continuada com que / se dirigem á mulher amada.

“Veja (1) p 256."

2. expressâo sublinhada no v. 138, "anjo da noite", e dois fios ligando ao escólio "Puta", nesta e na página seguinte - estudo da psicologia: avatares da figura feminina na poesia do romantismo:

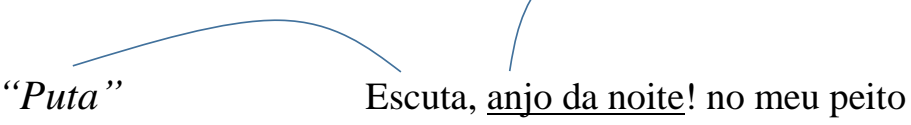


Nota da pesquisa: Com a indicação "Veja (1) p 256", MA remete ao comentário dele à margem de "Thereza", onde escreve: "Volta a adorar em Tereza os 15 annos, o que passa". Compara o poema, logo em seguida, ao "Madrigal melancólico", de Manuel Bandeira, que também emprega, reelaborada, a fórmula "O que eu adoro em ti" (Nota MA, In: AZEVEDO, Álvares de. Obras. Ed. cit., vol. 1, p. 256).

P. 229:

Notas MA:

1. v. 142 sublinhado e cruzeta - seleção de ideias;

2. expressão sublinhada no v. 143 e escólio "puta" à esquerda - estudo da psicologia: avatares da figura feminina na poesia do romantismo;

“puta $=" \quad \frac{\text { A alma da formosura é sempre virgem! }}{\text { Minha virgem, irmã, meu Deus! comtigo! }} \quad X$

3. termo sublinhado no v. 144, "hespanhola", e comentário - estudo da psicologia: avatares da figura feminina e imaginário geográfico da poesia do romantismo:

Nossos olhos tão negros d'hespanhola. $\quad$ “Começam as / espanholas. E as italianas"

4. verbo corrigido no v. 150, “É”, pelo acréscimo do acento - correção tipográfica:

Que tens, mancebo?

$$
\text { - Nada. É cedo ainda. }
$$

P. 230:

Nota MA: v. 154 e 155 destacados por traço triplo e escólio "Morte" - estudo da psicologia:

"Morte” $\quad\left(/\left(\begin{array}{l}- \text { Se a morte é soffrimento, eu soffro tanto... } \\ \text { Que a mudança do mal será consolo; }\end{array}\right.\right.$

P. 231:

Nota MA: v. 185-194 destacados por traço vertical - seleção de ideias:
É pois a voz unanime dos mundos,
Das longas gerações que se agonizão,
Que sobe aos pés do Eterno como incenso?
Serás tu como os bonzos te tingirão?
Sublime Creador, porque engeitaste
A pobre creação? porque a fizeste
Da argilla mais impura e negro lodo
E a lançaste nas trevas errabunda
Co'a pallidez na fronte como anathema, 


\section{Notas MA:}

1. v. 195-201 destacados por traço vertical - seleção de ideias;

2. verbo corrigido no v. 199, "É" - correção;

3. comentário ao final da parte VIII:

Qual lança a borboleta as azas d'oiro

No pantano e no sangue?

Tudo é sina!

O crime é um destino! o genio, a gloria

São palavras mentidas! a virtude

É a mascara vil que o vicio cobre!

O egoismo! - eis a voz da humanidade.

Foste sublime, Creador dos mundos!

"Eis realmente uma pagina estupenda. A ironia / que a termina é das mais amargas que ha. Pode-/rá ser errada, pessimista, romantica... é / pagina natural, sentida, vivida. E A. de A. / disse aqui as palavras que iluminam. / Perfeito."

4. v. 204-206 destacados por traço vertical e sublinha, e expoente “(1)” remetendo ao comentário no rodapé - seleção de ideias:

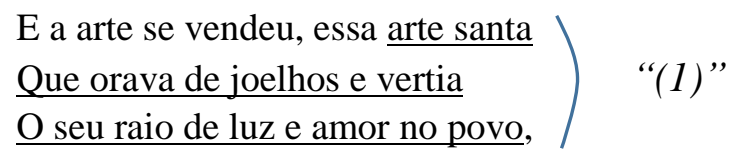

“(1) Citar isso pra fortificar o que digo sobre / o conceito de arte em A. de A. e que está em / nota na pg. 227 dêste vol."

P. 234:

Notas MA:

1. preposição sublinhada no v. 237 e cruzeta - estudo linguístico: emprego de "para/pra":

$X \quad$ E o mundo? Não me entende. Para as turbas

2. preposição sublinhada nos v. 239 e 243 e fio prendendo-as - estudo linguístico: emprego de "para/pra":

A gloria é essa. P'ra viver um dia

[...]

Para um pouco de pão ganhar da turba

P. 235:

Nota MA: v. 254 assinalado por expoente “(1)”, remetendo ao comentário na margem superior:

“(1)” Ó santa inspiração! fada nocturna, Porque a fronte não beijas do poeta? 
“(1) O defeito principal deste poema é ser / quasi que unicamente um rozario de invo/cações. Cansa. Invocação pra isto. Invocação / pra aquilo. Cansa. Veja 2 pgs. seguintes."

Nota da pesquisa: A página é incluída na rubrica "Eloquência romântica, invocações", no plano com as "Ideias gerais" para o livro inacabado Lirismo romântico no Brasil, documento no dossiê do manuscrito Castro Alves (MA-MMA-26-04).

P. 236:

Nota MA: v. 275-279 assinalados por escólio - estudo do estilo: invocações:

Amor! amor! meu sonho de mancebo!

"Mais invocação" Minha sêde! meu canto de saudade!

Amor! Meu coração, labios e vida

A ti, sol do viver, erguem-se ainda,

E a ti, sol do viver, erguem-se embalde!

P. 237:

Notas MA:

1. comentário à esquerda do v. 290:

"Mais invocação" Ah! vem, alma sombria que pranteias, Amor! amor! meu sonho de mancebo!

2. expressão sublinhada no v. 293 - estudo da psicologia: sentimento amoroso/pureza:

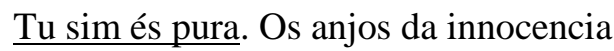

3. preposição sublinhada no v. 302 e cruzeta à direita - estudo linguístico: emprego de "para/pra":

Eu tenho amores para encher de encantos $\quad X$

4. v. 306-308 destacados por traço vertical e escólio "Mãi" - estudo da psicologia: mãe e irmã:

Maldita minha mãe, que entre os joelhos

Mãi

Não soubeste apertar, quando eu nascia,

O meu corpo infantil! Maldita! ...

Nota da pesquisa: No rol de imagens da mãe aludidas em "Amor e medo", MA cita os v. 316-318: "E si pedindo perdão ao Imperador pra Pedro Ivo, acha de pedir 'por vossa mãe', o que aliás pode ser tomado apenas como lugar-comum, faz Bocage (I, 237) acabar amaldiçoando a mãe, em versos cujo teor importa psicologicamente muito" ("Amor e medo", In: Aspectos da literatura brasileira, ed. cit., p. 221).

P. 239:

Nota MA: preposição sublinhada no v. 337 e cruzeta - estudo linguístico: emprego de "para/pra": 
Para aos pés lhe morrer e sem ao menos

$X$

$*$

P. 241-242

No ALBUM DA EXMA. SRA. D. O.... (4 estrofes)

P. 241:

Nota MA: repetição sublinhada no v. 10 - estudo linguístico: brasileirismo sintático:

Que não é não amor, nem amizade,

P. $243-248$

PEDRO IVO (15 estrofes)

P. 245:

Notas MA:

1. v. 35 destacado por aspas, sublinha e cruzeta - seleção de ideias:

“Glorias... e liberdade!” $\quad X$

2. preposição sublinhada no v. 40 e cruzeta - estudo linguístico: emprego de "para/pra":

- Perdão para essa fronte laureada! $\quad X$

3. termo sublinhado no v. 48 e cruzeta à direita - estudo linguístico: emprego de "para/pra":

Para esses - maldição! que o leito cavão $\quad X$

Nota da pesquisa: No dossiê do manuscrito Castro Alves, onde se acham reunidos esboços e notas de trabalho para o livro inacabado Lirismo romântico no Brasil, MA propõe: "Fazer um estudo comparativo entre os dois poemas de Pedro Ivo de Alvares de Azevedo e de Castro Alves, mostrando quanto o daquele é superior embora menos excitante e exteriormente agradavel. A grandiloquencia ficticia de Castro Alves, puro discursoacademico. No entanto o palavriado vazio, tão brasileiro, era tambem veso de Alvares de Azevedo. Provam-no as prosas deste. Mas nele era mais intenso, mais verdadeiro, mais $\underline{\text { constante, }}$ mais continuado, permanente o lirismo psicologico, por isso o seu Pedro Ivo é mais eloquente, da legitima eloquencia da comoção ao passo que os surtos epicos de Castro Alves não passam na grande maioria das vezes de formulas de grandiloquencia pra agradar povo. Não nascem do ser inteiro nem duma intenção de pensamento duma vontade da idea." (MA-MMA-26-08).

P. 249

A Minha MÃI (15 estrofes)

P. 248: 
Nota MA: verbo sublinhado no v. 8, cruzeta e expoente "(1)" remetendo ao comentário no alto da página:

$$
\text { Pranteando sobre uma alma que pranteia. } \quad X \text { “(1)” }
$$

“(1) Em Alvares de Azevedo nenhum artificio pra / enfaceirar o verso. Nada. Pura poesia. Mesmo / conviria dizer que mais lirismo que poesia. Ain-/da não chegara áquela maturidade, áquela / expansão plena do genio em que da escolha entre lirismos puros e lirismos falsos, conven-/cionais, o artista aceita aqueles e esconde estes / dentro da artefação. Assim livre e despi-/do, quando a gente encontra dentro da / poesia dele efeito como este grifado é certo / que o poeta tinha mesmo que falar assim / e não foi artificio que o levou á repetição."

P. 252:

Nota MA: termo sublinhado no v. 53 e cruzeta - estudo do estilo: vocabulário:

Desfolhando da pallida corôa $\quad X$

P. $255-258$

THEREZA (15 estrofes)

P. 256:

Nota MA: v. 21-24 destacados por traço vertical e expoente “(1)" remetendo ao comentário no rodapé:

$$
\text { “(1)” } \quad\left(\begin{array}{l}
\text { O que eu adoro em ti é no teu rosto } \\
\text { O angelico perfume da pureza, } \\
\text { São teus quinze annos n'uma fronte santa } \\
\text { O que eu adoro em ti, minha Thereza! }
\end{array}\right.
$$

“(1) Volta a adorar em Tereza os 15 annos, o que pas-/sa. E notar a curiosa coincidencia de ex-/pressão e dissidencia de idea com Ma-/noel Bandeira que diria bem mais tarde a uma mulher: O que eu adoro em ti é a vida."

Nota da pesquisa: A fórmula "O que eu adoro em ti" arremata o "Madrigal Melancólico" de Manuel Bandeira (1886-1968). Datado de 11 de julho de 1920, foi incluído em Ritmo dissoluto e publicado no volume Poesias (Rio de Janeiro: Edição da Revista de Língua Portuguesa, 1924). Na Biblioteca MA, no IEB/USP, o exemplar com dedicatória do autor contém notas de margem, embora o poema não tenha marcas de leitura. Já em 1924, MA publica um estudo sobre Manuel Bandeira na Revista do Brasil (a. 9, n. 107. Rio de Janeiro, nov. 1924, p. 215-224), em que menciona o poema: "Só raras vezes a alusão [à tuberculose] é muito forte, como no lancinante 'Madrigal melancólico' que acaba num dos gritos mais comoventes que ouvi" (LOPEZ, Telê Porto Ancona (org.). Manuel Bandeira: verso e reverso. São Paulo: T. A. Queiroz, 1987, p. 74).

P. 257:

Notas MA: 
1. v. 41-44 destacados por traço vertical triplo e escólio "Amada dormida";

2. expressão sublinhada no v. 44 e expoente “(1)”, remetendo ao comentário no rodapé - estudo da psicologia: amor e medo:

Não acordes tão cedo! emquanto dormes Eu posso dar-te beijos em segredo... "Amada dormida" Mas, quando nos teus olhos raia a vida, Não ouso te falar... eu tenho medo! "(1)”

“(1) É engraçado este medo... poetico dos nossos ro-/manticos. Tambem Casemiro o teve."

Nota da pesquisa: MA acusa o tema do "Amor e Medo" sob a rubrica "Psicologia do Romantismo Brasileiro", indicando esta página no plano da obra inacabada Lirismo romântico no Brasil (MA-MMA-26-04). A percepção que anima o ensaio de 1931, para a Revista Nova, acha-se em seu momento inicial.

$\underline{\text { P. 259-262 }}$

A Meu Amigo J. F. Moreira (11 estrofes)

P. 259:

Nota MA: v. 1 assinalado por expoente “(1)”, remetendo ao comentário no rodapé seleção de ideias:

A vida é uma comedia sem sentido, “(1)”

“(1) No 'Gloria Moribunda' já está pg 223 deste: / 'A vida é um escarneo sem sentido'.”

P. 260-261:

Notas MA:

1. termo sublinhado no v. 26, "lyra", e anotação "dic" à direita - pesquisa para o

Dicionário musical brasileiro:

Que gela as mãos do trovador na lyra dic

2. v. 31-54 destacados por traço vertical - seleção de ideias:

E quem sabe? - é a duvida medonha!

Quem os véos arregaça do infinito

E os tumulos destampa?

Quem, quando dorme ou vela, ou quando sonha,

Ouviu revelações no horrendo grito

A rebentar da campa?

E quem sabe? é a duvida terrivel,

É a larva que aos labios nos aperta,

Entre-abrindo o sudario! 
A realidade é um pesadelo incrivel!

Semelha um sonho a lapida deserta

E o leito mortuario!

E quando acordarão os que dormitão?

Quando estas cinzas se erguerão tremendo,

Em nuvens se expandindo?

Perguntai-o aos cyprestes que se agitão,

Ao vento pela treva se escondendo,

Nas ruinas bramindo!

E comtudo parece um desvario,

Blasphemia atroz o cantico atrevido

Que rugem os atheos;

Sem a sombra de Deus é tão vasio

O mundo - cemiterio envilecido!...

Oh! creiamos em Deus!

P. 263-264

SONETO (4 estrofes)

P. 263:

Nota MA: título destacado por cruzeta.

Nota da pesquisa: O poema figura entre os "sonetos românticos" arrolados por MA no plano da obra inacabada Lirismo romântico no Brasil (MA-MMA-26-04). Em "Amor e medo", MA classifica Álvares de Azevedo de "maior sonetista que foi dentre os nossos românticos" ("Amor e medo", In: Aspectos da literatura brasileira. Ed. cit., p. 219-220).

P. 265-266

A Minha Esteira (5 estrofes)

P. 266:

Notas MA:

1. v. 13-16 destacados por colchete e escólio "Amada";

2. comentário ao final do poema:

"Amada"

Nem o arabe Califa, adormecendo

Nos braços voluptuosos da estrangeira,

Foi no amor da Sultana mais ditoso

Que o poeta que sonha em sua esteira!

"O artificio da repetição 'esteira'. Caso / rarissimo no poeta, na poesia seguinte / tem o refrão 'Si eu morresse amanhã'.'

Nota da pesquisa: MA refere-se ao poema, em "Amor e medo", para caracterizar a recorrência de imagens de sono na poesia de Álvares de Azevedo: "Em Minha Esteira, o 
califa é pintado "adormecendo nos braços voluptuosos da estrangeira" (ANDRADE, Mário de. "Amor e medo", In: Aspectos da literatura brasileira. Ed. cit., p. 210). O ensaio, desde a publicação na Revista Nova, equivoca-se ao referir o título do poema como "Minha estrela".

P. $267-268$

SE EU MORRESSE AMANHÃ! (4 estrofes)

P. 267:

Nota MA: v. 1-4 destacados por traço vertical - estudo da psicologia: mãe e irmã:

Se eu morresse amanhã, viria ao menos Fechar meus olhos minha triste irmã;

Minha mãi de saudades morreria, Se eu morresse amanhã!

P. 268:

Nota MA: correção a erro de impressão no v. 16 e cruzeta:

X Seư e/morresse amanhã! leu

P. 269-270

SONETO (4 estrofes)

P. 269:

Nota MA: trecho sublinhado nos v. 5 e 6 e traço vertical - estudo da psicologia: mãe e irmã:

$$
\begin{aligned}
& \text { E que doudo que eu fui! como eu pensava } \\
& \text { Em mãi, amor de irmã! em socegado }
\end{aligned}
$$

Nota da pesquisa: O poema é incluído no rol de sonetos românticos organizado por MA no plano da obra Lirismo romântico no Brasil (MA-MMA-26-04).

P. 271-364

O POEMA DO FRADE (5 cantos)

CANTO PRIMEIRO

P. 275:

Nota MA: termo sublinhado no v. 38, "peituga", e cruzeta - estudo do estilo: vocabulário:

Não sentes que a peituga te lateja? $\quad X$

P. 276:

Nota MA: v. 57-64 destacados por traço vertical e comentário: 
Quero a orgia que á noite desvaria,

Quando fresco o luar no céo fluctúa

E a vaga se pratêa de ardentia!

Perfumes, flôres, a vertigem sua

Vertendo no festim que me inebria!

Lasciva a dansa voluptuosa e nua

Nas rosas que desfolho trepidando!

Pagens louros as taças coroando!...

"Amor e medo / Notar / a falsi-/dade da / sensuali-/dade e / mesmo da sexua-/lidade nesItes versos, que / enfim voltam / ao desejo de dormir. / 'Dormir co'a lou-/ra' é verda-/de, mas a / propria re-/petição da / palavra, e / da imagem da / amada dormida / dão a importancia / e a significação / exata do verbo / aqui. É bem / dormir / ...o sono da inocencia. Aliás, ver es-/trofes XIX e XX ele faz logo depois a / apologia do sono."

Nota da pesquisa: MA assinala em muitos passos da obra de Álvares de Azevedo a tendência do eu lírico a resolver em imagens de sono o medo de amar, seja dormindo ele próprio, seja cantando o sono da mulher amada: "Foi esse o jeito que o rapaz descobriu pra disfarçar seu medo e evitar a coreografia do amor: durmamos! O sono é a mais original invenção do seu lirismo. Adora dormir." (ANDRADE, Mário de. "Amor e medo", In: Aspectos da literatura brasileira. Ed. cit., p. 223).

\section{P. 277-278:}

Nota MA: v. 65-87 destacados por traço vertical e termo sublinhado no v. 83, "dormir" estudo da psicologia: sono:

E as roupas onde o seio transparece, As formas crystallinas desenhando,

Collos onde o suor limpido desce

Nos seios como perolas rolando,

$\mathrm{E}$ as tremulas madeixas ondeando,

E a valsa que se agita e que resvala

E entre perfumes lubricos se embala...

Trovas cheias de amor, que afogão beijos,

E o afan a ondular os niveos seios,

O collar que na alvura se palleja,

E o olhar que enlanguesce nos enleios,

Vestes soltas ao fôgo dos desejos

E respirando os labios devaneios,

Amantes e o Xerez em taças bellas

E a embriaguez mais louca em meio d'ellas!...

E após ebrio de amor no frouxo leito,

Entre os aromas de esfolhadas flôres,

Quero dormir co' a loura peito a peito,

No labio o labio d'ella, as vivas côres

Quero as ver desmaiar n'um ai desfeito, 
Amal-a ao luar, viver de amores!

Ó noite! da illusão que a vida esquece

Que mais doce tremôr nos enlanguesce?

P. 279:

Nota MA: v. 112-117 destacados por traço vertical e expoente "(1)" remetendo ao comentário no rodapé:

Mas não vos pedirei perdão comtudo

Se d'esta canção negra não gostais...

Não penseis que me enterre em longo estudo

Por vossa alma fartar de outra harmonia:

Se varío no verso e ideias mudo

É que assim me desliza a phantasia...

“(1)"

“(1) Infelizmente si o verso varia a idea / não muda. Observar si A. A. não é vario denItro do mesmo assunto."

P. 280:

Nota MA: termo sublinhado no v. 120 e fio prendendo-o aos v. 123 e 124 - seleção de ideias: metáforas da crítica:

A critica é uma bella desgraçada

Que nada cria, nem jamais criara,

Tem entranhas de areia regelada,

É a esposa de Abrão, a pobre Sara

Que nunca foi por anjo fecundada,

P. 281:

Nota MA: v. 137-143 destacados por traço vertical e escólio "Sequestro" - ligação com a pesquisa de MA do tema do Sequestro da dona ausente no folclore brasileiro:

\begin{tabular}{l|} 
Aos fumos do charuto recendente \\
E do rhum nos vapores vem risonha \\
Nas scismas lhe dansar alegremente, \\
Esquecer-lhe a viagem enfadonha \\
A Andalusa gentil de labio ardente, \\
E embala-se em monotono descante \\
Sonhando os seios da morena amante!
\end{tabular} \mid

Nota da pesquisa: O termo "sequestro" cristaliza, na marginália, a convergência de projetos, aproximando a poesia romântica, erudita, da criação anônima do povo. Remete em primeiro lugar a $O$ sequestro da dona ausente, longa pesquisa de MA no âmbito do folclore luso-brasileiro, que investiga o encontro amoroso - frustrado pelas navegações e pela escassez de mulheres no Novo Mundo - como objeto de elaboração estética. Em paralelo, constitui versão autoral e aproximativa para o Verdrängung/refoulement, conceito psicanalítico que tem papel-chave em "Amor e medo". A circunstância cultural que dá origem à tópica da dona ausente é caracterizada por MA em artigo na revista Atlântico: "O mar todo-poderoso exige dos que lhe manejam o rito, viverem em castidade 
completa. Mas a saudade da mulher persegue o casto, o desejo dela o castiga demais. E o marujo, especialmente o lusitano que foi o maior dos navegadores, busca disfarçar o martírio nas imagens e nos símbolos da poesia. $\mathrm{O}$ folclore luso-brasileiro se enriqueceu, com isso, de uma série numerosa e admirável de quadrinhas e cantigas" (ANDRADE, Mário de. "A dona ausente". Atlântico, $\mathrm{n}^{\circ}$ 3. Lisboa/Rio de Janeiro, Serviço Nacional de Propaganda/ Departamento de Investigação e Propaganda, 1943, p. 9).

O dossiê da pesquisa, na série Manuscritos MA, abriga planos, esboços e notas prévias, num total de 1.221 documentos (MA-MMA-106). O f. 590 traz referência a esta página: "Sequestro // n 223 p 7". Ricardo Souza de Carvalho transcreveu e analisou o conjunto em Edição genética d'O sequestro da dona ausente de Mário de Andrade, Dissertação de Mestrado no Programa de Pós-graduação em Literatura Brasileira, FFLCH-USP, 2001.

P. 282:

Notas MA:

1. v. 170 sublinhado e primeira sílaba assinalada por retângulo - estudo da versificação: métrica/anacruse:

\section{No deserto lodaçal, em frio leito}

2. v. 173 e 174 sublinhados, marcação entre a terceira e a quarta sílabas e seta ligando as duas ocorrências da expressão "Um adeus" - estudo do estilo: artifício/repetição:

Um adeus á flor que se perdia,

Um adeus á lembrança do passado,

Nota da pesquisa: A anacruse assinalada no v. 171 justifica a referência a esta página no plano da obra Lirismo romântico no Brasil, como exemplo do "Modo de contar sílabas" de Álvares de Azevedo (MA-MMA-26-04).

P. 283:

Notas MA:

1. traço vertical duplo, à esquerda dos v. 176-183 - seleção de ideias: espontaneidade;

2. v. 183 sublinhado e expoente (1) remetendo ao comentário no rodapé;

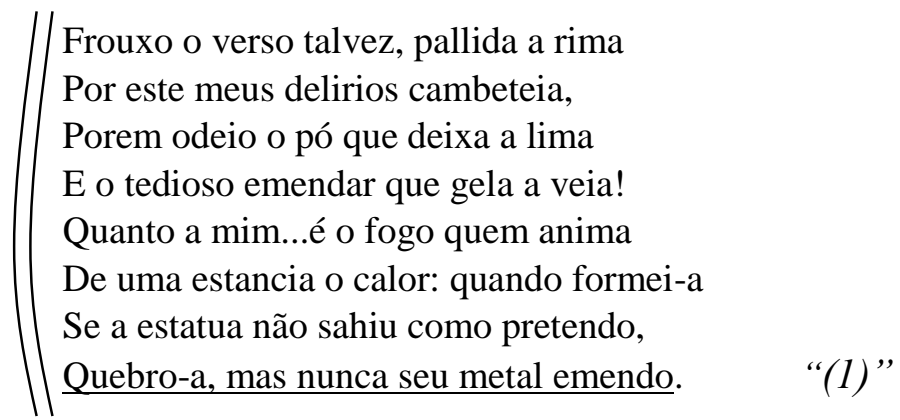

“(1) O que prova que não é a ignorancia a provo-/cadora da indigencia artistica do poeta."

P. 284: 
Nota MA: expressão sublinhada no v. 198 e comentário - seleção de ideias: epíteto:

"Excelente Nem Bocage d'esquina, vate immundo, expressão"

P. 285:

Nota MA: comentário entre as estrofes 28 e 29:

“...trespassado de golpes e de beijos... Que / estranha analogia com Bilac!”

P. 286:

Nota MA:

1. v. 238 e 239 destacados por traço vertical;

2. verbo e complemento sublinhados nos v. 238 e 239 - seleção de ideias / estudo da psicologia: pessimismo:

Preferia das noites na demencia

Boiar - como um cadaver! na existencia!

P. 287:

Notas MA:

1. termo sublinhado no v. 251 e escólio "dic" - pesquisa para o Dicionário musical brasileiro:

Sobre o peito a guitarra the gemia! dic

2. correção ao erro de impressão no v. 256, suprimindo o "s":

/ $\quad$ Os labios no\$ pallor que bafejavão...

3. pronome assinalado no v. 260 - estudo da versificação:

E a sua philosophia executava...

Nota da pesquisa: MA traslada o pronome marcado no v. 261 para o plano do livro Lirismo romântico no Brasil, último item no rol "Modo de contar sílabas" de Álvares de Azevedo (MA-MMA-26-04).

P. 288:

Nota MA: v. 271 destacado por traço vertical duplo - seleção de ideias / estudo da psicologia: biografia:

Mas não quero contar a minha vida. 
P. 289:

Notas MA:

1. v. 1-4 destacados por traço vertical e comentário;

2. expressão sublinhada no v. 3 - estudo da psicologia: amor e medo/mãe e irmã.

Dorme ao collo do amor, pallido amante, Repousa, sonhador, nos seios d'ella....

Amore

Qual em seio de mãi, febril infante! medo

No olhar, nos labios da infantil donzella

$[\ldots]$

"Amor e / medo / Reunir / isto ao / episodio da / cama da / mãi."

Nota da pesquisa: As referências à mãe assinaladas por MA, neste e em outros versos de Álvares de Azevedo, são reunidas em "Amor e medo", confirmando o plano registrado na marginália. No ensaio para a Revista Nova, MA embasa seu argumento no trecho em destaque: "Na descrição dos amores sexuais, Álvares de Azevedo ainda encontra repetidamente imagens de maternidade. Tanto no Poema do Frade, como na Glória Moribunda, a amante embala ao colo o rapaz morto. E, ainda no Poema do Frade, os versos dizem: [cita os v. 1-3] para repetir em seguida (I, p. 289 e 363), e com mais vigor, a mesmíssima ideia [...] A imagem foi tão grata, que a decorou e repetiu, plagiando-se." (“Amor e medo", In: Aspectos da literatura brasileira, ed. cit., p. 220 e 221). A alusão ao episódio da cama liga-se à Nota MA na p. 214, transcrita e anotada pela pesquisa.

P. 293:

Notas MA:

1. expoente "(1)” ao final da estrofe 8 , remetendo ao comentário no rodapé;

“(1) Alvares de Azevedo e a sua indiferença diante / da natureza. Só mesmo no Alto-daSerra, ante a pano vista / colossal se comoveu e descreveu."

2. termo sublinhado no v. 76 e fio prendendo-o ao comentário - estudo da psicologia: biografismo:

Maldizia no tedio a negra vida, $\quad$ O poeta não quer $[\ldots]$

"O poeta não quer / porem muito se des-/creve aqui como em / todo verso"

Nota da pesquisa: MA remete à indiferença de Álvares de Azevedo ante a natureza, segundo ele, no Diário Nacional, em 22 de março de 1931: "O monocronismo [dos românticos brasileiros] se manifesta mesmo por um lado curioso que creio inda ninguém observou: a falta de sentimento da natureza. Falam nela e alguns bastante, sei bem. Mas são incapazes de a sentir e a transmitir." (ANDRADE, Mário de. "Álvares de Azevedo II", in Táxi e Crônicas no Diário Nacional. São Paulo: Livraria Duas Cidades/Secretaria da Cultura, Ciência e Tecnologia, 1976, p. 361). 
Nota MA: expressão sublinhada no v. 96, cruzeta e remissão - estudo da psicologia: amada dormida:

$$
\begin{aligned}
& X \quad \text { Era tão bella assim... e ela dormia! } \\
& \text { " } p \text { 298”" }
\end{aligned}
$$

Nota da pesquisa: MA assinala a recorrência da imagem da amada dormida à p. 298, nos v. 159-160 do mesmo Poema do Frade: "Na sacada onde o vento se expandia / Candida e bella mulher ahi dormia!"”.

P. 296:

Nota MA: comentário à esquerda da estrofe 16 - estudo do estilo: investigação de matrizes:

Amar! amar e sempre! eternamente!

Como da infancia os tremulos desejos!

Amar, por que a alma se alimente

Na seiba do prazer que manão beijos!

Amar! como aos crepusculos do Oriente

A sultana das noites aos bafejos!

Amar! por que das convulsões do peito

A hora mais divinal se esvae no leito!

\section{"Este poema / é por / demais / inspirado / em / Rolla"}

Nota da pesquisa: "Rolla": poema de Alfred de Musset (1810-1857). A Biblioteca MA no IEB/USP abriga dois títulos do escritor francês: Oeuvres complètes. Nouvelle édition revue, corrigée et complétée de documents inédits, précédée d'une notice biographique sur l'auteur et suivie de notes par Edmond Biré (Paris: Garnier, n.d, 4v.), com anotações de leitura, e Choix de poésies de Musset (Rio de Janeiro: Americ-Edit, 1944). No vol. 1 das Obras completas, MA sublinha termos em específico e versos inteiros ("Comme elle est belle au soir, aux rayons de la lune", em Don Paez, IV), destaca passagens longas e apõe notas de margem. Em "Les marrons du feu", p. ex., escreve: "(1) Notar a extraordinaria liberdade do verso e os entroncamentos magistrais" (ed. cit., p. 35). No vol. 2, onde se encontra o poema "Rolla", MA não registrou marcas de leitura.

P. 297:

Nota MA: v. 145-152 destacados por traço vertical duplo - seleção de ideias:

Miserrimos de nós! Nossa existencia

O hoje abrange só, vermes de um dia!

Hontem foi de um anhelo a impaciencia

Um desejo fogoso que incendia!

E que importa amanhã seja a inclemencia

Á intemperie do ar, á noite fria?

Peregrinos! no barco adormeçamos...

Que em mar desconhecido navegamos!

P. 289: 


\section{Notas MA:}

1. traço vertical e cruzeta à esquerda dos v. 159-160;

2. expressão sublinhada no v. 160 - estudo da psicologia: amada dormida;

3. fio prendendo esta nota à outra, no v. 177:

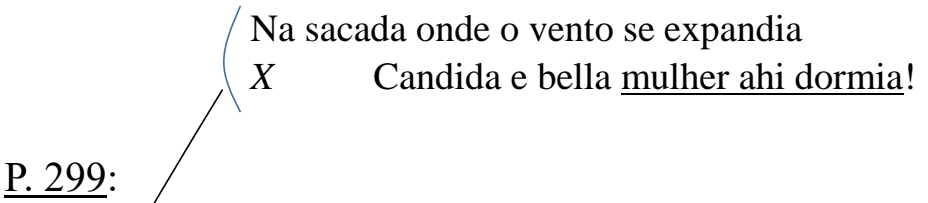

Notas MA:

1. trecho sublinhado no v. 177 e traço duplo à esquerda - seleção de ideias:

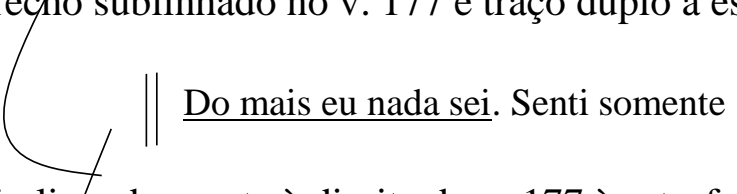

2. fio ligando a nota à direita do v. 177 à estrofe XXIV;

3. v. 185-190 destacados por traço vertical e anotação, "segue" - seleção de ideias:

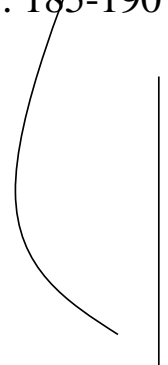

Depois o véo do leito estremecendo

Vi duas creaturas soerguidas,

Como dois anjos, pallidas gemendo!

Invocavão as virgens consumidas

Em desejos de amor, a Deus se erguendo:

As folhas que se beijão recendidas,

"segue"

\section{P. 300:}

Nota MA: v. 191-200 destacados por traço vertical - seleção de ideias:

Que palpitão á luz, e em fogo lento

Murchão de gozo ao halito do vento!

Mystico beijo se escoôu sentido,

Como de pombos candidos que adejão

O susurro de vôo estremecido!

E sobre os peitos que febris latejão

Suffocava-se o tumido gemido,

Como donzellas que de amor se beijão!

Almas cheias de vida! parecião

Que as vidas n'uma vida confundião!

\section{CANTO TERCEIRO}

P. 304:

Notas MA:

1. expressão sublinhada no v. 11 - seleção de ideias; 
2. número da estrofe corrigido, trocando "VI" por "IV" - correção tipográfica:

Quanto a mim, eu adoro a variedade

P. 306:

Notas MA:

1. v. 59 e 60 destacados por traço vertical - seleção de ideias;

2. termo sublinhado no v. 59, "harpa", e escólio "dic" - pesquisa para o Dicionário musical brasileiro:

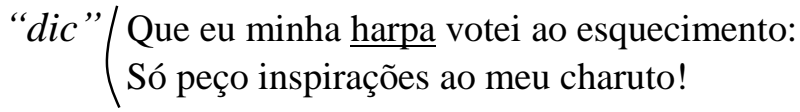

\section{P. 310:}

Notas MA:

1. v. 115-117 destacados por traço vertical - seleção de ideias;

2. verbo sublinhado no v. 116, "Revelas", e fio prendendo ao escólio na margem superior, "o charuto" - seleção de ideias:

\section{o charuto}

Por que n'essa illusão que a amar convida
Revelas a morena adormecida
A que banha pallor os doces traços,

Nota da pesquisa: Em “Amor e medo", MA confere um sentido psicológico à preferência por charutos: "Álvares de Azevedo fez tudo em suas obras, pra passar por libertino e farrista. Blasona de conhecedor dos vícios. Mas dentre os vícios escolhe o que não é vício: entre álcool e fumo, tem marcadíssima preferência pelo segundo, como demonstrou Luís da Câmara Cascudo pela Revista Nova (ano I, n. 3)" ("Amor e medo", In: Aspectos da literatura brasileira. Ed. cit., p. 204). Ao comentar o poema "Spleen e charutos", o autor do Dicionário do folclore brasileiro observa: "Raramente o poeta menino adota a divisa do Dom Juan que ele tanto cita, 'drink and love'. Quasi sempre dispensa o vinho e o substitui pelo fumo" (CASCUDO, Luís da Câmara. "Álvares de Azevedo e os charutos", in Revista Nova. Ano 1, no 3, p. 427).

P. 311:

Nota MA: repetição da conjunção sublinhada no v. 139 e fio prendendo as duas ocorrências - estudo linguístico: brasileirismo sintático:

Eu nấQ rio-me, não! a voz do peito

P. 315:

Nota MA: termo sublinhado no v. 213, "assonias", e escólio "dic" - pesquisa para o Dicionário musical brasileiro:

No murmurar das molles assonias "dic" 


\section{P. 317:}

Notas MA: v. 241-246 destacados por colchete, cruzeta e escólio “Amor e medo" - estudo da psicologia: amor e medo:

$X \quad$ Era uma estatua! sim: um deus a erguera N'um rir d'escarneo e dó, de lôdo cheia, Nem sol de amor o peito lhe accendera, "Amore O morto coração era de areia! medo" Como o céo nos crepusculos do dia, No vapor da vaidade ella dormia!

\section{P. 319:}

Nota MA: repetição da conjunção sublinhada no v. 275 e fio prendendo as duas ocorrências - estudo linguístico: brasileirismo sintático:

Não sabem, não! de Prometheo no leito

P. 320:

Nota MA: v. 301-306 destacados por traço vertical e escólio "Sequestro" - ligação com a pesquisa de MA do tema do Sequestro da dona ausente no folclore brasileiro:

“Sequestro" $\mid \begin{aligned} & \text { Mas que importa nas sombras da existencia } \\ & \text { Se mentiu-me o sonhar, quando eu sentia } \\ & \text { Um dos pallidos anjos do innocencia } \\ & \text { Pousar-me a face ao peito que gemia! ... } \\ & \text { Se n'um sonho de amor, em noite bella } \\ & \text { Nos suspiros do mar amei com ella! }\end{aligned}$

Nota da pesquisa: A rubrica "sequestro" entrelaça o interesse de MA pelo folclore e pela psicanálise. Vocábulo autoral, remete à hipótese defendida em $O$ sequestro da dona ausente, de que os marinheiros portugueses teriam sublimado a libido em cantigas, trovas, quadrinhas e outras formas de expressão oral - levados a tal sublimação pela circunstância da vida no mar. O processo identificado pelo escritor com base em suas leituras psicanalíticas é comentado pela pesquisa, em maior detalhe, na transcrição da marginália MA n'As Primaveras, de Casimiro de Abreu, denominado "poeta do sequestro" pelo escritor modernista (V. nota de trabalho no dossiê Sequestro da dona ausente, conservado no Arquivo do IEB/USP, MA-MMA-106-591).

P. 320-321:

Nota MA: v. 306-318 destacados por traço vertical e comentário - ligação com a pesquisa de MA do tema do Sequestro da dona ausente no folclore brasileiro:

Era uma lua pallida e sombria

Que seu leito nas ondas embalava!

Na mão de neve a face lhe pendia

E nos sonhos a virgem se enlevava!

E que estrellas no céo! e que ardentia! 
Que perfume seu véo estremecia!

E que sonhos, meu Deus! e que ventura!

E que vento de amores palpitava

$\mathrm{Na}$ escuma do batel a vaga pura

E lascivos suspiros the arrulhava!...

E em torno mar e céo, a noite bella,

Nos meus braços a inânida donzella!
"Ver nota

$[\ldots] "$

"Ver nota / p 325, que / explica esta / entrada oca-/sional e bem / tipica do Seques-/tro (como se-/questro) no / teor afobado do poema."

P. 325:

Nota MA: v. 391-396 destacados por colchete e expoente “(1)” remetendo ao comentário no rodapé - seleção de ideias: intertextos:

$\left.\begin{array}{l}\text { Onde vou? onde vou? Oh! quão diversos } \\ \text { Do meu trilho meus passos desvarião! } \\ \text { Onde correis, meus desgraçados versos?... } \\ \text { - A tempo os açaimei: onde corrião!?... } \\ \text { No phantastico pó que elles pisavão } \\ \text { Entre nuvens ardentes galopavão. }\end{array}\right]$

“(1) Como a prosa de A. de A. tambem to-/do este Poema do Frade possui uma li/berdade tematica extraordinaria. É/bem um Lautreamont, dum surrealis/mo avant-lalettre, dum surrealismo ainda ex-/cessivamente intelectual, mas já puramente associaItivo de imagens, sem principio meio nem fim, livre e, por assim dizer, incompreensivel (ver grifo / pg 352)”

Nota da pesquisa: MA resgata a comparação com o poeta franco-uruguaio Isidore Ducasse, Conde de Lautréamont (1846-1870), em nota de trabalho, no dossiê Amor e medo: "Realmente A. de A. embora falto da imaginação criadora dum Rimbaud, dum Lautréamont especialmente, embora cheio de reflexões às vezes inteligentes, e de ditosde-espírito admiráveis, tinha na sua prosa uma irreflexão, um fantasioso que não era apenas de moço mas de gênio. Ou de maluco, si quiserem." (MA-MMA-05-23). Tratando da prosa de Azevedo, em artigo no Diário Nacional, a 30 de agosto de 1931, MA comenta a aptidão daquele para o béstia acadêmico: "Dessas imagens, dessas visões eloquentes, Álvares de Azevedo havia de fazer mais tarde misturas e não integralmente esplêndidas de consciência, subconsciência e fulgor natural, em passagens que fazem lembrar Rimbaud e Lautréamont. (ANDRADE, Mário de. "Álvares de Azevedo - II", in Táxi e Crônicas no Diário Nacional. ed. cit., p. 422).

A Biblioteca de MA no IEB/USP conserva duas edições de Les chants de Maldoror (Paris: Ed. de la Sirène, 1920; Paris: Albert Skira, 1934); nenhuma delas com marcas de leitura. O volume de 1934 - edição de colecionador, numerado - traz a assinatura de Salvador Dalí, autor das 42 águas-fortes que acompanham o texto de Lautréamont. A nota dos editores observa: "Les cuivres ayant servi au tirage des illustrations ont été rayés par l'Artiste, en présence de l'Éditeur". A prática, característica 
das edições de luxo, é recomendada por MA ao amigo Murilo Miranda, quando este planeja publicar tiragens de colecionador na Editora Revista Acadêmica.

P. 326:

Nota MA: verbo sublinhado no v. 404 e cruzeta - estudo do estilo: vocabulário:

$$
\text { Vejo a morte n'um peito que se engoia... } \quad X
$$

\section{P. 328:}

Nota MA: termo sublinhado no v. 443 e escólio "dic" - pesquisa para o Dicionário musical brasileiro:

$$
\text { E sobre elle da noite a monodia "dic" }
$$

\section{CANTO QUARTO}

P. 334:

Nota MA: correção ao erro de impressão, realocando o v. 18 por meio de tracejado e fio:

Era a febre, o tremor, o beijo ardente...

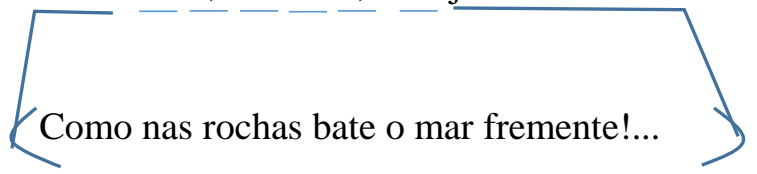

P. 337:

Nota MA: v. 61-66 destacados por traço vertical - estudo da psicologia: amada dormida:

Ella dormia: a rosa desmaiada,

Que a noite serenou, nem é tão pura

Nos molles véos da nevoa mergulhada!

Dos sonhos no frescor, na santa alvura

Era mais bella que de luz divina

A pallidez em nuvem peregrina.

P. 342:

Nota MA: termo sublinhado no v. 157, “entrebeijão" - estudo linguístico e psicológico: vocabulário:

Ás flôres que na morte se entrebeijão!

Nota da pesquisa: "Delicioso de pegajosismo", o verbo entrebeijar cauciona a percepção de MA quanto à obsessão romântica do beijo; é referido na Antepágina e à p. 1 deste volume (Notas MA, In: AZEVEDO, Álvares de. Obras. Ed. cit., vol. 1).

\section{CANTO Quinto}


P. 348:

Nota MA: v. 17 e 18 destacados por traço vertical - estudo da psicologia: sentimento amoroso:

Filho da dor! para esquecer a vida

Bastão os seios da mulher perdida!

P. 350:

Nota MA: termo sublinhado no v. 43, "cantilena", e escólio "dic" - pesquisa para o Dicionário musical brasileiro:

Os monotonos sons da cantilena "dic"

P. 352:

Nota MA: v. 91 e 92 sublinhados e cruzeta - estudo da psicologia: pessimismo:

É sombrio, confesso-vos, meu canto...

E obscuro demais, o que é defeito

P. 354:

Nota MA: termo sublinhado no v. 114 e cruzeta - estudo linguístico: emprego de "para/pra":

$X \quad$ Os filhos mortos p'ra cevar a fome!

P. 355:

Notas MA:

1. v. 135-138 destacados por traço vertical - estudo do estilo: realismo satírico:

Contemplando o luar e o mar dormente:

Poderá apanhar-te de repente

Fria constipação, febre amarella,

Ou alguma prosaica dor n'um dente.

2. v. 140 sublinhado e retângulo assinalando a falta de uma sílaba - estudo da métrica: irregularidade:

$$
\underline{\text { Vai, tu soffres, implorar sedento }}
$$

Nota da pesquisa: A edição crítica preparada por Péricles Eugênio da Silva Ramos difere do exemplar anotado por MA, grafando o v. 140 como "Vai, tu que sofres, implorar sedento" (Poesias completas; edição crítica de Péricles Eugênio da Silva Ramos; organização de Iumna Maria Simon (Campinas: Editora da Unicamp / São Paulo: Imprensa Oficial, 2002, p. 355).

P. 356:

Notas MA: 
1. v. 145-150 destacados por traço vertical e juízo de valor - estudo do estilo:

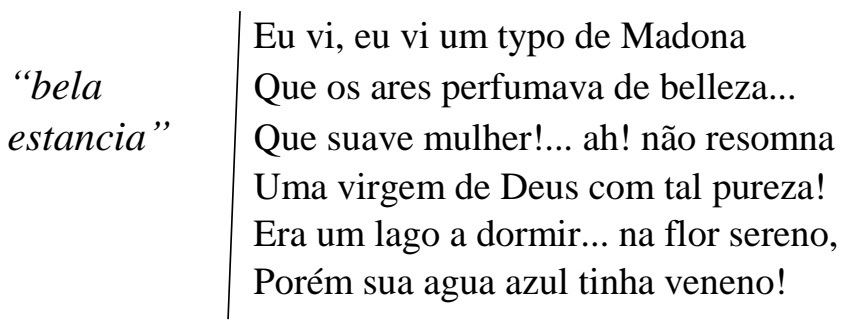

2. v. 151-162 destacados por traço vertical;

3. termo sublinhado no v. 162 e cruzeta - estudo linguístico: emprego de "para/pra";

3. v. 164 sublinhado e cruzeta - seleção de ideias: autoimagem;

4. v.168 destacado por parêntese triplo - seleção de ideias: poética;

5. verso sublinhado - seleção de ideias.

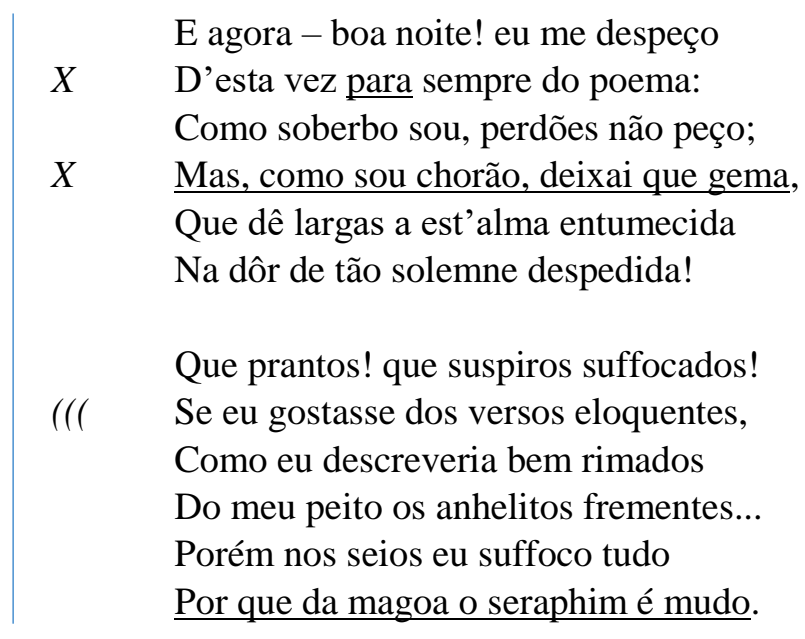

Nota da pesquisa: A página é arrolada entre as invocações que atestam a "Eloquência romântica" de Álvares de Azevedo e dos demais poetas estudados por MA, conforme rubrica no plano da obra Lirismo romântico no Brasil (MA-MMA-26-04).

\section{P. 357:}

Nota MA: v. 163-300 destacados por traço vertical:

Silencio, coração que a dor inflamma, Alem do escarneo, sons! quero o meu leito Das lagrimas banhar que a dor derrama! Quero chorar, quero chorar, meu peito! Dizer adeus ao sonho que eu sentira, Sem profanar as illusões na lyra!

Nota da pesquisa: Desde a estrofe 26, à p. 356, até o final do poema, à p. 364, todas os versos são assinalados, continuamente, por traço vertical de página inteira. Como a nota se prolonga de modo idêntico por oito páginas, as estrofes não são transcritas na íntegra, apenas no caso de os versos conterem outras marcações. 


\section{P. 358:}

Notas MA:

1. v. 181-198 destacados por traço vertical;

2. termo sublinhado no v. 182, "avendiços", e cruzeta - estudo do estilo: vocabulário:

Como o sopro dos ventos avendiços, $\quad X$

3. comentário junto à estrofe 32 - estudo de métrica e rima/estudo do estilo: identificação/atribuição de matrizes:

"Até a sextilha"Adeus!... é renunciar n'uma agonia

[...] A esperança que ainda nos palpita,

Sentir que os olhos cegão-se, que esfria

O coração na lagrima maldita,

Que inteirição as mãos e a alma afflicta,

Como Agar no deserto era sombria!

"Até a sextilha / com rimas discricionarias / na colocação, tão usada / por Musset, / Alvares de / Azevedo empre/ga."

P. 359:

Nota MA: v. 199-216 destacados por traço vertical.

P. 360:

Nota MA: v. 217-234 destacados por traço vertical.

P. 361:

Nota MA: v. 235-252 destacados por traço vertical.

P. 362:

Notas MA:

1. v. 253-270 destacadas por traço vertical;

2. termo sublinhado no v. 258, "nênia", e escólio "dic" - pesquisa para o Dicionário musical brasileiro:

"dic" De escravo á nenia estranha que soava

P. 363:

Nota MA:

1. v. 271-288 destacados por traço vertical;

2. v. 271-274 destacados por colchete e escólio "Amor e medo";

3. termo sublinhado no v. 271, "sonhei" - estudo da psicologia: sentimento amoroso;

4. v. 274 sublinhado - estudo da psicologia: mãe;

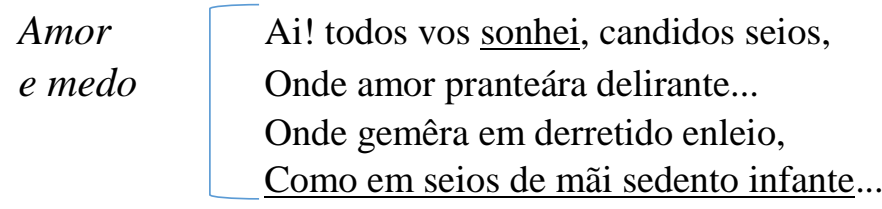


Nota da pesquisa: Os v. 271-274 são citados por MA em "Amor e medo", quando discorre sobre a recorrência de imagens de maternidade na poesia de Álvares de Azevedo ("Amor e medo", In: Aspectos da literatura brasileira, ed. cit., p. 221). A despeito de não conter remissão à página, uma nota de trabalho no dossiê do manuscrito "Castro Alves" liga-se ao trecho transcrito acima, esclarecendo o interesse do crítico no sublinhar o verbo "sonhei": "Alvares de Azevedo apesar da sensualidade de palavras e de (seios etc) e de gestos de amor que descreve permanece um idealista em amor. Mesmo na poesia. No que se diferencia bem de C. Alves." (MA-MMA-26-06).

\section{P. 364:}

Nota MA:

1. v. 289-300 destacados por traço vertical;

2. comentário ao final do poema:

"Todo êste final é admiravel de / suavidade, de expressão sentida e / natural, de verdade correntia. É / o que se salva do poema, na ver-/dade. 
AZEVEDO, Álvares de. Obras de Manoel Antonio

Bibl MA: [A/II/d/42]

Álvares de Azevedo precedidas do juizo critico de escriptores nacionaes e estrangeiros e de uma noticia sobre o auctor e suas obras por J. Norberto de S. S. 7. ed. Rio de Janeiro: Garnier, 1900. 3 v. [Poesia]

IEB: MA 869.908 A994o 7.ed v.2

\section{VOLUME 2}

\section{FOLHA DE GUARDA 2}

\section{Notas MA:}

1. anotação no alto, à direita, " $n^{\circ} 191$ ”, sinalizando a inclusão do volume na Bibliografia para Na pancada do ganzá;

2. recolha de verbetes para o Dicionário musical brasileiro e para a pesquisa Zoofonia, bem como cruzeta indicando o aproveitamento.

Dic-monodia 6-zoof sabiá 81-rabeca 85-/ harmonia 84-treno 97 - menestrel 111 - / bandolim 128-bronze 130-tuba 142 - nitris 154 - / nenia 164-rontó 195 - guizo 205 - viola 224 - / marimbau 229-soido 249-bandolim e guitarra con-/fundidos 325 e 326 - assonia 329 - violão 335 - / frata 335 - musica 28 - monodia 168 - / rabeca 240 - romance 284 - notas 298 - "

Notas da pesquisa:

1. O escólio “Zoof”, a grafite, de ocorrência frequente na marginália de MA, em todas as áreas de sua biblioteca, absorve a denominação de pesquisa encetada por Hercule Florence e colige matéria destinada ao projeto do escritor de reunir palavras e expressões representando as vozes dos animais. Liga-se, de imediato, ao manuscrito Zoofonia, reservatório e estudo particular desses termos, composto de documentos musicais, recortes de jornal e notas de trabalho, transcritas de publicações ou captadas em pesquisa de campo por MA e seus colaboradores. Em entrevista de 1943, MA filia seu projeto a Green Mansions: a Romance of the Tropical Forests, de William Henry Hudson (V. ANDRADE, Mário de. Entrevistas e depoimentos. Edição organizada por Telê Porto Ancona Lopez. São Paulo: T.A. Queiroz, 1983, p. 93).

"Zoof" prende-se, também, à coleta de termos para o Dicionário musical brasileiro e $O$ banquete, obra na área de Estética, interrompida pela morte de MA em 1945. Nesta, o capítulo 8 previa: "O Passeio em Pássaros. Zoofonia. O canto-enfeite no cio. A mulher vestida de homem e a Lei do Peso. Música da natureza e música descritiva." (V. ANDRADE, Mário de. O banquete. Ed. preparada por Jorge Coli e Luiz Dantas. São Paulo: Livraria Duas Cidades, 1977, p. 167).

2. O escólio "dic", a grafite, fartamente encontrado na marginália, nos títulos da poesia do romantismo brasileiro, indica a pesquisa de elementos para abonar verbetes no Dicionário musical brasileiro, projeto do escritor testemunhado em sua biblioteca, no manuscrito desse título e de outros, em seu arquivo e, na edição póstuma coordenada por Oneyda Alvarenga e Flávia Camargo Toni (Brasília: Ministério da Cultura/São Paulo: IEB-USP - Edusp/ Belo Horizonte: Editora Itatiaia Ltda, 1989). 


\section{FOLHA DE GUARDA 4}

\section{Notas MA:}

1. escólios e indicação de página;

2. comentário - planejamento do livro Lirismo romântico no Brasil:

"vaporenta 57, sobre Poesia 150, Aretino 216,

pra 134,216

órgia 252 ,

$\operatorname{pg} 128,171$,

Observar no Romantismo a transformação da mulher / da ninfa anterior em anjo do céu."

\section{P. $1-352$}

\section{LYRA DOS VINTE ANOS}

\section{P. 3-6}

\section{PREFACIOS}

P. 4:

Nota MA: parágrafo destacado por traço vertical duplo - seleção de ideias: binomia:

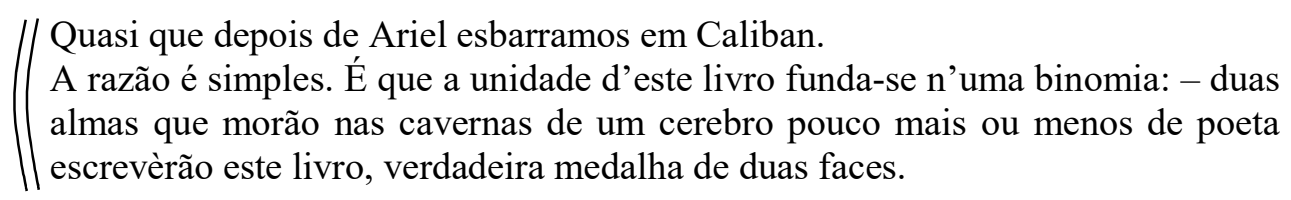

\section{P. 5:}

Nota MA: parágrafo destacado por traço vertical triplo - seleção de ideias: concepção de poesia:

\footnotetext{
O poeta acorda na terra. Demais, o poeta é homem: Homo sum, como dizia o celebre Romano. Vê, ouve, sente e, o que é mais, sonha de noite as bellas visões palpaveis de acordados. Tem nervos, tem fibra e tem arterias - isto é, antes e depois de ser um ente idealista, é um ente que tem corpo. E, digão o que quizerem, sem esses elementos, que sou o primeiro a reconhecer muito prosaicos, não ha poesia.
}

Nota da pesquisa: O último verso de "Carnaval Carioca" (1923) dialoga com a fórmula de Álvares de Azevedo no "Prefácio" - "Vê, ouve, sente e, o que é mais, sonha de noite as bellas visões palpaveis de acordados". Após gozar sensualmente a folia dos blocos, o eu lírico descansa em dia consigo mesmo: "Então o poeta vai deitar. // Lentamente se acalma no país das lembranças / A invasão furiosa das sensações. / O poeta sente-se mais seu. / E puro agora pelo contato de si mesmo / Descansa o rosto sobre a mão que escreverá. // Lhe embala o sono / A barulhada matinal de Guanabara... / Sinos buzinas clácsons campainhas / Apitos de oficinas / Motores bondes pregões no ar, / Carroças na rua transatlânticos no mar... / É a cantiga-de-berço. / E o poeta dorme. // O poeta dorme 
sem necessidade de sonhar." (ANDRADE, Mário de. "Carnaval Carioca", In: Clã do jabuti. Poesias completas. Ed. cit., vol. 1, p. 224 e 225).

P. 6:

Notas MA:

1. trecho destacado por traço vertical duplo - seleção de ideias:

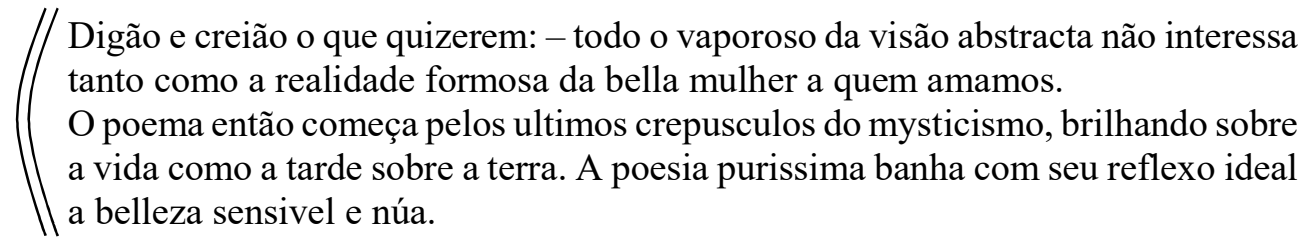

2. trecho sublinhado e escólio "dic" - seleção de ideias: dualidade / pesquisa para o Dicionário musical brasileiro:

"dic" $\quad$ Nos mesmos labios onde suspirava a monodia amorosa, vem a satyra que morde.

\section{$\underline{\text { P. } 7}$}

\section{Á MinHA MÃI}

Nota da pesquisa: Mãe e irmã teriam sido "os estímulos familiares" de Álvares de Azevedo - postula MA em "Amor e medo". A dedicatória do livro embasa a análise do crítico: "A mãe é que o obseca furiosamente. E variadamente. À mãe ele dedica a Lira dos vinte anos, e o faz em versos de grande importância psicológica, indicando que o livro oferecido é a volta do poeta ao seio materno, pela imagem da árvore cujas flores esfolhadas tombam sobre o chão que deu vida a ela. Essa aspiração de retorno ao seio materno me parece fundamentalmente característica da matéria psicológica de Álvares de Azevedo. Complexo de Édipo, dirão os psicanalistas... Mas a mãe de Álvares de Azevedo entrou também no jogo muito... Talvez menos inocentemente do que era lícito esperar daquele tempo discreto." MA evoca, na sequência, o "importante caso da cama", narrado por Domingo Jacy Monteiro no vol. 1 - a mãe de Álvares de Azevedo teria sonhado com a morte do poeta no leito dela, e feito a ele o relato. Em menos de três meses, segundo a anedota, ela assiste à confirmação do pesadelo. Ancorado na leitura de Freud, MA avança a interpretação dele para o episódio: "Não me parece possível, diante de certas noções contemporâneas de psicologia, aceitar como simples dados de sentimentalismo romântico os pormenores que dei desse caso. Tanto mais ajuntando-se a isso a dedicatória de Lira dos vinte anos. Aceitemos lealmente, com Joaquim Norberto, que tanto a mãe como o filho, foram vítimas de seus puríssimos amores". Depois de caucionar sua interpretação com diversos trechos do autor de Macário, conclui: "Por tudo isso percebe-se que o amor pela mãe era, si não anormal, pelo menos absolutamente excessivo e obsecante em Álvares de Azevedo. É o seu delírio, a sua maior elevação consciente, o seu maior gozo inconsciente, a razão mais importante da sua inexperiente rapazice." (ANDRADE, Mário de. "Amor e medo", In: Aspectos da literatura brasileira. Ed. cit., p. 219-220).

P. $9-144$

PRIMEIRA PARTE 
P. 9-12

NO MAR (9 estrofes)

P. 9:

Nota MA: escólio e comentário junto à primeira estrofe - estudo da psicologia:

Era de noite: - dormias

"Amor e medo

Do sonho nas melodias, (todo o poema)"

Ao fresco da viração,

Embalada na falua,

Ao frio clarão da lua,

Aos ais do meu coração!

P. 10:

Nota MA: v. 22-24 destacados por traço vertical e comentário:

$\left(\begin{array}{l}\text { Que a vida que se bebia } \\ \text { Na noite que parecia } \\ \text { Suspirar de sentimento! }\end{array}\right.$

\section{"Parece Catullo / Cearense"}

Nota da pesquisa: A Biblioteca de MA conserva um título apenas de Catulo Cearense, Cantor de modinhas brasileiras (Rio de Janeiro: Quaresma, 1927), sem notas de margem. MA também relaciona Catulo Cearense a Castro Alves, no corpus da pesquisa, em anotação de margem no poema "Tyrana", confirmada no ensaio sobre o poeta baiano para a Revista do Brasil: "Castro Alves antecipa nitidamente Catulo Cearense, e não foi à toa que este cantador, também genial nos seus primeiros livros, lhe pôs música à Tirana." ("Castro Alves", In: Aspectos da literatura brasileira, ed. cit., p. 114)

P. 9-12

NO MAR (9 estrofes)

P. 11:

Nota MA: v. 55-60 destacados por traço vertical - estudo da psicologia:

Como virgem que desmaia,

Dormia a onda na praia!...

Tua alma de sonhos cheia

Era tão pura, dormente,

Como a vaga transparente

Sobre seu leito de areia!

$\underline{\text { P. } 13-16}$

SONHANDO (9 estrofes)

P. 15:

Nota MA: v. 33-48 destacados por colchete - estudo da psicologia: amada dormida: 
Deitou-se na areia que a vaga molhou.

Immovel e branca na praia dormia;

Mas nem os seus olhos o somno fechou

E nem o seu collo de neve tremia...

O seio gelou?...

Não durmas assim...

O' pallida fria,

Tem pena de mim!

Dormia: - na fronte que niveo suar...

Que mão regelada no languido peito...

Não era mais alvo seu leito do mar,

Não era mais frio seu gelido leito!

Nem um resomnar...

Não durmas assim...

O pallida fria.

Tem pena de mim!

P. $17-18$

SCISMAR (4 estrofes)

P. 17:

Nota MA: v. 2 assinalado por expoente “(1)”, remetendo ao comentário no rodapé:

Ai! quando de noite, sózinha á janella,

Co’ a face na mão te vejo ao luar, "(1)”

“(1) Verso de 10 silabas porém ritmado / como onze, coisa que Gui e eu faze-/mos. Citar tese Ritmo de Gui pg 22 ”

Notas da pesquisa:

1. Gui: Guilherme de Almeida. A Coleção MA na Biblioteca do IEB/USP conserva dezessete títulos do destacado poeta do movimento modernista. O exemplar de Encantamento (São Paulo: Livraria do Globo, 1925), sem notas de margem, traz a dedicatória: "Mario - muito ás pressas, pra / você ler em viagem e pensar mui-/to em nós: Baby, Guy e eu. / [assinatura] Guilherme / S. Paulo, 3.VI.1925". No corpus da pesquisa, Guilherme de Almeida também é aludido na leitura de MA do poema IX da Juvenília, de Fagundes Varela (V. Nota MA em Obras completas de L. N. Fagundes Varella. Rio de Janeiro/Paris: Garnier, 1919, v. 1, p. 27), e de "Rosa murcha", de Casimiro de Abreu (V. Nota MA em ABREU, Casimiro J. M. de. As primaveras: com poesias inéditas do autor, o juízo crítico de diferentes escritores e um prólogo por F. D. Ramalho Ortigão. Porto: Livraria Chardron, 1909. $3^{\text {a }}$ ed., p. 23). Trata-se de ligação importante, referendando uma preocupação do leitor em aproximar duas estéticas. Em 9 de março de 1930, nas páginas do Diário Nacional, MA celebra a eleição do amigo para a Academia Brasileira de Letras e discorre sobre sua obra: "No momento presente, não vejo na literatura brasileira, uma organização mais integral de poeta que a dele: lirismo, grande faculdade imaginativa, artista incomparável. Personalidade fixa, nenhuma vagueza psicológica, cultura adequada e aquele pingo ácido de liberdade em relação aos homens e às coisas, que é parte pela qual os poetas verdadeiros são incomensuráveis pro metro humano." (ANDRADE, Mário de. "Guilherme de Almeida", in Táxi e Crônicas no Diário Nacional. Estabelecimento 
do texto, introdução e notas de Telê Porto Ancona Lopez. São Paulo: Livraria Duas Cidades/Secretaria da Cultura, Ciência e Tecnologia, 1976, p. 194).

2. O exemplar da tese de Guilherme de Almeida - Rhytmo: elemento de expressão - não contém notas de margem na p. 22, que apresenta as seguintes considerações: "Rhytmo bem entendido, rhytmo puro, não apenas 'metro'. Que o rhytmo, quando verdadeiro, isto é, quando da idéa e da expressão a um tempo, é superior ao metro, não se prende dentro do estricto rigorismo de um certo numero de syllabas ou de uma certa accentuação. Prova: - nos 'enjambements' bem feitos, o rhytmo persiste imbricando os versos; é a continuidade da idéa. // E o rhytmo póde mais que o metro, pois consegue, illudindo o ouvido, dar a idéa de qualquer verso metrificado, sem o ser, isto é, sem o numero mathematico das syllabas precisas nem a invariabilidade do accento. Exemplo: Imitação, pelo rhytmo, do verso de 11 syllabas: METRO: - Sou india, sou virgem, sou linda sou debil - / E' quanto vós outros, ó tapes, dizeis... (11 syllabas) // RHYTMO: - As galéras guerreiras que vieram de longe (12 syllabas) / cravavam no céo os mastros audazes (10 syllabas) / e fincavam nas aguas a espora de bronze... (12 syllabas)" (ALMEIDA, Guilherme de. Rhytmo: elemento de expressão. São Paulo: Garraux, 1926).

P. 18:

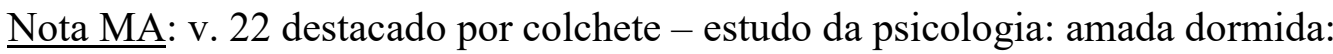

Acorda! não durmas da scisma no véo!

$\underline{\text { P. } 21-25}$

ANJINHO (14 estrofes)

P. 23:

Nota MA: termo sublinhado no v. 46, "c'roada", e cruzeta - estudo linguístico: emprego de "coroa/c'roa":

Alguma estrella perdida,

Do céo c'roada donzella... $\quad X$

P. 24:

Notas MA:

1. v. 71 e 72 destacados por traço vertical e indagação - estudo do estilo: linhagens:

"Origem de $\quad$ ( Pelo astro ou a donzella,
Bilac?"

2. correção a erro de impressão no v. 76, substituindo o artigo:

"/a" Chora $\Theta$ onda quando vê

P. 25:

Nota MA: termo sublinhado no v. 77, "irerê", e escólio “(Brasil)” - estudo do estilo: vocabulário / imagem brasileira:

A boiar uma irerê "(Brasil)"

Morta ao sol do meio-dia? 
P. 26-27

ANJOS DO MAR (5 estrofes)

P. 26:

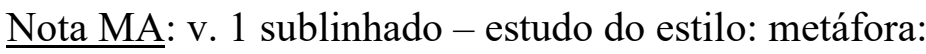

As ondas são anjos que dormem no mar...

Que tremem, palpitão, banhados de luz...

P. 27:

Nota MA: v. 17-20 destacados por colchete e escólio "Sequestro" - ligação com a pesquisa de MA do tema do Sequestro da dona ausente no folclore brasileiro:

Ai! quando tu sentes dos mares na flôr

Os ventos e vagas gemer, palpitar...

"Sequestro"

Porque não consentes, n'um beijo de amor,

Que eu diga-te os sonhos dos anjos do mar?

Nota da pesquisa: O termo "sequestro" cristaliza, na marginália, a convergência de projetos, aproximando a poesia romântica, erudita, da criação anônima do povo. Remete em primeiro lugar a $O$ sequestro da dona ausente, longa pesquisa de MA no âmbito do folclore luso-brasileiro, que investiga o encontro amoroso - frustrado pelas navegações e pela escassez de mulheres no Novo Mundo - como objeto de elaboração estética. Em paralelo, constitui versão autoral e aproximativa para o Verdrängung/refoulement, conceito psicanalítico que tem papel-chave em "Amor e medo". A circunstância cultural que dá origem à tópica da dona ausente é caracterizada por MA em artigo na revista Atlântico: "O mar todo-poderoso exige dos que lhe manejam o rito, viverem em castidade completa. Mas a saudade da mulher persegue o casto, o desejo dela o castiga demais. E o marujo, especialmente o lusitano que foi o maior dos navegadores, busca disfarçar o martírio nas imagens e nos símbolos da poesia. $\mathrm{O}$ folclore luso-brasileiro se enriqueceu, com isso, de uma série numerosa e admirável de quadrinhas e cantigas" (ANDRADE, Mário de. "A dona ausente". Atlântico, no 3. Lisboa/Rio de Janeiro, Serviço Nacional de Propaganda/ Departamento de Investigação e Propaganda, 1943, p. 9).

O dossiê da pesquisa, na série Manuscritos MA, abriga planos, esboços e notas prévias, num total de 1.221 documentos (MA-MMA-106). O f. 590 traz referência a esta página: "Sequestro // n 223 p 7". Ricardo Souza de Carvalho transcreveu e analisou o conjunto em Edição genética d'O sequestro da dona ausente de Mário de Andrade, Dissertação de Mestrado no Programa de Pós-graduação em Literatura Brasileira, FFLCH-USP, 2001.

P. 28-30

[SEM TÍTULO] (6 estrofes)

P. 28:

Notas MA:

1. verbo sublinhado no v. 4, "geme" e "gemias", e fio ligando-os - estudo do estilo: artifício/repetição / estudo da psicologia: sentimento amoroso: 
Tenho um seio que delira

Como as tuas harmonias!

Que treme quando suspira

Que geme como gemias!

2. termo sublinhado no v. 5, "musicas", e escólio "dic / (no sentido / de peça mu-/sical)" - pesquisa para o Dicionário musical brasileiro:

"dic Tenho musicas ardentes

(no sentido Ais do meu amor insano,

de peça $\mathrm{mu}^{-} \quad$ Que palpitão mais dormentes

sical"

Do que os sons do teu piano!

P. 31-35

A CANTIGA DE SERTANEJo (16 estrofes)

P. 33:

Nota MA: v. 43-45 destacados por colchete - estudo da psicologia: sentimento amoroso/amada dormida:

Se viesses innocente
Adormecer docemente
A noite no peito meu!...

P. 34:

Notas MA:

1. termo sublinhado no v. 53, "amor" e "amores", fio ligando-os e expoente "(1)", remetendo ao comentário no rodapé - estudo do estilo: artifício/repetição:

Bebendo amor nos amores

Das borboletas azues! "(1)”

“(1) Na Lyra dos 20 Anos Alvares de A. é mais / trabalhado. Eé pena. Estes $1^{\circ}$ s poemas são bem / inferiores aos do $1^{\circ}$ livro."

2. termo sublinhado no v. 61, "donzella", e comentário - estudo da psicologia: figuração da mulher:

Ah! se viesses, donzella,

"Donzella por

Verias que a vida é bella

toda a parte"

No silencio do sertão!

3. v. 67-72 assinalados pelo escólio "Irmã" - estudo da psicologia: sentimento amoroso/irmã:

Junto ás agoas da torrente

Sonharias indolente

"Irmã " Como n'um seio d'irmã!...

- Sobre o leito de verduras

$\mathrm{O}$ beijo das creaturas 
Suspira com mais afan!...

Nota da pesquisa: O trecho marcado pelo escólio é transposto para "Amor e medo": "Também confunde irmã e amada (II, 34)" (In: Aspectos da literatura brasileira. Ed. cit., p. 221).

P. 35:

Nota MA: comentário ao final do poema:

"Tudo isto é falso sob o ponto-de-/vista brasileiro quanto mais sertanejo. / Alias Azevedo é mesmo muito menos brasi-/lico que Casemiro e C. Alves."

\section{P. 36-37}

[SEM Título] (6 estrofes)

P. 36-37:

Notas MA: v. 5-12 destacados por traço vertical e expoente "(1)", remetendo ao comentário no rodapé:

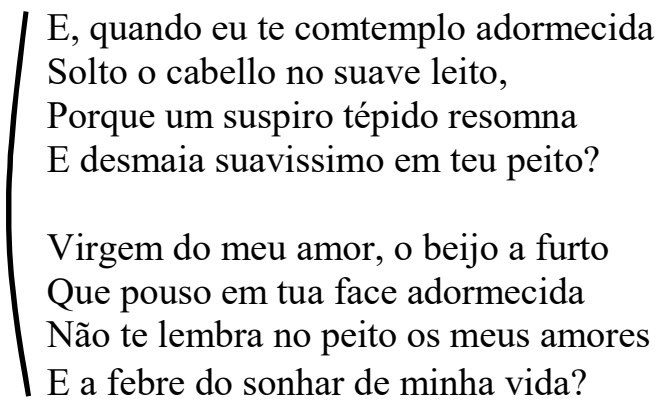

$$
\text { “(1)” }
$$

“(1) Nesta estrofe resultante do tema / Amor e Medo, repete A. de A. uma / idea que é constante nele: beijar a / amada dormida. Sequestro do amor. / Azevedo foi um timido? A constante / audacia dos amores versificados dele, a / sensualidade aparatosa dos seus versos / poderiam provar que sim... (pg 62)"

Nota da pesquisa: No ensaio para a Revista Nova, ao tratar da ênfase com que Álvares de Azevedo cria imagens da amada dormida, MA converte o comentário - a princípio interrogativo - em afirmação, mencionando o poema: "A imagem da amada dormindo pode-se dizer que é toda a obra de Álvares de Azevedo, tão abundantemente frequenta qualquer criação dele. Uma poesia ele dedica exclusivamente a essa imagem (II, 36)" (ANDRADE, Mário de. "Amor e medo", In: Aspectos da literatura brasileira. Ed. cit., p. 210).

$\underline{\text { P. } 38-41}$

O POETA (10 estrofes)

P. 38:

Nota MA: v. 1 e 2 destacados por traço vertical, presos por fio aos v. 7-9, também destacados por traço vertical, e comentário: 


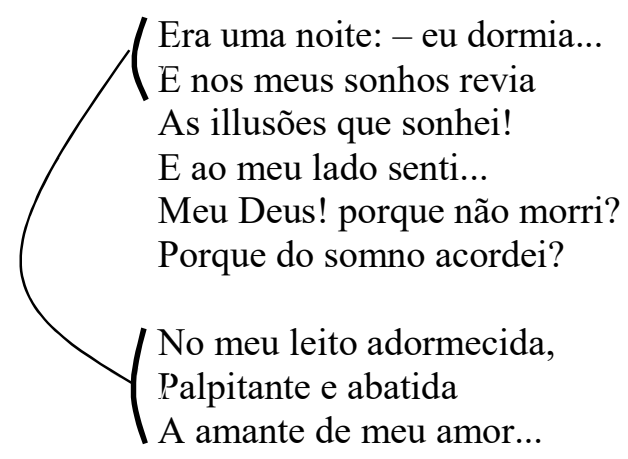

"O sequestro é tão / fixo que o poeta / chega a dormindo / sonhar com a / amada dor-/mida!!"

\section{P. 39:}

Notas MA:

1. v. 19-24 assinalados pelo expoente “(1)”, remetendo ao comentário no rodapé:

Não era um sonho mentido
Meu coração illudido
O sentiu e não sonhou...
E sentiu que se perdia
N'uma dôr que não sabia
Nem ao menos a beijou! (1)",

"A contemplação da amada ador-/mecida é incontestavelmente uma / das sensualidades do poeta. 3 vezes já / nesta Lira dos 20 Anos. I

2. fio ligando o comentário no rodapé a seu complemento na lateral:

e aparece no $1^{\circ}$ volume tambem várias ve-/zes. procura-las.

\section{P. 42-45}

[SEM TítUlo] (12 estrofes)

P. 45:

Nota MA: ilegível; apagada.

\section{P. 46-49}

[SEM TÍTULO] (15 estrofes)

\section{P. 47:}

Nota MA: v. 13-16 destacados por colchete e escólio “Amada dormida" e verbo destacado no v. 16 , "descançar-me" - estudo da psicologia: sentimento amoroso/amada dormida:

Talvez terias dó da magoa insana Que minh'alma votou ao desalento... E consentiras, ó virgem dos amores,
"Amada / dormida" 
Descançar-me no seio um só momento!

Nota da pesquisa: Os v. 15 e 16 convergem para "Amor e medo", onde são citados na íntegra, de modo a reforçar o argumento de MA de que a imagem da amada dormindo é "toda a obra de Álvares de Azevedo" (ANDRADE, Mário de. "Amor e medo", In: Aspectos da literatura brasileira. Ed. cit., p. 225).

P. 48:

Notas MA:

1. v. 29-32 destacados por colchete e escólio "Amada dormida" - estudo da psicologia: sentimento amoroso/amada dormida:

"Amada $\begin{aligned} & \text { dormida } \\ & \text { A meu peito juntei que amor definha! } \\ & \text { A furto apenas eu senti medrosa } \\ & \text { Tua gelida mão tremer na minha!... }\end{aligned}$

2. termo sublinhado no v. 40, "criança", e escólio "Criança prá amada" - estudo da psicologia: figuração da mulher:

Não queria callar-se a um beijo d'ella,

Nos seios d'essa pallida criança! "Criança prá / amada"

Nota da pesquisa: MA cita os v. 29-32 em "Amor e medo"; ilustram o argumento de que o tremor seria sintoma do medo de amar, projetado na mulher: "Nas Saudades, a imagem da estrela faz ele sentir que a alma da amada está tremendo (...) ao que ajunta ainda o tremer das mãos dela, nas estrofes do Quando falo contigo... (ANDRADE, Mário de. "Amor e medo", In: Aspectos da literatura brasileira. Ed. cit., p. 211).

P. 49:

Nota MA: comentário ao final do poema:

"Notar que a ritmica do decassilabo / neste poema é clássica e não roman-/tica. Observar nos outros poemas / pra ver si A. A. conservou-se na / ritmica decassilaba classica."

\section{$\underline{\text { P. 50-55 }}$}

NA MiNHA TERRA (23 estrofes)

\section{P. 55:}

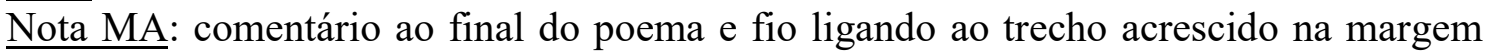
superior:

“A. de Azevedo é um genio em perspectiva. Rara-/mente conseguiu realizar-se. O Não é como Casemiro, G. Dias / e Castro Alves que dexam de si expressões totais. E nisso / A. de Azevedo é muito inferior aos outros embora se / pressinta nele um <ilegível> de lirismo formidavel. / Si raramente ele chega mesmo a ser legivel como / nesta embalada e tão gostosa Minha terra: É por / excelencia o poeta cantor. O feitio amoroso dele, duIma banalidade absoluta de perspectiva na modi-/nha chorosa de hoje em dia e que dá

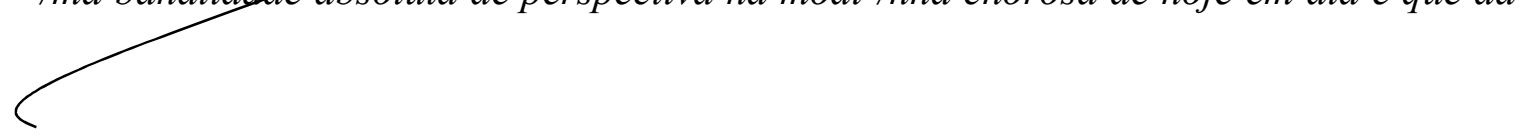


de vez em / quando expressões tão perfeitas e maravilhosas como / 'a flor que melindrosa se balança' ou como a / tão conhecida Casa branca da Serra"

"Ele não tinha siquer a pa-/ciencia da beleza que foi bem / consciente em G. Dias, C. Alves, e / Varela."

$\underline{\text { P. } 56-60}$

ITALIA (20 estrofes)

P. 57:

Nota MA: termo sublinhado no v. 23, "vaporentas" - estudo do estilo: vocabulário:

Nas tardes vaporentas se perfuma

E dorme, á noite, na illusão da vida!

P. 58:

Nota MA: expressão sublinhada no v. 41, "terra da harmonia", e fio ligando ao escólio no rodapé - pesquisa para o Dicionário musical brasileiro:

Ama-te o sol, ó terra da harmonia!

Do levante na briza te perfumas,

Nas praias de ventura e primavera

Vae o mar estender seu véo d'escumas!

"por musica"

P. 60:

Nota MA: comentário ao final do poema:

"Notar a diferença do burguesismo de Casemiro / prá da tendencia prá nobreza de pensamento de / A. de Azevedo. Só tendencia alias que possivel-/mente ficou apenas num esmartismo de ideas / e desejos. Esta poesia é linda. A evocação da / Italia na $2^{a}$ parte é o que ha de mais roman-/ticamente falso e lugar-comum porém / está admiravelmente dita."

$\underline{\text { P. } 61-63}$

A T... (4 estrofes)

P. 62:

Nota MA: trecho sublinhado no v. 23, "um anjo que dorme", expoente "(1)", cruzeta e fio ligando ao comentário no rodapé:

Estrella do mysterio! em tua fronte

Os céos revela e mostra-me na terra...

$X$ "(1)" Como um anjo que dorme, a tua imagem

$E$ teus encantos, onde o amor estende

N'essa morena tez a côr de rosa.

“(1) Amada dormindo e p 76”

P. 63: 
Nota MA: comentário ao final do poema:

"Belo poema. A estranha / sinceridade que se sente / lendo-o."

P. 64-67

CREPUSCULO DO MAR (15 estrofes)

P. 66:

Nota MA: correção ao erro de impressão, separando os termos no v. 43, "rúbida bandeira":

Floreando ao vento a rúbida/bandeira,

P. 68-72

CREPUSCULO NAS MONTANHAS (16 estrofes)

S/Nota MA

$\underline{\text { P. 73-74 }}$

DESALENTO (8 estrofes)

P. 73:

Nota MA: v. 1 e 2 assinalados por traço vertical triplo e comentário - estudo da psicologia: projeção:

$$
\begin{gathered}
\text { (\( Feliz d'aquelle que no livro d'alma } \\
\text { Não tem folhas escriptas } \\
\text { E nem saudade amarga, arrependida, } \\
\text { Nem lagrimas maldictas! }
\end{gathered}
$$

\section{"Parece que éo caso dele exa-}

$$
\text { to." }
$$

P. 73:

Nota MA: v. 17 e 18 assinalados por traço vertical e escólio "dormir" - estudo da psicologia: sentimento amoroso/dormir:

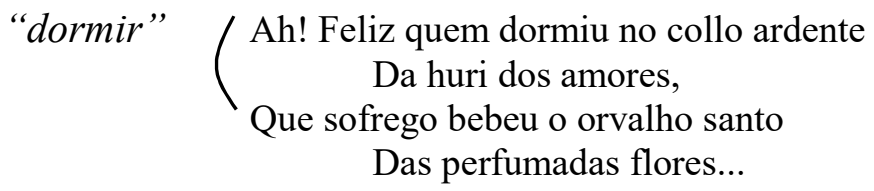

Nota da pesquisa: Os v. 17-20 são transpostos integralmente para "Amor e medo", de maneira a indicar a fuga da realização sexual por meio de imagens de sono, seja do eu lírico, seja de sua amada (ANDRADE, Mário de. "Amor e medo", In: Aspectos da literatura brasileira. Ed. cit., p. 224).

$\underline{\text { P. } 75-76}$

PALLIDA INNOCENCIA (5 estrofes)

P. 73: 
Nota MA: v. 22-24 destacados por traço vertical, expoente "(1)" e fio ligando ao comentário no rodapé:

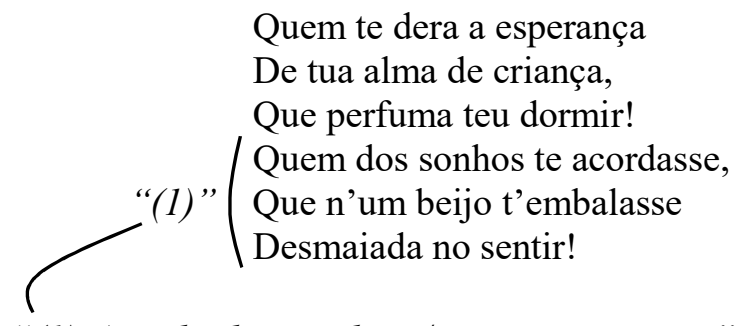

"(1) Amada dormindo e / veja pg seguinte"

\section{P. 77}

SONETO (5 estrofes)

P. 77:

Notas MA:

1. título assinalado por três cruzetas e expoente "(1)", remetendo ao comentário no rodapé;

2. v. 5 e 6 destacados por traço vertical e escólio "Sequestro" - ligação com a pesquisa de MA do tema do Sequestro da dona ausente no folclore brasileiro:

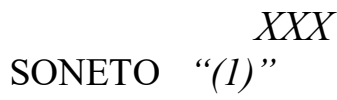

Pallida, á luz da lampada sombria,

Sobre o leito de flores reclinada,

Como a lua por noite embalsamada,

Entre as nuvens do amor ella dormia!

Era a virgem do mar! na escuma fria

Pela maré das agoas embalada

- Era um anjo entre nuvens d'alvorada

"Sequestro"

Que em sonhos se banhava e se esquecia!

“(1) Aqui a amada dormindo dá pro / poeta uma obra-prima. Estuda-/la. Segue pg 80”

P. 78-83

ANIMA MEA (14 estrofes)

P. 79:

Notas MA: v. 15-30 destacados por colchete e escólio "dormir" - estudo da psicologia: sentimento amoroso/dormir:

É doce então das folhas no silencio

Penetrar o mysterio da floresta,

Ou reclinado á sombra da mangueira

Um momento dormir, sonhar um pouco!

Ninguem que turve os sonhos de mancebo,

Ninguem que o indolente adormecido

Roube das illusões que o acalentão

"dormir" 
E do molle dormir o chame á vida!

E é tão doce dormir! é tão suave

Da modorra no collo embalsamado

Um momento tranquillo deslizar-se!

Creaturas de Deus se peregrinão

Invisiveis na terra, consolando

As almas que padecem... certamente

Que são anjos de Deus que aos seios tomam

A fronte do poeta que descança!

Nota da pesquisa: Em “Amor e medo", MA cita parte dos versos assinalados em "Anima mea" (v. 18-24 e v. 29-30) para caracterizar dois aspectos psicológicos atribuídos por ele à poesia de Álvares de Azevedo: a recorrência do sono e a fixação na mãe, ambas manifestações do suposto medo de amar do poeta. O crítico indica, no ensaio, "as imagens maternas que também neste passo frequentam o desejo do poeta", grafando-as em destaque: "que o acalentam", "no colo", "que aos seios tomam". Arremata, assim, o raciocínio: "E se observe como frequentissimamente, em quasi todas estas citações, ele está expressivamente indolente, entregue, sem nenhuma iniciativa, sem atividade." (ANDRADE, Mário de. "Amor e medo", In: Aspectos da literatura brasileira. Ed. cit., p. 224).

\section{P. 80:}

Notas MA:

1. v. 47-53 assinalados por expoente “(1)”, remetendo ao comentário no rodapé;

2. comentário no rodapé ligado por um fio ao verbo sublinhado no v. 79, "adormeçamos", à página seguinte:

$\begin{array}{ll} & \text { Tudo dorme, não vês? dorme co'migo, } \\ \text { "(1) }) & \text { Pousa na minha tua face bella } \\ \text { E o pallido setim da tez morena... } \\ \text { Fecha teus olhos languidos... no somno } \\ \text { Quero sentir os tumidos suspiros } \\ \text { De teu seio arquejar, morrer nos labios... } \\ \text { E no somno teu braço me enlaçando! }\end{array}$

“(1) Amada dormindo

P. 81:

Notas MA:

1. v. 61-78 destacados por traço vertical e escólio "Sabia" - estudo do estilo: descrição da natureza;

2. verbo sublinhado no v. 79, "adormeçamos", e fio ligando-o à remissão "e pg 94 ":

Além, além nas arvores tranquillas

Uma voz acordou como um suspiro...

São ais sentidos de amorosa rôla

Que nos beijos de amor palpita e geme?

Ah! nem tão doce a rôla suspirando

Modula seus gemidos namorados,

Não trina assim tão longa e mollemente...

Em argentinas perolas o canto 
Se exhala como as notas expirantes

De uma alma de mulher que chora e canta...

É a voz do sabiá: elle dormia

Ebrioso de harmonia e se embalava

No silencio, na briza e nos effluvios

Das flores de laranja... Ilná, ouviste?

É o canto saudoso da esperança,

É dos nossos amores a cantiga,

Que o aroma que exhalão teus cabellos,

Tua languida vóz... talvez lhe inspirão!

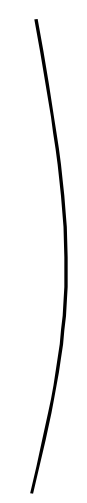

Vem, Ilná, dá-me um beijo: adormeçamos...

P. 83:

Notas MA:

1. correção a erro de impressão, acrescentando "r" ao verbo no v. 104, "lembrar":

Quero lembrar um cantico de amores...

2. comentário ao final do poema:

"Poema lindo, sobretudo a parte / referente á natureza, no inicio / até "E tu, Ilná, vem pois!". O / decassilabo de ritmo classico / domina absolutamente."

\section{P. $84-87$}

A HARMONIA (9 estrofes)

P. 84:

Nota MA: título sublinhado, escólio "dic / (no sentido de musica)" e remissão "veja p. 58 ” - pesquisa para o Dicionário musical brasileiro:

$$
\begin{aligned}
& \text { "dic" A HARMONIA } \\
& \text { "(no sentido de musica) } \\
& \text { (veja p 58" }
\end{aligned}
$$

P. 85:

Nota MA: termo sublinhado no v. 16, "rabeca", e escólio "dic" - pesquisa para o Dicionário musical brasileiro:

Oh! Paganini! quando moribundo

Inda a rabeca ao peito comprimias, "dic"

P. 88-92

VIDA (17 estrofes)

P. 91:

Nota MA: v. 55 e 56 destacados por traço vertical e escólio "Mãi e irmã á amada" estudo da psicologia: sentimento amoros/mãe e irmã: 


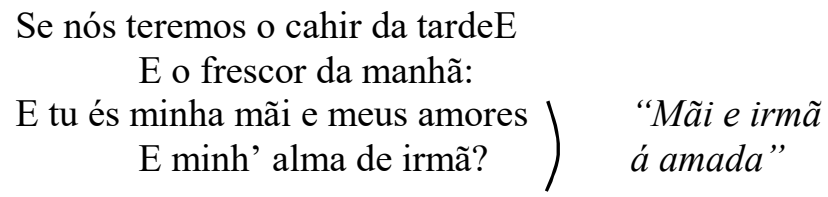

Nota da pesquisa: O escólio que associa mãe e irmã à mulher amada converge para o ensaio de 1931, no qual MA observa: "Na descrição dos amores sexuais, Álvares de Azevedo ainda encontra repetidamente imagens de maternidade. (...) E noutro passo (II, 91), chama a amante fundidamente de mãe e irmã." (ANDRADE, Mário de. "Amor e medo", In: Aspectos da literatura brasileira. Ed. cit., p. 221)

$\underline{\text { P. } 93-95}$

C...(8 estrofes)

P. 93:

Notas MA:

1. correção a erro de impressão, separando os termos no v. 2, "com as rosas":

Sim! coroemos as noites

Com/as rosas do hymeneo...

P. 94:

Notas MA:

1. verbo sublinhado no v. 17 , "soltarei-te", e cruzeta:

$X \quad$ Eu soltarei-te os cabellos...

Quero em teu collo sonhar...

2. v. 27 e 28 destacados por traço vertical e expoente “(1)”, remetendo ao comentário no rodapé:

É doce amar como os anjos

Da ventura no hymeneo:

"(1)" ( Minha noiva, ou minh'amante

“(1) Amada dormindo e pg 102”

P. 95:

Nota MA: comentário ao final do poema:

“Delicioso. Bem trabalhado."

P. 96-97

EPITAPHIO (6 estrofes)

P. 97:

Notas MA:

1. v. 17-20 destacados por traço vertical - estudo do estilo: imprecação: 
2. termos sublinhados nos v. 22 e 24, "threnos" e "dulias", e escólio "dic" - pesquisa para o Dicionário musical brasileiro:

A vida é noite! o sol tem véo de sangue...

Tactêa a sombra a geração descrida!...

Acorda-te, mortal! é no sepulchro

Que a larva humana se desperta á vida!

Quando as harpas do peito a morte estala

Um threno de pavor soluça e vôa...

"dic"

E a nota divinal que rompe as fibras

Nas dulias angelicas echôa

\section{P. 98-99}

O PASTOR MORIBUNDO (4 estrofes)

P. 99:

Nota MA: comentário ao final do poema:

"Não foi um cantador. Teve / mesmo um brasileirista em / A. de A.? Estudar a questão. Pedro / Ivo..."

P. $100-102$

TARDE DE VERÃO (12 estrofes)

P. 102:

Nota MA: v. 44 sublinhado e fio ligando-o ao comentário no rodapé:

Vem! a areia do mar cobri de flores,

Perfumei de jasmins teu doce leito,

Podes suave, ó noiva do poeta,

Suspirosa dormir sobre meu peito!

"Amada dormindo e p 114"

P. 103-109

TARDE DE OUTOMNO (20 estrofes)

P. 103:

Notas MA:

1. página assinalada por cruzeta - seleção de ideias;

2. epígrafe assinalada por expoente “(1)”, remetendo ao comentário na margem superior:

Un souvenir heureux est peut-être sur terre

Plus vrai que le bonheur.

“(1)”

AlFRED DE Musset

“(1) Já na poesia O Poeta esta mesma / citação." 
P. $110-112$

CANTIGA (11 estrofes)

P. 111:

Nota MA: termo sublinhado no v. 16, "menestrel” - pesquisa para o Dicionário musical brasileiro:
Voão os sonhos errantes
Do leito sob o docel
E suspirão no alaúde
As notas do menestrel.

Nota da pesquisa: MA alude ao poema em "Amor e medo": "O sono que tanto aspira, não é pra ele apenas o momento para, libertado dos perigos do amor, sonhar os atos do amor; também sabe apreciar o sono sem sonho, o sono que é ignorância da vida, como está na simbologia de Cantiga." (ANDRADE, Mário de. "Amor e medo", In: Aspectos da literatura brasileira. Ed. cit., p. 224).

\section{$\underline{\text { P. } 113-116}$}

\section{SAUDADES (14 estrofes)}

\section{P. 114:}

\section{Notas MA:}

1. v. 11 e 12 sublinhados, ligados por um fio ao escólio e à remissão no rodapé - estudo da psicologia: sentimento amoroso/amada dormida:

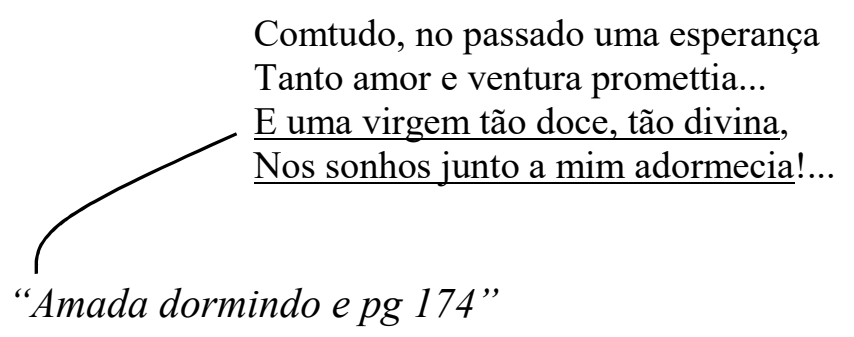

2. v. 21 e 22 destacados por colchete, termo sublinhado no v. 21, "tremer", e escólio "Amor e medo" - estudo da psicologia: sentimento amoroso/amor e medo:

"Amore
medo" $\quad \begin{aligned} & \text { Eu sentia a tremer e a transluzir-lhe } \\ & \text { Nos olhos negros a alma innocentinha... } \\ & \text { E uma furtiva lagrima rolando } \\ & \text { Da face d'ella humedecer a minha! }\end{aligned}$

Nota da pesquisa: O tremor é tratado no ensaio para a Revista Nova como sintoma do medo de amar, atribuído por MA à poesia de Álvares de Azevedo: "Minha convicção é que o paulista não teve apenas temor, mas uma verdade fobia do amor sexual. Não é como os outros, nos quais o assunto, por isso mesmo que mais temático, mais assunto poético que realmente sentido, não teve dúvida em se confessar com franqueza. Álvares de Azevedo sequestrou o seu medo de amor. E disso vem o tema do amor e medo se manifestar nele numerosíssimas vezes, mas sempre camuflado, inconsciente. Assim: 
como que numa transposição do medo dele à amada, si ele jamais confessa tremer de medo, como os que já citei (e ainda Varela numa estrofe das Estâncias, em que reconhece que a amada tem um não-sei-quê de grande e imaculado que o faz estremecer...), é repetidamente grato a Álvares de Azevedo reconhecer que a amada treme. (...) Nas Saudades, a imagem da estrela faz ele sentir que a alma da amada está tremendo [cita os v. 21-24]." (ANDRADE, Mário de. "Amor e medo", In: Aspectos da literatura brasileira. Ed. cit., p. 210).

P. 116:

Nota MA: juízo de valor ao final do poema:

"Bellissimo poema"

P. 120-124

VIRGEM MORTA (19 estrofes)

P. 120:

Nota MA: título sublinhado - estudo da psicologia: figuração da mulher:

\section{$\underline{\underline{\text { VIRGEM MORTA }}}$}

P. 121:

Nota MA: v. 25-28 destacados por colchete - estudo da psicologia: sentimento amoroso/amada dormida:

Que importa que ella durma descorada

E velasse o pallor a côr do pejo?

Quero a delicia que o amor sonhava

Nos labios d'ella presentir n'um beijo

HYMNOS DO PROPHETA

$\underline{\text { P. } 125-133}$

I - UM CANTO DO SECULO (28 estrofes)

P. 128:

Notas MA:

1. termo sublinhado no v. 54, "bandolim" - pesquisa para o Dicionário musical brasileiro:

E a sombra solitaria que eu sonhava

Languida como vibração perdida

De roto bandolim...

2. v. 67-69 destacados por traço vertical triplo - estudo da psicologia: ideal:

$$
\| /\left(\begin{array}{c}
\text { Eu vaguei pela vida sem conforto, } \\
\text { Esperei minha amante noite e dia } \\
\text { E o ideal não veio... }
\end{array}\right.
$$

P. 129: 
Nota MA: v. 87 assinalado por expoente “(1)”, remetendo ao comentário no rodapé e margem superior:

Quantos hei visto desbotarem frios,

Manchados de embriaguez da orgia em meio

Nas infamias do vicio! "(1)"

“(1) Notar a insatisfação do vicio pros roman-/ticos, ao passo que ele satisfez a muito / poeta da geração posterior Bilac e depois / principalmente Ribeiro Couto e Guilherme de / Almeida. Notar a mesma insatisfa-/ção tomando outro aspeto (Carnaval) em / Manuel Bandeira."

P. 130:

Nota MA: termo sublinhado no v. 101, "bronze", e escólio "dic" - pesquisa para o Dicionário musical brasileiro:

Sublime como a nota obscura, eterna,

"dic" Que o bronze vibra em noites de mysterio

No escuro campanario!

P. 131:

Nota MA: termo sublinhado no v. 122, "seiba" - estudo do estilo: vocabulário:

São tristes d'este seculo os destinos!...

Seiba mortal as flores que despontão

Infecta em seu abrir...

P. 132:

Nota MA: trecho sublinhado nos v. 145 e 146 - estudo da psicologia: autoimagem:

Eu, pobre sonhador! eu, terra inculta

Onde não fecundou-se uma semente,

Comvosco dormirei...

$\underline{\text { P. } 133-139}$

II - LAGRIMAS DE SANGUE (24 estrofes)

P. 134:

Nota MA: preposição sublinhada no v. 14, "p'r'as" - estudo linguístico: emprego de "para/pra":

Pela treva do espirito lancei-me,

P'r'as esperanças suicidei-me rindo...

Suffocando-as sem dós...

P. 136:

Nota MA: termo sublinhado no v. 64, "angoia", e cruzeta - estudo do estilo: vocabulário:

Quando na morte a palpebra se angoia, $X$

$\mathrm{O}$ anjo desperta em nós e subitaneo

Vôa ao mundo da luz! 
P. 139:

Nota MA: juízo de valor ao final do poema:

"Muito bonito"

$\underline{\text { P. } 140-143}$

III - A TEMPESTADE (24 estrofes)

P. 142:

Nota MA: termo sublinhado no v. 45, "tuba" - pesquisa para o Dicionário musical brasileiro:
A tuba da tempestade
Rouqueja nos longos céos,
De joelhos na montanha
Espero agora meu Deus!

P. 143:

Nota MA: comentário ao final do poema:

"A incapacidade de descrever em A. de Aze-/vedo, aliás caracter bem brasileiramente ro-/mantico e quasi universal. Mas em Azevedo / é tão forte que nem pode descrever recontos; ve-/ja-se o Poema do Frade em comparação aos con-/tos versificados de Musset, de Byron e de Gon-/çalves Dias (Y Juca Pirama). Tudo é em função do / eu interior pra A. Azevedo. Veja-se estas tempes-/tade e a descrição das estancias desta pg, descrição / invisivel, descrição em tese, palavras gerais / sem o elemento descritivo que é particular, des-/crição enfim que é um simbolo subjetivo, ele-/mento de expressão subjetiva e nada tem de / descritivo. Aliás os Hinos do Profeta são magistrais."

$\underline{\text { P. } 144-146}$

LEMBRANÇA DE MORRER (24 estrofes)

P. 145-146:

Notas MA:

1. v. 25-32 destacados por colchete e escólio "Amor e medo" - estudo da psicologia: sentimento amoroso/amor e medo:

Se uma lagrima as palpebras me inunda, Se um suspiro nos seios treme ainda É pela virgem que sonhei!... que nunca Aos labios me encostou a face linda!

Ó tu, que á mocidade sonhadora Do pallido poeta déste flôres... Se vivi... foi por ti! e de esperança De na vida gozar de teus amores.
"Amor e medo"

2. comentário ao final do poema: 
"É das mais belas coisas da lingua. Mais / belo que o cantico identico de Musset, o / Plantez un saule au cimetière. E mais / puro, mais universal, menos escolastica-/mente romantico, menos tema e fulmi-/nante, imortal, sublime explosão de / lirsimo tristonho."

Nota da pesquisa: MA sustenta, em "Amor e medo", a irrealização do amor na obra de Álvares de Azevedo, como efeito da timidez e repugnância pelo amor sexual: "Sem dúvida o amor não realizado é constante no poeta, e pode-se dizer que a única tecla de amor que ele sabe repetir nos seus vinte anos, porém não se realiza por causas obscuras, por causas que o poeta não diz claro, como é o caso das Saudades, e da "virgem que sonhou' na Lembrança de Morrer." (ANDRADE, Mário de. "Amor e medo", In: Aspectos da literatura brasileira. Ed. cit., p. 223)

\section{SEGUNDA PARTE}

P. 147-166

UM CADAVER DE POETA

P. 147-148:

I (4 estrofes)

P. 148:

Nota MA: trecho sublinhado no v. 19 e expoente “(1)” na sobrelinha, remetendo ao comentário no rodapé:

$$
\text { “(1)” }
$$

Tua estrella mentiu. E do fadario

De tua vida a pagina primeira

Na tumba se rasgou...

Pobre genio de Deus! nem um sudario!

Nem tumulo, nem cruz! como a caveira

Que um lobo devorou!...

“(1) É verdade profunda em relação a A. de Azevedo. / Ver o que digo alhures sobre os romanticos bra-/sileiros que conseguirar milhor que êste realizar-/se, Casemiro e Castro Alves sobretudo. Esses si / viveram pouco conseguiram dar expressões / totais das personalidades deles. A. de Azevedo / mais se the a gente lhe pressente o genio que / este se realiza. Sua estrela mentiu."

P. $149-153$

II (12 estrofes)

P. 150:

Nota MA: v. 48-65 assinalados pelo escólio "Poesia" e v. 61-65 destacados por traço vertical duplo - seleção de ideias: poesia / estudo do estilo: fatura:

"Poesia" A poesia é de certo uma loucura:

Seneca o disse, um homem de renome.

É um defeito no cerebro... Que doudos!

É um grande favor, é muita esmola 
Dizer-lhes - bravo! á inspiração divina...

E, quando tremem de miseria e fome,

Dar-lhes um leito no hospital dos loucos...

Quando é gelada a fronte sonhadora

Porque ha de o vivo, que despreza rimas,

Cançar os braços arrastando um morto,

Ou pagar os salarios do coveiro?

A bolsa esvasiar por um miserrimo,

Quando a emprega melhor em lodo e vicio?...

/ E que venhão ahi fallar-me em Tasso!

Culpar Affonso d'Este - um soberano,

Por não lhe dar a mão da irmã fidalga!

Um poeta é um poeta: apenas isso...

Procure para amar as poetizas.

P. 151:

Nota MA: v. 66-88 destacados por traço vertical - estudo do estilo:

Se na França a princeza Margarida,

De Francisco primeiro irmã formosa,

Ao poeta Alain Chartier adormecido

Deu nos labios um beijo... é que esta moça,

Apesar de princeza, era uma douda...

É a prova é que tambem rondós fazia.

Se Riccio, o trovador, teve os amores

- Novella até bastante duvidosa -

D'essa Maria Stuart formosissima,

É que ella - sabe-o Deus! - fez tanta asneira...

Que não admira que a um poeta amasse!

|| Por isso adoro o libertino Horacio:

Namorou algum dia uma parenta

Do patrono Mecenas? Parasita...

Só pedia dinheiro, no triclinio

Bebia vinho bom... e não vivia

Fazendo versos ás irmãs de Augusto.

E quem era Camões? Por ter perdido

Um olho na batalha e ser valente,

As esmolas valeu. Mas quanto ao resto,

Por fazer umas trovas de vadio

Deverião lhe dar, além de gloria,

- E essa derão-lhe á farta! - algum bispado?

P. 152:

Nota MA: v. 89-111 destacados por traço vertical - estudo do estilo:

Alguma d'essas gordas sinecuras

Que se davão a idiotas fidalguias?

Deixem-se de visões, queimem-se os versos:

O mundo não avança por cantigas.

Creião do poviléo os trovadores

Que um poema não val meia princeza. 


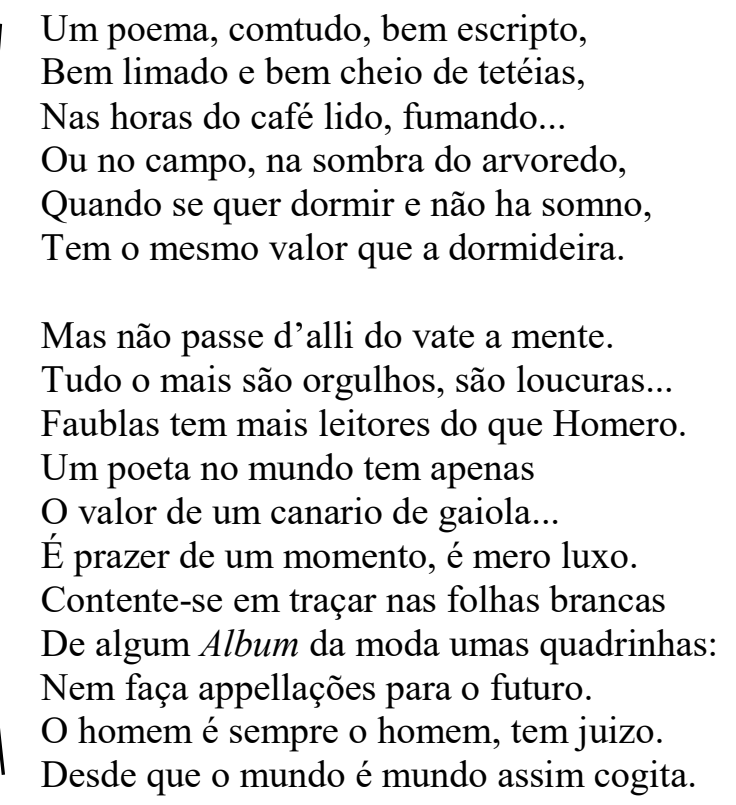

P. 153:

Nota MA: v. 112-125 destacados por traço vertical e comentário ao final do poema:

Nem ha negal-o: não ha doce lyra, Nem sangue de poeta ou alma virgem Que valha o talisman que no oiro vibra: Nem musicas, nem santas harmonias Igualão o condão, esse electrismo, A ardente vibração do som metallico...

Meu Deus! e assim fizeste a creatura? Amassaste no lodo o peito humano? Ó poetas, silencio! - é este o homem! A feitura de Deus! a imagem d'elle! O rei da creação!...

Que verme infame! Não Deus, porém Satan no peito vacuo Uma corda prendeu-te - o egoismo! Oh! miseria, meu Deus! e que miseria!

"Estes versos são esplendidamente / realizados"

P. $153-155$

III (6 estrofes)

P. 154:

Nota MA: verbo sublinhado no v. 137, "nitrindo" - estudo do estilo: vocabulário:

O cavallo do rei, sentindo o morto, Tremente de terror parou nitrindo...

$\underline{\text { P. } 155:}$ 
Notas MA:

1. expressão sublinhada no v. 160, "glosador de sobremesas" - estudo do estilo: epíteto:

Grisalha cabellereira esparramada,

Tremendo narigão, mas testa curta

Em summa um glosador de sobremesas.

2. v. 166 sublinhado e expoente “(1)”, remetendo ao comentário no rodapé e na margem superior:

Orgulho desmedido!.. e quanto aos versos

Morava como um sapo n'agoa doce...

Não sabia fazer um trocadilho..." “(1)”

“(1) Eis toda a essencia do lirismo romantico bra-/sileiro e todo o seu desmerecimento atual. Com ex-/cepção de Castro Alves poeta que adotou formulas artis-/ticas de expressão os outros não têm aquela tradição / de arte que organiza a factura em formulas e fôrmas. / Abriam a boca e cantavam só. Não sabiam fazer um / trocadilho! De tudo isso a gente observa o esplendido / valor de Gonçalves Dias que sem o amaneirado artistilco de Castro Alves, amaneirado que em grande / parte provocou o reviver da sua memoria porque / engajapou facilmente os credulos deste seculo, / daí o grande valor de Gonçalves Dias que sem mo-/das consegue ser o finissimo artesão que / foi."

$\underline{\text { P. } 156-158}$

IV (5 estrofes)

P. 156:

Notas MA:

1. verbo sublinhado no v. 171, "madornando", e cruzeta - estudo do estilo: vocabulário;

2. v. 174 sublinhado - estudo do estilo: descrição:

Ia cahindo o sol. Bem reclinado

No vagaroso coche, madornando, $\quad X$

Depois de bem jantar fazendo a sésta,

Roncava um nedio, um barrigudo frade...

Bochechas e nariz, em cima uns oculos.

$\underline{\text { P. } 159-164}$

$\mathrm{V}$ ( estrofes)

P. 160:

Notas MA:

1. trecho sublinhado no v. 249 - estudo da psicologia: sentimento amoroso/mãe e irmã:

“Tancredo!... Vêde!?... é o trovador Tancredo!

Coitado! assim morrer! um pobre moço...

Sem mãi e sem irmã! E não o enterrão? 
2. preposições sublinhadas nos v. 258 e 259, "p'ra" e "para", e cruzetas - estudo linguístico: emprego de "para/pra":

$$
\begin{array}{ll} 
& \text { "Tendes um coração: tomai, mancebo, } \\
& \text { Tomai esta pulseira... Em ouro e joias } \\
X & \text { Tem bastante p'ra erguer-lhe um monumento } \\
X & \text { E para longas missas lhe dizerem } \\
& \text { Pelo repouso d'alma...” }
\end{array}
$$

Nota da pesquisa: MA aproveita o trecho sublinhado no v. 249 para sustentar que Álvares de Azevedo "ajunta mãe e irmã por várias vezes ainda (I, 267, 269; II, 160; III, 406)" (ANDRADE, Mário de. "Amor e medo", In: Aspectos da literatura brasileira. Ed. cit., p. 211).

P. 163:

Nota MA: v. 304-314 destacados por sublinha e traço vertical - estudo da psicologia: autoimagem:

"Quem sou? um doudo! uma alma de insensato

Que Deus maldice e que Satan devora!

Um corpo moribundo em que se nutre

Uma scentelha de pungente fogo!

Um raio divinal que dóe e mata,

Que doira as nuvens e amortalha a terra!...

Uma alma como o pó em que se pisa!

Um bastardo de Deus! um vagabundo

A que o genio gravou na fronte - anathema!

D'esses que a turba com o dedo aponta...

Mas não; não hei de sel-o! eu juro n'alma,

P. 164:

Nota MA: termo sublinhado no v. 328, "nenias", e escólio "dic" - pesquisa para o Dicionário musical brasileiro;

Depois vibrou na lyra estranhas magoas,

Carpiu á longa noite escuras nenias,

"dic"

Cantou: banhou de lagrimas o morto.

P. 166:

Nota MA: v. 358 sublinhado preso por fio ao comentário/escólio na margem superior seleção de ideias: preparação do ensaio:

"O amor de C. Alves por / Agnese T. Murri"

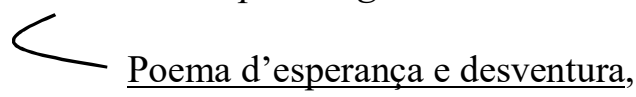

P. 167-181

IDÉAS INTIMAS (17 estrofes)

P. 167:

Notas MA: 
1. comentário na margem superior:

"Talvez a obra-prima de Alvares de Azevedo. Que / naturalidade, que lirismo puro e que união prodi-/giosa de toros os seus caracteres mais pessoais em-/bora com repercussões ou exemplos anteriores no / romantismo europeu. E a expressão integral e li-/vre do spleen, da amolação de viver que ninguem / representou tão exatamente. O spleen de Baudelaire / de Byron e o de A Azevedo. E os volteios do tempera-/mento: a ironia amarga, o carinho, o amor ideali-/zado, uma como que profunda piedade sem / vontade, sem gôsto, uma piedade sincera, irrepri-/mivel mas com vontade de mandar tudo á putalque-o-pariu, mesmo a sonhada amante. É / formidavel."

2. v. 3 e 4 sublinhados e expoente “(1)”, remetendo ao comentário no rodapé:

Ossian - o bardoo, é triste como a sombra

Que seus cantos povôa. O Lamartine

É monotono e bello como a noite,

Como a lua no mar e o som das ondas...

“(1)”

“(1) Esta é a expressão que serve bem pra / quasi todo o romantismo brasileiro, / com excepção porventura só de Castro Alves."

Nota da pesquisa: A percepção quanto a "Ideias íntimas" ser a obra-prima de Álvares de Azevedo confirma-se no ensaio para a Revista Nova. Nele, o poema é mencionado por MA para respaldar a suposta fixação do autor romântico na mãe: "Nas Ideas Intimas, talvez o que fez de maior como poesia, diz que venera igualmente pai e mãe, mas é certo que essa igualação é puramente bem educada e artificial." MA também menciona o poema ao caracterizar, na Lira dos vinte anos, o gosto do eu lírico por dormir - sintoma, segundo o crítico, de sua irrealização erótica: "Nas Ideias íntimas considera o seu 'leito juvenil' como a 'página de ouro da sua vida', e evoca os atos de amor que nele praticou... em sonho" (ANDRADE, Mário de. "Amor e medo", In: Aspectos da literatura brasileira. Ed. cit., p. 219).

P. 168:

Notas MA:

1. v. 5-7 destacados por traço vertical - seleção de ideias:

Que pranteião eternas monodias.

Tem na lyra do genio uma só corda,

- Fibra de amor e Deus que um sopro agita!

2. trecho sublinhado nos v. 15 e 16 - estudo da psicologia: tédio:

Meu coração deleita-se... Comtudo,

Parece-me que vou perdendo o gosto,

Vou ficando blasé: passeio os dias

Pelo meu corredor, sem companheiro,

Sem ler, nem poetar... Vivo fumando.

Nota da pesquisa: A edição crítica das Poesias completas de Álvares de Azevedo indica outra versão para o v. 5, sem acusar a existência da variante: "Mas pranteia uma eterna monodia" (Poesias completas; edição crítica de Péricles Eugênio da Silva Ramos; 
organização de Iumna Maria Simon. Campinas: Editora da Unicamp / São Paulo: Imprensa Oficial, 2002, p. 152).

P. 170-171:

Notas MA:

1. v. 64-66 destacados por traço vertical e comentário:

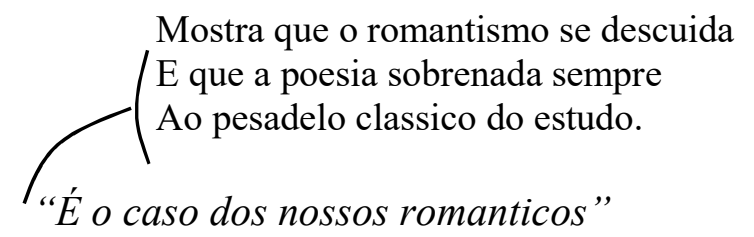

2. v. 67-76 destacados por traço vertical

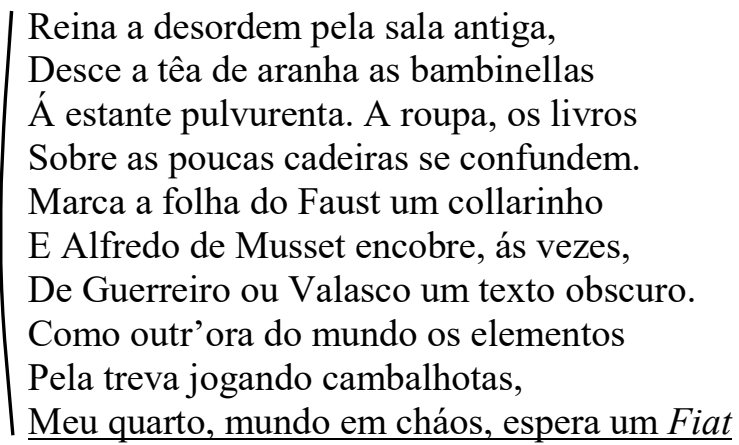

P. 172:

Notas MA: v. 95-113 destacados por colchete e comentário ao final:

Pallido, pensativo, a fronte erguida, Olhar de Bonaparte em face austriaca, Foi do homem secular as esperanças: No berço imperial um céo de agosto Nos cantos de triumpho despertou-o...

As aguias de Wagram et de Marengo Abrião flammejando as longas azas, Impregnadas do fumo dos combates, Na purpura dos Cesares, guardando-o... E o genio do futuro parecia Predestinal-o á gloria. A historia d'elle?... Resta um craneo nas urnas do estrangeiro. Um loureiro sem flores nem sementes... E um passado de lagrimas... A terra Tremeu ao sepultar-se o Rei de Roma. Póde o mundo chorar sua agonia E os louros de seu pai na fronte d'elle Infecundos depôr... Estrella morta, Só póde o menestrel sagrar-te prantos!

"Nunca ninguem disse milhor do rei / de Roma. Vale mais que o drama interi-/nho de Rostand o que aliás não aquilata / do valor de A. de Azevedo, é logico." 
Nota da pesquisa: A obra dramática "L'aiglon", de Edmond Rostand (1868-1918), foi encaminhada por MA à Biblioteca Municipal de Araraquara.

2. trecho sublinhado no v. 118 - seleção de ideias:

É um retrato talvez. N'aquelle seio Porventura sonhei doiradas noites, Talvez sonhando desatei sorrindo Alguma vez nos hombros perfumados

P. 174:

Notas MA: v. 129-139 destacados por traço vertical, escólio e remissão “Amada dormindo e pg 201"- estudo da psicologia:

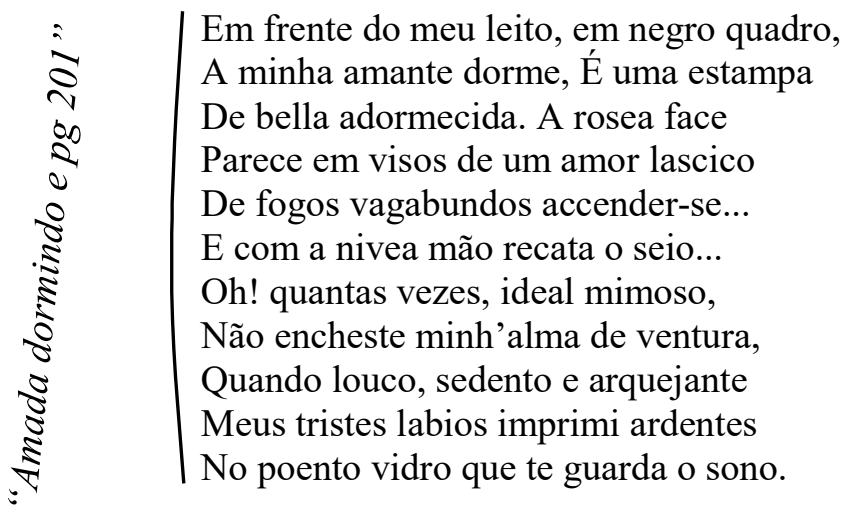

P. 175:

Notas MA:

1. trecho sublinhado nos v. 142 e 143 e fio prendendo ao comentário na margem superior - estudo da psicologia: poesia e verdade:

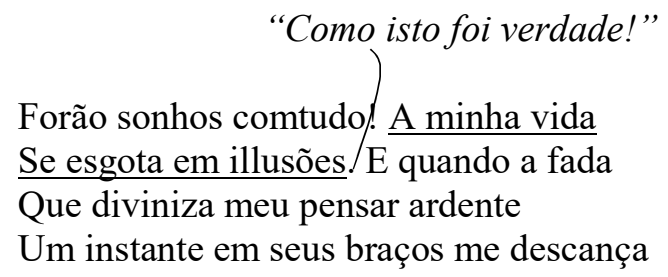

2. v. 156 e 157 sublinhados - estudo da psicologia:

O encanto do meu sonho se evapora...

E das nuvens de nacar da ventura

Rólo tremendo á solidão da vida!

P. 178:

Notas MA:

1. v. 206 sublinhado e expoente “(1)”, remetendo ao comentário logo abaixo:

Ó meus sonhos de amor e mocidade,

Porque ser tão formosos, se devieis

Me abandonar tão cêdo... e eu acordava

Arquejando a beijar meu travesseiro? "(1)” 
“(1) O que dá uma força extraordinaria de / realidade ao lirismo de A. de Azevedo, tiran/do por completo a aparencia de romantismo / convencional que tantas vezes é inerente á / obra dos romanticos brasileiros, sobretudo / G. Dias, é sua mistura de comoção profun-/da e comicidade amargosa. Ele não é só / profundamente sincero, pois que podese / ser sincero até no convencional, ele é pro-/fundamente verdadeiro, no que nem / C. Alves o atingiu."

2. v. 210 e 211 destacados por traço vertical duplo - estudo do estilo: imagem:

( $\begin{aligned} & \text { Meu velho candieiro se espreguiça } \\ & \text { E parece pedir a formatura. }\end{aligned}$

3. v. 212-222 destacados por traço vertical e expoente “(2)”, remetendo ao comentário no rodapé:
Ó meu amigo, ó velador noturno,
Tu não me abandonaste nas vigilias,
Que eu perdesse a noite sobre os livros,
Quer, sentado no leito, pensativo
Relesse as minhas cartas de namoro...
Quero-te muito bem, ó meu comparsa
Nas doudas scenas de meu drama obscuro!
E n'um dia de spleen, vindo a pachorra,
Hei-de evocar-te d'um poema heroico
Na rima de Camões e de Ariosto,
Como padrão ás lampadas futuras! "(2)”

“(2) Esta passagem maravilhosa onde não / se pode distinguir o que é ironia, o que é / caçoada mesmo e o que é comoção seria. / Alias a propria caçoada em A. Azevedo é mui/to mais como aqui uma comoção senti um / sentimento ardente."

P. 181:

Nota MA: comentário ao final do poema:

"A. de Azevedo não era absolutamente um an-/ precoce, um anormal. Era 20 anos dos mais / normalissimos. Era um sensacionista. Co-/lhia sensações, colhia tambem ideas nasci-/das ou nascituras daquelas e dos estudos e / que germinando dariam mais tarde numa floração prodigiosa pela aparencia de poe-/sia genial de lirismo e pensamento. Não / é possivel deplorar a morte de quem morre / em critica mas é certo que si os outro[s] poetas / romanticos brasileiros morrendo cedo dei-/xaram representações absolutas do homem-/poeta deles, é certo que A. de Azevedo ficou na / colheita ainda. As suas milhores obras, como / esta obra-prima das Ideas Intimas, a sua mais / perfeita representação de 20 anos o prova. (O / que é 20 anos normal. Passagem sobre o 20 anos / normal) Ideas e filosofias é possivel que / A. de Azevedo já as tivesse, mas de colheita, / não digeridos, não pessoais, não dando filhos / ainda. Por isso ficou apenas sensacionista."

P. $182-219$

BOHEMIOS

P. 183: 


\section{Notas MA:}

1. correção a erro de impressão, acrescentando a sílaba final a "Turco", no v. 9 do diálogo entre Níni e Puff:

\section{Como o Papa Alexandre ou como um Tur "co"}

2. v. 12-16 destacados por traço vertical, escólio “Amor e medo" e expoente “(1)”, remetendo ao comentário no rodapé:

$$
\begin{aligned}
& \text { Embalde quiz dormir. Na minha mente } \\
& \text { Fermenta um mundo novo que desperta. } \\
& \text { Escuta, Puff: eu sinto no meu craneo, } \\
& \text { Como em seio de mãi, um feto vivo... } \\
& \text { Na minha insomnia vela o pensamento: }
\end{aligned}
$$

“(1) A ironia sentimental de A. A. é tão / inata que sente-se que ele caçoava até / de si mesmo. E do Romantismo e das / imagens e tendencias romanticas tambem, / tal e qual neste trecho."

Nota da pesquisa: A leitura de matriz psicanalítica proposta em "Amor e medo", que atribui a Álvares de Azevedo uma obsessão pela mãe, alude aos versos assinalados por MA: "Nos Boêmios, com bastante mau gosto, encontramos a ideia do feto fazendo imagem: '...na minha mente / Fermenta um mundo novo que desperta. / Escuta, Puff: eu sinto no meu crânio, / Como em seio de mãe, um feto vivo...' Essa imagem do feto, que foi Álvares de Azevedo, creio, o único a sentir dentre os nossos grandes românticos, inda lhe volta no Macário (III, 310)." (ANDRADE, Mário de. "Amor e medo", In: Aspectos da literatura brasileira. Ed. cit., p. 220)

P. 191:

Notas MA: preposição sublinhada nos v. 139 e 148, "para" e "p'ra”, e cruzetas - estudo linguístico: emprego de "para/pra":

$$
\begin{array}{ll}
\text { Sinto que não nasci para coveiro } & X \\
\text { Os mortos despe p'ra vestir os filhos } & X
\end{array}
$$

Nota da pesquisa: Embora não acuse a existência da variante, a edição crítica das Poesias completas de Álvares de Azevedo apresenta outra versão para o v. 148: "O morto estava nu, pois o carrasco / Despindo os mortos dá vestido aos filhos" (Poesias completas. Ed. cit., p. 169).

\section{P. 192:}

Nota MA: preposição sublinhada no v. 156, "para”, e cruzeta - estudo linguístico: emprego de "para/pra":

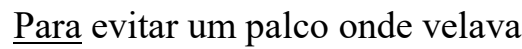

P. 194:

Nota MA: correções a erros de impressão nos v. 193 e 194:

“/ea” Rechedos capões fervendo ainda! 
“/l” Perús! olhas podridas! costelletas...

P. 195:

Nota MA: termos sublinhados no v. 211, "rondós" e "tarantela", e escólio "dic" pesquisa para o Dicionário musical brasileiro:

Esquece a erysipela já sem cura,

Canta rondós e dança a tarantela... "dic"

P. 197:

Nota MA: preposição sublinhada no v. 253, "para", e cruzeta - estudo linguístico: emprego de "para/pra":

E o mundo para mim é como um sonho $\quad X$

P. 198:

Nota MA: v. 267-286 destacados por traço vertical e escólio "Sequestro" - ligação com a pesquisa de MA do tema do Sequestro da dona ausente no folclore brasileiro:

\begin{tabular}{l|l} 
“Sequestro" & $\begin{array}{l}\text { Vagabundo, uma vez, junto das ondas } \\
\text { O principe encontrou na areia fria } \\
\text { Uma branca donzella desmaiada, } \\
\text { Que um naufragio na praia arremessara: } \\
\text { Revelavão-lhe as roupas gotejantes } \\
\text { O bello talhe niveo, o melindroso }\end{array}$ \\
$\begin{array}{l}\text { Das bem moldadas formas. O mancebo } \\
\text { Nos braços a tomou e foi com ella } \\
\text { Esconder-se no bosque. }\end{array}$ \\
$\begin{array}{l}\text { Suspirando acordou, o bello principe } \\
\text { Aos pés d'ella velava de joelhos. } \\
\text { Amarão-se. É a vida. Elles vivêrão } \\
\text { D’esse desmaio que dá corpo aos sonhos, } \\
\text { Que realiza visões e aroma a vida } \\
\text { Na sua primavera. A lua pallida, } \\
\text { As sombras da floresta e d'entre a sombra } \\
\text { As aves amorosa que suspirão } \\
\text { Virão aquellas frontes namoradas, } \\
\text { Ouvirão suffocando-se n'um beijo, } \\
\text { Suspiros que o deleito evaporava. }\end{array}$
\end{tabular}

P. 200:

Nota MA: preposição sublinhada no v. 309, "para", e cruzeta - estudo linguístico: emprego de "para/pra":

$X \quad$ E convidou el-rei para um passeio

P. 201:

Nota MA: v. 310-320 destacados por traço vertical, escólio "Amada dormindo" e expoente "(1)" remetendo ao comentário no rodapé - estudo da psicologia: sentimento amoroso/amada dormida: 
Ora, por uma triste desventura, $O$ rei entrando na Cabana Verde Achou só a mulher... adormecida

"Amada dormindo

(1)"

No desalinho descuidoso e bello

Com que ellas dormem, soltos os cabellos,

A face sobre a mão e os seios lindos

Batendo á solta na macia tela

Da roupa de dormir que os modelava...

Não digo mais...

Loriolo pôz-se á espreita.

$\mathrm{O}$ rei de leve despertou a bella,

Acordou-a n'um beijo...

"(1) Não contente com sua amada descrever / dormida, faz aqui o rei encontrar a / moça dormindo e quando fala em / moças encantadas veja p 216"

P. 205:

Nota MA: termo sublinhado no v. 372, "guizo", e escólio "dic" - pesquisa para o Dicionário musical brasileiro:

\section{Loriolo}

Trocou de guizo o boné sonoro "dic"

P. 206:

Nota MA: preposição sublinhada no v. 395, "p'ra", e cruzeta - estudo linguístico: emprego de "para/pra":

$$
\begin{aligned}
& \text { (E que nem dentes amarellos tinha } \\
& X \quad \underline{\text { P'ra ser de Adamastor, as gambias finas, }}
\end{aligned}
$$

P. 207:

Nota MA: preposição sublinhada no v. 413, "para”, e cruzeta - estudo linguístico: emprego de "para/pra":

De obito e nascimento e baptisterio

E até de casamento! e para prova

PRÓlOGO

P. 214-215:

Nota MA: v. 1-24 destacados por traço vertical e expoente “(1)”, remetendo ao comentário no rodapé e às margens direita e superior:

Dom Quichote, sublime creatura!

Tu sim! foste leal e cavalleiro,

O ultimo heróe, o paladim extremo

De Castella e do mundo. Se teu cerebro

Toldou-se na loucura, a tua insania

Vale mais do que o siso d'estes seculos

Em que a Infamia, Dagon cheio de lodo, 
Recebe as orações, myrrhas e flores... E a louca multidão renega o Christo! Tua loucura revelava brio:

No triste livro do immortal Cervantes Não posso crêr um insolente escarneo De cavalleiro andante aos nobres sonhos, Ao fidalgo da Mancha, cuja nodoa

Foi só ter crido em Deus e amado os homens

E votado seu braço aos opprimidos.

Aquellas folhas não meu causão riso, Mas desgosto profundo e tedio á vida.

Soldado e trovador, era impossivel

Que Cervantes manchasse um valeroso

Em vil caricatura! e desse á turba, Como presa de escarneo e de vergonha, Esse homem que á virtude, amor e cantos Abria o coração!...

“(1) Estupenda passagem duma perfeita e / larguissima visão critica e que profetiza / o pensamento de A. de Azevedo. É curioso de notar-se / que Dom Quixote, talvez a figura mais intrinsecamente romantica / dos grandes livros classicos, não foi muito importante pro Romantismo. / O Romantismo esqueceu a milhor representação e imagem dele que era o / heroi de Cervantes. Esta tirada tão extemporanea e por isso tão rica de / Alvares de Azevedo redime a culpa, o es-/quecimento romantico."

Nota da pesquisa: A edição crítica das Poesias completas explica que, em todas as edições anteriores - como é o caso do volume anotado por MA -, o "Prólogo" era disposto ao final, como um epílogo (Poesias completas. Ed. cit., p. 181).

P. 216:

Notas MA:

1. v. 31 sublinhado, termo - "dormida" - assinalado por parênteses e fio prendendo o comentário na margem superior:

"amada dormindo, em vez de / moças escravas de orações etc, se / inspira na Bela Adormecida.

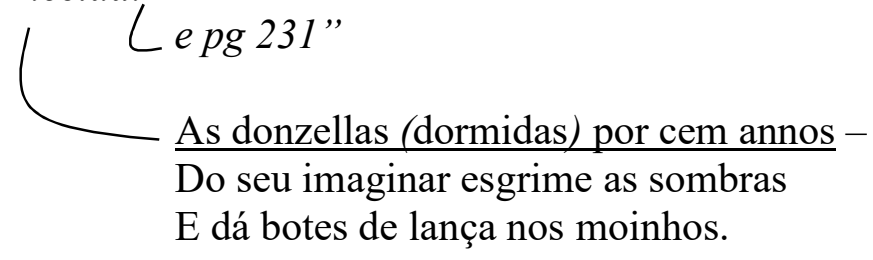

2. preposições sublinhadas nos v. 38 e 41, "P'ra" e "Para", e cruzetas - estudo linguístico: emprego de "para/pra":
$X \quad$ P'ra realce maior, presentes vicios,
Não segue Juvenal e nem embebe
Em venenoso fel a penna escura
$X \quad$ Para nodoas pintar no manto alheio.

3. correçao a erro de impressão no v. 42: 
O tempo em que se passa agora a scens " $/ a$ "

4. termo sublinhado no v. 44, "c'rôa", e expoente "(1)”, remetendo ao comentário no rodapé - estudo linguístico: "c'rôa":

Depôz na fronte a Raphael gelado

Sua c'rôa $^{(1)}$ divina e o segue ao tumulo.

“(1) É muito provavel que a dicção da palavra coroa soasse / quasi exatamente como crôa por que os no tempo / de 1840 pra 1870 mais ou menos. Em Castro Alves tam-/bem vem croa. Procurar nos outros romanticos. É o mes-/mo caso do pra. Não é licença propriamente, / é uma elisão trazida pela naturalidade da dicção oral."

5. v. 46-51 assinalados por escólio, “Aretino”, e sublinha no v. 51 - seleção de ideias:

$\begin{array}{ll}\text { "Aretino" } & \text { Ticiano inda vive. O rei da turba } \\ \text { É um genio maldito - o Aretino, } \\ \text { Que vende a alma e prostitúe as crenças. } \\ \text { Aretino! essa incrivel creatura, } \\ \text { Poeta sem pudor, onde de lodo } \\ \text { Em que do genio profanou-se a perola... }\end{array}$

P. 217:

Notas MA:

1. v. 55 sublinhado - estudo do estilo: imagem:

Vaso d'oiro que um oxydo sem cura

Azinhavrou de morte... homem terrivel

Que tudo profanou co'as mãos immundas,

Que latiu como um cão mordendo um seculo!

2. preposição sublinhada no v. 77, "Para", e cruzeta - estudo linguístico: emprego de "para/pra":

Para com elle abandonar o mundo $\quad X$

E angelica voltar ao céo dos Anjos.

P. 219:

Nota MA: comentário ao final do poema:

"A ironia, um humorismo pesado, extra/latino, quasi ou bem alemão, muito / engraçado sempre dentro duma tal ou / qual amargura de contemplar seria-/mente a vida, sempre dentro duma tal / ou qual inquietação... êsse o humoris-/mo de A. de Azevedo."

\section{SPLEEN E CHARUTOS}

P. 220-222

I - SOLIDÃO (7 estrofes)

P. 221: 


\section{Notas MA:}

1. epíteto sublinhado no v. 8 e expoente “(1)”, remetendo ao comentário no rodapé estudo da psicologia e do estilo: epíteto:

Vem núa e bella procurar amantes...

- É douda por amor da noite a filha “(1)”

“(1) Si a puta (I vol) é 'mulher da noite' / e é 'rainha da noite' a Lua é filha da / mesma...”

2. v. 15 e 16 destacados por traço vertical, em ambos os lados, e juízo de valor - estudo do estilo: imagem:

$$
\left(\begin{array}{l}
\text { Ó lua, as doces brizas que susurrão } \\
\text { Coão dos labios teus como suspiros! }
\end{array}\right) \text { "linda imagem" }
$$

\section{P. 222-223}

II - MEU ANJO (5 estrofes)

P. 223:

Nota MA: comentário ao final do poema:

"Do milhor Heine, do milhorissimo! Que carinho, que / graça amorosa e atenta no pintar e no fundo um / grande desdem. A. de Azevedo ama desprezando. / D'aí talvez serem seus unicos e verdadeiros amores / os ideais em que é impossivel desprezar. (Citar por / contraste de ideal alguns versos das Ideas Intimas."

\section{P. 223-225}

III - VAGABUNDO (10 estrofes)

P. 224:

Notas MA:

1. termo sublinhado no v. 6, "viola" e escólio "dic" - pesquisa para o Dicionário musical brasileiro:

2. v. 8 sublinhado - seleção de ideias:

Ando rôto, sem bolsos, nem dinheiro...

"dic" Mas tenho na viola uma riqueza:

Canto á lua de noite serenatas...

E quem vive de amor não tem pobreza.

3. v. 17-20 destacados - estudo do estilo: ritmo / estudo da psicologia:

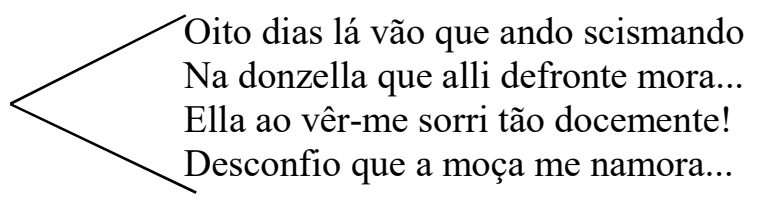


IV - A LAGARTIXA (4 estrofes)

P. 226:

Notas MA:

1. v. 5 destacado por colchete e escólio "Sono" - estudo da psicologia: sono:

"Sono" $\quad$ Amo-te como o vinho e como o somno, Tu és meu copo e amoroso leito...

2. termos sublinhados no v. 9, "para" e "corôas", e remissão a nota de margem - estudo linguístico: emprego de "para/pra" e "c'rôa":

$$
\begin{aligned}
& \text { Posso agora viver: para corôas } \\
& \text { Não preciso no prado colher flores }
\end{aligned}
$$

Nota da pesquisa: MA menciona o poema no ensaio para a Revista Nova; identifica nele um traço importante da psicologia do sentimento amoroso na obra Álvares de Azevedo: "Foi esse o jeito que o rapaz descobriu pra disfarçar seu medo e evitar a coreografia do amor: durmamos! O sono é a mais original invenção do seu lirismo. Adora dormir. No Spleen e Charutos diz pra amada: "Amo-te como o vinho e como o sono!" (ANDRADE, Mário de. "Amor e medo", In: Aspectos da literatura brasileira. Ed. cit., p. 223)

$\underline{\text { P. } 228-230}$

VI - O POETA MORIBUNDO (10 estrofes)

P. 229:

Notas MA:

1. termo sublinhado no v. 12, "marimbáo", e escólio "dic" - pesquisa para o Dicionário musical brasileiro:

Emquanto ao cemiterio não te levão,

Casa no marimbáo a alma divina! "dic"

2. v. 17-20 destacados por traço vertical - estudo da psicologia:

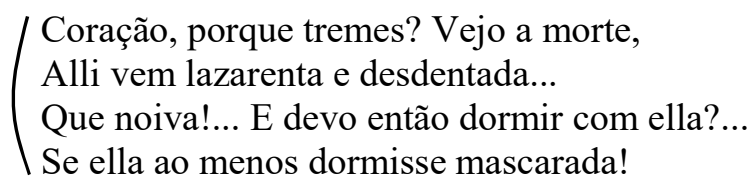

P. 230:

Nota MA: v. 29-32 destacados por traço vertical - estudo da psicologia:

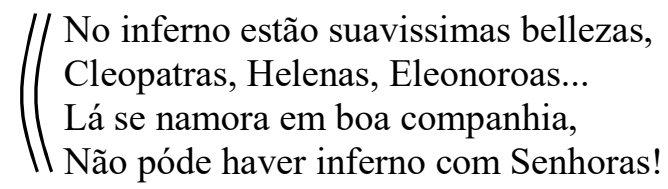

Nota da pesquisa: Em "Amor e medo", MA reporta-se ao trecho assinalado: "[AA] Também se arrota manchado por todas as maldades do mundo. Mas a verdade é que, si 
pra Macário as mulheres que não têm cabelo na cabeça o têm no coração (III, 259), si 'não pode haver inferno com senhoras' (II, 230), si na estância do Poema do Frade, aquele tipo tão puro de Madona era um lago a dormir, 'porém sua água azul tinha veneno'; si ainda pra Macário (III, 268), as mulheres paulistanas 'são mulheres, isto é, são lascivas': tudo isso são falsificações sistematizadas inconscientemente, de quem soube achar expressões delicadas mesmo pra designar a mulher prostituída, "vagabunda do amor', 'mulher da noite', 'anjo da noite', 'rainha da noite'." ("Amor e medo", In: Aspectos da literatura brasileira, ed. cit., p. 204).

P. 231-233

É ELLA! É ELLA! (10 estrofes)

P. 231:

Nota MA: v. 9 e 10 destacados por traço vertical, escólio e remissão, "Amada / dormida / e p 236" - estudo do estilo:

$\begin{array}{ll}\text { Esta noite eu ousei mais atrevido } & \text { "Amada } \\ \text { Nas telhas que estalavão nos meus passos } & \text { dormida/ } \\ \text { Ir espiar seu venturoso somno, } & \text { e p 236” } \\ \text { Vêl-a mais bella de Morphêo nos braços! } & \end{array}$

P. 233:

Nota MA: comentário ao final do poema:

"Mistura formidavel de carinho e de ironia e / sobretudo amargura, amargura que provoca e / acentua a ironia ao mesmo tempo que verifica / e acentua o carinho, neste poeta talvez de todos / os romanticos o que teve maior elevação de sen-/timento no sentido ideal de nobreza, de aristocra-/cia, isso, A. de Azevedo foi de todos os romanticos / o de alma mais aristocrata. D'ai talvez o seu / tedio de viver numa sociedade de pobreza men-/tal e burguesice de sentimento que as estu-/dantadas não chegavam a disfarçar. Mas / notar o amor pelos pais e pela irmã. Aliás mostrar / pela carta que escreve a esta no aniversario dela / como a sua afeição era sem realidade / critica, mais exarcebação sentimental e / quasi tese que outra coisa. Pela mãi, não, sente-se amor que pulsa verdadeiro."

\section{TERCEIRA PARTE}

P. 235-236

MeU DESEJo (6 estrofes)

P. 236:

Nota MA: v. 11 e 12 e v. 17-20 destacados por traço vertical, ligados entre si por fio, escólio e remissão, "Amada dormindo e p 249" - estudo da psicologia: amada dormida:

Meu desejo? era ser o cortinado

Que não conta os mysterios de teu leito,

Era de teu collar de negra seda

Ser a cruz com que dormes sobre o peito.

Meu desejo? era ser o teu espelho 


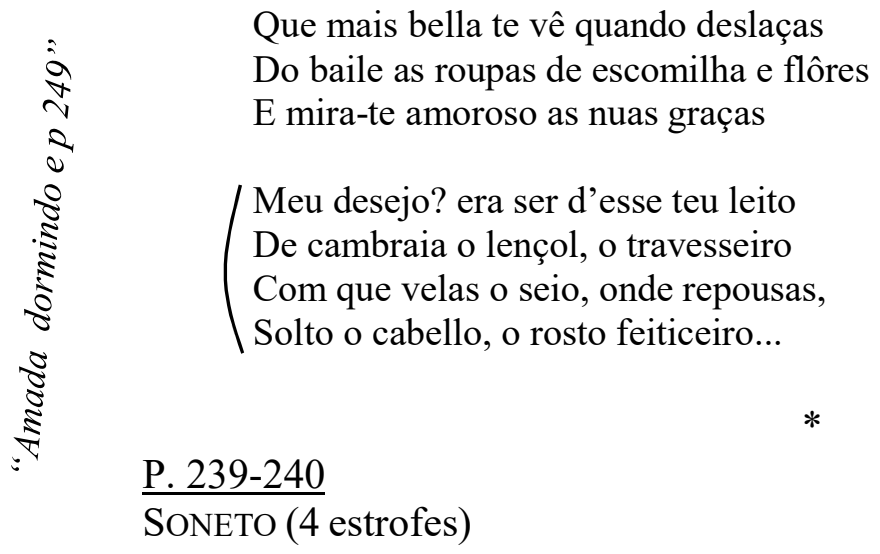

P. 239:

Nota MA: trecho sublinhado no v. 3 - estudo do estilo: imagem:

$\underline{\text { Roncava a todo o panno o tal bregeiro }}$

Do vinho nos vapores se expandindo!

P. 240:

Nota MA: termo sublinhado no v. 11, "rabeca", e escólio "dic" - pesquisa para o Dicionário musical brasileiro:

"dic" $\quad$ De uma esquina lodosa no retiro

P. 247-250

PHANTASIA (12 estrofes)

P. 249:

Notas MA:

1. termo sublinhado no v. 31, "soído", e escólio "dic" - pesquisa para o Dicionário musical brasileiro;

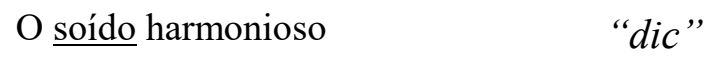

Fallava em noites de gozo

Como nunca eu as senti,

2. v. 46-48 destacaos por traço horizontal, escólio e remissão, "Amada dormida / e pg 305 " - estudo da psicologia: amada dormida:

Dormias junto de mim...

E um anjo nos dice assim:

"Pobres amantes, dormi! "Amada dormida e p 305 "

$\underline{\text { P. 251-253 }}$

LAGRIMAS DA VIDA (8 estrofes) 


\section{P. 252:}

Nota MA:

1. termo sublinhado no v. 14, “orgias", e expoente “(1)”, remetendo ao comentário no rodapé:

E por te amar, por teu desdem, perdi-me...

Tresnoitei-me nas orgias “(1)” macilento,

“(1) Órgia, como C. Alves tambem empregou”

2. v. 20 sublinhado - seleção de ideias / estudo da psicologia:

O peito e lyra se estalárão juntos...

E morro sem ter tido primavera!

P. 254-255

SONETO (4 estrofes)

P. 255:

Nota MA: comentário ao final do poema:

"A. de Azevedo escreveu dos mais belos / sonetos da lingua e talvez mesmo do / universo. Poucos sonetos tem no mundo / iguais a êste. Enfraquece um pouco nos dois pri-/meiros versos do ultimo terceto o que poderia argu-/mentar-se como imperfeição grave num soneto. É. Po-/rem não se trata de perfeição ou imperfeição de / poema, trata-se de grandeza de lirismo se expressan-/do por aquela combinação sutil de acentos e formas / orais que dá no maximo de comoção e de poesia. / O chamar a visão ou mulher sentida de talis-/man é meio besta. Armida é artificial e / passadista no Romantismo. O segundo verso / $2^{\circ}$ terceto vem por precisão de encher o ter-/ceto e nada mais, apesar de lindo verso. Im-/perfeição como arte, sublime como Poesia, pois / a imperfeição não é tão grande que che-/gue a desnaturar a idea, o sentimento ou a / expressão."

$\underline{\text { P. } 256-259}$

LEMBRANÇA DOS QUINZE ANNOS (16 estrofes)

S/Notas MA

P. 260-261

MEU SONHO (5 estrofes)

P. 261:

Notas MA:

1. v. 12 sublinhado e correção a erro de impressão, invertendo a ordem:

E galopas do valle atraves...

Oh! da estrada acordando as poeiras 
Não escutas gritar as caveiras

E morder-te nos pés o phantasma?

"(E morder-te o fantasma nos pés?"

2. comentário ao final do poema:

"Lindo. Ritmo admiravelmente / bem escolhido. Galopante."

P. $262-264$

O CONEGO FILIPPE (8 estrofes)

P. 262:

Nota MA: v. 7-9 destacados por traço vertical duplo:

/ $\begin{aligned} & \text { Voltemos ao assumpto. A minha musa, } \\ & \text { Como um fallado imperador romano, } \\ & \text { Distrae-se, ás vezes, apanhando moscas. }\end{aligned}$

P. 262:

Nota MA: v. 36 sublinhado - seleção de ideias / estudo da psicologia:

Mas esta vida é sempre deleitosa.

As almas d'homem ao harem se voltão...

$\underline{\text { Ser um dia sultão quem não deseja? }}$

\section{P. 265-266}

TRINDADE (4 estrofes)

P. 266:

Nota MA: comentário ao final do poema:

"Notar a curiosa disposi-/ção das rimas."

P. 267-268

SONETO (4 estrofes)

P. 268:

Nota MA: título sublinhado para destacar o poema.

P. 268:

Nota MA: comentário ao final do poema:

"de leve sabor classico. / é ũa maravilha."

P. 269-271

MinHA AMANTE (10 estrofes) 
P. 270:

Nota MA: v. 17 destacado por colchete - estudo da psicologia: sentimento amoroso/amor e medo:

[ Desmaio-me de amor, descóro e tremo...

Morno suor me banha o peito langue...

Meu olhar se escurece e eu te procuro

Com os labios sedentos!

Nota da pesquisa: MA cita os versos acima em "Amor e medo", em meio à observação de que "os nossos românticos quando queriam, eram bem realistas e expressivos". Segundo ele, os tremores do eu lírico em "Amemos", de Castro Alves, e "Segredos", de Casimiro de Abreu, contrastam com a projeção, mais frequente, do medo de amar na mulher; seriam manifestações dorde impaciência e/ou ansiedade. No rodapé, acrescenta: “Álvares de Azevedo (II, 270) também toca, muito mais inexpressivamente na mesma tecla: [cita os v. 17-20]. Aliás, todo esse poema da Minha Amante é tão fraco, tão inventado como essa estrofe pálida. Incontestavelmente o poeta vivera muito pouco o amor. Em todo caso, é curioso observar os elementos novos que o poeta acrescenta a esse estado psicológico. São todos fortemente... fracos, pouco masculinos. O poeta descora, desmaia, sua, e sente o peito 'langue'." (ANDRADE, Mário de. "Amor e medo", In: Aspectos da literatura brasileira. Ed. cit., p. 209).

P. $272-273$

EUTHANASIA

P. 272:

Nota MA: termo sublinhado na 1. 5, "ancião", e fio ligando ao comentário ao lado do título:

"Reparar como ele / perde a noção inteli-/gente das frases, aca-/bando aqui interrogati/vamente o que inicara / por interjeição."

P. 273:

Notas MA:

1. preposição corrigida na 1. 20, "dos" - correção tipográfica:

Por que pensal-a... a noite $\mathrm{d} \phi$ mortos, fria e trevosa como os ventos de “/os" inverno!

2. verbo sublinhado na 1. 31, "sobreaguava" - estudo do estilo: vocabulário:

Era uma fronte larga e calva, umas faces contrahidas e amarellentas, uns labios seccos, gretados, em que sobreaguava amargo sorriso, uns olhares onde a febre tresnoitava suas insomnias...

3. comentário ao final do poema:

"Notar a concepção estética de poesia / como é larga em A. de A. a ponto de / por êste poema não metrificado entre / poesias: era o mais inteligente dos romanticos." 
$\underline{\text { P. 277-280 }}$

PANTHEISMO ( 7 estrofes)

P. 280:

Nota MA: v. 80 sublinhado - estudo da psicologia:

Tanta melancolia! e nos meus sonhos, Filho de amor e Deus, eu amo e creio!

$\underline{\text { P. } 281-283}$

DESANIMO (7 estrofes)

P. 282:

Notas MA:

1. trecho sublinhado no v. 25 e expoente “(1)”, remetendo ao comentário no rodapé seleção de ideias;

2. v. 29-32 destacados por colchete, trecho sublinhado no v. 31 e escólio "genio" seleção de ideias: genio:

“(1)" Eu soffro tanto! meus exhaustos dias

Não sei por que logo ao nascer manchou-os

De negra prophecia um Deus irado.

Outros meu fado invejão... Que loucura!

Que valem as ridiculas vaidades

De uma vida opulenta, os falsos mimos

De gente que não ama? Até o genio

"genio"

Que Deus lançou-me á doentia fronte,

"(1) Isto é como refrão na obra de A. de Azevedo"

$\underline{\text { P. 283: }}$

Nota MA: preposição sublinhada no v. 46, "p'ra”, e cruzeta - estudo linguístico: emprego de "para/pra":

D'aquelles homens que, p'ra rir um pouco, $\quad X$

Encobrem sob a mascara o semblante,

\section{P. 284-285}

O LENÇO D'ELLA (4 estrofes)

P. 284:

Nota MA: termo sublinhado no v. 5, "romance" - pesquisa para o Dicionário musical brasileiro:

Um romance cantou de despedida, Mas a saudade amortecia o canto! 
$\underline{\text { P. } 288-290}$

NAMÔRO A CAVALLO (10 estrofes)

P. 289:

Notas MA:

1. artigo suprimido por parênteses no v. 16, "a" - correção tipográfica:

Se ella quizesse eu acabava a historia

Como toda (a) comedia - em casamento...

2. "que" - correção tipográfica:

Hontem tinha chovido... fue desgraça! "/Q"

Eu ia a trote inglez ardendo em chamma,

Mas lá vae senão quando... uma carroça

Minhas roupas tafúes encheu de lama...

P. 297-299

MinHA MUSA (5 estrofes)

P. 298:

Nota MA: termo sublinhado no v. 12, "notas", e escólio "dic" - pesquisa para o Dicionário musical brasileiro:

São lyrios da mocidade

Que murchão por que te amei!

"dic" As minhas notas ardentes

São as lagrimas dementes

Que em teu seio derramei!

P. 304-306

Pensamentos D’Ella (10 estrofes)

P. 304:

Notas MA:

1. v. 5-7 sublinhados, destacados por traço vertical e escólio "Amor e medo"-

Talvez, á noite, quando a hora finda

Em que eu vivo de tua formosura,

Vendo em teus olhos... n'essa face linda

A sombra de meu anjo de ventura,

"Amor e
medo" $\quad \frac{\begin{array}{l}\text { Tu sorrias de mim por que não ouso } \\ \text { Leve turbar teu virginal repouso, }\end{array}}{\text { A murmurar ternura. }}$

P. 305:

Notas MA: 
1. v. 12-32 destacados por traço vertical, ligados por um fio ao escólio "Amor e medo" na página anterior - estudo da psicologia: sentimento amoroso/amor e medo:

Estrella morta em noite de verão!

( Prefiro amar-te bella no segredo!

Se foras minha tu verias cedo

Morrer tua illusão!

Eu não sou o ideal, alma celeste,

Vida pura de labios recendentes,

Que teu imaginar de encantos veste

E sonhas nos teus seios innocentes!..

Flôr que vives de aromas e luar,

$\mathrm{Oh}$ ! nunca possas ler do meu penar

As paginas ardentes!

Se em canticos de amor a minha fronte

Engrinaldo por ti, amor cantando,

Com as rosas que amava Anacreonte,

É que alma dormida, palpitando...

No raio de teus olhos se illumina,

Em ti respira inspiração divina

E ella sonha cantando!

Não a acordes comtudo. A vida n'ella

Como a ave no mar suspira e cai...

Ás vezes, teu alento de donzella

E de teus labios o morrer de um ai,

Tua imagem de fada, n'um instante

2. comentário no rodapé:

"Amor e medo se pega aqui / em plena ação de criar a ima-/gem da amada dormindo $p$ $336 ”$

P. 306:

Nota MA: verbo corrigido no v. 42, "murchou" - correção tipográfica:

Quando tremesses mais, não te doera

"/ur" Mplchou a vida em flôr?

P. $315-321$

12 DE SETEMBRO (18 estrofes)

P. 320:

Nota MA: v. 83 assinalado por expoente “(1)”, remetendo ao comentário no rodapé:

Fôra bello talvez sentir no craneo

"(1)" A alma de Goethe e reunir na fibra

Byron, Homero e Dante;

Sonhar-se n'um delirio momentaneo 
A alma da creação e o som que vibra

A terra palpitante...

"É curiosa esta fixação de que a / alma está dentro do cerebro. Várias vezes Alvares de Azevedo repete / isso."

\section{P. 322-331}

SOMBRA DE D. JUAN (28 estrofes)

P. 323:

Nota MA: verbo sublinhado no v. 12, "entrebeija" - estudo do estilo: vocabulário:

Te susurra delicias vaporosas...

E o formoso estrangeiro adormecido

Entrebeija tremendo?

Nota da pesquisa: Na folha de guarda do vol. 1, MA qualifica o verbo "entrebeijar" como "delicioso de pegajosismo (V. Nota MA, In: AZEVEDO, Álvares de. Obras ... Ed. cit., vol. $1)$.

P. 325:

Nota MA: termo sublinhado no v. 55, "bandolim", e escólio "dic" - pesquisa para o Dicionário musical brasileiro:

\section{Cantava: ao peito o bandolim saudoso "dic"}

Apertava, qual nú e perfumado

A Madona seu filho;

P. 326:

Nota MA: termo sublinhado no v. 68, "guitarra", escólio "dic" e expoente “(1)", remetendo ao comentário no rodapé - pesquisa para o Dicionário musical brasileiro:

"Ó faces morenas! ó labios de flôr!

"dic Ouvi-me a guitarra que trina louçan,

(1)" Vos trago meu peito, meus beijos de amor...

"Alvares de Azevedo fala em bando-/lim mas Dão João concerta mais / espanhol pra guitarra. E o poeta vol-/ta a falar em bandolim p 328."

P. 327:

Nota MA: termo corrigido no v. 96, "lodo" - correção tipográfia:

"E tão bellas, meu Deus! e as niveas perolas

Mergulhei-as no lado uma per uma, "/o"

De meus sonhos de amor nada me resta!

P. 328:

Notas MA:

1. adjetivo corrigido no v. 110, "lentas" - correção tipográfica:

Como virgem nas lqhtas agonias " " $/ e ”$ 
Os seus olhos azues aos céos erguendo

Co'as mãos niveas no seio...

2. termo sublinhado no v. 117, "casualina" - estudo do estilo: vocabulário:

Exhala ainda o canto harmonioso...

Casualina pendida onde susurra

O anoitecer da vida..

3. termo sublinhado no v. 120, "bandolim", e escólio "dic" - pesquisa para o Dicionário musical brasileiro:

$\begin{array}{ll}\text { "dic } & \text { Assim nos labios e nas cordas meigas } \\ \text { Do palpitante bandolim a magoa }\end{array}$

P. 329:

Notas MA:

1. termo sublinhado no v. 123, "lagoa", e exclamação - estudo do vocabulário: expressão da paisagem brasileira:

Gemia como o vento...

Como o cysne que boia, que se perde...

$\mathrm{Na}$ lagoa da morte geme ainda

O cantico saudoso!

2. termo sublinhado no v. 127, "assonias", e escólio "dic" - pesquisa para o Dicionário musical brasileiro:

Mas depois no silencio uma risada

Convulsiva arquejou... rompeu as cordas

Das ternas assonias, "dic"

$\underline{\text { P. } 332-336}$

NA VARZEA (12 estrofes)

P. 333:

Nota MA: termo sublinhado no v. 33, "casualina" - estudo do estilo: imagem:

Lá onde mais suave, entre os coqueiros,

$\mathrm{O}$ vento da manhã nas casualinas

P. 334:

Nota MA: v. 57-58 assinalados e escólio, "Dormida" - estudo da psicologia: amada dormida:

$\begin{array}{ll}\text { "Dormida" } & \text { Vem co'migo, mancebo: aqui sentemo-nos... } \\ \text { Ella dorme: a janella inda cerrada }\end{array}$

P. 335:

Notas MA: 
1. expressão sublinhada no v. 63, "violão divino", e escólio "dic" - pesquisa para o Dicionário musical brasileiro:

Mais doce o canto foge de mistura

Co'as doces notas do violão divino!

"dic"

2. termo sublinhado no v. 74, "frauta", e escólio "dic" - pesquisa para o Dicionário musical brasileiro:

Quando a briza seus ais melhor afina,

Quando a frauta no mar branda suspira, "dic"

P. 336:

Notas MA: v. 86-102 destacados por traço vertical e escólio "Amada dormida" - estudo da psicologia:

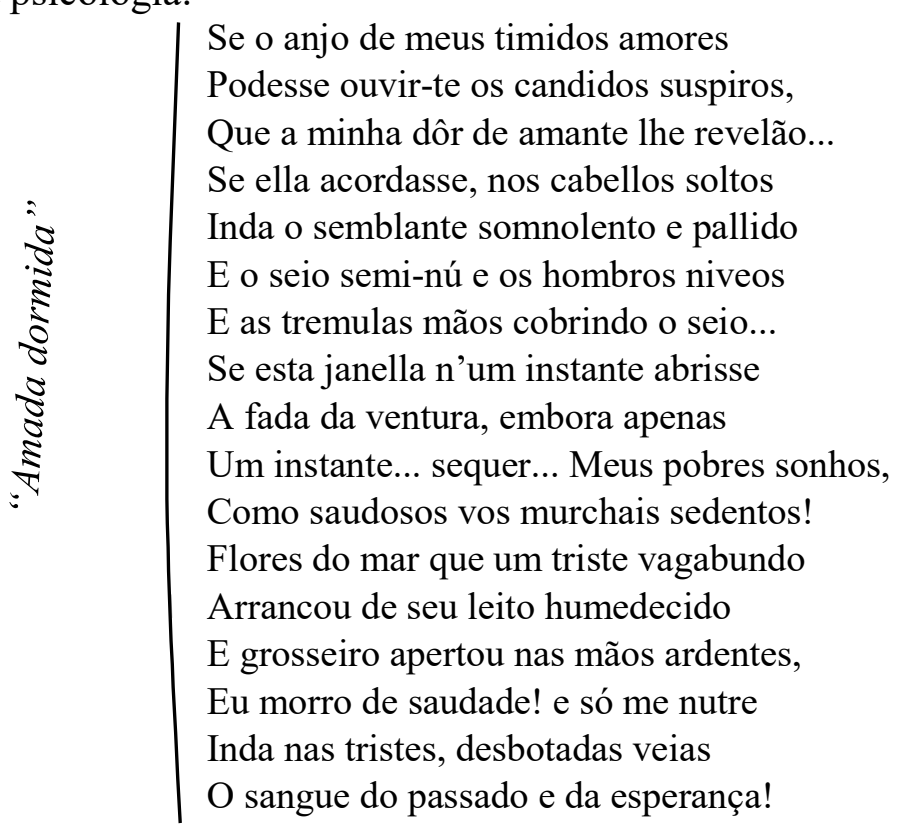

P. $337-340$

O EDITOR ( 7 estrofes)

P. 338:

Notas MA:

1. v. 21-28 destacados por traço vertical e escólio "Aretino" -

2. v. 24 sublinhado e expoente “(1)”, remetendo ao comentário no rodapé:

“Aretino" $\left|\begin{array}{l}\text { - Aretino! essa incrivel creatura } \\ \text { Livida, tenebrosa, impura e bella, } \\ \text { Sublime... e sem pudor, onde de lodo } \\ \text { Em que do genio profanou-se a perola, } \\ \text { Vaso d'ouro que um oxydo terrivel } \\ \text { Envenenou de morte, alma - poeta } \\ \text { Que tudo profanou com as mãos immundas } \\ \text { E latio como um cão mordendo um seculo... }\end{array}\right|$ "(1)” 
"(1) A. de Azevedo já disse isso tudo noutro poe-/ma. Ele tem assim especies de refrãos / que lhe organizam o tedio criador."

Nota da pesquisa: O poema "Boêmios" contém os mesmos versos, com pequenas variantes.

P. 339:

Notas MA:

1. v. 35-39 destacados por traço vertical triplo - a

Se houvesse o Deus - Vintem no Paraiso

Eva não se tentava pelas fructas,

Pela rubra maçan não se perdera:

Preferira de certo o louro amante

Que tine tão suave e é tão macio!

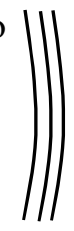

2. termo sublinhado no v. 46, "fabuleiro" - estudo do estilo: vocabulário:

Desde Homero (que até pedia cobre),

Virgilio, Horacio, Calderon, Racine,

Boileau e o fabuleiro Lafontaine

E tantos que melhor de certo fora

P. 340:

Nota MA: juízo de valor ao final do poema:

"Admiravel simplesmente"

P. 341-343

OH! NÃO MALDIGÃO! (12 estrofes)

P. 341:

Nota MA: termo sublinhado no v. 2, “orgias”, e expoente “(1)”, remetendo ao comentário no rodapé:

Oh! não maldigão o mancebo exhausto

Que nas orgias "(I)" gastou o peito insano...

“(1) A. de Azevedo diz órgia sempre. Seria / pronúncia do tempo?”

\section{P. 344-345}

DINHEIRO (1 estrofe)

P. 344:

Nota MA: trecho sublinhado nos v. 3 e 4 e destacado por seis traços verticais - seleção de ideias:

Sem elle não ha cova! quem enterra

Assim gratis, aDeos? O baptizado 


\section{III Tambem custa dinheiro. Quem namora \\ | ||| || Sem pagar as pratinhas ao Mercurio?}

P. 345:

Nota MA: comentário ao final do poema:

"Ver a poesia Editor tam-/bem sobre dinheiro."

P. 350-352

PAGINA ROTA (8 estrofes)

P. 350:

Notas MA: epígrafe assinalada por expoente “(1)”, remetendo ao comentário no rodapé:

“(1)” Et pourtant que le parfum d'un pur amour est suave! GEORGE SAND

“(1) A. de Azevedo repete citações. É engraça-/do. Esta e me parece que outra do Turlquety, não me lembro mais, aparecem duas vezes cada." 


\section{VOLUME 3}

\section{FOLHA DE GUARDA}

\section{Notas MA:}

1. anotação no alto, à direita, " $n^{\circ} 191$ ”, referindo-se à inclusão do volume na Bibliografia para Na pancada do ganzá;

2. lista de verbetes para o Dicionário musical brasileiro e cruzeta indicando o aproveitamento.

$$
\text { " } n^{\circ} 191
$$

Dic - unissona 29 - trom 36 - teorba 40 - jogrete 43 - diakenastas, rapsodos, homeridas 60 - pocema 78 -assonia 119 - ritma 123 e 131 - guzla 129 - epinicios 130 - trino 136 murmuriar 141 - soído 143 - trino 147 - corno (por buzina de chifre) 167 - toque 170 sonoroso 170 - metafora musical 175-retroar 176 - tuba 183 - trova 183 - jogral 187 tuba 188 - aedos 198 - homerida 198 - solfa 200 - pocema 201 - metafora musical 209 tanger (substantivo) 206 - balata 246 - nenia 249 - zoof (reflexão geral canto dos passarinhos) 257 - rabeca 279 - toada 292 - stradivarius (por violino) 295 - musica 295 -tom 322 - nenia 338 - fandango 352 - harmonia 392”

\section{Notas da pesquisa:}

1. O escólio "Zoof" [Zoofonia], a grafite, de ocorrência frequente na marginália de MA, em todas as áreas de sua biblioteca, absorve a denominação da pesquisa encetada por Hercule Florence (1804-1879) e colige matéria destinada ao projeto do escritor de reunir palavras e expressões representando as vozes dos animais. Liga-se, de imediato, ao manuscrito Zoofonia, reservatório e estudo particular desses termos, composto de documentos musicais, recortes de jornal e notas de trabalho, transcritas de publicações ou captadas em pesquisa de campo por MA e seus colaboradores. Em entrevista de 1943, MA filia seu projeto a Green Mansions: a Romance of the Tropical Forests, de William Henry Hudson (V. ANDRADE, Mário de. Entrevistas e depoimentos. Edição organizada por Telê Porto Ancona Lopez. São Paulo: T.A. Queiroz, 1983, p. 93).

"Zoof" prende-se, também, à coleta de termos para o Dicionário musical brasileiro e $O$ banquete, obra na área de Estética, interrompida pela morte de MA em 1945. Nesta, o capítulo 8 previa: "O Passeio em Pássaros. Zoofonia. O canto-enfeite no cio. A mulher vestida de homem e a Lei do Peso. Música da natureza e música descritiva." (V. ANDRADE, Mário de. O banquete. Ed. preparada por Jorge Coli e Luiz Dantas. São Paulo: Livraria Duas Cidades, 1977, p. 167).

2. O escólio "dic", a grafite, de ocorrência farta na marginália de MA, nos títulos de diversas áreas em sua biblioteca, e frequente nos títulos da poesia do romantismo 
brasileiro, indica a pesquisa de elementos para abonar verbetes no Dicionário musical brasileiro, projeto do escritor testemunhado em suas estantes e em seu arquivo, especificamente no manuscrito desse título e nas referências em outros. V. a edição póstuma do Dicionário musical brasileiro, coordenada por Oneyda Alvarenga e Flávia Camargo Toni (Brasília: Ministério da Cultura/São Paulo: IEB-USP - Edusp/ Belo Horizonte: Editora Itatiaia Ltda, 1989).

\section{$\underline{\text { FOLHA DE ROSTO }}$}

Nota MA: anotação "tarde p. 28", no alto, ao centro, remetendo a um trecho da carta de Álvares de Azevedo para seu amigo Luiz Antonio da Silva Nunes.

\section{P. $1-30$}

\section{CARTAS DO AUCTOR}

\section{CARTAS ESCRIPTAS DE S. PAUlo EM 1851}

[12 DE AGOSTO]

\section{$\underline{\text { P. 5: }} \underline{\text { S/Notas MA }}$}

Nota da pesquisa: A carta de Álvares de Azevedo à sua irmã, em 12 de agosto de 1851, não apresenta marcas de leitura; é referida, porém, em nota de trabalho no dossiê do manuscrito Amor e medo: "Carta de amor á irmã III, 5" (MA-MMA-05-29). No ensaio, MA alude às relações entre o poeta e a irmã: "A respeito da mana Maria Luíza, que Álvares de Azevedo muito amou, de cujo amor fraternal teve experiência, tanto nos versos a ela, como nas cartas, o poeta gravou com intensa objetividade, com admirável violência mesmo, o amor fraternal que sentia. E isso contrasta em prova boa com a falta de objetividade na descrição dos seus amores sexuais." ("Amor e medo", in: Aspectos da literatura brasileira. ed. cit. p. 204 e 218). O trecho não consta da versão do ensaio na Revista Nova; é acrescido por MA em seu exemplar de trabalho - no dossiê do manuscrito Amor e medo (MA-MMA-05-099) - com vistas à edição "O Aleijadinho e Álvares de Azevedo", organizada por Murilo Miranda (Rio de Janeiro: R. A. Editora, 1935).

Cartas ao seu amigo Luiz Antonio da Silva Nunes

[SÃo PAULO, 11 DE MAIO, 1848]

P. 10:

Nota MA: termo corrigido, "sopro" - correção tipográfica.

\section{P. 11: S/Notas MA}

Nota da pesquisa: Embora sem notas de margem embora, o parágrafo final desta carta de Álvares de Azevedo, é reproduzido no rodapé de "Amor e medo"; respalda o argumento de que a mulher, figurada como "anjo, virgem, criança, visão", é excluída de "sua 
plenitude feminina". Esta nota de rodapé tampouco consta da versão original do ensaio, para a Revista Nova. O acréscimo a grafite surge no exemplar de trabalho, com vistas à edição do livro "O Aleijadinho e Álvares de Azevedo": “(1) "Contudo, Luís, não sinto que eu ame nenhuma delas. A N. I pareceu-me um anjo num momento de fascinação. A L. I parece uma santa; e não poderia sentir amor por ela: / às santas adora-se, mas não se ama." (Carta de Álvares de Aze-/vedo a Luis Antonio da Silva Nunes, em 1848)." (MAMMA-05-98).

[SÃo PAULO, 26 DE JULHO]

P. 14:

Notas MA: termos sublinhados no v. 19, "tremelêa", e v. 32, "c'roa", e cruzetas - estudo do estilo: vocabulário/licenças poéticas.

$X \quad$ Tremelêa uma perola de rocio.

- Despregada da c'roa d'algum anjo $\quad X$

Nota da pesquisa: MA inclui o verbo sublinhado em nota de trabalho no dossiê do manuscrito Amor e medo, na qual relaciona muitos termos ilustrativos do estilo de Álvares de Azevedo: "Tremelear III, 14" (MA-MMA-05-30). No dossiê do manuscrito Castro Alves, o plano de capítulo para o livro Lirismo romântico no Brasil propõe: "Reunir o caso de croa, do pra, dos decassílabos diminuídos ou aumentados de sílaba num capitulinho sobre as Licenças Poéticas do Romantismo, bem como as rimas toantes e deficientes. Nesse capítulo observar a tendência pro pra e considerações sobre a linguagem brasileira." (V. MA-MMA-26 09).

P. 16:

Nota MA: termo sublinhado no v. 81 , "enfastiado", e comentário à direita - estudo da psicologia: tédio:

E o que hei de eu mais fazer!?... enfastiado

"Sempre o

tedio"

Nota da pesquisa: MA comenta o tédio do autor de Noite na taverna na crônica de 6 de setembro, 1931, publicada no Diário Nacional: “Álvares de Azevedo é ainda tipicamente o revoltado, que não se adapta a coisa nenhuma. O não conformismo dele é de essência exclusivamente individualista. É um dos lados por onde o tédio o havia de atacar fatalmente, porque seu não conformismo o levava a não se interessar por coisa nenhuma." (“Álvares de Azevedo - III", in: Táxi e Crônicas no Diário Nacional. ed. cit., p. 426). Em "Amor e medo", rápida alusão a este traço, interpretando-o como mise-en-scène autoral: "Suas grosserias eram mais um desvio, mais ilusão, mais inverdade, que o transpunham pra fóra de sua existência natural e de si mesmo. Daí o tédio em grande parte, uma fadiga prematura, cujos acentos são as mais das vezes ferintemente sinceros. Spleen, fadiga, não de blasé propriamente, mas de artista dramático que não representava 
apenas nas noites de espetáculo (as farras em que possivelmente andou com outros estudantes de Paulicéa), porém, que fizera da própria vida que cantou em verso e prosa, e imaginava ser a dele, uma falsificação de teatro." ("Amor e medo", In: Aspectos da literatura brasileira, ed. cit., p. 204).

\section{[SÃo PAULO, 4 DE SEPTEMBRO]}

P. 22:

Nota MA: trecho sublinhado e expoente (1) à esquerda, remetendo ao comentário na margem superior - estudo da criação: poesia:

\section{“(1) Alvares de Azevedo tambem emendava / e aperfeiçoava os poemas dele!”}

Fallas na minha imitação de Ducis. Vejo que entendeste mal o que eu te disse na carta em que te dizia que estava fazendo uma imitação do $5^{\circ}$ acto do Othello. A minha imitação é directamente de Shakspeare. Quando se pode ir à fonte, não se bebe agoa nos regos da rua. Está acabada: só o que me falta é resolução de aperfeiçoal-a e emendal-a.

Notas da pesquisa:

1. MA aponta o trecho assinalado como indício do caráter artístico de Álvares de Azevedo, incluindo esta página na rubrica "Artista", em nota de trabalho no dossiê do manuscrito Amor e medo (MA-MMA-05-02).

2. A carta de Álvares de Azevedo ao amigo Luiz Antonio da Silva Nunes contém, traduzida, a "descrição do crepúsculo de Byron (Parisina)". Embora sem marcas de leitura, o verso "Murmurião no ouvido silente" justifica a remissão a esta página em nota de trabalho no mesmo dossiê, onde MA elenca traços estilísticos: "Murmuriar III, 22" (MA-MMA-05-30).

[SÃo PAULO, 18 DE ABRIL DE 1849]

P. 24:

Notas MA: trecho destacado por três fios à esquerda - estudo da criação: lirismo.

[...] mas nem eu os leio: truncados em meio, sem fim ás vezes, nascerão-me elles, como esses sentimentos d'alma que um importuno quebra, como um d'esses sonhos doirados que em meio se apagão. Para mim ali ha uma traducção, embora infiel, um reflexo, embora embaciado, do que se me passa aqui no fundo d'alma; para os outros talvez nada lá haja, talvez os aches frios e seccos, quando ao escrevel-os nem sabes quanta quente lagrima orvalhou-me o papel! Perguntasme porque não te deixei meus versos. Dir-t'o-hei. Não foi falta de confiança em ti, longe de mim, longe de ti tal idéa. Mas tu vês, Luiz, aqui n'esta minha solidão, n'este exilio de tudo quanto de caro para mim vive ahi n'esse mundo, só elles me restão, n'elles acho eu muita recordação doce, muita lembrança de muita scismada ventura. 
Nota da pesquisa: A criação poética tal como descrita no trecho assinalado guarda semelhança com a concepção de lirismo esposada por MA no "Prefácio interessantíssimo": "Ribot disse algures que inspiração é telegrama cifrado transmitido pela atividade inconsciente à atividade consciente que o traduz." (in: Pauliceia desvairada, in: Poesias completas. ed. cit., vol. 1, p. 72). Ao caracterizar o prefácio como "rojão do meu eu superior", MA qualifica os poemas como "paisagem do meu eu profundo" (ibidem, vol. 1, p. 73), no que parece se aproximar da ideia de Álvares de Azevedo de que os poemas seriam "tradução, embora infiel, um reflexo, embora embaciado, do que se me passa aqui no fundo d'alma". Mas no "Prefácio interessantíssimo", é mister lembrar, a concepção de poesia compõe-se não apenas do "estado afetivo sublime - vizinho da sublime loucura": é também a arte de "mondar mais tarde o poema de repetições fastientas e sentimentalidades românticas" (ibidem, vol. 1, p. $63)$.

[RIO, $1^{\circ}$ DE MARÇO DE 1850]

P. 27:

Notas MA: termo sublinhado, "desvivel-a", e cruzeta à direita - estudo do estilo: vocabulário:

(...) eu poderia ainda ter vida bastante para desvivel-a ahi no voluptuoso de um espasmo, para morrer ahi na loucura de um sonho de beijos... $\quad X$

Nota da pesquisa: MA reproduz o neologismo grifado em nota de trabalho no dossiê do manuscrito Amor e medo, precisando-lhe a acepção: "desviver (no sentido de gastar a vida) III, 27 e 233; III, 160" (MA-MMA-05-30). O verbo desviver mostra-se no poema "Quando eu morrer": "As mãos atirem por aí, / Que desvivam como viveram, / As tripas atirem pro Diabo, / Que o espírito será de Deus. / Adeus." (v. 25-29; in: "Lira paulistana"; in: Poesias completas. Ed. cit., vol. 1, p. 525).

P. 28:

Nota MA: traço à esquerda, destacando a caracterização da tarde, conforme nota aposta à folha de rosto do volume:

( São sonhos - sonhos... Luiz! É loucura abrir tanto as azas de anjo do coração a essas brizas enlevadas que, á tarde, vem tão sussurrantes de enleio, tão impregnadas de aromas de beijos! É loucura!

P. 29:

Notas MA: termo sublinhado, "unisonas", e escólio "dic" - pesquisa para o Dicionário musical brasileiro:

A belleza do espiritualismo é o amor das almas, essa afinação que as palpita unisonas par a par ainda na separação (...) "dic"

P. 31-64

DISCURSOS ACADEMICOS

P. $33-50$ 
Discurso RECITADO NA SESSÃo ACADEMICA COMMEMORADORA DO ANNIVERSARIO DA CREAÇÃO dOS CURSOS JURIDICOS NO BRASIL [14 DE AGOSTO DE 1849]

P. 34:

Nota MA: traço vertical em meio ao texto e fio até o comentário na margem superior seleção de matrizes: preparação do romance:

“Até aqui o principio do discurso / de João Bobo. Tomar nota no romance."

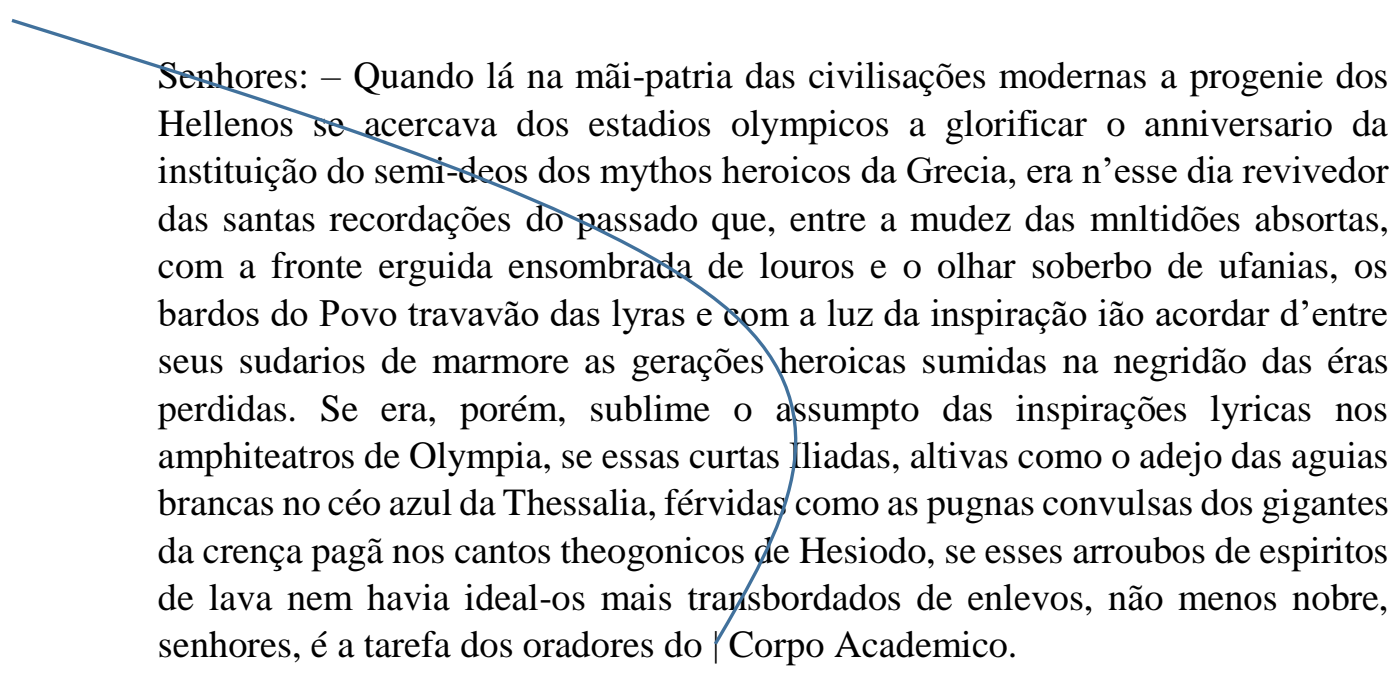

Nota da pesquisa: "João Bobo (romance)" é incluído entre as obras em preparo anunciadas por MA no verso da página de rosto de Amar, verbo intransitivo (São Paulo: Casa Editora Antonio Tisi, 1927). A menção se repete, com a mesma indicação de gênero, no livro de contos Belazarte (São Paulo: Editora Piratininga, 1934).

\section{P. 36-37:}

Notas MA:

1. termo sublinhado, "trons", e escólio "dic" - pesquisa para o Dicionário musical brasileiro:

dic (...) impregnou-se do fumo suffocador dos trons da guerra.

2. termo sublinhado, "humidez", e cruzeta à esquerda - estudo do estilo: vocabulário:

$X \quad$ O grão que começa a rebentar do seu involucro na humidez da terra [...]

3. termo sublinhado, "despear", e cruzeta à esquerda - estudo do estilo: vocabulário;

4. trecho destacado por traço vertical e expoente (1) remetendo ao comentário no rodapé da p. 37:

Quando, depois que essa alluvião de homens, que se chamou a invasão dos barbaros, passou arremessada no despear de sua corrida assoladora, como um tufão, sobre o Pantheon de marmore de Roma, a decahida; quando, após o côro blasphemo das lubricas saturnaes d'esses espurios e degenerados netos dos 
severos republicanos, d'esses que ahi despirão engeitada a cota de malhas dos tempos epicos pela tunica sybarita das orgias, cerrou-se a grande tragedia romana com os hymnos barbaros do triumpho d'essas guerreiras tiuphadias da Cimbria e da Mongolia e os membrudo homens dos desertos enterrárão os coutos das lanças sangrentas de seus estandartes selvagens na fronte rochea do Capitolio pagão e a noite trevosa d'essas éras de barbaria descahio cerrada e negra com seu véo de brumas abafadoras, - não ha hi quem o deslembre, - forão então as ordens religiosas que resguardárão da trovejada e escura ventania da ignorancia, que ahi bramia fóra, á sombra das muralhas claustraes, os tremulos clarões da civilisação moribunda.

"(1) Alvares de Azevedo consegue apesar da pou-/ca idade atingir dentro da esdruxularia da / oratoria verdadeira beleza e esplendor como / neste periodo."

Notas da pesquisa:

1. MA inclui o neologismo "humidez" no dossiê do manuscrito Amor e medo, entre expressões características do estilo de Álvares de Azevedo (MA-MMA-05-30).

2. Conforme se verá, a marginália aposta a este volume contendo a produção em prosa do autor - cartas, discursos acadêmicos, orações fúnebres, estudos literários e dramáticos, incluindo-se Macário e Noite na taverna - desenvolverá a ambivalência anunciada pelo comentário: a oratória por vezes esdrúxula de Álvares de Azevedo, do ponto de vista de MA, é também exemplo de "verdadeira beleza e esplendor".

P. 39:

Nota MA: trecho assinalado por exclamação à direita - seleção de ideias: reivindicação romântica de liberdade formal:

E vos todos sabeis quem foi Sá de Miranda, o philosopho poeta; e Ferreira, esse poeta que nos legou uma unica tragedia, mas bella como as creações Gregas e Romanas e sellada do cunho do genio como os sonhos ardentes de Shakespeare, foi um poeta como tinha de o ser o tragico Inglez e que, de tamanho, não foi comprehendido por seu tempo. Esse rebate contra o triangulo suffocador das unidades classicas; essa obra onde resumbra a futura poesia, livre de pêas, do romantismo, adornada com as flôres perfumosas das capellas das cabeças douradas das nymphas, pranteada com as lagrimas dos Amores [...]

P. 40:

Nota MA: termo sublinhado, "tiorba", e escólio "dic" - pesquisa para o Dicionário musical brasileiro:

dic com as cordas rotas a tiorba romantica de Bernardim Ribeiro.

P. 42:

Notas MA: trecho sublinhado, fio duplo à esquerda e expoente (1) remetendo ao comentário na margem superior - seleção de ideias: planejamento da obra Lirismo romântico no Brasil:

“(1) Citação de início pro livro Romantismo Brasileiro.” 
As letras nacionaes ainda não se enriquecerão de um livro que não fosse bebido no outro hemispherio. Nisso, comtudo, não póde cifrar-se-nos o porvir.

Nota da pesquisa: MA remete ao trecho assinalado no fichamento crítico com as "Ideias gerais" para o livro Lirismo romântico no Brasil. No fólio, sob a rubrica "Observações gerais”, escreve: “A. de A. III, 42” (MA-MMA-26-04).

\section{P. 43:}

Notas MA:

1. termo corrigido, "Nibelungen", traço, cruzeta e interrogação à esquerda - correção tipográfica;

2. termo corrigido, "Minnesänger", inclusão de um “ä" na entrelinha e supressão do "s" final por meio de parênteses - correção tipográfica;

3. termo sublinhado, "jogretes", cruzeta e escólio "dic" à direita - pesquisa para o Dicionário musical brasileiro:

$/ X ? \quad$ a epopéa dos Nibeluengen, com seus diluvios de sangue $[\ldots]$
$\ddot{a}$
esses outros tantos poemas cyclicos dos Minnesingers allernães $[\ldots]$

$[\ldots]$ e as trovas soltas dos menestreis e jogretes Provençaes $\quad X \quad$ dic

P. 44:

Nota MA: termo corrigido, "pagãs", com supressão do "o" e acréscimo do "s" para indicar plural - correção tipográfica.

/s nas crentes hordas pagão do Norte e dos Agarenos [...]

P. 45:

Nota MA: trecho sublinhado - seleção de ideias.

Embora uma utopia, é uma sublime idéa essa de um publicista contemporaneo do papel do Continente Americano na direcção das civilisação das idades por vir.

P. 46-48:

Nota MA: trecho destacado por traço vertical à esquerda e à direita - seleção de ideias: eloquência/figuração autoral; estudo do estilo na oratória:

E o caminho para esse pavez enlourado de regedor de turbas, de guiador por entre desertos - como o Moysés do Povo Hebreu - das Nações que tambem peregrinão sua romagem para a Canaan do progresso - é a Sciencia. E o que ha hi mais bello que o amor litterario? Vestindo embora o manto andrajoso de mendigo, esse velho cantor da sublime epopéa dos tempos antigos, não achaisl-o grandioso ainda assim, com sua lyra no hombro, a longa e rugosa fronte auri-rubra das tintas deslumbradoras dos crepusculos orientaes, immovel e sublime como o Jupiter tonante de seu poema? E Ossian, o bardo-rei de Morven, cégo tambem, cégo como Homero e como depois tinha de sêl-o o tenebroso Poeta do Paraizo Perdido, 
despertando nos saguões mudos dos desertos paços reaes de Selma, pelo rugir do embate das armaduras ferreas de encontro ás muralhas, ás bafagens do vento da noite e dependurando a harpa do muro, a cantar, solitario ancião com as cans derramadas em ondas marmoreas sobre a trave d'ella! os canticos de guerra dos homens do passado, entre as trevas espessas da alta noite; ou nos serros geosos de Inisfail aos albôres nevoentos dos sombrios luares de inverno e os olhos cégos erguidos sob o triplice anadema da fronte sobranceira do rei, poeta e ancião e como a perguntar ás nuvens phantasticas do céo ensombrado, encastelladas nas alturas, historias dos Clans de Inistora, Erim e Tura e dos valentes pares de Fingal e Oscar, ahi dormidos em torno, de somno de palpebras da plumbeas sob o hervaçal deserto e frio das urzes da montanha? Dizei-me: nunca imaginastes Petrarcha com sua grinalda de eloendros e mimosos myrtos da Italia, pallido vate embevecido em sonhos de Laura - flôr aberta nas leivas da serra e voltando o calix branco ao céo a enamorar-lhe lá uma estrellinha? E Camões, o extremado guerreiro o trovador dos brios portuguezes e transumpto do heroismo das assombradoras e altivas lendas do passado de uma nação valente, que n'um poema ia legar-lhes os cultos do universo a essas almas de Romanos da terra Elysa!... nunca o imaginastes na sua caverna de Macáo arrebatado de enthusiasmo patrio, ou enternecido e saudoso de amores que além do mar lhe ficárão? E dizeime, Senhores, entre essa tanta magoa e padecimento, a esses homens que, na phrase de Lerminier, erão Deus pelo genio não lhes acrediates vós venturas?

Que importa esse peregrinar do desterrado Ghibelino de Florença, o sombrio Alighieri, que, da terra patria, além do coração afogado de saudades só levava a espada com que comprára o seu poema tenebroso? Que importão o hospital do vate dos Luziadas, o suicidio de Chatterton, o cadafalso de André Chénier? Que importa que os louros do Capitolio só pousassem na fronte gelida e hirta do morto poeta de Leonora, o sonhador da grande epopéa christã, travada á sombra dos palmares santos da Palestina? Que importa se mais bella a apotheóse da gloria se lhes erguia, radiante e louça como a Venus do paganismo das escumas argenteas do Oceano? Que prova a ingratidão dos seculos para com essas grandes imaginações - tamanhas que desentendidas foi-lhes sina passar entre as multidões - contra a sublimidade do sacrificio á sciencia? Lembrai-vos, Senhores, dos versos do fatidico evocador das scenas pavorosas dos frescos da Sixtina, dos paineis gigantes do juizo derradeiro:

Pur foss'io tal.

Per l'aspro esilio suo com sua virtute

Darei al mondo, il piú felice stato.

P. 50:

Nota MA: comentário à esquerda - seleção de ideias: "influência":

"Mazepa! / Sempre / Mazepa"

O genio é esse sofrego corsel dos stepps do Mar Negro onde estorcia-se a transudar agonias cruentes o heróe do poema de Byron: Away! away! Avante! avante! - Eis o brado das gerações inteiras.

Notas da pesquisa: 
1. MA refere-se ao trecho assinalado sob a rubrica "Influência decisiva europeia" (MAMMA-26-04). O ponto é desenvolvido no mesmo dossiê do manuscrito Castro Alves, onde se encontram reunidas as ideias para o livro Lirismo romântico no Brasil: "Lembrar minimamente a Europa dentro dessa evolução que foi natural, fatal, psicologica e universal. A influencia da Europa foi mais uma adopção que outra coisa. Mostrar que pequenina a influencia de Byron e de Goethe e de Musset sobre A de Azevedo e mesmo quasi que so formal de $\mathrm{V}$. Hugo sobre $\mathrm{C}$. Alves, poetas que apesar de todas as citações estrangeiras foram nacionalissimos e nada quasi influenciados." (MA-MMA-26-10).

2. Duas das crônicas de teor crítico publicadas no Diário Nacional ("Álvares de Azevedo I e II", em 22 e 29 de março de 1931) negam ao romantismo a pecha de fenômeno de imitação: "Jamais uma coisa importada vinga que não tenha uma razão essencial de ser, uma eficiência nacional, nos países importadores. Que mundo de processo e de invenções artísticas nós importamos da Europa e que não encontram eco, não vingam entre nós. (...) o que especifica mais o nosso Romantismo, é a sua extrema necessidade racial, o nosso individualismo incontestável, a flagrante contrariedade entre a nossa entidade geográfica e étnica e a civilização falsa (porque importada) em que nos debatemos. Esta última razão, se manifesta especificamente em Álvares de Azevedo, que, muito mais ainda que Nabuco, foi um ser que viveu de corpo no Brasil, e de espírito na Europa." A mesma crônica, dando continuidade às exclamações na marginália e ao fichamento para o Lirismo romântico no Brasil, destaca o autor da Lira dos vinte anos: "Poeta dotado duma leitura quase decorada dos românticos europeus, procurando imitá-los, buscando macaqueá-los, numa sujeição espiritual amorosíssima e impressionante, a imitação propriamente se limitou nele a berrar de minuto a minuto nas obras os nomes dos que supunha imitar, e a reproduzir deles os parvos entrechos dramáticos dos poemas e a idealização das praias do Mediterrâneo. Quer dizer: tudo falso, tudo indiferente à verdadeira entidade de Álvares de Azevedo, nada essencial nele, nada característico, nada virtual." (“Álvares de Azevedo - II", in Táxi e Crônicas no Diário Nacional. ed. cit., p. 356).

\section{P. 51-64}

Discurso PRONUNCIAdo NA SESSÃO DA InSTALlaÇÃo DA SOCIEDADE ACADEMICA / ENSAIO PHILOSOPHICO [9 DE MAIO DE 1850]

\section{P. 51:}

Notas MA:

1. termo corrigido, "É", pela inclusão do acento agudo - correção tipográfica;

2. termo sublinhado, "desroupa", e cruzeta à direita - estudo do estilo: vocabulário;

3. trecho destacado por colchete e escólio à direita - seleção de ideias: aristocracia e figuração autoral:

[...] a d'aquelle que se desroupa dos andrajos de sua pobreza litteraria por tomar a tunica sublime do missionario do progresso: é talvez insania, quando Deus lhe não assellára, pela febre das noites de insomnia, a aristocracia soberba do genio.

Notas da pesquisa:

1. Os dossiês dos manuscritos Amor e medo e Artigos por escrever conservam documentos que relacionam o escólio "aristocracia" às crônicas de teor crítico publicadas no Diário Nacional e ao editorial redigido por MA para a Revista Nova - cuja direção era por ele compartilhada com Paulo Prado e Antônio de Alcântara Machado. No dossiê 
Amor e medo, o envelope de Augusto Meyer, aproveitado como abrigo das notas de trabalho, mostra que as transformações no projeto de crítica da poesia do romantismo passam por este escólio "aristocracia". A menção ao livro inacabado aparece a lápis-tinta vermelho, "Lirismo romântico"; o ensaio de 1931 sobrepõe-se a grafite, "Amor e medo"; no verso, a mesma rubrica "Aristocracia", a grafite, remete às ideias do editorial, reconfigurado nas crônicas para o Diário Nacional (MA-MMA-05-1).

2. No dossiê do manuscrito Artigos por escrever, as notas de trabalho indiciam o entrelaçamento de aspectos formais, de estilo, ao ethos ou posição de classe do autor: "Aristocracia // Artigo sobre Álvares de Azevedo" (MA-MMA-11-2); “Alv. de Azevedo Aristocracia: Falta de provérbios Falta de caráter cancioneiro popular. O decassílabo é na realidade o único verso dele. Falta do refrão e de qualquer caráter provocado na poética pela poesia ser popularmente sempre cantada." (MA-MMA-11-4) Também consta no dossiê nota preparatória ligada a esta página: "Alvares de Azevedo // Aristocracia // III p 51 // do gênio" (MA-MMA-11-5).

3. O editorial redigido por MA para a Revista Nova, no dossiê Artigos por escrever, será transformado por ele nas três crônicas de teor crítico publicadas entre agosto e setembro de 1931 no Diário Nacional: "Álvares de Azevedo I, II e III” (ANDRADE, Mário de. Táxi e Crônicas no Diário Nacional. ed. cit., p. 417-427), conforme se percebe pelo cotejo dos textos. Outro fólio, este no dossiê do manuscrito Amor e medo, acusa a elaboração do editorial: "O primeiro episódio do Macário é formidável, uma obra-prima. O segundo já vira discurso brasileiro, muito vazio, muita oratória banal. Da mesma forma é colossal o primeiro capítulo da Noite na Taverna, que hoje publicamos." (MA-MMA-05-25; sublinhei). É possível que o texto divulgado na Revista Nova seja de autoria de MA, por sua semelhança com os juízos críticos da marginália e das notas de trabalho no Arquivo, assim como pela existência dos esboços, com o mesmo título - "Momento" - e parágrafo inicial idêntico ("Com este número a Revista Nova comemora o centenário do nascimento de Álvares de Azevedo, publicando alguns inéditos da sua prosa e estudos sobre ele”); é certo, pelo menos, que o editorial publicado se ancora na marginália e em notas de trabalho de MA.

Quanto ao escólio "aristocracia", o manuscrito do editorial reitera em versão mais elaborada o juízo presente nas notas de trabalho no dossiê Amor e medo. No texto autógrafo, como depois nos artigos publicados, MA apresenta os porquês de o centenário de Álvares de Azevedo causar mal-estar entre os contemporâneos: "É que as voltas sociais do tempo tornam para o dia de hoje a figura de Alvares de Azevedo eminentemente odiosa. A qualidade do espirito dele era integralmente aristocrata e Alvares de Azevedo foi o mais aristocrático dos nossos Românticos, para não dizer de toda a nossa literatura." (MA-MMA-11-13).

4. No Diário Nacional, em 22 de março, 1931, completando o raciocínio de que Álvares de Azevedo não era um despaisado, pois em sua obra o "Brasil funciona necessariamente", o crítico sugere um sentido político atual para o aristocratismo do autor de Macário: "Tão nacional que com espaço de sessenta anos quase, chegou a ser regional (e muito mais e essencialmente regional), por aquela maneira sutil com que reflete o aristocratismo paulista de que o Perrepê foi a desastrada conclusão. Álvares de Azevedo foi o único ser aristocrático da nossa poesia romântica." ("Álvares de Azevedo - I", in Táxi e Crônicas no Diário Nacional, ed. cit., p. 357). O Diário Nacional cabe lembrar, veiculava as ideias do Partido Democrático, alinhado aos vencedores da Revolução de 30 e, como se sabe, adversário do Partido Republicano Paulista.

5. Em 6 de setembro de 1931, MA reitera ter sido o autor da Lira dos vinte anos "o mais aristocrata de nossos românticos, para não dizer de toda a nossa literatura" (reiteração que confirma ipsis litteris o teor do f. 13). Os parágrafos finais da crônica desenvolvem o 
raciocínio conciso da marginália e das notas preparatórias: "E ainda é curioso como ele se excepcionaliza entre os românticos, na maneira de criar. Mesmo no diálogo chão do primeiro episódio do Macário, há uma falta enorme de populismos, de provérbios. O jeito cancioneiro popular de poesia é raro e desengonçado na obra dele, não tem a naturalidade deliciosa com que aparece nos outros grandes românticos. As suas modinhas... não são culpa dele. Não tem mesmo a espécie que era então comuníssima na modinha-de-salão burguesa, comum a Gonçalves Dias, Varela. O decassílabo, que é o verso aristocrático por excelência da nossa língua, é bem o verso dele; e isso é tanto mais sintomático que usa com preferência formidável o decassílabo de ritmo heroico, e não o acentuado na quarta e oitava sílabas, em que se remeleixou exaustivamente toda a poesia romântica. $\mathrm{E}$ inda confessou, ou pelo menos sentiu, que tinha gênio (em DESÂNIMO) pra afirmar conscientemente que ter gênio era possuir uma aristocracia soberba: '...Quando Deus lhe não asselara, pela febre das noites de insônia, a aristocracia soberba do gênio'. // Se Casimiro de Abreu é o protótipo da chatice burguesa, Álvares de Azevedo é o excepcional por excelência, fragilizado pelo requinte de inutilidade, revoltado pelo requinte de individualismo. Daí a significação social certamente odiosa que ele tem pros nossos dias socialistas, comunistas, pragmatizados na luta das classes, nas perseguições religiosas. Não é apenas o incolor desaproveitável e esquecível que nem o 'kulak' Casimiro de Abreu: antes deverá subir no cadafalso e gozar da mesma morte que... que pelo menos Maria Antonieta." (“Álvares de Azevedo - III", in op. cit., ed. cit., p. 427).

6. O verbo "desroupar (por despir)" consta entre os termos que ilustram o estilo de Álvares de Azevedo, em nota preparatória no dossiê do manuscrito Amor e medo (MAMMA-05-30).

\section{P. 52-53:}

Notas MA:

1. termo sublinhado, "nuez", e cruzeta à esquerda - estudo do estilo: vocabulário;

$$
X \quad \text { (...) perdão áquelle que vem com a cabeça descoberta, em sua nuez ingloria }
$$

2. traço duplo e expoente (1) à esquerda, remetendo ao comentário no rodapé - estudo do estilo: prosa;

"(1) Pra citar bem como o belo trecho grifado do / discurso anterior pra demonstrar onde poderia / atingir a beleza estilística de Alvares."

Perdão pois á insania do pastor errante, que ao despertar nas quebras das serranias, galgou o topo dos Andes por alembrar aos condores que o sol já avermelha de coraes as faces da noite e as aves acordão no susurro das folhas, que as florestas tremem, os frescos do orvalho se desnevoão e os ventos nos mares e o oceano nas cavernas resoão a hosannas da antemanhã.

3. termo sublinhado, "recovava", e cruzeta à esquerda - estudo do estilo: vocabulário;

$X \quad$ Quando a antiguidade macilenta se recovava no sen tumulo [...]

4. termo destacado por retângulo, "como", assinalando a recorrência das comparações estudo do estilo: metáfora. 
[...] como o craneo perdido do Beduino aos ardores do areal e as ossadas gigantéas lhe estalavão ao passar entre nitridos o cavallo anguento de Attila-o selvagem, na agonia da Roma prostituta dos Cesares; quando aquella anciã civilisação tressuava de afan e escaldava na febre da insania, como o velho rei Shakspeariano apertando a seu peito mirrado o cadaver de Cordelia; por aquelle chão quente de mortualha e aberto de sepulchros passou um acto de um grande drama. Em meio ao retumbar de um echo, fatal e terrivel como o dos cabeços folhudos das serras da Phocida debruçados ao passar da tempestade, agoureiro e lugubre como a voz que bradava nas trevas pelos mares da Sicilia: "os deoses morrêrão!"; ao erguerse brilhante de luzes, como a noiva das nupcias eternas de Deus, a madrugada de Bethlem, a perfumosa, sobre os cumes desertos da Roma do paganismo, a Niobe das nações, na dicção Byronica, n'aquelles combros de ruina surgiu uma turba de homens novos.

Era uma raça de frontes abaçanadas e de olhares onde o fogo da inspiração lampejava como as nuvens pelo cinabrio dos céos do Oriente.

5. trecho sublinhado - estudo do estilo.

[...] que se chrismárão nas lagrimas de Magdalena do remorso e herdárão do Christo a pallidez das faces e a lava da eloquencia dos labios.

Notas da pesquisa:

1. O "exagero metafórico" é registrado em nota de trabalho no dossiê do manuscrito Amor e medo, com remissão a esta página (MA-MMA-05-24).

2. MA inclui "nuez" e "recovar" entre os termos característicos do estilo de Álvares de Azevedo, em nota de trabalho no dossiê do manuscrito Amor e medo (MA-MMA-05-30).

\section{P. 54:}

Notas MA:

1. trecho destacado por traço vertical à esquerda;

2. trecho sublinhado e exclamações à esquerda - estudo do estilo.

[...] As pantheras da Nubia e os leões treinados em cêvo feroz e sanguinoso, as ruinas detorroadas de Carthago, os ultimos saibos de sangueira nas lageas rotas e lavradas do incenio tinhão rolado no arrepio de seus urros, no afan dos somnos da saciedade sobre as ossadas a muitos dos que orárão outr'ora, lado a lado com os homens das catacumbas, sobre os sepulchros dos martyres. Mas o salpicar do pó funerario tinha sido orvalho áquella palmeira altiva do Christianismo, que, bem como o freixo Ygdrasil da crença do norte, tendia a ligar céo á terra. Rompei a mortalha negra ao passado, esbatei no rosto áquelle cadaver o clarão do lampadario da sciencia; e elle, evocado como os mortos aos sortilegios agourentos da feiticeira livida de Lucano - o Homero miltonico do morticinio liberticida de Pharsalia, vos contará muitas de suas lendas memorandas. E por todo aquelle relembrar, vel-as-heis, sempre laureadas e deslumbrantes de gloria, as sociedades de homens unidos peito a peito n'uma sêde de amor aos pés de Deus.

P. 55:

Nota MA: parágrafo destacado por traço vertical e comentário - estudo do estilo: prosa: 
"Aqui a bobagem fica comica"

O carro do progresso, porque rode, ha mister do impulso d'aquella onda perfumosa que se acorda iriante aos sonhos do poeta, ás lucubrações da philosophia. A aridez dos estudos historicos se apura no balsamico das inspirações que vem impregnar de perfume aquellas tradições. O direito, a philosophia, tudo se abrilhanta n'esse prisma de ideas. É Lerminier - Lerminier aos vintes annos! arrebatando nas torrentes de seu enthusiasmo a mocidade franceza de então, onde a philosophia do seculo XIX e a poesia liberal contemporanea, no parecer de Capefigue, produzirão a insurgencia de idéas que fez a quéda da restauração bourboniana, como a philosophia e litteratura do seculo XVIII fizerão a da França monarchica por direito divino.

P. 56:

Notas MA:

1. termos sublinhados, "falsía" e "falsárão", e cruzetas - estudo do estilo: vocabulário:

[...] a mentira no que existe e temem a falsía no que póde vir, entre o vacuo de utopias que falsárão e do empyrismo que renega de todos os principios de sciencia;

2. termo sublinhado, "reléo", e cruzeta - estudo do estilo: vocabulário:

[...] ao bramir suffocado do povo que se dóe da mordaça que o açaima e engeita $X$ o reléo do absolutismo,

Nota da pesquisa: Os termos assinalados na marginália, indicativos do estilo de Álvares de Azevedo, são trasladados por MA para nota de trabalho no dossiê do manuscrito Amor e medo: "falsia III, 56 - falsar" (MA-MMA-05-30).

\section{P. 57:}

Notas MA:

1. trecho sublinhado, "porque a chaga do povo é funda" - seleção de ideias: metáfora política;

2. trecho destacado por traço vertical à esquerda e expoente (1) remetendo ao comentário, registrado no rodapé e à margem direita:

( E, senhores, como eu já vol-o disse: - a palma e a capella com que vos heis de victoriar são a philosophia e a poesia. (1)

A philosophia e a poesia - eis-ahi os dous grandes caminhos das nações, as grandes bóssas onde se lê o progresso ao craneo popular.

“(1) É possível que o cantor de Pedro Ivo viesse / tambem a se tornar um poeta social como Castro / Alves. As tendencia pra isso está aqui. Mas, este / discurso é de 50, maio, e alguma coisa devia transparecer / e não se vê nos poemas desse ano e do seguinte. I Estariam madurando as ideas. Não é de esperar no / romantismo. Alvares era bem um lirico do tedio / e da amargura. lirico no sentido / psicologico do termo." 


\section{P. 58:}

Notas MA:

1. trecho sublinhado - seleção de ideias: concepção de história:

Quando uma organisação social descahe, é sobre as ruinas d'ella que se alevanta a outra: quando um povo passa, é sobre seus tumulos que se celebram os banquetes da geração nova.

2. termo sublinhado, "murchez", e cruzeta à esquerda - estudo do estilo: vocabulário:

[...] revivem e remoção depois da segunda murchez.

P. 59:

Nota MA: comentário à direita - estudo do estilo: prosa.

“Que misturada!”

Comparai a philosophia dos tempos e os poetas: sonhai o labyrintho tenebroso da philosophia Hindustanica de Vyasa, Capila e Gantana, onde porventura Pythagoras bebêra as theorias da metempsycose, Socrates e Platão seu idealismo; entrevêde-a no mysterio dos pagodes e varellas, com seu Sanskrito esquecido pelo povo e seus Brahmanes silenciosos; lêde o Mahabharata; acordai Catão - o suicida e erguei a purpura humida ao leito sanguento de Lucano - o poeta; lembrai as praticas taciturnas do puritanismo, seus templos sem estatuas, onde apparecia na sombra a fronte de Cromwell e folheai o Paraiso perdido; embebei-vos no transcendentalismo allemão - Kant, Fichte, Abichte no idealismo mais puro e vaporoso, reduzindo o pantheismo de Spinosa e a visão em Deus de Malebranche ao egotismo de Fichte e Hegel; e passai as longas noites de vigilia com a Messiada de Klopstock, o Faust de Goethe e as creações negras de Johann Paulus Richter.

P. 60:

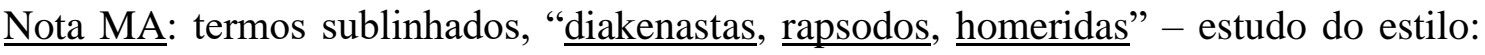
prosa:

[...] na poesia são os diakenastas, rapsodos, homeridas que rastejão no solio dos poemas monumentaes, como os cyclicos gregos e romanos junto a Homero, quiçá Macpherson junto a Ossian,

P. 61:

Notas MA:

1. trecho sublinhado e parágrafo destacado por traço vertical à direita - seleção de ideias: cultura nacional;

Sem uma philosophia, sem uma poesia nacional, como quereis uma nação? A copia livida do que vai pelo mar além poderá ser o sangue de uma nação? O parasitismo scientifico poderá ser condição de vida para a intelligencia de um povo?

2. termo corrigido, "liberdades" - correção tipográfica;

3. trecho sublinhado e cruzeta - seleção de ideias: metáfora política/cultura nacional: 


\begin{abstract}
ld quizerão ainda realizar a promessa do lábaro das nossas liberpades, que nos garante Universidades, por timidos talvez, como os olhos quebrados do doentio, de que se dissipe a nuvem de ignorancia, que é a parceira do despotismo
\end{abstract}

Nota da pesquisa: MA remete ao parágrafo destacado sob a rubrica "Brasileiro", em nota de trabalho no dossiê do manuscrito Amor e medo (MA-MMA-05-02).

P. 62-63:

Notas MA:

1. trecho destacado por traço duplo à esquerda e expoente (1) remetendo ao comentário no rodapé - estudo do estilo: prosa:

“(1) O progresso feito do outro pra este discur-/so é enorme. O outro é infantil; este é o dum / homem. São ideas gerais, não muito ricas é / verdade, mas ideas grandes e sobretudos ver-/dadeiras. Um pouco sofregas pois ainda não era / bem tempo de perguntar à monarquia com vinte / anos e pouco mais pra consolidação da inde/pendencia politica o que fazia pra consolida-/ção duma nacionalidade intelectual, nisso está / a juvenilidade deste gentil discurso eloquente / e de grande estilo, porém as ideas são de <conjectural> homem / e na republica os deputados ainda não falaram / milhor sinão raramente, meu Deus!"”

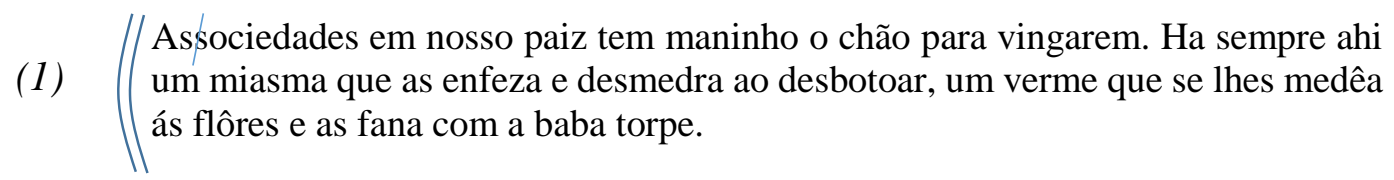

2. termo corrigido, "elephantiasis", com o acréscimo de "/le" à esquerda - correção tipográfica.

P. 64:

Notas MA:

1. termo sublinhado, "murchez", e cruzeta à esquerda - estudo do estilo: vocabulário:

$X$

(...) d'aquelle embate dos influxos reciprocos dos costumes e leis, das acções de desenvolvimento ou murchez dos climas, como disse Bentham,

2. parágrafo final destacado por traço duplo - estilo: hipérbole estribando a ênfase:

//E quando um dia, senhores, nosso corpo adormecer no nada e os homens da terra esquecerem aquillo que foi nossa intelligencia, restará de nós, pelo mar túrbido das peregrinações do progresso, a trilha assignalada pelo rasto de ardentias que deixa a náo sumida no horizonte dos mares pelas noites dos tropicos!

Nota da pesquisa: MA lista o substantivo assinalado junto a outros exemplos do estilo de Álvares de Azevedo, em nota preparatória no dossiê do manuscrito Amor e medo: "murchez, 64" (MA-MMA-05-30).

\title{
$\underline{\text { P. } 65-74}$
}

\section{ORAÇÕES FUNEBRES}




\section{P. $67-72$}

POR OCCASIÃO DE DAR-SE A SEPULTURA O CORPO DE FELICIANO COELHO DUARTE

[S. PAULO, 22 DE SETEMBRO DE 1850]

\section{P. 67-69:}

Nota MA: trecho destacado por traço vertical à direita e à esquerda - estudo do estilo: tratamento de questão existencial:

É uma hora solemne aquella em que a morte se estampa n'uma fronte macilenta; quando o athleta indo no começo do estadio se entende no pó; quando o templo ainda resôa dos echos suffocados da musica dos mortos, o incenso ondula pelas naves escuras, os cirios derramão nas frontes seu clarão amarellento e poucos amigos se debrução á bocca de um tumulo cheio.

Não é preciso que eu venha escrever sobre esse tumulo um nome - que eu vos acorde reminiscencias do passado - que eu vos diga que essa fronte fria é a de um nosso irmão de letras, que áquelle peito pulsou fervente no enthusiasmo santo do poeta, e aquella cabeça sublime sonhava no porvir os louros da gloria que não as flôres murchas e cheias de cinza da capella do finado.

Porque morreu? - Perguntai ás aves de arribação porque as leva de vencida o tufão da tempestade! ás estrellas porque desmaião e mergulhão nas ondas! a Chatterton e Jacopo Ortiz, porque uma hora de febre esqueceu-os de uma existência!

E sua existência se fadava brilhante! As glorias da tribuna, os triumphos do genio e talvez que outras palpitações mais ardentes, o amor: tudo isso era o seu futuro, azul e puro como os sonhos de vinte annos! E tudo isso murchou ao sopro do nada! E o vento da morte ao correr pela selva sagrada mirrou o cedro mais soberbo!

Porque morreu! - É um mysterio sombrio e profundo, que ficou entre o homem e Deus na vida, e foi consummar-se no leito de agonia, no mysterio ainda mais escuro do ser e do não ser!

Porque morreu! - Respeito ao cadaver, senhores! As grandes vidas, como essa o foi, não morrem das doenças miseráveis, legados ulcerosos que a humanidade herda a seus filhos, como um escravo! Quando as harpas santas rompem suas cordas, é que o vento de Deus roçou terrível por ellas!

Dorme pois, creatura sublime! Era outra de certo a "boa noite!" que eu quizera saudar-te! Dorme em paz! e os anjos te alumiem nos teus sonhos, como as estrellas do céo as noites escuras da terra! $\mathrm{E}$ a ti, que sentias como poeta, a quem talvez o genio matou n'um beijo de fogo, a quem Deus daria na existencia a corôa mystica dos amores, a gloria suas visões, as noites seus perfumes, as luas suas lampadas de ouro - Boa noite!

\section{P. $75-162$}


$\underline{\text { P. } 77-86}$

LUCANO

P. 78:

Nota MA: termo sublinhado, "pocema", escólio "dic" à esquerda e expoente (1) remetendo ao comentário no rodapé - estudo do vocabulário; registro do processo de leitura aliado ao trabalho crítico:

"(1) Que quererá dizer pocema aqui? / Será pôça? A mania do altissonante / levou A. de A. a se enganar e de po-/ça ou pocilga, dar o sinonimo pocema”

"dic Rienzi foi um meteóro que só serviu para mostrar as trevas de um povo morto

(1)” de ebriedade, cahido de pocema em pocema, [...]

P. 79:

Nota MA: parágrafo destacado por tracejado à direita - seleção de ideias: caracterização do poeta como reflexo do leitor:

Lucano é uma pagina dos fastos d'essa Roma. Caracter brilhante, a luz que aureolava aquella fronte de poeta só serviu para mostrar a escuridão de um povo inteiro labutando nas trevas do paganismo, nas saturnaes de um culto absurdo e maldito no torpe de seus mythos.

P. 81:

Notas MA:

1. trecho sublinhado e expoente (1) remetendo ao comentário no rodapé - definição do gênero: epopeia:

“(1) Estupenda síntese, verdadeira definição. / Cita-la quando falar no epico a respeito dos / Timbiras e do Evangelho das Selvas provando-lhe / o lirismo do $1^{\circ}$ e o epismo lirico do $2^{o \text { " }}$

“(1)” $\quad$ A epopéa, isto é, o sublime da historia, clama por seu evocador, como a amante por seu poeta.

2. termo sublinhado, "vaporento", e cruzeta à direita - estudo do estilo: vocabulário.

$$
\text { [...] no róseo vaporento dos verões } \quad X
$$

3. traço vertical à direita - seleção de ideias: caracterização do poeta.

Lucano é assim um poeta ao geito de Meonio.

Notas da pesquisa:

1. Ao final do canto IV d'Os timbiras, MA confirma a classificação de gênero deste comentário: "Os Timbiras, poema lírico..." (Nota MA in DIAS, Gonçalves. Obras posthumas de Antonio Gonçalves Dias precedidas de uma noticia de sua vida e obras pelo Dr. Antonio Henrique Leal; Poesias posthumas. Rio de Janeiro: H. Garnier, 1909). Em Anchieta, ou o Evangelho nas Selvas, em cujo volume MA deixa fartas notas, é possível relacionar ao "epismo lírico" registrado em Álvares de Azevedo o comentário no rodapé do Canto VI: "Uma certa eloquência épica de vez em / quando ainda se nota 
em Varela como nes-/te lindo passo. Nos parece efeito de mero aca-/so, excepção na obra dele." (Nota MA in VARELA, Obras completas de L. N. Fagundes Varella: edição organisada e revista, e precedida de uma noticia biographica por Visconti Coaracy e de um estudo critico pelo Dr. Franklin Tavora. Rio de Janeiro/Paris: Garnier, 1919, vol. 3, p. 173).

2. Ao qualificar os poetas do romantismo brasileiro de "essencialmente líricos, nada tendo de trágicos ou épicos", em esboço para o livro Lirismo romântico no Brasil, MA planeja "examinar ainda a narração no Evangelho das Selvas e nos Timbiras e Paulo Afonso" (MA-MMA-26-07). O lápis do crítico tende a escrever "Evangelho das selvas" no lugar de "Evangelho nas selvas", conforme se vê nesta nota e na classificação da marginália MA nas obras de Fagundes Varela.

3. "Vaporento", seguido da indicação desta página, figura entre os termos que respaldam o juízo crítico de MA quanto à riqueza vocabular da prosa de Álvares de Azevedo, em nota de trabalho no dossiê do manuscrito Amor e medo (MA-MMA-05-30).

P. 82:

Nota MA: trecho destacado com um traço vertical à esquerda - seleção de ideias: caracterização do poeta:

[...] um vapor vertiginoso de crepusculo de verão que travava do espirito e que Lucano concentrava em sua alma afervorada,

P. 84:

Notas MA: trecho destacado por traços verticais à esquerda - seleção de ideias: reivindicação romântica de liberdade formal e transitoriedade/historicidade estética:

E tambem, depois da poesia helleno-latina era impossível acordar aquelles colossos do paganismo com brilhantismo homerico, não só por que Homero viera primeiro, e por que fôra o genio maior da antiguidade; mas tambem por que Homero cria e Lucano, á decadência descrida de Roma, não cria — e a poesia da religião é a fé.

Assim pois, não ha julgar a epopéa de Lucano pela Poetica Aristotelica. A poetica, como todas as leis, deve variar com as suas condições de existencia, com suas mudanças de relações. Leis irrevogaveis - eis uma utopia muito maior ainda na arte - um de cujos fins é o bello e o aperfeiçoamento do bello, do que na legislação — cujo fim é o justo e a realisação do justo.

P. 85:

Nota MA: expressão sublinhada - seleção de ideias: crítica:

Pobres críticos! E com tudo, nem o Tiberio de J.-M. Chénier, nem sequer o Britannico de Racine... a nada d'isso vale o pergaminho do annalista Romano. Pobres criticos!

\section{P. 87-114}

JORGE SAND

P. 87:

Notas MA: termo sublinhado, "communismo" - seleção de ideias: política. 
[...] n'aquella sua theoria ardente, balanceada entre o socialismo e o communismo, entre Platão e Fourier

P. 88:

Nota MA: expressão sublinhada e expoente (1) remetendo ao comentário na margem superior.

“(1) Já então se falava nisto!”

[...] embora humilde espectador da riqueza do crepusculo brilhante de poesia (1)

P. 100:

Notas MA:

1. trecho destacado por uma cruzeta à esquerda - seleção de ideias: criação.

Ainda! e o tempo corre! e nada escripto!

(Lê.)

Harold! Harold!... ó Christo! Harold!... o duque Guilherme... E que me importa esse Harold, eu vo-lo pergunto? Nem posso entender como escrevi isto!

2. trecho destacado por um traço triplo à esquerda e anotação, "Poesia" - seleção de ideias: criação:

“Poesia” $\quad|| \begin{aligned} & \text { Onde vou? onde vou? A palavra leva de rojo a idéa á força... O’ céo! a loucura } \\ & \text { não lavra assim? Eis com que assustar os mais valentes... Eia! calma-te... - Eu } \\ & \text { relia isto... sim... Este poema não é bello de certo... Escripto muito a correr... } \\ & \text { escripto para viver!... oh! supplicio! A batalha de Hastings! os velhos Saxões!... } \\ & \text { os jovens Normandos!... Interessei-me eu n’isso? não. Porque pois fallei-o? } \\ & \text { Quando tanto havia a dizer sobre o que vejo! }\end{aligned}$

P. 103:

Notas MA:

1. acréscimo de acento, "dê" - correção tipográfica;

2. termo sublinhado, "pastío", fio e cruzeta - estudo do estilo: vocabulário:

Tenho n'alma só a dôr; é preciso que de pastío ás minhas dores... Rir- /ê

te-has talvez!

Nota da pesquisa: MA arrola "pastio" entre as palavras que denotam o estilo lexical imaginoso da prosa de Álvares de Azevedo, em nota de trabalho no dossiê Amor e medo (MA-MMA-05-30).

\section{P. 115-162}

ALFREDO DE MUSSET

P. 116:

Notas MA: termos sublinhados, "ourar" e "alembra", e cruzeta - estudo do estilo: vocabulário.

$X \quad[\ldots]$ é Oreste que blasphema no seu ourar que queima, 
$X \quad[\ldots]$ um porejar vermelho que alembra as garras da aguia dos Alpes ou do condor selvagem d'esses Andes

Nota da pesquisa: Ambas as palavras são incluídas em nota de trabalho no dossiê do manuscrito Amor e medo, na qual MA dá conta do vocabulário de Álvares de Azevedo (MA-MMA-05-30).

\section{P. 118:}

Nota MA: parágrafo destacado com um traço vertical à esquerda, trecho sublinhado e expoente (1) remetendo ao comentário no rodapé - estudo da criação: influências/matrizes.

“(1) É o que se pode tambem dizer de Alvares / de Azevedo a respeito de Byron e de Heine. Parece / isto uma defesa pro domo"

Alfredo de Musset é uma d'essas almas de poeta, que se baptizárão no scepticismo das ondas turvas de Byron. Não é um plagiario, comtudo, não é um árido imitador. $(1)$ - Mal fôra dizer de algum de seus poemas: eis uma cópia. $\mathrm{O}$ que ha é uma harpa acordada aos sons rugidores de um concerto da noite, um cerebro que se esbraseou nos sonhos de outro cerebro. Namouna, Mardoche são inspirações de Beppo e Don Juan. No licôr com que Musset purpurisa sua taça, sente-se o resaibo dos vinhos queimadores de Lord Byron, a opála doirada do Johannisberg e o fogo do gin, como os perfumes das rosas no falerno romano. A taça e os labios é a visão de Manfredo, o fel de Arnold - o corcovado, é uma nuvem d'aquelles ideaes que voltêa nevoenta pelo sonho de Frank - o Tyroliano. Zampieri descrido, o Dalti da Porcia, Rolla - eis o sombroso pallôr de Lara. É uma idéa funda, como que um liquido negro que se lhe injectou pelas arterias, uma vida febril de alheia seiva que se lhe denuncia nas tintas.

\section{P. 119:}

\section{Notas MA:}

1. acréscimo do acento indicativo de crase, "á” - correção tipográfica;

2. termo sublinhado, "assonia", e escólio "dic" à direita; pesquisa para o Dicionário musical brasileiro:

$$
\text { [...] nas phantasias allemãs de Hoffmann e na assonia de Lamartine, }
$$

P. 121:

Nota MA: termo sublinhado, "languinhenta" - estudo do estilo: vocabulário.

Sue - dahi ao dormir affrontoso - do rubor do fogo dos vinhos á pallidez languinhenta do libertino: eis seu resvalar de vida.

P. 124:

Nota MA: termo sublinhado, "cadav'rosa" - estudo do estilo: vocabulário.

$X \quad$ Na cadav'rosa tez da infamia o sello

P. 126-127:

Notas MA:

1. trecho destacado com um traço vertical, que se prolonga à p. 127, e escólio "Musica"

- seleção de ideias; 
2. termos sublinhados, "trasflores", "vaporentas" e "deslumbre", e cruzetas à direita estudo do estilo: vocabulário;

3. trecho sublinhado e expoente (1) remetendo ao rodapé da p. 127.

“(1) Citar isto pra caracterizar o verso-livre / dos romanticos nossos, talvez mesmo só pra / Varella."

\begin{tabular}{l|l} 
Musica & O verso trina-lhe argentino e melodioso: fôra-nos delirio crer esplhal-o no
\end{tabular} opáco de uma traducção nossa. O mais que póde fazer o traductor é dar inteiro o metal: o artistico do florilegio, o suavissimo dos arabescos, o iriante das trasflores de Cellini fundem-se, disformão-se no cadinho ingrato. Na poesia, como na prosa de Lamartine e V. Hugo, de Mendes Leal e Alexandre Herculano, o rhytmo embala, o som é uma sensação que inebria, como os sonhos das noites vaporentas nos devaneios do poeta. Ha hi, ás vezes, uma palavra suave que evoca por si uma illusão, como o condão do Manfred no iris das torrentes dos Alpes a Fada das montanhas, em todo o seu deslumbre e belleza de espirito. Parece que, ao deslizar fluente de um verso, ao cahir de uma cesura, o sentir se assemelha ao inanido escorrer de arroio limpido em leito de nenuphares curvos ou ao tombar das gottas de chuva de um salgueiro desgrenhado na face azul da lagôa. É essa uma doçura que só tem comparação com tudo que ha mais vaporoso, mais frouxo em um suspiro por labios de mulher bella, em um perfume por cabellos humidos.

Ha quem não conceba a harmonia do som, quem adormecêra ás melodias languidas de Bellini, quem descrêra do susurro das virações deo crepusculo n'aquelle mar de ondas doiradas que se chama - o alaúde do poeta, para quem a musica expirando das faces da Noiva de Abydos e as phrases peregrinas e aêreas do Raphael de Lamartine, a mollidão do Soneto em seu

Notas da pesquisa:

1. O dossiê do manuscrito Amor e medo conserva a rubrica "Música" e a indicação desta página em nota de trabalho (MA-MMA-05-29).

2. O fichamento crítico para o Lirismo romântico no Brasil registra sob a rubrica "Técnica do Romantismo Brasileiro" a "monotonia decassilábica", o "modo de contar sílabas", o "brasileirismo expressional", entre outras precisões, e remete a nota de margem em Gonçalves Dias (Poesias. Paris/Rio de Janeiro: Garnier, 1919, vol. 1, p. 312) na qual MA afirma que os românticos "não revolucionaram o verso" (MA-MMA-26-04).

3. A versificação desponta entre os aspectos-chave da marginália MA nas Obras completas de Fagundes Varela. Acusando juízos por vezes contraditórios, as notas atestam a admiração de MA, conforme escreve à margem de "A despedida": "Incontestavelmente Varela indica um progresso de preocupação da forma poética em relação aos outros românticos" (Nota MA in VARELA, Fagundes. Obras completas. ed. cit., vol. 1., p. 221). Em "Conforto”, observa: “(...) como / Varela é gostoso em certos poemas só pela forma. A gente lê, vai se deixando levar pelo embalo do verso, não carece compreender vai até o fim. É verdade que isso gera facilmente o fastio, o fastio vem. Aqui é esplêndido." (ibidem, vol. 1, p. 224).

P. 128: 


\section{Notas MA:}

1. termo sublinhado, "rhitma", e escólio "dic"- pesquisa para o Dicionário musical brasileiro;

2. traço vertical e fio ligando o trecho em destaque ao expoente (1) na p. 129 - seleção de ideias;

3. traços verticais (triplo e depois simples) - seleção de ideias: liberdade de formas:

"dic" embalar nas nevoas macias da rhitma é objecto de um riso estupido. Pobre gente! "não tem musica na alma" como Byron o disse; não comprehendem // essa intimidade da musica e da pintura de que falla Mme de Stael; e achão absurdo para traduzir o incerto do sentimento ou o vago das fórmas buscar o fluctuar vaporoso das expressões! É lastima que até Gustavo Planche satyrise as Orientaes do poeta das Folhas do Outomno, pelo seu titulo mais bello - o culto dos sons.

3. termo corrigido, "perpessa", anulando o "e" e substituindo-o por um "a": "perpassa" correção tipográfica.

P. 129:

Notas MA:

1. traço vertical à direita, destacando o parágrafo e expoente (1) remetendo ao comentário no rodapé - seleção de ideias: ritmo;

2. termo sublinhado, "guzla", e escólio “dic" à direita - pesquisa para o Dicionário musical brasileiro;

3. termo corrigido em "suas garças branca debruçadas" pelo acréscimo do "s", "brancas" - correção tipográfica:

“(1) Provar que é estupido se dizer que quan-/do a idea é justa e bem pensada tem estilo. / Aqui por exemplo a idea é uma tolice frou-/xa, não diz absolutamente o que é o ritmo; / porem faça-se abstração da idea e é um / admirável trecho literario do milhor estilo."

O rhitmo, releve-se-nos a digressão, é o tom fugitivo do bandolim da Grenadina; a resonancia melancolica da guzla do Klephta montanhez; o escorrer dos borrifos da chuva da noite pela melena lustrosa dos coqueiros, onde o sol nascente iría mil côres; o fluctuoso dos rios das nossas varzeas, com suas ilhas de verdura, suas garças brancas ${ }^{s}$ debruçadas no espelho das aguas, suas largas flôres aquaticas abrindo os seios de setim. E, quando o ciciar do som peregrino vai de mistura com a escarlata de uns labios, passalhe na onda como que um tremor voluptuoso de roupagens de donzella e, como o cahir na molle purpura de flôres esfolhadas, a nuez lasciva da Diana, qual a sonhou o paganismo, inda orvalhosa das bagas de aljofar das ondas do lago...

P. 130:

Notas MA:

1. trecho destacado por traço vertical à esquerda - seleção de ideias/estudo do estilo.

2. termo sublinhado, "epinicio", e escólio "dic": pesquisa para o Dicionário musical brasileiro; 
3. termo corrigido, "esarneo", pelo acréscimo de "sc" à direita, "escárneo": correção tipográfica;

4. termo corrigido, "almodar-se", para "amoldar-se"; correção tipográfica:

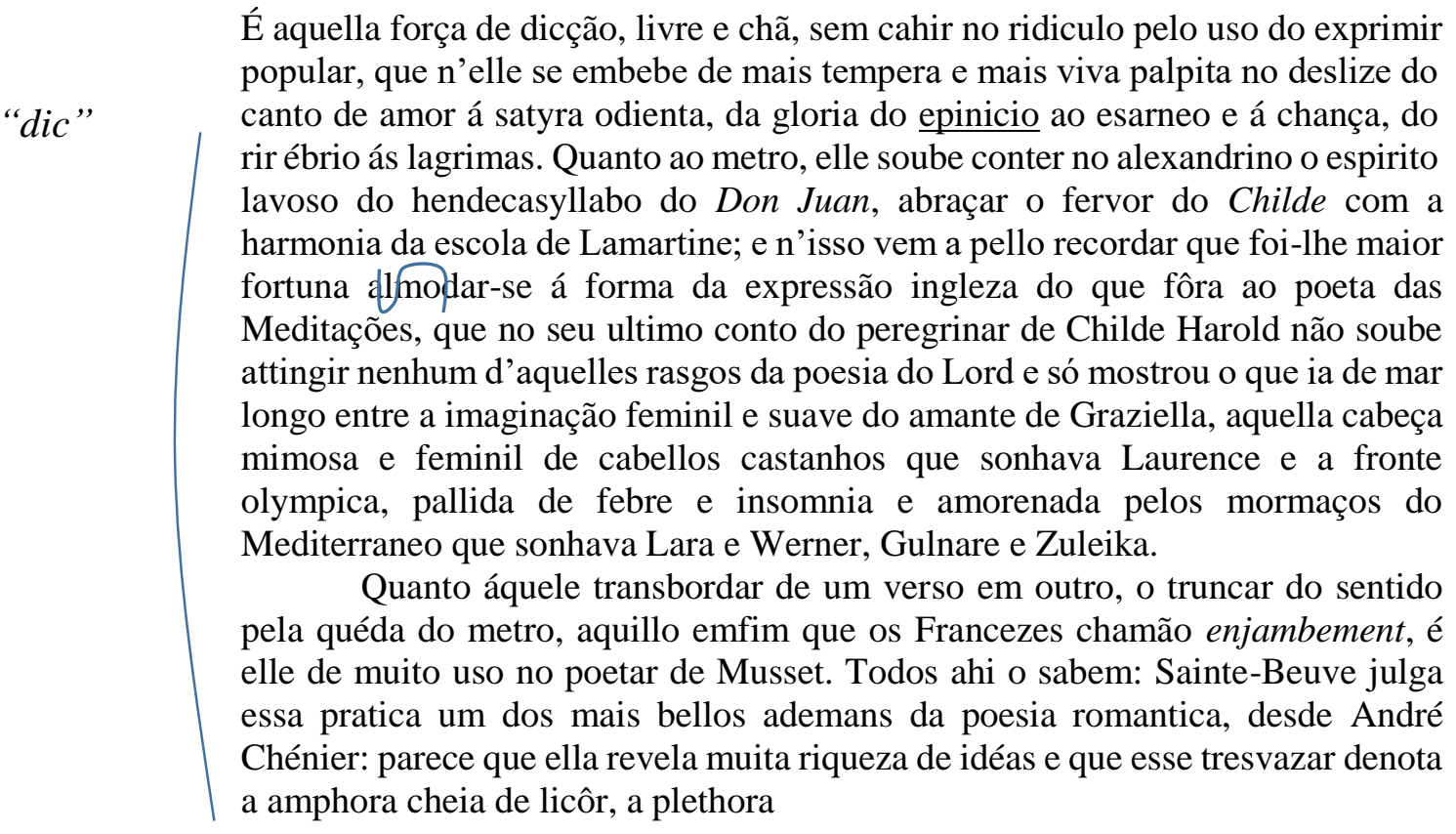

P. 131:

Notas MA:

1. texto destacado por traço vertical - seleção de ideias: crítica;

2. termo sublinhado, "aluziava", e cruzeta - estudo do estilo: vocabulário;

3. termo sublinhado, "rhitmas", e escólio à esquerda, "dic": pesquisa para o Dicionário musical brasileiro:

do sangue nas arterias. Em nossa litteratura antiga, quando ella se aluziava de brilhantismo em Camões e Ferreira, vemos-lhe o abundar: á medida, porem, que se dissipava a poesia original - a poesia pessoal, como a chama o Sr. Maquin e que Jouffroy quer por unica e verdadeira, quando a imitação latina escorregou gélida como uma serpente no lyrismo degenerado, então, a modo que, á proporção decrescente de poesia e idéas, o verso se intumecia em seu vacuo, como um somnolento que se espreguiça. Fez-se inutil aquelle transbordamento que assemelha os versos dos $2^{\circ}$ e $3^{\circ}$ canto de Don Juan a um molde estatuario, cujo metal doirado tressua. Comtudo, classificariamos o abuso d'esse atavio nas regras limitadoras do quidlibet audendi horaciano. Quando a liberdade poetica bastardêa em licença e desregramento, somos d'aquelles que a reprovão e peferem Byron por mais perfeito em algumas paginas do Childe que n'outras de Don Juan, Beppo e da Visão do Juizo, que o saborêão mais nas estancias spencerianas do seu heróe peregrino do que na soltura e córte dos vesos e ás vezes nas strophes cuja ligação se intima e solda tanto com as immediatas que, nem ha "dic" sentir a cadencia do metro, o quêbro das cesuras, o écho das rhitmas e a separação das estancias. Porisso, em Musset, preferimos seu poetas de Rolla, onde menos abunda isso, ao desalinho do Mardoche e ainda a esse ultimo as sextilhas, não tantas vezes truncadas, de Namouna.

P. 132:

Notas MA: 
1. trecho destacado por traço vertical - seleção de ideias: crítica;

2. termo sublinhado, "repugnal-o", e cruzeta - estudo do estilo: vocabulário:

\begin{abstract}
Quanto á linguagem, dissemol-o, ageita-se á feição do seu modelo: Rolla amantase como o Cavalleiro do mar. Não se ennubla nas melodias confusas da escola franceza, reflexo macio das bellas harmonias do Lakismo de Wordsworth, mas a que se pudéra applicar as palavras da rainha Agandecca de Jorge Sand ao pallido Aldo - o bardo "poeta, és bello como a lua á meia noite e monotono como ella". Nem tambem offusca na sobejidão de brilho como o pompear das Orientaes, ou na riqueza luxuriosa de imagens como o poema porventura de mais imaginação que tenhamos lido, o Ahasvero de Quinet. Evitou tambem um grande defeito do seculo - o archaismo. Certo que é lei o fluxo e refluxo das linguas e que, na expressão de Victor Hugo, quando ellas se fixão morrem; e que o poeta deve remoçar as velhas expressões de outr'ora, enriquecer a litteratura contemporanea com os thesouros do passado, avival-a com aquillo que Saint-Beuve chama - um perfume de antiguidade. Entre nós, por exemplo, que tão opulento havemos o idioma patrio, são de irrecusaveis meritos aquelles que retemperão as idéas de hoje no fogo das expressões dos mestres da lingua: por isso os escriptos dos Srs. Alexandre Herculano e Garrett, A. F. de Castilho e Mendes Leal (quando esses dous ultimos não resvalão nos trocadilhos do seiscentismo), além de seu quilate litterario, tem esse valor. Mas desde que o excesso vem, teremos de repugnal-o, e nos lamentar
\end{abstract}

\title{
P. 133:
}

\section{Notas MA:}

1. trecho destacado por traço vertical - seleção de ideias: crítica;

2. termo sublinhado, "antiquaria", e cruzeta à direita - estudo do estilo: vocabulário;

3. comentário/juízo crítico ao final do texto:

\section{"Muito critério e mesmo fineza / de observação"}

do sacrificio das idéas e da poesia a um lavor pelo exprimir, bello sim, mas morto, da lingua antiga, d'esse abandono da laurea de bardo pela gloria de antiquario, pela imitação dos poemas de Chatterton e da seita erudita de W. Scott. É isso desconhecer a missão de aperfeiçoamento da lingua. A combinação dos elementos da dicção moderna com os da envelhecida póde ser um progresso: a imitação servil do estylo do primeiros seculos é um regresso. Portanto, só como exercicios eruditos de antiquaria poderemos olhar o estylo das Memorias de P. L. Courrier, das Cem Novellas de Balzac, das poesias da pseudo-Clotilde de Surville; e, em nossa litteratura, o do Rausso por homizio do Sr. Rebello da Silva, talvez o do D. Sebastião o Encoberto do Sr. Abranches, o de alguns soláos do Sr. Serpa Pimentel e A. P. da Cunha e o das Sextilhas de Frei Antão do nosso mais mavioso poeta brazileiro - o Sr. A. G. Dias.

Notas da pesquisa:

1. Em nota de trabalho no dossiê do manuscrito Amor e medo, MA reitera os termos da marginália: "Na crítica uma indigestão famosa de noções e 'sensações' mal digeridas e desorganizadas, mal de que não se escapa mesmo no Brasil. Assim mesmo no estudo sobre Musset tem critério e fineza de observação.” (MA-MMA-05-24). 
2. O editorial da Revista Nova (a. 1, n. 3) indica esta página como ilustrativa da "clarividência às vezes notável" das observações de Álvares de Azevedo, em específico no que diz respeito ao "caráter do estilo".

P. 135:

Nota MA: poema assinalado por cruzeta:

$x \quad$ Deixar o globo, Faust! não scismáras

Da noite na agonia, em que máo anjo

No afogueado manto, como sombra,

Pelo teu ether te levou, suspenso, ás plantas!

P. 136:

Notas MA:

1. termo sublinhado, "trinos", e escólio à esquerda, "dic" - pesquisa para o Dicionário musical brasileiro;

2. preposição sublinhada, "para", e cruzeta - estudo linguístico: emprego do para/pra:

"dic" Na escada molle, da manhãa aos trinos,

Os beijos embalava e adeus infindo!

Quinze annos! luz que á arvore da vida,

No morno oásis do deserto olente,

Banha aureos pomos de ambrosia, myrrha

$X \quad$ Gue evola para o ar, como a palmeira

O defumado véo esfralda apenas

Do Oriente ás virações... Romêo! quinze annos,

P. 137:

Nota MA: termo sublinhado, “desnocal-o", e cruzeta - estudo do estilo: vocabulário.

Oh! cháos eterno! prostituir a infancia!

Melhor não fôra em thalamo indefeso

Ferir-lhe o corpo no segar da fouce,

Tomar o collo niveo e desnocal-o?

$X$

Nota da pesquisa: MA lista inúmeros neologismos de Álvares de Azevedo irmanados pelo prefixo "des-", em nota de trabalho no dossiê do manuscrito Amor e medo: "desnucar III, 137” (MA-MMA-05-30).

P. 138:

Nota MA: preposição sublinhada, "para", e cruzeta - estudo linguístico: emprego do para/pra:

$X \quad$ Para ir-se á orgia tu lavaste-a mesmo,

P. 140:

Notas MA:

1. preposição sublinhada, "para", e cruzeta - estudo linguístico: emprego do para/pra:

$X \quad \underline{\text { Para ir-te a sós vagar, pallida a fronte, }}$ 
2. verso sublinhado - estudo do estilo: versificação/métrica.

Que te sussurra da Cruz o Christo livido?

Nota da pesquisa: O fichamento crítico para o livro Lirismo romântico no Brasil faz referência a este verso como exemplo do "Modo de contar as sílabas" (MA-MMA-2604).

P. 141:

Notas MA:

1. verso sublinhado e comentário à direita - estudo do estilo: versificação/métrica:

Olha! não amão! nem amárão jamais! "Bem mais errado"

2. termo sublinhado, "Murmuria", e escólio "dic" - pesquisa para o Dicionário musical brasileiro:

X Murmuria e derrama? Objecto estranho dic

Nota da pesquisa: $\mathrm{O}$ verso é referido por MA no fichamento crítico do Lirismo romântico no Brasil, sob a rubrica "Modo de contar sílabas" (MA-MMA-26-04).

P. 143-144:

Notas MA:

1. termo sublinhado, "soidoso", e escólio "dic" à direita - pesquisa para o Dicionário musical brasileiro;

2. trecho destacado por traço vertical e juízo de valor, "Fino" - seleção de ideias;

3. termo sublinhado, "deslumbres", e cruzeta à direita - pesquisa para o Dicionário musical brasileiro:

Porque? Não sentis o peso d'aquella palavra que dobra a fronte de Jacques? Quando o céo se azula e a vida se arreia ufana aos deslumbres da manhã, não sentisl-a mais dolorenta aquella febre que não crê, que não póde, que não quer crêr, porque a crença na hora do suicidio lhe fôra ainda mais amarga que o descrer? Não imaginais a dôr do Tantalo sem amor, sedento d'elle, que ahi perece e á sêde, sem já querer crêr-lhe - e a dôr d'esse Ixion que sente a nuvem correr-lhe pelo peito, balsamica no seu mentir fugitivo,

Fino como o halito da Deosa? E não o crêdes mui queimador... aquelle ferrete que Margarida lêra na fronte de Mephistopheles - não poder amar!?

P. 144:

Notas MA:

1. trecho destacado por traço vertical, transcrito acima, e juízo de valor: "Fino";

2. termo sublinhado, "pesadumes", e cruzeta à esquerda - estudo do estilo: vocabulário:

$X \quad$ Toda aquela hora de pesadumes, no triste silenciar de um homem entre os restos de uma orgia (...) 
P. 146:

Nota MA: verso sublinhado - estudo do estilo: versificação/métrica:

\section{$\underline{\text { E logo que m'o dão minha mãi o toma }}$}

Nota da pesquisa: MA relaciona o verso assinalado no fichamento crítico para o livro Lirismo romântico no Brasil como exemplo do "Modo de contar sílabas" (MA-MMA26-04).

P. 147:

Nota MA: termo sublinhado, "trinos", e escólio "dic" - pesquisa para o Dicionário musical brasileiro:

$$
\text { (...) e aquelles trinos erão da calhandra! dic }
$$

P. 150:

Nota MA: termo sublinhado, "desfreio" - estudo do estilo: vocabulário:

No descrer de Musset, como ainda ás vezes no de Byron, ao desfreio d'aquelle poetar, que soube transpôr os limiares do prostibulo sem o sarcasmo cynico dos labios amargos de George Crabbe...

Nota da pesquisa: MA registra o substantivo em nota preparatória no dossiê do manuscrito Amor e medo, arrolando exemplos do vocabulário imaginoso do autor de Literatura e Civilização em Portugal: "desfreio III, 150” (MA-MMA-05-30).

\section{P. 153:}

Notas MA:

1. termo sublinhado, "libame", e cruzeta - estudo do estilo: vocabulário:

Mais um exemplo sobre Byron: - Cançado o bandido do mar, ao libame de uns labios que se abrem, por elle hesita na descrença;

2. termo sublinhado, "desfear", e cruzeta - estudo do estilo: vocabulário:

Entretanto... é mais atroz o scepticismo de Arouet de Voltaire, quando elle se desnuda no inteiro desfêar de seu descarnado, nas horas mais negras em que aquelle imaginar de vampiro debruçava-se de uma fronte linda e santa de donzella.

Nota da pesquisa: MA repete o verbo sublinhado em nota de trabalho no dossiê do manuscrito Amor e medo, na qual lista neologismos de Álvares de Azevedo: "desfear III, 199" (MA-MMA-05-30).

\section{P. 154-155:}

Notas MA:

1. trecho destacado por traço vertical - seleção de ideias;

2. termo sublinhado, "hecatombas", e cruzeta - estudo do estilo: vocabulário;

3. termo sublinhado, "descôr", e cruzeta - estudo do estilo: vocabulário: 


\begin{abstract}
No parallelismo historico dos factos e dos homens, certo o nome de Byron traz uma grande recordação - a revolução franceza. A infancia do herdeiros dos cavalleiros normandos se embalava ao estrondear de um cataclysmo. O sanguinolento drama de mil annos de peleja debatida peito a peito da tradição guerreira, com suas roupas de ouro e brocado sobre o peito nú e suarento do plebêo, se afundára no mar de sangue da vingança. E um seculo inteiro de espectadores presenciou, ao clarão dos incendios, n'um chão ensopado do sangue do baptismo da liberdade recem-nada, a scena das hecatombes... os afôgos de Nantes por Carrier - o sanguinario, a descôr da cabeça angelica e suavissima de Lamballe borrifada de lodo e sangue, aquella cabeça de Maria Antonieta, embranquecida n'uma noite de agonia e a loura e divina Carlota Corday - o anjo do assassinato, na expressão de Lamartine, corando ainda após de decepada ao esbofetear da mão vermelha do victimario plebêo!... Byron como Lucano acordára á vida entre o alarido da guerra civil...
\end{abstract}

Nota da pesquisa: MA registra em nota de trabalho o termo assinalado: "descor III, 155" (MA-MMA-05-30).

P. 156:

Nota MA: termo sublinhado, "ennoitado", e cruzeta - estudo do estilo: vocabulário:

$X \quad$ A época que produziu Byron e Werner se treslada em muita fronte de poeta de então. E em toda essa litteratura transverbera no seu ennoitado, no incerto de suas tendencias, uma d'aquellas horas solemnes de transformação da vida social.

P. 157:

Notas MA: trecho destacado por um traço vertical e juízo de valor: "Esplendido":

Os poemas de Byron são o espelho d'aquella época toda. Quando uma philosophia inteira estabelecia o axioma do scepticismo e quando a população dormia esquecida de Deus sobre os tumulos vasios de seus reis, quando a cruz se estalára no frontispicio das cathedraes e a fronte livida e eburnea dos crucifixos se despedaçára nas lageas do templo profanado... não era de espanto que a poesia viesse entoar o cantico dos funeraes da crença no cadaver da religião. 


\section{$\underline{\text { P. } 163-234}$}

\section{LITTERATURA E CIVILISAÇÃO EM PORTUGAL}

Nota da pesquisa: O dossiê do manuscrito Amor e medo contém nota de trabalho sobre este estudo: "Prosa de A. de A. Toda a parte inicial do 'Literatura e Civilização em Portugal', não tem nada de crítica e aliás o processo de crítica pro rapazelho de 20 anos só podia mesmo ser esse de poucas ideias e muitas palavras, mas toda essa parte é uma série admirável de quadros, ditos na mais sonorosa e bem ritmada linguagem. Uma deliciosa bebedeira vocabular. Um poder formidável de evocação assombrada e fantasmagórica. Do milhor.” (MA-MMA-05-20)

P. 165:

Notas MA:

1. título corrigido, substituindo "Lusos et Portuguezes" por "Literatura do Norte Europeu" - correção tipográfica.

2. trecho destacado por traço vertical - seleção de ideias:

\section{Literaturas do Norte Europeu}

\section{LUSOS ET PORTUGUEZES}

As litteraturas do norte, onde as brumas das noites de invernada se alongão no assomar como as sombras dos heróes dos tempos idos, onde a cerração pende suas roupas brancas nas ramagens desnuadas e negras como sombras melancolicas, á maneira dos lemures do gentilismo romano, resentemse do clima nevado e d'esse imaginar nevoento das frontes cahidas na spleenética monotonia d'aquelles invernos.

$\mathrm{E}$, por isso, se accordes gaelicos vem prenhes do embeber de melancolias nas harpas d'esse além, nos fragmentos tradicionaes dos poemos de Ossian e nos Eddas Islandezes, ha sempre que ver n'esses cantos talvez a belleza dos cysnes nos lagos bracios de Inisfail e dos bandos alvos de grous e cegonhas, nas atalaias dos torreões ruinosos dos thanes das montanha... ha uma melodia, sim, mas é uma pureza de murmurios bellos, monotona como as brumas e as chuvas de Escossia.

\section{P. 166:}

Notas MA:

1. trecho destacado por traço vertical, transcrito acima - seleção de ideias;

2. termo sublinhado, "crusta", e cruzeta - estudo do estilo: vocabulário;

3. termo corrigido, substituindo "traindade" por "trindade", eliminado o "a" - correção tipográfica;

4. observação crítica ao final:

"Reparar o tamanhão das frases”

P. 167

Notas MA:

1. termo corrigido, substituindo "quando" por "quanto" - correção tipográfica; 
2. termo sublinhado, "corno", e escólio "dic" - pesquisa para o Dicionário musical brasileiro:

E lá ao fundo - o Naflegar funebre, com os gigantescos remadores do Hrymen adormecidos á guarda do acordar do corno de Gallar nos labios sonoros de Heimdall,

P. 168:

Notas MA:

1. expressão sublinhada, "Saxonio - o grammatico", cruzeta e expoente (1) remetendo ao comentário no rodapé - seleção de ideias: epítetos;

2. termo sublinhado, "delaidal-as", e cruzeta - estudo do estilo: vocabulário:

“(1) Justamente na prosa A. de A. é mais / artista. Por isso os processos aparecem. Na / poesia se contentou de ser poeta."

$X \quad$ Relêde Ossian o gaelico, os Scaldas runicos da Thule e da Gothia de Strabo, (1) conservados por Savonio - o grammatico e Olaus Wormsio; descei mesmo por esse Chersoneso cimbrico, que é hoje o Jutland; embrenhai-vos pelo florestal dos Ingoevonos, Istoevonos e Burgundios Germanios; roçai mesmo os duans dos bardits Celti-Gallos; a poesia ahi resente-se toda de uma poesia só: o genio dos bardos e a historia provavel d'essas raças ensopa-se em tres origens - a friez congelada do polo, - as crenças arraigadas de Odin ou Wodden - e os recontos $X$ das façanhas, que não ha delaidal-as, dos autochtones primévos do Norte.

Notas da pesquisa:

1. O dossiê do manuscrito Amor e medo conserva nota de trabalho onde MA avança as ideias da marginália: "Como na poesia A. de A. é mais poeta, na prosa ele se torna artista. Os processos aparecem e mesmo alguns fatigantissimos, como esse de dar um epiteto a cada coisa. Isso às vezes é dum comico impagavel como quando ao iniciar um estudo critico sobre romance de Jorge Sand, êle principia 'Jorge Sand, a loura', mas também na prosa ele enriquece mais a expressão e os qualificativos, abandona aquela naturalidade vulgar que tem na poesia dele e aliás de toda a poesia romantica. $\mathrm{Na}$ prosa não, são expressivos, inspirados e por vezes mesmo extraordinariamente fortes como aquelas 'eguas desabridas' e nos 'frankisks goticos suados de sangue' de que fala no estudo sobre Literatura e Civilisação em Portugal." (MA-MMA-5-24).

2. A sequência de ideias é reformulada, com pequenas variantes, na crônica de 30 de agosto de 1931: "Na prosa Álvares de Azevedo enriqueceu logo a expressão. Apesar daquele processo insuportável de xingar as pessoas, de mais qualquer coisa, "George Sand, a loura...": os qualificativos já muitas vezes abandonam a naturalidade vulgar que têm na poesia dele, e dos mais românticos, tornam-se expressivos, inesperados e por vezes mesmo extraordinariamente fortes, como aquelas 'éguas desabridas', os '(frankisks) góticos suados de sangue' e as 'tragédias prateadas de tristura'." ("Álvares de Azevedo II”, in Táxi e Crônicas no Diário Nacional. ed. cit., p. 423).

P. 169:

Notas MA:

1. trecho destacado por traço vertical e expoente “(1)” remetendo ao rodapé planejamento do livro Lirismo romântico no Brasil;

2. expressão sublinhada, "serralhos arquejantes de danças", e cruzeta - estudo do estilo: imagem: 
Mudai as relações do paiz e a litteratura muda. Correi esse panorama do Oriente com seu céo de crepusculos rubros, seus rosaes perdidos no collear das valladas, seus minaretes doirados e luzentes ao sol como um elmo de emir, suas cidades

$X$ estendidas como uma alcatifa de Bagdad, suas casarias sem janellas exteriores, suas albuferas estreitas e tortuosas, seus serralhos arquejantes de danças, onde $\mathrm{o}$ lenço branco do Pachá preguiçoso nomeia a favorita...

\section{“(1) Quando falar da atração de Varela pelo Oriente citar este periodo”}

Nota da pesquisa: O fichamento crítico para o livro Lirismo romântico no Brasil, no dossiê do manuscrito Castro Alves, contém indica esta página, exemplificando os "sentimentos reflexos, falsos", bem como a "mania" pelo Oriente (MA-MMA-26-04).

P. 170:

Nota MA: termos sublinhados, "toques" e "sonorosa", e escólio "dic" - pesquisa para o Dicionário musical brasileiro.

"dic" de largos toques épicos, resoada da voz sonorosa dos descantes primitivos,

P. 171:

Notas MA:

1. expressão sublinhada, "eguas desabridas", e juízo de valor, "Bom epiteto" - estudo do estilo: imagem:

Não! ahi a poesia scintilla como um areal palhetado de fogo iriante, como a miragem enlevada do deserto e a sombra phantastica dos cavalleiros com seus longos albornozes soltos ao vento nas eguas desabridas, aos raios do sol horizontal que se abysma n'um mar de fogo...

2. termo sublinhado, "insomniar", e cruzeta: estudo do estilo: vocabulário.

n'esse insomniar de um fogoso sentir

$X$

Nota da pesquisa: A expressão sublinhada, "éguas desabridas", indicia a expressividade atribuída por MA à prosa de Álvares de Azevedo, conforme o dossiê do manuscrito Amor e medo (MA-MMA-05-24) e a crônica de 30 de agosto de 1931 ("Álvares de Azevedo II", in Táxi e Crônicas no Diário Nacional. ed. cit., p. 424).

P. 173:

Notas MA:

1. termo sublinhado, "marejada", e cruzeta - estudo do estilo: vocabulário:

Vêdesl-a a terra selvatica onde o estertor da marejada sôa a perder-se no estridulo farfalhar dos juncaes,

2. trecho destacado por um traço vertical duplo - seleção de ideias: filosofia: 
A missão puramente monetaria e industrial revestiu-se ahi do manto sagrado da missão litteraria. É que tudo tende á sciencia como os vapores ao sol: o homem material é o instrumento do $e u$ moral e o estudo onde se afunda o psychólogo; e é tudo assim: da pedra que rola vai-se á theoria de Newton da gravitação.

P. 174:

Nota MA: termo sublinhado, "calcas", e cruzeta - estudo do estilo: vocabulário:

$X \quad$ Foi o bispo anglicano quem primeiro apontou á Europa essas calcas de religiões idas e os vestigios de uma civilisação inteira,

P. 175:

Notas MA:

1. termo sublinhado, "orchestra", traço vertical e juízo de valor: "bom";

2. trecho destacado por traço vertical, expressão sublinhada e juízo de valor, "ruim".

onde o olhar se escurenta de vertigens e os ouvidos susurrão como aos echos da orchestra satanica da tormenta...

bom

É um mundo novo, a que um novo Colombo ia romper o véo dos seculos, - o novo panorama de uma creação incognita como as abobadas subterraneas dos monumentos tumulares da India, com seus renques de mumias mirradas e millenarias, hieroglyphos e seus deoses barbaros na garupa dos esphingescolossos. Era uma nova solfa de claves todas ainda não ouvidas, desde as ternuras trementes do Karparou, do Eremita de Kandu e do Ramayana e a pallidez de Dasaratha ao pé da agonia de Yadnatta, até o lamentar da mãi do triste, gemebunda, lançada sobre o corpo inanido do filho.

P. 176:

Nota MA: termo sublinhado, "retrôa", e escólio "dic" - pesquisa para o Dicionário musical brasileiro:

"dic" retrôa pelo acampamento, onde os elephantes repousão sobre carcassas de cadaveres

P. 177:

Notas MA:

1. trecho destacado com um fio - estudo do estilo: prosa;

2. termo sublinhado, "Desrolaremos", e cruzeta - estudo do estilo: vocabulário.

3. comentário ao final:

"É engraçada a impertinencia pretenciosa / do rapazola. Aliás a prosa dele é quase sempre / pretenciosa. Mas dentro dessa pretensão ele atin-/giu a grandeza nas las paginas da Noite na / Taverna”

Fomos talvez longos. Desvairámo-nos pela theogonologia boreal, pelo dedálico do labyrintho de colossos do Mahabharata. O leitor nol-o perdôe. Deixaremos breve este assumpto, para lançarmo-nos n'um outro mais palpitante e em seguida á prova do nosso aphorismo - da intima ligação das litteraturas e das civilisações, da poesia e do sentir e crer dos povos: aphorismo que temos muito de fé, porque para nós a litteratura é a civilisação e a poesia o sentir e o crer das nações. 
Desrolaremos com seu fausto e suas decadencias alguns periodos da litteratura portugueza.

Nota da pesquisa: MA indica esta página em nota de trabalho no dossiê do manuscrito Amor e medo, sob o título "Prosa de Álvares de Azevedo": "Mais uma vez A. de A. reconhece que se desviou do assunto. E ainda na p 189 reconhece que 'longe fomos; não duvidamos que demais para um preambulo.' $E$ inda pede licença pra dizer mais umas palavras! que serão 7 páginas!” (MA-MMA-05-21).

P. 178:

Notas MA:

1. acréscimo do "A" - correção tipográfica;

2. expressão sublinhada e cruzeta à direita - estudo da criação: inteligência:

Não pareça uma theoria aerêa, essa que ahi trago de influencia judaica na Hespanha. Leião-se os trabalhos de J. P. Ribeiro sobre litteratura moderna dos judeus hespanhóes e ver-se-ha o alto gráo de illustração dos rabbis. Provado esse primeiro ponto não ha duvidar do resto. $\underline{A \text { intelligencia é como o oleo, sobrenada }}$ a tudo. $\quad X$

Notas da pesquisa:

1. A expressão sublinhada respalda o juízo de MA quanto à inteligência de Álvares de Azevedo em contraste com os demais românticos. A metáfora emprestada arremata o raciocínio do crítico, em nota de trabalho no dossiê do manuscrito Amor e medo: "O que torna A. de A. muito mais interessante que os outros românticos é que nele a reação intelectual é constante quer sob o ponto-de-vista artístico quer sob o de pensamento. Nossos grandes românticos Gonçalves Dias, Castro Alves, Varela, Casemiro de Abreu, foram o que se pode chamar poetas eminentemente burros. Mesmo as 'intenções' que levaram C. Alves ao seu abolicionismo deram reações líricas puramente sentimentais. A. de A. nos desperta constantemente a percepção da inteligência. Nos outros a reação intelectual desaparece. Em A. de A. como ele mesmo falou 'a inteligência é como o óleo, sobrenada a tudo'." (MA-MMA-05-24).

2. O editorial da Revista Nova ressalta a inteligência de Álvares de Azevedo nos mesmos termos do trecho citado acima: "Em Álvares de Azevedo a preocupação da inteligência, das explicações filosóficas da vida, é constante" (a. 1, n. 3, p. 313). A oração destacada por MA na marginália também é reproduzida: "E se o Macário chegava prematuramente àquela profunda afirmativa que 'as ideias do homem o fascinam mas não o esclarecem', o moço não pôde abandonar jamais as forças raríssimas de inteligência que possuía, porque soube reconhecer também que 'a inteligência é como o óleo, sobrenada a tudo'." (ibidem, p. 314).

P. 179:

Nota MA: termo corrigido, substituindo "unas" por "nas", com a eliminação do "u" correção tipográfica.

P. 180

Nota MA: trecho destacado por traço vertical - seleção de ideias: 
E ao norte estendião-se as grimpas de brava serrania, desde o Mare internum até ao Mare magnum Atlanticum, onde os barcos peregrinos do aventureiro forão buscar entre seus gelos a Thule mysteriosa d'esse nevoento Mare Germanicum, que banhava o longo das costas calcareas da Britannia de Julio Cesar, do norte da Gallia, d'esse costeal escandinavo da Gothia e do Chersoneso Cimbrico, em cujas abras se escondião os veleiros hiates dos piratas northmans e dinamarquezes e as enseadas d'essa indomavel cordoalha dos Pictos e Escotos, os terriveis invasores da Britannia, que a fizerão no optar de duas escravidões preferir a Saxonia.... lá essa Caledonia, onde nas brumas arcticas as ventanias das Orcadas rugião como ululadas de afogo nos basaltos gigantêos e fatidicos da escura caverna de Fingal.

Nota da pesquisa: Na crônica de 6 de setembro de 1931, ao observar a insensibilidade da poesia romântica brasileira ante a natureza - Álvares de Azevedo em particular -, MA comenta que "Só mesmo os aspectos grandiosos da natureza parecem interessá-lo um bocado, o Alto-da-Serra que descreve bem, a gruta de Fingal, a tempestade." ("Álvares de Azevedo - III", in Táxi e Crônicas no Diário Nacional. ed. cit., p. 426).

$\underline{\text { P. } 181}$

Nota MA: termos sublinhados, "cataclysticas", "longor" e "enlodárão", e cruzetas estudo do estilo: vocabulário:

(...) perdidos por uma natureza de alluviões cataclysticas aberta em despenhadeiros surdos, ao pendor dos cumes concavos e nús dos montes agourentos.

$x \quad$ Quando, depois que as armas do Aragonense, filho de Joanna - a louca e Isabel - a castelhana, corrêrão desde o cimo das Alpuxarras, pelo longor das planicies sevilhanas, como montanhas de gelo despegadas das cumiadas alpinas, a raça agarena e as koranitas hordas de Berebéres e Almogaures passárão fugitivas, como sombras, a Mourana, d'onde o appello vingativo do conde Julião (o pobre vassallo, o pobre pai, cujas barbas de velho se enlodárão da affronta de D. Cava Florinda

Nota da pesquisa: MA registra "enlodar" em nota de trabalho que reúne marcas lexicais do estilo de Álvares de Azevedo, no dossiê do manuscrito Amor e medo (MA-MMA-0530).

\section{P. 182-183:}

Notas MA:

1. termo corrigido, "esmate", para "esmalte", com o acréscimo de "al" à esquerda correção tipográfica;

2. expoente (1) ao final do parágrafo, remetendo ao comentário no rodapé:

“(1) Esta frase é um monumento da mais alta / comicidade. Misturada impagavel de coisas / bonitas, coisas pretenciosas e coisas sem / relevo. Anotar ainda que em grande numero / de frases como esta A. Azevedo se deixa / levar por uma pura associação de ima-/gem. Digressão sobre a associação de ima-/gem entre os poetas brasileiros que a em-/pregaram liricamente, isto é, sem ser pro-/vocada artificialmente pelo artesão por necessidade / de rima e outros elementos de pura tecnica formal. Esses / anunciadores $e$ empregadores da associação de imagens / (não de ideas, acentuar) são A. Azevedoe 
Eruz e Sousa como / elemento lirico, aliás esporadicamente lirico, são Alvares / Azevedo e Cruz e Sousa. Prova-lo. Azevedo na prosa princi-/palmente. Cruz e Sousa no verso. Azevedo mesmo chega / a lembrar singularmente Rimbaud e Lautreamont. / Prova-lo por essas frases apocalipticas. Sob esse aspeto / são Azevedo e Sousa curiosos precursores de certo <rasura> lado / do lirismo modernista, embora nada tenham, e infelizmente, / nos influenciado. Infelizmente. É veso brasileiro comprar laran-/jas da Baia vindas da Califórnia."

(...) n'esse mixto da civilisação romano-gothica das gentes barbaras de Sertorio e Viriato e da provincia carthagineza, onde as muralhas de Sagunto e Carthago-a nova, se tinhão abalado ás gritas bellicas dos republicanos de Bruto, precipitouse, como o ouro na infusão do chlorureto de platina, a civilisação arabe. (1)

3. termo sublinhado, "tubas", e escólio "dic" - pesquisa para o Dicionário musical brasileiro:

os antigos sons das tubas de Aljubarrota dic

4. termos sublinhados, "trova" e "jograes" e escólio "dic" - pesquisa para o Dicionário musical brasileiro:

O romancero do Cid, essa trova de jograes que derão á Provença os lais de amor e o romance da Rosa (de Meung)

5. trecho sublinhado e cruzeta à esquerda - seleção de ideias: autonomia literária:

$X$

As linguas separão-se de então e as litteraturas tambem; pois, segundo nosso muito humilde parecer, sem lingua á parte não ha litteratura á parte.

Notas da pesquisa:

1. Ao constatar a falta de 'influência' de Azevedo e Souza sobre os modernistas, MA retraça considerações de história literária esboçadas no dossiê do manuscrito Castro Alves: "A nossa literatura não segue propriamente por evolução; antes por superposição. É o que geralmente se observa em todas as literaturas caudatárias. Não existe essa continuidade tão robusta em si, pela qual cada grande artista, alimentado pelo suco das heranças do passado artístico da pátria dá um passo para frente - passo que reflete as riquezas novas alcançadas no meneio das heranças e no trabalho da personalidade. Isso é evolução. Mas isso geralmente se dá só nas grandes literaturas autônomas e condutoras." (V. MA-MMA-26-12).

2. No dossiê do manuscrito Amor e medo, o trecho sublinhado - "sem lingua á parte não ha litteratura á parte" - é seguido da pergunta rasurada: "Não seria razão consciente da lingua brasileirista que êle emprega?" (V. MA-MMA-5-30). O mesmo fólio registra "o brasileirismo inconsciente que põe sertanejos e toadas de viola na Italia e em estalagens aportuguesadas fala em nhô Quito (Macario)". É provável que o trecho sublinhado justifique a menção a esta página no fichamento crítico para o livro Lirismo romântico no Brasil, sob a rubrica "O pronome obliquo inicial" (MA-MMA-26-04). A colocação pronominal identificada em poemas de Gonçalves Dias e Castro Alves constitui uma marca da língua portuguesa falada no Brasil, segundo o ponto de vista do crítico, respaldando o critério proposto por Álvares de Azevedo. 
3. MA recorre, em seu comentário, a metáfora empregada em Klaxon (n. 2, p. 17), em junho de 1922. A seção "Luzes e refraccções censura Ribeiro Couto, em nota não assinada, por alimentar ideias de separatismo paulista: "O paulista, é verdade, tem orgulho de ser paulista.. Mas o bahiano tambem se orgulha de ser bahiano. São Paulo progrediu devido, em grande parte, á terra mansa que Deus lhe deu. A Bahia permittiu que suas laranjas fossem constituir uma das riquezas da California. A culpa é de São Paulo? E seria justo que cruzassemos os braços na penuria, só para ficarmos eguaes a um ou outro irmão? Assegura-te, amigo: os paulistas são brasileiros e querem ser brasileiros. É preciso e justo porém que os demais brasileiros não nos venham lembrar mensalmente uma idéa pretenciosa que poderia assim fructificar." (Klaxon: mensário de arte moderna - edição fac-similiar. Organização: Pedro Puntoni e Samuel Titan Jr. São Paulo: Imprensa Oficial do Estado de São Paulo, Biblioteca Brasiliana Guita e José Mindlin, 2014).

4. O raciocínio na marginália é sintetizado em nota preparatória no dossiê do manuscrito Amor e medo: "O pretencioso de comicidade impagável / A digressão sobre nacionalismo literário é importantíssima. Bem pensada embora por vezes sentimentalmente fragmentada". No mesmo fólio, remete ao comentário: "Notas pgs 182 e 197” (MAMMA-25-05).

5. A biblioteca de MA no IEB/USP contém dois títulos do simbolista João da Cruz e Sousa (1861-1898): Ultimos Sonetos (Paris/Lisboa: Livrarias Aillaud e Bertrand/Aillaud, Alves e Cia., 1905) e Obras completas de Cruz e Sousa: I - Poesias. Broqueis - Pharoes - Ultimos sonetos. Com introdução e annotações de Nestor Victor (Rio de Janeiro: Edição do Annuario do Brasil. 1923). No volume dos Ultimos sonetos, a marginália é composta de sublinhas nos títulos. Nas Obras completas, MA destaca os decassílabos de duas palavras, numera aliterações e registra comentários. Observa, p. ex., que "o branco era uma obsessão no poeta-negro" (Nota MA in op. cit., ed. cit., p. 85). No poema "Violões que choram", remete a Rimbaud: "Inegavelmente uma obra prima. O Bateau Ivre da literatura brasileira." (Nota MA in op. cit., ed. cit., p. 195). E por duas vezes relaciona Cruz e Sousa aos dadaístas, datando o comentário (para alegria do pesquisador): "Cruz e Sousa, sem intenção de fazer espi-/rito, muito mais que perturbado por sim-/bolismos, é um verdadeiro precursor do / dadaismo. Atingindo o impressionismo / mais destructivo, por meio de sucessões / de ideas que se ligam não mais por / meio de inteligencia, mas muito mais / por associações, muitas vezes total-/mente subconscientes e pessoais. A / rima é um meio constructor defini-/tivo dos seus poemas. Mais do que / a Banville. As ideas nascem das / rimas e daí muitas vezes um / imprevisto delicioso, desconcertante, I eminentemente lirico, mas eminente-/mente impressionista e destructivo tambem. // Estes poemas longos dos Farois / são caracteristicos a esse respei-/to. O poeta é escravo das associa-/ções. Não sabe o que vai dizer. /Tem um moto lirico inicial: será / a mãi escrava, será a recordação / do amigo. Mas a atenção é fra-/gilima. E o tema sem lume / segue ao leo das associações, cor-/re, bordeja, afunda, sobe á / tona e morre finalmente sob / o impulso ondulado das ri-/mas. / Agosto de 923" (Nota MA, in op. cit., ed. cit., pp. 164$5)$.

\section{P. 184:}

Notas MA:

1. preposição “de" acrescida à direita - correção tipográfica;

$$
\text { no Lallah-Rook / Thomas Moore, /de }
$$


2. traço vertical duplo, destacando o trecho - seleção de ideias: situação literária do Brasil; 3. termo corrigido, "demada", para "demanda", pelo acréscimo de "an": correção tipográfica:

lan $\quad /$ E demais, ignoro eu que lucro houvera - se ganha a demada - em não querermos derramar nossa mão cheia de joias n'esse cofre mais abundante da litteratura patria: por causa de Durão, não podermos chamar Camões nosso! por causa, por causa de quem?... (de Alvarenga?) nos resignarmos a dizer estrangeiro o livro de sonetos de Bocage!

Nota da pesquisa: O editorial da Revista Nova (a.1, n. 3) alude à "clarividência às vezes notável das suas observações [de Álvares de Azevedo], como as sobre a situação literária do Brasil em relação a Portugal" e remete aos trechos assinalados por MA nestas páginas 184,185 e 186.

P. 185-186:

Notas MA:

1. trecho sublinhado e expoente (1) remetendo ao comentário no rodapé da p. 185 seleção de ideias: situação literária do Brasil:

As linguas, eis-ahi tambem o resultado das relações; e mais frisante é o exemplo dos dous reinos da Peninsula Iberica, a esse respeito, que começárão ambos com a mesma lingua e cujos idiomas se mudárão e tornárão-se diversos em virtude da variedade de accidentes de civilisação. (1)

“(1) Exactissimo e por onde se discute o gri-/fo da pg. anterior. Digressão incitando ao / brasileirismo os poetas brasileiros."

2. trecho destacado por traço vertical e expoente (1) ao final, remetendo ao comentário no rodapé da p. 186 - seleção de ideias: brasilidade de Santa Rita Durão e Basílio da Gama:

José Bazilio e Durão não forão tão poetas brazileiros como se pensa. Os heróes do Uruguay e do Caramurú erão portuguezes. Não ha nada n'esses homens que resumbre brazileirismo, nem sequer um brado de homem livre da colonia, nada... até ao canto enthusiasta da mocidade ardente de Antonio Pereira de Souza Caldas, até as gritas livres da insurreição do Tira-dentes, esse preludio sublime de uma orchestra de clamores de guerra ao brilhar das palmas da independencia, procellaria que ahi vinha desgarrada ante o bafo da tormenta. E comtudo o poeta representante d'essa época, Gonzaga, apesar de todos os lavores do "Parnaso" e do "Plutarco" do Dr. Pereira da Silva, não está muito claramente provado que fosse Brazileiro. Eis portanto: os usos erão os mesmos; os homens de áquem-mar sentião como os colonisadores; Fernandes Vieira e Amador Buenos erão a cópia bella dos guerreiros das Indias. (1)

“(1) Toda esta digressão é importantíssima e quase sempre muito bem pensada.”

3. termo sublinhado, “desfreima”, e cruzeta - estudo do estilo: vocabulário:

$X \quad$ são tão reflexivos n'uma e n'outra os toques da cavalleirosa desfreima 
Nota da pesquisa: No fichamento crítico da obra de Álvares de Azevedo, conservado no dossiê do manuscrito Amor e medo, MA indica as páginas 184 e 185 sob a rubrica "Brasileiro", caucionando a brasilidade atribuída por ele ao autor de Literatura $e$ Civilização em Portugal (MA-MMA-05-02).

P. 187:

Nota MA: trechos destacados por traço vertical duplo e juízo de valor, "Lindas frases" estudo do estilo: prosa:

Camões, denodado pelejador de Ceuta, o desterrado guerreiro das Indias, cantou os "Lusiadas" na India, em Macáo, em toda a parte onde o vento nas palmeiras da Asia lhe fallava das glorias do passado. Corte-Real foi o poeta de Diu e do naufragio da Sepulveda. Garcilasso, o neto dos Incas, como disse W. Schlegel, escrevia suas canções de amor sobre os destroços de Carthago, o mausoléo de frases passadas ruinas, onde Caio Mario, soberbo e Romano, se assentára sublime no / seu vagabundo passar de desterrado.

P. 188:

Notas MA:

1. termo sublinhado, "tuba", e escólio "dic" - pesquisa para o Dicionário musical brasileiro:

“dic” É que os Homeros são os cantores que forão embalados ás tubas da guerra!

2. termo sublinhado, "laxidão", e cruzeta - estudo do estilo: vocabulário.

$X \quad$ é um padrão do estado vergonhoso de esfalfamento e laxidão, do afan de um dormir de escrava, d'essa pobre Lusitania!

P. 189:

Nota MA: termo corrigido, "florestas", substituindo " $n$ " por "s" - correção tipográfica.

P. 190:

Notas MA:

1. termo sublinhado, "chrysocál", e cruzeta - estudo do estilo: vocabulário:

Comtudo, nem sempre a poesia peninsular ergueu-se á sombra dos velhos cantos guerreiros; quasi sempre ella renega do passado romantico de Camões e $X \quad$ Bernardim pelo chrysocál da escola de V. Hugo.

2. expressão sublinhada - seleção de ideias: construção do imaginário romântico:

É o lyrismo do canto das "Orientaes", dourando ás vezes o gosto antigo das peripecias e enredos de Calderon e Vega, revivido por Corneille e acordado de seu segundo somno pela imaginação hespanhola de V. Hugo.

P. 191:

Nota MA: trecho destacado por traço vertical - seleção de ideias: sentimentos reflexos: 
É uma cousa que, no meu muito humilde juizo de mesquinho leitor, eu lamento muito a essa escola em cujo frontal dourárão o nome de Shakspeare, como um symbolo de independencia, a esses mancebos que não quizerão ser classicos com Euripides e Sophocles para sel-o com Hugo e Dumas. A sua sentença está no mestre da escola: - a imitação mata o genio, a copia destróe o lampejo de originalidade, seja de um classico, seja de um romantico. Os chefes de systemas litterarios são mais por admirar e estudar que por copiar. Goethe lamentava-se dos seus imitadores, criticava acerbo o sentimentalismo falso que seu Werther fizera brotar nos romances e o desregrado do drama que seu desordenado, mas bello Goetz de Berlichingen fizera bemquerer. Châteaubriand queixava-se do bronco de expressão, do exagerado de idéas, que sua reacção romantica acordára nas escolas do bello horrível que excedêrão todo o medonho da ronda de horrores e lascivias de Lewis e das mortualhas dramaticas de Mathurin. É que os discipulos, na fascinação da apotheose que erguem ao genio, no tresladar, no arremedo de suas bellezas, imitão-lhe também, e mais que o resto, defeitos, porque foi no embellezal-os, em escondel-os sob flôres, que os mestres envidárão suas forças.

Nota da pesquisa: Esta página é elencada como exemplo dos "sentimentos reflexos, falsos" na técnica romântica, como a "mania por Itália e Espanha" e pelo Oriente (MAMMA-26-04).

P. 192:

Notas MA: termo sublinhado, "hirteza", e cruzeta à direita - estudo do estilo: vocabulário:

$X \quad$ e, como Chatterton, sacrificou porventura o scintillar das idéas pela hirteza de um fallar elaborado

P. 194:

Notas MA:

1. termos sublinhados, "monotypa", e cruzeta - estudo do estilo: vocabulário:

X ellas são todas bellas, sim, mas bellas de uma belleza monotypa

2. termo sublinhado, "alembra", e cruzeta - estudo do estilo: vocabulário:

$X \quad$ Talvez haja bem o leitor em não reprehender aquelle critico que alembra a justiça da Revista de Edimburgo

Nota da pesquisa: O verbo "alembrar" é registrado em nota de trabalho no dossiê do manuscrito Amor e medo (MA-MMA-05-30).

P. 195:

Notas MA: trecho destacado por cruzeta - seleção de ideias: juízos sobre Alexandre Herculano:

$x$ Quanto ao Sr. Alexandre Herculano, o romancista do Eurico, do Monge de Cister, d'Arrhas por fôro de Hespanha etc., de tantos romances primazes, o poeta da Harpa do Crente, o historiador das velhas chronicas portuguezas, se não lhe 
cabem os laureis scenicos, muitos e muitos lhe sobrão na fronte de poeta e pensador para que se lhe sentisse falta d'aquelles.

P. 196:

Notas MA:

1. expressão sublinhada, exclamação e interrogação - seleção de ideias: juízo sobre Almeida Garret:

Quanto ao Sr. Almeida Garret, o que José Agostinho de Macedo sonhára debalde, ?! $\quad$ alcançou-o o herdeiro das glorias de Philinto, o laureado da realeza poetica pela mocidade portugueza.

2. expressão sublinhada - seleção de ideias: juízo sobre Almeida Garret:

Eis-ahi porque o Sr. J. B. de A. Garret não é só o primeiro poeta portuguez do seculo, o digno par do erudito Sr. Alexandre Herculano, mas tambem, segundo o autor contemporaneo dos Ensaios de Critica, é uma litteratura.

P. 197:

Notas MA:

1. expoente “(1)” remetendo ao comentário no rodapé;

“(1) Este periodo tambem é impagavel. Notar que / afinal das contas grande parte de Rimbaud, Lau-/treamont não passa disso. E a incompreensibi-/lidade deles misteriosa interessou aos franceses / pelo ineditismo. A nós não, estamos acostumados. / Só que Alvares de Azevedo supera o comum e o ge-/ral do discurso academico. E nestes palanfrarios / eloquentes, ritmados, sonorosos, associativos, livres da / inteligencia em grandissima parte, descubro certo / encanto e certamente grandeza. Eminentemente li/rico."

O Edda das proezas Elysias não é só os Lusiadas. Cada lauda dos fastos dos páramos e serranias de áquem do Aqueda e do Guadiana, dos campos baptizados no sangue infiel dos homens da contracosta é um canto de Iliada architectonica, como os Nibelungen e o Antar Oriental, coroado de sacrosantas reminiscencias, é a Biblia das velhas tradições portuguezas, como o Edda Islando-Scandinavo, ou o Chanameh Persa, a epopéa mythica do Oriental, onde elle entrelaçára, como um baixo relevo de Pompeia, os feitos dos homens antigos no seu véo de mysticas tradições, ou porventura os threnos dos bardos cymbricos nos dolmens druidicos de Hirmensul - corôa gigantesca entresachada de flôres poeticas, que enlourão victorias e onde desapertão enliçadas rosas rúbidas e violetas de amethysta de langues aromas em seus halitos mimosos, d'essa grinalda das molles canções que se chama o amor...

2. termo sublinhado, "historial", e cruzeta - estudo do estilo: vocabulário:

se não a houvessemos tão de crença historial

$X$

Nota da pesquisa: No dossiê Artigos por escrever, o manuscrito do editorial para a Revista Nova, convertido na série de artigos para o Diário Nacional, insiste na comparação com Rimbaud e Lautréamont: "Porém é na prosa que estão as milhores páginas de Álvares de Azevedo e o lugar dele não é entre os poetas e sim entre os prosadores. Nos béstias 
acadêmicos ele atingiu verdadeiras magnificências de vazio, colorido e sonoridade. É a prosa oratória no que ela tem de mais tola e entusiasmante. Aturde. Si Alvares de Azevedo ficasse nisso, não seria mais do que o protótipo do chamado "béstia acadêmico" no que ele tem de mais romântico e mais juvenil, porém foi muito mais longe. Não só nesse genero ele nos deixou páginas alucinantes que chegam a antecipar curiosamente os processos psicológicos de prosar dum Rimbaud e dum Lautréamont, como na Noite na Taverna e no Macário nos deixou páginas da mais bela prosa brasileira. Prosa brasileira "sulista" porventura, sem fulgurações e clangores de nenhum tropicalismo é verdade, mas bela prosa branca e tipográfica, de carne magra porém rija e musculosa." (MA-MMA-1112).

\section{P. 198:}

Notas MA:

1. termo sublinhado, "resvalle" e cruzeta - estudo do estilo: vocabulário:

$X \quad$ nome perdido no resvalle dos seculos e jazido ignoto

2. termos sublinhados, "Aedas" e "Homeridas" - estudo do estilo: vocabulário:

Os Sagas das révoras faustosas, os memoradores da herdança de um passado tamanho - Fernão Lopez, Eannes de Zurara, Barros, Couto, Camões, serião então os Aedas e Homeridas de um imaginar colossal,

P. 199:

Notas MA:

1. trecho destacado por traço vertical;

2. expressão sublinhada e comentário; estudo do estilo: prosa.

"Bonito. Na / prosa A. A. / é mais viril / e mais ener-/gico que na / poesia. É na / prosa que os / epitetos ilu-/minantes e / as expressoes / e imagens / insubstitui-/veis aparecem / com frequencia."

E entre o estrondear dos peitoraes de aço milanez, ao sobranceiro florear dos lábaros semi-rotos das quinas Adefonsiadas, ao ranger dos gladios lascados, á queda dos frankisks gothicos suados de sangue, entre o tropear dos murzellos ardegos das turmas cavalleiras, aos brados de Allah-Akbar cortados em meio de gargantas infieis pela folha das adargas trifidas nas carnes levedadas, no reverso da medalha de pelejas, d'essas corôas borrifadas de sangue, na expressão do padre Vieira, o esmalte da victoria e d'essas nutadas convulsões de passamento, da grande facha do Pantheon guerreiro, ha episodios sublimes e lacrimosos como o naufragio de Sepulveda, a morte de Maria Telles, a quem, no dizer poetado de João de Lemos, "tão sem ventura a mão do esposo ceifa a rosa da vida no descuido da noite" e a lenda de ternezas de um Infante e uma dama.

Nota da pesquisa: O dossiê do manuscrito Amor e medo, em trecho já citado, alude à expressão "frankisks gothicos suados de sangue" como exemplo dos qualificativos "expressivos, inspirados e por vezes mesmo extraordinariamente fortes" (V. MA-MMA5-24), juízo que se confirma na crônica de 30 de agosto de 1931 ("Álvares de Azevedo II", in Táxi e Crônicas no Diário Nacional. ed. cit., p. 423). 


\section{Notas MA:}

1. expressão sublinhada, "prateada de tristuras", e cruzeta - estudo do estilo: imagem:

$X \quad$ essa tragedia tão bella, tão prateada de tristuras,

2. termo sublinhado, "solfa", e escólio "dic" - pesquisa para o Dicionário musical brasileiro:

"dic" porque acordares na tua solfa de menestrel a fibra rispida da ironia á velha nação
das victorias?

P. 201:

Notas MA:

1. expressão sublinhada, "vagabundo romeiro do scepticismo", e cruzeta - estudo do estilo: imagem e epíteto de Byron:

E ignoravas, vagabundo romeiro do scepticismo, que a nação de que rias, real entre as demais, tinha mais Homeros que a Europa toda!

2. termo sublinhado, "pocema", e escólio "dic" - pesquisa para o Dicionário musical brasileiro:

E entre essa tanta infamia de uma nação cadaver e prostrada na pocema de um capitolio de glorias,

"dic"

P. 202:

Nota MA: comentário ao final:

"Esta invocação a Byron é belissima."

Nota da pesquisa: A observação encontra-se ipsis litteris em nota de trabalho no dossiê do manuscrito Amor e medo (MA-MMA-5-25).

P. 205:

Nota MA: termos sublinhados, "solfa" e "harpejo", traço vertical e escólio "dic" acompanhado de exclamação - pesquisa para o Dicionário musical brasileiro:

o hendecasyllabo ás vezes prosaico, elevar a solfa das notas porque o canto tenha um harpejo digno d'elle.

P. 206:

Notas MA: termo sublinhado, "tangeres", e escólio "dic" - pesquisa para o Dicionário musical brasileiro:

"dic" Saem doces tangeres, doces cantos...

P. 207:

Nota MA: trecho destacado por traço vertical e expoente “(1)”, sem remissão a comentário - seleção de ideias: beleza. 
Não é verdade que isso é bello? muito bello, ao geito dos Gregos e á maneira de Shakspeare? porque a belleza é bella de um fulgor irmão, de uma sensação que acorda e vibra de um mesmo tremuloso palpitar?

\section{P. 216:}

Notas MA:

1. termo corrigido, "contido", pelo acréscimo do "c" - correção tipográfica;

2. termo sublinhado, "esvaliar-se", e cruzeta à esquerda - estudo do estilo: vocabulário;

3. termo sublinhado, "imaginando" - estudo da psicologia: imaginação/estudo do estilo: vocabulário psicológico:

não n'a vêdes lá essa altivez de homem de guerra, com o peito mal $c$ ontido sob $X \quad$ as escamas da couraça e a idéa erradia a esvaliar-se-lhe incerta, ao rodar de lagrima furtiva, imaginando na vida - ao acordar de uma idéa - sonho de guerra ou amor?

Nota da pesquisa: MA registra o verbo "imaginar" em nota de trabalho no dossiê do manuscrito Amor e medo (MA-MMA-05-30).

P. 217:

Notas MA:

1. termo sublinhado, "romar", e cruzeta - estudo do estilo: vocabulário:

como imagem do Ghibelino, no romar peregrinante, $\quad X$

2. termo sublinhado, "glorifico", e cruzeta - estudo do estilo: vocabulário:

o naufrago que ao salvar-se a nado erguia na dextra o padrão glorifico de seu poema.

P. 220:

Nota MA: expressão sublinhada, “o copo vermelho", e expoente (1) remetendo ao comentário no rodapé - estudo do estilo: metáfora:

“(1) Bonita expressão por copo cheio de vinho.”

(1) Não vêdes ali na sombra do lupanar o semblante espavorido, o olhar incerto e uns cabellos louros espalhados pela fronte alta, na mão ainda o copo vermelho,

P. 221:

Nota MA: termo sublinhado, "levadia", e cruzeta à direita - estudo do estilo: vocabulário:

E, em meio d'aquella grande levadia da maré das civilisações européas, $\quad X$

P. 222:

Nota MA: expressão sublinhada, "mulheres anjos", e expoente (1) remetendo ao comentário no rodapé - seleção de ideias: mulher:

“(1) Quando falar da idealização romantica do amor citar / este "mulheres anjos” de A. Azevedo" 
Não... não vos direi a noite d'esse homem de vida errante, a quem porventura ardêra no sangue de moço amor de glorias como a Luiz de Camões, amor de mulheres-anjos como a Petrarca, a quem o mundo fizera misanthropo como Rousseau, gelado no seu sensualismo enthusiasta...

Nota da pesquisa: MA alude a esta nota no fichamento crítico para o livro Lirismo romântico no Brasil: "Do tema 'Amor e Medo' decorre o Respeito á Mulher, ou aquele dêste. Mulher é 'anjo' A. de A. III, 222; 'virgem' ‘criança' A. A. antepagina II; raramente mulher" (MA-MMA-26-04; sublinhei). No mesmo dossiê, o crítico contrasta Álvares de Azevedo e Castro Alves quanto ao realismo na representação da mulher: "Alvares de Azevedo apesar da sensualidade de palavras (seios etc) e de gestos de amor que descreve permanece um idealista em amor. Mesmo na poesia. No que se diferencia bem de C. Alves" (MA-MMA-26-04).

Em "Amor e medo", MA entende o respeito à mulher como "primeira grande lateralidade em que a timidez de amar se fixa nos românticos": "Nos versos, a mulher vira anjo, virgem, criança, visão, denominações que a excluem da sua plenitude feminina" (in Aspectos da literatura brasileira, ed. cit., p. 201).

P. 223:

Nota MA: termo sublinhado, "louquejar", cruzeta e expoente "(1)" remetendo ao comentário no rodapé - estudo do estilo: vocabulário:

"(1) Outro lado rimbaldico do processo de / escrever de A. de A. esse continuo des/bordar pra fora da lingua, criando / neologismos sobre neologismos."

em vez do borbulhar nas arterias de um sangue de Ibero, do fervor de um coração de Portuguez, crestado e cinéreo no louquejar das lupercaes...

P. 225:

Notas MA:

1. expressão sublinhada, "leprada de materialismo", e cruzeta - estudo do estilo: imagem:

Sua alma, leprada de materialismo, matizada ainda de frescuras de poesia na luta do corpo e da alma, da eiva de materialidade e da seiba de vida do espirito, precisava de um pousio ás agitações que a enfebrecião.

2. expressão sublinhada, "escuridos do vaporar", e duas cruzetas - estudo do estilo: imagem:

São duas feições louras, com olhos córados do azul dos céos do Norte; ambos escuridos do vaporar de suas tripodes pythonicas; ambos razões debeis, arrebatados como a Lenora a galope.

P. 227:

Nota MA:

1. termo corrigido, "dopulaça", substituindo o "d" por "p", "populaça" - correção tipográfica;

2. trecho por sublinha e traço duplo vertical - estudo do estilo: imagem: 
todo aquelle turbilhão de almas pendias da torrente dos labios do vate e a voz d'elle se afogava no phrenesi dos applausos, como a do hymno do vento na ancia das ondas

3. nome corrigido, "Boeage", substituindo o "e" por "c", "Bocage" - correção tipográfica.

P. 228:

Notas MA: trecho sublinhado e escólio "Amizade” - seleção de ideias:

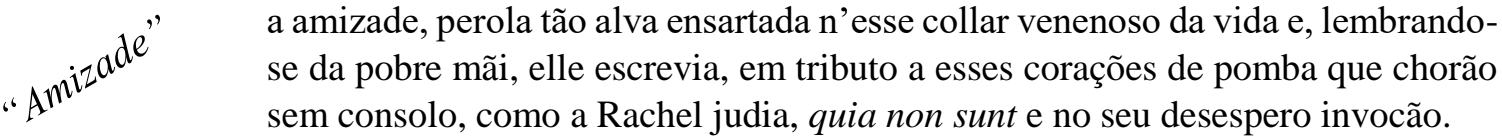

Nota da pesquisa: No dossiê do manuscrito Castro Alves, o fichamento crítico com vistas ao livro Lirismo romântico no Brasil remete ao escólio nesta página: "Conceito de Amizade; A. de A. III, 228" (MA-MMA-26-04).

P. 230:

Nota MA: termo corrigido, "pelo"; correção tipográfica.

P. 231:

Nota MA: termo corrigido, "depravavão", substituindo o "v" por “ç”, "depravação" correção tipográfica.

P. 232:

Nota MA: trecho destacado por traço vertical e escólio à esquerda, "Portugal instrução" - seleção de ideias:

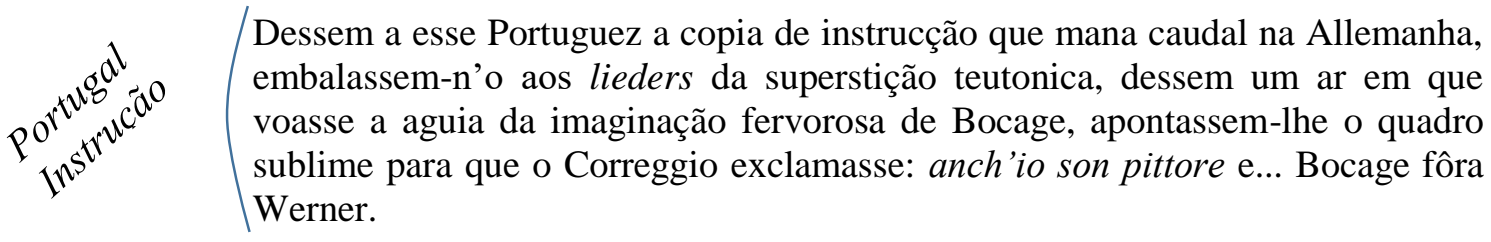

Nota da pesquisa: O fichamento crítico com vistas ao livro Lirismo romântico no Brasil, no dossiê do manuscrito Castro Alves, remete ao escólio desta e da p. 234, exemplificando a "Inferioridade do Romantismo brasileiro, Casimiro pg 120 / A. de. A. III, 232; 234" (MA-MMA-26-04).

P. 233:

Nota MA: termo sublinhado, “desviver”, e cruzeta - estudo do estilo: vocabulário:

(...) o levar de um desviver de perdição, oscillado entre a taça regurgitada de vinho e o leito da barregan... 
Nota da pesquisa: Última referência ao neologismo "desviver (no sentido de gastar a vida)", conforme elencado por MA em nota de trabalho no dossiê do manuscrito Amor e medo (MA-MMA-05-30).

P. 234:

Notas MA: trecho destacado por quatro traços verticais - seleção de ideias.

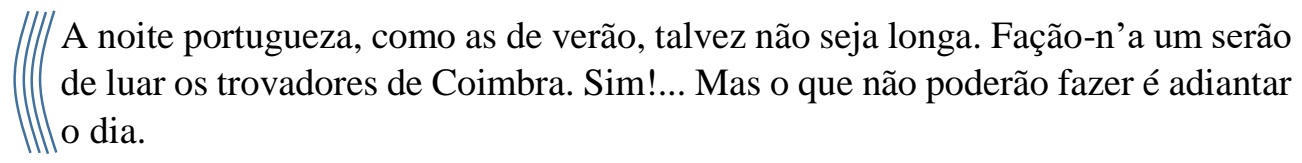

Nota da pesquisa: O fichamento crítico sugere que o trecho assinalado por MA liga-se à rubrica "Inferioridade do Romantismo brasileiro, Casimiro pg 120 / A. de. A. III, 232; 234" (MA-MMA-26-04).

P. 235-415

\section{ESTUDOS DRAMATICOS}

P. 237-241

CARTA SOBRE A ACTUALIDADE DO THEATRO ENTRE NÓS

P. 238:

Notas MA:

1. termo deslocado, "tradução", para consertar o fluxo do texto - correção tipográfica;

2. trecho destacado por traço vertical duplo - seleção de ideias: crítica ao caráter mercantil das produções teatrais;

3. conjunção "e" separada da palavra que a antecede, "moralisador" - correção tipográfica;

4. expressão sublinhada, "sentimentos de homem", e expoente (1) remetendo ao comentário no rodapé:

\footnotetext{
Quando o theatro se faz uma especie de taberna de vendilhão, vá que se especule com a ignorancia do povo. Mas quando a Companhia do theatro está debaixo da inspecção immediata do Governo, deverá continuar esse systema verdadeiramente immundo?

Não: o theatro não deve ser escola de depravação e máo gosto. O theatro tem um fim moralisadore litterario: é um verdadeiro apostolado do bello. D'ahi devem sahir as inspirações para as massas. Não basta que o drama sanguinolento seja capaz de fazer agitarem-se as fibras em peitos de homens-cadaveres. Não basta isto: é necessario que o sonho do poeta deixe impressões ao coração e agite n'alma sentimentos de homem. "(1)"
}

“(1) Notar que Alvares diz com grande / largueza critica 'sentimentos do homem' e não / sentimentos morais no sentido de moralizantes."

Notas da pesquisa:

1. No fichamento crítico para o livro Lirismo romântico no Brasil, esta página aparece indicada sob a rubrica "Moralismo", (MA-MMA-26-04). 
2. Os comentários de Álvares de Azevedo sobre o teatro são elogiados no editorial da Revista Nova: "Não bastará mostrar as justas noções com que fixa o que deve ser o teatro, não apenas na Carta sobre a Atualidade do Teatro no Brasil, como no monólogo de Puff; e que fazem do Macário a certamente mais elevada invenção teatral que nunca se escreveu entre nós." (a. 1, n. 3, p. 313).

P. 239:

Notas MA: preposição corrigida, "para" - correção tipográfica.

\section{$\underline{\text { P. 240: }}$}

Notas MA:

1. trecho destacado por traço vertical e comentário: "Como isto é bem escrito" - seleção de ideias e juízo crítico;

2. termo sublinhado, "vertiginoso", e comentário no rodapé - estudo do estilo: vocabulário:

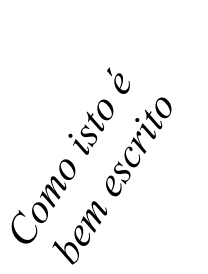

E com tudo Molière - um genio! - era comico. Shakspeare preferia a galhofa das alegres mulheres de Windsor - What you will, A tempestade, etc., aos monologos de Henrique III, ao desespero do rei Lear, á duvida de Hamlet. Kean despia o albornoz e o turbante e o andar vertiginoso, as faces ardentes de embriaguez do bon vivant cavalleiro da noite, amante da lúa, sir Jack Falstaff!

"Vertiginoso não quer dizer rapido pra A. de / A. Quer dizer incerto, intercadenciado, / cheio de vertigens. Na p 220, como aqui, / essa é a acepção de vertiginoso."

\section{P. 241:}

Nota MA: comentário sobre a prosa de Álvares de Azevedo:

"Ás vezes me ponho pensando imaginando que / em Alvares de Azevedo o prosador nascente ainda / era superior ao poeta. Esta carta é admiravel e ri-/quissima de ideas. E estupendamente escrita. Si / lembrarmos a mentalidade brasileira de então, so-/bretudo na critica artistica e si lembrarmos que / isto não é mais que os primeiros passos dum moço / de 20 anos, Alvares de Azevedo cresce enormemente / ao nosso julgamento."

Nota da pesquisa: O comentário é referido em nota de trabalho no dossiê do manuscrito Amor e medo: "Iniciar com nota pg 241" (MA-MMA-05-05). A crônica de 30 de agosto de 1931, a partir do segundo parágrafo, desdobrará o argumento da marginália de que "o prosador nascente ainda era superior ao poeta": "Toda a gente, creio, está acostumada a considerar Álvares de Azevedo um poeta, e em todos os tratados da nossa Literatura ele vem assim. Ora pela conformação do espírito dele, pela seriação das suas obras, pelas excelências que demonstrou como criador e como artista, tudo me leva a crer que a poesia era pra Álvares de Azevedo apenas o ginete da mocidade. A mocidade é por essência fácil. A prosa é muito mais difícil que a poesia tanto na realização técnica como na organização do lirismo psicológico." (“Álvares de Azevedo - II", in Táxi e Crônicas no Diário Nacional. ed. cit., p. 421). 
$\underline{\text { P. 243-330 }}$

MACARIO

Notas da pesquisa:

1. O dossiê do manuscrito Castro Alves carrega comentários extensos sobre Macário; representam prováveis esboços de MA para o livro Lirismo romântico no Brasil, parcialmente aproveitados por MA nas crônicas de teor crítico no Diário Nacional. Em nota de trabalho, MA registra a fartura de metáforas: "A violência ou a abundância da imagem mesmo nas descrições dos nossos poetas prejudica a realidade em favor da sensação pela deformação expressionista continuada. Os trechos de 'como' em abundância que marquei no Macário. Estamos longe dos franceses e italianos e portugueses como talento narrativo (observar Ferreira, Camões, Tasso e Racine. Aproximamo-nos mais dos ingleses e dos alemães muito mais líricos. Estou quase tentado a lançar Alvares de Azevedo mais como prosador que como poeta. Parece que na prosa ao menos ele chegou a realizar-se" (MA-MMA-26-07).

2. Ao preparar o editorial da Revista Nova - documento conservado no dossiê do manuscrito Amor e medo - MA tece elogios à obra de Álvares de Azevedo: "Macario apesar dos chavões de mau teatro do segundo episódio é uma obra-prima românti[ca] [rasura a lápis até este ponto] O primeiro episódio do Macário é formidável, uma obraprima. O segundo já vira discurso brasileiro, muito vazio, muita oratória banal. Da mesma forma é colossal o primeiro capítulo da Noite na Taverna, que hoje publicamos. Perfeitamente narrado. Nítido, simples, uma perfeição de estilo. Prosa branca, sem arrebique" (MA-MMA-05-25).

3. Na crônica de 30 de agosto de 1931, ao advogar a superioridade do prosador ante o poeta, MA afirma: "Antes de mais nada: a criação mais extraordinária, mais estonteante dele é em prosa, o Macário. Todo o primeiro episódio que afinal é um enorme diálogo entre Satã e Macário, é uma página magistral como limpidez de estilo, diálogo corredio, invenções dramáticas (não teatrais, propriamente) esplêndidas. O segundo episódio, na Itália, enfraquece bem. Álvares de Azevedo, parece que fatigou; dá largas àquela facilidade oratória com que nos discursos de Academia ele atingira a francamente verdadeiras e curiosíssimas magnificências de vazio, colorido e sonoridade." ("Álvares de Azevedo - II", in Táxi e Crônicas no Diário Nacional. ed. cit., p. 422).

P. 243:

Notas MA: trecho sublinhado, "algumas idéas theoricas" e fio ligando ao comentário na margem superior:

\section{"É mesmo o unico romantico que teve teorias no Brasil"}

Criei para mim algumas idéas theoricas sobre o drama. Algum dia, se houver tempo e vagar, talvez as escreva e dê a lume.

Nota da pesquisa: MA alude à expressão em nota de trabalho, no dossiê do manuscrito Amor e medo: "Criei para mim algumas ideias teoricas pg 243" (MA-MMA-05-25). Na crônica de 23 de agosto, 1931, após desenvolver a ideia de que a genialidade de Álvares de Azevedo não se realizou - ao contrário dos outros românticos, que não poderiam dar mais do que deram - MA pontua: "Álvares de Azevedo, pelo contrário, prometia ir enormemente além do tédio e da fúria de juventude em que viveu. Preocupavam-no as 
suas leituras ainda mal digeridas mas absolutamente incomuns, lançava-se no labirinto das filosofias (...) E a preocupação de filosofias, de problemas críticos, de problemas psicológicos se manifestava nele com uma liberdade criadora, detestável prás inquisições" (“Álvares de Azevedo - I”, in Táxi e Crônicas no Diário Nacional, ed. cit., p. 418).

P. 244:

Notas MA:

1. trecho sublinhado, "verdadeira castração de Othello de Shakespeare";

2. trecho sublinhado, "genio vagabundo do autor de Hamlet";

3. trecho destacado por traço vertical duplo - seleção de ideias: crítica:

Não se pareceria com o de Ducis, nem com aquella traducção bastarda, verdadeira castração de Othello de Shakespeare, feita pelo poeta sublime do Chatterton, o conde Vigny. Quando não se tem alma adejante para emparelhar com o genio vagabundo do autor de Hamlet, haja ao menos modestia bastante para não querer emendal-o. Por isso o Othello de Vigny é morto. Era uma obra de talento, mas devia ser um rasgo de genio.

\section{P. 245:}

Notas MA:

1. trecho destacado por traço vertical duplo - seleção de ideias: reivindicação romântica de liberdade formal;

2. artigo sublinhado, "o", e cruzeta à direita - estudo do estilo/linguístico: provável interesse pela regência verbal.

É difficil encerrar a torrente de fogo dos anjos decahidos de Milton ou o pantano de sangue e lagrimas do Alighieri dentro do pentametro de marmore da tragedia antiga. Contão que a primeira idéa de Milton foi fazer do Paraiso Perdido uma / tragedia, um mysterio... não sei o que... $\quad X$

Notas da pesquisa:

1. MA indicia o artigo em nota de trabalho no dossiê do manuscrito Amor e medo, acusando provável interesse pela regência verbal, captando talvez a tendência, em certas regiões do Brasil, de empregar o artigo ao lado do pronome: "O que sofres? II, 282 no que scismas 192, pg 90 e III, 245; III, 312” (MA-MMA-05-30; destaquei).

2. A reivindicação de liberdade formal assinalada em Álvares de Azevedo sugere um aspecto em comum entre MA e os poetas do romantismo. Assim, em Pauliceia desvairada, o "Prefácio interessantíssimo" postula: "Não acho mais graça nenhuma nisso da gente submeter comoções a um leito de Procusto para que obtenham, em ritmo convencional, número convencional de sílabas. Já, primeiro livro, usei indiferentemente, sem obrigação de retorno periódico, os diversos metros pares. Agora liberto-me também desse preconceito. Adquiro outros. Razão para que me insultem?" (ANDRADE, Mário de. In: "Pauliceia desvairada"; in: Poesias completas, ed. cit., vol. 1, p. 65-6). No mesmo sentido: "Preocupação de métrica e de rima prejudica a naturalidade livre do lirismo objetivado." (ibidem, p. 71).

P. 246:

Notas MA:

1. termo sublinhado, "balata", e escólio "dic" - pesquisa para o Dicionário musical brasileiro; 
2. trecho destacado por traço vertical e expressão sublinhada - seleção de ideias: crítica:

\begin{abstract}
Se eu imaginasse o Othello, seria com todo o seu esgar, seu desvario selvagem, com aquella fórma irregular que revela a paixão do sangue. É que as nodoas de sangue quando cahem no chão não têm forma geometrica. As agonias da paixão, do desespero e do ciume ardente quando côão n'um sangue tropical não se derretem em alexandrinos, não se modulão nas fallas banaes d'essa poesia de convenção, que se chama - conveniencias dramaticas.
\end{abstract}

Nota da pesquisa: MA refere-se ao trecho sublinhado como exemplo da "sutileza crítica" de Álvares de Azevedo, em nota de trabalho no dossiê do manuscrito Amor e medo: "Subtileza critica citar grifo pg 246" (MA-MMA-05-25).

\title{
$\underline{\text { P. 249: }}$
}

Notas MA:

1. trecho destacado por traço vertical duplo - estudo do estilo: ironia/realismo irônico;

2. termo corrigido, "nãote" - correção tipográfica;

3. termo sublinhado, "nenia", e escólio "dic" - pesquisa para o Dicionário musical brasileiro:

\section{MACARIO.}

Eis-ahi o resultado das viagens. Um burro frouxo, uma garrafa vazia. (Tira uma garrafa do bolso.). Cognac! és um bello companheiro de viagem. És silencioso como um vigario em caminho, mas no silencio que inspiras, como nas noites de luar, ergue-se ás vezes um canto mysterioso que enleva! Cognac! Não te ama quem não te entende! nãote amão essas boccas feminis acostumadas ao mel enjoado da vida, que não anceião prazeres desconhecidos, sensações mais fortes! E eis-te ahi vasia, minha garrafa! vasia como mulher bella que morreu! Hei-de fazer-te uma nenia.

P. 251:

Nota MA: termos sublinhados e unidos por traço vertical - estudo do estilo: caracterização de Satã:

\section{MACARIO.}

Tal e qual... por signal que era fria como o focinho de um cão.

O DESCONHECIDO.

Era eu.

P. 252:

Notas MA: trecho destacado por traço vertical e expoente (1) remetendo ao comentário - seleção de ideias: descrição da paisagem:

\section{O DESCONHECIDO.}

Vistes-me duas vezes. Eu vos vi ainda outra vez. Era na serra, no alto da serra. A tarde cahia, os vapores azulados do horizonte se escurecião, um vento frio sacudia as folhas da montanha e vós contemplaveis a tarde que cahia. Além, n'esse horizonte, o mar como uma linha azul orlada de escuma e de areia... e no valle, 
como bando de gaivotas brancas sentadas n'um paúl, a cidade que algumas horas antes tinheis deixado. D'ahi vossos olhares se recolhião aos arvoredos que vos rodeavão, ao precipicio cheio das flôres azuladas e vermelhas das trepadeiras, ás torrentes que mugião no fundo do abysmo; e defronte vieis aquella cachoeira immensa que espedaça suas aguas amarelladas, n'uma chuva de escuma, nos rochedos negros do seu leito. E olhaveis tudo isso com um ar perfeitamente romantico. Sois poeta?

"(1) Parece descrição do alto da serra na Estrada do / Mar, olhando pra Santos até a cachoeira."

Nota da pesquisa: A crônica de 29 de março, 1931 confirma no Diário Nacional a identificação da paisagem: "Álvares de Azevedo tem aqueles trechos deliciosos do Macário em que descreve o Alto-da-Serra e a chegada em São Paulo. Varela, que apesar de tudo foi o mais paisagista dos românticos (o que não quer dizer propriamente ter sentimento da natureza), deixou também do Alto-da-Serra uma descrição comovente no Diário de Lázaro. Mas é comovente... para quem conhece o Alto-da-Serra. É o aprazível sentimental de reconhecer ou descobrir que leva a gente a comover-se diante dessas descrições. Aos outros isso não passará de literatura." ("Álvares de Azevedo - II", in Táxi e Crônicas no Diário Nacional, ed. cit., p. 361). Em 6 de setembro de 1931, nova alusão ao trecho destacado: "Só mesmo os aspectos grandiosos da natureza parecem interessálo um bocado, o Alto-da-Serra que descreve bem, a gruta de Fingal, a tempestade." (ibidem, p. 426).

P. 257-258:

Notas MA:

1. trecho sublinhado e escólio "zoof" - estudo da zoofonia;

MACARIO.

(...) Os passarinhos sabem só uma cantiga, o luar é sempre o mesmo e este mundo é monotono a fazer morrer de somno.

2. trecho sublinhado e escólio "Poesia" - seleção de ideias: concepção de poesia/aristocratismo:

\section{MACARIO}

"Poesia"

Emquanto era a moeda de outro que corria só pela mão do rico, ia muito bem. Hoje trocou-se em moeda de cobre; não há mendigo, nem caixeiro de taverna que não tenha esse vintem azinhavrado. Entendeis-me?

Notas da pesquisa:

1. No dossiê do manuscrito Artigos por escrever, o esboço de editorial para a Revista Nova recorre ao trecho assinalado como indício do desprezo de Macário pela poesia (MAMMA-11-13), reiterado por MA na crônica de 6 de setembro de 1931: "Macário, embora tenha alguma noção social exata do que seja o destino socializador da arte, chega a desprezar a própria poesia, numa 'boutade' irritada". A crônica cita, então, a mesma fala em destaque (“Álvares de Azevedo - III”, in Táxi e Crônicas no Diário Nacional. ed. cit., p. 425).

2. O editorial da Revista Nova (a. 1, n. 3) indica esta p. 258 ao aludir à explicação de Satã "a uma teoria de Macário passível de interpretação falsa". 
P. 259:

Nota MA: trecho destacado por traço vertical duplo - estudo da psicologia feminina:

\section{MACARIO.}

/ Uma mulher! Todas ellas são assim. As que não são assim por fóra o são por dentro. Algumas em falta de cabellos na cabeça os tem no coração.

Nota da pesquisa: Em “Amor e medo", MA reporta-se ao trecho assinalado, mesclando a fala da personagem à biografia do escritor: "[AA] Também se arrota manchado por todas as maldades do mundo. Mas a verdade é que, si pra Macário as mulheres que não têm cabelo na cabeça o têm no coração (III, 259), si 'não pode haver inferno com senhoras' (II, 230), si na estância do Poema do Frade, aquele tipo tão puro de Madona era um lago a dormir, 'porém sua água azul tinha veneno'; si ainda pra Macário (III, 268), as mulheres paulistanas 'são mulheres, isto é, são lascivas': tudo isso são falsificações sistematizadas inconscientemente, de quem soube achar expressões delicadas mesmo pra designar a mulher prostituída, 'vagabunda do amor', 'mulher da noite', 'anjo da noite', 'rainha da noite'." (“Amor e medo", In: Aspectos da literatura brasileira, ed. cit., p. 204).

\section{P. 260-261:}

Notas MA:

1. termo sublinhado, "irmã", e cruzeta à esquerda - estudo da psicologia: mãe/irmã:

$X \quad$ Quantos lábios além dos de tua irmã?

2. termo sublinhado, "falla" - estudo do estilo: conjugação:

Falla claro.

3. expressão sublinhada, "se chamas" - estudo do estilo: conjugação;

4. trecho destacado por fio às pp. 260 e 261 - estudo da psicologia: sentimento amoroso;

5. termo sublinhado, "adevinha", e cruzeta - estudo do estilo: vocabulário/brasileirismo:

Mais claro que o dia. Se chamas o amor a troca de duas temperaturas, o aperto de
dous sexos, a convulsão de dous peitos que arquejão, o beijo de duas boccas que
tremem, de duas vidas que se fundem... tenho amado muito e sempre!... Se
chamas o amor o sentimento casto e puro que faz scismar o pensativo, que faz
chorar o amente na relva onde passou a belleza, que adevinha o perfume d'ella
na briza, que pergunta, ás aves, á manhã, á noite, ás harmonias da musica que
melodia é mais doce que sua voz e ao seu coração que formosura ha mais divina
que a d'ella... eu nunca amei. Ainda não achei uma mulher assim. Entre um
charuto e uma chavena de café lembro-me ás vezes de alguma fórma divina,
morena, branca, loura, de cabellos castanhos ou negros.

Nota da pesquisa: A alusão à irmã é incluída por MA em nota de trabalho (MA-MMA05-29); cauciona a leitura de teor psicanalítico acerca da obra de Álvares de Azevedo, consolidada no ensaio: "Numa outra feita (III, 260) é bem tendenciosa a pergunta que o Desconhecido faz pra Macário: 'Falas como um descrido, como um saciado! E contudo ainda tens os beiços de criança! Quantos seios de mulher beijaste além do seio de tua ama de leite? Quantos lábios além dos de tua irmã?’ De forma que o nosso Macário faz o 
Desconhecido dizer do Macário que este fala como si fosse um saciado, mas tendo ainda os beiços de criança." ("Amor e medo", In: Aspectos da literatura brasileira, ed. cit., p. 222).

P. 262:

Notas MA: conjugação corrigida, "quererias", pela supressão do "s" final - correção tipográfica.

P. 263:

Nota MA: trecho sublinhado e escólio "Mundo" - seleção de ideias: mundo/tédio:

MACARIO.

Duvido sempre... descreio ás vezes. Parece-me que este mundo é um logro. "Mundo" O amor, a gloria, a virgindade, tudo é uma illusão.

\section{P. 264:}

Notas MA:

1. trecho destacado por traço vertical e traços duplos - estudo da psicologia: erotismo/sentimento amoroso;

2. comentários à fala de Satã, entendida como projeção do poeta:

"Porem A. de A. se conserva puro na / alma imensamente. Um infantil."

/(O DESCONHECIDO.

Tua comparação é exacta. A meretriz é um cadaver.

(/MACARIO.

Vale-nos ao menos que sobre seu peito não se morre de frio!

O DESCONHECIDO.

Admira-me uma cousa. Tens vinte annos: deverias ser puro como um anjo e és ) devasso como um conego!

MACARIO.

Não é que eu não voltasse meus sonhos para o céo. A cisterna tambem abre seus labios para Deus e pede-lhe uma agua pura - e o mais das vezes só tem lôdo. Palavra de honra que, ás vezes, quero fazer-me frade.

O DESCONHECIDO.

Frade! Para que?

P. 265:

Notas MA: trecho destacado e comentários sobre a fatura dramática:

“A dialogação é excelente. Quasi nada romantica. / Nada eloquente. Fala não discursa."

"Notar quanto Alvares de Azevedo é vario na prosa / e bem afeiçoa-se ao assunto. Orador grandiloquo. / Critico de prosa limpida. Artista de prosa lite-/raria admiravel. Dramaturgo aqui conhecedor." 
MACARIO.

É uma loucura. Enche esse copo. (Bebe). Pela Virgem Maria! Tenho somno. Vou dormir.

O DESCONHECIDO.

E eu tambem. Boa noite.

P. 268:

Notas MA:

1. trecho destacado por traço vertical duplo - seleção de ideias: ironia;

2. trecho destacado por traço vertical e escólio "São Paulo" - seleção de ideias: caracterização de São Paulo.

SATAN.

// Mulheres, padres, soldados e estudantes. As mulheres são mulheres, os padres são soldados, os soldados são padres e os estudantes são estudantes: para fallar mais claro, as mulheres são lascivas, os padres dissolutos, os soldados ebrios, os estudantes vadios. Isto salvo honrosas excepções, por exemplo, de amanhã em diante tu.

MACARIO.

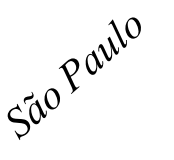

/Esta cidade deveria ter o teu nome.

\section{SATAN}

Tem o de um santo: é quasi o mesmo. Não é o habito que faz o monge. Demais, essa terra é devassa como uma cidade, insipida como uma villa e pobre como uma aldêa. Se não estás reduzido a dar-te ao pagode, a suicidar-te de spleen, ou a alumiar-te a rôlo, não entres lá. É a monotonia do tedio. Até as calçadas...

P. 270:

Nota MA: trecho sublinhado - seleção de ideias: mulher:

SATAN.

Mas as moças poucas vezes têm bons dentes.

P. 272:

Notas MA: repetição suprimida, “de”; correção tipográfica.

P. 276:

Notas MA: trecho sublinhado e expoente (1) remetendo ao comentário no rodapé:

“(1) Liberdade de juizo critico. Consciencia / de si e do seu tempo.”

SATAN.

Eis o que é profundamente verdade! Perguntai ao libertino que venceu o orgulho de cem virgens e que passou outras tantas noites no leito de cem devassas, perguntai a D. Juan, a Hamlet ou ao Faust o que é a mulher e... nenhum o saberá

(1) dizer. E isso que te digo não é romantismo.

P. 278:

Nota MA: trecho sublinhado - seleção de ideias: sinceridade. 
MACARIO.

(...) Essa alcova era immunda. Eu estava ahi frio: o contacto d'aquelle corpo amollecido não me excitava sensações; e comtudo eu mentia á minha alma, dando-lhe beijos.

P. 279:

Notas MA:

1. termo sublinhado, "rabeca", e escólio "dic" - pesquisa para o Dicionário musical brasileiro;

2. trecho destacado por traço vertical - seleção de ideias: mãe:

SATAN.

(...) Dizem que se a rabeca de Paganini dava sons tão humanos, tão melodiosos, é que elle fizera passar a alma de sua mãi, de sua velha mãi moribunda, pelas dic cordas e pela caverna de seu instrumento. Sentes frio, que te embuças assim no teu capote?

P. 281:

Notas MA: trecho sublinhado - estudo do estilo: imagem:

\section{SATAN.}

Deixa eu beber um trago de curaçáo. Vamos. A lua parou no céo: tudo dorme... é a hora dos mysterios.

P. 283:

Notas MA: trecho sublinhado e escólio - estudo do estilo: ênfase na repetição do verbo:

MACARIO.

(...) Depois eu vi uma fórma de mulher pensativa. Era núa... e seu corpo era perfeito como o de um anjo, mas era livido como o marmore. Seus olhos erão

Albalat! vidrados, os labios brancos e as unhas roxeadas. Seu cabello era louro, mas tinha uns reflexos de branco.

Nota da pesquisa: Três livros de Antoine Albalat (1856-1935) foram encaminhados por MA para a constituição do acervo da Biblioteca Municipal de Araraquara: Le travail du style; A formação do estilo pela assimilação dos autores e A arte de escrever em vinte lições. Nenhum deles se acha disponível ainda naquela coleção.

P. 284:

Notas MA: expoente (1) remetendo ao comentário no rodapé:

(1) Quem é?

“(1) Este sonho é simplesmente curiosissimo. / Uma alucinação danada sobre a assexuali-/dade dos anjos, uma invenção de Satan que / nem se pode mesmo chamar de 'diaboli-/ca'. Mas está mal descrito e não tem a vi-/talidade, a força convincente das Fantasma-/gorias, canto IV do Conde Lopo." 
Nota da pesquisa: MA alude a esta passagem no parágrafo final de "Amor e medo", perguntando-se do tédio de Álvares de Azevedo, que não se esgota, para o crítico, na influência europeia: "Há várias constâncias e pormenores nos escritos de Álvares de Azevedo, que poderiam nos levar a suposições psicopatológicas que não me interessam aqui por serem deste ou daquele indivíduo. Não têm o valor universal do tema do amor e medo, que é de todos. Mas não me assusta imaginar que em grande parte foi o medo de amor, a incapacidade que levou Macário a se morrer. E sob esse ponto-de-vista, inda a gente poderá estudar certos detalhes do pesadelo do Conde Lopo: a obsessão do frio, a capa que os diabinhos tiram do conde, a recusa de amar o esqueleto... vivo da prostituta, etc. Mais importante ainda é, no sonho do Macário, a mulher-anjo-homem assexuado que Satan explica assim: 'Era um anjo. Há cinco mil anos que ela tem o corpo da mulher e o anátema duma virgindade eterna. Tem todas as sêdes, todos os apetites lascivos, mas não póde amar. Todos aqueles em que ela toca se gelam. Repousou seu seio, roçou suas faces em muitas virgens e prostitutas, em muitos velhos e crianças, bateu em todas as portas da criação, estendeu-se em todos os leitos e com ela o silêncio... Essa estátua ambulante é quem murcha as flores, quem desfolha o outono, quem amortalha as esperanças.' 'Quem é?', Macário pergunta. Mas Satan muda de conversa." ("Amor e medo", in: Aspectos da literatura brasileira, ed. cit., p. 229).

P. 285:

Notas MA: trecho destacado por traço vertical - estudo do estilo: prosa:

MACARIO.

Não ouviste um ai? um outro ai ainda mais dorido?

SATAN.

É algum bacuráo que passou, algum passarinho que acordou nas garras de uma coruja.

P. 286:

Notas MA: termos separados, "por/quem" - correção tipográfica.

P. 287:

Notas MA: comentário no rodapé e planejamento do ensaio - estudo da psicologia: sentimento amoroso/mãe e irmã:

"Final grandemente romantico mas estupendamen-/te dramatico e forte. Cita-lo ao lembrar a tendencia / dos nossos romanticos pro amor filial e fraternal."

Nota da pesquisa: MA alude a este comentário ao assinalar, no fichamento crítico para o Lirismo romântico no Brasil, "O amor por mãi e irmã" (MA-MMA-26-04). Em nota de trabalho no dossiê do manuscrito Amor e medo, também há remissão à p. e ao comentário: "Mãi III, 287 nota" (MA-MMA-05-29). O final do diálogo entre Macário e Satã é reproduzido em "Amor e medo", logo após o seguinte raciocínio: "Mas é sempre, e agora sintomaticamente, Álvares de Azevedo o que evoca e versa o tema de mãe e irmã numa quasi obsessão. Um dos momentos esplêndidos do Macário, a coisa mais genial que o poeta criou, é quando o estudante escuta um ai, e pergunta de quem é." (In: Aspectos da literatura brasileira, ed. cit., p. 219). 
P. 291:

Notas MA: expressão sublinhada e cruzeta - estudo do estilo: brasileirismo sintático:

\section{A MULHER.}

$X \quad$ Não morreu, não... Elle está dormindo.

Nota da pesquisa:

1. Sob a rubrica "O pronome obliquo inicial", o fichamento crítico para o livro Lirismo romântico no Brasil alude à expressão sublinhada, relacionando-a a outras marcas de brasileirismo entre os românticos (MA-MMA-26-04).

2. MA reitera a referência a essa construção sintática brasileira, junto a outra, análoga, "Eu não rio-me não", em nota de trabalho no dossiê do manuscrito Amor e medo (MAMMA-05-30).

\section{P. 292:}

Notas MA:

1. comentário crítico na margem superior - estudo do estilo: diálogo:

"As falas enfraquecem muito neste / principio de ato, não por causa do romantismo porém por-/que tem chavões de mau teatro, conta pro espectador, pre-/ocupação de I esclarecer."

2. expressão sublinhada, "toada monotona da viola", e escólio "dic" - pesquisa para o Dicionário musical brasileiro;

3. termo sublinhado, "sertanejo" e escólio "na Italia": seleção de ideias: brasilidade/nacionalismo:

Mais longe a toada monotona da viola se mistura á cantilena do sertanejo, ou aos improvisos do poeta singelo da floresta, alma ignorante e pura que só sabe das emoções do sentimento e dos cantos que lhe inspira a natureza virgem de sua terra.

na Italia

Notas da pesquisa:

1. Ao elogiar Macário em nota de trabalho no dossiê do manuscrito Amor e medo, MA reproduz a expressão da marginália, depois rasurada: "Macario apesar dos chavões de mau teatro do segundo episédio é uma obra-prima românti $O$ primeiro episódio do Macário é formidável, uma obra-prima. O segundo já vira discurso brasileiro, muito vazio, muita oratória banal. Da mesma forma é colossal o primeiro capítulo da Noite na Taverna, que hoje publicamos. Perfeitamente narrado. Nítido, simples, uma perfeição de estilo. Prosa branca, sem arrebique" (MA-MMA-05-25).

2. No dossiê do manuscrito Amor e medo, MA utiliza o termo sublinhado como prova do "brasileirismo inconsciente que põe sertanejos e toadas de viola na Italia e em estalagens aportuguesadas fala em nhô Quito (Macario)" (MA-MMA-05-30). A primeira na série de cinco crônicas no Diário Nacional acerca do autor de Noite na taverna, em 22 de março de 1931, invoca o mesmo exemplo assinalado pela marginália no afirmar: "O esboço de cultura forte, apesar de bêbeda, que se percebe nas obras de Álvares de Azevedo, não o despaísa absolutamente. Antes despaísa as invenções que ele localiza na Europa, como aquele caso engraçado de falar em sertanejos na Itália, se não me engano no segundo ato de Macário. Álvares de Azevedo não era um despaisado. Pelo contrário, é difícil a gente encontrar um escritor nacional em que o Brasil funcione mais 'necessariamente' do que 
nele.” (“Álvares de Azevedo - I”, in Táxi e Crônicas no Diário Nacional. ed. cit., p. 356). Em 6 de setembro de 1931, imagem e argumento são repisados pelo crítico: "E ele, tão instintivamente brasileiro que chega a botar 'uma viola monótona de sertanejo' em plena Itália, deixou ver inda mais tipicamente a sua aristocrática revolta contra a natureza, atacando os desertores dela" ("Álvares de Azevedo - III", in Táxi e Crônicas no Diário Nacional. ed. cit., 426).

P. 295:

Notas MA:

1. escólio "Mulher": seleção de ideias;

2. cacófato sublinhado, "ca d'ellas", e cruzeta - estudo do estilo: prosa;

3. termo sublinhado, "stradivarius", e escólio "dic" - pesquisa para o Dicionário musical brasileiro;

4. escólio, "Musica"; seleção de ideias.

PENSEROSO.

A mulher! Oh! se todos os homens as entendessem! Essas almas divinas são como as fibras harmoniosas de uma rabeca. O ignorante não arranca d'ellas um som melodioso... embalde suas mãos grosseiras revolvem e apertão o arco sobre ellas... embalde! sómente sons asperos resoão. Mas que a mão do artista as vibre, que a alma do musica se derrame n'ellas, e do instrumento grosseiro do mendigo ignorante ou do cégo vagabundo, como do stradivarius divino, exhalão-se ais, vozes humanas, suspiros e accentos entrecortados de lagrimas.

\section{MACARIO.}

Oh! sim! Se na vida ha uma cousa real e divina é a arte; e na arte se ha um raio Mulher $X$ do céo é na musica, na musica que nos vibra as cordas da alma, que nos acorda da modorra da existencia a alma embotada. Oh! é tão doce sentir a voz vaporosa que trina, que nos enleva e que parece que nos faz desfallecer, amar e morrer!

P. 297:

Nota MA: fala de "Satan" destacada por colchete e interrogação; seleção de ideias: homossexualidade:

Vamos... E como é bello descorado assim! com seus cabellos castanhos em desordem, seus olhos entreabertos e humidos e seus labios feminis! Se eu não fôra Satan, eu te amaria, mancebo... (Vai leval-o).

Nota da pesquisa: O dossiê do manuscrito Amor e medo conserva nota de trabalho remetendo ao trecho marcado nesta p.: "Alv. de Azevedo // Homossexualidade // III, 297" (MA-MMA-05-26).

P. 298:

Nota MA: termo sublinhado, "Queimo-me"; estudo linguístico: colocação pronominal:

MACARIO.

Sou infeliz no jogo. Queimo-me e perco. Quando aposto e perco, tenho desejos de atirar com as cartas á cara do banqueiro. 
Nota da pesquisa: O termo sublinhado reaparece em nota de trabalho, no dossiê do manuscrito Amor e medo, onde MA elenca marcas lexicais e sintáticas do estilo de Álvares de Azevedo: “Queimar-se III, 298” (MA-MMA-05-30).

P. 300:

Notas MA:

1. trecho destacado por traço vertical e escólio "Amor e medo" - estudo da psicologia: sentimento amoroso;

2. termo corrigido, "merecião", substituindo "p" por "m" - correção tipográfica;

3. trecho sublinhado e traço vertical - estudo da psicologia: sentimento amoroso:

Amore
medo

SATAN.

(...) Fazia sonhar a amante do rei quando, semi-núa sentada sobre as bordas do leito, repousando a mão sobre a face, sentia as lagrimas do amor e da saudade banharem-lhe os olhos ao luar. Isto que te digo, o moço o pensou. Foi um nunca findar de versos, de passeios romanticos pelos valles, pelas encostas das montanhas, um inteiro viver e morrer por ella, como elle o dizia n'algum soneto... Vês que torno-me poetico... Quando vi o moço com a cabeça tonta, revolvendose pallido nos seus delirios esperançosos, á fé de bom Diabo que sou! interesseime por elle. Demais, perecião morrer um pelo outro. Os apertos de mãos a furto, os olhares cheios de languidez, tudo isso parece que azoinou a mente virginal da donzella. Uma noite, na sombra, a medo beijárão-se. Aquelle beijo tinha amor e loucura nos labios. O moço perdeu-se de amor. Escreveu-lhe uma carta: transbordou ahi todas as suas poesias, toda a febre de seu devanei. Não te rias, é d'estylo, Macario. $\mathrm{O}$ que ha de mais serio e risivel que o amor? As fallas de Romeo ao luar, os suspiros de Armida, os sonetos de Petrarca tomados ao serio dão desejos de gargalhar...

A partida estava proposta, as paradas feitas, e eu para assegurar o jogo tinha chumbado os dados. Era de apostar a minha cabeça contra a de um santo, todas as mulheres bellas da terra por uma bruxa...

Nota da pesquisa: "Já falei que Álvares de Azevedo alardeava de desabusado em amor; mas Satã (III, 300), numa frase extremamente pessimista e respeitosa, acha que não tem nada de 'mais sério e mais risível' que o amor.": afirma MA em "Amor e medo", aproveitando a oração assinalada (In: Aspectos da literatura brasileira, ed. cit., p. 222).

P. 301:

Nota MA: termo sublinhado e cruzeta - estudo do estilo: vocabulário.

SATAN.

(...) e n'uma risada innocente chuleou-me a parada. $\quad X$

P. 302:

Notas MA:

1. trecho sublinhado e cruzeta - seleção de ideias: mulher;

SATAN.

Isso de mulheres, nem eu, que sou o Diabo, as entendo. Quem entende o vento,

$X \quad$ as ondas e o murmurar das folhas? A mulher é um elemento. A santa mais santa, a virgem mais pura, ha instantes em que se daria a Quasimodo e Messalina era capaz de engeitar Romeu ou Dom Juan. Mas emfim... Macario? 
2. trecho destacado por colchete - seleção de ideias: caracterização do personagem Penseroso/estudo do estilo: comparação:

\section{MACARIO.}

Que idéa rola no teu cerebro inflammado, meu poeta... Como um ramo despido de folhas que se dobra ao peso de um bando de aves da noite, porque tua cabeça se inclina ao peso dos pensamentos?

P. 304:

Nota MA: termo sublinhado, "vertiginoso"; estudo do estilo: vocabulário.

MACARIO.

(...) cujos beijos tem o perfume vertiginoso das magnolias e o ardor do sangue meridional.

Nota da pesquisa: MA traslada o termo para nota de trabalho no dossiê do manuscrito Amor e medo, onde recolhe várias marcas do estilo rico da prosa azevediana (MA-MMA05-30).

P. 308:

Notas MA:

1. trecho destacado por traço vertical duplo e expoente (1) remetendo ao comentário no rodapé - seleção de ideias;

“(1) Ve-se aliás desde a pg. atrás que Alvares de / Azevedo se critica a si mesmo.”

(1) (...) Esperanças! e esse Americano não sente que elle é o filho de uma nação nova,
não a sente o maldito cheia de sangue, de mocidade e verdor?

2. trecho destacado por traço vertical duplo - seleção de ideias: esperança:

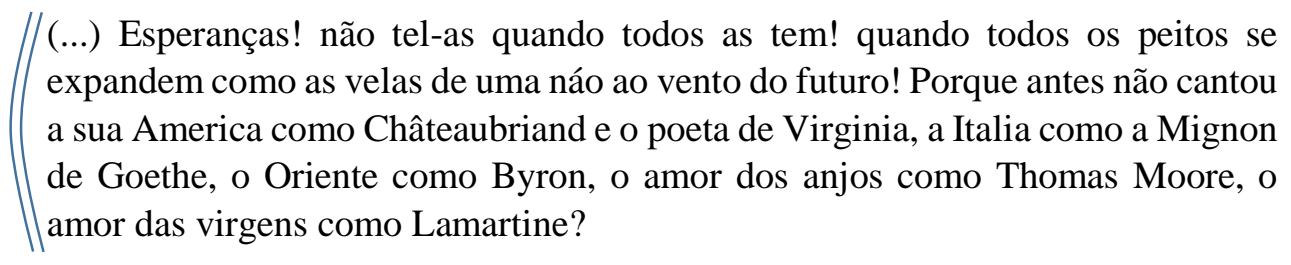

Nota da pesquisa: As observações de Penseroso sobre os filhos da América provam a "clarividência às vezes notável" de Álvares de Azevedo, segundo o editorial da Revista Nova (a. 1, n. 3, p. 313).

P. 309:

Notas MA:

1. trecho destacado por traço vertical e escólio "Aristocracia" - seleção de ideias: aristocracia:

MACARIO

Muito bem, Penseroso. Agora cala-te: fallas como esses Oradores de lugares Aristocracia communs, que não sabem o que dizem. A vida está na garrafa de cognac, na fumaça de um charuto de Havana, nos seios voluptuosos da morena. Tirai isso da 
vida - o que resta? Palavra de honra que é deliciosa a agua morna de bordo de vossos navios! que tem um aroma saudavel as machinas de vossos engenhos a vapor! que embalão n'um far-niente balsamico os vossos calculos de commercio! Não sabeis da vida. Accende esse charuto. Penseroso, fuma e conversemos.

2. trecho sublinhado, destacado por traço vertical e cruzeta - seleção de ideias: ironia das idealizações românticas:

Em quanto não se inventar o meio de ter mocidade eterna, de poder amar cem mulheres n'uma noite, de viver de musica e perfumes e de saber-se a palavra magica que fará recuar das salas do banquete universal o espectro da morte... antes d'isso pouco tereis adiantado.

Nota da pesquisa: O dossiê do manuscrito Artigos por escrever conserva nota de trabalho em que MA alude ao caráter aristocrático do autor de Macário, remetendo a este trecho: "Alv. de Azevedo Aristocracia dele. Veja III, p 309 e ss" (MA-MMA-11-8). A crônica de 6 de setembro de 1931 também reproduz o trecho assinalado: "A sua inutilidade revoltada, inda tem mais esta aristocrática irritação de Macário contra o ramerrão da vida" (“Álvares de Azevedo - III”, in Táxi e Crônicas no Diário Nacional. ed. cit., 426).

\section{P. 310:}

Notas MA:

1. trecho sublinhado e cruzeta - seleção de ideias: gênio:

\section{MACARIO.}

(...) Não sabem o que dizem esses homens que para apaixonar-se pelo canto esperão que o hosanna da gloria tenha saudado o cantor. São estereis em si como a parasita. Musicos - nunca serão Beethoven, nem Mozart.

2. trecho destacado por traço vertical - seleção de ideias: ironia da idealização romântica.

$$
\begin{aligned}
& \text { (...) Fallão nos gemidos da noite no sertão, nas tradições das raças perdidas da } \\
& \text { floresta, nas torrentes das serranias, como se lá tivessem dormido ao menos uma } \\
& \text { noite, como se acordassem procurando tumulos e perguntando como Hamleto no } \\
& \text { cemiterio a cada caveira do deserto o seu passado. }
\end{aligned}
$$

\section{P. 311-312:}

Notas MA:

1. trecho destacado por traço vertical e expoente (1) remetendo ao comentário no rodapé;

“(1) Contra Romantismo, contra G. Dias, defenden-/do-se. Alvares de Azevedo, o mais romantico / dos nossos romanticos, não foi um romantico / de escola, como G. Dias e C. Alves mesmo."

Mentidos! Tudo isso lhes veio á mente, lendo as paginas de algum viajante que esqueceu-se talvez de contar que nos mangues e nas aguas do Amazonas e do Orenoco ha mais mosquitos e sezões do que inspiração, que na floresta ha insectos repulsivos, reptis immundos, que a pelle furta-côr do tigre não tem o perfume das flôres... que tudo isto é sublime nos livros, mas é soberanamente desagradavel na realidade!

2. trecho sublinhado e três cruzetas; 
3. trecho destacado por traço à direita e, na p. seguinte, cinco traços à esquerda e expoente (1) remetendo ao comentário no rodapé da p. 312 - seleção de ideias: reivindicação de liberdade formal:

“(1) Esplendido de razão e formidavel pra aquele tempo. Auto-defesa magistral e ardente contra... si mesmo! Porque Alvares de Azevedo era um temperamento critico, o mais critico do nosso Romantismo."

Se as fibras da harpa desafinão, se a mão rispida as estala, se a harpa destôa, é que elle não pensou nos versos quando pensava na poesia, é que elle cria e crê que a estancia é uma roupa como outra apenas, como o diz George Sand, a arte é um manto para as bellezas núas; é que elle preferira deixar uma estatua despida, a pespontar de ouro uma tunica de velludo para embuçar um manequim; é que elle pensa que a musica do verso é o acompanhamento da harmonia das idéas e ama cem vezes mais o Dante com sua versificação dura, os rasgos de Shakspeare com seus versos asperos, do que os alexandrinos feitos a compasso de SainteBeuve ou Turquety. (1)

Nota da pesquisa: A desidealização da natureza destacada por MA será citada integralmente na crônica de 6 de setembro de 1931: "E ele, tão instintivamente brasileiro que chega a botar 'uma viola monótona de sertanejo' em plena Itália, deixou ver inda mais tipicamente a sua aristocrática revolta contra a natureza, atacando os desertores dela: 'Mentidos! (...)"” (“Álvares de Azevedo - III”, in Táxi e Crônicas no Diário Nacional. ed. cit., 426).

P. 312:

Nota MA: trecho sublinhado e cruzeta - estudo do estilo/estudo linguístico: brasileirismo sintático:

\section{MACARIO}

$X \quad$ Crer? e no que? No Deus d'esses sacerdotes devassos?

Nota da pesquisa: MA também faz remissão a este trecho em nota de trabalho no dossiê do manuscrito Amor e medo (MA-MMA-05-30), elencando a construção sublinhada entre as marcas linguísticas de brasileirismo na obra de Álvares de Azevedo.

P. 313:

Nota MA: trecho sublinhado, duas cruzetas à direita, e juízo de valor, "Profundo".

A philosophia é vã. É uma crypta escura onde se esbarra na treva. As idéas do homem o fascinão, mas não o esclarecem. Na cerração do espirito elle estala o $\quad X X)$ craneo na loucura ou abysma-se no fatalismo ou no nada.

Nota da pesquisa: O editorial da Revista Nova menciona o trecho assinalado, reprisando o adjetivo na marginália: "E se o Macário chegava prematuramente àquela profunda afirmativa que 'as ideias do homem o fascinam mas não o esclarecem', o moço não pôde abandonar jamais as forças raríssimas de inteligência que possuía” (a. 1, n. 3, p. 314).

P. 314-316:

Notas MA: 
1. longo trecho destacado por traço vertical e expoente (1), ao fim, remetendo ao comentário no rodapé da p. 316 - estudo do estilo: prosa;

2. expressão sublinhada, "tua mãi", e cruzeta - estudo da psicologia: sentimento amoroso/ mãe:

\section{PENSEROSO}

Vê: o mundo é bello. A natureza estende nas noites estrellados o seu véo magico sobre a terra, e os encantos da creação fallão ao homem de poesia e de Deus. As noites, o sol, o luar, as flôres, o sorriso da infancia, até mesmo a agonia consolada e esperançosa do moribundo ungido que se volta para Deus... tudo isso será mentira? As esperanças espontaneas, as crenças que um olhar de virgem nos infiltra, as vibrações unanimes das fibras sensiveis serão uma irrisão? O amor de tua mãi, as lagrimas do teu amor... tudo isso não te acorda o coração? Serás como essas harpas abandonadas cujas cordas róe a humidade e a ferrugem e onde ninguem póde acordar uma harmonia? Porque estalárão? que dôr profunda as rebentou? Quando tu'alma ardente abria seus vôos para pairar sobre a vida cheia de amor, que vento de morte murchou-te na fronte a corôa das illusões, apagoute no coração o fanal do sentimento, e despio-te das azas da poesia? Alma de guerreiro, deu-te Deus porventura o corpo inteiriçado do paralytico? Coração de Romeo, tens o corpo do lazarento ou a fealdade de Quasimodo? Lyra cheia de musicas aspirosas, negou-te a creação cordas argentinas? Oh! não! abreu teu peito e ama. Tu nunca viste uma tua illusão gelar-se na fronte da amante morta, teu amor degenerar nos labios de uma adultera. Alma fervorosa, no orgulho de teu scepticismo não te suicides na atonia do desespero. A descrença é uma doença terrivel; destróe com seu bafo corrosivo o aço mais puro: é ella quem faz de Rembrandt um avarento, de Bocage um libertino!... Para os peitos rotos, desenganados nos seus affectos mais intimos, onde sepultão-se como cadaveres todas as crenças, para esses... aquillo que se dá a todos os sepulchros: uma lagrima! Aquelle que jogou sua vida como um perdulario, que eivou-se n'uma dôr secreta, que sentiu cuspirem-lhe nas faces sublimes... esses que rião como Democrito, duvidem como Pyrrhon, ou durmão indifferentes no seu escarneo como Diogenes - o cynico, no seu tonnel. A esses leva uma torrente profunda: revolvem-se na treva da descrença como Satan no infinito da perdição e do desespero! Mas nós, mas tu e eu, que somos moços, que sentimos o futuro nas aspirações ardentes do peito, que temos a fé na cabeça e a poesia nos labios, a nós o amor e a esperança, a nós o lago prateado da existencia. Embalemo-nos nas suas aguas azues, sonhemos, cantemos e creiamos! Se o poeta da perdição dos anjos nos conta o crime da creatura divina, liba-nos da despedida do Eden o beijo de amor que fez dos dous filhos da terra uma creatura, uma alma cheia de futuro... se na primeira pagina da historia da passagem do homem sobre a terra ha o cadaver de Abel e o ferrete de Caim - o anathema, n'aquellas tradições resôa o beijo de mãi de Eva pallida sobre os labios de seu filho!

Nota da pesquisa: MA faz referência a este trecho, em função da expressão sublinhada, em "Amor e medo": "Nas razões que Penseroso alega pra que "se acorde o coração de Macário' (III, 314), vêm fundidos o 'amor de tua mãe, as lágrimas do teu amor'.” (In: Aspectos da literatura brasileira, ed. cit., p. 221).

P. 316:

Notas MA:

1. trecho destacado por traço vertical, transcrito acima, e expoente (1) remetendo ao comentário no rodapé - estudo do estilo: prosa;

2. termo sublinhado, "fluctuoso", e cruzeta; estudo do estilo: vocabulário: 
“(1) Absolutamente admiravel até como / grandeza moral. Aqui o bestia academico / se apura, no estilo sem perder a sonoridade / de dicção, nem o seu balanço do ritmo søn / solene, se despe de ouropeis, de clangores falsos, / de palavreado, a idea se torna limpida, ni-/tida, tudo se equilibra. É uma pagina / magistral de prosa, das mais belas da /lingua."

Nota da pesquisa: A crônica de 30 de agosto, 1931, em trecho já citado, faz referência a esta fala de Penseroso. Nela, MA reitera o juízo crítico sobre o segundo episódio de Macário e observa: "E na oposição (que é da mais perfeitamente estética concepção teatral) entre pessimismo e confiança na vida, o confiante Penseroso tem aquele discurso: 'Vê: o mundo é belo'..., que ninguém se lembrou de perceber que é uma verdadeira página de antologia, até como elevação moral. Aí o béstia acadêmico se apura; sem perder a sonoridade de dicção nem o embalanço do ritmo, o estilo se despe de clangor falso, a ideia se torna límpida, nítida, tudo se equilibra." (“Álvares de Azevedo - II", in Táxi e Crônicas no Diário Nacional. ed. cit., p. 422).

P. 317:

Notas MA: trecho destacado por traço vertical e escólio "Amante dormida" - estudo da psicologia: sentimento amoroso:

Eu amei muito essa mulher. E por vel-a uma hora ao pé de mim, seminúa, embora fosse adormecida, só por vêla e por beijal-a de leve eu daria minha vida inteira ao nada.

Nota da pesquisa: A imagem da "amada dormida", segundo o crítico, é "toda a obra de Álvares de Azevedo, tão abundantemente frequenta qualquer criação dele". Depois de elencar à exaustão as ocorrências na poesia, MA cita o trecho em destaque: "Macário (III, 317) quer vê-la e beijá-la de leve, embora fosse adormecida!" ("Amor e medo", In: Aspectos da literatura brasileira, ed. cit., p. 227).

P. 318:

Notas MA:

1. trecho sublinhado e cruzeta - seleção de ideias: pessimismo;

MACARIO.

(...) Adeus, Penseroso. Ai d'aquelle a quem um verme roeu a flôr da vida, como a Werther! A descrença é a filha engeitada do desespero.

2. trecho sublinhado e cruzeta - estudo do estilo: brasileirismo sintático:

PENSEROSO, SÓ, escreve.

$X \quad$ Não escreverei mais: não. Calarei o meu segredo e morrerei com elle.

Notas da pesquisa:

1. O editorial da Revista Nova remete ao trecho assinalado ao louvar a "clarividência ás vezes notável" das observações de Álvares de Azevedo, como no caso de seus comentários "sobre a descrença (III, 318)" (a. 1, n. 3, p. 313).

2. A expressão "Não escreverei mais: não" indicia o achado de marcas sintáticas brasileiras na prosa de Álvares de Azevedo, conforme nota de trabalho no dossiê do 
manuscrito Amor e medo: “"Eu não rio-me não.' I - 311, III, 291; III, 318” (MA-MMA05-30; sublinhei).

P. 319:

Notas MA:

1. termo sublinhado, "casuarina", e cruzeta - estudo do estilo: vocabulário;

2. trecho destacado por traço vertical e correção tipográfica em "oração", com o acréscimo do til - estudo da psicologia: mãe e avó:

Eis-ahi o veneno. Ó minha terra! ó minha mãi! mais nunca te verei! Meu pai, meu santo pai! e tu, mãi de minha mãi que sentias por mim, cuja vida era uma oraçao la por mim, que enxugavas tuas lagrimas nos teus cabellos brancos pensando no teu pobre neto! adeus! Perdão! perdão!

Nota da pesquisa: MA registra o trecho destacado em nota de trabalho no dossiê do manuscrito Amor e medo, sob a rubrica "Mãi e Avó" (MA-MMA-05-29). No ensaio, o crítico observa: "Por tudo isso percebe-se que o amor pela mãe era, si não anormal, pelo menos absolutamente excessivo e obsecante em Álvares de Azevedo. É o seu delírio, a sua maior elevação consciente, o seu maior gozo inconsciente, a razão mais importante da sua inexperiente rapazice. É curioso mesmo notar que chama a avó de 'mãe de minha mãe' (III, 319), demonstrando bem que o que predomina nele é o amor pela mãe." ("Amor e medo", In: Aspectos da literatura brasileira, ed. cit., p. 221).

\section{P. 320:}

Nota MA:

1. trecho sublinhado - seleção de ideias: predestinação;

2. termo sublinhado, "socia" - estudo do estilo: vocabulário:

Se ha um homem que crêsse no futuro, fui eu. Tive confiança no orgulho de meu coração e no genio que sentia na minha cabeça. Eu sinto-o!... Deus me fez poeta. Esse mundo, a natureza, as montanhas, o effluvio luminoso das noites de luar, tudo isso me acordava vibrações, me revelava no peito cordas que nunca escutei senão nos poetas divinos, que nunca senti no peito cavernoso e vazio dos outros homens. Sou rico, moço, morrerei pouco mais velho que o desgraçado Chatterton! E por todo o meu futuro, minhas glorias, toda essa ambição immensa, essa sêde fogosa de um'alma que não se socia com os prazeres de convenção da vida sumptuosa dos palacios esplendidos e das acclamações da fama, eu só queria seu peito junto do meu... sua mão na minha. $\mathrm{O}$ andrajo do miseravel não me doeria se eu tivesse o manto de ouro do seu amor.

Nota da pesquisa: MA refere-se ao neologismo de Álvares de Azevedo em seu infinitivo hipotético, "Sociar-se", em nota de trabalho no dossiê do manuscrito Amor e medo (MAMMA-05-30). O termo sugere a incorporação do francês "se soucier", mantida, no entanto, a regência do equivalente luso-brasileiro, "preocupar-se".

P. 321:

Notas MA: comentário crítico:

“(1) O que principalmente se nota na tristeza justifi-/cavel dos nossos romanticos é um desejo puramente des-/perdiçado de amar o amor mais do que amar a / vida em si. E 
naturalmente um amor ideal. Uma / raiva amatoria mal empregada, tão! desconhecendo in-/teiramente os direitos, a necessidade, a realidade, a / própria vitalidade da vida. Dizer que angustiosa monstruosi-/dade da nossa natureza nos faz tristes eque não basta pra justifi-/car a tristeza dos nossos romanticos. Pelo contrario, embora essa mons/truosidade pudesse atuar inconscientemente, os romanticos sobrepujaram / facilmente esse efeito pela ilusão sentimental e pelo entusiasmo / com que viram o Brasil com a aparencia voluptuosa dum Eldorado / benfeitor. Só Alvares não o viu assim. Os nossos romanticos com a excep-/ção de G. Dias, o proprio Castro Alves foram insensiveis á natureza. E no pro-/prio G. Dias si pela persistencia com que a natureza penetra-lhe a obra se per-/cebe que amou e gosou a natureza, quan-/do a vê como patria a intelectualiza e / quando a vê como universo a beneficia / e a varre, a lava, a seca e a beneficia/segundo os mais idealistas processos ro-/manticos para lhe dar milhor cheiro, / milhor cor e milhor corpo pra que possa atingir / bom tipo e boa classificação no mercado romanti-/co. A tristeza dos nossos romanticos si viesse do fundo / tradicional da terra e do homem apenas seria com-/pensada pelo entusiasmo e pela visão cega. A gran-/de tristeza deles foi devido ao total desprezo da vida, ao / esquecimento da vida, trocada totalmente pela ma-/nia de ideal á força e principalmente do amor. Amadores de <termos ilegíveis> rimaram-na necessariamente com vertigem. Vertigem / de forças, de coragem e de visão larga. Os mais animosos procuraram / ainda evitar essa vertigem e saldar a desilusão. Alvares de Azevedo quis / esquecer-se na saturnal e encontrou tedio. Castro Alves quis esquecer-/se no trabalho social e fez bulha e muita bulha. Os outros dois grandes / foram incapazes de realizar dentro da vida. Casimiro medroso caiu no / saudosismo mais pifio embora admiravelmente caracteristico. G. Dias / direi pelo metodo psicanalista que sublimou o amor de amar, amar / a mulher <restante da frase ilegível pelo corte da página $>$ maior sinão unico do grupo e verda-/deiro e integral Poeta. Porque os outros / foram liricos mais que poetas e Cas-/tro Alves na grande maioria das / obras mais artífice e virtuose que / poeta."

Nota da pesquisa: MA faz menção a este comentário no fichamento crítico onde planeja o livro Lirismo romântico no Brasil: "O sentimentalismo amoroso [antepágina A.A. I; $\underline{\mathrm{A}}$ de A III, 321; 329] do brasileiro, gente sincera, gente dada, hospitaleira, levando tudo a sério, grafada pelo romantismo. Só Alvares de Azevedo é irônico e é sarcástico e desabusado, sobretudo sarcástico que é traço individual, o brasileiro é irônico também por timidez ou desconfiança" (MA-MMA-26-04; sublinhei).

\section{P. 322:}

Notas MA:

1. termos sublinhados, "tom" e "estrella", e escólio "dic" - pesquisa para o Dicionário musical brasileiro;

2. trecho sublinhado, "o amor é o ouro dos rochedos", e expoente (1) remetendo ao comentário no rodapé;

Nos crepusculos de verão eu a levaria pelas montanhas a embriagar-se de vida, nos aromas da terra palpitante, pelos valles ainda humidos de orvalho e ao tom das aguas sem pensar na vida, pensando só que o amor é o ouro dos rochedos brancos da existencia, (1) a estrella dos céos mysteriosos, a palavra sacramental e magica que rompe as cavernas do infinito e da ventura!

“(1) Que coisa esquisita, puxa! Alvares de Aze-/vedo é de todos os nossos romanticos aliás o que / menos compreendeu e amou a natureza, uma / incompreensão quasi que total." 
3. comentário ligado por um fio ao término das "Páginas de Penseroso":

"É boa a antitese entre Penseroso um cheio / de ilusões e esperanças e Macario moço tam-/bem porém desiludido, sem esperanças, / o cinico. Toda esta fala é fatigante de / banalidade porém embala e é mesmo tris-/te.

"Desde que Penseroso aparece A. Azevedo dá / largas ao instinto oratorio dele. Até Macario vi-/ra declamador brasileiro: coisas vazias em ge-/ral, porem cheias de traços de espirito e boniteza / oratoria."

Notas da pesquisa:

1. Em nota de trabalho, no dossiê do manuscrito Amor e medo, MA considera: "O primeiro episódio do Macario é formidável, uma obra-prima. O segundo já vira discurso brasileiro, muito vazio, muita oratoria banal" (MA-MMA-05-25).

2. Na crônica de 30 de agosto, 1931, reitera o juízo crítico: "O segundo episódio do Macário tem essa oratória sem essas belezas e curiosidades. Mas está continuadamente bordado de observações finas e até profundas. E na oposição (que é da mais perfeitamente estética concepção teatral) entre pessimismo e confiança na vida" ("Álvares de Azevedo - II”, in Táxi e Crônicas no Diário Nacional. ed. cit., p. 422).

P. 327:

Notas MA:

1. trecho destacado por traço vertical, escólio "Mãi”;

Este cordão de cabellos quero que seja entregue a ella: são cabellos de minha mãi... de minha mãi que morreu. Trouxe-os sempre no meu peito. Quero que ella $M \tilde{a} i$ os beije ás vezes e lembre-se de mim.

2. expoente (1) ao final da fala de Penseroso, remetendo ao comentário no rodapé - estudo da psicologia: sentimento amoroso:

“(1) Mas porquê toda esta encrenca de Penseroso si / ela o ama! Que pandega! Mas é o eterno Amor e Medo / dos romanticos, na sua multipla manifestação e que / devastou a alegria romantica."

Ah! que dôres horriveis! tenho fogo no estomago... Minha cabeça se suffoca... Ar! ar! preciso de ar? Eu te amei, eu te amei tanto!... (1)

Notas da pesquisa:

1. MA remete a esta página no fichamento crítico para o livro Lirismo romântico no Brasil, sob a rubrica "Psicologia do Romantismo Brasileiro / Tema "Amor e Medo", (MA-MMA-26-04). O ensaio aproveita a nota de margem, ao tratar a constância do amor não realizado em Álvares de Azevedo: "Muito expressivo disso é aquele passo francamente extravagante, pra não dizer amalucado, do Macário, em que Penseroso faz uma gritaria danada porque a Italiana não o ama, quando ela está falando que ama sim, Mas é sempre o estragoso amor e medo que faz a personagem fugir do amor... - Te amo, Penseroso! - Qual! não me amas não! Penseroso prefere amar sozinho, que não tem perigo nem fantasmas de derrotas ou precariedades de qualquer espécie. Era o aspecto mais lamentável do amor, porém menos doloroso prás dúvidas e hesitações do rapaz." ("Amor e medo", in Aspectos da literatura brasileira, ed. cit., p. 223).

2. O trecho destacado, sobre a mecha de cabelos maternos guardada por Penseroso, enseja referência no dossiê do manuscrito Amor e medo (MA-MMA-05-29). 


\section{P. 329:}

Nota MA: trecho sublinhado, "realisem na tua fronte os sonhos de seu hysterismo", e expoente (1) - estudo da psicologia: seleção de ideias sobre o sentimento amoroso, planejando o livro Lirismo romântico no Brasil:

“(1) Citar esta frase quando no livro fizer a digressão sobre o amar do amor nos romanticos e cuja sintese está na pagina 321 , deste."

Nota da pesquisa: MA elenca esta página ao comentar o sentimentalismo amoroso do brasileiro, no fichamento crítico para o livro Lirismo romântico no Brasil (MA-MMA26-04).

\section{$\underline{\text { P. } 331-415}$}

\section{NOITE NA TAVERNA}

\section{P. 331-336}

I - UMA NOITE DO SECULO

P. 332:

Notas MA:

1. escólio identificando as personagens por suas iniciais, "J" e "B", à esquerda das falas;

2. termo corrigido, "vapore a", substituído por "vapores de" - correção tipográfica.

P. 333:

Notas MA: trecho sublinhado e comentário:

A taverneira ahi nos trouxe mais vinho: uma saude! O fumo é a imagem do idéalismo, é o transumpto de tudo quanto ha mais vaporoso n'aquelle espiritualismo que nos falla da immortalidade da alma! e pois, ao fumo das Antilhas, á imortalidade da alma! "esta mistura é genial e digna de Rimbaud"

P. 334:

Nota MA: preposição corrigida, “dos”, substituída por “das” - correção tipográfica.

Nota da pesquisa: Embora livre de marcas de leitura, esta página é referida pelo editorial da Revista Nova (a. 1, n. 3), que assinala a metempsicose como exemplo das "especulações doutrinárias, sem nenhuma espécie de didatismo" de Álvares de Azevedo, "sobretudo a metempsicose pregada por Solfieri (III, 334) e aceita na Gloria Moribunda".

P. 336:

Nota MA: comentários:

"O que é mais estupendo nesta pagina / é o sopro nitido quente de bebedeira / que perpassa nela. A. Azevedo te-/la-ia escrito completamente na-chu-/va? É a melhor pagina bebeda que / conheço. É perfeita.

“Este primeiro cap. é simplesmente / colossal. É um trecho classico de lin-/gua, da mais pura linguagem, do mais / elevado romantismo. Que ritmo formi-/davel dentro dum 
colorido discreto em / que a palavra não é tomada pelo valor / sonoro da palavra e nem a frase é rema-/tada por boniteza de cadencia á moda / portuga. É uma eloquencia ardorosa e / intima da mais alta perfeição / e beleza. Comparavel a Rimbaud / e a Lautreamont. Fazer uma com-/paração do tom alucinatorio nos / tres. A superioridade realistica de / Alvares de Azevedo. Notar a que / essencia romantica refinadissi-/ma atinge aqui o poeta brasileiro. / Observar-lhe a filosofia e salienta-lo / como unico entre os nossos que se preocu-/pou com ela. Seguindo nisso a tradição / da escola mineira erudita. E tinha / só 20 anos!..."

Nota da pesquisa: A comparação entre Álvares de Azevedo e os dois autores de expressão francesa reaparece em nota de trabalho, no dossiê do manuscrito Amor e medo: "Realmente A. de A. embora falto da imaginação criadora dum Rimbaud, dum Lautréamont especialmente, embora cheio de reflexões às vezes inteligentes, e de ditosde-espírito admiráveis, tinha na sua prosa uma irreflexão, um fantasioso que não era apenas de moço mas de gênio. Ou de maluco, si quiserem. Basta pra isso aproximar a prosa dele daquela charra, chã e bem pensante de Gonçalves Dias. [...] A. A. é besta e béstia mas vagueia pelas grimpas." (MA-MMA-05-23).

No aproximar genialidade e loucura, MA retoma ideias do livro Poésie et folie, de autoria dos psiquiatras franceses Antheaume e Dromard (Paris: Octave Doin, 1908). O exemplar pertencente ao escritor é ricamente anotado. Já nos parágrafos iniciais da obra, MA escreve em francês a questão que lhe serve de escólio: "Le génie est un fou?" (Nota

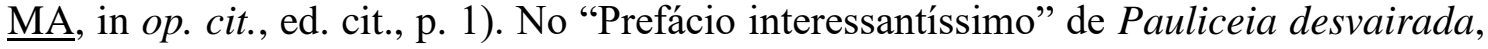
o autor diferencia-se do profeta Maomé, afirmando: "julguei mais conveniente apresentar-me como louco" (ANDRADE, Mário de. "Prefácio interessantíssimo", in Poesias completas. ed. cit., p. 60). Conforme se verá no trecho assinalado à p. 359 deste volume, Álvares de Azevedo caracteriza a miséria e a loucura do poeta Werner, em Noite na taverna.

P. 337-343

II - SOLFIERI

P. 337:

Notas MA:

1. comentários na margem superior, já transcritos;

2. trecho sublinhado destacado por traço vertical - estudo do estilo: prosa;

Era em Roma. Uma noite a lua ia bella, como vai ella no verão por aquelle céo morno, o fresco das aguas se exhalava como um suspiro do leito do Tibre.

3. trecho sublinhado - estudo do estilo: prosa:

A face d'aquella mulher era como de uma estatua pallida á lua. Pelas faces d'ella, como gottas de uma taça cahida, rolavão fios de lagrimas.

P. 338:

Nota MA: termo sublinhado, "nenia”, e escólio “dic”; pesquisa para o Dicionário musical brasileiro.

dic aquella voz era sombria como a do vento á noite nos cemiterios, cantando a nenia das flôres murchas da morte. 
P. 339:

Notas MA: trecho sublinhado - estudo da psicologia: sentimento amoroso:

Uma noite, e após uma orgia, eu deixára dormida no leito d'ella a condessa Barbora. Dei um ultimo olhar áquella fórma núa e adormecida com a febre nas faces e a lascivia nos labios humidos, gemendo ainda nos sonhos, como na agonia voluptuosa do amor. Sahi.

Nota da pesquisa: Desdobrando a análise acerca da "amada dormida", MA escreve: "De fato Solfieri (que aliás já deixou a condessa Barbora adormecida!...) quando rouba o cadáver da igreja e quer saciar-se nele, na verdade está possuindo uma bela adormecida, pois que a moça fôra apenas tomada dum sono cataléptico" ("Amor e medo". In: Aspectos da literatura brasileira. ed. cit., p. 227). MA considera esta página uma exceção à "falta de objetividade" das frases de Álvares de Azevedo sobre o amor: "O amor sexual the repugnava, e pelas obras que deixou é difícil reconhecer que tivesse experiência dele. Raríssimas passagens, uma no romance inédito $O$ Livro de Fra Gondicario, aquela nítida expressão de Solfieri (Obras, Garnier, $7^{a}$ ed., vol. III, p. 339), e poucas mais, escapam da falta de objetividade das suas frases sobre o amor. De resto, mesmo estas poderiam ser explicadas por experiência de leitura, ou solitária, ou pura intuição de artista." (op. cit., p. 202).

$\underline{\text { P. 344-365 }}$

III - BERTRAM

P. 344:

Notas MA: preposição corrigida, "a", pelo acréscimo do acento indicativo de crase correção tipográfica.

P. 348:

Nota MA: termo sublinhado, "atirava", e cruzeta - estudo do estilo: vocabulário:

Bebia já como uma Ingleza, fumava como uma Sultana, montava a cavallo

$X$ como um Arabe e atirava as armas como um Hespanhol.

P. 352:

Notas MA:

1. termo sublinhado, "fandango", e escólio "dic"; pesquisa para o Dicionário musical brasileiro;

2. termo corrigido, "ralento", substituído por "relento"; correção tipográfica.

dic ou dançando o fandango lascivo nos bailes ao ralento!

le

P. 355:

Nota MA: termo corrigido, "moder", substituído por "morder”; correção tipográfica.

P. 356:

Notas MA: trecho sublinhado - seleção de ideias: metafísica: 
Era um Oceano como aquelle de fogo, onde cahirão os anjos perdidos de Milton - o cego, quando elles passavão cortando-as a nado as aguas do pantano de lava se apertavão: a morte era para os filhos de Deus, não para o bastardo do mal!

P. 359:

Nota MA: trecho destacado por traço vertical duplo; seleção de ideias:

Não bradastes - miséria e loucura! - vós, almas onde talvez borbulhava o sopro de Deos, cérebros que a luz divina do gênio esclarecia, e que o vinho enchia de vapores, e a saciedade de escarneos? Enchei as taças até á borda! enchei-as e bebei; bebei á lembrança do cérebro que ardeu nesse craneo, da alma que ahi habitou, do poeta - louco - Werner! e eu bradarei ainda uma vez: - miséria e loucura!

P. 360:

Nota MA: trecho destacado por traço vertical duplo - seleção de ideias:

Na verdade, senhores, o homem é uma creatura perfeita' Estatuario sublime, Deos esgotou no talhar desse mármore todo o seu esmero. Prometa divino encheu-lhe o craneo protuberante da luz do gênio. Ergueu-o pela mão, mostrou the o mundo do alto da montanha, como Satan quatro séculos depois o fez a Christo, e disselhe: Vê; tudo isso é bello - valles e montes, águas do mar que espumão, folhas das florestas que tremem e susurrão como as azas dos meus anjos-tudo isso e teu. Fiz-te o mundo bello no véo purpureo do crepúsculo, dourei-t'o aos raios de minha face. Ei-lo, rei da terra! banha a fronte olympica nessas brisas, nesse orvalho, na escuma dessas cataractas. Sonha como a noite, canfa como os anjos, dorme entre as flores! Olha! entre as folhas floridas do valle dorme uma creatura branca como o véo das minhas virgens, loura como o reflexo das minhas nuvens, harmoniosa como as aragens do céo nos arvoredos da terra. - É tua: acorda-a : ama-a, e elle te amará; no seio delia, nas ondas daquelle cabello, afoga-te como o sol entre vapores. Rei no peito delia, rei na terra, vive de amor e crença, de poesia e de belleza, levanta-te, vai e serás feliz!

P. 361:

Nota MA: trecho sublinhado - estudo do estilo: metáfora:

Isso tudo, senhores, para dizer-vos uma cousa muito simples... um facto velho e batido, uma pratica do mar, uma lei do naufragio - a anthropophagia.

P. 362:

Nota MA: trecho destacado por traço vertical - seleção de ideias:

Oh! a esperança é pois como uma parasita que morde e despedaça o tronco, mas quando elle cahe, quando morre e apodrece, ainda o aperta em seus convulsos braços!

P. 364:

Notas MA:

1. termo sublinhado, "entuviada", cruzeta e interrogação; estudo do estilo: vocabulário: 
$X$ ? $\quad$ As gargalhadas frias vinhão mais de entuviada...

2. trecho destacado por traço vertical - estudo do estilo: prosa:

Não sei que delirio estranho se apoderou de mim. Uma vertigem me rodeava. O mar parecia rir de mim e rodava em torno, escumante e esverdeado, como um sorvedouro. As nuvens pairavão correndo e parecião filtrar sangue negro. $\mathrm{O}$ vento que me passava nos cabellos murmurava uma lembrança...

De repente sentim-me só. Uma onda me arrebatára o cadaver. Eu o vi boiar pallido como suas roupas brancas, semi-nú, com os cabellos banhados de agua; eu vi-o erguer-se na escuma das vagas, desapparecer e boiar de novo; depois não o distingui mais: - era como a escuma das vagas, como um lençol lançado nas aguas...

Quantas horas, quantos dias passei n'aquella modorra, nem o sei... Quando acordei d'esse pesadelo de homem desperto, estava a bordo de um navio.

Era o brigue inglez Swallow, que me salvára...

Olá, taverneira, bastarda de Satan! não vês que tenho sêde e as garrafas estão seccas, seccas como tua face e como nossas gargantas?

P. 366-377

IV - GENNARO

P. 366:

Notas MA:

1. termo corrigido, "outono", pela aproximação das sílabas; correção tipográfica;

2. comentário na margem superior:

"As visões ingenuamente terriveis da Noi-/te na Taverna, dum necrofilismo exagerado, I sem transcendencia, absurdo, um necro-/filismo de vinte-anos mocinhos. Exaspera-/do pela idade inda mais que pelo Roman-/tismo, A. de Azevedo inda cria que o amor / no meio de mortes, de sangueira e até / antropofagia é mais comovente e mais / medonho que simplesmente o amor. I Me parece que ninguem como A. de A. so-/freu do mal-democidade. A mocida-/de é o maior defeito da obra dele."

\section{P. 368: $\underline{\text { S/Notas MA }}$}

Nota da pesquisa: Em "Amor e medo", ressaltando a recorrência do sono e do dormir na obra de Álvares de Azevedo, MA faz menção a Gennaro, surpreendido por Laura enquanto ainda dorme: "Gennaro (III, 396), tem coragem de profanar Laura porque, acordando do sono, a encontra na cama dele" (“Amor e medo", In: Aspectos da literatura brasileira, ed. cit., p. 224). A indicação de página (III, 396) está incorreta em todas as versões publicadas.

P. 371:

Nota MA: termo corrigido, "maitre", substituído por "tremia"; correção tipográfica.

P. 376:

Nota MA: trecho destacado por traço vertical e cruzeta - seleção de ideias: aristocracia e escravidão.

$X \quad \begin{aligned} & \text { Ao ver-me salvo assim d'aquella morte horrivel, póde ser que se apiedasse de } \\ & \text { mim, que me perdoasse; e então eu seria seu escravo, seu cão, tudo o que }\end{aligned}$ 
houvesse mais abjecto n'um homem que se humilha - tudo! - com tanto que elle me perdoasse.

Notas da pesquisa:

1. MA remete a este trecho em nota de trabalho no dossiê do manuscrito Artigos por escrever, onde compila observações sobre o caráter aristocrático de Álvares de Azevedo: “A. de A. Aristocracia // A escravidão pra ele, única referência a ela III, 376 // E ainda p 393 'serei vosso escravo e vosso cão"” (MA-MMA-11-06).

2. A crônica de 22 de março de 1931 faz uso da nota preparatória: "O negro pra ele é apenas um animal desprezado, o escravo e o cachorro, andam sempre unidos na obra dele" (“Álvares de Azevedo - I”, in: Táxi e Crônicas no Diário Nacional. ed. cit., p. 357). 3. Também a crônica de 6 de setembro de 1931 cita esta passagem: "O escravo pra ele só serve pra fazer imagem. E nessa imagem se associa ao cachorro. Por duas vezes na Noite na Taverna, aparece a associação. Hermann diz que 'serei vosso escravo e vosso cão'; e Gennaro, inda melhormente dá o conceito de baixeza e que Álvares de Azevedo funde no de escravo" [reproduz-se o trecho assinalado na marginália] ("Álvares de Azevedo - III", in: Táxi e Crônicas no Diário Nacional. ed. cit., p. 425).

P. 377:

Notas MA: trecho sublinhado e expoente (1) remetendo ao comentário - estudo do estilo: prosa:

Eu o vi: - da bocca lhe corria uma escuma esverdeada. (1)

“(1) O artistico desta frase.”

P. 378-401

V-CLAUDIUS HERMANN

P. 378:

Nota MA: comentário na margem superior:

"A pavorosa sucessão de contos necrofilos da Noite na Taverna”

P. 379:

Nota MA: termo sublinhado, "sobreague", e cruzeta; estudo do estilo: vocabulário.

sobreague n'aquelle não-ser o effluvio de alguma lembrança pura! $\quad X$

P. 381:

Notas MA: trecho destacado por traço vertical e escólio, "Poesia" - seleção de ideias: poesia.

- Meio cento de palavras sonoras e vans que um pugilo de homens pallidos entende, uma escada de sons e harmonias que áquellas almas loucas parecem déas e lhes despertão illusões omo a lua as sombras...

Nota da pesquisa: O editorial da Revista Nova refere-se a esta página entre os "estudos críticos e preocupações de estética" de Álvares de Azevedo, exemplo de que sua 
“preocupação da inteligência, das explicações filosóficas da vida, é constante" (a. 1, n. 3, p. 313).

P. 382:

Nota MA: trecho sublinhado e escólio "Poesia" - seleção de ideias.

$$
\begin{array}{ll}
\text { e tudo isso é inanido e vazio como uma caveira secca, mentiroso como os vapores } \\
\text { Poesia } & \text { infectos da terra que o sol no crepusculo iría de mil côres e que se chamão as } \\
\text { nuvens, ou essa fada zombadora e nevoenta que se chama a poesia! }
\end{array}
$$

P. 386:

Nota MA: preposição corrigida, “per”, substituída por “por” - correção tipográfica.

P. 392:

Nota MA: termo sublinhado, "harmonia", e escólio "dic" à direita; pesquisa para o Dicionário musical brasileiro.

"dic" No theatro, entre o arfar das ondas da harmonia

\section{P. 393: S/Notas MA}

Nota da pesquisa: Esta página, livre de notas de margem, é referida em nota de trabalho, no dossiê do manuscrito Artigos por escrever; liga-se ao suposto espírito aristocrático de Álvares de Azevedo (MA-MMA-11-6). É provável que a remissão se deva à passagem em que Claudius Hermann, pedindo compaixão a Eleonora, oferece-se como escravo: "Perdoai-me, senhora, aqui me tendes a vossos pés! tende pena de mim, que eu soffri muito, que amei-vos, que vos amo muito! Compaixão! que serei vosso escravo, beijarei vossas plantas..."

P. 394:

Notas MA: trecho destacado por traço vertical - seleção de ideias:

a elle, poeta e amente! da corôa de illusões as flôres uma per uma, que pela noite da desgraça amor insano de mãi consentiria que lhe suffocassem sobre o seio a creatura de seu sangue, o filho de sua vida, a esperança de suas esperanças?

Nota da pesquisa: $\mathrm{O}$ trecho em destaque é aludido em nota de trabalho no dossiê Amor e medo, sob a rubrica "Mãi e Avó" (MA-MMA-05-29), e também no ensaio para a Revista Nova: "A proteção que a mãe concede aos filhos inda fracos de vida, vem na Noite na taverna, 'que pela noite da desgraça amor insano de mãe consentiria que lhe sufocassem sobre o seio a criatura do seu sangue, o filho da sua vida, a esperança das suas esperanças?” (“Amor e medo", In: Aspectos da literatura brasileira, ed. cit., p. 222).

P. 396:

Notas MA: trecho sublinhado - estudo do estilo: metáfora/estudo da psicologia: sentimento amoroso:

E aqui, Eleonoroa, aqui terás meu peito e meu amor, uma vida só para ti, um homem que só pensará em ti e sonhará sempre comtigo, um homem cujo mundo serás tu, serão teus risos, teus olhares, teus amores, que se esquecerá de hontem e de amanhã para fazer, como um Deus, de ti a sua Eternidade. 
P. 397:

Notas MA: termo sublinhado, “c'rôas", e cruzeta - estudo do estilo: licenças poéticas do romantismo:

Murchei no escarnio as c'rôas do poeta, $\quad X$

P. 398:

Notas MA:

1. termo sublinhado, "c'rôa", e cruzeta - estudo do estilo/estudo linguístico: licenças poéticas do romantismo;

2. verso sublinhado; estudo do estilo: versificação/métrica:

$X \quad$ Lancei eu proprio ao mar da c'rôa as folhas, Troquei a rosea tunica da infancia

Pelo manto das orgias

Nota da pesquisa: Verso indicado sob a rubrica "Modo de contar sílabas", no fichamento crítico com vistas ao livro Lirismo romântico no Brasil (MA-MMA-26-04).

P. 399:

Nota MA: termo sublinhado, "Lavarei-me", e cruzeta - estudo do estilo: brasileirismo pronominal:

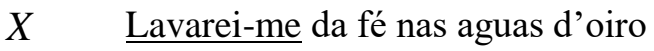

P. 400:

Nota MA: termo sublinhado, "alembro", e cruzeta - estudo do estilo: vocabulário:

$X \quad$ - A Duqueza... é verdade! Mas como esqueci tudo isso que não me alembro!....

P. 401:

Nota MA: trecho sublinhado e expoente (1) remetendo ao comentário no rodapé - estudo do estilo: sarcasmo:

Dormia pesado e fundo como o apostolo S. Pedro no Horto das Oliveiras... O caso é que ambos tinhão ceado á noite...

“(1) Tem profunda pincelada duma ironia satanica que nem esta.”

P. 402-409

VI - JOHANN

P. 402:

Nota MA: comentário na margem superior:

"Realmente como estilo e como cria-/ção só mesmo o $1^{o}$ capitulo da Noite / na Taverna é que é uma perfeição."

P. 406:

Notas MA: 
1. trecho sublinhado e expoente (1) remetendo ao comentário - estudo da psicologia: sentimento amoroso ligado a mãe e irmã:

Ajoelhou-se. Á vista d'aquelle moço de joelhos - talvez sobre um tumulo lembrei-me que eu tambem tinha mãi e uma irmã... e que eu as esquecia.

\section{“(1) Tambem aqui mãi e irmã.”}

Nota da pesquisa: MA elenca diversas menções a mãe e irmã na obra de Álvares de Azevedo, em nota de trabalho no dossiê do manuscrito Amor e medo. Os itens rasurados acusam o aproveitamento da lista (MA-MMA-05-29). Também no ensaio há remissão a esta página, como prova de que o escritor romântico "ajunta mãe e irmã por várias vezes ainda" (“Amor e medo", In: Aspectos da literatura brasileira, ed. cit., p. 222).

P. 407:

Notas MA: termo corrigido, "Podre", substituído por "Pobre" - correção tipográfica.

P. 409:

Nota MA: comentário no rodapé: "Este conto é perfeitamente narrado."

P. 410-415

VII - ÚLTIMO BEIJO DE AMOR

\section{P. 413: S/ Notas MA}

Nota da pesquisa: Sustentando que "o sono é a mais original invenção do lirismo" do escritor romântico, MA refere-se ao último conto de Noite na taverna: "Arnold (III, 413), numa trapalhada que é preciso ler, pra se observar bem o quanto os sentimentos naturais de Álvares de Azevedo se sobrepunham ao que ele inventava apenas com a inteligência, pedindo pra Giorgia que lhe sente nos joelhos, que deite a cabeça no ombro dele, o que quer é passar uma hora no seio dela, derramar lágrimas no colo dela, e confessar-se, fazer confidências, contar como profanou a alma e o passado, contar filialmente ou fraternalmente tudo. Mais que o prazer ativo do amor, o que Álvares de Azevedo aspira é dormir, mas dormir de verdade, passivamente, no seio da amante. Dormir de verdade e até morrer, como na nota, atrás, em que Macário fala em morrer de amor." ("Amor e medo", In: Aspectos da literatura brasileira, ed. cit., p. 224).

P. 415:

Nota MA: comentário ao final:

"Uma tendencia aqui pronunciada / pro diabolico asqueroso. Porque só / assim Alvares de Azevedo ainda sen-/tia vibrar o seu tedio continuo / inenarravel, o maior tedio que jamais / se viu em artista de lingua portu-/guesa. // Romantismo alemão da mais des/bragada desenvoltura."

Nota da pesquisa: Apontando a insistência do amor fraternal na obra de Álvares de Azevedo, MA observa a propósito deste conto: “Também a irmã o preocupou muito. No último conto da Noite na taverna, admirável de urdidura romântica, o caso se passa entre irmãos: a irmã profanada pelo irmão, que ainda mata por isso outro irmão; de tudo ressaltando muito bem, e com violenta sensualidade, a esplendidez do ente irmã." ("Amor e medo", In: Aspectos da literatura brasileira, ed. cit., p. 222). 


\section{FOLHA DE GUARDA}

Notas MA:

1. anotação no alto, à direita, " $N^{\circ} 192$ ", referindo-se à inclusão do volume na Bibliografia para Na pancada do ganzá;

2. lista de verbetes para o Dicionário musical brasileiro e cruzeta indicando o aproveitamento:

Dic - adufe III - descantar IV - plectro IX - ouvertura 21 - / harmonia 39 - soído 39 Brinde 47 - treno 53 - Variaçôes 73-1 soúdo-90-contradança 109 - estrondar 121 -"

Notas da pesquisa:

1. O no 192 sinaliza a inclusão das Obras completas de L. N. Fagundes Varella na Bibliografia para Na pancada do ganzá, conjunto de 837 títulos arrolados por MA para apoiar a organização de seu vasto projeto sobre o folclore brasileiro. Os títulos da poesia dos autores românticos focalizados em seu ensaio "Amor e medo" fazem parte da lista bibliográfica.

2. O escólio "dic", a grafite, de ocorrência farta na marginália, nos títulos da poesia do romantismo brasileiro, indica a pesquisa de elementos para abonar verbetes no Dicionário musical brasileiro, projeto do escritor testemunhado em sua biblioteca, no manuscrito desse título e de outros, em seu arquivo e, na edição póstuma coordenada por Oneyda Alvarenga e Flávia Camargo Toni (Brasília: Ministério da Cultura/São Paulo: IEB-USP Edusp/ Belo Horizonte: Editora Itatiaia Ltda, 1989).

\section{PREFÁCIO}

\section{P. III:}

Nota MA: termo sublinhado, "adufe", e escólio "dic" - pesquisa para o Dicionário musical brasileiro:

"dic" - onde de um lado do quadro dança a ligeira e suave Zingara com os crespos soltos nos hombros morenos, batendo o seu adufe,

P. IV:

Nota MA: termo sublinhado, "descantar", e escólio "dic” - pesquisa para o Dicionário musical brasileiro:

“dic" como uma serpente junto da mangueira onde descantão as aves, 
P. IX:

Nota MA: termo sublinhado, "plectro", e escólio "dic" - pesquisa para o Dicionário musical brasileiro:

"dic" dessa lyra que deixára as entesadas cordas metallicas dos tempos épicos para nos soltos nervos, no acompanhamento das flautas lydias e dos plectros cretenses,

P. XII:

Nota MA: trecho sublinhado e cruzeta - estudo do estilo: digressão:

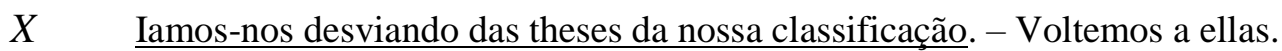

P. XIV:

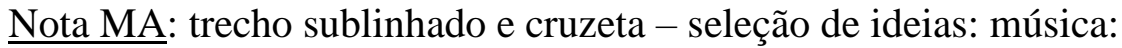

ou nesses matizes dos crepusculos de outomno e verão, e os sons são mais doces ao ouvido quando reunidos na orchestra, combinados com arte e gosto nessas peças

$X \quad$ de Bellini e Donizetti, assim tambem mais se lhes realça o valor a esses tres generos de bello, quando se reunem num objecto.

PRIMEIRA PARTE

$\underline{\text { PRIMEIRA PAGINA }}$

P. 11:

Nota MA: trecho sublinhado no v. 5, "fisgas escorrega", e cruzeta - estudo do estilo:

Do campo santo onde o lethargo dormem

Fundo e sem fim os que viventes forão,

No silencio das sombras - estendida

Jaz muita lousa ennegrecida e humida,

Por cujas fisgas escorrega o musgo

$X$

$\mathrm{E}$ a cicuta das ruinas.

P. 12:

Nota MA: preposição sublinhada no v. 22, "p'ra", e cruzeta - estudo linguístico: emprego de "para/pra":

Onde calou seu erguedor um nome

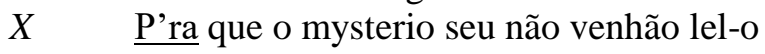

\section{OUVERTURA}

P. 21:

Notas MA: título e subtítulo sublinhados, "ouvertura" e "symphonia, e fio prendendo ao escólio "dic" - pesquisa para o Dicionário musical brasileiro: 


\section{OUVERTURA}

(SYMPHONIA)

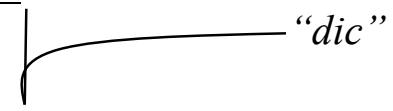

\section{P. 24:}

Nota MA: expressão sublinhada no v. 87, "Rainha da noite", e cruzeta - estudo do estilo: epíteto:

$X \quad$ Vem! Rainha da noite, eu quero amar-te

Co'os rubros labios humidos de vinho!

P. 25:

Nota MA: verbo sublinhado no v. 106, "beberei-te", e cruzeta - estudo linguístico: colocação pronominal:

O Siciliano primoroso nectar. -

Dá-mo agora - beberei-te um brinde! $\quad X$

P. 26:

Nota MA: termo sublinhado no v. 126, “ancejo" - estudo do estilo: vocabulário:

De uma alma de poeta num fervido ancejo $\quad X$

Que valhão-te um beijo?

P. 27:

Nota MA: v. 136-154 destacados por traço vertical e escólio “Amada dormida” - estudo da psicologia:

Co'a face bella no meu quente seio Que fazes, muda assim? dormes, Sultana?

Fraqueou-te o vinho, de cançada - a mente

E dormes na embriaguez immensa idéa

Dos termos do viver?

Oh! como és bella!

Dormida assim com entreabertos labios,

Como rubins de uma romã partida

Pelo estallar da madurez - purpureos, Chamando beijos no sonhar da vida?

4

Dorme, ó anjo de amor, teu quêdo somno Pelo anciar de meu peito acalentada; Máos sonhos não viráõ pousar-te n'alma Em dôr de coração! Tepida a aragem Fagueira corre nas abertas flôres. Um raio de luar por entre os vidros, Da janella coado vem pousar-te

\section{"Amada dormida"}


Sobre a fronte nevada - dorme! e entanto

Nesses teus labios que um sorrir descerra

Como rosa á manhã, purpureos, breves,

Nota da pesquisa: Em "Amor e medo", MA refere esta página: "Entoa acalantos prá amante dormida, como no Conde Lopo (p. 27)" (In: Aspectos da literatura brasileira. Ed. cit., p. 226).

P. 28:

Nota MA: termo sublinhado no v. 169 , "casualinas", e cruzeta - estudo do estilo: vocabulário:

$X \quad$ Além a briza as casualinas freme,

Gemedoras suspirão as ramagens

Num languido soar - a lua frouxa

\section{CANTO I}

P. 35:

Nota MA: termo sublinhado no v. 88 , “enloda", e cruzeta - estudo do estilo: vocabulário:

Pois essas vis que a perdição enloda $\quad X$

Em charco apodrecido - e a esse nome

De vendida mulher - de prostituta

Ligaste o nojo e o desprezo - apenas.

P. 36:

Nota MA: termo sublinhado no v. 106, “orgias", e cruzeta - estudo do estilo: vocabulário:

Para a fronte febril. Amára as orgias

$X$

Pois das taças á luz, ao som de cantos

Como as amava o grande-rei de Byron

P. 38:

Nota MA: v. 163-171 destacados por traço vertical - estudo da psicologia:

VII
Ergueu-se a linda, a languida mulher,
Uma e uma vibrou as cordas aureas
Da harpa melodiosa, e co'a mão breve
As madeixas lançou por sobre as costas
Que mais alvas ficaram p'lo negrume
Das reluzentes, copiosas ondas. -

Cantou; - da noite adormecidos echos

Da viração nas azas resoaram 
O harmonico languor dos labios della.

P. 39:

Notas MA:

1. termo sublinhado no v. 180, "harmonia", e escólio "dic" - pesquisa para o Dicionário musical brasileiro:

A vida a palpitar, alma a partir-se

Numa harmonia, numa voz fugindo. $\quad$ "dic (por melo-/dia, por / musica)"

2. termo sublinhado no v. 194, "soído", e escólio "dic / (por melodia, por musica)" pesquisa para o Dicionário musical brasileiro:

Disse-lhe o moço entre um sorrir:

"Que scisma

Minha bella o soido então gelou-te "dic"

P. 47-48:

Nota MA: v. 371-383 destacados por traço vertical e escólio "Brinde" - pesquisa para o Dicionário musical brasileiro:

- "Um enterro! que admira? nunca vistes "Brinde"

Gelar-se ao homem o calor da vida?

Deixai o morto que se estire longo

Pelo lençol da cal que fria o enlaiva.

Morreu! que importa mais? materia apenas!

Eil-o só podridão. Porque gelar-vos,

E os calices vermelhos sobre a mesa

Nas horas do festim, deixal-os virgens?

Eia, mancebos, empunhai as taças!

Um brinde, um brinde, a esse que dormiu

Somno fundo da morte em leito frio!

Um brinde á hora dos torpôres humidos!

Á morte! aos mortos!"

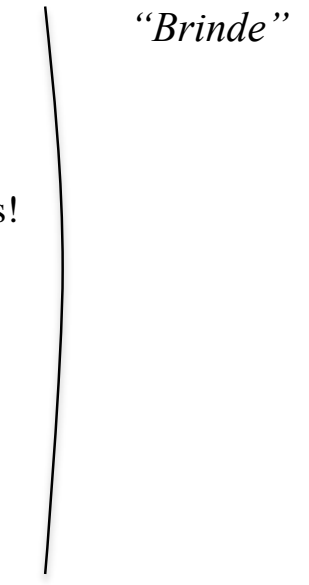

\section{$\underline{\text { AGONIA NO CALVARIO }}$}

P. 53:

Nota MA: termo sublinhado no v. 94, "treno", e escólio “dic”- pesquisa para o Dicionário musical brasileiro:

Eram ao mundo d'agonia um threno "dic"

De negro desespero em frios labios!

\section{CANTO II}


P. 61:

Nota MA: termo sublinhado no v. 105, "Tarpi-alo", assinalando o erro de impressão para "turpículo":

Do orvalho e chuva e do urinar do negro

Tarpi-alo morcego e dos immundos

Frios reptis que passam lá - e apenas!

\section{SEGUNDA PARTE}

P. 73:

Nota MA: termo sublinhado no subtítulo, "Variações", e escólio "dic" - pesquisa para o Dicionário musical brasileiro:

\section{INVOCAÇÃO \\ VARIAÇÕES EM TODAS AS CORDAS "dic"}

P. 77:

Notas MA:

1. traço horizontal na entrelinha dos v. 107 e 108 e observação corrigindo a edição:

Derão-te nenias no sussurro tremulo, "(falta 1 verso)"

Byron, se o nome teu lembra um espirito

Das glorias decahido,

2. juízo crítico no rodapé:

"(Muito boa esta invocação)"

Nota da pesquisa: A observação de MA, supondo a falta de um verso, não se confirma em Poesias completas; edição crítica de Péricles Eugênio da Silva Ramos; organização de Iumna Maria Simon (Campinas: Editora da Unicamp / São Paulo: Imprensa Oficial, 2002, p. 430).

\section{CANTO III}

P. 86-87:

Nota MA: v. 91-126 destacados por colchete - estudo da psicologia:

Eu amo a lua pallida passando

$\mathrm{Na}$ fulgencia do céo por entre alvores

Qual entre nevoas

De assombrado jardim - deslisa, envolto

Em roupas niveas, um fantasma á noite!

Alma de virgem, no dizer do povo,

Voltando sempre ao descahir das sombras 
Candida e fria com os labios alvos

Estremecidos n'um fallar mimoso, As sombras desflorando aéria e leve.

Eu amo a lua pallida, sozinha A s'escôar entre a mudez dos astros Aqui e alli occulta em véo de nevoas Que o halito das brizas adelgaçam, Melancolica sempre - qual sentada No solitario barbacan de pedra Do gothico torreão, loura donzella Saudades a scismas, ouvindo ao longe De erradio cantor as tróvas soltas Que a viração da noite, esvai, confunde,

Co'os suspiros do valle. -

Eu amo a lua pallida nascendo

Ou morrendo no mar, listando as vagas

D'auri-argenteo clarão - ou entre as folhas

Da floresta sombria s'escondendo

Partindo - sem adeus e sem saudade.

Eu amo a lua pallida, alta noite, Quando tudo é silencio - e desgarrado Vago dos campos na mudez, sozinho, Ao languido pallor das luzes d'ella; Sentindo o peito se enlevar sorvendo Os halitos da aragem que me envolve Como braços de virgem: - Amo a lua... Alvissima passando entre o silencio Na fulgencia do céo limpido e claro Semeado d'estrellas!

P. 88:

Nota MA: termo sublinhado no v. 138, “verdes", e cruzeta - estudo do estilo: vocabulário:

Que alma de trovador foi lá sentar-se

Nas rochas da montanha erma e varrida

Pelos caudaes do tormentoso inverno,

$X \quad$ Na pedra núa onde não brotão verdes?

P. 91:

Nota MA: trecho sublinhado no v. 223, "no que scismas?", e cruzeta - estudo do estilo: sintaxe:

"E no que scismas? viste ahi na terra

Alguma face pallida embebida

Em amargo pensar que te acordasse

Do amor no seio teu alguma fibra?

P. 99: 
Nota MA: termo sublinhado no v. 404, "soído", e escólio "dic" - pesquisa para o Dicionário musical brasileiro:

Os seus gorgeios magicos - durou-lhe Longo o soído nos floridos labios. "dic"

CANTO QUARTO

P. 101:

Nota MA: comentário ao Canto IV:

"Todo este canto é excelente."

P. 104:

Nota MA: termo sublinhado no v. 35 , "praino", cruzeta e observação, " $\left(2^{a}\right.$ vez $)$ " - estudo do estilo: vocabulário:

Do Oceano frio a galopar tão rapido
Como no praino dos compridos valles.
"(2 $2^{a}$ vez $) "$

P. 109:

Notas MA:

1. v. 133-137 destacados por traço vertical;

2. termo sublinhado no v. 134, "contradança", e escólio "dic" - pesquisa para o Dicionário musical brasileiro:

Co'a idéa turva a lhe voltar na mente Em ebria contradança - qual de inglezes No frenesi de um baile, o acanhamento Pelo ponche á romana esvaecido, Vão as ruivas Myladies requebradas

2. termo sublinhado no v. 141, "liseiras", e cruzeta - estudo do estilo: vocabulário:

Dos gnomos careteiros nas liseiras $\quad X$

De assombrada floresta...

P. 115:

Nota MA: verbo sublinhado no v. 294, "esclarear-se", e cruzeta - estudo do estilo: vocabulário:

Pouco e pouco elle via esclarear-se

Ao longe o fim de um corredor. - Seguindo

P. 116: 
Nota MA: trecho sublinhado no v. 315 e cruzeta - estudo linguístico / do estilo: sintaxe brasileira:

Um fantasma de pé - na mão direita

$X \quad$ Não tinha a taça - não - tinha-a vazia;

P. 117:

Nota MA: v. 335-340 destacados por traço vertical - estudo do estilo: descrição:

Um fantasma de cão que adormecera

Da meza do festim roendo os ossos

Que os convivas lhe davam despertou-se,

E os descarnados ossos das queixadas

No liquido molhou, bebendo soffrego

$\mathrm{O}$ vinho dos finados.

P. 118:

Nota MA: verbo sublinhado no v. 362, "irá-te", e cruzeta - estudo linguístico: colocação pronominal:

Por ventura será - bem ébria e louca
$X \quad$ Dos ossos no tremôr irá-te a noite.

Nota da pesquisa: MA refere esta página em "Amor e medo": "[Álvares de Azevedo] faz a confusão da dormida e da morta (II, 121; Conde Lopo, 118) (In: Aspectos da literatura brasileira. Ed. cit., p. 226).

P. 121:

Nota MA: termo sublinhado no v. 437, "estrondar", e escólio "dic" - pesquisa para o Dicionário musical brasileiro:

E ouviu-se em torno o estrondar das lages "dic"

Cahindo sobre as entreabertas boccas

Dos fetidos sepulcros.

TERCEIRA PARTE

CANTO V

P. 138:

Notas MA:

1. termo sublinhado no v. 271, "fauces", e exclamação - estudo do estilo: vocabulário;

2. preposição sublinhada no v. 273, "para", e cruzeta - estudo linguístico: emprego de "para/pra":

Prazeres de riqueza, luxo e sedas, 
Se eu te sonhar em horas, alta noite,

! Co'as fauces resequidas pela fome?

Que importa a vida delirada, tépida

$X \quad$ Para mim, se eu pensar-te entregue ao frio

No marco do caminho...

P. 139:

Nota MA: termo sublinhado no v. 286, "descôr", e cruzeta - estudo do estilo: vocabulário:

Que não de orgias, mas de causa interna

Me vinha essa descôr? quando dormias

$X$

Junto de mim, junto a meu peito, nunca

P. 145:

Nota MA: verbo corrigido no v. 438, "fechou-se” - correção tipográfica:

Batendo n'agua - e azul o mar fecho-se “/ou”

\section{CANTO VI}

P. 150:

Nota MA: termo sublinhado no v. 23, “descôr", e cruzeta - estudo do estilo: vocabulário:

Sómente uma lagrima da face a descôr $\quad X$

Quente - humedeceu!

P. 154:

Nota MA: termo sublinhado no v. 63, “descôr", e cruzeta - estudo do estilo: vocabulário:

$X \quad$ De uma descôr lethal, mas tão suave

Que eu a vi ajoelhado

\section{CANTO VII}

P. 173:

Nota MA: preposição sublinhada no v. 363, "p'ra”, e cruzeta - estudo linguístico: emprego de "para/pra":

O bom do velho offereceu-me pouso -
P'ra lá volvo-me.

$\underline{\text { CANTO VIII }}$

P. 178: 
Nota MA: verbo sublinhado no v. 36, "vertiginava", e cruzeta - estudo do estilo: vocabulário:

$X \quad$ O perfume das trovas vertiginava

Em feroz alegria entre as bombardas

P. 180-181:

Nota MA: v. 82-102 destacados por traço vertical - estudo do estilo:

O CONDE

Cavalleiro,

De um castello feudal na torre negra

Do perpassar do tempo, nasci nobre. -

$\mathrm{O}$ ar de Italia perfumou-me o berço

Com seus eloendros e cheirosas murtas.

Nas fraldas do Apenino em rochas negras

De pico inaccessivel por um lado,

Por outro unido á verdejante serra,

De meu pai - nobre Conde - se assentava

O invencivel solar. - Dissereis ninho

D'aguia voadora na garganta escura

De um serro não trilhado por humanos: -

Lá de cima o olhar corria livre

Os campos da Toscana. - Essa morada

Fizera meus avós reis dos terrenos

Que á vista se estendiam - reis de facto

Se de direito não. - Mas brando jugo

Era aos servos da baixa da planicie

Cultivadores das amenas varzeas

Que devassavam os potentes donos

Do soberbo castello das montanhas.

P. 192:

Nota MA: v. 376-385 destacados e escólio “Irmão” - estudo da psicologia: irmã:

\section{O IRMÃO}

"Irmão"

- Irmã te seja

Essa meiga donzella. - Porque tremes

O' minha noiva, assim? Elle ha de amar-te,

Tem bom coração -

Ergueu-lhe a renda

De véo branco -

Fitei-a. Era ella mesma,

Mas pallida e a tremer, o rosto frio

E os labios descorados...

Despertei-me

Do desvairar da mente. Cortejei-a 
"Amam-se! E ella trahiu-me! - Ella tão bella

Que eu nunca o pensaria... Anjos mentidos!

P. 196:

Nota MA: preposição sublinhada no v. 468, “p'ra”, e cruzeta - estudo linguístico: emprego de "para/pra":

Magdalena
$X \quad$ P'ra mim morta é de ha muito. - Foi um sonho
Cheio de flôres e clarões ethereos.

P. 197:

Notas MA:

1. preposição sublinhada no v. 484, "para", e cruzeta - estudo linguístico: emprego de "para/pra":

Ha uma hora, senhora, era eu ditoso.

Com ardencias de moço galopava

Para encurtar estradas, anhellante $\quad X$

2. verbo sublinhado no v. 487, "interrompais", e cruzeta - estudo linguístico: conjugação:

Oh! não me interrompais. - Deixai que eu falle. $X$

Será curto o viver do desgraçado.

Nota da pesquisa: MA menciona trechos de $O$ Conde Lopo no parágrafo final de "Amor e medo", de modo a caucionar sua leitura quanto ao sequestro amoroso na obra de Álvares de Azevedo: "Mas não me assusta imaginar que em grande parte foi o medo de amor, a incapacidade que levou Macário a se morrer. E sob esse ponto de vista, inda a gente poderá estudar certos detalhes do pesadelo do Conde Lopo: a obsessão do frio, a capa que os diabinhos tiram do conde, a recusa de amar o esqueleto... vivo da prostituta, etc." (In: Aspectos da literatura brasileira. Ed. cit., p. 229). 
DIAS, A. Gonçalves. Poesias. Nova edição organizada e

Bibl MA: [A/II/d/62]

revista por J. Norberto de Souza Silva e precedida de

uma notícia sobre o autor e suas obras pelo Cônego

Doutor Fernandes Pinheiro. Paris/Rio de Janeiro:

IEB: MA 869.9133 D541p

Garnier, 1919. 2 vol.

V.1

\section{VOLUME 1}

\section{$\underline{\text { FOLHA DE GUARDA }}$}

Notas MA:

1. anotação no alto, à direita, " $n^{\circ} 199$ ", referindo-se à inclusão do volume na Bibliografia para Na pancada do ganzá;

2. lista de verbetes para o Dicionário musical brasileiro e para a pesquisa Zoofonia, e cruzeta indicando o aproveitamento:

Dic-bandolim 41 - corno 45 - endecha 48 - / frauta 57 - harmonia 61 - orgão 67 cantar 69 - / descantar 72 - descante 73 - trovador 73 - frauta 75 - / concertar 84 salterio 84 - harpa, lira, alaúde 85 - / timbre 94 - sonoroso 105 - nota 112 - decantar 114 - moda 117 - nênia 121 - cítara 128 - motete 133 - / musico (adj) 139 - harmonia 141 - modular 145 - harpejo 146 - Tharmonico 147 -melodia 152 - guzla 158-harmonia 164 - / trompa 182 - ressoar 185 - trovar 188 - Harmonias 237 - / trompa 241 - tuba 241 - clangor 248 - altisona 249 - som 259 - / zoof. chilro 260 - canoro 277 - salterio 291 - harpa eolia 281 - / zoof. pititar 306 - trompa 325 - harmonia 334 - "

Nota da pesquisa: O $\mathrm{n}^{\mathbf{0}} 199$ sinaliza a inclusão das Poesias na Bibliografia para $\mathrm{Na}$ pancada do ganzá, conjunto de 837 títulos arrolados por MA para apoiar a organização de seu vasto projeto sobre o folclore brasileiro. Os títulos da poesia dos autores românticos focalizados em seu ensaio "Amor e medo" fazem parte da lista bibliográfica. O escólio "dic", a grafite, de ocorrência farta na marginália, nos títulos da poesia do romantismo brasileiro, indica a pesquisa de elementos para abonar verbetes no Dicionário musical brasileiro, projeto do escritor testemunhado em sua biblioteca, no manuscrito desse título e de outros, em seu arquivo e, na edição póstuma coordenada por Oneyda Alvarenga e Flávia Camargo Toni (Brasília: Ministério da Cultura/São Paulo: IEB-USP - Edusp/ Belo Horizonte: Editora Itatiaia Ltda, 1989).

O escólio “Zoof”, a grafite, de ocorrência frequente na marginália de MA, em todas as áreas de sua biblioteca, absorve a denominação de pesquisa encetada por Hercule Florence e colige matéria destinada ao projeto do escritor de reunir palavras e expressões representando as vozes dos animais. Liga-se, de imediato, ao manuscrito Zoofonia, reservatório e estudo particular desses termos, composto de documentos musicais, recortes de jornal e notas de trabalho, transcritas de publicações ou captadas em pesquisa de campo por MA e seus colaboradores. 
Em entrevista de 1943, MA filia seu projeto a Green Mansions: a Romance of the Tropical Forests, de William Henry Hudson (V. ANDRADE, Mário de. Entrevistas e depoimentos. Edição organizada por Telê Porto Ancona Lopez. São Paulo: T.A. Queiroz, 1983, p. 93).

"Zoof" prende-se, também, à coleta de termos para o Dicionário musical brasileiro e $O$ banquete, obra na área de Estética, interrompida pela morte de MA em 1945. Nesta, o capítulo 8 previa: "O Passeio em Pássaros. Zoofonia. O canto-enfeite no cio. A mulher vestida de homem e a Lei do Peso. Música da natureza e música descritiva." (V. ANDRADE, Mário de. O banquete. Ed. preparada por Jorge Coli e Luiz Dantas. São Paulo: Livraria Duas Cidades, 1977, p. 167).

P. 5-19

SOUZA SILVA, J. Norberto. "Prefácio da setima edição".

P. 6:

Nota MA: trecho destacado por traço vertical e escólio "Poesia" - seleção de ideias:

"Poesia" $\quad \begin{aligned} & \text { Casar assim o pensamento com o sentimento - o coração com o entendimento - a } \\ & \text { ideia com a paixão - colorir tudo isto com a imaginação, fundir tudo isto com a } \\ & \text { vida e com a natureza, purificar tudo com o sentimento da religião e da } \\ & \text { divindadade, eis a Poesia - a Poesia grande e santa - a Poesia com eu a } \\ & \text { comprehendo sem a poder definir, como eu a sinto sem a poder traduzir. }\end{aligned}$

Nota da pesquisa: $\mathrm{O}$ trecho assinalado por MA é transposto para o fichamento crítico das obras de Gonçalves Dias, no dossiê do manuscrito Amor e medo: "Conceito de Poesia pra G. D. I, 6" (MA-MMA-05-04).

P. 21-37

PINHEIRO, J. C. Fernandes. "Noticia sobre a vida e obras d'Antonio Gonçalves Dias".

P. 27:

Nota MA: escólio "Primeiros Cantos 23 anos" - seleção de ideias: biografia e cronologia das obras:

"Primeiros

Cantos

23 anos"
Foi no anno de 1846 que pela primeira vez avistou o Pão d'assucar que devêra depois celebrar na bellissima allegoria do Gigante de Pedra. Nesse mesmo anno deu ao prelo os seus Primeiros Cantos que lhe valerão honroso e justo louvor d'um dos maiores sabedores de nosso idioma

P. 28:

Nota MA: escólio "Sextilhas 25 anos" - seleção de ideias: biografia e cronologia das obras: 
Os curtos lazeres que lhe deixava o fiel e exacto cumprimento de seus deveres, "Sextilhas consagrava-os elle ao ameno trato das musas, dando á estampa en 1847 o melhor 25 anos" de seus dramas intitulado Leonor de Mendonça, e no anno seguinte as Sextilhas de frei Antão, mounumento d'erudição philologica.

P. 29:

Nota MA: escólio "29 anos" - seleção de ideias: biografia e cronologia das obras:

De volta de sua excursão ao norte do império, foi despachado official da secretaria "29 anos" d'estado dos negócios estrangeiros (em 1852); e nesse mesmo anno contrahio matrimonio com a senhora D. Olympia da Costa, filha do estimável e venerando D. Claudio Luiz da Costa. Desse matrimonio resultou apenas una menina que falleceu em tenra idade.

P. 30:

Nota MA: escólio "34 anos” - seleção de ideias: biografia e cronologia das obras:

Achando-se em Leipzig proporcionou-se-lhe ensejo d'entreter amigáveis relações com o muito conceituado livreiro Brockhaus, que suggerio-lhe a ideia d'uma edição de seus Cantos, que forão dados a lume com o titulo de Primeiros, Segundos

"34 anos" e Últimos Cantos. Por esse mesmo tempo (1857) confiou aos typos o seu Diccionario da língua Tupy, chamada língua geral dos Indígenas do Brasil, e os quatro primeiros cantos d'uma epopéa americana denominada: Os Tymbiras.

P. 32:

Nota MA: escólio “41 anos” - seleção de ideias: biografia e cronologia das obras:

Firme no propósito annunciado embarcou-e a 14 d'esse mez e anno na barca Ville

"41 anos" de Boulogne, com destino ao Maranhão, e quando soffregos aguardavão-lhe a vinda amigos, parentes e affeiçoados, soou a luctuosa noticia de sua morta occorrida no naufragio da mencionada barca.

P. 35:

Nota MA: trecho destacado por traço vertical - seleção de ideias:

Em uma palavra, Gonçalves Dias aproxima-se da ballada; acha-se no melhor caminho para crear uma poesia verdadeiramente nacional e revestida de forma apropriada ao gosto do nosso tempo. Não é pois para admirar que as suas Poesias Americanas tenhão adquirido no Brazil uma grande popularidade (1).

P. 39-249

POESIAS DIVERSAS

$\underline{\text { P. } 39-50}$

O SOLDADO HESPANHOL (7 partes) 
P. 41:

Nota MA: termo sublinhado, "bandolim", e escólio "dic" - pesquisa para o Dicionário musical brasileiro:

E o hespanhol viril, nobre e formoso,

$$
\text { No bandolim "dic" }
$$

P. 45:

Nota MA: termo sublinhado, "corno", e escólio "dic" - pesquisa para o Dicionário musical brasileiro:

Corno ebúrneo embocou muitas vezes, "dic"

P. 46-47:

Nota MA: estrofes destacadas por traço vertical - estudo do estilo: canção:

'Tenho Castello soberbo

N'um monte, que beija um rio,

De terras tenho no Douro

Geiras cem de lavradio;

'Tenho lindas haquenéas,

Tenho pagens e matilha,

Tenho os melhores ginetes

Dos ginetes de Sevilha;

'Tenho punhal, tenho espada

D'alfageme alta feitura,

Tenho lança, tenho adaga.

Tenho completa armadura.

'Tenho fragatas que cingem

Dos mares a lympha clara.

Que vão preiando piratas

Pelas rochas de Megára.

'Dou-te o castello soberbo

$\mathrm{E}$ as terras do fértil Douro,

Dou-te ginetes e pagens

E a espada de pomo d'ouro.

'Dera a completa armadura

E os meos barcos d'alto-mar, Que nas rochas de Megára

Vão piratas captivar.

'Falla de amores teo canto,

Falla de accesa paixão...

Ah! senhora, quem tivera

Dos agrados teus condão! 
'Eu sou mancebo, sou Nobre

Sou nobre moço infanção;

'Assim pudesse o meu canto

Algemar-te o coração,

Ó Dona, que eu dera tudo

Por vencer-te essa isenção!

Nota da pesquisa: No fichamento crítico das obras de Gonçalves Dias, documento no dossiê do manuscrito Amor e medo, MA indica o trecho assinalado sob a rubrica "Pedaços belos" (MA-MMA-05-04).

\section{P. 48-49:}

Notas MA:

1. termo sublinhado, "endechas", e escólio "dic" - pesquisa para o Dicionário musical brasileiro:
E n'outra noite saudosa
Bem junto della sentado,
"dic" Cantava brandas endechas
O gardingo namorado.

2. verbo sublinhado, "careço", e cruzeta - estudo do estilo: vocabulário:

$$
X \quad \begin{aligned}
& \text { "Careço de ti, meu anjo, } \\
& \text { Careço do teu amor, } \\
& \text { Como da gota d'orvalho } \\
& \text { Carece no prado a flor." }
\end{aligned}
$$

3. versos destacados por traço vertical - seleção de ideias:

$$
\left(\begin{array}{l}
\text { "Sinto afflicção quando choras; } \\
\text { Se te ris, sinto prazer; } \\
\text { Se te ausentas, fico triste, } \\
\text { Que só me falta morrer." }
\end{array}\right.
$$

Notas da pesquisa:

1. Os versos assinalados com traço vertical convergem para o fichamento crítico das obras de Gonçalves Dias, onde abonam a rubrica "Pedaços belos" (MA-MMA-05-04).

2. No vol. 2 das Poesias, MA registra à margem do "Canto Segundo", em Os Tymbiras: "Gonçalves Dias diz sistematicamente carecer por precisar" (Nota MA, In: DIAS, A. Gonçalves. Poesias. Ed. cit., vol. 2, p. 168).

\section{P. 50:}

Notas MA:

1. preposição sublinhada, "para", e cruzeta - estudo do estilo: emprego de "para/pra":

E a dextra do infanção maneja o ferro, Porque tão grande affronta lave o sangue, 
$X \quad$ Pouco, bem pouco para injuria tanta.

2. expoente (1) remetendo ao comentário no rodapé - estudo da versificação: métrica:

No peito de soffrer cançado e cheio,

Cheio qual na praia fica a esponja,

Quando a vaga do mar passou sobre ella.

“(1) Decassilabo sem a silaba inicial.”

Nota da pesquisa: Em nota de trabalho no dossiê do manuscrito Castro Alves, MA observa: "Não esquecer tam-/bem os esdruxulos contados com uma silaba / de menos, coisa muito usada por Castro Alves / mas que G. D. me parece que não empregou" (MA-MMA-26-09).

$\underline{\text { P. } 51-52}$

A LEVIANA (7 estrofes)

P. 52:

Notas MA:

1. v. 28-30 destacados por traço vertical - estudo da psicologia: sentimento amoroso;

2. preposição sublinhada, "para", e cruzeta - estudo do estilo: emprego de "para/pra":

"Assim, beijar-te receio,

Contra o seio

Eu tremo de te apertar;

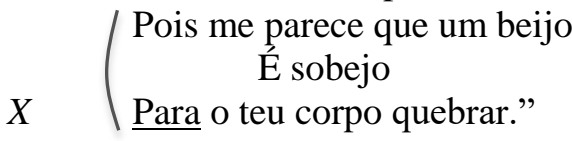

3. comentário ao final do poema:

"No principio G. D. era um deli/cioso cantador e apenas. Já no Soldado Espanhol / tem uma canção linda de feitio popular luso / que assinalei!"

$\underline{\text { P. } 52-56}$

A MinHA MusA (21 estrofes)

P. 53:

Nota MA: trecho destacado por colchete - estudo da psicologia / seleção de ideias:

Elle ama a solidão, ama o silêncio,

Ama o prado florido, a selva umbrosa

E da rola o carpir.

Ella ama a viração da tarde amena,

O susurro das agoas, os accentos

De profundo sentir. 
P. 54:

Nota MA: trecho destacado por colchete - estudo do estilo: descrição:

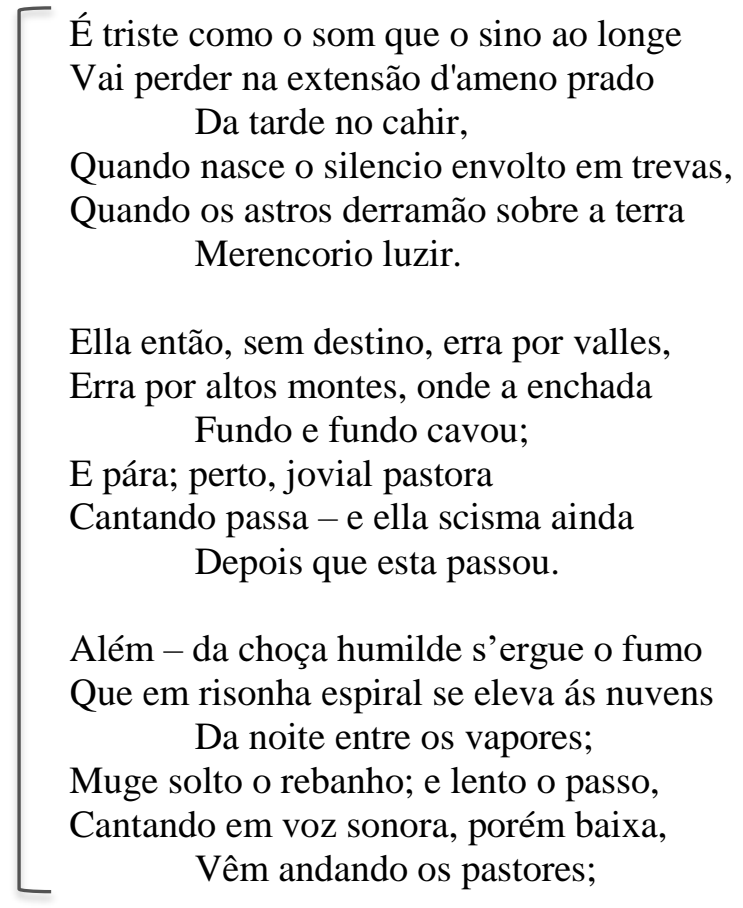

P. 56:

Nota MA: comentário ao final do poema:

"Esta tristeza de G. D. sim me parece bem / tema, bem artificial. Seus versos, seu sentiImento, sua expressão bem menos impulsi-/va e brotada não revelam aquela tristeza / de Casemiro e a amargura cheia de tedio de / Alvares de Azevedo. Pura mascara. Ao menos a / tristeza he-/roica de / C. Alves era / ditada por / uma idea / social. A / de G. Dias nem isso! / Romantismo / da pior especie, romantismo de escola."

Nota da pesquisa: A percepção de MA quanto à tristeza artificial de Gonçalves Dias justifica a inclusão desta página sob a rubrica "Poeta de inteligencia", no fichamento crítico que integra o dossiê do manuscrito Amor e medo: "I, 56 (não é a toa que salienta igual ao sentimento a inteligencia em I, 6); 58; 58; 68; 172; 184; 191; 205; 229; 287" (MA-MMA05-04). Ao comentar o poema "Desejo", na mesma página, MA registra a avaliação oposta.

$\underline{\text { P. } 56}$

DESEJO ( 1 estrofe)

Notas MA:

1. termos sublinhados, "sinta" e "sentir" - estudo da psicologia / da criação: sinceridade;

2. expoente "(1)" ao final do poema, remetendo ao comentário no rodapé: 
Ah! que eu não morra sem provar ao menos

Siquer por um instante, n'esta vida

Amor igual ao meu!

Dá, Senhor Deos, que eu sobre a terra encontre

Um anjo, uma mulher, uma ombra tua,

Que sinta o meu sentir;

Uma alma que me entenda, irmã da minha,

Que escute o meu silêncio, que me siga

Dos ares na amplidão!

Que em laço estreito unidas, juntas, presas,

Deixando a terra e o lodo, aos céos remontem

N'um extasis de amor! "(1)"

"Que beleza. Aqui sim me parece tão natural. / Tão impulsivo! E que arte. A gente sente uma / rima que não existe tanto isto é sonoro, é / bem cadenciado. E alem disso um pensamen-/to já bem mais sutil que o dos outros."

$\underline{\text { P. } 57-58}$

SEUS OlHOS (11 estrofes)

P. 57:

Nota MA: termo sublinhado, "frauta", e escólio "dic"-pesquisa para o Dicionário musical brasileiro:

Seus olhos tão negros, tão bellos, tão puros,

Tem meiga expressão,

Mais doce que a briza, - mais doce que o nauta

De noite cantando, - mais doce que a frauta "dic"

Quebrando a soidão.

P. 58:

Notas MA:

1. termos sublinhados, "pensa" e "pensar", e expoente "(1)”, remetendo ao comentário no rodapé - estudo [da psicologia] da criação: sinceridade:

Assim lindo infante, que dorme tranquillo,

Desperta a chorar;

“(1)” ( E mudo e sisudo, scismando mil coisas,

“(1) Notar a frieza de pensamento de G Dias. / Como é já muito mais vivo, muito mais / rico que os outros. E como encontra aquelas / frases que revelam com exatidão a verdade /psicologica."

2. versos destacados por traço vertical e fio ligando ao comentário na margem superior: 
"Aqui G. D. definiu a sua arte. Ele tambem criou uma arte 'que chora sem causa, um pranto sem dôr'."

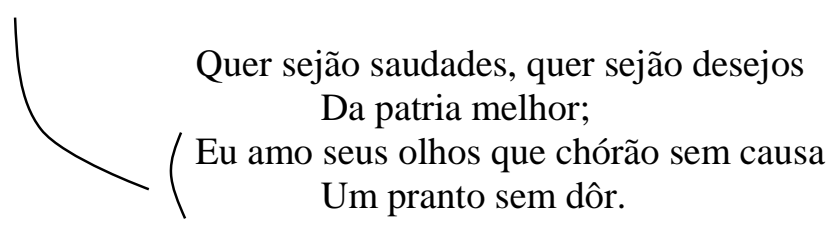

Nota da pesquisa: Os versos destacados em "Seus olhos" indiciam a inteligência de Gonçalves Dias, conforme o fichamento crítico no dossiê do manuscrito Amor e medo (MA-MMA-05-04).

P. 59-60

INNOCENCIA (5 estrofes)

P. 59:

Nota MA: expressões sublinhadas, "de tão cedo", "pouco dura", "como a rosa", "como a flôr" - estudo do estilo: artifício/repetição:

Por innocente tens medo

De tão cedo

De tão cedo ter amor;

Mas sabe que a formosura

Pouco dura,

Pouco dura, com a flôr.

Corre a vida pressurosa,

Como a rosa,

Como a rosa na corrente.

Amanhã terás amor?

Como a flôr,

Como a flôr fenece a gente.

P. 60:

Nota MA: comentário ao final do poema:

"So G. Dias no Romantismo tradicionaliza / os nossos arcades, sobretudo o repique / gracioso, de enorme delicadeza de Dirceu"

Nota da pesquisa: A biblioteca de MA, no IEB/USP, contém dois títulos de Tomás Antônio Gonzaga (1744-1810). Marilia de Dirceo - em edição revista e prefaciada por José Verissimo (Rio de Janeiro / Paris: H. Garnier, Livreiro-Editor, 1910) - não conserva notas de margem a indicar o estudo do "repique gracioso", ou de outros aspectos das liras de Gonzaga.

\section{P. 60-61}




\section{PEDIDO (7 estrofes)}

P. 60: S/Notas MA:

Nota da pesquisa: Em meio à caracterização da "filosofia pessimista do amor, bem wagneriana, pra não dizer schopenhauriana" de Gonçalves Dias, MA remete aos versos desta página, como exemplo da infidelidade atribuída à mulher, com frequência, por parte do eu lírico ("Amor e medo", In: Aspectos da literatura brasileira. Ed. cit., p. 215).

P. 61-62

O DESENGANO (10 estrofes)

P. 61:

Notas MA:

1. v. 8 sublinhado, termos sublinhados, "notas" e "harmonia", e escólio "dic" - pesquisa para o Dicionário musical brasileiro:

Meu amor era puro, extremoso, Era amor que meu peito sentia, Erão lavas de um fogo teimoso, Erão notas de meiga harmonia. " $\underline{\underline{\text { hic }}}$

2. termos sublinhados, "meigo" e "meiga" - estudo do estilo: artifício/repetição:

E o que era o teu amor, que me embalava Mais do que meigos sons de meiga lyra?

Um dia o decifrou - não mais que um dia -

Fingimento e mentira!

Nota da pesquisa: MA lista o poema como exemplo da infidelidade frequentemente atribuída à mulher ("Amor e medo", In: Aspectos da literatura brasileira. Ed. cit., p. 215).

P. 62:

Notas MA:

1. expressão sublinhada nos v. 17 e 20, "nosso amor" - estudo do estilo: artifício/repetição:

$$
\left(\begin{array}{c}
\text { Tão bello o nosso amor! — foi só de um dia, } \\
\text { Como uma flôr! } \\
\text { Porque tão cedo o talisman quebraste } \\
\text { Do nosso amor? }
\end{array}\right.
$$

2. v. 43-46 destacados por traço vertical e comentário ao final do poema:

$$
\begin{aligned}
& \text { Tão bello o nosso amor! — foi só de um dia, } \\
& \text { Como uma flôr! } \\
& \text { Oh! que bem cedo o talisman quebraste }
\end{aligned}
$$


Do nosso amor?

"Notar e explicar a enorme musicalidade / de G. Dias, o mais musical dos nossos poetas. / Musicalidade oral e musical tambem. / Esta se prova pela estribilhação constan-/te e pelas repetições de palavras, de elemen-/tos logicos na frase, como na musica se / repetem temas, rondós, elementos ritmi-/cos e melodicos. Ver quantas repetições deste / ultimo genero no Pedido e nos grifos $\sim \operatorname{pg}$ 62, 58, / 59, em Seus Olhos uma quanto desproposito, 56, etc /63, 64, 65, 66"

P. 63-65

MINHA VIDA E MEUS AMORES (12 estrofes)

P. 63:

Notas MA:

1. termo sublinhado no v. 7, "lindeza", e cruzeta - estudo do estilo: vocabulário:

Agora, logo, aqui, além, notando

Uma pedra, uma flôr, uma lindeza, $\quad X$

Um seixo da corrente, uma conchinha

A beiramar colhida!

2. termo sublinhado no v. 13, "linda" - estudo do estilo: artifício/repetição:

E esta era linda, como é linda a aurora

No fresco da manhã tingindo as nuvens

De rosea côr fagueira;

P. 64:

Notas MA:

1. v. 33 sublinhado - estudo da psicologia: sentimento amoroso:

A fugaz borboleta as flôres todas

Elege, e liba e uma e outra, e foge

Sempre em novos amores enlevada:

N'este meu paraiso fui como ella,

Inconstante vagando em mar de amores.

2. termo sublinhado nos v. 48 e 49, "virgem" - estudo do estilo: artifício/repetição:

Dá, meu Deus, que eu possa amar,

Dá que eu sinta uma paixão,

$X \quad$ Torna-me virgem minha alma,

E virgem meu coração.

3. expressão sublinhada no v. 50 e cruzeta - estudo linguístico: sintaxe lusa: 
$X \quad$ Um dia, em qu'eu sentei-me junto d'ella,

Sua voz murmurou nos meos ouvidos,

- Eu te amo! - Ó anjo, que não possa eu crer-te!

P. 65:

Notas MA: v. 78-81 destacados por traço ondulado - estudo do estilo: artifício/repetição:

$\left\{\begin{array}{l}\text { Antes vai collar teu rosto, } \\ \text { Collar teu seio nevado } \\ \text { Contra o rosto mudo e frio, } \\ \text { Contra o seio d'um finado. }\end{array}\right.$

"Como G. Dias lida peritamente a / redondilha portuguesa. Isto lhe per-/mitiu a arte fina com que construiu / as Sextilhas. Variedade ritmica do / seu heptassilabo."

$\underline{\text { P. } 66}$

RECORDAÇ̃̃o (2 estrofes)

P. 66:

Notas MA: expressões sublinhadas nos v. 15 e 16, "teus olhos" e "meus olhos" - estudo do estilo: artifício/repetição:

Volvo aos instantes de ventura, e penso

Que a sós comtigo, em pratica serena,

Melhor futuro me augurava, as doces

Palavras tuas, sôfregos, attentos

Sorvendo meus ouvidos, - nos teus olhos

Lendo os meus olhos tanto amor, que a ida

Longa, bem longa, não bastará ainda

P. $67-68$

TRISTEZA (5 estrofes)

P. 67:

Nota MA: termo sublinhado no v. 26, "orgão", e escólio “dic" - pesquisa para o Dicionário musical brasileiro:

Suspira ainda a nota maviosa,

O derradeiro argar d'orgão solemne. "dic"

P. 68:

Nota MA: comentário ao final do poema: 
"Sublime simplesmente. Mostrar por ele quan-/to é calma, quanto é regrada e discreta, I quanto é bem educada, por assim dizer / parnasiana a tristeza de G. Dias. Não é / bem uma tristeza, antes uma contempla-/ção desenganada e <ilegível> - contemplação / carinhosa."

Nota da pesquisa: MA inclui o poema entre as "Obras-primas" de Gonçalves Dias, conforme se lê no fichamento crítico que integra o dossiê do manuscrito Amor e medo (MA-MMA-05-04). No mesmo documento, a rubrica "Poeta de inteligencia" também refere esta página.

$\underline{\text { P. } 69-74}$

O TROVADOR (34 estrofes)

P. 69:

Nota MA: termo sublinhado no v. 7, "cantar", e escólio "dic” - pesquisa para o Dicionário musical brasileiro:

Nenhum saráo se acabava Sem a lyra de marfim, Pois cantar tão alto e doce "dic" Nunca alguém ouvíra assim.

E o Trovador conheceu Que era trahido - por fim; Poz-se a andar, e só se ouvia Nos seus labios: ai de mim!

Notas da pesquisa:

1. O poema "O Trovador" lastreia a rubrica "Poeta de inteligencia", no fichamento crítico que integra o dossiê do manuscrito Amor e medo (MA-MMA-05-04).

2. No ensaio para a Revista Nova, MA inclui esta página entre os exemplos de infidelidade atribuída pelo eu lírico à mulher amada ("Amor e medo", In: Aspectos da literatura brasileira. Ed. cit., p. 215).

P. 70:

Nota MA: termo sublinhado no v. 34, "lindeza", e cruzeta - estudo do estilo: vocabuário:

$$
\begin{aligned}
& \text { “Teu rosto engraçado e bello } \\
& \text { "Tem a lindeza da flôr; } \\
& \text { "Mas é risonho o teu rosto; } \\
& \text { "Não tens de sentir amor! }
\end{aligned}
$$

P. 71:

Notas MA:

1. termo sublinhado no v. 63, "breve" - estudo do estilo: artifício/repetição: 
"Aos homens da mulher enganão sempre

"O sorriso, o amor;

"É este breve, como é breve aquelle

"Sorriso enganador.

2. v. 77-80 destacados por traço vertical duplo e e escólio: "Amor”:

"Amor" $\| \begin{aligned} & \text { "O amor é como a aragem que murmura } \\ & \text { "Da tarde no cahir — pela folhagem; } \\ & \text { "Não volta o mesmo amor á formosura, } \\ & \text { "Bem como nunca volta a mesma aragem. }\end{aligned}$

3. conjunção sublinhada, "não", fio e cruzeta - estudo linguístico: brasileirismo:

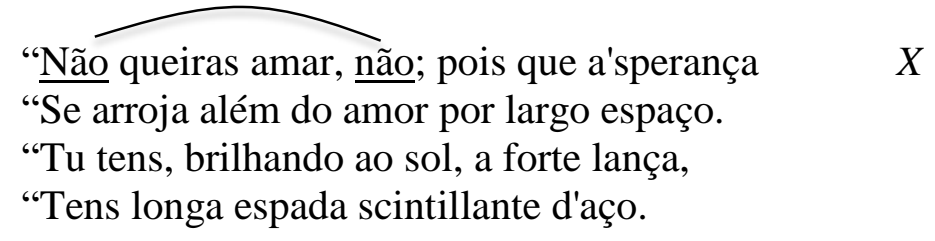

P. 72:

Notas MA:

1. v. 94 assinalado e expoente “(1)”, remetendo ao comentário no rodapé - estudo da versificação: métrica:

\footnotetext{
"Oh! não queiras amar! - Como entre a neve

"O gigante volcão borbulha e ferve

"(1)" "E sulfurea chamma pelos ares lança,

"Que após o seu cahir torna-se fria;
}

“(1) decassilabo com uma silaba anterior que / se funde na ultima silaba muda do verso / antecedente."

2. termo sublinhado no v. 109, "descanta", e escólio "dic" - pesquisa para o Dicionário musical brasileiro:

“dic" "Quando em festejos descanta,

"Rasgado o peito com dôr,

\section{P. 73:}

Notas MA:

1. termo sublinhado no v. 116, "descantes", e escólio "dic" - pesquisa para o Dicionário musical brasileiro:

"Canta, diz-lhe: quero ouvir-te;

"Quero descantes de amor! "dic" 
2. v. 120 sublinhado, expressão sublinhada, "truão trovador", e escólio “dic" - pesquisa para o Dicionário musical brasileiro:

“- Minha dama quer ouvir-te,

“" "Canta, truão trovador! -

2. expressões sublinhadas nos v. 139 e 140, "pezar lhe dá" e "dá-lhe pezar" - estudo do estilo: repetição/artifício:

"Que triste que é n'este mundo

"O fado d'um Trovador!

"Pezar lhe dá sua Lyra,

"Dá-lhe pezar seu amor!"

P. 74:

Nota MA: expoente “(1)” ao final do poema, remetendo ao comentário no rodapé:

E o Trovador n'este ponto

A corda extrema arrancou;

E n'um arco do caminho

A Lyra sua quebrou:

Ninguem mais a voz sentida

Do Trovador escutou!

“(1)”

"(1) G. Dias é muito baladoso. Afeiçoou perfei-/tamente no seu sentir o romance tra/dicional popular. Nisto ainda demons-/tra uma arte boa. Vê-se a origem da sua / lirica mas não são 'à la manière de...' que / só usará por brinquedo nas Sextilhas."

P. 74-77

AMOR! DELIRIO - ENGANO (8 estrofes)

P. 74:

Nota MA: termo sublinhado nos v. 11 e 12, "encanto", e expoente "(2)”, remetendo ao comentário na margem superior - estudo do estilo: artifício/repetição:

Habitámos uma hora; e logo o tempo

Com a foice roaz quebrou-lhe o encanto,

Doce encanto que o amor nos fabricára.

“(2) Observar como êsta maneira / musical tende a se tornar processo no / poeta e mesmo a sistematizar-se por demais."

P. 75:

Notas MA: 
1. v. 27-29 destacados por traço vertical e escólio "dic" - seleção de ideias / pesquisa para o Dicionário musical brasileiro:

\begin{tabular}{l|l} 
Nos fugitivos sons de alguma frauta, \\
Que da noite o silencio realçavão, \\
Os ares e a amplidão divinisando, \\
Ouvião meus ouvidos; e de ouvil-o \\
Arfava de prazer meu peito ardente.
\end{tabular} \mid "dic"

2. termo sublinhado no v. 40, "futuravão", e cruzeta - estudo do estilo: vocabulário;

3. termo sublinhado nos v. 41 e 42 , "esp' rança" - estudo do estilo: artifício/repetição:

Mil venturas colhi dos labios d'ella,

Que instantes de prazer me futuravão

$X$

Cada sorriso seu era uma esp'rança,

E cada esp'rança enlouquecer de amores.

4. v. 43-48 destacados por colchete e escólio "amada infiel" - estudo da psicologia: sentimento amoroso:

E eu amei tanto! — Oh! não! não hão de os homens

Saber que amor, á ingrata, havia eu dado;

Que affectos melindrosos, que em meu peito

"amada

Tinha eu guardado para ornar-lhe a fronte!

Oh! não, - morra commigo o meu segredo;

Rebelde o coração murmure embora.

Nota da pesquisa: Em “Amor e medo", esta página consta entre os exemplos da infidelidade atribuída à mulher (In: Aspectos da literatura brasileira. Ed. cit., p. 215).

P. 76:

Notas MA:

1. termo sublinhado no v. 68, "terra" - estudo do estilo: artifício/repetição:

2. v. 68 e 69 destacados por traço vertical triplo e cruzeta - estudo da psicologia: sentimento amoroso:

Em extasis divino aos céos me alçárão,

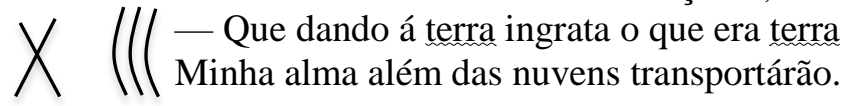

3. termo sublinhado no v. 75 , "vida" - estudo do estilo: artifício/repetição:

E ella!... ella talvez nos braços d'outrem

Com sua vida alimenta uma outra vida,

Com o seu coração o de outro amante,

Que mais feliz do que eu, inferno! a goza.

P. 77: 
Nota MA: trecho assinalado por comentário:

Abutre roedor, cruel ciume,

Oh! não poder-te,

Tua funda raiz e a imagem d'ella

No peito em sangue espedaçar raivoso!

"Prometeu, a / imagem, o simbolo / de que mais se / tem abusado / do Romantismo / pra cá."

$\underline{\text { P. } 77-79}$

DELIRIO (5 estrofes)

P. 78:

Notas MA:

1. termo sublinhado no v. 13, "visão" - estudo do estilo: artifício/repetição:

Visão, fatal visão, porque derramas

Sobre o meu rosto pallido

A luz de um longo olhar, que amor exprime

E pede compaixão?

2. expressão sublinhada no v. 41, "Fracos, mais fracos", e fio ligando à expressão sublinhada no v. 43, à p. seguinte - estudo do estilo: artifício/repetição:

Balbucias uns sons, que eu mal percebo,

Doridos, compassados,

Fracos, mais fracos; - lagrimas despontão

Nos teus olhos brilhantes...

P. 79:

Notas MA:

1. expressão sublinhada no v. 43, "Choras! tu choras!", ligada por um fio ao v. 41, na p. anterior;

2. termo sublinhado no v. 46, "procurão-me" e "procuro-te" - estudo do estilo: artifício/repetição:

Choras! tu choras!... Para mim teus braços

Por força irresistivel

Estendem-se, procurão-me; procuro-te

Em delirio afanoso.

P. 79-81

EPICEDIO (10 estrofes)

P. 80: 


\section{Notas MA:}

1. termo sublinhado no v. 7, "coração", e expoente “(1)”, remetendo ao comentário no rodapé:

\section{“(1)” Coração que tanto amava}

Já hoje não sente amor;

"(1) Notar que essa maneira antiga de dar / o substantivo sujeito sem artigo ou possessivo / que o anteceda veio a se tornar brasilei-/rismo hoje. G. Dias é certo não fazia, nessa / sua maneira, brasileirismo e sim imitava / o antigo."

2. v. 9-10 e 15-16 destacados por traço vertical, ligados por fio, e escólio "Musicalidade"; 3. termo sublinhado nos v. 9 e 10, "anjo", e nos v. 15 e 16, "terra" - estudo do estilo: artifício/repetição/musicalidade:

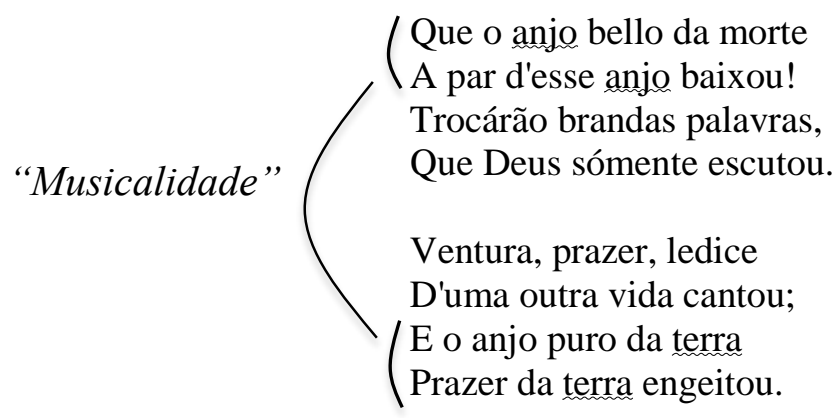

P. 81:

Nota MA: v. 37-40 destacados por traço vertical e comentário ao final do poema:

Não choremos essa morte,
Não choremos casos taes;
(Quando a terra perde um justo,
Conta um anjo o céo de mais.

\section{"Bonito e delicadíssimo"}

Nota da pesquisa: No dossiê do manuscrito Amor e medo, o fichamento crítico das obras de Gonçalves Dias indica esta página, de modo a reunir os versos assinalados à rubrica "Pedaços belos" (MA-MMA-05-04).

P. 81-82

SOFFRIMENTO (11 estrofes)

P. 81:

Nota MA: expressão sublinhada no v. 1, "Meu Deus, Senhor meu Deus" - estudo do estilo: artifício/repetição:

Meu Deus, Senhor meu Deus, o que ha no mundo 
Que não seja soffrer?

P. 82:

Notas MA:

1. termos sublinhados nos v. 30, "perdão", e 31, "sinto" - estudo do estilo: artifício/repetição:

Não escutes, meu Deus, esta blasfemia;

Perdão, Senhor, perdão!

Minha alma sinto ainda, - sinto, escuto

Bater-me o coração.

2. expressão sublinhada nos v. 41 e 43, "uma outra vida" - estudo do estilo: artifício/repetição;

Bemdigo o nome teu, que uma outra vida

Me fez descortinar,

Uma outra vida, onde não há só trevas.

E nem há só pensar.

3. comentário ao final do poema:

"Na parte geral do meu livro fazer conside-/rações sobre essa insinceridade sincera que I fez tornar o sofrimento como norma de vida e / de lirismo, mostrar o que teve de artificial em / versos como estes, mas como esse preconceito se / tornou natural e por assim dizer vivido. G. Dias / é aquele em que mais artificial transparece / essa insinceridade sincera. Qualquer roman-/tico inconsciente, que não seja romantico artis/tico como G. Dias, um Casemiro, um Alvares de / Azevedo por exemplo, tomaria a noticia da morte / em vida tetricamente, dolorosamente um Casemiro / e talvez em amargura estafada e ironica um / Alvares de Azevedo, ao passo que G. Dias tomou-/o faceciosamente como prova ofacsimile I da carta que escreveu a A. Henriques e que vem / antes da pg 21 deste volume."

\section{P. 84-85}

CANÇÃO (4 estrofes)

P. 84:

Notas MA: termo sublinhado no v. 7, "concerta", e no v. 8, "salterio", e escólio "dic" pesquisa para o Dicionário musical brasileiro:

Foi o Senhor quem m'a deu, De santas palmas coberta,

"dic Que as notas suas concerta

dic" Aos sons do salterio hebreu!

P. 85: 
Notas MA: v. 25-32 assinalados por colchete e escólio "dic" - pesquisa para o Dicionário musical brasileiro:

Votei assim ao meu Deus A minha harpa religiosa, A ti a lyra mimosa, O grave alaúde aos meus!

$\underline{\text { P. } 86-88}$

AGORA E SEMPRE (10 estrofes)

P. 87:

Nota MA: expressão sublinhada no v. 14, "gritos do condor", e escólio "zoof" - pesquisa da zoofonia:

Alli aos urros do leão sedento,

Aos crebros gritos do condor alpestre, "zoof"

Ardendo em chammas d'este amor sem termo,

Direi: Eu te amo!

$\underline{\text { P. } 92-93}$

O AMOR (5 estrofes)

P. 92:

Nota MA: termo sublinhado no v. 7, "amor" - estudo do estilo: artifício/repetição:

Sympathica attracção d'almas sinceras

Que unidas pelo amor, no amor se apurão,

Por quem suspiro, serás nome apenas?

P. 93:

Nota MA: v. 30-33 assinalados por colchete - estudo da psicologia: sentimento amoroso:

Prendi-me aos teus grilhões, rojei por terra...

E o lucro?... forão lagrimas perdidas,

Foi roxa cicatriz qu'inda conservo,

Desbotada a ilusão e a vida exhausta!

Nota da pesquisa: MA evoca esta página, em "Amor e medo", como exemplo da infidelidade sofrida pelo eu lírico (In: Aspectos da literatura brasileira. Ed. cit., p. 215).

P. 94-95

SEMPRE ELLA (8 estrofes)

P. 94: 
Nota MA: termo sublinhado no v. 7, "timbre", escólio "dic" e expoente "(1)”, remetendo ao comentário rasurado no rodapé - pesquisa para o Dicionário musical brasileiro:

"dic Tem um timbre de voz que n'alma echôa,

(1)” Tem expressões d'angelica doçura,

"No sentido inexato de corpo, de voz,"

$\underline{\text { P. } 100-102}$

SONHO (8 estrofes)

P. 100:

Nota MA: termo sublinhado no v. 5 e 6, "sonhar" - estudo do estilo: artifício/repetição:

Divina e mimosa...

Sonhar é ventura;

Deixai-me sonhar!

P. 101:

Nota MA: termo sublinhado nos v. 33, 34 e 37, "cintura", e fio ligando as três ocorrências - estudo do estilo: artifício/repetição:

Emquanto apertava a ligeira cintura,

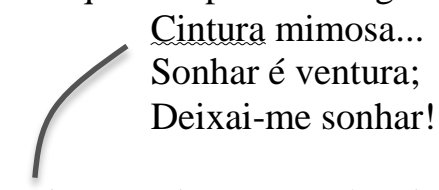

Cintura mimosa! - depois vos tecia

Grinalda que a fronte vos fosse adornar,

$\underline{\text { P. } 105-106}$

A UM POETA EXILADO (10 estrofes)

P. 105:

Nota MA: termo sublinhado no v. 15, "sonorosos", e escólio "dic" - pesquisa para o Dicionário musical brasileiro:

Os filhos de Minerva, novos cysnes, Que a fonte dos amores meigos cria, E alguns de Lysia sonorosos vates, "dic"

Sisudos mestres;

P. 106-110

PALINODIA (25 estrofes) 
Nota da pesquisa: O poema é incluído por MA entre as "Obras-primas" de Gonçalves Dias, no fichamento crítico que integra o dossiê do manuscrito Amor e medo (MA-MMA-0504).

P. 107:

Nota MA: v. 21-32 destacados por colchete - estudo da psicologia: sinceridade:

Mentistes quando amor tinheis nos labios,

Mentistes a compor meigos sorrisos,

Mentistes no olhar, na voz, no gesto...

Fostes bem falsa!

Falsa, como a mulher que em bruta orgia

Finge extremos de amor que ella não sente,

E o rosto off'rece a osculos vendidos,

Ao sigillo da infamia.

Quantas vezes, Senhora, não cahistes

Humilhada, a meus pés, desfeita em pranto,

Chorando - e que choraveis? - a jurar-me...

- Que juraveis então?

Nota da pesquisa: MA remete a esta página, em "Amor e medo", como exemplo da infidelidade atribuída pelo eu lírico à mulher amada (In: Aspectos da literatura brasileira. Ed. cit., p. 215).

P. $110-112$

Os SUSPIROS (8 estrofes)

P. 112:

Notas MA:

1. verbo sublinhado no v. 49, "amo", cruzeta e exclamação;

2. termos sublinhados no v. 51, "nota harmoniosa", escólio "dic" - pesquisa para o Dicionário musical brasileiro;

3. fio ligando os v. 51 e 52 aos versos finais - estudo do estilo: artifício/repetição:

Eu amo ouvir teus suspiros, $\quad X$ !

Ó doce virgem mimosa,

/ $\left\{\begin{array}{l}\text { Como nota harmoniosa, } \\ \text { Como um cantico de amor! }\end{array}\right.$

Mais do que a flôr entre as vagas

Sem destino fluctuando,

Folgo de os ver expirando

Em labios de rubra côr.

Mais que a longinqua harmonia,

Que o alento fraco, incerto,

Que o diamante coberto 


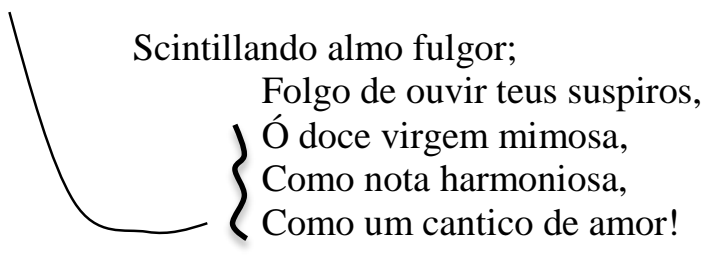

P. $113-116$

QUEIXUMES (27 estrofes)

\section{P. 113:}

Notas MA:

1. termo sublinhado nos v. 23 e 24, "braços" - estudo do estilo: artifício/repetição;

2. expressão sublinhada nos v. 31 e 32, "mais a mim" - estudo do estilo: artifício/repetição:

Inda chóro essa noite medonha,

Longa noite de má despedida!

Teu amor me deixaste nos braços,

Nos teus braços levaste-me a vida!

Oh! cruel, que então foste commigo,

Que te hei feito que punes-me assim?

Teu navio que tantos levava,

Não podia levar mais a mim?

Mais a mim! - que importava que eu fosse?

Não me ouvira a tormenta chorar,

E morrer me seria mais doce

Junto a ti, — que o meu triste penar!

P. 114:

Nota MA: termos sublinhados nos v. 59 e 60, "decantando" e "modas", e escólio "dic" pesquisa para o Dicionário musical brasileiro:

Quando vires passar a Andaluza

Pelos montes, com ar magestoso,

Decantando nas modas de que usa "dic dic"

As loucuras do Cid amoroso;

P. 116:

Nota MA: v. 107-110 destacados por traço ondulado, assim como os v. 119-122, idênticos - estudo do estilo: artifício/repetição:

Oh! que o homem fosse eu, mulher tu fosses,

Ou fosse tempestade ou calmaria,

Ou fosse mar ou terra, Hespanha ou Grecia,

Só de ti, só de ti me lembraria! 
P. 116-118

AO ANNIVERSARIO DE UM CASAMENTO (10 estrofes)

P. 116-117:

Nota MA: v. 1-4 destacados por traço ondulado, assim como os v. 29-32, idênticos - estudo do estilo: artifício/repetição:

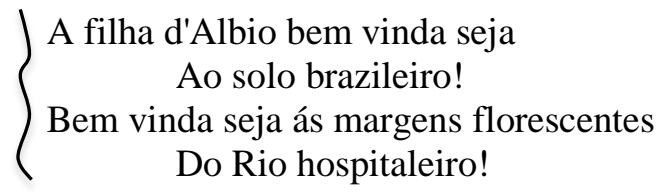

$\underline{\text { P. } 121-125}$

NENIA (22 estrofes)

P. 121:

Nota MA: título sublinhado e escólio "dic” - pesquisa para o Dicionário musical brasileiro.

P. $125-127$

OLHOS VERDES (7 estrofes)

Nota da pesquisa: Livre de notas de margem, o poema é referido por MA, em "Amor e medo", para completar a caracterização da "filosofia pessimista" de Gonçalves Dias no que diz respeito ao amor: "E de fato, si ainda morre por amar nos versos do Protesto e dos Olhos Verdes: a morte de amor lhe percorre toda a parte mais consciente, mais conceptiva da ficção, o teatro, ruim teatro." (In: Aspectos da literatura brasileira. Ed. cit., p. 216).

P. 128-129

CUMPRIMENTO DE UM VOTO (8 estrofes)

P. 128:

Notas MA:

1. termo sublinhado no v. 4, "cythara", escólio "dic" e seta até o próximo escólio pesquisa para o Dicionário musical brasileiro:

Será mudo o cantor, nem ha de aos echos

"dic" A cythara incivil fallar de amores?

2. termo sublinhado no v. 21, "toada", e escólio "dic" - pesquisa para o Dicionário musical brasileiro:

"dic" E a meiga toada

Repetem aos echos do bosque sombrio. 
P. 131-134

A PASTORA (14 estrofes)

P. 132:

Nota MA: v. 25-30 destacados por traço ondulado - estudo do estilo: artifício/repetição:

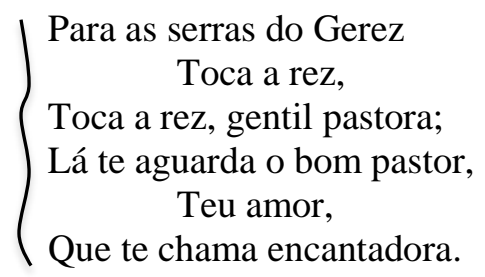

P. 133:

Nota MA: termo sublinhado no v. 63, "motetes", e escólio “dic" - pesquisa para o Dicionário musical brasileiro:

Te dizem - será mentira -

Que lhe atira

Seus motetes muita vez; "dic"

P. 134:

Nota MA: v. 79-84 destacados por traço ondulado - estudo do estilo: artifício/repetição:

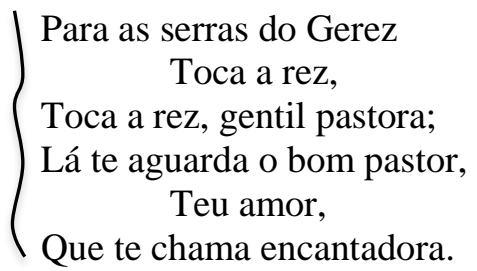

P. 139-140

MENINA E MoçA (5 estrofes)

P. 139:

Nota MA: termo sublinhado no v. 10, "musicos", e escólio "dic" - pesquisa para o Dicionário musical brasileiro:

É bella a virgem risonha

Com seus musicos accentos, "dic"

P. 141-143

COMO EU TE AMO (16 estrofes) 
P. 141:

Nota MA:

1. termo sublinhado no v. 18, "harmonia", e escólio "dic" - pesquisa para o Dicionário musical brasileiro:

2. v. 17-20 destacados por traço ondulado - estudo do estilo: artifício/repetição:

Como se ama o calor e a luz querida,

A harmonia, o frescor, os sons, os céus, "dic

Silencio, e côres, e perfume, e vida, por musica"

( Os pais e a patria e a virtude e a Deus:

P. 142:

Nota MA:

1. v. 37 destacado por traço ondulado - estudo do estilo: artifício/repetição:

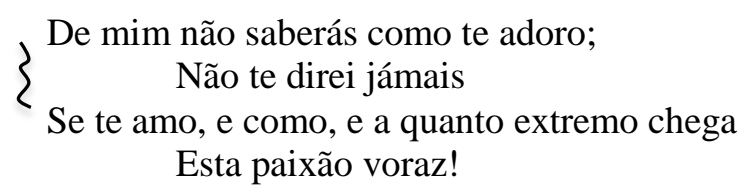

2. v. 55 destacado por traço ondulado - estudo do estilo: artifício/repetição:

Mesmo lendo estes versos, que m'inspiras,

Não pensa em mim, dirás:

Imagina-o, si o pódes, que os meus labios

\{ Não t'o dirão jámais!

P. 143:

Notas MA:

1. expressão sublinhada nos v. 58 e 76, "canção singela", e fio ligando as duas ocorrências

- estudo do estilo: artifício/repetição:

Sim, eu te amo; porém nunca

Saberás do meu amor;

A minha canção singela

Traçoeira não revela

O premio santo que anhela

O soffrer do trovador!

[...]

E então dirás: "Objecto

Fui de santo e puro amor:

A sua canção singela,

Tudo agora me revela;

Já sei o premio que anhela

O soffrer do trovador. 
2. v. 80-83 destacados por traço ondulado, idênticos aos v. 17-20 - estudo do estilo: artifício/repetição:

$\left.\begin{array}{l}\text { “Amou-me como se ama a luz querida, } \\ \text { Como se ama o silencio, os sons, os céus, } \\ \text { Qual se amão côres e perfume e vida, } \\ \text { Os pais e a patria, e a virtude e a Deus!" }\end{array}\right\}$

Nota da pesquisa: MA invoca o poema como prova do "consolo de amor dentro da morte", recorrente, segundo ele, na obra de Gonçalves Dias: "Nesta poesia, a amada só saberá do grande amor do poeta, D'Arvers, depois da vida, quando estiver insexuada e angélica, nos lugares 'onde a luz nunca falece'." (“Amor e medo", In: Aspectos da literatura brasileira. Ed. cit., p. 215).

$\underline{\text { P. } 144-146}$

AS DUAS CORÔAS ( 9 estrofes)

P. 145:

Nota MA: termo sublinhado no v. 42, "modula", e escólio "dic" - pesquisa para o Dicionário musical brasileiro:

Mas o vate, quando soffre,

Modula em meigos accentos "dic"

Seus doridos pensamentos,

A sua interna afflicção;

$*$

P. $146-148$

HARPEJOS (9 estrofes)

P. 146:

Nota MA: título sublinhado e escólio "dic" - pesquisa para o Dicionário musical brasileiro.

P. 147:

Nota MA: termo sublinhado no v. 9, "harmonico", e escólio "dic" - pesquisa para o Dicionário musical brasileiro:

Tudo é silencio harmonico "dic"

E doce amenidade,

P. 148:

Nota MA: pronome sublinhado no v. 41, "te", e cruzeta - estudo linguístico: sintaxe/colocação pronominal:

$X \quad \underline{T e}$ vejo, te procuro, 
Teus mudos passos sigo, Emquanto, leve sombra, Fugindo vais de mi'!

P. $150-156$

VELHICE E MOCIDADE (31 estrofes)

P. 152: termo sublinhado no v. 58, "melodia", e escólio "dic" - pesquisa para o Dicionário musical brasileiro:

"Hoje existo sómente porque existes,

Desfructo outro viver que não vivia,

Quando escutão-te a voz os meus ouvidos, "dic" Como sons de celeste melodia.

P. 153:

Nota MA: verbo corrigido no v. 90, "falta" - correção tipográfica:

- Sinto que alento me falte, “ “

Que longe foge de mim;

P. 154:

Nota MA: v. 94 e 95 destacados por traço ondulado, assim como os v. 100-101 e v. 106107, idênticos - estudo do estilo: artifício/repetição:

Sinto minha alma rasgar-se

Por te deixar só assim;

Meu bom pai, como está breve

¿ Da tua filha o triste fim!

P. 155:

Nota MA: preposição sublinhada no v. 131, “p'ra”, e cruzeta - estudo linguístico: emprego de "para/pra":

"Anjo de amor e bondade,

Porque me deixaste assim!

Tu morta, e na sepultura

Que eu tinha aberto pr'a mim! $\quad X$

$\underline{\text { P. } 156-159}$

AS FLORES (7 estrofes)

P. 156:

Nota MA: v. 15 e 20 destacados por traço ondulado - estudo do estilo: artifício/repetição:

\Meigas flôres gentis, quem vos não ama? 
Em vós inspirações o bardo encontra, Devaneios de amor a ingenua virgem, A abelha o mel, a humanidade encantos, Odores, nutrição, balsamo e côres. \Meigas flôres gentis, quem vos não ama?

P. 157:

Notas MA:

1. preposição sublinhada no v. 24, "para", e cruzeta - estudo linguístico: emprego de "para/pra":

Para cingir com ella a fronte e a coma, $X$ Que os anos no passar não enrugárão,

2. termo sublinhado no v. 30, “c'rôa” - estudo do estilo: licenças poéticas:

Meiga c'rôa d'angelica pureza, $\quad X$

Ornamento da vida - que se rompe

3. v. 36 destacado por traço ondulado - estudo do estilo: artifício/repetição:

\Meigas flôres gentis, quem vos não ama?

Nota da pesquisa: Em nota de trabalho, no dossiê do manuscrito Castro Alves, MA planeja: "Reunir o caso de croa, do pra, dos decassila-/bos diminuidos ou aumentados de silaba / num capitulinho sobre as Licenças Poeticas / do Romantismo, bem como as rimas toantes e / deficientes. Nesse capitulo observar a tenden-/cia pro pra e considerações sobre a lingua/gem brasileira. G. Dias já é tempo que passa / como classico da lingua brasileira. Não a / formou porem está entre os precursores dela. / É classico nosso mais ou menos como Dom / Dinis o é da portuguesa. Não esquecer tam-/bem os esdruxulos contados com uma silaba / de menos, coisa muito usada por Castro Alves / mas que G. D. me parece que não empregou" (MA-MMA-26-09).

P. 158:

Notas MA:

1. v. 58 destacado por traço ondulado - estudo do estilo: artifício/repetição:

\Meigas flôres gentis, quem vos não ama?

2. termo sublinhado no v. 60, "guzla", e escólio "dic" - pesquisa para o Dicionário musical brasileiro:

Respeitosa e cruel lhe espreita os gestos:

"dic" Chora a guzla mourisca ao som dos ferros,

3. v. 79 sublinhado e fio ligando ao comentário;

4. v. 81 destacados por traço ondulado - estudo do estilo: artifício/repetição:

Bem-fadadas do sol, do amor bemquistas, 
O orvalho as cria, as lagrimas as murchão:

\Meigas flôres gentis, quem vos não ama?

"Verso parnasiano"

$\underline{\text { P. } 159-161}$

O QUE MAIS DÓE NA VIDA (9 estrofes)

P. 160:

Notas MA:

1. v. 7 sublinhado, expoente “(1)”, remetendo ao comentário no rodapé, e fio ligando-o aos v. 13,19 e 25 ;

2. v. 20 sublinhado e número " 7 " - estudo da versificação: métrica;

3. v. 25 sublinhado e expoente “(1)”, remetendo ao comentário no rodapé - estudo da versificação: métrica;

4. v. 31 sublinhado e juízo de valor - estudo do estilo:

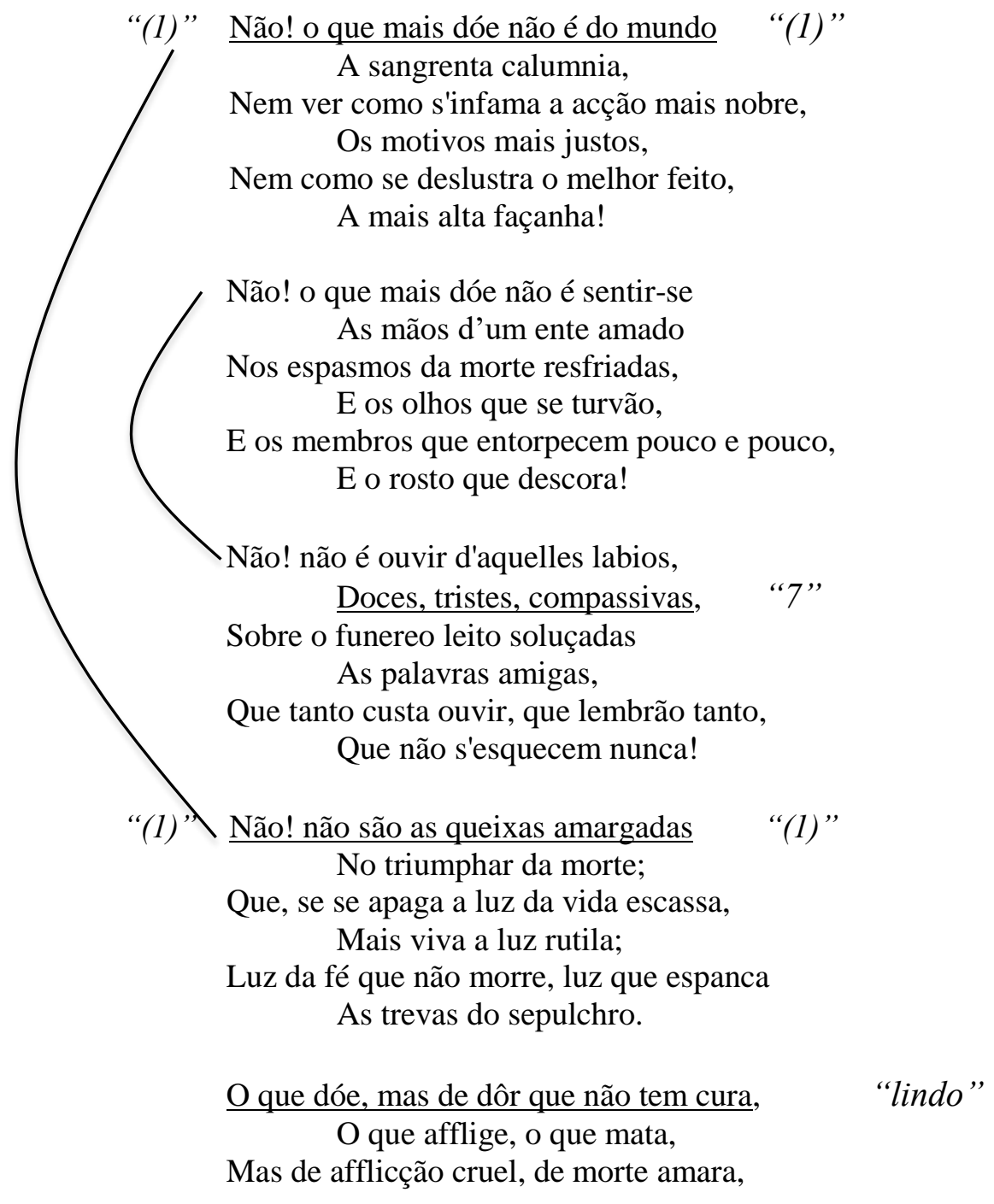




$$
\text { ( } \begin{gathered}
\text { É morrermos em vida } \\
\text { No peito da mulher que idolatramos, } \\
\text { No coração do amigo! }
\end{gathered}
$$

"(1) Decassilabo sem a silaba inicial, ou milhor / a $2^{a}$ silaba, devido ao intenso silêncio contado / como silaba apos o não interjectivo inicial."

Nota da pesquisa: Os versos assinalados por MA - em especial o v. 31 - justificam a indicação desta página no fichamento crítico sob a rubrica "Pedaços belos" (MA-MMA05-04). O traço vertical, destacando os três versos finais, deve estar ligado à interpretação de MA quanto à natureza schopenhauriana do sentimento amoroso em GD, conforme aponta em "Amor e medo".

P. 161-163

FLÔR DE BELLEZA (6 estrofes)

P. 161:

Nota MA: expressões sublinhadas nos v. 7 e 8, "n'uma hora" e "n'outra hora" - estudo do estilo: artifício/repetição:

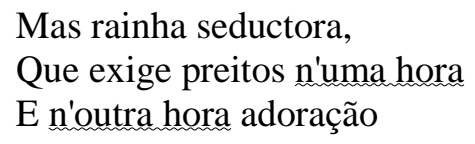

P. 162:

Notas MA: expressões sublinhas nos v. 11 e 12, "que a renderem-te" e "Beijárão-te" estudo linguístico: sintaxe/colocação pronominal:

Fôras rainha! e ditosos

Teus vassallos extremosos, Que a renderem-te seus preitos $\quad X$

Beijárão-te a nivea mão.

P. 163:

Nota MA: comentário ao final do poema:

"Notar a tendencia pra fabordão que tem / G. Dias. Como as mesmas rimas se repe-/tem proxitalmente ou inconscientemente / dentro da mesma poesia."

$\underline{\text { P. 163-164 }}$

O ANJO DA HARMONIA (9 estrofes)

P. 164:

Notas MA:

1. v. 21 e 22 destacados por traço vertical; 
2. termo sublinhado no v. 22, "harmonia", e escólio "dic" - pesquisa para o Dicionário musical brasileiro:

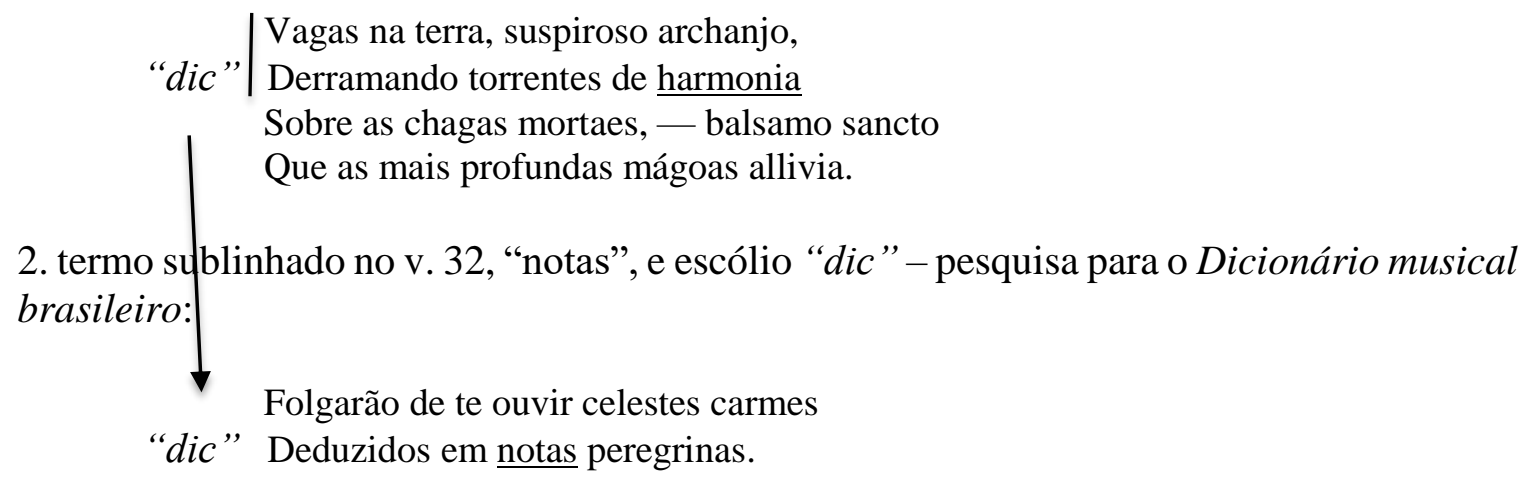

3. trecho sublinhado nos v. 35 e 36 - seleção de ideias:

E dirão: - Nunca ás plagas do infinito

Subiu mais terna voz, mais fresca e pura!

Se o corpo é de mulher, sua alma é vaso

$\underline{\text { Onde o incenso de Deus se afina e apura. }}$

$\underline{\text { P. } 165-166}$

A Historia (4 estrofes)

P. 165:

Nota MA: termo sublinhado no v. 26, "mumia", e escólio "mumía” - estudo linguístico:

pronúncia:

E qual do Egypto nos festins funereos,

Maldizem bons e máos sua memoria,

Lançando á face da real mumia "mumía"

Dos crimes seus a lacrymosa historia.

P. 166:

Nota MA: trecho sublinhado nos v. 36-38 e escólio “Historia” - seleção de ideias:

Além golfeja sangue e súa crimes.

Tal foi, tal é retrato desbotado

Onde se mira a geração que passa,

Sem côr, sem vida, - e ao mesmo tempo espelho,

"Historia"

Que há de ser nova cópia á gente nova,

Como os annos aos annos se succedão:

Ondas de mar sereno ou tormentoso,

As mesmas na apparencia, que se quebrão

Sobre as d'areia fluctuantes praias.

$\underline{\text { P. } 166-167}$ 
A CONCHA E A VIRGEM (6 estrofes)

P. 167:

Notas MA:

1. v. 23 e 24 sublinhados - estudo do estilo: artifício/repetição:

- Vais onde te leva a sorte,

$\mathrm{Eu}$, onde me leva Deus:

Buscas a vida, - eu a morte;

Buscas a terra, - eu os céus!

2. comentário:

"Das mais perfeitas canções do Romantismo / e dos melhores empregos de ideas paralelas I e antiteses que conheço. V. Hugo nada fez tão / puro e belo. Sempre fabordão ainda."

Nota da pesquisa: O poema converge para o fichamento crítico, no dossiê do manuscrito Amor e medo, sob a rubrica “G. D. cantador" (MA-MMA-05-04).

$\underline{\text { P. } 167-168}$

SEI AMAR (10 estrofes)

P. 168:

Nota MA: v. 18 sublinhado e escólio "Parnasianismo" - estudo da versificação: enumeração:

Nem corre o seu volatil pensamento, Quando fallo, a pensar n'outros amores, N'outra voz, n'outros sons, n'outro momento.

"Parnasianismo"

Nota da pesquisa: Os versos "Porém, que fosse minha, e que eu soubesse / Que os labios que beijei são meus sómente, / Nem pensa em outro, nem de mim se esquece" representam bem as preocupações do eu lírico com a infidelidade da mulher amada. O comentário de MA sobre esse ponto, em "Amor e medo", remete ao poema (In: Aspectos da literatura brasileira. Ed. cit., p. 215).

$\underline{\text { P. } 168-169}$

AMANHÃ (7 estrofes)

P. 169:

Nota MA: escólio “Fabordão” ao final do poema - estudo do estilo: fabordão.

$\underline{\text { P. } 170-172}$

POR UM AI (15 estrofes) 
P. 170:

Nota MA: termo sublinhado no v. 13, “olhos" - estudo do estilo: artifício/repetição:

Meus olhos sobre os teus olhos,

Meu coração a teus pés;

Por um olhar que me deites,

Por um só ai que me dês:

P. 171:

Nota MA: v. 49-56 destacados por colchete - estudo da psicologia / da criação: sinceridade:

Não quero palavras falsas,

Não quero um olhar que minta,

Nenhum suspiro fingido,

Nem voz que o peito não sinta.

Basta-me um gesto, um aceno,

Uma só prova, - e verás

Minha alma, presa em teus labios,

Como de amor se desfaz!

$\underline{\text { P. } 172-173}$

PROTESTO / IMITAČÃO DE UMA POESIA JAVANEZA (10 estrofes)

P. 172:

Nota MA: subtítulo sublinhado e expoente “(1)”, remetendo ao comentário no rodapé:

“(1) Poeta de inteligencia: Imita; escolhe estilos pra / versejar (Sextilhas) etc; Escolhe indianismo, não como / C. Alves escolheu a escravidão por sentimento, porem por / inteligencia"

Nota da pesquisa: Com o trecho assinalado, MA abona a rubrica "Poeta de inteligencia", no fichamento crítico que compõe o dossiê do manuscrito Amor e medo (MA-MMA-0504).

P. 173:

Nota MA: v. 39-40 destacados por colchete e juízo de valor ao final do poema:

Se pois souberes que os meus dias findão, Não creias que o destino inexoravel

M'os corta - antes me tem, antes me julga

Morto por ti de amores!

\section{"Lindo"}


Nota da pesquisa: Em "Amor e medo", MA refere o poema para mostrar a inclinação do eu lírico pela morte na obra de Gonçalves Dias (In: Aspectos da literatura brasileira. Ed. cit., p. 216).

P. 173-175

FADARIO (8 estrofes)

P. 175:

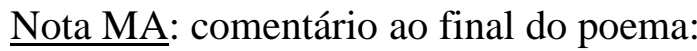

"Estupendo como é cantande, como é / modinha e como as imagens embora / um pouco molgadas [?] vem artisticamente / retornando pros diversos aspectos da suposi-/ção do poeta. Aqui as imagens é que fazem refrão."

$\underline{\text { P. } 176-178}$

O ASSASSINO (8 estrofes)

P. 176:

Nota MA: trecho sublinhado no v. 14:

Quando os labios descerra, só murmura

Frases, cujo sentido não se alcança,

Ou blasfemias a Deos, que o soffre em vida!

P. 175:

Nota MA: comentário ao final do poema:

"Carece ter a coragem de dizer que isto é / esplendido, perfeitamente bem dito, em-/bora irrite a nossa inteligencia desabusada / de modernos. Estes versos são perfeitos. Uma / eloquencia natural, candente, uma psicolo-/gia daquele tempo mas duma moral / energica e por isso mesmo... enternecedo-/ra. Não vale nada nem corrigirá nenhum / que tenda pra assassino. Não mexe na / alma da gente mas é perfeitamente belo / no tempo. Tudo isto revela alias a profunda / leitura de portugueses que G. Dias tinha. Isto / não é nada brasileiro, é profundamente por-/tuga e se nota que artificial embora o poeta / o pudesse imaginar sentido. O que interessa é / notar a arte perfeita desses versos, a nobreza / de expressão, o equilibrio, a desenvoltura da / frase culta e puramente tradicional. G. Dias era / um grandissimo artista mais que tudo. E / baste prá gente verificar que nem Castilho nem / Herculano escreveram versos mais perfeitos que / esses."

$\underline{\text { P. } 178-179}$

A UNS ANNOS (6 estrofes)

P. 179: 
Nota MA: preposição sublinhada no v. 21, "p'ra”, fio, cruzeta e comentário - estudo linguístico: emprego de "para/pra":

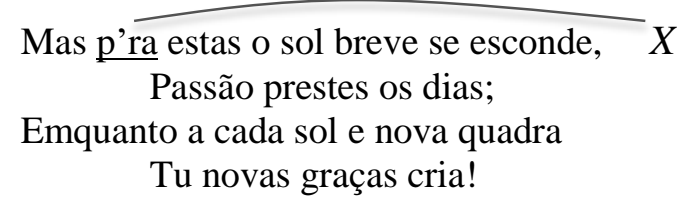

"Notar por este pra que G. Dias / dizia pra que evita nos seus versos artisticos / mas que emprega nestes versos de circuns-/tancia. Não lhes quis tirar a naturalidade fami-/liar e empregou pra."

Nota da pesquisa: No dossiê do manuscrito Castro Alves, MA planeja um capítulo sobre as "Licenças Poéticas do Romantismo": "Nesse capitulo observar a tenden-/cia pro pra e considerações sobre a lingua-/gem brasileira. G. Dias já é tempo que passa / como classico da lingua brasileira. Não a / formou porem está entre os precursores dela. / É classico nosso mais ou menos como Dom / Dinis o é da portuguesa" (MA-MMA-26-09).

P. 179-184

QUANDO NAS HORAS (29 estrofes)

P. 182:

Nota MA: termo sublinhado no v. 70, "trompa", e escólios "dic" e "Juizo final" - pesquisa para o Dicionário musical brasileiro:

E quando o anjo espedaçar as campas

Ao som da trompa de fragor horrendo, "Juizo Final”

Que ha de o lethargo despertar dos mortos

Na vida eterna,

P. 183:

Notas MA:

1. acréscimo no v. 93 - correção tipográfica:

Prazer não acho de avistar $a$ lua

Pallida e bella na soidão do espaço;

2. termos sublinhados nos v. 110, 111 e 112, "meigos", "labios" e "meigos labios" - estudo do estilo: artifício/repetição:

Mas já que os olhos sobre mim pousaste,

Teus meigos olhos, donde o amor lampeja;

Pois que os teus labios para mim se abrírão,

Teus meigos meigos labios.

P. 184:

Notas MA: expoente “(1)” no v. 120, remetendo ao comentário no rodapé: 
Já posso a vida supportar, já devo

Soffrer o peso da existencia inutil;

Já do passado e do porvir me esqueço,

E o meu presente de te amar se ameiga. "(1)"

“(1) Este poema incontestavelmente belissimo / sobretudo na $2^{a}$ parte consegue convencer de / que é sincero tal a força de convicção de / sua obra bela. Em parte talvez a insin/ceridade temática que se nota em G. Dias / provenha de ter ele expresso os seus / sentimentos romanticos numa lingua / arcade embora sem os tropos nem as / imagens arcades. Tudo o que se extereotipa / é mais ou menos insincero ao menos na / aparencia. Porem não tem duvida que G. Dias / é tematico por demais ou que diverge essencial-/mente de Alvares de Azevedo e Casemiro."

Nota da pesquisa: Os versos assinalados e o comentário são recolhidos à rubrica "Poeta de inteligencia", no fichamento crítico das obras de Gonçalves Dias (MA-MMA-05-04).

P. $184-186$

RETRACTAÇão (13 estrofes)

Nota da pesquisa: MA elenca o poema entre os exemplos da preocupação constante com a infidelidade da mulher na poesia de Gonçalves Dias ("Amor e medo", In: Aspectos da literatura brasileira. Ed. cit., p. 215).

P. 185 :

Notas MA:

1. comentário aos v. 29-32:

"Artificial, artificial, be-/lissimo!"

2. termo sublinhado no v. 35, "resôa" e escólio "dic" - pesquisa para o Dicionário musical brasileiro:

Feliz o doce poeta,

Cuja lyra sonorosa

Resôa como a queixosa, "dic"

Trépida fonte a correr;

Que só tem palavras meigas,

Brandos ais, brandos accentos,

Cuja dôr, cujos tormentos

Sabe-os no peito esconder!

P. 186:

Nota MA: expressão sublinhada nos v. 45-47, "que lhe não deu" - estudo linguístico: sintaxe/colocação pronominal / estudo do estilo: artifício/repetição: 
Que lhe não deu sua lyra,

Que lhe não deu seus cantares,

Que lhe não deu seus pezares,

Nem junto della quedou!

$\underline{\text { P. } 187}$

ANHELO (6 estrofes)

P. 187:

Nota MA: termo sublinhado nos v. 13, 14, 17 e 21, "c'rôa", cruzetas e comentário -

Que outra c'rôa melhor, que outra mais pura $\quad X$

Que uma c'rôa d'amor em fronte virgem?! $\quad X$

Não pesa sobre a fonte, não esmaga,

Não punge o coração, — é toda amores!

Que outra c'rôa melhor, que outra mais bella

Que a aureola, que Deos concede aos vates?

Com sorriso de amor, talvez com pranto,

Cede-a o vate á mulher que mais o inspira!

Eu t'a cedo, eu t'a dou! C'rôo-te, imagem $\quad X$

Resplendente, invejada entre as mulheres; Um beijo só de amor tu me concedas,

Um suspiro sequer do peito exhales.

"Horrendo por causa do português Croa. 11 vez passa mas 4!”

P. 188

QUE ME PEDES? (4 estrofes)

\section{Notas MA:}

1. termo sublinhado no v. 2, "trovar", e escólio "dic" - pesquisa para o Dicionário musical brasileiro;

2. termo sublinhado nos v. 3 e 4, "triste" - estudo do estilo: artifício/repetição:

Tu pedes-me um canto na lyra de amores,

"dic" Um canto singelo de meigo trovar?!

Um canto fagueiro já — triste — não póde

Na lyra do triste fazer-se escutar.

3. termo sublinhado no v. 16, "trahido", estrofe destacada por traço vertical e escólio "Fabordão" - 


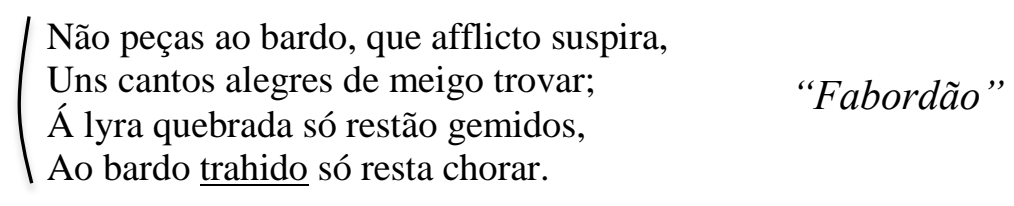

Nota da pesquisa: A aflição do bardo "trahido" justifica MA no arrolar esta página como exemplo da infidelidade atribuída "frequentissimamente" à mulher, na poesia de Gonçalves Dias (“Amor e medo", In: Aspectos da literatura brasileira. Ed. cit., p. 215).

$\underline{\text { P. 189-191 }}$

O CIUME (12 estrofes)

P. 189:

Nota MA: estrofes destacadas por colchete - estudo da psicologia e do folclore: dona ausente / estudo :

Ou balançada n'um ligeiro barco, Que de um lago tranquillo as aguas frisa Soltando a voz ás brisas namoradas, Que de te ouvir suspirão;

Ou n'uma bronca penha descalvada O mar e os céos contemples pensativa, E a redeas sôltas do pensar divagues

Nos campos do infinito;

P. 190:

Nota MA: v. 60-65 destacados por traço vertical - estudo da psicologia: sentimento amoroso:

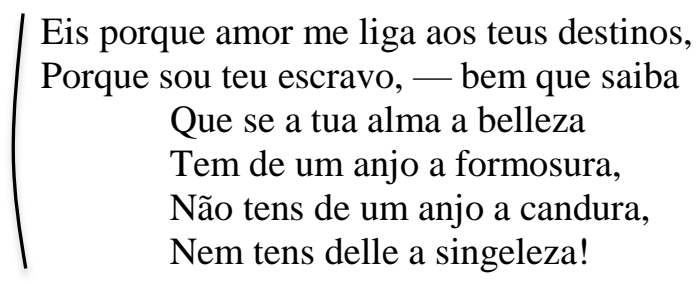

Nota da pesquisa: Os indícios vagos - "Não tens de um anjo a candura / Nem tens delle a singeleza" - não impedem MA de incluir esta página como exemplo de que o eu lírico "acha frequentissimamente que a mulher é infiel" ("Amor e medo", In: Aspectos da literatura brasileira. Ed. cit., p. 215).

P. 191:

Notas MA:

1. v. 71 sublinhado e expoente "(1)", remetendo ao comentário na margem superior;

2. termo sublinhado no v. 72, "labios" - estudo do estilo: artifício/repetição: 
Mas que importa este amor que me consome?

Eu quero sentir dôr;

Quero labios que entornem nos meus labios

Alento escaldador!

“(1) Eis bem uma verdade. G. Dias mais quis sentir / dor do que a sentiu realmente. A tristeza de G. Dias / é mais uma aspiração que uma realidade."

Nota da pesquisa: MA interpreta o trecho como exemplo de que Gonçalves Dias foi um "Poeta de inteligencia" (MA-MMA-05-04).

P. 191-192

A NuVEM DOIRADA (4 estrofes)

P. 192:

Nota MA: termo sublinhado no v. 14, "lyra" - estudo do estilo: artifício/repetição:

Por isso quem ama, quem sente no peito

Cantar-lhe das lyras a lyra melhor,

Os carmes lhes ouve, que os bardos só cantão

Saudades, perfumes, enlevos e amor!

P. 192-197

SONHO DE VIRGEM (20 estrofes)

P. 193:

Notas MA:

1. termo sublinhado no v. 19 e comentário - estudo do estilo:

Que faz a donzella,

Que scisma, ou medita?

Talvez lá cogita

Fruir algum bem;

Então porque chora?

Se curte agras dôres

D'ingratos amores,

$\mathrm{O}$ riso a que vem?

"! um dos raros des-/cuidos do poeta, que / varias vezes aparece”

2. expressão sublinhada no v. 26, "que ri-se" - estudo linguístico: brasileirismo/colocação pronominal:

Semelha a donzella,

Que ri-se e que chora, 
Nota da pesquisa: MA classifica como brasileirismo, no manuscrito d'A gramatiquinha da fala brasileira (MA-MMA-51-66), o exemplo "Que havendo-lhe", encontrado em Ambrósio Fernandes Brandão: Diálogos das grandezas do Brasil. Introdução de Capistrano de Abreu e notas de Rodolpho Garcia (Rio de Janeiro: Publicações da Academia Brazileira - II Historia/Officina Industria Graphica, 1930. V. ALMEIDA, Aline Novais de. Op. cit., p. 244, vol 1).

P. 194:

Nota MA: expressão sublinhada nos v. 38 e 48, "Virgem, virgem de amor", fio ligando as duas ocorrências e anotação na margem superior - estudo do estilo: artifício/repetição:

"Rosa, rosa de amor"

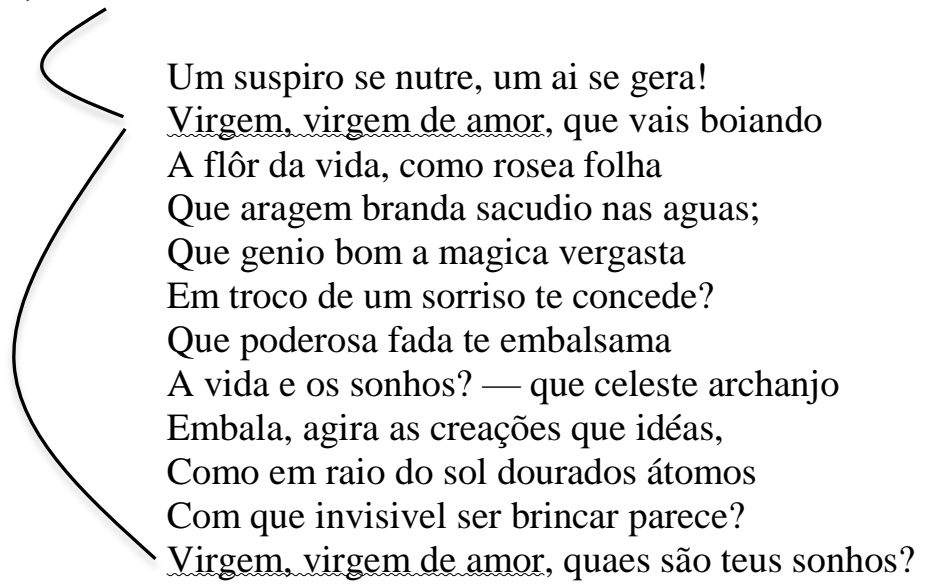

P. 197:

Nota MA: comentário ao final do poema:

"G. Dias vai firmando a metrica do seu verso / e a norma ritmica das suas estancias não / como diz no prefácio conforme a necessidade / de expressão porem pela metrica que lhe brota / naturalmente no momento, dentre as que conhece / e usa. / D'ai essa / variedade / ritmica / que usa den-/tro dum mes-/mo poema e que lhe enri-/quece o mo-/vimento da poesia. / Fica bem compara-/vel não apenas á diversidade de movi-/mentos musicais, sonata, suite, mesmo peças / curtas, mas ás vezes é mesmo um verdadei-/ro rubato."

\section{$\underline{\text { P. } 197-198}$}

MEU ANJO, ESCUTA (4 estrofes)

P. 198:

Nota MA: comentário ao final do poema:

"Aqui já muito amaneirado, embora curio-/so como união ritmica de metros. / Fabordão."

P. 199: 
Nota MA: v. 31-36 destacados por colchete - estudo da psicologia / criação: sinceridade:

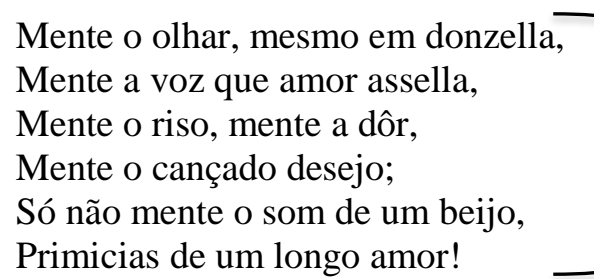

Nota da pesquisa: Esta página é mencionada por MA, em "Amor e medo", como prova da frequência com que o eu lírico julga infiel sua amada (In: Aspectos da literatura brasileira. Ed. cit., p. 215).

P. 201-203

DESESPERANÇA (7 estrofes)

P. 202:

Nota MA: preposição sublinhada no v. 18, "p'ra”, e cruzeta - estudo linguístico: emprego de "para/pra":

Via o mundo ao travez dos meus prantos

A sorrir-se p'ra mim caroavel, $\quad X$

P. 203-205

SE QUERES QUE EU SONHE (9 estrofes)

P. 205:

Nota MA: v. 41-45 destacados por colchete, termo sublinhado no v. 44, "mentido", e comentário ao final do poema:

Vem junto ao meu leito, quando eu fôr dormido,

Que eu sinta os perfumes que exhalas passando;

Não soffro - direi:

E ao menos nas azas de um sonho mentido,

Perdido - arroubado, talvez diga: - amei! -

"Como sempre bonito. Refrão. A tristeza de G. Dias / é principalmente tematica e insincera por-/que não é maior que a da infinita gene-/ralidade dos mortais. Viver é sofrer. (Ver / papel de notas em $\odot$ "

Notas da pesquisa:

1. Último exemplo recolhido por MA para embasar sua avaliação de que Gonçalves Dias foi "Poeta de inteligencia" (MA-MMA-05-04).

2. No dossiê do manuscrito Castro Alves, onde estão reunidos os apontamentos para o livro inacabado Lirismo romântico no Brasil, o f. 9 - caracterizando-se como marginália apensa - dá seguimento ao comentário: "Continuação á nota do G. Dias I, 205 = G. Dias não / 
pode ter aquela tristeza sinistra de Alvares de Aze-/vedo, tristeza maior que a comum proveniente / dum tedio pavoroso duma antevisão da morte, / duma total incapacidade de organizar a vida / pelo ideal. [...] A vida / de G. Dias não foi a incorreta sucessão de fes/tas de lupanar, e amores comprados que nem / a de Alvares de Azevedo, nem era um femeeiro / inconstante e igualmente apaixonado em cada / amor sucessivo que nem Castro Alves. G. Dias / não tem do romantismo-vida aquele transbor-/damento de sentimentos e vontades que trazia / traz necessariamente o desequili-/brio, a vida contrastada e os grandes sofrimen-/tos pela oposição entre realidade e ideal. Era / um homem organizado dentro da vida dele, sofreu / amores, sofreu falta de dinheiro, sofreu a idea / de patria, mas esses sofrimentos eram pro seu / espirito organizado e instruido, motivos de / contemplação, de verificação, de observação. Os / seus sofrimentos expressos na sua arte não / são sofrimentos vividos são sofrimentos / ideais. E daí a grandeza da sua arte que con-/segue nos comover pela sua transposição / artistica, puramente artistica, enormemente / artistica, mas insincera em relação ao movimento / lirico que nele foi sempre menor que a reali/zação ao passo que em Alvares de Azevedo, em / Casimiro era maior que a realização e em Castro / Alves se deformava expressionistamente na reali-/zação. (Mostrar que todo espirito maduro e desen-/volvido no estudo se liberta do sofrimento do / corpo e mesmo diminui a intensidade desses / sofrimentos porque vive aplicado ás astucias, aos / estudos e tem na propria vida vivida exemplos / e motivos de aprendizado mais que realidades de / existencia. A precisão de se libertar da inteligen-/cia erudita pra realmente gosar e sofrer. A sutile-/za e verdade do pensamento platonico de que o / sabio se liberta da dor e da alegria. Ante qual-/quer desamor, ante qualquer ausencia e nostalgia / o espirito culto contempla e em toda parte se / sente bem. A nostalgia de G. Dias afastado da / patria não podia ser tão intensa como a de / Casimiro e o não foi porquê G. Dias sábio e eru-/dito, inteligencia madura e desenvolvida se sen- / tiria bem em / toda parte. A propria grandeza da sua nostalgia patrio-/tica o prova. As coisas pequenas, diretamente presas á / nossa pessoinha dão sofrimentos mais grandes / que as grandes ideas e os grandes ideais cujo so/frimento apenas provem duma incapacidade de / solucionar. Notar pela tranquilidade com / que se manifesta quanto é contemplativa a / dor de G. Dias. Aliás ele proprio e admiravel/mente no Desalento mostra como recebe a dor / (grifo da pg 210) e toda a fala que está dentro / desse poema ainda mostra a tematização i-/dealista dos seus sofrimentos." (MAMMA-26-09).

3. Em "Amor e medo", MA refere esta página entre os casos de infidelidade atribuída à mulher pelo eu lírico de Gonçalves Dias (In: Aspectos da literatura brasileira. Ed. cit., p. 215).

\section{$\underline{\text { P. 205-208 }}$}

O BAILE (7 estrofes)

P. 206:

Notas MA:

1. expressão sublinhada nos v. 23, 31 e 41, “Triunfo ás bellas!" - estudo do estilo: artifício/repetição;

2. v. 23-31 destacados por traço vertical e comentário: 
Triunfo ás bellas! o prazer começa:

Correm nas taças vinhos espumosos,

Gratos licores;

Tangida pela mão dos Trovadores

Desfaz-se a lyra em sons melodiosos, Em cantico de amores.

Soltão mais viva luz as brancas velas, Melhor perfume as flôres.

Activa-se o prazer; triunfo ás bellas!

Aqui, alli, além, pnil rostos meigos,

Da valsa ao gyro rapido se mostrão,

De gemmas ennastrados os cabellos;

E o peito que anhelante

Palpita entumecido

Nas ondas de prazer ebrifestante,

D'um leve colorido

Banha o semblante,

Que mais e mais co'a noite se enrubece:

Triunfo ás bellas, —o prazer recresce!
"Estupenda-/mente

artis-/tico. / Raimundo.”

P. 207:

Nota MA: termos sublinhados nos v. 58 e 61, "devora" e "devoradora" - estudo do estilo: artifício/repetição:

Então digo entre mim: - Talvez aquella,

Que tem melhores côres,

Que mais lêda se mostra,

Que mais feliz no gesto se revela,

Sente mais finas dôres;

$\mathrm{O}$ intimo desgosto,

A febre que a devora

Lhe dá calor ao rosto,

E no silencio chora,

Presa de uma afflicção devoradora.

P. 208:

Nota MA: comentário / planejamento ao final do poema:

“Obra-prima. Perfeito nas suas duas partes. / Analisar êste poema."

Nota da pesquisa: A rubrica "Obras-primas", no fichamento crítico das obras de Gonçalves Dias, confirma o comentário da marginália e guarda referência ao poema (MA-MMA-0504).

P. 208-211

DESALENTO (13 estrofes) 
P. 210:

Nota MA: v. 67-72 destacados por traço vertical triplo - estudo da psicologia: dor:

Mal aceito conviva me despeço!...

As calumnias que soffro, a dôr que passo,

Não me ferem profundas;

Bem como a rôla que das matas desce,

E nas azas recebe o pó da estrada,

Que voando sacode.

Notas da pesquisa:

1. A rubrica "Obras-primas", no fichamento crítico das obras de Gonçalves Dias, inclui referência ao poema (MA-MMA-05-04).

2. MA aproveita o trecho assinalado em nota de trabalho/marginália apensa, no dossiê do manuscrito Castro Alves. Ao esboçar as ideias para o livro Lirismo romântico no Brasil, comenta: "As coisas pequenas, diretamente presas á nossa pessoinha dão sofrimentos mais grandes que as grandes ideas e os grandes ideais cujo sofrimento apenas provem duma incapacidade de solucionar. Notar pela tranquilidade com que se manifesta quanto é contemplativa a dor de G. Dias. Aliás ele proprio e admiravelmente no Desalento mostra como recebe a dor (grifo da pg 210) e toda a fala que está dentro desse poema ainda mostra a tematização idealista dos seus sofrimentos." (MA-MMA-26-09).

P. 211:

Nota MA: v. 73-78 destacados por traço vertical - estudo da psicologia: morte:

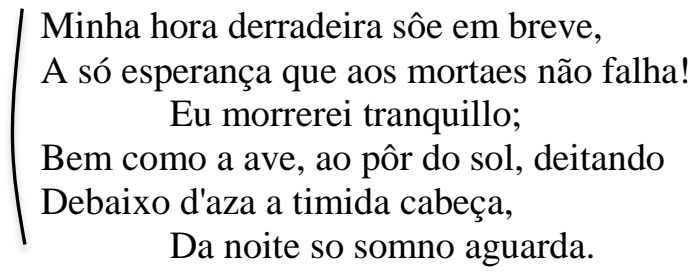

$\underline{\text { P. 211-213 }}$

A QUEDA DE SATANAZ - TRADUÇÃO (7 estrofes)

P. 212:

Nota MA: termo sublinhado no v. 44, "c'rôa", e cruzeta - estudo do estilo: vocabulário / licenças poéticas:

Que cheio d'impio orgulho já sentia

Uma c'rôa de rei cingir-lhe a fronte.

P. 213-216

CANÇÃO DE BUG-JARGAL - TRADUÇÃO (12 estrofes) 
P. 213:

Nota MA: expressão sublinhada nos v. 1 e 2, "porque me foges" - estudo do estilo: artifício/repetição:

Maria, porque me foges,

Porque me foges, donzella?

Minha voz! o que tem ella,

Que te faz estremecer?

P. 215:

Nota MA: termo sublinhado no v. 48, "c'rôa", e cruzeta - estudo do estilo: vocabulário / licenças poéticas:

Que de cabellos dava ares,

De c'rôa tendo o 'splendor

P. 216:

Nota MA: comentário / planejamento ao final do poema:

"Compara-la á tradução do mesmo trecho por / Castro Alves."

Nota da pesquisa: No exemplar das Obras completas de Castro Alves localizado na Biblioteca MA, o poema "Canto do Bug-Jargal" não contém comentários: MA sublinha termos para o Dicionário musical brasileiro e registra um sinal de interrogação à margem do substantivo "uragan" (Notas MA, In: ALVES, Castro. Obras completas. Edição crítica comemorativa do cincoentenário do poeta... com um retrato, introducção bibliographica e annotações de Afranio Peixoto. Rio de Janeiro: Francisco Alves, 1921, vol. 2, p. 58-59).

P. 218-226

AGAR NO DESERTO (42 estrofes)

P. 218:

Nota MA: expressão sublinhada no v. 59 e 60, “d'um lado areias" - estudo do estilo: artifício/repetição:

Pede sombra o triste infante;

Não ha sombra: - agora supplica;

Exhaurido o vaso fica,

Pede mais d'instante a instante...

Pobre escrava, oh! quanto dó!

Pudesse rasgar as veias,

Tornar agoas innocentes

Tuas lagrimas ardentes;

Mas só vês d'um lado areias,

D'outro lado areias só.

P. 220: 
Nota MA: v. 114 sublinhado:

Crescem, dominão; largo reino ingente

Mesquinha habitação presta a seus netos,

Convertida em nação a grei potente,

Que opprime a cerviz mobil dos desertos.

P. 222:

Notas MA:

1. v. 169 e 170 destacados por traço vertical - estudo da versificação: ritmo;

2. comentário ao final do poema:

Entrou e vio! mas o fulgor crastino

Ri-se mais brando aos peitos soffredores;

(( Passa o rei, como orvalho matutino,

( $\mathrm{E}$, por onde passou, rescendem flôres!

Mudando o sonho, a fugitiva escrava

Estranhos povos nota, estranhas terras,

Que o Darro ensopa e o Guadalete lava,

Nadando em sangue de cruentas guerras.

"Este sonho é perfeito. Notar a heroicidade da / mutação ritmica."

Nota da pesquisa: No mesmo sentido, MA inclui a passagem entre os "Pedaços belos" da obra de Gonçalves Dias, conforme o fichamento crítico que compõe o dossiê do manuscrito Amor e medo (MA-MMA-05-04).

P. 223:

Nota MA: termo sublinhado no v. 198, "c'rôa", e cruzeta - estudo do estilo: vocabulário / licenças poéticas:

Da nobre moça, - a c'rôa

Te cáe da fronte ao chão;

P. 224:

Nota MA: termo sublinhado no v. 248 , "c'rôa", e cruzeta - estudo do estilo: vocabulário / licenças poéticas:

Porém do largo imperio

De Cordova e Granada

A c'rôa cahe pesada

$\mathrm{Na}$ fronte amollecida

Do moço Boabdil.

P. 226:

Notas MA:

1. rima imperfeita sublinhada nos v. 286 e 289 e fio ligando - estudo da versificação: rima; 
2. comentário ao final do poema:

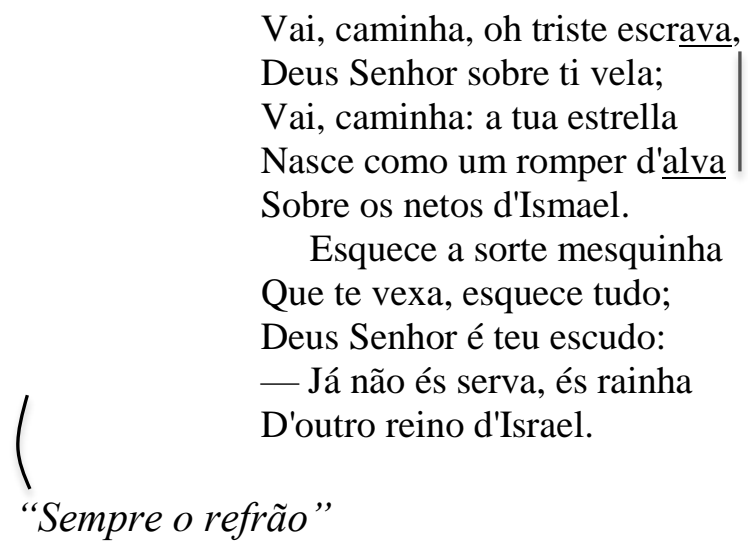

Vai, caminha, oh triste escrava,

Deus Senhor sobre ti vela;

Vai, caminha: a tua estrella

Nasce como um romper d'alva

Sobre os netos d'Ismael.

Esquece a sorte mesquinha

Que te vexa, esquece tudo;

Deus Senhor é teu escudo:

- Já não és serva, és rainha

D'outro reino d'Israel.

"Sempre o refrão"

$\underline{\text { P. 226-229 }}$

LAGRIMAS SEM DÔR - E DÔR COM LAGRIMAS (18 estrofes)

P. 227:

Notas MA:

1. expressão sublinhada nos v. 2633 e 46, “Anjo - encanto - mulher”, e fio ligando as três ocorrências - estudo do estilo: artifício/repetição:

2. termo sublinhado nos v. 27 e 28, "triste" - estudo do estilo: artifício/repetição:

3. termo sublinhado no v. 31, "pudesse" - estudo do estilo: artifício/repetição:

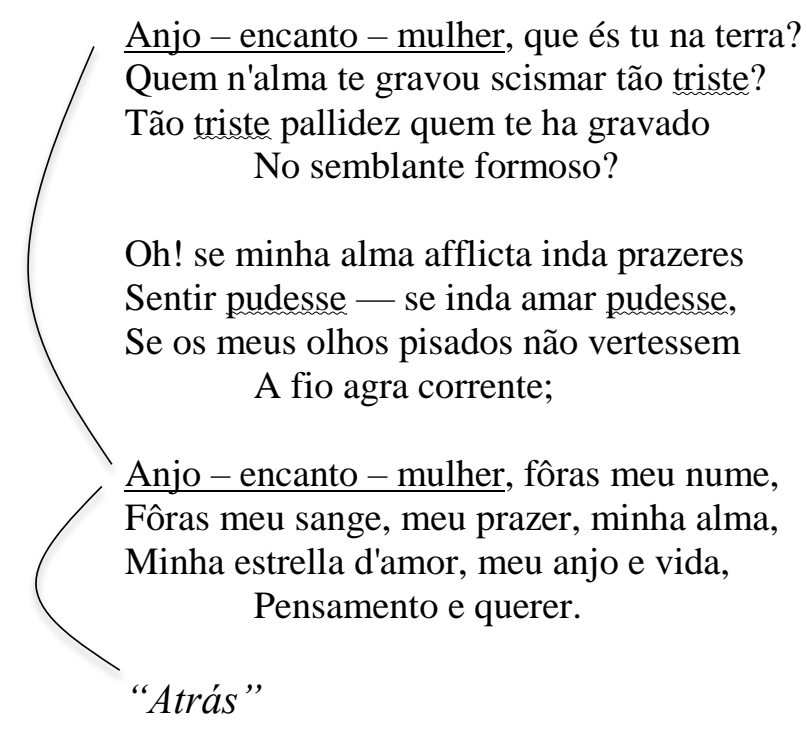

\section{P. 228:}

Notas MA:

1. expressão sublinhada no v. 46, "Anjo - encanto - mulher" - estudo do estilo: artifício/repetição:

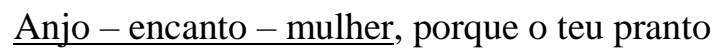


Corre agora espontaneo sobre as aguas

Do limpido regato, como lagrimas

De Náyade gentil?

2. expressão sublinhada no v. 56, "Não o fizera, não" - estudo do estilo / estudo linguístico: brasileirismo sintático:

Não o fizera, não, - que tal façanha

Não a faz coração d'homem, que sente,

Que vê taes graças;

P. 229:

Notas MA: v. 71-73 destacados por traço vertical e expoente “(1)”, remetendo ao comentário na margem superior - estudo da criação: sinceridade:

Ah! chora sempre e sempre; - corre o pranto

Espontaneo e fagueiro n'essa idade,

Como orvalho da noite;

Emquanto o máu blasfema, o bom soluça,

Alma do céo, folga em chorar sósinha
N'este exilio da terra.

“(1) Ver por aqui quanto a tristeza de G. Dias / é mais uma teoria romantica que realidade”

P. 229-232

MISERRIMUS (12 estrofes)

P. 229:

Nota MA: expressão sublinhada no v. 7, "nuvens trovejadas" - estudo do estilo: imagem:

Quando o inverno chegou, - por sobre a terra

O robre secular espalha a coma,

Que o rábido tufão cortou de morte.

Despida e núa jaz a flôr mimosa,

Agora hástea somente; e o sol brilhante

Despede a custo a luz que mal penetra

As nuvens trovejadas que o circumdão.

P. 230:

Nota MA: v. 13-23 destacados por colchete - seleção de ideias:

Mas quando o desengano, qual tormenta

Que por desertos só valente reina,

Do quente coração arranca, esmaga

Esp'ranças que o amor enfeitiçava,

Em vão a natureza ufana brilha, 
Em vão de puro orvalho a flôr se arreia, Em vão dardeja o sol seus quentes raios, Em vão!... que o coração jaz frio e murcho, E não mais viverá! - que a alma sentida Conhece que o amor é só mentira, Que é mentira o prazer, mentira tudo!

Nota da pesquisa: O desengano do eu lírico é transposto por MA para "Amor e medo"; no ensaio, esta página serve de exemplo para a infidelidade imputada pelo eu lírico à mulher (In: Aspectos da literatura brasileira. Ed. cit., p. 215).

\section{P. 232:}

Notas MA:

1. termo corrigido no v. 74, "morte" - correção tipográfica:

E elle o conheceu! - por precipicios

Descrido se arrojou, sentindo a merte, "o"

Seu berço entre sepulchros procurando.

2. v. 79 sublinhado - estudo da psicologia: amizade / estudo da criação: sinceridade:

E só no seu morrer, qual só na vida,

Na terra se estendeu; nem dôr, nem pranto

Tinha no coração que era já morto!

3. termo sublinhado no v. 85, "p'ra”, e cruzeta - estudo linguístico: emprego de "para/pra":

E alguem que alli passou, vendo um cadaver

De sanie e podrião comido e sujo,

Co'o pé n'um fosso o revolveu - e terra

Cahida acaso o sepultou p'ra sempre.

4. v. 86 sublinhado e expoente “(1)” remetendo ao comentário no rodapé - estudo da psicologia: amizade / estudo da criação: sinceridade:

Amizade! - illusão que os annos somem; “(1)”

Amor! - um nome só, bem como o nada

A dôr no coração, delicias n'alma,

Nos labios o prazer, nos olhos pranto

— Tudo é vão, tudo é vão, excepto a morte!

“(1) Ora G. Dias cultivou a amizade e / tem fieis amigos que êle mesmo ce-/lebrou...”

P. 233-237

O DONZEL (29 estrofes) 
P. 234:

Notas MA:

1. termo sublinhado no v. 22, "carpido" e escólios "zoof" e "dic" - pesquisa da zoofonia e Dicionário musical brasileiro:

Não escuta o arfar dos bosques,

Nem das aves o carpido, "zoof

Nem das vagas o rugido; dic"

2. v. 33-36 destacados por traço vertical duplo e escólio “Velhice” - seleção de ideias:

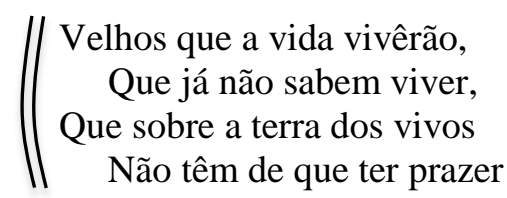

P. 237:

Nota MA: v. 113-120 destacados por colchete - estudo da psicologia: sentimento amoroso:

Virgem! virgem! que o amor recompensas

Por tal arte, tão dura e cruel,

Nunca sintas amor em tua vida,

Nunca extremos de nobre Donzel!

Nunca escutes a meiga lingoagem

De sincera, infinita paixão;

E nas vascas da morte impiedosa

Do que estimas te colha a traição!

P. 237-240

HARMONIAS (17 estrofes)

P. 237:

Nota MA: título sublinhado e escólio "dic" - pesquisa para o Dicionário musical brasileiro.

P. 238:

Nota MA: termos separados no v. 4, “e doce” - correção tipográfica:

E d'entre as folhas uma voz suspira

Que diz prazer, eldoce amor accende;

P. 241-247

A DESORDEM DE CAXIAS - 1839 (20 estrofes) 
P. 241:

Nota MA: termos sublinhados nos v. 1 e 2, "trompa" e "tuba", e escólio "dic" - pesquisa para o Dicionário musical brasileiro:

"dic Que feios sons de surda e rouca trompa!

dic" Echôa a bronzea tuba as duras vozes,

Que hão de os valles cobrir de miserandos,

Insepultos guerreiros!

P. 244:

Notas MA:

1. v. 95 sublinhado e expoente “(1)”, remetendo ao comentário no rodapé:

No antropophago altar, madido, impuro

Em holocausto correu d'hostia innocente "(1)"

Humano sangue, fumegante e rubro.

“(1) Decassilabo com uma silaba demais / ligada ao / anterior verso.”

2. v. 107 sublinhado e expoente “(2)”, remetendo ao comentário no rodapé:

E se a vergonha vos não tinge o rosto,

Tinja o rosto do ancião, do infante "(2)"

Que em qualquer parte vos roçar fugindo.

“(2) Decassilabo sem a primeira silaba ou / sem elisão em 'tinja $\mid o$ '. Verso imperfeitissimo, raro / isso no poeta. O anterior tambem mesmo explicavel, / é mal feito na elisão dum pra outro verso, é elisão / forçada."

\section{P. 246:}

Notas MA:

1. v. 147 e 148 sublinhados e expoente “(1)”, remetendo ao comentário no rodapé:

Não irei ao sepulchro esquecido Insultar o mesquinho finado; Miserando! foi duro o seu fado, Que um amigo sequer não deixou!

"(1) A preocupação do amigo sempre. Ainda / na maldição de I-Juca Pirama ela se repeItirá angustiosissima, perversa."

2. preposição sublinhada no v. 154, "p'ra”, e cruzeta - emprego de "para/pra":

Murchas flôres p'ra terra inclinadas! $\quad X$

P. 247-249

Ao ANNIVERSARIO DA INDEPENDENCIA DE CAXIAS (5 estrofes) 
P. 248:

Nota MA: termo sublinhado no v. 17, "clangor", e escólio “dic" - pesquisa para o Dicionário musical brasileiro:

Eis o som do tambor atrôa os valles,

O clangor da trombeta, os sons das armas, "dic"

A terra abalão, despertando os échos.

P. 249:

Nota MA: termo sublinhado no v. 58, "altissonas", e escólio "dic" - pesquisa para o Dicionário musical brasileiro:

Acclamações altisonas "dic"

Corram nos lares da immortal Caxias:

P. 251-257

SAUDADES / A MINHA IRMÃ (11 estrofes)

P. 254:

Nota MA: v. 92 sublinhado e escólio “V.pg 257” - estudo do estilo: artifício/repetição:

Ave educada nas floridas selvas, "V.pg 257"

Vim da praia beijar a fina areia.

P. 256-257:

Nota MA: v. 152-168 destacados por traço vertical - estudo da psicologia: sentimento amoroso:

Sim, amei; fosse embora um só momento!

Meu sangue, requeimado ao sol dos tropicos,

Em vivas labaredas conflagrou-se.

Feliz n'aquelle incendio ardeu minha alma,

Um anno, talvez mais! Qual foi primeiro

A soltar, a romper tão doces laços,

Não pudera dizel-o, em que o quizesse.

Tão louco estava então, - dôres tão cruas,

Magoas tantas depois me acabrunhárão,

Que desse meu passado extincta a idéa,

Deixou-me apenas um soffrer confuso,

Como quem de um máo sonho se recorda!

Assim, depois de arder um denso bosque

Dos ventos á mercê revôa a cinza

N'um páramo deserto! Nada resta;

Nem sequer a vereda solitaria,

A cuja extremidade o amor velava! 
Nota da pesquisa: MA alude ao poema como prova, na obra de Gonçalves Dias, da infidelidade tantas vezes atribuída pelo eu lírico à mulher que ama ("Amor e medo", In: Aspectos da literatura brasileira. Ed. cit., p. 215).

P. 257:

Nota MA:

1. v. 182 e sublinhado e escólio “ $V . p .254$ " - estudo do estilo: artifício/repetição:

Essa mesma esperança não me illude;

Ave educada nas floridas selvas, "V.p. 254"

Um tufão me expellio do patrio ninho.

2. juízo / escólio de valor ao final do poema:

\section{"Sublime."}

Nota da pesquisa: O amor intenso dos românticos por suas mães e irmãs, segundo MA, integra as causas do amor e medo: "Gonçalves Dias também versa por várias vezes o tema, e dedicou à mana um dos seus mais belos poemas, as Saudades. Tanto neste, como no 'Lá, bem longe daqui...', em que celebra a morte da irmã dum amigo, deixou expressões sentidas sobre a felicidade de ter irmã." ("Amor e medo", In: Aspectos da literatura brasileira. Ed. cit., p. 218).

\section{P. 259-261}

DIES IRAE (6 estrofes)

\section{P. 259:}

Nota MA: termo sublinhado no v. 16, "sons", e escólio "dic" - pesquisa para o Dicionário musical brasileiro:

Co'os mesmos sons, co'a mesma queda; as brisas

Inda conversão nos soturnos bosques;

P. 260:

Notas MA:

1. termos sublinhados nos v. 23 e 24, "homem" e "deos creado", fio ligando-os e escólio "Homem"- seleção de ideias:

O mesmo orgulho e intelligencia o homem,

O rei da creação, o deos creado,

"Homem"

De quando vinhão, por pedir-lhe os nomes,

Cetaceos, aves e os reptis e aquellas

Creaturas-montanhas, que passárão

Entre Adão e Noé á flor de terra!

2. termo sublinhado no v. 35, "chilros" e escólio "zoof" - pesquisa da zoofonia: 
Jaz como o predio a desfazer-se em ruinas,

Onde um guarda solícito não móra,

E entregue ás aves más, que em chilros prégão, "zoof"

Que alli na ausencia do senhor imperão.

P. 261:

Notas MA:

1. termo sublinhado no v. 67, "soverter", e interrogação - estudo do estilo: vocabulário:

E em furia ardendo, arroja aos altos cimos

Cruzados vagalhões, qual se tentára

Sovertel-os; os ventos se contrastão!

"?"

2. trecho sublinhado nos v. 77 e 78 e escólio “Tempo” - seleção de ideias:

Satisfez-se o Senhor. Que resta? - O cháos,

O horror, a confusão, o vulto enorme "Tempo"

Do tempo, que escurece o fundo abysmo,

Onde por todo o sempre jaz captivo;

P. 262-264

ESPERA! (10 estrofes)

P. 262:

Nota MA: expressão sublinhada nos v. 3 e 4, "cabe a todos!" - estudo do estilo: artifício/repetição:

Quem ha no mundo que afflicções não passe,

Que dôres não supporte?

Mais ou menos d'angustias cabe a todos,

A todos cabe a morte.

$\underline{\text { P. } 263-266}$

A SAUDADE ( 8 estrofes)

P. 264:

Notas MA:

1. v. 30-42 destacados por colchete;

2. termo sublinhado no v. 37, "saudade", e fio ligando ao escólio "Saudade" e ao epíteto sublinhado no v. 39, "Hera do coração" - estudo do estilo: imagem:

3. v. 40 sublinhado e fio ligando à repetição na p. seguinte - estudo do estilo: artifício/repetição;

4. comentário no rodapé:

Véu escuro, 
Que nem sempre a ilussão nos adelgaça,

Nos encobre os caminhos do futuro.

O que nos resta pois? - Resta a saudade, Que dos passados dias

De mágoas e alegrias

Balsamo santo extrahe consolador!

Resta a saudade, que alimenta a vida

"Saudade"

Áluz do facho que adormenta a dôr!

Hera do coração, memoria delle,

Ó Saudade, ó rainha do passado,

Semelhas a romantica donzella

De roupas alvejantes

“Imagem sublime. Isso é raro em G. D. cuja / imagem em geral é vulgar."

P. 265:

Notas MA: v. 60 sublinhado e fio ligando-o ao v. 40, na p. anterior - estudo do estilo: artifício/repetição:

Ó Saudade, ó rainha do passado,

P. 267-268

NÃO ME DEIXES! (6 estrofes)

P. 267:

Nota MA: comentário ao final do poema:

"Joia imperecivel da / mais delicada gentileza / e doçura. Fabordão"

P. 269-270

ANGELINA (6 estrofes)

P. 269:

Notas MA:

1. escólio "Fabordão" ao lado do título - estudo do estilo: fabordão;

2. termo corrigido no v. 20, "bardo" - correção tipográfica:

Que de amor quando suspira

“/o" O barda quebrará a lyra,

De mofina;

P. 270:

Nota MA: comentário ao final do poema:

Eu que não sei descrevel-a, 
Só sei que me arrouba o vel-a

Tão divina;

A lyra seus cantos cesse,

Mas minha alma não s'esquece

D'Angelina!

“Fabordão parnasiano. Este / D'Angelina portuga... Porém por mais influenciado por / Portugal o sentimento, a psicologia; a sensibilidade de G. D. I é brasileirissima. Sobretudo nas canções onde a graça sen-/sual que tem é coisa que nunca portugues teve."

P. 270-271

RôLA (3 estrofes)

P. 270:

Nota MA: v. 13 sublinhado e expoente “(1)”, remetendo ao comentário no rodapé:

“(1)" $\begin{aligned} & \text { Amo-te, quero-te, adoro-te, } \\ & \text { Abraso-me quando em ti penso, } \\ & \text { E em fogo voraz, intenso, } \\ & \text { Anceio louca de amor! }\end{aligned}$

“(1) Primeira vez em que um esdruxulo é con/tado em 2 silabas por G. Dias. E ainda se / poderá argumentar que é uma redondilha / de acentuação ritmica igual á anterior, que tem / uma silaba a mais no principio que está ligada / á ultima do verso anterior. Exemplo magis-/tral, perfeito desta maneira plausivel exata / de contar silabas."

P. 271:

Nota MA: comentário ao final do poema:

"Deliciosa lirica. Obra-/prima”

Nota da pesquisa: As rubricas "Obras-primas" e "G. D. cantador", no fichamento crítico das obras de Gonçalves Dias, remetem ao poema (MA-MMA-05-04).

P. 271-275

AINDA UMA VEZ - ADEOS! (18 estrofes)

P. 271:

Nota MA: escólio "Tema do Amor e Medo" ao lado da primeira estrofe - estudo da psicologia: sentimento amoroso:

Emfim te vejo! - emfim posso, 
Curvado a teus pés, dizer-te Que não cessei de querer-te, Pezar de quanto soffri.

Muito penei! Crúas ancias, Dos teus olhos afastado, Houverão-me acabrunhado A não lembrar-me de ti!
"Tema do

Amor e Medo"

P. 272:

Nota MA: preposição sublinhada no v. 26, "para", e cruzeta - estudo linguístico: emprego de "para/pra":

$$
\begin{aligned}
& \text { Vivi; pois Deos me guardava } \\
& X \quad \underline{\text { Para }} \text { este logar e hora! }
\end{aligned}
$$

\title{
P. 273:
}

Nota MA:

1. preposição sublinhada no v. 55, "para", e cruzeta - estudo linguístico: emprego de "para/pra":

\author{
Devêra, podia acaso \\ Tal sacrificio acceitar-te \\ $X \quad \underline{\text { Para no cabo pagar-te, }}$ \\ Meus dias unindo aos teus?
}

2. expressão sublinhada nos v. 63 e 64, "meu/teu quinhão", e os versos destacados por traço vertical duplo - estudo do estilo: artifício/repetição:

De minhas preces, contava

Que o bom Deos me acceitaria

O meu quinhão de alegria )

Pelo teu quinhão de dôr! )

P. 275:

Notas MA:

1. preposição sublinhada no v. 113, "p'ra", e cruzeta - estudo linguístico: emprego de "para/pra":

És d'outro agora, e p'ra sempre! $\quad X$

2. v. 121-124 destacados por traço vertical e comentário:

Dóe-te de mim, que t'imploro

Perdão, a teus pés curvado;

Perdão! de não ter ousado

Viver contente e feliz!

"Ainda o tema de / Amor e Medo co-/mum a todos os / nossos romanticos / maiores" 
3. comentário ao final do poema:

"Isto é sublime como perfei-/ção, fluencia e talvez comoção. É duma / grandeza! G. Dias encontrou as palavras / unicas que isto poderiam dizer. É a o-/bra-prima do Amor e Medo em que se exerce/ram os nossos romanticos / num estranho, singular / e espaçado jogo floral de timidez."

Nota da pesquisa: Classificado no ensaio para a Revista Nova como "uma das expressões mais comoventes do amor e medo", "Ainda uma vez, adeus!" é o objeto central dos poucos comentários acerca do medo de amar na poesia de Gonçalves Dias. MA descobre nessa obra "mais um aspéto do tema" e aproveita para o ensaio a mesma expressão registrada na marginália: "O poeta ama e é amado, porém sacrifica o seu amor porque um motivo qualquer, posição social provavelmente, o induz a isso (...) É a modalidade nova, com que o grande poeta entra vigoroso nesse jogo-floral da timidez. Os medos o assaltaram, não 'ousou' sacrificar nada, preferiu amar em silêncio, pois que assim já fizera, e tudo se passara tão bem, nas estrofes da Como eu te amo." ("Amor e medo", In: Aspectos da literatura brasileira. Ed. cit., p. 202, 214 e 215, grifei).

$\underline{\text { P. } 276}$

O SOMNO (3 estrofes)

Nota MA: escólio “Fabordão” ao final do poema - estudo do estilo: fabordão.

$\underline{\text { P. } 277-278}$

SE EU FOSSE QUERIDO! (3 estrofes)

P. 278:

Nota MA: escólio “Fabordão” ao final do poema - estudo do estilo: fabordão.

$\underline{\text { P. } 277-280}$

A FLÔR DO AMOR (12 estrofes)

P. 277:

Nota MA: termo sublinhado no v. 12, "canora", e escólio "dic" - pesquisa para o Dicionário musical brasileiro:

Descanção todos da penosa lida

Á voz canora, que o cantor alçou!

P. 278:

Nota MA: preposição sublinhada no v. 30, "para", e cruzeta - estudo linguístico: emprego de "para/pra": 
Jazendo em sitio escuso e solitario,

$X \quad$ Esforços é mister p'ra conhecel-a,

P. 279:

Nota MA: expressão sublinhada no v. 67, "que achando-a", e cruzeta - estudo linguístico: colocação pronominal:

"Ai! porém do que a vê, e a não conhece,

Do que a suspira em vão, e a em vão procura,

Ou que achando-a, desiste da ventura $X$

Por não entrar no oásis seductor.

P. 280:

Nota MA: comentário ao final do poema:

"Estranho fabordão provavelmente incons-/ciente: 3 estancias em ou, 7 em or e 2 finais ou. ."

P. 280-281

A SUA VOZ (4 estrofes)

P. 280:

Nota MA: termo sublinhado no v. 4, "timbre" - pesquisa para o Dicionário musical brasileiro:

Retratado o pudor tinha no rosto,

E um suave dizer, um timbre doce

P. 281:

Notas MA:

1. termo sublinhado no v. 26, "salterios" - pesquisa para o Dicionário musical brasileiro:

Tanto como a sua voz! - somente o forão

Dulias notas de mysticos salterios "dic"

2. termo sublinhado no v. 34, "harpa eolia" - pesquisa para o Dicionário musical brasileiro:

Trouxera n'alma uma harpa eolia, "dic”

Dia e noite vibrando,

P. 282-284

SE SE MORRE DE AMOR! (6 estrofes)

P. 282: 
Nota MA: título assinalado com três cruzetas.

Nota da pesquisa: A ênfase de MA ao assinalar o título é reiterada no fichamento crítico das obras de Gonçalves Dias, que abriga o poema sob a rubrica "Obras-primas" (MAMMA-05-04).

P. 283:

Nota MA: preposição sublinhada no v. 35, "para", e cruzeta - estudo linguístico: emprego de "para/pra":

Amar, e não saber, não ter coragem

Para dizer que amor que em nós sentimos; $\quad X$

Nota da pesquisa: Desenvolvendo a hipótese de que Gonçalves Dias possui uma "filosofia pessimista do amor", MA alude ao poema como mostra do "consolo de amor dentro da morte": "[GD] Acha frequentissimamente que a mulher é infiel (...), mas si acaso ela corresponde sinceramente ao amor, em vez de preferir que este se realize, deseja, ou acha preferível morrer de amor. Ninguém ignora o entusiasmo dionisiado com que ele provou que 'se morre de amor'. (“Amor e medo", In: Aspectos da literatura brasileira. Ed. cit., p. 215).

P. 282-284

A MORTE É VARIA (11 estrofes)

P. 285:

Nota MA: v. 12 sublinhado, “p”, em “cryptas”, assinalado, e comentário no rodapé - estudo linguístico: suarabácti / estudo da versificação: métrica:

A pallida libré nem todos vestem,

Nem sobre todos jaz murada a porta

Nas cry/p/tas sombrias! "4 silabas"

"(1) Criptas com 3 silabas"

$*$

P. 290-291

ESTANCIAS (8 estrofes)

P. 290:

Nota MA: preposição sublinhada no v. 10, "para", e cruzeta - estudo linguístico: emprego de "para/pra":

E esses labios que a jura de esposa

$X \quad \underline{\text { Para mim não darião no altar, }}$ 
P. 291-292:

SONETO

Nota MA: comentário ao final do poema:

"Lindo soneto, não alcança os de Alvares de Azevedo."

Nota da pesquisa: MA alude ao soneto em "Amor e medo", projetando no poema a ambivalência psicológica explorada no ensaio: "Gonçalves Dias tem um soneto de mocidade em que o destemor de amar está deliciosamente expressado [citação do poema na íntegra]. Mas o cômico nesse poema é decidir si ele prova destemor real, ou justamente amor e medo. Me inclino pelo segundo juízo, e me parece que Gonçalves Dias ao caçoar da literatice dos poetas é que está fazendo literatice, libertando-se duma preocupação por meio duma comicidade que não era propriamente dele, garganteando o que não sentia. Ele seria mais tarde, já bem vivido, dos poetas que mais sentiram o prestígio romântico da mulher, e entre nós o que deu uma das expressões mais comoventes do amor e medo, com o Ainda uma vez, adeus!" (ANDRADE, Mário de. "Amor e medo", In: Aspectos da literatura brasileira. $5^{\text {a }}$ ed. São Paulo: Livraria Martins Editora, 1974, p. 202). MA formula, como se vê, uma interpretação tipicamente psicanalítica ao reiterar o juízo dele quanto à insinceridade de Gonçalves Dias: a criação poética sublima o medo de amar, e o faz "por meio duma comicidade".

P. 292-294

A MinHa FiLHa (10 estrofes)

P. 292:

Nota MA: v. 1-7 destacados por traço vertical e comentário:

$$
\begin{aligned}
& \text { O nosso indio errante vaga; } \\
& \text { Mas por onde quer que vá, } \\
& \text { Os ossos dos seus carrega: } \\
& \text { Por isso, onde quer que chega, } \\
& \text { Da vida n'amplo deserto, } \\
& \text { Como que a patria tem perto, } \\
& \text { Nunca dos seus longe está! }
\end{aligned}
$$

\section{"Lindo emprego de imagem brasileira"}

\section{P. 294:}

Notas MA:

1. preposição sublinhada no v. 47, "para", e cruzeta - estudo linguístico: emprego de "para/pra":

\footnotetext{
Sei que ao partir-me da vida,
Minha alma andará perdida
Para saber onde estás!
} 
2. v. 48-59 destacados por traço vertical - estudo da psicologia: atração da morte:

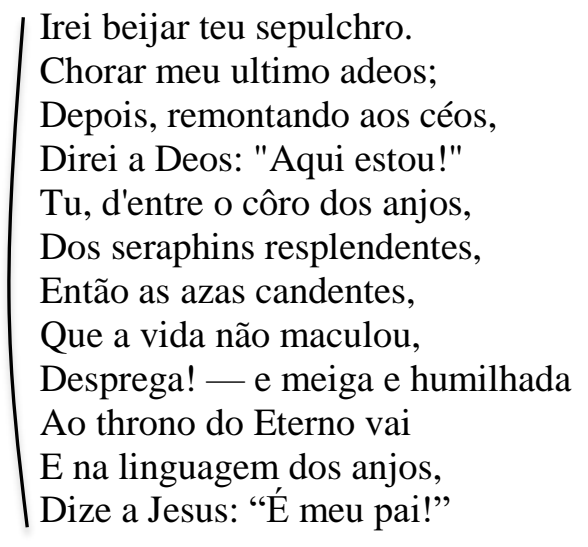

3. preposição sublinhada no v. 64, "para", e cruzeta - estudo linguístico: emprego de "para/pra":

Mas d'homem, não; porque os céos

Não tinhão bastante espaço

$X \quad$ Para um homem pai de Deos!

4. comentário ao final do poema:

Bem sabe elle quanta gloria

Sente o pai que um anjo tem!

Julgará que, pois perdida

Teve uma filha na vida,

Não a perca lá tambem!

"Não viria destas ultimas estancias / pra Afonso Celso a ideia do Anjo Enfêrmo? / Me parece."

Nota da pesquisa: O trecho destacado abona a rubrica "Pedaços belos", no fichamento crítico das obras de Gonçalves Dias, documento no dossiê do manuscrito Amor e medo (MA-MMA-05-04).

P. 295-297

O MAR (7 estrofes)

P. 297:

Notas MA:

1. preposição sublinhada no v. 50, "p'ra", e cruzeta - estudo linguístico: emprego de "para/pra":

Mas n'esse instante que me está marcado,

Em que hei de esta prisão fugir p'ra sempre $\quad X$ 
Irei tão alto, ó mar, que lá não chegue

Teu sonoro rugido.

2. v. 54 sublinhado e expoente “(1)” remetendo ao comentário no rodapé:

Então mais forte do que tu, minha alma,

Desconhecendo o temor, o espaço, o tempo,

Quebrará n'um relance o circ'lo estreito

Do finito e dos céos!

“(1) Decassilabo com 1 silaba exce-/dente anterior”

3. comentário ao final do poema:

"Apesar de algumas belas estro-/fes sobre o mar, ver como G. Dias / escapa do assunto e da fruição / da natureza, pra se preocupar con-/sigo."

P. 298-301

IDEIA DE DEOS (21 estrofes)

P. 298:

Nota MA: preposição sublinhada no v. 14, "para", e cruzeta - estudo linguístico: emprego de "para/pra":

A morte, as afflicções, o espaço, o tempo,

O que é para o Senhor?

P. 301-305

O ROMPER D'Alva (20 estrofes)

P. 302:

Nota MA: expressão sublinhada nos v. 11 e 12, "da tormenta o furor" - estudo do estilo: artifício/repetição:

Da tormenta o furor the accende os brios

Da tormenta of furor lh'enfreia as iras,

P. 305-309

A TARDE (8 estrofes)

P. 306:

Notas MA:

1. expoente “(1)” no v. 22, remetendo ao comentário no rodapé: 
Não póde supportal-a homem que soffre, “(1)” Orfãos de coração, não podem vel-a.

“(1) Este é processo comum a G. Dias. Quando tem / de exaltar qualquer coisa, descobrelhe similes, / ou outras coisas que reputa inferiores. No Se se / morre de amor emprega o mesmo processo. Ver / mais exemplos."

2. termo sublinhado no v. 34, "pipitão" e escólio "zoof" - pesquisa da zoofonia:

A brisa que murmura na folhagem,

As aves que pipitão docemente, "zoof"

P. 308:

Notas MA:

1. v. 68 sublinhado - estudo do estilo: imagem;

2. termo corrigido no v. 69, "mais" - correção tipográfica:

Socia do forasteiro, tu, saudade,

N'esta hora os teus espinhos mais pungentes

3. expoente “(1)” entre os v. 95 e 96, remetendo ao comentário no rodapé:

Tão feliz! quando a morte envolta em pranto

Com gelado suor lh'enerva os membros,

Procura inda outra mão co'a mão sem vida,

E o extremo scintillar dos olhos baços,

De um ente amado procurando os olhos,

Sem prazer, mas sem dôr, alli se apaga.

"Notar que G. Dias alem da nostalgia idea-/lista da patria, sentiu também aqui e nos versos / dedicados á mana a nostalgia do lar. E si / a disse bem certo não a disse nos versos / impereciveis de Casemiro."

P. 309-312

O TEMPLO (5 estrofes)

P. 312:

Nota MA: comentário ao final do poema:

"Os romanticos não foram em nada revolu-/cionarios do verso como estrutura. Notar neles a falta, a / indigencia do entroncamento."

P. 312-313

TE DEUM ( 7 estrofes) 
P. 313:

Notas MA:

1. trechos sublinhados nos v. 14-17, "tu quem dás" e "quem rouquejas" - estudo linguístico: concordâncias verbal:

És tu quem dás rumor á quieta noite, És tu quem dás frescor á mansa brisa, Quem dás fulgor ao raio, azas ao vento,

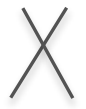
Quem na voz do trovão longe rouquejas.

2. comentário ao final do poema:

"Magistral, digno do hinario do Senhor! / A religiosidade tradicional dos roman-/ticos mas de fé ardente em G. Dias."

Nota da pesquisa: MA classifica "Te Deum" como uma das "Obras-primas" de Gonçalves Dias; a rubrica integra o fichamento crítico, no dossiê do manuscrito Amor e medo (MAMMA-05-04).

P. $313-316$

ADEOS (4 estrofes)

P. 314:

Nota MA: v. 35 sublinhado e expoente “(1)”, remetendo ao comentário no rodapé:

“(1)” E que eu morresse entre vós! Mas força occulta, Irresistivel, me persegue e impelle.

"Decassilabo com 1 silaba demais elidi-/da na silaba muda ultima do verso / anterior."

$\underline{\text { P. } 316-319}$

A LUA (8 estrofes)

P. 316-317:

Nota MA: v. 7-12 assinalados por traço ondulado, do mesmo modo que os v. 85-90, idênticos, na p. 319 - estudo do estilo: artifício/repetição:

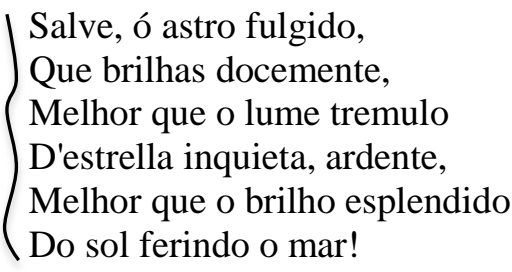

P. 319: 
Nota MA: v. 85-90 assinalados por traço ondulado, do mesmo modo que os v. 7-12, idênticos, na p. 316 - estudo do estilo: artifício/repetição:

Salve, ó astro fulgido,

Que brilhas docemente,

Melhor que o lume tremulo

D'estrella inquieta, ardente,

Melhor que o brilho esplendido

Do sol ferindo o mar!

P. 320-322

A NOITE (9 estrofes)

P. 320:

Notas MA:

1. v. 1 sublinhado e fio ligando aos v. 9, 17 e 41 - estudo do estilo: artifício/repetição:

Eu amo a noite solitaria e muda,

2. v. 9 sublinhado:

Eu amo a noite taciturna e quêda!

3. v. 17 sublinhado:

Eu amo a noite taciturna e quêda!

P. 321:

Nota MA: v. 41 sublinhado - estudo do estilo: artifício/repetição:

Eu amo a noite solitaria e muda;

P. 322-327

A TEMPESTADE (21 estrofes)

P. 325:

Notas MA:

1. nome sublinhado no v. 66, "Mazeppa", e cruzeta - estudo dos lugares-comuns da poesia romântica:

Qual foi Mazeppa no veloz ginete $\quad X$

Por desertos, por syrtes arenosas

Jungido e preso e attonito levado;

2. termo sublinhado no v. 74, "c'rôa", e cruzeta - estudo do estilo: vocabulário / licenças poéticas: 
Pareceu que alli tem a régia c'rôa $\quad X$

3. termo sublinhado no v. 84, "trompa", escólio "dic" e fio até o comentário no rodapé pesquisa para o Dicionário musical brasileiro:

Assim, meu Deus, assim será no dia,

Do final julgamento, quando o anjo

Soprar a trompa que desfez os muros "dic"

De Jerichó soberba!

"Comparações? / Não. Ver o / que segue”

P. 326:

Notas MA: preposição sublinhada no v. 88, "para", e cruzeta - estudo linguístico: emprego de "para/pra":

Virá para sorver, com furia brava,

Ilhas e continentes.

P. 328-334

O MEU SEPULCHRO (9 estrofes)

P. 329:

Nota MA: expressão sublinhada no v. 36 e cruzeta - estudo do estilo: imagem:

O moimento faustoso, que se erige,

$X \quad$ Arranco da vaidade, sobre a campa

De um corpo transitorio, acaso empece

Aos que alli pascem, vermes esfaimados,

De roerem-lhe as visceras?! — Solemnes

P. 330:

Nota MA: trecho sublinhado no v. 67 - estudo da psicologia:

Mas eu, que vago sôlto, como a folha,

P. 331:

Nota MA: v. 99-110 destacados por traço vertical - estudo do estilo:

Cheio de melancholica incerteza,

Dir-te-hei: bem-vinda, - ô morte! quando os olhos

Voltar atraz na percorrida estrada;

E chorarei talvez, como quem deixa

$\mathrm{O}$ carcere medonho, onde engastada

Nas escaras da dôr gemeu sua alma

Largos annos de antigo soffrimento; 


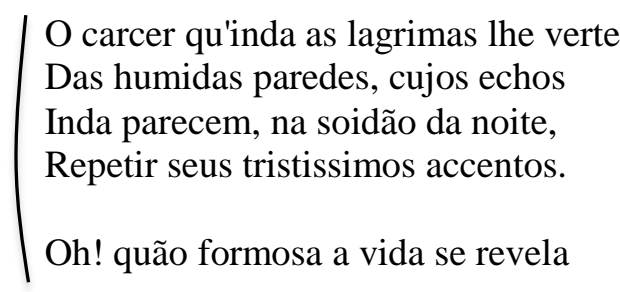

Nota da pesquisa: Os versos em destaque municiam a rubrica "Pedaços belos", no fichamento crítico das obras de Gonçalves Dias; o documento integra o dossiê do manuscrito Amor e medo (MA-MMA-05-04).

P. 332: termo sublinhado no v. 137, "c'rôa", e cruzeta - estudo do estilo: vocabulário / licenças poéticas:

Que importa que eu não tenha um só ç'rôa,

P. 334-336

$*$

A HARMONIA (6 estrofes)

P. 334:

Nota MA: título sublinhado e escólio "dic" - pesquisa para o Dicionário musical brasileiro.

P. 336:

Nota MA: comentário ao final do poema:

"Belo poema! Fabordão inconsciente / em ar."

P. 337-342

A TEMPESTADE (19 estrofes)

P. 342:

Nota MA: comentário ao final do poema:

"Prova mais cabal do artificialismo de / G. Dias não tem. No entanto é uma perfei-/ção" 


\section{VOLUME 2}

\section{$\underline{\text { FOLHA DE GUARDA }}$}

\section{Notas MA:}

1. anotação no alto, à direita, “ $n^{\circ} 199$ ”, referindo-se à inclusão do volume na Bibliografia para Na pancada do ganzá;

2. lista de verbetes para o Dicionário musical brasileiro e para a pesquisa da zoofonia e cruzeta indicando o aproveitamento:

Dic-soido 28 - epicedio 33 - cantico 34 - ditirambo 51 - / dobrar 65 - nota harmonica 74 - / boré 90 -zoof carpido 91 - / maracá 91 - zoof coruja 93 - maraca 93 - boré 96 nenia 103 - / palreiro 104 - zoof atito 106 - murmuré 112 guau 113 - / boré 113 janubia 113 - maracá 121 - harpa 145 - toada 147 t toré 160 - memby 161 - clarim 161 - zoof atitar 166 - / cascavel 169 - makaéa 169 - zoof acauan 170 - / maracá 173 nenia 177 -descantam 177 - pocema 190 - guau 190 - memby 191 - boré 196 -dançatriz. 197 - maracá 200-/ repicar 223-troar, atabales, istromentos 226-folia 239-/arrabel 240 - zoar 244 - arrabel 246 - trova 283 - / tenção 284 - trompa 285 - rimance 295 soláu 272 / sotau 295 - menestrel 299 - folia 305 - Boré 324 - maracá 325 - mukemuré 328 guau 328 - janubia 329 -

\section{P. 5-74}

\section{VISÕES}

P. 5-19

$\overline{\mathrm{A} \text { VISÃO }}$

P. 6:

Nota MA: termo corrigido no v. 30, "custosa" - correção tipográfica:

$$
\begin{aligned}
& \text { Expunha a seda do Indostão, de Tyro } \\
& \text { A purpura brilhante, a damasquina } \\
& \text { Custose tela entretecida d'oiro. }
\end{aligned}
$$

P. 7:

Nota MA: expressão sublinhada no v. 42, "zimborio retumbante", e cruzeta - estudo do estilo: imagem:

Sobre o zimborio retumbante e vasto $X$

Ondas e ondas de vapor crescião.

P. 9:

Nota MA: expressão destacada por sublinha dupla e círculo no v. 121, "o bom do velho" - estudo do estilo/linguístico: sintaxe/brasileirismo: 
Dizia o bom(do)velho: - "Irmão, nas ancias, $X$ "No extremo agonisar da morte amiga

"Ergue os olhos ao céo;

P. 12:

Nota MA: expoente “(1)” no v. 188 , remetendo ao comentário no rodapé - estudo da versificação: ritmo/métrica:

“(1)” - Não tinha quem lhe cerrasse os olhos

Nem quem chorando lhe abrandasse o amargo

Do extremo agonisar.

“(1) Decassilabo sem a silaba inicial. Enfim / ritmo em latencia qual muito / verso livre meu, do Manuel do / Gui. São alexandrinos em laten-/cia. Mostra-lo."

P. 14:

Notas MA:

1. termo sublinhado nos v. 245 e 246, "volve" - estudo do estilo: artifício/repetição:

$\mathrm{O}$ rosto ossificado em torno volve,

Volve a suja caveira;

Do liso craneo os longos dedos varrem

A funebre poeira.

2. v. 263 e 264 destacados por traço vertical duplo - estudo da psicologia: sentimento amoroso:

"Doce amor, minha vida no mundo,

Desse mundo em que parte serás;

(/Em que scismas, que pensas, que fazes,

( Onde estás, meu amor, onde estás?

P. 16:

Nota MA: expressão sublinhada nos v. 288 e 289, "Não se acaba" - estudo do estilo: artifício/repetição:

"Nossa adultero affecto no mundo

Não se acaba; - assim quiz o Senhor!

Não se acaba... — qu'importa? — hei gozado

Teus encantos gentis, teu amor.

P. 18:

Notas MA:

1. preposição sublinhada no v. 346, "p'ra", e cruzeta;

2. preposição sublinhada no v. 348 , "para", e cruzeta - estudo linguístico: emprego de "para/pra":

- Mas em parte a dôr me cura

Um pensamento, que é meu, -

Lembro aos humanos que a terra

$X \quad$ É só passagem p'ra o céo. 
- Faço ao triste erguer os olhos

$X \quad$ Para a celeste mansão;

Em labios que nunca orárão

Derramo pia oração.

P. 19-21

O VATE (8 estrofes)

P. 19-20:

Nota MA: expressão sublinhada nos v. 1 e 6, "Vate! vate! que és tu?" - estudo do estilo: artifício/repetição:

Vate! vate! que és tu? - Nos seus extremos

Fadou-te Deus um coração de amores,

Fadou-te uma alma acesa borbulhando

Hardidos pensamentos, como a lava

Que o gigante Vesuvio arroja ás nuvens.

Vate! vate! que és tu? - Foste ao principio

Sacerdote e propheta;

Erão nos céos teus cantos uma prece,

$\mathrm{Na}$ terra um vaticinio.

E ella cantava então: - Jeovah me disse,

Magestoso e terrivel:

P. 21-24

A Morte Prematura da ILMA. SRA. D (8 estrofes)

P. 21:

Nota MA: v. 8 sublinhado e escólio interrogativo "alexandrino?" - estudo da versificação: métrica:

Que de vezes do sol, não foi ella pendente "alexandrino?"

Dos braços fraternaes em meigo abraço;

P. 22:

Notas MA:

1. v. 21-24 destacados por traço ondulado - estudo do estilo: artifício/repetição:

Se fechou sobre o ente esmorecido

Ao despontar de vida

Tão rica de esperanãs e tão cheia

De formosura e graças!...

2. v. 33-36 destacados por traço ondulado - estudo do estilo: artifício/repetição:

Tu, que tragas o ente que esmorece

Ao despontar de vida

Tão rica de esperanças e tão cheia

De formosura e graças?! 


\section{P. 23:}

Notas MA:

1. trecho sublinhado no v. 51 e cruzeta - estudo do estilo: artifício:

$$
\begin{aligned}
& \text { Não poder eu a troco de meu sangue } \\
& \text { Poupar-te dessas lagrimas metade! } \\
& \text { Oh! poder que eu pudesse! - e almo sorriso, } \\
& \text { Que tanto me compraz ver-te nos labios, } \\
& \text { Inda uma vez brilhasse! }
\end{aligned}
$$

2. v. 59-60 destacados por colchete e escólio "Manuel Bandeira" - estudo d

Mas lá dos immortaes sobre os teus dias

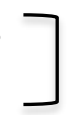

\section{"Manuel}

A suspirada irmã vela incessante.

\section{Bandeira"}

3. termo sublinhado no v. 63 , "c'rôas", e cruzeta - estudo do estilo: vocabulário / licenças poéticas:

Vinde, candidas lagrimas, açucenas,

Vinde, roxas saudades;

Orvalhai, tristes lagrimas, as c'rôas, $\quad X$

P. 24-29

A MENDiGA ( estrofes)

P. 24:

Nota MA: expressão sublinhada no v. 9, "pobre mendiga", e exclamação - estudo do estilo:

Era uma pobre mendiga, !

Porém candida donzella:

Pudibunda, affavel, doce,

Amorosa, e casta, e bella.

P. 25:

Notas MA:

1. v. 15-16 destacados por traço vertical duplo - estudo do estilo: artifício:

Vestia rotos andrajos,

Que o seu corpo mal cubrião;

Por vergonha os olhos d'ella

Sobre ella se não volvião.

2. v. 21-29 destacados por colchete e comentário - estudo da psicologia: irmão e irmã:

E qual vemos dos céos descendo rapido

Um fugaz meteóro, vi descendo

Um anjo do Senhor: - parou sobre ella,

E mudo a contemplava. - Uma tristeza

Sympathica, indizivel pouco e pouco

Do anjo nas feições se foi pintando: 
Qual tristeza de irmão que a irmã mais nova

Conhece enferma e chóra. - Ella no peito

Menor sentio a dôr, e humilde orava.

\section{"Irmã e / irmão / fazendo / imagem"}

\section{P. 27:}

Notas MA:

1. expressão sublinhada no v. 85 e exclamação - estudo do estilo:

E eu dizia tambem: - O' bella Dona,

Dai-lhe uma esmola, dai; - de que vos serve

Um óbolo mesquinho, que não póde

Siquer um diche sem valor comprar-vos?

2. preposição sublinhada no v. 91, "para", e cruzeta - estudo linguístico: emprego de "para/pra":

Para a salvar do vortice do crime, $\quad X$

O preço d'ellas, de uma só, da coisa

Que sem valor julgardes, é bastante.

\section{P. 28:}

Notas MA:

1. termo sublinhado no v. 107, "nota"

2. termo sublinhado no v. 109, "soído",

3. v. 107-111 destacados por colchete e traço vertical - estudo da psicologia: sentimento amoroso:

E o anjo, como afflicto sob um peso,

Um gemido soltou; era uma nota

"dic" Melancolica e triste, - era um suspiro

Mavioso de virgem, - um soído

Subtil, mimoso, como d'Harpa Eólia,

Que a brisa da manhã roçou medrosa.

P. 29-32

A ESCRAVA

P. 29:

Nota MA: v. 1 e 2 destacados por traço ondulado - estudo do estilo: artifício/repetição:

Oh! doce paiz de Congo,

Doces terras d'além mar!

P. 30:

Nota MA: v. 19 e 20 destacados por traço ondulado - estudo do estilo: artifício/repetição:

Oh! doces terras de Congo,

¿ Doces terras d'além mar! 
Notas MA:

1. v. 57-60 destacados por traço vertical duplo - estudo da psicologia: sentimento amoroso:

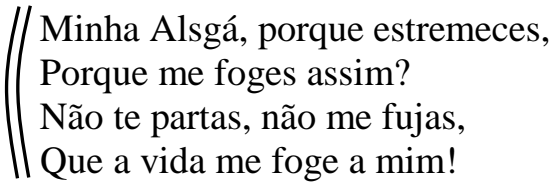

2. v. 67 e 68 destacados por traço ondulado - estudo do estilo: artifício/repetição:

¿ Oh! doces terras de Congo,

¿oces terras d'além mar!

Nota da pesquisa: O caráter cantador de Gonçalves Dias fundamenta-se, entre outros, nos versos assinalados, conforme se vê no fichamento crítico das obras do poeta, no dossiê do manuscrito Amor e medo (MA-MMA-05-04).

P. 32:

Nota MA: comentário ao final do poema:

"Primeiro poema interessante entre estas paus Visões. Notar que não é o sofrimento do escravo e a sua condição social que comovem o poeta, é o conceito de patria e o banzo por ela I principalmente."

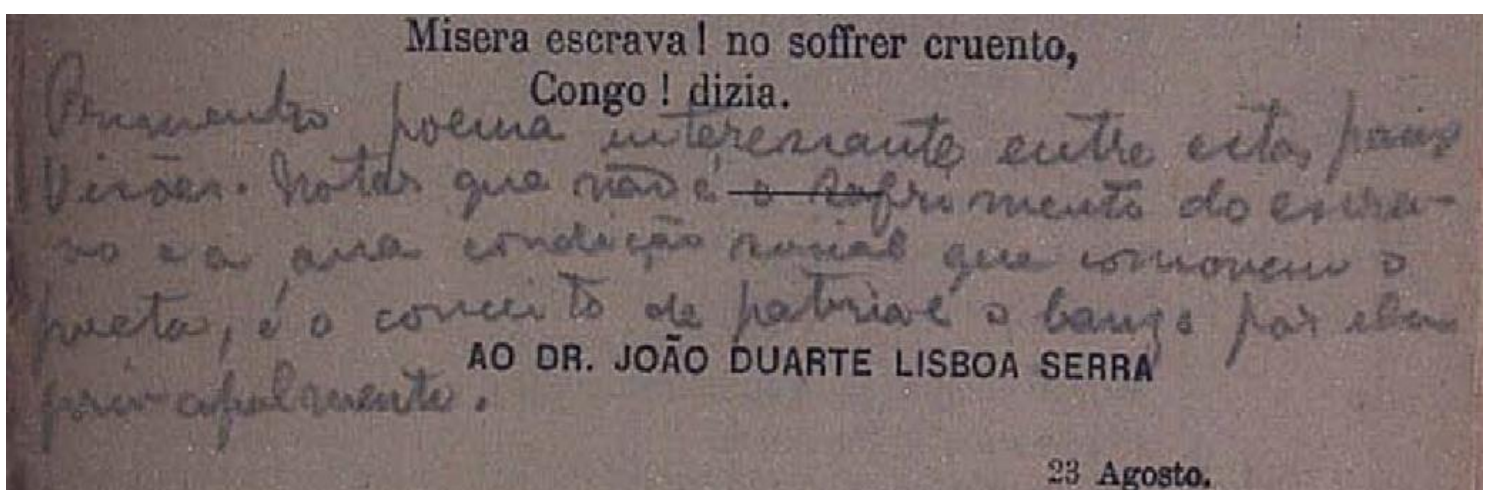

P. 32-35

Ao Dr. J. D. LISBOA SERRA ( estrofes)

P. 33:

Notas MA:

1. termo sublinhado no v. 15, "epicedio", e escólio "dic" - pesquisa para o Dicionário musical brasileiro;

2. expoente “(1)” no v. 17 , remetendo ao comentário no rodapé:

Do bardo, era um perenne sacerdocio

De lagrimas e dôr; - tomei uma Harpa:

Na corda da afflicção gemeu minha alma,

Foi meu primeiro canto um epicedio;

"dic"

Minha alma baptizou-se em pranto amargo, 
Na fragoa do soffrer purificou-se! "(1)”

"(1) Notar o artificialismo e a mentira / destes versos. G. Dias foi um romantico / á portuguesa e não sincero e franco / á brasileira que nem os outros."

3. preposição sublinhada no v. 26, "p'ra", e cruzeta - estudo linguístico: emprego de "para/pra":

Voltou-se então p'ra Deos o meu espirito, $\quad X$

E a minha voz queixosa perguntou-lhe;

4. pronome corrigido no v. 30, "minha" - correção tipográfica:

Não fez seccar da maginh pida a seve,

P. 34:

Notas MA:

1. termo sublinhado no v. 46, "mais" - estudo do estilo: artifício/repetição:

Sobre quem chora mais elle mais vela!

Seu amor divinal é como a lampada,

$\mathrm{Na}$ abobada d'um templo pendurada,

Mais luz filtrando em mais opácas trevas.

2. termo sublinhado no v. 57, "canticos", e escólio "dic" - pesquisa para o Dicionário musical brasileiro:

"dic" Seguindo o som dos canticos dos anjos

Que na presença do Senhor se elevão;

\section{P. 35-38}

O DESTERRo De UM Pobre Velho ( estrofes)

P. 35:

Notas MA:

1. expressão sublinhada nos v. 5 e 7, "bem mansa" - estudo do estilo: artifício/repetição;

Bem mansa na branca areia

Onda queixosa murmura,

Bem mansa aragem fagueira

Entre a folhagem susurra.

2. expressão sublinhada nos v. 9 e 10, “é hora cheia" - estudo do estilo: artifício/repetição:

É hora cheia de encantos,

É hora cheia de amor;

A relva brilha enfeitada,

Mais fresca se mostra a flôr.

P. $38-39$ 


\section{O ORGULHOSO ( estrofes)}

P. 38:

Nota MA: expoente “(1)” no v. 1, remetendo ao comentário no rodapé:

“(1)” Eu o vi! - tremendo era no gesto,

Terrivel seu olhar;

E o senho carregado pretendia

O globo dominar.

“(1) Decassilabo sem a quarta silaba / devorada pela acentuação importan-/ti da $3^{a}$. Mistura enfim de metrica / qualitativa e quantitativa, sendo o vi / silaba longa, valendo 2 breves."

P. 39:

Notas MA:

1. preposição sublinhada nos v. 14 e 15, "para", e cruzeta - estudo linguístico: emprego de "para/pra":

$$
\begin{array}{cc} 
& \text { Que a um filho seu talvez quizera o nobre } \\
X & \text { Para um Executor; } \\
X & \text { Ou para o leito infesto alguma filha } \\
& \text { Do triste agricultor. }
\end{array}
$$

2. comentário ao final do poema:

“Estas Visões onde todo o carolismo e mo-/ralismo patetico de G. Dias se expande..."

P. 39-41

O COMETA ( estrofes)

P. 41:

Nota MA: comentário ao final do poema:

"Versos onde Bilac se inspirou talvez pra aquela / estranha maravilha sua "O Cometa","

P. 41-42

O OIRO ( estrofes)

$\underline{\text { P. } 42-45}$

$\overline{\text { A UM MENINO ( estrofes) }}$

P. 43:

Notas MA: verbo sublinhado nos v. 7 e 8, "adormeces", fio ligando as duas ocorrências e expoente "(1)", remetendo ao comentário no rodapé:

- Dos teus brinquedos te esqueces

Á noitinha, - e te entristeces 
Como a bonina, - e adormeces,

Adormeces a sonhar

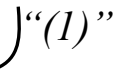

"(1) Notar a musicalidade desta repeti-/ção, processo de que o poeta se utiliza / ás vezes, e varias só nesta poesia."

P. 45:

Nota MA: comentário ao final do poema:

Só aquelle que da morte

Soffre o terrivel córte,

Não tem dôres que supporte,

Nem sonhos o acordarão:

Gentil infante, engraçado,

Que vives tão sem cuidado,

Serás homem - mal peccado!

Findará teu sonho então.

"Gracioso. Delicioso e bem aplicado ritmo. / Aqui G. Dias soube encontrar as frases / que falam."

$\underline{\text { P. } 45-50}$

O PIRATA (31 estrofes)

P. 46:

Nota MA: v. 5-12 destacados por colchete e expoente “(1)”, remetendo ao comentário no rodapé:

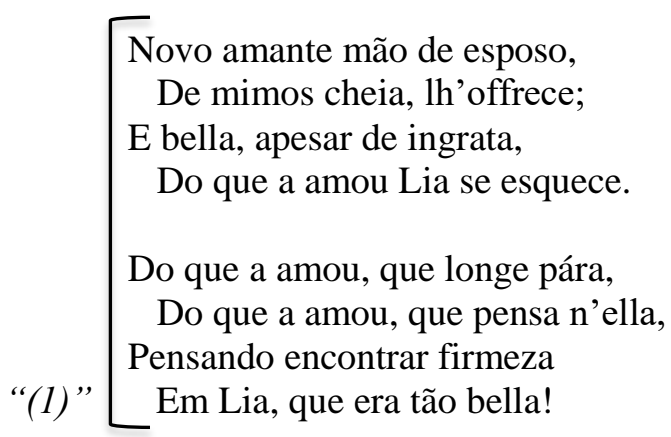

"(1) Aliás este mesmo assunto / já G. Dias tratou no $1^{\circ}$ volume, / provando que o fere de perto. E é com / acento tradicional de romanceiro. / Veja I, p. 39, "O Soldado Espanhol". Curioso / que neste o soldado mata a ingrata. Aqui / G. Dias mais velho e experiente, faz o des-/leixado partir."

Nota da pesquisa: A ingratidão de Lia respalda o comentário de MA, em “Amor e medo", quanto à recorrência da infidelidade feminina na obra de Gonçalves Dias (In: Aspectos da literatura brasileira. Ed. cit., p. 215).

P. 48:

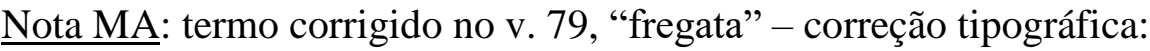


Nada mais que essa fregata! $/ a$

Nada mais de quanto amava!

P. 50:

Notas MA: preposição sublinhada nos v. 120 e 124, "para", e cruzeta - estudo linguístico: emprego de "para/pra":
Erão chorosos seus olhos,
Os olhos seus enxugou;
E o telescopio de novo
$X \quad$ Para essa vela apontou.
Quem era o vulto tão triste
Parece reconheceu;
Mas a vela no horisonte
$X \quad$ Para sempre se perdeu.

P. 50-57

A VILLA MALDITA (36 estrofes)

P. 51:

Nota MA: termo sublinhado no v. 17, "dithyrambo", e escólio "dic" - pesquisa para o Dicionário musical brasileiro:

E o livre dithyrambo, a atroz blasphemia, "dic"

Os cantos immoraes, canções impudicas,

Gritos e orgias envolta em negro manto

De fumo e vinho, - os ares aturdião;

P. 53-54:

Notas MA:

1. v. 85-88 e 101-104 destacados por traço ondulado - estudo do estilo: artifício/repetição:

$\left\{\begin{array}{l}\text { Eis o aço da guerra lampeja, } \\ \text { Do fogoso corsel o nitrido, } \\ \text { Eis o bronzco canhão que rouqueja, } \\ \text { Eis da morte represso o gemido. }\end{array}\right.$

2. comentário ao final da parte IV:

“G. Dias tem um talento especial pra descrições / de lutas, guerras, maldições em que emprega com / grande felicidade o ritmo de 9 silabas."

P. 55:

Notas MA:

1. expoente "(1)” no v. 126, remetendo ao comentário no rodapé;

2. v. 125-142 destacados por traço vertical:

E o exercito contrario entra rugindo

Na villa, que as suas "(1)" portas lhe franqueia:

Rasteiro corre o incendio e surdamente 
O custoso edificio ataca e mina.

Eis que a chamma roaz amostra as fendas

Das portas que se abrazão; descortina

O torvo olhar do vencedor - apenas -

Lá dentro o incendio só, fóra só trevas!

Urros de frenesí, de dôr, de raiva

Escutão dos que, ás subitas colhidos,

Contra os muros em brasa se arremeção;

Dos que, perdido o tino, intentão loucos

Achar a salvação, e a morte encontrão.

Lá dentro confusão, silencio fóra!

São carrascos aqui, victimas dentro,

Geme o travejamento, estrala a pedra,

Cresce horror sobre horror, desaba o tecto,

E o fumo ennegrecido se ennovella

P. 56:

Notas MA:

1. v. 143-159 destacados por traço vertical e comentário lateral;

2. expoente "(1)" ao final, remetendo ao comentário no rodapé:

Co’o vertice sublime os céus roçando.

Como o vulcão que a lava arroja ás nuvens

Como ignea columna que da terra

Hiante rebentasse, - tal se eleva,

Tal sóbe aos ares, tal se empina e cresce

A labareda portentosa; e baixa,

E desce á terra, e o edificio enrola,

E o sorve inteiro, qual se forão vagas

Que a dura rocha do alicerce abalão,

Que a enlação, como a prêa, - e ao fundo pégo

Levão, deixando o mar branco d'espuma.

No horror da noite, sibilando os ventos,

Lingoas pyramidaes do atroz incendio,

Fumosas pelas ruas estalando,

Tingem da côr do inferno a côr da noite,

Tingem da côr do sangue a côr do inferno!

- O ar gritos, fumo o céu, e a terra fogo. "(1)”

"Belo e forte / Entroncamentos afoitos livres / continuados / como Alberto de / Oliveira e Gui / os fariam mais / tarde."

“(1) Lindissima esta $6^{a}$ Parte.”

$\underline{\text { P. 57-65 }}$

QUADRAS DA MiNHA VIDA / RECORDAÇÃO E DESEJO

P. 58:

Nota MA: v. 13-35 destacados por traço vertical: 


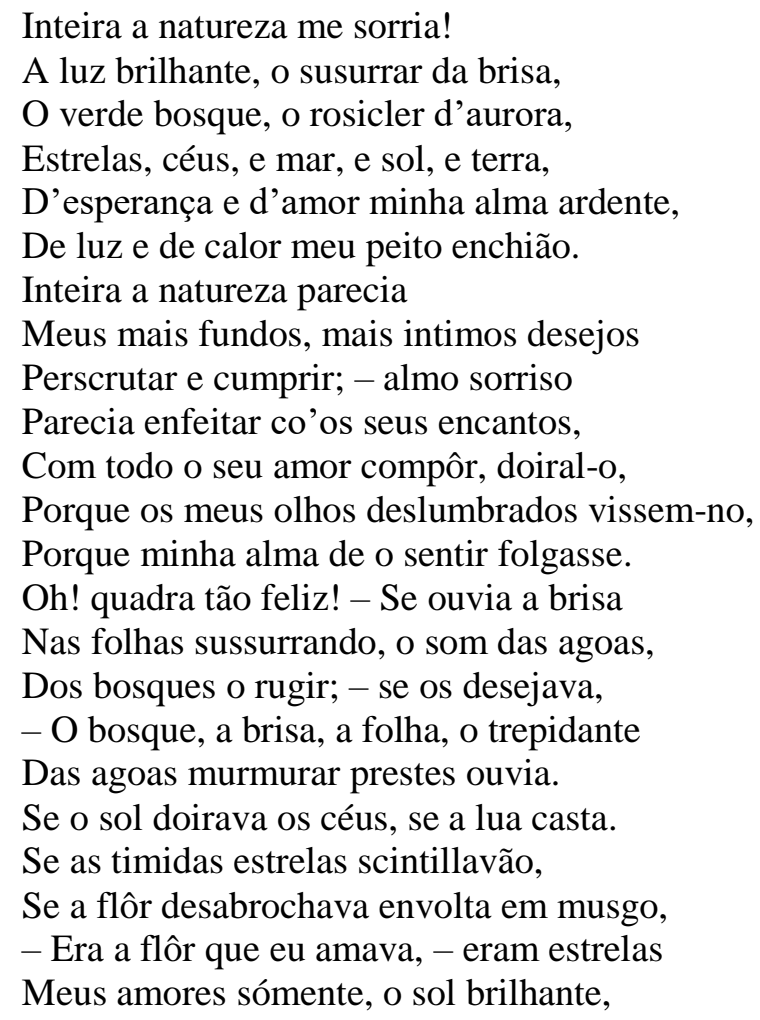

P. 59:

Notas MA:

1. v. 36-49 destacados por traço vertical -

2. preposição sublinhada no v. 40, "para", e cruzeta - estudo linguístico: emprego de "para/pra":
A lua merencoria - os meus amores! Oh! quadra tão feliz! - doce harmonia, Acôrdo estreme de vontade e força, Que atava minha vida á natureza! Ella era para mim bem como a esposa Recem-casada, pudica sorrindo; Alma de noiva - coração de virgem, Que a minha vida inteira abrilhantava! Quando um desejo me brotava n'alma, Ella o desejo meu satisfazia;
E o quer que ella fizesse ou me dissesse, Esse era o meu desejo, essa a voz minha, Esse era o meu sentir do fundo d'alma, Expresso pela voz que eu mais amava.

\section{P. 62:}

\section{Notas MA:}

1. v. 117 sublinhado, cruzeta e sílaba inicial assinalada por colcheta - estudo da versificação: métrica / anacruse;

2. preposição sublinhada no v. 122, "para", e cruzeta - estudo linguístico: emprego de "para/pra":

$$
X \quad \text { Infante e velho! - princípio e fim da vida! - }
$$


Gozando ambos da aurora; - um sobre a terra,

E o outro lá nos céus. - O Deus, que é grande,

Do pobre velho compensando as dores,

O chama para si; o Deus clemente

Sobre a inocência de continuo vela.

3. v. 131-142 destacados por traço vertical - estudo da psicologia: sentimento amoroso / amizade:

Houve tempo, em que possível

Eu julguei no mundo achar

Dois amigos extremosos,

Dois irmãos do meu pensar:

Amigos que compr'endessem

Meu prazer e minha dor,

Dos meus lábios o sorriso,

Da minha alma o dissabor;

Amigos, cuja existência

Vivesse eu co'o meu viver:

Unidos sempre na vida,

Unidos - té no morrer.

\section{P. 63:}

Notas MA:

1. v. 143-168 destacados por traço vertical;

2. expoente "(1)" ao final da parte V, remetendo ao comentário no rodapé:

Amizade! - união, virtude, encanto -

Consórcio do querer, de força e d'alma -

Dos grandes sentimentos cá da terra

Talvez o mais recíproco, o mais fundo!

Quem há que diga: Eu sou feliz! - se acaso

Um amigo lhe falta? - um doce amigo,

Que sinta o seu prazer como ele o sente,

Que sofra a sua dor como ele a sofre?

Quando a ventura lhe sorri na vida,

Um a par doutro - ei-los lá vão felizes;

Quando um sente aflição, nos braços do outro

A aflição, que é só dum, carpindo juntos,

Encontra doce alívio o desditoso

No tesouro que encerra um peito amigo.

Cândido par de cisnes, vão roçando

A face azul do mar co'as níveas asas

Em deleite amoroso; - acalentados

Pelo sereno espreguiçar das ondas,

Aspirando perfumes mal sentidos,

Por vesperina aragem bafejados,

É jogo o seu viver; - porém se o vento

No frondoso arvoredo ruge ao longe,

Se o mar, batendo irado as ermas praias,

Cruzadas vagas em novelo enrola,

Com grito de terror o par candente 
“(1)” Sacode as níveas asas, bate-as, - fogem.

"Aqui enfim G. Dias dá largas ao ideal / de amizade que sonhava."

P. 64:

Notas MA:

1. pronome sublinhado no v. 185, cruzeta e escólio "1 silaba"-

Não tinha uma harmonia a natureza

1 silaba $X \quad$ Comparada a sua voz; não tinha cores

Formosas como as dela, - nem perfumes

2. trecho sublinhado nos v. 193 e 194 e cruzeta - estudo da psicologia: mulher;

3. verbo sublinhado no v. 197, "carecia", cruzeta e escólio "brasil." - estudo do estilo: vocabulário / estudo linguístico: brasileirismo:

Ouviam com prazer; meus olhos vagos

De a ver não se cansavam; lábios d'homens

Não puderam dizer como eu a amava!

$X \quad$ E achei que o amor mentia, e que o meu anjo

Era apenas mulher! chorei! deixei-a!

E aqueles, que eu amei co'o amor d'amigo,

A sorte, boa ou má, levou-mos longe,

brasil $X \quad$ Bem longe quando eu perto os carecia.

4. v. 202-204 destacados por traço vertical triplo - estudo da psicologia: amizade / sentimento amoroso:

Concluí que a amizade era um fantasma,

Na velhice prudente - hábito apenas,

No jovem - doudejar; em mim lembrança;

Lembrança! - porém tal que a não trocara

$/ /\left(\begin{array}{l}\text { Pelos gozos da terra, }- \text { meus prazeres } \\ \text { Foram só meus amigos, }- \text { meus amores } \\ \text { Hão de ser neste mundo eles somente. }\end{array}\right.$

Nota da pesquisa: Achando que o amor mentia, e que "o anjo era apenas mulher", o eu lírico do poema municia a percepção de MA quanto à frequência da infidelidade (atribuída à amada) nos poemas de Gonçalves Dias ("Amor e medo", In: Aspectos da literatura brasileira. Ed. cit., p. 215).

P. 65:

Notas MA:

1. termo sublinhado no v. 210, "dobrar", e escólio "dic" - pesquisa para o Dicionário musical brasileiro:

Quando ouvia o sino escuro

Em sons pesados dobrar, "dic"

E os cantos do sacerdote

Erguidos junto do altar 
2. v. 218 sublinhado, destacado por cruzeta e número " 1 " - estudo da versificação: métrica:

Feliz quem dorme sob a lousa amiga,

$X$

1 Tepida talvez com o pranto amargo

Dos olhos da afflicção;

3. trecho sublinhado nos v. 232 e 233 - estudo da psicologia: morte:

No teu silencio fundo asilo eterno!

Ahi não pulsa o coração, nem sente

Martyrios de viver quem já não vive.

P. 66-69

PhANTASMAS (17 estrofes)

S/ Notas MA

P. 70-74

O BARDO (14 estrofes)

P. 71:

Notas MA:

1. termo sublinhado no v. 40, "mundo", e sublinha - estudo do estilo: artifício/repetição;

2. preposição sublinhada no v. 42, "para", e cruzeta - estudo linguístico: emprego de "para/pra":

3. preposição sublinhada no v. 43, "p'ra”, e cruzeta - estudo linguístico: emprego de "para/pra":

Somos do mundo sem saber do mundo;

Aprouve ao Senhor Deus lançar-nos nelle,

Sem vida para nós, com tanta vida, $\quad X$

Com tanta força de querer p'ra os outros. $\quad X$

P. 72:

Notas MA:

1. preposição sublinhada no v. 56, "para", e cruzeta - estudo linguístico: emprego de "para/pra":

$X \quad$ Mas se hospicios haveis para os que soffrem,

Nos soffremos tambem, - tambem mendigos,

Trocamos, como outr' ora o velho Homero,

Celestes carmes por um pão de azyma!"

2. v. 60 e 61 sublinhados e destacados por traço vertical triplo - estudo da psicologia da criação: sinceridade / estudo do estilo: artifício / repetição:

(/( - Fallais do mundo sem saber do mundo,

E do vosso mister sem saber delle; 
3. pronome sublinhado no v. 72, “tua”, e cruzeta - estudo da versificação: métrica:

$X \quad$ Quero crer na tua crença; e se és propheta,

Eu t'o supplico, do porvir me falia !-

4. v. 74-84 destacados por traço vertical duplo - estudo do estilo: imagens da natureza:

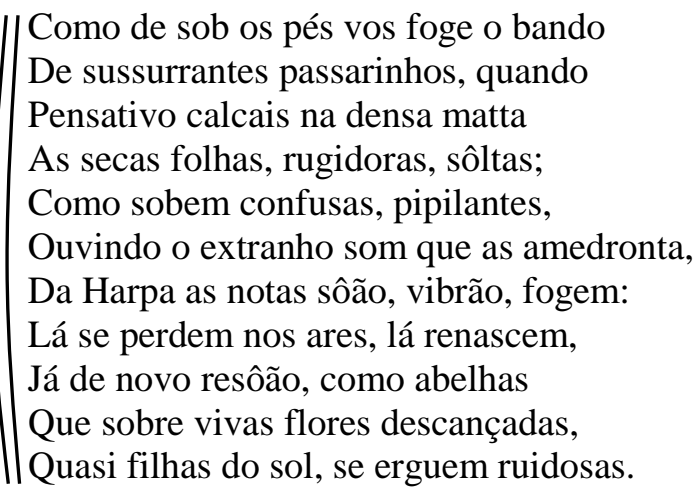

P. 73:

Notas MA:

1. termo sublinhado, "c'roado", e cruzeta - estudo do estilo: c'roa / licenças poéticas:

Ali morno silencio qual precede

Da batalha o fragor - troava o sino,

E foi c'roado... escravo! $\quad X$

2. v. 97 sublinhado, cruzeta e número " 1 " - estudo da versificação: métrica / anacruse:

3. trecho sublinhado no v. 107 e cruzeta - estudo da psicologia: amizade:

4. v. 97-108 destacados por traço vertical - seleção de ideias: sina do poeta:

1 Mas quando o Senhor Deos um bardo cria, $\quad X$

Funde-lhe a mente de trovões, de raios,

De nobre fogo lh'incendeia o peito

De colera e de amor!

E o manda sobre a terra ingrata e nua,

Que vôe sobre os astros, que a sentença,

Que Balthasar temeu, grave nos muros

D'impudico festim!

Que suspire, que gema, que soluce,

Que se lembre dos céus cantando a terra,

Que um amigo não tenha, que a sua vida

E' soffrer e cantar!

P. 74:

Notas MA:

1. v. 135 destacado por traço vertical;

2. expressão sublinhada no v. 136, "nota harmoniosa", e escólio "dic" - pesquisa para o Dicionário musical brasileiro;

3. v. 139-142 destacados por traço vertical, ligados ao v. 135 por um fio - seleção de ideias: poesia / estudo do estilo: imagens: 
( - Assim do bardo os feiticeiros versos!

Resôão, como nota harmoniosa, "dic"

Como suspiro d'innocente virgem

Na placidez da noite adormecida;

Resôão, mas tambem se extinguem prestes,

Como nota de uma harpa vaporosa,

Como o perfume que uma flôr exhala,

Como o suspiro que uma virgem sólta!

\title{
P. $75-85$
}

\section{POEMETO / ANALIA}

\section{$\underline{\text { CANTO I }}$}

P. 75-76:

Nota MA: v. 9-21 destacados por traço vertical e comentário:

\author{
Noite não era já, não era dia; \\ Porém a fresca, matutina brisa \\ Começava a correr, prenhe de aromas, \\ Por entre as verdes folhas dos olmeiros, \\ Como o suspiro que remata o somno \\ De uma virgem que dorme. D'entre as ramas \\ Em desafio as aves entornavão \\ As notas varias do seu hymno eterno, \\ A cujos sons a natureza acorda \\ E o coração se alegra; da neblina \\ Os densos rôlos - dos profundos valles \\ E dos cimos erguidos - procuravão, \\ Attrahidos do sol, mais alta esphera!
}

"Bela des-/crição, antes / invocação"

P. 77:

Nota MA: v. 51 sublinhado e expoente “(1)”, remetendo ao comentário no rodapé:

Mal distinctas palavras murmurão:

Não voz, porém accentos mal formados,

Quasi grito e rugidos, que passavão

De um peito a outro sem roças nos labios;

"Verso positivamente errado"

P. 79:

Nota MA: v. 112 sublinhado - estudo da versificação: estrutura em quiasmo:

A vida off'rece a quem the dera a vida,

Que a amava tanto! - seu amor confessa,

Finezas d'elle, que a vencêra amando, 


\section{$\underline{\text { CANTO II }}$}

P. 80:

Nota MA: v. 1-16 destacados por traço vertical - estudo da psicologia: sentimento amoroso:

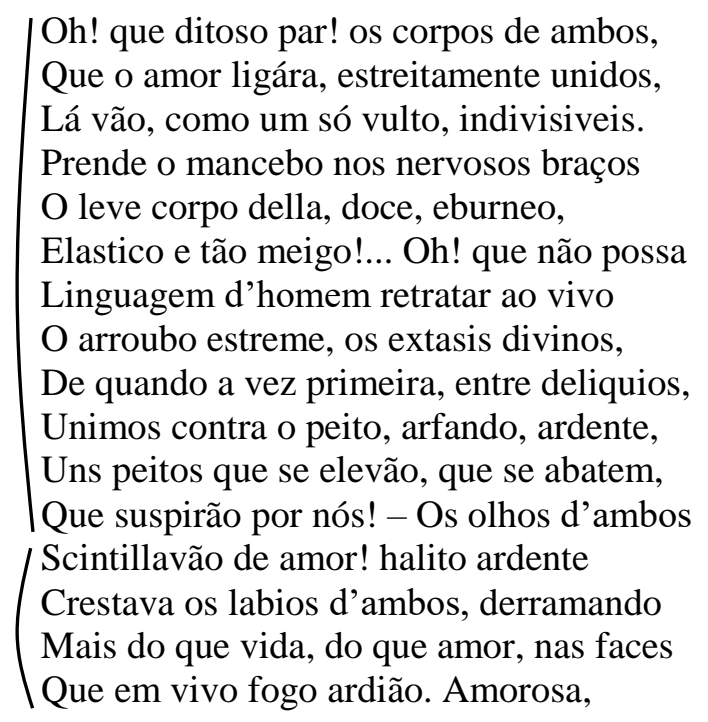

Nota da pesquisa: A rubrica "Pedaços belos" também refere esta página, no fichamento crítico das obras de Gonçalves Dias (MA-MMA-05-04).

P. 81:

Nota MA: v. 27-34 destacados por colchete - estudo da psicologia: sentimento amoroso:

Não sabes! por te amar daria a vida,

Até a gota extrema, que em meu peito,

Qu'inda em meu coração girar sentisse;

E quando a propria vida me faltára,

Minha alma, e o que me espera além da morte,

Daria por te amar. - É fraca a prova

De soffrer doce peso algumas horas

Por viver em delicias longos annos."

Nota da pesquisa: Os versos são transpostos para "Amor e medo", onde embasam o argumento de MA quanto à "fillosofia pessimista do amor" que tem Gonçalves Dias: "É bem já uma concepção ansiosa de aniquilamento, dita com vigor, a gente percebe que o poeta não está apenas fazendo madrigal. É uma concepção intimamente dele.” (In: Aspectos da literatura brasileira. Ed. cit., p. 216).

P. 85:

Nota MA: comentário ao final do poemeto:

"Esta ascenção tão falada e não descri-/ta é bem romantica. Porem G. D. con-/segue apesar disso interessar muito, gra-/duando com arte infinita. As falas ro-/manticas são belas aqui, ardentes, vibrando / como em idealizado ardor. De descrição / só o indispensavel, porem este indispen-/savel arqueja com realidade e consegue / sustentar o entusiasmo. O poemeto é po-/sitivamente belo." 
P. $87-148$

\section{POESIAS AMERICANAS}

$\underline{\text { P. } 87-88}$

CANÇÃO DO EXILIO (5 estrofes)

P. 88:

Notas MA:

1. preposição sublinhada no v. 20, "para", e cruzeta - estudo linguístico: emprego de "para/pra":

2. escólio "Fabordão" - estudo da versificação / do estilo: fabordão;

3. comentário ao final do poema:

Não permitta Deos que eu morra,

$X \quad$ Sem que eu volte para lá;

Sem que desfructe os primores

Que não encontro por cá;

Sem qu'inda aviste as palmeiras,

Onde canta o Sabiá.

\section{"Fabordão}

Esta quoda de G. D. comove e sublima pelo senti-/mento geral que a ditou e pela musicalidade ge-/nial. É som puro que nem o milhor de Goethe Hei-/ne Verlaine. Porém ideias fracas. Erradas mesmo. Sa-/biá cantando na palmei-/ra já muito se falou que só mes-/mo estudante de Coimbra podia / pregar mentirada dessas. Duma / feita me escutando ressoar ês-/ses versos um sitiante / me secundou: Homem... / até agora no alto do / coqueiro só enxerguei / urubú dormindo."

P. $88-92$

O CANTO DO GUERREIRO (9 estrofes)

P. 90:

Nota MA: termo sublinhado no v. 43, "boré", e escólio "dic" - pesquisa para o Dicionário musical brasileiro:

$$
\begin{aligned}
& \text { Se as matas estrujo } \\
& \text { Co'os sons do Boré, } \\
& \text { Mil arcos se encurvão, } \\
& \text { Mil setas lá voão, }
\end{aligned}
$$

P. 91:

Notas MA:

1. termo sublinhado no v. 56, "carpido", e escólio "zoof" - pesquisa da zoofonia:

$\mathrm{O}$ vento gemendo

$\mathrm{E}$ as matas tremendo

E o triste carpido "zoof"

D'uma ave a cantar, 
2. termo sublinhado no v. 61, "maracá", e escólio "dic" - pesquisa para o Dicionário musical brasileiro:

E o Piaga se ruge

No seu Maracá,

“dic"

A morte lá paira

Nos ares frechados,

P. 92-95

O CANTO DO PIÁGA (20 estrofes)

P. 92:

Nota MA: expressão sublinhada nos v. 13 e 14, "um phantasma" - estudo do estilo: artifício/repetição:

Eis rebenta a meus pés um phantasma,

Um phantasma d'immensa extensão;

Liso craneo repousa a meu lado,

Feia cobra se enrosca no chão.

\section{P. 93:}

Notas MA:

1. v. 31 e 32 destacados por colchete e escólio "zoof" - pesquisa da zoofonia:

Tu não viste nos céos um negrume

Toda a face do sol offuscar,

Não ouviste a coruja, de dia, ] "zoof"

Sons estridulos torva soltar?

2. termo sublinhado no v. 42, "maracá", e escólio "dic" - pesquisa para o Dicionário musical brasileiro:

Ouve o annuncio do horrendo phantasma,

Ouve os sons do fiel Maracá; "dic"

Manitôs já fugirão da Taba!

Ó desgraça! ó ruina! ó Tupá!

\section{P. 94:}

Notas MA:

1. v. 59 e 60 destacados por colchete -

Oh! quem foi das entranhas das aguas,

O marinho arcabouço arrancar?

Nossas terras demanda, fareja...

Esse monstro... - o que vem cá buscar?

2. escólio entre os v. 68 e 70, "a civilização industrial”:

Vem trazer-vos crueza, impiedade,

Dons crueis do cruel Anhangá; 
Vem quebrar-vos a maça valente,

Profanar, Manitôs, Maracás.

¿ "a civilização

Vem trazer-vos algemas pesadas,

Com que a tribu,Tupi vai gemer:

P. 95:

industrial"

Notas MA:

1. escólio acima do v. 77, "brios";

2. comentário ao final do poema:

"brios"

Vossos Deoses, ó Piagá, conjura,

Susta as iras do féro Anhangá.

Manitôs já fugirão da Taba,

Ó desgraça! ó ruina! ó Tupá!

"Belissimo. G. Dias o que manejou milhor o ritmo / de nove silabas na lingua. Esta imprecação se ajunta / ao grupo que lembro na pg 54 deste vol. A pieda-/de de G. Dias pelo indio é uma pura pieda-/de intelectual. O tema indigena foi pra êle / mais propriamente um meio de criação arItistica que um meio de expressão. G. Dias u-/nico romantico que foi mais aproximadamente / arte-pura. E atinge Camões neste poema."

\section{P. 95-281}

O CANTO DO INDIO (13 estrofes)

P. 96:

Notas MA:

1. termo sublinhado no v. 28, "boré" - pesquisa para o Dicionário musical brasileiro:

Passára a vida inteira a contemplar-te,

Ó Virgem, loira Virgem tão formosa,

Sem que dos meus irmãos ouvisse o canto,

Sem que o som do Boré que incita á guerra

2. expressões sublinhadas nos v. 36 e 37, "uma voz" e "terna voz" - estudo do estilo: artifício/repetição:

Outra vez - d'entre os seus labios

Uma voz se desprendia;

Terna voz, cheia de encantos,

Que eu entender não podia.

$\underline{\text { P. } 97-98}$

CAXIAS (4 estrofes)

P. 98:

Nota MA: termo sublinhado no v. 23, "c'roa", e cruzeta - estudo do estilo: c'roa / licenças poéticas: 
$X \quad$ Da pompa e luxo amiga, hão de cahir-te

$X \quad$ Aos pés então - da poesia a c'roa

E da innocencia o cinto.

\section{P. 98-100}

DEPRECAÇÃO (12 estrofes)

P. 98:

Nota MA: pronome assinalado no v. 6, "tua" - estudo da versificação: métrica:

Tupan, ó Deus grande! teu rosto descobre:

$X \quad$ Bastante soffremos com tu/a vingança!

Já lagrimas tristes chorárão teus filhos

Teus filhos que chórão tão grande mudança.

P. 99:

Nota MA: v. 13-16 assinalados por traço vertical duplo-

$$
\| \begin{aligned}
& \text { E a terra em que pisão, e os campos e os rios } \\
& \text { Que assaltão, são nossos; tu és nosso Deus: } \\
& \text { Porque lhes condedes tão alta pujança, } \\
& \text { Se os raios de morte, que vibrão, são teus? }
\end{aligned}
$$

P. 100:

Nota MA: trecho sublinhado nos v. 41 e 45, "descobre o teu rosto" - estudo do estilo: artifício/repetição:

Tupan, ó Deus grande! descobre o teu rosto

Bastante soffremos com tua vingança!

Já lágrimas tristes chorarão teus filhos,

Teus filhos que chórã 0 tão grande tardança.

Descobre o teu rosto, resurjão os bravos,

Que eu vi combatendo no albor da manhã;

Conheção-te os féros, confessem vencidos

Que és grande e te vingas, qu'és Deus, ó Tupan!

"Notar a admiravel musicalidade dos re-/frãos que perpassão toda a poesia. É de-/licioso, dum encantamento sonoro."

P. 100-101

TAByra, Dedicatoria aos Pernambucanos (6 estrofes)

P. 101:

Nota MA: termo corrigido no v. 31, "muito" - correção tipográfica:

“/X” Não vivem muitos as flôres: são meus versos

Ephemeros como ellas; côr sem brilho,

Ou perfume apagado. 
P. $102-108$

TABYRA (25 estrofes)

P. 103:

Notas MA:

1. v. 50 sublinhado - estudo do estilo: imagem;

2. termo sublinhado no v. 52, "nenias", e escólio "dic" - pesquisa para o Dicionário musical brasileiro;

3. trecho sublinhado no v. 54 - estudo linguístico: sintaxe:

Vivem homens de pel' côr da noite

Neste solo, que a vida embelleza;

Podem, servos, debaixo do açoite,

Nenias tristes da patria cantar!

dic

Mas o indio que a vida só préza

$X \quad$ Por amor dos combates, e festas

Dos triunfos sangrentos, e sestas

Resguardadas do sol no palmar;

P. 104:

Notas MA:

1. termo sublinhado no v. 61, "palreiro", e escólio "zoof" - pesquisa da zoofonia:

"zoof" Ama as selvas, e o vento palreiro,

Ama a gloria, ama a vida; mas antes

Que viver amargados instantes,

Quer e póde e bem sabe morrer!

2. v. 71 sublinhado e cruzeta - estudo do estilo: artifício/repetição:

Poucos são, mas briosos soldados;

Não são homens de aspecto jocundo!

$X \quad$ Restos são, mas são restos d'um mundo;

Poucos são, mas soldados por fim!

P. 105:

Notas MA:

1. preposição sublinhada no v. 97, "para", e cruzeta - estudo linguístico: emprego de "para/pra":

2. trecho sublinhado no v. 104, "quem menti", e cruzeta - estudo linguístico: concordância verbal:

$X \quad$ "Para o vosso terreiro vos chamo,

Contra mim vinde todos, - sou forte:

Occorrei ao meu nobre reclamo!

Aqui sou, nem me parto d'aqui!

Vinde todos em densa cohorte:

Travaremos combate sangrento;

Mas por fim do triunfo cruento

Direis vós se fui eu quem menti." $\quad X$

$\underline{\text { P. 106: }}$ 


\title{
Notas MA:
}

1. v. 120 sublinhado - estudo do estilo: artifício/repetição / estudo da versificação: estrutura:

Todo o campo descobre occupado Por guerreiros, - no extremo horisonte Não distingue, nas faldas do montes, O que é gente, o que gente não é.

2. termo sublinhado no v. 133, "atitos", e escólio "dic" - pesquisa para o Dicionário musical brasileiro:

\author{
dic Já com silvos e atitos voavão \\ Muitas outras, que o triste gemido \\ No conflicto, abafado e sumido, \\ Talvez derão, — mas fraco, mas vão!
}

3. v. 137-146 destacados por traço vertical - estudo do estilo: descrição:

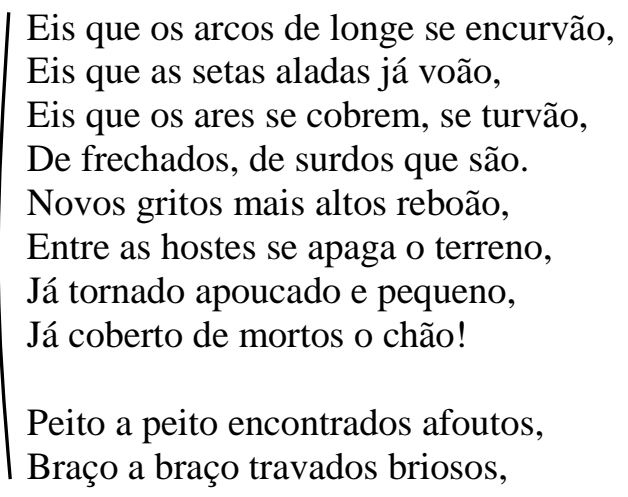

P. 107:

Notas MA:

1. v. 147-176 destacados por traço vertical;

2. v. 169 sublinhado e escólios "realismo / homerico / Descritivo / sublime" - estudo do estilo: descrição:

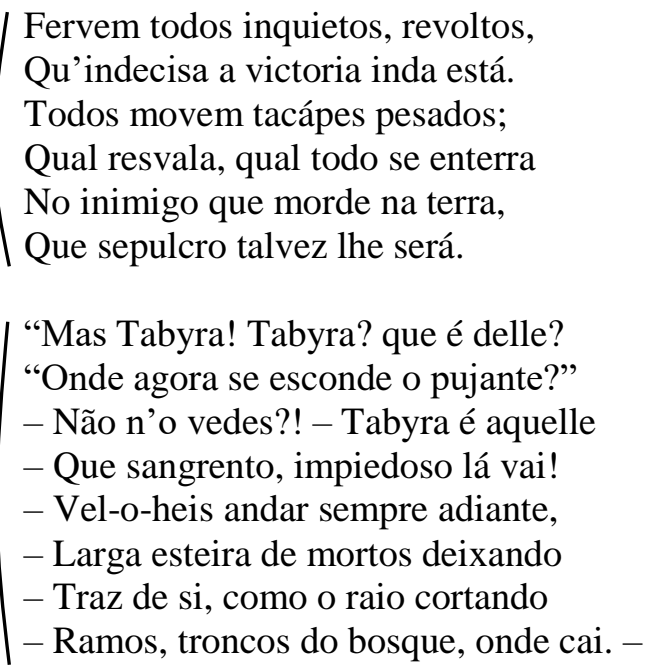


"Foge! foge! leal Tobajara;

"Quantos arcos que em ti fazem mira?!"

- Muitos são; porém medos encara

- Face a face, quem é como eu sou! -

Muitas setas cravejão Tabyra:

Bello quadro! - mas vel-o era horrivel!

Porco-espim que sangrando e terrivel

Duras cerdas raivando espetou!

Tem um olho d'um tiro frechado!

"realismo

Quebra as setas que os passos lh'impedem,

homerico

E do rosto, em seu sangue lavado,

Frecha e olho arrebata sem dó!

Descritivo

$\mathrm{E}$ aos imigos que o campo não cedem,

sublime"

Olho e frecha mostrando extorquidos,

Diz, em voz que mais erão rugidos:

- Basta, vís, por vencer-vos um só!

P. 108:

Notas MA:

1. termo corrigido no v. 182, "indo" - correção tipográfia:

lo Inda á fera mais torva e bravia

Disputando guarida d'um dia

No mais fundo do vasto sertão!

2. termo sublinhado nos v. 187 e 188, "povo" - estudo do estilo: artifício/repetição;

3. v. 191 e 192 destacados por traço vertical - seleção de ideias: bravura e escravidão:

Potiguares, que a aurora risonha

Vio nação numerosa e potente,

Não já povo na tarde medonha,

Mas só restos d'um povo infeliz!

Insepultos na terra inclemente

Muitos dormem; mas ha quem lh'inveja

(Essa morte do bravo em peleja,

Quem a vida do escravo maldiz!

4. comentário ao final do poema:

"Mostrar a diferença entre a função social / da poesia negra de Castro Alves e a fun/ção artistica da poesia indianista de / G Dias. Nos 2 versos e estancia final apenas / deste poema ele parece comover-se mas não / buscar comover com a condição precaria do / indio escravo ao passo que C. Alves não, nem / se percebe bem que se comova, antes procura / comover porque fez da poesia um instru-/mento de combate. Por aí se justificaria / em parte a grandiloquencia falsa e re-/buscada de que abusa pois busca como-/ver e trazer pro seu partido o povo sen-/do como foi um poeta popular. G. Dias / busca os temas de que o indio sai no-/bilitado e heroi, busca temas de tradição / ou heroicos. C. Alves busca temas / em que o negro sai rebaixado e / desinfeliz. Nada tem de tradicional / ou erudito. G Dias é um erudito e / um artista." 
O GigANTE DE PEDRA (22 estrofes)

P. 110:

Nota MA: preposição sublinhada no v. 37, “p'ra”, e cruzeta - estudo linguístico: emprego de "para/pra":

$X \quad$ Já descahe p'ra o occidente,
E em globo de fogo ardente
Vai-se no mar esconder;

P. 112:

Notas MA:

1. expressão sublinhada no v. 81, "phantasmas sombrias", e escólio "feminino" - estudo do estilo: vocabulário / estudo linguístico: gênero:

Sempre, incessante a cahir,

Tombão as horas e os dias,

Como phantasmas sombrias, "feminino"

Nos abysmos do porvir!

2. v. 88-92 destacados por traço vertical e expoente “(1)”, remetendo ao comentário no rodapé:

“(1)" $\begin{aligned} & \text { Com soberba indifferença } \\ & \text { Sente extincta a antiga crença } \\ & \text { Dos Tamoyos, dos Pagés; } \\ & \text { Nem vê que duras desgraças, } \\ & \text { Que lutas de novas raças } \\ & \text { Se lhe atropellão aos pés! }\end{aligned}$

“(1) Mais razoavel que C. Alves não vê / unilateralmente uma só desgraça, a do negro, / mas mais pensador e sabio, percebe a infelici-/dade universal. Ainda e sempre mais inteli-/gencia que sensibilidade."

3. termo sublinhado no v. 102, "murmuré", e escólio "dic" - pesquisa para o Dicionário musical brasileiro:

Vio primeiro os incolas

Robustos, das florestas,

Batendo os arcos rigidos,

Traçando homereas festas,

A luz dos fogos rutilos,

"dic" Aos sons do murmuré!

P. 113:

Notas MA:

1. termos sublinhados nos v. 105 e 108, "guáu" e "boré" - pesquisa para o Dicionário musical brasileiro:

E em Guanabara esplendida

As danças dos guerreiros,

E o guáu cadente e vário

Dos moços prazenteiros, 
E os cantos da victoria

Tangidos no boré.

2. termo sublinhado no v. 117, “janubia" - pesquisa para o Dicionário musical brasileiro:

E os cantos da janubia

Junto ás lenhas accesas,

Quando o tapuya misero

Seus feitos vai narrar!

3. termo sublinhado no v. 132, "maracá" - pesquisa para o Dicionário musical brasileiro:

Lá vai a gente improvida,

Nação vencida, imbelle,

Buscando as matas invias,

Donde outra tribu a expelle;

Jaz o pagé sem gloria,

Sem gloria o maracá.

P. 114:

Notas MA:

1. termo corrigido no v. 145 , "tempos" - correção tipográfica:

2. v. 147 e 148 destacados por traço vertical duplo - seleção de ideias: nacionalismo:

Mudarão-se os tempe e a face da terra, "/os"

Cidades alastrão o antigo paúl;

Mas inda o gigante, que dorme na serra,

Se abraça ao immenso cruzeiro do sul.

3. v. 151-156 destacados por traço vertical e escólio "Nacionalismo" - seleção de ideias: nacionalismo:

Nas duras montanhas os membros gelados,

Talhados a golpes de ignoto buril,

Descança, ó gigante, que encerras os fados,

Que os terminos guardas do vasto Brazil.

"Nacionalis-/mo"

Porém se algum dia fortuna inconstante

Puder-nos a crença e a patria acabar,

Arroja-te ás ondas, ó duro gigante,

Inunda estes montes, desloca este mar!

P. $115-116$

LEITO DE FOLHAS VERDES (9 estrofes)

P. 115:

Nota MA: v. 16 sublinhado e assinalado por cruzeta - estudo da psicologia: sentimento amoroso:

Brilha a lua no céo, brilhão estrellas,

Correm perfumes no correr da brisa,

A cujo influxo magico respira-se 


\section{Um quebranto de amor, melhor que a vida $\quad X$}

P. 116:

Notas MA:

1. v. 29 e 30 assinalados por traço vertical e escólio "Refrão" - estudo da versificação: refrão / estudo do estilo: artifício/repetição:
"Refrão" (Do tamarindo a flôr jaz entre-aberta, (Já solta o bogari mais doce aroma;
Tambem meu coração, como estas flôres,
Melhor perfume ao pé da noite exhala!

2. juízo de valor ao final do poema:

"Sublime. Perfeito. Inigualavel."

Nota da pesquisa: "Leito de folhas verdes" é classificado por MA - no fichamento crítico que integra o dossiê do manuscrito Amor e medo - como uma das "Obras-primas" de Gonçalves Dias; (MA-MMA-05-04).

\section{$\underline{\text { P. } 116-133}$}

Y-JUCA PIRAMA (53 estrofes)

P. 116:

Nota MA: advérbio sublinhado no v. 11, "lá", e fio ligando-o ao v. 17, na página seguinte - estudo da versificação:

São todos Tymbiras, guerreiros valentes!

Seu nome lá vôa na bocca das gentes,

Condão de prodígios, de gloria e terror!

P. 117:

Notas MA:

1. termo sublinhado no v. 15, "maracás", e cruzeta - pesquisa para o Dicionário musical brasileiro;

2. advérbio sublinhado no v. 17, "lá", fio ligando-o ao v. 11, na página anterior, e expoente “(1)”, remetendo ao comentário na margem superior - estudo da versificação:

As tribus vizinhas, sem forças, sem brio,

As armas quebrando, lançando-as ao rio,

O incenso aspirárão dos seus maracás: $\quad X$

Medrosos das guerras que os fortes accendem,

Custosos tributos ignavos lá rendem, "(1)”

Aos duros guerreiros sujeitos na paz.

"(1) G. Dias tem a mania de encher o verso com / este lá principalmente e não me lembro agora mais / que monossilabo. Estas Americanas então es-/tão cheias de "lá"."

P. 119:

Notas MA: 
1. expressão sublinhada nos v. 72 e 73, "folga morrendo" - estudo do estilo: artifício/repetição;

2. v. 73-76 e 85-88 destacados por traço ondulado - estudo do estilo: artifício/repetição:

Que tens, guerreiro? Que temor te assalta

No passo horrendo?

Honra das tabas que nascer te viram,

Folga morrendo.

Folga morrendo; porque além dos Andes

Revive o forte,

Que soube ufano contrastar os medos

Da fria morte.

$[\ldots]$

Que temes, ó guerreiro? Além dos Andes

Revive o forte,

Que soube ufano contrastar os medos

Da fria morte.

P. 121:

Nota MA: v. 142-145 destacados por colchete e termo sublinhado no v. 145, "maracás" - seleção de imagens / pesquisa para o Dicionário musical brasileiro:

$\left.\begin{array}{l}\text { E os campos talados, } \\ \text { E os arcos quebrados, } \\ \text { E os piagas coitados } \\ \text { Já sem maracás; }\end{array}\right]$

P. 125:

Nota MA: preposição sublinhada no v. 264, "para”, e cruzeta - estudo linguístico: emprego de "para/pra":

- As setas da aflição já se esgotaram,

Nem para novo golpe espaço intacto $X$

Em nossos corpos resta.

P. 127:

Nota MA: comentário ao final da parte VI:

"Sublime esta fala. Não valeu teoria romantica / nenhuma. Nada de discursos. Soberbo de sintese, duma / grandeza sublime de pobreza. É total."

P. 129:

Nota MA: v. 384 e 385 destacados por colchete - estudo da psicologia: amizade:

Não encontres amor nas mulheres,

Teus amigos, se amigos tiveres,

Tenham alma inconstante e falaz!

P. 132: 
Notas MA:

1. preposição sublinhada no v. 453, "para", e cruzeta - estudo linguístico: emprego de "para/pra":

- Basta, guerreiro ilustre! Assaz lutaste,
$X \quad$ E para o sacrifício é mister forças. -

2. v. 461-466 antecedidos pelo escólio "Fabordão" - estudo do estilo / versificação: fabordão:

"Fabordão" Um velho Tymbira, coberto de gloria,

Guardou a memoria

Do moço guerreiro, do velho Tupi!

E á noite, nas tabas, se alguém duvidava

Do que elle contava,

Dizia prudente: - "Meninos, eu vi!

P. 133:

Notas MA:

1. comentário ao final do poema:

"Pra acabar fabordão, pura / necessidade musical, tão intima, tão forte em / Gonçalves Dias como porventura em nenhum outro / poeta brasileiro. E no entanto são estes tão musicais."

2. comentário na margem superior:

"I-Juca Pirama a grande obra-prima da poesia brasi-/leira em lingua portuguesa. Poema a que nada falta, I sem falha de concepção, sem falha de realização, uni-/do todo, um marco de literatura universal, a mais perfeita / obra literaria inspirada, pelo exotico existente no mundo. Cha-/teaubriand desaparece. A pureza deste exotismo em com/paração com o exotismo romantico das outras poesias. Não / é verdade que os herois de G. Dias estejam vestidos de sen-/timentos de civilização cristão, são selvagens, o jovem tupi / morre entre as lagrimas de prazer do pai, G Dias não transporta / os seus herois pra dentro de si, transporta-se pra dentro deles, / e consegue a inconcebivel virtuosidade de realizar os / indios num portugues maravilhoso, perfeito, dando o que mi-/lhor tinha de si na musicalidade: no ritmo, na graça leve-/mente arcaisante e amaneirada. É formidavel."

\section{P. 133-135}

MARABÁ (11 estrofes)

P. 134:

Notas MA:

1. expressão sublinhada nos v. 14 e 16, "bem pretos" - estudo do estilo: artifício/repetição:

Responde enojado: "mas es Marabá:

"Quero antes uns olhos bem pretos, luzentes,

"Uns olhos fulgentes,

"Bem pretos, retinctos, não côr d'anajá!" 
2. verbo corrigido no v. 29 , "resvala" - correção tipográfica;

3. v. 30 sublinhado e cruzeta - estudo da psicologia: sentimento amoroso:

- Meu collo de leve se encurva engraçado,

- Como hastea pendente do cactos em flôr;

"resvala" - Mimosa, indolente, resvalo no prado,

- Como um soluçado suspiro de amor! - $\quad X$

P. 135:

Nota MA: comentário ao final do poema:

"O artificialismo absoluto desta deliciosissi-/ma lirica."

$\underline{\text { P. } 135-138}$

CANÇÃO DO TAMOYO (10 estrofes)

S/Notas MA

P. $139-140$

A MANGUEIRA (7 estrofes)

P. 139:

Notas MA:

1. v. 1, 2, 6 e 7 destacados por traço vertical, ligados por um fio - estudo do estilo: artifício/repetição;

2. v. $8,9,13$ e 14 destacados por traço vertical, ligados por um fio - estudo do estilo: artifício/repetição;

3. v. $15,16,20$ e 21 destacados por traço vertical, ligados por um fio - estudo do estilo: artifício/repetição;

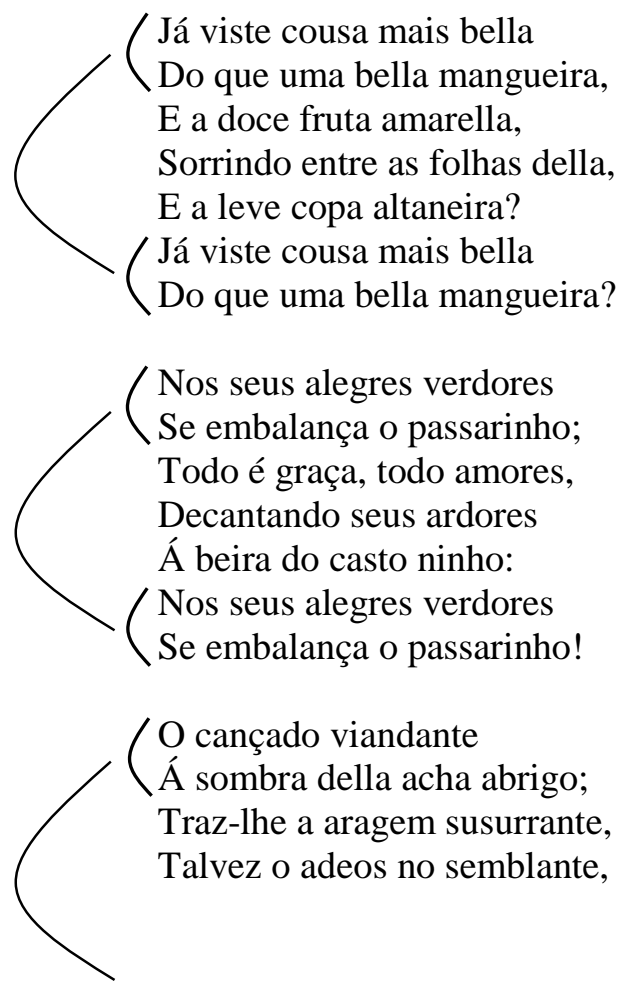


Talvez o adeos d'um amigo;

(E o cançado viandante

Á sombra della acha abrigo.

4. comentário na margem superior:

"Realmente só a meio se pode como Alexandre / Herculano deplorar não sejam mais numerosas / as Poesias Americanas de G. Dias. Só podiam ser / mais numerosos os temas geograficos, vegetais do / poeta. Na terra ele encontraria com efeito mais temas / do que usou porém o indianismo era pobre e utiliza-/do do gosto romantico pode-se dizer que G. Dias explo-/rou tudo o que ele daria de milhor. Com efeito, apesar / da vastidão de pensamento de Machado de Assis / e da habilidade e riqueza de imaginativa de Bilac / nada mais se tirou do indianismo, nem mesmo o Evange-/lho das Selvas. Só Machado conseguiu ainda uma obra / prima essa mesma só com uma ligeira base no espiritualismo indigena amerindio. O Indianismo / era necessariamente um tema intelectual, não um moto li-/rico organizado da sensibilidade que nem a escravidão (vista, / em redor do poeta) o amor, o lar etc. D'ai serem os poetas de inteli-/gencia e os artifices grandes como G. D. Machado e Bilac os que se pre-locuparam com ele. $O$ indianismo do Evangelho das Selvas é um / incidente local apenas, o tema é a religião."

P. 140:

Nota MA: preposição sublinhada no v. 30, "para”, e cruzeta - estudo linguístico: emprego de "para/pra":

O mancebo namorado
$X \quad \underline{\text { Para ella se encaminha; }}$

P. $140-148$

A MÃe D’ÁguA (35 estrofes)

P. 140:

Nota MA: v. 3 sublinhado e fio ligando-o ao v. 34, na p. seguinte - estudo do estilo: artifício/repetição:

"Minha mãe, olha aqui dentro

Olha a bella creatura,

Que dentro d'agoa se vê!

São d'ouro os longos cabellos,

P. 141:

Notas MA:

1. termo sublinhado no v. 23, "rosa", e escólio interrogativo "galicismo?" - estudo do estilo: vocabulário;

2. preposição sublinhada no v. 26, "para", e cruzeta - estudo linguístico: emprego de "para/pra":

Olha agora que me avista

A bella moça formosa,

Como se fez toda rosa, "galicismo?" 
Toda candura e jasmim!

Dize, mãe, dize: tu julgas

Que ella se ri para mim?

$X$

3. v. 34 sublinhado, fio ligando-o ao v. 3, na página anterior, e comentário:

"Este verso se repete / adiante. O concei-/to musical de repetição de frases e meandros de fra-/ses é dos mais estilizados por G. Dias e um dos traços / mais caracteristicos da poetica dele."

P. 142:

Notas MA:

1. trecho sublinhado no v. 39:
A imagem que te embelleza
É mais do que uma princeza,
É menos do que é a gente.

2. v. 45 sublinhado e remissão ao comentário na página anterior - estudo do estilo: artifício/repetição:

Foi porque derão ouvidos

Á leve sombra enganosa,

Que dentro d'agoa se vê!! "Ver nota atrás"

3. v. 46-49 destacados por colchete e escólio "Mãi e / irmã" - estudo da psicologia: mãe e irmã:

4. hiato assinalado no v. 49 - estudo da versificação: métrica:

"Mãi e
irmã $\left[\begin{array}{l}- \text { O seu sorriso é mentira, } \\ \text { Não é mais que sombra vã; } \\ \text { Não vale aquilo que eu valho, } \\ \text { Nem o que val tu/a irmã: }\end{array}\right.$

P. 143:

Notas MA:

1. preposição sublinhada nos v. 73 e 75, "para", e cruzeta - estudo linguístico: emprego de "para/pra":

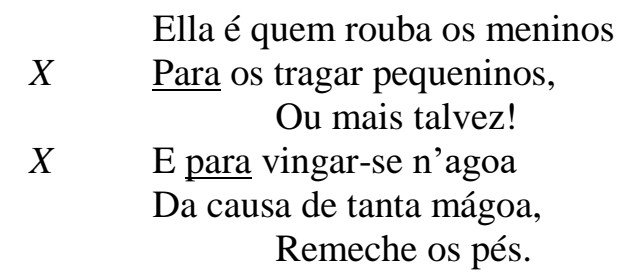

2. v. 88 e 89 , idênticos aos v. 94 e 95 , destacados por traço vertical e remissão:

Minha mãe, bem que indulgente,

(Só por não me ver contente,

Me repr'hendeu. - 


\section{P. 144:}

Notas MA:

1. v. 94 e 95 destacados por traço vertical - estudo do estilo: artifício/repetição:

Oh! minha mãe certamente

(Só por não me ver contente,

Me repr'hendeu. -

2. preposição sublinhada no v. 100, "para", e cruzeta - estudo linguístico: emprego de "para/pra":

$$
\begin{array}{ll}
X \quad \text { E na fonte cristallina } \\
\quad & \text { Para ver todo se inclina } \\
\text { Se a póde ver! }
\end{array}
$$

3. v. 110 sublinhado e comentário - estudo do estilo: artifício/repetição:

E de triste arrependido

Diz comsigo entristecido:

- Que mal fiz eu!...

"Esta frase tambem / é repetição"

P. 145:

Notas MA:

1. termo sublinhado no v. 122, "harpa", e escólios "harpa na mão / da Iara !! / dic" pesquisa para o Dicionário musical brasileiro:

Uma harpa a seu lado frisava a corrente,

"harpa na mão

Gemendo queixosa da leve pressão,

da Iara!!

Como harpas ethereas, que as brisas conversão,

dic"

Achando-as perdidas em mesta soidão.

2. expressão sublinhada no v. 130, "harpa dourada", e fio ligando aos escólios "harpa na mão / da Iara!! / dic"” - pesquisa para ODicionário musical brasil фiro:

A harpa dourada de subito vibra,

A charpa se agita do seio ao travez;

Das franjas garbosas as pedras reflectem

Infindos luzeiros nos humidos pés.

3. expressão sublinhada no v. 144, "harpa dourada", e fio ligand $\phi$ aos escólios "harpa na mão / da Iara !! / dic" - pesquisa para o Dicionário musical brasileiro:

"Vem meu amigo" dizia

A bella fada engraçada,

Pulsando a harpa dourada:

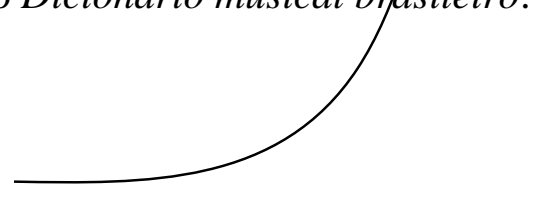

"Sou boa, não faço mal,

Vem ver meus bellos palacios,

Meus dominios dilatados

Meus thesouros encantados

No meu reino de crystal. 
P. 146:

Notas MA:

1. planejamento ao final da fala da Iara:

"Vem, te chamo: vê a lympha

Como é bella e crystallina;

Vê esta areia tão fina,

Que mais que a neve seduz!

Vem, verás como aqui dentro

Brincão mil leves amores,

Como em listas multicores

Do sol se desfaz a luz.

"Se não achas borboletas

Nem as vagas mariposas,

Que brincão por entre as rosas

Do teu ameno jardim;

Tens mil peixinhos brilhantes,

Mais luzentes e mais bellos

Que o oiro dos meus cabellos,

Que a nitidez do setim.”

"Compara-la com a fala do Erlkönig e / com os versos do poema As Yaras musicado / por Nepomuceno”"

2. v. 166-169 destacados por traço vertical e comentário:

Emtanto o menino se curva e se inclina

Por ver de mais perto a donosa visão;

E a mãe, longe delle, dizia: - Meu filho,

Não oiças, não vejas, que é má tentação. -

"Refrão / No poema / Gigante de / Pedra. G. Dias empre-/ga este mesmo processo / de refrão."

Notas da pesquisa:

1. MA não deixa notas de leitura às margens do poema "Erlkönig", de Goethe (17491842).Na Biblioteca de MA, no IEB/USP, todo o volume primeiro de Goethes lyrische und epische Dichtungen (Leipzig: Inselverlag, 1920) está livre de notas de margem. No volume, que corresponde às poesias líricas de Goethe, entre os anos de 1756 e 1813, achase apenas a dedicatória de Else Schöler, professora de alemão de MA: "Sr. Mario de Andrade / z. Erinnerung aus / E. Schöler." No volume segundo, com as obras líricas até 1832, mais a poesia épica, MA remete às páginas 121 e 547, na folha de guarda. Naquela, os versos iniciais de "Hatem" são assinalados por traço vertical: "Nicht Gelegenheit macht Diebe, / Sie ist selbst der Grösste Dieb; / Denn sie stahl den Rest der Liebe, / Die mir noch im Herzen blieb." À p. 547, MA assinala termos que desconhece, no poema Hermann und Dorothea; sublinha as palavras, traduzindo-as à margem, sempre a lápis.

2. "As Yaras": poema musicado por Alberto Nepomuceno (1864-1920).

P. 147:

Nota MA: termo sublinhado no v. 184, "toadas", e escólio "dic" - pesquisa para o Dicionário musical brasileiro: 
Mil figuras apparecem,

Mil donzellas encantadas

Com angelicas toadas "dic"

De ameigar o coração.

\section{P. 148:}

Notas MA:

1. preposição sublinhada no v. 203, "para", e cruzeta - estudo linguístico: emprego de "para/pra":

Emtanto o menino se curva e se inclina

$X \quad$ Para a visão;

E a mãe lhe dizia: - Não vejas, meu filho,

Que é tentação. -

2. comentário ao final do poema:

"Parece incontestavel que G. Dias neste poema fra-/co de que só valem mesmo as 2 primeiras partes / se inspirou no Erlkönig, ficando aliás muito aquem / da sublime lied de Goethe. Mesma forma, 2 falas / do duende, morte final."

\section{$\underline{\text { P. } 149-218}$}

\section{OS TYMBIRAS}

\section{$\underline{\text { P. } 151-153}$}

INTRODUCÇÃO

\section{P. 152:}

Notas MA:

1. versos destacados por traço vertical duplo;

2. trecho sublinhado, "palmeira escolho", e fio ligando ao comentário na página seguinte;

3. versos destacados por traço vertical e expoente "(1)", remetendo ao comentário no rodapé:

Escute-me. - Cantor modesto e humilde,

A fronte não cingi de myrto e louro,

Antes de verde rama engrinaldei-a,

// D'agrestes flôres enfeitando a lyra;

Não me assentei nos cimos do Parnaso,

Nem vi correr a lympha da Castalia.

Cantor das selva, entre bravas mattas

Aspero tronco da palmeira escolho.

Unido a elle soltarei meu canto,

“(1)", l $\begin{aligned} & \text { Emquanto o vento nos palmares zune, } \\ & \text { Rugindo os longos encontrados leques. }\end{aligned}$

"(1) Os tons descritivos de G. Dias embora / mais parcos que os de Varela são mais / incisivos e realistas. Alias tem sempre / em G. Dias, quasi sempre, uma tal ou qual / secura realista de pensamento. Se observe / por exemplo na Mãe D'agua como tudo o / que esta canta ou quasi, é tirado das possi-/bilidades de encantação do proprio fundo do 
rio ou das / condições da Mãe D'agua mesmo. E inumeros traços realis-/tamente descritos a todo instante nestas Americanas. Na pg. / anterior, como é eficaz por ex. as setas caindo uma depois / da outra e ficando no caminho como que a indica-lo."

P. 153:

Notas MA:

1. comentário ao final da introdução:

"É uma das mais belas invocações / de inicio de poema que conheço. Compara-/la á dos Lusiadas."

2. comentário ligado por um fio ao verso, na página anterior:

"Nacionalismo: / É curioso de se notar que o naciona-/lismo naturalista, quero dizer, em I relação á natureza, dos nossos romanticos / si aquartelou na copa da palmeira qua-/si que só. A Varela coube ir um pouco / alem. Os outros desque falam no Brasil / nacionalistamente, ou por saudade ou / por exaltação patriotica lá vem palmei-/ra."

\section{$\underline{\text { P. } 154-281}$}

CANTO PRIMEIRO

P. 156:

Nota MA: preposição sublinhada, "para", e cruzeta - estudo linguístico: emprego de "para/pra":

Assim o pae sorri ao filho imberbe,

Que desprezado o arco seu pequeno,

$X \quad$ Talhado para aquellas mãos sem forças,

Tenta d'outro maior curvar as pontas

P. 157:

Nota MA: trecho sublinhado e fio ligando-o ao escólio na margem superior, "traço homerico" - estudo do estilo: descrição / matriz homérica:

"traço homerico"

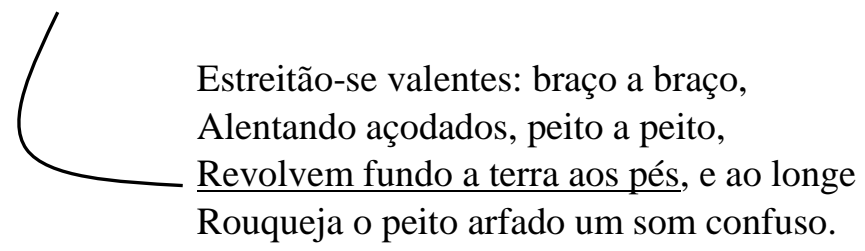

P. 159:

Nota MA: versos destacados por traço vertical e escólio "realismo" - estudo do estilo: descrição:

Emquanto assim medita, vae levando

Por onde o céo e as selvas se confundem,

Por onde o rio, em tortuosos gyros, "realismo"

Queixoso lambe as empedradas margens. 
P. 160:

Notas MA:

1. termo sublinhado, "boré", e escólio "dic" - pesquisa para o Dicionário musical brasileiro;

2. versos destacados por traço vertical e escólio "realismo" - estudo do estilo: descrição:

"dic" E os sons guerreiros do boré, e os cantos

"realismo" $\quad\left(\begin{array}{l}\text { Do combate; parece, d'irritado, } \\ \text { Tão grande peso agora a flôr lhe corta, } \\ \text { Que o rio vae sorver as altas margens." }\end{array}\right.$

P. 161:

Notas MA:

1. termo sublinhado, "boré", e escólio “dic / veja p. seg." - pesquisa para o Dicionário musical brasileiro;

2. trecho sublinhado, "clarim, nuncio de guerra", e escólio "dic" - pesquisa para o

Dicionário musical brasileiro;

$\mathrm{O}$ atroador memby ${ }^{(l)}$ soprou com força.

“dic/veja p. seg."

$\mathrm{O}$ tronco, o arbusto, a moita, a rocha, a pedra,

Convertem-se em guerreiros; mais depressa,

Quando sôa o clarim, nuncio de guerra, "dic"

“(1) Me parece que G. Dias se engana. O mem-/bi era uma flauta e portanto não atroa/va."

P. 162:

Notas MA:

1. termo sublinhado, "buzio", escólio "memby / dic" e fio ligando ao termo "memby troante", na página seguinte - pesquisa para o Dicionário musical brasileiro:

"memby Aos sons do cavo buzio conhecido,

dic"

2. versos destacados por traço vertical e escólio "realismo" - estudo do estilo: descrição:

"realismo" $\left(\begin{array}{l}\text { Jucá desprende o golpe, e furta o corpo: } \\ \text { Onde estavão seus pés, as duras garras } \\ \text { Encravão-se enganadas, e onde as garras }\end{array}\right.$

P. 163:

Nota MA: expressão sublinhada, "memby troante", cruzeta e fio ligando ao termo "buzio", na página anterior - pesquisa para o Dicionário musical brasileiro:

Os sons guerreiros do memby troante

$X$

P. 164:

Nota MA: termo corrigido, "temperado" - correção tipográfica: 
Vallioso e prestante. Alli, mil vezes,

Havia com prudencia temperado " " $e$ (?)"

P. 166:

Nota MA: verbo sublinhado, "attitão", e escólio "zoof” - pesquisa da zoofonia:

Altercão elles nas ruidosas tabas,

Emquanto Jurucey com pé ligeiro

"zoof" Caminha: as aves docemente attitão,

P. $167-181$

CANTO SEGUNDO (4 estrofes)

P. 167:

Nota MA: verso sublinhado - estudo do estilo: imagem / interesse etnográfico:

Era pujante o chefe dos Tymbiras,

Sem conto seus guerreiros, tres as tabas,

Opimas, - uma e uma derramadas

Em gyro, como dança dos guerreiros.

P. 168:

Nota MA: verbo sublinhado, "carece", cruzeta e expoente "(1)", remetendo ao comentário no rodapé - estudo do estilo: vocabulário:

$X \quad$ Rudas palhoças só! que mais carece

“(1)”

"Gonc. Dias diz sistematicamente / carecer por precisar."

P. 169:

Notas MA:

1. verso sublinhado - estudo do estilo: imagem:

2. expressão sublinhada, "nem que" - estudo linguístico: sintaxe:

De Itajuba separão-se os guerreiros;

Mudos, ás portas das sombrias tabas,

Immoveis, nem que fossem duros troncos,

3. versos destacados por traço vertical - estudo do estilo: descrição;

4. termos sublinhados, "cascaveis" e "maracá", e escólio "dic" - pesquisa para o Dicionário musical brasileiro;

Cercão-lhe os pulsos cascaveis loquazes, "dic"

Respondem outros, no tripudio sacro,

Dos pés. Vem magestoso, e grave, e cheio

Do Deos, que o peito seu, tão fraco, habita.

E emquanto o fumo the volteia em torno, 
Como neblina em torno ao sol que nasce,

Ruidoso maracá nas mãos sustenta, "dic"

Sólta do sacro rito os sons cadentes.

P. 170:

Notas MA:

1. termo sublinhado, "maracá" - pesquisa para o Dicionário musical brasileiro;

2. verso sublinhado e escólio "refrão" - estudo do estilo / da versificação: refrão:

Escute-me Tupan! Sobre vós outros,

Poder do maracá por mim tangido,

"refrão" Os sonhos desção, quando o orvalho desce!

3. termo sublinhado, "caraibêbes", e cruzeta - interesse etnográfico;

4. versos destacados por traço vertical e escólio "defumação / Catimbo" - estudo do estilo: descrição / interesse etnográfico;

5. expressão sublinhada, "poder do fumo" - interesse etnográfico:

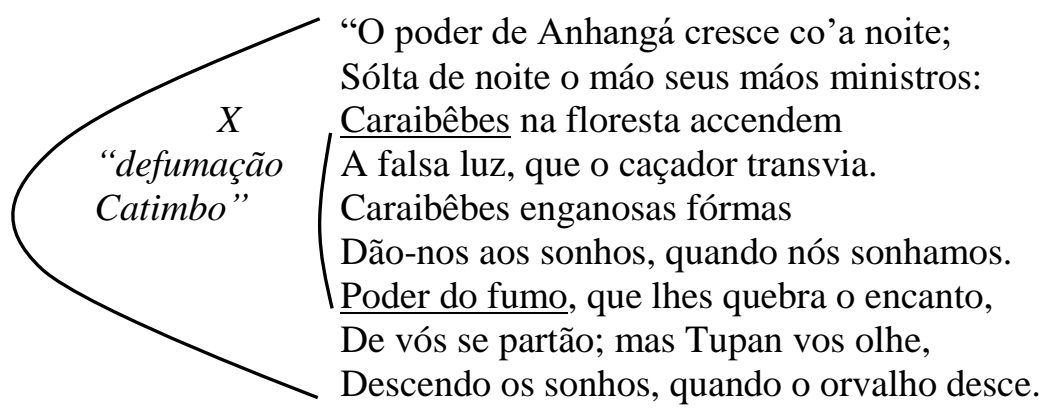

6. versos destacados e escólio "zoof" - pesquisa da zoofonia;

7. versos destacados por traço vertical - estudo do estilo: descrição / interesse etnográfico / preparação do romance:

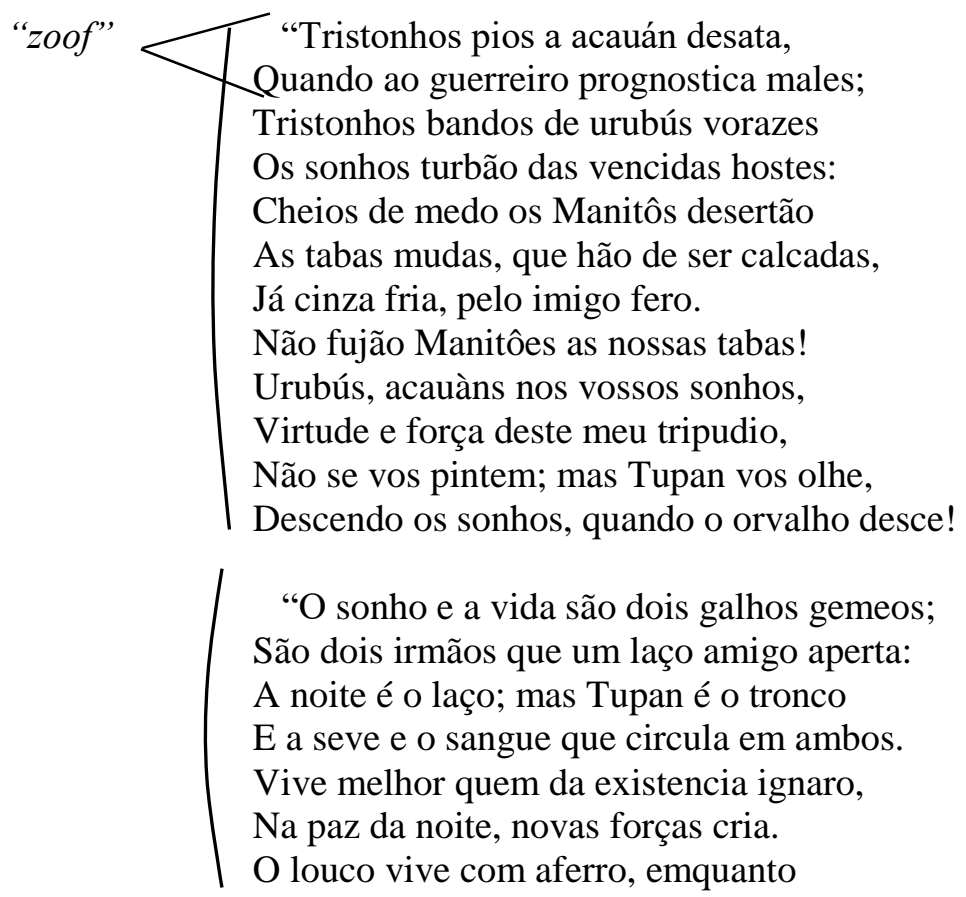




\section{P. 171:}

Notas MA:

1. versos destacados por traço vertical - estudo do estilo: descrição / interesse etnográfico / preparação do romance;

2. verso assinalado por expoente "(1)”, remetendo ao comentário no rodapé;

3. versos destacados por colchete e escólio "dança / ritual do / piaga” - estudo do estilo: descrição / interesse etnográfico / preparação do romance;
N'alma lhe ondeião do delirio as sombras,
De vida espurias; Deos porém lh'as rompe,
E na loucura do porvir nos falla!
Tupan vos olhe, e sobre vós de Ibake
Os sonhos desção, quando o orvalho desce." “(1)”
Assim cantava o piága merencorio,
Tangia o maracá, dançava em roda
Dos guerreiros: pu'dera ouvido attento
Os sons finaes da lagubre toada
Na placida mudez da noite amiga
De longe, em côro ouvir: "Sobre nós outros
Os sonhos desção, quando o orvalho desce."
"Dança ritual do piága"

“(1) Observar pela ligação dos decassilabos de acentuação heroica e acentuação romantica a admiravel ritmica desta invocação."

4. nome sublinhado, "Areskí", e escólio "Indios / Deus da Guerra" - interesse etnográfico:

Mas que medita o chefe dos Tymbiras?

Bosqueja por ventura ardís de guerra,

Fabrica e enreda as asperas ciladas,

E a olhos nús do pensamento enxerga

Desfeita em sangue revolver-se em gritos

Morte pavida e má?! ou sente e avista,

Escandecida a mente, o Deos da guerra

Impavido Areskí, sanhudo e forte, "Indios

Calcar aos pés cadaveres sem conto Deus da Guerra"

$\mathrm{Na}$ dextra ingente sacudindo a maça,

Donde certeira, como o raio, desce

A morte, e banha-se orgulhosa - em sangue?

P. 172:

Notas MA:

1. crase corrigida - correção tipográfica:

Não tem poder a noite em seus sentidos,

"/á" Que a mesma ideia de continuo volvem.

2. versos destacados por traço vertical - estudo do estilo: lirismo: 


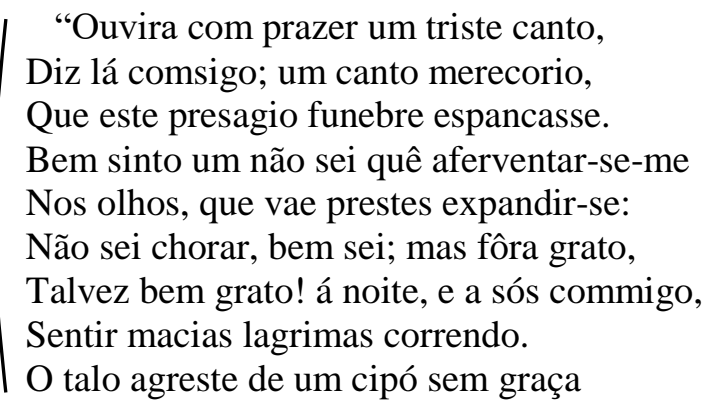

P. 173:

Notas MA:

1. versos destacados por traço vertical e expoente “(1)”, remetendo ao comentário no rodapé:

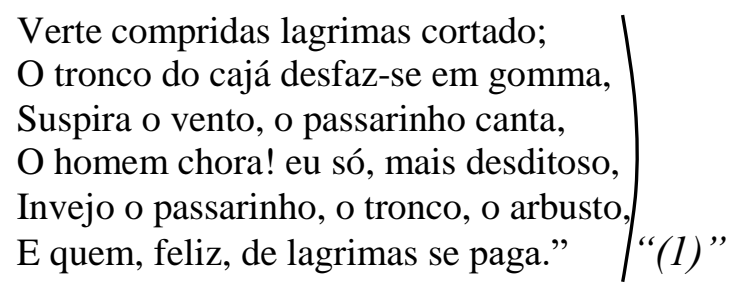

“(1) Estes 15 versos são um delicioso soneto lírico.”

2. versos assinalados pelo escólio "dança / profana" - interesse etnográfico;

3. termo sublinhado, "maracá" - pesquisa para o Dicionário musical brasileiro;

4. termo corrigido, "passos" - correção tipográfica:

Emmudeceu, na taba quasi escura, Com pé alterno a dança vagarosa, Aos sons do maracá, traçava os paȩos.

Nota da pesquisa: Exemplo recolhido à rubrica "Pedaços belos", no fichamento crítico das obras de Gonçalves Dias (MA-MMA-05-04).

P. 174:

Notas MA: verso sublinhado, versos assinalados por traço vertical e escólio "refrão" estudo do estilo: artifício/repetição:

"refrão" (Coema, luz de amor, flôr de belleza,

P. 175:

Nota MA: verso sublinhado - estudo do estilo: artifício/repetição:

Narrava do Mair; nunca os ouviras,

Flôr de belleza, luz de amor, Coema!

P. 177:

Notas MA:

1. versos destacados por traço vertical e expoente “(1)”, remetendo ao comentário no rodapé; 
2. termo sublinhado, "compasso", e escólio "metafora" - estudo do estilo: imagem:

$$
\text { "(1)" } \mid \begin{aligned}
& \text { "Descança agora o pallido cadaver } \\
& \text { (Continúa o cantor) junto á corrente } \\
& \text { Do regato, que volve areias d'ouro. } \\
& \text { O modestes flôres lhe matizão } \\
& \text { Descantão tristes nenias ao compasso } \\
& \text { Das aguas, que tambem nenias solução. }
\end{aligned} \text { "metafora" }
$$

"(1) G. Dias nunca descreve a paisagem / pela paisagem. O interesse humano / dentro da paisagem de G. Dias. / A contribuição da paisagem pro / elemento humano."

P. 180:

Nota MA: expressão sublinhada, "não vê-me", e cruzeta - estudo linguístico / do estilo: sintaxe/colocação pronominal:

Tambem me não lembra que tempo hei vivido.

Nem por que razão

Da morte me queixo, que vejo, e não vê-me, $\quad X$

Tão sem compaixão."

P. 182-201

\section{CANTO TERCEIRO}

\section{P. 184:}

Notas MA:

1. vero sublinhado e escólio "Brasil" - seleção de ideias;

2. veros destacados por traço vertical duplo e comentário:

\begin{tabular}{|c|c|}
\hline \multirow{3}{*}{ "Brasil" } & \\
\hline & \\
\hline & $\begin{array}{l}\text { Do pae aos filhos e do filho aos netos, } \\
\text { Porque um delles de todo apague a culpa, }\end{array}$ \\
\hline & II Virá correndo a maldição - contínua, \\
\hline maldições & Como fuzis de uma cadeia eterna. \\
\hline imprecações & Myriadas de sombras miserandas, \\
\hline etc é sempre & Scarnecendo, seccar o nosso orgulho \\
\hline forte" & De nação; mas nação que tem por base \\
\hline & Os frios ossos da nação senhora, \\
\hline & E por cimento a cinza profanada \\
\hline & Dos mortos, amassada aos pés de escravos \\
\hline & Não me deslumbra a luz da velha Europa; \\
\hline & Ha de apagar-se, mas que a inunde agora: \\
\hline & E nós!... sucámos leite máo na infancia, \\
\hline & $\begin{array}{l}\text { Hol corrompiao o ar que respiramos, } \\
\text { Havemos de acabar talvez primeiro. }\end{array}$ \\
\hline
\end{tabular}

P. 187:

Notas MA:

1. versos destacados - estudo do estilo: descrição; 
2. termo sublinhado, "maracá" - pesquisa para o Dicionário musical brasileiro:

Vem por fim Itajuba. O piága austero,

Volvendo o maracá nas mãos myrrhadas,

Pergunta: "Foi o espirito comvosco,

O espirito da força, e os ledos sonhos,

Ministros de Tupan, nuncios da gloria?"

- Sim, forão, lhe respondem, ledos sonhos,

Correios de Tupan; mas o mais claro

É duro nó que o piága só desata. -

"Dizei-os pois, que vos escuta o piága."

Disse, e maneja o maracá: das boccas

Do mysterio divino, em puros flocos

De neve, o fumo em borbotões golfeja.

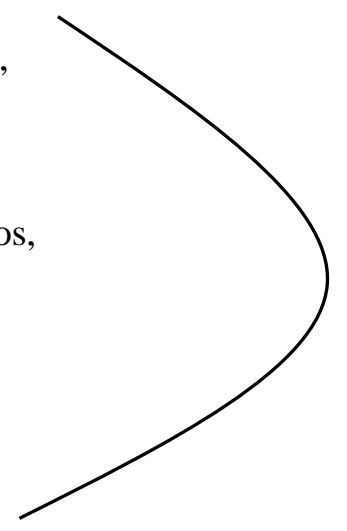

P. 190:

Notas MA:

1. termo sublinhado, "guáu”, e cruzeta - pesquisa para o Dicionário musical brasileiro:

Emquanto cada qual memora em cantos

"dic" Os feitos proprios: reina o guáu, que passa

D’estes áquelles com cadencia alterna.

2. termo sublinhado, "pocemas", e nota ilegível, possivelmente escólio "dic"-provável pesquisa para o Dicionário musical brasileiro:

"dic" Soão festivos gritos, e as pocemas -

Dos guerreiros, que soffregos escutão

P. 191:

Nota MA: termos sublinhados, "memby / Troôu medonho", traço vertical e escólio "dic" - pesquisa para o Dicionário musical brasileiro:

Lhe foi a virtude, nem por tal a acceita.

Nunca o memby guerreiro em seus ouvidos
Troôu medonho, inhospito combate,

P. 196:

Nota MA: termo sublinhado, "boré", e cruzeta - pesquisa para o Dicionário musical brasileiro:

Que ousa lutas ferir, travar discordias,

Quando o imigo boré tão perto sôa!”

P. 197:

Nota MA: termo sublinhado, "dansatriz", e escólio "dic" - pesquisa para o Dicionário musical brasileiro:

Sobre-está-lhe fatal; - cantos se entôão

E a turba dansatriz em torno gyra. "dic" 
P. 199:

Nota MA: versos destacados por traço vertical e comentário:

Jatyr, do arco seu curvando as pontas, Sacode a seta fina e sibilante,

Que vara o couro e o corpo e surge fóra. "o traço homerico mas sem a riqueza homerica"

P. 200:

Notas MA:

1. termo sublinhado, "maracá";

2. verso sublinhado e expoente "(1)", remetendo ao comentário no rodapé:

3. versos destacados por traço vertical - estudo do estilo: descrição / interesse etnográfico:

$$
\mid \begin{aligned}
& \text { Não fui, eu mesmo, nos terreiros vossos } \\
& \text { Fincar o santo maracá? Debalde, }
\end{aligned}
$$

\section{“(1) Positivamente errado”}

4. termo sublinhado, "donas”, e expoente “(2)”, remetendo ao comentário no rodapé:

Quando campeião tantos homens d'arco

Nas tabas de Itajuba, - tantas donas "(2)"

$\mathrm{Na}$ cultura dos campos adextradas.

“(2) Uma certa impropriedade de termos / portugueses já notei varias vezes nos / Timbiras. No entanto, nas Americanas em / geral G. Dias se esquece com muita arte de / Portugal portuguesista."

P. 201:

Notas MA:

1. verso sublinhado e cruzeta;

2. trecho sublinhado e cruzeta - estudo do estilo: artifício / seleção de ideias:

Já deslembrados do que ausente chorão (Favor das turbas que tão leve passas!) $X$

Ledos no peito, ledos na apparencia

Todos se incumbem da tarefa usada.

Trabalho no prazer, prazer que moras

$X \quad$ Dentro de tanto afan! festa que nasces

Sob auspicios tão máos, possa algum genio,

Possa Tupan sorrir-te carinhoso,

E das alturas condoer-se amigo

Do triste, orfão de amor, e pae sem filho! 
P. 202-218

CANTO QUARTO

P. 203:

Notas MA:

1. verso sublinhado e expoente “(1)”, remetendo ao comentário no rodapé:

Não veio Jurucey? Posto de fronte,

Arco e frecha na mão feito pedaços,

Certo signal do respeitoso encargo,

Por terra não lançou? - Que pois augura

Tal vinda, a não ser que o audaz Tymbira "(1)"

Melhor conselho toma; e por ventura

2. verso sublinhado e comentário - estudo linguístico / da versificação: suarabácti;

3. termo sublinhado, "crôa", e cruzeta - estudo do estilo: vocabulário / licenças poéticas;

4. expressão sublinhada, "mas porém", e cruzeta - estudo linguístico: brasileirismo/redundância:

As arbas, que no Ibáke hão-de servir-lhe,

E junto ao corpo, que foi seu, as plumas,

Emquanto vivo, insignias do mando.

Embora ostente o chefe dos Tymbiras

O ganhado trophéo; embora á cinta

Ufano prenda o gadelhudo craneo,

$X \quad$ Aberto em crôa, do infeliz Gamella.

"Aqui G. Dias faz

valer o $g$ de

insignia como

sílaba."

Embora; mas porém amigas quedem $X$

Do Tymbira e Gamella as grandes tabas,

E largo em roda na floresta imperem,

Que o mundo em peso, unidas, affrontárão!

P. 207:

Nota MA: verso assinalado por cruzeta - interesse etnográfico:

P. 209:

\section{$X$}

"Se o orgulho desce a ponto no Tymbira,

Que pazes nos propõe, diz Itapeba

Com dura voz e cavernoso accento,

Nota MA: verso sublinhado e expoente “(1)”, remetendo ao comentário no rodapé:

E bate o chão, e o pé na areia enterra, "(1)"

Orgulhoso e robusto: o vulgo applaude,

De prazer e rancor soltando gritos

“(1) É curioso de notar que o traço realis-Ita em G. Dias se refere sempre a chão, I "morder o chão" "enterrar pé na areia". / Isso é constante nas Americanas."

P. 210:

Nota MA: verso sublinhado e "d”, no termo "adventício", assinalado - estudo linguístico / da versificação: suarabácti: 
Um Tapuya, guerreiro a/d/venticio,

Filhado acaso á tribu dos Gamellas,

Pede attenção, - prestão-lhe ouvidos todos.

P. 218:

Nota MA: comentário ao final do poema:

"Os Timbiras, poema lirico..."

P. $219-321$

\section{SEXTILHAS DE FREI ANTÃO}

$\underline{\text { P. 219-281 }}$

LOA DA PRINCEZA SANCTA (4 estrofes)

P. 219:

Nota MA: comentário na margem superior:

"A riqueza artistica de G. Dias muito supe-/rior á dos outros romanticos unilaterais. Só / G. Dias Castro Alves dele se aproximou. Mas G. Dias / mais do que o outro exercitou e sempre com ga-/lhardia e <ilegível> em todos os caminhos, diversas / orientações artisticas: Solaus, baladas, lieder, india-/nismo, arcaismo, romantismo amoroso, hinos e / até discursos patrioticos e poemas de circunstan-/cia.

P. 220:

Nota MA: preposição sublinhada no v. 17, "para", e cruzeta - estudo linguístico: emprego de "para/pra":

\section{$X \quad$ Para os armar cavalleiros \\ A armada se apercebia.}

P. 223:

Notas MA:

1. preposição sublinhada no v. 105, "para", e cruzeta - estudo linguístico: emprego de "para/pra":

$$
\begin{array}{ll}
\text { Só deixarei a leitura } \\
X \quad \underline{\text { Para escrever estes carmes, }}
\end{array}
$$

2. termo sublinhado no v. 124, "repicar", e escólio "dic" - pesquisa para o Dicionário musical brasileiro:

Acordão alegres echos

Os sinos a repicar "dic"

P. 224:

Nota MA: termos assinalados no v. 153, "sanctas" e "Sanctos" - estudo do estilo: artifício/repetição:

Nossas capellas que temos, 
Nossos mosteyros custosos,

São obras sanctas de Sanctos,

P. 225:

Nota MA: comentário no rodapé:

"A bonhomia gorda e humoristicamente / pessimista de frei Antão é uma delicia nes-Ites comentarios com que dá plano aos recon-/tos."

P. 226:

Nota MA: termos sublinhados nos v. 193, 194 e 195, "troando", "atabales" e "istromento", e escólio "dic" - pesquisa para o Dicionário musical brasileiro:

"dic" Vem os muzicos troando

"dic" Nos atabales guerreiros,

"dic" Tangem outros istromentos

D'esses climas forasteiros,

P. 227:

Notas MA:

1. v. 217-222 destacados por traço vertical;

2. v. 223-234 destacados por traço vertical duplo - estudo do estilo:
Luzião os olhos d'ellas,
Como pedras muito finas;
Devião ser finas bruxas,
Inda qu'erão bem meninas,
Que estas mouras da Mourama
Nascem já bruxas cadimas.

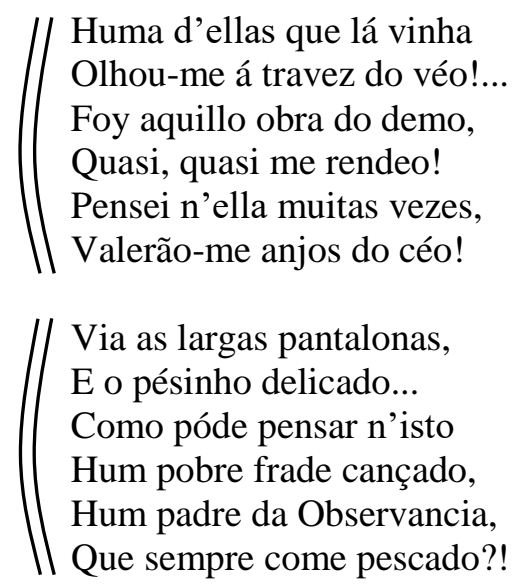

P. 228:

Nota MA:

1. verbo sublinhado no v. 263, "sabe" - estudo do estilo: artifício/repetição;

2. v. 263 e 264 destacados por traço vertical triplo e expoente "(1)”, remetendo ao comentário no rodapé:

E diz-se d'hum rey de França, 
Ludovico, creio eu:

Hum pobre frade mesquinho

Só trata em cousas do céo;

“(1)”|l(Sabe elle que muito sabe,

( ( Se a bem morrer aprendeo.

“(1) A pobreza de pensamento de frei Antão é real-/mente a milhor satira e perfeita representação, cer-/tamente intencional da pobreza do pensamento / portuga."

P. 229:

Nota MA: rimas sublinhadas nos v. 284, 286 e 288 e fio ligando-as - estudo da versificação: rima:

Traçava hum mantéo vistoso

Sobo-las suas espaldas,

E as largas roupas na cinta

Prendia em muitas laçadas;

Seos olhos valião tanto

Como duas esmeraldas.

P. 231:

Nota MA: v. 343-348 destacados por traço vertical - estudo do estilo: arcaísmo:

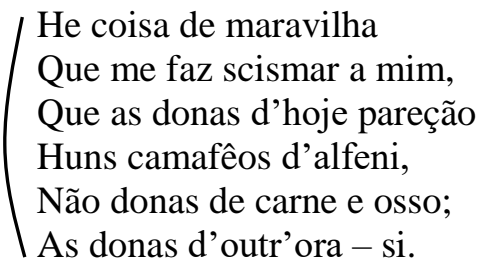

P. 233:

Nota MA: v. 405 e 406 destacados por traço vertical - estudo do estilo: arcaísmo:

"Digo pois a vossa Alteza,

E digo com muita fé,

(Deve a offerta ser tamanha

Quamanha foy a mercê,

Não do nobre rey pujante,

Mas do sancto rey qual he.

P. 236:

Nota MA: v. 492-498 destacados por traço vertical e escólio "Repetição" - estudo do estilo: artifício/repetição:

“Repetição" $\mid \begin{aligned} & \text { Bom tempo foy o d'outrora } \\ & \text { Quando o reyno era christão, } \\ & \text { Quando nas guerras mouriscas } \\ & \text { Era o rey nosso pendão, } \\ & \text { Quando as donas consumião } \\ & \text { Seos teres em devação. }\end{aligned}$ 
GULNARE E MustaPHÁ (160 estrofes)

P. 239:

Notas MA:

1. adjetivo sublinhado nos v. 71 e 72, "larga" e "largo" - estudo do estilo: artifício/repetição:

Vierão aquelles feios

Netos d'Agar, inda mal!

Traçando vastas roupagens

Á maneira oriental;

Larga faxa na cintura,

Na faxa largo punhal.

2. termo sublinhado no v. 81, "folias", e escólio "dic" - pesquisa para o Dicionário musical brasileiro:

Levar traz si tanta gente

Nunca a ninguem vi assi;

Nem folias, nem cantares

Vi com tal cauda apoz si,

Bôdo, nem festa d'orago,

Bufão, e nem bolatí.

\section{P. 240:}

Notas MA:

1. termo sublinhado no v. 112, "arrabel”, e escólio "dic" - pesquisa para o Dicionário musical brasileiro;

2. termo sublinhado no v. 117, "instromento", ligado ao escólio "dic" no v. 112, e remissão "Veja 226” - pesquisa para o Dicionário musical brasileiro:

Aquella abelha sem dardo,

Aquella pomba sem fel

Passava noites inteiras

"dic" Tangem n'hum arrabel,

Coando vivas saudades

Dos labios, em leite e mel.

E, alta noite, nas trevas

Ouvindo na solidão

Aquelle triste instromento "Veja 226"

Al não disseras, senão

Que o mesmo demo voltado

Era n'aquella feição.

P. 244:

Nota MA: termo sublinhado no v. 226, "zoar", e escólio “dic" - pesquisa para o Dicionário musical brasileiro:

"Pois hum sancto como aquelle:

Quem he que o ha de tentar?"

Eis senão quando começa 
“dic" Voz, não sei donde, a zoar Que Frei Antão ja não sabe No seo rosairo rezar!

P. 246:

Nota MA: termo sublinhado no v. 299, "arrabel", e escólio "dic" - pesquisa para o Dicionário musical brasileiro:

"dic" Os sons do arrabel mourisco Sómente daly se ouvia.

P. 248:

Notas MA:

1. termo sublinhado e acentuado no v. 352, "Edén" - estudo linguístico / da versificação: métrica/ritmo:

Vergonha foy o que eu tive,

Vergonha que todos têm;

Ultimo fructo colhido

N'aquelles jardins do Edén;

2. v. 355-360 destacados por traço vertical - estudo do estilo: imagem:
Como está no fundo do lago
$\mathrm{O}$ verde limo acamado,
Assi deitado e mimoso
Brilha lustre avelludado;
Tal é aquella vergonha,
Que vem apoz o peccado.

P. 249:

Notas MA:

1. v. 369 e 370 destacados por traço vertical e escólio "Realismo" - estudo do estilo: descrição:

Aly mil serpes occultas

Vivem, cruzando laçadas,

“Realismo",((Muitos sapos bufadores,

Muitas rãs esverdinhadas;

Humas coizas de má sina,

Outras coisas mal fadadas.

2. verbo corrigido no v. 393, “Ardia” - correção tipográfia:

Entrei no quarto da moira

Leixando a mais gente vil,

“/ia" Ardi doce perfume

Em transparente viril;

P. 251:

Nota MA: v. 443 e 444 destacados por traço vertical - estudo do estilo: imagem:

Era menina e fermosa, 
Nunca lhe vi sua igual!

Coiza assim tam primorosa

E tanto celestial,

(Ou era filha dos anjos,

Ou filha do pay do mal.

P. 252:

Notas MA:

1. v. 461 e 462 destacados por traço vertical - seleção de ideias: anoitecer:

Quanto o sol mais se abaixava,

Tanto mais alto gemia

Aquella moira mimosa,

Que as suas mágoas carpia:

( $($ He hora que espalha enlevos

A hora do fim do dia!

2. v. 473 sublinhado e escólio "Imagem" - estudo do estilo: imagem:

As froles do sol viuvas

Definhão, só de tristura;

O mar soluçando geme,

Mais alto a fonte murmura,

"Imagem" Reina o silencio que falla,

Bafeja a doce frescura.

P. 256:

Nota MA: v. 589-594 destacados por traço vertical triplo - estudo do estilo: imagem:

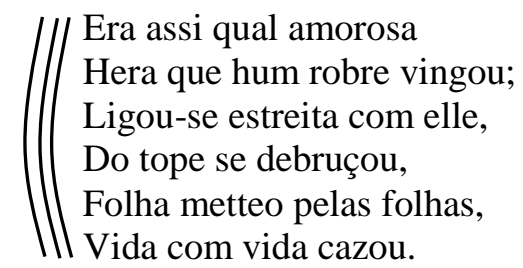

P. 261:

Nota MA: termo sublinhado no v. 749, "c'roas", e cruzeta - estudo do estilo: vocabulário / licenças poéticas:

$X \quad$ "C'roas de pedra lavrada

P. 262:

Notas MA:

1. v. 775-780 destacados por traço vertical duplo e escólio "Livros ruins";

2. v. 783-786 destacados por traço vertical duplo:

“Livros $\quad \| \begin{aligned} & \text { E d'outros que só por artes } \\ & \text { Fruem da voga que têm, } \\ & \text { Quins } "\end{aligned} \quad \begin{aligned} & \text { Que não sei onde he seu preço, } \\ & \text { Nem donde apreço lhe vem, } \\ & \text { Senão por vias occultas, }\end{aligned}$ 
Que as não descobre ninguem!

Mas deixemos estas coisas,

Que não são de boa avença!

O livro que eu reprovára

Por muito justa sentença

Trouxera-me coyta grave,

Com mais grave malquerença.

P. 264:

Nota MA: expressão sublinhada nos v. 831 e 832, "moça moira" e "moço moiro" - estudo do estilo: artifício/repetição:

Huma lagrima brilhante,

Como que a furto luzia

Nos olhos da moça moira

Que o moço moiro cingia;

Em que nada lhe dicesse,

Muitas coisas lhe pedia.

P. 268:

Nota MA: v. 958-960 destacados por traço vertical - seleção de ideias:

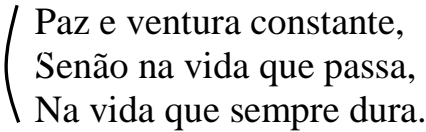

P. 269-281

SOLÁO DO SR. REY D. JOÃO

P. 269:

Nota MA: termo sublinhado no v. 5, "primeiro" - estudo do estilo: artifício/repetição:

Primeiro na devoção,

Primeiro mais que o primeiro,

Mais que nenhum rey christão.

P. 271:

Nota MA: termos sublinhados no v. 83 e 84, "homem(ns)" e "judeo(s)" - estudo do estilo: artifício/repetição:

Entregue por hum eleito

Nas garras dos Fariseos,

Homem morreo pelos homens

Morreo judeo por judeos.

P. 272:

Nota MA: termos sublinhados nos v. 85 e 86, "c'roou" e "c'roa", e cruzetas - estudo do estilo: vocabulário / licenças poéticas:

$X \quad$ C'roou a fronte sagrada

$X \quad$ C'roa d'espinhos tecida;

Correrão dados infames 
Em taboa vil, denegrida;

P. 273:

Nota MA: v. 121-124 destacados por traço vertical - seleção de ideias:

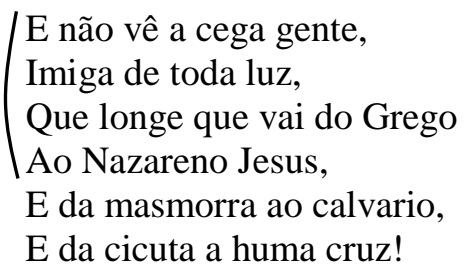

P. 275:

Nota MA: verbos sublinhados nos v. 179, "praz" e "prazamos" - estudo do estilo: artifício/repetição:

Praz a Deos que lhes prazamos,

Pois vem delle a realeza.

P. 276:

Nota MA: v. 209 e 210 destacados por traço vertical duplo - seleção de ideias:

( Leys dos homens não se cazão,
Não seguem ás leys de Deos.

P. 282-301

SOLÁO DE GONÇALO HERMigUEZ (96 estrofes)

P. 283:

Nota MA: termo sublinhado no v. 36, "trovas", e escólio "dic" - pesquisa para o Dicionário musical brasileiro;

Desenfiando hum rosairo

De trovas e ninharias. "dic"

P. 284:

Notas MA:

1. trecho sublinhado nos v. 53 e 54 e escólio "Lua" - seleção de ideias:

Não pedia manto ás sombras,

Nem ao silencio mercê,

Nem do sol se arreceiava,

Como homem que pouco vê,

Nem da lua appellidada

"Lua" A casta, não sei porquê.

2. termo sublinhado no v. 60, "tenções", e escólio "dic" - pesquisa para o Dicionário musical brasileiro:

Mas antes no amphitheatro,

Coberto de espectadores,

Onde mais povo corria, 
Mais bellas e justadores,

$\mathrm{Na}$ arena se apresentava

"dic" Com letra e tenções d'amores.

P. 285:

Notas MA:

1. termo sublinhado no v. 73, "trompa", e escólio "dic" - pesquisa para o Dicionário musical brasileiro;

2. expressão sublinhada no v. 77, "feita pedaços", e cruzeta - estudo do estilo:

Silencio! que sôa a trompa, "dic"

A justa vai começar!

Entre si ferem mil lutas

Guerreiros a par e par:

Da lança feita pedaços

$X$

Voão estilhas ao ar.

3. v. 89 e 90 destacados por traço ondulado - estudo do estilo: artifício/repetição:

Que aos pés da bella entre as bellas

O seo trophéo vem depor:

$\{$ Ao mais valente a mais bella

$\sum$ Ao mais gentil mais amor.

4. v. 95 e 96 destacados por traço ondulado - estudo do estilo: artifício/repetição:

Era a ley, - e até parece

De acordo co'a natureza,

Que se compraz no consorcio

Da força co'a gentileza;

$\{$ Mais alma com mais coragem

$\sum$ Mais brio com mais nobreza.

P. 286:

Nota MA: v. 121-126 destacados por traço vertical - seleção de ideias:

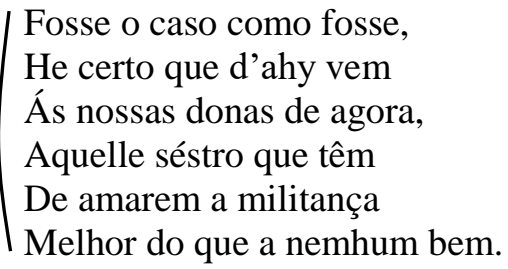

P. 287:

Nota MA: v. 155 e 156 destacados por traço vertical triplo, escólio “A Beleza” e comentário - seleção de ideias: beleza:

Que n'este mundo mesquinho

He tudo engano e abusão.

/( E té que a propria belleza

He coiza de convenção!

“A Beleza / Inteligentissima / observação naque-/le tempo." 
P. 288:

Nota MA: rimas sublinhadas nos v. 170, 172 e 174 e fio ligando-as - estudo da versificação: rima:

Era moço e mui donoso,

De mui boa nomeada:

Fiava el-rey muito delle,

E a rayna Mafalda

Folgava de ouvir-lhe os cantos

Aos sons da lyra afinada.

P. 289:

Nota MA: rimas sublinhadas nos v. 194, 196 e 198 e fio ligando-as - estudo da versificação: rima:

Mas se tinhão tento n'elle,

Era outro conto ruim!

Cahia logo em desmaios,

Que era hum desmaio sem fim!

Dó era ver tal sugeito

Prostrado e defuncto assi.

P. 291:

Nota MA: termo sublinhado no v. 282, "c'rôa", e cruzeta - estudo do estilo: vocabulário / licenças poéticas:

Em rija pedra assentada,

Como pedra preciosa

Em ferrea c'roa engastada. $\quad X$

P. 293:

Nota MA: v. 313-318 destacados por traço vertical duplo - estudo da psicologia:

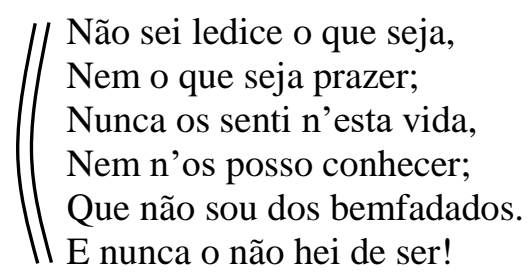

P. 295:

Notas MA:

1. termos sublinhados no v. 387 e 388, "rimance" e "soláo", escólio "dic" e seta ligando ao escólio no v. 398 - pesquisa para o Dicionário musical brasileiro;

2. v. 389 e 390 destacados por traço vertical duplo - estudo do estilo: metáfora;

3. termo sublinhado no v. 398, "trompa", e escólio "dic" - pesquisa para o Dicionário musical brasileiro:

Oh! que festas! que alegrias!

Que arruido vai no prado!

Que bem cantado rimance, 
Que soláo tão bem cantado; ( Não têm as aves atito,

( Nem gorgeio mais brincado!

\section{$[\ldots]$}

Eis nisto... estranho arruido!

Rouca trompa abala o ar;

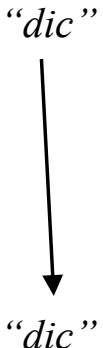

Logo assomão cavalleiros

Com figuras de espantar:

Allah nos valha, mofinas!

Dizem moiras a chorar

P. 297:

Nota MA: v. 438 sublinhado e assinalado por cruzeta - seleção de ideias: mulheres:

Quem lá foge em debandada!

Ficão moiras prisioneiras,

$X \quad$ Mulheres - gente coitada!

P. 298:

Nota MA: v. 473 e 474 destacados por traço vertical e comentário - estudo do estilo: descrição:

Mal podia a mão sinistra

Vibrar a sangrenta espada,

Co'o peso d'aquella moira

Disputada e desmaiada,

( Cujo corpo em dois pendia,

Como huma frecha quebrada.

"Bem dado / traço. Aliás / toda êsta descrição. / Frei Antão des-/creve primorosa/mente."

P. 299:

Notas MA:

1. v. 499-510 destacados por traço vertical duplo, escólio "realismo" e comentário estudo do estilo: descrição/realismo:

\footnotetext{
"realismo || Vão assi feros monteiros

[...] Traz d'hum urso mal sangrado,

Que de repente a carreira

Revira, e vólta agastado/

Parão monteiros ao vel-o

Raivoso e mal assombrado;

E a fera, d'aquelle pasmo

Sabendo, em seo bem, valer-se

Vai a passos descançados

Em densa mata esconder-se,

Sem temor da monteria,

Sem dos monteiros temer-se.
} 
"realismo / Alias a riqueza / extraordinaria / de concepção da / psicologia de Frei / Antão demonstra / suficientemente / que grande criador / e artista era / G. D. As Sextilhas / são um monumento / de criação psicologica. / O realismo português, po-/breza de loucura lirica / expressionista, que já / G. Aranha reparou."

2. v. 514-516 destacados por traço vertical - seleção de ideias;

3. termo sublinhado no v. 516, "menestrel”, e escólio "dic" - pesquisa para o Dicionário musical brasileiro:

Tal o forte Traga-mouros

Salta dentro do baixel;

Na praia ficão pasmados

Mouros, do feito novel,

Tamanho, que nem sonhado

Foy jamais por menestrel. "dic"

P. 300:

Notas MA:

1. v. 529-534 destacados por traço vertical duplo - estudo do estilo:

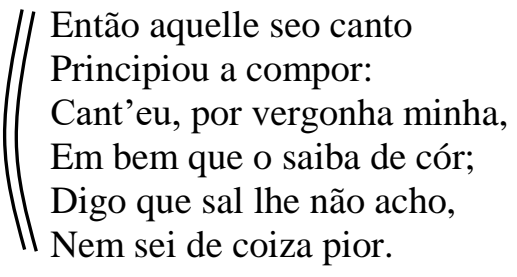

2. v. 541-546 destacados por traço vertical duplo - estudo do estilo:

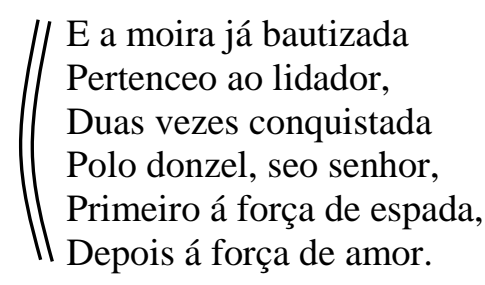

P. 302-321

LENDA DE SAM GONÇALO (95 estrofes)

P. 302:

Notas MA:

1. v. 3 e 4 destacados por traço vertical duplo - seleção de ideias: crítica a Portugal;

2. trecho sublinhado nos v. 5 e 6, "que sanctos ditos" e "que sanctas obras" - estudo do estilo: artifício/repetição:

Agora de hum grande Sancto

Embora lhe cabe a vez;

(/ Bom Sancto foy Sam Gonçalo,

Pezar que foy Portuguez,

Que sanctos ditos que disse! 
Que sanctas obras que fez!

P. 304:

Nota MA: v. 81 e 82 destacados por traço vertical - seleção de ideias: pecado:

Antes, Senhor, que me esqueça

Quanto fizestes por mi,

(Lavai-me dos meos peccados,

Que eu como galas vesti

Levai-me desta amargura,

Levai-me, Senhor, daqui!

P. 305:

Nota MA: termo sublinhado no v. 100, "folias", e escólio "dic" - pesquisa para o Dicionário musical brasileiro:

Antes que eu veja crianças

Prégarem ás cans nevadas,

A correr de noite as ruas

Com folias e toadas, "dic"

Por ver azas de cometa

P. 308:

Immensamente alongadas.

Notas MA:

1. v. 183 e 184 destacados por traço vertical triplo - seleção de ideias:

Vivia como se fôra

Dos seos pobres dispenseiro,

// Tudo com elles gastava,

Que não sómente dinheiro;

Fiava que Deos iria

Compondo o seo mealheiro.

2. rimas sublinhadas nos v. 194, 196 e 198 e fio ligando-as - estudo da versificação: rima:

Isto não he coiza nova,

Antes coiza mui provada,

Que Deos não quer ser vencido

Em cortezia extremada;

Seja a prova aquelles Monges

Do deserto da Thebaida;

P. 310:

Nota MA: termo sublinhado no v. 255, "lidimo", e cruzeta - estudo da versificação: métrica/ritmo:

He nada o trem d'hum romeyro;

O Sancto se apresta azinha,

Chama hum parente lidimo, $\quad X$

P. 312:

Portas a dentro o mantinha;

Nota MA: v. 301-306 destacados por traço vertical duplo - estudo do estilo: descrição satírica: 


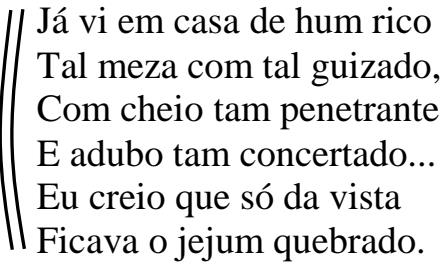

P. 315:

Nota MA: v. 401 e 402 destacados por traço vertical duplo - estudo do estilo: descrição satírica:

Alva e rara cabelleira,

Como prata, reluzia;

Rosto de rugas cortado,

Barba que ao peito descia:

(/ Homem de carne não era,

( Senão pura notomia.

P. 319:

Nota MA: verbo sublinhado no v. 534, "sovertestes”, e cruzeta - estudo linguístico / do estilo: vocabulário:

"É vossa a força que eu tenho,

Disse elle: em uso a não puz,

Que tambem sobre o calvario,

Vós, Senhor meo, bom Jezus,

Nem o calvario afundastes,

Nem sovertestes a cruz.

P. 321:

Nota MA: comentário ao final do poema:

"É curioso de notar-se a ironia um pouco / desabusada com que G. Dias / pra criando a figura de frei Antão, / que é a principal criação artistica das / Sextilhas, trata das coisas da religião / tornando-as ridiculas embora dum / ridiculo inocente. Isto dá que pensar. I É possivel que o carolismo de tantos / poemas seja mais um tema embora / a religiosidade do poeta seja indis-/cutivel. Mas é incontestavel que a / religião catolica foi tambem um I tema romantico como a ... saturnal."

\section{NOTAS}

P. 323-333

A's POESIAS AMERICANAS

P. 324:

Nota MA: termo sublinhado, "Boré", e cruzeta - pesquisa para o Dicionário musical brasileiro.

X $\quad \underline{B o r e ́}$ - instrumento musico de guerra; dá apenas algumas notas, porém mais asperas, e talvez mais fortes que as da trompa.

P. 325: 
Nota MA: termo sublinhado, "Maracá", e cruzeta - pesquisa para o Dicionário musical brasileiro.

Maracá - entre os Indios, o instrumento sagrado, como o Psalterio entre os Hebreus, ou o Orgão entre os Christãos; era uma cabaça crivada, cheia de pedras ou buzios, e atravessada por um hastil ornado de pennas multi-côres, que lhe servia de cabo. O antigo viajante Roloux Baro, testemunha da veneração que os Indios lhe tributavão, chamava-o Le diable porté dans une calebasse "o diabo dentro d'uma cabaça." - A esta palavra vão alguns modernos buscar a etymologia da palavra "America".

P. 328:

Notas MA: termos sublinhados, "Murémuré" e "Guáu", cruzeta e escólio "dic" pesquisa para o Dicionário musical brasileiro.

“dic" $\quad$ Murémuré escreve o padre Vasconcellos nas suas "Noticias Curiosas": collige-se $X \quad$ que é um instrumento feito de ossos de defuntos, como alguns outros, de que se servião.

$[\ldots]$

"dic" Guáu - dansa. "São mui dados a saltar e dansar de differentes modos, a que chamão guáu em geral." VASCONCELLOS. Noticias curiosas. L. 1. - n. 143.

P. 329:

Nota MA: termo assinalado por cruzeta, "Janubia", e escólio "dic" - pesquisa para o Dicionário musical brasileiro.

Janubia. - Lery escreve diversamente: des cornets, qu'ils nomments inubia, de la grosseur et longueur d'une demie pique, mais par le bout d'en bas larges "dic" d'environ un demi-pied comme un hautbois. -Obra cit., pag. 202. 


\section{FOLHA DE GUARDA 1}

Nota MA: escólio e remissão de página - seleção de ideias: preparação de artigo:

"política 149 - "

Nota da pesquisa: $\mathrm{O}$ escólio remete à nota de margem no poema "Que cousa é um ministro". Os versos assinalados à p. 149 são citados por MA no artigo "Mosqueiro no 2", em 19 de abril, 1931, no Diário Nacional (ANDRADE, Mário de. Táxi e Crônicas no Diário Nacional. Estabelecimento de Texto, Introdução e Notas de Telê Porto Ancona Lopez. São Paulo: Livraria Duas Cidades / Secretaria da Cultura, Ciência e Tecnologia, 1976, p. 369).

\section{FOLHA DE GUARDA 2}

Nota MA:

1. anotação no alto, à direita, “ $n^{\circ} 198$ ”, referindo-se à inclusão do volume na Bibliografia para Na pancada do ganzá;

2. lista de verbetes para o Dicionário musical brasileiro e cruzeta indicando o aproveitamento;

3. indicação de página para os escólios "amigos" e "longor":

Dic-lira 28 - musico adj. 29-búzio-42-Lclangor 65 -altíssena 66 -cadente 79 - I maracá 89 - carme 95 - flautear 149 - argentino 191 - / acorde 223 trompa 300 -

amigos $67-t \theta$

longor 198 -”

Nota da pesquisa: O n 198 sinaliza a inclusão das Obras posthumas na Bibliografia para $\mathrm{Na}$ pancada do ganzá, conjunto de 837 títulos arrolados por MA para apoiar a organização de seu vasto projeto sobre o folclore brasileiro. Os títulos da poesia dos autores românticos focalizados em seu ensaio "Amor e medo" fazem parte da lista bibliográfica. O escólio "dic", a grafite, de ocorrência farta na marginália, nos títulos da poesia do romantismo brasileiro, indica a pesquisa de elementos para abonar verbetes no Dicionário musical brasileiro, projeto do escritor testemunhado em sua biblioteca, no manuscrito desse título e de outros, em seu arquivo e, na edição póstuma coordenada por Oneyda Alvarenga e Flávia Camargo Toni (Brasília: Ministério da Cultura/São Paulo: IEB-USP - Edusp/ Belo Horizonte: Editora Itatiaia Ltda, 1989). 
LEAL, A. H. "Prologo".

$\underline{\text { P. IX-LIII }}$

BIOGRAPHIA DE A. GONÇAlves Dias PElo Doutor ANTONIO HENRIQUES LEAL

P. XXIV:

Nota MA: parágrafo destacado por traço horizontal e cruzeta - estudo da biografia: leituras:

(...) O tempo que ao menino Dias sobrava de aturar freguezes, entretinha-se elle com outro da mesma idade, tambem orphão, e companheiro de travessuras, de nome João Baptista (2) em ler tudo quanto de Marmontel, Montolieu e DucraiDumesnil lhes cahia debaixo da vista.

$X$

São os nossos sertanejos, pela vida solitaria que levam a mór parte do tempo, pelas viagens longiquas e atravez de campinas desertas, pelo genero d'industria a que se dedicam, curando de gados e luctando não raro com reptis e onças, pela rudeza e franqueza de seu character, e indole hospitaleira, uma especie de beduinos, e como tal amigos de contos aventurosos e de narrações de façanhas extraordinarias, e por isso é para elles um livro mimoso e predilecto a Historia do Imperador Carlos Magno e dos dozes pares de França, que lhes anda nos alforges, como o pabulum vitae, ainda que não saibam ler; e não ha maior e mais relevante serviço que se lhes preste do que ler-se-lhes um d'aquelles capitulos mais cheios de aventuras e combates com gigantes. Gonçalves Dias era um dos mais bemquistos ledores d'aquelles homens das brenhas, frequentadores de Caxias, como emporio do commercio do sertão, e alli lhe apparecia, entre outros, um velho, sabido em contos maravilhosos e nas façanhas de Roldão, de Oliveiros, de Ricareto, de Bernardo del Carpio, e de outros celebres personagens da Historia de Carlos Magno.

\section{P. $1-35$}

\section{VERSOS MODERNOS}

P. $18-20$

COMO! Es TU? (9 estrofes)

P. 19:

Nota MA: trecho sublinhado no v. 26 e cruzeta - estudo linguístico: sintaxe:

Contradições d'alma humana!

Fui, sim, quem te dei o exemplo, $\quad X$

Isso quiz, e ora contemplo

Essa grinalda - a chorar,

A fronte pallida, pallida,

E o branco véo a ondular!

P. 27-28

D. EMILIA (7 estrofes)

P. 28: 
Nota MA: termo sublinhado no v. 25, "lyra", e escólio "dic"-pesquisa para o Dicionário musical brasileiro:

"dic" O céo faz dom da lyra aos que mais ama.

Feliz quem pode a dôr lenir cantando,

Mas inda mais feliz

Quem da existencia os arreboes, com ella,

Dissolve nas mil faces desse prysma

Que vida e amor se diz.

P. 29-30

É ALEGRE A FLOR QUE BROTA (5 estrofes)

P. 29:

Nota MA: termo sublinhado no v. 10, "musicos", e escólio "dic" - pesquisa para o Dicionário musical brasileiro:

É bella a virgem risonha

Com seos musicos acentos, "dic"

Com seos virgens pensamentos,

Com seos mimos infantis.

$\underline{\text { P. 31-32 }}$

SEO NOME (6 estrofes)

P. 31:

Nota MA: termo sublinhado no v. 14, "pipitar", e escólio "zoof” - pesquisa da zoofonia:

É como a luz do sol, como o perfume

De missiva d'amor, ou semelhante

Ao silencio da noite, á luz do dia,

Ao pipitar dos passaros no bosque,

“zoof”

Ao murmurar da fonte em quadra estiva.

P. 37-323

\section{VERSOS ANTIGOS}

$\underline{\text { P. } 39-45}$

O INDIO

P. 42:

Notas MA:

1. termo sublinhado, "grasno", e cruzeta - pesquisa da zoofonia:

O terno sabiá - nos ermos onde

$X \quad$ O funebre urubú desata o grasno; 
2. termo sublinhado, "busio", e escólio "dic" - pesquisa para o Dicionário musical brasileiro:

"Foi meo pae dos Tupis - ultimo chefe,

"dic" E quando o busio atroador soprava

Tres mil guerreiros concorrião prestes

$\underline{\text { P. } 57-58}$

No ALBUM DE MEO AMIGO ANTONIO CARDoso Avelino

P. 58:

Notas MA: v. 37-48 destacados por traço vertical:

Esse homem - foi tua alma,

Foi delle o teo pensamento,

Tua foi sua alegria,

Delle foi o teu tormento,

Chorastes ambos pensando

Na longa separação.

Fostes amigos sinceros

Extremos ambos scismastes

Foi elle - que te amou tanto,

Foi a quem tanto amastes,

Que de ti - tão longe vive

Tão perto - no coração!

$\underline{\text { P. 65-66 }}$

MONOLOGOS / III - AO ANNIVERSARIO DA INDEPENDENCIA DE CAXIAS

P. 65:

Nota MA: termo sublinhado no v. 17, "clangor" - pesquisa para o Dicionário musical brasileiro:

O clangor da trombeta aballa a terra:

P. 66:

Nota MA: termo sublinhado no v. 45, "altisonas", e escólio "dic" - pesquisa para o Dicionário musical brasileiro:

"dic" Aclamações altisonas

Corrão nos ares da immortal Caxias,

P. 71-72

A Violeta (No album DE A. G. O. C.) (5 estrofes)

P. 72:

Nota MA: correção a erro de impressão, acrescentando uma cunha e o termo "cores?" ao v. 18: 
Aquella no perfume se revela,

Tu nas singelas $V$ que revestes:

"V cores?"

Occultas ambas - sem as ver sentimos

$\mathrm{O}$ aroma puro dos jardins celestes.

\section{P. 79}

AS ARTES SÃO IRMÃS

P. 79:

Nota MA: v. 7 e 8 destacados por traço vertical, termo sublinhado, "cadentes", e escólio "dic" - pesquisa para o Dicionário musical brasileiro:

Ou languida na lyra se transforma

Em sons cadentes, que derramão n'alma "dic"

Idéas do praser - do mal no olvido!

P. 83-92

POEMA AMERICANO

FRAGMENTO

P. 89:

Nota MA: termo sublinhado, "maracás", e escólio "dic" - pesquisa para o Dicionário musical brasileiro:

Unamos pois, e os maracás se ajuntem, "dic"

A ti e mim cabendo igual imperio.

P. 91:

Nota MA: termo sublinhado, "xerimbabo", e cruzeta:

E de Taboa o xerimbabo invejem!”- $\quad X$

P. 95-97

POSSEIDON

P. 95:

Nota MA: termo sublinhado no v. 8, "carmes", e escólio "dic" - pesquisa para o Dicionário musical brasileiro:

A ler os cantos da Odyssea, os carmes "dic"

Antigos, mas eternamente bellos

\section{SONETOS}

P. 104

III - A Notre-DAme DE V. HugO 
P. 104:

Nota MA: preposição sublinhada no v. 5, "p'ra", e cruzeta - estudo linguístico: emprego de "para/pra":

$X \quad$ Ora o diabo tem queda p'ra a ironia.

$\underline{\text { P. } 107}$

VII

P. 107:

Nota MA:

1. título assinalado por cruzeta;

2. correção a erro de impressão no v. 1, "humido elemento":

$$
\text { "/ u" }
$$

Baixel veloz, que ao hamido elemanto " $e$ "

A voz do nauta experto afoito entrega,

$\underline{\text { P. } 110}$

IX

P. 110:

Nota MA: título assinalado por cruzeta e comentário:

"Veja seguinte X/ (mas está na mo-/cidade)"

\section{VOLTAS E MOTTES GLOSADOS}

P. $127-128$

III (5 estrofes)

P. 127:

Nota MA: termos ligados por fio - estudo da versificação: rima:

É por ventura rasão

Que aquellas que são voluveis

Tenhão, sós, indissoluveis

Amores por galardão?

\section{SATYRAS}

$\underline{\text { P. } 148-153}$

QUE COUSA É UM MINISTRO

P. 149:

Notas MA: 
1. v. 25-32 destacados por colchete - estudo do estilo: sátira / seleção de trechos: preparação do artigo:

Cançai-vos pois! - Quem veste aquella farda
Hade faser o que mui bem quiser!
Vem-lhe com ella uma sabença em barda!
Por isso acerta, quando Deos lá quer!
Se lhe lanças baldões na propria cara
Diz a alguem que o deffenda, e chega a si
Com intrinseco amor a pasta cara,
E exclama: "ó patria, morrerei por ti!

2. termo sublinhado no v. 40, "flautear", e escólio "dic" - pesquisa para o Dicionário musical brasileiro:

Pois que farieis vós? Verter do peito

O melhor sangue... pela patria acabar!...

Imbecis! - pois mais vale com proveito

Da patria á custa a vida flautear! "dic"

Nota da pesquisa: Os versos assinalados convergem para o artigo "Mosqueiro no 2", em 19 de abril, 1931. Nas páginas do Diário Nacional, MA contextualiza a citação do poema, atualizando o sentido satírico para as circunstâncias históricas de elaboração do artigo: "E aí Gonçalves Dias, como piaga, sossobra romanticamente. Diz que os monstros vêm matar nossos bravos guerreiros, coisa discutibilíssima, e vêm mais pra nos roubar filha e mulher. Não. No geral os monstros já vêm casados. O que eles querem é aquele mesmo Oiro, que o piaga cantou numa das Visões, o oiro... 'regedor da Terra, que dá honra e valor, virtude e força'. E então, apossado do oiro, mesmo do oiro transitório que a posição dá, o adventício do Canto do Piaga adquire valor e honra, força e virtude. Ou como diz o próprio Gonçalves Dias numa das suas raras sátiras: [cita os v. 25-32]" (ANDRADE, Mário de. Táxi e Crônicas no Diário Nacional. Estabelecimento de Texto, Introdução e Notas de Telê Porto Ancona Lopez. São Paulo: Livraria Duas Cidades / Secretaria da Cultura, Ciência e Tecnologia, 1976, p. 369).

P. 151:

Nota MA:_correção a erro de impressão no v. 64, substituindo "e" por "o", em "homo":

o / Memento, hemo! - Está bem morto já!

\section{ECHOS D'ALÉM-MAR}

/ TRADUCÇÕES DE A. GonÇALVES Dias

I - NoIVA DE MESSINA

P. 166:

Nota MA: preposição sublinhada, "p'ra", e cruzeta:

X - Apercebei-vos pois p'ra recebel-os 
P. 191:

Notas MA:

1. termo sublinhado, "argentinos", e escólio "dic" - pesquisa para o Dicionário musical brasileiro:

Nisto argentinos sons ouvi d'um sino "dic"

2. correção a erro de impressão, acrescentando “j” em "juventude”:

Assim, era-lhe o claustro asylo apenas

Da verde juventude, e não sepulchro?

P. 198:

Nota MA: termo sublinhado, "longor" - estudo do estilo: vocabulário:

Disei-o: em que havemos d'empregar-nos,

Pois que da lucta os principes descanção.

Para encurtar a vacuidez das horas

E do tempo o longor interminavel?

P. 214:

Nota MA: termo sublinhado, "noitibós" - estudo do estilo: vocabulário:

Como de noitibós á noite affeitos

Dos arruinados combros, onde tinhão

P. 223:

Nota MA: termo sublinhado, "acordes", e escólio "dic" - pesquisa para o Dicionário musical brasileiro:

De cem acordes vozes a elevar-se "dic"

P. 265:

Nota MA: repetição sublinhada - estudo do estilo: artifício/repetição:

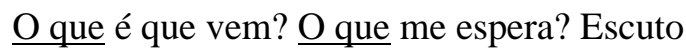

$X$

Da morte os surdos sons, funebres cantos

P. 291:

Nota MA: termo sublinhado, "Carece”, e cruzeta - estudo do estilo: vocabulário:

Tu, irmão, poupa os dias teos queridos,

Para tua mãe, vive! Ellle do filho

Carece; mas da filha, que achou hoje, $\quad X$

Pois nunca a possuio, a perda é leve!

\section{$\underline{\text { POESIAS LYRICAS }}$}

P. 299-302

PROFECIA DO TEJO 
P. 300:

Nota MA: termo sublinhado no v. 32, "trompa", e escólio "dic" - pesquisa para o Dicionário musical brasileiro:

"Ouve que o céo já toca

"dic" Com temeroso som a trompa fera,

P. 309

FORTIFICA-ME, Ó DEOS!

P. 309:

Nota MA: correção a erro de impressão no v. 14, anulando "com":

Quem desta vida inquieta já transido

Á ridente mansão fosse comvosco! 
VARELLA, L. N. Fagundes. Obras completas de L. N.

Fagundes Varella: edição organisada e revista, $e$ $12 \times 19,5 \times 2,5 \mathrm{~cm}$ precedida de uma noticia biographica por Visconti Coaracy e de um estudo critico pelo Dr. Franklin Tavora. Rio de Janeiro/Paris: Garnier, 1919. 3 v.

A 869.9138 V293o

\section{VOLUME 1}

\section{$\underline{\text { FOLHA DE GUARDA }}$}

Notas MA:

1. anotação no alto, à direita, “ $n^{\circ} 224 /$ I vol”, referindo-se à inclusão do volume na Bibliografia para Na pancada do ganzá;

2. lista de verbetes para o Dicionário musical brasileiro e cruzeta indicando o aproveitamento:

Dic - rabeca 73 -dançante (subs) 74 - monodia 81 - harmonia das esferas 86 - psalmo 120 - modular 146 - nota 148 e 150-sonoroso 207 - cantata 235 - resoar 242 harmonicamente 270 -"

Notas da pesquisa:

1. $\mathrm{O} \mathrm{n}^{\circ} 224$ sinaliza a inclusão das Obras completas de L. N. Fagundes Varella na Bibliografia para Na pancada do ganzá, conjunto de 837 títulos arrolados por MA para apoiar a organização de seu vasto projeto sobre o folclore brasileiro. Os títulos da poesia dos autores românticos focalizados em seu ensaio "Amor e medo" fazem parte da lista bibliográfica.

2. O escólio "dic", a grafite, de ocorrência farta na marginália, nos títulos da poesia do romantismo brasileiro, indica a pesquisa de elementos para abonar verbetes no Dicionário musical brasileiro, projeto do escritor testemunhado em sua biblioteca, no manuscrito desse título e de outros, em seu arquivo e, na edição póstuma coordenada por Oneyda Alvarenga e Flávia Camargo Toni (Brasília: Ministério da Cultura/São Paulo: IEB-USP - Edusp/ Belo Horizonte: Editora Itatiaia Ltda, 1989).

\section{P. 5-43:}

TÁVORA, Franklin. "Estudo crítico".

P. 6:

Nota MA: nome sublinhado, "F. Octaviano", e expoente “(1)" remetendo ao comentário no rodapé:

Muitas e galantes musas enchiam de gratas harmonias por esse tempo, ao norte e ao sul, o céo da patria. Algumas tiveram posteriormente os labios sellados pela mão da morte: o paiz ainda pranteia Castro Alves, Almeida Braga, Torres Bandeira, Mendonça, e ultimamente Carvalhal, quasi desconhecido desta Côrte. A outras impoz silencio a politica, a descrença ou o fastio á vida literaria, tão 
pobre de attractivos entre nós: ha quanto tempo não se escutam as suavissimas vozes poeticas de F. Octaviano (1), Teixeira de Mello, Amaral, Bittencourt Sampaio, Dias Carneiro, Cesario de Azevedo e alguns outros?

\section{“(1) Não esquecer Francisco Otaviano / na deliciosa tradução dos Cantos de / Selma”}

Nota da pesquisa: A tradução de Francisco Otaviano (1825-1889) para Os cantos de Selma (Rio de Janeiro: Tipografia da República, 1872), poemas de Ossian, não consta da Biblioteca MA.

\section{P. 7:}

Nota MA: termo corrigido, "oxigenio" - correção tipográfica:

(...) cada um, como o Antheu recebia forças da mãe-terra, recebe da patria, da mulher, do povo, ou da natureza o exigenio que lhe avigora as inspirações.

P. 8:

Nota MA: trecho destacado por traço vertical - seleção de ideias:

Que nume deverá presidir ao nascimento do filho da sua imaginação? Bazilio da Gama, Durão, Gonzaga ou Magalhães? Nenhum destes. Nenhum destes é seu irmão no lyrismo pantheista, primeiro meio de manifestar a admiração pela alma da natureza americana, essa alma que se levanta mysteriosamente nas florestas verdes e nas montanhas azues.

P. 12:

Nota MA: termo corrigido, "sahirá" - correção tipográfica:

“/á" (...) Demais, o Evangelho nas selvas, pela importancia e pelos meritos, exige um exame especial que sahira a lume opportunamente.

P. 23:

Nota MA: preposição corrigida, "a" - correção tipográfica:

As formas descriptivas que apparecem confusas, trazendo o sello da imitação, em Mauro o escravo; que são imcompletas e angulosas em Gualter o pescador; que são flacidas e tumidas por extremo nas Nevoas e na Enchente; que são vagas ou delirosas na Madrugada e beira mar, na Varzea e na Noite saudosa...

P. 26:

Nota MA: fio e comentário no rodapé:

O balanço da rêde, o bom foge Sob um tecto de humilde sapé; A palestra, os lundús, a viola, O cigarro, a modinha, o café;

Um robusto alazão, mais ligeiro Do que o vento que vem do sertão Negras crinas, olhar de tormenta, Pés que apenas rastejam no chão;

E depois um sorrir de roceira, 
Meigos gestos, requebros de amor,

Seios nús, braços nús, tranças soltas,

Molles falas, idade de flôr;

Beijos dados nas vastas planicies

Risos francos, alegres serões,

Mil brinquedos no campo ao sol posto,

Ao surgir da manhã mil canções:

Eis a vida nas vastas planicies

Ou nos montes da terra da Cruz,

Sobre o solo só flores e glorias,

Sob o céu só magia e só luz.

"Infelizmente o ritmo é besta pro / assunto."

P. 37:

Nota MA: termo corrigido, "assusta-me" - correção tipográfica:

Querer falar, e assustaf-me “ $/ x$ ”

o accento da minha voz!

P. 47-51

NOTICIA BIOGRAPHICA

P. 47:

Nota MA: escólio, "11 anos" - seleção de ideias: biografia:

Em 1852, tendo sido seu pai nomeado juiz de direito de Catalão, na remota provincia de Goyaz, teve o menino que acompanhar sua familia.

11 anos

P. 48:

Nota MA: escólio, “24 anos" - seleção de ideias: biografia:

Em 1865, matriculou-se na faculdade de S. Paulo. Ao ser examinado em francez, para sua admissão, foi-lhe por sorte designado um trecho de poesia. Immediatamente verteu-o elle em excellentes versos portuguezes, com applauso dos examinadores e circumstantes. Começara assim, por um triumpho, a sua vida academica.

P. 50:

Notas MA:

1. escólio, "Morte" - seleção de ideias: biografia;

2. parágrafo destacado por traço vertical - seleção de ideias: criação:

"Morte" A 18 de Fevereiro de 1875 falleceu na cidade de Nitherohy, victima de uma apoplexia cerebral.

Varella escrevia sempre inspirado, como de improviso de uma vez, as suas composições, os seus cantos; e o que se deve notar, não os relia nunca para corrigil-os. 
Nota da pesquisa: Os escólios à margem da "Noticia biographica" compõem indiretamente a elaboração de "Amor e medo"; no ensaio, MA recorre a elementos da vida de Fagundes Varela para defender, p. ex., que este tratou a mulher com objetividade maior: "Não esqueçamos que ele casou duas vezes..." (ANDRADE, Mário de. "Amor e medo", In: Aspectos da literatura brasileira. Ed. cit., p. 201).

\section{VOZES DA AMERICA}

$\underline{\text { P. 55-79 }}$

MAURO, O ESCRAVO

P. 62:

Nota MA: v. 163-167 destacados por traço vertical - seleção de ideias: natureza:

I
Na hora em que o horizonte empallidece, Em que a briza do céo vem suspirosa
De humidos beijos afagar as flôres,
E um véo ligeiro de subtis vapores
Baixa indolente da montanha umbrosa;

P. 63:

Nota MA: v. 168-182 destacados por traço vertical e comentário - seleção de ideias: natureza:

\section{II}

Na hora em que as estrellas entremecem, Lagrimas de ouro no sidéreo manto, E o grillo canta, e o ribeirão suspira, E a flôr mimosa que ao frescor transpira Peja os desertos de suave encanto;

III

Na hora em que o riacho, a veiga, o insecto, A serra, o taquaral, o brejo e a matta Fallam baixinho, a cochichar na sombra, $\mathrm{E}$ as molles felpas da campestre alfombra Molham-se em fios de fundida prata;

IV

Na hora em que se abala o santo bronze Da igrejinha gentil no campanario, Uma voz lacerada, enfraquecida, "Começa a dese-/nhar-se a Levantava-se amarga e dolorida atração / pela natureza."

Da sombria morada de Lotario.

Notas da pesquisa:

1. A percepção de MA é confirmada no fichamento crítico das obras de Fagundes Varela, no dossiê do manuscrito Amor e medo, no qual esta página é referida - em função dos traços verticais e nota de margem - como exemplo da "Atração da natureza". Entre 
parênteses, MA pontua que Varela teria sido o "único que a sentiu no R.” [Romantismo] (MA-MMA-05-05).

2. Nas Obras completas de Castro Alves, MA assinala o v. 80 de "Aves de arribação" "Tendo por musa o amor e a natureza" - e planeja aproveitá-lo como epígrafe para o capítulo dedicado a Fagundes Varela no livro Lirismo romântico no Brasil; a intenção é transposta para o manuscrito (V. MA-MMA-26-04 e Nota MA, In: ALVES, Castro. Obras completas. Edição crítica comemorativa do cincoentenário do poeta... com um retrato, introducção bibliographica e annotações de Afranio Peixoto. Rio de Janeiro: Francisco Alves, 1921, vol. 1, p. 193).

P. 66:

Nota MA: v. 232-235 destacados por traço vertical duplo - estudo do estilo: descrição:

IX

Ao vivo encanto de uma aurora esplendida

Voltando o rosto a noite despeitada

Cedeu-lhe a creação, e foi ciosa

Esconder-se em seus antros. As florestas

Nota da pesquisa: No fichamento crítico das obras de Fagundes Varela, a página inaugura a rubrica "Falso descritivo" (MA-MMA-05-05), rica de exemplos coletados por MA.

P. 70:

Notas MA:

1. termo sublinhado no v. 363 , "corôa", e cruzeta - estudo do estilo: licenças poéticas;

2. preposição sublinhada no v. 364, "para", e cruzeta - estudo linguístico: emprego de "para/pra";

3. v. 368-387 destacados por traço vertical e comentário na p. 71:

$X \quad$ Adeus! misera irmã, tu és ditosa!
$X \quad \underline{\text { Deus te deu corôa do martyrio, }}$
Espera-te sorrindo... e eu inda fico,
E tenho de esgotar até ás fezes
A taça envenenada da existencia!

I

Tu passaste na terra como as flôres

Que a geada hibernal derriba e mata, Foram teus dias élos de teus ferros, E teus prazeres lagrimas!

\section{II}

Negou-te a primavera um riso ao menos;

Dos sonhos na estação, nenhum tiveste;

A aurora que de luz inunda os orbes

Te abandonou nas trevas! 
III

Alma suave a transpirar virtudes,

Genio maldito arremessou-te ao lodo!

Buscaste as sendas lucidas do Empyreo,

E apontaram-te o cahos!

IV

A Providencia que os coqueiros une, Quando a tormenta pelo espaço ruge, Até o braço de um irmão vedou-te,

Oh! planta solitaria!

V

"A propensão pra / nenias desde o /

A morte agora te escutou, criança!

Trouxe a alvorada que esperaste embalde,

princípio cria esta / bela obra."

E adormecida nos seus molles braços

Pousou-te junto a Deus!...

Nota da pesquisa: A rubrica "Elegíaco", no fichamento crítico das poesias de Fagundes Varela, inclui remissão à página (MA-MMA-05-05).

P. 73:

Nota MA: termo sublinhado no v. 414, "rebeca", e cruzeta - pesquisa para o Dicionário musical brasileiro:

Quando convulso o arco estremecia

Nas cordas da rebeca, e os olhos languidos

$X$

P. 74:

Notas MA:

1. termo sublinhado no v. 442, "para", e cruzeta - estudo linguístico: emprego de "para/pra":

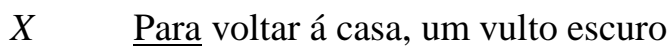

2. termo sublinhado no v. 460, "dançantes", anotação "subs." e escólio "dic" - pesquisa para o Dicionário musical brasileiro:

V

A orchestra proseguia, ardente, forte,

"dic" Seus ruidosos accordes; dos dançantes "subs."

Poucos se achavam do salão no meio,

P. 81-91

PREDESTINAÇÃO (37 estrofes)

P. 81:

Notas MA: 
1. expressão sublinhada no v. 12, "emquanto que" - estudo linguístico: brasileirismo sintático;

2. termo sublinhado no v. 19, "monodias", e escólio "dic" - pesquisa para o Dicionário musical brasileiro:

Emquanto que vacillante

Nas campinas do Levante

A lua caminha errante

Com seu pallido clarão.

É a hora dos mysterios!

Ao longe nos cemiterios

Gyram phantasmas funereos

Entre horrendas monodias;

"dic"

Nota da pesquisa: No manuscrito d'A gramatiquinha da fala brasileira, MA lista "brasileirismos sintaxicos", como a colocação de pronomes e a obliteração dos possessivos, e inclui: “i) emprego de 'enquanto que' no povo analfabeto" (MA-MMA$51 \lcm{261}$ ).

P. 84:

Nota MA: cruzeta - estudo do estilo: pontuação:

Poeta ou louco, sonhador ou sabio,

Mineiro do passado, ou nauta ousado

Dos mares do porvir,

Basta de scismas! abandona o vôo

De tu'alma arrogante entre as espheras,

São horas de dormir!

$X$

A luz da alampada fragil

Lucta co'as trevas em vão,

Depois se estorce, soluça,

Lança um ultimo clarão.

P. 85:

Nota MA: comentário à margem dos v. 134-137:

O teu rosto é mais puro do que a neve,

A lua oriental sobre o Hymalaia;

Teus seios como as vagas preguiçosas

Que suspiram na praia.

"a preocupação da
natureza é tal em
Varela que em vez de
como Alvares de Aze-

vedo ver a ita-/liana, a hespa-/nhola, descreve as / paisagens exoticas"

Nota da pesquisa: A rubrica "Atração da natureza" remete a esta página no fichamento crítico das obras de Fagundes Varela (MA-MMA-05-05).

P. 86:

Nota MA:

1. comentário à margem dos v. 150-153: 
Eras tu, eras tu! no céo, na terra,

Na briza da manhã, no val', na flôr...

Eras tu minha unica esperança,

Eras tu meu amor!...

\section{"Preocupado com / a natureza chega / a ver virgens i-/deais nela"}

2. v. 161-164 sublinhados - estudo do estilo: repetição/seleção de ideias;

3. escólio "dic" no v. 164 - pesquisa para o Dicionário musical brasileiro:

Porque tentas erguer-te á luz das luzes,

E amores mendigar a ethereos sêres

Que aos pés do Creador eternos tecem

"dic" A harmonia incessante das espheras?

Nota da pesquisa: MA elenca esta página entre os exemplos de "Atração da natureza", no fichamento crítico das obras de Fagundes Varela, dossiê do manuscrito Amor e medo (MA-MMA-05-05).

P. 88:

Nota MA: v. 217-222 assinalados por expoente "(1)" remetendo ao comentário no rodapé:

"(1)" As torrentes despenham-se cantando

Em leitos de esmeralda e aos céos enviam

Borrifos de diamantes...

E das tendas sem fim que ao longe alvejam

Levanta-se a canção melodiosa

De um povo de gigantes.

“(1) Descrições a que não falta nunca / a torrente convulsa dos pintores ro-/manticos.”

Nota da pesquisa: MA indica esta página sob a rubrica "Falso descritivo", no fichamento crítico das obras de Fagundes Varela, fólio no dossiê do manuscrito Amor e medo. Elaborado no processo de redação do livro Lirismo romântico no Brasil, o documento ancora em 1931 o preparo do ensaio para a Revista Nova (MA-MMA-05-05).

P. 89:

Nota MA: v. 229-234 assinalados por expoente “(1)" remetendo ao comentário no rodapé:

Um mundo inteiro de prazer e festas,

Hymnos, perfumes, saudações e beijos

Rola e bate no céo;

E o rio, a serra, as solidões e o homem

Se espreguiçam sorrindo ao sol divino

Da volupia no véo. "

"(1) Raramente Varela atinge o traço carac-/teristico e mais realistamente pinturesco ou / mais expressionistamente visionado, é a / tela de paisagem romantica, tediosa e par/lamentar." 
Nota da pesquisa: Também esta página é referida por MA na rubrica "Falso descritivo", no fichamento crítico das obras de Fagundes Varela (MA-MMA-05-05).

P. 91:

Notas MA:

1. v. 282 e 283 destacados por traço vertical e expoente “(1)”remetendo ao comentário no rodapé:

Alleluia! Alleluia! ergue-se o dia,

Trinam as aves desabrocham flôres,

E a lampada dos seculos se balança "(1)"

Entre jorros de luz no azul das nuvens; )

“(1) A palavra Sol não aparece nunca; glo-/riosa e ardente por si mesma, é um / Sol frio que Varela ama, enevoado na / cerração das metaforas e / dos circunloquios.

2. v. 289-291 destacados por traço vertical e expoente “(2)” remetendo ao comentário no rodapé:

Sabeis quem era esse mancebo pallido?

Era - Colombo o Genovez, e a plaga

Que elle avistára ao longe - o Novo Mundo.

(1) Eis uma coisa que surpreende de /verdade. Ninguem podia imaginar!”

Nota da pesquisa: A rubrica "Imagem", no fichamento crítico das obras de Fagundes Varela, guarda remissão a esta página (MA-MMA-05-05).

$\underline{\text { P. } 92-95}$

O PROSCRIPTO (8 estrofes)

P. 93:

Notas MA:

1. trecho sublinhado nos v. 36-38 e destacado por traço vertical - estudo da psicologia: pessimismo:

Muito cedo, meu Deus! Que lei sinistra

Me impelle a povoar de treva e luto

Tudo o que ha de mais bello e mais formoso

2. termo sublinhado no v. 47, "o sol", e cruzeta - estudo do estilo: imagem:

Como o sol que levanta-se das ondas, $\quad X$

Ondas de chammas derramando aos orbes.

Nota da pesquisa: O período destacado por MA cauciona a indicação desta página como exemplo do caráter "elegíaco" da poesia de Fagundes Varela, conforme se lê no fichamento crítico (MA-MMA-05-05). 
Nota MA: comentário ao final do poema:

Cresce, meu filho amado, inda te vejo,

Inda me é dado te apertar ao seio,

Beijar-te a rosea face! este momento

É mais que a eternidade! Cresce, vive!

E, si algum dia no meu livro escuro

Esta folha encontrares, vota ao menos

Á fronte que a pensou um triste pranto,

Vê que teu pai soffreu e não mentiu.

"Dentro de toda a musicalidade de G. / Dias o seu verso tivre branco tem uma tal / ou qual secura e frieza provinda talvez / do meneio arcaisante levemente da fra-/se, meneio que pode dar graça, pode / dar luis-quinzismo mas que é estam-/pa, não da valor nem intimidade. Is-/so: ao fraseado de G. Dias falta intimi-/dade, falta calor recostado de coisa co-/nhecida, lidada. É Varela que a tem e / o seu verso-branco é adoravel, facil, I quente sem valor grande, gostoso. E / tem uma dolencia, uma sensualida-/de alias purissima duma gostosissi-/ma leitura. Comparar verso-branco de / I-juca-pirama e do Cantico do Calvario pra / provar isso. O verso branco de Alvares de / Azevedo apesar de camarada não é inti-/mo não é familiar. É desabusado. Tem a / secura livre do que passou pelo fogo do / pecado. Desculpem. / Não estou fantasian-/do não. É isso mes-/mo. A gente sente como ele essa fami-/liaridade um pouco assustada com que / o gosto o gosto honesto da leitura, do / mesmo jeito com / que a gente tem / uma familia-/ridade um / pouco inti-/midade com / parente far-/rista e meio / maluco."

Nota da pesquisa: A musicalidade comentada por MA nesta página justifica sua inclusão no fichamento crítico das obras de Fagundes Varela: "Musicalidade I, 95; 102; 112; 129; III,153; 173; 230; 237; A. de A. III, 127" (MA-MMA-05-05). O documento, no dossiê do manuscrito Amor e medo, remete à Nota MA no vol. 3 das Obras completas de Álvares de Azevedo, em que o crítico sublinha trecho de estudo sobre Musset - "o rhytmo embala, o som é uma sensação que inebria" - e planeja, no rodapé, "Citar isto pra caracterizar o verso-livre dos romanticos nossos, talvez mesmo só pra Varella." (V. Nota MA, In: AZEVEDO, Álvares de. Obras de Manoel Antonio Álvares de Azevedo precedidas do juizo critico de escriptores nacionaes e estrangeiros e de uma noticia sobre o auctor e suas obras por J. Norberto de S. S. 7. ed. Rio de Janeiro: Garnier, 1900, vol. 3, p. 127).

$\underline{\text { P. } 96-98}$

VINGANÇA (12 estrofes)

P. 97:

Nota MA: termo corrigido no v. 39, "furacões" - correção tipográfica:

Nas azas se approxima dos furações incertos " $/ c$ "

Agudo e retumbante o som de uma buzina.

P. 99-102

NAPOLEÃO (15 estrofes) 
P. 102:

Nota MA: comentário ao final do poema:

"Segundo fabordão em 'ão,”

Nota da pesquisa: MA remete ao fabordão assinalado nesta página sob a rubrica "Musicalidade", no fichamento crítico das obras de Varela (MA-MMA-05-05).

$\underline{\text { P. } 103}$

SONETO

P. 103: $\underline{\text { S/Notas MA }}$

Nota da pesquisa: A rubrica "O soneto romantico" - no fichamento crítico elaborado com vistas ao livro Lirismo romântico no Brasil - conserva remissão ao poema (MA-MMA26-04).

P. 104-105

ILLUSÃO (5 estrofes)

P. 105:

Nota MA: comentário ao final do poema:

Corro a seus braços tremulo, incendido

De febre e de paixão... A noite é negra, Ruge o vento no matto;

Os pinheiros se inclinam, murmurando:

- Onde vai este pobre cavalleiro

Com seu sonho insensato?...

"Curioso porque afinal é uma / alucinação bem concatenada e / sobretudo bem finalizada."

Nota da pesquisa: Ao observar, nos versos de Varela, o apuro da composição e o alucinar bem-concatenado, MA explica a presença desta página na lista de 29 itens que ilustram a rubrica "Artista", no fichamento crítico que integra o dossiê do manuscrito Amor e medo: "Artista I, 105; 110; 189; 201; 232; 241; II, 13; 16; 25; 73; 105; 107; 109; 137; 159; 165; $212 ; 222 ; 238 ; 263 ; 283 ; 292 ;$ III, 52; 184; 227; 248; 255; 256; 287” (MA-MMA-05-05). Cabe lembrar que, na definição de poesia proposta por MA em 1922, com base na leitura de Paul Dermée, o elemento "arte" equivale a "mondar mais tarde o poema de repetições fastientas, de sentimentalidades românticas, de pormenores inúteis ou inexpressivos" (ANDRADE, Mário de. "Prefácio interessantíssimo", In: Pauliceia desvairada; In: Poesias completas. Ed. cit., vol. 1, p. 63).

P. 106

IDEAL (5 estrofes)

P. 106:

Nota MA: comentário ao final do poema: 
"Isto é pandego e idiotissimo. / Dos romanticos maiores o que mais / frequentemente atinge estas idiotices / é Varella."

Nota da pesquisa: MA faz referência a esta página no fichamento crítico; abre a rubrica "Mau gôsto" (MA-MMA-05-05).

P. 110

O VIZIR (1 estrofe)

P. 110:

Nota MA: título destacado por cruzeta e comentário ao final:

- Não derribes meus cedros! murmurava

O genio da floresta apparecendo

Adiante de um vizir, senão eu juro

Punir-te rijamente! E no emtanto

O vizir derribou a santa selva!

Alguns annos depois foi condemnado

Ao cutelo do algoz. Quando encostava

A cabeça febril no duro cepo,

Recuou aterrado: - Eternos deuses!

Este cepo é de cedro! E sobre a terra

A cabeça rolou banhada em sangue!

"Fabula excelente. Sintese magistral em sujeito bem prolixo e falador."

Nota da pesquisa: O exemplo municia a rubrica "Artista", no fichamento crítico das obras de Fagundes Varela (MA-MMA-05-05).

P. $111-112$

NÃO TE ESQUEÇAS DE MIM! (7 estrofes)

P. 112:

Nota MA: comentário ao final do poema:

"A superioridade da musicalidade / do decassilabo de Varela sobre o de / G. Dias é que neste a musicalidade / não é tão intrinseca, sendo pelos / processos que aponto uma musicali-/dade mais musical que propriamen-/te oral. Ora esta é que é da Poesia. I Varela tem uma musicalidade / oral estupendissima. Natural-/mente: romantica.

Numa nota pg 95 deste, sobre o mesmo / assunto caracterizar: G. Dias, maneirismo / Varela, naturalidade"

Nota da pesquisa: O comentário final - que classifica a musicalidade de Gonçalves Dias como "maneirismo" e a de Fagundes Varela como "naturalidade" - reforça, também sob esse aspecto, a posição singular em que MA situa o autor dos Primeiros cantos em meio aos demais poetas do romantismo brasileiro. Em nota de trabalho no dossiê do manuscrito Castro Alves, MA assim caracteriza o poeta: “Gonçalves Dias é artista intelectual. A arte 
dele está principalmente no dominio da inteligencia sobre a inspiração organizando-lhe a tematica as normas, os ideais, as maneiras de se manifestar-Castro Alves é artista formal. A sua arte é mais exterior, mais de frase que a de Gonçalves Dias. Daí as antiteses, as ideas paralelas, as comparações, as imagens, os estupendos refrões. Dizer isso separadamente quando tratar individualmente dos 2 poetas. E na parte geral anterior á critica individual so afirmar rapidamente a superioridade artistica de Gonçalves Dias e dar rapido os porquês." (MA-MMA-26-08).

P. 113

SONETO

Nota MA: título destacado por cruzeta e escólio "Sequestro" - ligação com a pesquisa de MA do tema do Sequestro da dona ausente no folclore brasileiro:

SONETO "Sequestro"
Eu passava na vida errante e vago
Como o nauta perdido em noite escura,
Mas tu te ergueste peregrina e pura
Como o cysne inspirado em manso lago.
Beijava a onda n'um soluço mago
Das molles plumas a brilhante alvura,
E a voz ungida de eternal doçura
Roçava as nuvens em divino afago.
Vi-te; e nas chammas de fervor profundo
A teus pés afoguei a mocidade
Esquecido de mim, de Deus, do mundo!
Mas ai! cedo fugiste!... da soidade,
Hoje te imploro d'esse amor tão fundo
Uma idéa, uma queixa, uma saudade!

Notas da pesquisa:

1. O termo "sequestro" cristaliza, na marginália, a convergência de projetos, aproximando a poesia romântica, erudita, da criação anônima do povo. Remete em primeiro lugar a $O$ sequestro da dona ausente, longa pesquisa de MA no âmbito do folclore luso-brasileiro, que investiga o encontro amoroso - frustrado pelas navegações e pela escassez de mulheres no Novo Mundo - como objeto de elaboração estética. O dossiê da pesquisa, na série Manuscritos MA, abriga planos, esboços e notas prévias, num total de 1.221 documentos (MA-MMA-106). O termo constitui versão autoral e aproximativa para o Verdrängung/refoulement, conceito psicanalítico que tem papel-chave em "Amor e medo". A circunstância cultural que dá origem à tópica da dona ausente é caracterizada por MA em artigo na revista Atlântico: "O mar todo-poderoso exige dos que lhe manejam o rito, viverem em castidade completa. Mas a saudade da mulher persegue o casto, o desejo dela o castiga demais. E o marujo, especialmente o lusitano que foi o maior dos navegadores, busca disfarçar o martírio nas imagens e nos símbolos da poesia. $\mathrm{O}$ folclore luso-brasileiro se enriqueceu, com isso, de uma série numerosa e admirável de quadrinhas e cantigas" (ANDRADE, Mário de. "A dona ausente". Atlântico, no 3. Lisboa/Rio de 
Janeiro, Serviço Nacional de Propaganda/ Departamento de Investigação e Propaganda, 1943, p. 9).

2. MA refere-se a este poema no fichamento crítico contendo as "Ideias gerais" para o livro Lirismo romântico no Brasil, fólio situado no dossiê do manuscrito Castro Alves (MA-MMA-26-04).

P. 116-119

ELEGIA (19 estrofes)

P. 118:

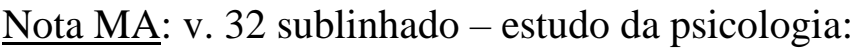

Não são dos invernos as frias geadas,

Nem longas jornadas que os annos apontam...

O tempo descora nos risos e prantos,

E os dias do homem por dôres se contam!

P. 119:

Nota MA: v. 75 e 76 destacados por traço vertical e expoente "(1)" remetendo ao comentário no final do poema:

Nós eramos jovens, e as vidas e os seios, $\mathrm{O}$ affecto prendera n'um candido nó!

“(1)” (Foi ella a primeira que o laço quebrando

Cahiu soluçando das campas no pó!

“(1) Notar como são infieis as mulheres mais / ou menos reais dos romanticos. Alias o / sofrimento em amor parece mais... poetico, / que nem reflete Poe na Filosofia da Composi-/ção. O que é curioso é que nenhum dos nos romanticos / se lembrasse de cantar a amante morta. Preferem / tomar taboa a assassinar os seus 'anjos' e crianças."

Nota da pesquisa: MA alude ao trecho de "A Filosofia da composição" no qual Edgar Allan Poe considera a morte de uma mulher bela como o mais poético dentre os assuntos: "the death of a beautiful woman is unquestionably the most poetical topic in the world, and equally is it beyond doubt that the lips best suited for such topic are those of a bereaved lover". O ensaio é destacado por sublinhas, traços verticais e comentários de MA, no volume Poems and Essays, localizado em sua biblioteca (Berlin: Internationale Bibliothek, 1922). O trecho referido na marginália, contudo, não preserva marcas. MA sublinha o interesse de Poe pela originalidade - "Keeping originality always in view for he is false to himself who ventures to dispense with so obvious and so easily attainable a source of interest" - e o caráter pretensamente matemático de sua criação: "the work proceeded, step by step, to its completion with the precision and rigid consequence of a mathematical problem" (Notas MA, p. 185 e 186). Também assinala um traço vertical no trecho: "Beauty is the sole legitimate province of the poem" (Nota MA, p. 188). Próximo ao final do ensaio, comenta no rodapé: "Poe não repara que em vez de / procurar a Beleza, como imagina / ser seu intento, procura a verda-/de psicológica, depois de certas de/terminações de construção. A beleza tornou-se pois / uma consequencia, como afirmo. Consequencia neces-/saria e subconsciente." (Nota MA, p. 197). Na página de guarda do volume, MA remete aos passos assinalados por ele, listando-os a grafite: "pgs = 125, 108, $114,185,186,188^{\prime \prime}$. 
P. $120-121$

TRISTEZA (12 estrofes)

P. 120:

Notas MA:

1. termos sublinhados no v. 18, "psalmos" e "troar", e escólio "dic" - pesquisa para o Dicionário musical brasileiro;

2. termo sublinhado no v. 19, "torrente", e cruzeta - seleção de ideias: natureza;

3. comentário ao final da estrofe:

Amo do templo, nas soberbas naves,

"dic" De tristes psalmos o troar profundo;

$X \quad$ Amo a torrente que na rocha espuma

E vai do abysmo repousar no fundo.

"sempre a torrente"

Notas da pesquisa:

1. No fichamento crítico das obras de Fagundes Varela, fólio no dossiê do manuscrito "Amor e medo", MA aponta esta página na rubrica "Falso descritivo" (MA-MMA-0505).

2. Comentando o interesse dos poetas românticos na natureza, em artigo para o Diário Nacional, publicado em 29 de março de 1931, MA afirma: "Falam nela e alguns bastante, sei bem. Mas são incapazes de a sentir e a transmitir. Fazem oleogravuras da mais detestável fixidez, sem terra, sem cheiro, sem nada, principalmente o dulcíssimo Varela, cujas paisagens são sempre duma sonoridade magnífica de linguagem, mas incapazes de nos contagiar." (ANRADE, Mário de. "Álvares de Azevedo - II", In: Táxi e Crônicas no Diário Nacional. Ed. cit., p. 361). Em “Amor e medo", tratando do mesmo aspecto, mas sem o tom negativo na comparação com a óleogravura, assinala a recorrência das cascatas no autor da "Juvenília": "Varela tinha a obsessão da natureza, a que aliás, com a beleza sonora um pouco açucarada do seu verso, ele dá um polido de oleogravura, em que setenta por cento das vezes a gente encontra uma eterna e irritante cascata." (ANDRADE, Mário de. "Amor e medo", In: Aspectos da literatura brasileira, ed. cit., p. 213).

\section{P. 121:}

Notas MA:

1. verbo sublinhado no v. 24, "abrevou", e cruzeta - estudo do estilo/linguístico: galicismo:

Amo a tormenta, o perpassar dos ventos,

A voz da morte no fatal parcel,

Porque minh'alma só traduz tristeza,

Porque meu seio se abrevou de fel.

$X$

2. v. 44 sublinhado e expoente “(1)” remetendo ao comentário no rodapé:

O céo de anil, a viração fagueira,

O lago azul que os passarinhos beijam,

A pobre choça do pastor no valle,

Chorosas flôres que no sertão vicejam. "(1)" 
“(1) Verso errado em que a explicação é mais / dificil. Porem o ritmo ainda continua cer-/to, a silaba res de flores sendo enorme-/mente muda. A acentuação ritmica exata / persiste pois."

P. $122-124$

$* * *(16$ estrofes $)$

P. 122:

Nota MA: v. 13-16 destacados por colchete e escólio "Sequestro" - ligação com a pesquisa de MA do tema do Sequestro da dona ausente no folclore brasileiro:

É tempo ainda; a viração susurra,

"Sequestro" Ergue-se a terra em maravilhas mil... Vem, minha fada, abandonemos juntos

Nosso barquinho pelo mar de anil.

P. 123:

Nota MA: v. 27 e 28 destacados por colchete - estudo da psicologia: amada dormida:

Vem! tu serás minha Atalá formosa,

Por quem na terra viverei de amores;

Teu meigo somno velarei cantando,

Teu brando jeito juncarei de flôres.

P. 124:

Nota MA: comentário ao final do poema:

"Nestes decassilabos e geralmente / em quasi todos (todos?) os rimados / a acentuação cantadeira e abrigada / na $4^{a}$ e $8^{a}$ silabas cança e enjoa hor/rorosamente. Nos versos brancos é / que Varela prima entremeando essa / maneira romantica de acentuar com / a acentuação heroica na $\sigma^{a}$ silaba."

Nota da pesquisa: MA alude a esta página, por seu comentário, na rubrica "Mau gôsto" do fichamento crítico (MA-MMA-05-05).

P. 125-129

ECHOS DO CARCERE (17 estrofes)

P. 126:

Nota MA: v. 22-24 e 45-47 destacados por traço vertical e presos por fio, e escólio "Refrão" - estudo do estilo:

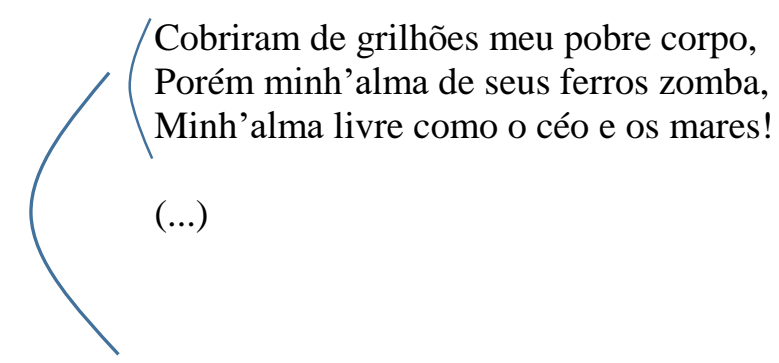


Refrão $\quad \begin{aligned} & \text { Cobriram de grilhões meu pobre corpo, } \\ & \text { Porém minh'alma de seus ferros zomba, } \\ & \text { Minh'alma livre como o céo e os mares! }\end{aligned}$

P. 126:

Nota MA: termo sublinhado no v. 64, "o sol”, e cruzeta - estudo do estilo: imagem:

Como era bello o sol e a terra lucida! $X$

P. 128:

Nota MA: v. 111 sublinhado - seleção de ideias:

Phalange heroica e brava, ah! eu a vejo Sempre junto de mim, ouço seus cantos Lançando aos orbes que no espaço rolam A epopéa soberba do futuro!

P. 129:

Nota MA: v. 123-125 destacados por traço vertical e comentário:

- Cobriram de grilhões meu pobre corpo, Porém minh'alma de seus ferros zomba, Minh'alma livre como o céo e os mares!

"Refrão. / pesadão. Mal-/colocado. Não vem natu-/ralmente e tem tres versos e meio pre/paratorios. Positivamente ruim."

Nota da pesquisa: Os versos ensejam a indicação da página sob a rubrica "Musicalidade", no fichamento crítico das obras de Fagundes Varela (MA-MMA-05-05).

P. $130-132$

O EXILADO (10 estrofes)

P. 132:

Nota MA: comentário ao final do poema:

"O refrão aqui irrita pela continuidade e / pela vulgaridade."

Nota da pesquisa: MA inscreve o poema no fichamento crítico das obras de Fagundes Varela, sob a rubrica "Mau gôsto" (MA-MMA-05-05).

P. $133-135$

AURORA (12 estrofes)

P. 133:

Notas MA:

1. expressão sublinhada no v. 2, "o rei dos astros", cruzeta, escólio "Sol" e expoente "(1)" remetendo ao comentário no rodapé;

2. termo sublinhado no v. 12, "sol”, e fio ligando-o ao escólio - estudo do estilo: imagem: 
Antes de erguer-se de seu leito de ouro,

O rei dos astros o Oriente inunda

De sublime clarão;

Antes de as azas desprender no espaço,

A tempestade agita-se e fustiga

O turbilhão dos euros.

As torrentes de idéas que se ruzam,

O pensamento eterno que se move

No levante da/vida,

São auras santas, arrebóes esplendidos,

Que precedem á yinda triumphante

De um sol immorredouro.

“(1) É sobretudo nas descrições de natu-/reza que Varela substitui a palavra Sol por / qualquer circunloquio."

$\underline{\text { P. 135: }}$

Notas MA: v. 57 sublinhado e escólio "Reflequiços” - estudo linguístico: suarabácti:

Como aos dias primeiros do universo,

O globo se erguerá banhado em luzes,

Reflexos de Deus; Reflequiços!

$E$ a raça humana sob um céo mais puro

Um hymno insigne enviará, prostrada

Aos pés do Omnipotente!

$\underline{\text { P. } 136-137}$

As SELVAS (10 estrofes)

P. 136:

Notas MA: expressão sublinhada no v. 4, "tufão murmura", e exclamação - seleção de ideias: natureza:

Selvas do Novo Mundo, amplos zimborios,

Mares de sombra e ondas de verdura,

Povo de Atlantes soberano e mudo

Em cujos mantos o tufão murmura. !

P. 137:

Nota MA: comentário ao final do poema:

"A acentuação na $6^{a}$ ainda luta por so-/breviver nas 2 primeiras estrofes mas / em seguida desaparece vencida e não apa-/rece mais. E seguinte poesia também."

P. $138-139$

A LuCILIA (7 estrofes)

P. 139:

Nota MA: comentário ao final do poema: 
"Aqui só o $1^{o}$ verso tem acentuação heroi-/ca."

P. 144-145

CANTIGA (9 estrofes)

P. 145:

Nota MA: estrofe destacada por traço vertical e cruzeta - estudo do estilo:

$$
X \quad \begin{aligned}
& \text { Mas olha que junto ao porto } \\
& \text { Soberbo gigante está, } \\
& \text { Elle dorme, dorme, dorme, } \\
& \text { Mas nem sempre dormirá! }
\end{aligned}
$$

Nota da pesquisa: MA alude à estrofe final de "Cantiga" como exemplo de beleza na obra de Fagundes Varela: "Passagens bonitas I, 145; II, 14; 193; III, 98; 100; 104; 118; 121; 175; 315" (MA-MMA-05-05).

P. 146-147

O SABIÁ (6 estrofes)

P. 146:

Nota MA: termo sublinhado no v. 16, "modula", e escólio "dic", acompanhado do comentário "no sentido / de cantar" - pesquisa para o Dicionário musical brasileiro:

Ergue-te, oh meu passarinho,

De teu ninho,

Vem gozar da madrugada...

dic Modula teu terno canto,

Dôce encanto

De minh'alma amargurada,

\section{P. 148-151}

HARMONIA

P. 148:

Notas MA:

1. termo sublinhado no v. 14, "notas", e escólio dic, acompanhado do comentário "por som" - pesquisa para o Dicionário musical brasileiro;

2. v. 17-19 destacados por traço vertical duplo - seleção de ideias: correspondências:

Onde o cantar plangente se estendia Deixando um rasto de abrasadas notas! Que sentimentos rebentavam n'alma Á vibração dorida d'esses threnos! /Ah! cada nota tem no seio humano Uma nota que dorme, irmã chorosa, Que acorda e vibra ao fraternal suspiro. dic

por som 
P. 149:

Nota MA: versos destacados por traço vertical e comentário:

Não há martyrio que ao martyrio iguale De uma lembrança perfumada e pura Nos dias lutulentos da desgraça!
Nessun magior dolore...

P. $152-154$

ESTANCIAS (9 estrofes)

P. 152:

Notas MA:

1. título destacado por cruzeta;

2. v. 4 sublinhado e expoente “(1)” remetendo ao comentário no rodapé:

Quando á tardinha rumorejam brizas

Roubando o aroma das agrestes flôres,

E dôce e grave, nas viçosas mattas,

Mais triste canto o sabiá desata,

Eu lembro-me de ti! (1)

“(1) Incrivel isto em Varela, tão natural e que / tão bem diria brasileiramente: Eu me lembro / de ti."

Nota da pesquisa: O uso da ênclise faz MA indicar este passo como exemplo de "Portuguesismo" no fichamento crítico, no âmbito da rubrica "Mau gôsto" (MA-MMA05-05).

P. $159-161$

ORIENTAL (10 estrofes)

P. 159:

Nota MA: termo sublinhado no v. 5, "nota", e escólio "dic" - pesquisa para o Dicionário musical brasileiro:

A nota triste e amorosa

"dic"

Da lyra do menestrel.

$*$

P. $172-190$

GUALTER O PESCADOR

P. 172:

Nota MA: expressão sublinhada no v. 2 e escólio "Sol" - estudo do estilo: imagem:

Sobre as ondas de anil do mar profundo

"Sol" Surge a esphera de luz, banhando as plagas 
De esplendido clarão;

Nota da pesquisa: MA recolhe o trecho assinalado ao fichamento crítico das obras de Fagundes Varela, no dossiê do manuscrito Amor e medo; remete à página sob a rubrica "Imagem" (MA-MMA-05-05).

P. 173:

Nota MA: termo sublinhado no v. 43, "Gualter", e expoente "(1)" remetendo ao comentário no rodapé:

- Ah! Gualter! (1) ... Gualter, eu não sei que tenho,

Mas voz sinistra me murmura n'alma

Que não deves partir!

- Não te aflijas, querida, diz o moço

Afagando-lhe a fronte; e os outros dias

Não se faz ella ouvir?

\section{“(1) Um Gualter misturado com mana-/cás e patativas.”}

Nota da pesquisa: A rubrica "Mau gôsto" remete à página, acolhendo o trecho assinalado no fichamento crítico das obras de Fagundes Varela, no dossiê do manuscrito Amor e medo (MA-MMA-05-05).

P. 175:

Nota MA: termo sublinhado no v. 91, "sol", e escólio "Sol" - estudo do estilo: imagem:

Põe-se o sol, Merencorio o céo se toda "Sol"

Em véos de brumas, que, deixando os montes,

Desenvolvem-se aos poucos:

Ligeiras virações o mar encrespam,

E um cardume de passaros se arroja

P. 179:

No espaço em pios roucos.

Nota MA: termo sublinhado no v. 188, "sol", e escólio "Sol” - estudo do estilo: imagem:

É tarde; ha muito nos feraes negrumes

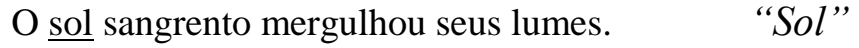

Bem como um brigue devorado em chammas,

A terra anceia, os pinheiraes se abalam,

E das florestas os Titães estalam

Lacerados, sem ramas!...

P. 181:

Notas MA:

1. preposição sublinhada no v. 247 , "p'ra", e cruzeta - estudo linguístico:

2. estrofe destacada por traço vertical e comentário:

Esher... adeus p'ra sempre!... O raio passa, $\quad X$

E a luz vermelha que o oceano abraça

Entre vozes de horror some o batel,

E os ventos berram nas espumas frias,

$\mathrm{E}$ as vagas brigam funeraes, bravias,

Nos hombros do parcel! 
"Esta descrição / de tempestade que / por aí vem não / é má. Pelo contra-/rio é das milhores."

Nota da pesquisa: É provável que MA aluda a esta página a contrario sensu na rubrica "Falso descritivo", no fichamento crítico das obras de Fagundes Varela (MA-MMA-0505).

P. 182:

Notas MA:

1. preposição sublinhada no v. 284, "para", e cruzeta - estudo linguístico: emprego de "para/pra";

2. termo sublinhado no v. 288 , "circulado", e cruzeta - estudo do estilo: imagem:

Aquelle adeus final, e o fragil lenho

$X \quad$ Para nunca se erguer baixou em lascas

No seio immenso da cruel voragem.

Longo tempo sem forças, desmaiado,

O moço fica n'essa movel cama,

$X \quad$ Circulado de espuma e de ardentias...

Mas pouco a pouco a vida vem tornando

E com ella a razão, a calma, o animo:

É forçoso pensar, buscar a praia,

Ver a filhinha, socegar a esposa

Que ha poucas horas no terror da morte

$X \quad$ Longe, perdidas para sempre cria!

P. 184:

Notas MA:

1. v. 342-347 destacados por traço vertical - estudo do estilo: imagem da natureza:
Porém nada responde; a ventania
Braveja no hervaçal, sacode as plantas
E da misera choça invade as frestas
Em longos assobios! O mancebo
Faz um supremo esforço, impelle a porta
E se arroja de um salto no aposento!

2. v. 349 sublinhado, cruzeta e sílaba indicada entre parênteses - estudo da versificação: métrica:

Mas, oh! quadro de horror! ... oh! negro quadro!

$X \quad$ Esther não (es)tá. Entorpecida, fria,

Cançada de chorar o pobre anjinho

Estremece no chão, molhada e núa!

3. v. 356-363 destacados por traço vertical e expoente (1) remetendo ao comentário no rodapé:

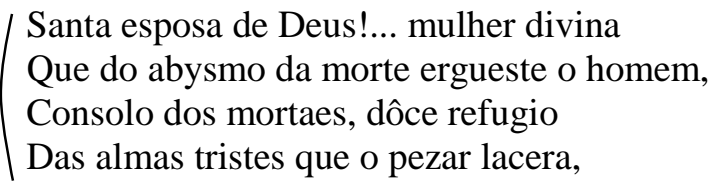




\footnotetext{
/ Como agora és medonha!... oh! como agora

D'esse pallido cyrio á luz mortiça

Enches de horror e funebres angustias

(1) Tudo quanto te cerca e te contempla!
}

"(1) Curioso se notar que a todo instante Varela / atinge traços energicos verdadeiramente rea-/listas neste romantiquissimo poema."

Nota da pesquisa: A rubrica "Falso descritivo" remete a esta página, no fichamento crítico da obra de Fagundes Varela (MA-MMA-05-05).

P. 185:

Nota MA: v. 387 sublinhado - estudo da psicologia:

A tormenta cessou, mais ai! na terra

As tormentas do céo são as menores!

P. 188 :

Nota MA: v. 465-470 destacados por traço vertical - estudo do estilo: descrição da natureza:
Tudo findou-se!
As estrellas desmaiam de agonia,
Entôa o vento funebres susurros,
E nas rochas escuras que se elevam
Uma linha de sangue inda espumosa
Gotteja e corre e vai sumir no abysmo.

P. 189:

Nota MA: v. 504-505 sublinhados e comentário:

Falla... conta...

- Ah! tem piedade,

A dôr me despedaça, e em breves dias

Talvez minh'alma os seguirá bem cedo!

"9 silabas. / Verso impossivel. / Totalmente errado"

Nota da pesquisa: A deficiência do verso é indicada por MA na rubrica "Artista", que faz referência a esta página (MA-MMA-05-05).

\section{NOCTURNAS}

P. 193-194

NEVOAS (12 estrofes)

P. 193:

Nota MA: comentário à direita do título e das estrofes:

Nas horas tardias que a noite desmaia,

Que rolam na praia mil vagas azues, 
E a lua cercada de pallida chamma

Nos mares derrama seu pranto de luz,

Eu vi entre os flocos de nevoas immensas,

Que em grutas extensas se elevam no ar,

Um corpo de fada, serena dormindo,

Tranquilla sorrindo n'um brando sonhar.

Na fórma de neve, purissima e núa,

Um raio da lua de manso batia,

$\mathrm{E}$ assim reclinada no turbido leito

Seu pallido peito de amores tremia.

Oh! filha das nevoas! das veigas viçosas,

Das verdes, cheirosas roseiras do céo,

Acaso rolaste tão bella dormindo,

E dormes, sorrindo, das nuvens no véo?

"Sequestro / Veja outra versão / do mesmo poema / em II vol, p 114. / Varela parece que / não se contentava / de imitar e tal-/vez mesmo plagiar / os outros, como refere / incomodado Franklin / Tavora (I, 12), mas / imitava-se a si / mesmo."

P. 197-198

ARCHETYPO (9 estrofes)

P. 197:

Notas MA:

1. v. 18 sublinhado e cruzeta - estudo do estilo: repetição:

Era-lhe a vida uma comedia insipida, Estupida e sem graça; elle a passava

Com a fria indifferença do marujo

Que fuma o seu cachimbo reclinado

Na prôa do navio olhando as vagas;

- Vivia por viver... porque vivia.

2. v. 23 sublinhado e cruzeta - estudo da psicologia:

Em nada acreditava; ha muito tempo

Que a idéa de Deus soprára d'alma

Como das botas a poeira incommoda...

O evangelho era um livro de anedoctas,

Beethoven torturava-lhe os ouvidos,

$X$

E a poesia lhe causava somno.

Nota da pesquisa: No fichamento crítico da obra de Fagundes Varela, MA cria rubrica com referência a esta página: "O inteligente sensível I, 197; 246; 277; II 175; 199; 224; 230; 301; III, 215; 255; 258; 311; 328” (MA-MMA-05-05).

P. 198:

Nota MA: comentário ao final do poema: 
"Não tem duvida... Digno / de Musset et Byron e Hei-/ne. A ironia e a satira nos / romanticos brasileiros."

Notas da pesquisa:

1. A Biblioteca MA no IEB/USP abriga dois títulos de Alfred de Musset (1810-1857): Oeuvres complètes (Paris: Garnier, n.d, 4v.), com anotações de leitura, e Choix de poésies de Musset (Rio de Janeiro: Americ-Edit, 1944), sem marcas. Do romântico inglês consta, sem notas, o extenso volume The poetical works of Lord Byron (London: Great New Street, 19-). De Heinrich Heine (1797-1856) figuram Gedichte (Wiesbaden: Volksbildugsvereins zu Wiesbaden, 1909), Heine's Buch der Lieden (Berlin: Deutsche Bibliotehek in Berlin, 1837) e L'Intermezzo / La mer du Nord (Paris: Payot, 19313). Em Gedichte, MA sublinha e traduz termos de "Leise zieht durch mein Gemüt", no qual o "Gemüt" do título é vertido como "Sentimentos", e "Geläute" como "carrilhões" (Notas MA in HEINE, op. cit., ed. cit., p. 32). O mesmo, em escala maior, ocorre no Heine's Buch der Lieden: a partir de "Lyriches Intermezzo" (1822-1823), as páginas são crivadas de sublinhas, fios e traduções - a grafite. MA assinala em outras páginas somente o primeiro verso, como em "Still ist die Nacht, es ruhen die Sassen" e "Ich stand in dunkeln Träumen" (Notas MA in HEINE, op. cit., p. 154 e 156). Heine é termo frequente de comparação para MA, no estudo dos poetas do romantismo brasileiro, conforme se percebe na marginália e nos dossiês Amor e medo e Castro Alves.

2. No ensaio para a Revista Nova, MA alude aos três poetas elencados na nota de margem, ao discorrer sobre o respeito à mulher como desvio do medo de amar: "Parece até cômico se denunciar respeito à mulher, na taverna em que os nossos românticos hospedaram os Heine, Musset e Byron, que tinham no coração" (ANDRADE, Mário de. "Amor e medo", In: Aspectos da literatura brasileira, ed. cit., p. 201).

P. 199-201

O FORAGIDO (13 estrofes)

P. 201:

Nota MA: comentário ao final do poema:

"Esta estranha cantiga em mau / ritmo."

Nota da pesquisa: A rubrica "Artista", no fichamento crítico das obras de Fagundes Varela, remete à página (MA-MMA-05-05).

P. 202-208

FRAGMENTOS (13 estrofes)

P. 202:

Nota MA: v. 16 sublinhado e expoente “(1)” remetendo ao comentário no rodapé:

De plaga em plaga como o hebreu maldito

Refugiei-me em vão, buscando d'alma

Expulsar o pezar que me roía!

Mendiguei um allivio ao céo de Italia, (1)

Aos cantos do barqueiro errei a noite

Nas ondas perfumadas de Sorrento, 
Adormeci na encosta do Vesuvio,

E visitei as lucidas paragens

Onde Laura e Petrarca suspiraram.

“(1) Coisa que mais ou menos fizeram / todos os romanticos. Que pandega! Sor-/rento...”

P. 205:

Nota MA: preposição sublinhada no v. 90, "pra”, e cruzeta - estudo linguístico: emprego de "para/pra":

P'ra que lançassem de minh'alma aos ermos $X$

De mim mesmo, um profundo esquecimento...

P. 207:

Nota MA: termo sublinhado no v. 176, "sonorosa", e escólio "dic" - pesquisa para o Dicionário musical brasileiro:

E nos gritos da orgia, e no delirio

Uma voz sonorosa me acordava "dic"

Do longo pesadelo de minh'alma,

E eu soluçava me lembrando d'ella!

P. 207:

Nota MA:

1. comentário junto à data;

2. comentário ao final do poema:

E tu, pobre infeliz, manchada, fria, Abafa no teu seio essas lembranças...

Nem um sonho siquer d'esse passado

Venha turbar teu pesadêlo immenso!

Rio Claro. - 1861 "Varela não tinha casado ainda."

"Varela é imensamente inferior a Alvares / de Azevedo, principalmente nestes passos roman-/ticos de tedio e infelicidade de amor. Varela / é pesadão. Em última análise dentro das /concepções vitais mais romanticas, mais / idealizadas assim como dentre os sofrimen-/tos mais sofridos e dos tedios mais deser-/tos e abafados tem sempre em Alvares / de Azevedo um rir desabusado e um / dar de ombros que torna tudo leve. A / gente acaba gostando tal a fluidez / dentro da qual no entanto se descobre / a comoção profunda e sobretudo uma / real miseria de gôso, um sofrimento / puro, fortissimo, uma incompatibilidade / real com a vida que os outros não tiveram."

Nota da pesquisa: As núpcias de Varela são mencionadas por MA em "Amor em medo", em passo eivado de biografismo: "Não esqueçamos que ele casou duas vezes... A mulher é tratada com uma certa franqueza macha, que foi o tom com que ela se sensualizou no texto das modinhas, quando estas passaram da espineta dos salões pro violão das esquinas" (ANDRADE, Mário de. "Amor e medo", In: Aspectos da literatura brasileira, ed. cit., p. 201). 
P. 209-210

A MULHER (7 estrofes)

P. 210:

Notas MA:

1. v. 28 sublinhado e expoente (1) remetendo ao comentário no rodapé;

2. juízo de valor ao final do poema, "Bonito":

O poeta a venera no silencio,

Bebe o pranto celeste que ella chora,

Ouve-lhe os cantos, lhe perfuma a vida...

- A mulher amorosa é como a aurora. "(1)"

“(1) E o Sol de amor que a não doirava outrora

Entra doirando a areia dos caminhos

Bilac"

Nota da pesquisa: A Biblioteca MA no IEB/USP contém três títulos de autoria do escritor parnasiano Olavo Bilac (1865-1918): Crítica e fantasia (Lisboa: A. M. Teixeira, 1904), Poesias (Rio de Janeiro/São Paulo/Belo Horizonte: Francisco Alves, 1909) e Tarde (Rio de Janeiro/São Paulo/Belo Horizonte: Francisco Alves, 1919). Em coautoria de Guimarães Passos, constam ainda Tratado de versificação (São Paulo: Francisco Alves, 1910) e Pimentões (Rimas d'O filhote) (São Paulo: Livraria Magalhães, 1897). A classificação da marginália aposta por MA na poesia do parnasianismo brasileiro inclusive os títulos de poesia de Bilac mencionados acima - foi objeto da pesquisa para o mestrado de Lígia Rivello Baranda Kimori, Os mestres no passado: Mário de Andrade lê os parnasianos brasileiros, no Programa de Pós-graduação em Literatura Brasileira, FFLCH-USP, 2014.

\section{P. 211}

SOBRE UM TUMULO (1 estrofe)

P. 211:

Notas MA:

1. v. 14 sublinhado e sílaba inicial destacada por retângulo - estudo da versificação: métrica;

2. termo sublinhado no v. 15, "para", e cruzeta à direita - estudo linguístico: emprego de "para/pra":

Roam-te o odio, a maldição, o olvido;

E quando as turbas um dia resurgirem,

- Apparencias de Deus! para afundar-se

$X$

No seio d'Elle, ardentes de alegria,

P. 212-214

TRISTEZA (10 estrofes)

P. 213: 
Nota MA: pronome sublinhado no v. 32, "sua", cruzeta à direita e anotação, "1 silaba" - estudo da versificação: métrica:

Vem, ó morte! a turba immunda

Em sua miseria profunda $\quad X$ "1 silaba"

Te odeia, te calumnía...

$\underline{\text { P. } 215-218}$

A ENCHENTE (8 estrofes)

P. 215:

Notas MA:

1. expoente “(1)” à direita do título, remetendo ao comentário no rodapé:

“(1) A mania das enchentes, tempestades, e / rios caudalosos que em tantos passos já / vimos dá agora esse poema dum excepcio-/nal valor e potencia ritmica; estupenda / maravilha romantica."

2. comentário à margem das estrofes:

Era alta noite. Caudaloso e tredo

Entre barrancos espumava o rio,

Densos negrumes pelo céo rolavam,

Rugia o vento no palmar sombrio...

Triste, abatido pelas aguas torvas,

Gyrava o barco na caudal corrente,

Luctava o remador e ao lado d'elle

Uma virgem dizia tristemente:

Como ao rijo soprar das ventanias

Os mortos boiam sobre as aguas frias!

"Sequestro. Aqui Va-/rela resvala pelo / sequestro - o que / me faz lembrar tam-/bem José de Alencar, / Peri e Ceci salvando-/se (?) nas aguas do / Paraiba."

3. v. 15 sublinhado e sílaba inicial destacada por retângulo - estudo da versificação: métrica:

\section{A felicidade é um sonho nebuloso...}

Notas da pesquisa:

1. A rubrica "Falso descritivo", no fichamento crítico da obra de Fagundes Varela, conserva remissão a esta página (MA-MMA-05-05).

2. Apenas dois títulos de José de Alencar (1829-1877) encontram-se na Biblioteca MA no IEB/USP: Diva: perfil de mulher (Rio de Janeiro: Garnier, 1875), com marginália, e As minas de prata (Rio de Janeiro: Garnier, 1926). MA cogitou dedicar Macunaíma ao autor de Iracema, mas, já com o livro no prelo, optou pela dedicatória exclusiva ao amigo Paulo Prado. A matriz alencariana na obra de MA é tratada por Fernando José da Silva e Alvim em "Mário de Andrade e o romantismo brasileiro: tradição, imaginário e consciência histórica nacional", dissertação de mestrado apresentada ao Programa de PósGraduação em Literatura Brasileira da FFLCH/USP, em 2012. 
$\underline{\text { P. } 219-220}$

A ESTATUA EQUESTRE ( 8 estrofes)

P. 220:

Notas MA:

1. v. 25-30 destacados por traço vertical - seleção de ideias:

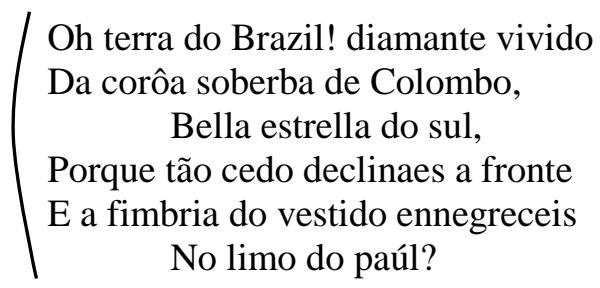

2. v. 57 sublinhado, "g" destacado por duas barras e anotação "Estiguima in" - estudo da versificação: métrica / estudo linguístico: suarabácti:

Embora o mundo me proclame louco,

Embora á fronte com furor me gravem

$\underline{\mathrm{Sti} / \mathrm{g} / \mathrm{ma} \text { infernal. }}$ "Estiguima in"

Não posso calmo vêr pisar-se as turbas,

Como o corcel de levantada estatua

O chão do pedestal!

3. comentário ao final do poema:

"A quem será dirigido isto? Nem / data tem..."

Nota da pesquisa: A despeito da nota inquisitiva, MA recorre ao poema para ilustrar a rubrica "Patriota e brasileiro", no fichamento crítico das obras de Varela (MA-MMA-05$05)$.

\section{P. 221-238}

\section{PENDAO AURIVERDE}

CANTOS SOBRE A QUESTÃO ANGLO-BRAZILEIRA

P. 223-224

AO BRAZIL (5 estrofes)

P. 223: S/Notas MA:

Nota da pesquisa: No fichamento crítico, o poema é indicado por MA junto à rubrica "Patriota e brasileiro". O "etc" que se segue à citação da página sugere que os demais "Cantos sobre a questão anglo-brazileira" igualmente abonam a rubrica no fichamento crítico (MA-MMA-05-05)

\section{$\underline{\text { P. 231-232 }}$}


HYMNO (7 estrofes)

P. 232:

Nota MA: versos 23 e 24 sublinhados e expoente “(1)”, remetendo ao juízo de valor no rodapé:

Avante, guerreiros! o genio das luctas

Seus cantos tremendos nos ares espalha,

Resvalão as balas, relinchão cavallos,

“(1)” Retumbão, ribombão bombarda e metralha!

\section{“(1) Boas honomatopeas”}

Nota da pesquisa: A percepção do crítico enseja a remissão a esta página sob a rubrica "Artista", no fichamento crítico das obras de Fagundes Varela (MA-MMA-05-05). Em 1917, ao publicar Há uma gota de sangue em cada poema, com o pseudônimo de Mário Sobral, MA também estiliza a representação do conflito armado, no âmbito da Primeira Guerra Mundial, por meio do ritmo bem-marcado e do emprego de fonemas plosivos e sibilantes. Na quarta estrofe de "Exaltação da Paz", quase paratática e, sob esse aspecto, mais moderna em comparação ao restante da obra, tem-se: "Tudo mudou!... Atra estralada de bombardas / em sanha, um clangorar de márcios trons reboando, / tempestades terrestres estrondeando, / tiritir, sibilar, zinir miúdo de balas / caindo sobre absconsas valas, / coriscos, raios levantando-se de covas, / batalhões infernais em soturnas atoardas, / clarins gritando, baionetas cintilando, / bramidos, golpes, ais, suspiros, estertores..." (ANDRADE, Mário de. "Exaltação da paz”, In: Há uma gota de sangue em cada poema, In: Obra imatura. São Paulo: Livraria Martins Editora, 1960, p. 16).

$\underline{\text { P. } 235-236}$

CANTO DO SERTANEJo (6 estrofes)

P. 235:

Notas MA:

1. título sublinhado e expoente “(1)”, remetendo ao comentário na margem superior:

“(1) É alvez a unica pagina que se sal-/va deste grupo. Belo e bom fabordão. / Bom sob o ponto de vista patriotico / se entende."

\section{CANTO DO SERTANEJO (1)}

2. termo sublinhado no v. 15, "torrentes" - estudo da psicologia: atração da água / estudo do estilo: imagem:

Bradão raivosas torrentes,

Quem é que teme o Bretão?

3. termo sublinhado no v. 19, "cantatas", e escólio "cantoria dic" - pesquisa para o Dicionário musical brasileiro:

Ah! correi filhos das mattas,

Atravez das cataractas, 
Entre suaves cantatas "cantoria dic"

Ao genio da solidão,

P. 236:

Nota MA: v. 25-32 destacados por traço vertical e expoente "(1)" remetendo ao comentário no rodapé:

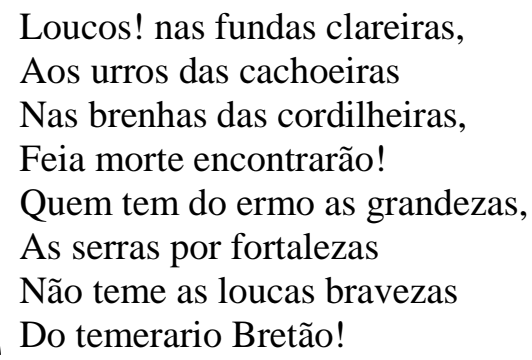

“(1) E afinal era bem possivel que /vencessemos o Bretão. Aqui depois / de tantos patriaamadas! gritados / e tantos gritos sem valor de vitoria / e certeza de vitoria Varela tem um / rasgo de bom-senso. Havia de ser / engraçado o Bretão herefordizado lu-/ tando na serrapilheira ou na caíva / com os sertanejos escondidos."

\section{P. $237-238$}

CANÇÃO (7 estrofes)

P. 238:

Nota MA: comentário ao final do poema:

"Aqui, mais lirico, Varela se / contenta de rever idealizada-/mente, amando-a, a patria ama-/da. Ama-a na natureza, que / é o seu milhor gesto de amor."

\section{CANTOS RELIGIOSOS}

\section{P. 241}

*** (1 estrofe)

P. 241:

Nota MA: juízo de valor ao final do poema:

"Excelente ideografia."

Nota da pesquisa: MA acolhe esta página sob a rubrica "Artista", no dossiê do manuscrito Amor e medo (MA-MMA-05-05).

\section{P. 242-243}

AVE, MARIA!! (8 estrofes)

P. 242: 
Nota MA: termo sublinhado no v. 6, "resôa", e escólio "dic" - pesquisa para o Dicionário musical brasileiro:

Na torre estreita de pobre templo

"dic" Resôa o sino da freguezia,

P. 243:

Nota MA: juízo de valor ao final do poema:

"Realmente belo."

Nota da pesquisa: "Ave, Maria!!” é classificado entre as "Obras-primas" de Fagundes Varela, no fichamento crítico (MA-MMA-05-05).

P. 246-247

VOZ DO POETA (3 estrofes)

P. 246:

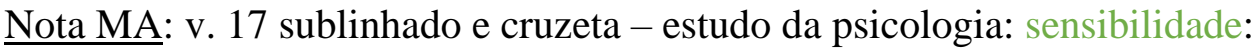

Da natureza inteira que aviventas

Todos os elos a teu ser se prendem,

Tudo parte de ti e a ti se volta;

Presente em toda parte, e em parte alguma,

Intima fibra, espirito infinito,

Moves potente a creação inteira!

Dás a vida e a morte, o olvido e a gloria!

Se não posso adorar-te face á face,

$X \quad$ Oh! basta-me sentir-te sempre, e sempre!

Nota da pesquisa: MA cita a página deste verso para caracterizar Fagundes Varela como "O inteligente sensível", rubrica do fichamento crítico (MA-MMA-05-05).

$\underline{\text { P. } 253-282}$

AVULSAS

P. 255-256

INVOCAÇÃO (5 estrofes)

P. 256:

Nota MA: v. 27 sublinhado e cruzeta - seleção de ideias:

Symbolizas os filhos do futuro,

Os homens da esperança e da verdade,

$X \quad$ Não tens de antigos o pensar escuro,

És só luz, pensamento e liberdade! 
P. 260-261

BEATRIZ HENRIQUES (6 estrofes)

P. 261:

Nota MA: comentário no rodapé, ao final do poema:

"Varella afinal é como Castro Al-/ves mais rico de assuntos que / os outros romanticos."

Nota da pesquisa: Comentário transposto para o dossiê do manuscrito Amor e medo, onde consta sob a rubrica "Variedade" (MA-MMA-05-05). Em crônica para o Diário Nacional, MA expressa avaliação diversa quanto à variedade de assuntos no autor das Espumas flutuantes: "Castro Alves morreu na hora certa porque é presumível não se poder esperar mais da sua fulgurante lira de tão poucas cordas. (...) E os temas dele eram poucos. E além de poucos inda permaneciam vivos, pelo que é lícito imaginar que ele continuaria numa enfim monótona ária com variações." (ANDRADE, Mário de. "Álvares de Azevedo - I", In: Táxi e Crônicas no Diário Nacional. Ed. cit., p. 417).

P. 270

HARMONICORDIO (1 estrofe)

Nota MA: título sublinhado e escólio "dic”, seguido de indagação: "neologismo?" pesquisa para o Dicionário musical brasileiro:

"dic. $\quad$ HARMONICORDIO

neologismo?"

P. $277-278$

CANÇÃO (8 estrofes)

P. 277:

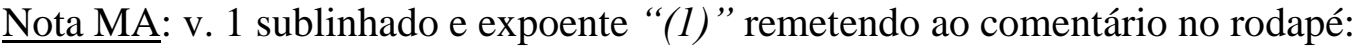

Machina de escrever e fazer versos, “(1)”

Já não sei mais cantar,

As florestas deixei, voei das serras

E vim cahir no mar.

"(1) Si eu tivesse a mania de exegese metaforica / com que os criticos italianos têm assombrado a obra / de Dante, podia mostrar V. como o precursor e pro-lfeta da maquina-de-escrever..."

Nota da pesquisa: A rubrica "O inteligente sensível", no fichamento crítico, é ilustrada com a indicação desta página (MA-MMA-05-05).

P. 279-281

VELHa CANÇÃo (13 estrofes)

P. 279: 
Nota MA: v. 7 e 8 destacados por colchete e escólio "loucura” - seleção de ideias: loucura:

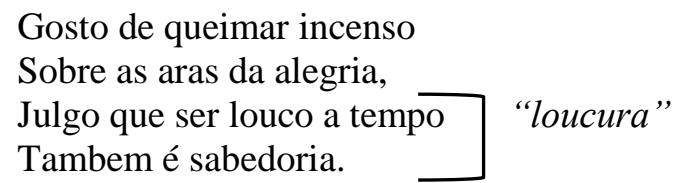

Nota da pesquisa: Nas Obras de Álvares de Azevedo, MA assinala trechos de manifestação da loucura: na carta ao amigo Luiz Antonio da Silva Nunes, em $1^{\circ}$ de março de 1850, p. ex., e nos capítulos "Uma noite do século" e "Bertram", de Noite na taverna (V. Notas MA, In: Obras de Manoel Antonio Álvares de Azevedo precedidas do juizo critico de escriptores nacionaes e estrangeiros e de uma noticia sobre o auctor e suas obras por J. Norberto de S. S. 7. ed. Rio de Janeiro: Garnier, 1900, vol. 3, p. 28, 336 e 359). MA também recorre à figura do louco, dotado de consciência crítica e lirismo livre, em vários passos de sua obra: no "Prefácio interessantíssimo", nos poemas de Pauliceia desvairada e Losango cáqui, bem como nas "Danças", incluídas em Remate de males (ANDRADE, Mário de. Poesias completas. Ed. cit., p. 60, 82, 84, 111-127, 136, 157, 296-312). A loucura dos poetas é tema de estudo, como revela seu exemplar de Poésie et folie (Paris: Octave Doin, 1908), obra dos psiquiatras Antheaume e Dromard, rico em notas de margem.

$\underline{\text { P. } 282}$

AMOR E VINHO (3 estrofes)

P. 282: S/Notas MA:

Nota da pesquisa: Escrito por Fagundes Varela no verso de uma nota de $10 \$ 000$, segundo a edição, o poema é indicado por MA como exemplo de "Variedade", no fichamento crítico (MA-MMA-05-05). 
VARELLA, L. N. Fagundes. Obras completas de L. N.

Bibl MA: [A/II/d/59]

Fagundes Varella: edição organisada e revista, e precedida de uma noticia biographica por Visconti Coaracy e de um estudo critico pelo Dr. Franklin

Tavora. Rio de Janeiro/Paris: Garnier, 1919. 3 v.

IEB: MA 869.9138 V293o

v. 2

\section{VOLUME 2}

\section{$\underline{\text { FOLHA DE GUARDA }}$}

Notas MA:

1. anotação no alto, à direita, " $n^{o} 224 /$ II vol”, referindo-se à inclusão do título na Bibliografia para Na pancada do ganzá;

2. lista de verbetes para o Dicionário musical brasileiro e cruzeta indicando o aproveitamento:

$n^{\circ} 224$

II vol

Dicionário - zoofonia 11 - endecha 30 - psalterio 30 - / trompa 38 - nota $=$ som 40 pandeiro 127 - plectro 138 -tanger 172 - /viola 252 e 277 - harmonia 307 .

Nota da pesquisa: O escólio "Zoof”, a grafite, de ocorrência frequente na marginália de MA, em todas as áreas de sua biblioteca, absorve a denominação de pesquisa encetada por Hercule Florence e colige matéria destinada ao projeto do escritor de reunir palavras e expressões representando as vozes dos animais. Liga-se, de imediato, ao manuscrito Zoofonia, reservatório e estudo particular desses termos, composto de documentos musicais, recortes de jornal e notas de trabalho, transcritas de publicações ou captadas em pesquisa de campo por MA e seus colaboradores.

O narrador-rapsodo de Macunaíma, o herói sem nenhum caráter faz referência ao projeto do pesquisador franco-brasileiro: "Então Hércules Florence caiu estuporado sobre a folha de taioba e principiou anotando com música uma memória científica sobre o canto dos passarinhos. Estava maluco. Macunaíma chispou." (Macunaíma, o herói sem nenhum caráter. Estabelecimento do texto por Telê Ancona Lopez e Tatiana Longo Figueiredo. Rio de Janeiro: Nova Fronteira, 2014, p. 134).

Em entrevista de 1943, MA filia seu projeto a Green Mansions: a Romance of the Tropical Forests, de William Henry Hudson (V. ANDRADE, Mário de. Entrevistas e depoimentos. Edição organizada por Telê Porto Ancona Lopez. São Paulo: T.A. Queiroz, 1983, p. 93).

"Zoof" prende-se, também, à coleta de termos para o Dicionário musical brasileiro e $O$ banquete, obra na área de Estética, interrompida pela morte de MA em 1945. Nesta, o capítulo 8 previa: "O Passeio em Pássaros. Zoofonia. O canto-enfeite no cio. A mulher vestida de homem e a Lei do Peso. Música da natureza e música descritiva." (V. ANDRADE, Mário de. O banquete. Ed. preparada por Jorge Coli e Luiz Dantas. São Paulo: Livraria Duas Cidades, 1977, p. 167).

\section{P. 5-92}




\section{CANTOS E PHANTASIAS}

\section{P. 7-28}

JUVENILIA (10 cantos)

CANTO 1 - LEMBRAS-TE, INAH?

P. 8:

Notas MA:

1. conjugação corrigida no v. 21, "Eras" - correção tipográfica:

Lembras-te, Inah? Eras bella,

Ainda no albor da vida,

Tinhas a fronte cingida

De uma innocente capella.

2. termo sublinhado no v. 44, "criança", e expoente "(1)" remetendo ao comentário no rodapé:

Ah! Inah! Quanta esperança

Eu não vi brilhar nos céos

Ao luzir dos olhos teus,

A teu sorrir de criança! (1)

“(1) Criança como comparação da amada.'

P. 9:

Notas MA: v. 51-54 destacada por traço vertical e comentário:

Como nas noites de estio,

Ao sopro do vento brando,

Rola o selvagem cantando

Na correnteza do rio;

"Imagem já / empregada / alhures. / Alberto de / Oliveira?"

$\underline{\text { P. 10: }}$

Notas MA: v. 75-80 destacados por traço vertical e escólio "Oriente" - seleção de ideias:

“Oriente" $\mid \begin{aligned} & \text { Irei ás nuvens serenas, } \\ & \text { Vestindo as ligeiras pennas } \\ & \text { Do mais ligeiro condor; } \\ & \text { Irei ao pégo espumante, } \\ & \text { Como da Asia o possante, } \\ & \text { Soberbo mergulhador! }\end{aligned}$

CANTO 2 - ERA Á TARDINHA

P. 11:

Notas MA: 
1. verbo sublinhado no v. 98, "Gemia", e escólio "zoofonia" - pesquisa da zoofonia:

Gemia a pomba... no ar "zoofonia"

2. termo sublinhado no v. 107, "cascatas", e expoente "(1)” remetendo ao comentário no rodapé - estudo da psicologia: atração da água:

Mais bella que ao meio-dia,

Mais carinhosa batia

A luz nos cannaviaes;

E o manso mover das mattas,

O barulho das cascatas

Tinhão notas divinaes. (1)

"Varela não passa sem cascatas, torrentes es-/pumosas, regatos, agua. Atração do mar, real-/mente: da água. Felizmente as torrentes do / $1^{o}$ livro se abrandaram. Viraram corguinhos."

Nota da pesquisa: MA municia a rubrica "Falso descritivo", remetendo à página no fichamento crítico das obras de Fagundes Varela, documento no dossiê do manuscrito Amor e medo (MA-MMA-05-05).

\section{P. 13:}

Notas MA:

1.termo sublinhado no v. 156, “criança", e expoente “(1)” remetendo ao comentário no rodapé:

Pobre criança mesquinha, “(1)”

Cuidas talvez que te esqueço!

“(1) Criança prá mulher amada."

2. termos sublinhados no v. 170, "sonhos" e "sonho", traço vertical e comentário:

Os sonhos que á noite sonho,

Tudo me falla de ti.

"Artificio comum ao / poeta"

3. comentário no rodapé, ao final do poema:

"A $2^{a}$ parte é uma obra-prima."

Nota da pesquisa: O juízo elogioso de MA reforça-se pela remissão à página na rubrica "Artista" (MA-MMA-05-05).

\section{CANTO 3 - TU ÉS A ARAGEM PERDIDA}

P. 14:

Notas MA: v. 179-183 destacados por traço vertical - estudo do estilo: 


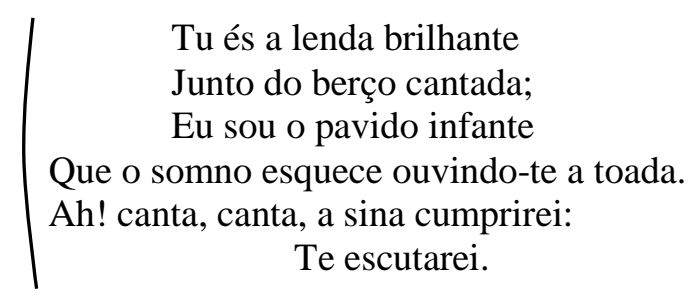

Nota da pesquisa: O trecho ilustra a rubrica "Passagens bonitas", no fichamento crítico das poesias de Fagundes Varela (MA-MMA-05-05).

\section{P. 16:}

Nota MA: comentário no rodapé, ao final da parte III:

"Aquela tortura da insuficiencia / expressiva da imagem, da compa-/ração e da metafora, culmina aqui / nesta lirica que pra ser tão bela / e pura como as de Heine só carecia / de ser menor."

\section{Notas da pesquisa:}

1. O comentário elogioso ilustra a rubrica "Artista", no fichamento crítico das poesias de Fagundes Varela (MA-MMA-05-05).

2. No ensaio "Castro Alves", publicado em 1939 na Revista do Brasil, MA repudia a largueza desproporcional dos versos ante temas restritos. "Castro Alves", segundo ele, "não sabia absolutamente pautar o tamanho das suas poesias". Na sequência, MA menciona poemas que mereciam cortes: "O Laço de Fita, com quatro estrofes apenas, seria uma joia. Com oito ficou desagradável de monotonia. A Se eu te dissesse, encurtada de umas três estrofes centrais, seria também de primeiríssima. Aquela mão está no mesmo caso. Em que pensas daria quatro ou cinco estrofes e não as 16, que deu. Manuela, A órfã na sepultura são ainda coisas desnecessariamente encompridadas. O Adeus, meu Canto, lindíssimo em sua primeira parte, já se enfraquece pela existência da segunda que três ou quatro ótimas estrofes parecem justificar." (ANDRADE, Mário de. "Castro Alves", In: Aspectos da literatura brasileira, ed. cit., p. 122).

\section{CANTO 4 - TEUS OLHOS SÃO NEGROS}

P. 17:

Notas MA: v. 224-234 destacados por traço vertical e juízo crítico no rodapé:

$$
\begin{aligned}
& \text { Teus olhos são negros, negros } \\
& \text { Como a noite nas florestas... } \\
& \text { Infeliz do viajante } \\
& \text { Se de sombras tão funestas } \\
& \text { Tanta luz não rebentasse! } \\
& \text { A aurora desponta e nasce } \\
& \text { Da noite escura e tardia: } \\
& \text { Tambem da noite sombria } \\
& \text { De teus olhos amorosos } \\
& \text { Partem raios mais formosos } \\
& \text { Que os raios da luz do dia. }
\end{aligned}
$$


“Completo. Heine. Magistral."

\section{CANTO 5 - NÃO VÊS QUANTOS PASSARINHOS}

P. 18:

Nota MA: comentário no rodapé:

“Estupendo. Que lírico me / saiu Varela nestas páginas de / Juvenília!”

CANTO 6 - ÉS A SULTANA DAS BRAZILEAS TERRAS

P. 19:

Notas MA:

1. termo sublinhado no v. 266, "sultana", e fio ligando-o ao escólio "Oriente";

2. v. 270 e 271 destacados por traço vertical duplo:

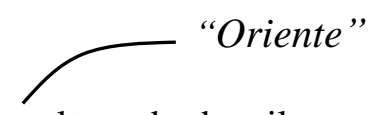

És a sultana das brazileas terras,

A rosa mais balsamica das serras,

A mais bella palmeira dos desertos;

Tens nos olhares do infinito as festas

( E a mocidade eterna das florestas

Na frescura dos labios entre-abertos.

Nota da pesquisa: MA emprega a mesma imagem de Fagundes Varela no poema "Noturno", de Pauliceia desvairada. Os "lábios entreabertos" contrastam a liberdade sexual, nas noites do Cambuci, com o desejo reprimido do eu lírico melancólio (ANDRADE, Mário de. Poesias completas. Ed.cit., vol. 1, pp. 98-99):

"Balcões na cautela latejante, onde florem Iracemas para os encontros dos guerreiros brancos... Brancos? E que os cães latam nos jardins! Ninguém, ninguém, ninguém se importa! Todos embarcam na Alameda dos Beijos da Aventura! Mas eu... Estas minhas grades em girândolas de jasmins, enquanto as travessas do Cambuci nos livres da liberdade dos lábios entreabertos!...

Arlequinal! Arlequinal! As nuvens baixas muito grossas, feitas de corpos de mariposas, rumorejando na epiderme das árvores... Mas sobre estas minhas grades em girândolas de jasmins, o estelário delira em carnagens de luz, e meu céu é todo um rojão de lágrimas!..."

2. v. 281-283 destacados por traço vertical;

3. verbo corrigido no v. 282, "levanta-se" - correção tipográfica: 


\section{E que aromas, meu Deos! o estio inteiro
/e $\quad \begin{aligned} & \text { Parece que làvanta-se fagueiro, } \\ & \text { Cheio de sombra e canticos de amor! }\end{aligned}$}

P. 20:

Notas MA:

1. repetição sublinhada no v. 300, "peito" - estudo do estilo: repetição:

Dizem que a essencia dos mortaes ha vindo

De um outro mundo mais formoso e lindo

Que um santo amor as bases alimenta;

Talvez n'esse outro mundo um laço estreito

A teu peito prendesse o triste peito

Que hoje sem ti nas trevas se lamenta!

"Artificio / comum ao / poeta"

2. juízo de valor no rodapé:

“Também belo."

CANTO 7 - AH! QUANDO FACE A FACE TE CONTEMPLO

P. 21:

Notas MA:

1. termo sublinhado no v. 319, "soberba", e expoente “(1)” remetendo ao comentário no rodapé;

2. expressão sublinhada no v. 316, "tenho medo de ti", e expoente (2), remetendo ao comentário na margem superior:

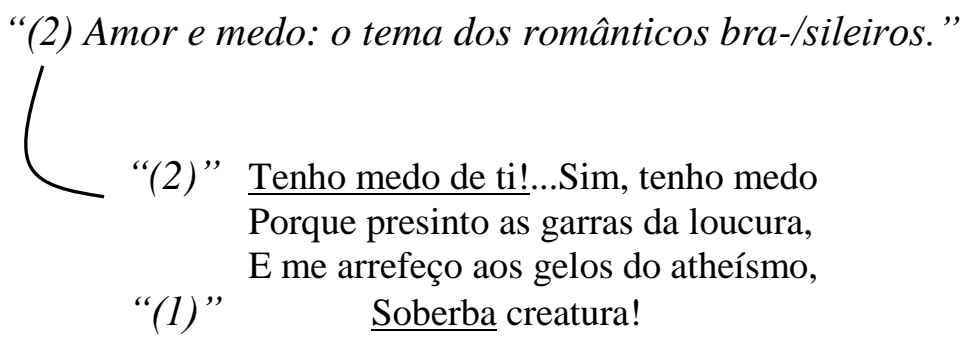

“(1) Impropriedade ante tanto lirismo delicado”

Nota da pesquisa: A impropriedade no verso de Varela converge para o fichamento crítico, onde consta sob a rubrica "Mau gôsto" (MA-MMA-05-05). É referida também em "Amor e medo", acusada pelo crítico de deturpar a beleza do poema sétimo da "Juvenília" (ANDRADE, Mário de. "Amor e medo", In: Aspectos da literatura brasileira, ed. cit., p. 213).

P. 22:

Notas MA: comentário ao final do poema:

Como adoro os desertos e as tormentas, 
O mysterio do abysmo e a paz dos ermos, E a poeira de mundos que prateia

A abobada sem termos!...

Como tudo o que é vasto, eterno e bello,

Tudo o que traz de Deos o nome escripto!

Como a vida sem fim que além me espera

No seio do infinito!

"Estupendo! Aqui Varela dá largas / ao amor dele pela natureza igualando-o / ao amor pela mulher amada. E si adora / a noite é... 'no alto mar', sempre aqua-/tico."

Notas da pesquisa:

1. Reproduzido integralmente em "Amor e medo", o poema sétimo da Juvenília é visto como "uma das expressões mais nítidas do medo de amar", em que o poeta "funde e confunde vigorosamente a natureza com a mulher amada". MA defende, no ensaio, que "Varela faz da amada um dos elementos furiosos da natureza e tem medo que a tempestade, o furacão, o mato virgem, o deserto, vençam ele na luta" (ANDRADE, Mário de. "Amor e medo", In: Aspectos da literatura brasileira, ed. cit., p. 213-214).

2. A rubrica "Falso descritivo" também guarda remissão a esta página, no fichamento crítico (MA-MMA-05-05).

\section{CANTO 8 - SAUDADES}

P. 23:

Nota MA: v. 346 sublinhado e comentário à direita - estudo da criação: intertextualidade:

Oh! minha infancia querida!

Oh! doce quartel da vida!

Como passaste depressa!

"Verso inteiro de / Casimiro no poema / sobre o mesmo / assunto."

Nota da pesquisa: MA conduz este ponto ao fichamento crítico, sob a rubrica "Reminiscencias"; reúne, dessa forma, no dossiê do manuscrito Amor e medo, versos de Fagundes Varela que lhe parecem tributários, por exemplo, de Casimiro de Abreu ou Gonçalves Dias (MA-MMA-05-05).

P. 24:

Nota MA: v. 365-371 destacados por traço vertical e escólios - estudo da psicologia: pai, mãe e irmã:

E as cantigas compassadas,

$E$ as legendas encantadas

Das éras que lá se vão.

De minha mãi era o mimo,

De meu pai era a esperança:

(Um tinha o céo, outro a gloria

Em meu sorrir de criança, 


\begin{tabular}{l|l} 
“Pai mai & $\begin{array}{l}\text { Ambos das luzes vivião } \\
\text { Que de meus olhos partião }\end{array}$ \\
& $\begin{array}{l}\text { Junto do alpendre sentado } \\
\text { Brincava com minha irmã, }\end{array}$
\end{tabular}

P. 25:

Notas MA:

1. v. 409-410 destacados por traço vertical duplo - estudo do estilo: repetição;

2. v. 409-412 destacados por traço vertical e comentário:

/( $\begin{gathered}\text { Parti, parti, mas minh'alma } \\ \text { Partida ficou tambem, } \\ \text { Metade alli, outra em penas } \\ \text { Que mais consolo não têm! }\end{gathered}$

"Excelente emprego / do artifício comum / ao poeta."

Nota da pesquisa: O fichamento crítico alude a esta página na rubrica "Artista" (MAMMA-05-05).

P. 26:

Notas MA:

1. termo sublinhado no v. 434, "p'ra", e cruzeta - estudo linguístico: emprego de "para/pra";

2. comentário no rodapé:

Do tempo nas cinzas frias

Repousão p'ra sempre os dias $\quad X$

De meu sonhar de criança!

"Esplendido tambem, em-/bora menos vivaz que os Meus / Oito Anos identicos de Casimiro. / Mas não lhe é inferior."

\section{CANTO 9 - UM DIA O SOL POENTE}

\section{P. 27:}

Notas MA:

1. v. 440-441 destacados por traço vertical duplo e escólio, "Guilherme de Almeida" estudo do estilo: imagem / linhagens poéticas:

\footnotetext{
((Estavamos sózinhos sentados no terraço Que a trepadeira em flôr cobria de perfumes:

Tu escutavas muda das auras os queixumes,

Eu tinha os olhos fitos na vastidão do espaço.
}

\section{"Guilherme / de / Almeida"}

2. termo sublinhado no v. 450, “criança", e expoente "(1)”, remetendo ao comentário no rodapé: 
Era tão lindo o céo, a tarde era tão calma...

E teu olhar brilhava tão cheio de candura,

"(1)" Criança! que não viste a tempestade escura

Que estas palavras tuas me despertaram n'alma!

“(1) 'Criança' empregado prá mulher amada”

Nota da pesquisa: A Coleção MA, na Biblioteca do IEB/USP, conserva dezessete títulos de Guilherme de Almeida (1890-1969), destacado poeta do movimento modernista. No corpus da pesquisa, o autor também é aludido em nota de margem no poema "Rosa murcha", de Casimiro de Abreu, no qual MA identifica a coincidência de rima em "novembro" e "lembro" (V. Nota MA, In: ABREU, Casimiro J. M. de. As Primaveras: com poesias inéditas do autor, o juízo crítico de diferentes escritores e um prólogo por F. D. Ramalho Ortigão. Porto: Livraria Chardron, 1909. $3^{\text {a }}$ ed., p. 23).

CANTO 10 - Á LUZ D’AURORA

P. 28:

Notas MA: expoente (1) remetendo ao comentário na margem superior:

Pomba innocente, nem siquer o indicio

Do escuro vicio presentiste apenas!

Nunca manchaste na charneca impura

A doce alvura das formosas pennas. "(1)"

“(1) Estas 2 ultimas liricas, sobretudo esta, são bem / inferiores. Seria curioso de analisar-se psicologica-/mente a evolução da força lirica nesta Juvenilia. I Porem isto poderia levar a erro dado que o poeta / pode ter á vontade modificado a ordem dos poe/mas que perfazem Juvenilia. E mesmo eles podem / ser de epocas diferentes. $O n^{\circ} 8$ por ex. parece ajun-/tado a coleção. E de inspiração diversa e quebra o / ritmo do poema. Em todo caso não fujo ao gosto / de notar que o zm lirismo inicial era flacido / e daquele aguado romantismo de sentimento / tão comum aos nossos poetas do romantismo. // Porem teve o benefício, psicologicamente isto muito waxx / dá-se, de provocar movimentos liricos mais fortes / e expressões formais concomitantemente mais perfeiItas. Surge imediatamente uma obra-prima, o "/Era á tardinha." e mais o "Tu és a aragem perdida" / mais outra obra-prima: "Teus olhos são negros", ainda / outra "Não vês quantos passarinhos". E principia a des-/falecer a força lirica: Vem o ainda bonito "És a sulta-/na", em que $\operatorname{xxx}$ as manias, os maneirismos de expres-/são do poeta já principiam a encher os vazios da inspira-/ção; surge a mania do oriente (És a sultana) $e$ a / abundância de comparações ajuntadas (Citar 3 versos ini-/ciais). A inspiração depois recresce outra vez dando / as sublimes estancias de "Ah! quando face a face te / contemplo" poema magistral, que a injustiça esqueceu, / vem depois o Meus Oito Anos em que a inspiração mor-/re realmente. É a æxxx ultima manifestação legitima / dela em Juvenilia. Os dois poemas finais que seguem / é puro encher linguiça."

Nota da pesquisa: No fichamento crítico das poesias de Fagundes Varela, MA propõe "Estudar Juvenilia" e remete ao longo comentário desta página (MA-MMA-05-05). 


\section{LIVRO DAS SOMBRAS}

P. 30-32

SCISMAS Á NOITE (14 estrofes)

P. 30:

Notas MA: termos sublinhados nos v. 5 e 7, "endecha" e "psalterio", e escólio "dic" pesquisa para o Dicionário musical brasileiro:

"dic" Tu és, quem sabe? a gemedora endecha De um ente amigo que afastado chora,

"dic" E ao som das fibras do psalterio eburneo Conta-me as dôres que padece agora!

P. 31:

Notas MA: v. 47 sublinhado - estudo do estilo: repetição:

Basta uma noite de luar nos campos,

O brando effluvio dos vergeis do sul,

Dous olhos bellos, como a crença bellos,

Fitos do espaço no fulgente azul!

P. 32:

Notas MA: comentário ao final do poema:

"Estancias admiraveis como sentimen-/to e suavidade. Notar que aqui apesar / da repetição do ritmo romantico decassi-/labico a ritmica do poema é perfeita-/mente suportavel e mesmo grata da / gente ouvir talvez sustida por, por que / meu Deus! é difícil da gente descobrir / por quê!! As visões são as mesmas agua-/das e inexpressivas... Talvez. aqui o poeta / tenha vivido os seus versos. Usava das ex-/pressões da poesia brasilica do tempo, / ainda perturbada pelo artificialismo / ideativo da escola pastoril mineira. Mas / viveu e foi bem lirico. Por isso comove / e domina a gente. O segredo dos xxx senti/mentos sinceros!..."

Nota da pesquisa: MA alça o poema à categoria das "Obras-primas", no fichamento crítico das obras de Fagundes Varela (MA-MMA-05-05).

$\underline{\text { P. } 35-36}$

HORAS MALDITAS (8 estrofes)

P. 36:

Nota MA: comentário ao final do poema:

"Varela tem a riqueza de inspiração / de Casto Muitos são os seus / temas.<smiles>CCCCCCCCCCO</smiles>

Nota da pesquisa: O teor do comentário é conservado sob a rubrica "Variedade", no fichamento crítico da poesia de Fagundes Varela (MA-MMA-05-05). Em crônica para o 
Diário Nacional, em 23 de agosto de 1931, MA reitera o sentido da rasura, ao confirmar Varela, junto a Gonçalves Dias, como mais variado do que Castro Alves: "Mas se eram poucos os seus temas [de Castro Alves], se ele não tinha aquela variedade temática resultante do espírito cultivado em Gonçalves Dias, e surpreendentemente espontânea e íntima em Fagundes Varela, é certo que tangeu as cordas do amor e da liberdade com uma fulguração que, mesmo na sua geral exterioridade, é esplêndica." (ANDRADE, Mário de. "Álvares de Azevedo - I”, In: Táxi e Crônicas no Diário Nacional. Ed. cit., p. 417).

P. $37-42$

CANTICO DO CALVARIO (12 estrofes)

P. 37:

Nota MA: nomes sublinhados no v. 18, "Ophir" e "Golgonda" - estudo do estilo: referência bíblica:

Correi! Um dia vos verei mais bellas

Que os diamantes de Ophir e de Golgonda

Fulgurar na corôa de martyrios

Que me circumda a fronte scismadora!

Nota da pesquisa: O fato de ser esta a página inicial do "Cântico do Calvário" explica a remissão sob a rubrica "Elegíaco", de que MA recolhe exemplos nas poesias de Varela (MA-MMA-05-05).

P. 38:

Notas MA:

1. v. 28 sublinhado - estudo da psicologia: pessimismo:

Minha esperança amargamente doce!

2. termo sublinhado no v. 41 "trompa", e escólio "dic" - pesquisa para o Dicionário musical brasileiro:

"dic" Vibrar a trompa sonorosa e leda

Do caçador que aos lares se recolhe!

P. 40:

Nota MA: termos sublinhados no v. 113, "nota" e "som", e escólio "dic" - pesquisa para o Dicionário musical brasileiro:

"dic" Por um verso, uma nota, um som apenas

Dos fecundos poemas que inspiraste!

$\underline{\text { P. 43-45 }}$

MADRUGADA A BEIRA-MAR (7 estrofes)

P. 43:

Nota MA: v. 1-16 destacados por traço vertical e comentário: 


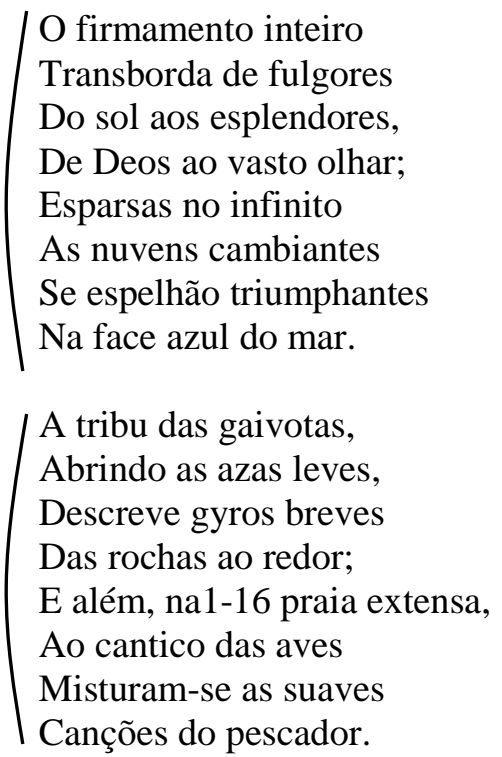

"Mais firme o traço / na descrição"

Nota da pesquisa: O comentário sugere mais uma vez as nuances da rubrica "Falso descritivo", no fichamento crítico da obra de Fagundes Varela (MA-MMA-05-05).

P. 48-50:

A VARZEA (11 estrofes)

$\underline{\text { P. 50: }}$

Nota MA: v. 61-66 destacados por traço vertical e expoente "(1)" remetendo ao comentário no rodapé:

$$
“(1) ” \quad\left(\begin{array}{l}
\text { Mas ah! quando contemplo } \\
\text { Teu magestoso templo, } \\
\text { A vasta creação, } \\
\text { Sinto brotar de novo } \\
\text { Da crença inda um renovo } \\
\text { No exhausto coração! }
\end{array}\right.
$$

“(1) Madrugada à beira-mar, A Varzea, Horas / Malditas demonstram bem a atração e a com-/preensão verdadeira que Varela teve da natu-/reza. Sabe aprecia-la até em momentos sutis / como nas Horas Malditas ou não apenas nas / tardes e noites romanticas porem nas / manhãs, e é certo que madrugada à / beira-mar tem traços firmes (citar os gri-/fados.)"

Nota da pesquisa: A rubrica "Atração da natureza" remete, no fichamento crítico, ao comentário localizado nesta página, (MA-MMA-05-05). De se notar a contradição com o raciocínio exposto no Diário Nacional, em trecho já citado: "Falam nela [natureza] e alguns bastante, sei bem. Mas são incapazes de a sentir e a transmitir. Fazem oleogravuras da mais detestável fixidez, sem terra, sem cheiro, sem nada, principalmente o dulcíssimo Varela, cujas paisagens são sempre duma sonoridade magnífica de linguagem, mas incapazes de nos contagiar." (ANRADE, Mário de. "Álvares de Azevedo - II”, In: Táxi e Crônicas no Diário Nacional. Ed. cit., p. 361). 
P. 51-52

QUEIXAS DO POETA (5 estrofes)

P. 51:

Notas MA:

1. v. 12 e 13 destacados por traço duplo - estudo da psicologia: atração da natureza:

(( $\begin{aligned} & \text { E as noites d'esta terra têm seducções tão bellas, } \\ & \text { Que as plantas, os rochedos e os homens electrizam. }\end{aligned}$

2. v. 22 sublinhado, cruzeta à direita e retângulo destacando o "p" em "reptís" - estudo linguístico: suarabácti / estudo da versificação: métrica:

Os reptís na sombra ás arvores se enlaçam; $\quad X$

Nota da pesquisa: MA dá os trechos assinalados como exemplo da "Atração da natureza", identificada na poesia de Fagundes Varela, conforme rubrica no fichamento crítico (MAMMA-05-05).

P. 53-54

RESIGNAÇÃO (7 estrofes)

P. 53:

Notas MA:

1. v. 13-16 sublinhado e comentário à direita:

Gigante da soledade,

"Expressivissimo e / bem a vida de / Varela"

Tenho na vida um consolo:

Si enterro as plantas no solo,

Chego a fronte á immensidade!

2. v. 17-20 destacados por traço duplo e juízo de valor:

"Bela $\quad$ Imagem $\quad \quad\left(\begin{array}{l}\text { Nada a meu fado se prende, } \\ \text { Nada enxergo junto a mim; } \\ \text { Só o deserto se estende } \\ \text { A meus pés, fiel mastim. }\end{array}\right.$

Nota da pesquisa: Os versos elogiados por MA justificam a indicação desta página no fichamento crítico das obras de Varela; remissão feita na rubrica "Imagem" (MA-MMA05-05).

P. 54:

Nota MA: comentário ao final do poema:

Á dor o orgulho sagrado

Deos ligou n'um grande nó...

Quero viver isolado, 
Quero viver sempre só!

E quando o raio incendido

Roçar-me, então cahirei

Em meu orgulho envolvido,

Como em um manto de rei.

"Notar a estranheza destes senti-/mentos quasi baudelairianos no / nosso meio romantico."

Nota da pesquisa: Os "sentimentos quasi baudelairianos" de Varela convergem para o fichamento crítico, onde MA abona a rubrica "Variedade" com remissão a esta página (MA-MMA-05-05). Charles Baudelaire (1821-1867) é autor de dois títulos na Biblioteca de MA no IEB/USP: Le spleen de Paris (Paris: Payot, s. d.) e Les fleurs du mal: précédées d'une notice par Théophile Gautier (Paris: Calmann Lévy, s.d.). Como tradutor, assina a edição de luxo da novela de Edgar Allan Poe La chute de la maison Usher (Paris: Editions Orion, 1929), ilustrada com gravuras de Alexandre Alexeieff.

Le spleen de Paris é ofertado a MA com dedicatória de Martim Damy - "Ao mais bizarro / e encantador espirito / dos moços que eu / conheço. / Natal de 1919. / Damy”. O exemplar não conserva notas de margem. Em Les fleurs du mal, MA assinala títulos, trechos e versos, e traduz expressões que desconhece. Personagens caras ao universo de Baudelaire - clowns e costureiras, p. ex., - ecoam na poesia de MA, como em Pauliceia desvairada. No livro de 1922, o olhar crítico do eu lírico sobre a cidade moderna também conta a poesia do simbolista francês como matriz importante (V. LOPEZ, Telê A. Mário de Andrade, a biblioteca e Baudelaire, in: Marioscriptor. Revista do Projeto Temático FAPESP/ IEB/ FFLCH-USP "Estudo do processo de criação de Mário de Andrade nos manuscritos de seu arquivo, em sua correspondência, em sua marginália e em suas leituras", no 1. São Paulo, agosto de 2010).

P. 55-57

PROTESTOS (16 estrofes)

P. 56-57:

Nota MA: expoente “(1)” remetendo ao comentário no final do poema:

De mais a mais se apertão nossos laços.

A ausencia...oh! que me importa! estás presente

Em toda a parte onde dirijo os passos. "(1)”

“(1) A natureza pra Varela está... / 'presente / Em toda a parte onde dirijo os passos. ,”

Nota da pesquisa: MA destina este exemplo ao fichamento crítico das obras de Fagundes Varela, sob a rubrica "Atração da natureza” (MA-MMA-05-05).

P. 58-59

DESEJO (7 estrofes) 
Nota MA: comentário ao final do poema:

"Notar como está bem expresso e / sutilmente bem revivido este tema / lugar-comum romantico."

Nota da pesquisa: O lugar-comum romântico, assinalado pelo crítico, é também objeto de criação para poeta. Em Lira paulistana, MA revive a tópica do poeta morrendo, também explorada por Álvares de Azevedo: "Quando eu morrer quero ficar, / Não contem aos meus inimigos, / Sepultado em minha cidade, / Saudade." (ANDRADE, Mário. "Quando eu morrer quero ficar”, In: Lira paulistana. Poesias completas. Ed. cit., vol. 1, p. 524).

P. 60-61

DESENGANO

P. 60:

Nota MA: v. 13 sublinhado e escólio "Poesia" - seleção de ideias: poesia:

A poesia é um sopro, "Poesia"

A sciencia uma illusão,

Ambas tactêão nas trevas

A luz procurando em vão.

$\underline{\text { P. 66-67 }}$

MELODIAS DO Estio / ASPIRAÇÕES (4 estrofes)

P. 67:

Notas MA:

1. v. 21-24 destacados por traço vertical à esquerda e expoente "(1)" remetendo ao comentário no rodapé:

$$
\text { “(1), } \quad\left(\begin{array}{l}
\text { Espanta-me a tormenta que as arvores derriba: } \\
\text { Mas o tufão que passa e a cerração fustiga } \\
\text { É util e propicio, porque descobre os montes } \\
\text { E deixa que eu comtemple os vastos horizontes, } \\
\text { Onde ao clarão suave de um sol brilhante e puro } \\
\text { Ostenta-se formosa a imagem do futuro!... }
\end{array}\right.
$$

"(1) Paixão pela natureza tal que Varela descobre que / como unica utilidade da tormenta: (citar estes / versos). É verdade, que no novo Sol ele descobre a / imagem do futuro, o pobre!

2. v. 30 assinalado por expoente “(2)”, remetendo ao comentário no rodapé:

Oh! não, peior mil vezes!...trazei-lhe a claridade;

Si o trilho está coberto, abre outro a liberdade!

Quando ouvirei nas praças, ao vento das paixões

Erguer-se retumbante a voz das multidões? "(2)”

“(2) Boa porcaria. Varela não se presta pra / essas eloquencias.” 
Nota da pesquisa: A página é indicada no fichamento crítico, como exemplo da "Atração da natureza" e do "Mau gôsto" na poesia de Fagundes Varela (MA-MMA-05-05).

$\underline{\text { P. 68-69 }}$

EM TODA A PARTE

P. 69:

Nota MA: comentário ao final do poema:

"Uma das boas manifestações da religiosida-/de de Varela. Mas nenhuma força intelectual, ne-/nhum raciocinio de inteligencia e muito menos ve-/rificação de cultura lhe dá bases espirituais ao / teismo tematico. É um sensualismo absoluto e / pouco consistente."

Nota da pesquisa: A rubrica "Religiosidade" remete, no fichamento crítico das obras de Fagundes Varela, ao comentário desta e da p. 298 (MA-MMA-05-05).

$\underline{\text { P. } 70}$

A UM ENGEITADO ( 3 estrofes)

P. 70:

Nota MA: v. 10-12 destacados e interrogação à direita - estudo do estilo: mau gôsto:

O meu primeiro momento

Foi um momento maldito,

Bem sei;

Filho do vício cruento,

Sempre a nodoa de prescito ?

Terei!

Nota da pesquisa: A interrogação explica-se com a inclusão da página na rubrica "Mau gôsto", no fichamento crítico das obras de Fagundes Varela (MA-MMA-05-05).

P. 71-73

NO ERMO (11 estrofes)

P. 71:

Nota MA: termo sublinhado no v. 3, "cachoeira", e cruzeta à direita - estudo do estilo: imagem / estudo da psicologia: atração da natureza:

Salve! erguidas cordilheiras,

Brenhas, rochas altaneiras,

D'onde as alvas cachoeiras $\quad X$

Se arrojam troando os ares!

P. 73:

Nota MA: v. 58 e 59 destacados por traço triplo à esquerda - estudo do estilo: repetição: 


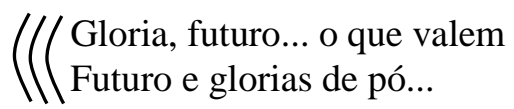

Nota da pesquisa: A rubrica "Artista" refere esta página no fichamento crítico das poesias de Fagundes Varela (MA-MMA-05-05).

P. 74

VOZES NO AR (5 estrofes)

P. 74:

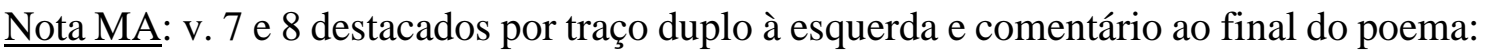

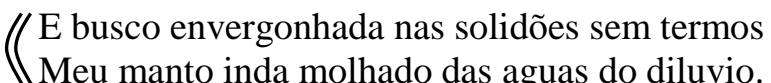

"Bela esta fala do Brasil. Bem menos / por que-me-ufanismo nela"

P. $75-82$

COLMAL (24 estrofes)

P. 75:

Nota MA: termo sublinhado no subtítulo, “Ossianica”, e comentário à direita:

Paraphrase Ossianica "Ossian outra / influencia di-/reta da Europa."

P. 83-84

IRA DE SAUL (6 estrofes)

P. 83:

Nota MA: expoente “(1)” à direita do título, remetendo ao comentário na margem superior:

"Perguntar quando falar de 'variedade' de temas em Varela, / Castro Alves etc: Mas variedade será mesmo uma qualidade? / Sim quando é vivida, espontanea e não apenas de escolha de / temas. O Formalismo Brasileiro é bem variado nos seus / temas porem que enorme monotonia em Emilio de Menezes, / em Tarde de Bilac, em (lembrar assim livros monotonos; / Observar a monotonia de A. Azevedo e de Dirceu: mo-/notonia sempre imprevista de poetas verdadeiros que / não cansam. Tambem a Via Lactea não cansa. (Como / complemento destas observações ver nota importante neste / tomo pg 131."

Nota da pesquisa:

1. A rubrica "Variedade" remete ao poema, no fichamento crítico das obras de Varela (MA-MMA-05-05).

2. O poeta parnasiano Emílio de Menezes (1866-1918) é autor de dois títulos na Biblioteca MA: Poemas (Rio de Janeiro: F. Alves, 1909) e Ultimas rimas (Rio de Janeiro: Leite Ribeiro \& Maurillo, 1917). 
P. 85-87

VERSOS SOLTOS (11 estrofes)

P. 85:

Nota MA:

1. termo corrigido no v. 76, "Mas", pelo acréscimo do "M" - correção tipográfica;

2. comentário ao final do poema:

Deixa que as turbas de terror escravas

Junto de falso throno se ajoelhem!

Os brindes e os folguedos continuão...

$M$ as a mão invisivel do banquete austera escreve

$\mathrm{O}$ aresto irrevogavel!

"Não é rúim, não."

Nota da pesquisa: Exemplo do aspecto "Social" da poesia de Varela, conforme consta do fichamento crítico das obras dele, no dossiê do manuscrito Amor e medo (MA-MMA-0505).

P. 93-208

\section{CANTOS MERIDIONAES}

P. 97-100

O ESCRAVO (19 estrofes)

P. 97:

Notas MA:

1. v. 9-16 destacados por traço vertical à direita - seleção de ideias: poesia social;

2. trecho sublinhado nos v. 11 e 12 - estudo do estilo: imagem:

Ninguem te disse o adeus da despedida,

Ninguem por ti chorou!

Embora! A humanidade em teu sudario

Os olhos enxugou!

A verdade luzio por um momento

De teus irmãos á grei:

Si vivo foste escravo, és morto... livre

Pela suprema lei!

Nota da pesquisa: Poema referido por MA como exemplo de poesia "Social", no fichamento crítico das obras de Fagundes Varela (MA-MMA-05-05).

P. 101-104

A CIDADE (19 estrofes)

P. 101:

Nota MA: v. 13-16 destacados por traço vertical e escólio "Natureza" - estudo da psicologia: atração da natureza: 
A cidade alli está: com ella o erro,

A perfidia, a mentira, a desventura...

Como é suave o aroma das florestas!

Como é doce das serras a frescura!
"Natureza”

Nota da pesquisa: Exemplo elencado no fichamento crítico das poesias de Fagundes Varela, na rubrica "Atração da natureza" (MA-MMA-05-05).

P. 103:

Nota MA: v. 57-60 sublinhados e retângulo assinalando o "b" em "abjectos" - estudo linguístico: suarabácti / estudo da versificação: métrica:

Alli a honra e o merito esquecidos, Mortas as crenças, mortos os affectos,

Os lares sem legenda, a musa exposta

Aos dentes vis de perros abjectos!

P. $105-107$

O CAVALLO (15 estrofes)

P. 105:

Nota MA: v. 14 sublinhado e termos destacados por retângulo, "flôr" e "flôres" - estudo do estilo: repetição:

Vamos, vamos, busquemos as terras

Onde habitão meus doudos amores,

Onde espera por mim, anciosa,

A mais lânguida flôr. entre as flôres

Nota da pesquisa: A repetição caracteriza a dimensão de "Artista" atribuída por MA a Fagundes Varela, conforme o fichamento crítico das obras dele no dossiê do manuscrito Amor e medo (MA-MMA-05-05).

P. 106:

Notas MA:

1. termos sublinhados nos v. 24, "insecto" e "chilrar";

2. v. 23 e 24 destacados por traço vertical e reticências:

Bebe a plenos pulmões as bafagens

Desta noite sombria, mas pura;

Deixa as feras rugirem no matto,

... Deixa o insecto chilrar na espessura!

P. 107:

Nota MA: comentário no rodapé, ao final do poema:

"Bom ritmo. Também é só.”

Nota da pesquisa: Outro caso do caráter "Artista" de Fagundes Varela, apontado por MA no fichamento crítico (MA-MMA-05-05). 
P. 108-109

AO RIO DE JANEIRO (10 estrofes)

P. 108:

Notas MA:

1. v. 2-4 sublinhados e expoente “(1)” remetendo ao comentário no rodapé - estudo do estilo: imagem:

Adeus! Adeus! Nas cerrações perdida

Vejo-te apenas, Guanabara altiva,

Molle, indolente, á beira-mar sentada, "(1)"

Sorrindo ás ondas em nudez lasciva.

(1) "Unico trecho agradavel da poesia. Cita-lo / quando lembrar a descrição da Guanabara / que está no Diario de Lazaro. Alem dela é boni-/ta a imagem da $5^{a}$ estrofe."

2. v. 19 e 20 destacados por traço vertical e escólio, "Imagem" - estudo do estilo: imagem:

Já no horizonte as plagas se confundem,

O céo e a terra abração-se discretos,

$\left.\begin{array}{l}\text { Leves os vultos das palmeiras tremem } \\ \text { Como as antennas de subtis insectos. }\end{array}\right)$ Imagem"

Nota da pesquisa: Os versos e o escólio convergem para a indicação desta página no fichamento crítico das poesias de Fagundes Varela: "Imagem II, 108" (MA-MMA-05$05)$.

P. 109:

Notas MA:

1. v. 33-36 destacados por traço vertical à direita e escólio - seleção de ideias: pátria:

Que importa? A patria do poeta o segue Por toda a parte onde o conduz a sorte, No mar, nos ermos, do ideal nos braços, "O Amor da patria

Respeita o sello imperial da morte! nos romanticos"

2. comentário no rodapé, ao final do poema:

"Fatura perfeita. Até parnasiana. Re-/parar na colocação dos agudos e na / disposição dos 2 ritmos decassilabicos."

Nota da pesquisa: A nota de margem converge para a rubrica "Artista", no fichamento crítico das poesias de Fagundes Varela, que guarda indicação a esta página (MA-MMA05-05).

P. 114-116

NEVOAS 
P. 114:

Nota MA: remissão à direita do título:

"Veja Vol I / poema mesmo / titulo"

$\underline{\text { P. } 117-119}$

A BAHIA

P. 117:

Nota MA: título corrigido, substituindo o artigo "O", "O Bahia", por "A" - correção tipográfica.

P. 119:

Nota MA: termo sublinhado no v. 62, "Oriente”, e traço à direta destacando os versos seleção de ideias: oriente / estudo do estilo: imagem:

Dorme, como as odaliscas

Nos palacios do Oriente,

Sob a guarda inconsciente

De comprados yatagans.

P. $120-121$

A FLOR $\not$ DO MARACUJA (7 estrofes)

P. 120:

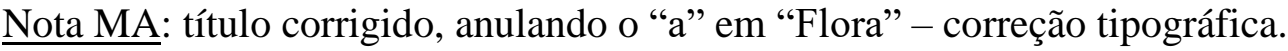

P. 121

Nota MA: comentário no rodapé, ao final do poema:

"Que burrada! Aliás todos estes / cantos meridionais até agora não / valem um derreis. Apesar de / maior emprego de palavras caracte-/risticas brasileiras Varela parece o que menos sente o Brasil"

Nota da pesquisa: MA transpõe o comentário para o fichamento crítico das poesias de Fagundes Varela, ao incluir esta página na rubrica "Patriota e brasileiro" (MA-MMA-0505).

P. $126-128$

A RoçA (13 estrofes)

P. 126:

Nota MA: título corrigido, substituindo "c" por "ç" - correção tipográfica.

P. 127:

Notas MA:

1. v. 27 e 28 destacados por traço vertical duplo; 
2. termo sublinhado no v. 27, "pandeiros", e escólio "dic" à direita - pesquisa para o Dicionário musical brasileiro:

Onde a infancia passei descuidoso.

Onde tantos idyllios sonhei,

\begin{tabular}{l|l} 
Onde ao som dos pandeiros ruidosos & $\|$ dic \\
Tantas dansas da roça dansei...
\end{tabular}

3. v. 33-40 destacados por traço vertical e comentário:

Si eu tivesse por livro as florestas,

Si eu tivesse por mestre a amplidão,

Por amigos as plantas e as aves,

Uma flecha e um cocar por brazão;

Não manchára minh'alma inspirada,

Não gastára meu proprio vigor,

Não cobrira de lama e de escarneos

Meus laureis de poeta e cantor!

"Foi bem o que faltou pros poetas brasileiros até agora"

$\underline{\text { P. } 129-131}$

A CREANÇA (8 estrofes)

P. 130:

Nota MA: v. 30 sublinhado e retângulo assinalando o "b" em "absintho" - estudo linguístico: suarabácti/ estudo da versificação: métrica:

E ella cresce, os vicios

Os passos lhe acompanham,

Seu anjo de azas brancas

Pranteia ou torna ao céo.

$O$ calice brilhante

Transborda de $\mathrm{b}$ bintho,

E a vida core envolta

N'um tenebroso véo!

P. 131:

Nota MA: comentário no rodapé, ao final do poema:

"É incrível a chateza em que cai Varela nestes / Cantos depois da elevação lirica a que subira / com Juvenilia. O que prejudica os nossos roman-/ticos em oposição mesmo a certos poetas do periodo / formalista é a raridade de inspiração, a inter-/mitencia dela. Só mesmo Alvares de Azevedo parece / de inspiração mais sustida e continua, embora / toasse quase que numa tecla só. Essa raridade / de inspiração é o que matou Varela e torna dificil / mesmo a leitura dos milhores romanticos. O criador / falha e o artifice não existe pra substitui-lo. É / curioso de notar-se que certos poetas são interessan-/tes mesmo nas poesias ruins. Nunca são ruins pro-/priamente ou porque curiosos na inspiração ou porque / a factura é curiosa. Os romanticos brasileiros, com excep-/ção de G. Dias quando dão pra ser ruins, são ruins / por inteiro. Intoleraveis. Carecia uma publicação de / Obras Escolhidas de cada um deles pra lhes demonstrar / a admiravel grandeza... dos dias em que foram grandes." 
$\underline{\text { P. } 132-133}$

EXPIAÇÃO ( 9 estrofes)

P. 132:

Notas MA:

1. cruzeta à esquerda do título;

2. v. 13 sublinhado e retângulo assinalando o "g" em "ignóbil" - estudo linguístico: suarabácti / estudo da versificação: métrica:

Não basta ainda essa ighobil farça,

Paginas negras que a teus pés compuz?

P. 133:

Nota MA: expressão sublinhada no v. 30, "Que dei-te” - estudo linguístico: colocação pronominal:

Oh! fui um doudo que segui teus passos!

Que dei-te, em versos, da belleza a palma!

P. 134-137

A EsTRELla dos MAGOS (15 estrofes)

P. 134:

Notas MA:

1. v. 7 sublinhado e expoente “(1)”, remetendo ao comentário no rodapé:

Salve! estação propicia aos pensadores! (1)

Salve! prodigio! Que luzeiro é esse

Que entre as sombras da noite resplandece

Offuscando os fulgores,

Apagando o clarão

Dos cyrios immortaes da vastidão?

“(1) Como é comico um verso destes em Varela!”

2. v. 17-20 destacados por traço vertical e expoente “(2)”, remetendo ao escólio no rodapé:

$$
\text { “(2)” } \quad\left(\begin{array}{l}
\text { Como és linda! Ao vêr-te, os astros } \\
\text { Por sobre as nuvens revoltas } \\
\text { Rolam como pedras soltas } \\
\text { De teu desfeito collar! }
\end{array}\right.
$$

“(2) Imagem de Luis Aranha.”

Notas da pesquisa:

1. MA refere-se à página nas rubricas "Falso descritivo" e "Imagem", no fichamento crítico das obras de Fagundes Varela (MA-MMA-05-05). 
2. O "Epigrama à Lua", de Luís Aranha Pereira (1901-1987), emprega imagem semelhante à do poema de Fagundes Varela, conforme marcado por MA: "Odalisca, / Nos coxins de paina do céu... / Olá / Tu deixaste romper o teu colar de pérolas...". MA cita o epigrama no ensaio de 1932 "Luís Aranha ou A poesia preparatoriana" (ANDRADE, Mário de. In: Aspectos da literatura brasileira. Ed. cit., p. 47-75). No acervo MA, no Arquivo do IEB/USP, conserva o datiloscrito de três poemas, oferecido por Luís Aranha a MA: "Drogaria de ether e de sombra", "Poema Pythagoras" e "Poema Giratorio". Os três poemas guardam notas de leitura. A lápis-tinta vermelho, MA assinala estrofes de "Drogaria de ether e sombra"; sublinha "Incêndio na minha Biblioteca de Alexandrinos!..." e comenta, a grafite: "Notar curiosa associação de Biblioteca de Alexandria com alexandrinos." (Nota MA, in: MA-MOE-43-4). Do poeta, a revista Klaxon publicou "O Aeroplano" ( $\mathrm{n}^{\circ}$ 2), "Paulicéa Desvairada" $\left(\mathrm{n}^{\circ} 4\right)$, "Crepusculo" $\left(\mathrm{n}^{\circ}\right.$ 6) e "Projectos" (n 8 e 9) (V. Klaxon: Mensário de arte moderna. Edição fac-similar. Organização: Pedro Puntoni e Samuel Titan Jr. São Paulo: Imprensa Oficial do Estado de São Paulo, Biblioteca Brasiliana Guita e José Mindlin, 2014).

P. 137:

Nota MA: comentário no rodapé, ao final do poema:

"Ao falar sobre a forma em Varela e mostran-/do quanto no verso branco ele compreendeu a / essencia-da-forma, mostrar que por outro lado / era mesquinha nele a compreensão da forma da / forma. Isso se prova principalmente pelos poe-/mas metrificados em que quando sai dos / tipos comuns Varela erra tipos hediondos de / estrofes. Veja-se este, o Escravo, mesmo o tipo / estrofico de Tu és a aragem perdida, de Juveni-/lia. (procurar outro). A frequencia de poesias com / o decassilabo romantico empregado sempre é ou-/tra prova."

Nota da pesquisa: A rubrica "Artista" recolhe o comentário ao fichamento crítico das obras de Fagundes Varela; conserva-o, assim, para etapas subsequentes da criação (MAMMA-05-05).

P. $138-139$

PLECTRO (10 estrofes)

P. 138:

Nota MA: escólio “dic” à esquerda do título - pesquisa para o Dicionário musical brasileiro.

P. $143-144$

CANÇÃO PARA MUSICA

P. 143:

Nota MA: cruzeta abaixo do título.

P. 144:

Nota MA: comentário ao final do poema:

"Bom. Não tem duvida que Varela / foi o mais liederesco dos nossos romanti-/cos." 
Nota da pesquisa: A rubrica "Cantador", no fichamento crítico das obras de Fagundes Varela, ancora-se, entre outros, no comentário desta página: "Cantador II, 144; 232; 264" (MA-MMA-05-05).

P. $148-150$

A UMA MULHER (14 estrofes)

P. 148:

Nota MA: v. 3 e 4 destacados por traço vertical e expoente "(1)" remetendo ao comentário no rodapé:

Não!... não arredes da verdade os olhos,

Ella foi sempre da belleza o throno:

"(1)" ( Porque mentir? As illusões se acabam

E a vida passa como um leve somno.

“(1) Cita-lo em relação aos proprios romanticos dian-/te da realidade da vida."

P. 150:

Notas MA:

1. v. 53-56 destacados por traço vertical duplo;

2. juízo de valor ao final do poema:

Vem, que me importa o murmurar do vulto?

O dubio riso? o escarnecer das gentes?

( $($ Si agoa precisas que teus erros lavem,

( Oh! de meus olhos verterei torrentes!

"Belo poema."

Nota da pesquisa: Ao ponderar sobre a concretude feminina na poesia de Fagundes Varela, MA remete a esta página no dossiê do manuscrito Amor e medo: "Apesar do emprêgo muito do "criança" reparar si a mulher não é mais menos divinizada por $\mathrm{V}$. Sente-se ela. II, 150” (MA-MMA-05-05).

P. $151-168$

ESPERANÇA / LENDA SELVAGEM (31 estrofes)

P. 151:

Nota MA: v. 9 e 10 destacados por traço vertical - estudo do estilo: imagem:

A porta está bem fechada, Temos quentura de mais,

A lenha que estala falla

De calma socego e paz:

Que importa que os ventos lutem

Lá fora nos matagaes? 
P. 152:

Nota MA: expressão sublinhada no v. 44 e escólio, "Sol" - estudo do estilo: imagem:

Nasci pobre, e alçando os olhos

Da pobreza em que vivia,

Me atrevi, como os condores,

A fitar o rei do dia! "Sol"

P. 154:

Nota MA: v. 69-72 destacados por traço vertical à esquerda e escólio "Artificio”;

"Artificio", $\quad \begin{aligned} & \text { Eram seus cabellos - noite! } \\ & \text { Os seus olhos eram - luz! } \\ & \text { Como o céo e o mar - profundos } \\ & \text { Como o mar e o céo - azues! }\end{aligned}$

P. 155:

Nota MA: v. 109 sublinhado e retângulo assinalando o "g" de "ignoro" - estudo linguístico: suarabácti / estudo da versificação: métrica:

\section{$\underline{\text { O que intentava? - Ignoro! }}$}

P. 159:

Nota MA: v. 209 e 210 sublinhados e escólio:

"Artificio" $\quad \frac{\text { Era uma turba selvagem }}{\text { De selvagens semi-nús, }}$

Cujos dorsos reluziam

Dos astros á tenue luz;

Nota da pesquisa: $\mathrm{O}$ artifício identificado neste, como em muitos versos de Varela, faz MA incluir a página na rubrica "Artista”, no fichamento crítico (MA-MMA-05-05).

P. 163:

Nota MA: termo corrigido no v. 321, "pobre", e expoente "(1)", remetendo ao comentário no rodapé:

Pobre filha das florestas “(1)”

Tu crêste no que eu fallava!

Minh'alma pensava em outra

Minha bocca te beijava!

\section{"(1) Casimiro 'Livre filho das florestas"”,}

Nota da pesquisa: A alusão a Casimiro de Abreu explica o uso da página como abonamento da rubrica "Reminiscencias", no fichamento crítico das obras de Fagundes Varela (MA-MMA-05-05).

P. 165:

Nota MA: v. 382 e 383 destacados por traço vertical e comentário:

Assim dizia commigo, 
\begin{tabular}{l|l} 
E o rumor crescia, ia & $\begin{array}{l}\text { “Curiosissimo entron- } \\
\text { Unir-se á voz das torrentes }\end{array}$ \\
Em longinqua serrania! & Varela.
\end{tabular}

Nota da pesquisa: O comentário enseja a menção à página na rubrica "Artista", no fichamento crítico das poesias de Fagundes Varela (MA-MMA-05-05).

P. 169-199

MiMOSA / POEMA DA ROÇA - EM TRÊS CANTOS

\section{CANTO PRIMEIRO}

P. 170:

Nota MA: v. 19 e 20 destacados por traço vertical e comentário:

Lançai vossos preceitos e tratados

Às chammas vivas de voraz incendio...

Alma que sente, que se inspira e canta ) "Não propriamente

Não conhece compendio.

isso."

P. 171:

Nota MA: v. 60 sublinhado - seleção de ideias: preguiça:

O lavrador recolhe-se á palhoça,

Reclina-se na esteira e se espreguiça.

E entre os folguedos da bemdita prole

$\underline{\text { Se entrega ao doce vicio da preguiça. }}$

P. 172:

Notas MA:

1. v. 68 assinalado por expoente "(1)”, remetendo ao comentário no rodapé;

2. v. 76-84 destacados por traço vertical - estudo do estilo: descrição:

A natureza inteira ama e soluça,

Ebria de aphrodisiacos perfumes,

E a mente solitaria do poeta

Se abrasa em chammas de insensatos lumes. "(1)"

Foi quando vi Mimosa a vez primeira,

Beija-flôr do deserto, agreste rosa,

Gentil como a Dalila da Escriptura,

Mais ingenua, porém, mais amorosa... 


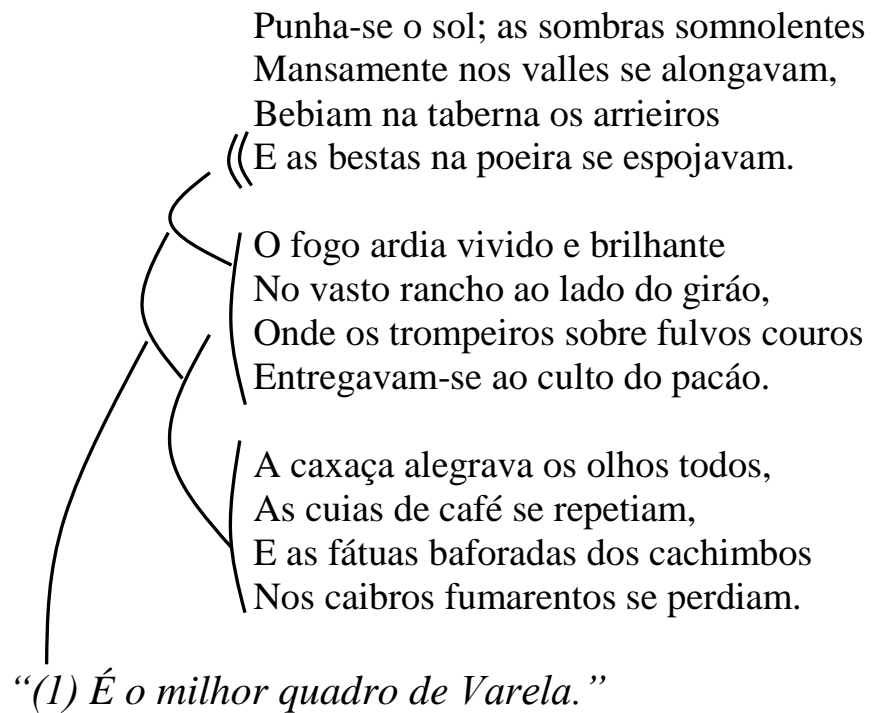

Nota da pesquisa: O exemplo abona a rubrica "Falso descritivo", conforme consta do fichamento crítico das obras de Fagundes Varela, no dossiê do manuscrito Amor e medo (MA-MMA-05-05). A contradição ante o comentário de MA, que reputa ser este o "milhor quadro de Varela", sugere a ambivalência da rubrica; é provável que nela o falso não tenha conotação necessariamente negativa. Sob ela, como se vê, MA recolhe tanto exemplos de descrição precária, quanto trechos elogiados por ele.

\section{P. 174:}

Notas MA:

1. termo sublinhado no v. 115, "Oriente" - seleção de ideias: oriente / estudo do estilo: imagem:

Parecia uma fada do Oriente,

Uma visão do opio entre neblinas.

2. expressão sublinhada no v. 126, “pés diminutivos", e comentário à direita:

Depois em tamanquinhos amarellos

Pés de princeza, pés diminutivos,

Cutis morena revelando á vista

Do pêcego e do jambo os tons lascivos. "pernostico, amulatado, delicioso, de graça infinita"

Nota da pesquisa: No fichamento crítico, a rubrica "Imagem" conserva referência a esta página, conforme se lê no dossiê do manuscrito Amor e medo (MA-MMA-05-05).

$\underline{\text { P. } 175}$

Nota MA: v. 145-148 destacados por traço vertical duplo - estudo do estilo: humor:

Póde bem ser que livros não abrisse,

Que não votasse amor a sábia casta,

Mas tinha o nome escripto entre os alumnos

Da escola de S. Paulo, e é quanto basta. 
Nota da pesquisa: Passo incluído por MA no fichamento crítico das obras de Fagundes Varela, nas rubricas "O inteligente sensivel" e "Humorista à A. Azevedo" (MA-MMA05-05).

P. 176-177:

Notas MA:

1. v. 161-164 destacados por traço vertical duplo - estudo do estilo: descrição:

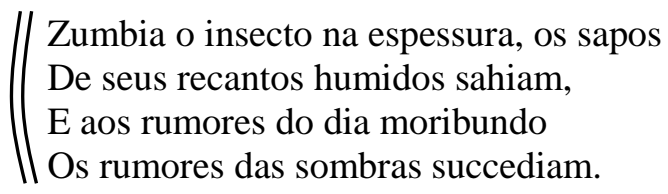

2. v. 183 e 184 destacados por traço vertical duplo e expoente “(1)”, remetendo ao comentário no rodapé - estudo do estilo: descrição;

3. v. 182 sublinhado e retângulo assinalando o "o" de "bugio" - estudo da versificação: métrica;

4. termo corrigido no v. 182, "satyrico" - correção tipográfica:

Cortiços á parede, sobre o tecto

Um bugio sat $\forall$ rico e farcista

Preso á janella verde papagaio

Grave e analysador como um legista.

“(1) Curioso de notar que no conceito poetico de / Varela parece que o traço realista, o traço verda-/deiro descritivo só é permitido no humorismo / como em toda esta poesia, e nos casos roceiros, meio / que regionalistas. Na descrição de poesia seria ele é / sempre vago, aguado, indeciso... Fom"

P. 178:

Nota MA: comentário ao final do canto primeiro:

"Esplendido. Ninguem poderia imaginar / que Varela desse em tão delicioso contador / de natureza e costumes brasileiros"

Nota da pesquisa: A rubrica "Patriota e brasileiro" refere este trecho no fichamento crítico das obras de Fagundes Varela, no dossiê do manuscrito Amor e medo (MA-MMA-0505).

$\underline{\text { P. } 179-190}$

CANTO SEGUNDO

P. 180:

Nota MA: v. 23 corrigido pelo acréscimo de "E tudo" - correção tipográfica:

E tudo quanto valho neste mundo, Por ti, por teu amor!

P. 183:

Notas MA: 
1. trecho sublinhado nos v. 107 e 108 - estudo do estilo: imagem:

A pobreza que atira ás espeluncas

Milhões de virgens, cujos corpos mata

Mercenario gosar,

Deixou-te aqui vedada aos libertinos, Inda ignorante da fatal sciencia

Que ensina o lupanar!

2. v. 125 sublinhado - estudo da psicologia: sentimento amoroso / estudo do estilo: imagem:

Assim fallei-lhe, e, como ao leve corpo

De uma leve creança, em meus joelhos

Brandamente a depuz;

Cerrei-a contra o peito, e largo tempo

Mudo assisti ás festas de su'alma

De seus olhos na luz.

Nota da pesquisa: MA indica a página no fichamento crítico das obras de Fagundes Varela, à rubrica "Imagem” (MA-MMA-05-05).

P. 184:

Nota MA: v. 154-156 destacados por traço vertical duplo e comentário:

De novo as illusões e os aureos sonhos

Que o mundo afugentára me surgiram

$\mathrm{Na}$ viva phantasia!

|| $\begin{array}{r}\text { O verdadeiro amor, o amor sagrado } \\ \text { Que prende o sonhador á natureza } \\ \text { N'uma estreita harmonia... }\end{array}$

"O amor / sonhado / pelos / romanticos? Nem tanto. Mais Varela que outra coisa, isto."

Nota da pesquisa: MA indica esta página na rubrica "Atração da natureza", no fichamento crítico das obras de Fagundes Varela (MA-MMA-05-05).

P. 185:

Nota MA: v. 199-210 destacados por traço vertical duplo e escólio:

"Cocteau

Berceuse."
Á noite, no terreiro, eu lhe fallava

Da harmonia dos astros, de seus gyros

E leis universaes;

Da existencia dos seres que pululam

Na eterna creação; da natureza

Das almas immortaes.

Eu lhe contava a vida da florinha,

A formação do seixo, a intima historia

Das arvores titães;

E pouco a pouco as relações mostrando

Das cousas e de Deus, me levantava

'Té ás idéas mãis... 
Nota da pesquisa: Jean Cocteau (1889-1963) - escritor, cineasta, dramaturgo, ator e diretor de teatro francês - conta onze títulos na Biblioteca MA, todos publicados entre 1918 e 1925. O número de edições, em intervalo relativamente curto, mostra a impregnação da leitura de Cocteau, por MA, nos anos iniciais de modernismo. "Berceuse", poema aludido no comentário marginal, encontra-se em duas edições: Le Potomak: 1913-1914; précédé d'un prospectus: 1916 et suivi des Eugènes de la guerre (Paris: Société Littéraire de France, 1919) e Le Potomak: 1913-1914; précédé d'un prospectus: 1916 (Paris: Stock, 1924).

Dedicado à poesia de Cocteau, o apêndice $\mathrm{C}$ de A escrava que não é Isaura menciona "Berceuse", classificando-o como ponto alto do livro: "Muito curiosa de observar-se é a evolução circunferencial de João Cocteau. Cultor decidido do verso-livre em Potomak onde se excetuam apenas dois ou três casos muito especiais de verso medido como a engraçada cançoneta do monstro. Ainda nas Poésies de 1920 o número de poemas em metro livre é de muito superior aos de métrica pré-determinada. Com seu último livro Vocabulaire espanta os cultores do verso-livre apresentando uma coleção de poesias quase todas metrificadas. A meu ver o poeta não tem razão. O que não impede que seja Vocabulaire a melhor de suas obras como conjunto embora não haja coisa alguma nela que se compare à 'Berceuse' e a mais dois ou três poemas do Potomak." (ANDRADE, Mário de. A escrava que não era Isaura, In: Obra imatura. São Paulo: Livraria Martins Editora, 1960, p. 280). Talvez marcado pela sonoridade e as imagens da "Berceuse" de Cocteau, MA tenha feito dois grandes poemas com o propósito de encantar o sono. Nas "Enfibraturas do Ipiranga", oratório profano que encerra Pauliceia desvairada, a personagem lírica, Minha Loucura, "suavemente entoa a cantiga de adormentar": "Chorai! Chorai! Depois dormi! / Venham os descansos veludosos / vestir os vossos membros!... Descansai! / Ponde os lábios na terra! Ponde os olhos na terra! / Vossos beijos finais, vossas lágrimas primeiras / para a branca fecundação! / Espalhai vossas almas sobre o verde! / Guardai nos mantos de sombra dos manacás / os vossos vagalumes interiores! / Inda serão um sol nos ouros do amanhã! / Chorai! Chorai! Depois dormi!"

Em Clã do jabuti, do mesmo modo, o poema final é o "Acalanto do Seringueiro": "Seringueiro brasileiro, / Na escureza da floresta / Seringueiro, dorme. / Ponteando o amor eu forcejo / Pra cantar uma cantiga / Que faça você dormir. / Que dificuldade enorme! / Quero cantar e não posso, / Quero sentir e não sinto / A palavra brasileira / Que faça você dormir... / Seringueiro, dorme...".

No extremo final da poesia de MA, em Lira paulistana, a edição póstuma organizada por Antonio Candido situa o "Acalanto para Luís Carlos, filho de Guilherme de Figueiredo com Alba" no remate do livro: "Nasceu Luís Carlos no Rio / E todo me transportei, / Luís Carlos do meu carinho. // Vive um Luís Carlos sozinho / E todo me apaixonei, / Luís Carlos do meu respeito. // Luís Carlos, dorme em meu peito, / Goza a infância sossegado, / Sonha, brinca, dorme, dorme! // Luís Carlos, fecundo, enorme, / Sofre o sonho amordaçado, / Não cede, não vive, flâmula!”.

P. 187:

Nota MA: termo corrigido no v. 234, "ralé" - correção tipográfica:

Depois foi se esquivando a seus gracejos, Por fim negou-se por uma vez ao trato Dessa indigna relé. 
Nota MA: v, 282 sublinhado, retângulo assinalando o "b", em "observou", e interrogação - estudo linguístico: suarabácti / estudo da versificação: métrica:

Deu-me uma trouxa, encarregou-se de outra,

E á porta do quintal se dirigindo,

Abrio, e obsservou. ?

P. 191-196

CANTO TERCEIRO

P. 191:

Notas MA:

1. v. 1 sublinhado e comentário à direita:

Verdade!...Estupida coisa!

Consocia eterna do mal!

Deidade nos desenganos!

Inimiga do ideal!

Verdade! porque me obrigas

Tão tristes scenas narrar,

Quando pudera esta historia

De outra maneira findar?
"Nem tanto quando

Varela se pôs no

Canto Primeiro a

desenhar a

natureza bra-

sileira"

2. v. 15 sublinhado e expoente “(1)” remetendo ao comentário no rodapé:

Tu que apalpas as feridas

Mais immundas dos mortaes,

Que não tens nojo de nada,

Que sempre despida estás;

Queres que um vate inspirado,

Que um heróe entre os sandeus,

Se esquive aos vôos do genio (1)

E siga os dictames teus!

"Varela positivamente o que não tem é / genio. No entanto, viveu falando nele / como um Beethoven. Este se salvou do / ridiculo porque de fato foi genio. Varela... Luis / Nicolau Fagundes Varela."

3. v. 21-24 destacados por traço vertical duplo e simples, e comentário:

Já que não tenho remedio,

Já que me prendes assim,

$\mathrm{O}$ resto de minha farça

Vou contar tim por timtim.

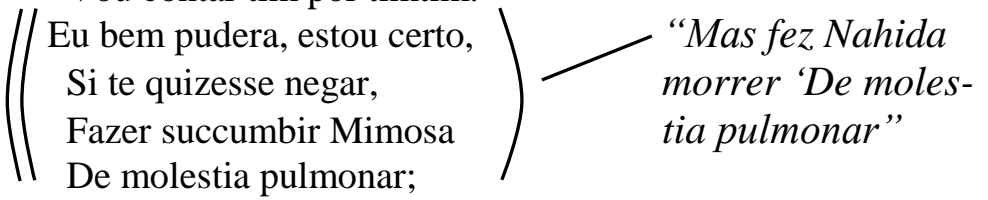

Nota da pesquisa: Sob a rubrica interrogativa - "Varela se pensava genio?" - MA refere esta página no fichamento crítico, junto a outras três deste volume: p. 260, 306 e 310. O 
mesmo documento, no dossiê do manuscrito Amor e medo, menciona-a como exemplo do "Humorista à A. Azevedo" (MA-MMA-05-05).

P. 193:

Notas MA:

1. v. 61-68 destacados por traço vertical e comentário:

E caminhei... Como gratas As florinhas me sorriam! "Por onde andaste, poeta?" Parece que me diziam!

Os cantos dos passarinhos,

Os brandos sopros da aragem, Fallavam: "Sê tu bem vindo! Conta nos tua viagem!"

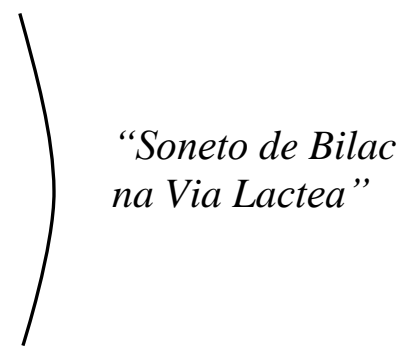

2. v. 69-84 destacados por traço vertical - estudo do estilo:

E os velhos cedros da matta,

Com gesto grave e sombrio,

Perguntavam-me severos:

"Por onde andaste, vadio?

Como vens tão bem vestido!

Que lindo collete trazes!

Que tôlas palavras dizes!

Que lindas momices fazes!

Perdeste a vista? Coitado!

Pobre, misero poeta!

Partio com olhos de lince,

Porém volta de luneta!

Aprendeste muito! Sabes

De cór a legislação?

Conheces bem o Digesto?

Leste as obras de Lobão?"

Nota da pesquisa: MA encaminha o trecho assinalado ao fichamento crítico das obras de Fagundes Varela, elencando esta página na rubrica "Passagens bonitas" (MA-MMA-0505).

P. 194:

Nota MA: v. 85-92 destacados por traço vertical - estudo da psicologia / seleção de ideias:

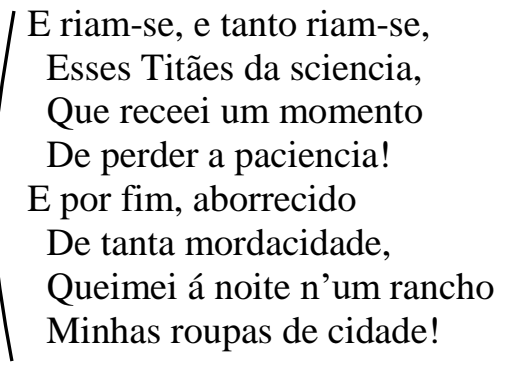




\section{EPILOGO}

P. 199:

Nota MA: comentário ao final do poema:

"Mimosa é das milhores coisas do / Romantismo. Deliciosamente sen-/timental, muitissimo bem contado / principalmente no terceiro canto, metri-/ficado á feição de romance de que / Catulo Cearense tanto soube aproveitar. A graça / no mais das vezes é vulgar e pesadona. / Isso não impede que o poemeto seja / portugamente comico. Tambem comico / alemão. Ninguem tome lembre pra exemplo / Heine, que é um alemão... heineano, / não serve prá imagem. Comico alemão / é sinônimo de graçola pesadona, que se / conta naquela anedota pesadona: Um alemão / contava pra outro: Fritz todo dia sobe na amei-/xeira e come ameixas. Ontem Fritz subiu outra / vez e não comeu ameixas. Fritz não comeu / ameixas porque subiu num eucaliptus."

Nota da pesquisa: MA destina o comentário à rubrica "O inteligente sensível", no fichamento crítico das poesias de Fagundes Varela (MA-MMA-05-05).

P. 200-208

ANTONICO E CORÁ (53 estrofes)

P. 201:

Notas MA:

1. rima sublinhada nos v. 26 e 28, "lembro" e "Setembro", e comentário:

2. expressão sublinhada no v. 26 e expoente "(1)”, remetendo ao comentário no rodapé:

Aonde fôra Antonico?

"(1)” Bem não sei, nem bem me lembro: "Citar também

Findava-se o mez, supponho, este exemplo de

De Setembro; Setembro com lem-

bro."

"(1) Sintaxe curiosa."

Nota da pesquisa: À margem do poema "Rosa murcha", de Casimiro de Abreu, MA compara a versos de Guilherme de Almeida a rima usada pelo romântico: "Gui num dos poemas de Encantamento tambem se serve de novembro pra rimar com lembro" (V. Nota MA, In: ABREU, Casimiro J. M. de. As Primaveras: com poesias inéditas do autor, o juízo crítico de diferentes escritores e um prólogo por F. D. Ramalho Ortigão. Porto: Livraria Chardron, 1909. $3^{\text {a }}$ ed., p. 23).

P. 204:

Nota MA: v. 93-96 destacados por traço vertical - estudo do estilo:

$\left(\begin{array}{c}\text { Assim fallou, e Antonico, } \\ \text { Fazendo uma reverencia, } \\ \text { Foi conversar com a pobre } \\ \text { Consciencia. }\end{array}\right.$

P. 208:

Nota MA: comentário ao final do poema: 
"Engraçadissimo. Digno dos contos / de Musset. É incrivel que esta pagina / esteja esquecida dos brasileiros. Que / bestas são os brasileiros. Infinitamente / superior aos recontos indianistas de Machado / de Assis nas Americanas (?)."

Nota da pesquisa: Na Biblioteca MA, Poesias completas de Machado de Assis (18391908) - composto de "Chrysalidas", "Phalenas", "Americanas" e "Occidentaes" - não apresenta notas de margem, exceto por duas correções tipográficas (Notas MA, In: Poesias completas: Chrysalidas, Phalenas, Americanas, Occidentaes. Rio de Janeiro / Paris: Garnier, 1924[?], p. 295 e 334). Em outros passos da marginália, no corpus da pesquisa, MA compara a obra indianista de Machado de Assis à poesia romântica de mesma cepa. É o caso da nota de margem em "A mangueira", de Gonçalves Dias, onde MA escreve: "Com efeito, apesar da vastidão de pensamento de Machado de Assis e da habilidade e riqueza imaginativa de Bilac nada mais se tirou do indianismo, nem mesmo o Evangelho das Selvas [sic]. Só Machado conseguiu ainda uma obra-prima, essa mesma só com uma ligeira base no espiritualismo amerindio. O Indianismo era necessariamente um tema intelectual, não um moto lirico organizado da sensibilidade que nem a escravidão (vista em redor do poeta), o amor, o lar etc. Daí serem os poetas de inteligencia e os artifices grandes como G. D. Machado e Bilac os que se preocuparam com ele." (V. Nota MA, In: DIAS, A. Gonçalves. Poesias. Nova edição organizada e revista por J. Norberto de Souza Silva e precedida de uma notícia sobre o autor e suas obras pelo Cônego Doutor Fernandes Pinheiro. Paris/Rio de Janeiro: Garnier, 1919, vol. 2, p. 139).

\section{P. 209-326}

\section{CANTOS DO ERMO E DA CIDADE}

P. 212-215

VIUVA E MoÇA (14 estrofes)

P. 212:

Nota MA: comentário na margem superior:

"Eis uma bela forma estrofica. Só com <ilegível> / Varela ás vezes dá recortes estroficos ruins, ainda / pela abundancia de variedade estrofica se pode / provar a sua propensão a grandeza pr prá ma-/nifestação formal do lirismo e grandeza dela. I Quando acerta como no Cavalo, como nos recontos / deste livro e como / nesta Viuva e Moça / é excelente."

Nota da pesquisa: MA remete a este poema e ao comentário sob a rubrica "Artista", no fichamento crítico das obras de Fagundes Varela (MA-MMA-05-05).

P. 214:

Notas MA:

1. letra "r" suprimida no v. 59 - correção tipográfica:

Senhor! Senhor! este mundo

Avido, sordido, immundo,

Faz-me descrer fté de ti! $\quad / X$ 
2. v. 75-77 destacados por traço vertical duplo - seleção de ideias:

A lei do dever é santa,

Mas a desdita a quebranta,

O mundo tem mais poder!

$\mathrm{O}$ espirito arqueja e cansa,

/( $\begin{aligned} & \text { O mundo a victoria alcança, } \\ & \text { Dos homens sobre a balança } \\ & \text { Mais peso sempre hade ter! }\end{aligned}$

P. 215:

Nota MA: comentário no rodapé, ao final do poema:

"Bem bonzinho no genero."

P. 216-218

EU AMO A NOITE (15 estrofes)

P. 216:

Nota MA: expressão sublinhada no v. 18 e cruzeta - estudo do estilo: imagem:

Amo o silencio, os areaes extensos,

Os vastos brejos e os sertões sem dia,

$X$

Porque meu seio como a sombra é triste,

Porque minh'alma é de illusões vazia.

Nota da pesquisa: MA inclui referência a esta página no fichamento crítico das poesias de Fagundes Varela: "Imagem II, 216” (MA-MMA-05-05).

P. 217:

Nota MA: v. 21 sublinhado e comentário à direita:

Amo o furor do vendaval que ruge,

Das azas densas sacudindo o estrago,

Silvos de balas, turbilhões de fumo,

Tribus de corvos em sangrento lago.
"Isto parece verdadei-

ro. Varela insiste

neste amor"

Nota da pesquisa: Exemplo recolhido à rubrica "Atração da natureza", no fichamento crítico das obras de Fagundes Varela (MA-MMA-05-05).

P. 218:

Notas MA:

1. v. 54 sublinhado e retângulo assinalando o "g" em "ignotos" - estudo linguístico: suarabácti / estudo da versificação: métrica;

2. juízo crítico ao final do poema:

Amo a tristezaz dos profundos mares,

As aguas torvas de ignotos rios,

$\mathrm{E}$ as negras rochas que nos plainos zombão 
Da insana furia dos tufões bravios.

Tenho um deserto de amarguras n'alma,

Mas nunca a fronte curvarei por terra!...

Ah! tremo ás vezes a tocar nas chagas,

Nas vivas chagas que meu peito encerra!

"Bom”

P. 221-223

A DESPEDIDA (12 estrofes)

P. 221:

Nota MA: v. 24 assinalado por expoente “(1)”, remetendo ao comentário no rodapé:

Muda, arruinada nos mundanos cantos,

Mas hoje bella e rica de harmonias,

Banhada ao sol de teus formosos dias,

“(1)” Sanctificada á luz de teus encantos!

“(1) Incontestavelmente Varela indica um / progresso de preocupação da forma poética I em relação aos outros romanticos."

Nota da pesquisa: O caráter "Artista", anunciado por MA no comentário, enseja a remissão a esta página no fichamento crítico das obras de Fagundes Varela, no dossiê do manuscrito Amor e medo (MA-MMA-05-05).

P. 224-225

CONFORTO (7 estrofes)

P. 224: S/Notas MA:

Nota da pesquisa: MA refere a página, embora não conserve notas de margem, na rubrica "O inteligente sensível", no fichamento crítico das obras de Fagundes Varela (MAMMA-05-05).

P. 225:

Notas MA:

1. v. 22 sublinhado e três cruzetas - estudo da psicologia: dor:

O orgulho é nobre quando a dôr o ampara, $\quad X X X$ E si lagrima verte é funda e vasta,

Tão vasta como o mar.

2. v. 28-30 destacados por traço vertical duplo - estudo da psicologia: dor:

É duro de soffrer, eu sei, o escarneo

Dos seres mais nojentos que se arrastão

Ganindo sobre o chão,

// Mas a dôr magestosa que incendêa

Dos eleitos a fronte, os vis deslumbra 
Com seu vivo clarão.

3. v. 38 sublinhado, retângulo assinalando a sílaba elidida e cruzeta à direita - estudo da versificação: métrica;

4. termo corrigido no v. 41, "senda" - correção tipográfica;

5. comentário ao final do poema:

Deixa passar a douda caravana,

Fica no teu retiro, dorme sem medo, $\quad X$

Da consciencia á luz;

Livres do mundo um dia nos veremos,

Tem confiança em mim, conheço a send $a$

Que ao repouso conduz.

"Belissimas estancias de grande ele-/vação de pensamento, sim, de pensa-/mento romantico. Alem disso como / Varela é gostoso em certos poemas só / pela forma. A gente $l \hat{e}$, vai se deixan-/do levar pelo embalo do verso, não / carece compreender vai até o fim. É/verdade que isso gera facilmente o fas-/tio, o fastio vem. Aqui é esplendido."

$\underline{\text { P. } 226}$

VISÕES DA NOITE (4 estrofes)

P. 226:

Nota MA: comentário no rodapé, ao final do poema:

"Bom. Registrar a excelencia dos / sonetos romanticos."

Nota da pesquisa: O fichamento crítico contendo as "Ideias gerais" para o livro Lirismo romântico no Brasil remete a este poema de Fagundes Varela na rubrica "O soneto romantico" - o documento integra o dossiê do manuscrito Castro Alves (MA-MMA-2604).

\section{P. 227-228}

O CANTO DOS SABIÁS (6 estrofes)

P. 228:

Nota MA: comentário ao final do poema:

"Excelente. Como recorte estrofi-/co e disposição de rimas é estupendo. / Adoravel estribilho. Adoravel mu-/sicalidade."

Nota da pesquisa: Exemplo acolhido pela rubrica "Patriota e brasileiro", no fichamento crítico das obras de Fagundes Varela, dossiê do manuscrito Amor e medo (MA-MMA05-05). Planejando o livro Lirismo romântico no Brasil, MA indica a entrada "O sabiá no romantismo"; marca, com isso, a intenção de abordar a recorrência da ave cantadora na fauna da poesia romântica (MA-MMA-26-06)

$\underline{\text { P. } 229-230}$ 
P. 230:

Nota MA: comentário no rodapé, ao final do poema:

"Salientar uma leve tendencia / pro didatismo em Varela, tendencia / porem que nunca atinge a inten-/sidade boba dum Castilho por exem-/plo. Os brasileiros muito mais liricos I que os portugas são incapazes de castilhar em verso. Varela é dos / mais didaticos. $O$ Cedro e o Vizir é a / milhor das paginas didaticas dele."

Notas da pesquisa:

1. $\mathrm{O}$ didatismo de Varela é recolhido por MA à rubrica "O inteligente sensivel", no fichamento crítico (MA-MMA-05-05).

2. Tratado de metrificação portugueza (Pelotas: Echenique Irmãos, 1907) - volume com marginália - é o único título de António Feliciano de Castilho (1800-1875) na Biblioteca de MA.

P. 232-233

SERENATA (4 estrofes)

P. 232: $\underline{\text { S/Notas MA }}$

Nota da pesquisa: MA cauciona com este poema a rubrica "Cantador" no fichamento crítico das obras de Fagundes Varela, dossiê do manuscrito Amor e medo (MA-MMA05-05).

P. 234-237

A SOMBRA (17 estrofes)

P. 236:

Nota MA: v. 62-73 destacados por colchete e escólio "Malhada"-

"Malhada" $\left[\begin{array}{l}\text { Porém quando no occidente } \\ \text { Vai baixando o orbe immortal, } \\ \text { As rezes sempre constantes } \\ \text { Se ajuntão todas no val. } \\ \text { E n’essa mesma paragem, } \\ \text { Onde as chamava o senhor, } \\ \text { Talvez do defunto á sombra } \\ \text { Reunem-se ao derredor. } \\ \text { E mugem, mugem debalde, } \\ \text { Tristonhas cavando o chão, } \\ \text { Fitando doridos olhos } \\ \text { No astro rei da amplidão. }\end{array}\right.$

P. 238-241

A DIVERSÃo (16 estrofes)

P. 238: 
Nota MA: v. 1-5 destacados por traço vertical e comentário:

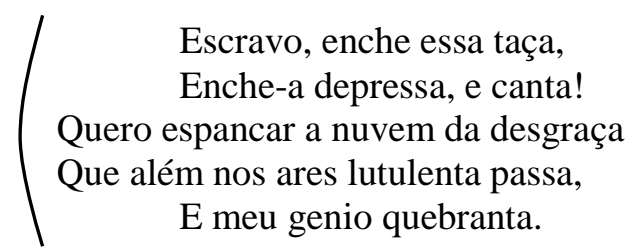

"Bom corte / estrofico"

Nota da pesquisa: Exemplo acolhido por MA na rubrica "Artista" do fichamento crítico das obras de Fagunde Varela (MA-MMA-05-05).

P. 239:

Nota MA: v. 36-40 destacados por traço vertical e escólio - estudo do estilo: imagem:

São as houris divinas

Que junto a mim perpassão,

Ou de Schiraz as virgens peregrinas,

Que cingidas de rosas purpurinas

Chorão Bulbul e passão?

\section{"Oriente"}

P. 242-247

A LENDA DO AMAZONAS

P. 247:

Notas MA:

1. v. 187 sublinhado, retângulo e juízo de valor - estudo da versificação:

No seid que soffre um doce balsamo. " "horrivel decassi-/labo."

2. comentário ao final do poema:

"Lindo. Um pouco monotono. / Varela insiste demais. Descobre bons / ritmos. Tem faculdade de invenção formal / estrofica. Mas insiste. Inventa mas não / tem bom gosto. Indiscreto."

Nota da pesquisa: O comentário confirma-se no fichamento crítico das obras de Fagundes Varela: a rubrica "Mau gôsto" remete à página (MA-MMA-05-05).

\section{P. 248-249}

ESTANCIAS (11 estrofes)

P. 248:

Notas MA:

1. expressão sublinhada no v. 1 e fio prendendo o comentário na margem superior: 


\section{"Manoel Bandeira" \\ O que eu adoro em ti não são teus olhos, \\ Teus lindos olhos cheios de mysterio, \\ Por cujo brilho os homens deixarião \\ Da terra inteira o mais soberbo imperio.}

2. v. 12 sublinhado e expoente “(1)” remetendo ao comentário no rodapé:

O que eu adoro em ti não é teu rosto

Perante o qual o marmor descorára,

E ao contemplar a esplendida harmonia

Phidias, o mestre, seu cinzel quebrara. (1)

\section{“(1) Esta ideia já vem noutro poema de / Varela”}

Notas da pesquisa:

1. MA recorre ao poema para caracterizar "A mulher pra V.: II, 248; 319; III, 122", no fichamento crítico das obras de Fagundes Varela, dossiê do manuscrito Amor e medo (MA-MMA-05-05).

2. A expressão "O que eu adoro em ti" arremata o "Madrigal Melancólico" de Manuel Bandeira (1886-1968), incluído em Ritmo dissoluto, volume Poesias (Rio de Janeiro: Edição da Revista de Língua Portuguesa, 1924). Na Biblioteca MA no IEB/USP, o livro, com dedicatória de Bandeira, contém notas de margem, mas o poema não carrega marcas. Já em 1924, MA publica um estudo sobre Manuel Bandeira na Revista do Brasil (a. 9, n. 107. Rio de Janeiro, nov. 1924, p. 215-224), no qual menciona o poema: "Só raras vezes a alusão [à tuberculose] é muito forte, como no lancinante 'Madrigal melancólico' que acaba num dos gritos mais comoventes que ouvi" (LOPEZ, Telê Porto Ancona (org.). Manuel Bandeira: verso e reverso. São Paulo: T. A. Queiroz, 1987, p. 74).

MA remete também ao "Madrigal melancólico", no corpus da pesquisa, ao anotar dois poemas de Álvares de Azevedo, "Gloria Moribunda" e "Thereza" (V. Notas MA, In: AZEVEDO, Álvares de. Obras. Ed. cit., vol. 1, p. 228 e 256).

\section{P. 249:}

Notas MA:

1. v. 29 destacado por colchete e escólio, “Amor e Medo" - estudo da psicologia: sentimento amoroso;

2. v. 29-44 destacados por traço vertical, fio prendendo ao colchete na primeira estrofe e juízo de valor, "Lindo" - estudo da psicologia: sentimento amoroso;

3. comentário no rodapé, ao final do poema:

Um não sei quê de grande, immaculado,

Que faz-me estremecer quando tu fallas, E eleva-me o pensar além dos mundos

Quando, abaixando as palpebras, te calas.

E por isso em meus sonhos sempre vi-te Entre nuvens de incenso em aras santas,

E das turbas solicitas no meio

Tambem contricto hei te beijado as plantas.

E como és linda assim! Chammas divinas

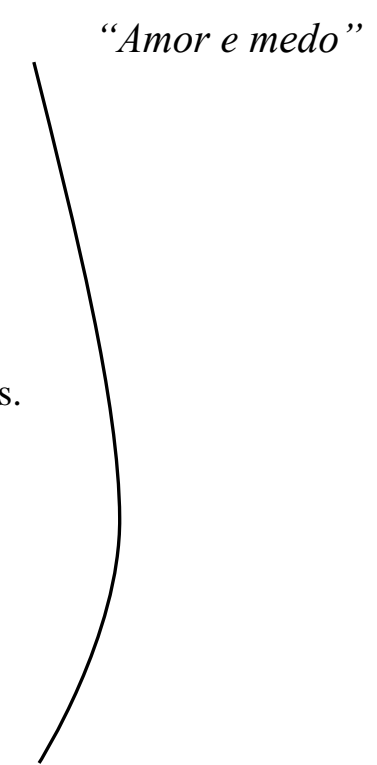


Cercão-te as faces placidas e bellas,

Um longo manto pende-te dos hombros

Salpicado de nitidas estrellas!

Na douda pyra de um amor terrestre

Pensei sagrar-te o coração demente...

Mas ao mirar-te deslumbrou-me o raio...

Tinhas nos olhos o perdão sómente!

\section{"Lindo"}

"Parece mesmo que a mulher pra V.é bem/menos 'criança' 'anjo' 'virgem'. Pelo menos é uma / coisa mais parecida com mulher, mais psicologica, não / é bem isto... mais mulher de verdade."

Nota da pesquisa: MA avança, em "Amor e medo", o raciocínio anunciado na marginália, em trecho já citado: "Mas apesar do emprego muito de 'criança' para designar a mulher, sente-se ela por assim dizer mais fisicamente, mais objetivamente em muitos poemas de Varela. Não esqueçamos que ele casou duas vezes... A mulher é tratada com uma certa franqueza macha, que foi o tom com que ela se sensualizou no texto das modinhas, quando estas passaram da espineta dos salões pro violão das esquinas" (ANDRADE, Mário de. "Amor e medo", In: Aspectos da literatura brasileira, ed. cit., p. 201). Segundo o crítico, o "sequestro" revela-se também no tremor dos amantes, seja o tremor do eu lírico, seja o de sua amada, na qual ele projeta o medo: “(...) Varela, numa estrofe das Estancias, reconhece que a amada tem um não-sei-quê de grande e imaculado que o faz estremecer..." (ibidem, p. 210).

P. 250-253

QUADRINHAS (21 estrofes)

P. 252:

Nota MA: termo sublinhado no v. 51, “ingázeiros", e expoente “(1)”, remetendo ao comentário no rodapé:

Que entre risos feiticeiros

Contemplais vossa belleza,

Á sombra dos ingázeiros, “(1)”

No espelho da correnteza!

“(1) Realmente Varela se serve constantemen-/te de coisa nacionais.”

2. termo sublinhado no v. 63, "viola", e escólio "dic" - pesquisa para o Dicionário musical brasileiro:

Quero ao descer as montanhas,

Á luz que o luar espalha,

dic Ouvir no valle a viola

Soar na choça de palha.

P. 253:

Nota MA: v. 77-80 destacados por traço vertical e comentário: 
Quero paz, quero harmonias,

Liberdade, inspiração,

Que a poeira das cidades

Me atrophia o coração.
"Refrão da

obra de Varela"

Nota da pesquisa: Os versos destacados indiciam a "Atração da natureza", fartamente assinalada por MA nas obras de Fagundes Varela, conforme o fichamento crítico no dossiê do manuscrito Amor e medo (MA-MMA-05-05).

$\underline{\text { P. } 254-260}$

O GENERAL JUAREZ (14 estrofes)

P. 254:

Nota MA: nome corrigido no título, "Juarez" - correção tipográfica.

P. 255:

Nota MA: v. 41-50 destacados por traço vertical e escólio, "homens inuteis":

Não era semelhante aos dos mais homens

Que nascem na mentira,

Crescem á sombra de interesses torpes,

Cevão-se de vaidades,

Furtão-se ao pharo augusto do futuro,

E após ligeiro prazo

De loucas ambições, de vicios negros,

Legão á mãi commum

Um punhado de cinza e de miserias,

Inuteis té na tumba! "homens

inuteis"

Nota da pesquisa: MA inclui o trecho assinalado no fichamento crítico das obras de Fagundes Varela, remetendo a esta página na rubrica "Social" (MA-MMA-05-05).

P. 260:

Nota MA: trecho sublinhado nos v. 193 e 194 e expoente “(1)”, remetendo ao comentário no final do poema:

Cantou, aceita o canto,

Aceita-o; no alcaçar dos potentadas

Jamais alguem o ouvio! "(1)”

“(1) Esta preocupação da propria / genialidade..."

Nota da pesquisa: Passo aludido por MA no fichamento crítico das obras de Fagundes Varela, na rubrica "Varela se pensava genio?" (MA-MMA-05-05).

P. 261-263

A FILHA DAS MONTANHAS 
P. 261:

Nota MA: v. 9 sublinhado e escólio:

O coração pollue-se nas cidades:

"Refrão de Varela"

Podem ser bons os homens isolados,

Mas si o nó social n'um corpo os liga,

Meu Deos! tornão-se atrozes!

Nota da pesquisa: Também estes versos caucionam a percepção de MA quanto à "Atração da natureza", sentida pelo eu lírico nas poesias de Varela (MA-MMA-05-05).

P. 263:

Notas MA:

1. v. 74 e 82 sublinhados - estudo do estilo: repetição;

2. comentário:

A virgem dormirá sem o zumbido

De torpes vates, de oradores torpes:

Poderá descansada ouvir os canticos

Dos anjos pelo espaço!

"O artifício fa-

miliar de Varela"

(...)

Feliz a virgem morta nas montanhas?

No ermo despertou, dorme no ermo!

$\mathrm{O}$ halito empestado das cidades

Não maculou-lhe a vida!

Nota da pesquisa: A "virgem morta nas montanhas" respalda a alusão a esta página no fichamento crítico das obras de Fagundes Varela, onde aparece sob a rubrica "Elegíaco" (MA-MMA-05-05). O "artifício familiar" da repetição ilustra a entrada "Artista", no mesmo fólio do manuscrito Amor e medo.

\section{P. 264-266}

O FILHO DE S. ANTONIO [CANÇÃO DE UM DEVOTO] (8 estrofes)

\section{P. 264: S/Notas MA}

Nota da pesquisa: No dossiê do manuscrito Amor e medo, o fichamento crítico das obras de Fagundes Varela junta esta página a outros exemplos do caráter "Cantador" atribuído à poesia dele (MA-MMA-05-05).

P. 265:

Nota MA: expressão sublinhada no v. 32, "pirralho celeste", e comentário:

Accende uma vela benta

Junto ao santo que offendeste,

Lançando a mão violenta

Contra o pirralho celeste.

Leva-lhe linda toalha

Cheia de finos bordados.

"Impropriedade!

Contudo a canção

Talvez a offerta te valha

é comica." 
O olvido de teus peccados.

P. 267-269

AS LETTRAS

P. 267:

Nota MA: comentário ao final do poema:

"Varela aqui varia muito bem / Lied lugar comum. Porém Não / está mau."

Nota da pesquisa: O fichamento crítico eleva o poema ao rol das "Obras-primas" de Fagundes Varela, no fichamento crítico, dossiê do manuscrito Amor e medo (MA-MMA05-05).

P. 270-280

ACUSMATA (31 estrofes)

P. 271:

Notas MA:

1. v. 20 sublinhado, indicação do número de sílabas, fio e indagação na margem superior - estudo da versificação: métrica:

"Não será influência de Teem (plural)?"

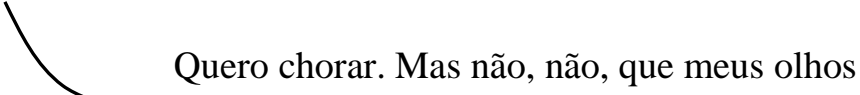

Quero chorar. Mas não, não, que meus olhos

$\frac{\text { Têm pudor, não chorão! E comtudo }}{\text { Sinto-os n'um mar de lagrimas perdidos! }}$

2. expressão sublinhada no v. 32, "rosados athêos", e expoente “(1)”, remetendo ao comentário no rodapé:

Detesto a escola funebre, e mentida

De gordos desditosos que padecem

Os revezes da sorte em lauta mesa;

Detesto os cantos scepticos, descrentes,

De rosados athêos, sabios ephemeros,

Impios provocadores da desgraça:

Detesto-os, porque soffro, e soffro muito,

Porque supporto um peso de miserias,

Tão grande que roxeia-me as espaduas!

“(1) Epiteto excelente. Realmente Varela / inicia entre os romanticos, embora / palidamente, a raridade do epiteto. **Alguns / homericos já encontrei, sinão me engano foi: 'Mar ilustre'. Por essa raridade do epiteto é que / muitas vezes é improprio e / ridiculamente de mau / gosto como venho assi-/nalando.

"Já em Alvares de Azevedo é comum na prosa o / epiteto, se não raro, pelo menos inesperado e / forte." 
Nota da pesquisa: A observação quanto à "raridade do epíteto" é aludida por MA na rubrica "Imagem", no fichamento crítico das obras de Fagundes Varela, dossiê do manuscrito Amor e medo (MA-MMA-05-05).

P. 272-273:

Notas MA:

1. v. 48 sublinhado e retângulo assinalando o "g" em "ignoto" - estudo da versificação: métrica / estudo linguístico: suarabácti:

Por um mundo ignoto! Aos ventos soltos

Desprender os andrajos derradeiros

2. termo sublinhado no v. 57, "genio", e cruzeta:

E o descampado horrendo, esteril, vasto,

$X \quad$ Ha succedido ao genio que accendia

As fibras de meu craneo!...

3. v. 69-72 destacados por traço vertical duplo - estudo da psicologia: morte:

E a morte que os estultos amedronta

Brota a meus olhos pensativa e meiga,

Coroada de flôres mais formosas

Que as tristes rosas dos jardins dos homens!

4. v. 73-81 destacados por traço vertical - seleção de ideias:

Somos a idéa, o sentimento, a essencia

Da creação inteira; a intima nota

De quanto brilha, corre, canta e chora;

Somos o fluido eterno, que circula,

Envolve o globo, os seres, e penetra-os

De um infinito amor; somos a cithara

Onde o sopro de Deos roça inflammado

E sacode no espaço a paz aos homens

N'um turbilhão de notas amorosas.

P. 275:

Nota MA: v. 129-135 destacados por traço vertical e expoente “(1)” remetendo ao comentário no rodapé:

Do cedro secular; a flôr guardada,

Entre os galhos do ipé, nas grossas folhas

De alpestre parasita; a molle acacia;

O manacá cheiroso que se ostenta

(1)

Á beira d'agua, pensativo e triste;

Os festões do ingázeiro e as açucenas,

Todas te amavão, te adoravão todas!

“(1) Há realmente uma evolução em Varela dos / primeiros livros pra este no emprego de coisas / nacionais" 
Nota da pesquisa: MA reserva lugar para o comentário no fichamento crítico das obras de Fagundes Varela, sob a rubrica "Patriota e brasileiro" (MA-MMA-05-05).

P. 276:

Nota MA: termo sublinhado no v. 162, “c'roa", e cruzeta - estudo do estilo: licenças poéticas:

Nos faria murchar, cahir sem vida,

Afim que o viandante nos tomasse

$X \quad$ Para tecer a c'roa derradeira,

A c'roa derradeira que te resta!

Nota da pesquisa: No dossiê do manuscrito Castro Alves, MA propõe, no plano de capítulo para o livro Lirismo romântico no Brasil: "Reunir o caso de croa, do pra, dos decassílabos diminuídos ou aumentados de sílaba num capitulinho sobre as Licenças Poéticas do Romantismo, bem como as rimas toantes e deficientes. Nesse capítulo observar a tendência pro pra e considerações sobre a linguagem brasileira." (MA-MMA26-09).

P. 277:

Nota MA: v. 199-207 destacados por traço vertical e juízo de valor:

Escutai os harpejos da viola,

São mais sentidos que o soprar do vento

Beijando a medo os arrozaes viçosos;

Prestai ouvido á voz do sertanejo,

Que ella falla de amor, e a patativa

"Lindo"

Nunca nos matagaes gemeu tão triste!

Filhas da serrania e das campinas,

Adornai-vos de rubras maravilhas,

Vinde, que a noite avança e o céo desmaia!

Nota da pesquisa: A entrada "Patriota e brasileiro", no fichamento crítico das obras de Fagundes Varela, é seguida de remissão a esta página (MA-MMA-05-05).

P. 280:

Nota MA: comentário ao final do poema:

"Dos poemas dialogados deste / genero é dos mais belos que sei. / Só realmente a fala das flores é / ruim."

Nota da pesquisa: O comentário, com a indicação de página, é recolhido por MA à rubrica "Obras-primas", no fichamento crítico das obras de Fagundes Varela (MA-MMA-05-05).

\section{P. 281-298}

A SÊDE (18 estrofes)

P. 283:

Nota MA: v. 77 sublinhado, termos assinalados por retângulo e escólio - estudo do estilo: repetição: 
$\underline{\text { Un frio beijo sobre a fronte fria. }}$ "O artificio"

Deitou-lhe ao lado o misero filhinho.

Nota da pesquisa: MA apanha mais este exemplo para ilustar a rubrica "Artista", no fichamento crítico de Fagundes Varela (MA-MMA-05-05).

P. 286:

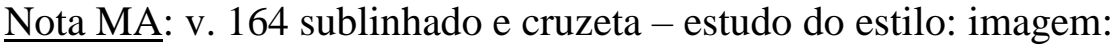

$X \quad$ Rima da noite, que se chama o somno!

Nota da pesquisa: A imagem é referida por MA no fichamento crítico das obras de Fagundes Varela, que conserva indicação a esta página na rubrica "Imagem" (MA-MMA05-05).

P. 287:

Nota MA: expressão sublinhada no v. 187 e escólio "Sol" - estudo do estilo: imagem:

Em breve no oriente o rei dos astros $\quad$ Sol

Foi-se mostrando aos poucos.

P. 292:

Nota MA: termo sublinhado nos v. 328 e 329, "lugubre", e escólio, "Artificio" - estudo do estilo: repetição:

$\mathrm{O}$ vulto tenebroso extenso e lugubre

Da lugubre fazenda se levanta, "Artificio"

Nota da pesquisa: No fichamento crítico, MA remete a esta página na rubrica "Artista" (MA-MMA-05-05).

P. 299

ENOJO (4 estrofes)

P. 299:

Nota MA: juízo de valor ao final do poema:

\section{"Excelente"}

Nota da pesquisa: O fichamento crítico com as "Ideias gerais" para o livro Lirismo romântico no Brasil, no dossiê do manuscrito Castro Alves, remete a este poema na rubrica "O soneto romantico" (MA-MMA-26-04).

P. 301

O MESMO (5 estrofes)

Nota MA: juízo de valor ao final do poema: 


\section{“Curiosissimo.”}

Nota da pesquisa: MA menciona esta página na rubrica "O inteligente sensivel", no fichamento crítico das obras de Fagundes Varela (MA-MMA-05-05).

P. 302-303

A UM MONUMENTO (6 estrofes)

P. 303:

Nota MA: comentário ao final do poema:

"Ainda o didatismo de / Varela"

Nota da pesquisa: O comentário é transposto para o fichamento crítico, onde consta a rubrica "Didatismo", acompanhada de remissão a esta página (MA-MMA-05-05).

P. 304-307

A PENNA (6 estrofes)

P. 305:

Nota MA: expressão sublinhada no v. 32 e comentário:

Meu Deos! Porque me lançaste,

A mim, levita da dôr,

Na terra onde derramaste

Tanta vida e tanto amor?

"Varela tem levita / de tudo. Uma / insuficiencia de / criação? Não me / parece. É o mais / variado dos ro-/manticos. Porem / certos artificios / e ideias que afei-/çoa repete sem / parar. Mais / propriamente / mau gosto, indis-/crição que outra / coisa."

Nota da pesquisa: O "mau gosto" atribuído por MA a certos passos de Fagundes Varela é recolhido ao fichamento crítico, sob aquela rubrica (MA-MMA-05-05).

P. 306:

Nota MA: v. 58-61 destacados por traço duplo - seleção de ideias: gênio:

$\| \begin{aligned} & \text { Tenho o orgulho da desgraça, } \\ & \text { Quanto mais á dor se abraça } \\ & \text { Mais força minh'alma cobra! }\end{aligned}$

Nota da pesquisa: MA aduz ao trecho, no fichamento crítico das obras de Fagundes Varela, sob a rubrica "Varela se pensava genio?" (MA-MMA-05-05).

P. 307:

Nota MA: termo sublinhado no v. 101, "harmonias", e escólio "dic" - pesquisa para o Dicionário musical brasileiro: 
Solta rudes harmonias, dic

Brinda a morte e as agonias,

Canta as coleras bravias

Dos precitos eternaes;

P. 308-321

LEVIANDADES DE CINTHIA

PAMPHILIO, AMPHILOPHIO, MARCULPHO

P. 309:

Nota MA: v. 18 sublinhado e retângulo assinalando a sílaba final de "perdoe" - estudo da versificação: métrica:

Deos me perdoe, sobre este vil planeta

Vale mais um defunto que um mendigo.

P. 310:

Nota MA: v. 59-62 sublinhados e traço vertical - seleção de ideias: gênio:

Talvez ao ler a lugubre noticia

A ingrata chore, e lá na eternidade

Eu goze do prazer de ver meu nome

Impresso em grossos typos.

Nota da pesquisa: Última referência elencada na rubrica "Varela se pensava genio?", no fichamento crítico das obras de Fagundes Varela, dossiê do manuscrito Amor e medo (MA-MMA-05-05).

P. 311-312:

Nota MA: v. 79-91 destacados por traço vertical e comentário à esquerda dos dois últimos versos:

\section{PANFILIO}

Ele tosse, aproxima-se da ponte, Volta, torna a tossir. Sejamos fortes, Fallemos. - Oh! vizinho! do outro lado, O que faz o senhor ahi sózinho? Porque passeia, escarra e estende os braços, Quando eu contemplo as aguas susurrantes D'este rio saudoso e merencorio?

Diga-me sem demora!

\section{AMPHILOPHIO}

\section{Por S. Pedro}

E o senhor o que faz? Vamos, responda-me.

Porque contempla as aguas susurrantes

D'este rio saudoso e merencorio

Quando eu passeio, escarro e estendo os braços? 
Nota da pesquisa: MA transpõe este passo para o fichamento crítico, incluindo-o sob a rubrica "Humorista à A. Azevedo" (MA-MMA-05-05).

P. 313:

Notas MA: v. 108-110 destacados por traço vertical duplo - estudo do estilo: humor:

As aguas d'este rio, malcriado...

Sinão lhe gravaria nas bochechas

Os principios de sã civilidade

E bôa educação!

P. 319:

Notas MA:

1. expressão sublinhada nos v. 227 e 228, parênteses assinalando a repetição e fio até o comentário no rodapé - estudo do estilo: repetição;

2. escólio à direita, "Mulher infiel" - estudo da psicologia: fidelidade:

\section{PANFILIO}

Vivamos, companheiro,

A ingrata Cinthia, a (estrella) impiedosa Mulher infiel

Da rua das (Estrellas), perseguida

Pelo remorso, chorará seus crimes,

Nos abrirá de novo os braços meigos,

E nós...

"artificio comum no / poeta"

Nota da pesquisa: O escólio converge para o fichamento crítico da poesia de Fagundes Varela, no dossiê do manuscrito Amor e medo, onde abona a rubrica "A mulher pra V." (MA-MMA-05-05).

P. 321:

Nota MA:

1. v. 263 sublinhado e retângulo assinalando o "g" em "indignado" - estudo linguístico: suarabácti / estudo da versificação: métrica;

2. comentário no rodapé, ao final do poema:

\section{MARCULPHO}

Não quero mais morrer! Já descobri-os!

Heide viver para vingar-me! Eu parto!

Eu parto, e em breve hade saber o mundo

O que fez um marido indignado!

"Estupendo. Comedinha engra-/çadissima e admiravelmen-/te bem contada. Creio des/cobrir certa influencia de Va-/rela sobre Machado de Assis poeta / É curioso como sendo $V$. um falso descri-/tivo conte tão bem. É porém sempre den-/tro do comico, do humoristico, que conta bem. / Sabia se afeiçoar ao caracteristico (porque tambem / por vezes conta bem quando quer ser sertanejo)." 
Nota da pesquisa: MA conserva remissão à página no fichamento crítico das obras de Fagundes Varela, na rubrica "Humorista à A. Azevedo" (MA-MMA-05-05).

P. 322-323

ORAÇÃO FUNEBRE (7 estrofes)

P. 322:

Notas MA:

1. verbo corrigido no v. 7, "Volta" - correção tipográfica;

2. comentário ao final do poema:

la Volte o olhar ao sol, o sopro dos ares,

A palavra á amplidão, e os membros todos

Ás plantas se misturem.

"Admirabilissimo. Embo-/ra inspirado no Rig Veda é / uma legitima criação tão / bela como As Pombas ou Mal / Secreto. Não tem importancia / que seja menos celebre. // Já prenuncia tambem o filosofis-/mo ocasional, proveniente da lei-/tura do Momento, que viria a / ser comum nos nossos poetas / posteriores ao Romantismo. Poetas / sem ideas gerais pessoais, ventoinhas / da filosofia historica, catalogos / de ideas contradictorias, florile-/gios de filosostrices, que tem / como prototipos Raimundo e Bilac. / São Pensadores de ocasião. // Duma feita na sua vida incerta /Varela topou com um exemplar / do Rig-Veda. Por acaso. Como tinha / sabido vagamente que o Rig Veda era / da India e o Oriente era uma cu-/riosidade romantica, comprou? antes / emprestou o volume / e leu, talvez meio caceteado. O acaso / fez com que lesse estes versículos do / poema indiano que concordavam com / a sua sensibilidade de elegíaco. / Se comoveu. Deu-se o moto lírico. Saiu / uma / obra-prima."

Notas da pesquisa:

1. Esta "Oração fúnebre" municia a percepção de MA sobre o caráter "elegíaco" da lírica de Fagundes Varela, conforme se lê no fichamento crítico (MA-MMA-05-05).

2. A folha de guarda das Obras de Álvares de Azevedo, vol. 1, conserva um comentário que apoia esta nota de margem: "Comentário à imitação e à sinceridade. Mostrar que uma não contraria a outra, ao contrário, a imitação provoca a sinceridade porque ninguém imita por esnobismo sinão raramente e não é o caso dos romanticos, imita-se por afinidade, imita-se por espelhar, imita-se a mesma coisa que se é, não se imita: identificase, corresponde-se." (V. Nota MA, In: AZEVEDO, Álvares de. Obras. Ed. cit, vol. 1, folha de guarda).

P. 326-327

HYMNO A AURORA (12 estrofes)

P. 327:

Nota MA: comentário ao final do poema:

"Realmente aqui a forma estrofica / é de seis versos." 
VARELLA, L. N. Fagundes. Obras completas de L. N.

Fagundes Varella: edição organisada e revista, e precedida de uma noticia biographica por Visconti Coaracy e de um estudo critico pelo Dr. Franklin

Tavora. Rio de Janeiro/Paris: Garnier, 1919. 3 v.

IEB: MA 869.9138 V293o

v. 3

\section{VOLUME 3}

\section{FOLHA DE ROSTO}

Notas MA:

1. anotação no alto, à direita, “ $n^{\circ} 224 /$ III", referindo-se à inclusão do volume na Bibliografia para Na pancada do ganzá;

2. lista de verbetes para o Dicionário musical brasileiro e cruzeta indicando o aproveitamento:

Dic-preludiar 38 - sino 49-salteris 5T-Tamborim 82 - cadencia 124 - tanger 146 I cantilena $196-$ guizo 321 -

\section{P. 5-303}

ANCHIETA, OU o EVANGElHo NAS SElvas

P. 7-46

CANTO PRIMEIRO (42 estrofes)

P. 10:

Nota MA: versos destacados por traço duplo - seleção de ideias:

(...)

$$
\| \begin{aligned}
& \text { Arvore da sciencia e do infortunio, } \\
& \text { Tu não nos dás os fructos da Esperança, } \\
& \text { E nem da Fé o balsamo suave, } \\
& \text { E nem o puro mel da Caridade! }
\end{aligned}
$$

P. 13:

Nota MA: versos destacados por traço vertical e comentário:

$$
\begin{aligned}
& \text { A noite estende vagarosa e muda } \\
& \text { O brando véo de estrellas salpicado. } \\
& \text { Bella como a princeza do Levante } \\
& \text { Quando ao cahir do dia ergue-se fresca } \\
& \text { Das marmoreas banheiras de seus paços, }
\end{aligned}
$$

"Mania de com-/parações com o / exótico"

P. 16: 
Nota MA: verso sublinhado e artigo "um” assinalado - estudo da versificação:

Está finda a romagem: um velho chefe,

De voz autorizada e grave porte,

Chama os da sua idade e se dirigem

Para o modesto e venerando asylo.

P. 17:

Nota MA: preposição sublinhada, "para", e cruzeta - estudo linguístico: emprego de "para/pra":

As abelhas das verdes espessuras

Para seu mel depôr, como as dos Hymetto $\quad X$

Do divino Platão sobre o moimento...

P. 18:

Notas MA:

1. versos destacados por traço vertical e escólio, “Imagem" - estudo do estilo: imagem:

Reina fundo silencio. Passo e passo,

O homem do Evangelho se encaminha

Para o meio das gentes reunidas;

Qual o astro que as veigas ilumina

E faz abrir a flôr, saltar o insecto,

Romper-se a bella e nitida chrysalida,

Cantar o passarinho, e a leve corça

Pular pelas campinas orvalhadas,

Assim rebenta a vida e o movimento

Á medida que o mestre se approxima.

\section{"Imagem”}

2. preposição sublinhada, "para", e cruzeta - estudo linguístico: emprego de "para/pra":

Ajoelham por fim, e o missionario,

$X \quad$ Para a imagem de Christo se voltando,

Repete as santas orações da noite.

Nota da pesquisa: No fichamento crítico das obras de Fagundes Varela, a rubrica "Imagem" abriga referência à página, no dossiê do manuscrito Amor e medo (MA-MMA05-05).

P. 19:

Nota MA: comentário ao final do trecho:

“Invocações por demais”

Nota da pesquisa: A rubrica "Mau gôsto" contém menção a esta página (MA-MMA-05$05)$.

P. 25: 
Nota MA: versos destacados por traço vertica, à esquerda e à direita - estudo do estilo: apóstrofe:

$$
\begin{aligned}
& \text { Assim estava escripto! - Roma! Roma! } \\
& \text { Foste fiel verdugo! Executaste } \\
& \text { Horrivelmente bem o mando eterno! } \\
& \text { Só tu, patria cruel das Messalinas, } \\
& \text { Dos Neros e Tiberios, tu sómente, } \\
& \text { Tão nefario papel representarás! } \\
& \text { Tu corrompida até vender teus filhos! }
\end{aligned}
$$

P. 28:

Notas MA:

1. termo corrigido de modo a "prazenteiros" - correção tipográfica:

Tardos jumentos; prazenteire outros " $/ o s "$

2. verso sublinhado e retângulo assinalando o "g" de "magnolia" - estudo do estilo: suarabácti:

\section{Pallido como a nivea magholia}

P. 31:

Nota MA: preposição sublinhada, "para", e cruzeta à direita - estudo linguístico: emprego de "para/pra":

\section{Para tão grande numero são poucas}

P. 32:

Nota MA: preposição sublinhada, "para", e cruzeta - estudo linguístico: emprego de "para/pra":

$X \quad \underline{\text { Para }}$ a celeste abobada, crivada

P. 35:

Notas MA:

1. verso sublinhado e parênteses assinalando o "b" em "absortos" - estudo linguístico: suarabácti:

Despertos, porém mudos, e a(b)sortos,

Buscam as horas illudir da noite,

2. termo sublinhado, "sol", e cruzeta - estudo da psicologia: imagem/atração da natureza:

Incolume dos Andes, reflectindo

A luz do sol nascente, eram as vestes $X$

P. 38:

Nota MA: termo sublinhado, "preludiam", e escólio "dic" - pesquisa para o Dicionário musical brasileiro: 
"dic" Os roxinoes despertos preludiam

Suavissimos cantos;

P. 41:

Notas MA:

1. expressão sublinhada e retângulo assinalando o "b" em "objecto" - estudo linguístico: suarabácti;

2. preposição sublinhada, "para", e cruzeta - estudo linguístico: emprego de "para/pra":

Qbjjecto de luxo e de vaidade,

Tornar-se horrivel, espumar de raiva,

Ás féras disputar o antro escuro

Para esconder a prole ameaçada!...

$X$

- Um coração de mãi produz milagres.

P. 42:

Nota MA: preposição sublinhada, "para", e cruzeta - estudo linguístico: emprego de "para/pra":

Dizem, volvendo para o céo os olhos;

$X$

Já não brilhava a fulgurante estrella.

P. 43:

Nota MA: preposição corrigida, "contra" - correção tipográfica:

Aquelles que elle amou, que procurava,

E sempre defendeu cronta a injustiça

P. 4?:

Nota MA: preposição sublinhada, "para", e cruzeta - estudo linguístico: emprego de "para/pra":

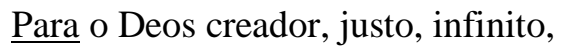

$X$

P. 45:

Nota MA: termo sublinhado, "sol", e cruzeta - estudo da psicologia: imagem/atração da natureza:

Quando a aurora raiar, quando mais alto

Brilhar o sol no immenso firmamento

$X$

P. 46:

Notas MA:

1. expressão sublinhada e cruzeta - estudo linguístico: colocação pronominal:

- O que fazias, filha? - Me lembrava

$X$

2. preposição sublinhada, "para", e cruzeta - estudo linguístico: emprego de "para/pra";

3. verso e termo sublinhados, e cruzeta - estudo da psicologia: imagem/atração da natureza:

Levanta-se Nahyda, e ambos caminham

$X \quad \underline{\text { Para }}$ a afastada, misera choupana, 
Onde a mãi da innocente, cuidadosa,

Grosseira refeição prepára, e espera

A delicada filha e o sabio mestre.

$X \quad-\mathrm{O}$ sol nascente as selvas illumina.

P. 49:

Notas MA:

1. termo sublinhado, "sol", e cruzeta - estudo da psicologia: imagem/atração da natureza;

2. termo sublinhado, "sinos", e escólio "dic" - pesquisa para o Dicionário musical brasileiro:

Das grandes cathedraes nas altas torres

O sol Oriental bate festivo,

$X$

Dourando as primorosas esculpturas

$\mathrm{E}$ as fréchas atrevidas; jubilosos,

Os sinos colossaes o espaço abalam,

"dic"

3. verbo sublinhado, "retorcia-se", e fio ligando-o ao comentário no rodapé - estudo da versificação: métrica:

Mais longe, alegre chusma de creanças

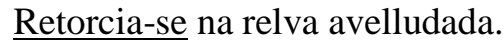

"Não será Retorce-se? Ou é mesmo o es-/drúxulo contado / como grave?

P. 47-74

CANTO SEGUNDO (15 estrofes)

P. 50:

Nota MA: termo sublinhado, "sol", e cruzeta - estudo da psicologia: imagem/atração da natureza:

E arrojam-se velozes pelos ermos:

Assim o sol na extrema do horizonte

$X$

P. 52:

Notas MA:

1. estrofe destacada por traço vertical e comentário;

2. preposição sublinhada, "para", e cruzeta - estudo linguístico: emprego de "para/pra":

Dos quatro pontos cardeaes, aos poucos,

Vêm chegando os fieis: o velho imbelle

Pelo filho amparado, o infante fragil

Sobre os hombros do pai - tristes extremos!

A mocidade alegre; a meia idade

Séria e calada. O caçador das brenhas,

O sagaz armador de finos laços,

Trazem para o banquete o mantimento;

As matronas severas, doces fructos,

Saudaveis confeições; flôres as virgens;

Delicadas offertas as creanças:

A multidão recresce, a ordem reina. 
"Isto é já repetição / do início do Canto I. A monotonia do Ev. das Selvas!..."

Nota da pesquisa: A rubrica "Artista" remete a esta página no dossiê do manuscrito Amor e medo (MA-MMA-05-05).

P. 53:

Nota MA: preposição sublinhada, "para", e cruzeta - estudo linguístico: emprego de "para/pra":

$X \quad$ Para o singelo altar. Longo sussurro,

Semelhante ao das ramas da floresta

P. 54:

Nota MA: preposição sublinhada, "para", e cruzeta - estudo linguístico: emprego de "para/pra":

Eu vos contava, irmãos, deveis lembrar-vos,

Da Sagrada Familia a retirada

$X \quad$ Para o famoso e celebrado Egypto,

P. 55:

Nota MA: preposição sublinhada, "para", e cruzeta - estudo linguístico: emprego de "para/pra":

$X \quad$ Para ir buscar no meio do vulgacho

Da mais pobre provincia, uma creança,

P. 56:

Nota MA: termo sublinhado, "salterios", e escólio "dic" - pesquisa para o Dicionário musical brasileiro:

Das harpas e salterios imitavam "dic"

As harmonias ternas e saudosas...

P. 57:

Nota MA: termo corrigido, "dois" - correção tipográfica:

Os principes, então, dos sacerdotes " "

Annaz e Caiphaz, entes perversos,

P. 58:

Notas MA:

1. preposição sublinhada, "para", e cruzeta - estudo linguístico: emprego de "para/pra":

Ora, n'aquelle tempo, dos desertos,

Das regiões incultas, que se estendem

$X \quad$ Para o Septentrião, onde só vivem

Sinistros corvos, esfaimadas aguias,

2. trecho sublinhado e cruzeta - estudo do estilo: imagem:

Em que o pharol brilhante da esperança 
$X \quad$ Clareia até o fundo dos abysmos;

P. 60:

Nota MA: preposição sublinhada, "para", e cruzeta - estudo linguístico: emprego de "para/pra":

$X \quad \underline{\text { Para esta gloria merecer! Minh'alma }}$

Devera ser por ti purificada,

Senhor! e tu me buscas!...

P. 61:

Notas MA: preposição sublinhada, "para", e cruzeta - estudo linguístico: emprego de "para/pra":

Que para as bandas do Emaús se estendem. $\quad X$

P. 62:

Nota MA: preposição sublinhada, "para", e cruzeta - estudo linguístico: emprego de "para/pra":

$X \quad$ Estende para o espaço a mão tisnada,

E com a voz temerosa assim lhe falla:

P. 63:

Notas MA:

1. termo sublinhado, "alcaçares" e comentário - estudo da versificação: métrica:

Os lucidos crystaes ornam as salas

Dos nobres alcaçares. Pelas praças, "Varela o faz grave."

2. versos destacados por traço vertical - seleção de imagens: oriente:

O berço de Vishnou, de Siva e Brahma,

A India adusta, a inexgotavel fonte

De etherea poesia, a grande mina

Das maiores riquezas do universo!

P. 64:

Notas MA:

1. versos destacados por traço vertical - seleção de ideias:

Abortos sociaes, mesclas sinistras

De riqueza e poder, de luz e trevas,

De esplendor e miseria! Á roda gyram,

2. preposição sublinhada, "para", e cruzeta - estudo linguístico: emprego de "para/pra":

$X \quad$ Volta-te agora para o Norte: a Syria

Desdobra-se risonha, limitada

P. 65:

Nota MA: preposição sublinhada, "para", e cruzeta - estudo linguístico: emprego de "para/pra": 
Para os thronos dos principes da Europa, $\quad X$

E para os templos de seus deuses mudos... $\quad X$

P. 66:

Nota MA: preposição sublinhada, "para", e cruzeta - estudo linguístico: emprego de "para/pra":

\section{$X \quad \underline{\text { Para a }}$ a ruidosa Europa, o illustre berço}

Dos filhos de Japhet... Oh! como airosas

P. 67:

Notas MA:

1. artigo sublinhado, "os", e cruzeta - estudo do estilo / linguístico: sintaxe:

Chypre, o lagar dos vinhos os mais puros, $\quad X$

2. verso sublinhado e retângulo destacando o "S" de "Sparta" - estudo linguístico: epêntese/estudo da versificação: métrica:

\section{Sparta, a destemida, encara ufana}

P. 68:

Notas MA: verso sublinhado e retângulo destacando o "g" de "magnânimo" - estudo linguístico: suarabácti/estudo da versificação: métrica:

M自ghanimo e baixo, escuro e mixto

De fereza e bondade, calma e raiva,

P. 70:

Notas MA:

1. verso assinalado por cruzeta - estudo do estilo: colocação do adjetivo:

$X \quad$ A joven filha da immortal Cybele.

2. termo sublinhado, "eximio", e expoente “(1)” remetendo ao comentário no rodapé:

“(1)" - Terra da promissão! descripta outr'ora Pelo eximio Moysés, oh! certamente,

“(1) Que impropriedade este eximio!”

3. trecho sublinhado e expoente "(2)” remetendo ao comentário no rodapé:

Semelhantes aos principes fastosos

“(2)” Das historias do Iran, por toda a parte,

“(1) Mais comparação exótica” 
Nota da pesquisa: A impropriedade assinalada por MA no rodapé converge para o fichamento crítico das obras de Fagundes Varela, na rubrica "Mau gôsto" (MA-MMA05-05).

P. 71:

Notas MA:

1. expressão sublinhada e expoente “(1)”, remetendo ao comentário no rodapé:

“(1)” Senhora das florestas. Indulgente

“(1) América, senhora das florestas... isto é / bonito, não tem dúvida."

2. verbo corrigido, "Conhece-lhe" - correção tipográfica:

"/C" Bonhece-lhe a existencia: nenhum padre

3. preposição sublinhada, "para", e cruzeta - estudo linguístico: emprego de "para/pra":

$X \quad$ Para comprar os thronos do Universo;

Nota da pesquisa: $\mathrm{O}$ epíteto de Fagundes Varela aparece no fichamento crítico de suas obras, que remete à página na rubrica "Imagem" (MA-MMA-05-05).

P. 72:

Nota MA: preposição sublinhada, "para", e cruzeta - estudo linguístico: emprego de "para/pra":

$X \quad$ Para que não tropeces, nem molestes

Os pés nas duras pedras!

P. 73:

Nota MA: comentário ao final da parte XIV:

"Esta parte XIV toda é muito boa sobretudo na visão descritiva / das nações terrestres. Culmina porém a descrição da América a-/<ilegível> mais por qualidades de poesia que pela fôrça de expressão e / de realidade. É nesses passos que Varela atinge uma suavidade, u-/ma doçura maravilhosa de musicalidade oral, intrin-/secamente oral. $E$ realmente estupendo. É o milhor passo / do poema até agora. Nada de grandeza de pensamento, nada / de originalidade nem de riqueza de ideia ou imaginação, / pura beleza oral mas da mais alta beleza. E originalida-/de é o que mais falta mesmo a Varella."

Nota da pesquisa: A rubrica "Falso descritivo" guarda remissão a esta página, no fichamento crítico das obras de Fagundes Varela (MA-MMA-05-05).

P. 78:

Nota MA: preposição sublinhada, "para", e cruzeta - estudo linguístico: emprego de "para/pra":

$X \quad$ Para ouvir tua historia e teus preceitos, 
Tudo está frio, desolado e morto?

P. 82:

Nota MA: termo sublinhado, "tamborins" e escólio "dic" - pesquisa para o Dicionário musical brasileiro:

"dic" Dos tamborins sonoros, algum tempo

P. 88:

Nota MA: versos destacados por traço vertical - seleção de ideias:
Que a seu aspeito horrorizados fogem:
Roxos tumores, putridas feridas
Cobrem-lhe os pés, as mãos, o peito e o rosto;
Esverdeado pús, aguado sangue,
Empastam-lhe os andrajos asquerosos;
Não mais conservam palpebras e labios
As fórmas primitivas, ora, apenas,
Esponjoso tecido de tuberculos...
Mostram, oh Deus!... os ultimos - um riso
De escancaradas chaga... As chagas riem!

Nota da pesquisa: Passo elencado sob a rubrica "Falso descritivo", no fichamento crítico das obras de Fagundes Varela (MA-MMA-05-05).

P. 75-109

CANTO TERCEIRO (37 estrofes)

P. 89:

Nota MA: crase corrigida, “à" - correção tipográfica:

Todo entregue a missão que o trouxe a terra, "/á"

P. 90:

Notas MA:

1. termo corrigido, "descoroçoados" - correção tipográfica;

2. preposição sublinhada, "para", e cruzeta - estudo linguístico: emprego de "para/pra":

lo Não descoraçoados, senão crentes, Guiados pela fé, mãi dos milagres,

Removem para um canto o desgraçado, $X$

3. preposição sublinhada, "para", e cruzeta - estudo linguístico: emprego de "para/pra": Olham para Jesus, para a mofina $X$

P. 91:

Nota MA:

1. verso sublinhado e retângulo destacando a sílaba inicial de "felicidade" - estudo da versificação: métrica;

2. expoente “(1)” remetendo ao comentário no rodapé: 
E afasta-se levando a felicidade

A seus afflictos pais. Maravilhado

Á roda de Jesus pondera o povo:

- Hoje vimos prodigios inauditos!

(1)

“(1) Não indico mais o para que é sistemático já em / Varela dos ultimos tempos. Indicarei só os prás si os tiver.”

P. 94:

Nota MA: escólio "Sermão da / montanha” - seleção de ideias:

"Sermão da / montanha"

- Afortunados sois, pobres de espirito,

Pois o reino dos céus é vossa herança;

Afortunados sois, brandos e mansos,

Que sem disputa possuis a terra;

Afortunado sois, vós que, chorando,

Atravessais a estrada da existencia,

Porque tereis das magoas lenitivo;

P. 95:

Nota MA: verbo corrigido, "recebereis" - correção tipográfica:

“ere” Recebeis além na eterna patria!

P. 98-99:

Nota MA: versos destacados por traço vertical - estudo do estilo:

Elle alli estava!... Livida, sem prantos,

Acceso o olhar, os labios resequidos,

Desprendendo da tremula garganta,

De quando em quando, um soluçar convulso,

Seguia a pobre mãi os frios restos

Do que mais estimava sobre a terra!

Aquella dôr prophetica, sinistra,

Chegou até Jesus! A vista immensa

Do Filho de Maria vence o tempo.

E vai cahir no cimo do Calvario!...

Ai! si não fôra um Deus, talvez chorasse!

Sahe do meio dos seus, abre passagem,

Faz parar o funéreo sahimento,

Volta-se á trsite mãi, que, ao vel-o, treme:

- Oh! não te afflijas, que teu filho dorme!

Diz com voz maviosa e compassiva.

E depois, acenando ao frio corpo:

- Levanta-te, mancebo, eu mando! exclama.

Senta-se o moço, encara os assistentes,

Lança por terra os lugubres adornos,

E, saltando do esquife, alegre e forte,

Aos pés do Salvador se prostra humilde! 
Nota da pesquisa: $O$ traço vertical explica-se no fichamento crítico das obras de Fagundes Varela, que remete a esta página na rubrica "Passagens bonitas" (MA-MMA-05-05).

P. 100-101:

Nota MA: versos destacados por traço vertical - estudo do estilo:

Ora, n'aquelles tempos ominosos, Quando a raça perjura, abandonando O templo de seu Deus, o altar da patria, Desvairada e febril tripudiava Nas orgias fataes dos vencedores; N'aquelles tempos de vileza e opprobrio, Vivia uma mulher, joven, fastosa, Esplendida de audacia e formosura. A nobreza de então gemia escrava Debruçada a seus pés; os magistrados $\mathrm{O}$ fiel da balança quebrariam Por um sorriso apenas! Muitos ricos Adormeceram ébrios de volupa Nas fôfas almofadas de seu leito; Mas... despertaram pobres. Desgraçada! Era como o arvoredo ameno e fresco, Que enfeitiça o cansado viajante, E o convida a dormir, mas cuja sombra Derrama a febre, o desespero e a morte!... Tinha visto Jesus e o tinha ouvido, A gloria de seu nome a deslumbrára.

Sabia onde Elle estava... Horrenda, escura Tentação de Satan! Tartareo sonho!...

Talvez!... fallou comsigo; e, pressurosa, Das mais finas roupagens se reveste, Adorna-se de joias e de flôres;

De aromas exquisitos se perfuma; Sólta os cabellos negros e profusos Sobre as niveas espaduas descobertas, E, tomando uma limpida redoma De precioso balsamo pejada, Ganha anciosa a rua e se dirige Do phariseu á casa, a largos passos.

Nota da pesquisa: Também esta é considerada uma das "Passagens bonitas" de Fagundes Varela, conforme o fichamento crítico de suas obras, no dossiê do manuscrito Amor $e$ medo (MA-MMA-05-05).

P. 104:

Nota MA:

1. preposição sublinhada, "para" - estudo linguístico: emprego de "para/pra":

Para lavar os pés um pouco d'agua,

2. comentário: 
"Tudo neste canto vem sendo muito bem descrito, com / uma infinita e deleitosa calma e com uma / suavidade realmente qualificavel de angelica. Aliás... / Varela entre os romanticos é o unico que / conta sem sinteses nem simultaneidade / as suas historias. Conta mais claro, mais / latinamente. Aliás não considero isso / uma qualidade."

Nota da pesquisa: A rubrica "Passagens bonitas", no fichamento crítico das obras de Fagundes Varela, conta esta página entre suas remissões (MA-MMA-05-05).

P. 106:

Nota MA: versos destacados por traço vertical e escólio, "Catulo Cearense" - estudo do estilo: imagem / linhagens:

(Oh! n'essas horas de poesia infinda,

Quem se despir da frivola sciencia

Das vaidosas escolas das cidades,

E, filho amante, repousar a fronte

No regaço feliz da natureza,

Um mundo encontrará nunca sonhado!...

\section{"Catulo Cearense"}

Notas da pesquisa:

1. No dossiê do manuscrito Amor e medo, MA remete a esta página na rubrica "Atração da natureza", no dossiê do manuscrito Amor e medo (MA-MMA-05-05).

2. A Biblioteca de MA conserva um título apenas de Catulo Cearense (1863-1946): Cantor de modinhas brasileiras (Rio de Janeiro: Quaresma, 1927), sem notas de margem. A menção ao poeta, suscitada pela leitura da poesia romântica, também se dá na parcela da marginália de MA nas Obras completas de Castro Alves (V. Nota MA, In: op. cit., ed. cit., p. 147).

P. 107:

Notas MA:

1. versos sublinhado e expoente “(1)” remetendo ao comentário no rodapé:

Dos sitios conhecidos, se dirige Ao de Genesareth extenso lago,

$$
\text { “(1) " }
$$

“(1) Primeira vez que esta formula arcaizante / surge nos versos de Varela. Deve ser antes recordação / de G. Dias."

2. versos destacados por traço vertical e juízo de valor - estudo do estilo:

Mas, pouco e pouco, as nuvens nacaradas,

Que no céo do Occidente refulgiam,

Conglobam-se rugindo, e se transformam

Em grossos rôlos de funereo crepe.

Frias lufadas de raivoso vento

Correm dobrando as arvores dos montes,

Erguendo turbilhões de folhas seccas

Do chão revolto e negro. Aves sinistras

Vôam, soltando pios lamentosos,

Em busca de um abrigo. $\mathrm{O}$ escuro lago
"Muito bom” 
Encrespa-se, braveja, as ondas cerra,

Joga de um lado e d'outro o pobre lenho,

Sem leme, sem governo, a vela rôta,

Alagado o franzino cavername!

E a noite estende lugubre, medonha,

Sobre a face do abysmo as amplas azas,

Retalhadas de rabidos coriscos!......

Nota da pesquisa: Página incluída nas rubricas "Falso descritivo" e "Patriota e brasileiro", no fichamento crítico das obras de Fagundes Varela (MA-MMA-05-05).

P. 108:

Nota MA: versos destacados por traço vertical e escólio - estudo do estilo: imagem / linhagens poéticas:

- Serenai! eu ordeno! exclama. Os ventos
Param na vastidão do torvo espaço,
Curvam-se as ondas bravas, irritadas,
E, quaes humildes cães á voz severa
De severo senhor, o dorso abaixam,
E lambem mansamente a escura barca...

"Tacito de Almeida"

Notas da pesquisa:

1. O trecho é recolhido por MA à rubrica "Imagem", no fichamento crítico das obras de Fagundes Varela (MA-MMA-05-05).

2. A série Manuscritos de Outros Escritores, no Arquivo MA no IEB/USP, contém quatorze poemas datiloscritos de Tácito de Almeida (1889-1940): "Desenho", "O abraço", "Pobreza", "Serenidade...", "Sourcier" (MA-MOE-025- 1 a 5); "Alegria", "Combate", "Dirigiveis", "Incendio Universal", "Insomnia", "Kermesse", "Luz", "Novo mundo" e "São Paulo" (MA-MOE-026- 1 a 13). O poema "Insomnia" assemelha-se ao trecho de Fagundes Varela destacado por MA, ao personificar os elementos da natureza: "Florestas suadas de emoção, / revolvendo-se como ondas. // O vento nervoso uivando. // Mil rios radiantes, / passando, cantando felizes, / coroados de estrellas! // Penachos de galla, muito brancos, das cachoeiras! // A Serra do Mar avançando, / desordenada, entre flamulas de nuvens! // E o Atlantico obeso, / suspendendo a ilha de Marajó, / como um escudo de ferro, / para suster os golpes do Amazonas!" (MA-MOE-026-9). Nos versos de "Alegria", MA traça uma cruzeta a lápis-tinta vermelho, assinalando o trecho: "O sol, como um gatuno, / arrombou as janellas de meu quarto. // E elle esta revistando o meu corpo, / apalpando o meu rosto. // Braços erguidos! / Nenhum movimento! // Como é alegre quem não tem desejos! / Como é bom ver o mundo a desejar-nos!" (Nota MA, In: "Alegria", MA-MOE-026-2).

O movimento de 1887: conferencia realizada pelo Dr. Tacito de Almeida no Club Athletico Bandeirante, em 20 de agosto de 1934 (São Paulo: Editora Revista dos Tribunaes, 1934) figura na Biblioteca de MA, no IEB/USP; o exemplar contém dedicatória do autor.

P. 110:

Nota MA: comentário:

"A pobreza de imaginação dos nossos ro-/manticos. Imaginação romantica sobretudo, I de criar fatos, inventar episodios. Sobretudo / pros poemas. Na imagem Castro Alves 
apenas / brilha um pouco mas de brilho falso por-/que a maioria das vezes forçado, muito em-/bora mesmo dentro da imagem forçada / alcance uma ou outra vez verdadeira / força de expressão como em //

\section{Porque a Inglaterra é um navio}

Que Deus na Mancha ancorou

Distinguir o exagero de imagem expressio-/nista (dar exemplos dos mestres de todas / as épocas "o vento senta no ombro das / velas" (Shakespeare) e o exagero condoreiro. Alquele expressivo duma excessiva sensibili-/dade que explode, este nas mais das vezes, I pura criação intelectual. $O$ expressionismo é / a realidade reforçada, o condoreirismo / é a idealidade reforçada, sua base não es-/tá no real está na ideia."

Nota da pesquisa: MA recorre à mesma imagem de Shakespeare no "Prefácio interessantíssimo", para respaldar, no cânone, o emprego de exageros em sua poesia: " $O$ vento senta no ombro das tuas velas!' Shakespeare. Homero já escrevera que a terra mugia debaixo dos pés de homens e cavalos. Mas você deve saber que há milhões de exageros na obra dos mestres." (ANDRADE, Mário de. "Prefácio interessantíssimo", In: Pauliceia desvairada. Poesias completas. Ed. cit., vol. 1, p. 64).

\section{P. $111-138$}

CANTO QUARTO (30 estrofes)

P. 118:

Nota MA: versos destacados por traço vertical e juízo de valor:

“Adoravel” $\begin{aligned} & \text { Quadro sublime! Sobre dura pedra, } \\ & \text { Qual primorosa estatua levantada } \\ & \text { Por mãos agradecidas, radiava } \\ & \text { Do divino Jesus a bella imagem; } \\ & \text { Prosternado a seus pés, tranquillo, humilde, } \\ & \text { Em muda adoração, fitos os olhos } \\ & \text { Nos olhos do Senhor, d'onde cahira } \\ & \text { A luz da salvação sobre su'alma, } \\ & \text { O possesso de outr'ora descansava. } \\ & \text { Aqui, alli, silentes, os discipulos, } \\ & \text { Irmãos amadaos que uma idéa anima, } \\ & \text { De ineffavel amor embevecidos, } \\ & \text { Contemplavam sorrindo o grande Mestre. }\end{aligned}$

Nota da pesquisa: A página abona a rubrica "Passagens bonitas", no fichamento crítico da poesia de Fagundes Varela (MA-MMA-05-05).

P. 121:

Nota MA: comentário ao final do trecho IX:

"Muito bom. Porem o outro poema Ave Maria ainda é milhor." 
Nota da pesquisa: O comentário é transposto para o fichamento crítico das obras de Fagundes Varela, através da inclusão desta página na lista de "Passagens bonitas". "Ave, Maria" abona a rubrica "Obras-primas" (MA-MMA-05-05).

P. 122:

Nota MA: expressão sublinhada e expoente “(1)” remetendo ao comentário no rodapé:

“(1)” Aves de Deus, as virgens e as creanças

Adormecem risonhas, occultando

Nas azas da innocencia as frontes santas...

"Citar esta imagem ao lembrar a predileção / dos romanticos pelas virgens $e$ virgindades."

2. versos destacados por traço vertical e escólio - estudo da psicologia: remorso:

“Remorso" $\mid \begin{aligned} & \text { Não ha luz que afugente as trevas d'alma! } \\ & \text { Nos vapores do vinho e nos banquetes, } \\ & \text { Nas orgias febris, nos jogos loucos } \\ & \text { Um momento se abranda e se entorpece } \\ & \text { O verme dos remorsos... Mais faminto } \\ & \text { Acordará nas horas do silencio. }\end{aligned}$

3. escólio assinalando o trecho XII, "Episódio de Salomé" - seleção de imagens:

XII

"Episodio de Os primores da Europa, o luxo d'Asia,

Salomé” O fausto d'esta, a profusão d'aquella

De Herodes o palacio aformoseiam.

Nota da pesquisa: "Varela, num passo do Evangelho nas Selvas (IV, 11), funde as virgens e as crianças, pra chamar-lhes 'aves de Deus'!", observa MA em "Amor e medo". O respeito à mulher - encarado como "primeira grande lateralidade em que a timidez de amar se fixa nos românticos" - faz com que as mulheres sejam transmutadas em "anjo, virgem, criança, visão", segundo o crítico. No fichamento das obras de Fagundes Varela, as imagens colhidas nesta página municiam a rubrica "A mulher pra V." (MA-MMA-05$05)$.

P. 124:

Nota MA: termo sublinhado, "cadencia”, escólio e anotação - pesquisa para o Dicionário musical brasileiro:

Escrava da cadencia, mas senhora

Dos requebrados, languidos meneios, "dic

sentido

metafórico"

P. 125:

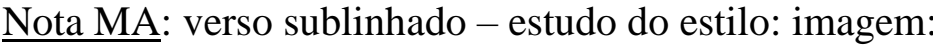


Cahe, petala de rosa, aos pés de Herodes.

Nota da pesquisa: MA refere esta página no fichamento crítico das obras de Fagundes Varela, na rubrica "Imagem" (MA-MMA-05-05).

P. 130:

Nota MA: crase corrigida, “á” - correção tipográfica:

Rende graças a amasia de teu amo, lá

Está findo o teu triste captiveiro!

P. 132:

Notas MA:

1. verso sublinhado, retângulo destacando a sílaba final de "discípulos" e comentário ao final do trecho:

Esta inaudita atrocidade assombra

Os discipulos de João. Mudos, errantes,

Chorando a ausencia do inspirado mestre,

E prevendo, talvez, igual destino,

Buscam as mais remotas soledades,

E depois de trabalhos excessivos,

De amargos soffrimentos, se dirigem

Da Galiléa ás placidas campinas,

Procurando Jesus e seus amigos.

"Talvez depois de Flaubert e de Wilde isto viesse mais / tolamente fantasiado"

2. expressão sublinhada, versos destacados por traço vertical e escólio - seleção de ideias:

"Transfiguração"

Meia noite!... Hora lugubre e sinistra!

Quando entre a lua e a sombra, vacilante,

Junto ao marco de bronze, pára o tempo,

Notas da pesquisa: Gustave Flaubert (1821-1880) e Oscar Wilde (1854-1900) estão representados na Biblioteca de MA no IEB/USP. O exemplar de Trois contes (Paris: Nelson Éditeurs, s. d.) possui dois trechos sublinhados. Em "Un coeur simple", MA destaca a grafite: "Les flots endormis, en tombant sur le sable, se déroulait le long de la grève". Em "La légende de Saint Julien l'Hospitalier", assinala: "Des rides énormes labouraient son front." (Notas MA, In: Trois contes, ed. cit., p. 35 e 184). As notas parecem revelar o interesse do polígrafo pela personificação: o narrador atribui um estado anímico à onda, assim como dinamiza as rugas da personagem, dotando-as de atitude. $\mathrm{O}$ conto "Hérodias" não contém notas de margem.

De Wilde são seis os títulos que compõem o acervo de MA: De profundis and The ballad of Reading gaol (Leipzig: B. Tauschnitz, 1908), Intentions (Londres: Methuen \& Co., 1913), Salomé; A florentine tragedy (Londres: Methuen, 1918), Poems of Oscar Wilde with The ballad of Reading gaol (Londres: Methuen, 1919), Salomé: drame en un acte (Paris: n. i., 1920) e Uma tragedia Florentina: drama num acto (Rio de Janeiro: America Brasileira, 1924). No exemplar de 1919, MA anota, nos versos de "The ballad 
of Reading gaol", sinônimos em inglês para termos que desconhece (V. Notas MA, In: Poems of Oscar Wilde, ed. cit., p. 277-303).

P. 135:

Nota MA: comentário ao final do trecho XXVII:

"Não está ruim. Mesmo era dificil / fazer milhor"

P. 137:

Nota MA: verso sublinhado e retângulo destacando a sílaba final de "discípulos" - estudo linguístico/estudo da versificação: métrica:

Dos discipulos os doze que elegera

$\underline{\text { P. } 139-166}$

CANTO QUINTO (15 estrofes)

P. 141:

Nota MA: verso sublinhado e expoente “(1)” remetendo ao comentário no rodapé estudo da psicologia: natureza:

\section{Oh Natureza! O’ Gloria do Universo! “(1)”}

“(1) É incontestavel o amor de Varela pela / natureza. É possivel que a sentisse. Mas como / romantico tudo deforma e idealiza. Porem / o volume <conjectural> de dons descritivos, raro lhe codaqui-/za a graça real, raro a descreve num / traço vivaz e mesmo raro a idealiza sem / monotonia e vulgaridade. Pauperrimo de imaginação e de saber, mesmo descrevendo / a natureza só vali a infinita doçura do / seu verso, porventura o mais doce verso-li-/vre. Acontece que Alvares de Azevedo e G. Dias / menos perfeitos no verso-livre como musicali-/dade, graça e doçura são superiores a Vare-/la porque mais ricos de expressão e mais /varios. Afinal a propria excessiva doçura / acaba por cansar."

Nota da pesquisa: A "Atração da natureza", comentada por MA, é incluída no fichamento crítico das obras de Fagundes Varela, no dossiê do manuscrito Amor e medo (MA-MMA05-05). Em 29 de março de 1931, nas páginas do Diário Nacional, MA formula a ideia do extremo monocronismo romântico, "que plantou em nosso jardim milietas de manacás, esquecido que havia outros arbustos florais". O monocrismo manifesta-se, igualmente, na "falta de sentimento da natureza", o que contrasta com a percepção expressa na nota de margem, sobre o "incontestável amor de Varela pela natureza" e a possibilidade de que a sentisse (ANRADE, Mário de. "Álvares de Azevedo - II", In: Táxi e Crônicas no Diário Nacional. Ed. cit., p. 359 e 361).

\section{P. 142:}

Notas MA:

1. versos destacados por traço vertical e escólio:

"Refrão" $\quad\left(\begin{array}{l}\text { E dirigil-a ao peito! Ó Natureza! } \\ \text { Musa da creação! Mãi compassiva } \\ \text { Dos simples corações, das almas puras! }\end{array}\right.$


2. termo corrigido, "tristes" - correção tipográfica:

Quando os sabios dormiam, tu vieste

Em socorro dos triste! Carinhosa "/es"

P. 144:

Notas MA:

1. trecho sublinhado, escólio, “G. Dias”, e seta ligando à nota seguinte - seleção de ideias: preparação do romance;

2. trecho sublinhado, escólio, “C. Alves”, e expoente "(1)” remetendo ao comentário no rodapé:

“G. Dias" $\quad$ Ossos, carnes, tremi!...

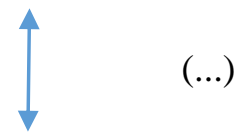

“C. Alves" (1) E o tigre e a presa agonizando juntos,

"(1) Amar, Verbo Intransitivo: 'Afinal F. Varela / é que acertou bem quando explicou indiretamente / no Evangelho da Selva 'o verso' Mas está entendido / que trata-se de Castro Alves. Pois..."

Notas da pesquisa:

1. Esta página figura como exemplo final da rubrica "Reminiscencias", no fichamento crítico das obras de Fagunges Varela. Nela, MA reúne trechos da poesia de Varela que evocam outros poetas do romantismo brasileiro (MA-MMA-05-05).

2. O narrador de Amar, verbo intransitivo refere-se ao poema "A Queimada", de Castro Alves, em meio ao longo comentário que contrasta a psicologia racial de japoneses e alemães (representados no romance/idílio pelos empregados da família Souza Costa, Tanaka e Elsa): "Castro Alves cantava que na última contingência da calamidade, quando a queimada galopa destruindo matos, sacudindo as trombas curtas de fogo no ar, a corça e o tigre vão se unir na mesma rocha. Não sei em que país do mundo Castro Alves viu a 'Queimada' dele... Talvez nalgum Éden bíblico ou nas bíblicas proximidades da moradia de Tamandaré, depois do dilúvio. [...] De mais a mais confesso que não vejo, entre os brutos escolhidos por Castro Alves para o mesmo habitat conciliatório, mais que antítese inócua, nem são tão opostos assim! Mais inimigos ainda, mais muitos mais! são o tigre e o tigre" (ANDRADE, Mário de. Amar, verbo intransitivo. Estabelecimento de texto e apresentação de Marlene Gomes Mendes. Rio de Janeiro: Nova Fronteira, 2013, p. 77). MA não deixa comentários à margem do poema "A Queimada", no corpus da pesquisa; assinala apenas o emprego do "para", estudo linguístico, e o "estampido" das queimadas, parte de sua pesquisa para o Dicionário musical brasileiro (Nota MA, In: ALVES, Castro. Obras completas. Ed. cit., vol. 2, p. 144).

P. 146:

Notas MA:

1. trecho sublinhado - seleção de ideias:

Assim elle ficou!... Do pobre leito

Tudo eu via e sentia! $\underline{O \text { mar de sombras }}$

Tambem cahiu então sobre minh'alma 
2. versos destacados por traço vertical;

3. termo sublinhado, "tangeres", escólio "dic" e comentário - pesquisa para o Dicionário musical brasileiro:

Doces, ternas canções acompanhadas

De tangeres estranhos, resoavam "dic"

Por aquelles sertões. Era distante,

“dic / Varela / costumava / substanti / var tan-/geres. Por / 2 vezes / já no / Evangelho”

P. 147:

Notas MA: expoente “(1)” remetendo ao comentário no rodapé:

Pouco tempo depois ergueu-se. - Vamos,

Disse enxugando os olhos lacrimosos,

Nossos irmãos esperam-nos inquietos. "(1)”

“(1) Este intermedio do sonho de Nahyda é bem / feito. Enfim com Varela encontra a gente um / romantico que sabe contar as coisas. O Evangelho / das Selvas é todo admiravelmente relatado."

Nota da pesquisa: MA relaciona esta página na entrada "Falso descritivo", no fichamento crítico das obras de Fagundes Varela (MA-MMA-05-05).

P. 151:

Notas MA: trecho sublinhado - estudo do estilo: imagem / estudo da psicologia: medo de amar plasmado à natureza:

Vai alta a noite. As pallidas estrellas

Medrosas da manhã que se approxima,

Apagam-se no azul do firmamento.

P. 153:

Nota MA: versos destacados por traço vertical e escólio, "Suavidade":

Qual fino tapete ou verde relva,

Firme, de pé, o rosto resplendente,

Jesus caminha sobre a lisa face

Do lago adormecido. Ao vel-o calmo,

Meio vendado pelas brancas nevoas,

Dir-se-hia que as aguas crystallinas

Tinham-se congelado, ou braços d'anjos

Invisiveis sustinham sobre o abysmo

Seu purissimo corpo. As longas vestes

$\mathrm{Na}$ fria superficie enxutas roçam,

Nem um respingo molha-lhe as sandalias

"Suavidade"

Que fundos frisos sobre as aguas deixam

A cada movimento; auras suaves

Agitam-lhe os cabellos mansamente

E nas dobras do manto alegres brincam,

Um meigo olhar, um candido sorriso 
Animam-lhe o semblante gracioso.

Nota da pesquisa: A rubrica "Musicalidade" acolhe referência a esta página no fichamento crítico das obras de Fagundes Varela (MA-MMA-05-05).

P. 161:

Nota MA: termo corrigido, "parábolas" - correção tipográfica:

Continúa Jesus propondo ainda

Mais algumas parablas singelas $\quad$ /bo

P. 163:

Nota MA: verso sublinhado - estudo do estilo: repetição:

Grande no vicio e grande na opulencia;

P. 166:

Notas MA:

1. verso sublinhado e escólio "Sol" - estudo do estilo: imagem / estudo da psicologia: atração da natureza:

"Sol" O glorioso principe dos astros

2. comentário no rodapé:

"É dos cantos mais fracos. Varela não / soube aproveitar as parabolas e os / milagres de Jesus."

Nota da pesquisa: MA alude ao trecho assinalado nesta página, sob a rubrica "Imagem", no fichamento crítico das obras de Fagundes Varela (MA-MMA-05-05).

P. $167-191$

CANTO SEXTO (15 estrofes)

P. 169:

Notas MA:

1. pontuação corrigida - correção tipográfica:

E as grimpas da floresta, e já formosa. ,

Embora descorada, se equilibra

2. termos sublinhados, "gandras" e "lezirias", e expoente "(1)" remetendo ao comentário na margem superior:

"(1) A falta absoluta de cor local apesar de / nos trechos referentes aos indios e natureza I brasilica apesar de Varela mais ou menos ter / essa cor local noutros poemas dele."

Junto do eremiterio, sobre as gandras

E $\underline{\text { lezirias }}{ }^{(l)}$ visinhas? Porventura 
Novos perigos e afflicções aguardam?

Nota da pesquisa: O comentário agrega objeções ao caráter "Patriotico e brasileiro", caracterizado por MA no fichamento crítico das obras de Fagundes Varela (MA-MMA05-05).

P. 171:

Notas MA:

1. comentário ao final da parte II:

"Varela não tem a palheta de G. Dias e C. Alves / pra descrever coisas terriveis e feitos de guerra / e horror. A própria doçura que tem o prejudica."

2. escólio "Lázaro":

Ora, depois dos factos mencionados

No ultimo serão, factos sublimes

Que eternos viverão no pensamento

"Lázaro" Das gerações remidas no Baptismo,

Perseguido o Senhor pelos tyrannos,

Retira-se a Bethania, aldeia humilde,

Onde Martha e Maria afflictas choram

Junto do pobre irmão, Lazaro, enfermo

Nota da pesquisa: A rubrica "Falso descritivo" contém indicação à página, no fichamento crítico das obras de Fagundes Varela (MA-MMA-05-05).

\section{$\underline{\text { P. } 173}$}

Notas MA:

1. versos destacados por traço vertical - estudo do estilo: narração;

2. trecho sublinhado e escólio, "Sol" - estudo do estilo: imagem / estudo da psicologia: atração da natureza:

3. versos destacados por traço vertical e expoente “(1)”, remetendo ao comentário no rodapé - estudo do estilo: imagem:

E chegaram emfim, tarde, bem tarde!

Já quatro vezes expellira o dia

Os lemures da noite, e quatro vezes

A noite pavorosa desfraldára

O pavilhão de sombras pelo espaço!

Já quatro vezes sob o olhar de fogo,

Implacavel olhar que tudo alcança

Do arbitro da luz, sobre si mesma,

Hydra captiva, se volvêra a terra,

Procurando romper o circo immenso

Das doze colossaes bronzeas muralhas!

E Lazaro dormia e não sonhava

Em seu leito de pedra, horrido leito,

Onde os vermes sómente não repousam!...

Quando, deixando o corpo, a alma divina

Libra-se logo aos pés do Omnipotente

Laureada de esplendidas virtudes,

"Sol" 
Brilhante de innocencia, a morte é bella!

$\mathrm{Na}$ face da materia inanimada

Ficam ainda placidos vestigios

D'aquella que passou. È bello sempre

O cadaver do justo, embora triste,

Um quê de intelligente, um quê de nobre

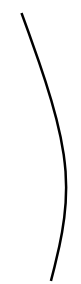

“(1) Uma certa eloquencia epica de vez em / quando ainda se nota em Varela como nesIte lindo passo. Nos parece efeito de mero aca-/so, excepção na obra dele."

Nota da pesquisa: As rubricas "Imagem" e "Musicalidade" guardam remissão à página no fichamento crítico das obras de Fagundes Varela, dossiê do manuscrito Amor e medo (MA-MMA-05-05).

P. 174:

Nota MA: versos destacados por traço vertical e comentário:

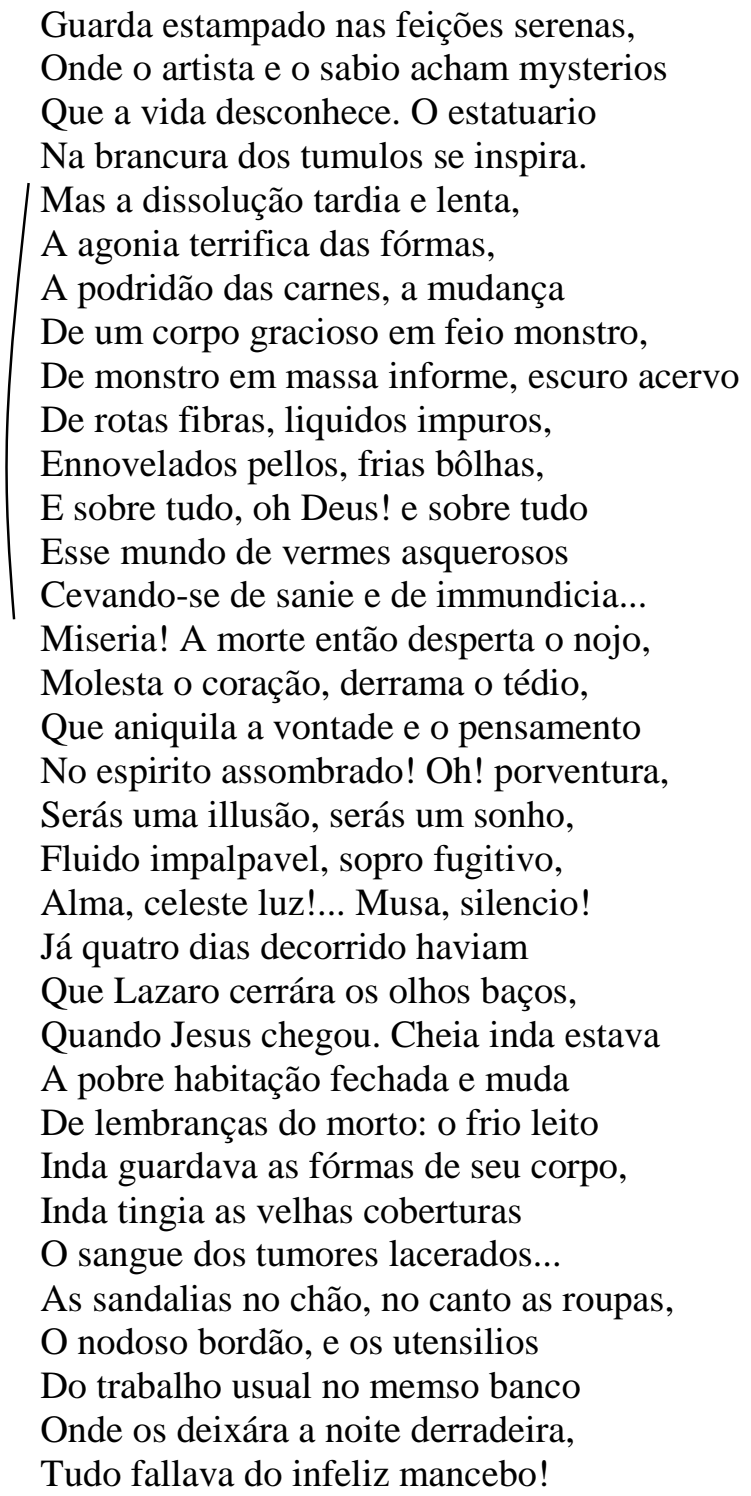

"Esta nenia é magistral. Belissima / e de rara energia. A propensão de Varela / prás nenias..." 
Nota da pesquisa: A propensão destacada por MA na marginália traslada-se para o fichamento crítico das obras de Fagundes Varela, na rubrica "Elegíaco" (MA-MMA-0505).

P. 175:

Nota MA: versos destacados por traço vertical - estudo do estilo:

V

Como o clarão de solitaria estrella

Entre os feios bulcões da tempestade

Consola os transviados navegantes

Na vastidão dos mares ominosos,

O doce aspeito do divino Mestre

Reanimou as decahidas frontes

Das lacrimosas, pallidas mulheres.

- Ah! se aqui fôras, dizem suspirando,

Não fenecera nosso irmão tão cedo,

Teu amigo, Senhor! Mas tudo pódes,

O que a teu Pai pedires será feito! -

- Não vos entristeçais, - responde Christo,

Elle ha de ressurgir. - No fim dos tempos,

No dia horrendo do juizo eterno,

Meu Deus, eu bem o sei! - Maria exclama.

- Sou a ressurreição, a excelsa gloria,

Prosegue o Salvador, - fonte da vida,

Quem ouve minha voz, sepulto, embora,

Triumphará da morte; o que respira,

E sente, e pensa, e crê, durma tranquillo,

Jamais perecerá! — Onde puzeste

$\mathrm{O}$ frio corpo desse pobre amigo? -

- Vem, e verás, responde a ingenua Martha.

Depois chamando a irmã silenciosa

Guia o Senhor ao tumulo de Lazaro,

Negro jazigo entre rochedos fundos.

VI

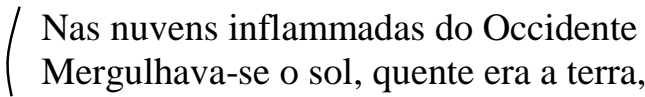

Nota da pesquisa: Os versos assinalados abonam a entrada "Passagens bonitas", no fichamento crítico da poesia de Fagundes Varela (MA-MMA-05-05).

P. 176:

Nota MA: versos destacados por traço vertical - seleção de ideias:

E os pincaros dos montes escabrosos,

$\mathrm{E}$ as grimpas dos salgueiros e cyprestes,

Ao purpureo clarão do céu do estio

Pareciam de sangue borrifados.

Um longinquo trovão, rouco, sinistro, 
Tredo como o bramir das grandes onças

Nas amplas furnas de fragosas serras,

Soava nas extremas do horizonte.

Nem uma leve aragem pelos campos!

Nem o piar de um passaro nas frondes

Dos bastos olivaesl Nem o balido

De uma ovelha medrosa nos outeiros!...

Então Martha parou mostrando a gruta

Onde jazia o irmão: - Eis o sepulchro,

Senhor, de vosso amigo! Ardente pranto

Corria-lhe dos olhos; arredada,

Maria soluçava entre os arbustos.

Bem no fundo da lapa cavernosa,

Frio abrigo das aves agoureiras,

Avuttava entre lugubres rochedos

O túmulo de Lazaro. Na sombra,

"Imagem" / Como um gênio cativo, murmurava

Occulto veio d'agua; sobre a lousa

Cruzava-se agitando as azas frouxas

Um turbilhão de stryges e morcegos,

Hybridos filhos dos trevosos antros;

De lado a lado esverdeadas penhas,

Broncos pedaços de granito escuro

Alongavam-se, rudes, como os dorsos

De feios crocodilos que guardassem

Furna de pavorosos maleficios.

Nota da pesquisa: Os dois versos acompanhados do escólio "Imagem" ilustram a rubrica homônima no fichamento crítico das obras de Fagundes Varela (MA-MMA-05-05).

P. 177:

Notas MA:

1. versos destacados por traço vertical e escólio - estudo do estilo: descrição:

"Imagem" $\quad \begin{aligned} & \text { Porém a vasta cupula celeste, } \\ & \text { Momentos antes abrazada forja, } \\ & \text { De pesada caligem se cobria: }\end{aligned}$

2. termo corrigido, “areia" - correção tipográfica:

Nuvens de areias erguendo pelo espaço. $\quad / x$

3. verso sublinhado - seleção de ideias:

Quem, anjo ou santo, mereceu tal premio?

Nota da pesquisa: MA elenca a página na rubrica "Falso descritivo", no fichamento crítico das obras de Fagundes Varela, no dossiê do manuscrito Amor e medo (MA-MMA-0505).

P. 178:

Nota MA: comentário ao final da parte VII: 
"Neste caso de Lazaro está talvez um dos / mais belos passos de toda a obra de /Varela."

Nota da pesquisa: A avaliação de MA consolida-se no fichamento crítico das obras de Fagundes Varela, que indica esta entre as "Obras-primas" (MA-MMA-05-05).

P. 183:

Nota MA: pronome sublinhado, "me", e cruzeta - estudo linguístico: colocação pronominal:

Sobre o ousado judeu. Me interrogaste

$X$

Em nome do Senhor... cala-te e escuta:

P. 184:

Notas MA:

1. termo sublinhado, “ao", e expoente "(1)” remetendo ao comentário no rodapé;

2. verso sublinhado - seleção de ideias:

E rudes publicanos, jubilosos,

Viram cahir a venda enganadora

Que lhes furtava a luz, e se curvaram

“(1)" $\quad$ Ao sublime estandarte do Evangelho!

Porém, negra loucura! os sacerdotes,

Contumazes no erro e na mentira,

Concertaram, crueis, tirar a vida

Áquelle que o Senhor tinha salvado!

A tanto a inveja e o odio se abalançam!

“(1) Como esta regencia mal feita, ao em vez de ante, por / varias vezes Varela já tem errado contra o portugues por / necessidade de metrica, verbos intranzitivos tranzitivados / etc."

3. conjunção corrigida, "e" - correção tipográfica:

Cheias de flôres, de frescura a sombra, /e

Nota da pesquisa: MA abriga este comentário sobre a fatura dos poemas sob a rubrica "Artista", no fichamento crítico das obras de Fagundes Varela (MA-MMA-05-05).

P. 186:

Nota MA: escólio "Fé Esperança e Caridade":

"Fé Esperança XIII

$e$

Caridade” Mas silencio? Lá fóra entre as rajádas

Indomitas do vento, tristes queixas

Se fizeram ouvir; depois no alpendre

Maviosas palavras resoáram.

- Dá-nos abrigo, oh Virgem gloriosa,

Que sahimos de longe e te buscamos!

Maria estremeceu: era tão meiga,

Tão doce a flébil voz que lhe fallava,

E tão medonha a noite, o céo tão negro, 
Tão funda a escuridão, que levantou-se,

Tomou o largo manto e abriu a porta.

Indizivel surpresa! Excelsa gloria!

Trez lucidas irmãs, trez mensageiras

Das regiões supremas, penetraram

No hospitaleiro asylo da virtude

P. 193-224

CANTO SÉTIMO (18 estrofes)

P. 196:

Nota MA: termo sublinhado, "cantilenas", e escólio "dic" - pesquisa para o Dicionário musical brasileiro:

“dic" Trazem da terra firme as cantilenas

Dos sanguinarios, rudes fetichistas!...

P. 199:

Nota MA: expoente “(1)” ao final da parte II, remetendo ao comentário no rodapé:

Franqueia á luz as portas do Oriente.

Salve, ethereos clarões da madrugada!

Brilhantes arrebóes, aragens brandas,

Silphos travêssos do deserto, salve! "(1)"

“(1) Esta evocação é ruim e francamente não tem / nada com a historia. As proprias interrupções do re-/conto biblico até aqui prejudicam a inteireza da con-/cepção, monotonizam o entrecho. O interesse descai."

Nota da pesquisa: A rubrica "Mau gôsto", no fichamento crítico das obras de Fagundes Varela, contém referência à página (MA-MMA-05-05).

P. 201:

Notas MA:

1. verso sublinhado e expoente “(1)”, remetendo ao comentário no rodapé:

Vamos... E entraram na ermida um após outro.. "(1)”

“(1) Curioso verso livre em que o Vamos está / solto, o resto formando um decassílabo em / que os dois ê iniciais não se fundem."

2. versos destacados por traço vertical e comentário perpendicular ao texto:

Como desfeita está! Como caminha

A filha do sertão, triste e abatida

Pela seva doença! Desbotaram

No gracioso rosto as bellas rosas,

Emblemas da viçosa mocidade,

Acabou-se a frescura de seus lábios,

E a luz suave dos fagueiros olhos 


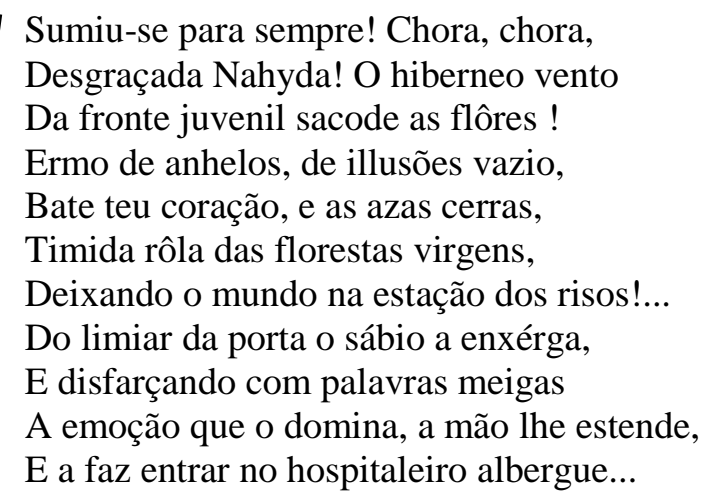

"Ora sebo! que vem / fazer esta Nahyda misteriosa / e sem valor no poema!"

Nota da pesquisa: A interjeição indignada é conduzida por MA ao fichamento crítico das obras de Fagundes Varela, onde consta sob a entrada "Mau gôsto" (MA-MMA-05-05).

P. 206:

Notas MA: verso sublinhado e cruzeta - seleção de ideias:

$X \quad \underline{\text { Os conceitos das antigas prophecias }}$

P. 215:

Notas MA:

1. verso sublinhado - estudo do estilo: artifício / repetição:

O que provém do tempo o tempo guarda,

2. adjetivo corrigido, "tristes" - correção tipográfica:

Nota da pesquisa: Exemplo da "inteligência sensível" de Fagundes Varela, conforme consta do fichamento crítico de suas obras, no dossiê do manuscrito Amor e medo (MAMMA-05-05).

P. 225-249

CANTO OITAVO (14 estrofes)

P. 227:

Notas MA: verbos sublinhados, cruzeta e expoente “(1)” remetendo ao comentário no rodapé - estudo do estilo:

Buscam de Guanabara. A patria os chama,

Correm a defender a patria afflicta. "X(1)"

Foram-se. No fastigio dos rochedos,

“(1) Formula dos caxinauás. Aqui é / de verdadeiro artista."

Notas da pesquisa:

1. MA alude a esta página como exemplo do caráter "Artista" de Fagundes Varela, no fichamento crítico situado no dossiê do manuscrito Amor e medo (MA-MMA-05-05). 
2. A fórmula dos índios caxinauás é apresentada por MA, em 1925, ao amigo Carlos Drummond de Andrade: "Olhe os índios caxinauás de que Capistrano de Abreu registrou o folclore tinham uma forma sintática duma formidável energia e síntese moderna, que tenho empregado e recomendo ao seu raciocínio. Eles diriam 'Parece que havia um rio, secou', em vez de duas frases como você e toda a gente bota. Exemplo estupendo: 'Quis casar com ela, fiz'. (ANDRADE, Mário de. A lição do amigo: cartas de Mário de Andrade a Carlos Drummond de Andrade, anotadas pelo destinatário. Rio de Janeiro: J. Olympio, 1982, p. 31).

P. 228:

Notas MA:

1. versos destacados por colchete e escólio "zoof” - pesquisa da zoofonia:

De feras erradias, e, entre as junças

Das profundas charnecas, agourentos "zoof" Gritam os jacarés. Horas sinistras

2. termo sublinhado, “eximio", e expoente “(1)”, remetendo ao comentário no rodapé:

Um momento depois, o eximio ${ }^{(1)}$ padre,

Alçando a voz sonoro, continúa

A gloriosa historia do Evangelho.

“(1) Que impropriedade! Certa home-/ricidade parece dum mau / gosto insuportavel.”

Nota da pesquisa: MA reitera a avaliação no fichamento crítico das obras de Fagundes Varela, indicando a página sob a rubrica "Mau gôsto" (MA-MMA-05-05).

P. 230:

Nota MA: versos destacados por traço vertical e expoente "(1)", remetendo ao comentário no rodapé:

$$
\text { “(1)" } \begin{aligned}
& \text { Anjo da solidão, formosa filha } \\
& \text { Das florestas da terra do Cruzeiro, } \\
& \text { Robustas expressões, fieis palavras, } \\
& \text { Para externar o horror do atroz conluio, } \\
& \text { Da intriga infame, do nefando ajuste? } \\
& \text { Da ingratidão de Judas? Porventura }
\end{aligned}
$$

"(1) Com efeito a musa de Varela não achou força / pra 'externar o horror do atroz conluio' nem outros es-/paços ardentes e temerosos do poema. Não era filho / das 'florestas da terra do Cruzeiro'."'

Nota da pesquisa: A deficiência assinalada por MA, no comentário, é acolhida sob a rubrica "Musicalidade", no fichamento crítico das obras de Fagundes Varela (MA-MMA05-05).

P. 231:

Nota MA: versos destacados por traço vertical e expoente “(1)” remetendo ao comentário no rodapé: 


“(1)" $\quad \begin{aligned} & \text { De memorandas eras respeitada. } \\ & \text { Placida e bella nos tranquillos campos } \\ & \text { Estendia-se a tarde, e as lindas flôres } \\ & \text { Que se inclinavam murchas, abatidas, } \\ & \text { Nas bordas dos arroios, levantavam-se } \\ & \text { Rescendentes de aromas aos bafejos } \\ & \text { Das aragens subtis; os passarinhos } \\ & \text { Despediam-se ao longe, nos silvados, }\end{aligned}$

“(1) A todo momento pretexto pra evocações / adocicadas de natureza, descrições moles I sem nenhum relevo."

Nota da pesquisa: O trecho assinalado e o comentário de MA explicam a inclusão da página na rubrica "Atração da natureza", no fichamento crítico das obras de Fagundes Varela (MA-MMA-05-05).

\section{P. 233:}

Nota MA: versos destacados por traço vertical - seleção de ideias:

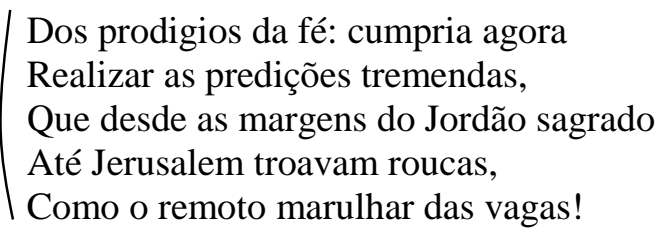

P. 236:

Notas MA:

1. verbo sublinhado e interrogação rasurados - estudo linguístico: colocação pronominal / estudo da versificação: métrica:

O calice de vinho, apresentou-lhes: $\quad ?$

2. verso sublinhado e retângulo assinalando a falta de uma sílaba - estudo da versificação: métrica / anacruse:

Christo suspirou baixando os olhos,

P. 237:

Notas MA: versos destacados por traço vertical e comentário:
É elle o delator. Junto de Christo,
Á dextra, estava João, o mais discreto,
$\mathrm{O}$ mais moço tambem, e o mais formoso
Da caridosa grei; entristecido
Ao ouvir estas lugubres palavras,
Escondera a cabeça graciosa
No seio de Jesus; e as loiras ondas
Dos lustrosos cabellos annelados,
Como um véo de áureos fios, lhe occultavam
As abundantes lagrimas. Bem cedo 
"Lindo / A musical-/lidade de / Varela é / menos obje-/tiva que a / de G. Dias / Porem não / é menos / intensa. Tal-/vez mais até."

Nota da pesquisa: O comentário compõe a rubrica "Musicalidade", no fichamento crítico das obras de Fagundes Varela (MA-MMA-05-05).

P. 248:

Notas MA: termo sublinhado, "livre", e expoente "(1)" remetendo ao comentário no rodapé - estudo do estilo: repetição:

A multidão prostrou-se, livre o pranto

Correu dos olhos d'esses homens livres,

“(1) Este artificio ocorre varias vezes na poeti-/ca de Varela."

Nota da pesquisa: A rubrica "Artista", no fichamento crítico das obras de Fagundes Varela, guarda remissão ao artifício assinalado (MA-MMA-05-05).

P. 249:

Notas MA: comentário ao final da parte XIV:

“(1) Comparar esta morte com a de / Lindoya."

Nota da pesquisa: No fichamento crítico das obras de Fagundes Varela, MA inclui esta página na rubrica "Falso descritivo" (MA-MMA-05-05). A pesquisa não localizou nenhum título de autoria de José Basílio da Gama (1741-1795) na Biblioteca de MA.

P. 251-287

CANTO NONO (20 estrofes)

P. 253:

Notas MA:

1. expressão sublinhada e escólio, "Sol" - estudo do estilo: imagem;

2. versos destacados por traço vertical e expoente "(1)" remetendo ao comentário no rodapé:

“(1)” $\quad\left(\begin{array}{l}\text { Rubro como um baixel incendiado } \\ \text { No procelloso mar, como a cratéra } \\ \text { De inflammado vulcão na raia escura } \\ \text { De longincuo horizonte, ou como o vulto } \\ \text { De condemnada esphera que declina } \\ \text { Para jámais surgir, o rei dos astros } \\ \text { Esconde-se nos terminos do occaso. }\end{array}\right.$

“(1) Varela tem a mania de não se contentar / com uma só comparação pra uma coisa. Por va-/rias vezes (duas ou tres) isto já se deu neste poema alem / desta. Na celebre nenia tambem naquele passo "Pomba, / varou-te a flexa do destino" etc."

Nota da pesquisa: A imagem do sol é transpota para o fichamento crítico das obras de Fagundes Varela, onde a página é referida duas vezes (MA-MMA-05-05). 
P. 255:

Notas MA:

1. versos destacados por traço duplo - seleção de ideias:

Do misero Jadir! Ha soffrimentos

Como os segredos da famosa esphinge,

Cumpre deixal-os no mysterio envoltos!...

2. expoente “(1)” remetendo ao comentário no rodapé:

Do guerreiro infeliz. Lhano responde

Ás saudações benevolas do povo;

Senta-se, e alçando a voz, distincta e clara,

Continúa a narrativa:

"(1) O episodio de Nahida complicado com o aparecimento / inutil deste Jadir romantico ainda mais acentua a mono-/tonia das interrupções. Serve para acentua-la."

2. expoente “(2)” remetendo ao comentário no rodapé:

Dos rancorosos padres e juizes,

Embusteiros legaes, nobres verdugos,

Illustres carniceiros, revestidos

“(2) As interrupções dão lugar a recapitulações, sinteticas, / irritantes que nem as que aparecem no inicio de cada / episodio dos filmes seriados."

Notas da pesquisa: O fichamento crítico das obras de Fagundes Varela alude a esta página em duas rubricas - "Artista" e "O inteligente sensível" (MA-MMA-05-05).

P. 256:

Nota MA: expressão sublinhada e fio ligando suas três ocorrências - estudo do estilo: repetição:

Jerusalém dormia. Entre os palacios,

As riquezas dos príncipes romanos,

As pontifícias galas, e a penuria,

A vil degradação da infima plebe;

Entre os vastos salões, as lautas mesas,

Os bellos camarins, os fofos leitos,

E os tugurios fumosos, negros, frios,

Os farrapos nojentos, as lareiras

Apagadas, vazias; rcsomnava

A geração de escravos e mendigos,

Em cujas veias circulava ainda

O sangue dos austeros patriarchas!

Jerusalém dormia. A raça impura,

Que outr'ora livre e farta no deserto,

Chorava pelo duro captiveiro

Das regiões do Egypto, e suspirosa

Lembrava-se das ôlhas abundantes,

E das amplas despensas e cozinhas

Do grande Pharahó... a raça estulta, 


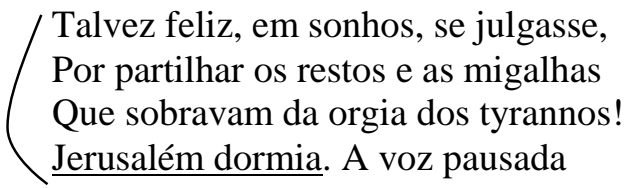

Nota da pesquisa: A rubrica "Artista" repercute o trecho assinalado, no fichamento crítico das obras de Fagundes Varela, no dossiê do manuscrito Amor e medo (MA-MMA-05$05)$.

P. 258:

Nota MA: trecho sublinhado - estudo da psicologia/do estilo:

Pergunta o que ha de novo... - Pobres turbas

Que tomam por verdade a propria sombra!

Nota da pesquisa: Exemplo coletado por MA para retratar Fagundes Varela como "O inteligente sensivel", no fichamento crítico de suas obras (MA-MMA-05-05).

P. 259:

Nota MA: particípio corrigido, "Impelido" - correção tipográfica:

/I $\quad$ Ұmpellido e espancado como a féra

P. 262:

Nota MA: expressão sublinhada e escólio, "Sol" - estudo do estilo: imagem:

"Sol" $\quad$ O rei das estações. No grande pateo

Nota da pesquisa: A imagem é trasladada por MA para o fichamento crítico das obras de Fagundes Varela, sob a rubrica "Imagem" (MA-MMA-05-05).

P. 264:

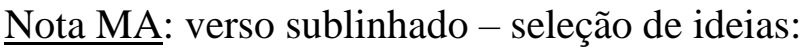

De uma fraqueza quasi que perfidia,

P. 267:

Nota MA: termo corrigido, "desfolhadas" - correção tipográfica:

Cahiram desfolhades no tapete... $\quad / a$

P. 271:

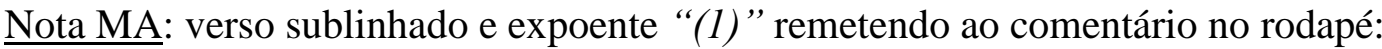

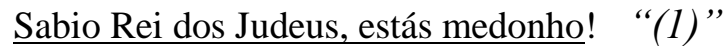

“(1) Até que enfim uma frase viva, for-/te."

Nota da pesquisa: A rubrica "Falso descritivo" remete à página, no fichamento crítico das obras de Fagundes Varela (MA-MMA-05-05). 
P. 273:

Nota MA: versos destacados por traço vertical e expoente "(1)" remetendo ao comentário no rodapé - estudo do estilo: imagem:

“(1)” $\quad \begin{aligned} & \text { Vacillou um instante: assim nos ermos } \\ & \text { Dobra-se e geme o delicado arbusto, } \\ & \text { Quando de arvore antiga um velho galho } \\ & \text { Verga e lhe opprime os ramos florescentes; } \\ & \text { Assim nas solidões se inclina o cervo, } \\ & \text { Quando de funda gruta a pedra solta } \\ & \text { Róla, e o dorso lhe curva macerado. }\end{aligned}$

“(1) Outra vez 2 comparações prá mesma / coisa.”

Nota da pesquisa: A duplicidade da imagem converge para o fichamento crítico das obras de Fagundes Varela - rubrica "Imagem" (MA-MMA-05-05).

P. 276:

Nota MA: verso sublinhado e retângulo assinalando a falta de uma sílaba - estudo da versificação: métrica/ritmo:

\section{Erguel Christo pelos frouxos braços,}

P. 277:

Nota MA: versos destacados por traço vertical e expoente “(1)” remetendo ao comentário no rodapé:

$$
\text { “(1),”|l } \begin{aligned}
& \text { Solio de santo horror, de santa gloria! } \\
& \text { Pyra da Redempção! Altar do mundo! } \\
& \text { Calvario soberano! Quão medonha }
\end{aligned}
$$

“(1) Metaforas sobre metaforas prá mesma / coisa. Nem Castro Alves!...

Nota da pesquisa: As imagens são recolhidas ao fichamento crítico das obras de Fagundes Varela, no dossiê do manuscrito Amor e medo (MA-MMA-05-05).

P. 278:

Nota MA: expressão sublinhada - estudo do estilo: imagem:

Pulam movidos de secreto fogo

Os levitas da morte; Chriso assaltam,

Nota da pesquisa: MA ilustra a rubrica "Imagem" - rica de exemplos coletados na poesia de Fagundes Varela - com indicação a esta página (MA-MMA-05-05).

P. 280:

Nota MA: verso sublinhado e retângulo assinalando a falta de uma sílaba - estudo da versificação: métrica:

$$
\text { Lançou Christo um brado angustioso: }
$$


P. 281:

Nota MA: termo corrigido, "entranhas" - correção tipográfica:

A vastidão do espaço. A terra treme,

E solta das entrenhas requeimadas " $/ a$ "

P. 285:

Nota MA: versos destacados por traço vertical e comentário:

Entre elles repousou, ceiou contente,

Sentado sobre a areia, ouvindo as queixas

Das águas boliçosas, e os sussurros

Das virações errantes nas folhagens

Das frondosos, antigos arvoredos.

"Vontade de / pôr natureza / em tudo"

P. 287-288:

Nota MA: comentário ao final do "Canto Nono":

"Varela é incontestavelmente o maior artifice do ver-/so branco brasileiro. No que só pode comparar-se com / Basilio da Gama no Brasil e Garret em Portugal. Ver-/dadeiro artista mesmo. Porque embora o encanto do seu verso branco seja intrinsecamente formal e nada de-/pendendo da ideia, do pensamento ou xxxx do liris-/mo psicologico (E é por aqui que um G. Dias e um Alva-/res de Azevedo o superam e mesmo o autor do Colombo, / alem dos dois citados acima) há que distinguir dentro / da forma a sua essencia intima dela, a sua fo es-/quema ideal, metafisico dela, o que se poderia chamar I a inspiração lirica da forma, e a sua realização já pu-/ramente material, nem isso: puramente perfilar, / exterior, a forma da forma enfim. O verdadeiro, / o defeito principal do parnasianismo foi esse de / tomar a forma da forma pela unica manifestação / da forma e cuidarem por isso principalmente da / metrica, da rima. Quanto á preocupação de escrever / portugues de Portugal não derivou propriamente da / recepção parnasiana porem foi um mal que / pandemico na literatura brasileira por toda a $2^{a} /$ metade do sec. 19 e alem. Essa forma da forma até / se poderá a gente poderá afirmar e provar que $G$. Dias / a teve mais exata e perfeita que Varela e nisso é ele, G. Dias com o Bocage (... de Olavo Bilac que pre-/ludiam em nossa língua portuga ao Parna-/sianismo brasileiro. Varela porem tinha mais completa (no fim da vida principalmente: Evan-/gelho das Selvas, Diario de Lazaro) a concepção total / da forma. Alem dessa forma da forma, foi o / que teve mais potente, mais caracteristica sobre-/tudo a materia formal, o que chamei de inspi-/ração lirica da forma. Relembro que estou tra-/tando só do decassilabo branco, a mais usada forma / de exteriorização romantica da poesia de lingua por-/tuguesa. Só mesmo Basilio da Gama e Garret podem-se / comparar a Varela nesse sentido. Em G. Dias, em Alva-/res de Azevedo sobretudo a essencia formal, a inspira-/ção lirica de forma é fugitiva, vaga, nada carac-/teristica e original. Oscila. G. Dias si se pode di-/zer qui é anguloso e seco nessa essencia formal, / transforma-se constantemente, e não por ne I necessidade de expressão (seria então uma qua-llidade essa variabilidade e não defeito). Ora / dulçoroso, ora aguado e mole, ora suave e meigo. I Não tem aquela plasticidade superior, elas-/tica e sensual de Basilio da Gama, não tem a / graça tenue e sobretudo a elegancia de Garret, / (unico romantico verdadeiramente elegante no / seu verso) (carece não confundir elegancia / com a languidez talvez donairosa de Alvares / de Azevedo, de Musset e de Heine). E ainda não / tem a suavidade natural, o verso ligando, cor-/redio; 
perfeitamente bem ajustado, sem um / choque, sem com rarissimo esforço de escoar-se, I de Varela. Sobretudo isso: a doçura, a suavidade / intima sem par, a melodia oral da frase. Tão mesmo / que chega a prejudicar a expressão do grandioso, do aspero / e do horrivel. Pego um passo em que isso se deveria / expressar: (Todo o capítulo XI pg. 270 deste volume). Mesmo / aqui é ainda a suavidade que domina, a melodia / não perde nada do seu bellinismo meigo. Daí o cho-/cante comoventissimo de certas frases, na força ex-/pressiva extraordinaria, quando a ideia adquirindo / vivacidade e maior força, tambem a essencia formal / busca uma ordenação de palavras e vozes mais forte. / Como este 'Sabio Rei dos Judeus está medonho”. (Ci-/tar os 13 últimos versos da pg 271 deste volume.)"

Notas da pesquisa:

1. A rubrica "Artista" remete a esta página no fichamento crítico das obras de Fagundes Varela, documento no dossiê do manuscrito Amor e medo (MA-MMA-05-05).

2. A Coleção MA na Biblioteca do IEB/USP compreende seis títulos de Almeida Garrett (1799-1854), entre os quais a edição das Obras completas, em 28 volumes (Lisboa: Empreza da Historia de Portugal, 1904). MA não deixou marcas de leitura nos vols. II (Lírica de João Minimo - Fabulas e Contos - Sonetos - Odes anacreonticas) e III (Flores sem fructos - Folhas cahidas), dedicados à poesia, onde se podia esperar assinalada a "graça tênue e sobretudo a elegância" do escritor português. Em ambos, a pesquisa encontrou apenas o trabalho de brocas e traças, e um resto de veneno.

P. 289-303

CANTO DÉCIMO / EPílOGO (9 estrofes)

P. 292:

Nota MA: expressão sublinhada, "Nilo Brazileiro”, e escólio/comentário:

Ao norte das uberrimas campinas

Onde desliza o Nilo Brazileiro, "Sempre Oriente"

O grande Parahyba, a quinze leguas

Da florescente aldeia consagrada

P. 293:

Nota MA: verso sublinhado e retângulo assinalando o "g" em "Rerigbá" - estudo linguístico: suarabácti / estudo da versificação: métrica:

Rerigbá feliz! Almo retiro,

Onde das lidas repousou do mundo

P. 295:

Notas MA:

1. trecho sublinhado nos versos e escólio "Oriente" - estudo do estilo: imagem;

2. versos destacados por traço vertical e expoente "(1)" remetendo ao comentário no rodapé:

Como se ostenta altivo o cedro umbroso

No seio da floresta... a massa enorme

De pesado granito nas montanhas...

O crocodilo dos juncaes espessos 
"Oriente" Das charnecas de Lybia... equiparados

“(1) Comparações e comparações. Varela tinha a / tortura da insuficiencia expressiva das metafo-/ras e comparações? Não é provavel pois que tão raro / foi expressivo at descrevendo."

Nota da pesquisa: A rubrica "Imagem", no fichamento crítico das obras de Fagundes Varela, contém referência a esta página (MA-MMA-05-05).

P. 296:

Nota MA: trecho sublinhado - estudo do estilo: imagem:

A luz, a luz, a imagem da esperança!

A condição suprema da belleza!

Nota da pesquisa: O trecho abona a entrada "Imagem", via remissão de página, no fichamento das obras de Fagundes Varela (MA-MMA-05-05).

P. 298:

Notas MA:

1. termo corrigido, "repouso" - correção tipográfica:

uso

Seguem-se alguns momentos de repo-ä

2. expressão sublinhada - seleção de ideias;

D'essa fascinação da Eternidade,

Que paralysa as forças da materia

3. comentário ao final do capítulo:

"Este cap. VI é magistral."

Nota da pesquisa: Passagens incluídas por MA nas rubricas "Religiosidade" e "Obrasprimas", no fichamento crítico das obras de Fagundes Varela (MA-MMA-05-05).

P. 302:

Nota MA: versos destacados por traço vertical duplo - seleção de ideias:

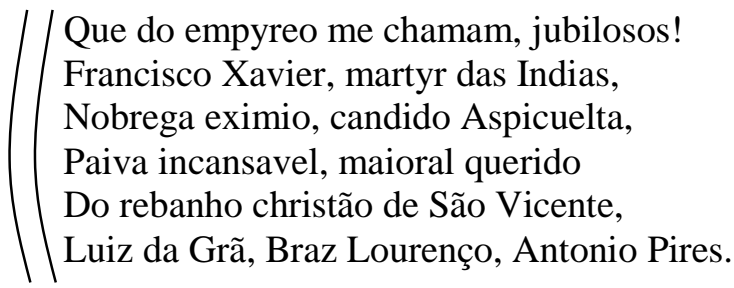

$\underline{\text { P. } 305-328}$

DIÁRIO DE LÁZARO

P. 307-318 
P. 307:

Nota MA:

1. versos destacados por traço vertical e juízo de valor, "verdade";

2. expressão sublinhada e juízo de valor, "mentira" - seleção de ideias: poesia e verdade:

Sim, eis-me aqui, não timido, curvado Ao peso da miseria e da insciencia, Mas forte pela crença, ennobrecido "verdade" "mentira" (Rico pelo saber! Quando brilhante, Aos fulgores d'aurora, d'entre as ondas,

Nota da pesquisa: MA emprega algumas vezes os critérios de verdade e mentira no estudo da poesia do romantismo brasileiro. À margem da "Canção do Exílio", de Gonçalves Dias, elogia o poema pela musicalidade e o sentimento que o ditou, mas contesta o teor das imagens: "É som puro que nem o milhor de Goethe Heine Verlaine. Porém ideias fracas. Erradas mesmo. Sabiá cantando na palmeira já muito se falou que só mesmo estudante de Coimbra podia pregar mentirada dessas." (Nota MA, In: DIAS, A. Gonçalves. Poesias. Ed. cit., vol. 2, p. 88). A mesma lógica de avaliar o teor de verdade dos poemas parece orientar a leitura dele da poesia modernista, como no caderno de Carlos Drummond de Andrade, remetido a MA em 1926. No poema "Convite", MA sublinha a expressão "vinho velho", no v. 29 - "Quando o relógio der a hora, / naquele banco nos sentaremos / para um repasto frugal / com um pouco de vinho velho / regando uma vianda tenra" - e escreve: "mentira". As expressões "repasto frugal" e "vianda tenra" são, por sua vez, classificadas como "horríveis" por MA (Documento na Série Manuscritos de Outros Escritores, no Arquivo do IEB/USP: MA-MOE-39-04).

P. 308-309:

Notas MA:

1. versos destacados por traço vertical e escólio:

“Guanabara" $\begin{aligned} & \text { Quanto és formosa, altiva Guanabara! } \\ & \text { Como a noiva do rei, o sol do estio } \\ & \text { Tisnou-te as bellas faces, e o sereno } \\ & \text { Molhou-te as tranças negras, e suspiras } \\ & \text { Mollemente inclinada á beira d'agua! } \\ & \text { As estrellas namoram-te do espaço, } \\ & \text { Lambem-te os pés as vagas gemêdoras, } \\ & \text { E, arredados de ti, velam attentos } \\ & \text { Os filhos do diluvio, horrendos monstros, } \\ & \text { Em cujos dorsos, emulos do bronze, } \\ & \text { Do raio a chamma ha laborado embalde! }\end{aligned}$

P. 309:

Nota MA: versos destacados por traço vertical, escólio "Santos" e expoente "(1)" remetendo ao comentário no rodapé:

"Santos" A cidade de Santos se levanta...

Como um bando de garças, acampadas

Ás margens de um marnel, Salve tres vezes, “(1)” 
“(1) Lembrar esta imagem quando citar a / descrição de Santos feita do Alto-da-Serra / por Alvares de Azevedo. Isto alias é bem descri-/to. O que faltou a V. e o fez ser falso descritivo foi talvez I o não descrever d'après nature, como fez em certos poemas I sertanejos e nos humorismos porem fazia das suas descrições / de natureza idealidades sonhadas romanticamente. Que acon-/teceu alem da falta de realidade, de objetividade, I até lhes faltou ar e espaço. Ficou na gravura / paisagistica dos pintores romanticos como modelo / e até renascentes, como estetica. / Pintura de ateliê."

Notas da pesquisa:

1. A rubrica "Falso descritivo" guarda remissão ao trecho assinalado, no fichamento crítico das obras de Fagundes Varela (MA-MMA-05-05).

2. Em 29 de março de 1931, MA alude a este passo em crônica no Diário Nacional: "Álvares de Azevedo tem aqueles trechos deliciosos do Macário em que descreve o Alto -da-Serra e a chegada em São Paulo. Varela, que apesar de tudo foi o mais paisagista dos românticos (o que não quer dizer propriamente ter sentimento da natureza), deixou também do Alto-da-Serra uma descrição comovente no Diário de Lázaro. Mas é comovente...para quem conhece o Alto-da-Serra. É o aprazível sentimental de reconhecer ou descobrir, que leva a gente a comover-se diante dessas descrições. Aos outros isso não passará de literatura." (ANRADE, Mário de. "Álvares de Azevedo - II". In: Táxi e Crônicas no Diário Nacional. Ed. cit., p. 361).

\section{P. 310:}

Notas MA:

1. escólio à esquerda, "Alto da Serra" - estudo do estilo: descrição;

2. verbo corrigido, "Dir-se-hia" - correção tipográfica;

3. expressão sublinhada - estudo do estilo: epíteto;

4. termo corrigido, "sentado" - correção tipográfica;

5. versos destacados por traço vertical e expoente "(1)" remetendo ao planejamento no rodapé:

Meu coração dilata-se. Minh'alma

É toda inspiração, jubilo, enlevo,

Amor e enthusiasmo! Que susurros,

Que bafejos suaves se levantam

Das mathas verde-negras! Dir-se-tia " $/ h$ "

A frescura das azas auri-brancas

Dos genios, que esvoaçam! Que prodigios,

Que maravilhas teu domínio abrange,

Ó Paranapiacaba! Audaz muralha,

Erguida pelas mãos do Omnipotente

Contra as furias do mar! Contempladora

Eterna do Oceano! Quantas horas,

( Na quadra festival da mocidade,

Não consumi santado em teus rochedos, " " $/ e$ "

Fitos os olhos na planicie immensa,

Que se estende a teus pés! Que longos dias

Não gastei a seguir as doces voltas

(1) Desses meandros de fundida prata,

Que lá embaixo fulguram! Quantas tardes

Não passei namorando as balsas verdes,

As lagôas serenas, as casinhas 
Erguidas no mysterio da espessura, O grupo das collinas, que fenecem Na linha azul do mar! Oh! bellos tempos! Tempos de ingenuidade e de candura, Passastes como as nuvens d'alvorada, Que os ventos do sertão varrem do espaço, Quando o sol apparece! Aos roseos sonhos, Aos contos de princezas encantadas,

“(1) comparar à descrição de Alvares de / Azevedo”

Notas da pesquisa:

1. O dossiê do manuscrito Amor e medo conserva referência a esta página na rubrica "Imagem", no fichamento crítico das obras de Fagundes Varela (MA-MMA-05-05).

2. Na crônica de 29 de março de 1931, citada acima, MA alude brevemente às duas descrições do Alto da Serra] (ANRADE, Mário de. "Álvares de Azevedo - II". In: Táxi e Crônicas no Diário Nacional. Ed. cit., p. 361).

\section{Alto DA SERRA DE PARANAPIACABA}

P. 311:

Nota MA: verso sublinhado - estudo da versificação: enumeração:

Succederam cruentos desenganos, Paixões ardentes, ambições funestas!...

Nota da pesquisa: MA alude ao trecho na rubrica "O inteligente sensivel" do fichamento crítico das obras de Fagundes Varela (MA-MMA-05-05).

\section{P. 312-313}

MARGENS DO TIETÊ, 20 DE MARÇO

P. 312:

Nota MA: versos destacados por traço vertical e comentário lateral:

E sobre a cruz humilde, que marcava Da mais terna das mães o frio leito, Um sabiá cantava tristemente.<smiles>C1CCCC1</smiles>

"Isto provavelmente / é mentira. A neces-/sidade de idealização / romantica empobrece / constantemente os / romanticos e especialmente / Varela. Exemplos são / essas descrições de Gua-/nabara Alto da Serra, / São Paulo."

Nota da pesquisa: O trecho encerra os abonamentos à rubrica "Falso descritivo", no fichamento crítico das obras de Fagundes Varela (MA-MMA-05-05).

MARGENS Do TIETÊ, 24 DE JULHO

P. 313: 
Nota MA: versos destacados por traço vertical e escólio "Amor e medo" - estudo da psicologia: medo / sentimento amoroso:

\begin{tabular}{l|l} 
"Amore & Meu Deus! Senhor meu Deus! eu tenho medo, \\
Medo" & Desta dita ineffavel que derramas \\
Sobre minha existencia, em almos dias, \\
Em noites sem iguaes! Sim, quasi sempre \\
No romance da vida a desventura, \\
Os desastres cruentos se anunciam \\
Por um sublime prólogo!...
\end{tabular}

Nota da pesquisa: MA ancora-se no escólio para citar os versos no ensaio para a Revista Nova: "No Diário de Lazaro, assim que se casa com Lucilia, a felicidade é tamanha, que ele [Varela] se volta pra Deus, atemorizado. (...) O medo de amar aqui se resume a um receio, a um pressentimento da visita de Nemesis" (ANDRADE, Mário de. "Amor e medo", In: Aspectos da literatura brasileira, ed. cit., p. 213).

P. 314:

Notas MA:

1. versos destacados por traço e escólio "Amor e medo" - estudo da psicologia: sentimento amoroso:

$\begin{array}{ll} & \text { Que depôr a teus pés! Ah! tu ouviste } \\ \text { "Amor } & \text { Minhas humildes preces, compassivo } \\ \text { e Medo" } & \text { Escutaste meus votos mais ardentes! } \\ \text { Duplicaste meu ser, minha existencia } \\ \text { Na posse da mulher, que idolatrava! }\end{array}$

2. verso sublinhado, retângulo assinalando a fusão das sílabas e escólio - estudo da versificação: métrica;

3. preposição sublinhada, "p'ra", cruzeta e expoente "(1)" remetendo ao comentário no rodapé - estudo linguístico: emprego de "para/pra":

A teus pés bocejou, abrindo as fauces

"11 silabas" Horriveis, escancaradas! Não fugiste

Quando sentiste o espirito da treva

Sobre a fronte estampar-te o sello em braza,

Que nesta vida te marcou p'ra sempre! "X(1)"

“(1) Na naturalidade mais familiar do Diario / de Lazaro de novo a gente encontra o pra."

P. 315:

Notas MA

1. preposição sublinhada, "para", e cruzeta - estudo linguístico: emprego de "para/pra":

Um outro mundo para mim desponta, $X$

2. versos destacados por traço vertical e juízo de valor:

30 de outubro. 
Sinto-me mal! Inquietação estranha,

Vaga, indizivel, tolda-me os sentidos.

Foge-me o somno. As veias se me incendem

De um fogo ardente. Negro abatimento,

Com seu cortejo de pensares torvos,

Todo o ser me domina. Deus eterno!

Que sentimento desgostoso, amargo,

Afasta-me de tudo o que inda ha pouco

Enchia-me de jubilo a existencia?...

Oh! é debalde que Lucilia busca,

Pobre Lucilia, sempre bôa e meiga,

"Excelente"

Distrair-me das furias afflictivas

Deste pezar sem nome, que me opprime!

— Meu Deus! meu Deus! que dores me reservas?!...

Nota da pesquisa: Último abonamento à rubrica "Passagens bonitas", no fichamento crítico das obras de Fagundes Varela (MA-MMA-05-05).

P. 317:

Nota MA: trecho sublinhado e escólio - seleção de ideias: medicina:

Torturam-se em pena. Espero agora

Que os homens da sciencia allivio busquem

A tanto soffrimento. Poucos dias

"Medicina"

P. 318:

Nota MA: versos destacados por traço vertical e escólio - seleção de ideia: medicina:

Que eu parta novamente, e só! Mesquinha, Triste sciencia! Quando nada enxerga, "Medicina" São seus recursos e remedios certos A mudança de clima, o ar, a vida No meio das montanhas, tudo quanto, Sem escolas, sem livros, sem doutores, A sabia natureza nos ensina!

Nota da pesquisa: $O$ trecho assinalado enriquece as dimensões da rubrica "Atração da natureza", no fichamento crítico das obras de Fagundes Varela (MA-MMA-05-05).

\section{P. 319-328}

SEGUNDA PHASE

P. 321:

Notas MA:

1. termo sublinhado, "guizos", e escólio "dic" - pesquisa para o Dicionário musical brasileiro;

2. trecho corrigido, "explica o raio" - correção tipográfica;

3. verso sublinhado e retângulo destacando o "E" inicial - estudo da versificação: anacruse;

4. versos destacados por traço vertical duplo e comentário: 
Que tivesse morrido!... - Ah ! inda vive! Inda vive, e a não vejo?... O que me afasta Assim da minha esposa? Porque a furtam Desta sorte a meus braços?... Novamente Lançou-me um fundo olhar, e respondeu-me: —É porque... e calou-se. -Por piedade Conclui, exclamei.- Tu tens nas veias, Elle me disse lentamente, a Morte!

Oh! não! peior que a morte, o mais funesto, O mal o mais tremendo que se estampa Das miserias humanas no catalogo! A morphéa!....

Meu Deus ! eu vi de perto A fome, a peste, a febre, o desalento; Senti soar-me nos ouvidos ebrios

"dic" O tinido dos guizos da loucura; Vi de perto o delírio, o suicidio, $\mathrm{O}$ atheismo e o nada; e firme e forte, Encarei-os sorrindo; mas o effeito Destas fataes palavras de meu sogro Não as explica/o/raio! Um mar de angustias Caiu sobre minh'alma; espessa nuvem De sangue circumdou-me os olhos turvos; Senti um turbilhão tomar-me o corpo, E depois rolar, rolar como o precito

"Admiravel. / Comoventissi-/mo. Aliás toda / esta parte da doen-/ça é formidavel / de interesse, viva-/cidade força comoção.

Nota da pesquisa: MA define o poema como "Obra-prima" no fichamento crítico das obras de Fagundes Varela (MA-MMA-05-05).

P. 322:

Notas MA:

1. versos destacados por traço vertical duplo e escólio "Imagem" - estudo do estilo: imagem:

“Imagem $" \mid \begin{aligned} & \text { Bravára seus vestigios, nos sentámos... } \\ & \text { A nossos olhos, turbidas, confusas, } \\ & \text { Como esquadrão, que exercito inimigo, } \\ & \text { Em passo estreito, a noite aperta e bate, } \\ & \text { E no doido pavor une-se o torvo, } \\ & \text { E rolam despenhando-se no abysmo } \\ & \text { Tontos, sem luz, corceis e cavalleiros, } \\ & \text { As aguas misturavam-se rugindo. }\end{aligned}$

2. verso sublinhado e expoente "(1)" remetendo ao comentário - estudo do estilo: imagem / estudo da psicologia: atração da natureza:

Sobre o mysterio esplendido das aguas. "(1)"

“(1) A atração de Varela pelas aguas se / condensa nesta admiravel expressão / parnasianista." 
Nota da pesquisa: $O$ verso e o comentário convergem para a rubrica "Atração da natureza", no fichamento crítico das obras de Fagundes Varela. O documento também remete a esta página na rubrica "Imagem" (MA-MMA-05-05).

P. 323:

Nota MA: verso sublinhado e retângulo assinalando o "p" de "reptil” - estudo linguístico: suarabácti / estudo da versificação: métrica:

De alegria feroz arremessei-me

De um salto ao reptil! Oh! sê bemdito!

P. 325:

Nota MA: preposição sublinhada, "para", e cruzeta - estudo linguístico: emprego de "para/pra":

Não empreguei para alcançar ao menos

$X$

A graça de te ver! Agora mesmo...

P. 326:

Notas MA:

1. verso sublinhado e retângulo assinalando a sílaba inicial, “Ai” - estudo da versificação: anacruse:

Ai! a não serem as vividas lembranças,

2. verso assinalado por expoente “(1)”, remetendo ao comentário no rodapé - estudo da psicologia: sentimento amoroso e atração da natureza:

Tão bellos que passamos! Ah! Lucilia,

Como era lindo o campo e o céo sereno (1)

Como cada florinha nos sorria!

“(1) No extase de amor lá vem ele a con-/fundir a natureza com o sentimento.”

3. preposição sublinhada, "para", e cruzeta - estudo linguístico: emprego de "para/pra":

$X \quad$ Começa para mim, mundo de sombras,

4. preposição sublinhada, "pra", e cruzeta - estudo linguístico: emprego de "para/pra":

Não mais me encontrará! Adeus p'ra sempre! $\quad X$

Nota da pesquisa: O trecho assinalado e o comentário de MA acerca da "confusão" do eu lírico entre sentimento e natureza convergem para o fichamento crítico das obras de Fagundes Varela, que inclui o trecho como exemplo derradeiro da atração do poeta pela natureza (MA-MMA-05-05).

P. 327:

Notas MA:

1. trecho sublinhado - estudo do estilo: imagem; 
2. versos destacados por traço vertical e comentário lateral:

Tão cheia de aversão não entra a virgem, Vestida de alvas roupas, no recinto De crapulosa e sordida miseria! O espirito da luz, timido, incerto, Sofraldar parecia as veste candidas, Receando manchal-as. Grossas vigas

"Estupendo. Varela acha / na sua miseria ex-/pressões formidaveis. / Esta duma delica/deza e tristura / que iluminam / a comoção da gente."

3. versos destacados por traço vertical e comentário:

Os morcegos em bando, as lagartixas Habitavam em paz, guardando á risca A regra do respeito á liberdade, Que o rei da creação posterga sempre. E nas paredes humidas, cobertas De avencas e de fetos, porejava A agua em fontes mil. O chão lodoso, Cheio de poças negras, semelhava O chão de um calabouço, praticado Nas velhas fortalezas, e onde as vagas Entram em preia-mar. Um sapo enorme, Cheio de lama e de amarellas nódoas, Bem defronte de mim sentado estava Com seus olhos medonhos, hediondos,

"Isto é de duvi-/dar. Deve de / ser idealização / romantica."

Nota da pesquisa: No fichamento crítico da poesia de Fagundes Varela, MA indica o trecho assinalado sob a rubrica "Imagem" (MA-MMA-05-05).

P. 328:

Notas MA:

1. expressão com sublinha dupla;

2. versos destacado por traço vertical duplo - seleção de ideias:

/ $\begin{aligned} & \text { Nada mais sinto; a dôr tem seus limites } \\ & \text { Além dos quaes, talvez, estranho gozo, } \\ & \text { Satanico prazer o seio inunde. }\end{aligned}$
Cerrei de novo os olhos. Sobre a terra
O proprio soffrimento era-me um sonho

Nota da pesquisa: A rubrica "O inteligente sensivel", no fichamento crítico das obras de Fagundes Varela, encerra-se com a indicação ao trecho assinalado (MA-MMA-05-05). 


\section{COMPLEMENTO}

\section{Dossiê do manuscrito Amor e medo}

\section{MA-MMA-05-01}

Lirismo Romantico / Amor / e / Medo, 15/08/[1931]: envelope branco (11,8 x 17,2cm) endereçado a Mário de Andrade, com selo e carimbo; timbre da Directoria da Bibliotheca Publical do Estado do/ Rio Grande do Sul; apresenta um corte na borda superior; autógrafo a tinta preta; Notas MA na frente e no verso indicam a utilização para guardar a pesquisa; duas etapas no estabelecimento do título: 1. a lápis vermelho: $1^{a}$ etapa: "Lirismo Romantico" (4 vezes); 2. a lápis-tinta: $2^{a}$ etapa: "Amor/ e / Medo" (2 vezes); e anotação a lápis preto: "Aristocracia”, verso; $n .01$.

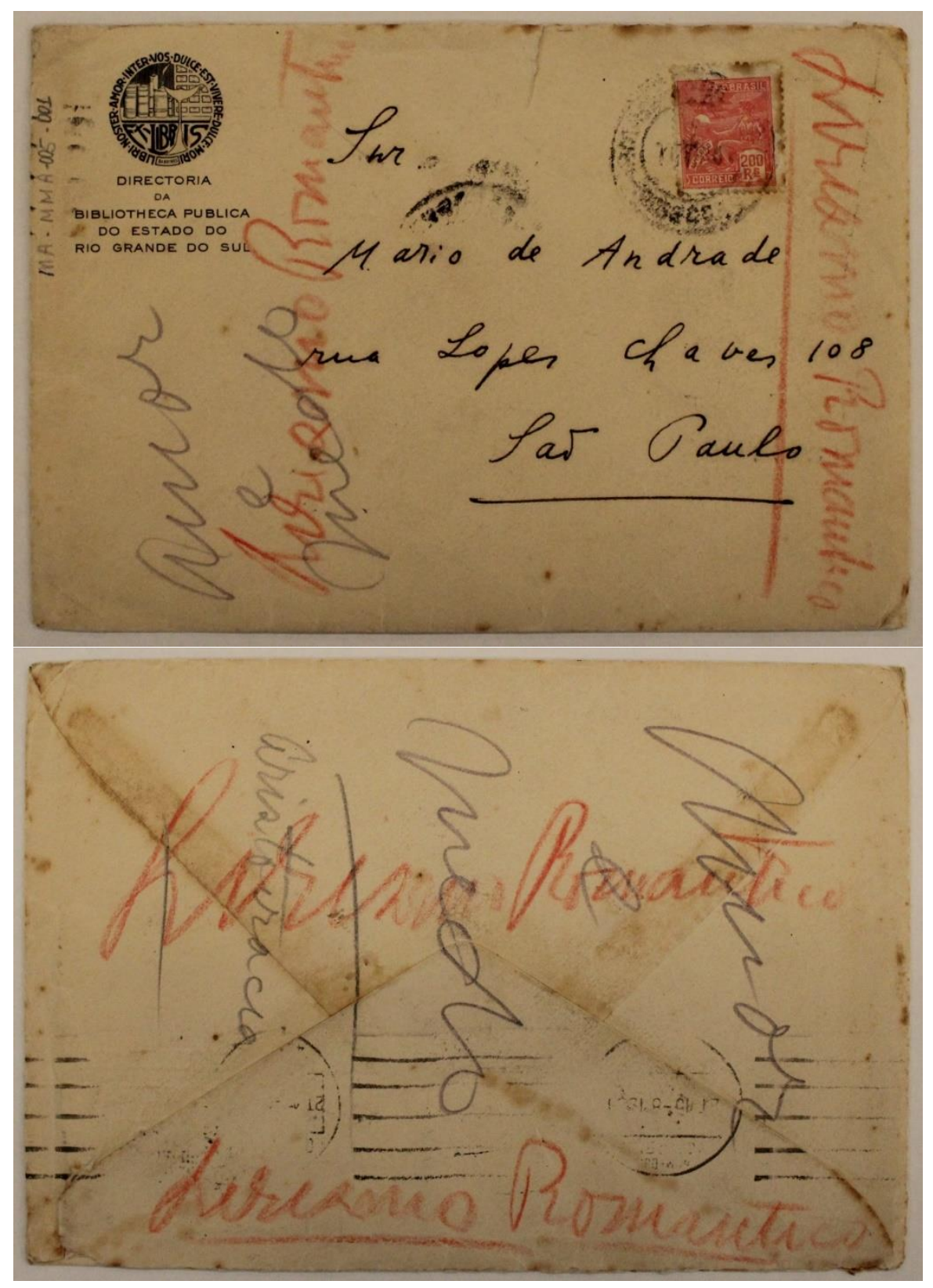


Notas da pesquisa:

1. O envelope reaproveitado por MA, de modo a abrigar notas de trabalho e esboços dele sobre a poesia do romantismo brasileiro, origina-se da correspondência com o escritor gaúcho Augusto Meyer (1902-1970). O timbre da Directoria da Bibliotheca Publica do Estado do Rio Grande do Sul explica-se na carta de 29 de dezembro de 1930, enviada por Meyer a MA: "Mário velho, conte alguma coisa de V., da sua vida. Escreva. O Bilú agora meteu na mala o bandoneon pra ser diretor da Bibliotheca Publica. A vida não pergunta: o que é que você quer ser? A gente vai sendo, conforme os trancos e barrancos permitirem." (MA-C-CPL-4735). Apesar do desgaste na tinta, o carimbo dos correios mostra a data de "15-8-1931".

2. A classificação do manuscrito foi realizada pela pesquisadora Cristiane Fátima Yamada Camara, no projeto "Mário de Andrade na crítica de Artes Plásticas, Literatura e Música através de seu arquivo", sob orientação da Profa. Dra. Telê Porto Ancona Lopez. 


\section{MA-MMA-05-02}

Alvares de Azevedo. Fichamento crítico tomando a obra publicada; autógrafo a tinta preta e a lápis preto; folha de papel branco quadriculado para fichário $(27,8 \times 21,5 \mathrm{~cm})$ amarelecida pelo tempo, com 3 furos, sendo que o segundo e o terceiro estão cortados até a margem; sem numeração; escrita utilizando o anverso da página: indicando duas fases: a tinta preta: $1^{a}$ fase; a lápis preto: $2^{a}$ fase; rasuras a lápis preto e a tinta preta: correção, supressão; $n^{o} 02$.

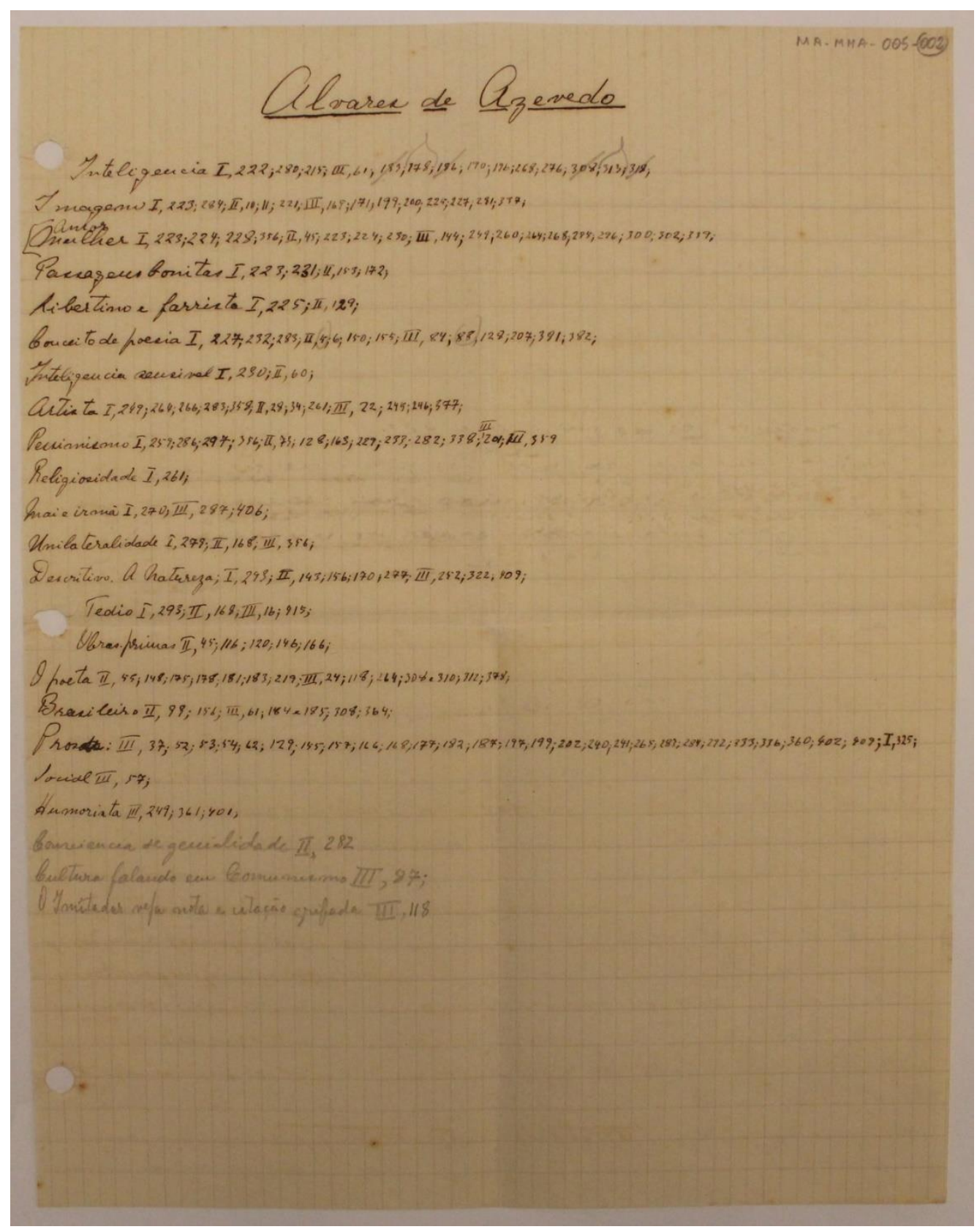




\section{$\underline{\text { Alvares }} \underline{\text { de }} \underline{\text { Azevedo }}$}

Inteligencia I, 222; 280; 215; III, 61; 133; 178; 186; 190; 196; 268; 276; 308; 313; 318

Imagem I, 223; 284; II, 10; II, 221; III, 169; 171; 199; 200; 225; 227; 281; 337;

Amor

Mulher I, 223; 224; 228; 356; II, 45; 223; 224; 230; III, 144; 259; 260; 264; 268;295; 296; $300 ; 302 ; 339$;

Passagens bonitas I, 223; 231; II, 153; 172;

Libertino e farrista I, 225; II, 129;

Conceito de poesia I, 227; 232; 283; II, 5; 6; 150; 155; III, 84; 88; 128; 207; 381; 382;

Inteligencia sensível I, 230; II, 60;

Artista I, 249; 264; 266; 283; 358; II, 28; 34; 261; III, 22; 245; 246; 377;

Pessimismo I, 259; 286; 297; 356; II, 73; 128; 163; 229; 233; 282; 338; III, 201; III, 359

Religiosidade I, 261;

Mai e irmã I, 270; III, 287; 406;

Unilateralidade I, 279; II, 168; III, 356;

Descritivo. A Natureza; I, 293; II, 143; 156; 170; 277; III, 252; 322; 409;

Tedio I, 293; II, 168; III, 16; 915;

Obras-primas II, 45; 116; 120; 146; 166;

O poeta II, 55; 148; 175; 178; 181; 183; 219; III, 24; 118; 264; 308 e 310; 312; 378;

Brasileiro II, 99; 156; III, 61; 184 e 185; 308; 364;

ProsaA: III, 37; 52; 53; 54; 62; 129; 155; 157; 166; 168; 177; 182; 187; 197; 199; 202; $240 ; 241 ; 265 ; 283 ; 284 ; 292 ; 333 ; 336 ; 360 ; 402 ; 409 ;$ I, 325;

Social III, 57;

Humorista III, 249; 361; 401;

Consciencia de genialidade II, 282

Cultura falando em Comunismo III, 87;

O Imitador veja nota e citação grifada III, 118 
Nota da pesquisa:O fichamento crítico das obras de Álvares de Azevedo reporta-se ao título Obras de Manoel Antonio Álvares de Azevedo precedidas do juizo critico de escriptores nacionaes e estrangeiros e de uma noticia sobre o auctor e suas obras por J. Norberto de S. S. 7. ed. Rio de Janeiro: Garnier, 1900. 3 v. [A/II/d/44]. O algarismo romano, no fichamento elaborado por MA, indica o volume da obra, enquanto os arábicos representam o número de página. O sistema de rubricas e remissões facilita o aproveitamento das notas de margem - e a indicação de página, quando necessário - no preparo dos textos de crítica de MA sobre o autor. 


\section{MA-MMA-05-03}

Casimiro de Abreu. Fichamento crítico tomando a obra publicada; autógrafo a tinta preta e a lápis preto; folha de papel branco quadriculado para fichário $(27,8 \times 21,5 \mathrm{~cm})$ amarelecida pelo tempo, com 3 furos, sendo que o segundo e o terceiro estão cortados até a margem; sem numeração; escrita utilizando o anverso da página: indicando duas fases: a tinta preta: $1^{a}$ fase; a lápis preto: $2^{a}$ fase; rasuras a lápis preto e a tinta preta: correção, supressão; $n^{\circ} 03$.

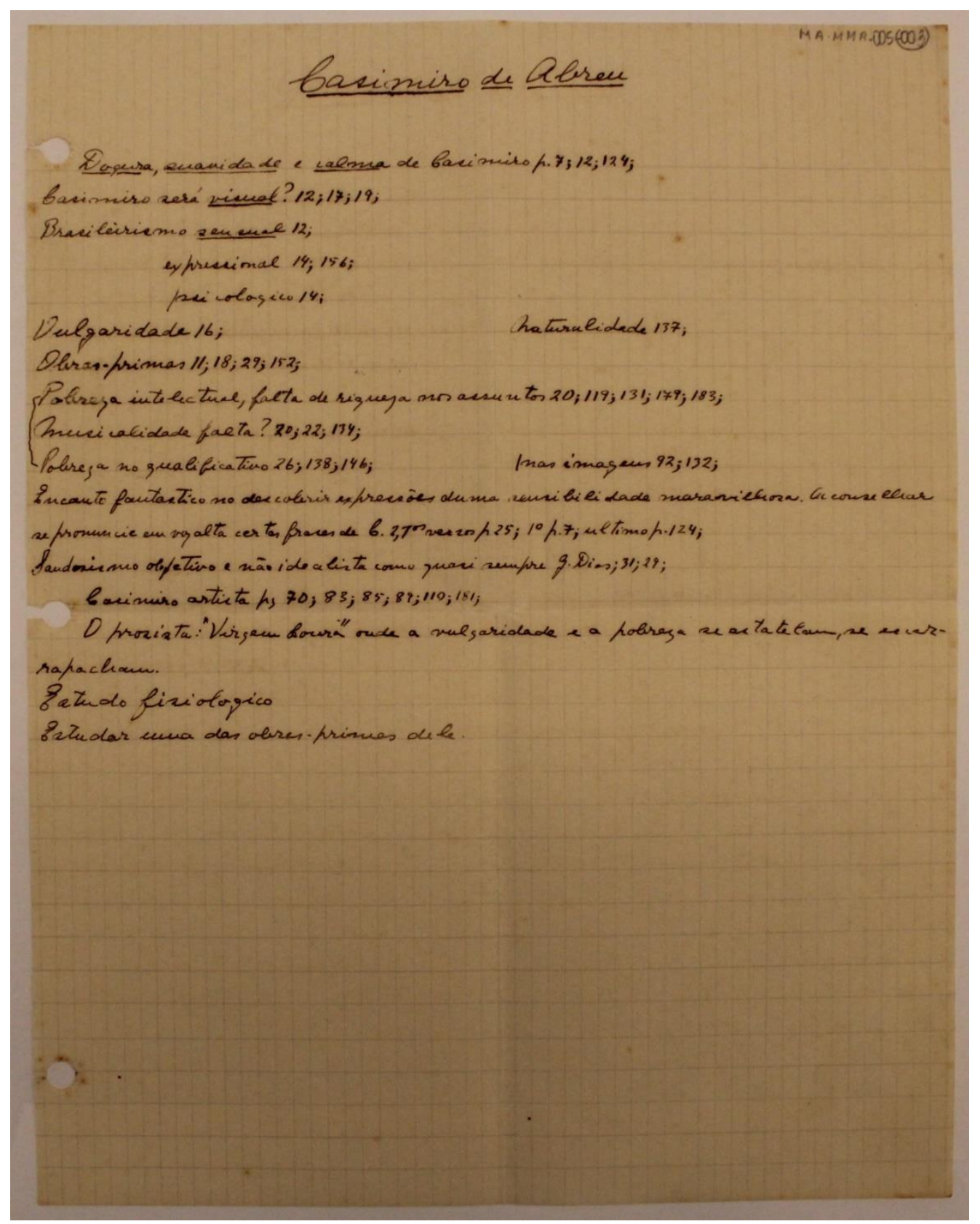




\section{$\underline{\text { Casimiro de }} \underline{\text { Abreu }}$}

Doçura, suavidade e calma de Casimiro p. 7; 12; 124;

Casimiro será visual? $12 ; 17 ; 19$;

Brasileirismo sensual 12;

expressional 14; 156;

psicologico 14;

Vulgaridade 16; $\quad$ Naturalidade 137;

Obras-primas $11 ; 18 ; 29 ; 152$;

Pobreza intelectual, falta de riqueza nos assuntos 20;119; 131; 179; 183;

Musicalidade falta? 20; 22; 134;

Pobreza no qualificativo 26; 138; 146; Inas imagens 92; 132;

Encanto fantastico no descobrir expressões duma sensibilidade maravilhosa.

Aconselhar/ se pronuncie em voz alta certas frases de C. 2, $1^{\text {os }}$ versos p 25; 10 p. 7; ultimo p. 124;

Saudosismo objetivo e não idealista como quasi sempre G. Dias; 31; 29;

Casimiro artista pg 70;83;85;89; 110; 181 ;

O prosista: "Virgem Loura" onde a vulgaridade e a pobreza se estatelam, se escar- / rapacham

Estudo fisiologico

Estudar uma das obras-primas dele.

\section{Notas da pesquisa:}

1. O fichamento refere-se ao volume ABREU, Casimiro J. M. de. As Primaveras: com poesias inéditas do autor, o juízo crítico de diferentes escritores e um prólogo por $F$. D. Ramalho Ortigão. Porto: Livraria Chardron, 1909. $3^{\text {a }}$ ed.

2. "Canção do exílio" (p. 11), "Saudades" (p. 18), "Meus Oito Anos" (p. 29) e "No Jardim” (p. 152) são os poemas indicados como obras-primas por MA 


\section{MA-MMA-05-04}

Gonçalves Dias. Fichamento crítico tomando a obra publicada; autógrafo a tinta preta e a lápis preto; folha de papel branco quadriculado para fichário $(27,8 \times 21,5 \mathrm{~cm})$ amarelecida pelo tempo, com 3 furos, sendo que o segundo e o terceiro estão cortados até a margem; sem numeração; escrita utilizando o anverso da página: indicando duas fases: a tinta preta: $1^{a}$ fase; a lápis preto: $2^{a}$ fase; rasuras a lápis preto e a tinta preta: correção, supressão; $n^{\circ} 04$.

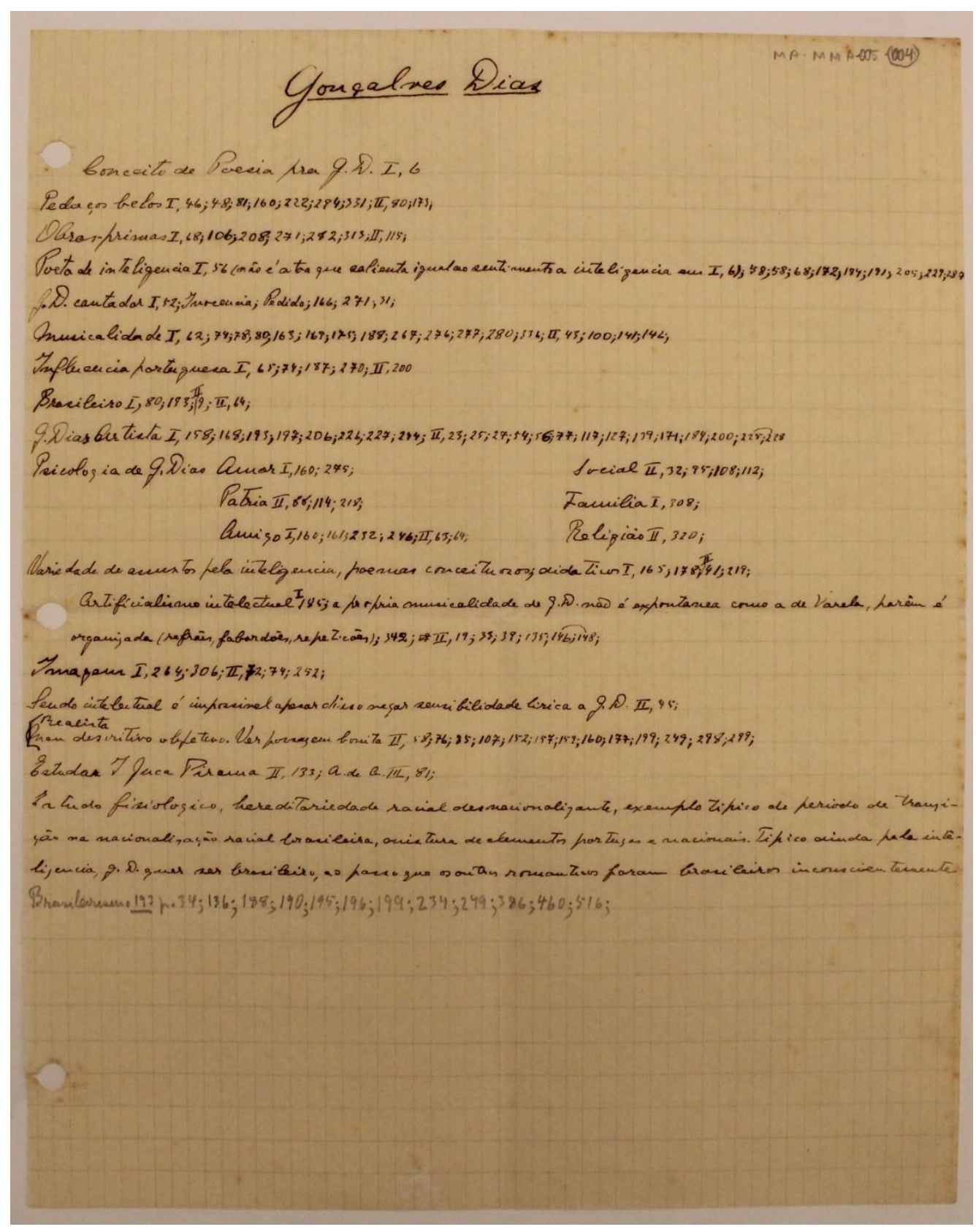




\section{Gonçalves Dias}

Conceito de Poesia pra G. D. I, 6

Pedaços belos I, 46; 48; 81; 160; 222; 294; 331; II, 80; 173;

Obras-primas I, 68; 106; 208; 271; 282; 313; II, 115;

Poeta de inteligencia I, 56 (não é a toa que salienta igual ao sentimento a inteligencia em I, 6); 58; 58; 68; 172; 184; 191; 205; 229; 287

G. D. cantador I, 52; Inocencia; Pedido; 166; 271; 31;

Musicalidade I, 62; 74; 78; 80; 163; 169; 175; 188; 267; 276; 277; 280; 336; II, 43; 100; $141 ; 142$;

Influencia portuguesa I, 65; 74; 187; 270; II, 200

Brasileiro I, 80; 193; II, 9; II, 64;

G. Dias Artista I, 158; 168; 193; 197; 206; 226; 227; 244; II, 23; 25; 27; 54; 56; 77; 117; $127 ; 139 ; 171 ; 184 ; 200 ; 225 ; 228$

Psicologia de G. Dias Amor I, 160; 275;

Social II, 32; 95; 108; 112;

Patria II, 88; 114; 218;

Familia I, 308;

Amigo I, 160; 161; 232; 246; II, 63, 64; Religião II, 320;

Variedade de assunto pela inteligencia, poemas conceituosos; didaticos I, 165; 178; II, $41 ; 219$;

Artificialismo intelectual I 185; a própria musicalidade de G. D. não é expontanea como a de Varela, porém é / organizada (refrões, fabordões, repetições); 342; 19 II, 19; 33; 39; $135 ; 146 ; 148$;

Imagem I, 264; 306; II, 72; 74; 252;

Sendo intelectual é impossivel apesar disso negar a sensibilidade lirica a G. D. II, 45;

Realista

Mau descritivo objetivo. Ver personagem bonita II, 58; 76; 85; 107; 152; 157; 159; 160; $177 ; 199 ; 249 ; 288 ; 299$;

Estudar I Juca Pirama II, 133; A. de A. III, 81;

Estudo fisiologico, hereditariedade racial desnacionalizante, exemplo tipico de periodo de transi- / ção na nacionalização racial brasileira, mistura de elementos portugas e nacionais. Tipico ainda pela inte- / ligencia, G. D. quer ser brasileiro, ao passo que os outros romanticos foram brasileiros inconscientemente.

Brasileirismo $\underline{193}$ p. $34 ; 136 ; 188 ; 190 ; 195 ; 196 ; 199 ; 234 ; 249 ; 386 ; 460 ; 516$; 
Nota da pesquisa: O fichamento crítico preparado por MA ancora-se na leitura das seguintes edições: (1) Poesias. Nova edição organizada e revista por J. Norberto de Souza Silva e precedida de uma notícia sobre o autor e suas obras pelo Cônego Doutor Fernandes Pinheiro. Paris/Rio de Janeiro: Garnier, 1919. 2 vol. [A/II/d/62]; e (2) Obras posthumas de A. Gonçalves Dias precedidas de uma noticia da sua vida e obras pelo Dr. Antonio Henriques Leal. Poesias posthumas. Paris: H. Garnier, Livreiro-Editor, s/d. As indicações de página no fichamento seguem dois padrões, conforme as edições a que se referem. Os três volumes das Poesias são referidos pela sequência de algarismos romanos e arábicos (p. ex., "Conceito de Poesia para G. D I, 6" = vol. 1, p. 6). MA remete às páginas e notas de margem apostas por ele nas Obras posthumas através do número "193" (p. ex., 193 p. 34), sob o qual o título foi incluído na Bibliografia para Na pancada do ganzá. 


\section{MA-MMA-05-05}

Fagundes Varela. Fichamento crítico tomando a obra publicada; autógrafo a tinta preta e a lápis preto; folha de papel branco quadriculado para fichário $(27,8 \times 21,5 \mathrm{~cm})$ amarelecida pelo tempo, com 3 furos, sendo que o segundo e o terceiro estão cortados até a margem; sem numeração; escrita utilizando o anverso da página: indicando duas fases: a tinta preta: $1^{a}$ fase; a lápis preto: $2^{a}$ fase; rasuras a lápis preto e a tinta preta: correção, supressão; $n^{\circ} 05$.

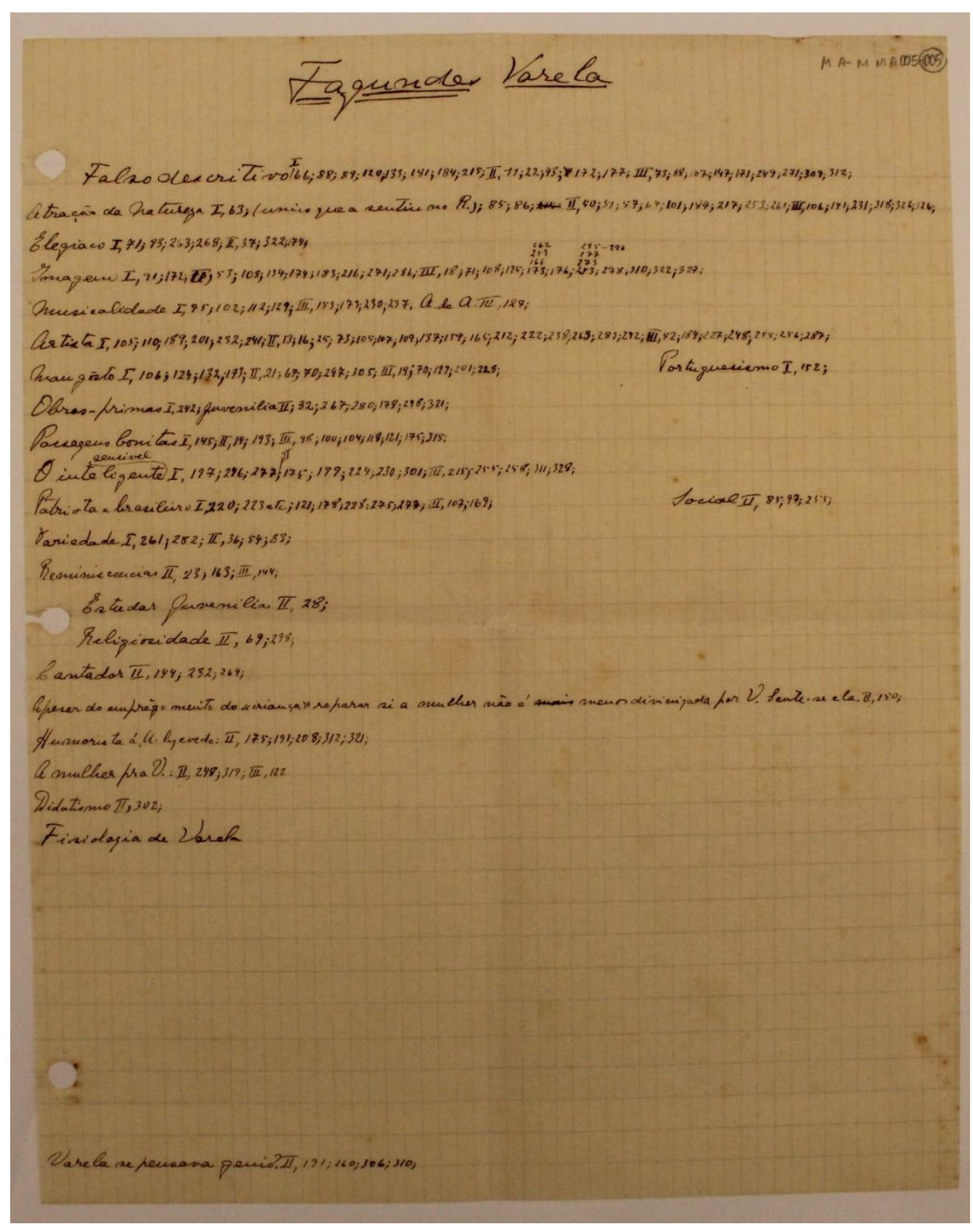




\section{$\underline{\text { Fagundes }} \underline{\text { Varela }}$}

Falso descritivo I 166; 88; 89; 120; 133; 181; 184; 215; II, 11; 22; 43; 172; 177; III, 73; $88 ; 107 ; 147 ; 171 ; 249 ; 271 ; 309 ; 312$;

Atração da natureza I, 63; (unico que a sentiu no R.); 85; 86; II, 50; 51; 57; 67; 101; $184 ; 217 ; 253 ; 261 ;$ III, 106; 141; 231; 318; 322; 326;

Elegiaco I, 71; 93; 263; 268; II, 37; 322; 174;

Imagem I, 91; 172; II, 53; 108; 134; 174; 183; 216; 271; 286; III, 18; 71; 108; 125; 173 166253 262; 176; 253273277295 - 296; 278; 310; 322; 327;

Musicalidade I, 95; 102; 112; 129; III,153; 173; 230; 237; A.de A.II, 127;

Artista I, 105; 110; 189; 201; 232; 241; II, 13; 16; 25; 73; 105; 107; 109; 137; 159; 165; $212 ; 222 ; 238 ; 263 ; 283 ; 292 ;$ III, 52; 184; 227; 248; 255; 256; 287;

Mau gôsto I, 106; 124; 132; 173; II, 21; 67; 70; 247; 305; III, 19; 70; 199; 201; 228;

Portuguesismo I, 152;

Obras-primas I, 242; Juvenilia II; 32; 267; 280; 178; 298; 321;

Passagens bonitas I, 145; II, 14; 193; III, 98; 100; 104; 118; 121; 175; 315;

O inteligente sensível I, 197; 246; 277; II 175; 199; 224; 230; 301; III, 215; 255; 258;

$311 ; 328$;

Patriota e brasileiro I, 220; 223 etc; 121; 178; 228; 275; 277; III, 107; 169; Social II, $85 ; 97 ; 255$;

Variedade I, 261; 282; II, 36; 54; 83;

Reminiscencias II, 23; 163; III, 144;

Estudar Juvenilia II, 28;

Religiosidade II, 69; 298;

Cantador II, 144; 232; 264;

Apesar do emprêgo muito do "criança" reparar si a mulher não é mais menos divinizada por V. Sente-se ela. II, 150;

Humorista à A. Azevedo: II, 175; 191; 208; 312; 321;

A mulher pra V.: II, 248; 319; III, 122

Didatismo II, 302;

Fisiologia de Varela

Varela se pensava genio? II, 191; 260; 306; 310; 
Nota da pesquisa:O fichamento crítico elaborado por MA ancora-se na edição Obras completas de L. N. Fagundes Varella: edição organisada e revista, e precedida de uma noticia biographica por Visconti Coaracy e de um estudo critico pelo Dr. Franklin Tavora. Rio de Janeiro/Paris: Garnier, 1919. 3 v. [A/II/d/58]. A exemplo do que ocorre nos demais fólios de mesma natureza, voltados estudo dos outros poetas do romantismo, o algarismo romano representa o volume, e o arábico, a página à qual o fichamento remete.

\section{MA-MMA-05-06 $\mathrm{a} 09 \mathrm{e}$, $11 \mathrm{a} 17$}

Fichamento e notas de trabalho tendo por objeto os poetas Álvares de Azevedo, Gonçalves Dias, Castro Alves, Casimiro de Abreu e os temas: "Amor e medo", "Lirismo Romântico", amizade, natureza, musicalidade, brasileirismo gramatical. Autógrafo a lápis preto; 11 fichas improvisadas em folhas destacadas de caderneta de bolso, sem pauta, 10 medindo 10,6 x 6,9cm e 1 ficha, 14,2 x 10,6cm; papel branco; não numeradas pelo A.; todas as folhas apresentam manchas de fungo; escrita utilizando a frente de todas as folhas e o verso da f. 17, segundo numeração do Arquivo IEB; rasuras a lápis preto: correção; $n^{\circ} 06-09,11-17$.
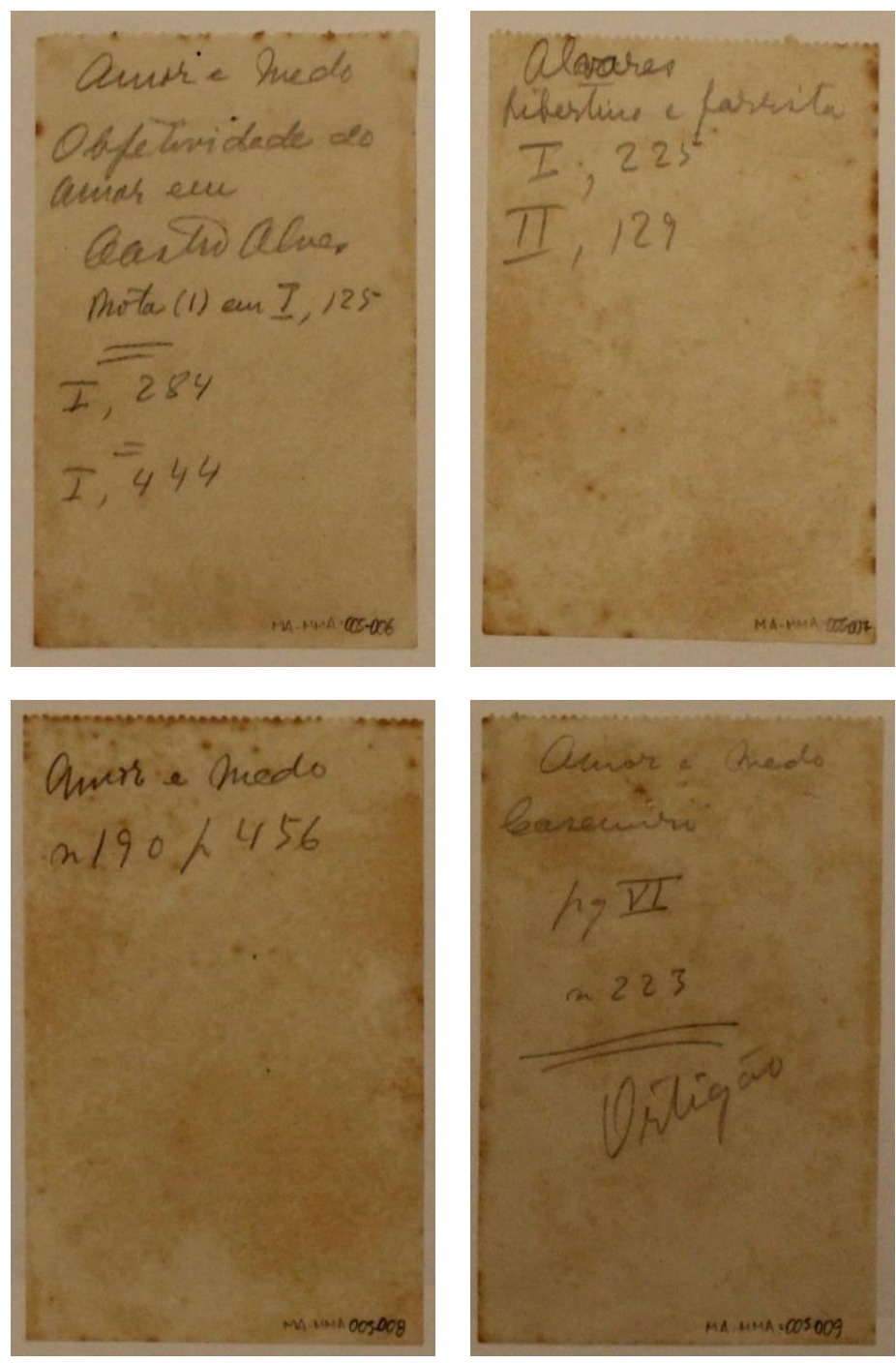


\section{MA-MMA-05 06}

Amor e Medo // Objetividade do amor em / Castro Alves // Nota (1) em I, 125

I, 284 // I, 444 //

MA-MMA-05-07

Alvares // Libertino e farrista // I, 225 // II, 129

MA-MMA-05-08

Amor e Medo // n 190 p 456

\section{MA-MMA-05 09}

Amor e Medo // Casemiro // pg VI // n 223 // Ortigão 


\section{MA-MMA-5-10}

[Notas sobre o Parnasianismo]. Anotação crítica sem título. Autógrafo a lápis preto no verso de certificado impresso de registro de remessa da Directoria Geral dos Correios (6,8 x 19,4 cm), com destino a Paris, [São Paulo?], 9 de abril [?]; com manchas de fungo; $n .10$.
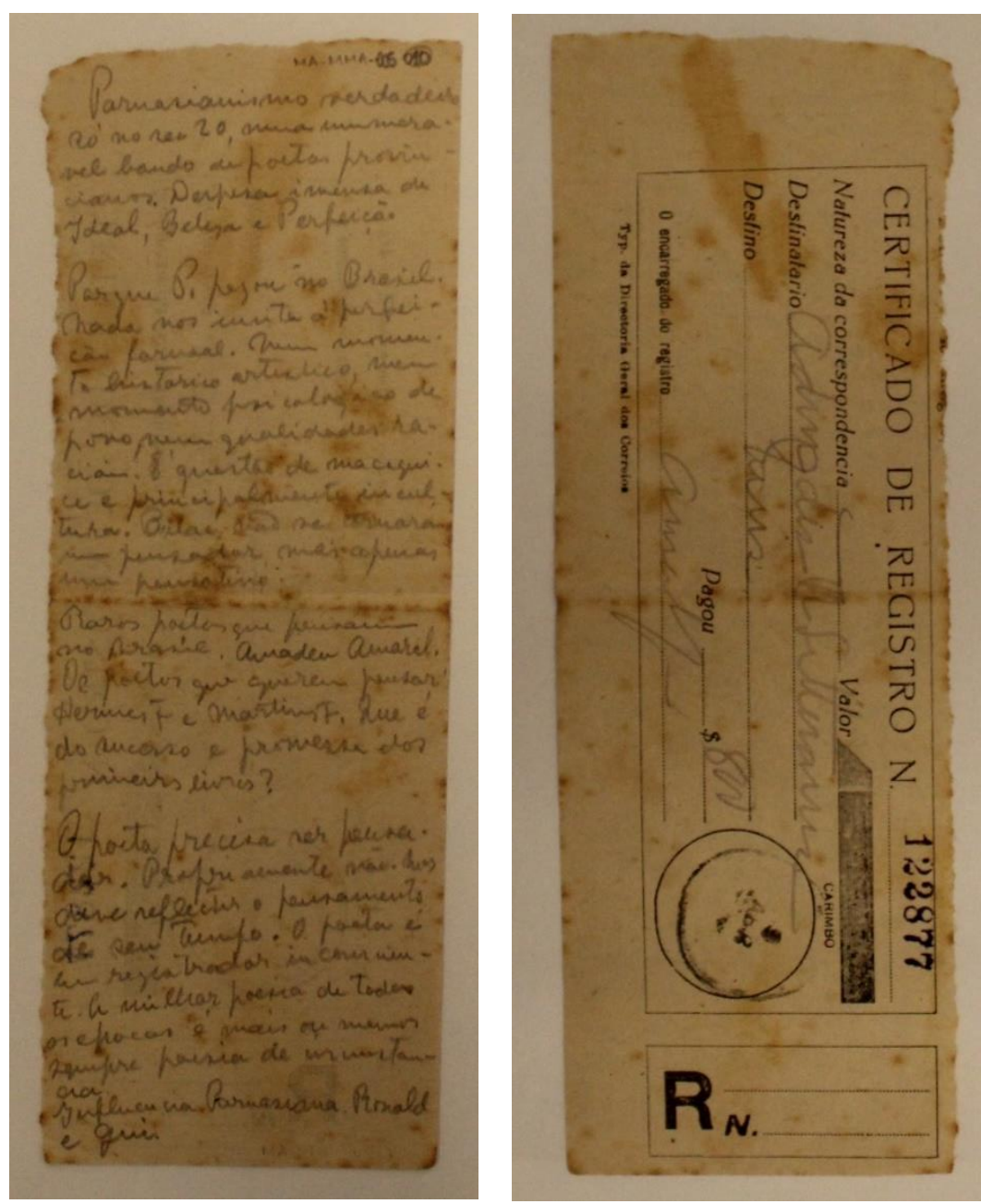

Parnasianismo verdadeiro / só no sec 20, num inumera-/vel bando de poetas provin- / cianos. Despesa imensa de / Ideal, Beleza e Perfeição.

Por que P. pegou no Brasil. / Nada nos incita à perfei-/ção formal. Nem momen-/to historico artistico, nem / momento psicologico de / povo, nem qualidade ra- / ciais. É questão de macaqui-/ce e principalmente incul-/tura. Bilac não se tornara / um pensador mas apenas / um pensativo.

Raros poetas que pensam / no Brasil. Amadeu Amaral. / Os poetas que querem pensar / Hermes F e Martins F. Que é / do sucesso e promessa dos / primeiros livros?

O poeta precisa ser pensa-/dor. Propriamente não. Mas / deve reflectir o pensamento / de seu tempo. O poeta é / um registrador inconscien-/te. A milhor poesia de todas / as epocas é mais ou menos / sempre poesia de circunstan-/cia.

Influencia Parnasiana. Ronald / e Gui. 


\section{MA-MMA-05-11}
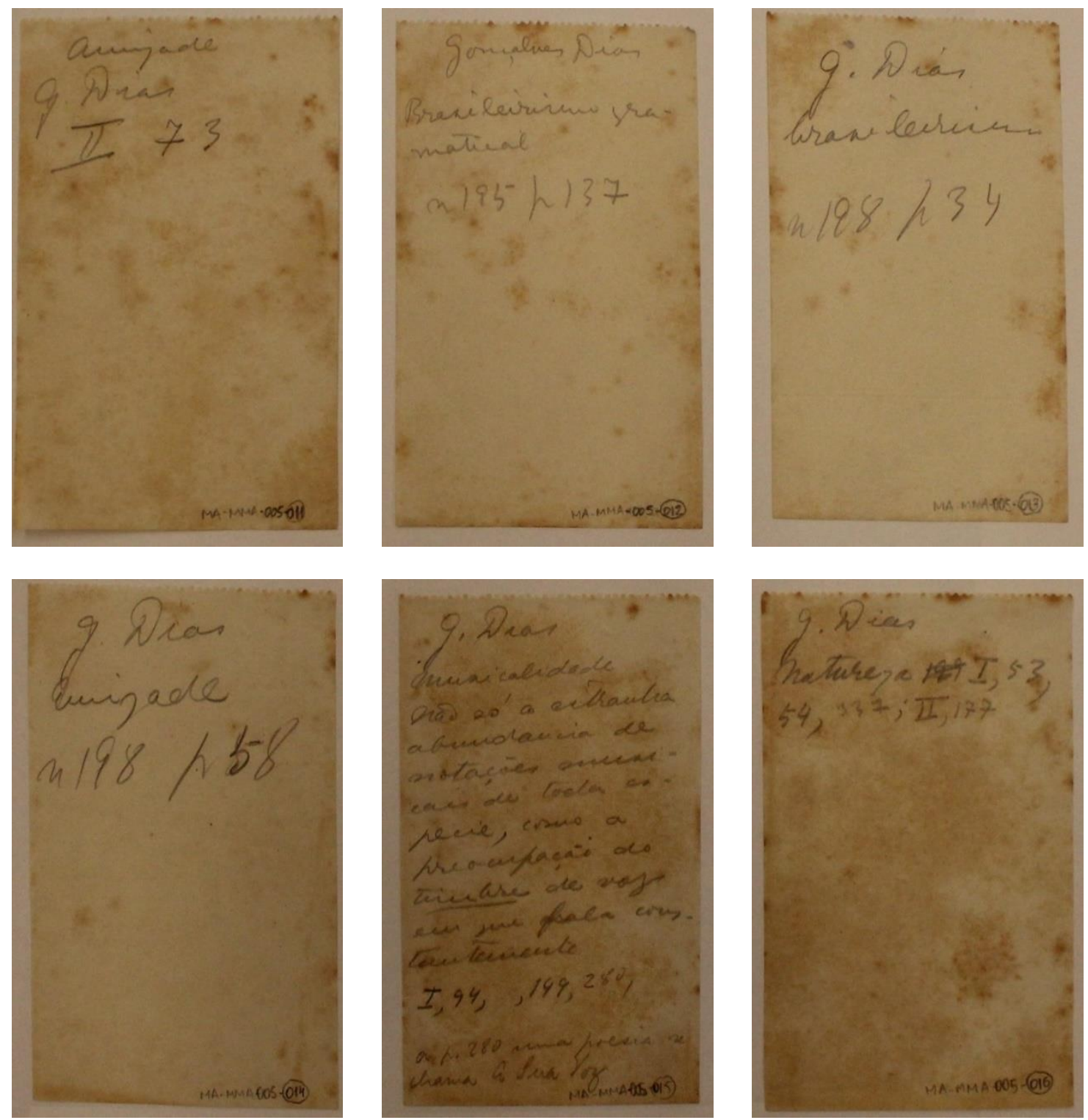

\section{MA-MMA-05-11}

Amizade // G. Dias // II 73

\section{MA-MMA-05-12}

Gonçalves Dias // Brasileirismo gramatical // n 195 p 137

\section{MA-MMA-05-13}

G. Dias // brasileirismo // n 198 p 34 


\section{MA-MMA-05-14}

G. Dias // Amizade // n 198 p 58

\section{MA-MMA-05-15}

G. Dias // Musicalidade // Não só a estranha / abundancia de / notações musi-/cais de toda es-/pecie, como a / preocupação do / timbre de voz / em que fala cons-/tantemente // I, 94, , 149, 280

A p. 280 uma poesia se chama A Sua Voz

\section{MA-MMA-05-16}

G. Dias // Natureza 199 I, 53, / 54, 337; II, 177

\section{MA-MMA-05-17}
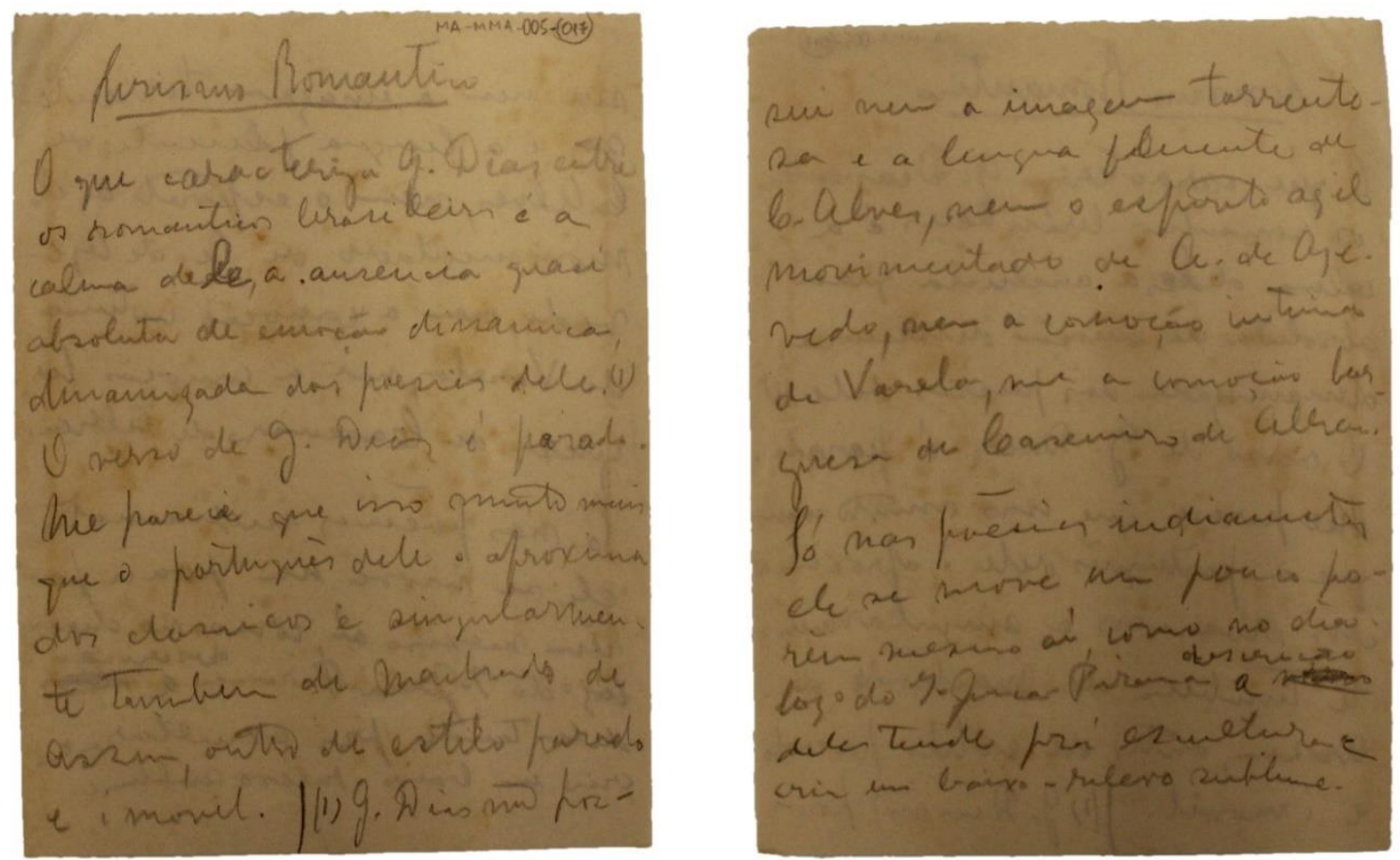


\section{$\underline{\text { Lirismo Romantico }}$}

O que caracteriza G. Dias entre / os romanticos brasileiros é a / calma dele, a ausencia quasi / absoluta de emoção dinamica, / dinamizada das poesia dele. (1) / O verso de G. Dias é parado. / Me parece que isso muito mais / que o português dele o aproxima / dos classicos e singularmen-/te tambem de Machado de / Assis, outro de estilo parado / e imovel. |(1) G. Dias não pos-//

sui nem a imagem torrento-/sa e a lingua fluente de / C. Alves, nem o espirito agil / movimentado de A. de Aze- / vedo, nem a comoção intima / de Varela, nem a comoção bur-/guesa de Casemiro de Abreu. //

Só nas poesias indianistas / ele se move um pouco po-/rém mesmo aí, como no diá-/logo do I-Juca-Pirama a descrição / dele tende pra escultura e / cria um baixo-relevo sublime.

\section{MA-MMA-05-18 $\mathbf{a} 32$}

Alvares / de / Azevedo: notas de pesquisa não numeradas pelo A., inseridas em capa improvisada em meia folha de papel jornal dobrada (16 x 21,9 cm); autógrafo a lápis preto; 10 folhas brancas sem pauta, destacadas de caderneta de bolso: 4 medindo 10,7 $x$ $6.6 \mathrm{~cm}$ (f. 19-21, 23 da numeração da pesquisa), 2 medindo 10,6 x 6,9 cm (f. 24-25, 2930 da numeração da pesquisa); 2 folhas sem pauta de papel branco pautado $(16,1 \times 11,2$ $\mathrm{cm}), f .31$ da numeração da pesquisa, arrancada de caderneta de contabilidade, apresentando 2 cortes laterais; f. 19-21, da numeração da pesquisa, presas por um alfinete (retirado); folhas amarelecidas em sua totalidade apresentando manchas de fungo; escrita utilizando a frente de todas as folhas e verso das $f$. 20-21, 24-25, 30-31 da numeração da pesquisa; rasuras a lápis preto: correção, supressão, acréscimo; $n$. 18 32. 


\section{MA-MMA-05-18}

Alvares / de / Azevedo: capa improvisada em meia folha de papel jornal dobrado (16 $x$ $21,9 \mathrm{~cm}$ ) contendo notas de trabalho (f. 18-32); autógrafo a lápis preto.

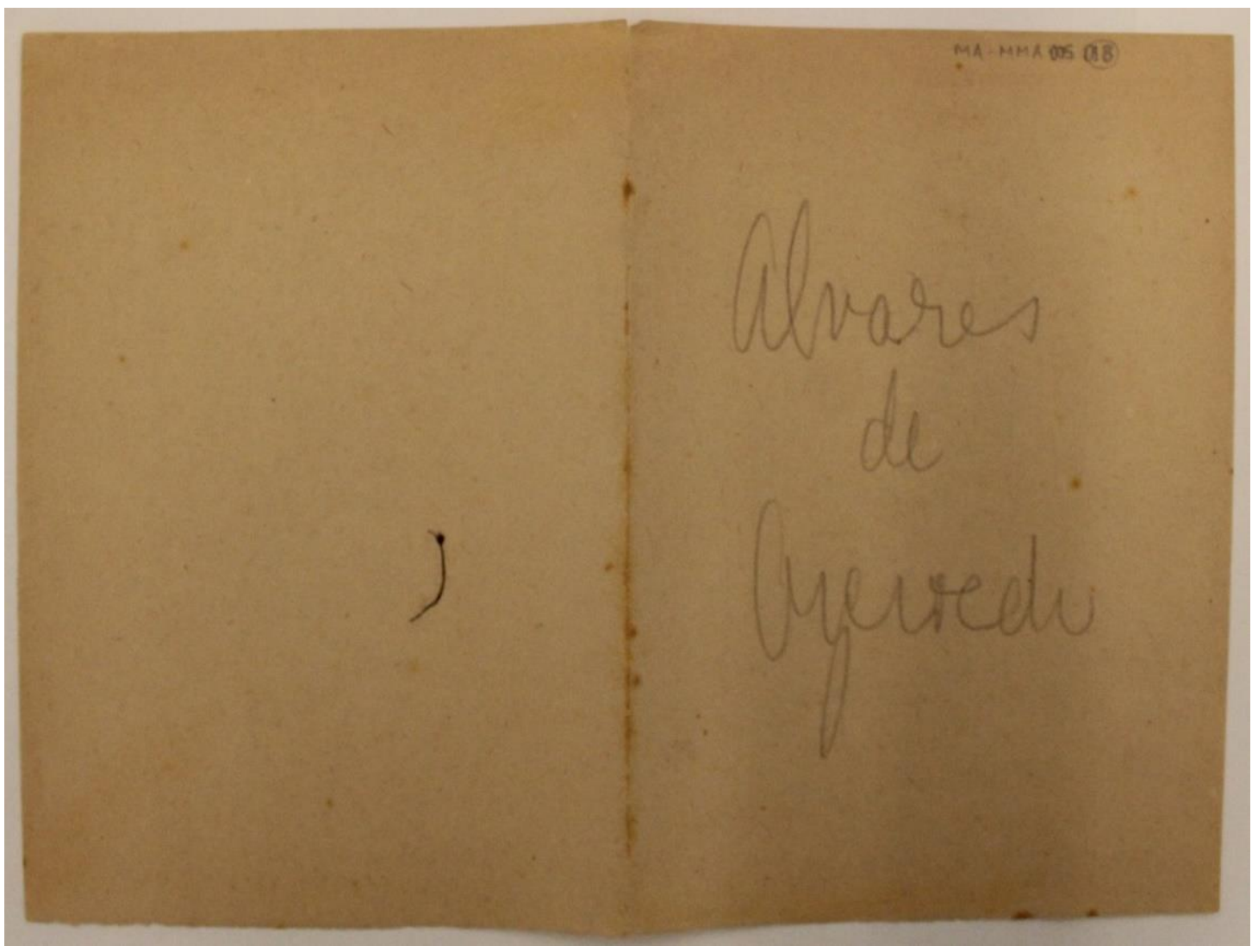

Alvares // de // Azevedo 


\section{MA-MMA-05-19 a 23}

Prosa // de A. de A. Folhas brancas, sem pauta, destacadas de caderneta de bolso, medindo 10,7 $6.6 \mathrm{~cm}$, presas por alfinete (retirado); papel amarelecido e com manchas de fungo; escrita utilizando frente e verso.
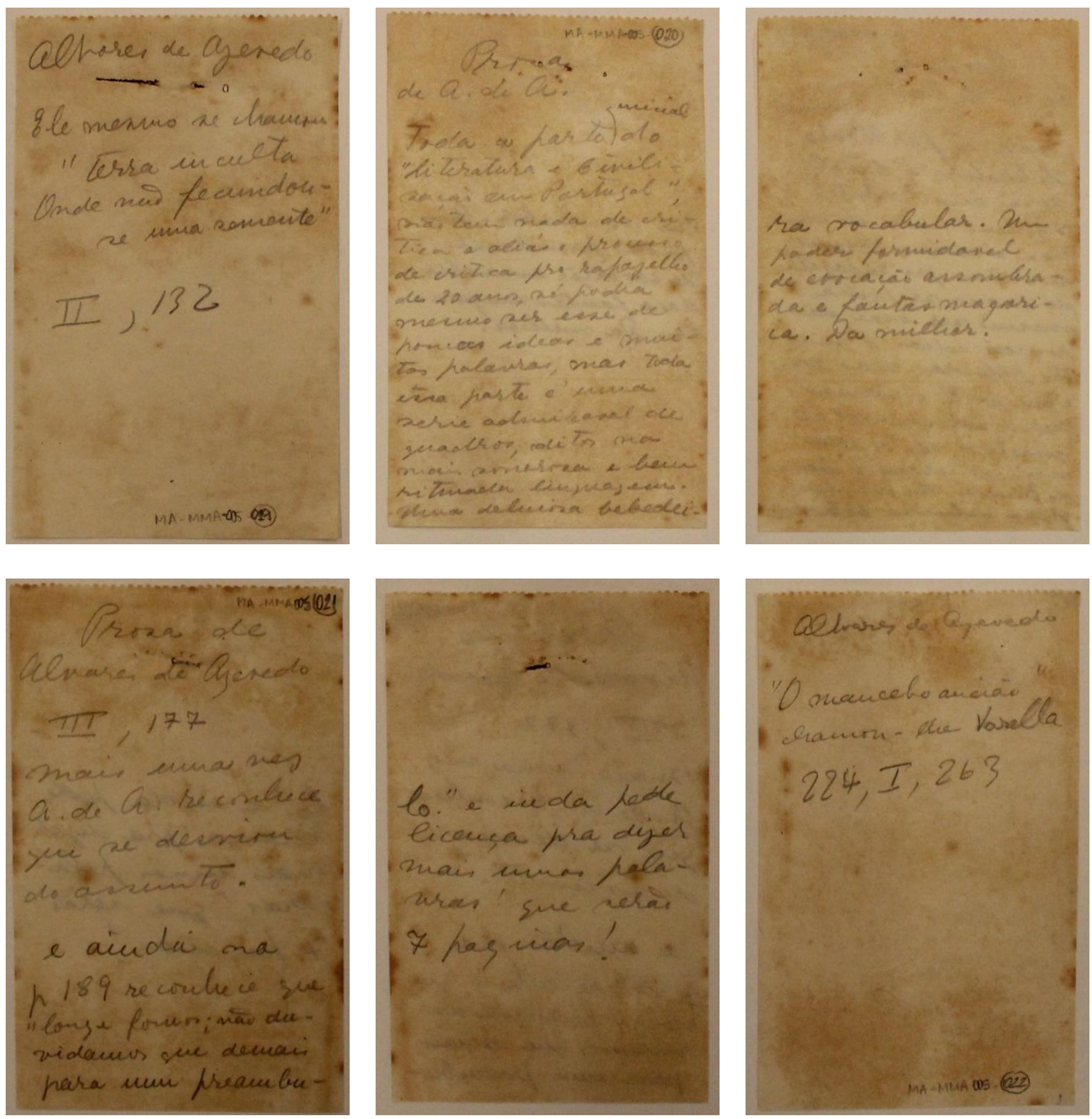


\section{MA-MMA-05-19}

Álvares de Azevedo // Ele mesmo se chamou / "terra inculta / onde não fecundou-/se uma semente" // II, 132

\section{MA-MMA-05-20}

Prosa // de A. de A. // Toda a parte inicial do / "Literatura e Civili-/sação em Portugal", / não tem nada de cri-/tica e aliás o processo / de crítica pro rapazelho / de 20 anos só podia / mesmo ser esse de / poucas ideias e mui-/tas palavras, mas toda / essa parte é uma / série admirável de / quadros, ditos na / mais sonorosa e bem / ritmada linguagem. / Uma deliciosa bebedei-/ra vocabular. Um / poder formidavel / de evocação assombra-/da e fantasmagori-/ca. Do milhor.

\section{MA-MMA-05-21}

Prosa de // Álvares de Azevedo // III, 177 // Mais uma vez / A. de A. reconhece / que se desviou / do assunto. // e ainda na / p 189 reconhece que / "longe fomos; não du-/vidamos que demais / para um preambu-/lo." e inda pede / licença pra dizer / mais umas pala-/vras! que serão / 7 paginas!

\section{MA-MMA-05-22}

Alvares de Azevedo // "O mancebo ancião" / chamou-lhe Varella // 224, I, 263 
MA-MMA-05 23
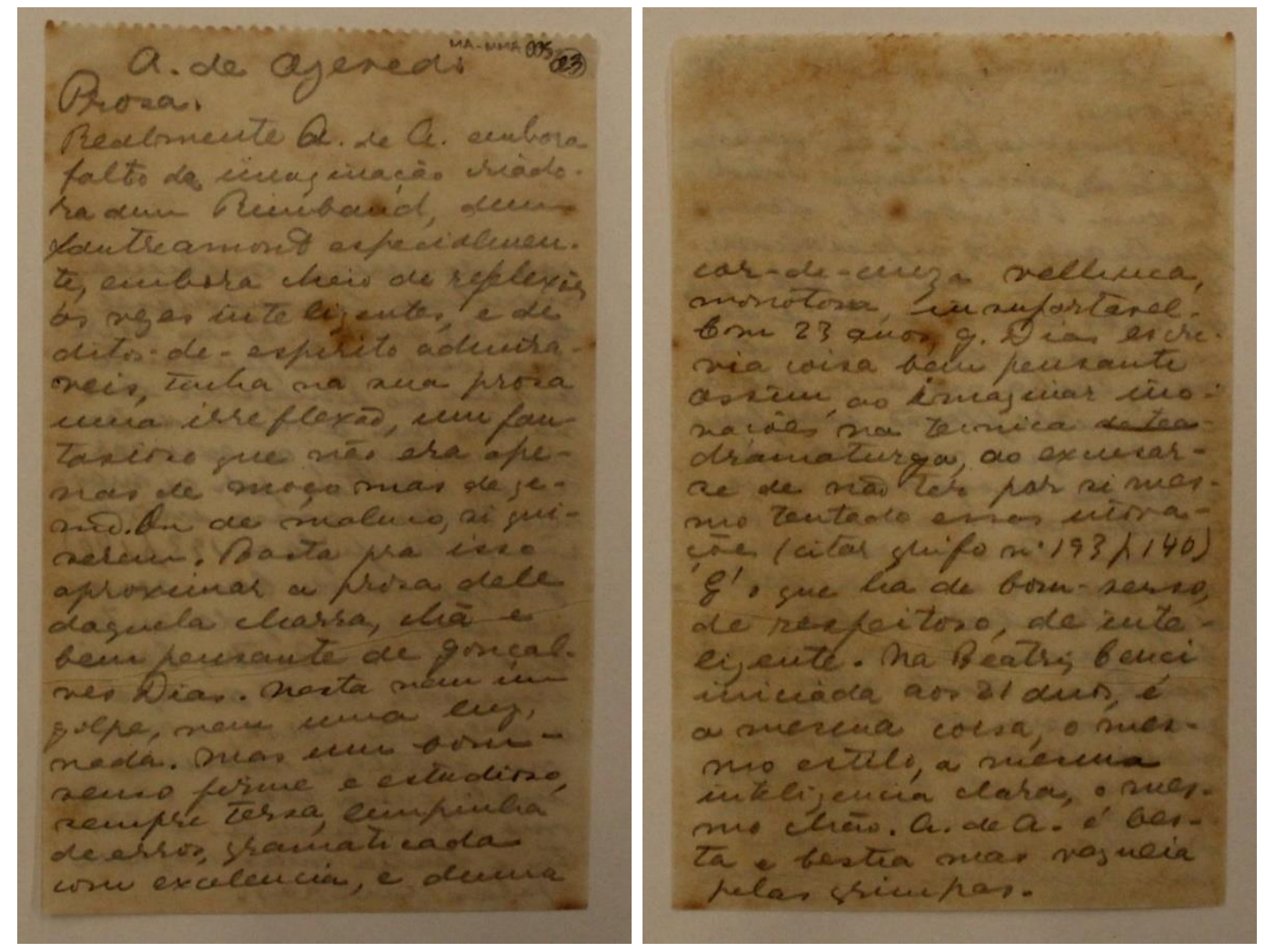

A. de Azevedo // Prosa. //

Realmente A. de A. embora / falto da imaginação criado-/ra dum Rimbaud, dum / Lautreamont especialmente, embora cheio de reflexões às vezes inteligentes, e de ditosde-espírito admiraveis, tinha na sua prosa uma irreflexão, um fantasioso que não era apenas de moço mas de genio. Ou de maluco, si quiserem. Basta pra isso aproximar a prosa dele daquela charra, chã e bem pensante de Gonçalves Dias. Nesta nem um golpe, nem uma luz, nada. Mas um bom-senso firme e estudioso, sempre tersa, limpinha de erros, gramaticada com excelencia, e duma // cor-de-cinza velhuca, monotona, insuportavel. Com 23 anos, G. Dias escrevia coisa bem pensante. Assim, ao imaginar inovações na técnica de tea dramaturga, ao excusar-se de não ter por si mesmo tentado essas inovações (citar grifo n 193 p 140). É o que há de bom-senso, de respeitoso, de inteligente. Na Beatriz Cenci iniciada aos 21 anos, é a mesma coisa, o mesmo estilo, a mesma inteligência clara, o mesmo chão. A. A. é besta e bestia mas vagueia pelas grimpas. 


\section{MA-MMA-05-24}
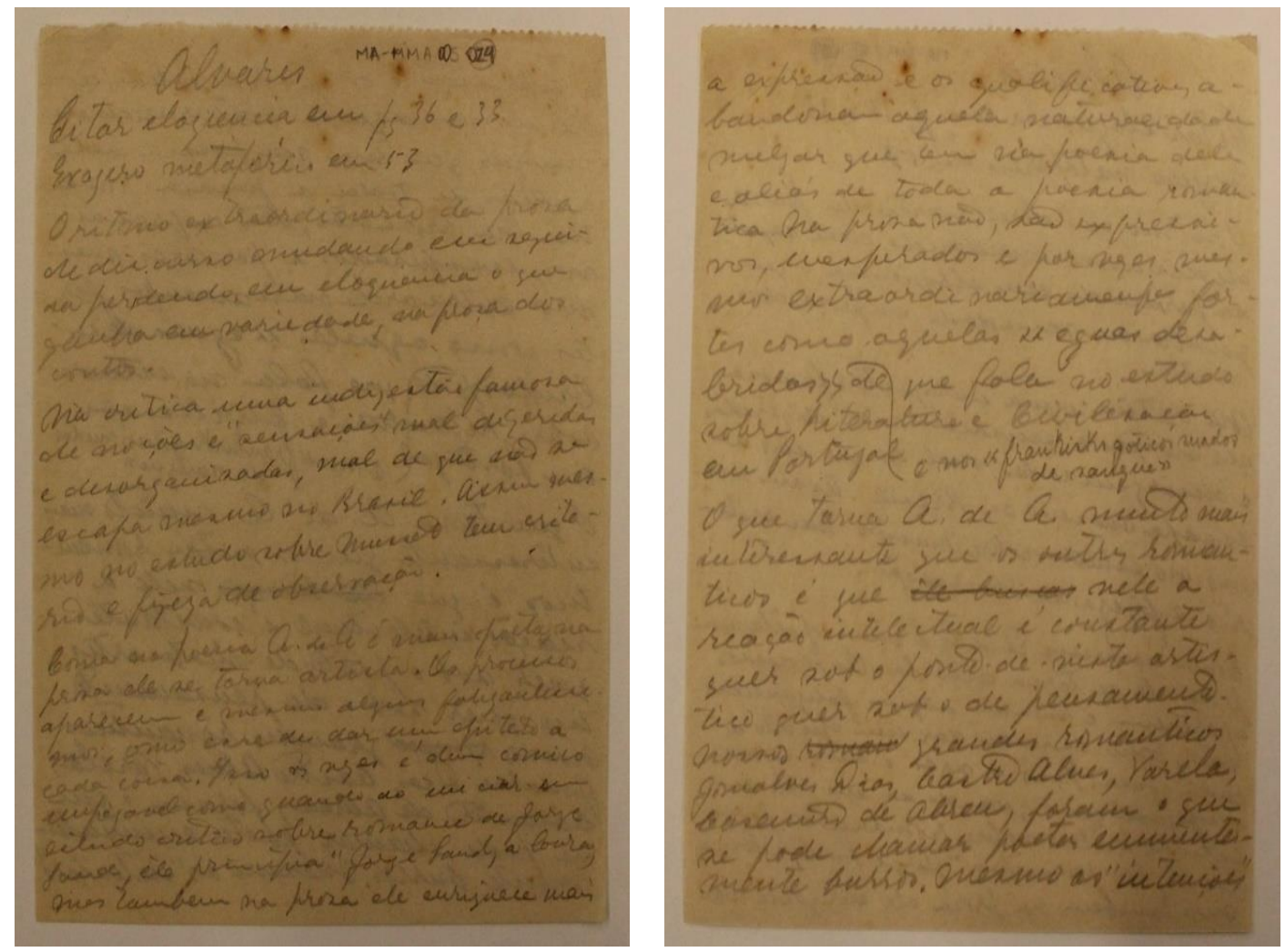

Alvares

Citar eloquencia em ps 36 e 33

Exagero metaforico em 53

O ritmo extraordinario da prosa / de discurso mudando em segui-/da perdendo em eloquencia o que / ganha em variedade, na prosa dos / contos.

$\mathrm{Na}$ critica uma indigestão famosa / de noções e "sensações" mal digeridas / e desorganizadas, mal de que não se / escapa mesmo no Brasil. Assim mes-/mo no estudo sobre Musset tem crite-/rio e fineza de observação.

Como na poesia A. de A. é mais poeta, na / prosa ele se torna artista. Os processos / aparecem e mesmo alguns fatigantissi/mos, como esse de dar um epiteto a / cada coisa. Isso às vezes é dum comico / impagavel como quando ao iniciar um / estudo critico sobre romance de Jorge / Sand, êle principia "Jorge Sand, a loura/, mas também na prosa ele enriquece mais

a expressão e os qualificativos, a-/bandona aquela naturalidade / vulgar que tem na poesia dele e aliás de toda a poesia roman-/tica. Na prosa não, são expressi-/vos, inesperados e 
por vezes mes-/mo extraordinariamente fortes como aquelas "eguas desabridas" e nos "frankisks goticos suados de sangue" de que fala no estudo sobre Literatura e Civilisação em Portugal.

O que torna A. de A. muito mais / interessante que os outros roman-/ticos é que êle busceu nele a / reação intelectual é constante / quer sob o ponto-de-vista artis-/tico quer sob o de pensamento. / Nossos roman grandes romanticos / Gonçalves Dias, Castro Alves, Varela, / Casemiro de Abreu, foram o que / se pode chamar poetas eminente-/mente burros. Mesmo as "intenções"

\section{MA-MMA-05 25}
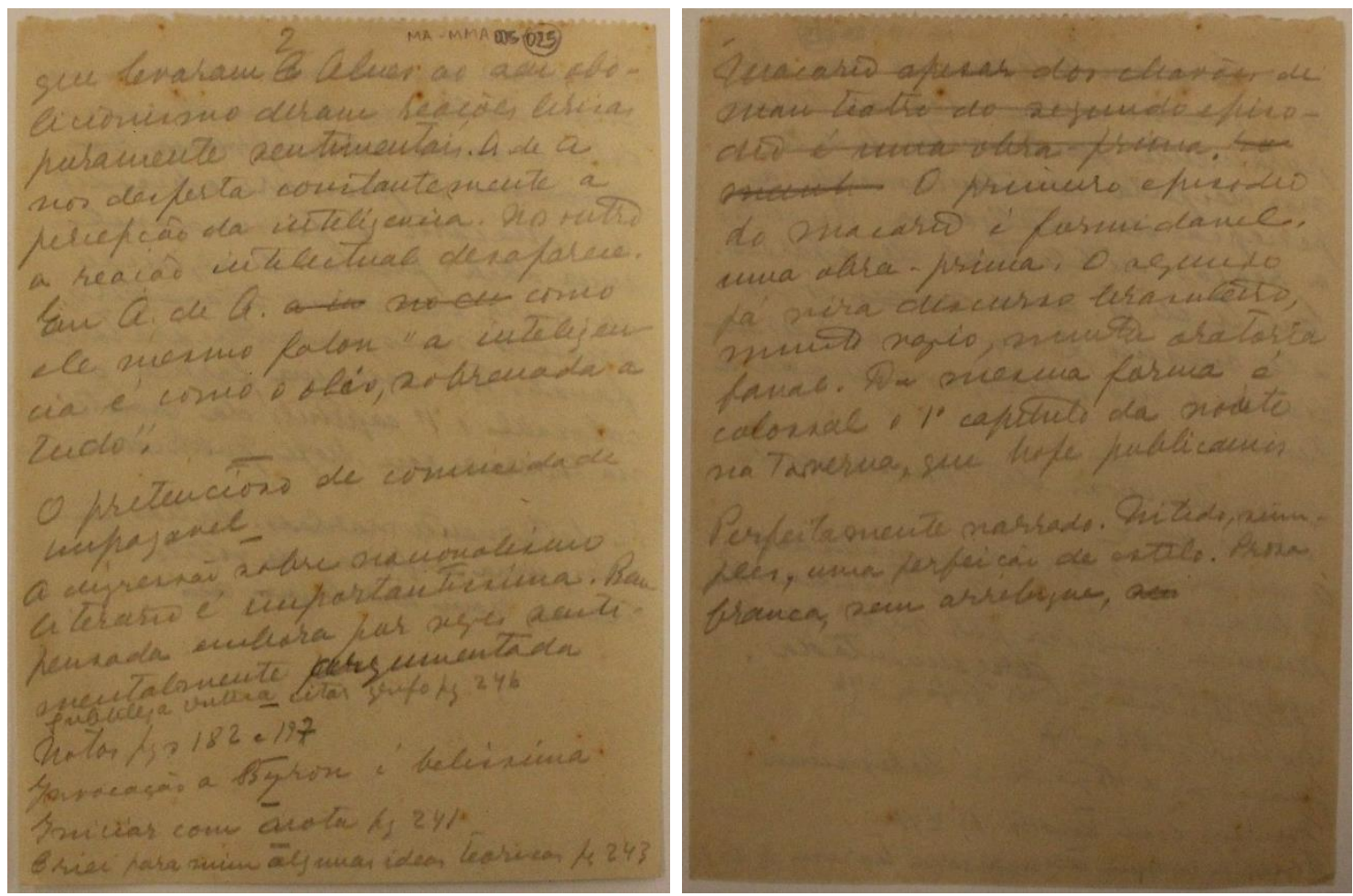

que levaram C. Alves ao seu abo-/licionismo deram reações liricas / puramente sentimentais. A. de A. / nos desperta constantemente a / percepção da inteligencia. Nos outros / a reação intelectual desaparece. / Em A. de A. a ca no de como / ele mesmo falou "a inteligen-/cia é como o olio, sobrenada a / tudo".

O pretencioso de comicidade / impagavel 
A digressão sobre nacionalismo / literario é importantíssima. Bem / pensada embora por vezes senti-/mentalmente argumentada

Subtileza critica citar grifo pg 246

Notas pgs 182 e 197

Invocação a Byron é belíssima

Iniciar com nota pg 241

Criei para mim algumas ideias teoricas pg 243

Macario apesar dos chavões de / mau teatro do segundo episo /dio é uma obra-prima roImanti O primeiro episodio / do Macario é formidavel, / uma obra-prima. O segundo / já vira discurso brasileiro, / muito vazio, muita oratoria / banal. Da mesma forma é / colossal o primeiro capítulo da Noite / na Taverna, que hoje publicamos

Perfeitamente narrado. Nitido, sim-/ples, uma perfeição de estilo. Prosa / franca, sem arrebique, sem

\section{MA-MMA-5-26 a 28}
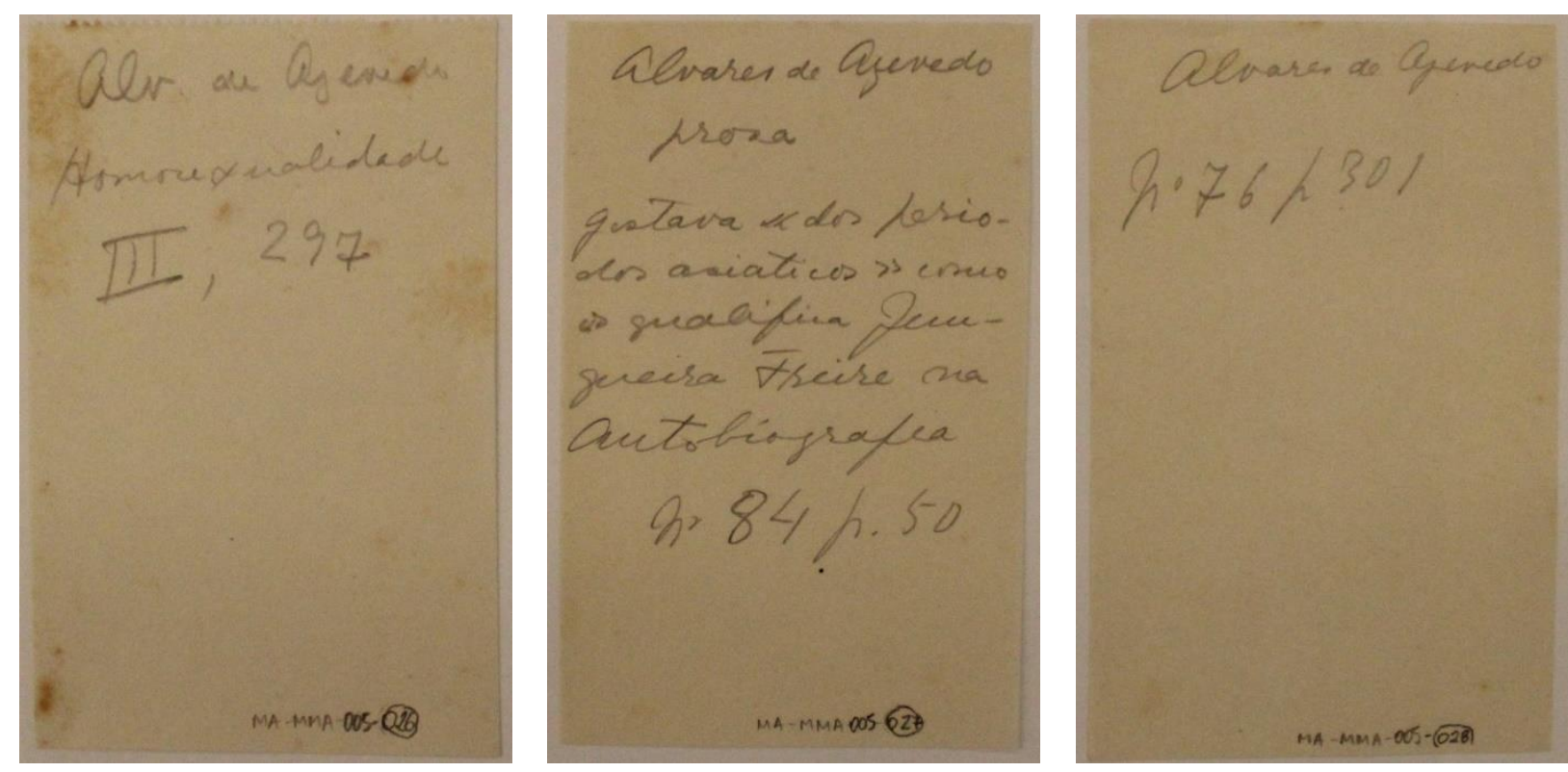


\section{MA-MMA-5 26}

Alv. de Azevedo // Homossexualidade // III, 297

\section{MA-MMA-5 27}

Alvares de Azevedo // prosa // Gostava "dos perio-/dos asiaticos" como / os qualifica Jun/queira Freire na / Autobiografia / n. 84 p. 50

\section{MA-MMA-5-28}

Alvares de Azevedo // n. 76 p 301

\section{MA-MMA-5 29}

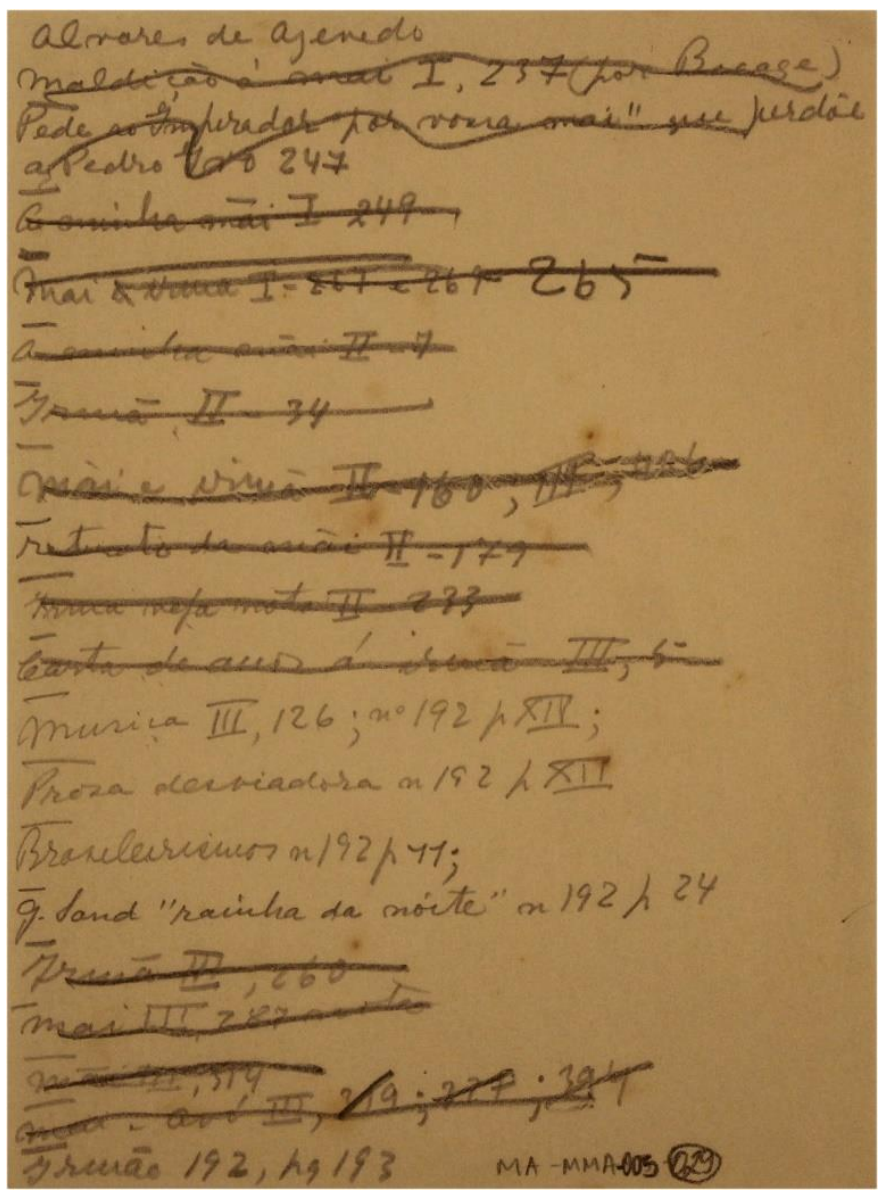


Alvares de Azevedo

Maldição à mãi I, 237 (por Bocage)

Pede ao Imperador “por vossa mãi” que perdoe / a Pedro Ivo 247

A minha mãi I, 249

Mãi e irmã I - 267 e 269265

A minha mãi II - 7

Irmã II -34

Mãi e irmã II - 160; III, 336

Retrato da mãi II - 179

Irmã veja nota II - 233

Carta de amor á irmã III, 5

Musica III, 126; nº 192 p XIV;

Prosa desviadora n 192 p XII

Brasileirismos no 192 p 11;

G. Sand "rainha da noite" n 192 p 24

Irmã III, 260

Mãi III, 287 nota

Mãi III, 314

Mãi e Avó III, 319; 227; 394

Irmão 192, pg 193 

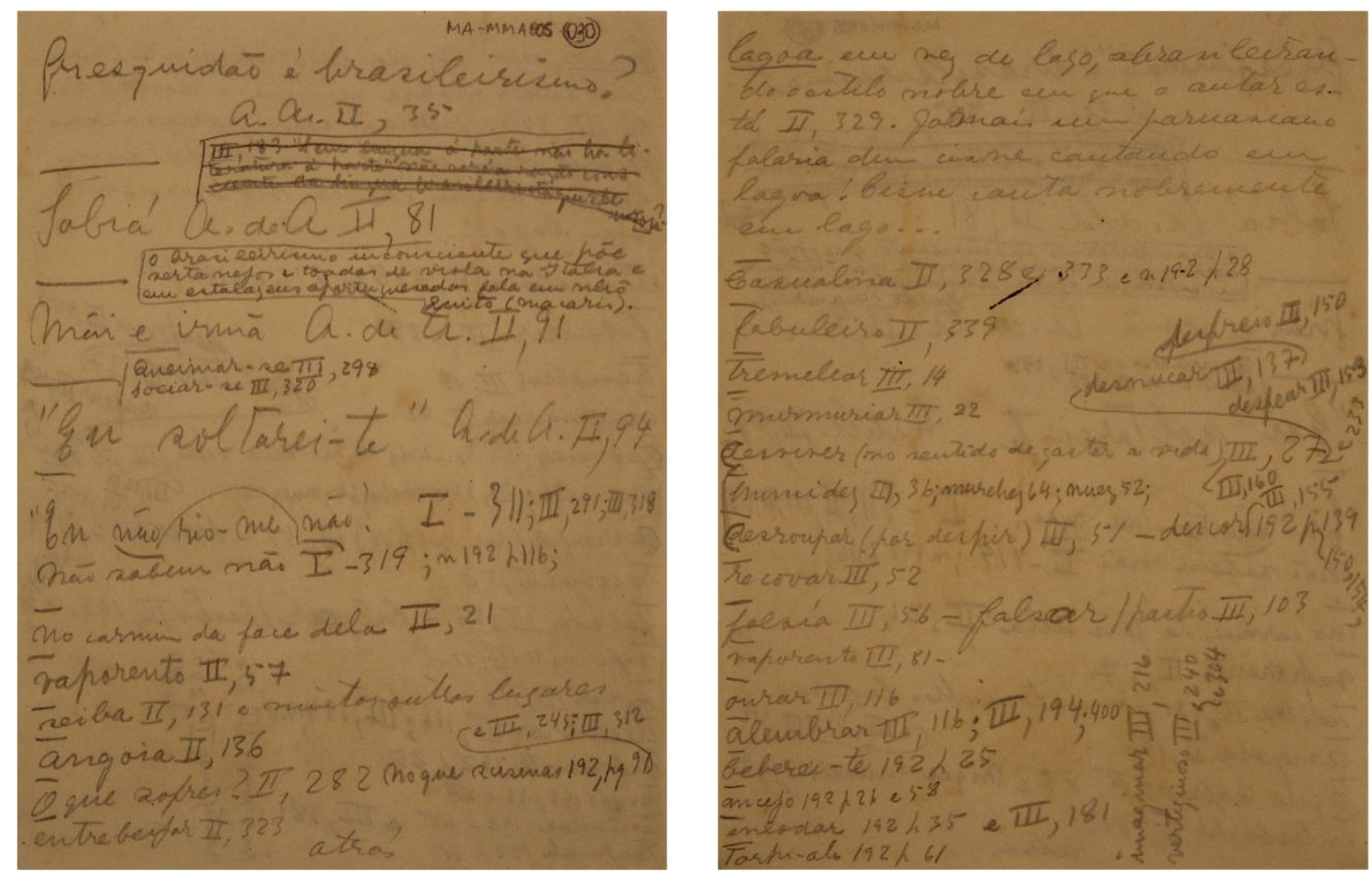

Fresquidão é brasileirismo?

\section{A.A. II, 35}

III, 183 “Sem língua à parte não há literatura à parte". Não seria razão consciente da lingua brasileirista que êle emprega?

Sabiá A. de A. II, 81

o brasileirismo inconsciente que põe sertanejos e todas de viola na Italia e em estalagens aportuguesadas fala em nhô ?? (Macario)

Mãi e irmã A. de A. II, 91

Queimar-se III, 298

Sociar-se III, 320

"Eu soltarei-te" A. de A. II, 94

“Eu não rio-me não.” I - 311, III, 291; III, 318

Não sabem não I - 319; n 192 p 116;

No carmim da face dela II, 21

Vaporento II, 57 
seiba II, 131 e muitos outros lugares

<Hegível> II, 136

O que sofres? II, 282 no que scismas 192, pg 90 e III, 245; III, 312

Entrebeijar II, 323

atras

lagoa em vez de lago, abrasileirando o estilo nobre em que o autor está II, 329. Jamais um parnasiano falaria dum cisne cantando em lagoa! Cisne canta nobremente em lago...

Casualina II, 328 e 333 e n 192 p 28

Tabuleiro II, 339

Tremelear III, 14

Murmuriar III, 22

desviver (no sentido de gastar a vida) III, 27 e 233; III, 160;

desnucar III, 137

desfear III, 153

desfreio III, 150

humidez III, 36; murchez 64; nuez 52;

desroupar (por despir) III, 51

descor III, 155; 192 p 139, 150, 157

recovar III, 52

falsia III, 56 - falsar / pastio III, 103

vaporento III, 81

ourar III, 116

alembrar III, 116; III, 194; 400

beberei-te 192 p 25

ancejo 192 p 26 e 58

enlodar 192 p 35 e III, 181

Torpi-alo 192 p 61

imaginar III, 216 
vertiginoso III, 240 e 304

\section{MA-MMA-05 31}
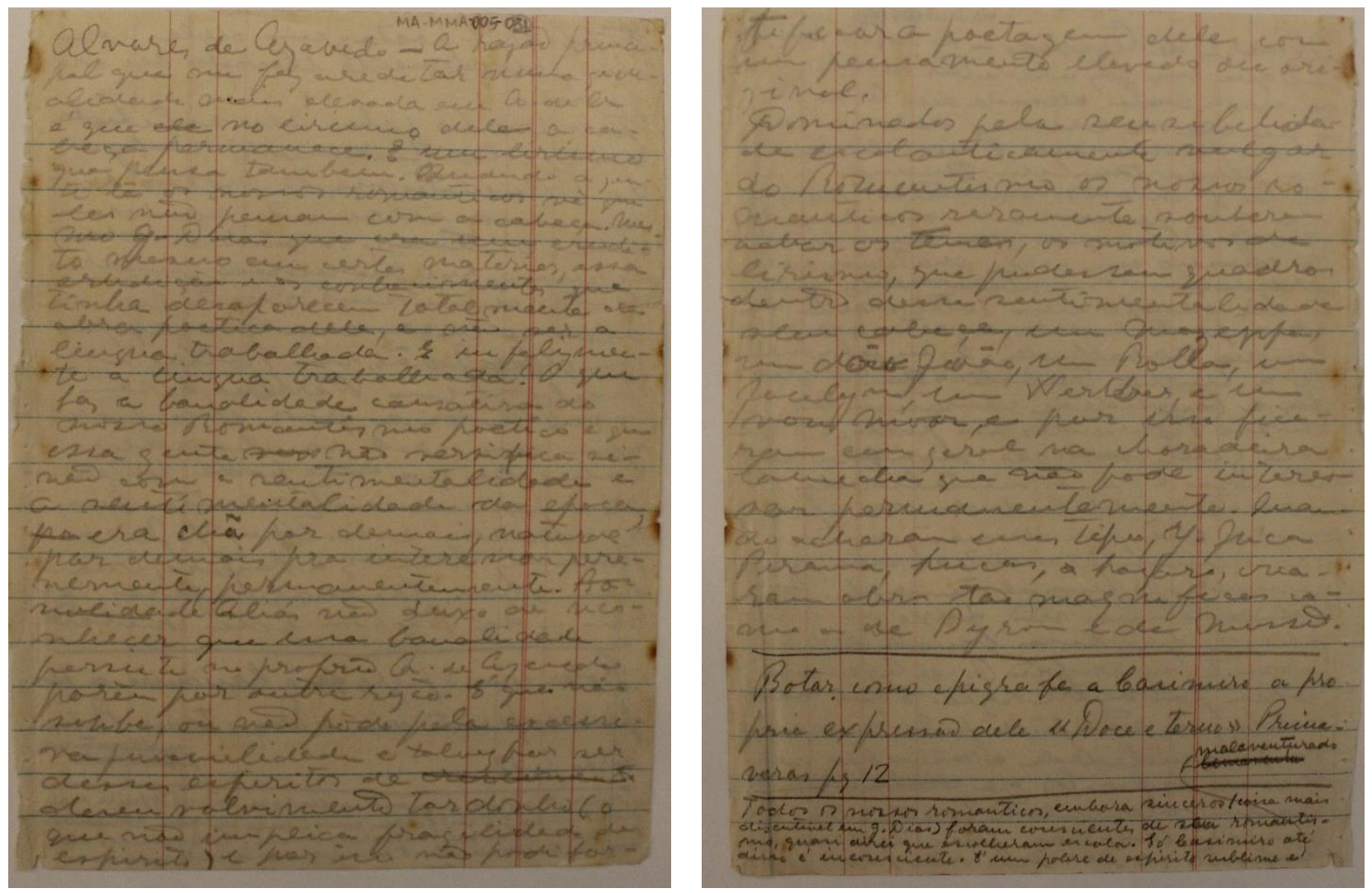

Alvares de Azevedo - A razão princi-/pal que nos faz acreditar numa geni-/alidade mais elevada em A. de A / é que ele no lirismo dele a ca-/beça permanece. É um lirismo / que pensa também. Quando a gen-/te lê os nossos romanticos vê que / eles não pensam com a cabeça. Mes-/mo G. Dias que era um erudi-/to mesmo em certas matérias, essa / erudição e os conhecimentos que / tinha desaparecem totalmente da / obra poetica dele, a não ser a / lingua trabalhada. E infelizmen-/te a lingua trabalhada! O que / faz a banalidade cansativa do / nosso Romantismo poetico é que / essa gente vers não versifica si-/não com a sentimentalidade e / a sentimentalidade da epoca, / pør era chã por demais, natural / por demais pra interessar pere-/nemente, permanentemente. Ba-malidade Aliás não deixo de reco-/nhecer que uma banalidade / persiste no proprio A. de Azevedo / porém por outra razão. É que não / soube, ou não pôde pela excessi-/va juvenilidade e talvez por ser / desses espiritos de eresciment desenvolvimento tardonho (o / que não implica 
fragilidade de / espirito) e por isso não pode for-/tificar a poetagem dele com / um pensamento elevado ou ori-/ginal.

Dominados pela sensibilida-/de escolasticamente vulgar / do Romantismo os nossos ro/manticos raramente souberam / achar os temas, os motivos de / lirismo, que pudessem quadrar dentro dessa sentimentalidade / sem cabeça, um Mazeppa, / um dom João, um Rolla, um /Jocelyn, um Werther, e um / novo <ilegível>, e por isso fica-/ram em geral na choradeira. / Comedia que não pode interes-/sar permanentemente. Quan-/do acharam esses tipos, Y-Juca / Pirama, Lucas, ө Lazaro, cria-/ram obras tão magnificas como as de Byron e de Musset.

Botar como epigrafe a Casimiro a pro-/pria expressão dele "Doce e terno" Prima-/veras $\operatorname{pg} 12$

Todos os nossos romanticos, embora sinceros (coisa mais / discutivel em G. Dias) foram conscientes de seu romantis-/mo, quase direi que escolheram escola. Só Casimiro até / disso é inconsciente. É um pobre de espirito sublime e / bemaventu malaventurado. 
Dossiê do manuscrito Artigos por escrever

MA-MMA-11 02

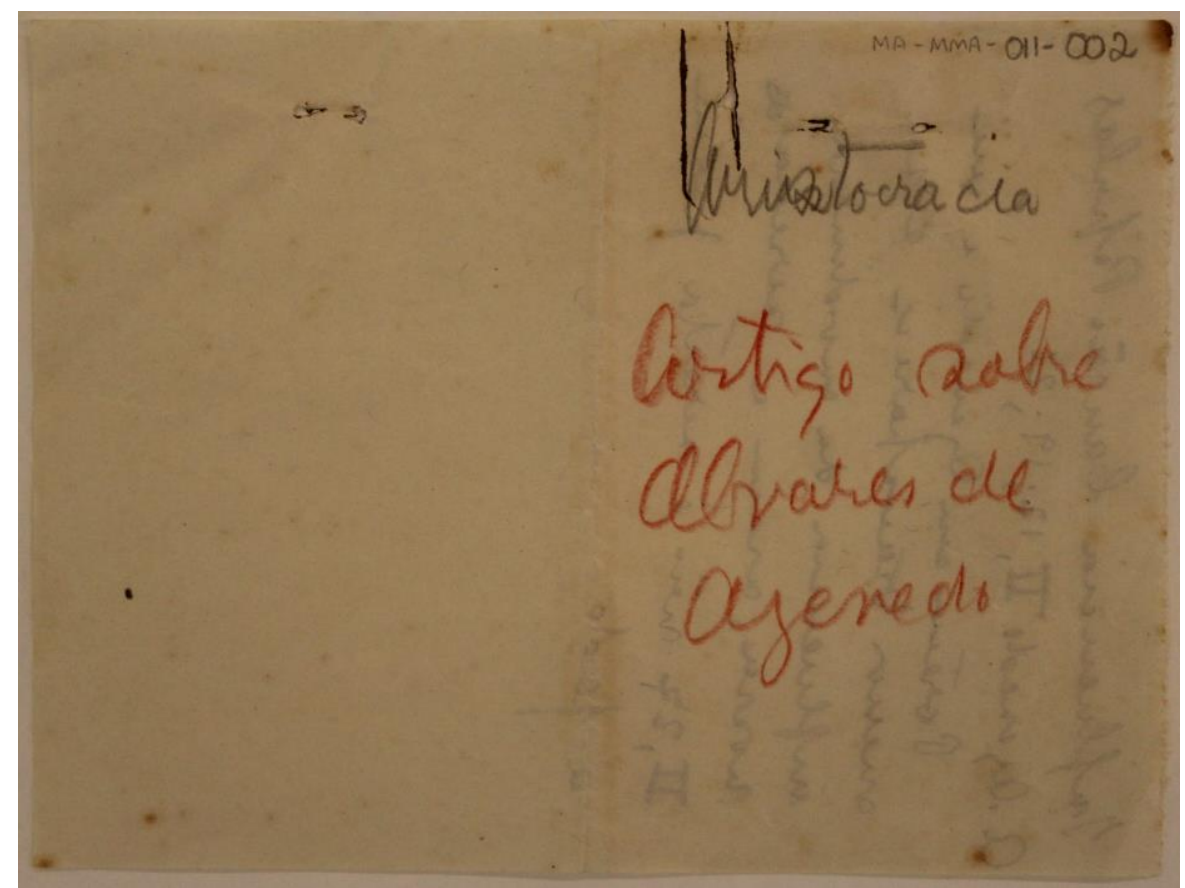

Aristocracia // Artigo / sobre / Alvares de / Azevedo

\section{MA-MMA-11 03}
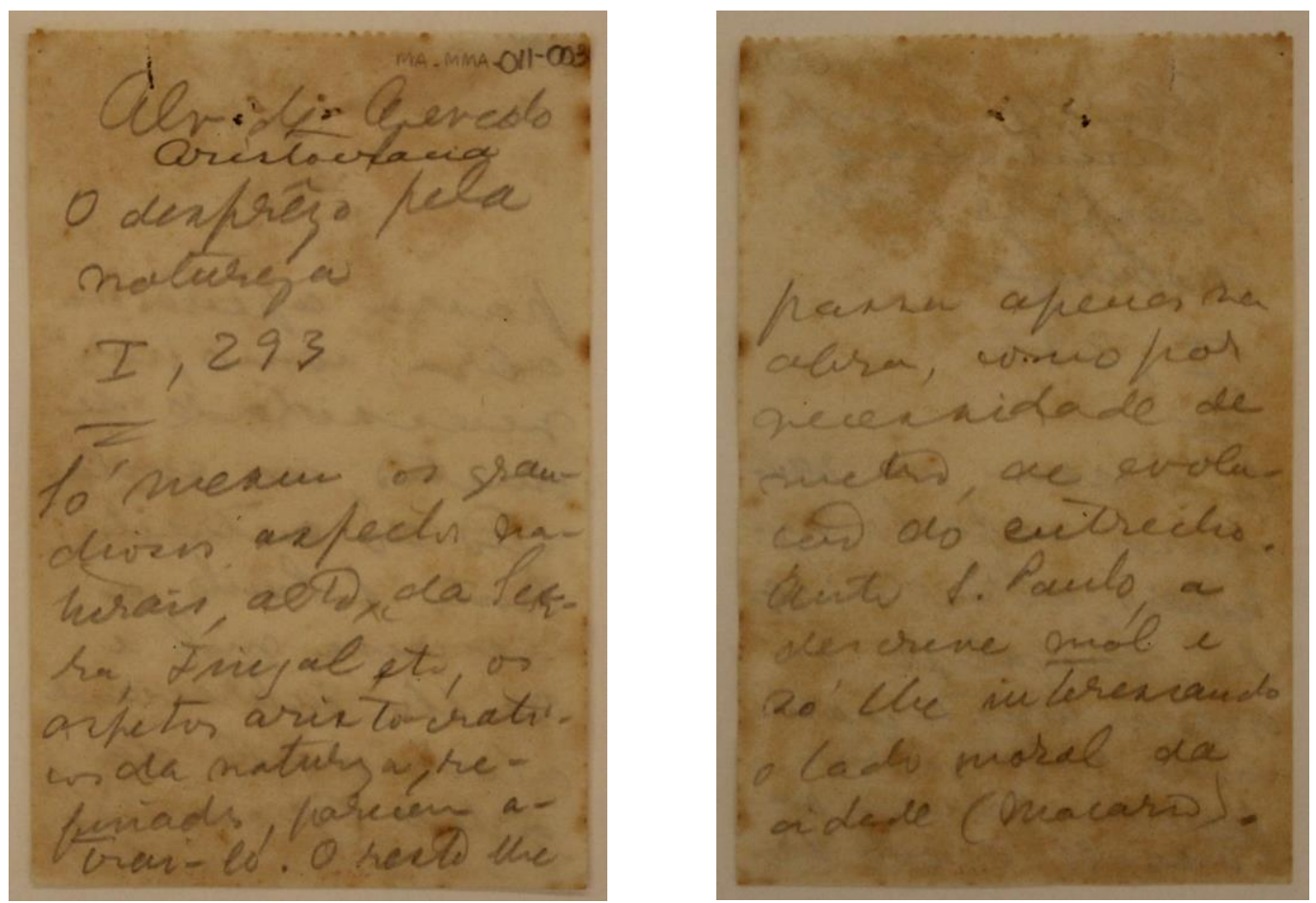

Alv. de Azevedo // Aristocracia // O desprêzo pela / natureza // I, 293 // Só mesmo os gran-/diosos aspectos na-/turais, alto da Ser-/ra, Fingal etc, os / aspetos aristocrati-/cos da natureza, re-/finados, porem a-/trai-lo. O resto lhe / passa apenas na / obra, como por / necessidade de / metro, de evolu/ção do entrecho. / Ante S. Paulo, a / descreve mal e / só lhe interessando / o lado moral da / cidade (Macario). 


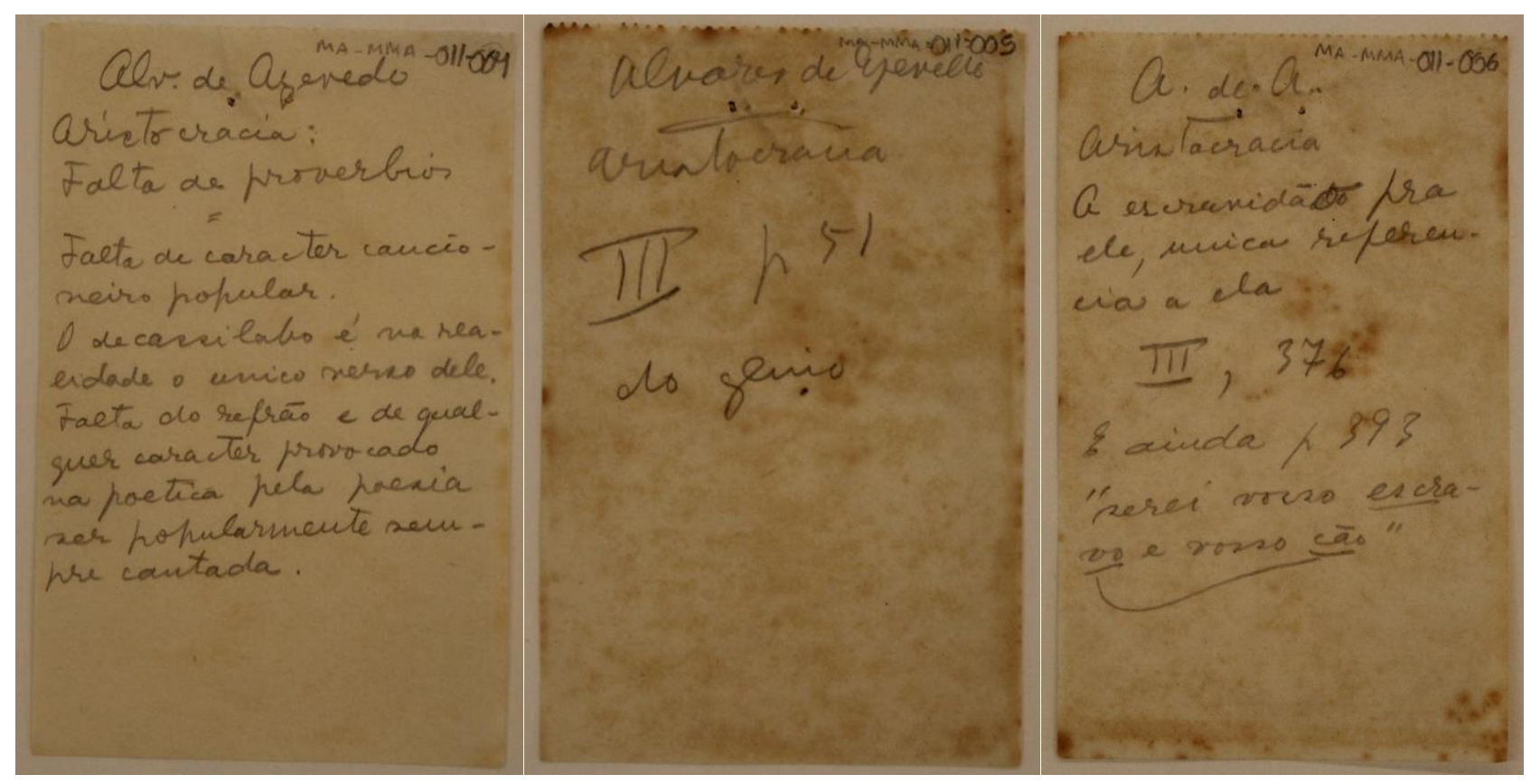

\section{MA-MMA-11 04}

Alv. de Azevedo // Aristocracia: // Falta de proverbios // Falta de caracter cancio-/neiro popular. // O decassilabo é na rea-/lidade o único verso dele. / Falta do refrão e de qual-/quer caracter provocado / na poetica pela poesia / ser popularmente sem-/pre cantada.

\section{MA-MMA-11 05}

Alvares de Azevedo // Aristocracia // III p 51 // do genio

\section{MA-MMA-11}

A. de A. // Aristocracia // A escravidão pra / ele, única referen-/cia a ela // III, 376 // E ainda p 393 / "serei vosso escra-/o e vosso cão" 
MA-MMA-11 07 e8
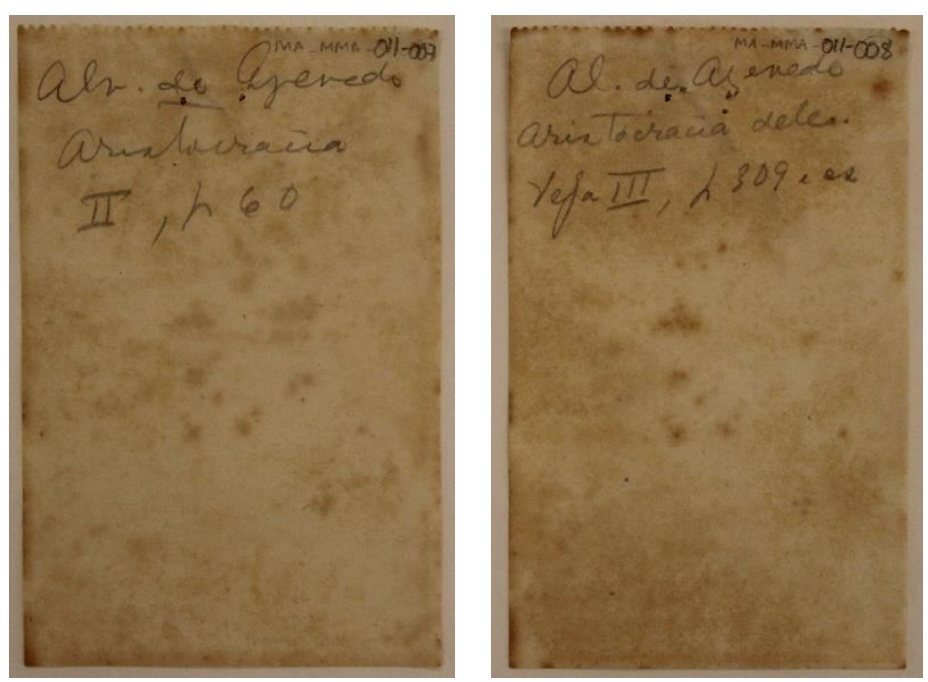

MA-MMA-11 07

Alv. de Azevedo // Aristocracia // II, p 60

MA-MMA-11 08

Alv. de Azevedo // Aristocracia dele. // Veja III, p 309 e ss

\section{MA-MMA-11 09 e 10}
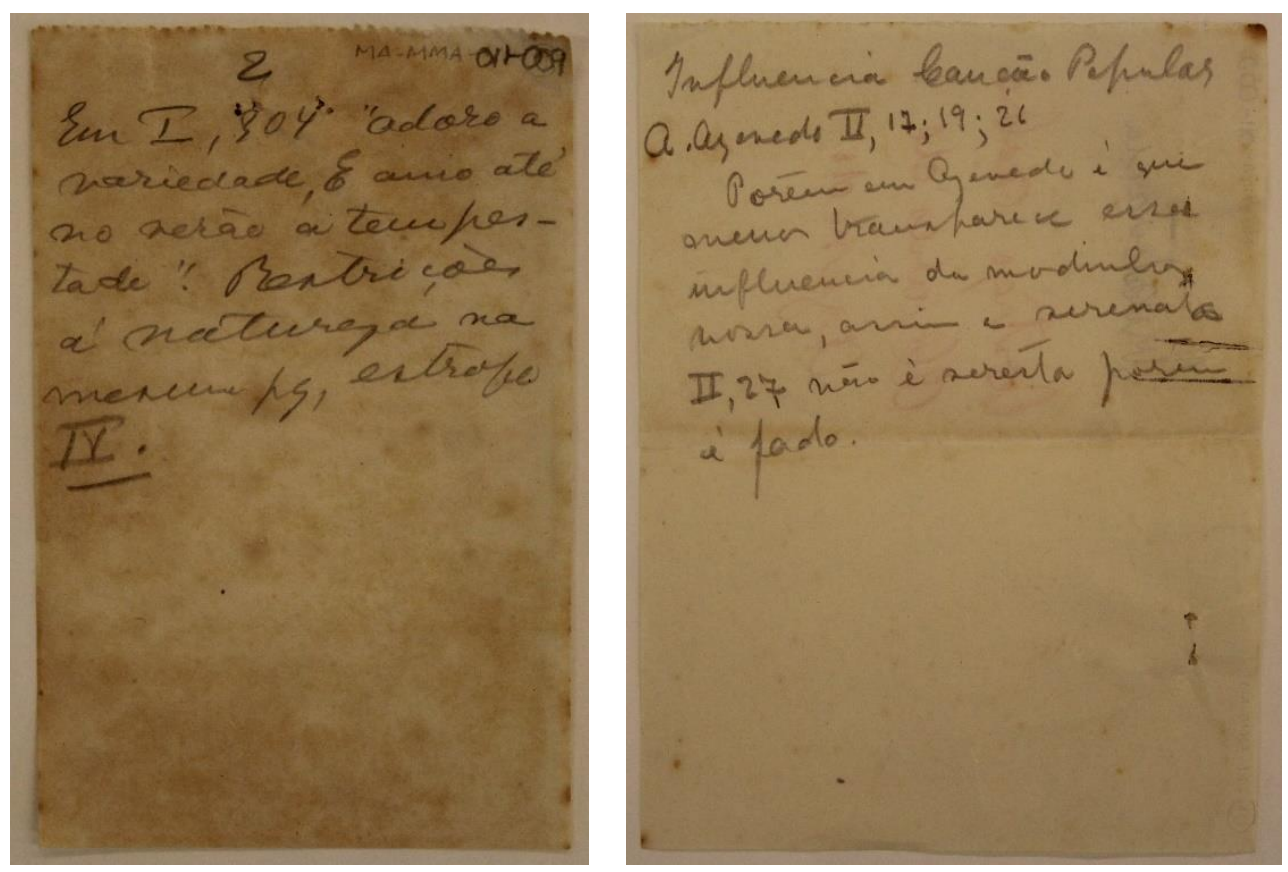


\section{MA-MMA-11-09}

2

Em I, 304 “adoro a / variedade, E amo até / no verão a tempes-/tade.” Restrições / á natureza na / mesma pg, estrofe / IV.

\section{MA-MMA-11 10}

Influencia Canção Popular // A. Azevedo II, 17; 19; 26 // Porém em Azevedo é que / menos transparece essa / influencia de modinha / nossa, assim a serenata / II, 27 não é seresta porém / é fado.

\section{MA-MMA-11 11 a 13}

Momento. Esboço de editorial para a Revista Nova; autógrafo a lápis preto; 3 folhas de papel branco milimetrado para fichário $(27,8 \times 21,5 \mathrm{~cm})$ amarelecidas pelo tempo, com 3 furos; marcas de dobra; manchas de fungo; numerado (1-3); escrita utilizando o anverso e o verso da página; rasuras a lápis preto: correção, supressão, acréscimo;
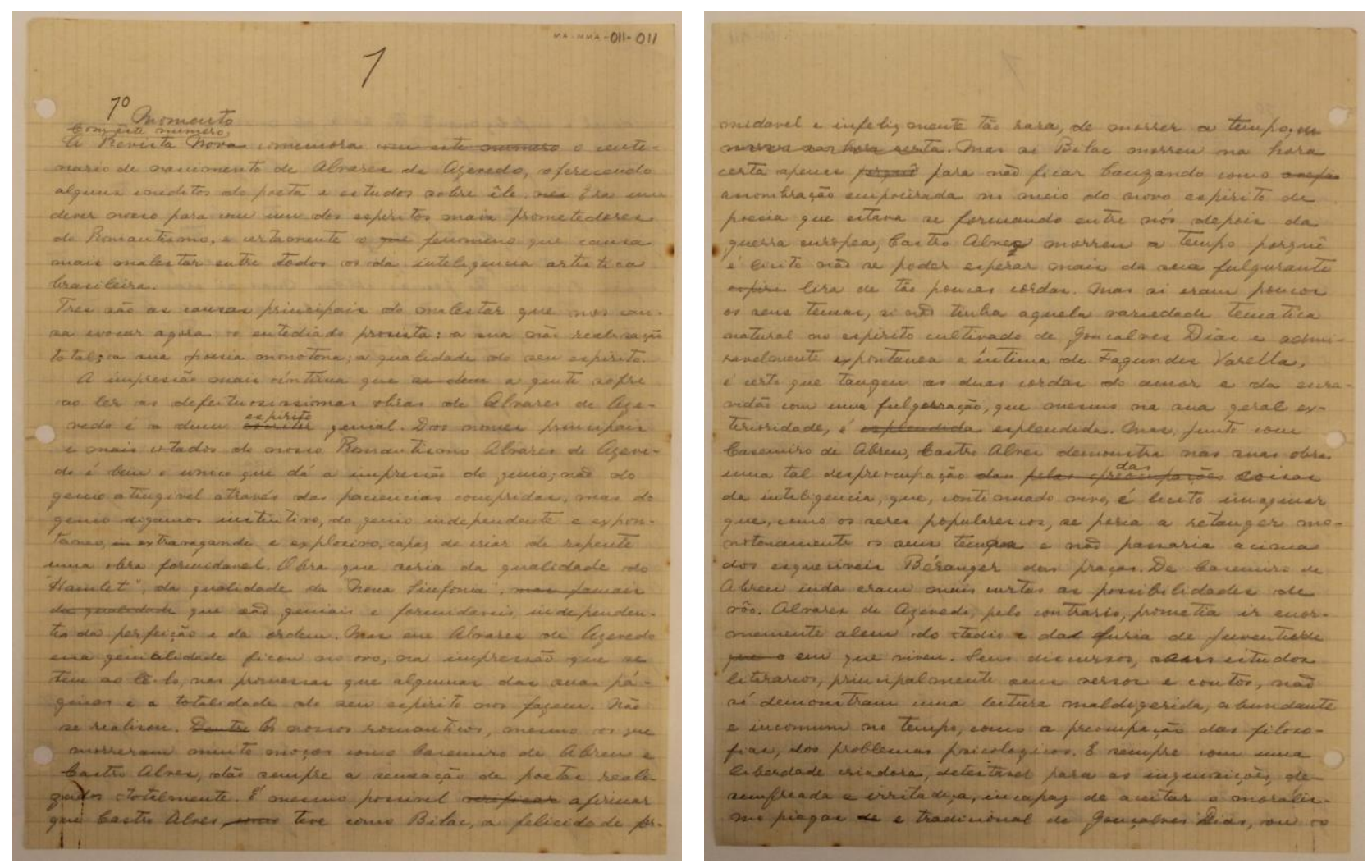


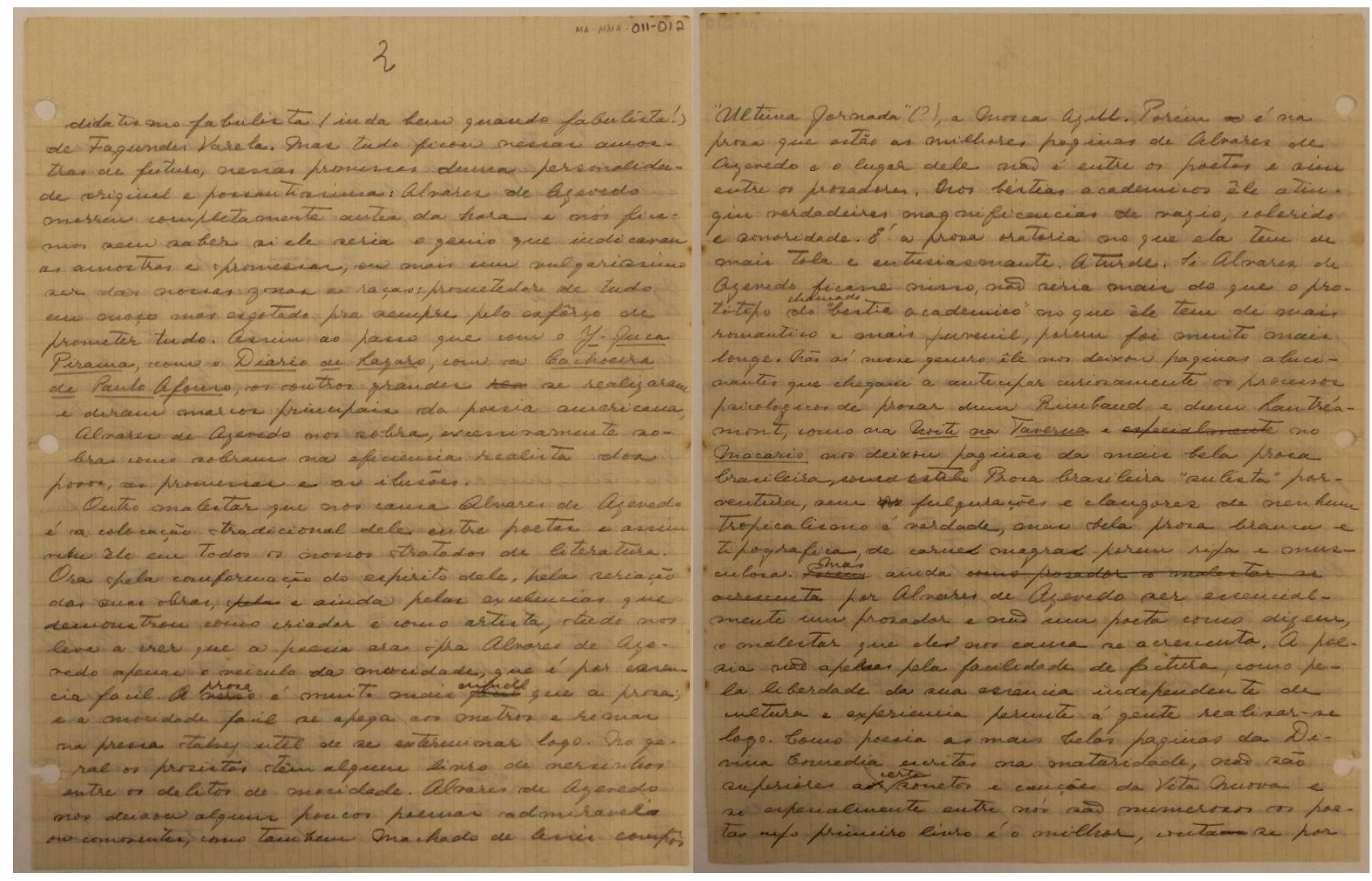

\section{$1^{\mathrm{o}}$ Momento //}

Com êste numero / A Revista Nova comemora o cente-/nario de nascimento de Alvares de Azevedo, oferecendo / alguns ineditos do poeta e estudos sobre êle. Era um / dever nosso para com um dos espiritos mais prometedores / do Romantismo, e certamente o que fenomeno que causa / mais malestar entre todos os da inteligencia artistica / brasileira. //

Tres são as causas principais do malestar que nos cau-/sa evocar agora o entediado prosista: a sua não realisação / total; a sua poesia monotona; a qualidade do seu espirito. // A impressão mais íntima que se dem a gente sofre / ao ler as defeituosissimas obras de Alvares de Aze- / vedo é a dum escritør espirito genial. Dos nomes principais / e mais cotados do nosso Romantismo Alvares de Azeve-/do é bem o único que dá a impressão do genio; não do / genio atingivel através das paciencias compridas, mas do / genio digamos instintivo, do genio independente e expon-/taneo, in extravagande e explosivo, capaz de criar de repente / uma obra formidavel. Obra que seria da qualidade do / "Hamlet", da qualidade da "Nona Sinfonia", mas jamais / da qualidade que são geniais e formidaveis, independen-/tes da perfeição e da ordem. Mas em Alvares de Azevedo / essa genialidade ficou no ovo, na impressão que se / tem ao lê-lo, nas promessas que algumas das suas pá-/ginas e a totalidade do seu espirito nos fazem. Não / se realisou. Đentre $\Theta$ Os nossos romanticos, mesmo os que / morreram muito moços como Casemiro de Abreu e / Castro Alves, dão sempre a sensação de poetas reali-/zados 
totalmente. É mesmo possível verificar afirmar / que Castro Alves, comø teve como Bilac, a felicidade for-/midavel e infelizmente tão rara, de morrer a tempo; de / morrer na horacerta. Mas si Bilac morreu na hora / certa apenas para não ficar banzando como anefãe / assombração empoeirada no meio do novo espirito de / poesia que estava se formando entre nós depois da / guerra europea; Castro Alves morreu a tempo porquê / é licito não se poder esperar mais da sua fulgurante / espiri lira de tão poucas cordas. Mas si eram poucos / os seus temas, si não tinha aquela variedade tematica / natural no espirito cultivado de Gonçalves Dias e admi- / ravelmente expontanea e intima de Fagundes Varella, / é certo que tangeu as duas cordas do amor e da escra- / vidão com uma fulguração, que mesmo na sua geral ex-/terioridade, é esplendida. Mas, junto com / Casemiro de Abreu, Castro Alves demonstra nas suas obras / uma tal despreocupação das pelas preecupaçẽes das coisas / da inteligencia, que, continuado vivo, é licito imaginar / que, como os seres popularescos, se poria a retanger mo- / notonamente os seus temas e não passaria acima / dos esqueciveis Béranger das praças. De Casemiro de / Abreu inda eram mais curtas as possibilidades de / vôo. Alvares de Azevedo, pelo contrario, prometia ir enor- / memente alem do tedio e das furia de juventude / que $\theta$ em que viveu. Seus discursos, seus estudos / literarios, principalmente seus versos e contos, não / só demonstram uma leitura maldigerida, abundante / e incomum no tempo, como a preocupação das filoso- / fias, dos problemas psicologicos. E sempre com uma / liberdade criadora, detestavel para as inquisições, de- / senfreada e irritadiça, incapaz de aceitar o moralis- / mo piegas de e tradicional de Gonçalves Dias, ou o /

\section{MA-MMA-11-12}

\section{2}

// didatismo fabulista (inda bem quando fabulista!) / de Fagundes Varela. Mas tudo ficou nessas amos/ tras de futuro, nessas promessas duma personalida-/de original e possantissima: Alvares de Azevedo / morreu completamente antes da hora e nós fica-/mos sem saber si ele seria o genio que indicavam / as amostras e promessas, ou mais um vulgarissimo / ser das nossas zonas e raças: prometedor de tudo / em moço mas esgotado pra sempre pelo esfôrço de / prometer tudo. Assim ao passo que com o $\underline{\mathrm{Y}-}$

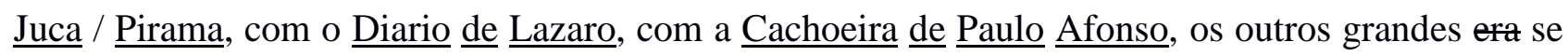
realizaram / e deram marcos principais da poesia americana, Alvares de Azevedo nos sobra, excessivamente so-/bra como sobram na eficiencia realista dos / povos, as promessas e as ilusões.

Outro malestar que nos causa Alvares de Azevedo / é a colocação tradicional dele entre poetas e assim / vem êle em todos os nossos tratados de literatura. / Ora pela conformação do espirito dele, pela seriação / das suas obras, pela e ainda pelas excelencias que / demonstrou como criador e como artista, 
tudo nos / leva a crer que a poesia era pra Alvares de Aze- / vedo apenas o veiculo da mocidade, que é por essen-/cia facil. A verse prosa é muito mais facil dificil que a prosa; / e a mocidade facil se apega aos metros e rimas / na pressa talvez util de se exterminar logo. No ge-/ral os prosistas têm algum livro de versinhos / entre os delitos de mocidade. / Alvares de Azevedo / nos deixou alguns poucos poemas admiraveis / ou comoventes, como tambem Machado de Assis compôs / "Ultima Jornada" (?), a Mosca Azul. Porém se é na / prosa que estão as milhores paginas de Alvares de / Azevedo e o lugar dele não é entre os poetas e sim / entre os prosadores. Nos béstias academicos êle atin-/giu verdadeiras magnificencias de vazio, colorido / e sonoridade. É a prosa oratoria no que ela tem de / mais tola e entusiasmante. Aturde. Si Alvares de / Azevedo ficasse nisso, não seria mais do que o pro-/tótipo do chamado "bestia academico" no que êle tem de mais / romantico e mais juvenil, porem foi muito mais / longe. Não só nesse genero êle nos deixou paginas aluci-/nantes que chegam a antecipar curiosamente os processos / psicologicos de prosar dum Rimbaud e dum Lautréa-/mont, como na Noite na Taverna e especialmente no / Macario nos deixou paginas da mais bela prosa / brasileira. como estile Prosa brasileira "sulista" por-/ventura, sem as fulgurações e clangores de nenhum / tropicalismo é verdade, mas bela prosa branca e / tipografica, de carnes magras porem rija e mus-/culosa. Porem Mas ainda como prosador o malestar se / acrescenta por Alvares de Azevedo ser essencial-/mente um prosador e não um poeta como dizem, / o malestar que ele nos causa se acrescenta. A poe-/sia não apełnas pela facilidade de factura, como pe-/la liberdade da sua essencia independente de / cultura e experiencia permite á gente realisar-se / logo. Como poesia as mais belas paginas da Di-/vina Comedia escritas na maturidade, não são / superiores aes certos sonetos e canções da Vita Nuova e / si especialmente entre nós são numerosos os poe-/tas cujo primeiro livro é o milhor, contam se por 


\section{MA-MMA-11 13}
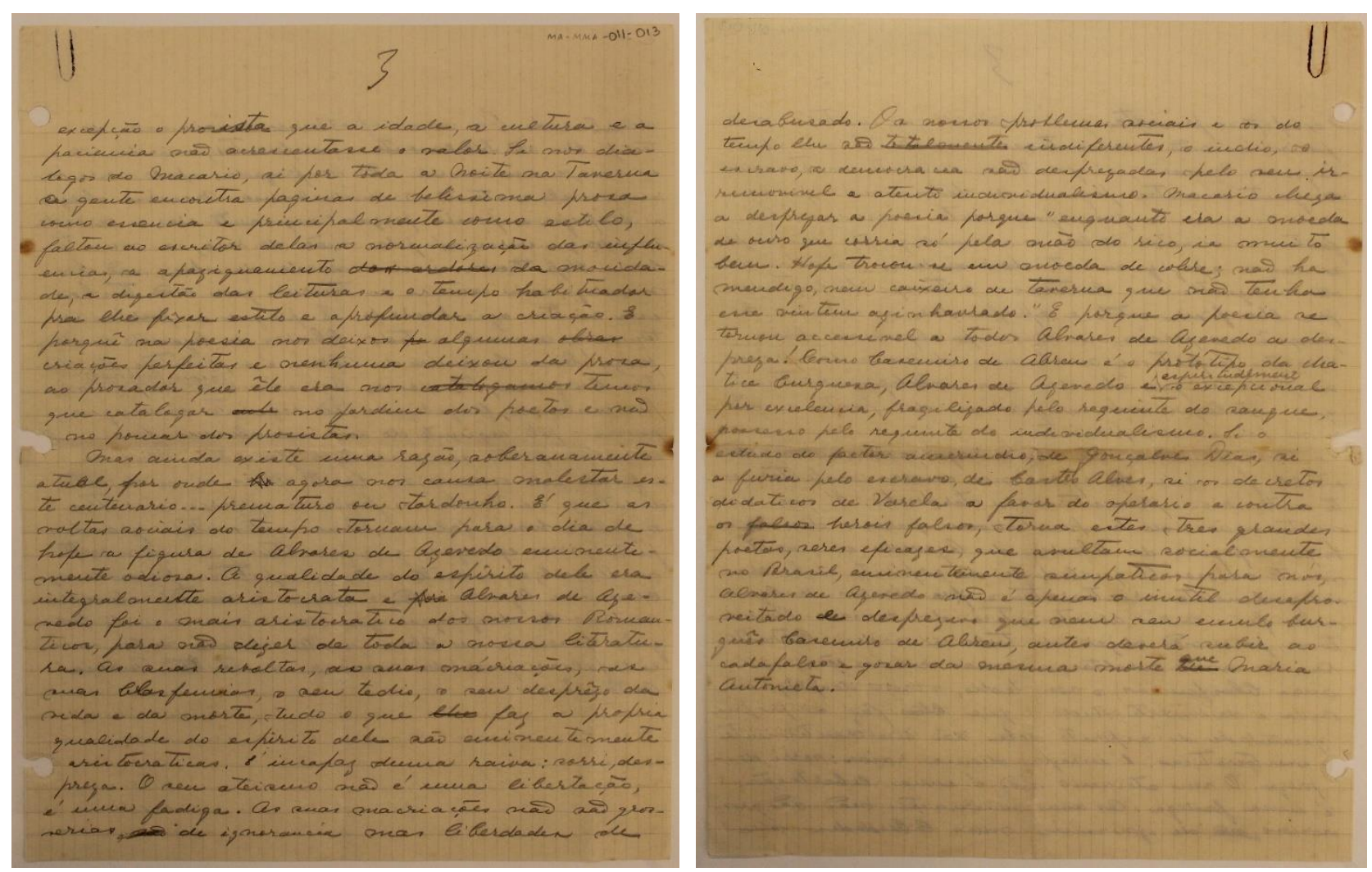

excepção o prosista que a idade, a cultura e a / paciencia não acrescentasse o valor. Si nos dia-/logos do Macario, si por toda a Noite na Taverna / a gente encontra paginas de belissima prosa / como essencia e principalmente como estilo, / faltou ao escritor delas a normalização das influ-/encias, a apaziguamento des ardores da mocida-/de, a digestão das leituras e o tempo habituador / pra lhe fixar estilo e aprofundar a criação. E / porquê na poesia nos deixou pe algumas øbras / criações perfeitas e nenhuma deixou da prosa, / ao prosador que êle era nos eatalogames temos que catalogar entr no jardim dos poetas e não / no pomar dos prosistas. // Mas ainda existe uma razão, soberanamente / atual, por onde he agora nos causa malestar es-/te centenario... prematuro ou tardonho. É que as / voltas sociais do tempo tornam para o dia de / hoje a figura de Alvares de Azevedo eminente-/mente odiosa. A qualidade do espirito dele era / integralmente aristocrata e føi Alvares de Aze-/vedo foi o mais aristocratico dos nossos Roman-/ticos, para não dizer de toda a nossa literatu-/ra. As suas revoltas, as suas mácriações, as / suas blasfemias, o seu tedio, o seu desprêzo da / vida e da morte, tudo o que the faz a própria / qualidade do espirito dele são eminentemente / aristocraticas. É incapaz duma raiva: sorri, des-/preza. O seu ateismo não é uma libertação, / é uma fadiga. As suas macriações não são gros-/serias, sãe de ignorancia mas liberdades de / desabusado. Os nossos problemas sociais 
e os do / tempo lhe são totalmente indiferentes, o indio, o / escravo, a democracia são desprezadas pelo seu ir-/removível e atento individualismo. Macario chega / a desprezar a poesia porque “enquanto era a moeda / de ouro que corria só pela mão do rico, ia muito / bem. Hoje trocou-se em moeda de cobre; não ha / mendigo, nem caixeiro de taverna que não tenha / esse vintem azinhavrado." E porque a poesia se / tornou accessível a todos Alvares de Azevedo a des-/preza! Como Casemiro de Abreu é o protótipo da cha-/tice burguesa, Alvares de Azevedo é espiritualmente o excepcional / por excelencia, fragilizado pelo requinte do sangue, / possesso pelo requinte do individualismo. Si o / estudo do factor amerindio, de Gonçalves Dias, si / a furia pelo escravo de Castro Alves, si os decretos / didaticos de Varela a favor do operario e contra / os falses herois falsos, torna estes tres grandes / poetas, seres eficazes, que avultam socialmente / no Brasil, eminentemente simpaticos para nós, / Alvares de Azevedo não é apenas o inutil desapro-/veitado de desprezo que nem seu emulo bur/guês Casemiro de Abreu, antes deverá subir ao / cadafalso e gosar da mesma morte de que Maria / Antonieta. 


\section{MA-MMA-26 - 01}

Castro Alves. Capa improvisada; autógrafo a lápis vermelho; 1 folha dupla de papel sulfite branco, amarelecida pelo tempo $(32,9 \times 21,8 \mathrm{~cm})$; manchas de fungo e marcas de ferrugem provocadas por clipe; título no anverso; f.01; contém os demais documentos, f. 02 - 13 .

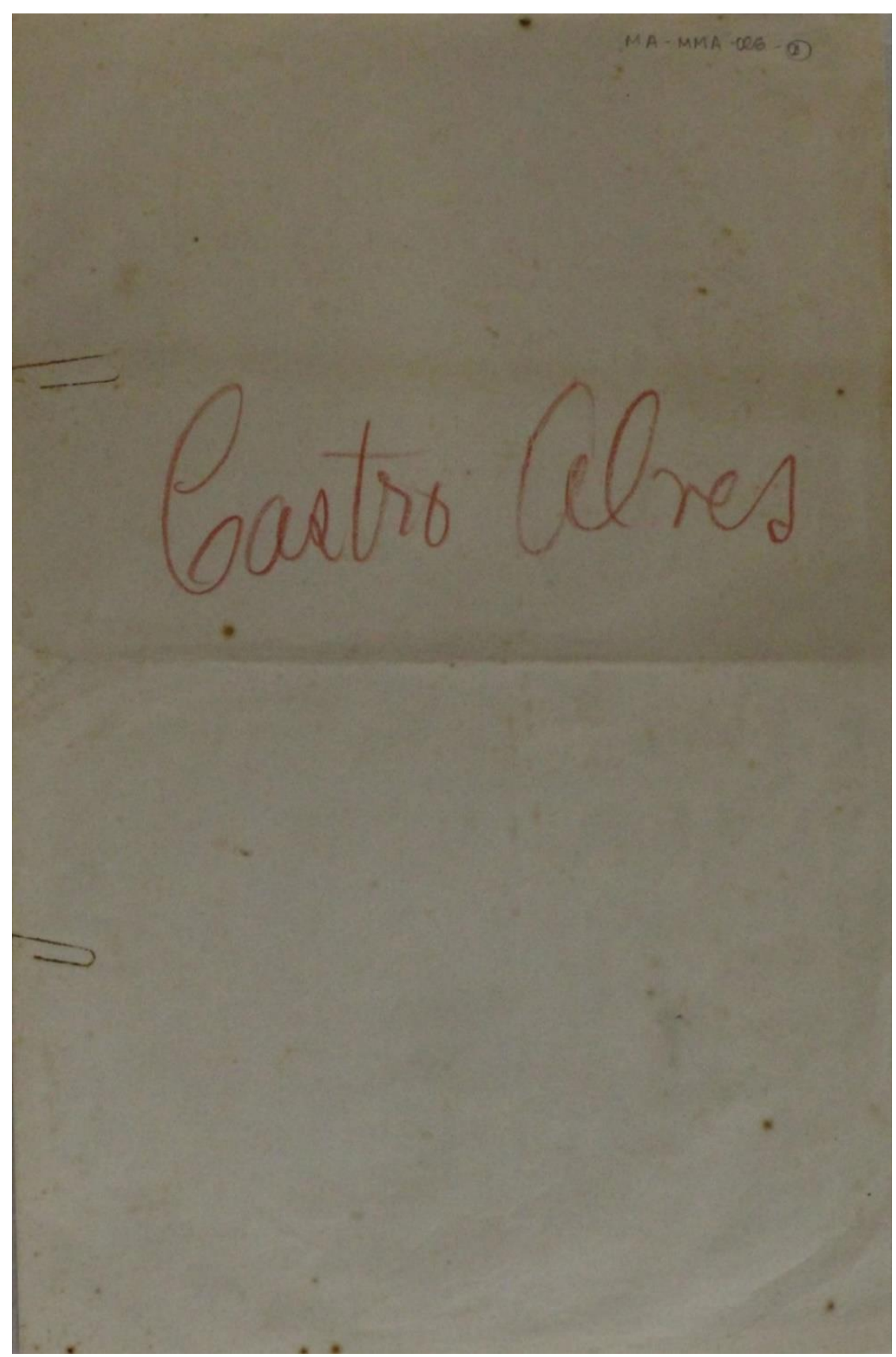

Nota da pesquisa: A classificação do manuscrito foi realizada pela pesquisadora Angela Teodoro Grillo, sob orientação da Profa. Dra. Telê Porto Ancona Lopez. 


\section{MA-MMA-26-02}

Castro Alves: fichamento crítico, nota prévia ou de trabalho; autógrafo a tinta preta; 1 folha de papel branco milimetrado, amarelecida pelo tempo $(27,8 \times 21,5 \mathrm{~cm}) ; 3$ furos para fichário cortados até margem; sinais de fungo; escrita no anverso; rasuras a tinta preta e a grafite; $\mathrm{f}$. 02 .

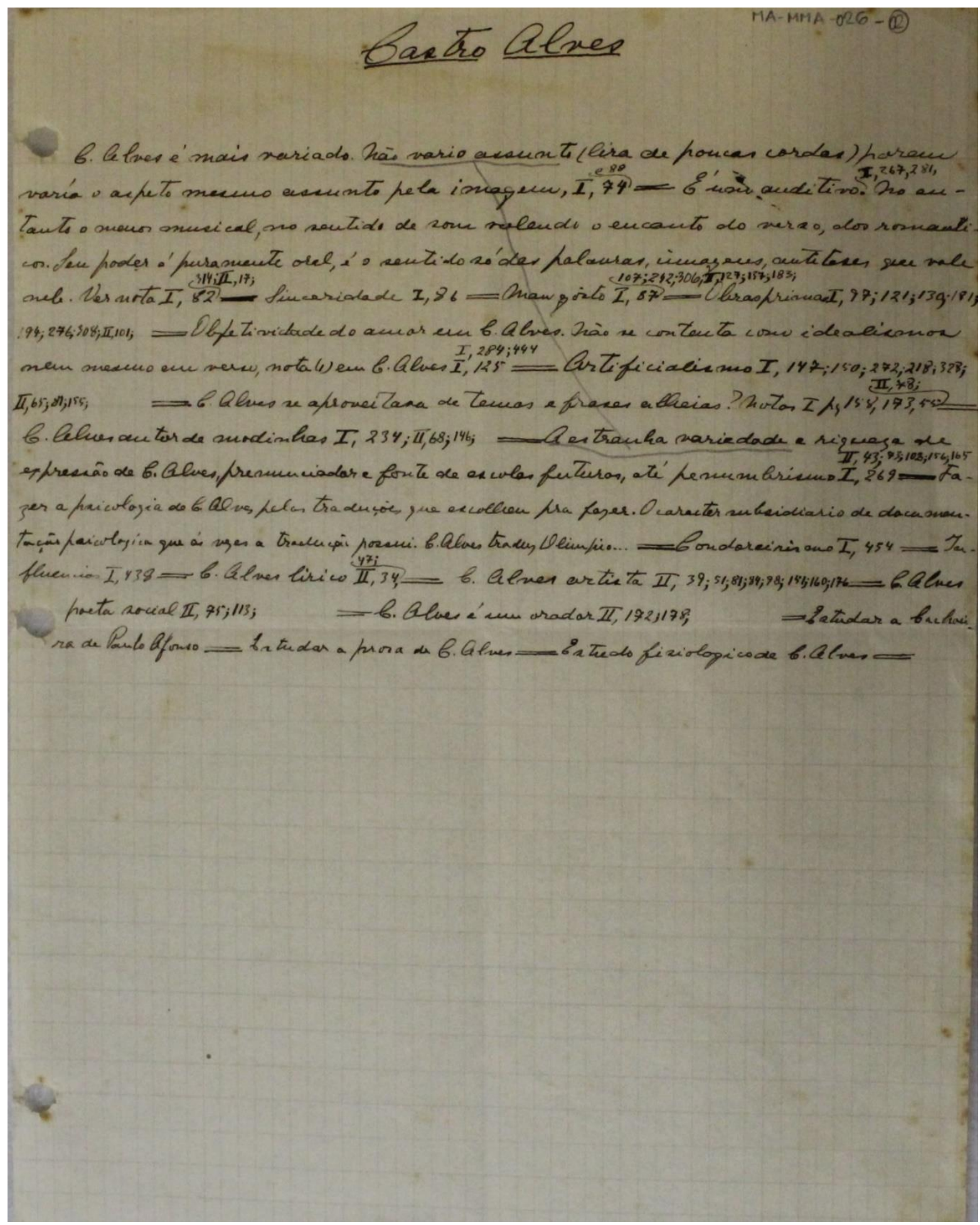




\section{$\underline{\text { Castro }} \underline{\text { Alves }}$}

C. Alves é mais variado. Não vario assunto (lira de poucas cordas) porem/ varía o aspeto mesmo assunto pela imagem, I, 74 e 88 == É um auditivo. I, 267, 281. No en-/tanto o menos musical, no sentido de som valendo o encanto do verso, dos romanti-/cos. Seu poder é puramente oral, é o sentido só das palavras, imagens, antiteses que vale/ nele. Ver nota I, 82, 314; II, 17; == Sinceridade, I, 86 == Mau gôsto I, 87 107; 242; 306; II, 127; 137; 183; == Obras primas I, 97; 121; 130; 181;/ 194; 276; 308; II, 101; == Objetividade do amor em C. Alves. Não se contenta com idealismos/ nem mesmo em verso, nota (1) em C. Alves I, 125 I, 284; $444==$ Artificialismo I, 147; 150; 272; 218; 328;/ II, 65; 81; 155; == C. Alves se aproveitava de temas e frases alheias? Notas I pg 158, 173, 55 II, 78; == / C. Alves autor de modinhas I, 234; II, 68; 146; == A estranha variedade e riqueza de / expressão de C. Alves, prenunciador e fonte de escolas futuras, até penumbrismo I, 269 II, 43; 73; 102; 156; $165==$ Fa-/zer a psicologia de C. Alves pelas traduções que escolheu pra fazer. O caracter subsidiario de documen-/tação psicologica que ás vezes a tradução possui. C. Alves traduz Olimpio... == Condoreirismo I, $454==$ In-/fluencias I, $438==$ C. Alves lirico II, 34, 47; == C. Alves artista II, 39; 51; 81; 84; 98; 151; 160; $176==$ C. Alves/ poeta social II, 75; 113; == C. Alves é um orador II, 172; 178; = Estudar a Cachoei-/ra de Paulo Afonso == Estudar a prosa de C. Alves == Estudo fisiologico de C. Alves ==

Nota da pesquisa: As indicações numéricas no manuscrito ligam-se às notas de margem apostas por MA nas Obras completas, ed. cit.: o algarismo romano corresponde ao volume da edição, e os arábicos, à página onde a Nota MA se situa. Assim, o primeiro item elencado no documento remete ao comentário de MA no poema "O Voo do gênio", à pág. 74, vol. 1, onde se lê: " $O$ que diferencia bastante $C$. Alves dos romanticos brasileiros é a variedade dos aspetos do mesmo assunto. A lira dele tambem possui pouquissimas cordas mas ele varia pela imagem o assunto, não propriamente pelo pensamento." No mesmo volume, à pág. 88, findo o poema "Tríplice diadema", MA escreve: "Notar por esta 'Triplice Diadema' a maneira já mais que brasileiramente romântica, porém posterior ao Romantismo, com que C. Alves dá assuntos temas ao seu assunto." O fichamento permite ao crítico retomar com facilidade a ideia registrada no volume impresso, mas a nota de trabalho conserva também definições não explicitadas na marginália. É o caso de "Penso em ti", em cuja página MA apenas assinala o emprego da preposição "para" e corrige a ordem do v. 24 ("Crenças desperta o teu olhar divino...”). O manuscrito, conforme se vê, avança em relação à nota de margem, classificando o poema entre as obras-primas de Castro Alves. Além da função remissiva, o documento lista propostas do crítico, como a de traçar a psicologia do autor a partir das traduções, bem como analisar-lhe a prosa e a fisiologia. No dossiê "Amor e medo", quatro fólios - em papel milimetrado, idêntico ao desta nota de trabalho e alternando, como aqui, a escrita a tinta preta e a grafite - utilizam o mesmo método de remissão à marginália. Referem-se aos autores estudados por MA no ensaio de 1931 e previstos para a obra inacabada Lirismo romântico no Brasil, junto a Castro Alves: Gonçalves Dias, Álvares de Azevedo, Casimiro de Abreu e Fagundes Varela. 


\section{MA-MMA-26 03}

Castro Alves / e a / Natureza. Nota de trabalho; autógrafo a grafite; 1 folha de papel branco amarelecida pelo tempo $(10,6 \times 21,5 \mathrm{~cm})$, destacada de caderneta de bolso, manchas de fungo e marcas de ferrugem provocadas por clipe; escrita utilizando o anverso; f. 03 .

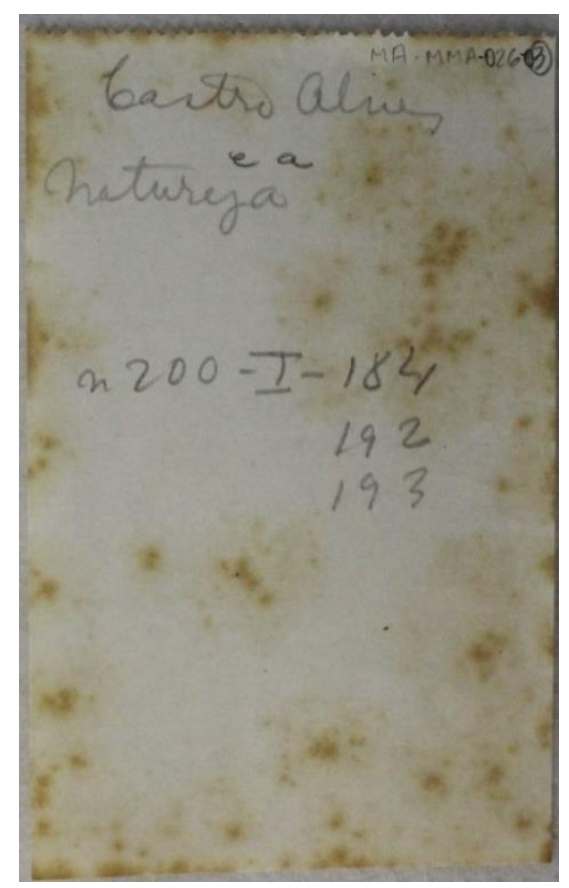

Castro Alves / e a / Natureza // n 200 - I - 184 / 192 / 193

Nota da pesquisa: $\mathrm{O} \mathrm{n}^{\mathrm{o}} 200$ refere-se à inclusão das Obras completas de Castro Alves (ed. cit) na Bibliografia para o Na pancada do ganzá, conjunto de 837 títulos arrolados por MA para apoiar a organização de seu vasto projeto sobre o folclore nordestino. A lista, divulgada no Dicionário musical brasileiro (Coordenação: Oneyda Alvarenga e Flávia Toni. Belo Horizonte: Itatiaia, Brasília: Ministério da Cultura, São Paulo: IEB-USP/ Edusp, 1989, p. 634-686), abriga os títulos da autoria dos "cinco grandes românticos" focalizados em "Amor e medo". Seguindo a indicação do manuscrito, encontra-se, à p. 184, o verso do poema "Coup d'étrier" sublinhado por MA: "Natureza! Eu voltei... e eu sou teu filho!". À p. 192, no poema "Aves de arribação”, MA destaca as estrofes 12-16 (trecho que parte do verso "Ás vezes, quando o sol nas mattas virgens" e termina em "Nascia ao longe a estrella vespertina"). À esquerda do trecho assinalado, escreve: "Lindíssimo”. No mesmo poema, à p. 193, sublinha o verso "Tendo por musa - o amor e a natureza" e cria uma nota no rodapé, em que planeja o livro Lirismo romântico no Brasil: “(1) Epígrafe pra Fagundes Varela”. 


\section{MA-MMA-26-04}

"Ideas gerais" / Lirismo Romantico. Esboço; autógrafo a tinta preta; 1 folha de papel branco quadriculado de fichário, amarelecida pelo tempo $(27,8 \times 21,5 \mathrm{~cm}), 3$ furos cortados até a margem, manchas de fungo; escrita utilizando anverso e verso da folha; rasuras a tinta vermelha e preta e a grafite; f. 04 .

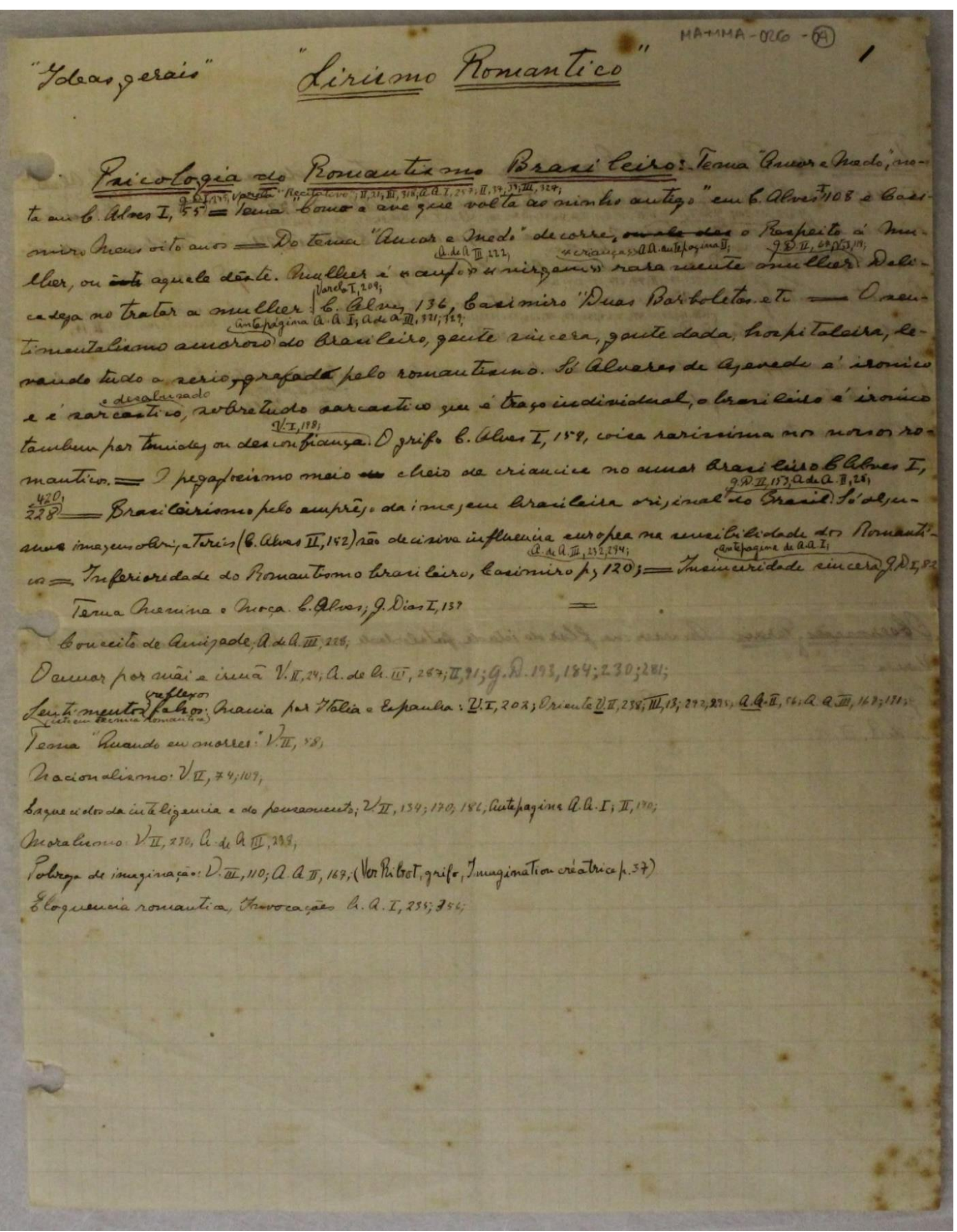


"Ideas gerais" "Lirismo Romantico"

Psicologia do Romantismo Brasileiro: Tema "Amor e Medo", no-/ta em C. Alves I, 55 <G.D. I, 275; Varela "Recitativo"; II, 21; III, 318; A.A. I, 257; II, 37; 39; III, 327;> == Tema "Como a ave que volta ao ninho antigo" em C. Alves I, 108 e Casi-/miro Meus oito anos == Do tema "Amor e Medo" decorre eu ele des o Respeito á Mu-/lher, ou êste aquele dêste. Mulher é "anjo" <A. de A. III, 222;> "virgem" <"criança" A. A. antepagina II;> raramente mulher <G. D. II, 64, V, I, 119;>. Deli-/cadeza no tratar a mulher: <Varela I, 209;> C. Alves, 136, Casimiro "Duas Borboletas etc $==\mathrm{O}$ sen-/timentalismo amoroso <antepágina A.A. I; A de A III, 321; 329;> do brasileiro, gente sincera, gente dada, hospitaleira, le-/vando tudo a serio, grafada pelo romantismo. Só Alvares de Azevedo é ironico/ e é sarcastico <e desabusado>, sobretudo sarcastico que é traço individual, o brasileiro é ironico/ tambem por timidez ou desconfiança <V. I, 198;>. O grifo C. Alves I, 154, coisa rarissima nos nossos ro-/manticos. $==$ Brasileirismo pelo emprêgo da imagem brasileira original do Brasil <G. D. II, 153; A. de A. II, 25;>. Só algu-/mas imagens obrigatorias (C. Alves II, 152) são decisiva influencia europea na sensibilidade dos Romanti-/cos == Inferioridade do Romantismo brasileiro, Casimiro pg 120 <A. de. A. III, 232; 234;>; == Insinceridade sincera G. D. I, 82 <antepagina de A.A. I; $>/ /$

Tema Menina e Moça. C. Alves; G. Dias I, 139//

Conceito de Amizade; A. de A. III, 228;

O amor por mãi e irmã V. II, 24; A. de A. III, 287; II, 91; G. D. 193, 184; 230; 281;

Sentimentos <reflexos> falsos >isto em Tecnica Romantica<: Mania por Italia e Espanha: V. I, 202; Oriente V. II, 238; III, 13; 292; 295; A. A. II, 56; A. A. III, 169; 191;//

Tema "Quando eu morrer": V. II, 58;//

Nacionalismo: V. II, 74; 109;//

Esquecidos da inteligencia e do pensamento; V. II, 134; 170; 186; Antepagina A. A. I; II, $170 ; / /$

Moralismo: V. II, 230; A. de A. III, 238;//

Pobreza de imaginação: V. III, 110; A. A II, 167; (Ver Ribot, grifo, Imagination créatrice p. 37) //

Eloquencia romantica, Invocações A. A. I, 235; 356;// 


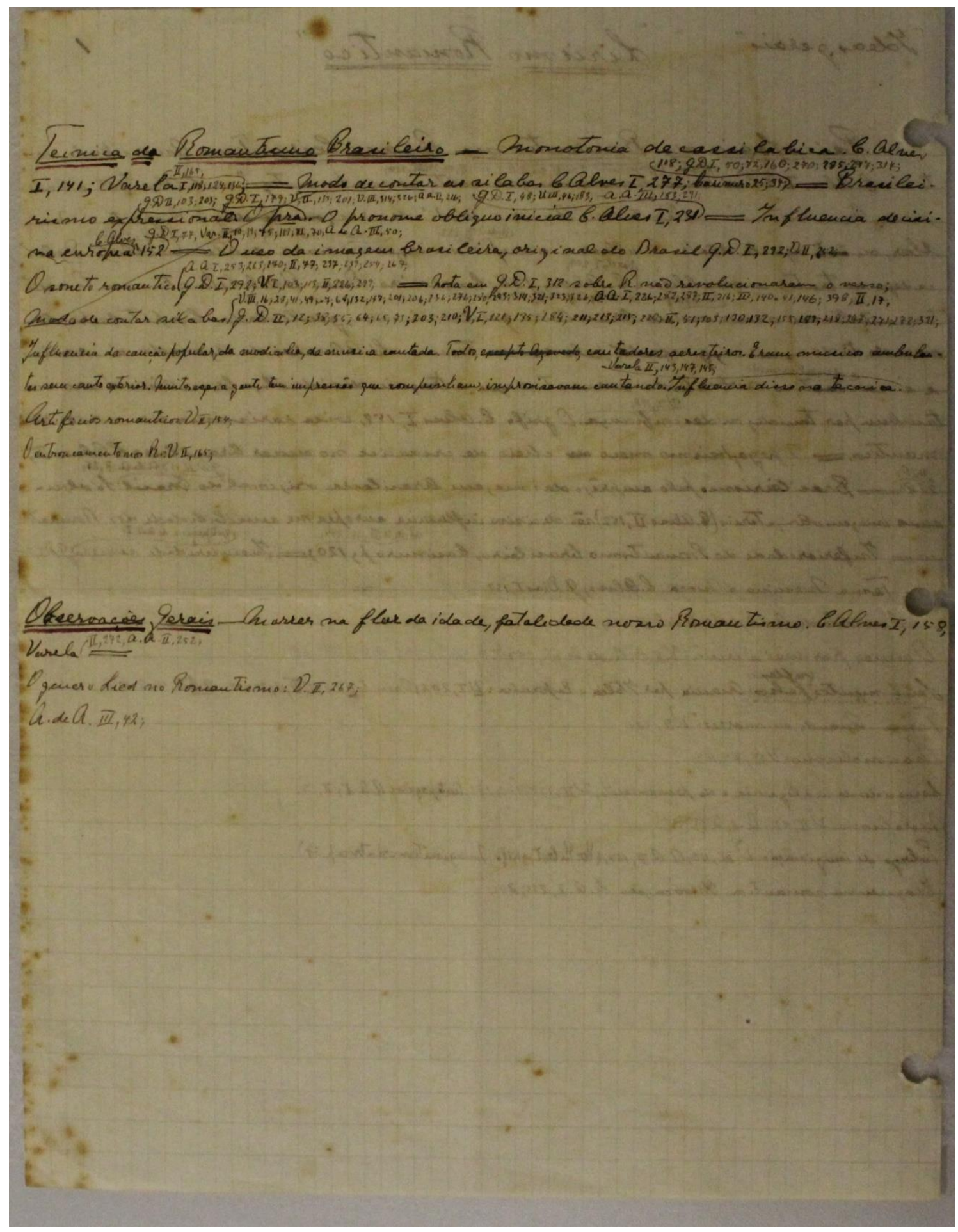


$\underline{\text { Tecnica do }} \underline{\text { Romantismo Brasileiro }}==$ Monotonia decassilabica. C. Alves/ I, 141; Varela I, 118; 124; 136; <II, 165;> == Modo de contar as silabas C. Alves I, 277; Casimiro 25; 34; $<108$; GD. I, 50; 72; 160; 270; 285; 297; 314; > == Brasilei-/rismo expressional <G.D II, 103; 203;> O pra <G.D. I, 179; V, II, 133; 201; V. III, 314; 326; A.A. II, 216;> O pronome obliquo inicial C. Alves I, 231 <G.D. I, 48; V. III, 46; 183; - A.A. III, 183; 291; == Influencia decisi-/va europea <C. Alves> $152<$ G.D. I, 77; Var. II, 10; 19; 75; 119; III, 70; A. de A. III, 50; == O uso da imagem brasileira, original do Brasil G. D. I, 292; V. II, 252;//

O soneto romantico (G. D. I, 292; V. I, 103; 113; II, 226; 299; <A.A. I, 253; 263; 270; II, 77; 237; 239; 254; 267;> == Nota em G. D. I, 312 sobre R. não revolucionaram o verso;//

Modo de contar silabas G. D. II, 12; 38; 55; 64; 65; 73; 203; 210; V, I, 121; 135; 184; 211; 213; 215; 220; II, 51; 103; 130; 132; 155; 189; 218; 247; 271; 272; $321<$ V. III, 16; 28; 41; $49 ; 67 ; 68 ; 132 ; 137 ; 201 ; 206 ; 236 ; 276 ; 280 ; 293 ; 314 ; 321 ; 323 ; 326$; A.A. I, 226; 282; 287; II, 216; III, 140 e 41; 146; 398; II, 17;> //

Influencia da canção popular, da modinha, da musica cantada. Todos, excepto-Azevedo, cantadores seresteiros. Eram musicos ambulan-/tes sem canto exterior. Muitas vezes a gente tem impressão que compunham, improvisavam cantando. Influencia disso na tecnica. $<$ Varela II, 143, 147, 145;//

Artificios romanticos. V. II, 154; //

O entroncamento nos R.: V. II, 165; //

Observações gerais <sublinhado duplo; segunda sublinha a tinta roxa> -- Morrer na flor da idade, fatalidade nosso Romantismo. C. Alves I, 158,/ Varela <II, 272; A. A. II, 252;> ==//

O genero Lied no Romantismo: V. II, 267; //

A. de A. III, 42; 
MA-MMA-26-05 - 09

[Lirismo romântico no Brasil]; esboço de introdução e notas de trabalho para o livro projetado; autógrafo a grafite; 5 folhas amarelecidas pelo tempo: 2 folhas de papel branco liso (21,7 x 16,6 cm), manchas de fungo; com marcas de dobra central f. 5-6; filigrana: globo terrestre e os dizeres: "Casa Pratt do Brazil S.A.", f. $5 ; 3$ folhas de papel branco pautado (16 x 11,6 cm), f. 7-9; dupla improvisada em folha de caderno dobrada, f. 8-9; escrita no sentido utilizando anverso e verso das folhas, rasuras a grafite e a lápis vermelho; f. $05-09$.

\section{MA-MMA-26-05}

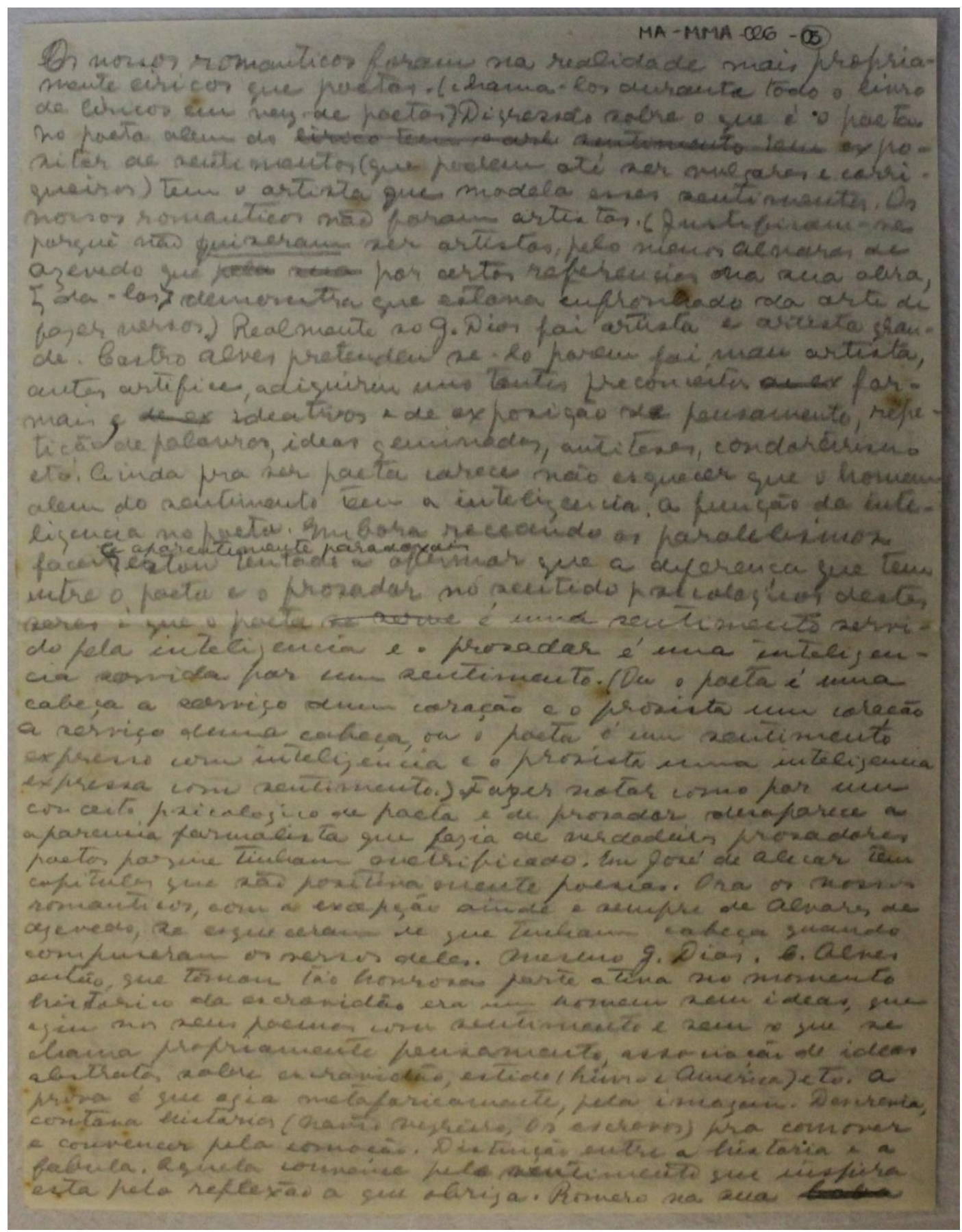


Os nossos romanticos foram na realidade mais propria-/mente liricos que poetas. (Chamalos durante todo o livro / de liricos em vez de poetas). Digressão sobre o que é o poeta./ No poeta alem do lirico tem 0 art sentimento tem expo-/sitor de sentimentos (que podem até ser vulgares e corri-/queiros) tem o artista que modela esses sentimentos. Os / nossos romanticos não foram artistas. (Justificam-se / porquê não quiseram ser artistas, pelo menos Alvares de / Azevedo que pela sua por certas referencias na sua obra, / [da-las] demonstra que estava enfronhado da arte de / fazer versos.) Realmente so G. Dias foi artista e artista gran-/de. Castro Alves pretendeu se-lo porem foi mau artista,/ antes artifice, adquiriu uns tantos preconceitos de ex for-/mais, de ex ideativos e de exposição de pensamento, repe-/tição de palavras, ideas geminadas, antiteses, condoreirismo / etc. Ainda pra ser poeta carece não esquecer que o homem / alem do sentimento tem a inteligencia. A função da inte-/ligencia no poeta. Embora receando os paralelismos / faceis e aparentemente paradoxais estou tentado a afirmar que a diferença que tem / entre o poeta e o prosador no sentido psicológico destes / seres é que o poeta se serve é uma sentimento servi-/do pela inteligencia e o prosador é uma inteligen-/cia servida por um sentimento. (Ou o poeta é uma / cabeça a serviço dum coração e o prosista um coração / a serviço duma cabeça, ou o poeta é um sentimento / expresso com inteligência e o prosista uma inteligencia / expressa com sentimento.) Fazer notar como por um / conceito psicológico de poeta e de prosador desaparece a / aparencia formalista que fazia de verdadeiros prosadores / poetas porque tinham metrificado. Em José de Alencar tem/ capitulos que são positivamente poesias. Ora os nossos / romanticos, com a excepção ainda e sempre de Alvares de / Azevedo, se esqueceram de que tinham cabeça quando / compuseram os versos deles. Mesmo G. Dias. C. Alves / então, que tomou tão honrosa parte ativa no momento / histórico da escravidão era um homem sem ideas, que / agiu nos seus poemas com sentimento e sem o que se / chama propriamente pensamento, associação de ideas / abstratas sobre escravidão, estudo (Livro e América) etc. A / prosa é que agia metaforicamente, pela imagem. Descrevia, / contava historias (Navio Negreiro, Os escravos) pra comover / e convencer pela comoção. Distinção entre a historia e a / fabula. Aquela comove pelo sentimento que inspira / esta pela reflexão a que abriga. Romero na sua boba / 


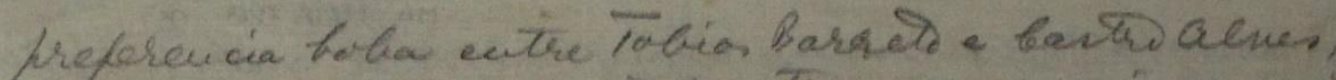

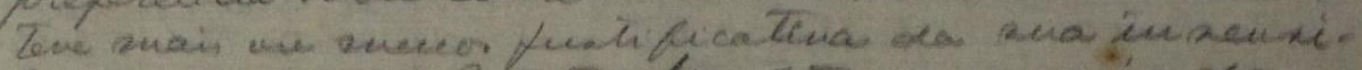

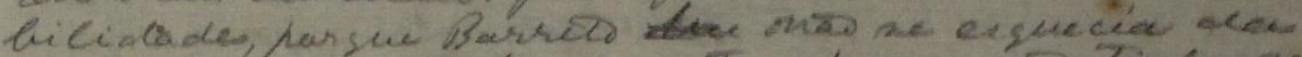

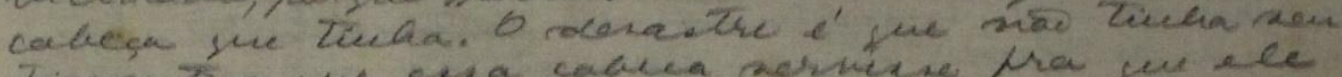

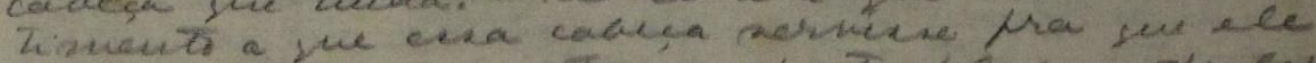

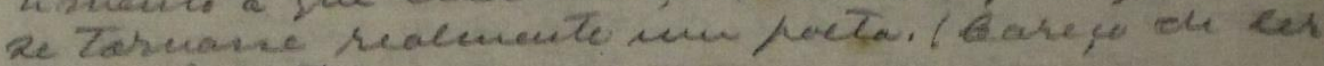
Toin Darresto)

Thera parte de idea, gerar, iniciac de Cero, dar

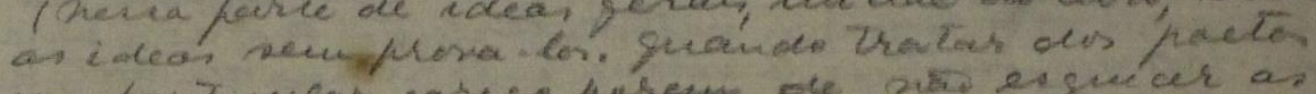

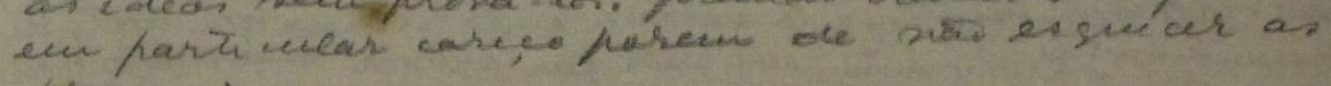
(rovar.)

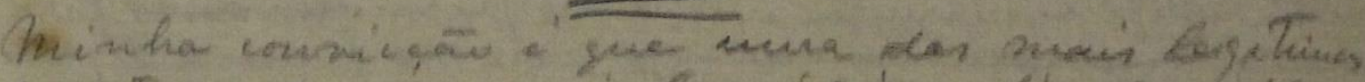

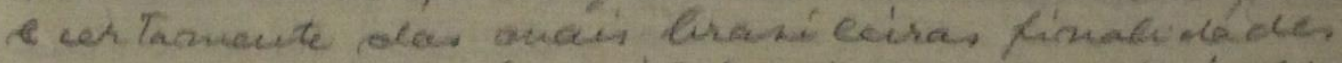

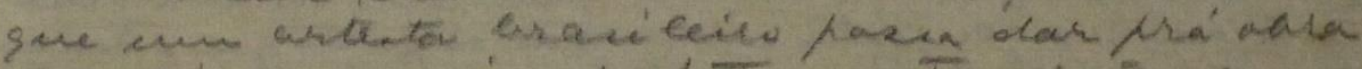
dele é we nesuir a perfetrai a trascicá ecor

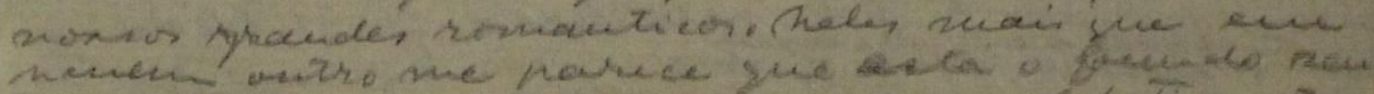

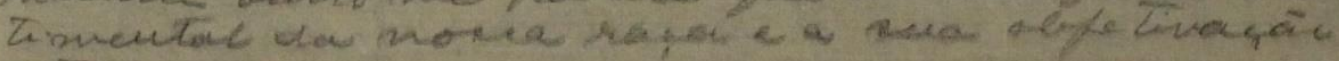
e. Terarito.

Fager distiu iäb precira entre a olia-prima excitanter tho

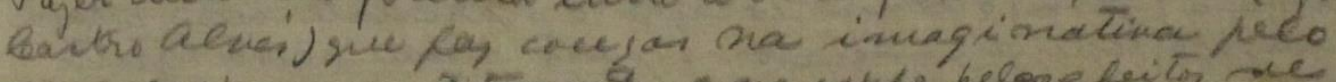

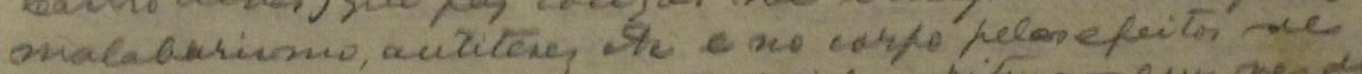

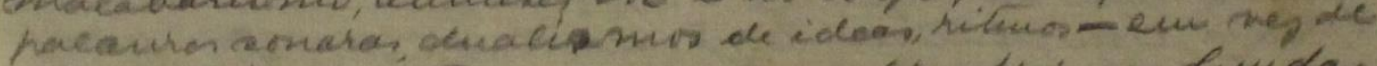
hen prophiamente eirico e a olira frima funda.

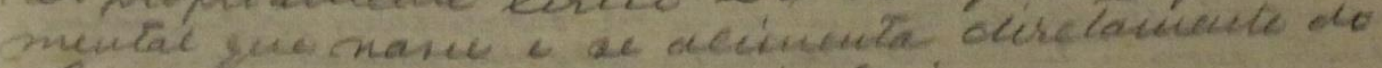
abivieurg da redeidade paicolejica

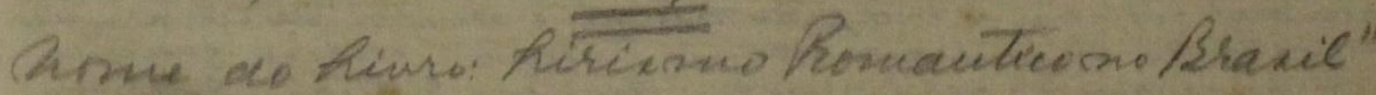

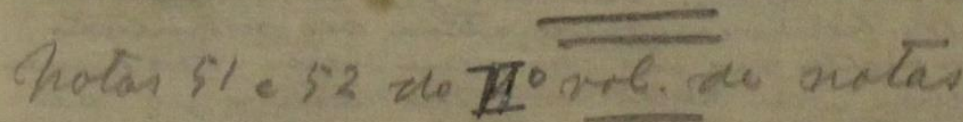

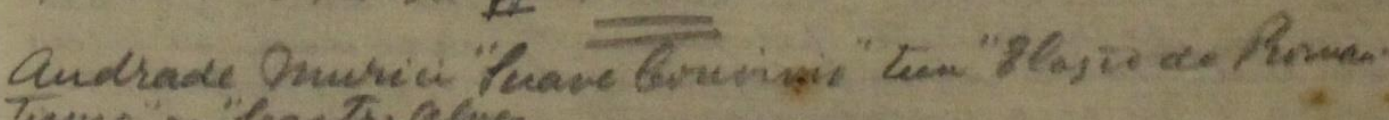

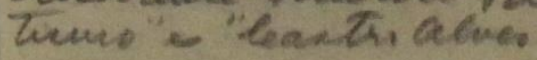

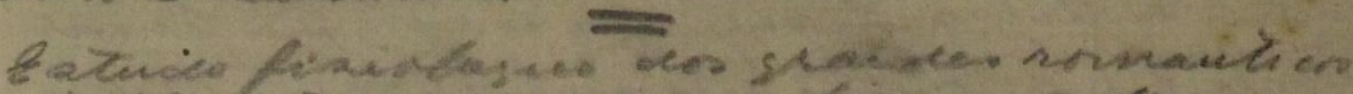

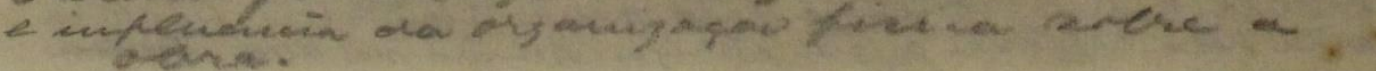


preferencia boba entre Tobias Barreto e Castro Alves, / teve mais ou menos justificativa da sua insensi-/bilidade, porque Barreto tin não se esquecia da / cabeça que tinha. O desastre é que não tinha sen-/timento a que essa cabeça servisse pra que ele / se tornasse realmente um poeta. (Careço de ler / Tobias Barreto) //

(Nessa parte de ideias gerais, inicial do livro, dar / as ideas sem prova-las. Quando tratar dos poetas / em particular careço porem de não esquecer as / provas.) //

Minha convicção é que uma das mais legitimas / e certamente das mais brasileiras finalidades / que um artista brasileiro possa dar prá obra / dele é de seguir e perpetuar a tradição dos / nossos grandes romanticos. Neles mais que em / nenhum outro me parece que está o fundo sen-/timental da nossa raça e a sua objetivação / literaria.

Fazer distinção precisa entre a obra-prima excitante (tipo / Castro Alves) que faz cocegas na imaginativa pelo / malabarismo, antiteses, etc e no corpo pelos efeitos de / palavras sonoras, dualismos de ideas, ritmos -- em vez de / ser propriamente lirico e a obra-prima funda/mental que nasce e se alimenta diretamente do / lirismo da realidade psicologica

Nome do Livro: "Lirismo Romantico no Brasil"

Notas 51 e 52 do II $^{\circ}$ vol. de notas

Andrade Murici "Suave Convivio" tem "Elogio do Romantismo" e "Castro Alves"

Estudo fisiologico dos grandes romanticos / e influencia da organização fisica sobre a / obra. 


\section{MA-MMA-26 -06}

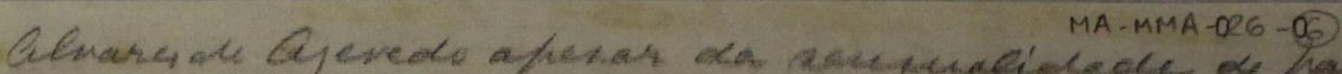

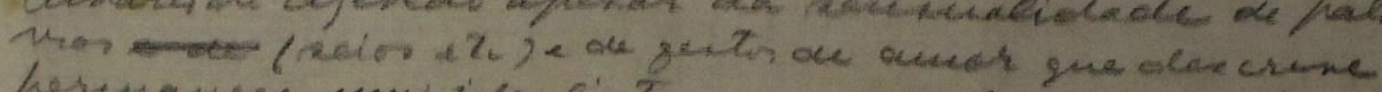

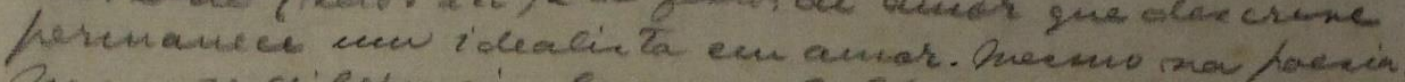

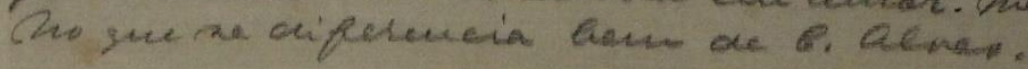

Ehisafe pra ) ane

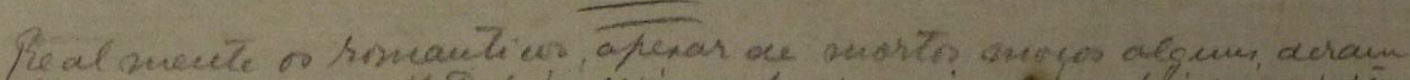

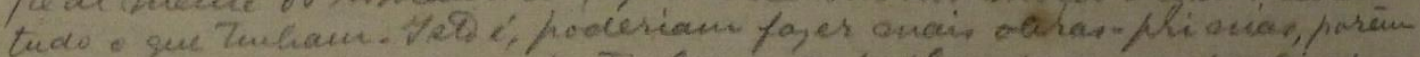

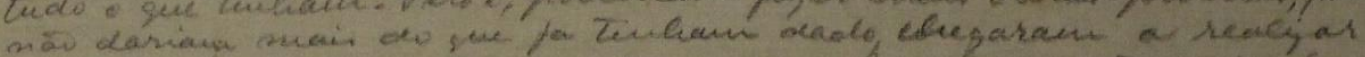

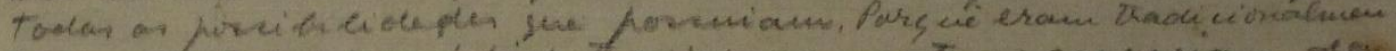

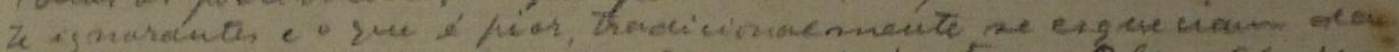

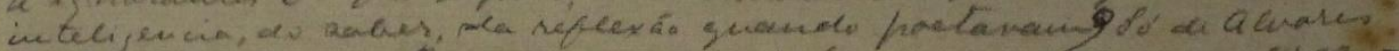

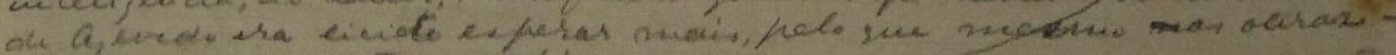

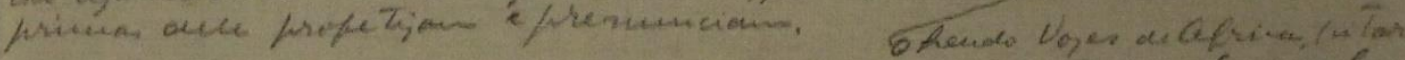

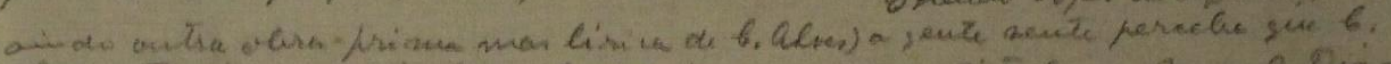

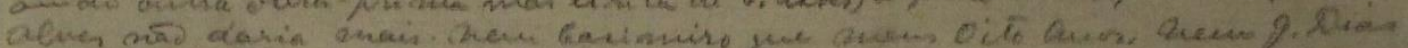

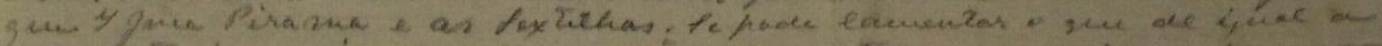

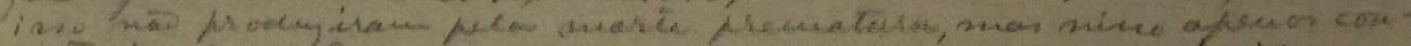

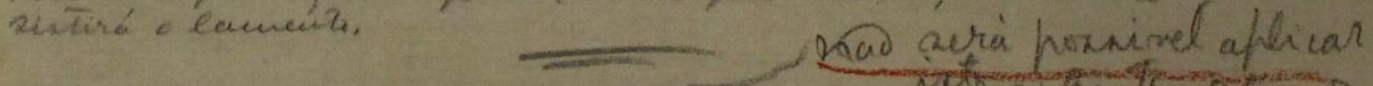

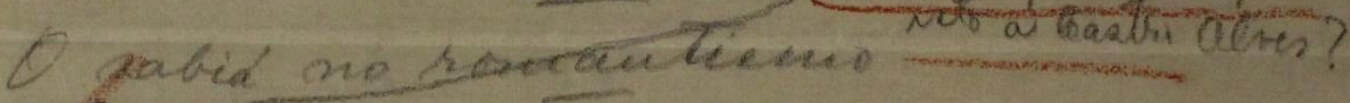

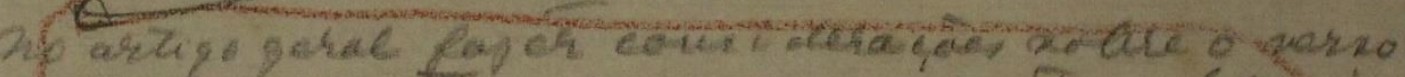

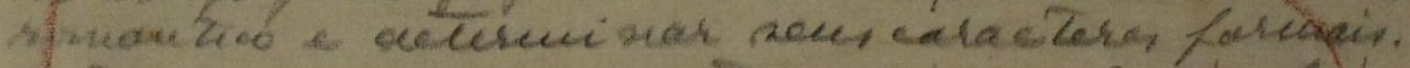

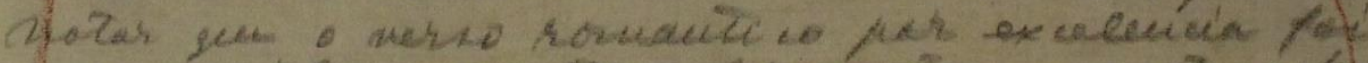

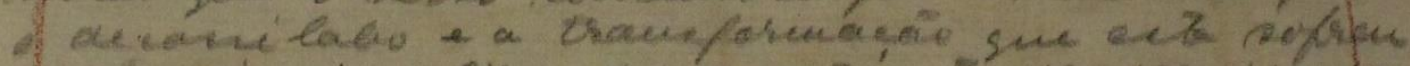

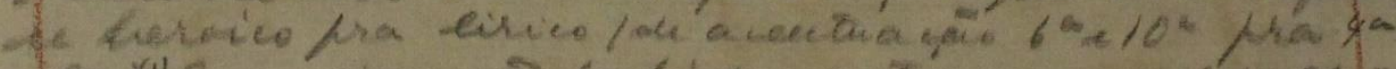

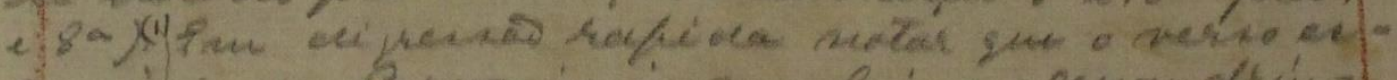

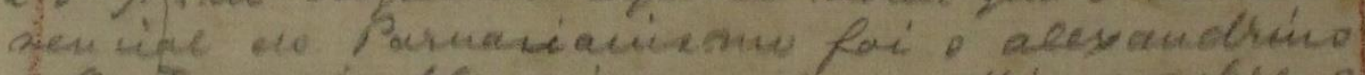

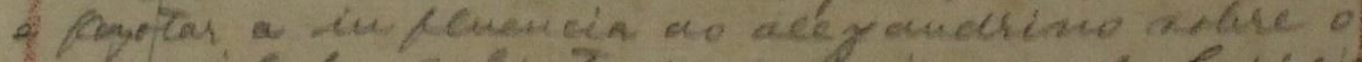

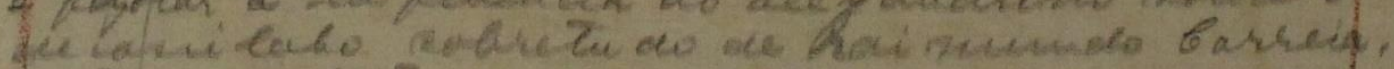

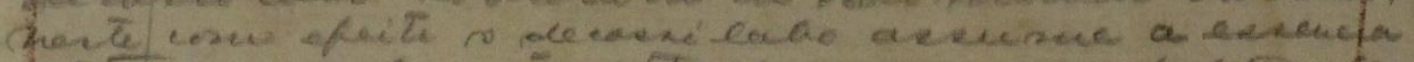

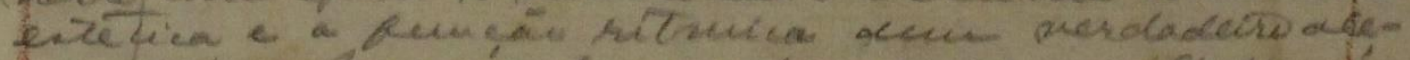

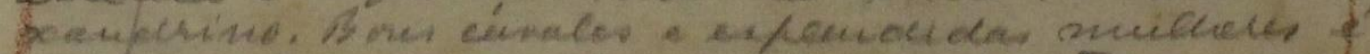

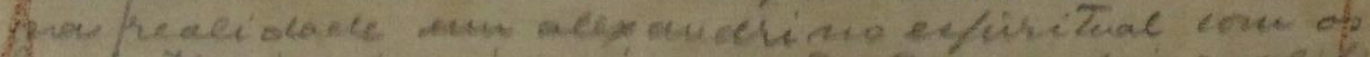

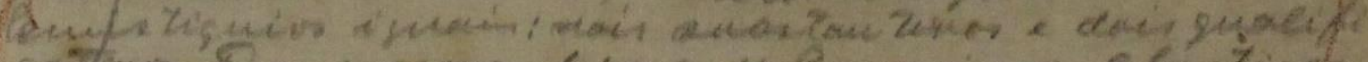

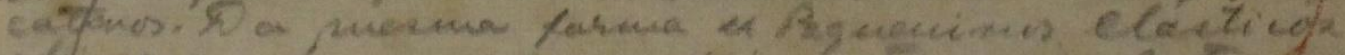

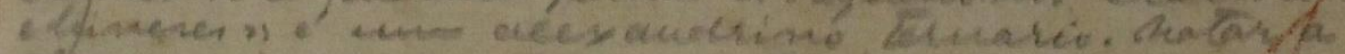

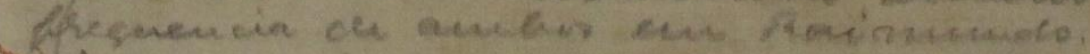

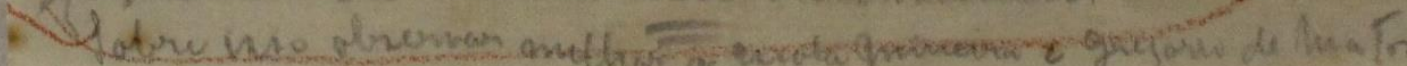


Alvares de Azevedo apesar da sensualidade de pala-/vras e de (seios etc) e de gestos de amor que descreve / permanece um idealista em amor. Mesmo na poesia. / No que se diferencia bem de C. Alves.

Não será possível aplicar isto a Castro Alves?

Epigrafe pra Varella: C. Alves I, 193

Realmente os romanticos, apesar de mortos moços alguns, deram / tudo o que tinham. Isto é, poderiam fazer mais obras-primas, porém / não dariam mais do que ja tinham dado, chegaram a realizar / todas as possibilidades que possuiam. Porquê eram tradicionalmen-/te ignorantes e o que é pior, tradicionalmente se esqueciam da / inteligencia, do saber, da reflexão quando poetavam*. Só de Alvares / de Azevedo era licito esperar mais, pelo que mesmo nas obras-/primas dele profetizam e prenunciam.

* Lendo Vozes de Africa (citar / ainda outra obra-prima mais lirica de C. Alves) a gente sente percebe que C. / Alves não daria mais. Nem Casimiro que Meus Oito Anos. Nem G. Dias / que Y Juca Pirama e as Sextilhas. Se pode lamentar o que de igual a / isso não produziram pela morte prematura, mas nisso apenas con-/sistirá o lamento.

O sabiá no romantismo

No artigo geral fazer considerações sobre o verso / romantico e determinar seus caracteres formais. / Notar que o verso romantico por excelencia foi / o decassilabo e a transformação que este sofreu / de heroico pra lirico (de acentuação $6^{\mathrm{a}}$ e $10^{\mathrm{a}}$ pra $\left.4^{\mathrm{a}} / \mathrm{e} 8^{\mathrm{a}}\right)^{(1)}$ Em digressão rapida notar que o verso es-/sencial do Parnasianismo foi o alexandrino/e notar a influencia do alexandrino sobre o / decassilabo sobretudo de Raimundo Correia. / Neste com efeito o decassilabo assume a essencia / estetica e a função ritmica dum verdadeiro ale-/xandrino. Bons cavalos e esplendidas mulheres é / na realidade um alexandrino espiritual com os / hemistiquios iguais: dois substantivos e dois qualifi-/cativos. Da mesma forma "Pequeninos elasticos / chineses" é um alexandrino ternario. Notar a / frequencia de ambos em Raimundo.

Sobre isso observar melhor a escola mineira e Gregorio de Matos.

Nota da pesquisa: No poema "Aves de arribação", MA sublinha o verso "Tendo por musa o amor e a natureza" e cria uma nota no rodapé, na qual antecipa o planejamento confirmado no manuscrito: “(1) Epígrafe pra Fagundes Varela” (Nota MA in ALVES, Castro. Obras completas. Ed. cit., p. 193, vol. 1). 


\section{MA-MMA-26 - 07}

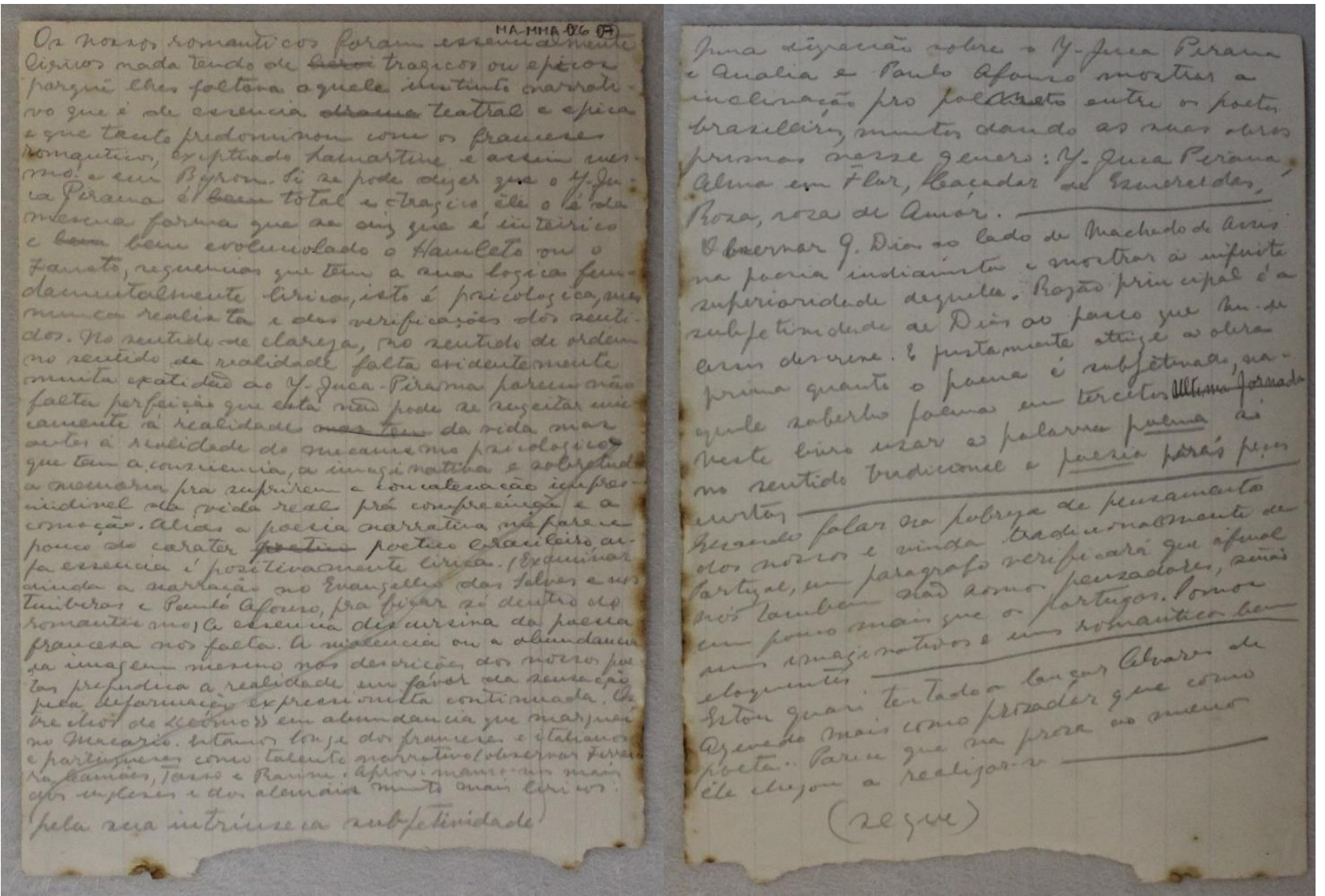


Os nossos romanticos foram essencialmente / liricos nada tendo de herøi tragicos ou epicos / porquê lhes faltava aquele instinto narrati-/vo que é de essencia drama teatral e epica / e que tanto predominou com os franceses / romanticos, exceptuado Lamartine e assim mes/mo! e em Byron. Si se pode dizer que o Y-Ju-/ca Pirama é bem total e tragico ele o é da / mesma forma que se diz que é inteirico / e bem bem evoluciolado o Hamleto ou o / Fausto, sequencias que tem a sua logica fun- / damentalmente lirica, isto é psicologica, mas / nunca realista e das verificações dos senti- / dos. No sentido de clareza, no sentido de ordem / no sentido de realidade falta evidentemente / muita exatidão ao Y-Juca- Pirama porem não / falta perfeição que esta não pode se sujeitar uni- / camente à realidade mas tem da vida mas / antes à realidade do mecanismo psicologico / que tem a consciência, a imaginativa e sobretudo / a memoria pra suprirem a concatenação impres- / cindivel da vida real pra compreenção e a / comoção. Alias a poesia nafrativa me parece / pouco do carater poetice poetico brasileiro, cu- / já essencia é positivarnente lirica. (Examinar / ainda a narração no Evangelho das Selvas e nos / Timbiras e Paulф Afonso, pra ficar sé dentro do / romantismo) A essencia discursiva da poesia / francesa nos falta. A violencia ou a abundancia / da imagem mesmo nas descrições dos nossos poe / tas prejudica a realidade em favor dą sensação / pela deformação expressionista continuada. Os / rechos de "como" em abundanciaque marquei / no Macario. Estamos longe dos franceses e italianos / e portugueses como talentonarrativo (observar Ferrei-/ra, Camões, Tasso e Racine. Aproximamo-nos mais / dos ingleses e dos alemães muito mais liricos.//

pela sua intrinseca subjetividade

Numa digressão sobre o Y-Juca Pirama / e Analia e Paulo Afonso mostrar a / inclinação pro poemeto entre os poetas / brasileiros, muitos dando as suas obras / primas nesse genero: YJuca Pirama, / Alma em Flor, Caçador de Esmeraldas, / Rosa, rosa de Amor. /I

Observar G. Dias ao lado de Machado de Assis / na poesia indianista e mostrar a infinita / superioridade daquela. Razão principal é a / subjetividade de Dias ao passo que M. de / Assis descreve. E justamente atinge a obra / prima quando o poema é subjetivado, na-/quele soberbo poema em tercetos Ultima jornada

Neste livro usar a palavra poema só / no sentido tradicional e poesia <sublinhado> prás peças / curtas /I

Quando falar na pobreza de pensamento / dos nossos e vinda tradicionalmente de / Portugal, um paragrafo verificará que afinal / nós também não somos pensadores, senão / um pouco mais que os portugas. Somos / uns imaginativos e uns romanticos bem / eloquentes //

Estou quasi tentado a lançar Alvares de / Azevedo mais como prosador que como / poeta. Parece que na prosa ao menos / êle chegou a realizar-se 
MA-MMA-26- 08

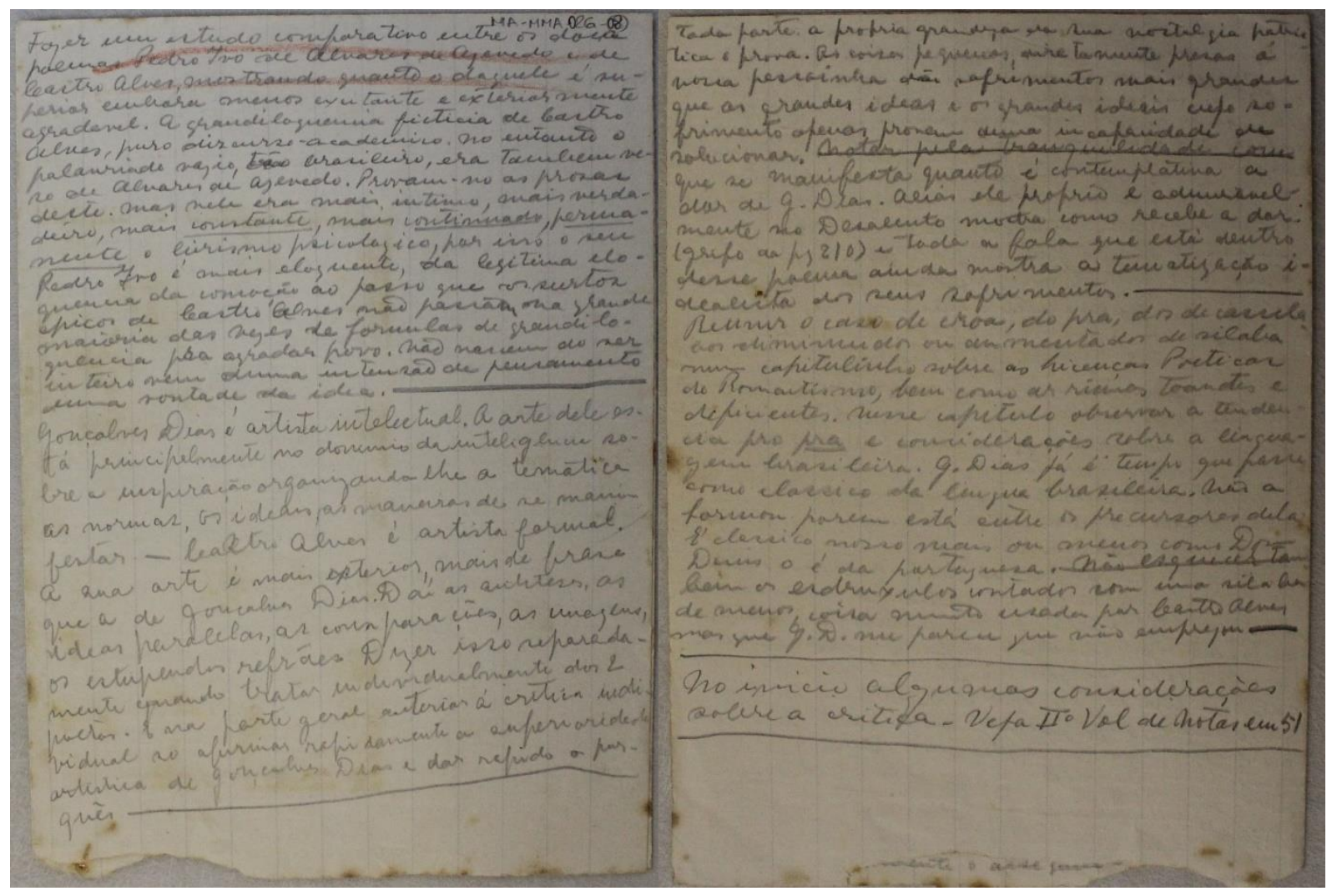

Fazer um estudo comparativo entre os dois / poemas de Pedro Ivo de Alvares de Azevedo e de / Castro Alves, mostrando quanto o daquele é su-/perior embora menos excitante e exteriormente / agradavel. A grandiloquencia ficticia de Castro / Alves, puro discursoacademico. No entanto o / palavriado vazio, tão <rasura, sobreposição a um começo de palavra> brasileiro, era tambem ve-/so de Alvares de Azevedo. Provam-no as prosas / deste. Mas nele era mais intenso, mais verda-/deiro, mais constante, mais continuado, perma-/nente o lirismo psicologico, por isso o seu / Pedro Ivo é mais eloquente, da legitima elo-/quencia da comoção ao passo que os surtos / epicos de Castro Alves não passam na grande / maioria das vezes de formulas de grandilo-/quencia pra agradar povo. Não nascem do ser / inteiro nem duma intenção de pensamento / duma vontade da idea.

Gonçalves Dias é artista intelectual. A arte dele es-/tá principalmente no dominio da inteligencia so-/bre a inspiração organizando-lhe a tematica / as normas, os ideais, as maneiras de se mani-/festar - Castro Alves é artista formal. / A sua arte é mais exterior, mais de frase / que a de Gonçalves Dias. Daí as antiteses, as / ideas paralelas, as comparações, as imagens, / os estupendos refrões. Dizer isso separada-/mente quando tratar individualmente dos 2 / poetas. E na parte geral anterior á critica indi-/vidual so afirmar rapidamente a superioridade / artistica de Gonçalves Dias e dar rapido os por-/quês 
MA-MMA-26-09

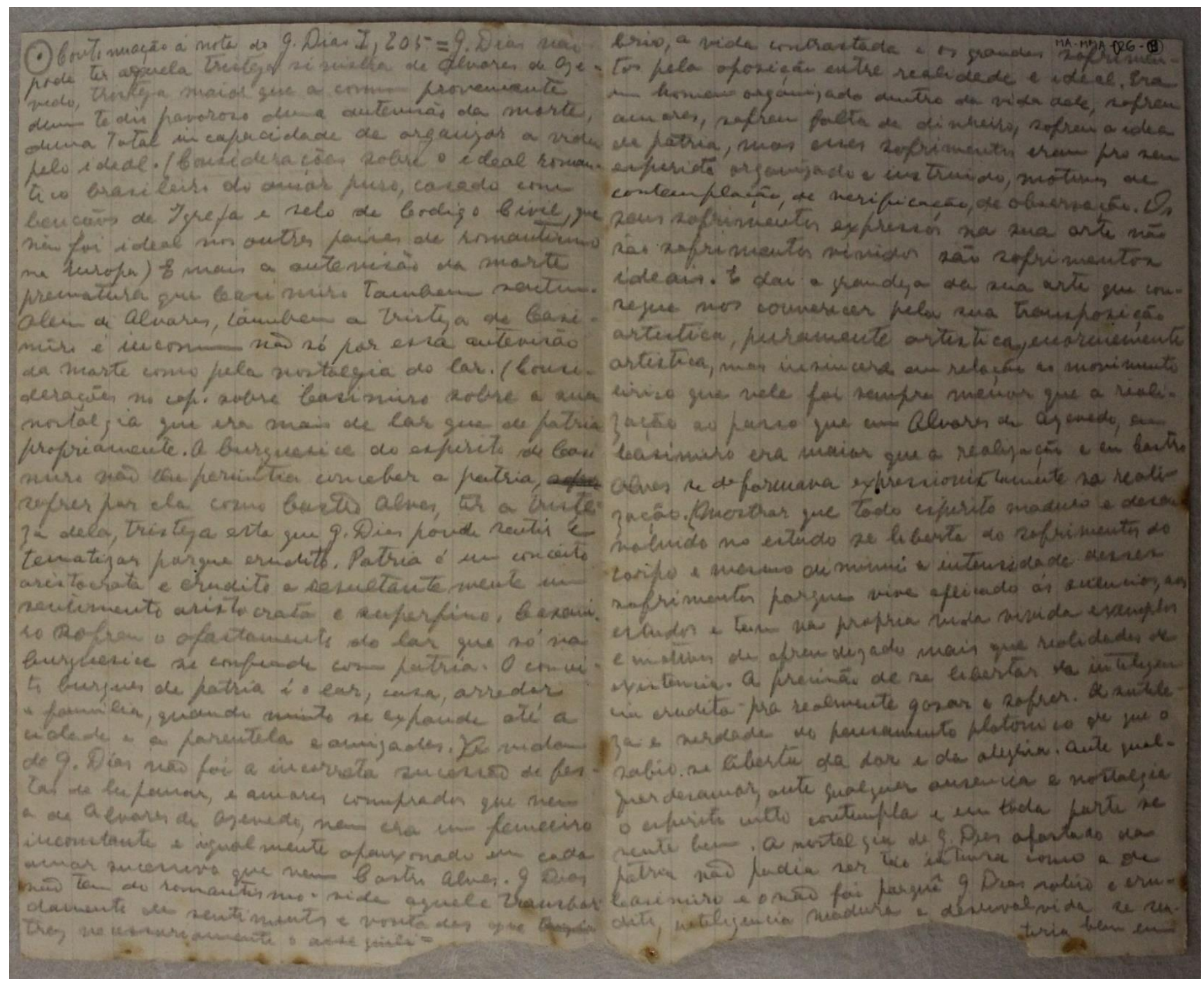

- Continuação á nota do G. Dias I, $205=$ G. Dias não / pode ter aquela tristeza sinistra de Alvares de Aze-/vedo, tristeza maior que a comum proveniente / dum tedio pavoroso duma antevisão da morte, / duma total incapacidade de organizar a vida / pelo ideal. (Considerações sobre o ideal roman-/tico brasileiro do amor puro, casado com bençãos de Igreja e selo do Codigo Civil, que / não foi ideal nos outros paises de romantismo / na Europa) E mais a antevisão da morte / prematura que Casimiro tambem sentiu. / Alem de Alvares, tambem a tristeza de Casi-/miro é incomum não só por essa antevisão / da morte como pela nostalgia do lar. (Consi-/derações no cap. sobre Casimiro sobre a sua / nostalgia que era mais de lar que de patria / propriamente. A burguesice do espirito de Casi/miro não lhe permitia conceber a patria, sofrer / sofrer por ela como Castro Alves, ter a triste-/za dela, tristeza esta que G. Dias poude sentir e / tematizar porque erudito. Patria é um conceito / aristocrata e erudito e resultantemente um / sentimento aristocrata e superfino. Casemi-/ro sofreu o afastamento do lar que só na / burguesice se confunde com patria. O concei-/to 
burgues de patria é o lar, casa, arredor / e família, quando muito se expande até a / cidade e a parentela e amizades.) A vida / de G. Dias não foi a incorreta sucessão de fes-/tas de lupanar, e amores comprados que nem / a de Alvares de Azevedo, nem era um femeeiro / inconstante e igualmente apaixonado em cada / amor sucessivo que nem Castro Alves. G. Dias / não tem do romantismo-vida aquele transbor-/damento de sentimentos e vontades que trazia / traz necessariamente o desequili-/

brio, a vida contrastada e os grandes sofrimen-/tos pela oposição entre realidade e ideal. Era / um homem organizado dentro da vida dele, sofreu / amores, sofreu falta de dinheiro, sofreu a idea / de patria, mas esses sofrimentos eram pro seu / espirito organizado e instruido, motivos de / contemplação, de verificação, de observação. Os / seus sofrimentos expressos na sua arte não / são sofrimentos vividos são sofrimentos / ideais. E daí a grandeza da sua arte que con-/segue nos comover pela sua transposição / artistica, puramente artistica, enormemente / artistica, mas insincera em relação ao movimento / lirico que nele foi sempre menor que a reali-/zação ao passo que em Alvares de Azevedo, em / Casimiro era maior que a realização e em Castro / Alves se deformava expressionistamente na reali-/zação. (Mostrar que todo espirito maduro e desen-/volvido no estudo se liberta do sofrimento do / corpo e mesmo diminui a intensidade desses / sofrimentos porque vive aplicado ás astucias, aos / estudos e tem na propria vida vivida exemplos / e motivos de aprendizado mais que realidades de / existencia. A precisão de se libertar da inteligen-/cia erudita pra realmente gosar e sofrer. A sutile-/za e verdade do pensamento platonico de que o / sabio se liberta da dor e da alegria. Ante qual-/quer desamor, ante qualquer ausencia e nostalgia / o espirito culto contempla e em toda parte se / sente bem. A nostalgia de G. Dias afastado da / patria não podia ser tão intensa como a de / Casimiro e o não foi porquê G. Dias sábio e eru-/dito, inteligencia madura e desenvolvida se sen- / tiria bem em / toda parte. A propria grandeza da sua nostalgia patrio-/tica o prova. As coisas pequenas, diretamente presas á / nossa pessoinha dão sofrimentos mais grandes / que as grandes ideas e os grandes ideais cujo so/frimento apenas provem duma incapacidade de / solucionar. Notar pela tranquilidade com / que se manifesta quanto é contemplativa a / dor de G. Dias. Aliás ele proprio e admiravel/mente no Desalento mostra como recebe a dor / (grifo da pg 210) e toda a fala que está dentro / desse poema ainda mostra a tematização i-/dealista dos seus sofrimentos.

Reunir o caso de croa, do pra, dos decassila-/bos diminuidos ou aumentados de silaba / num capitulinho sobre as Licenças Poeticas / do Romantismo, bem como as rimas toantes e / deficientes. Nesse capitulo observar a tenden-/cia pro pra e considerações sobre a lingua/gem brasileira. G. Dias já é tempo que passa / como classico da lingua brasileira. Não a / formou porem está entre os precursores dela. / É classico nosso mais ou menos como Dom / Dinis o é da portuguesa. Não esquecer tam-/bem os esdruxulos contados com uma silaba / de menos, coisa muito usada por Castro Alves / mas que G. D. me parece que não empregou

No inicio algumas considerações / sobre a critica. Veja II $^{\circ}$ Vol de Notas em 51 
Notas da pesquisa:

1. À margem do poema "Se queres que eu sonhe", MA escreve: "Como sempre bonito. Refrão. A tristeza de G. Dias é principalmente temática e insincera porque não é maior que a da infinita generalidade dos mortais. Viver é sofrer. (Ver papel de notas em $\odot$ )" (Nota $\underline{\mathrm{MA}}$ in DIAS, A. Gonçalves. Poesias. Nova edição organizada e revista por J. Norberto de Souza Silva e precedida de uma notícia sobre o autor e suas obras pelo Cônego Doutor Fernandes Pinheiro. Paris/Rio de Janeiro: Garnier, 1919, vol 1, p. 205).

2. MA destaca com um traço triplo a seguinte estrofe do poema "Desalento" (Nota MA in DIAS, A. Gonçalves. Poesias. Ed. cit, p. 210):

Mal aceito conviva me despeço!...

As calumnias que soffro, a dôr que passo,

Não me ferem profundas;

Bem como a rôla que das matas desce,

E nas azas recebe o pó da estrada,

Que voando sacode. 


\section{MA-MMA-26-10-11}

[Lirismo romântico no Brasil.] Notas de trabalho ligadas ao livro projetado; autógrafo a grafite; 1 folha dupla de papel de carta infantil, norte-americano (?), amarelecida pelo tempo (11,7 x 9,4 cm); manchas de fungo e marca de dobra central; desenho impresso no canto superior esquerdo, colorido a mão com lápis de cor: menino pescando em uma tina e legenda impressa: "SIMPLE SIMON"; escrita utilizando anverso e verso das folhas; $f$. 1011.
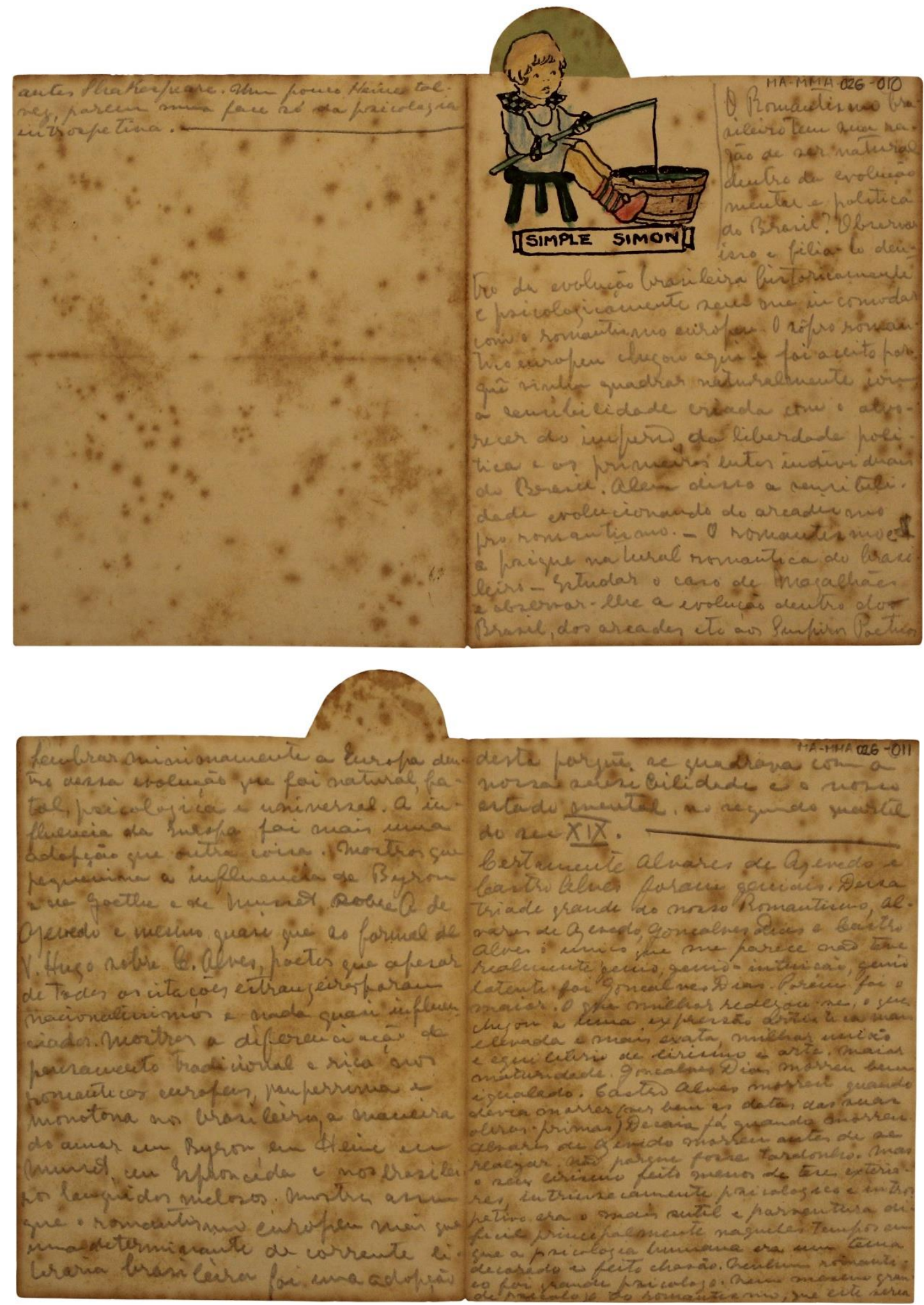
O Romantismo bra-/sileiro tem sua ra-/zão de ser natural / dentro da evolução / mental e politica / do Brasil? Observar / isso e filia-lo den-/tro da evolução brasileira historicamente / e psicologicamente sem me incomodar / com o romantismo europeu. O sôpro roman-/tico europeu chegou aqui e foi aceito por-/quê vinha quadrar naturalmente com / a sensibilidade criada com o alvo-/recer do imperio da liberdade poli-/tica e os primeiros entes individuais / do Brasil. Alem disso a sensibili-/dade evolucionando do arcadismo / pro romantismo. - $\mathrm{O}$ romantismo e / a psique natural romantica do brasi-/leiro - Estudar o caso de Magalhães / e observar-lhe a evolução dentro dos / Brasil, dos arcades etc aos Suspiros Poeticos //

Lembrar minimamente a Europa den-/tro dessa evolução que foi natural, fa-/tal, psicologica e universal. A in-/fluencia da Europa foi mais uma / adopção que outra coisa. Mostrar que / pequenina a influencia de Byron / e de Goethe e de Musset sobre A de / Azevedo e mesmo quasi que so formal de / V. Hugo sobre C. Alves, poetas que apesar / de todas as citações estrangeiras foram / nacionalissimos e nada quasi influen-/ciados. Mostrar a diferenciação de / pensamento tradicional e rico nos / romanticos europeus, pauperrima e / monotona nos brasileiros, a maneira / do amor em Byron, em Heine em / Musset, em Espronceda e nos brasilei-/ros languidos melosos. Mostrar assim / que o romantismo europeu mais que / uma determinante de corrente li-/teraria brasileira foi uma adopção // desta porquê se quadrava com a / nossa sensibilidade e o nosso / estado mental, no segundo quartel / do sec XIX.

Certamente Alvares de Azevedo e / Castro Alves foram geniais. Dessa / triade grande do nosso Romantismo, Al-/vares de Azevedo, Gonçalves Dias e Castro / Alves o unico que me parece não teve / realmente genio, genio-intuição, genio / latente foi Gonçalves Dias. Porém foi o / maior. O que milhor realizou-se, o que / chegou a uma expressão artistica mais / elevada e mais exata, milhor / união e equilibro de lirismo e arte. Maior / maturidade. Gonçalves Dias morreu bem / igualado. Castro Alves morreu quando / devia morrer (ver bem as datas das suas / obras-primas). Decaia já quando morreu. / Alvares de Azevedo morreu antes de se / realizar. Não porque fosse tardonho. Mas / o seu lirismo feito menos de teses exterio-/res, intrinsecamente psicologico e intros-/petivo era o mais sutil e porventura di-/ficil principalmente naqueles tempos em / que a psicologia humana era um tema / decorado e feito chavão. Nenhum romanti-/co foi grande psicologo. Nem mesmo gran-/de psicologo do romantismo, que este seria /antes Shakespeare. Um pouco Heine tal-/vez, porem numa face só da psicologia / introspetiva. 
MA-MMA-26-12- 13

[Lirismo romântico no Brasil.] Esboço de trecho para o livro projetado; autógrafo a grafite; 2 tiras de papel sulfite verde, desbotadas $(14 \times 10,9 \mathrm{~cm} ; 28,2 \times 10,8 \mathrm{~cm})$, numeradas em arábico: 1-3; f. 13 da numeração da pesquisa, com marca de dobra central; filigrana: "L. BOND”, f. 12-13; escrita no anverso e verso das folhas; rasuras a grafite; f. 12.13 .

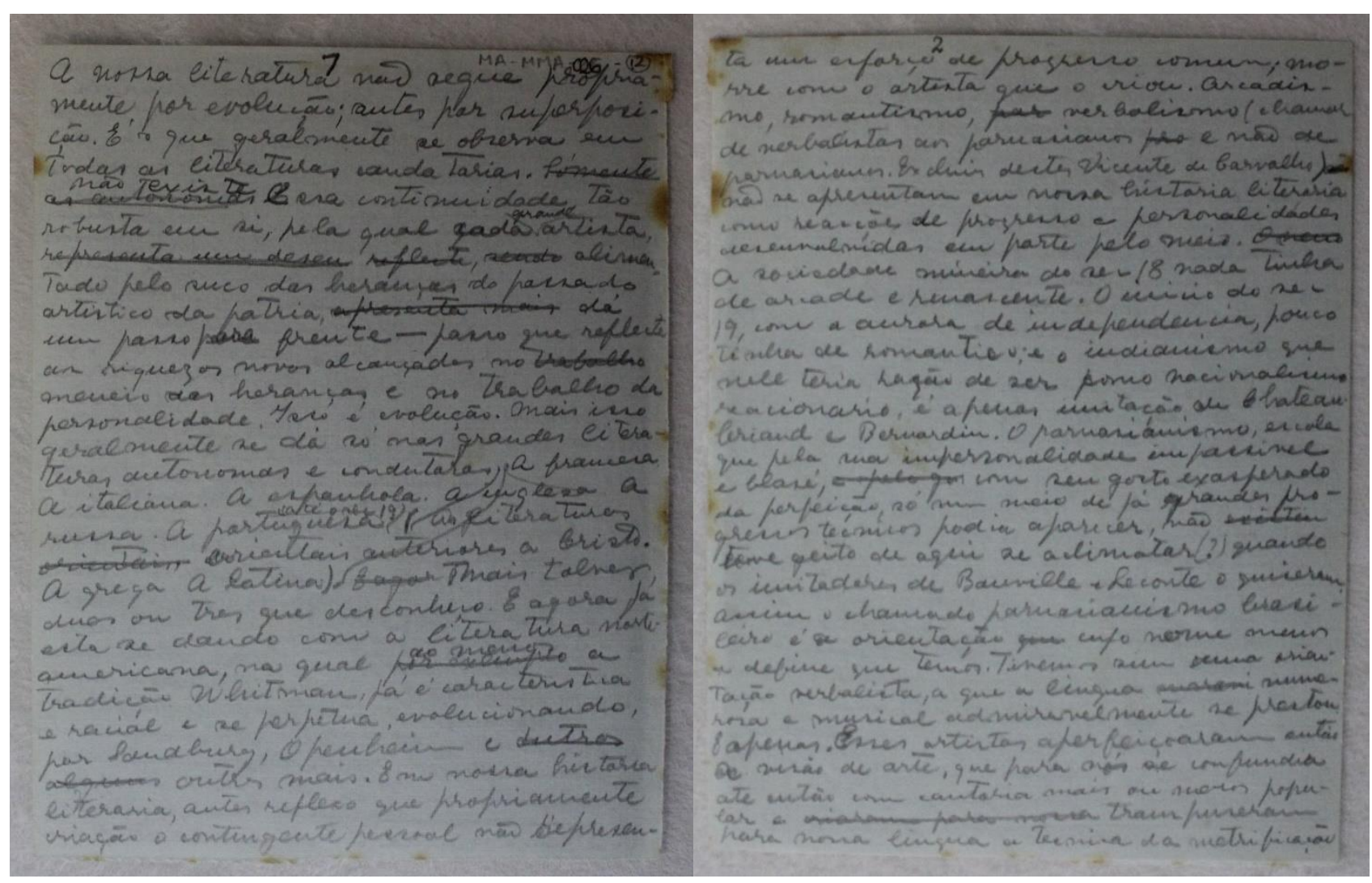

A nossa literatura não segue propria-/mente por evolução; antes por superposi-/ção. É o que geralmente se observa em / todas as literaturas caudatarias. Somente_/ as autonomas_não existe essa continuidade tão / robusta em si, pela qual cada grande artista, / representa um desen reflecte, sende alimen-/tado pelo suco das heranças do passado / artistico da patria apresenta mais_dá / um passo para frente - passo que reflecte / as riquezas novas alcançadas no trabalhe / meneio das heranças e no trabalho da / personalidade. Isso é evolução. Mas isso / geralmente se dá só nas grandes litera-/turas autonomas e condutoras.. A francesa. / A italiana. A espanhola. A inglesa. A / russa. A portuguesa (até o sec 19). (As literaturas / erientais orientais anteriores a Cristo. A grega. A latina). E agor Mais talvez, / duas ou tres que desconheço. E agora já / esta se dando com a literatura norte-/americana, na qual pør exemple ao menos a / tradição Whitman, já é caracteristica / e racial e se perpetua, evolucionando, / por Sandburg, Openheim e eutros / alguns_outros mais . Em nossa historia / literaria, antes reflexo que propriamente / criação o contingente pessoal não represen- / 
ta um esforço de progresso comum; mo-/rre com o artista que o criou. Arcadis-/mo, romantismo, par verbalismo (chamar de verbalistas aos parnasianos pre e não de / parnasianos. Excluir destes Vicente de Carvalho) nãe / não se apresentam em nossa historia literaria / como reacções de progresso e personalidades / desenvolvidas em parte pelo meio. $\Theta$ meio / A sociedade mineira do sec 18 nada tinha / de arcade e renascente. O inicio do sec / 19, com a aurora de independencia, pouco / tinha de romantico; e o indianismo que / nele teria razão de ser como nacionalismo / reacionario, é apenas imitação de Chateau-/briand e Bernardin. O parnasianismo, escola / que pela sua impersonalidade impassivel / e blasé, e pelo gos com seu gosto exasperado / da perfeição, só num meio de já grandes pro-/gressos técnicos podia aparecer, não existił / teve jeito de aqui se aclimatar (?) quando / os imitadores de Banville e Leconte o quiseram. / Assim o chamado parnasianismo brasileiro é a orientação que cujo nome menos / a define que temos. Tivemos sim uma orien-/tação verbalista, a que a língua maravi nume-/rosa e musical admiravelmente se prestou. / E apenas. Esses artistas aperfeiçoaram então / a visão de arte, que para nós se confundia / até então com cantoria mais ou menos popu-/lar e criaram para nossa transpuseram / para nossa língua a tecnica da metrificação // 
MA-MMA-26 - 13

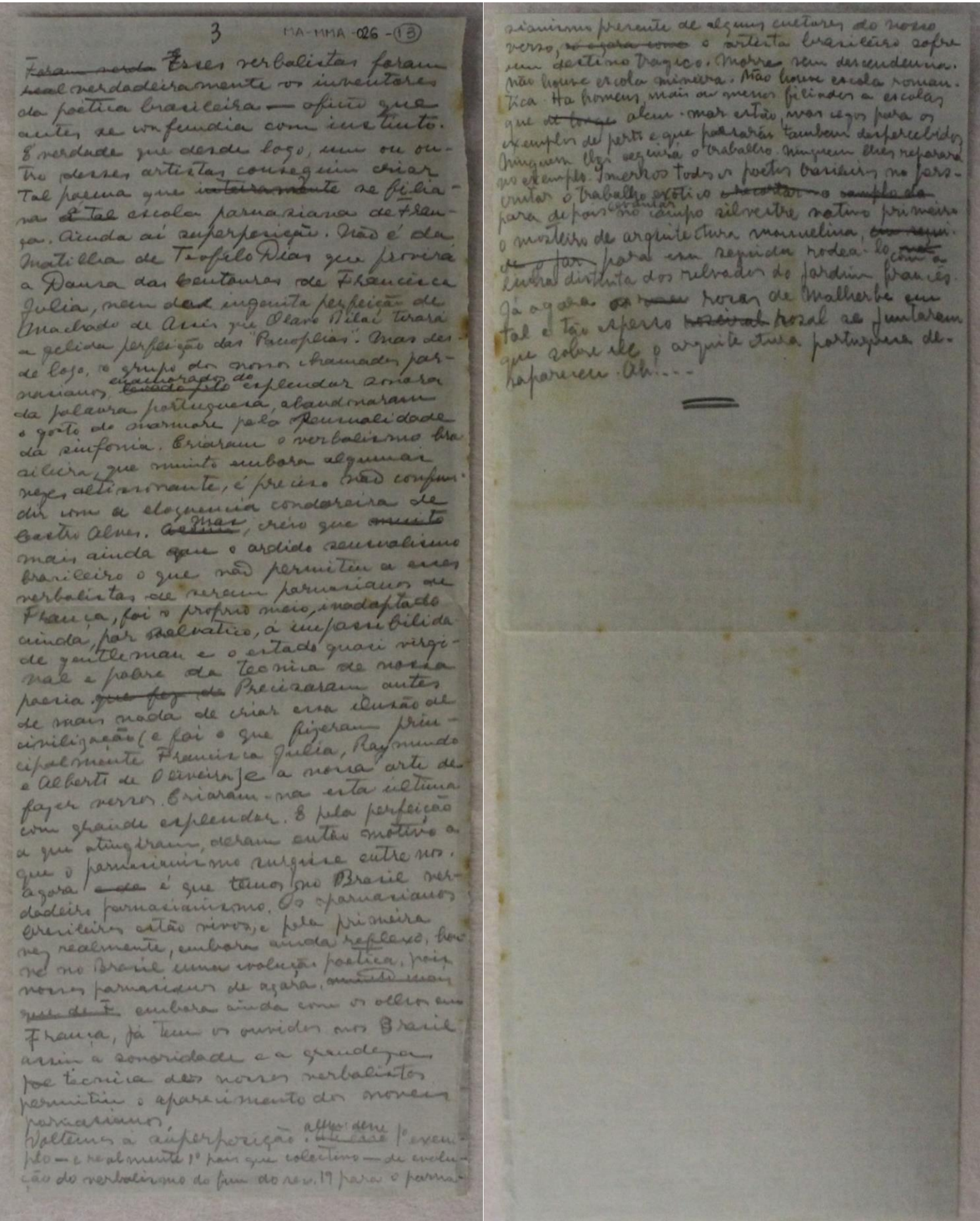


Foram verda Esses verbalistas foram / real verdadeiramente os inventores / da poética brasileira - ofício que / antes se confundia com instinto. / É verdade que desde logo, um ou ou-/tro desses artistas conseguiu criar / tal poema que inteiramente se filia-/va a tal á escola parnasiana de Fran-/ça. Ainda aí superposição. Não é da / matilha de Teofilo Dias que provirá / a Deusa das Centauras de Francisca / Julia, nem de ingenita perfeição de / Machado de Assis que Olavo Bilac tirará / a gelida perfeição das "Panoplias". Mas des-/de logo, o grupo dos nossos chamados par-/nasianos, levado pele enamorados do esplendor sonoro / da palavra portuguesa, abandonaram / o gosto do marmore pela sensualidade / da sinfonia. Criaram o verbalismo bra-/sileiro, que muito embora algumas / vezes altissonante, é preciso não confun-/dir com a eloquencia condoreira de Castro Alves. Assim Mas, creio que muitø / mais ainda que o ardido sensualismo / brasileiro o que não permitiu a esses / verbalistas de serem parnasianos de / França, foi o próprio meio inadaptado / ainda, por selvatico, à impassibilida-/de gentleman e o estado quasi virgi-/nal e pobre de tecnica de nossa / poesia. que fez de Precisaram antes / de mais nada de criar essa ilusão de / civilização (e foi o que fizeram prin-/cipalmente Francisca Julia, Raymundo / e Alberto de Oliveira) e a nossa arte de / fazer versos. Criaram-na esta última / com grande esplendor. E pela perfeição / a que atingiram, deram então motivo a / que o parnasianismo surgisse entre nos. / Agora e de é que temos no Brasil ver-/dadeiro parnasianismo. Os parnasianos / brasileiros estão vivos; e pela primeira / vez realmente, embora ainda reflexo, hou-/ve no Brasil uma evolução poetica, pois / nossos parnasianos de agora, muito mais / que de F embora ainda com os olhos em / França, já tem os ouvidos no Brasil. / Assim a sonoridade e a grandeza / poe tecnica dos nossos verbalistas / permitiu o aparecimento dos noveis / parnasianos. //

Voltemos a superposição. Até esse Alem desse $1^{\circ}$ exem- /plo - e realmente $1^{\circ}$ pois que colectivo - de evolu-/ção do verbalismo do fim do sec 19 para o parna-//sianismo presente de alguns cultores do nosso / verso, sé agora com o artista brasileiro sofre / um destino tragico. Morre sem descendencia. / Não houve escola mineira. Não houve escola roman/tica. Ha homens mais ou menos filiados a escolas / que de longe_alem-mar estão, mas cegos para os / exemplos de perto e que passarão tambem despercebidos. / Ninguem lhes seguirá o trabalho. Ninguem lhes reparará / no exemplo. Imersos todos os poetas brasileiros no pers/crutar o trabalho exotico e recortar no exemplo da/ para depois levantar no campo silvestre nativo primeiro / o mosteiro de arquitectura manuelina, em segui/da o jar para em seguida rodea-lo na com a / linha distinta dos relvados do jardim francês. / Já agora as rosei rosas de Malherbe em / tal e tão espesso roseiral rosal se juntaram / que sobre ele a arquitectura portuguesa de-/sapareceu. Ah!... 


\section{Referências bibliográficas}

Obras de Mário de Andrade

ANDRADE, Mário de. Aspectos da Literatura Brasileira. $5^{\mathrm{a}}$ ed. São Paulo: Livraria Martins Editora, 1974.

Aspectos da Música Brasileira. São Paulo: Livraria Martins

Editora, 1965

Dicionário musical brasileiro. Ed. preparada por Oneyda

Alvarenga e Flávia Toni. Belo Horizonte: Itatiaia, Brasília: Ministério da Cultura, São Paulo: IEB-USP/ Edusp, 1989.

. Macunaíma. Ed. crítica prep. por Telê Ancona Lopez e Tatiana Longo Figueiredo. Rio de Janeiro: Nova Fronteira, 2012.

Obra Imatura. São Paulo: Livraria Martins Editora, 1960.

Poesias Completas. Edição de texto apurado, anotada e acrescida de

documentos por Tatiana Longo Figueiredo e Telê Ancona Lopez. Rio de Janeiro: Nova Fronteira, 2013, 2 vol.

1972 ( $3^{\mathrm{a}}$ edição).

O empalhador de passarinho. São Paulo, Martins; Brasília, INL/Mec,

O Turista Aprendiz. Estabelecimento de Texto, Introdução e Notas de Telê Ancona Lopez. São Paulo: Livraria Duas Cidades, 1983.

Táxi e Crônicas no Diário Nacional. São Paulo: Duas Cidades, Secretaria da Cultura, Ciência e Tecnologia, 1976.

Edusp/Hucitec, 1993.

Vida Literária. Ed. prep. por Sônia Sachs. São Paulo,

\section{Obras sobre Mário de Andrade}

ALVARENGA, Oneyda. Mário de Andrade, um pouco. Rio de Janeiro: José Olympio, 1974.

ALVES, Henrique. Mário de Andrade. São Paulo: Editora do Escritor, 1973.

CAMPOS, Haroldo. "Mário de Andrade: a imaginação estrutural" e "Da Razão Antropofágica: Diálogo e Diferença na Cultura Brasileira". In: Metalinguagem e outras metas. São Paulo: Perspectiva, 2013. 
CARVALHO, Lílian. “A Revista francesa L'Esprit Nouveau na formação das idéias estéticas e da poética de Mário de Andrade". Orientadora: Telê Porto Ancona Lopez. Tese de Doutorado, USP, 2008

DE PAULA, Rosangela Asche. O expressionismo na biblioteca de Mário de Andrade: da leitura à criação. Tese de doutoramento no Programa de Pós-Graduação em Literatura Brasileira; FFLCH-USP; 2007.

FERES, Nites Therezinha. Leituras em francês de Mário de Andrade: seleção e comentários com fundamento na marginália. São Paulo: IEB, 1969.

FIGUEIREDO, Tatiana Longo. Entre fichas e livros: trajetos da criação de Mário de Andrade. Anais do X Congresso Internacional da APCG (Associação de Pesquisadores em Crítica Genética). Porto Alegre: PUCRS, 2012.

- Crítica genética antes da Crítica genética no Arquivo Mário de Andrade. Marioscriptor, $\mathrm{n}^{\mathrm{o}}$ 2. Revista eletrônica do Projeto temático Fapesp/ IEB/ FFLCH-USP Estudo do processo de criação de Mário de Andrade nos manuscritos de seu arquivo, em sua correspondência, em sua marginália e em suas leituras, novembro de 2011, http://www.ieb.usp.br/marioscriptor_2/escritos/critica-genetica-antes-da-criticagenetica-no-arquivo-mario-de-andrade.html ; Verbo de Minas: Letras, v. 11, n 19 (ISSN 1516-0637-B 1. Juiz de Fora, julho-dezembro, 2012.

O Fichário analítico de Mário de Andrade: apontamentos de um leitor particular. Cadernos Neolatinos $\left(\mathrm{n}^{\mathrm{o}}\right.$ especial dedicado ao $4^{\circ}$ Simpósio Internacional de Letras Neolatinas: Livro, Leitor, Leituras - Desafio para as Letras). Rio de Janeiro: Universidade Federal do Rio de Janeiro, no prelo.

. As primeiras fichas do polígrafo modernista Mário de Andrade. Remate de Males. Campinas, DTL-IEL-UNICAMP, [número eletrônico especial sobre Modernismo em comemoração aos 90 anos da Semana de Arte Moderna, no prelo.

GREMBECKI, Maria Helena. Mário de Andrade e L'Esprit Nouveau. São Paulo: IEBUSP, 1969.

KNOLL, Victor. Paciente Arlequinada: uma leitura da obra poética de Mário de Andrade. São Paulo: Hucitec, 1983.

LAFETÁ, João Luiz. 1930: A Crítica e o Modernismo. São Paulo: Livraria Duas Cidades, 1974.

—. Figuração da intimidade: imagens na poesia de Mário de Andrade. São Paulo: Martins Fontes, 1986.

LOPEZ, Telê Ancona. Mariodeandradiando. São Paulo: Editora Hucitec, 1996.

Cidades, 1972.

. Mário de Andrade: Ramais e Caminho. São Paulo: Livraria Duas 
. "Os manuscritos no arquivo e na biblioteca de Mário de Andrade".

In: NITRINI, Sandra (Org.). Tessituras, interações, convergências. São Paulo: HUCITEC/ ABRALIC, 2011, p. 409-424.

. "Catálogo analítico dos Manuscritos de Mário de Andrade: um aporte metodológico". Marioscriptor: Revista eletrônica do Projeto Temático Estudo do processo de criação de Mário de Andrade nos manuscritos de seu arquivo, em sua correspondência, em sua marginália e em suas leituras, FAPESP/ IEB/ FFLCH-USP, $\mathrm{n}^{\circ}$ 2. São Paulo, novembro, 2011.

MICELI, Sérgio. Intelectuais e Classe Dirigente no Brasil (1920-1945). São Paulo: Difel, 1979.

MORAES, Marcos Antonio (org. introd. e notas). Correspondência Mário de Andrade \& Manuel Bandeira. $2^{a}$ ed. São Paulo, Edusp/IEB, 2001.

Paulo, 13/10/1990. . "Os postais". Caderno de Cultura. O Estado de S. Paulo. São

PAULINO, Ana Maria. "Os livros". Caderno de Cultura. O Estado de S. Paulo. São Paulo,13/10/1990.

PERRONE-MOISÉS, Leyla. Vira e Mexe, nacionalismo: paradoxos do nacionalismo literário. São Paulo: Companhia das Letras, 2007.

SANTIAGO, Silviano (org. e notas). Carlos e Mário - Correspondência de Carlos Drummond de Andrade \& Mário de Andrade. Rio de Janeiro: Bem-te-vi, 2002.

SOUZA, Gilda de Mello e. A ideia e o figurado. São Paulo: Duas Cidades; Ed. 34, 2005. Exercícios de leitura. São Paulo: Ed. 34, 2009.

\section{$\underline{\text { Obras de crítica genética }}$}

BELLEMIN-NOËL, Jean. Le texte e l'avant texte. Paris, Larousse, 1972.

BOCKELKAMP, Marianne. "Comment décrire un manuscrit moderne?" Suivi de Standard descriptif pour manuscrits modernes. Cahiers de textologie, n 2, Paris: Minard, 1988.

CONTAT, Michel (Edição). L'auteur et le manuscrit. Paris: PUF, 1991. Coleção Perspectives critiques.

GRÉSILLON, Almuth. Eléments de critique génétique. Paris, Presses Universitaires de France, 1994. 
HAY, Louis. A literatura dos escritores : questões de crítica genética. Belo Horizonte : Editora UFMG, 2007.

LOPEZ, Telê Porto Ancona. "A biblioteca de Mário de Andrade: seara e celeiro da criação". In: ZULAR, Roberto, org. Criação em processo: Ensaios de crítica genética. São Paulo: FAPESP/ Iluminuras/ CAPES, 2002.

genética, n $^{\circ}$ 7. São Paulo, 1998.

"Manuscritos: Dimensões". In: Manuscrítica: Revista de crítica

NEEFS, Jacques. "Critique génetique et histoire littéraire. In: BÉHAR, Henri \& FAYOLLE, Roger L'Histoire littéraire aujourd'hui. Paris: Armand Colin, 1990.

PONGE, Francis. Pratiques d'écritures, ou l'inachevement perpetuél. Paris: Hermann, 1984.

SALLES, Cecília Almeida. Crítica genética: uma (nova) introdução. São Paulo, Educ, 2000 .

1999 Manuscrítica, revista de crítica genética. São Paulo: Annablume, "Poder de descobertas". In: Manuscrítica: Revista de crítica genética, $\mathrm{n}^{\circ}$ 7. São Paulo, 1998.

Gesto inacabado. Processo de criação artística. São Paulo,

Annablume, 1998.

WILLEMART, Philippe. Bastidores da criação literária. São Paulo, FAPESP/Iluminuras 1999.

. "Mais ainda em Crítica Genética e em psicanálise?" In:

Proust, poeta e psicanalista, Ateliê Editorial: São Paulo, 2000.

ZULAR, Roberto (org.). Criação em processo: Ensaios de crítica genética. São Paulo: Iluminuras/ FAPESP, 2002.

\section{Obras de história e crítica literária}

ABRAMS, J. H. O espelho e a lâmpada. São Paulo: Editora Unesp, 2011.

ABREU, Casimiro de. As primaveras. Introdução, organização e fixação de texto de Vagner Camilo. São Paulo: Martins Fontes, 2003.

ADORNO, T. W. Notas de literatura 1. São Paulo: Duas Cidades; Editora 34, 2012. . Filosofia da nova música. São Paulo: Perspectiva, 2011.

ALVES, Castro. Espumas flutuantes e os escravos. Introdução, organização e fixação de texto Luiz Dantas, Pablo Simpson. São Paulo: Martins Fontes, 2001. 
AUERBACH, Erich. Mimesis: a representação da realidade na literatura ocidental. São Paulo: Perspectiva, 2013.

BARTHES, Roland. La préparation du roman. Paris : Éditions du Seuil, 2003.

BÉNICHOU, Paul. Romantisme français I et II. Paris: Quarto Gallimard, 2004.

BOSI, Alfredo. História concisa da literatura brasileira. 47ª ed. São Paulo: Cultrix, 2006.

CAMILO, Vagner. Risos entre pares - poesia e humor românticos. São Paulo: Edusp, 1997.

CANDIDO, Antonio. Formação da Literatura Brasileira: Momentos Decisivos (17501880). 12a edição. São Paulo: Ouro sobre Azul, 2009.

Literatura e sociedade. Rio de Janeiro: Ouro sobre Azul, 2010.

A Educação pela Noite. São Paulo: Ouro sobre Azul, 2010.

COUTINHO, Afrânio (dir.). A Literatura no Brasil. Rio de Janeiro: Editora Sul Americana, 1956.

CUNHA, Cilaine Alves. O Belo e o Disforme: Álvares de Azevedo e a Ironia Romântica. São Paulo: Edusp, 1998.

CURTIUS, E. R. Literatura Europeia e Idade Média Latina. São Paulo: Edusp, 2013.

DIAZ, J-L. L'Écrivain imaginaire: Scénographies auctorales à l'époque romantique. Paris: Honoré Champion Éditeur, 2007.

Éditeur, 2007.

. Devenir Balzac. L'invention de l'écrivain par lui-même. Paris : Christian Pirot

. L'homme et l'oeuvre: contribution à l'histoire de la critique. Paris : Presses Universitaires de France, 2011.

GENETTE, Gérard. Seuils. Paris : Éditions du Seuil, 1987.

HADDAD, Jamil Almansur. Revisão de Castro Alves. São Paulo: Edição Saraiva, 1953.

—. Teresa - Revista de literatura brasileira, $n^{\circ}$ 12/13. São Paulo: Ed. 34, 2014.

LAFETÁ, João Luiz. 1930: A Crítica e o Modernismo. São Paulo: Livraria Duas Cidades, 1974.

Figuração da intimidade: imagens na poesia de Mário de Andrade. São Paulo: Martins Fontes, 1986.

SEVCENCO, Nicolau. Orfeu extático na metrópole: São Paulo, sociedade e cultura nos frementes anos 20. São Paulo: Companhia das Letras, 1992. 